\title{
Toxic Substances Control Act (TSCA) Polychlorinated Biphenyl (PCB)/Radioactive Waste Annual Inventory for Calendar Year 2013
}

June 2014

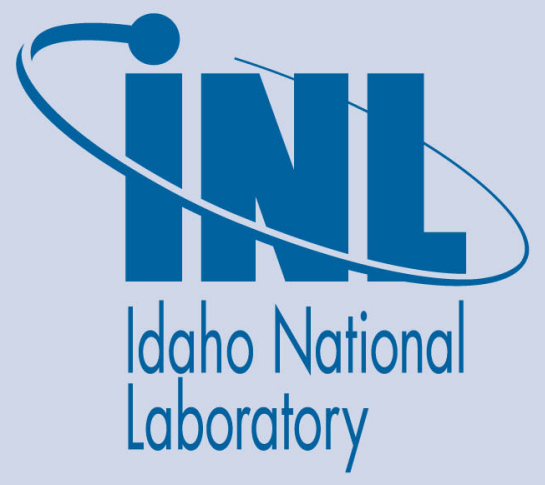

The INL is a U.S. Department of Energy National Laboratory operated by Battelle Energy Alliance 
INL/EXT-14-31796

\section{Toxic Substances Control Act (TSCA) Polychlorinated Biphenyl (PCB)/Radioactive Waste Annual Inventory for Calendar Year 2013}

June 2014

Idaho National Laboratory
Idaho Falls, Idaho 83415

http://www.inl.gov

Prepared for the

U.S. Department of Energy

Office of Nuclear Energy

Under DOE Idaho Operations Office

Contract DE-AC07-05ID14517 


\author{
TOXIC SUBSTANCES CONTROL ACT (TSCA) \\ ANNUAL RADIOACTIVE-CONTAMINATED \\ POLYCHLORINATED BIPHENYL (PCB) INVENTORY \\ FOR CALENDAR YEAR 2013 \\ For the \\ IDAHO NATIONAL LABORATORY \\ P. O. BOX 1625 \\ IDAHO FALLS, ID 83415 \\ EPA ID Nos. ID4890008952 (INL Site) and ID6890190089 (INL Research Center) \\ Prepared by \\ Battelle Energy Alliance, LLC (BEA) \\ June 2014
}

\title{
1.0 INTRODUCTION
}

The Toxic Substances Control Act, 40 CFR 761.65(a)(1) provides an exemption from the one year storage time limit for $\mathrm{PCB} /$ radioactive waste. $\mathrm{PCB} /$ radioactive waste may exceed the one year time limit provided that the provisions at 40 CFR 761.65(a)(2)(ii) and 40 CFR 761.65(a)(2)(iii) are followed. These two subsections require, (ii) "A written record documenting all continuing attempts to secure disposal is maintained until the waste is disposed of" and (iii) "The written record required by subsection (ii) of this section is available for inspection or submission if requested by EPA."

EPA Region 10 has requested the Department of Energy (DOE) to submit an inventory of radioactive-contaminated PCB waste in storage at the Idaho National Laboratory (INL) for the previous calendar year.

The annual inventory is separated into two parts, INL without Advanced Mixed Waste Treatment Project (AMWTP) (this includes Battelle Energy Alliance, LLC, CH2M-WG Idaho, LLC, and the Naval Reactors Facility), and AMWTP. 


\subsection{CONTINUING ATTEMPTS TO SECURE DISPOSAL OF RADIOACTIVE-CONTAMINATED PCB WASTE}

The following summarizes the INL and AMWTP continuing endeavors to secure disposal of PCB/Radioactive waste:

1. A total of 26 items or containers (excluding AMWTP) totaling approximately $54,755 \mathrm{~kg}$ of radioactively contaminated PCBs were shipped for disposal, or disposed during the calendar year 2013. Facilities used for disposal included a TSCA permitted incinerator capable of burning radioactively contaminated PCB liquids; a Resource Conservation and Recovery Act (RCRA) permitted Subtitle C facilities capable of accepting radioactively contaminated PCB solids and the Waste Isolation Pilot Plant (WIPP).

2. A total of 2269 items or containers totaling approximately $338,801 \mathrm{~kg}$ of radioactively contaminated PCBs from the AMWTP were shipped for disposal, or disposed during calendar year 2013. Facilities used for disposal included a TSCA permitted incinerator capable of burning radioactively contaminated PCB liquids; RCRA permitted subtitle $\mathrm{C}$ facilities capable of accepting radioactively contaminated PCB solids and WIPP. 
3.0 INL RADIOACTIVELY-CONTAMINATED PCB WASTE IN STORAGE AWAITING DISPOSAL (excluding AMWTP) 


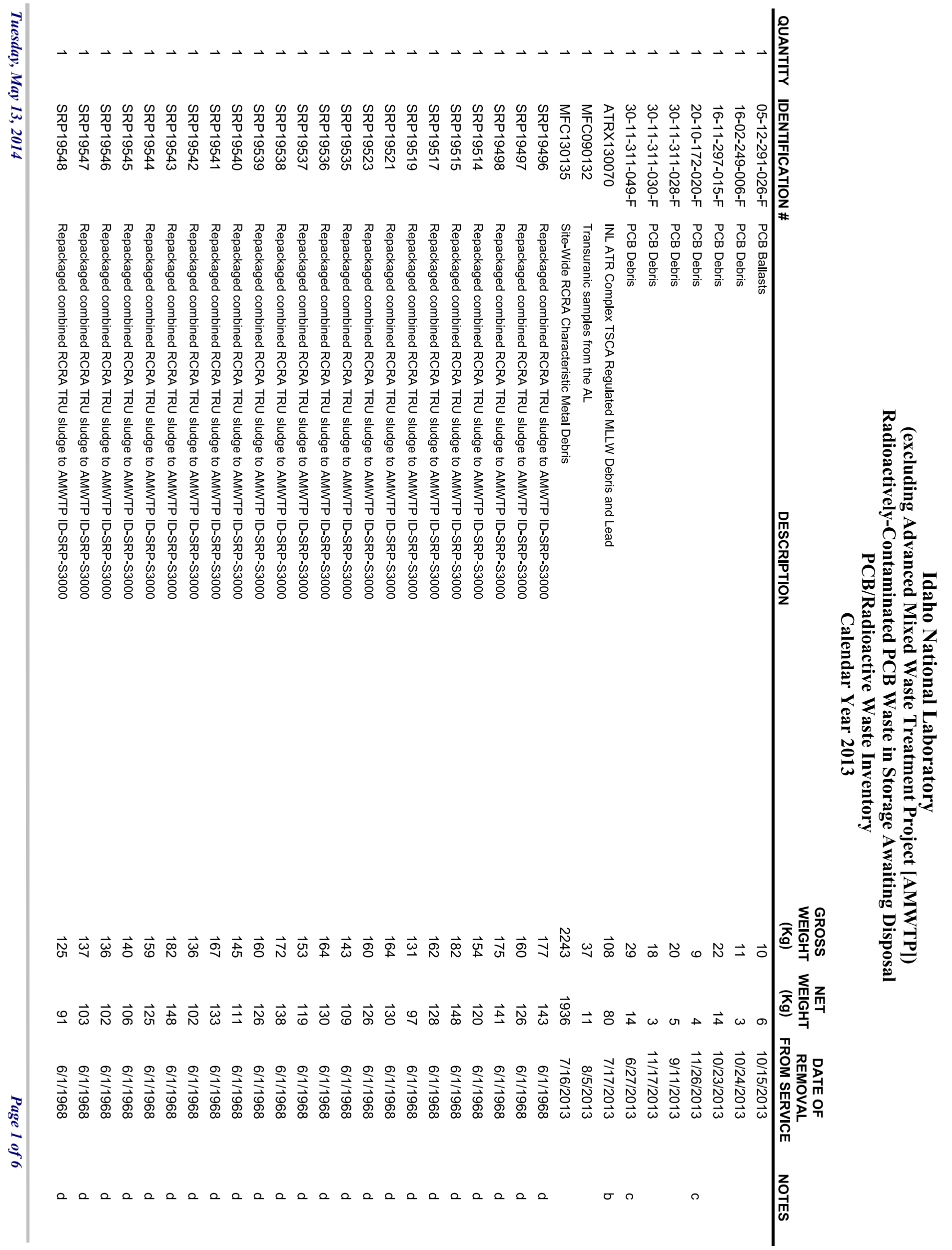




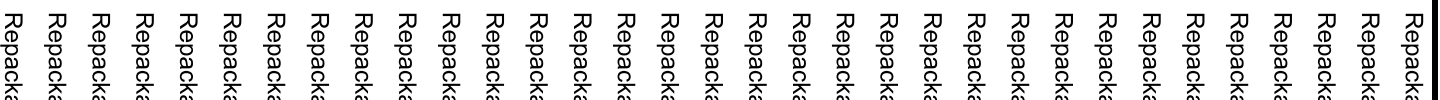
क क

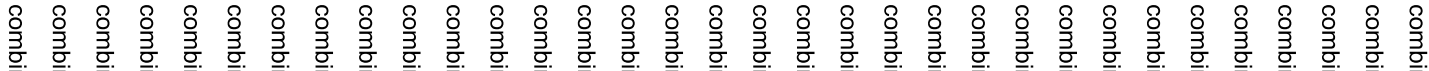

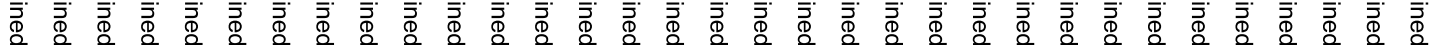
穴 穴

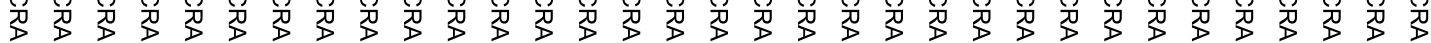

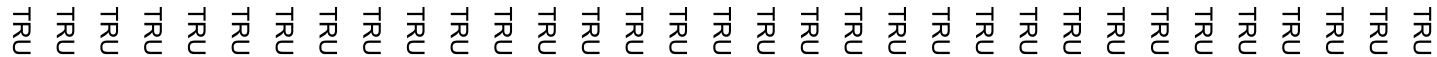

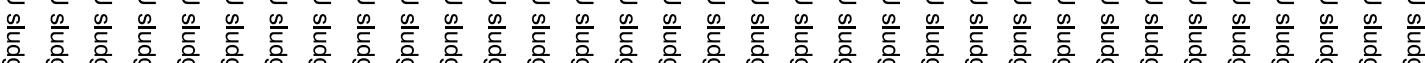
ब

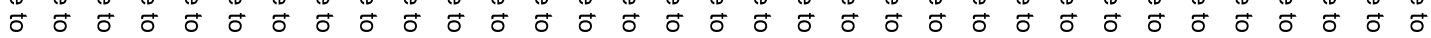

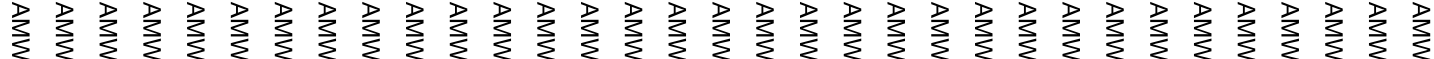

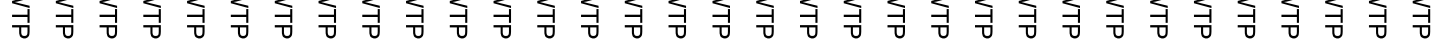

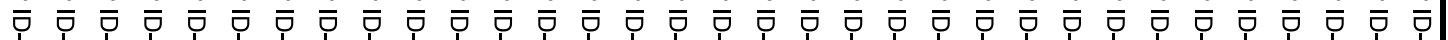

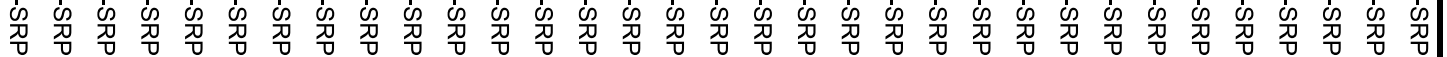

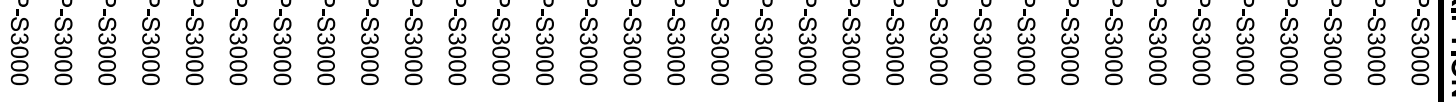

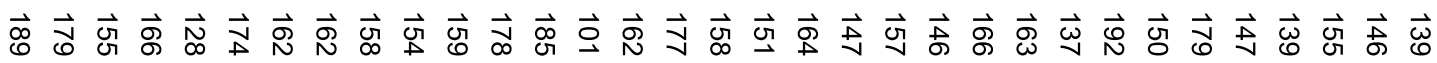

ठढ जि

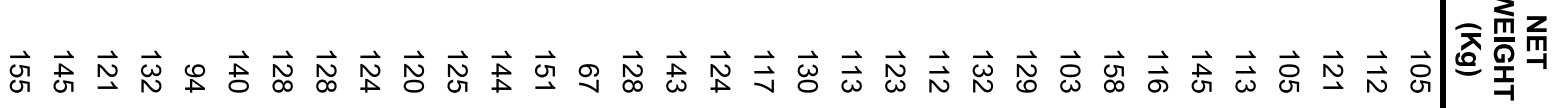




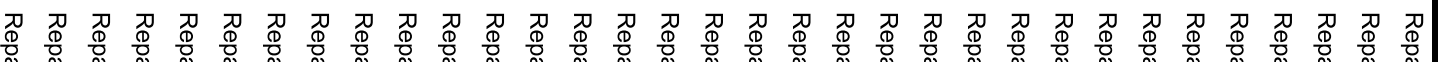

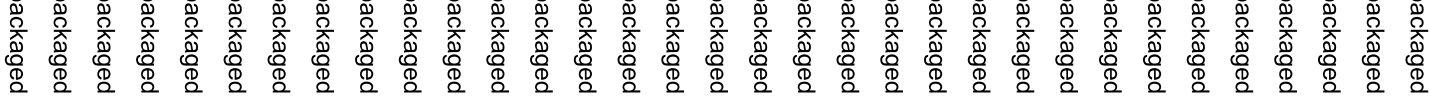

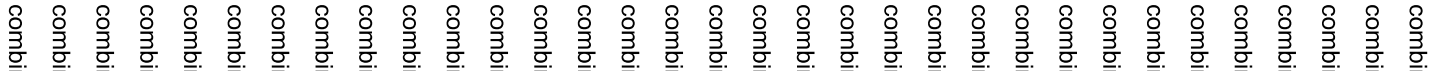

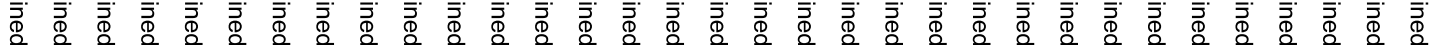
㐁 开

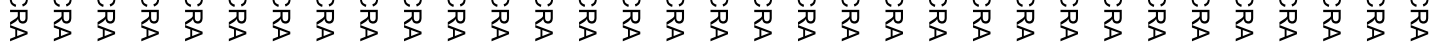

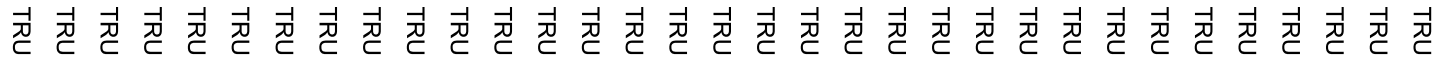

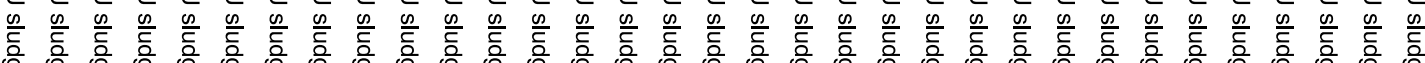
ब

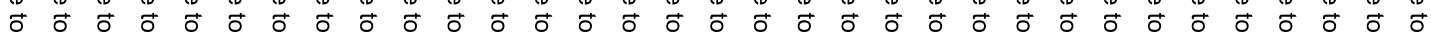

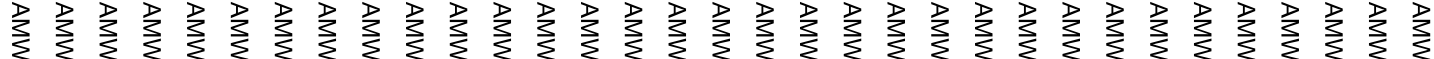

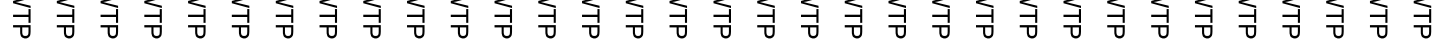

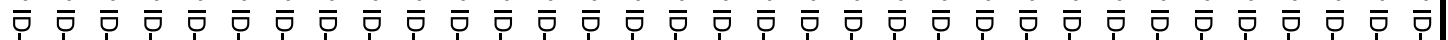

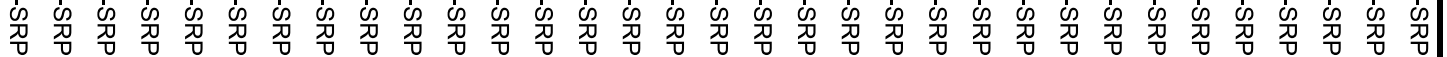

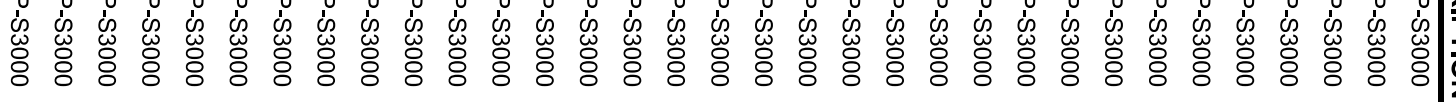

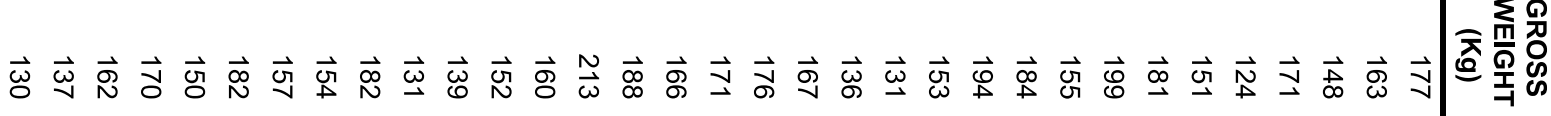




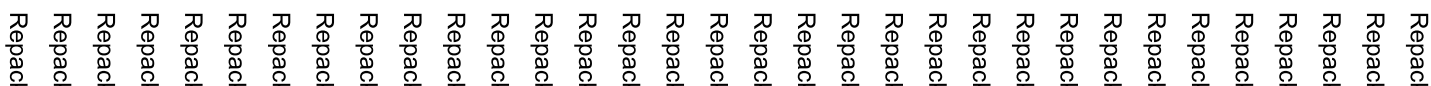

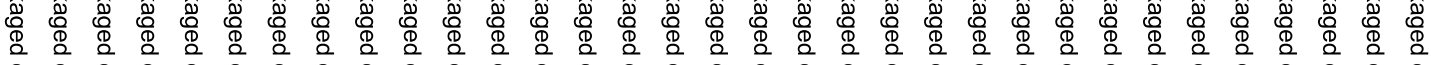

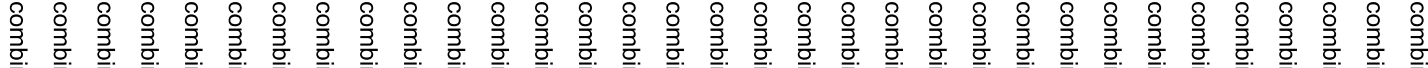

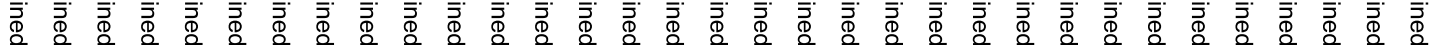

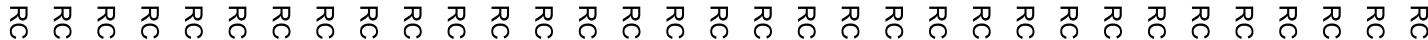

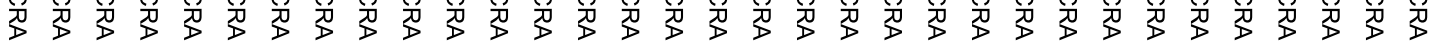

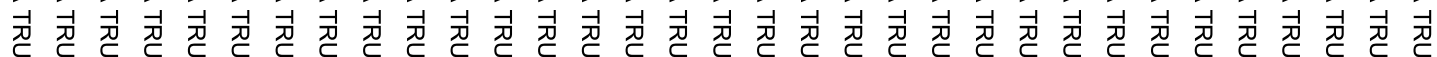

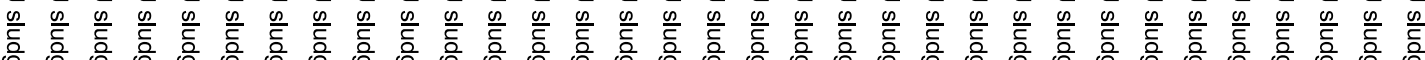

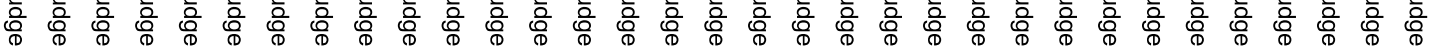

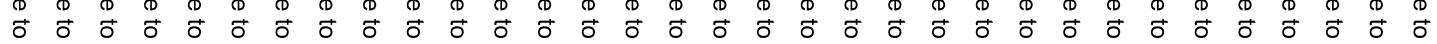

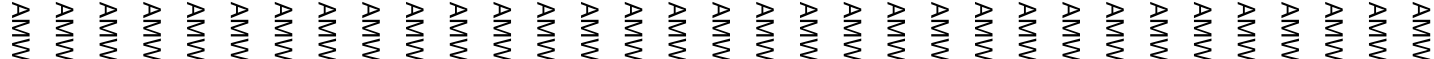

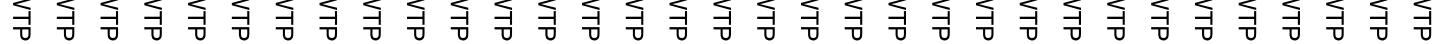

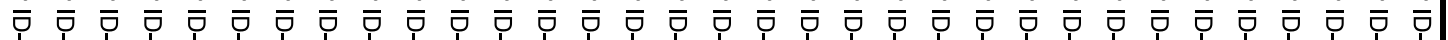

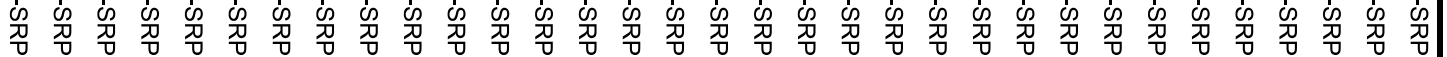

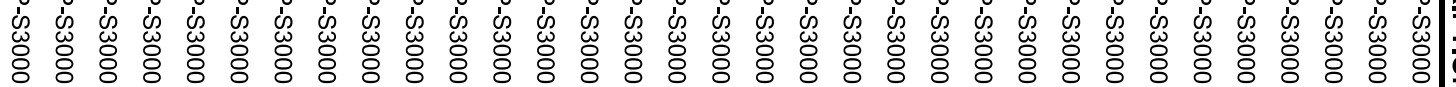




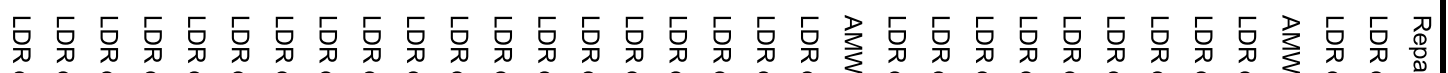

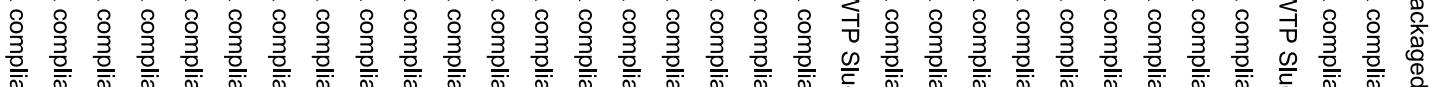

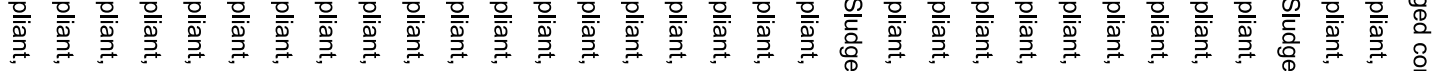

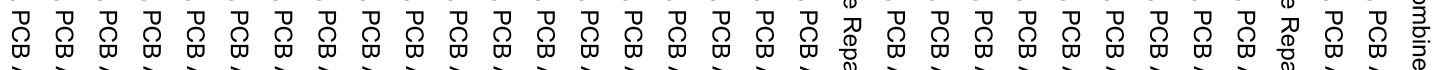

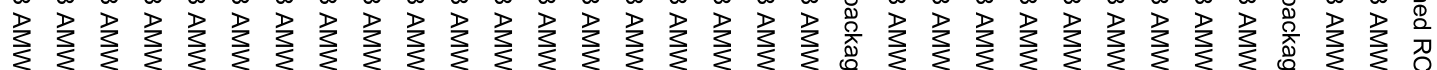

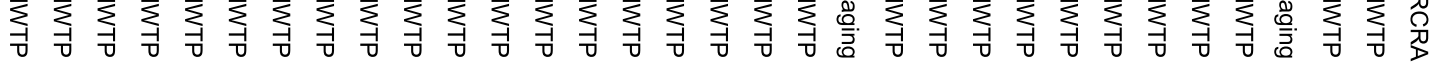

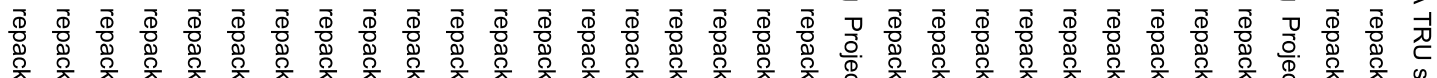

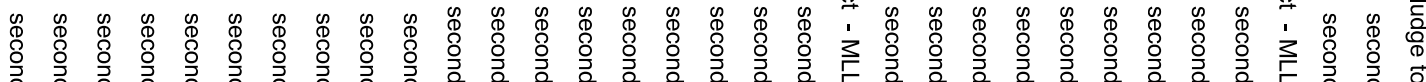

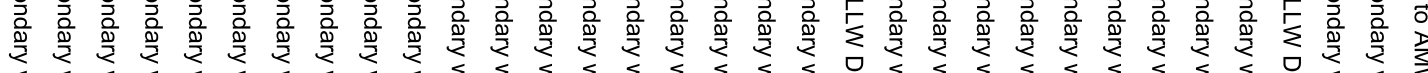

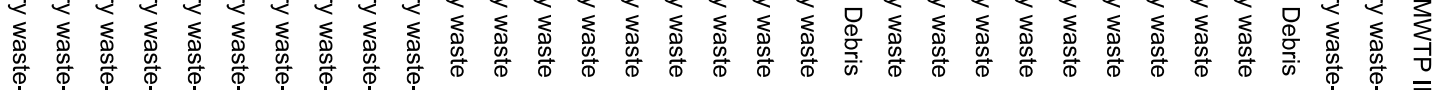

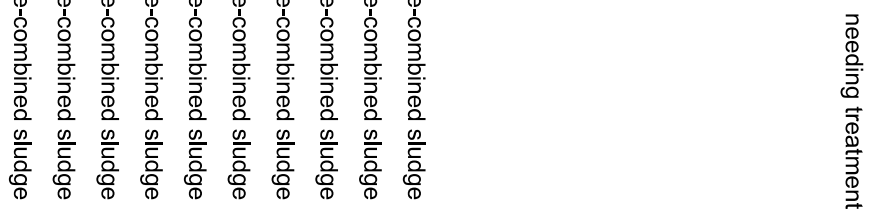

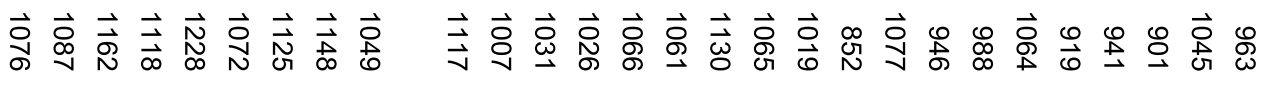

๙ै 

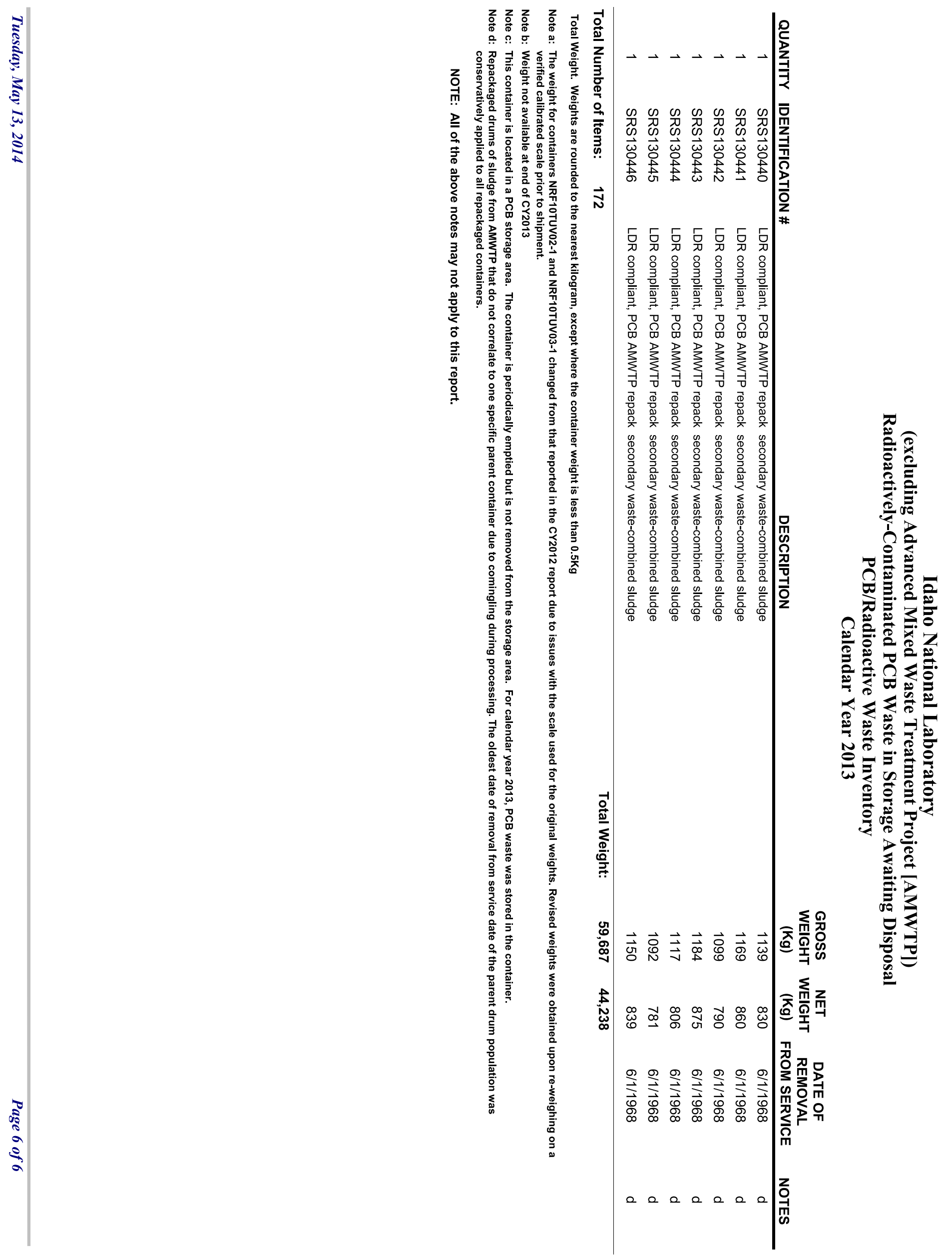
4.0 INL RADIOACTIVELY-CONTAMINATED PCB WASTE REMOVED FROM SERVICE, SHIPPED AND/OR DISPOSED DURING CALENDAR YEAR 2013

(excluding AMWTP) 


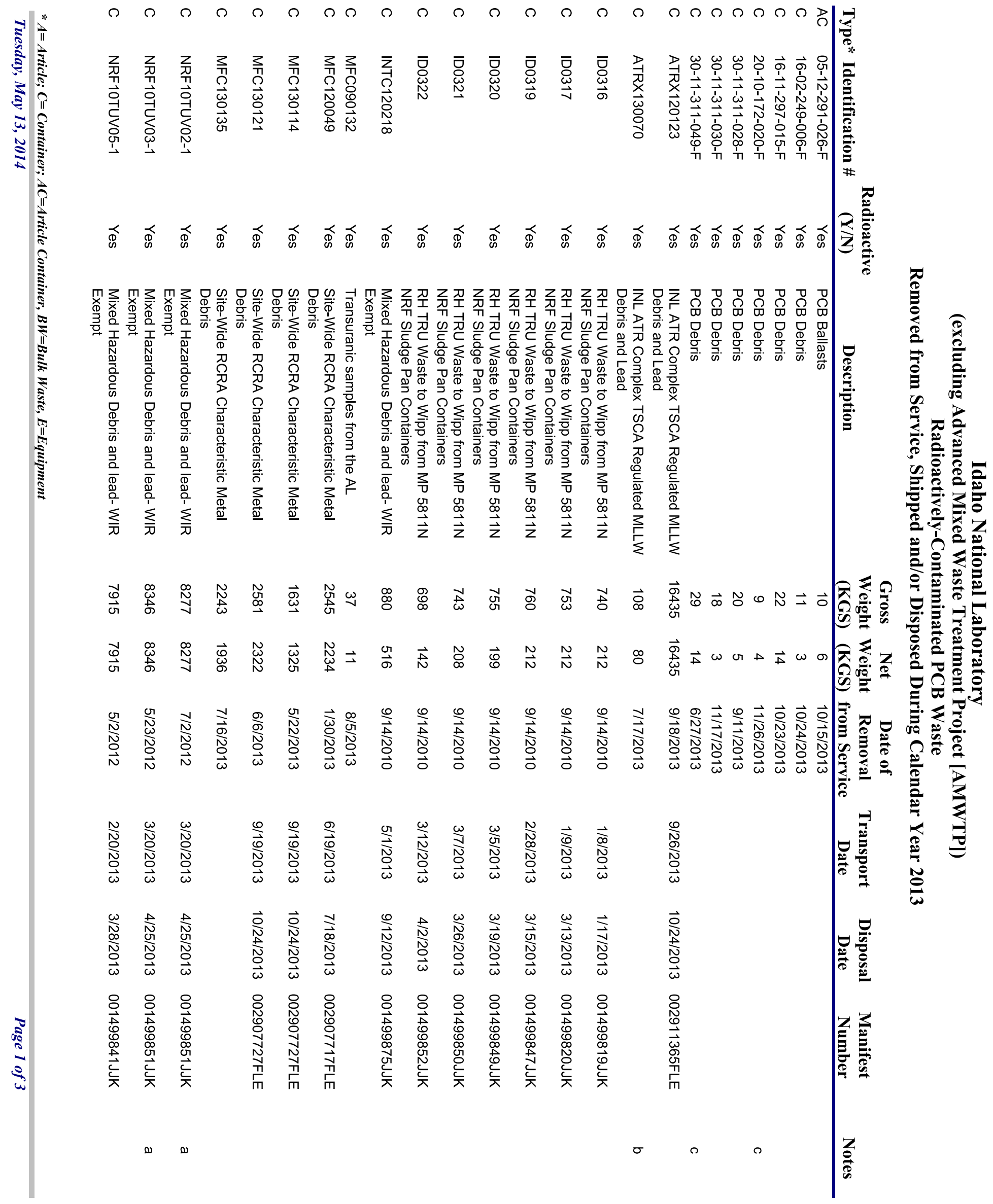




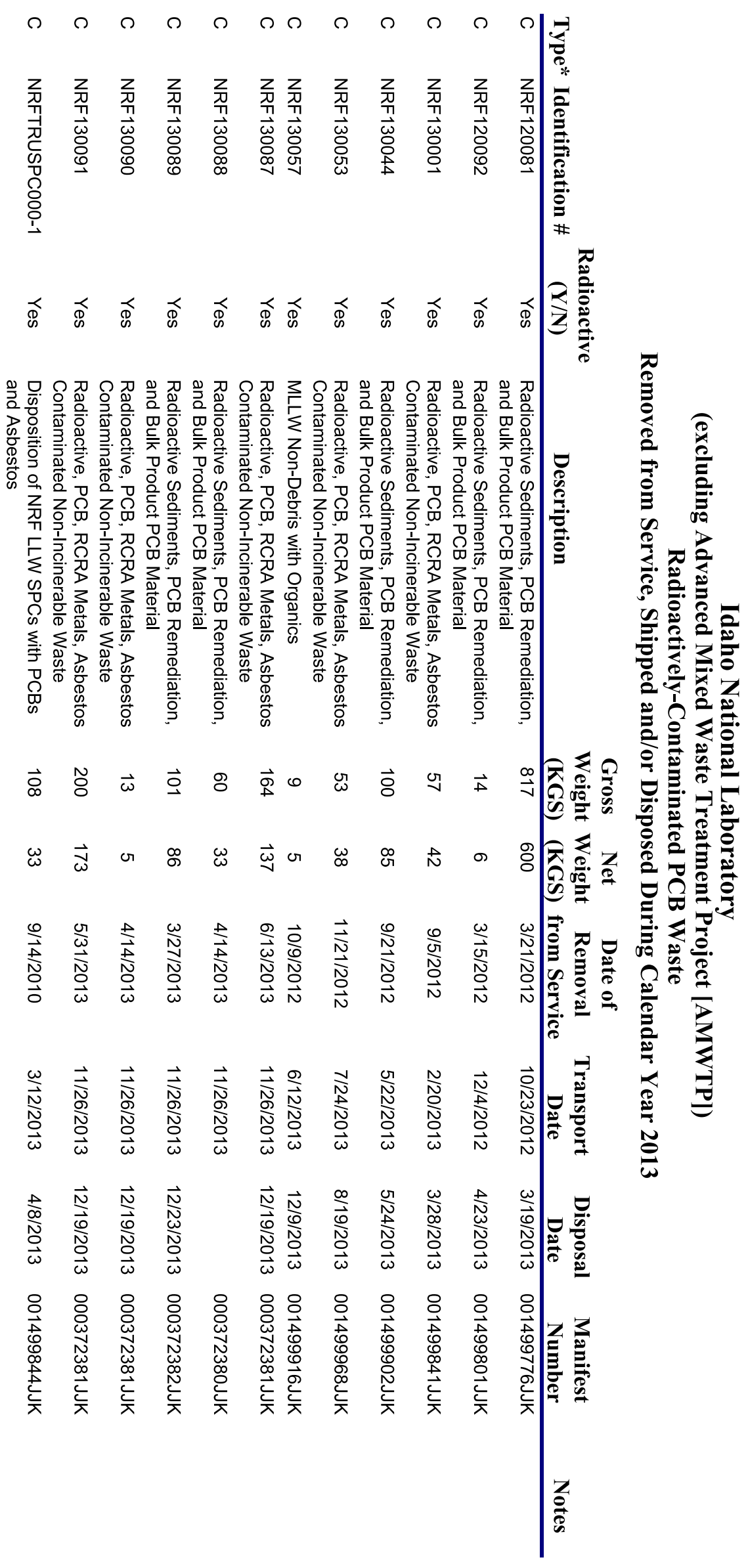




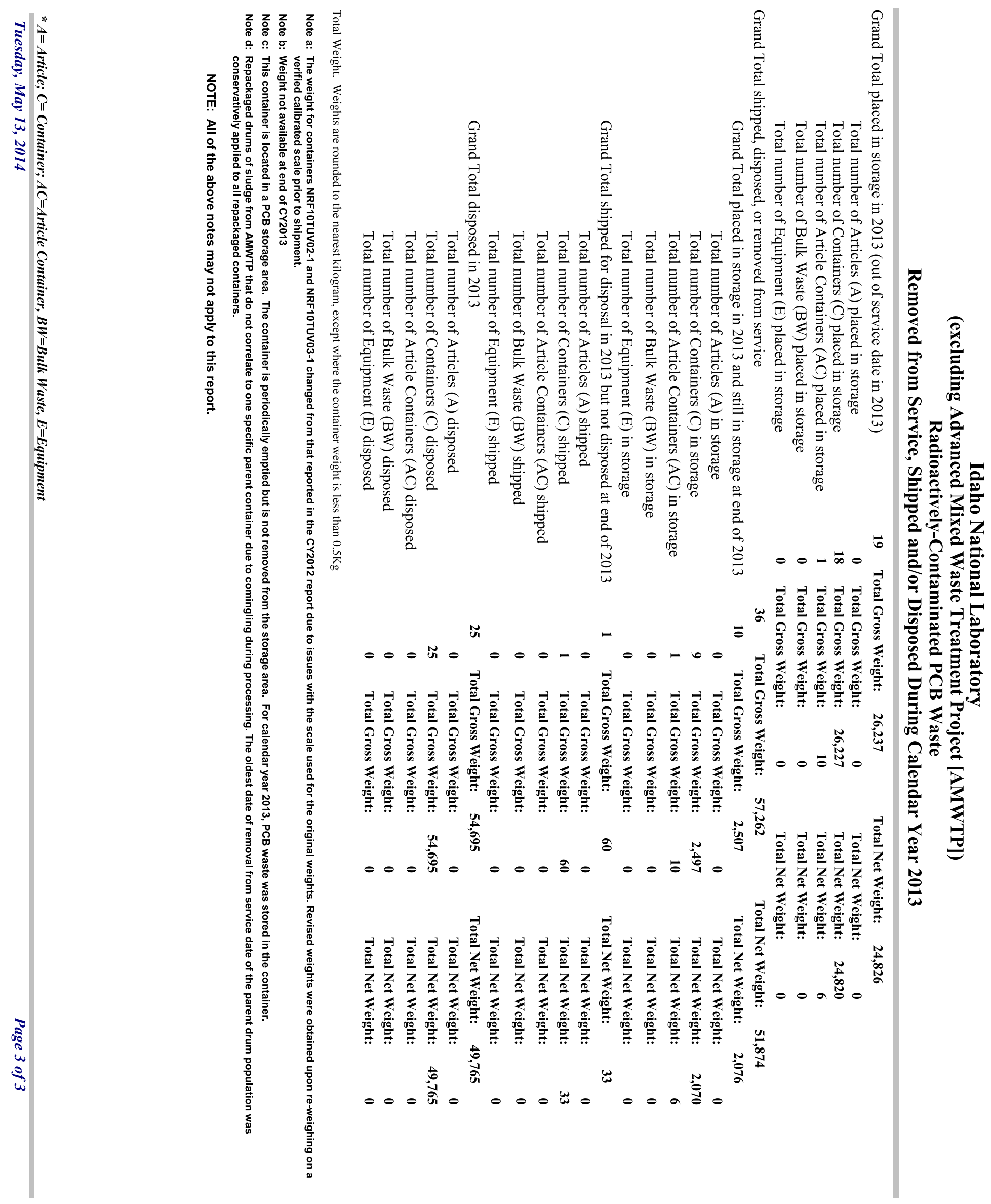


5.0 AMWTP RADIOACTIVELY-CONTAMINATED PCB WASTE IN STORAGE AWAITING DISPOSAL 


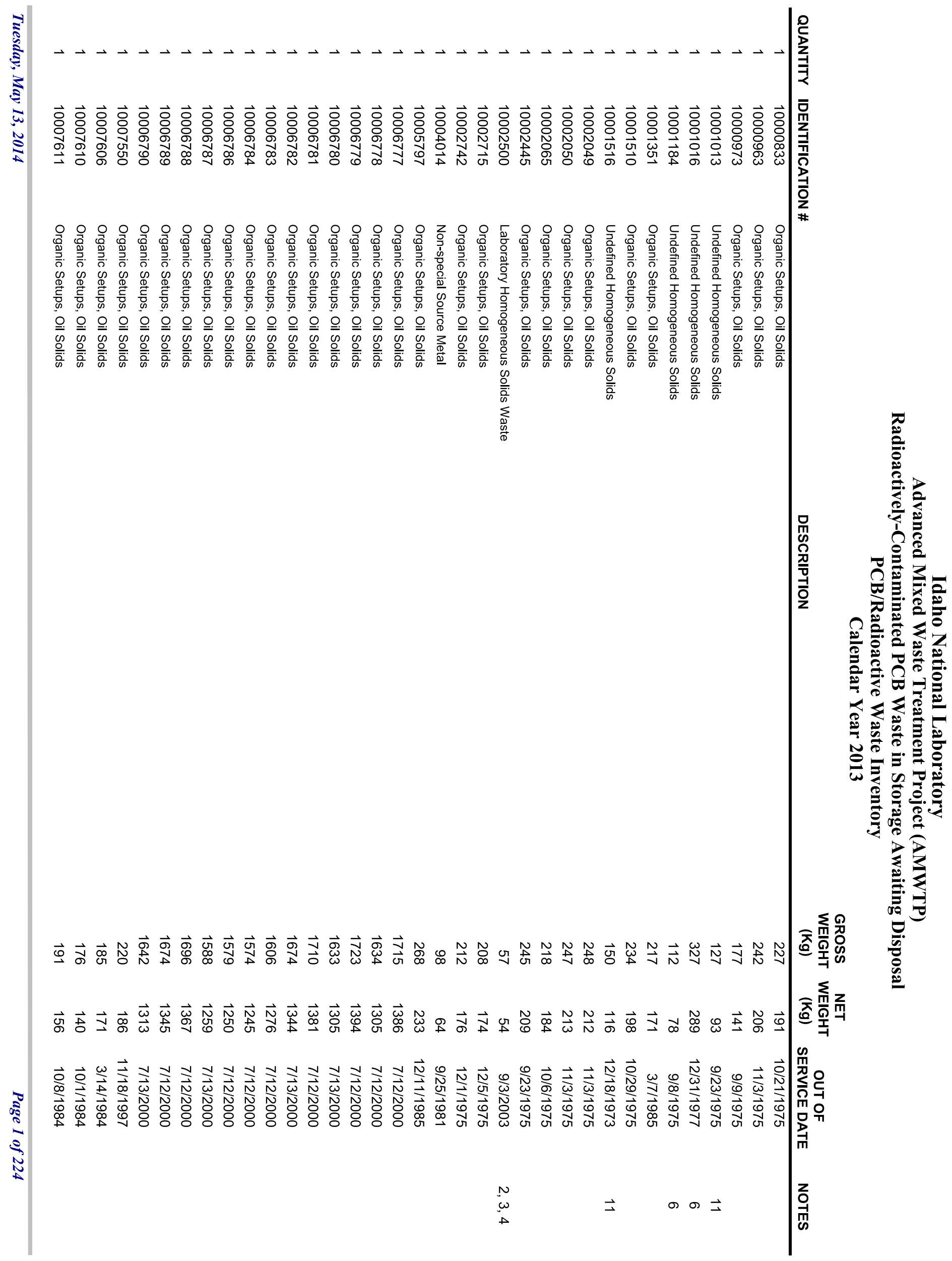




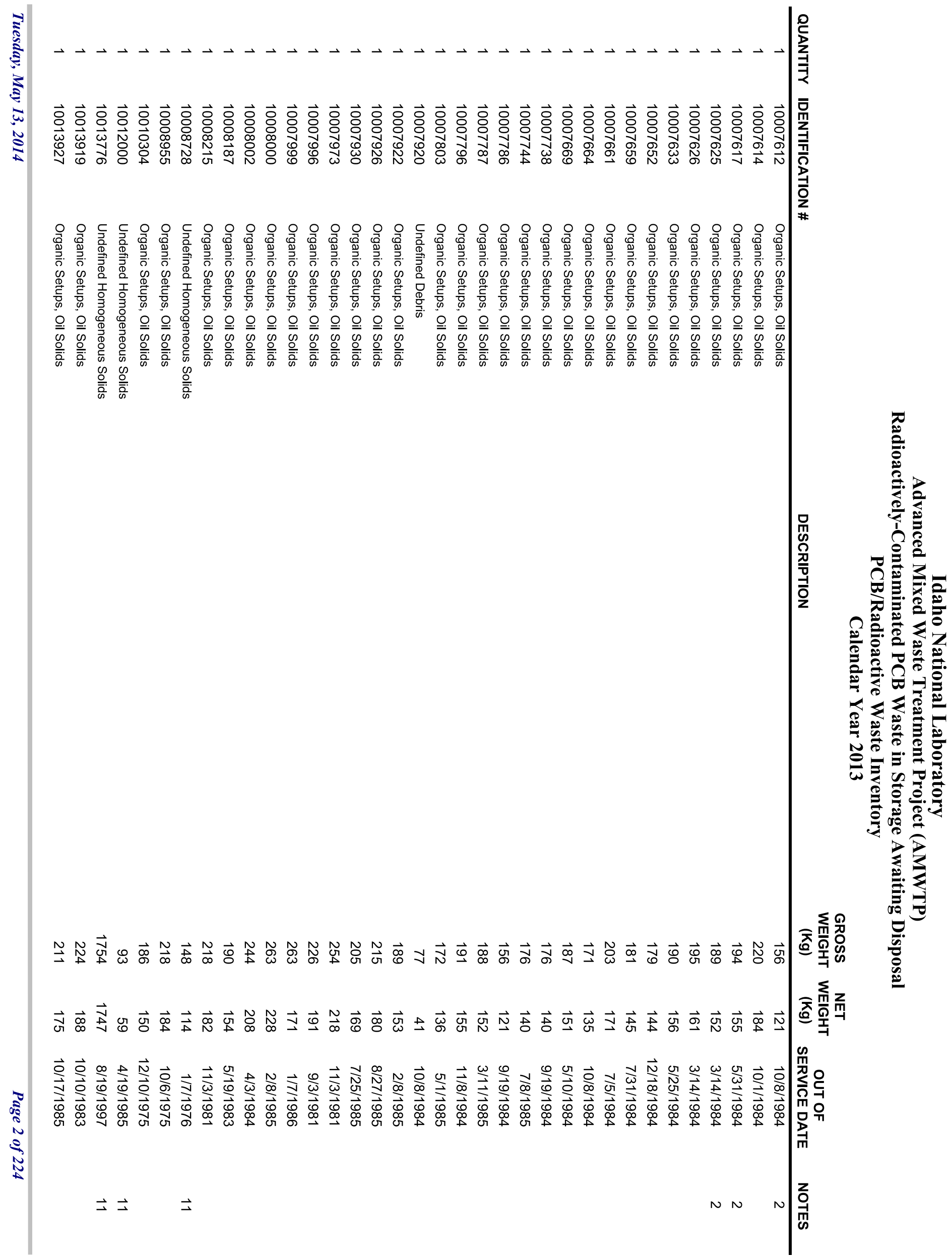




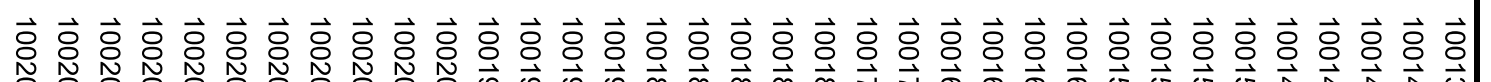

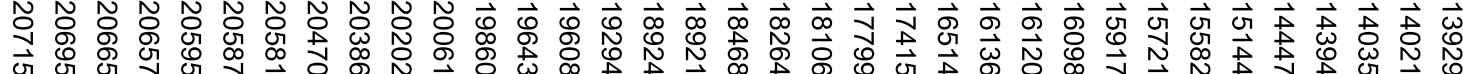

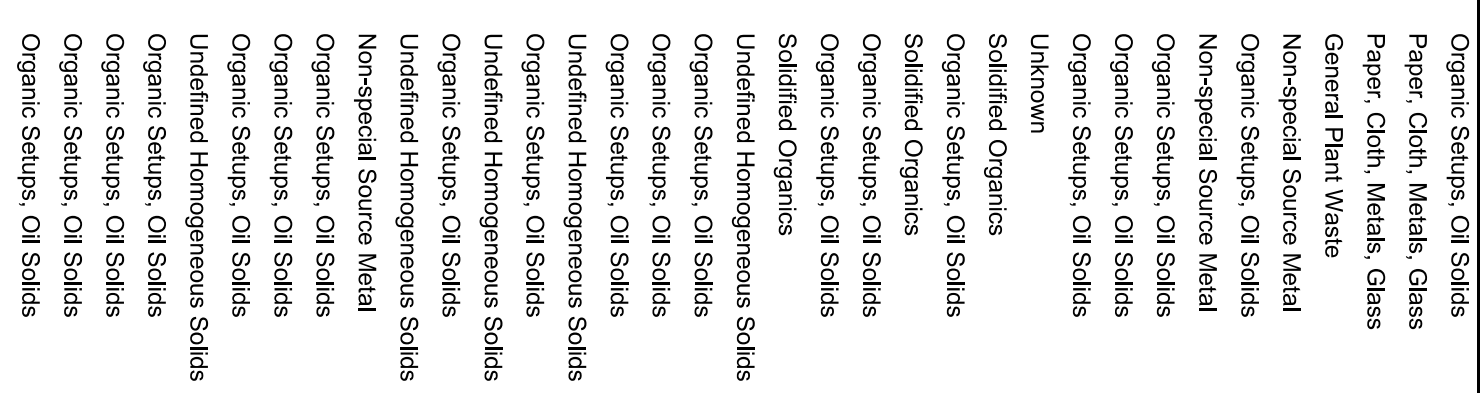

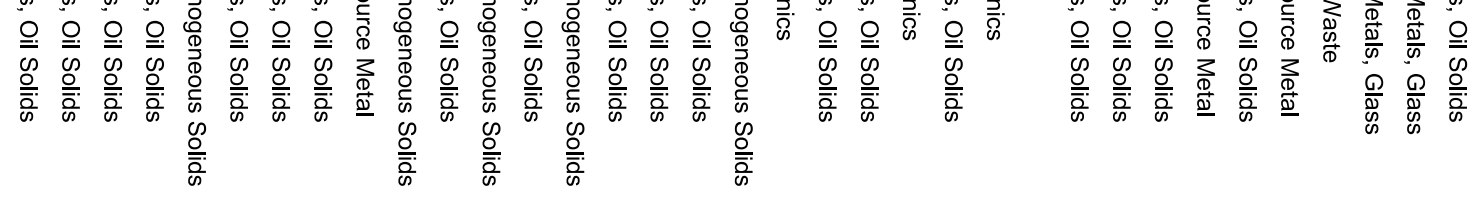

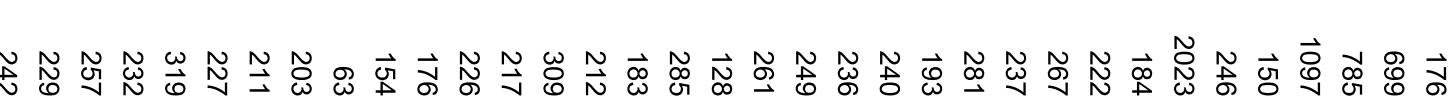

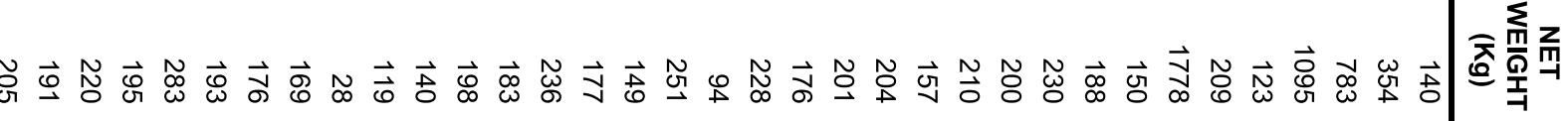

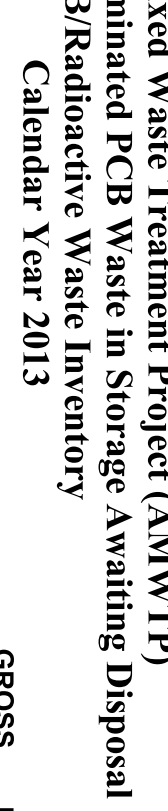

${\underset{n}{n}}_{\substack{2 \\ \infty}}^{2}$

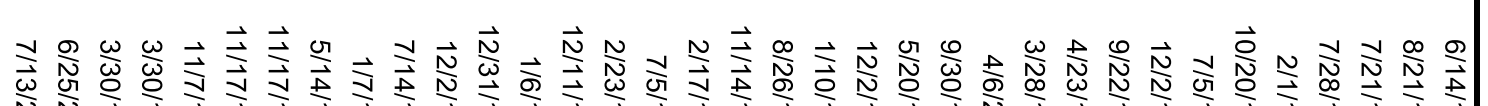

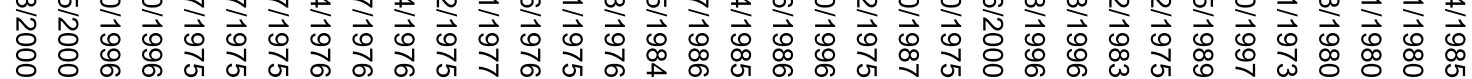

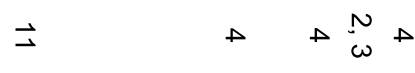




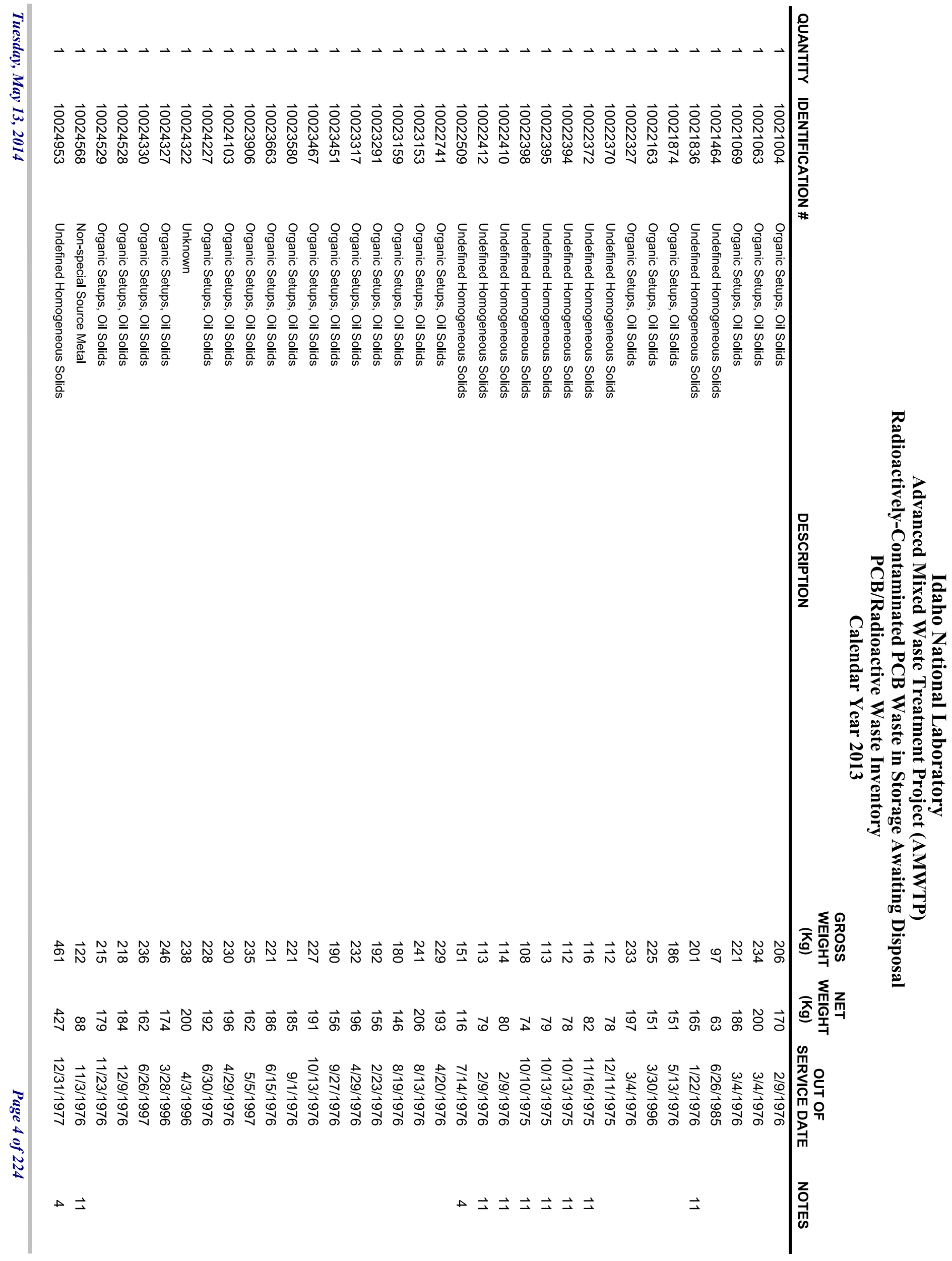




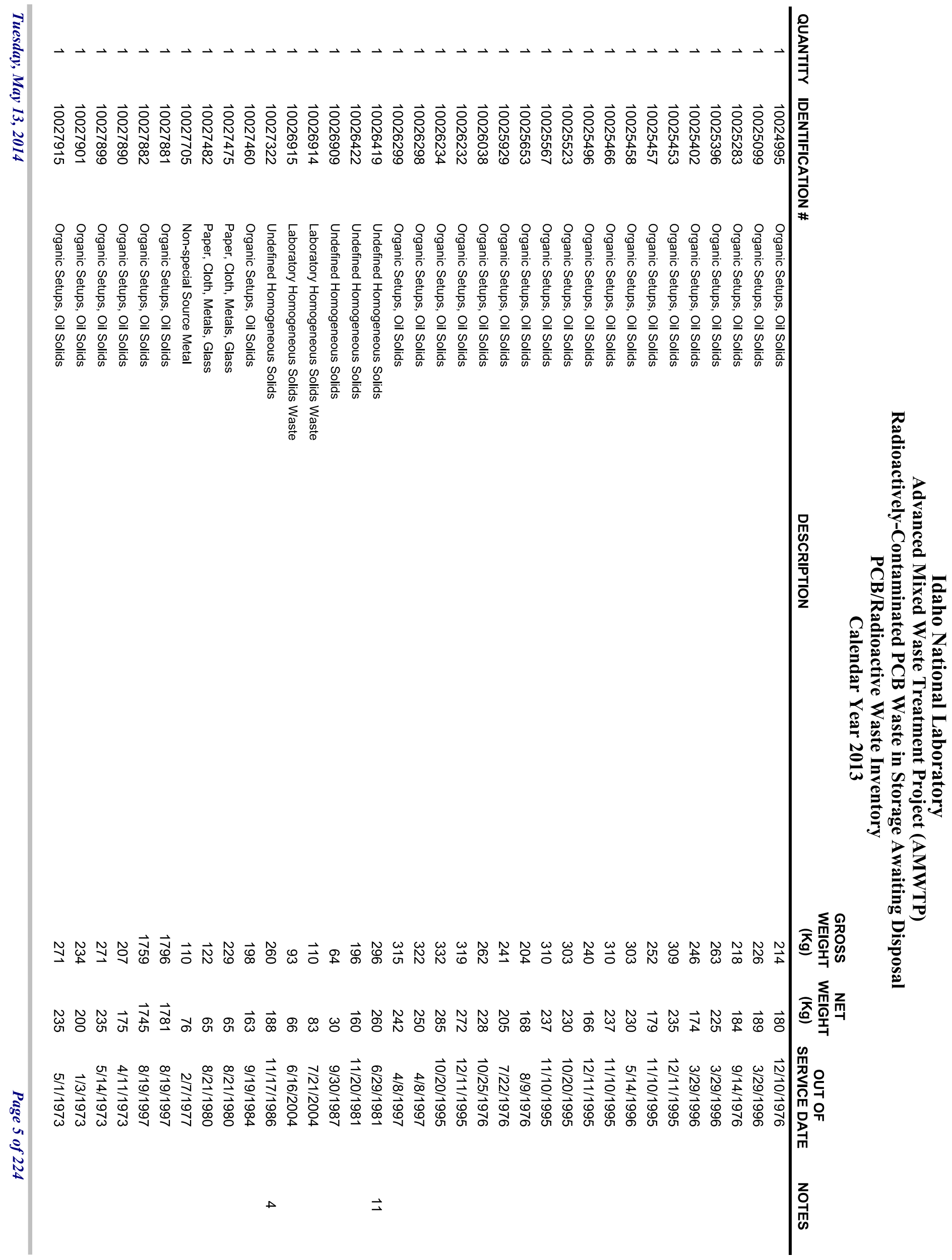




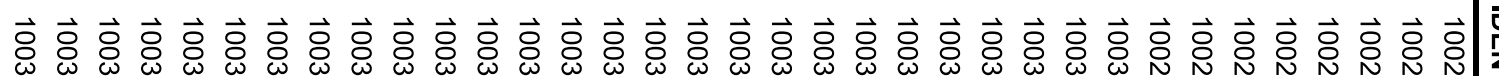

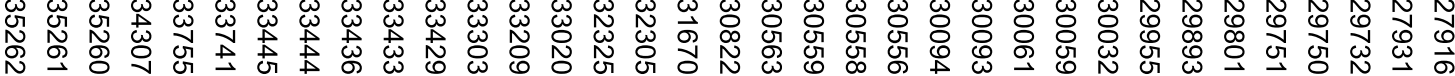

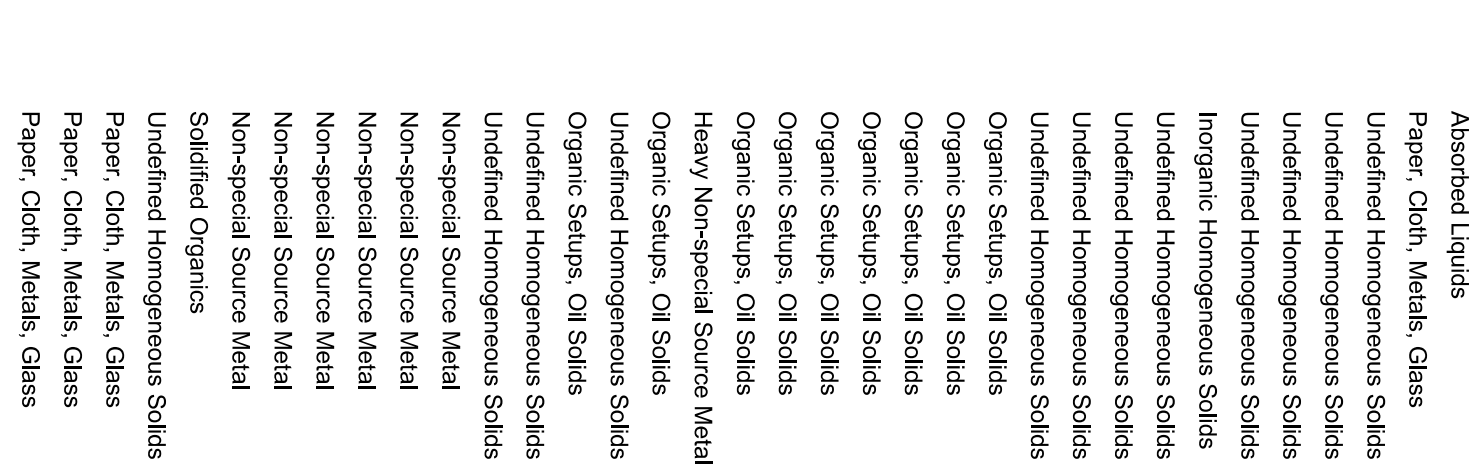

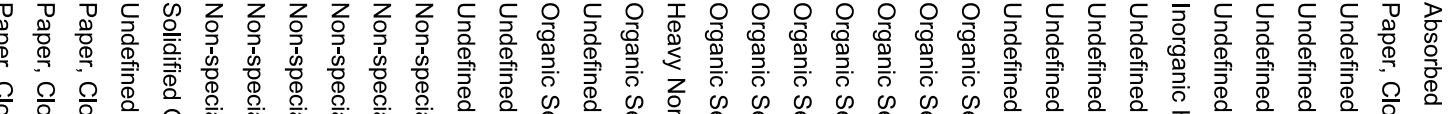

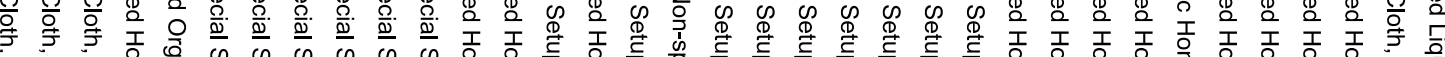

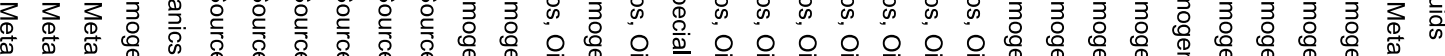

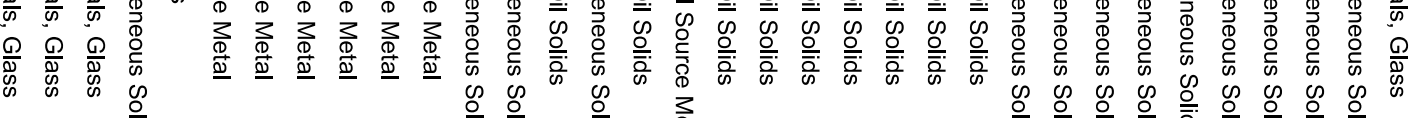

$\vec{\delta} \vec{\circ}$ \&

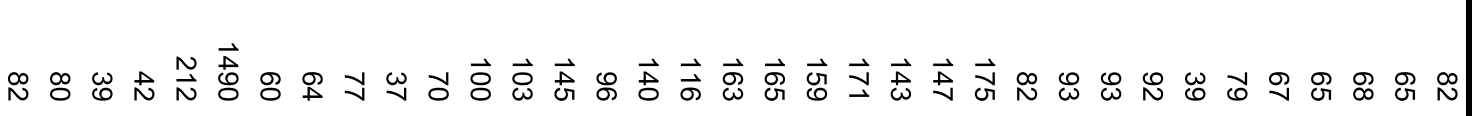




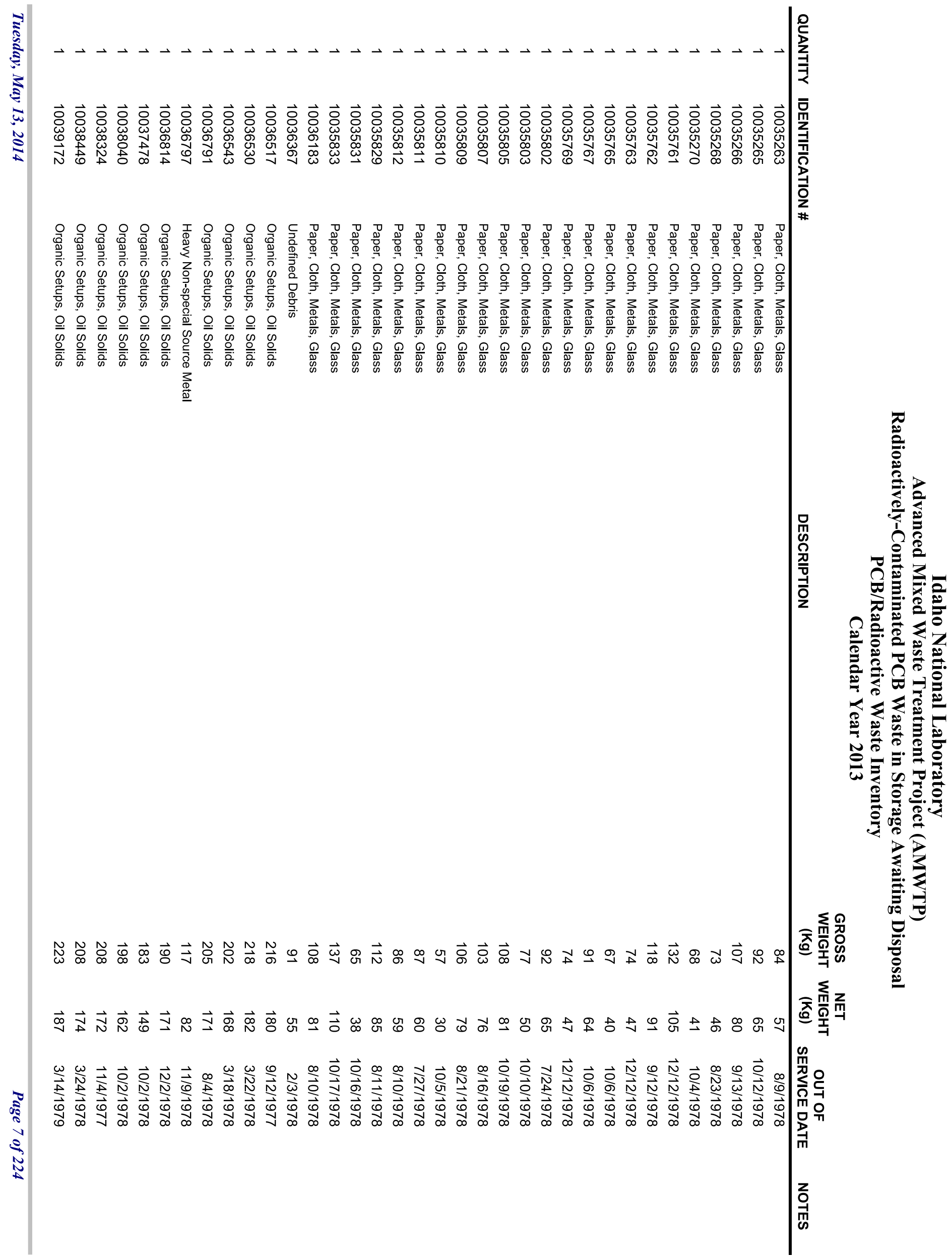




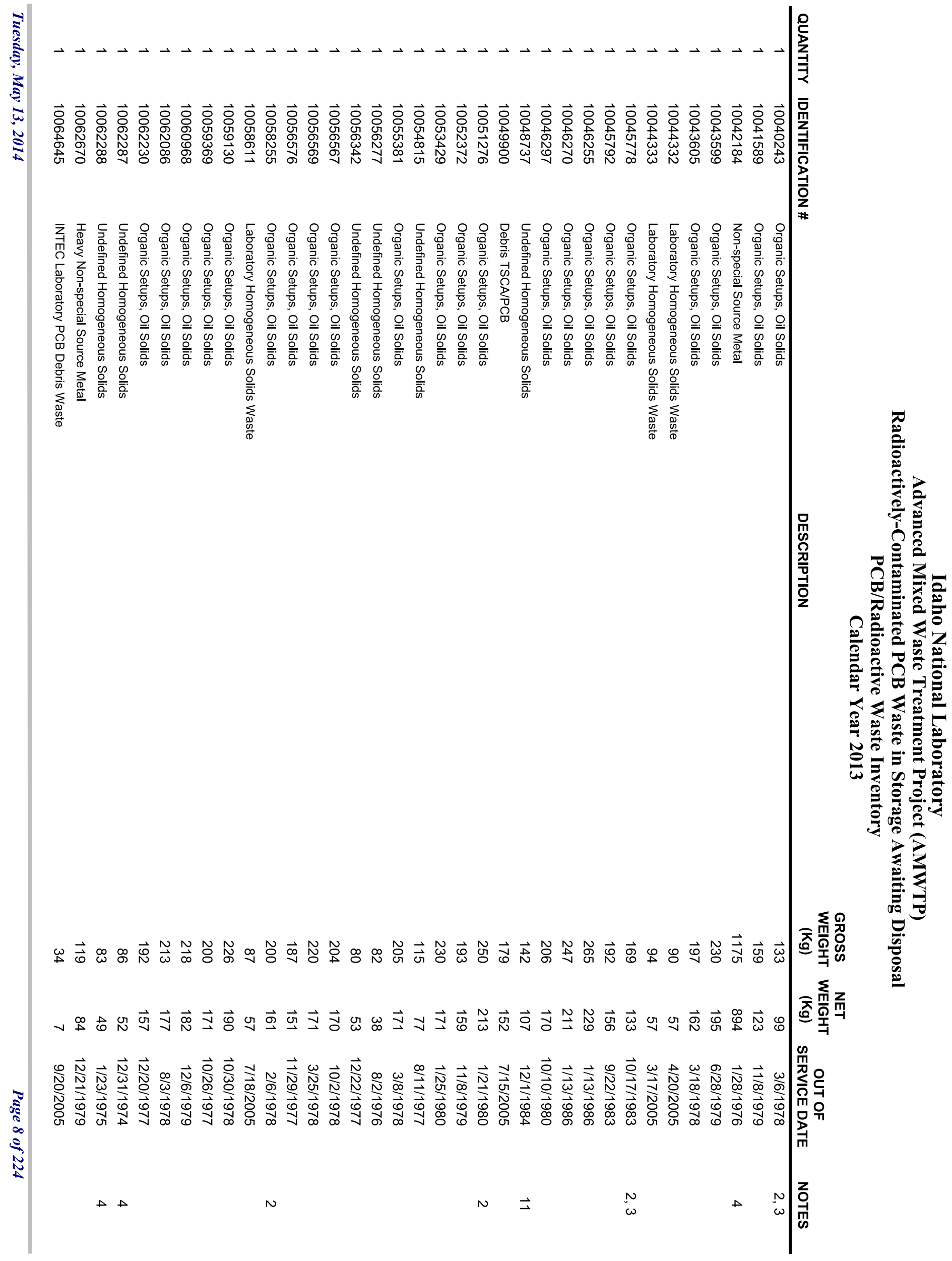




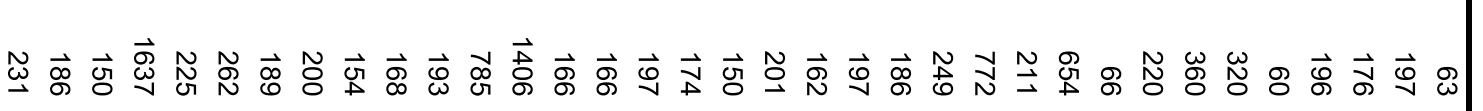




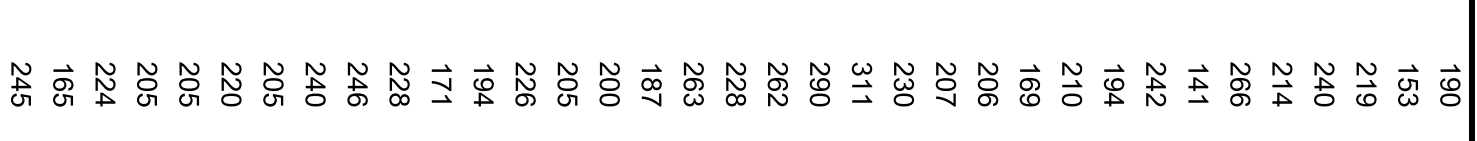

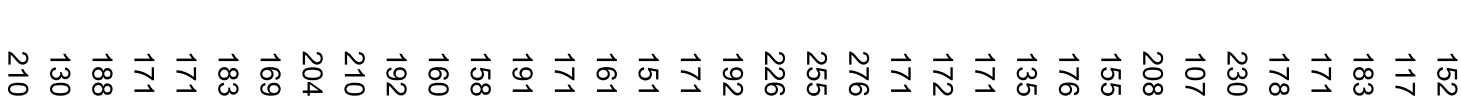
界学

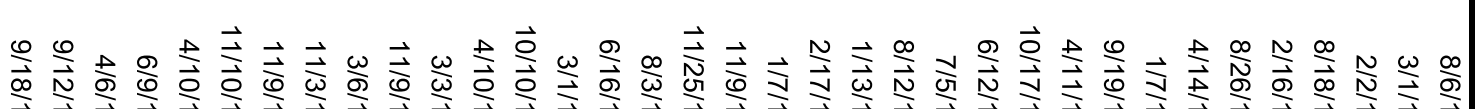

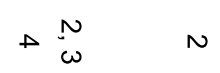

$$
\stackrel{\sim}{\omega}
$$




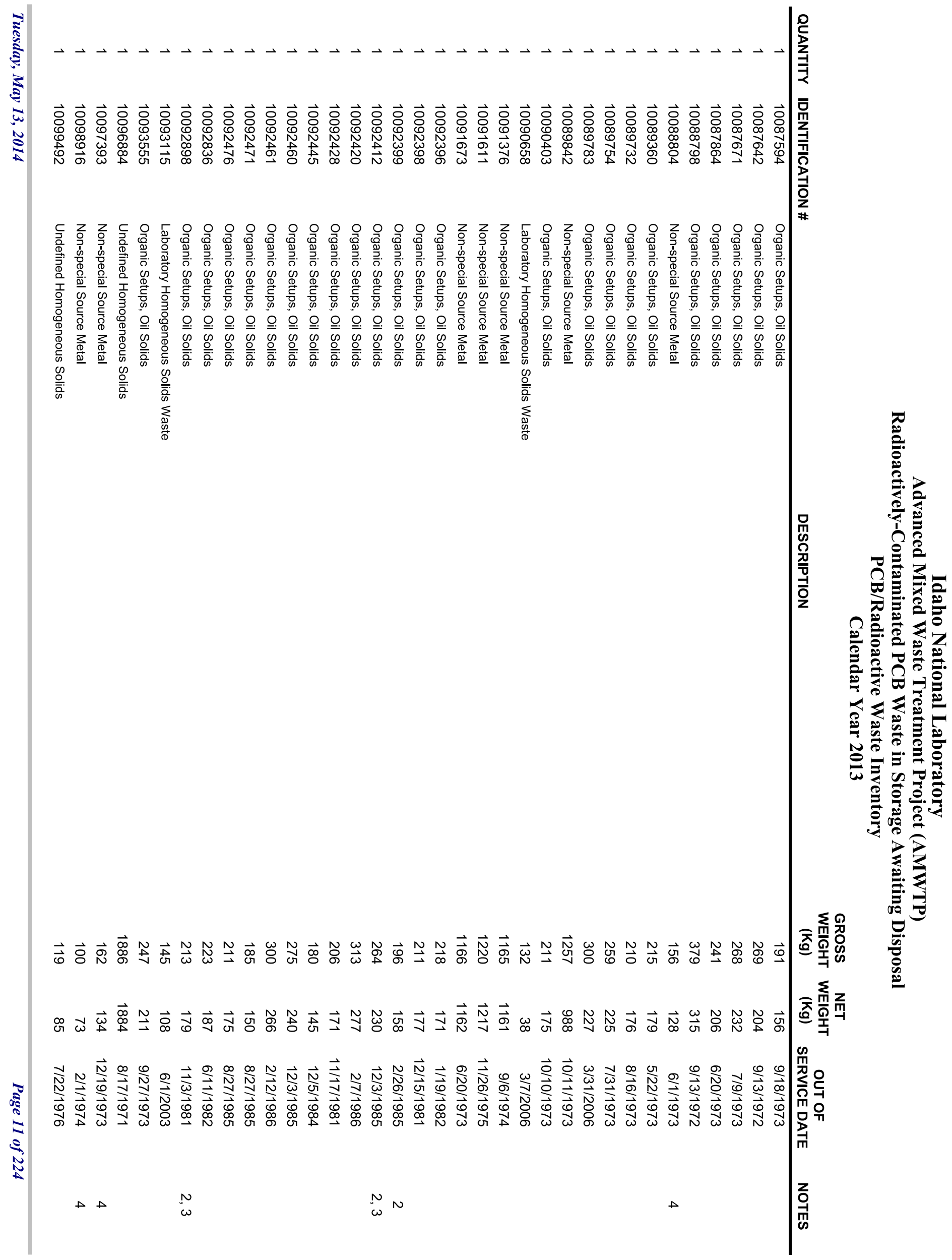


$\overrightarrow{0} \overrightarrow{0} \overrightarrow{0} \overrightarrow{0} \overrightarrow{0} \overrightarrow{0} \overrightarrow{0} \overrightarrow{0} \overrightarrow{0} \overrightarrow{0} \overrightarrow{0} \overrightarrow{0} \overrightarrow{0} \overrightarrow{0} \overrightarrow{0} \overrightarrow{0} \overrightarrow{0} \overrightarrow{0} \overrightarrow{0} \overrightarrow{0} \overrightarrow{0} \overrightarrow{0} \overrightarrow{0} \overrightarrow{0} \overrightarrow{0} \overrightarrow{0}$ $\vec{N} \vec{N} \vec{N} \vec{N} \vec{N}$ o o

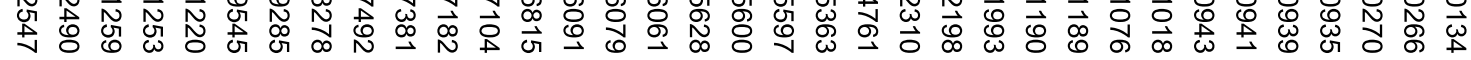

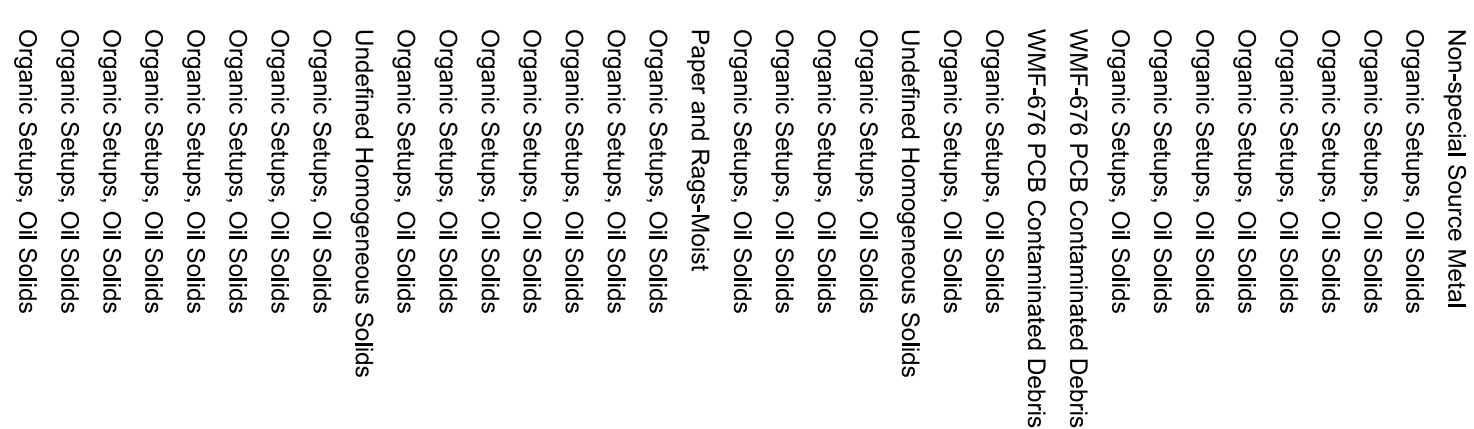

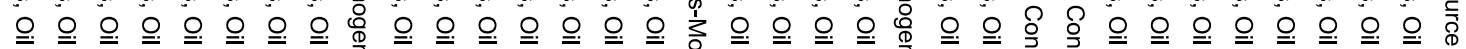

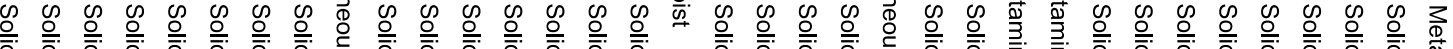

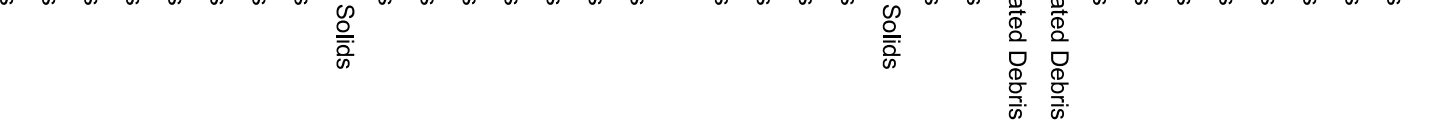

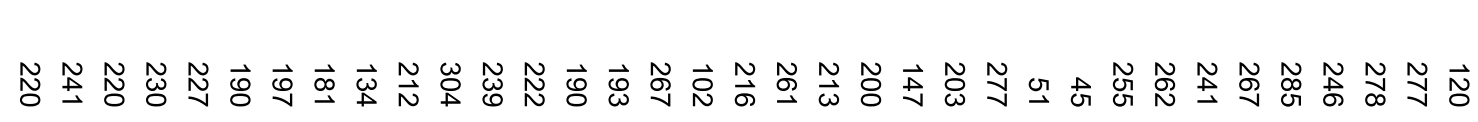

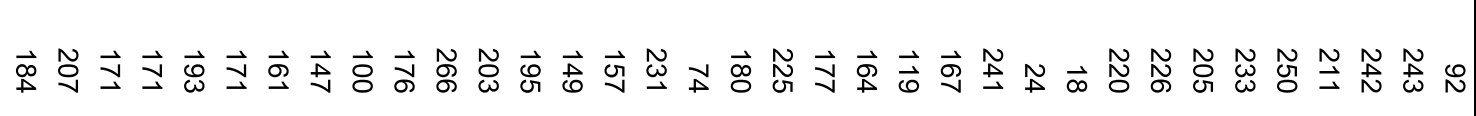

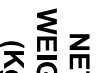

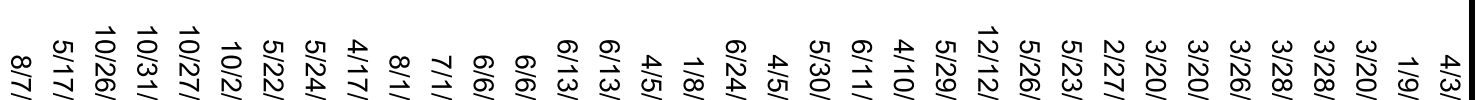

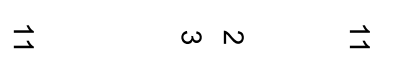

$\rightarrow$

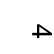

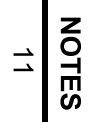




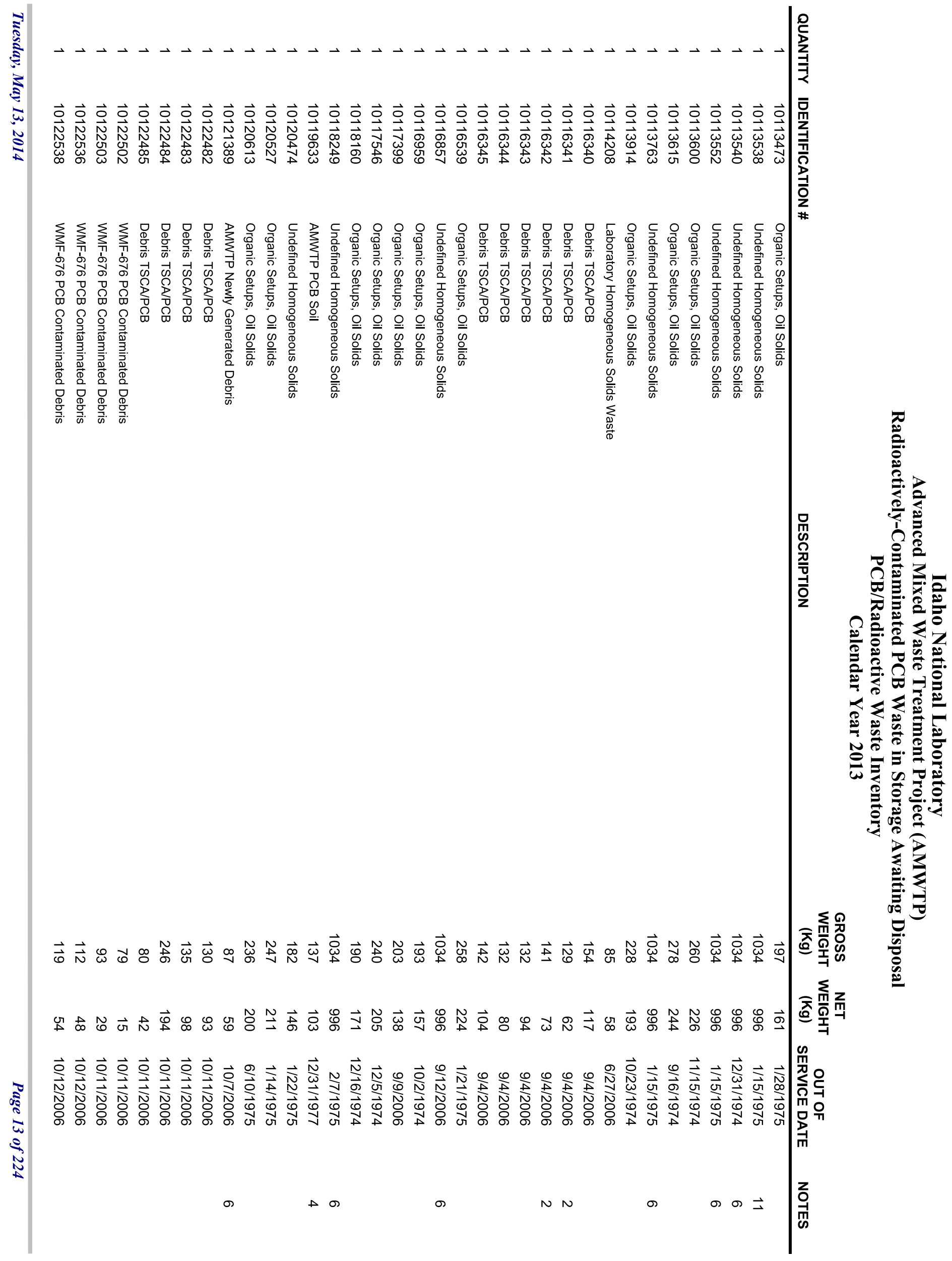




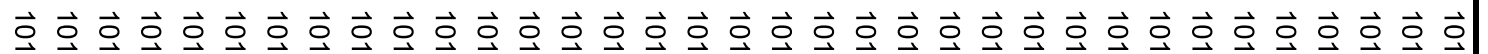

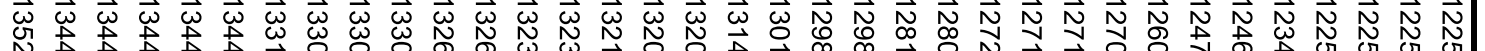

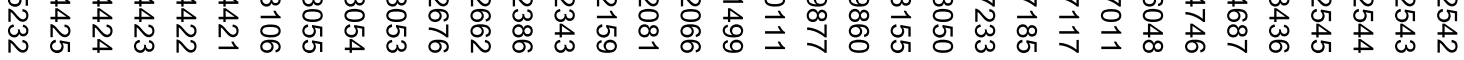

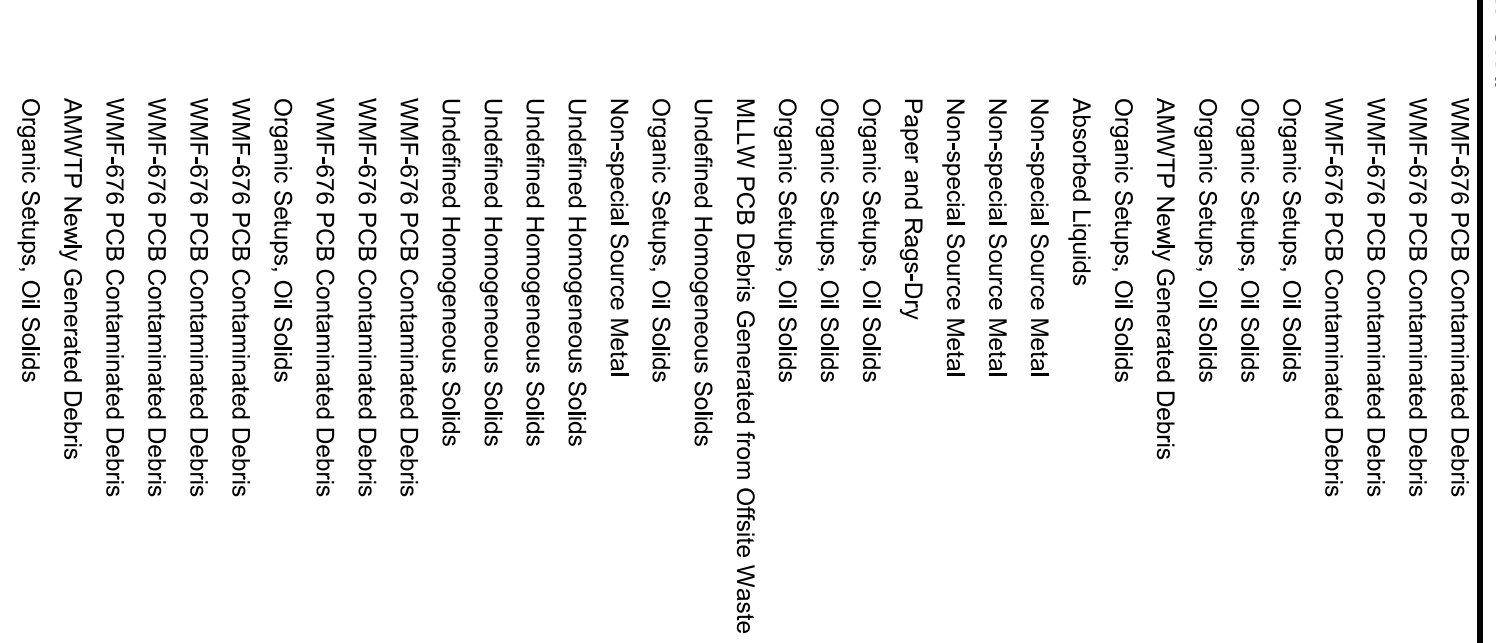

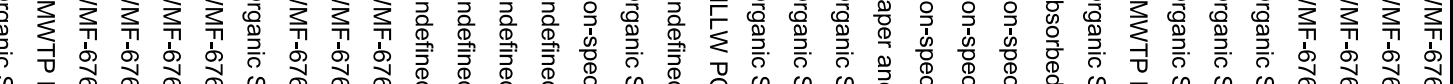

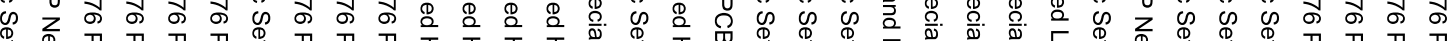

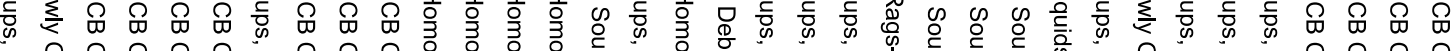
잉

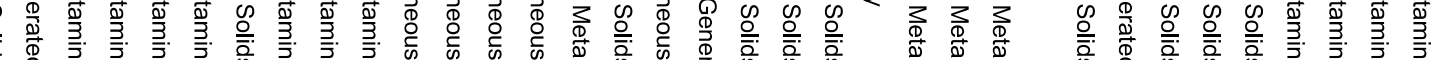

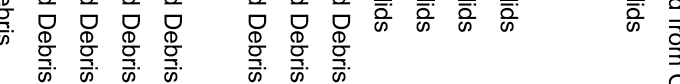

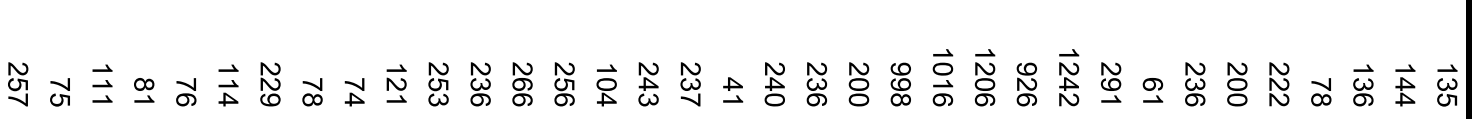

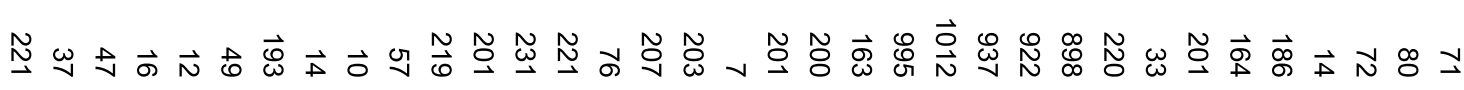
亩兴

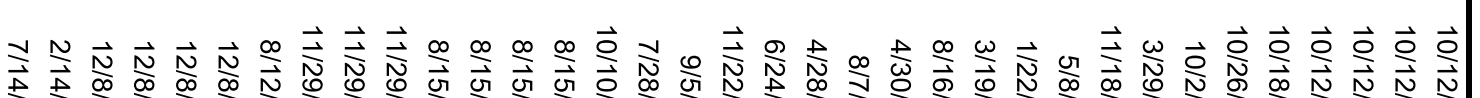
$\overrightarrow{0}$
v
0

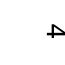

N

$n \rightarrow$

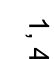

N 
$\overrightarrow{0} \overrightarrow{0} \overrightarrow{0} \overrightarrow{0} \overrightarrow{0} \overrightarrow{0} \overrightarrow{0} \overrightarrow{0} \overrightarrow{0} \overrightarrow{0} \overrightarrow{0} \overrightarrow{0} \overrightarrow{0} \overrightarrow{0} \overrightarrow{0} \overrightarrow{0} \overrightarrow{0} \overrightarrow{0} \overrightarrow{0} \overrightarrow{0} \overrightarrow{0} \overrightarrow{0} \overrightarrow{0} \overrightarrow{0} \overrightarrow{0}$

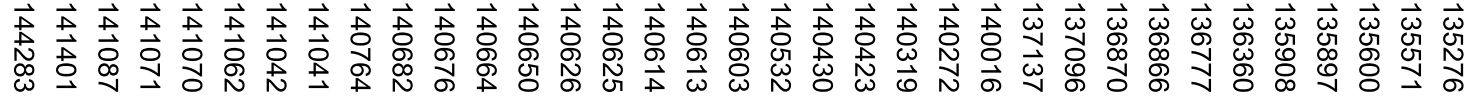

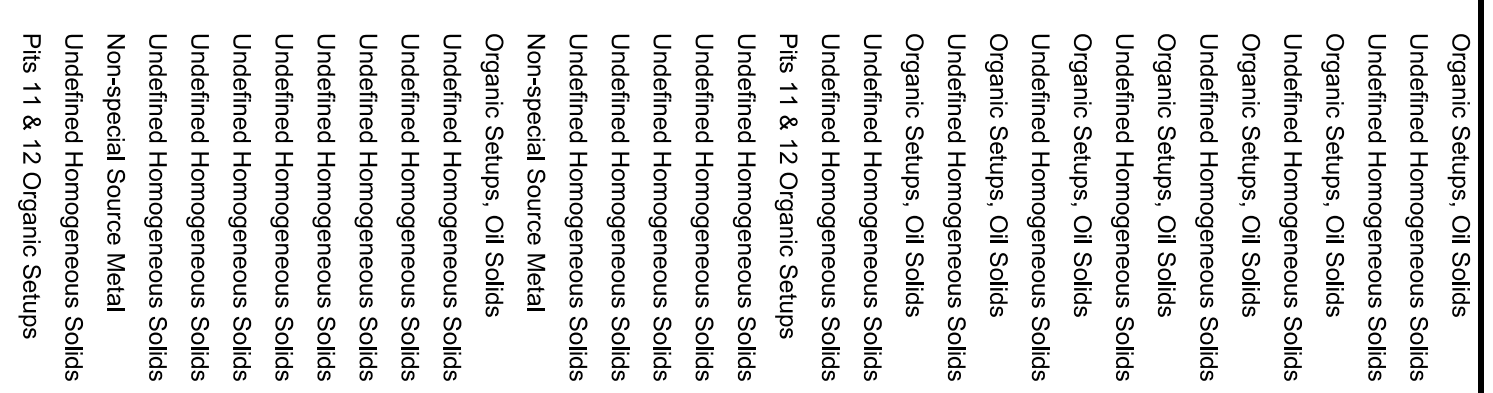




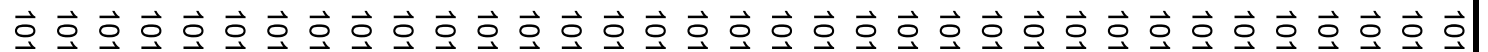

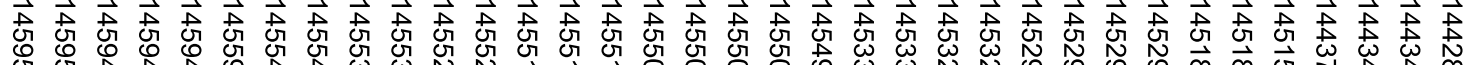
次

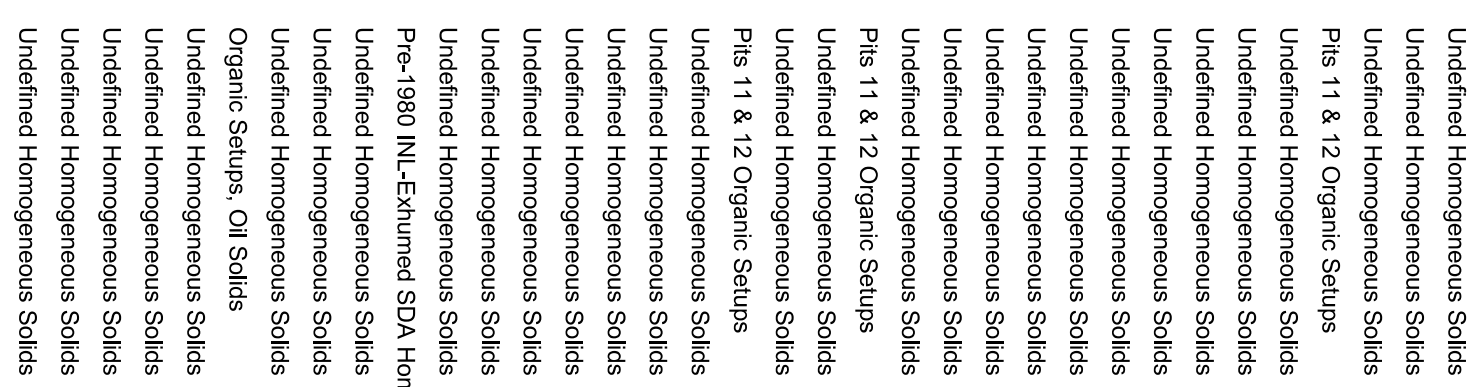

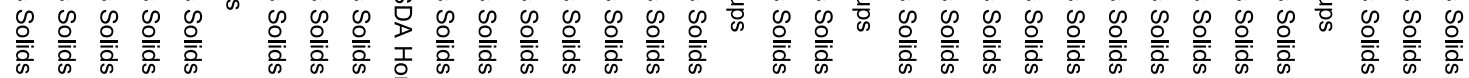

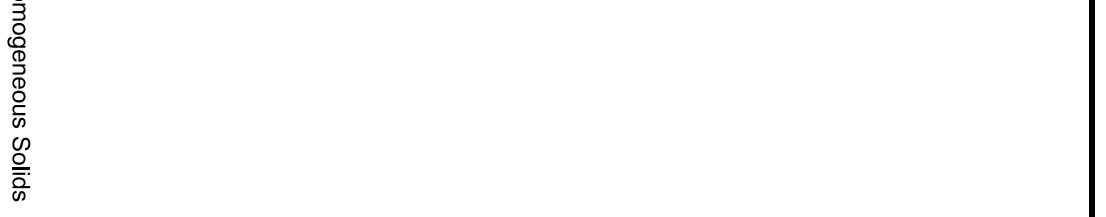




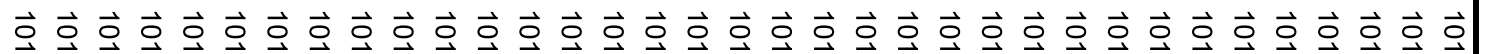

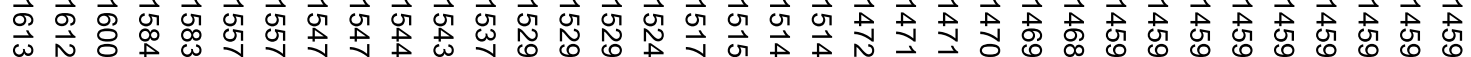

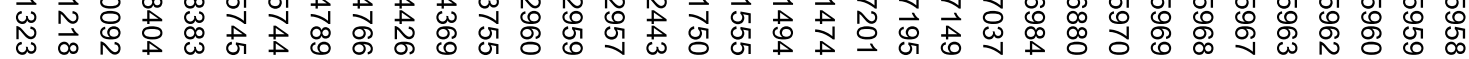

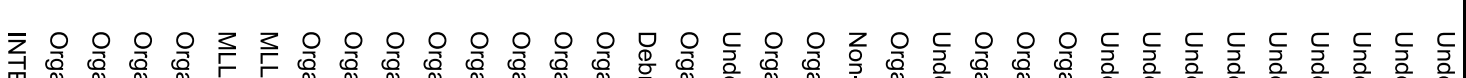

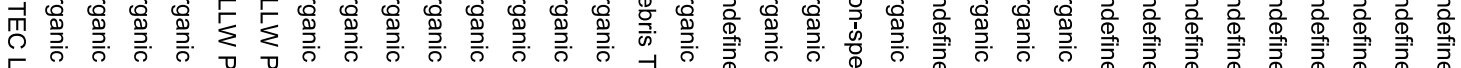

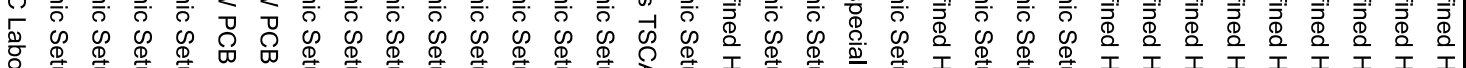

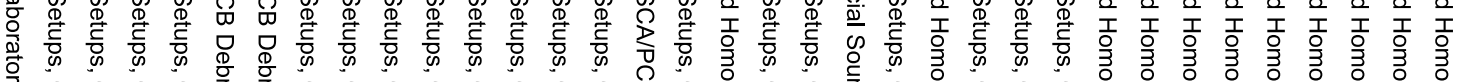

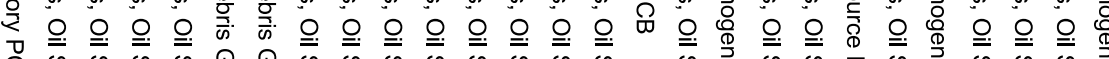

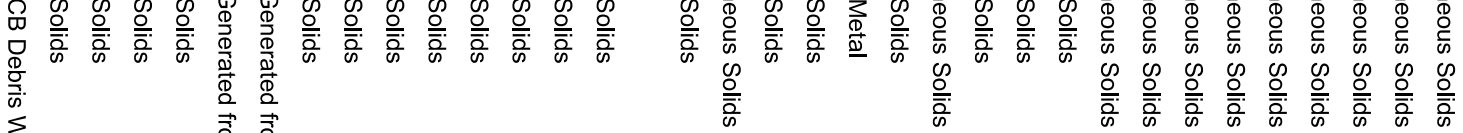
$\sum_{\substack{\infty \\ 0}}^{\infty}$

$\overrightarrow{\stackrel{\overrightarrow{0}}{3}} \stackrel{\overrightarrow{0}}{3}$

올

$\sum_{\substack{\infty \\ 0}}^{\infty} \sum_{\substack{\infty \\ \frac{0}{0}}}^{\infty}$

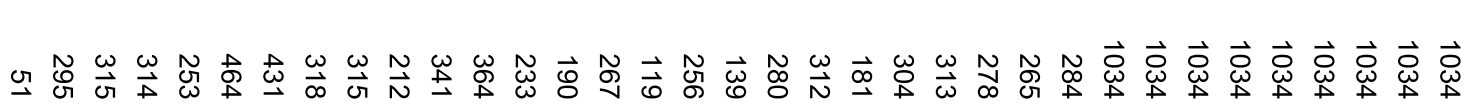

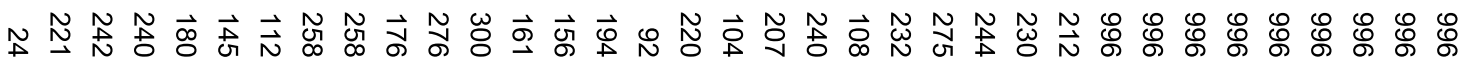
玄

20

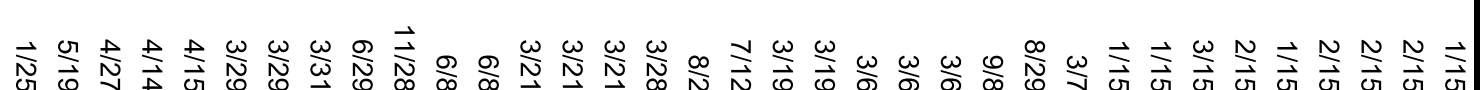

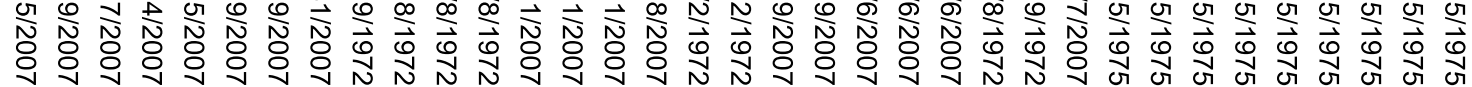

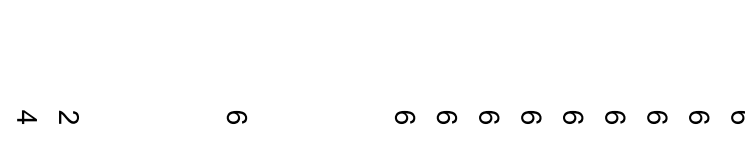




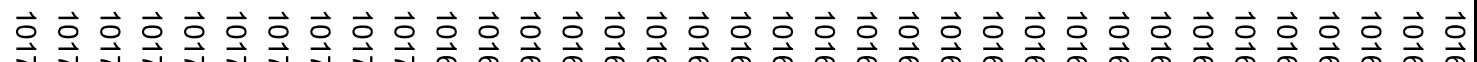

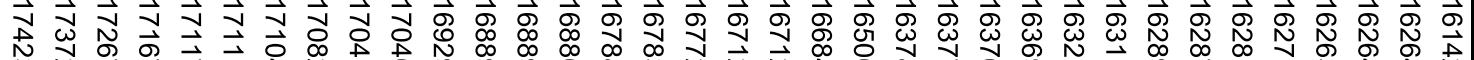
岕

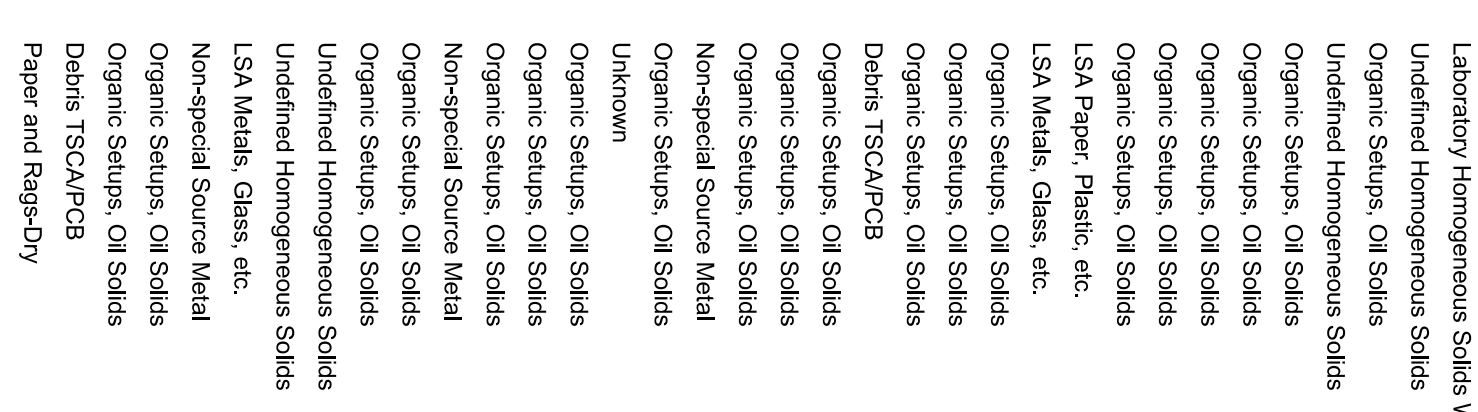

D.

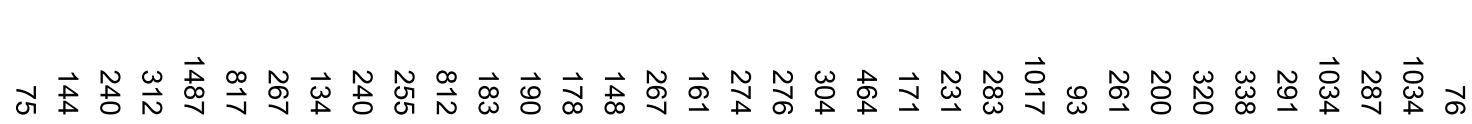

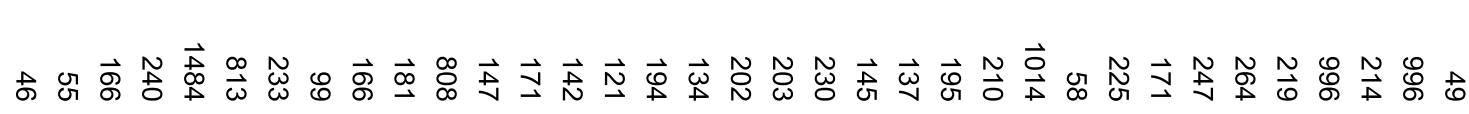

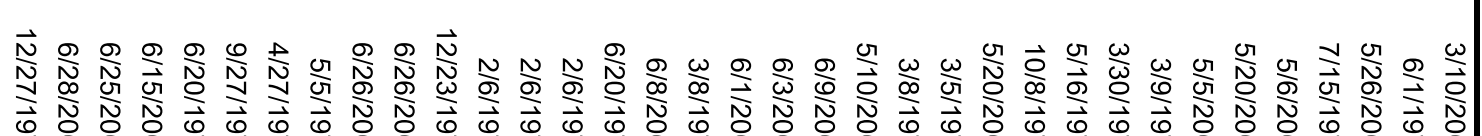
沗吕 


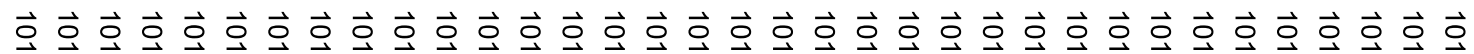

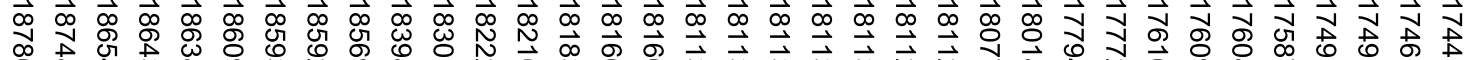

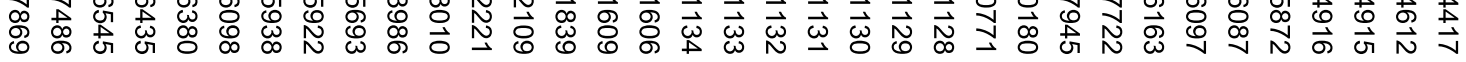

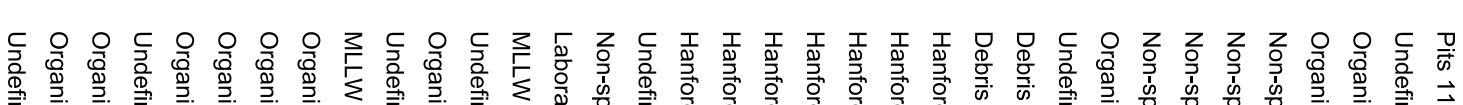

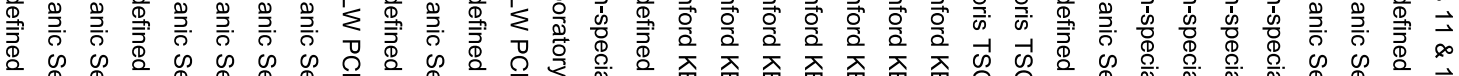

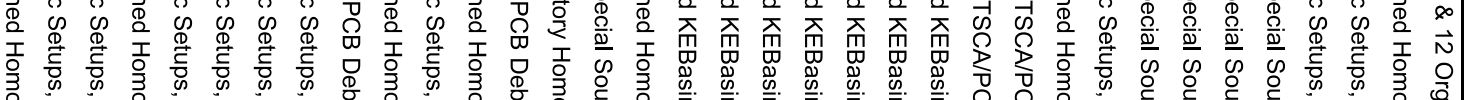

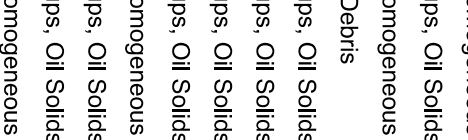

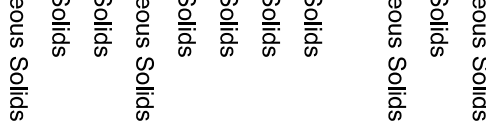

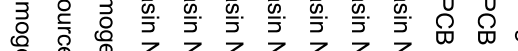

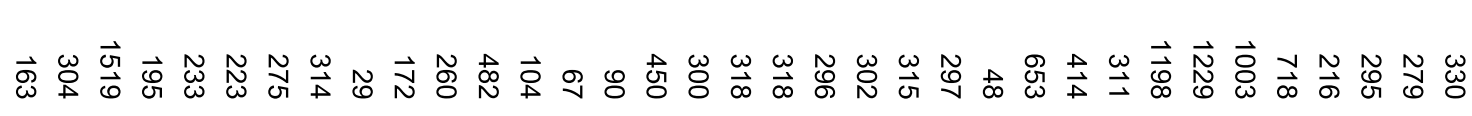

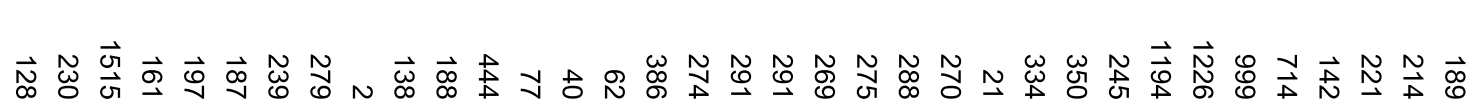
交兴

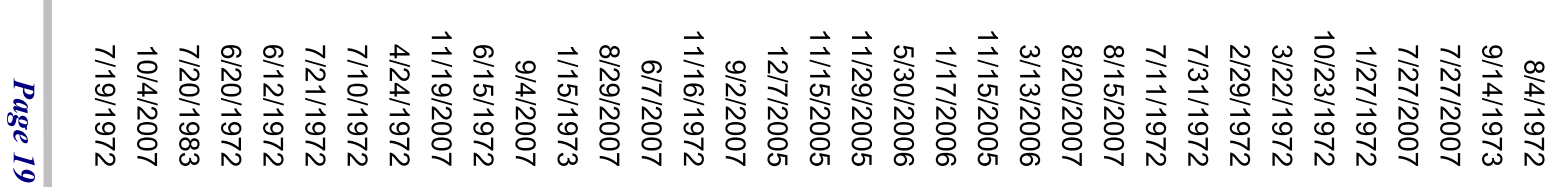

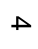
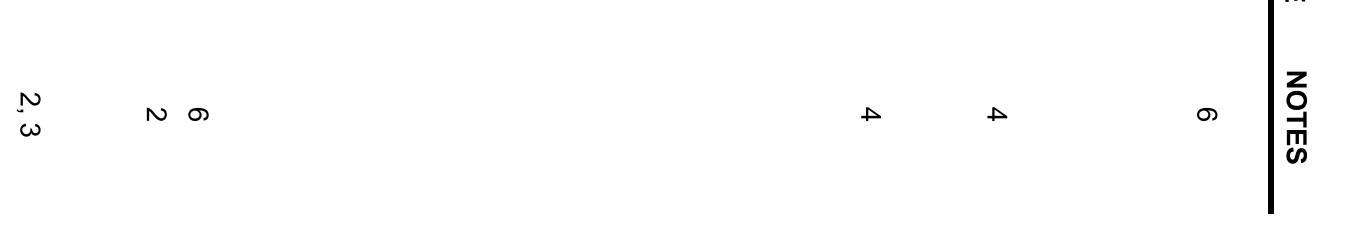


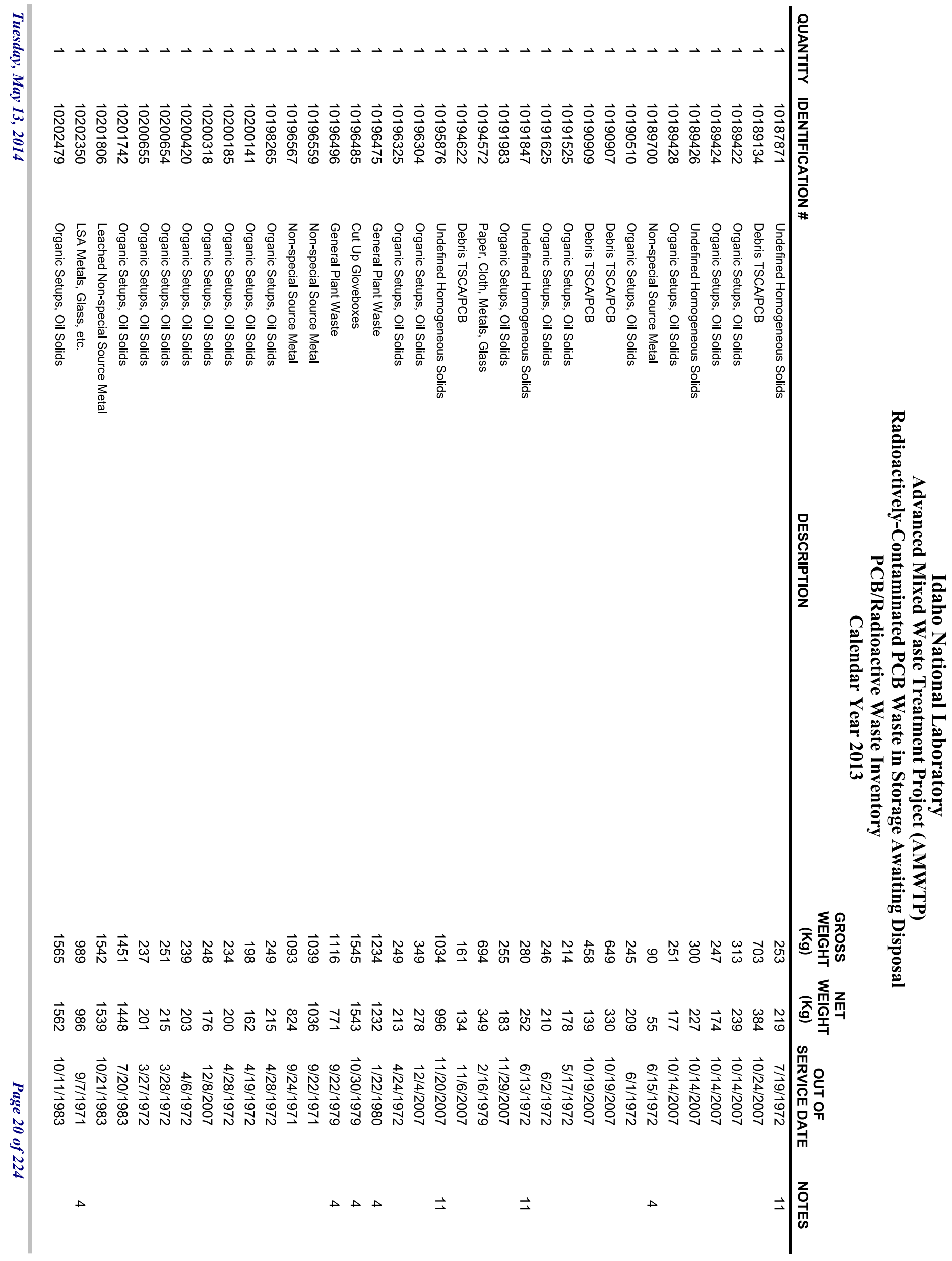




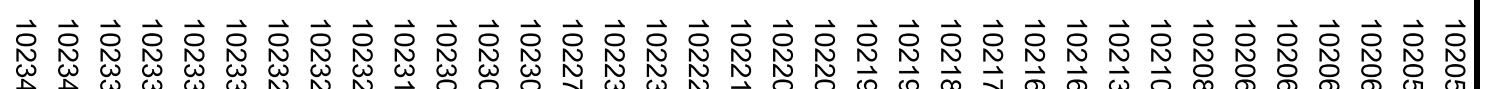

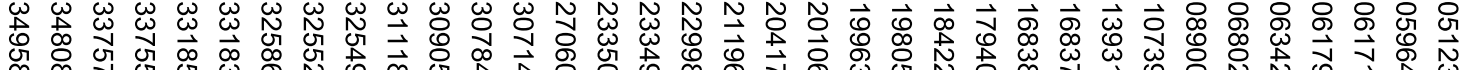
(1)

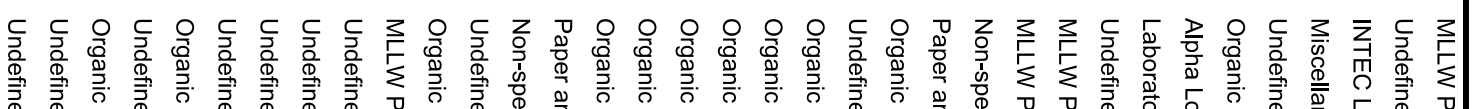

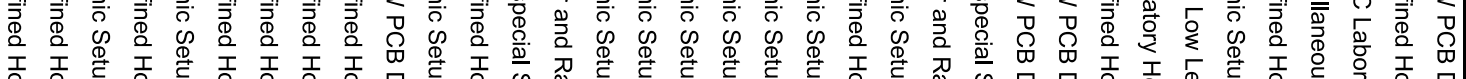

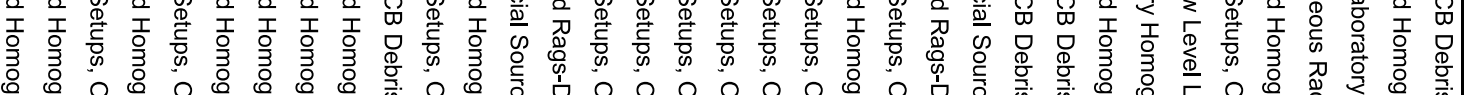

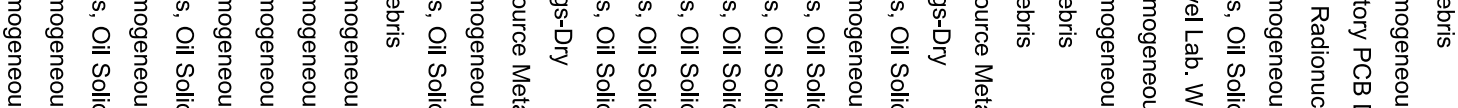

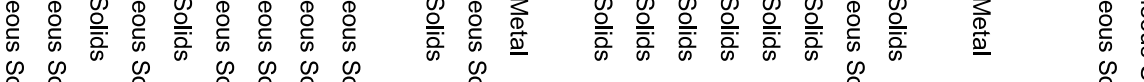

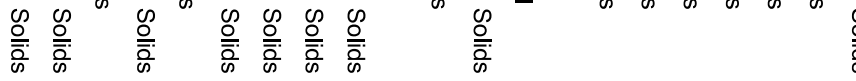

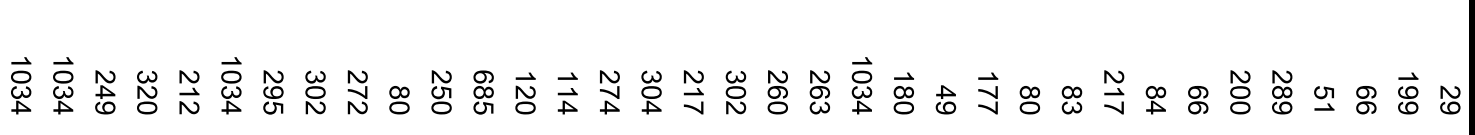

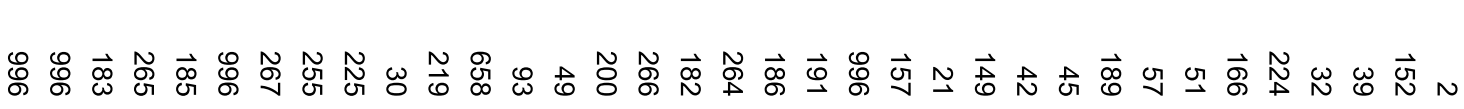




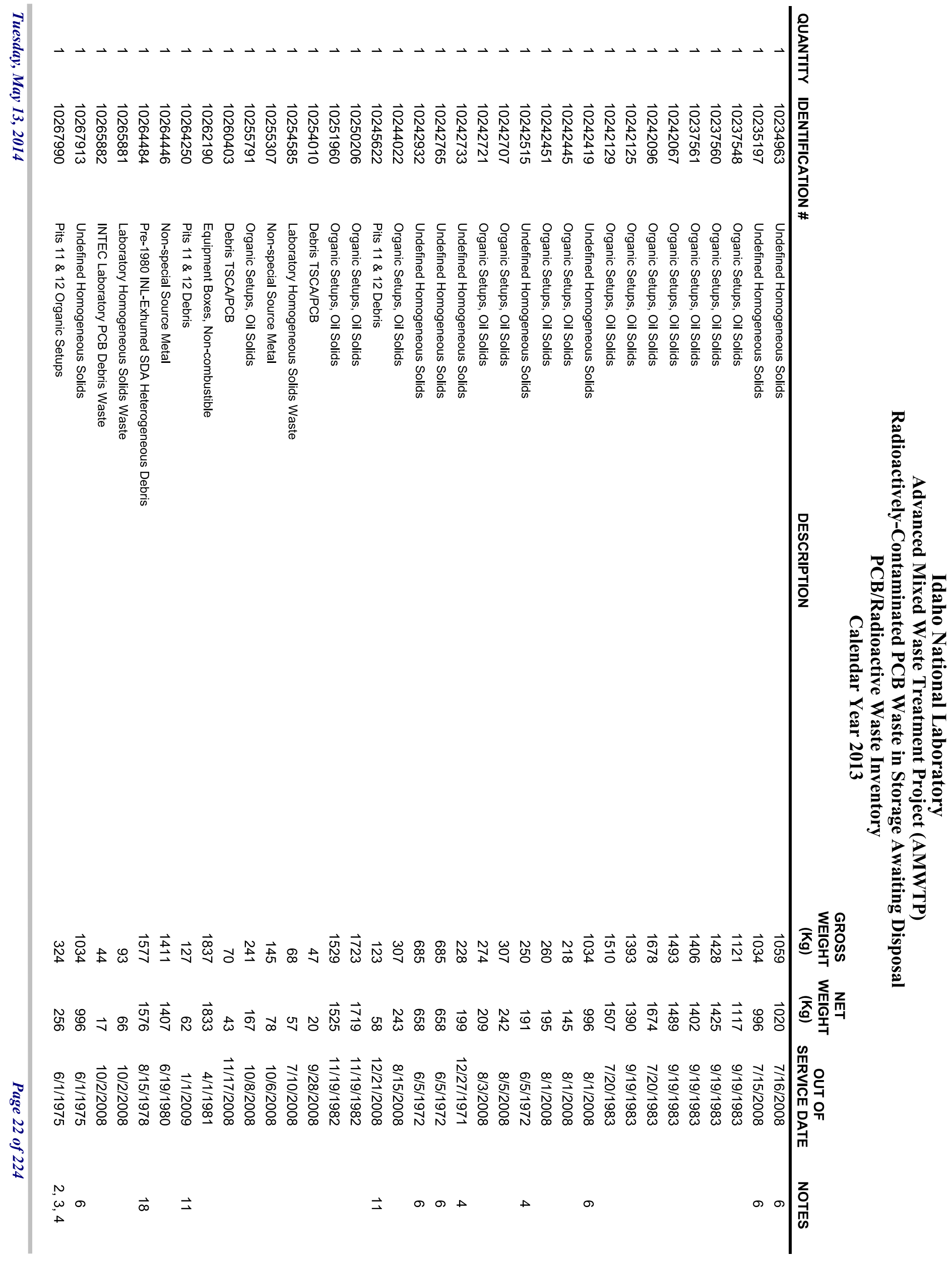




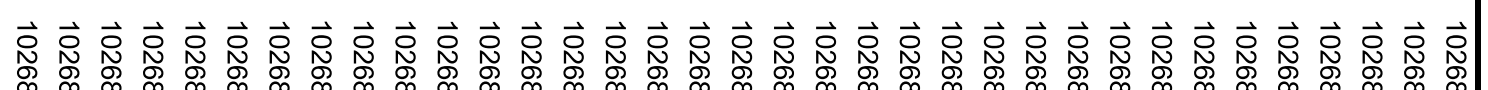

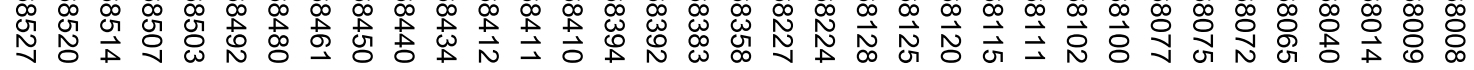

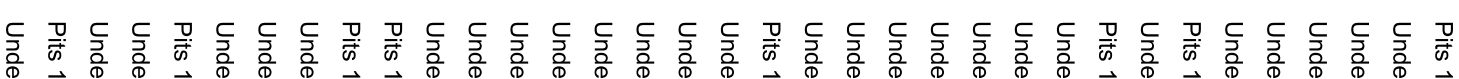

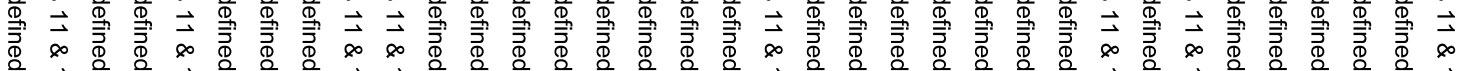

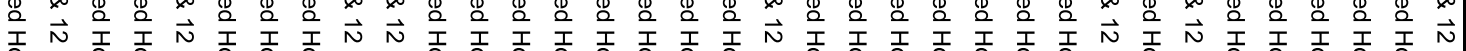

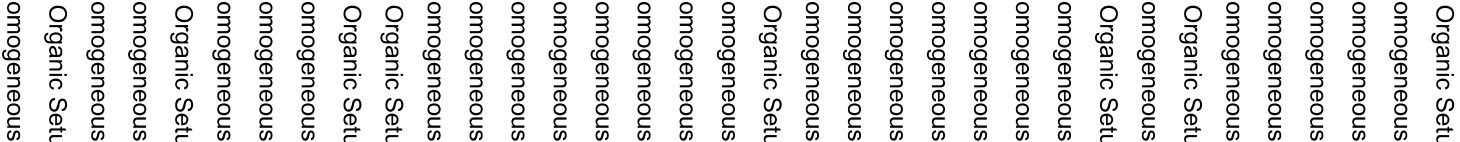

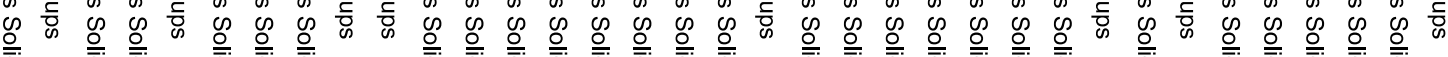

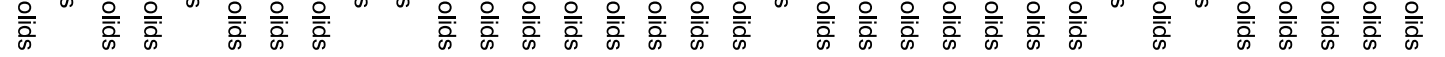

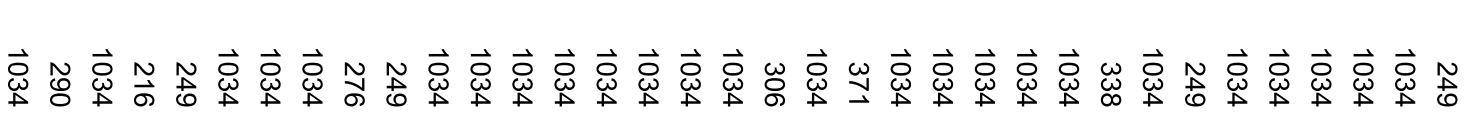

\& 슝 囬兴

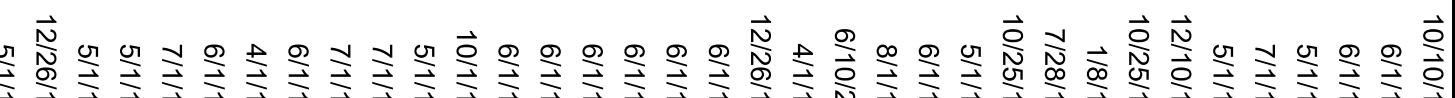

の 


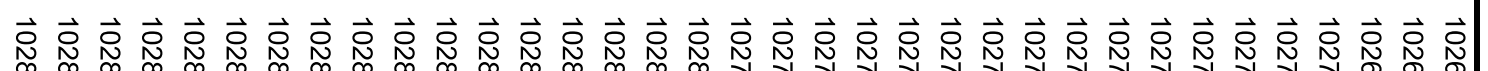

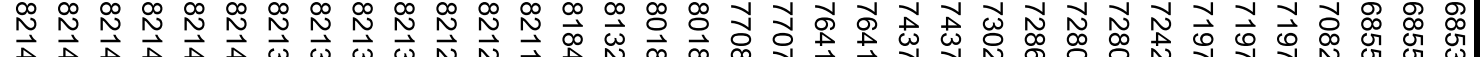

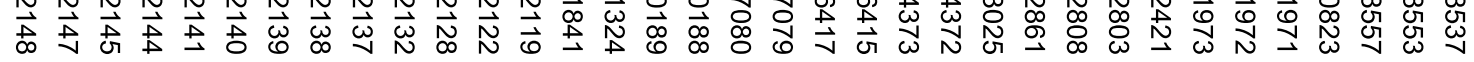

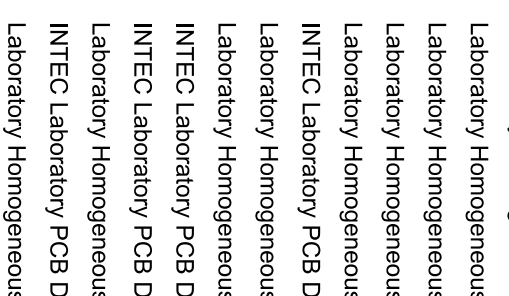

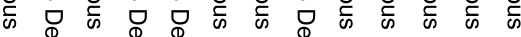

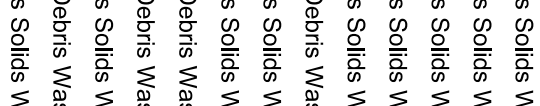

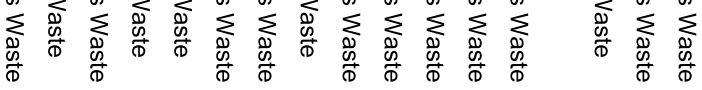
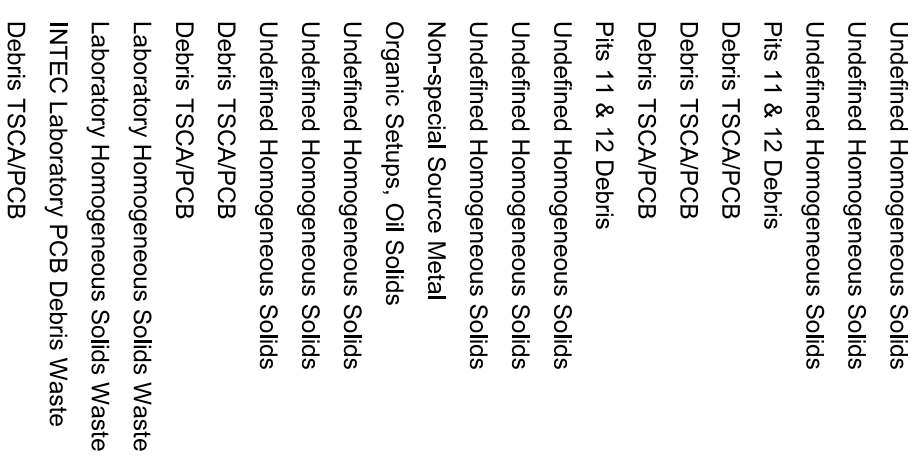

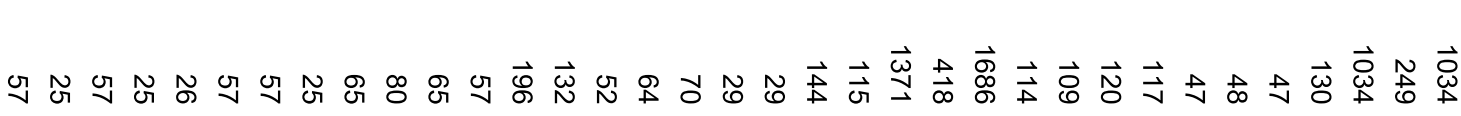

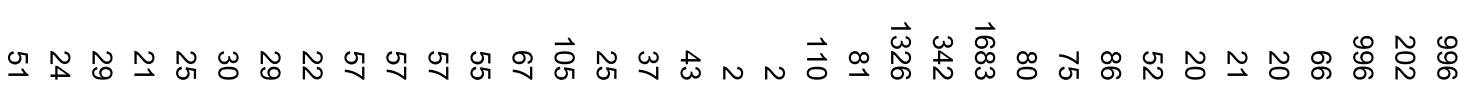

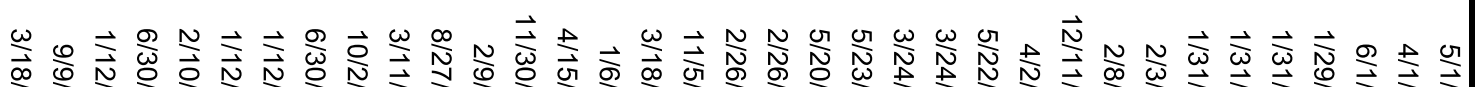

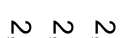

$\omega \omega \omega \omega$

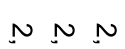

$\stackrel{N}{\omega} \vec{N}$

जबの $\vec{\Delta} \sigma \vec{\Delta}$

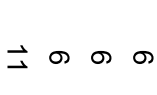




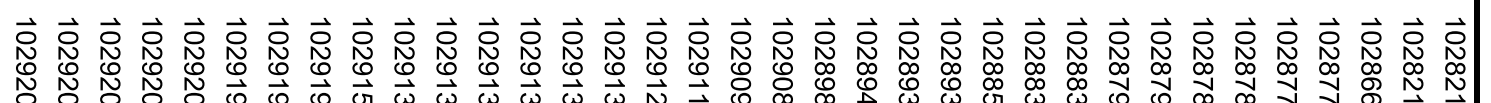

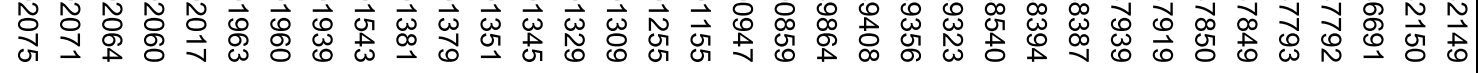

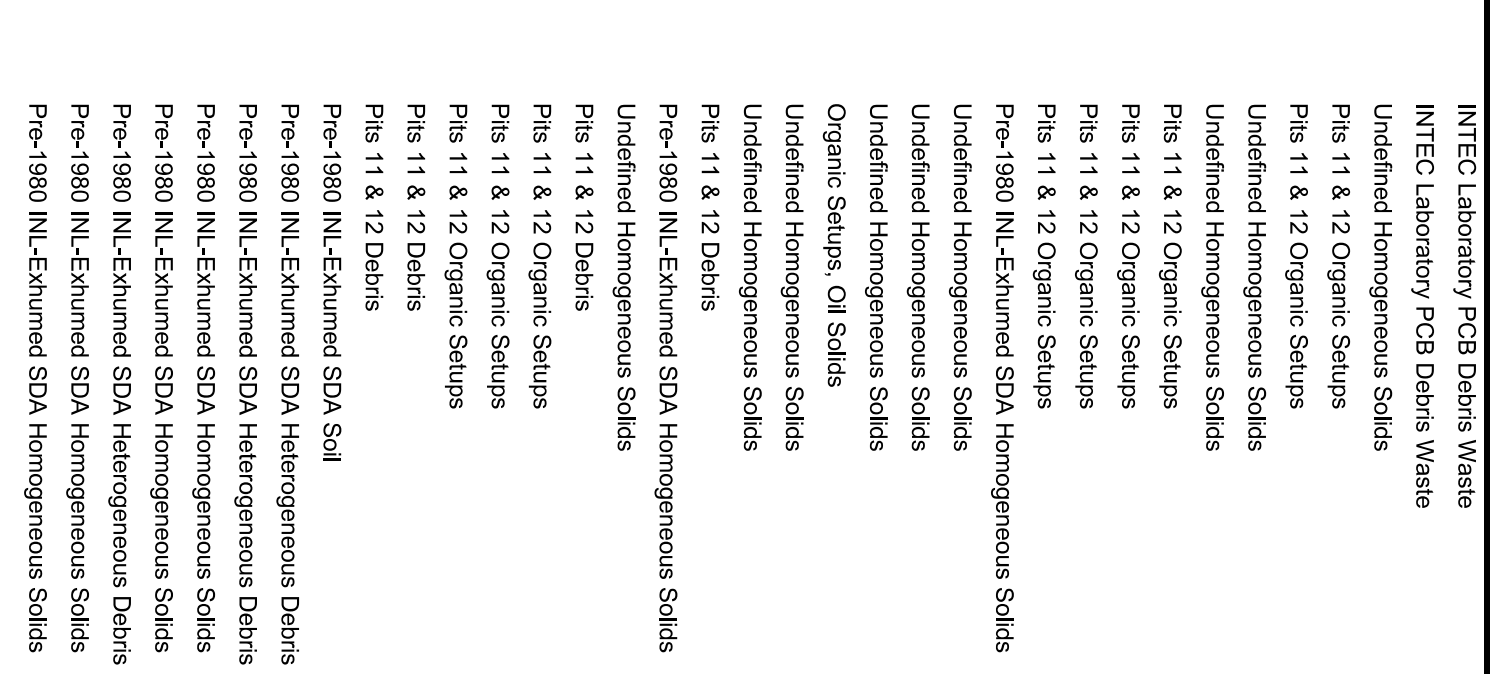

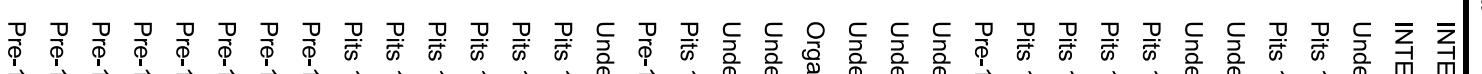

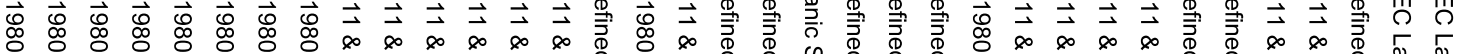

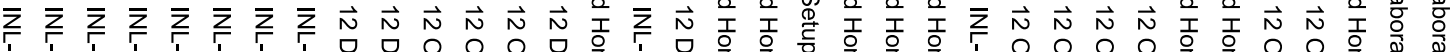

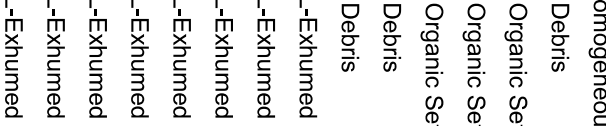

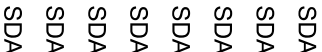

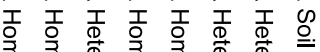

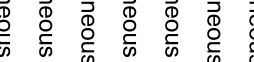

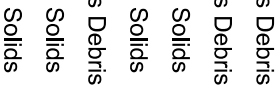

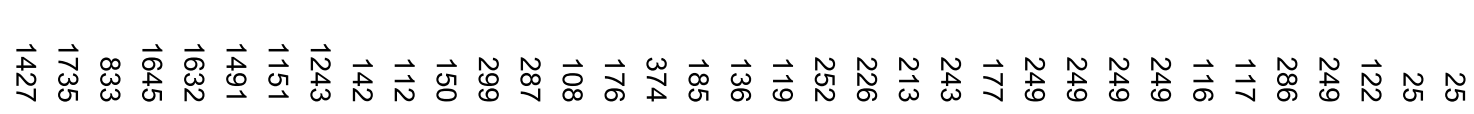

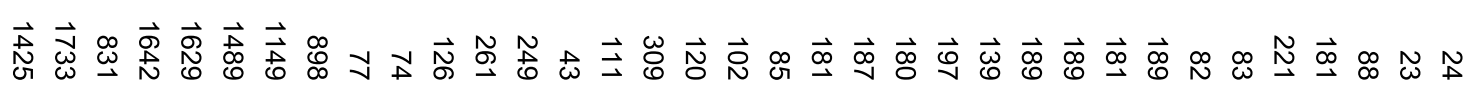

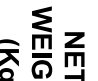

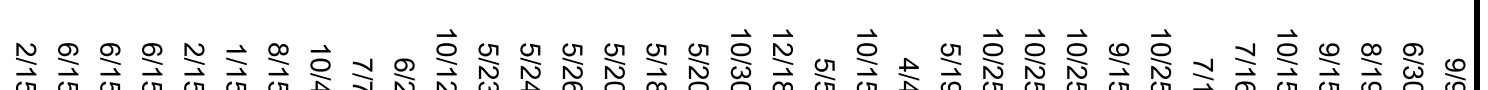
觉

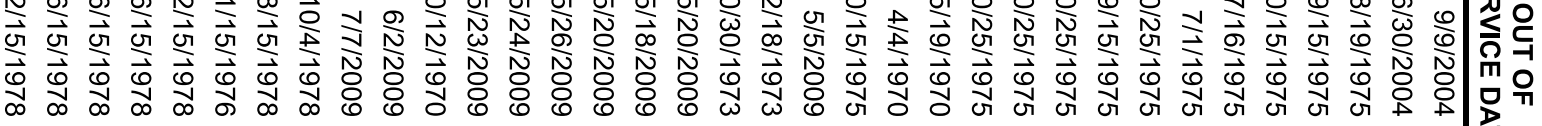

$\stackrel{\substack{n\\}}{2}$

$\vec{\infty} \vec{\infty} \vec{\infty} \vec{\infty} \vec{\infty}+$

$$
\stackrel{\sim}{\omega} \stackrel{\sim}{\omega} \vec{A} \quad \overrightarrow{ \pm} \rightarrow \infty
$$$$
\text { の の } \vec{A}+
$$$$
\stackrel{n}{n}
$$

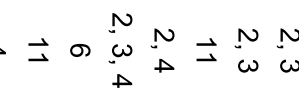




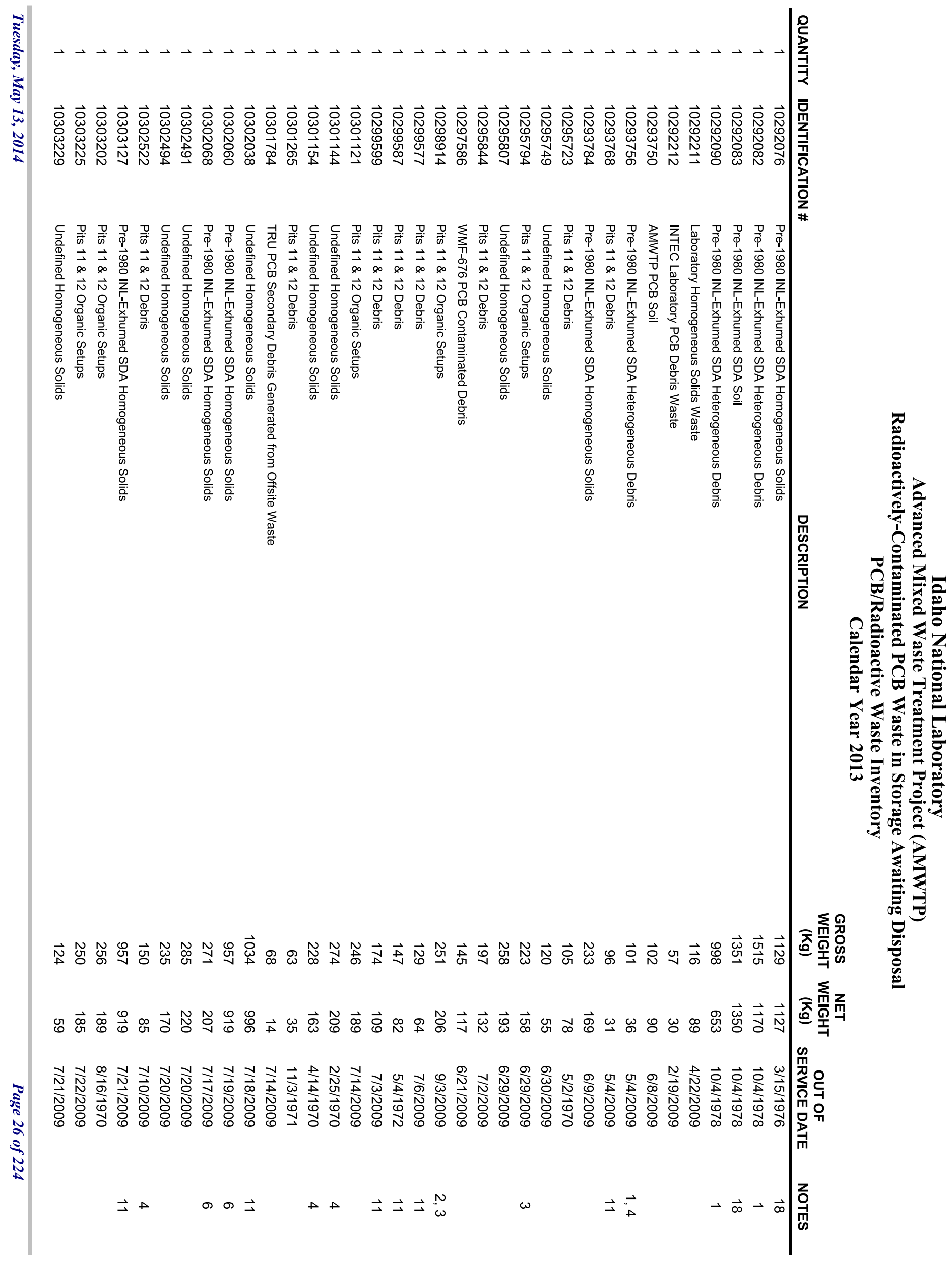




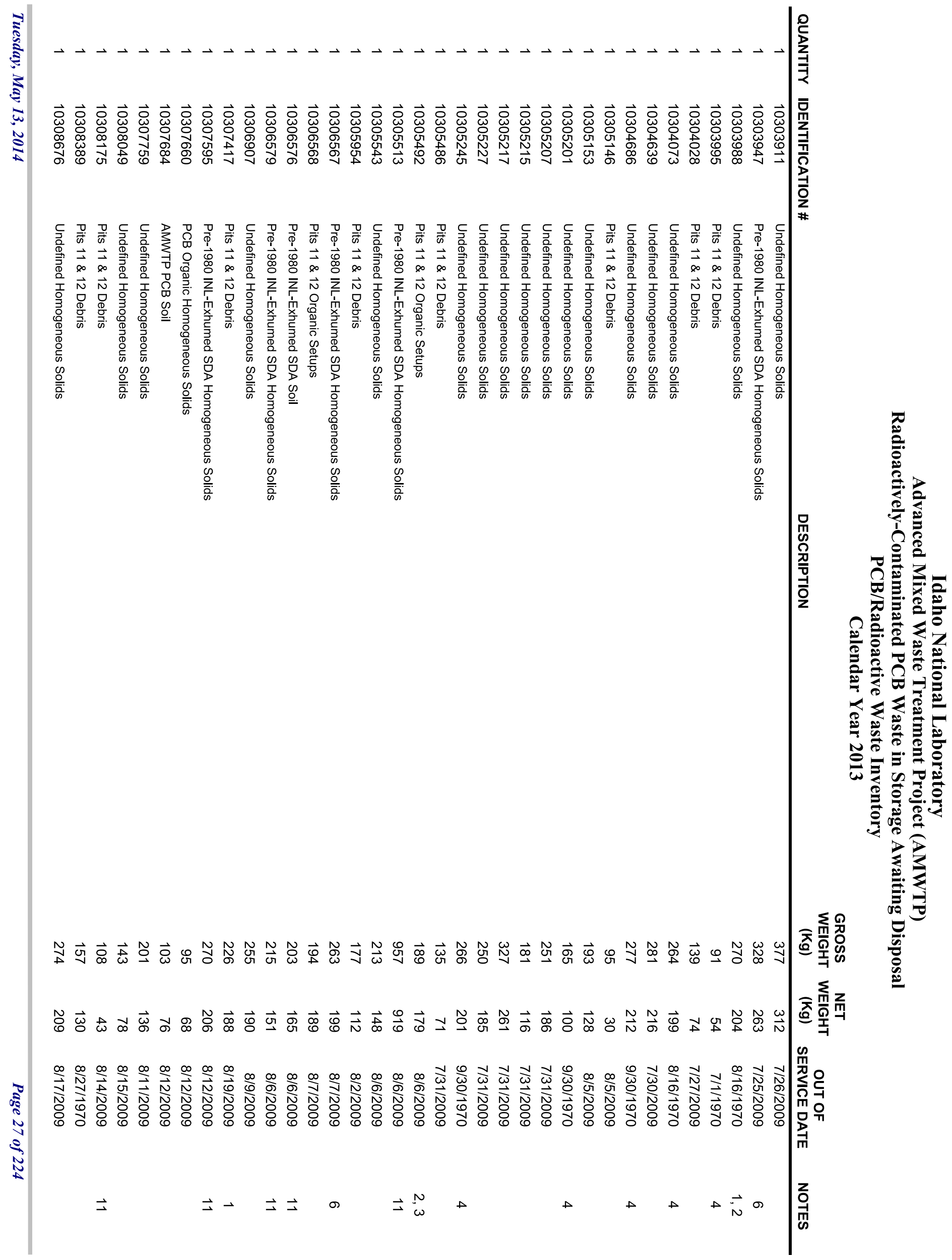




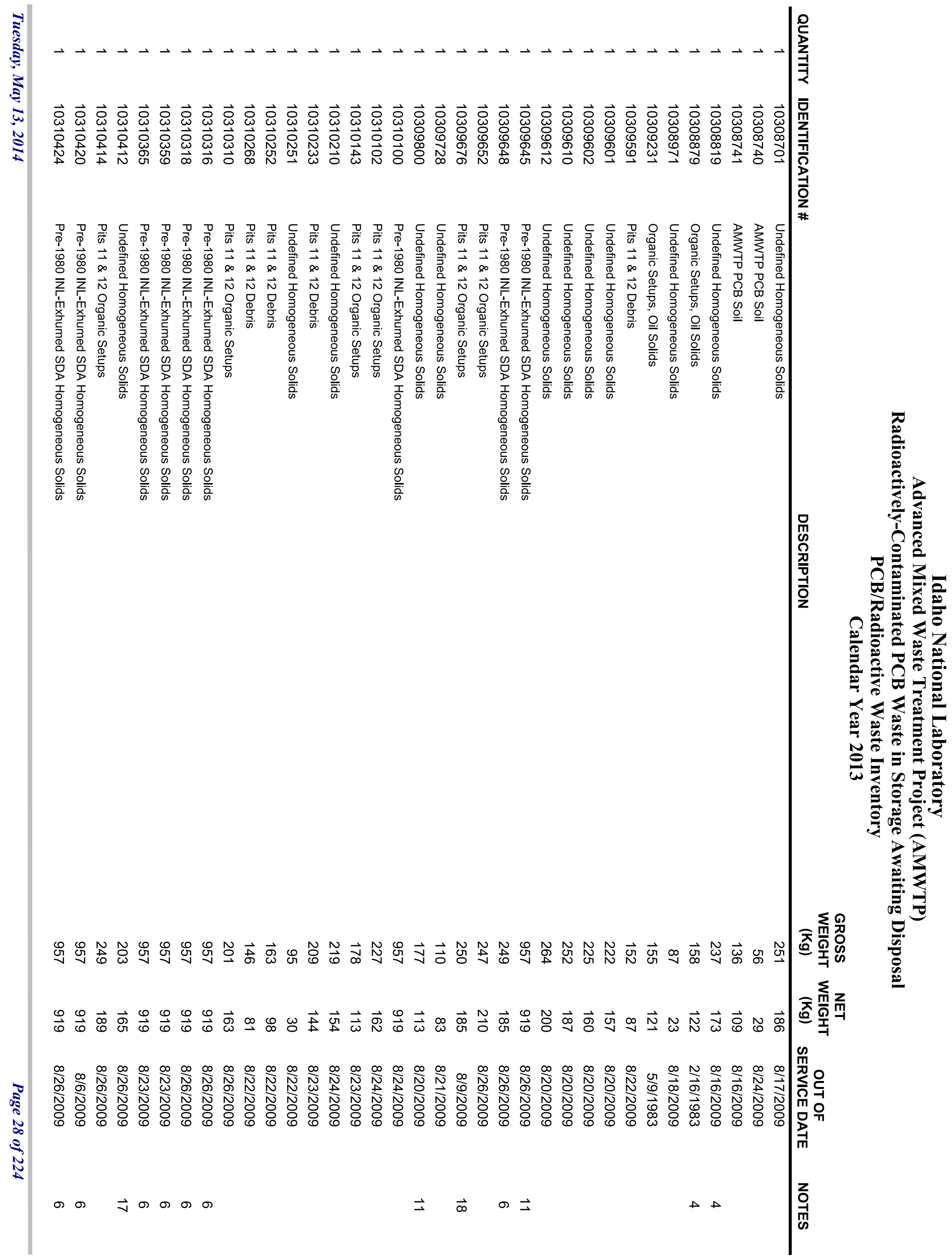




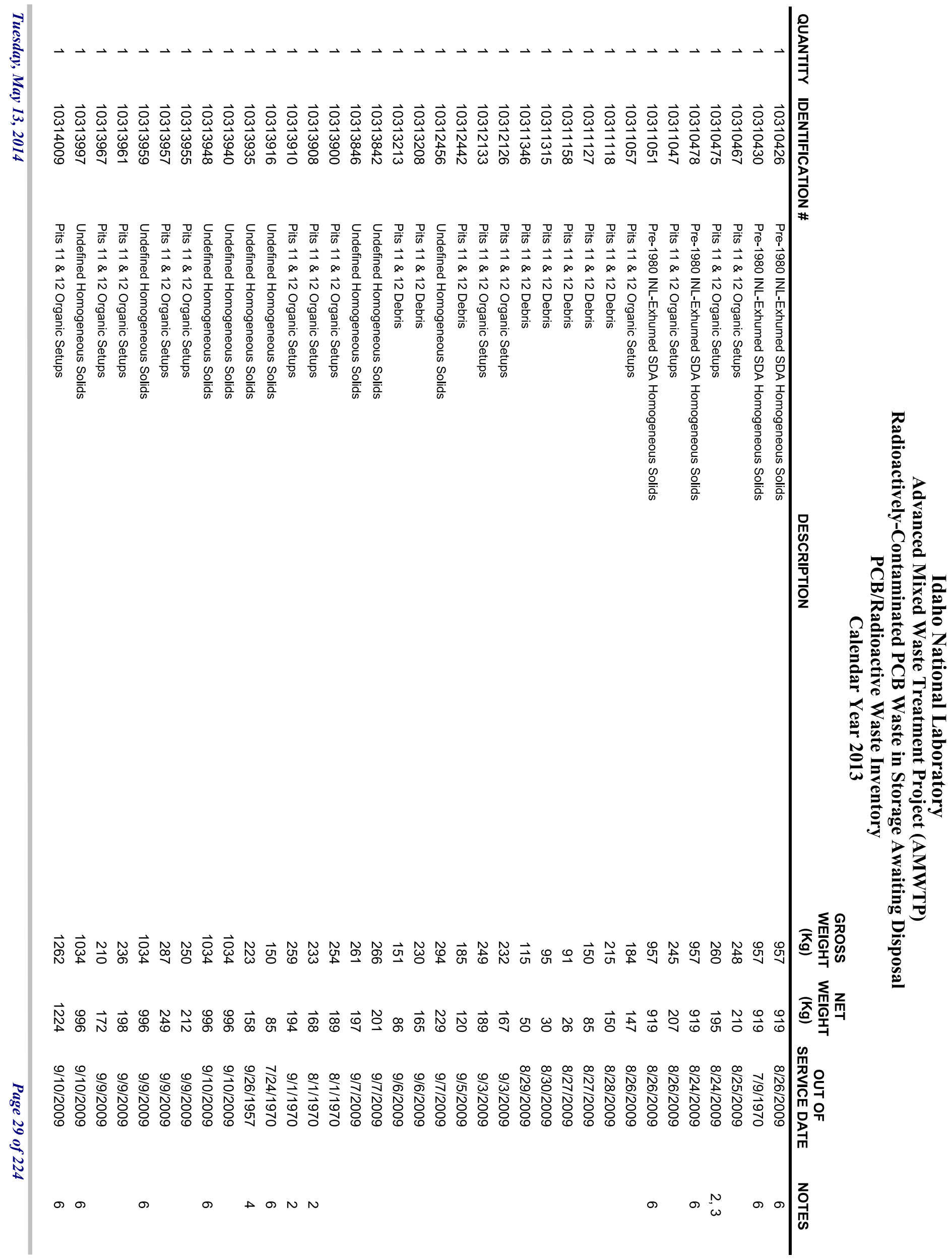




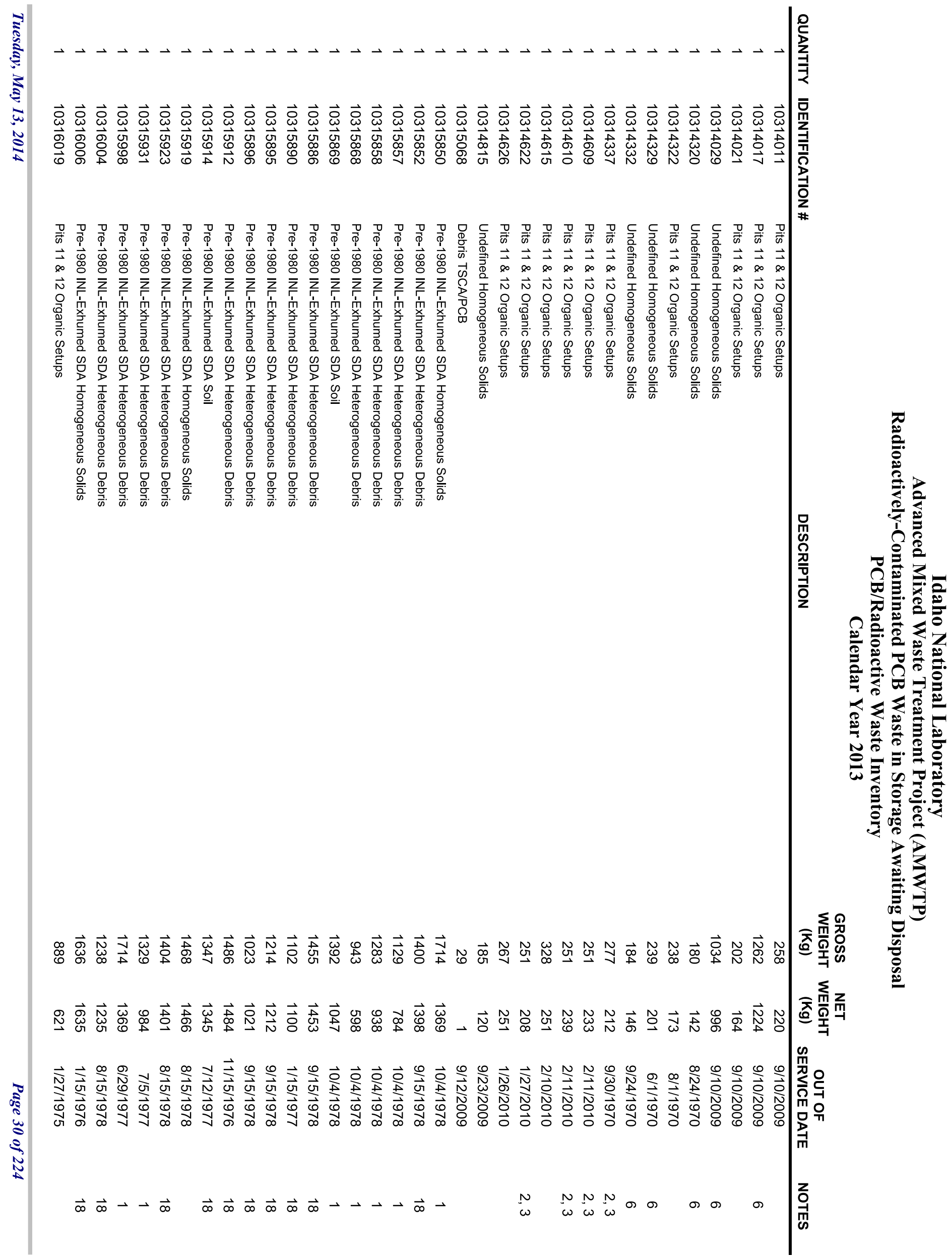




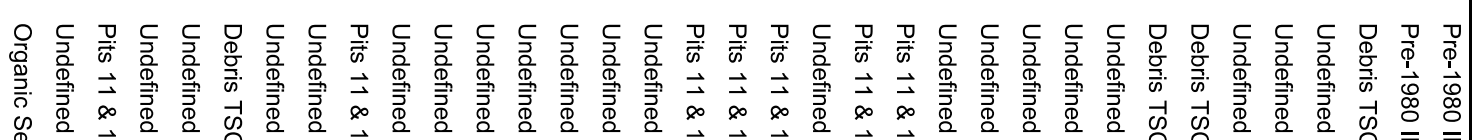

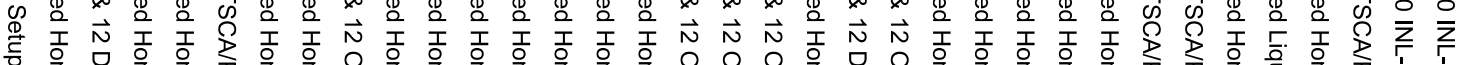

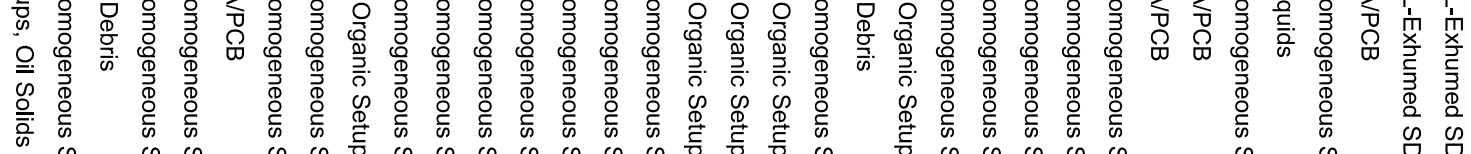

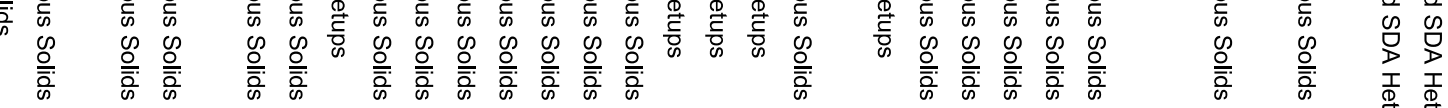

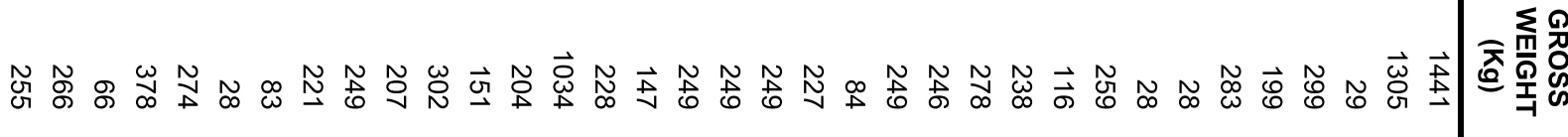

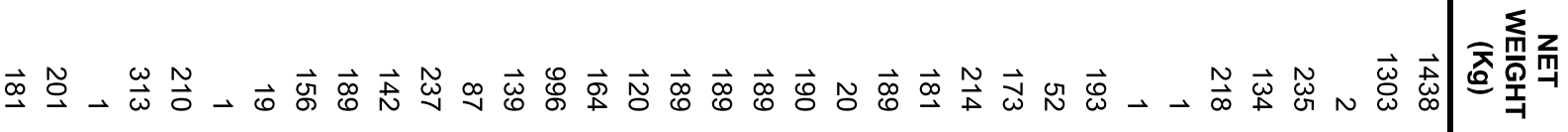

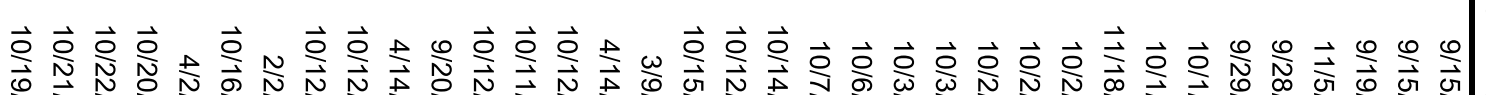

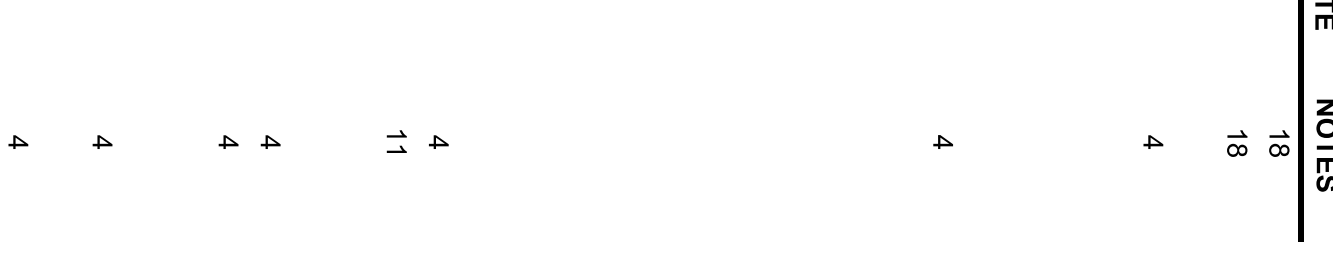




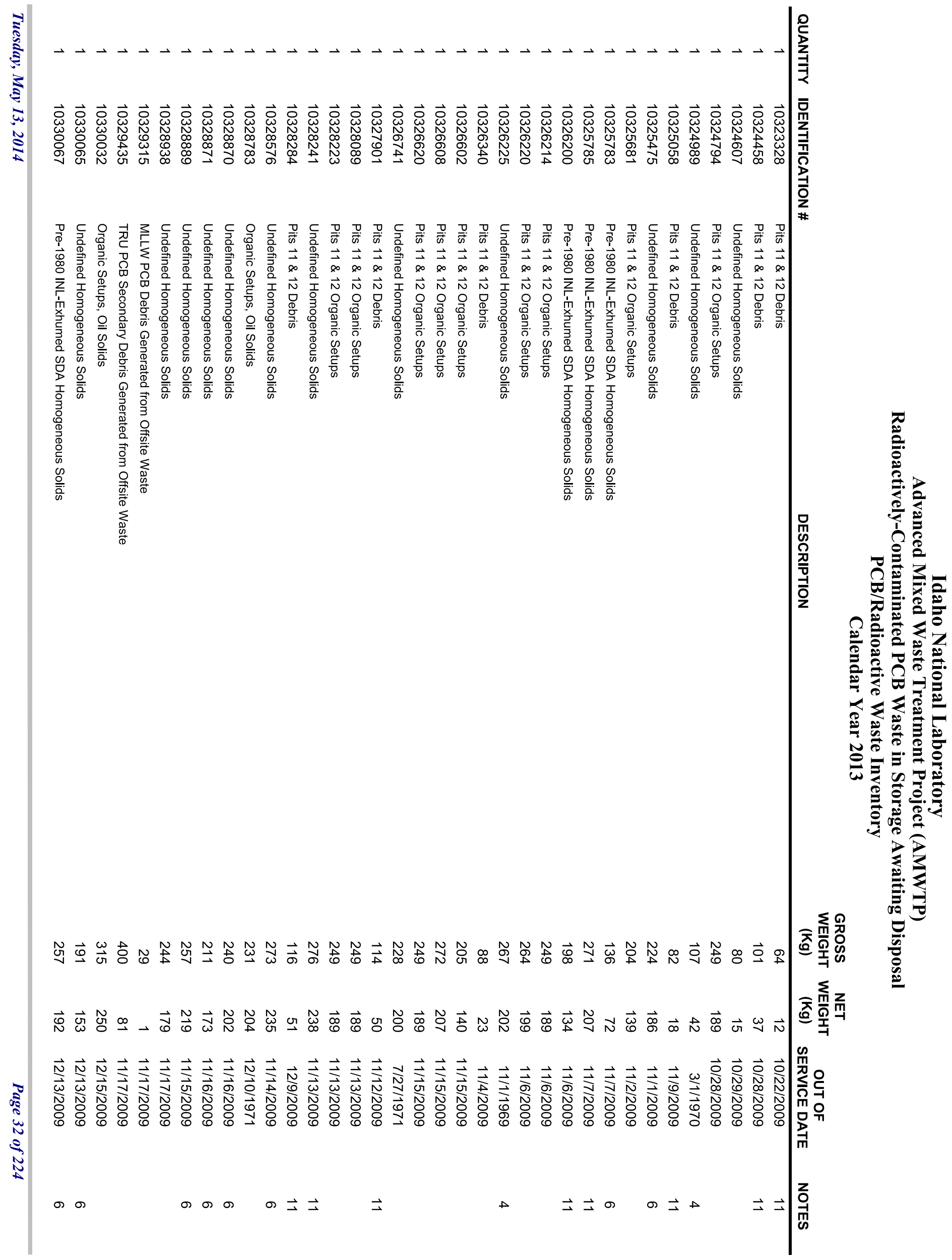




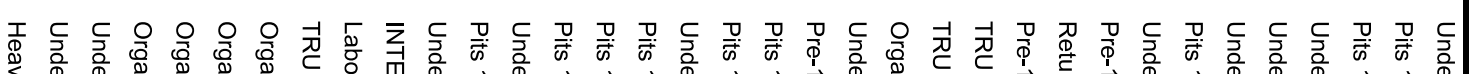

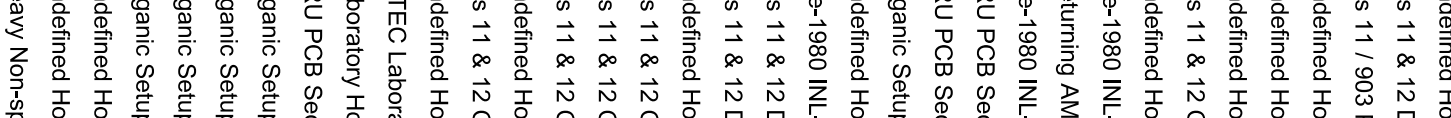

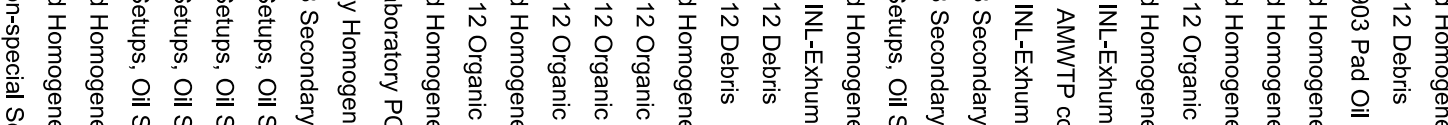

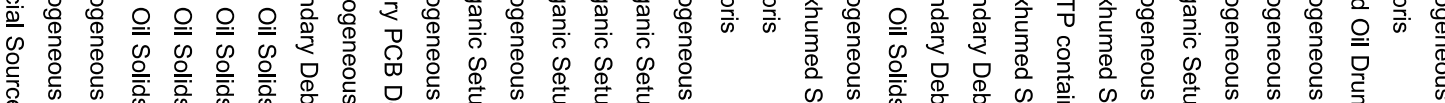

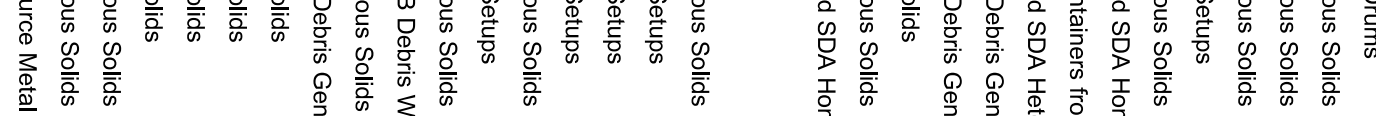
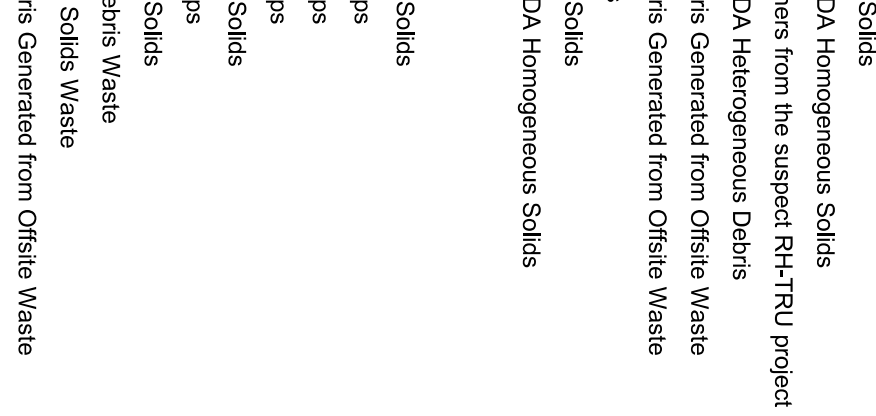

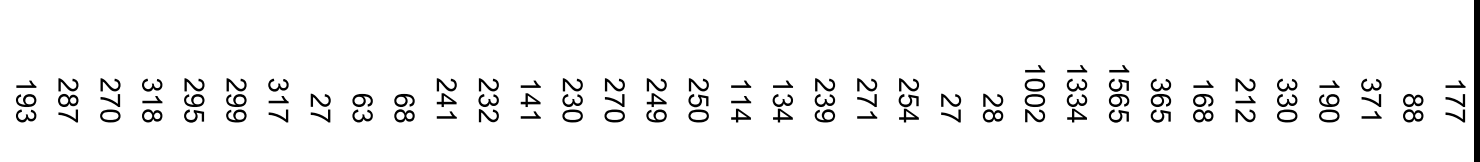

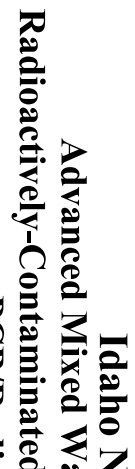

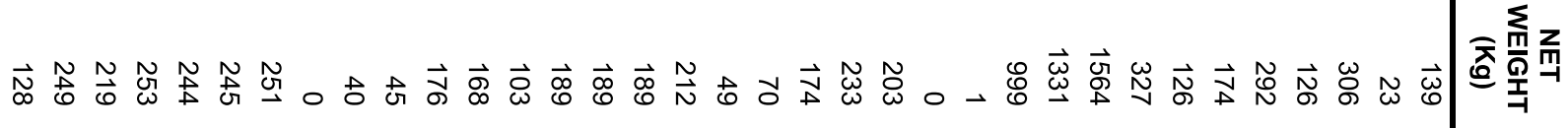

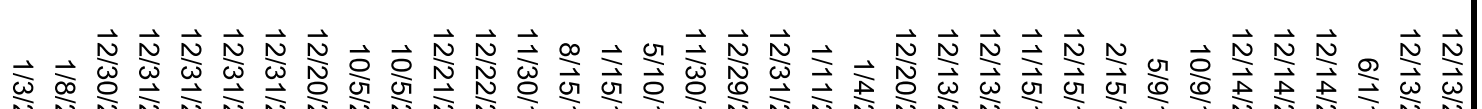

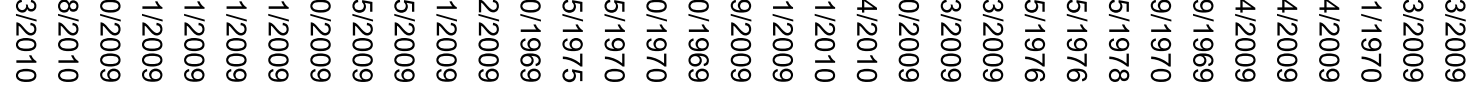

$\infty \sigma$

$\stackrel{\sim}{\omega} \sim \vec{H}$ 


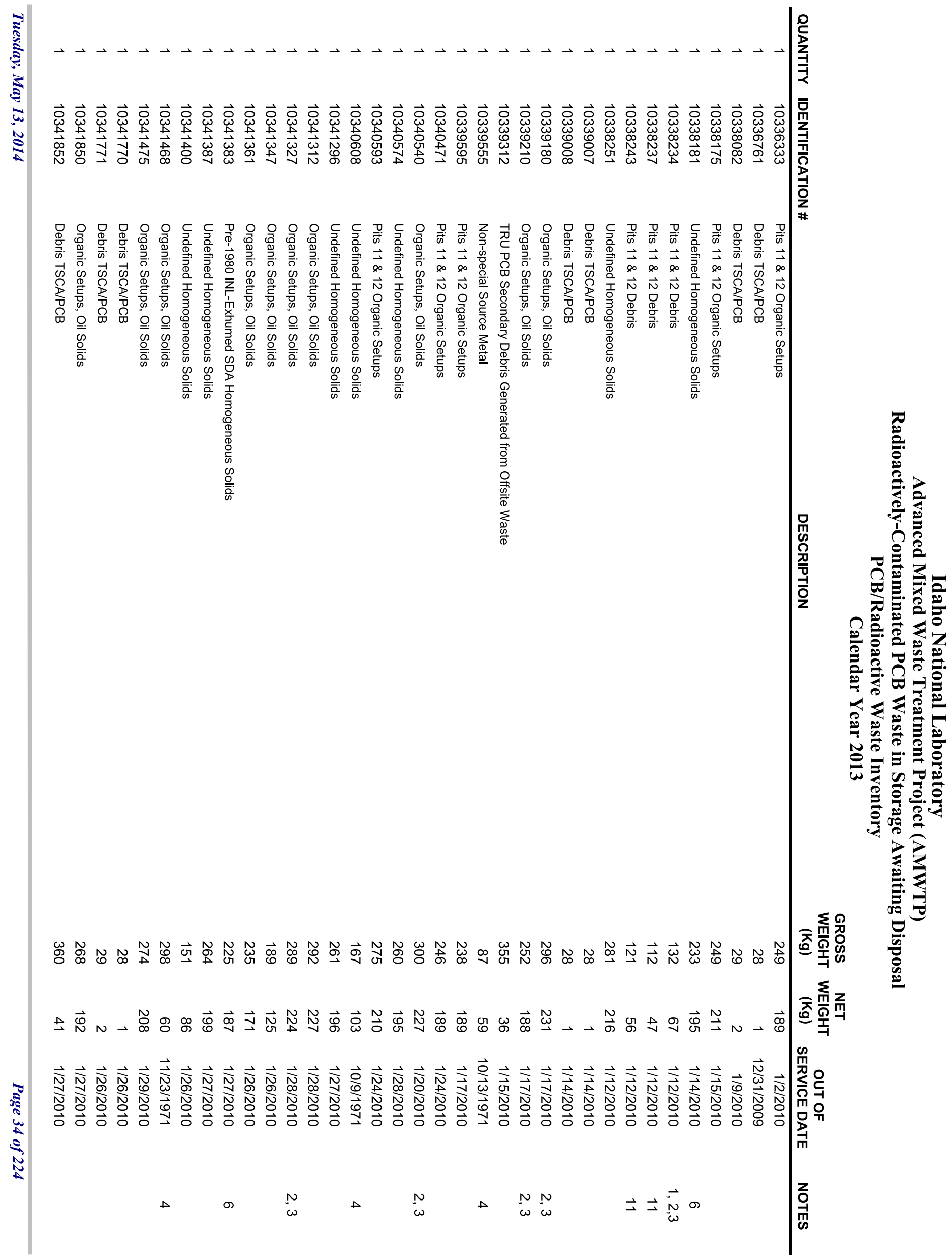




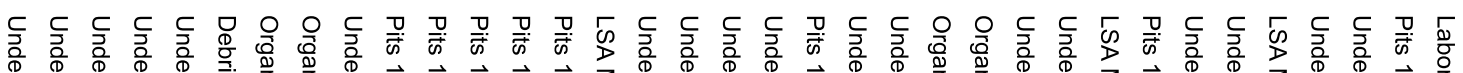

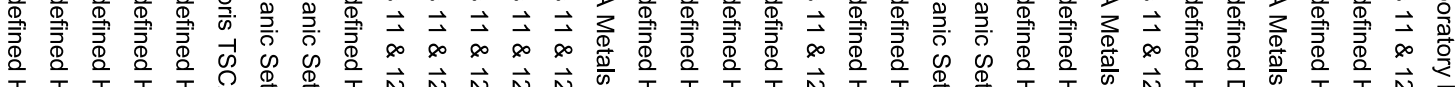

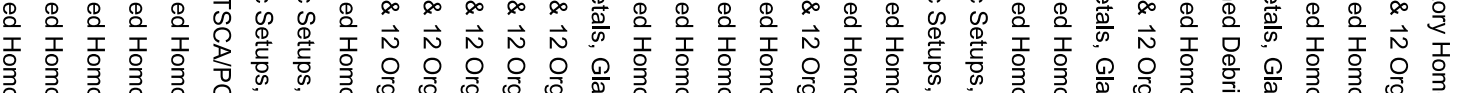

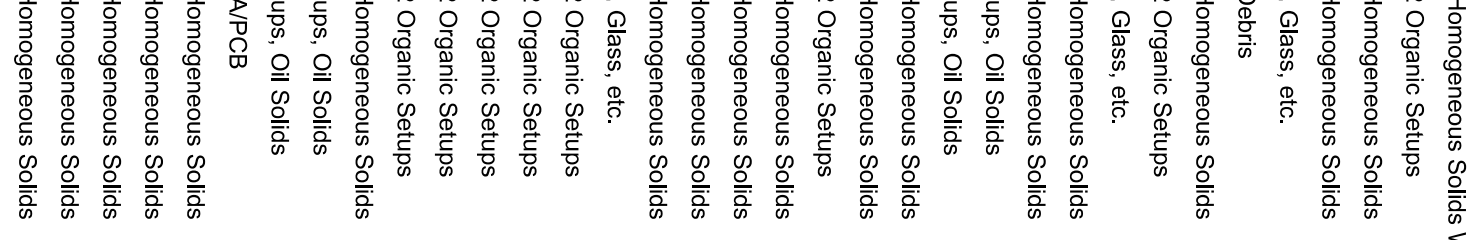

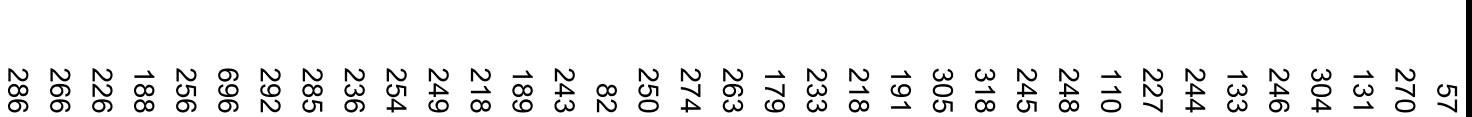




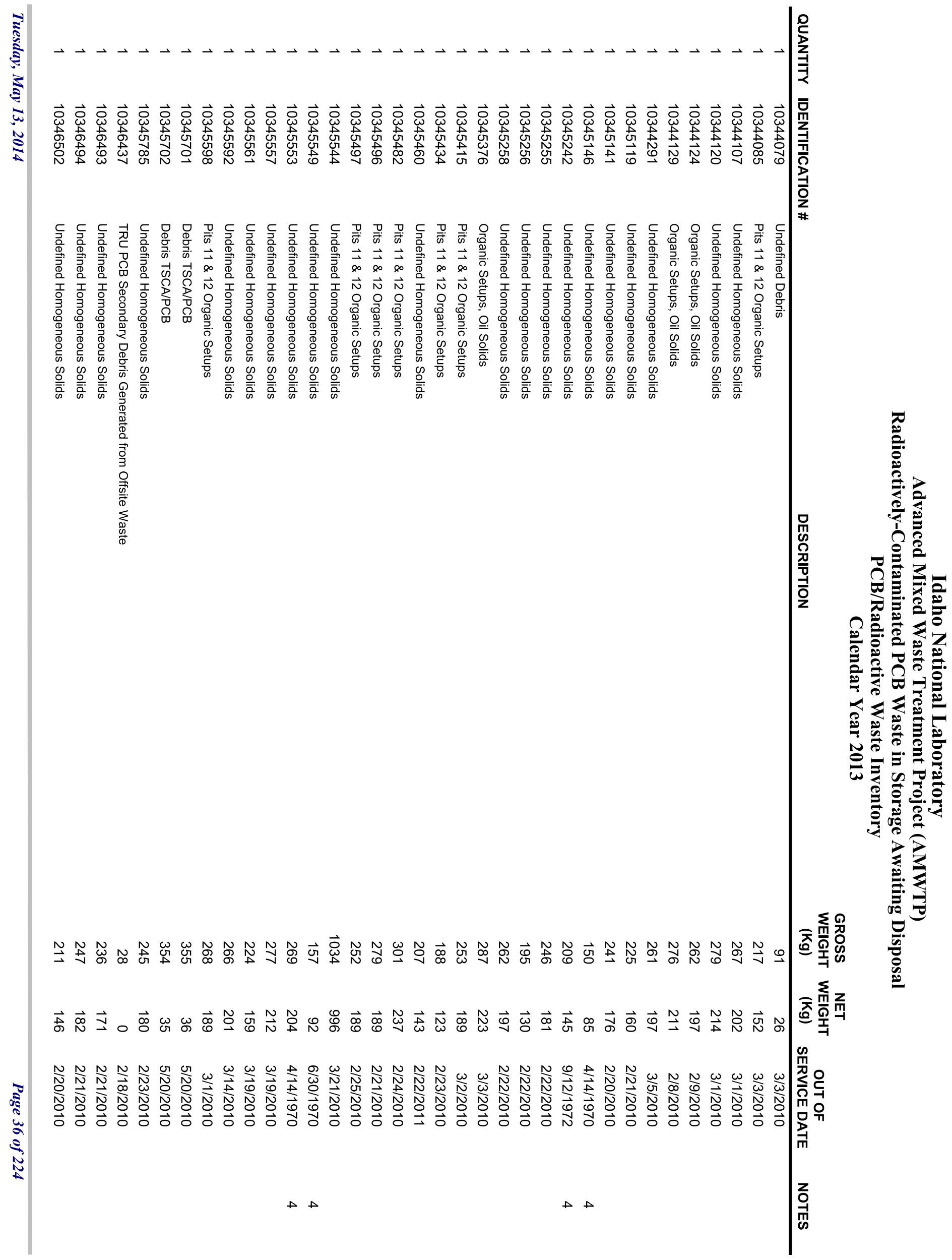




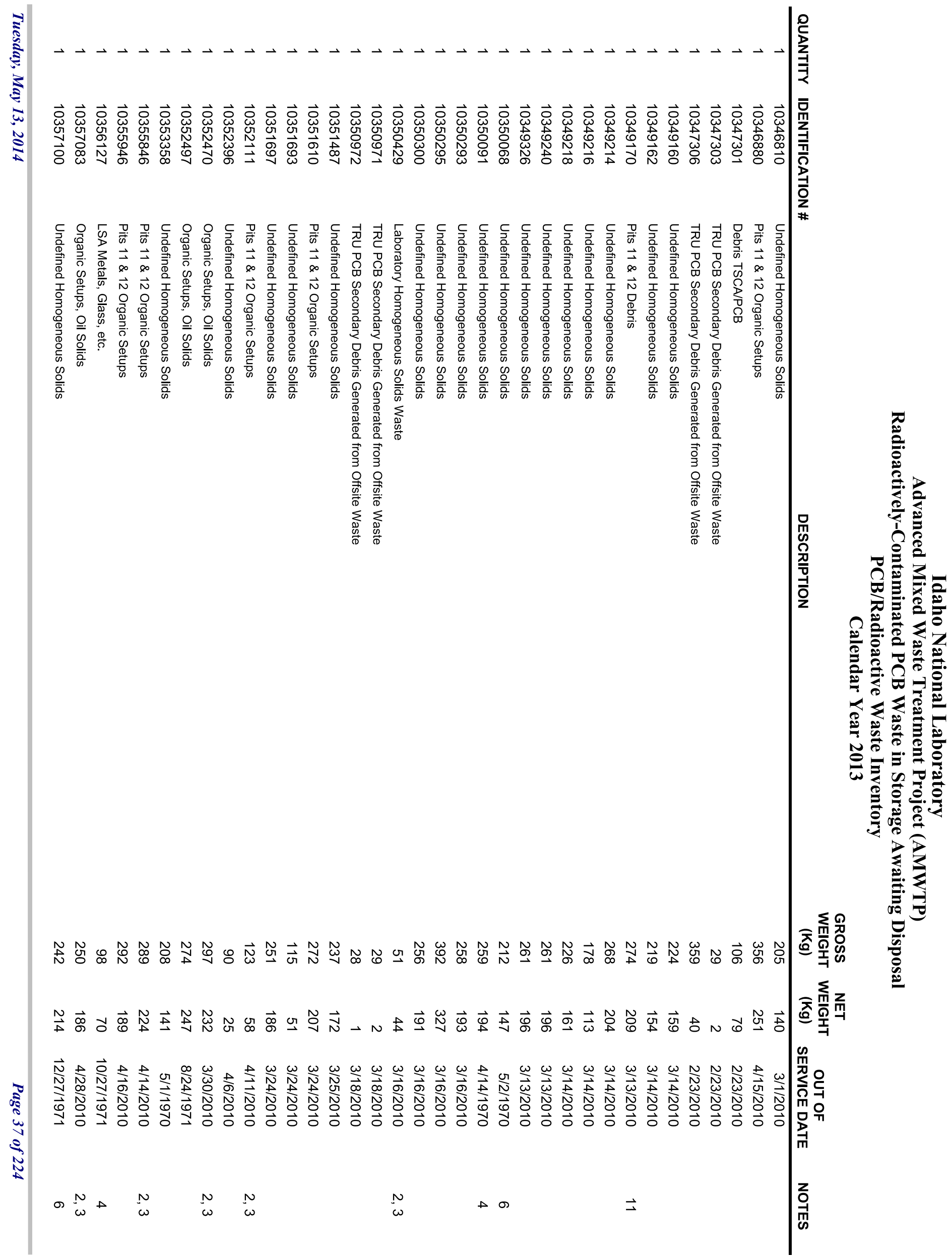




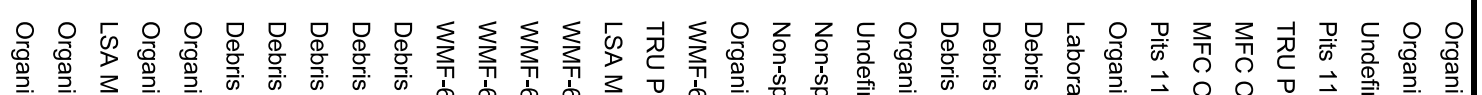

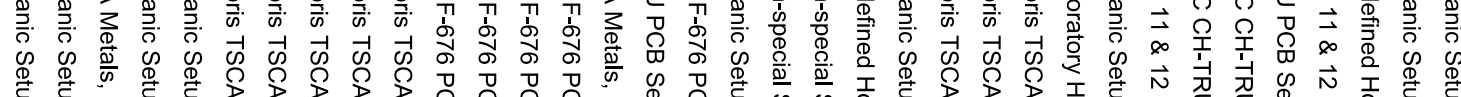

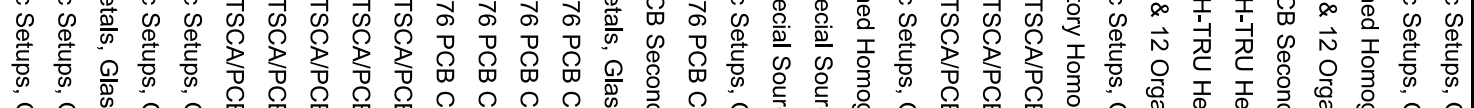
을

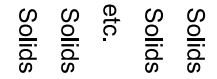
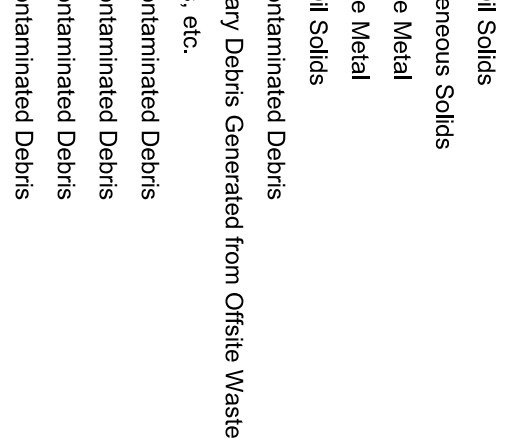

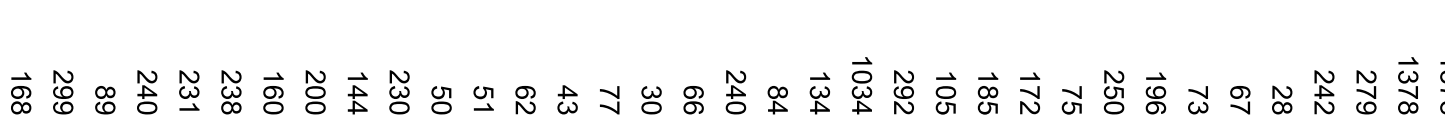

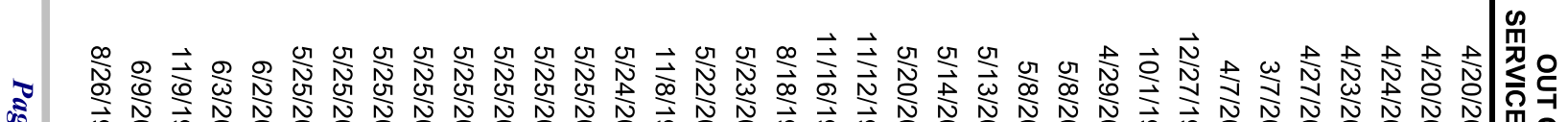

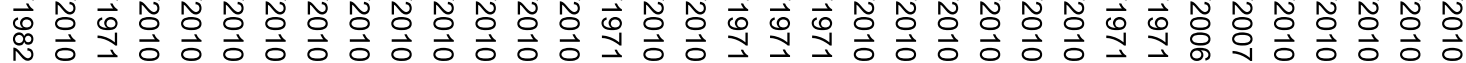




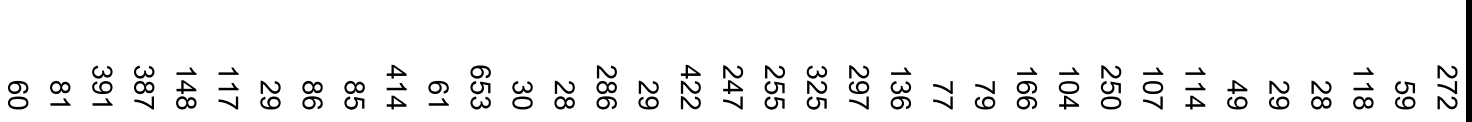




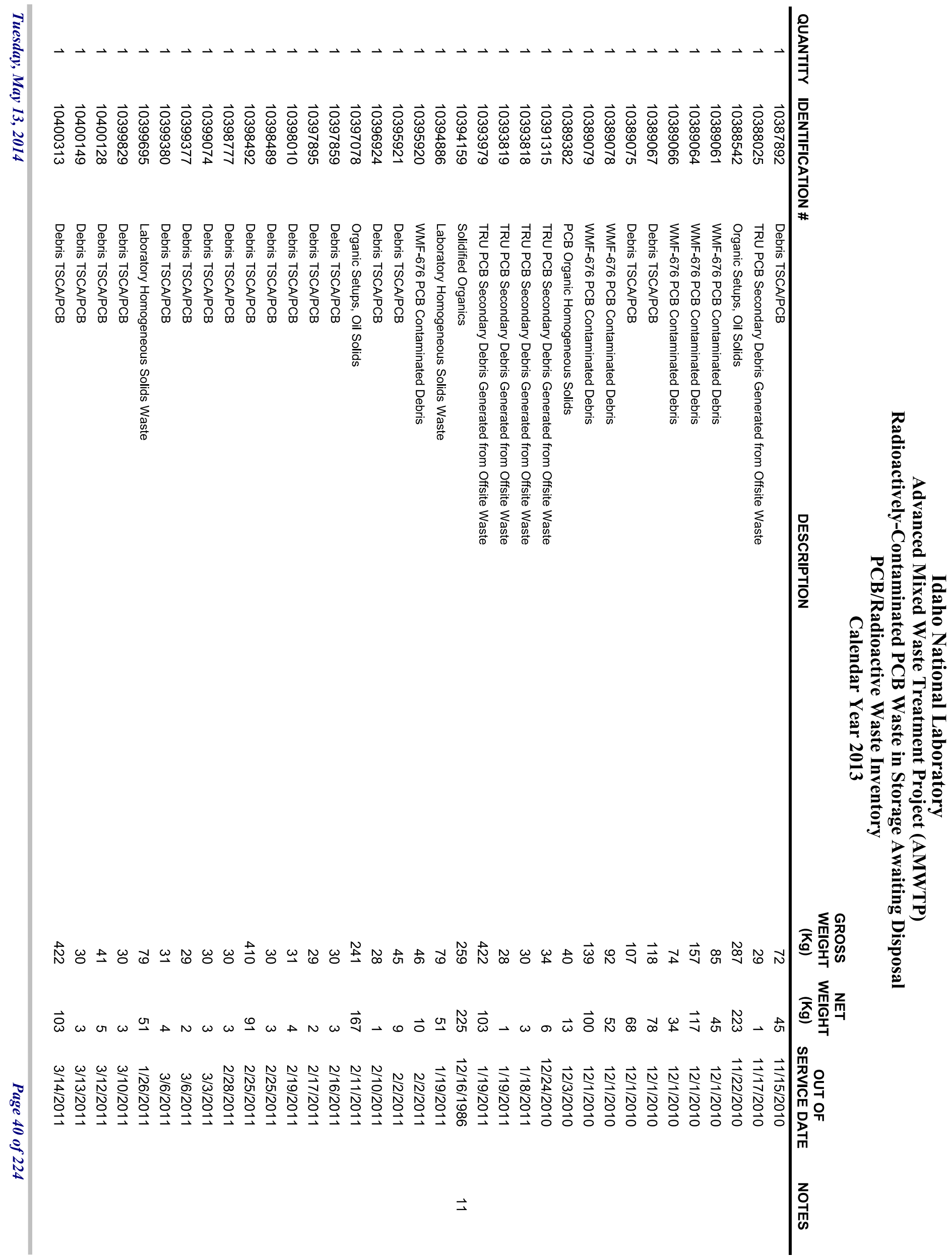




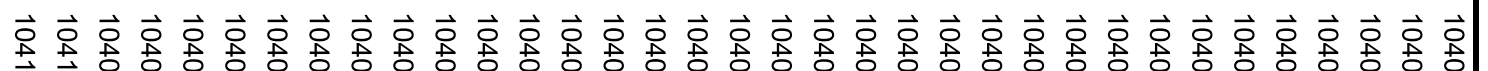

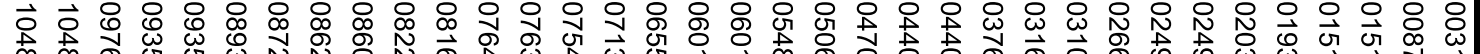

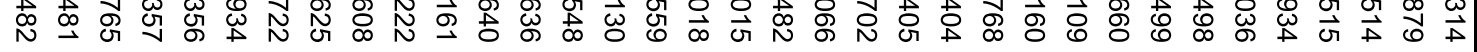

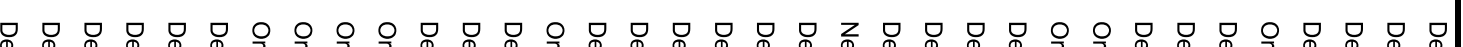

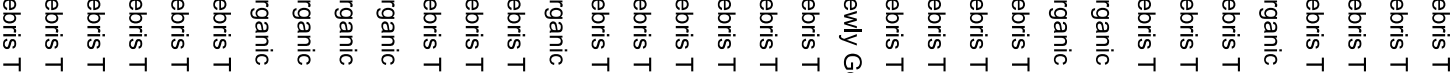

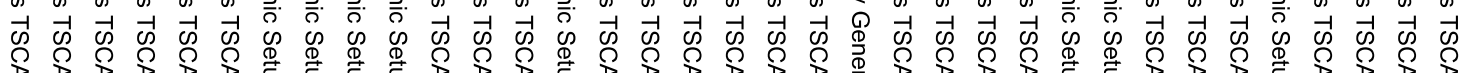

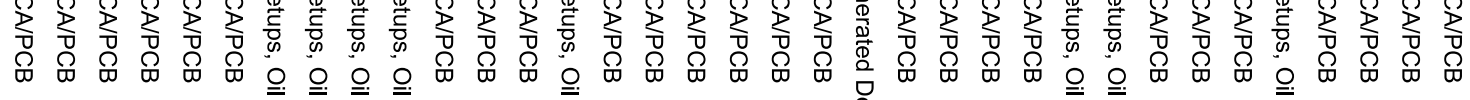

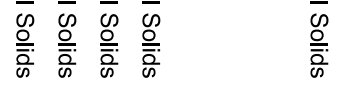

$\omega \omega \omega \omega$

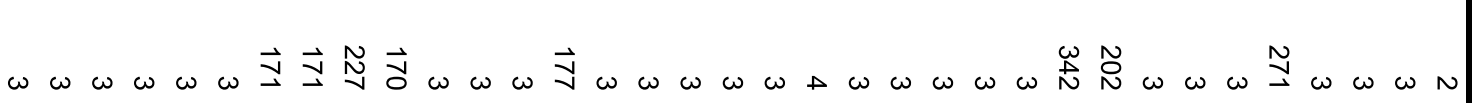

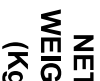

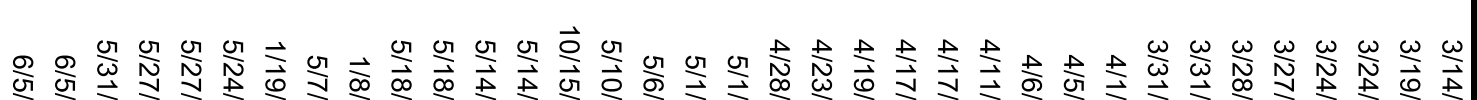

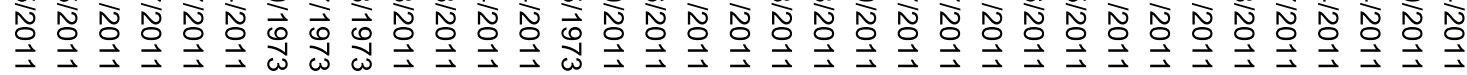




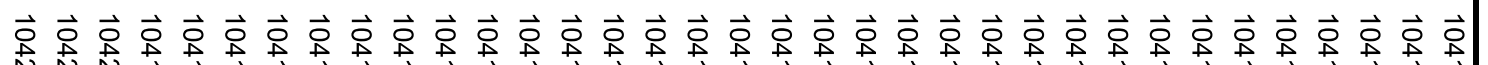

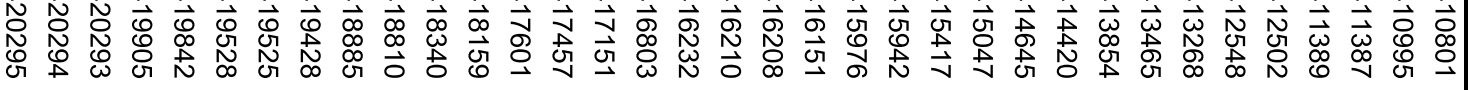

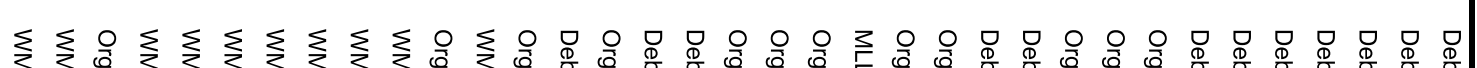

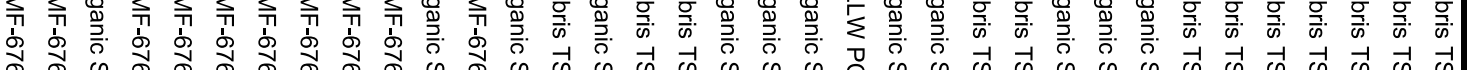

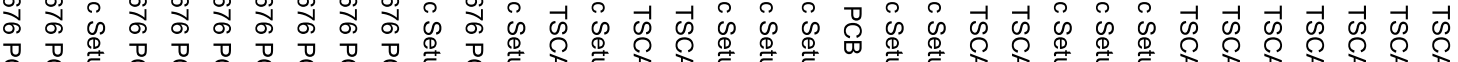

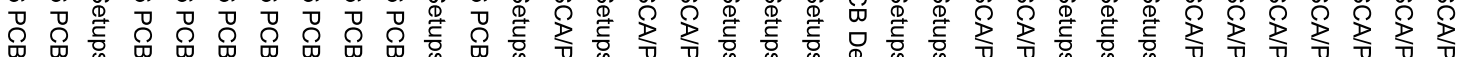

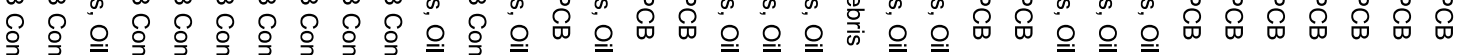

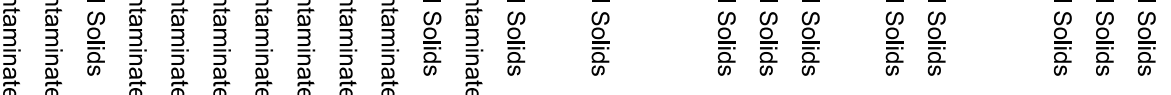

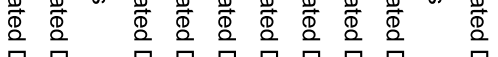

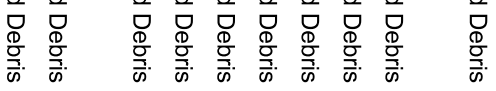

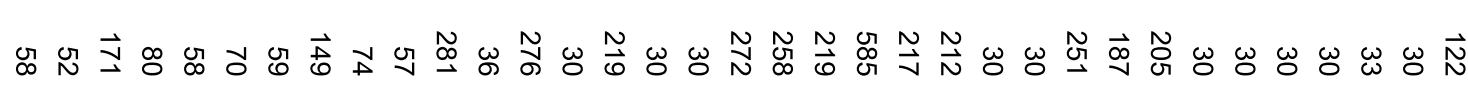

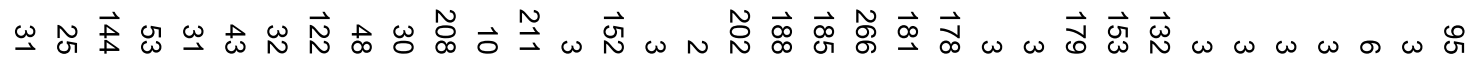
$\sum_{z}$ 츠을

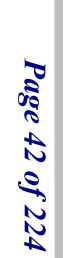

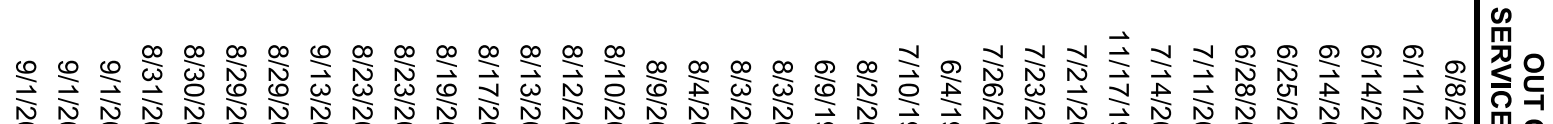

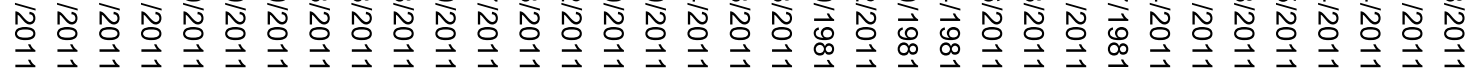




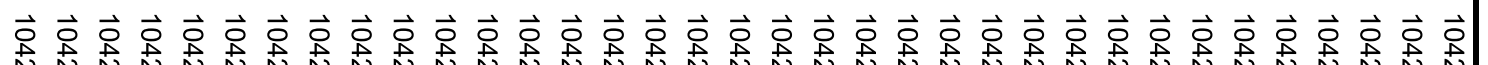

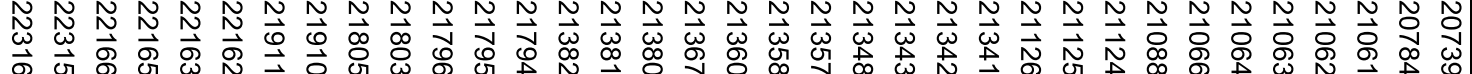

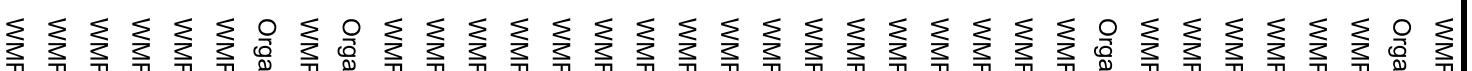
ஸे

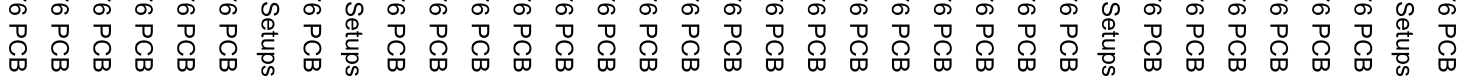

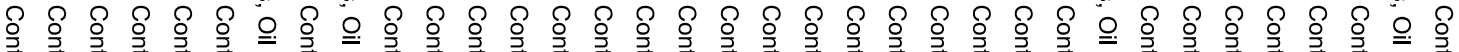

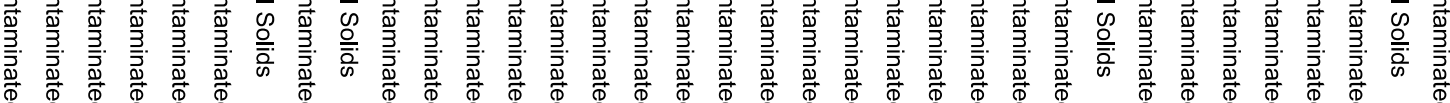

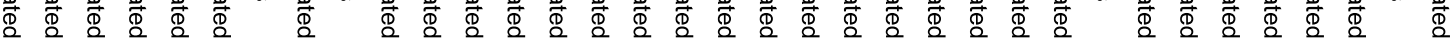

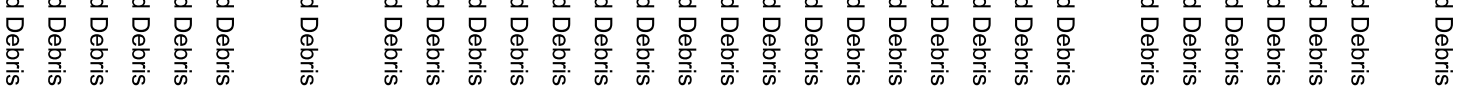

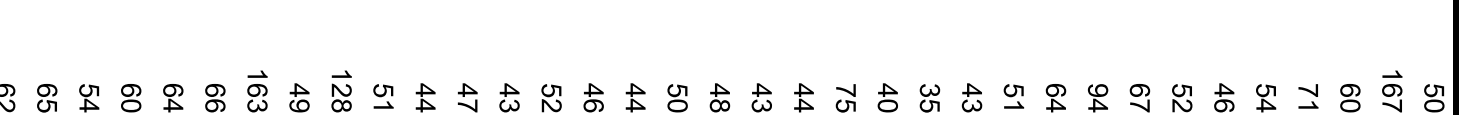




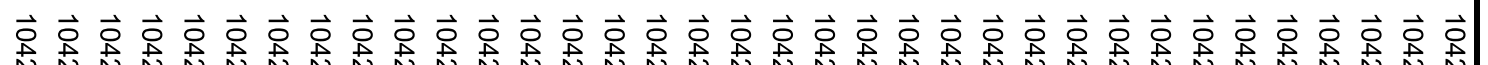

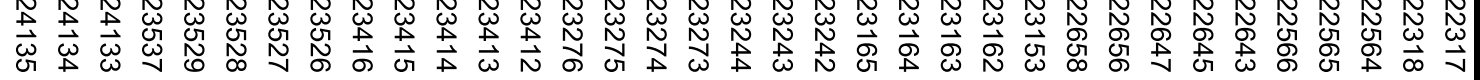

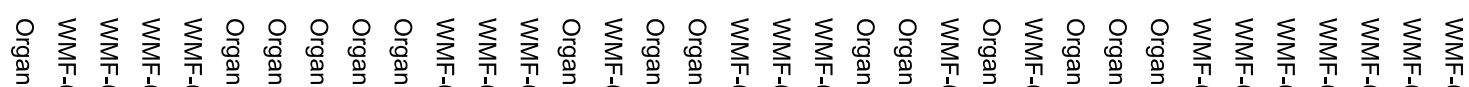
స.

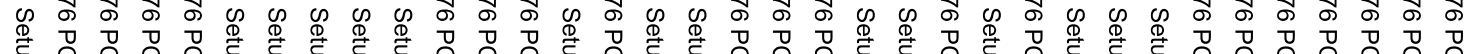

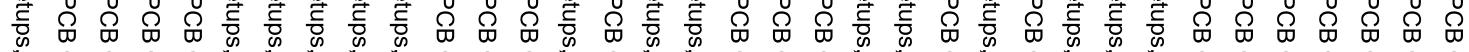

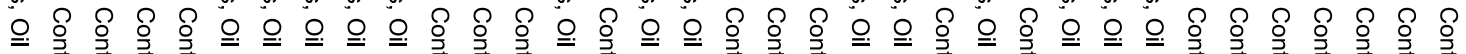

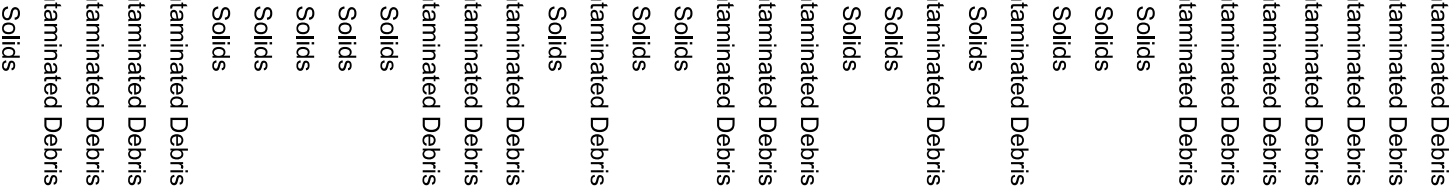

(1)

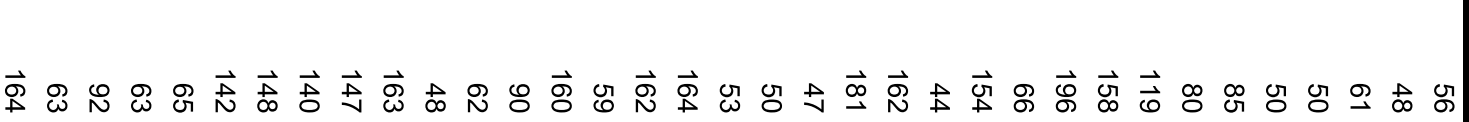




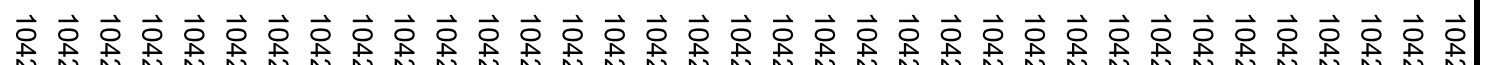

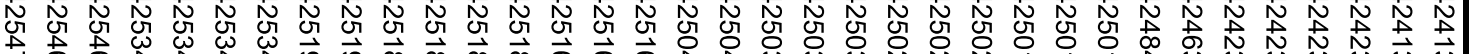

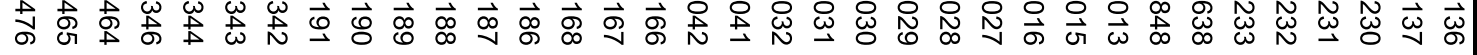

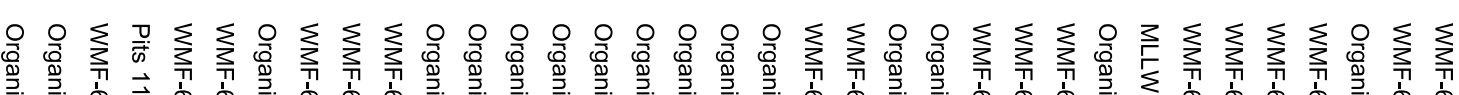
产.

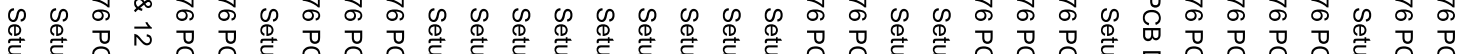

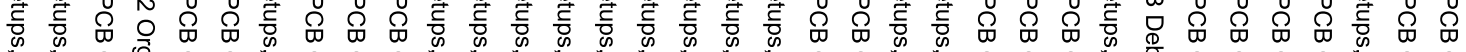

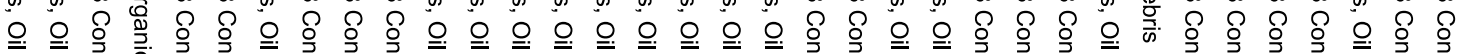

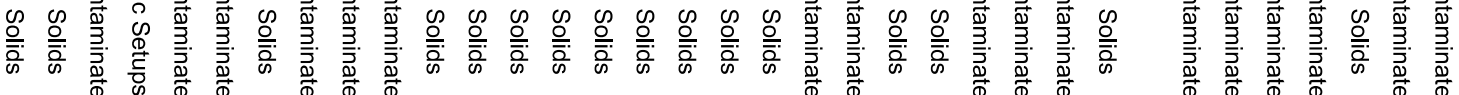

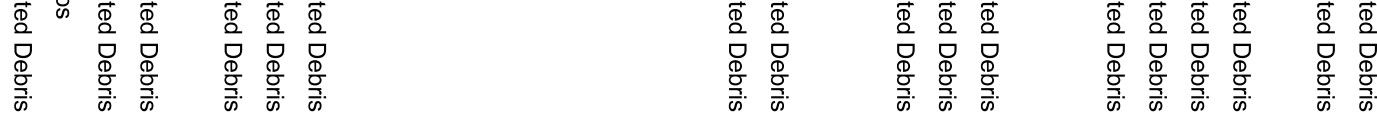

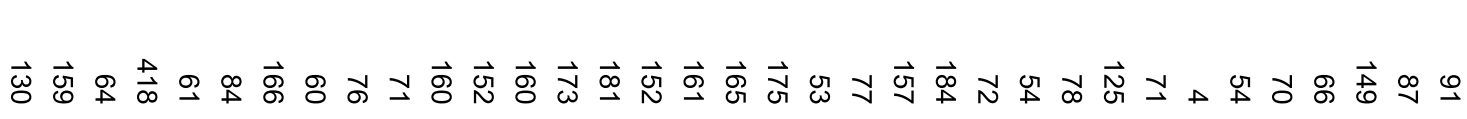

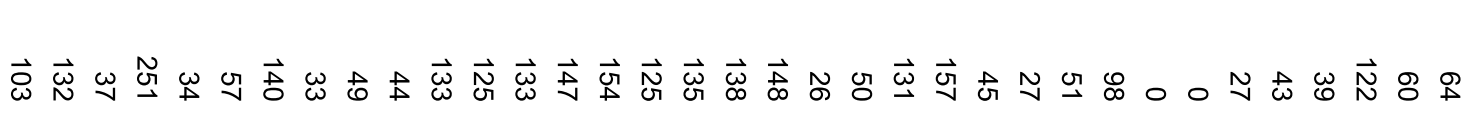

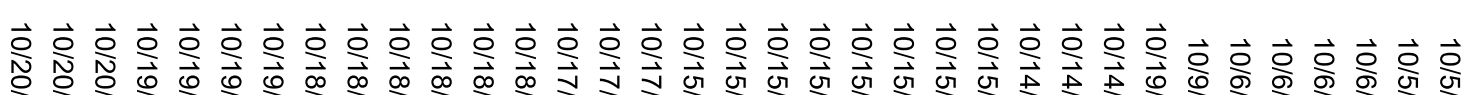




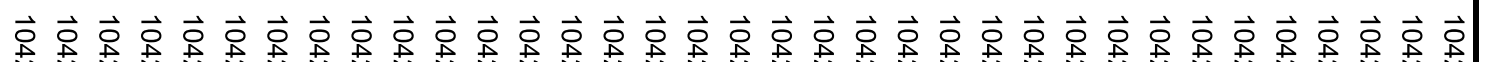
N $\mathcal{O}$ 虽

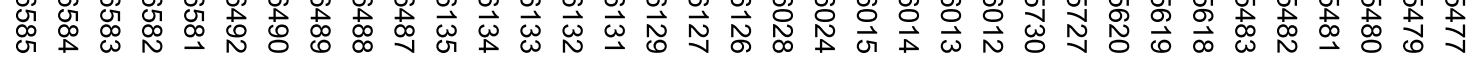

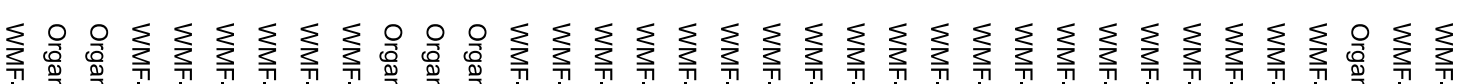

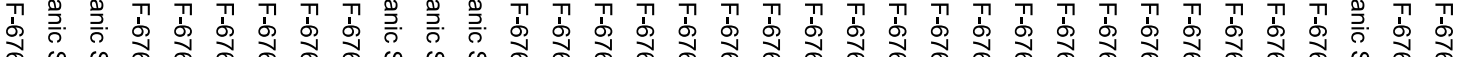
م.

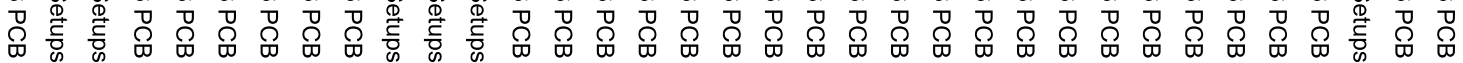

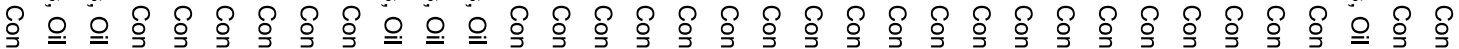

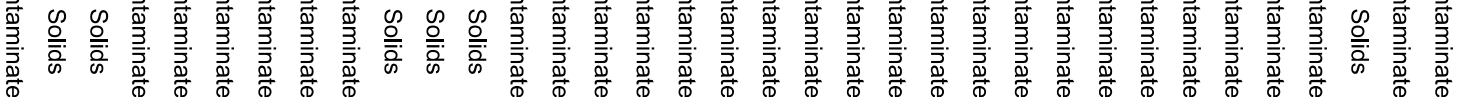

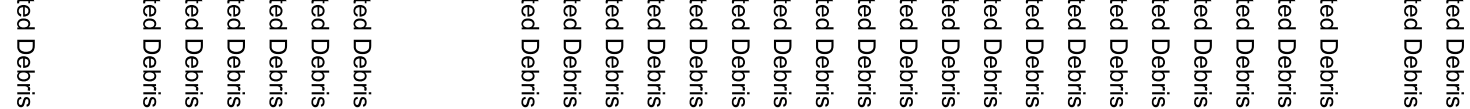

œ $\vec{\omega} \vec{d}$

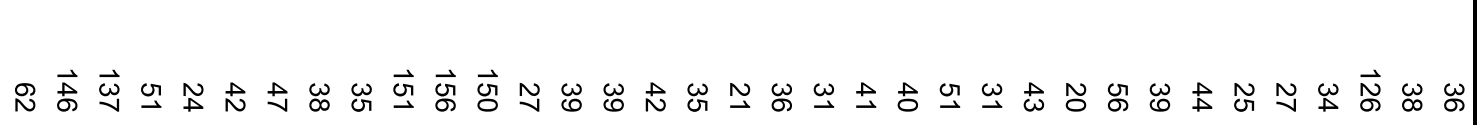
囬兴

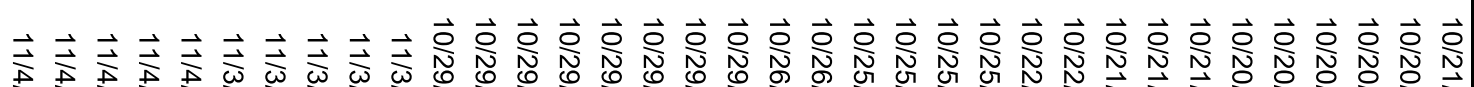


$\vec{\circ} \vec{\circ} \vec{\circ} \vec{\circ} \vec{\circ} \vec{\circ} \vec{\circ} \vec{\circ} \vec{\circ} \vec{\circ} \vec{\circ} \vec{\circ} \vec{\circ} \vec{\circ} \vec{\circ} \vec{\circ} \vec{\circ} \vec{\circ} \vec{\circ} \vec{\circ} \vec{\circ} \vec{\circ} \vec{\circ} \vec{\circ} \vec{\circ} \vec{\circ} \vec{\circ}$ 언

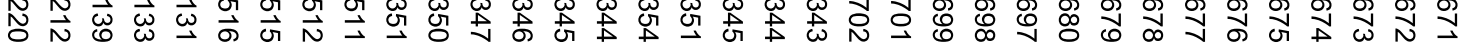

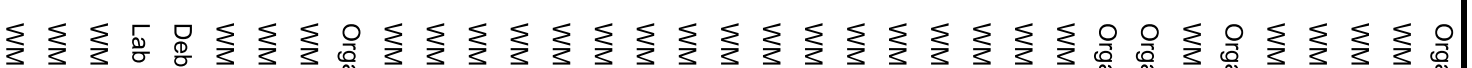

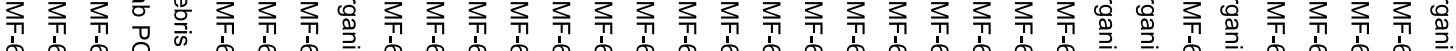

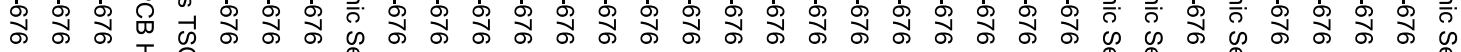

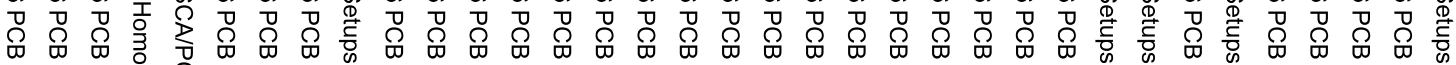
§ $९$ ○

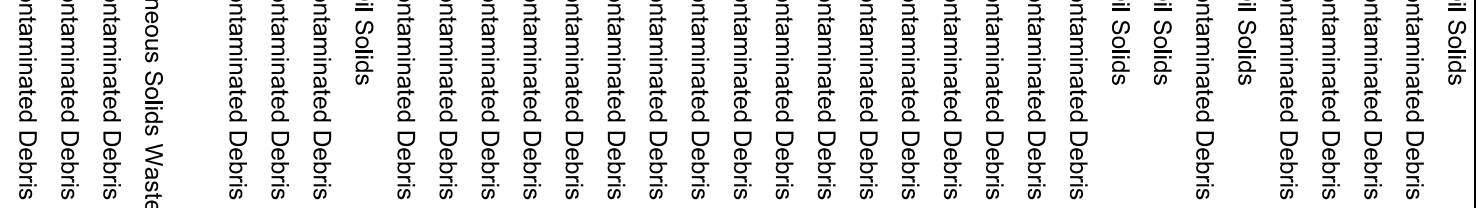

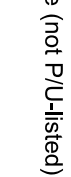

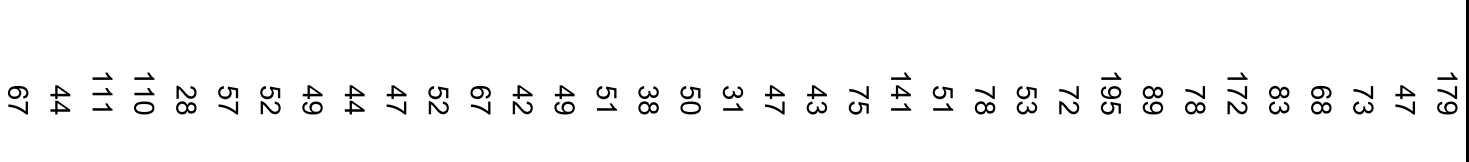

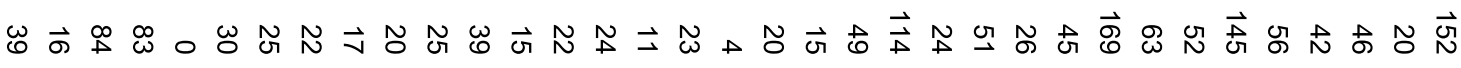
츠으.

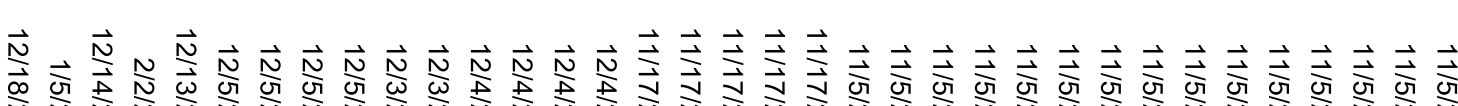


$\vec{\circ} \vec{\circ} \vec{\circ} \vec{\circ} \vec{\circ} \vec{\circ} \vec{\circ} \vec{\circ} \vec{\circ} \vec{\circ} \vec{\circ} \vec{\circ} \vec{\circ} \vec{\circ} \vec{\circ} \vec{\circ} \vec{\circ} \vec{\circ} \vec{\circ} \vec{\circ} \vec{\circ} \vec{\circ} \vec{\circ} \vec{\circ} \vec{\circ} \vec{\circ} \vec{\circ}$

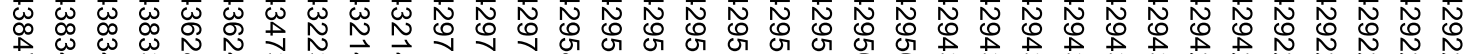

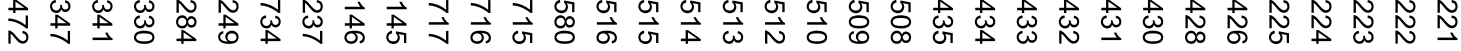

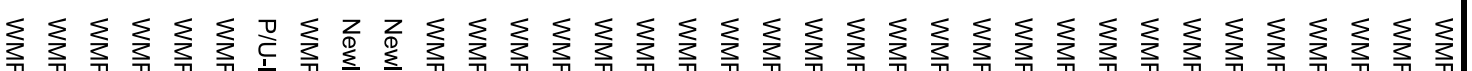
ఏ่

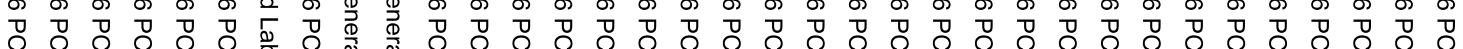
権 ○

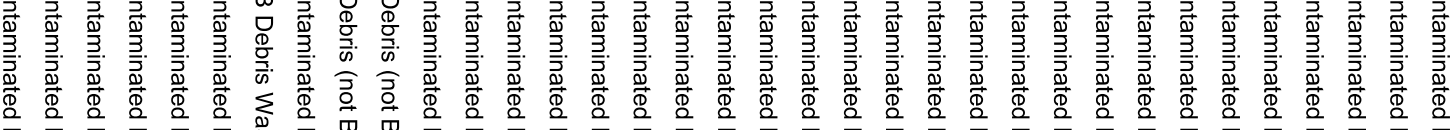

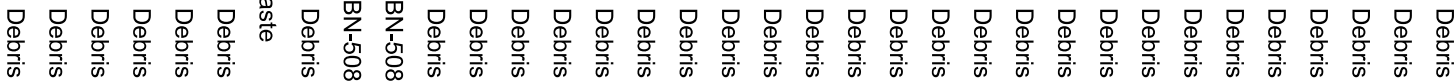

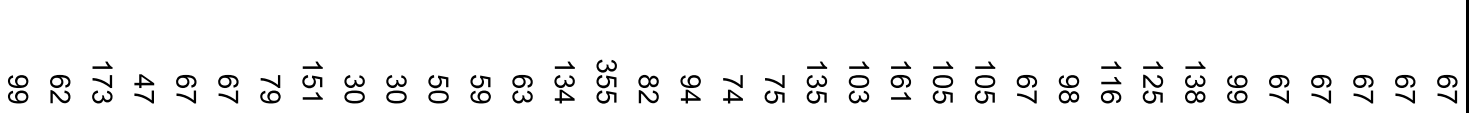

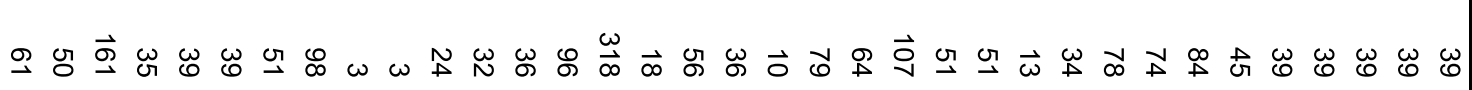

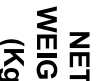

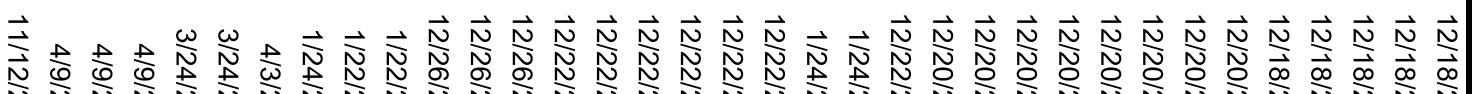
O

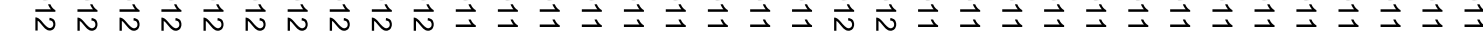




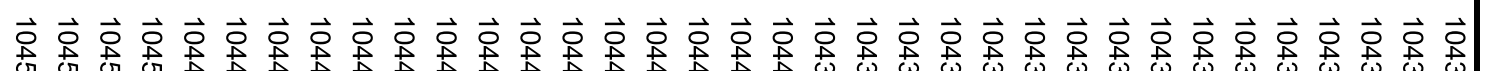

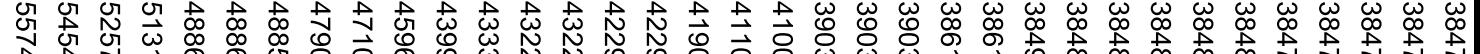

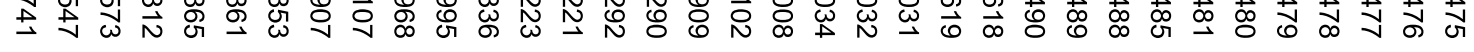

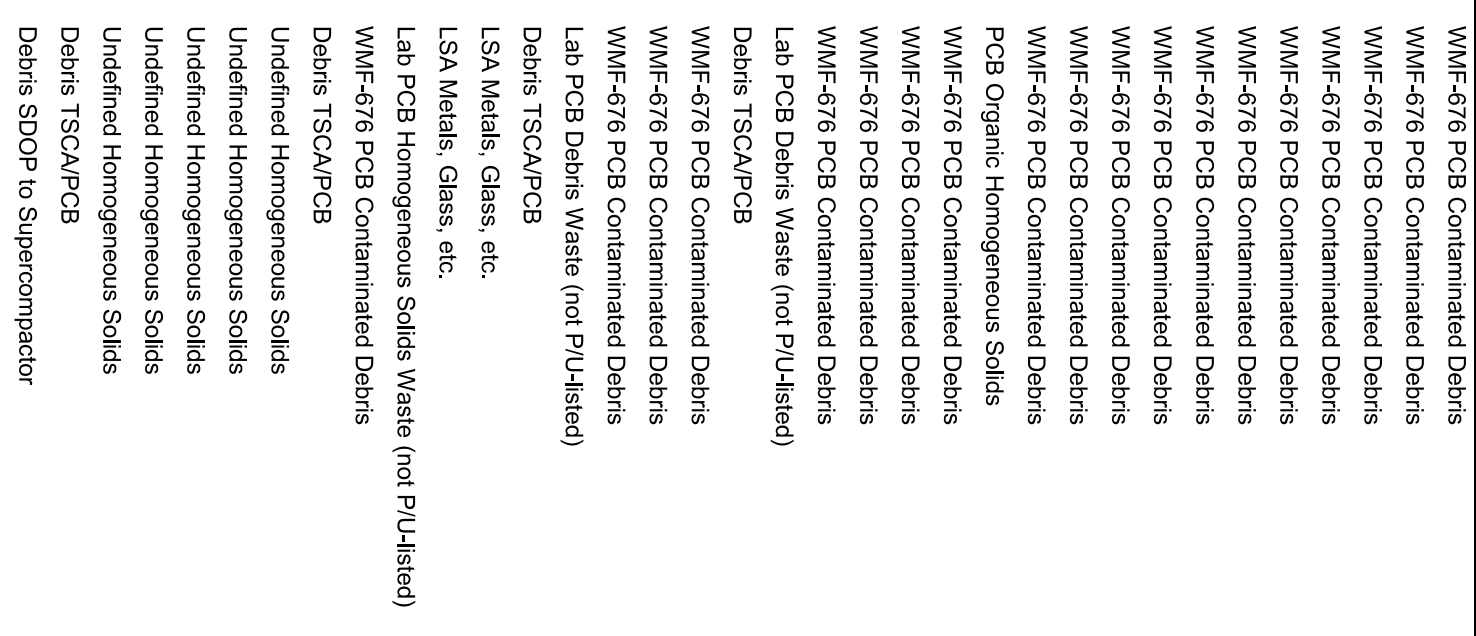

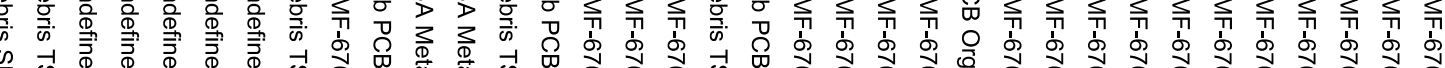

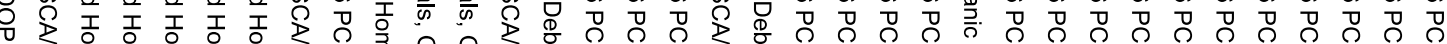




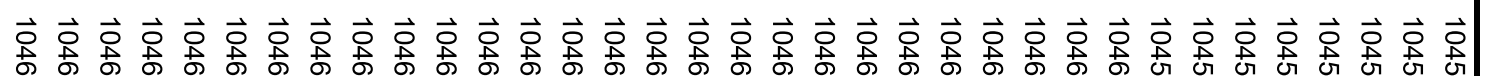

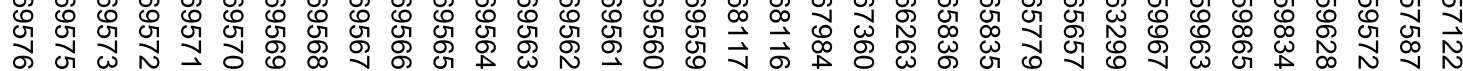

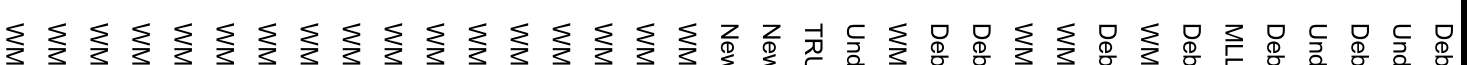

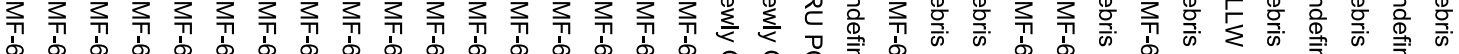

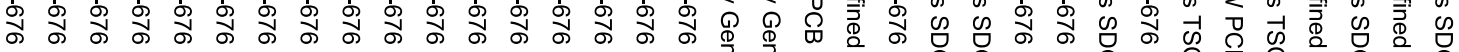

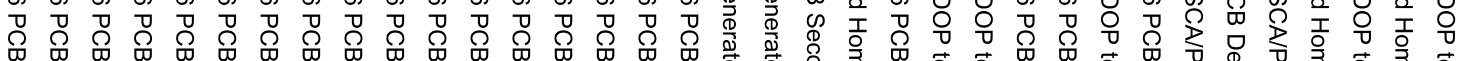

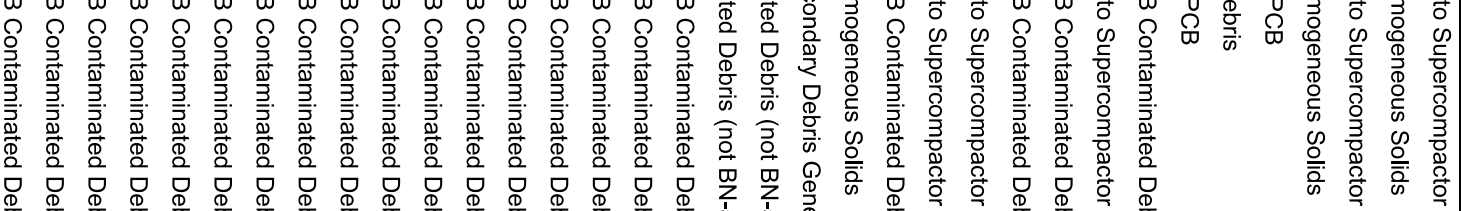

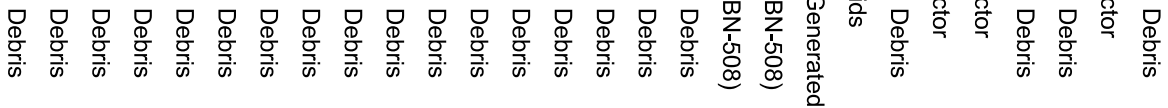

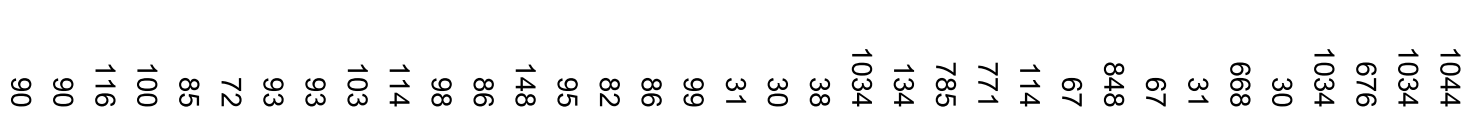

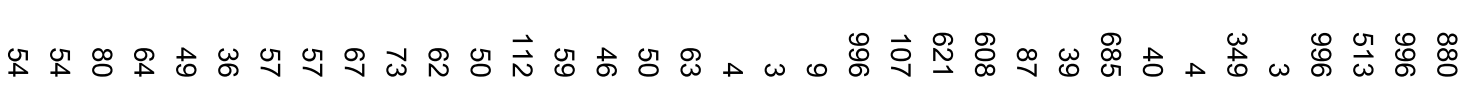

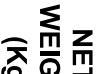

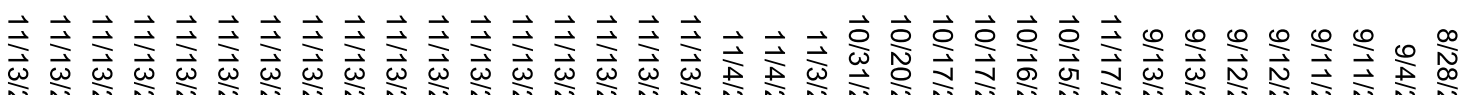

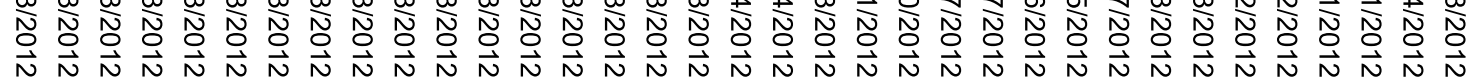

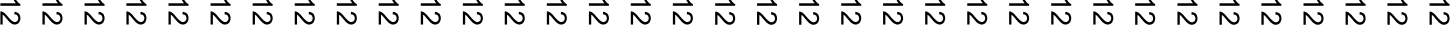




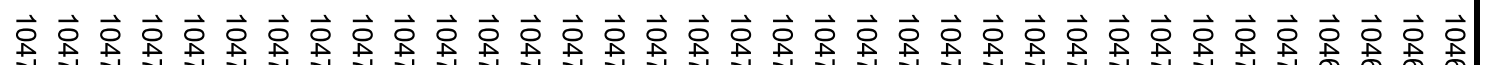

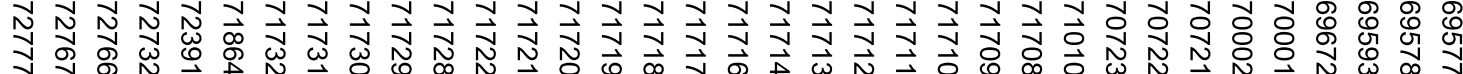

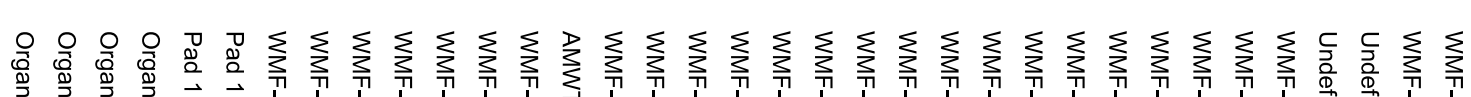

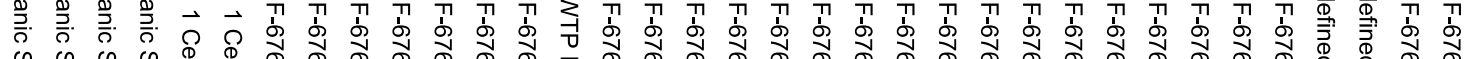

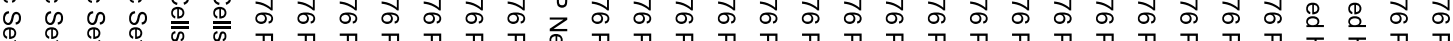

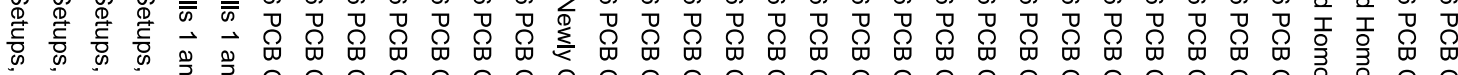
$\circ 0$

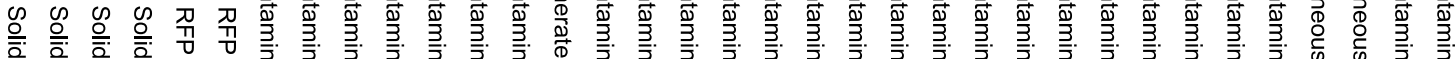

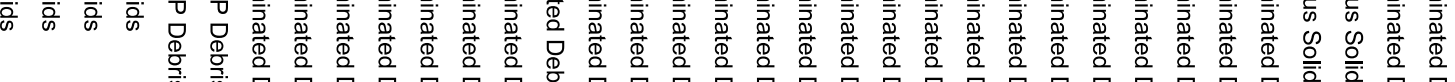

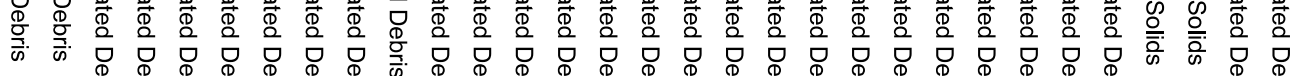

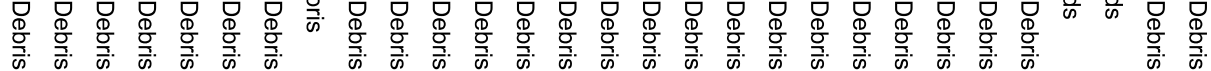

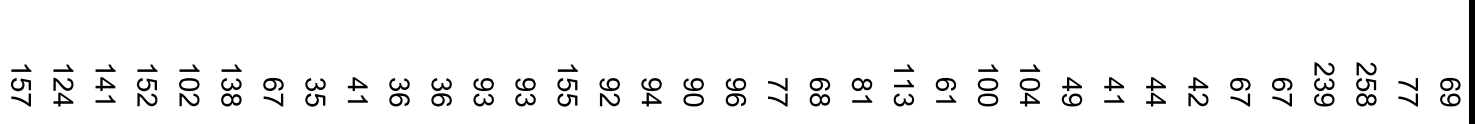

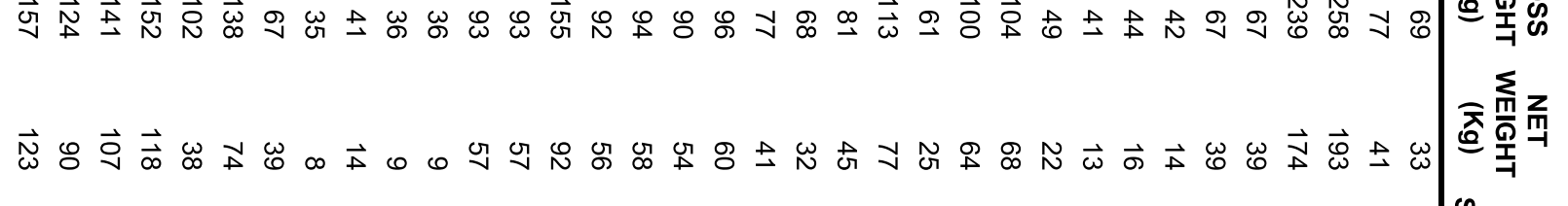

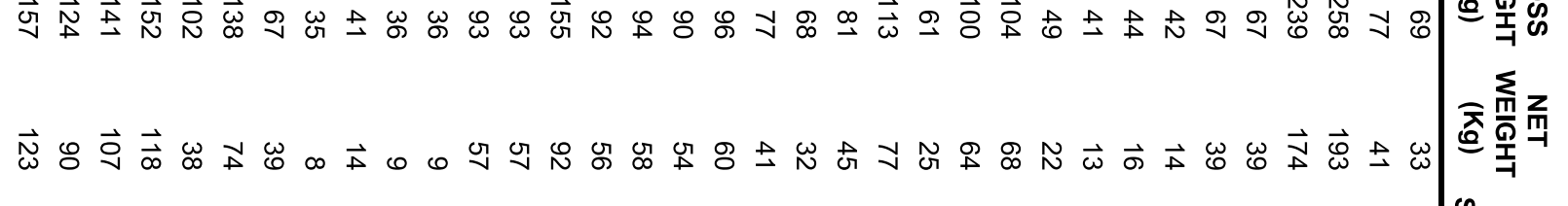

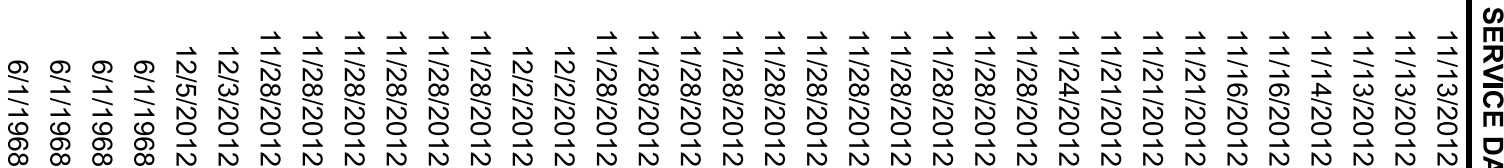




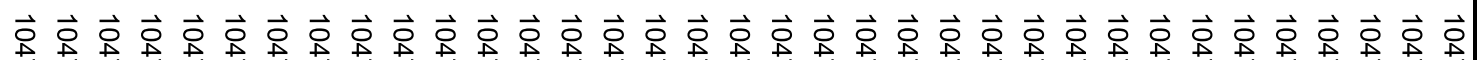
仓ै ○

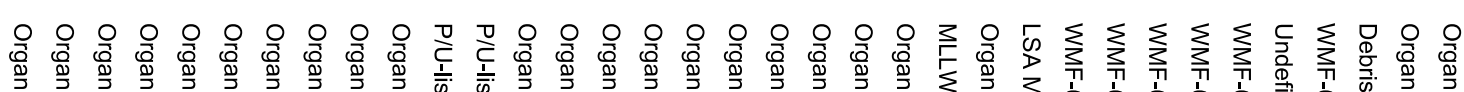

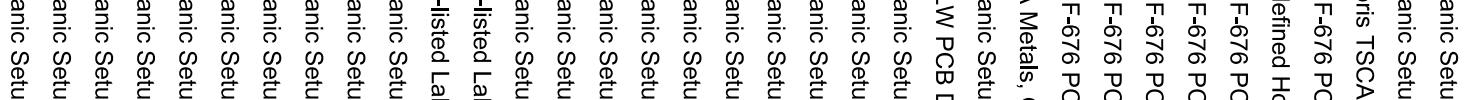

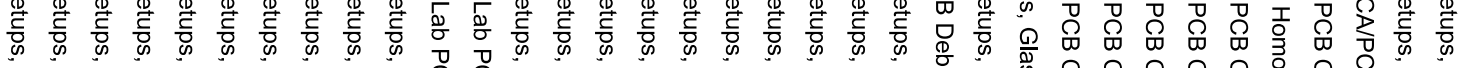

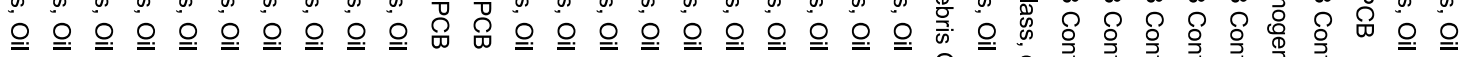

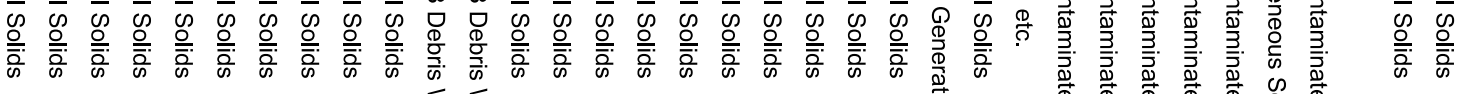

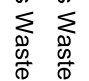

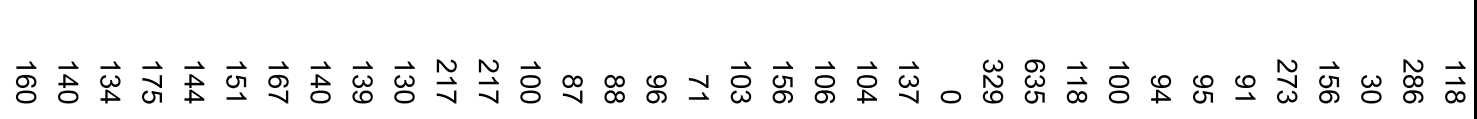

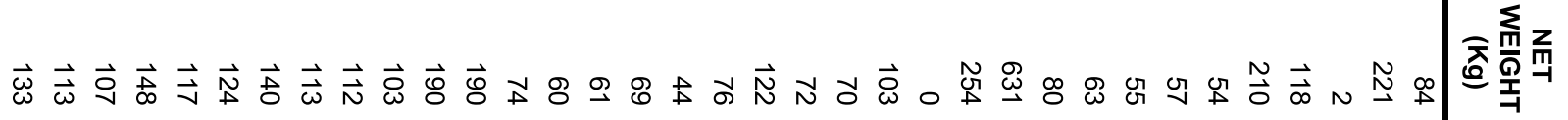

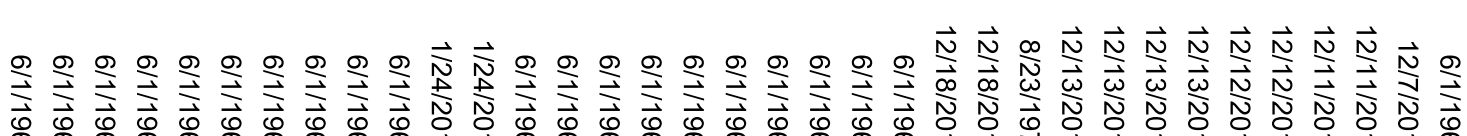

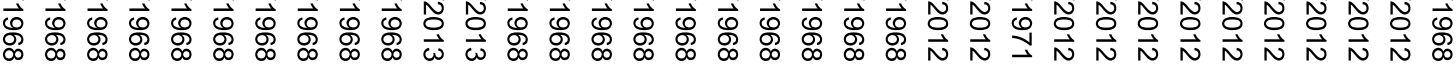




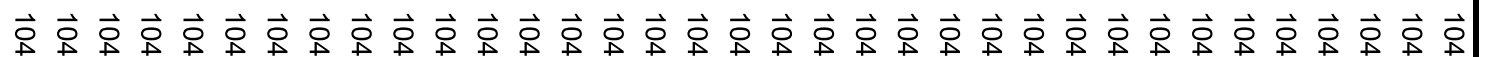

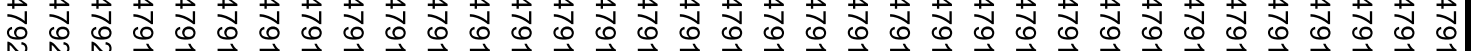

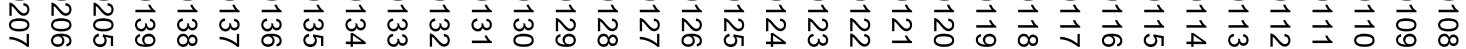

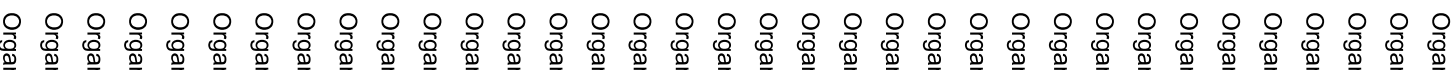

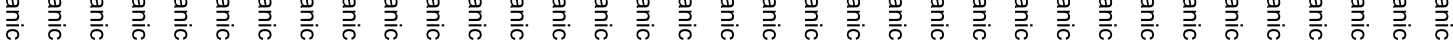

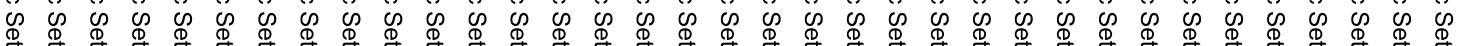

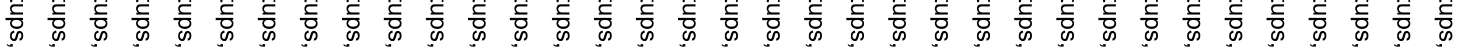

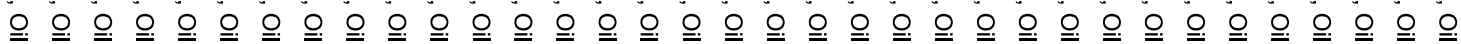

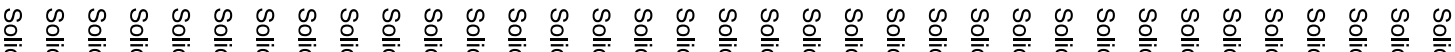

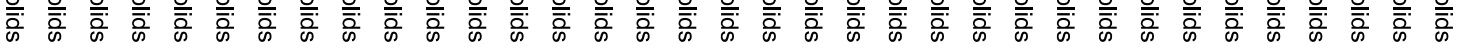

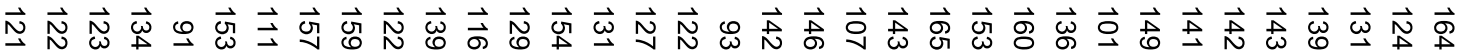




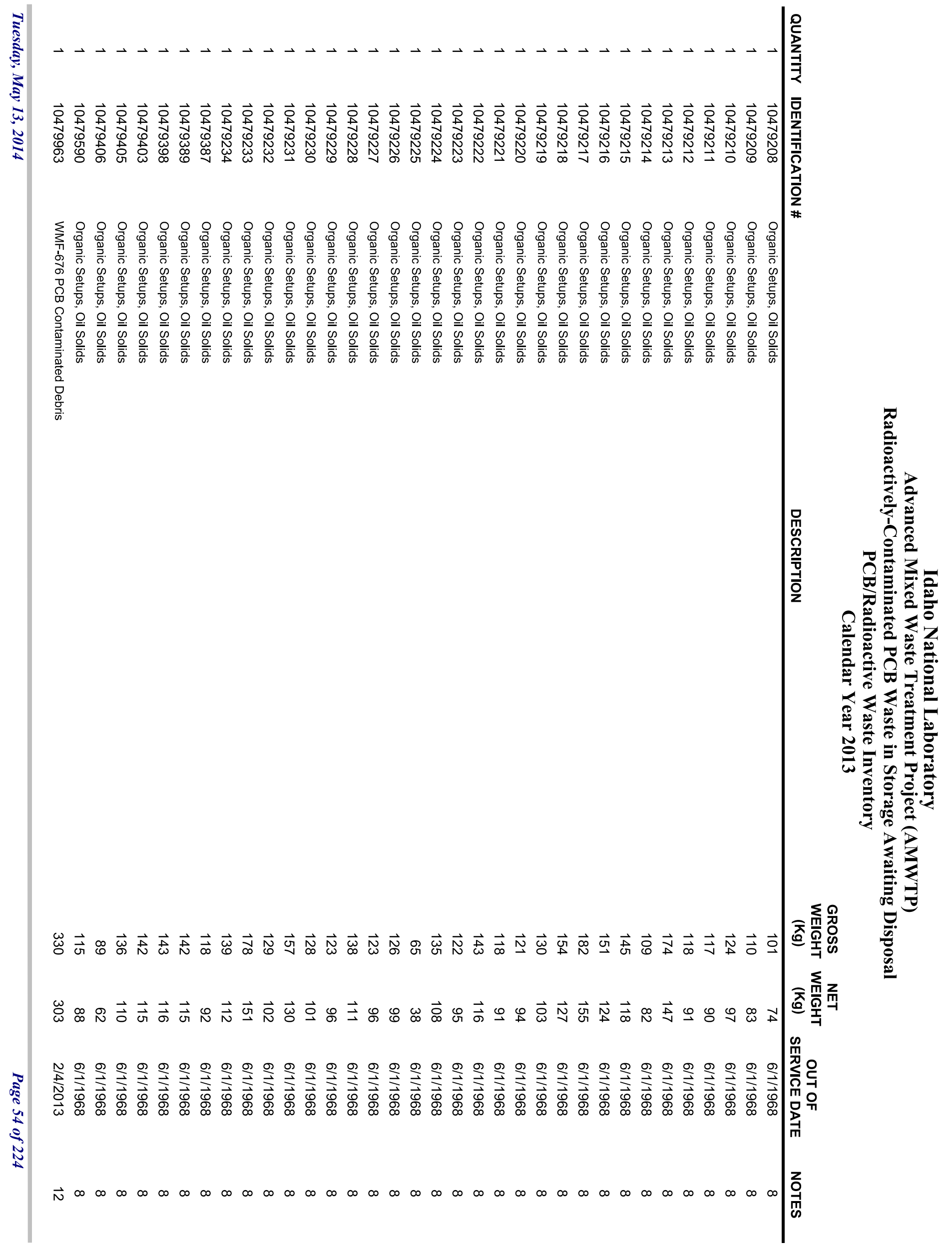




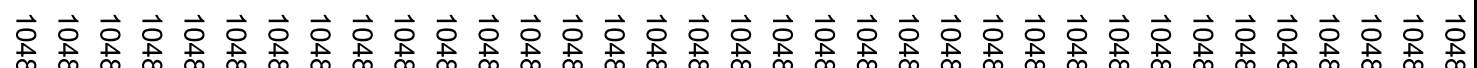

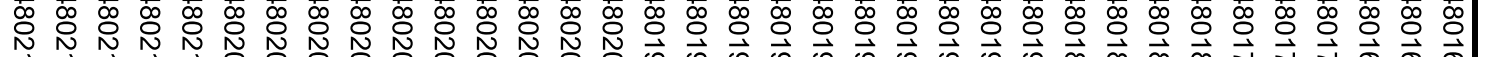

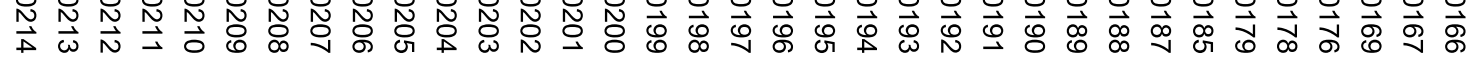

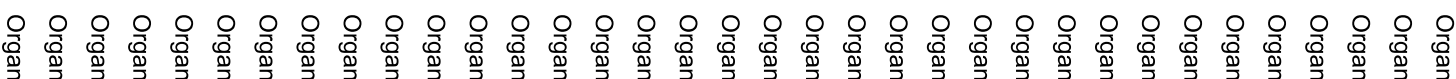

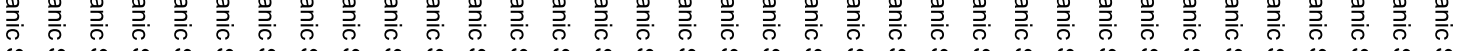

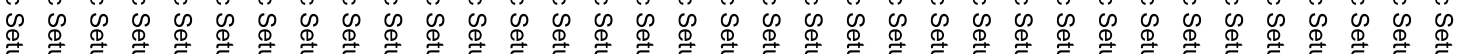

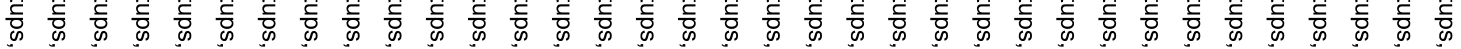

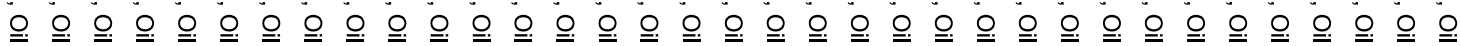

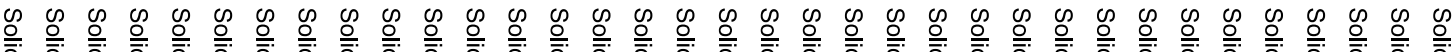

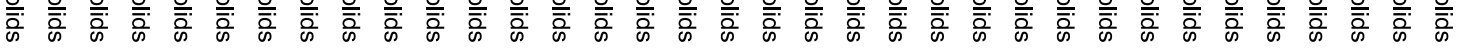

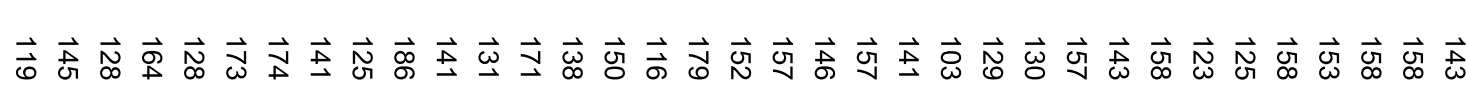




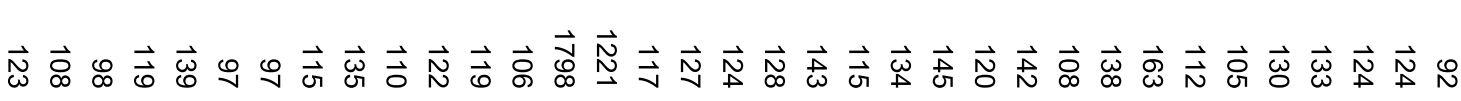




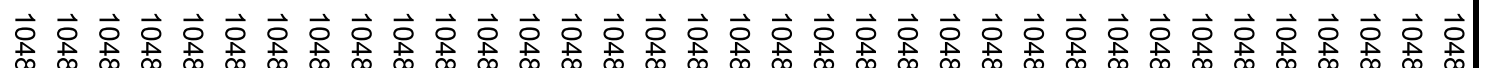

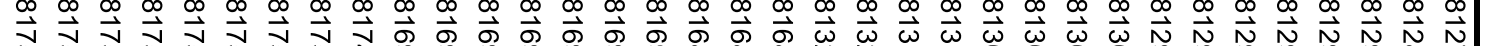
讨 出

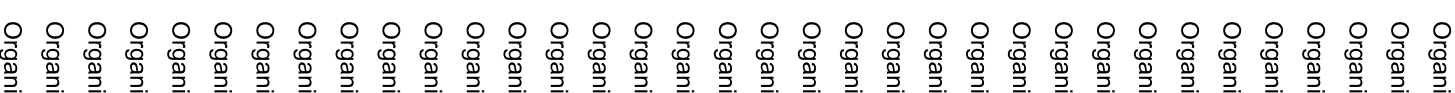

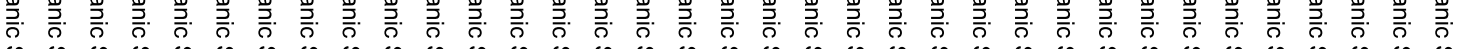

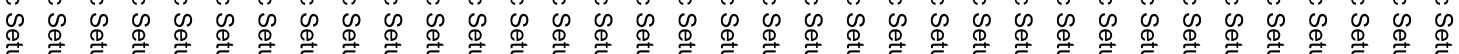

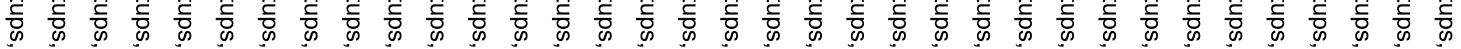

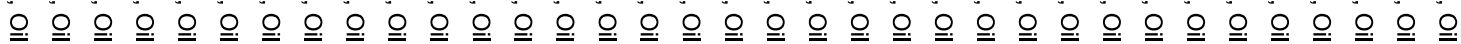

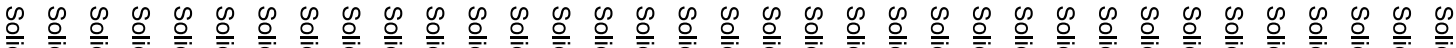

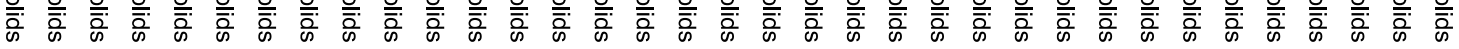

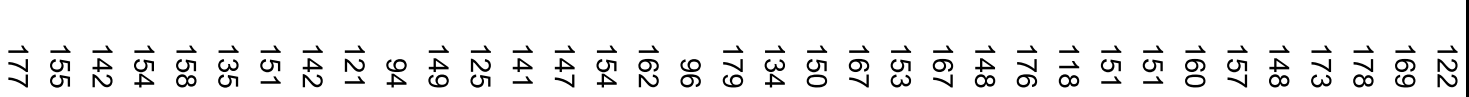




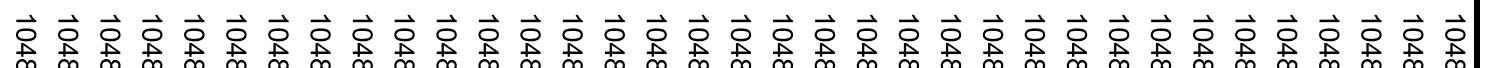
苻

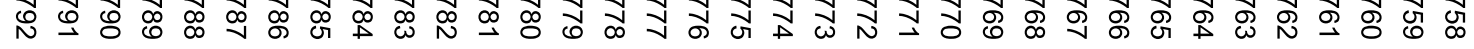

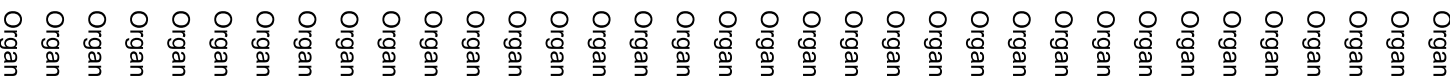

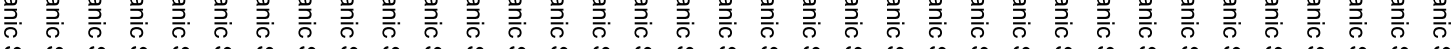

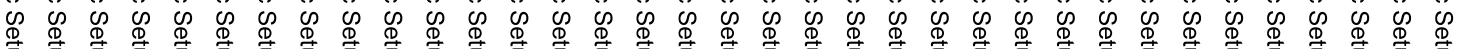

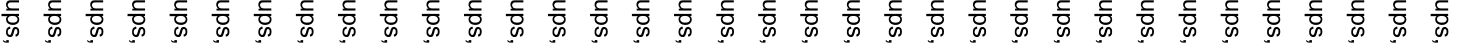

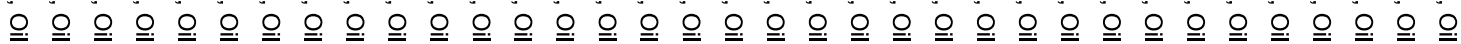

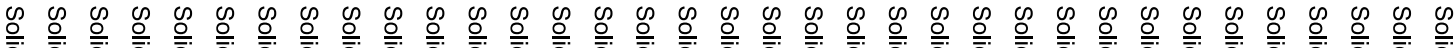

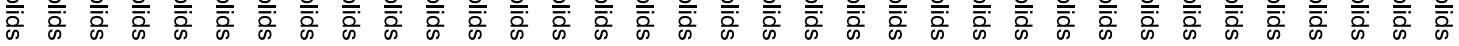

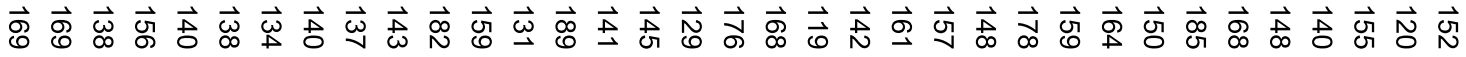




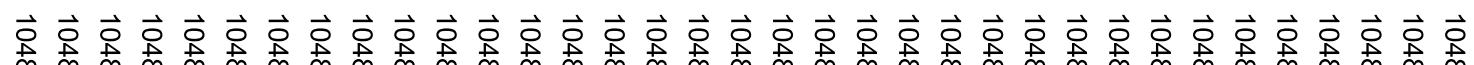

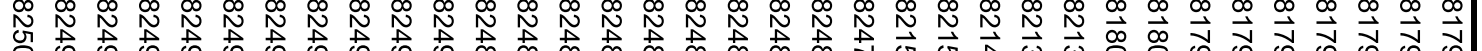

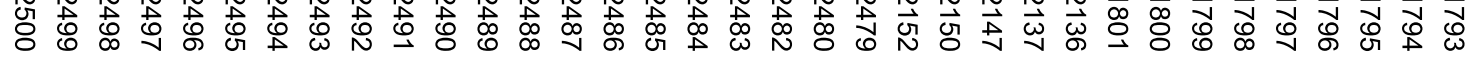

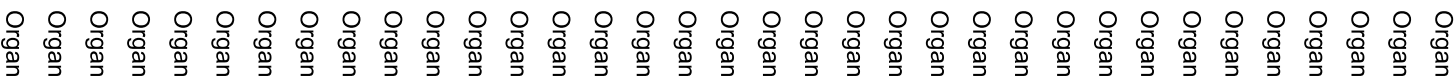

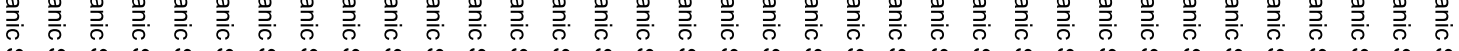

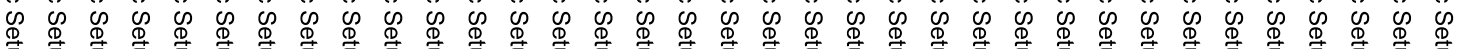

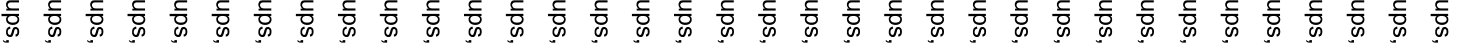

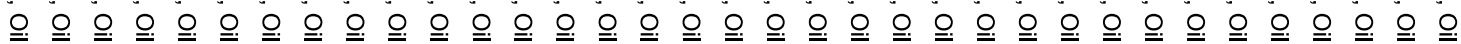

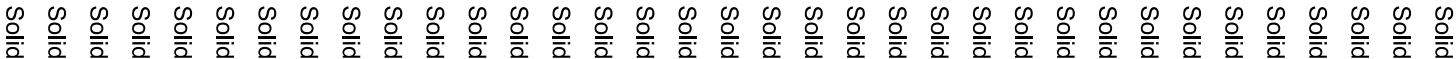

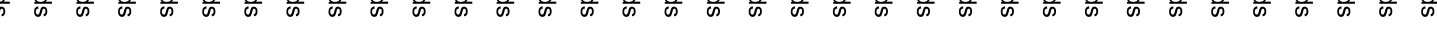

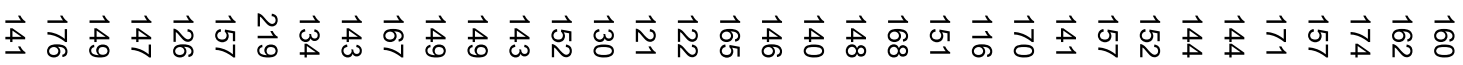

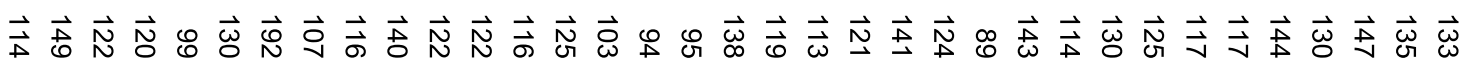
交兴 


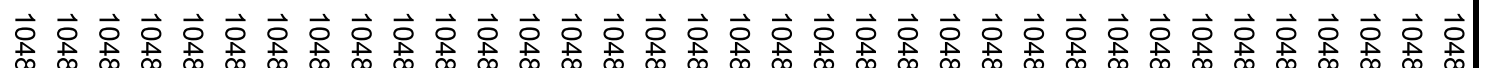

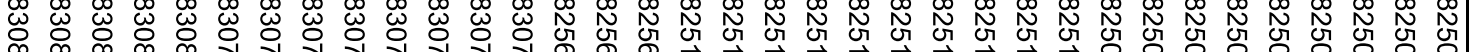

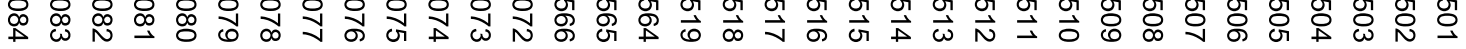

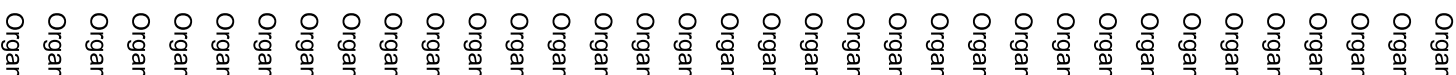

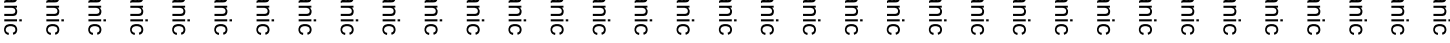

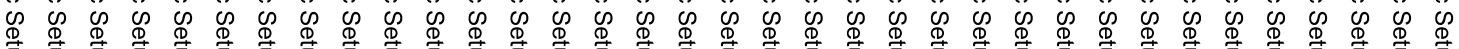
密

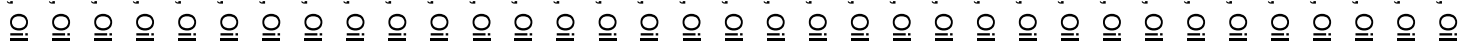

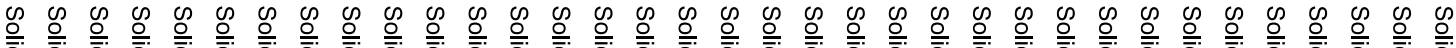

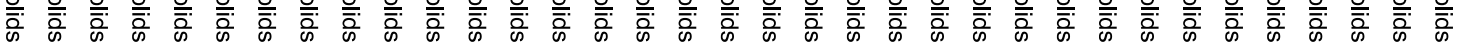

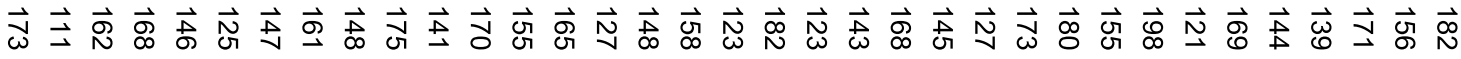




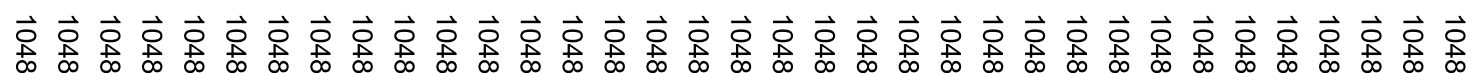

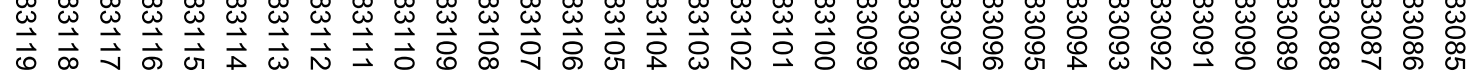

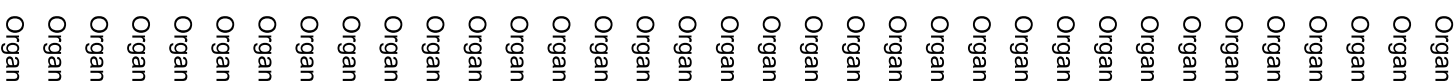

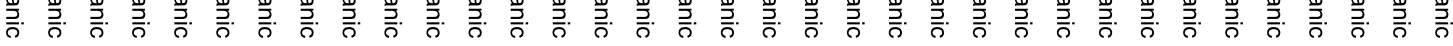

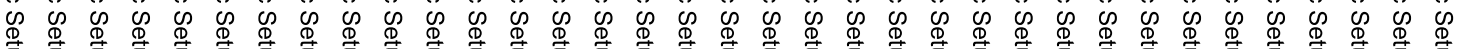
密

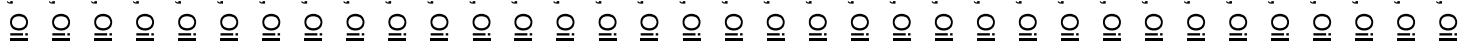

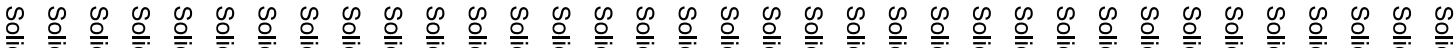

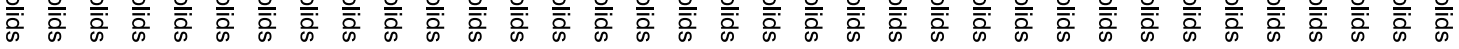

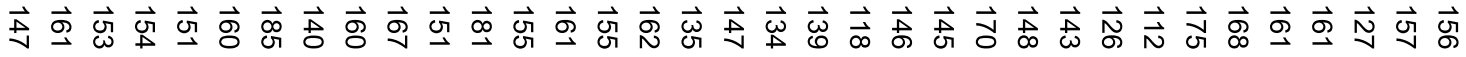




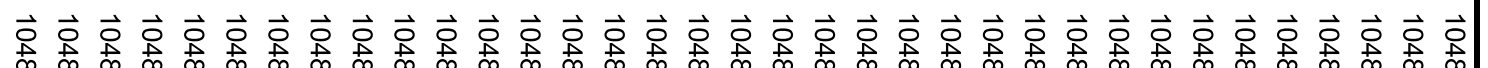

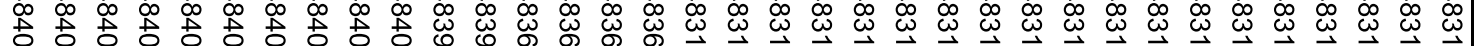

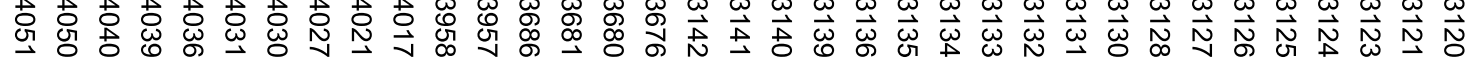

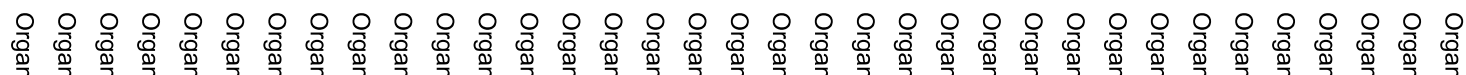

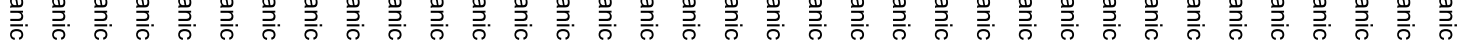

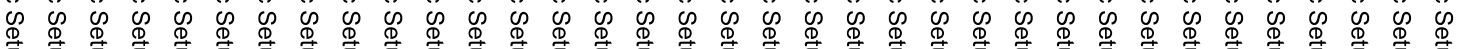
密

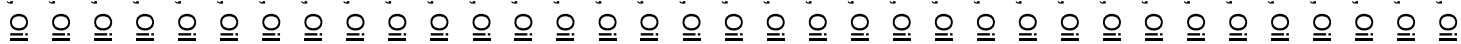

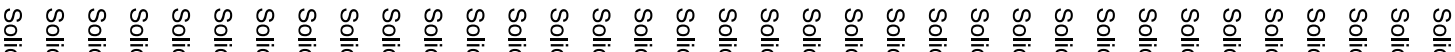

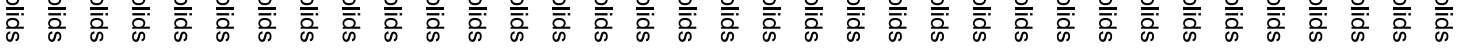

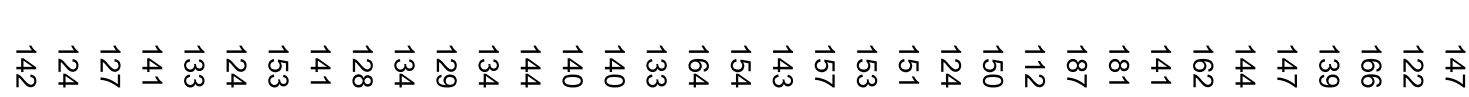




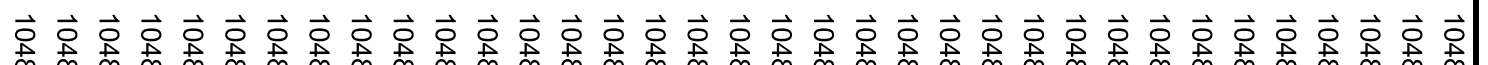

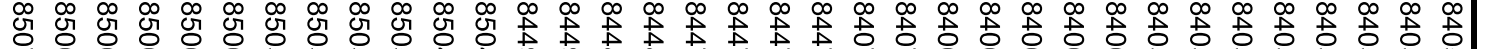

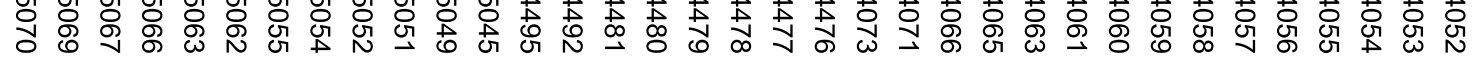

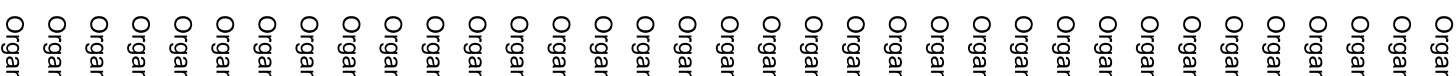

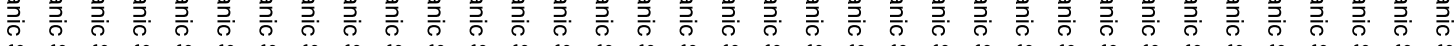

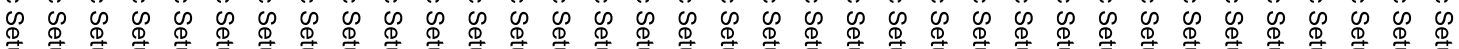
密

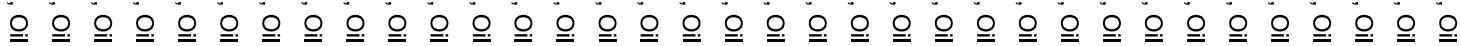

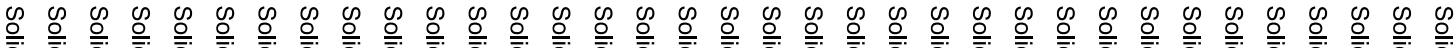

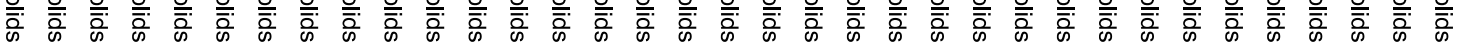

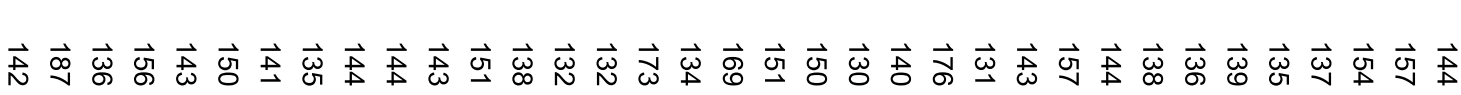

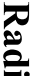




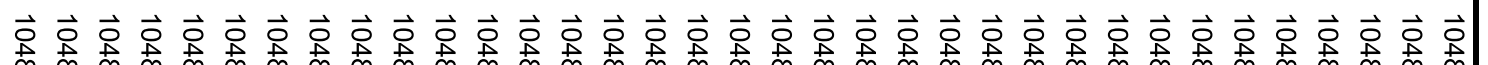

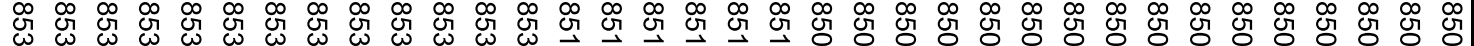

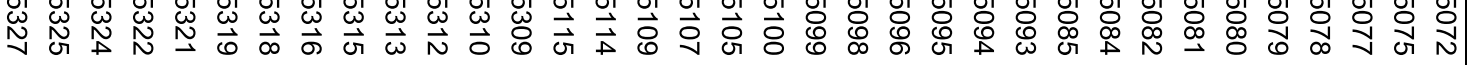

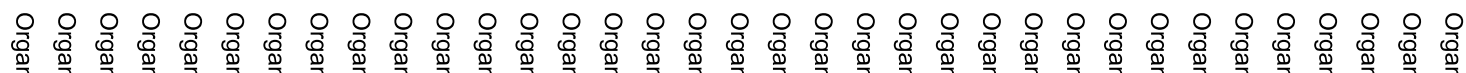

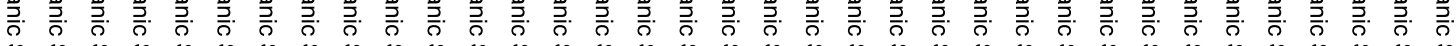

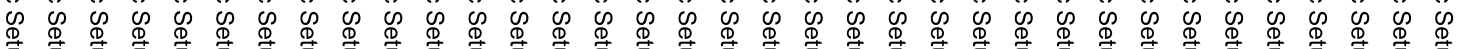

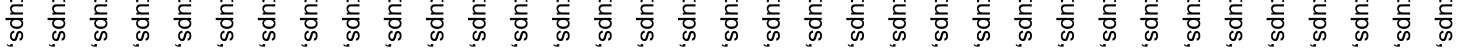

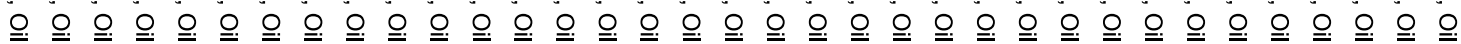

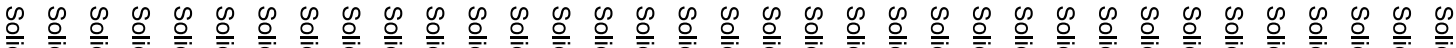

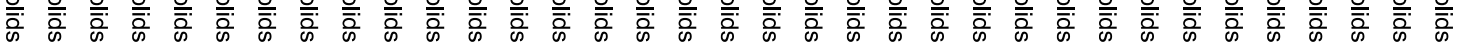

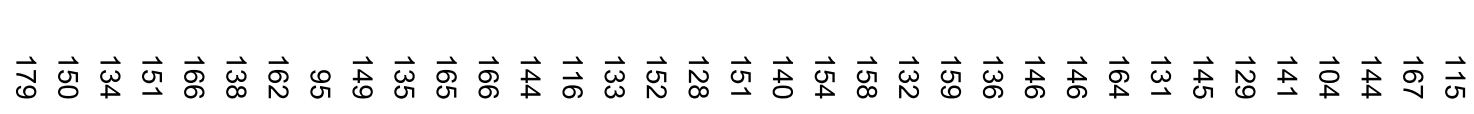




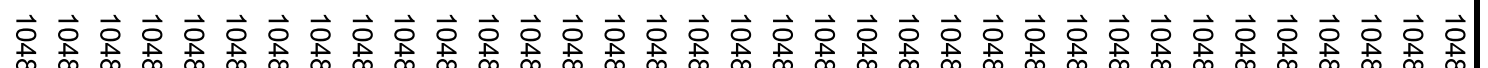

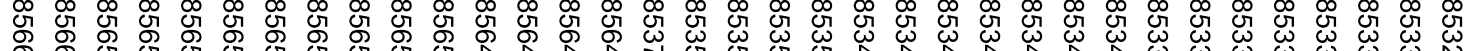

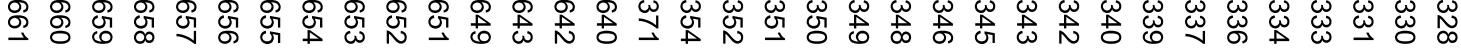

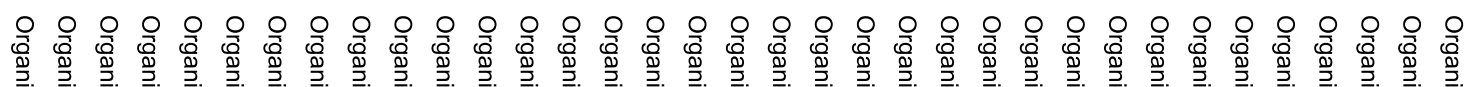

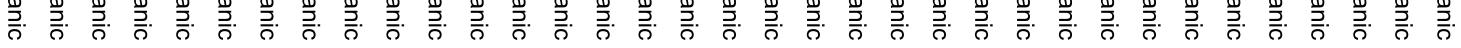

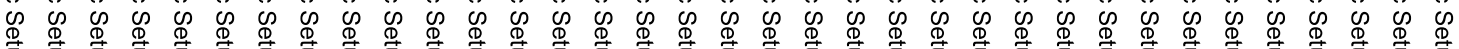
密

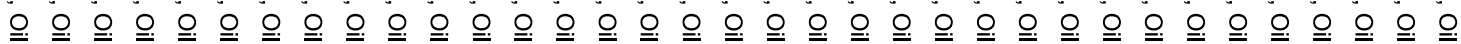

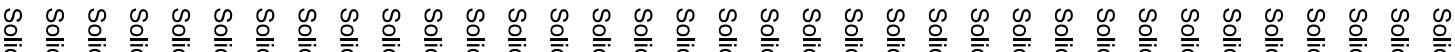

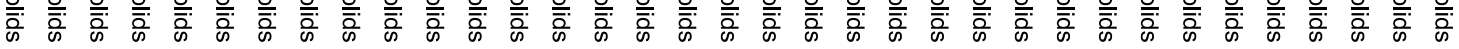

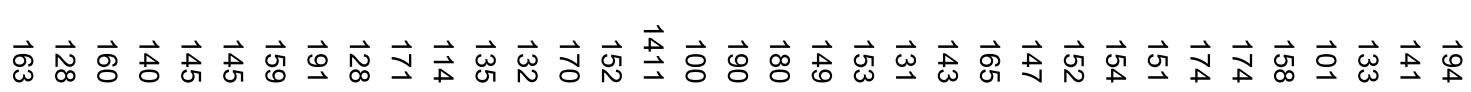




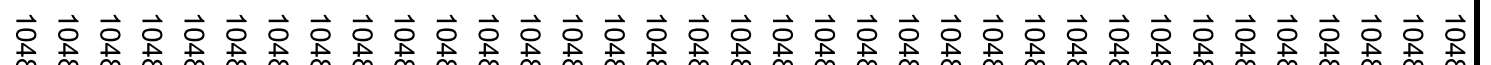

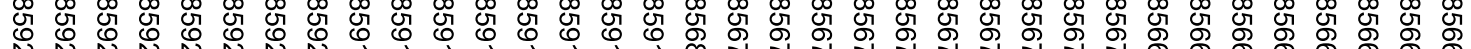
N $N$ N

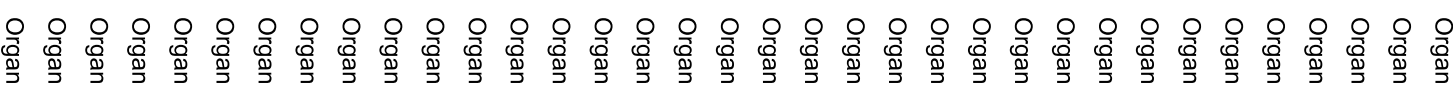

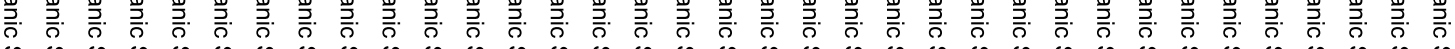

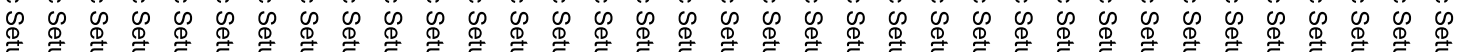
骔

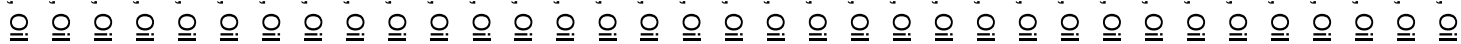

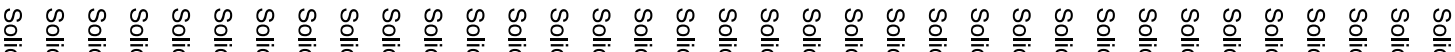

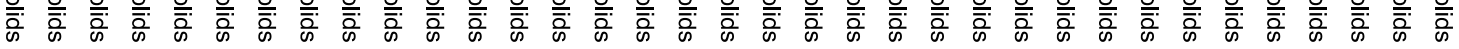

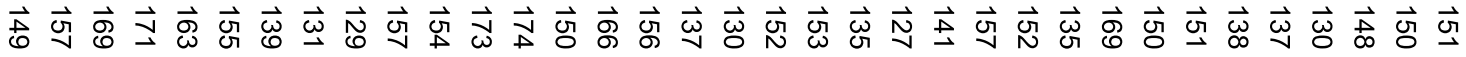




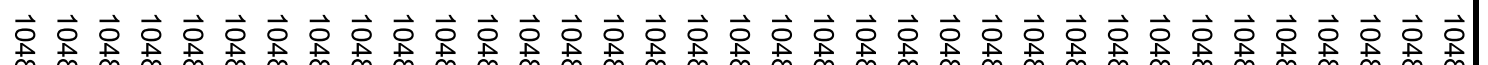

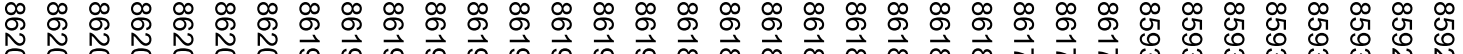

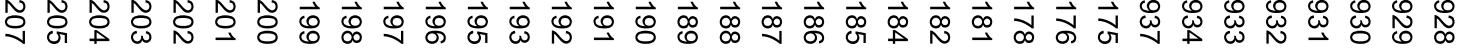

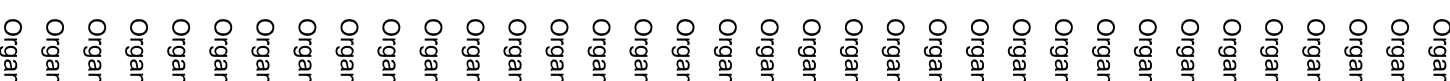

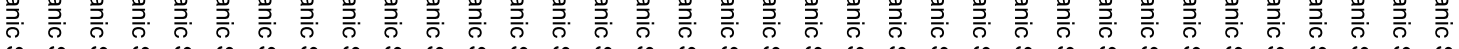

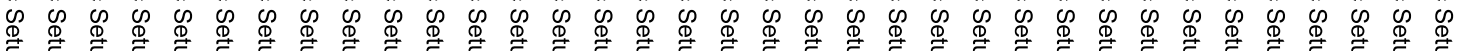
密

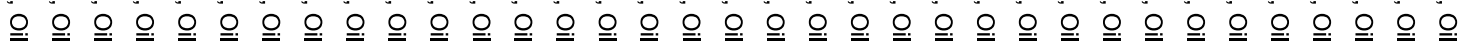

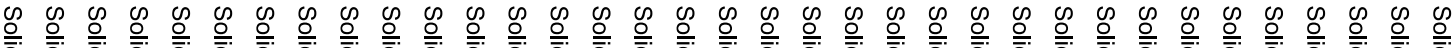

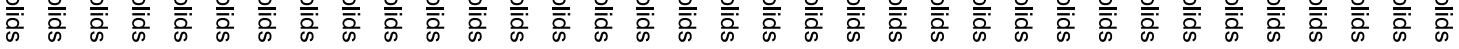

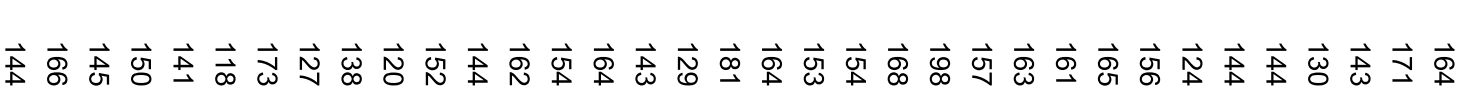




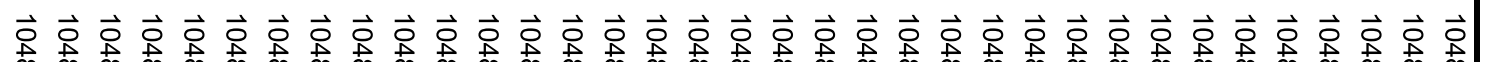
象央

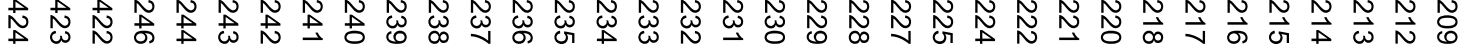

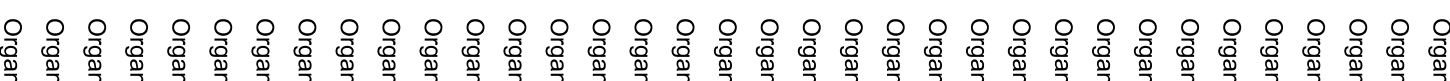

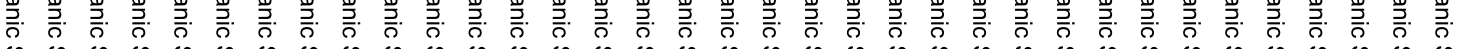

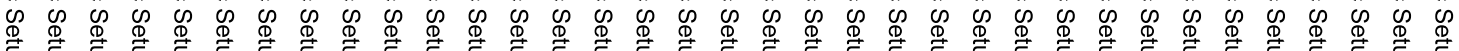
密

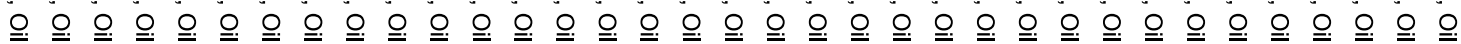

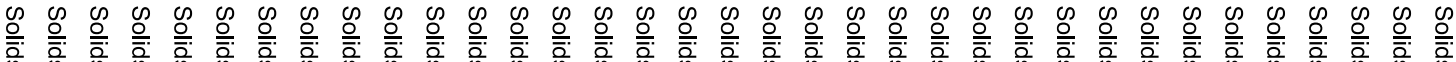

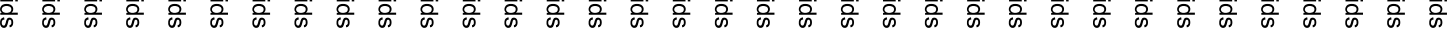

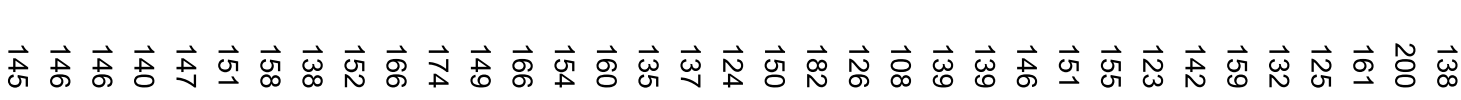




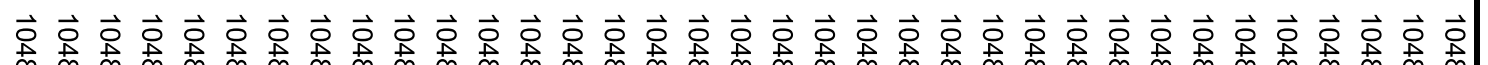

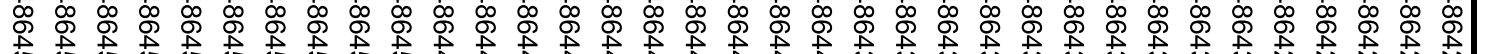

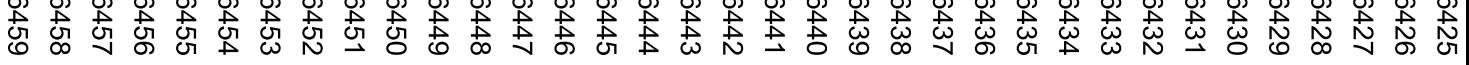

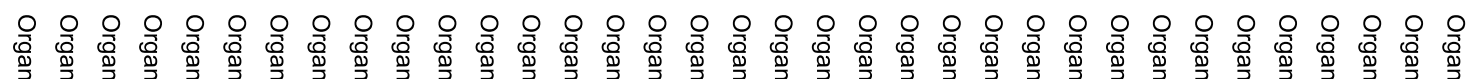
亏.

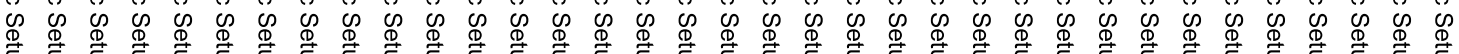

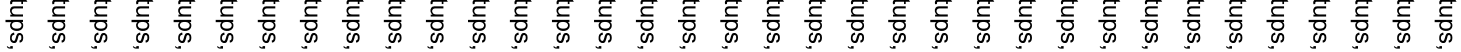

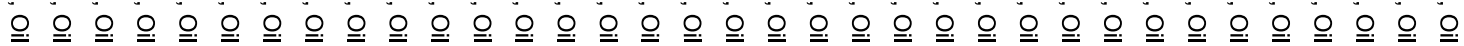

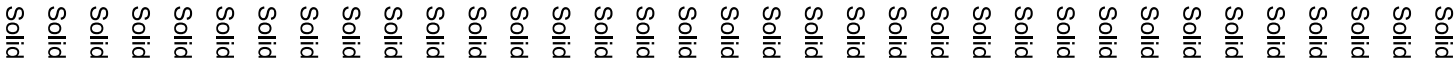

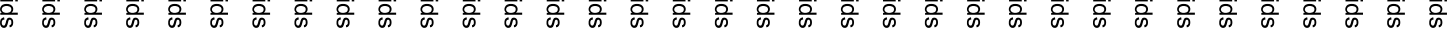

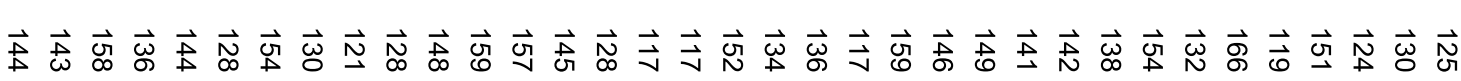

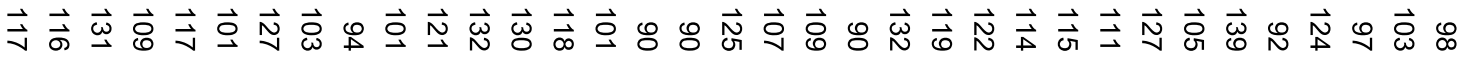

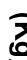


$\vec{\circ} \vec{\circ} \vec{\circ} \vec{\circ} \vec{\circ} \vec{\circ} \vec{\circ} \vec{\circ} \vec{\circ} \vec{\circ} \vec{\circ} \vec{\circ} \vec{\circ} \vec{\circ} \vec{\circ} \vec{\circ} \vec{\circ} \vec{\circ} \vec{\circ} \vec{\circ} \vec{\circ} \vec{\circ} \vec{\circ} \vec{\circ} \vec{\circ} \vec{\circ}$

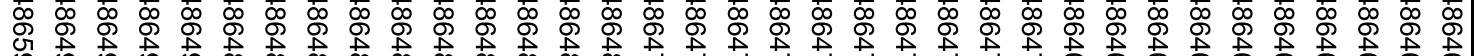

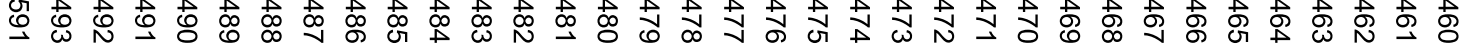

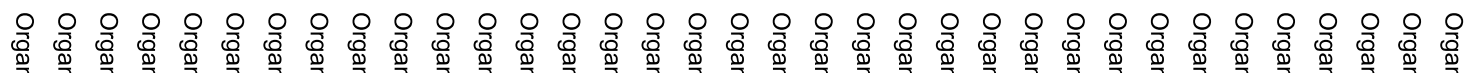

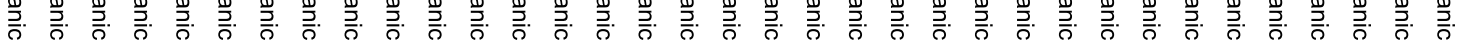

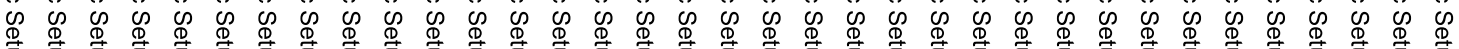
密

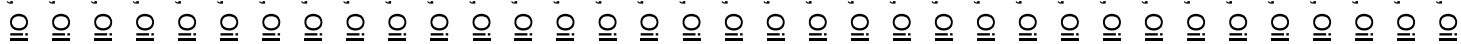

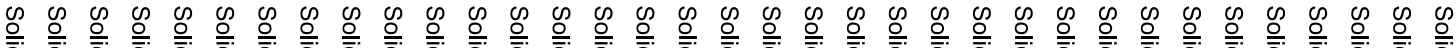

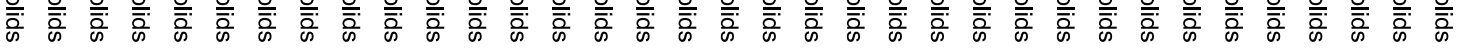

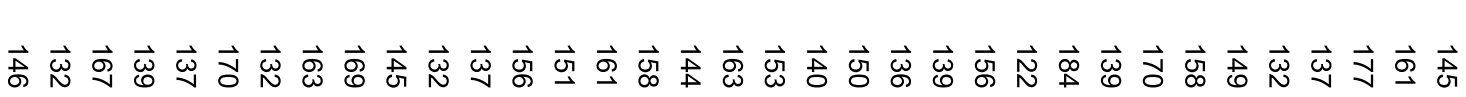




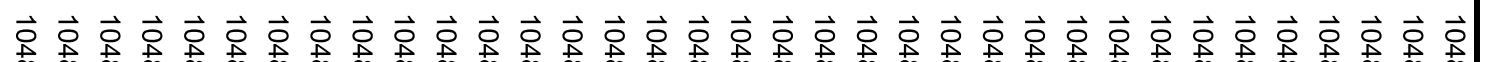

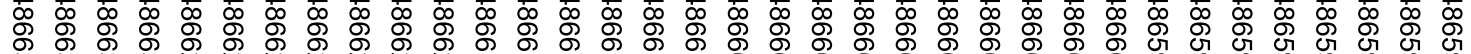

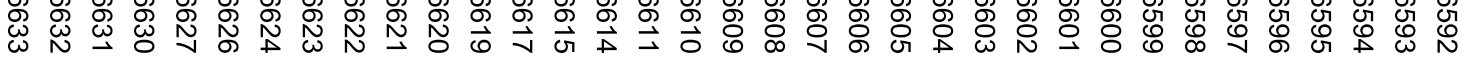

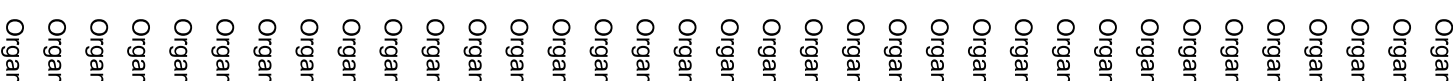

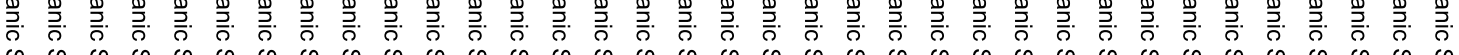

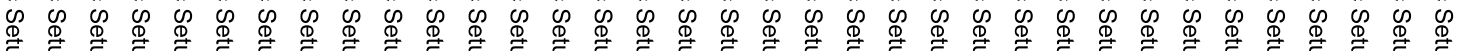

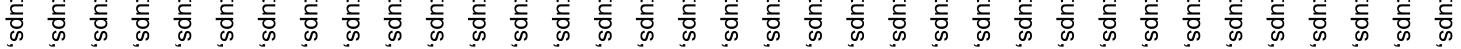

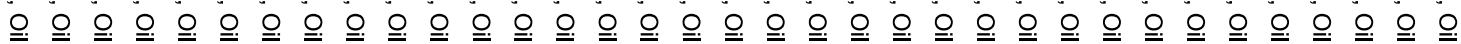

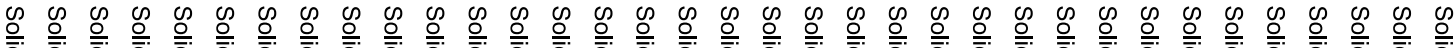

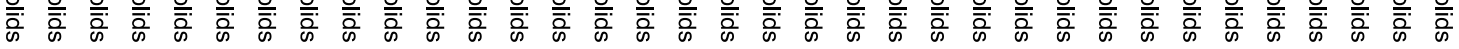

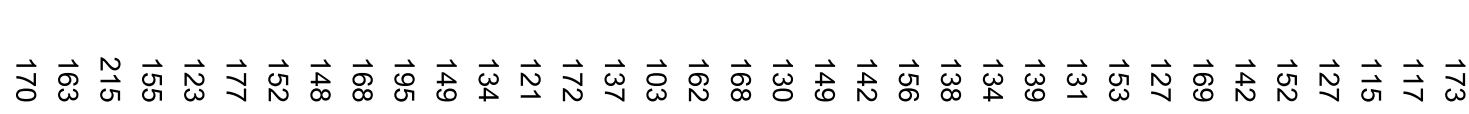


$\vec{\circ} \vec{\circ} \vec{\circ} \vec{\circ} \vec{\circ} \vec{\circ} \vec{\circ} \vec{\circ} \vec{\circ} \vec{\circ} \vec{\circ} \vec{\circ} \vec{\circ} \vec{\circ} \vec{\circ} \vec{\circ} \vec{\circ} \vec{\circ} \vec{\circ} \vec{\circ} \vec{\circ} \vec{\circ} \vec{\circ} \vec{\circ} \vec{\circ}$

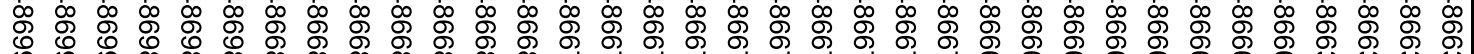
传

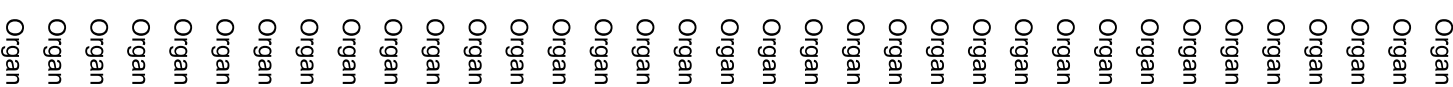

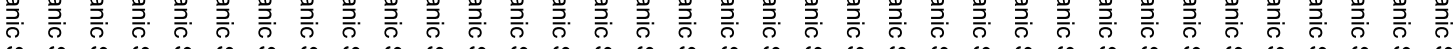

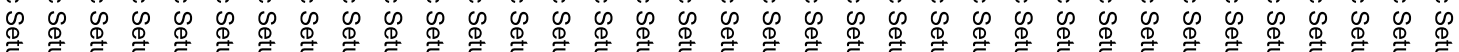
骔

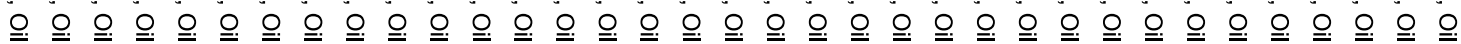

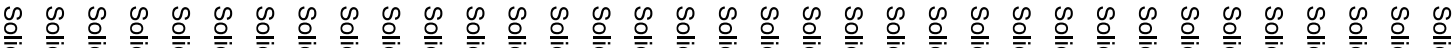

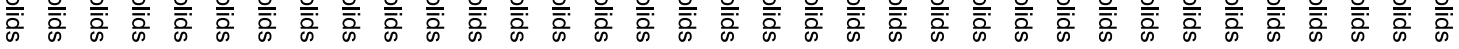

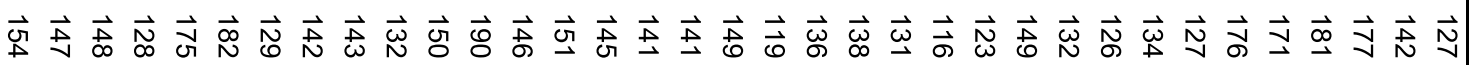

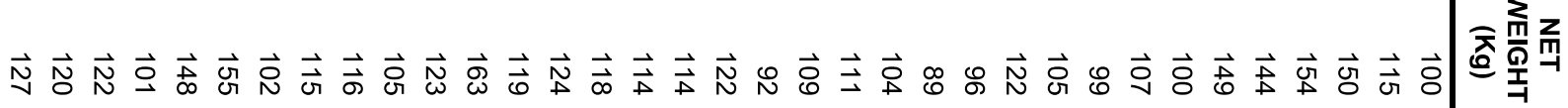




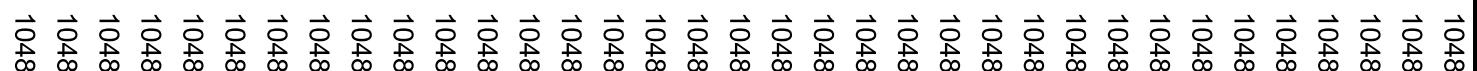

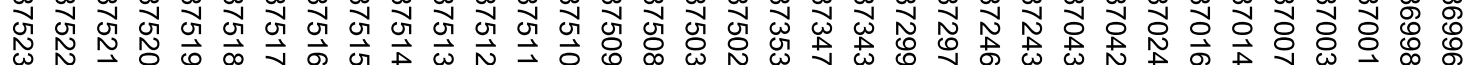

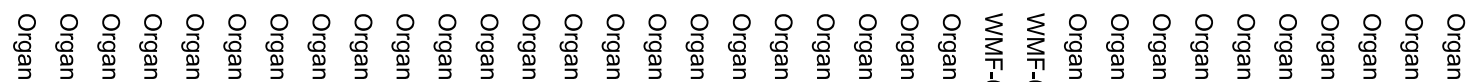

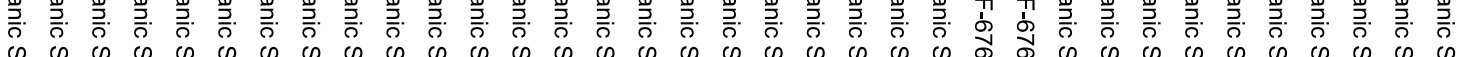

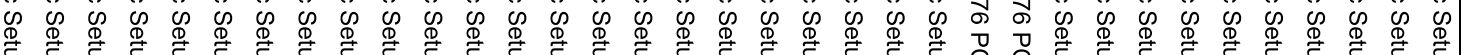

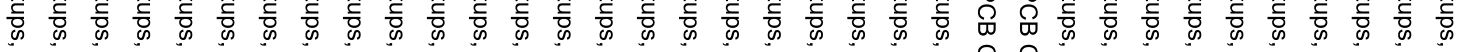

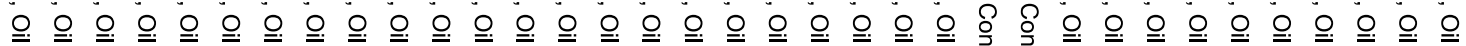
心

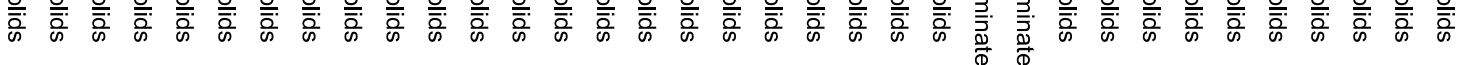

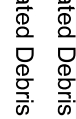

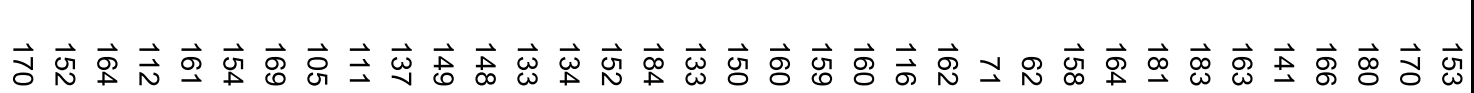




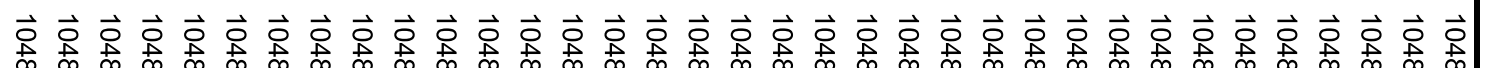

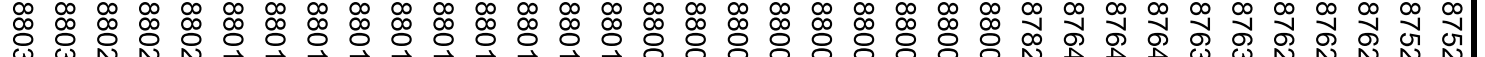
U

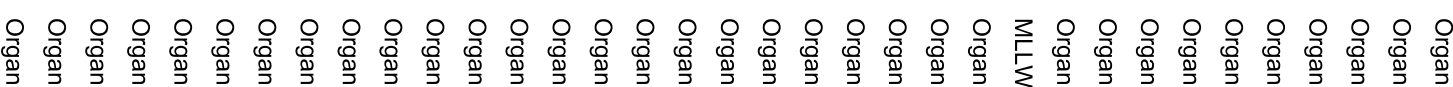

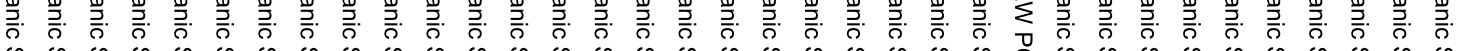

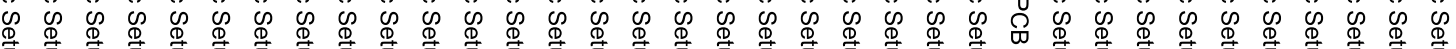
骔

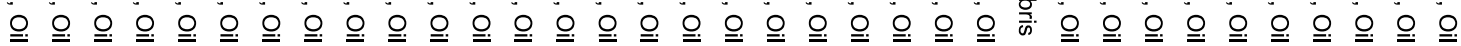

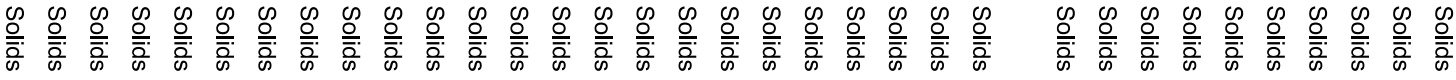

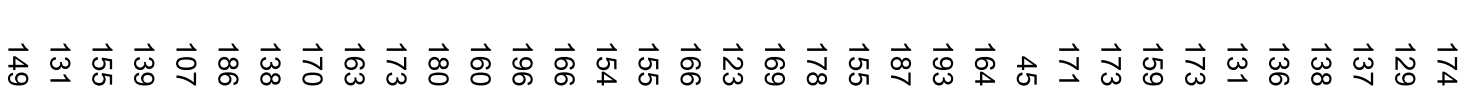


$\vec{\circ} \vec{\circ} \vec{\circ} \vec{\circ} \vec{\circ} \vec{\circ} \vec{\circ} \vec{\circ} \vec{\circ} \vec{\circ} \vec{\circ} \vec{\circ} \vec{\circ} \vec{\circ} \vec{\circ} \vec{\circ} \vec{\circ} \vec{\circ} \vec{\circ} \vec{\circ} \vec{\circ} \vec{\circ} \vec{\circ} \vec{\circ} \vec{\circ}$

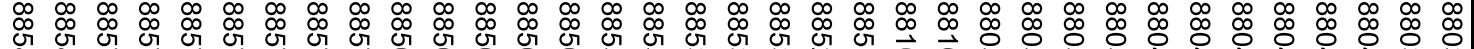

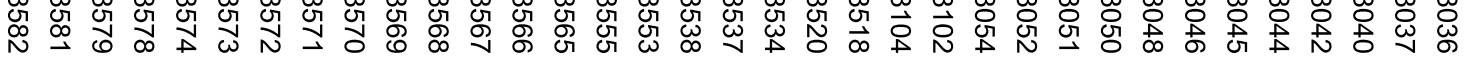

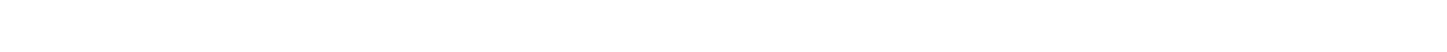

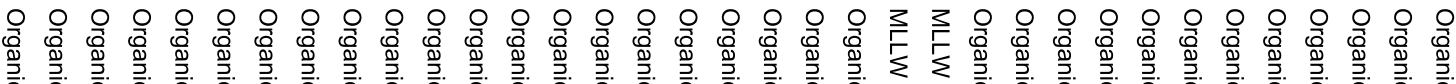
人 ने

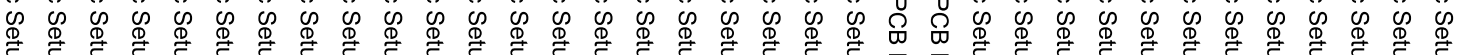
骔

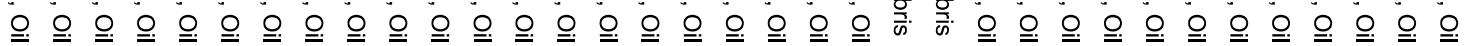

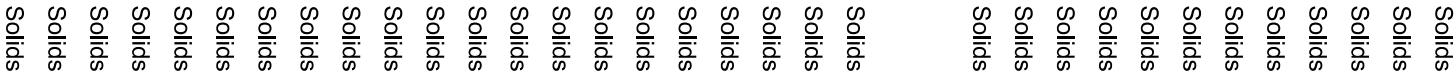

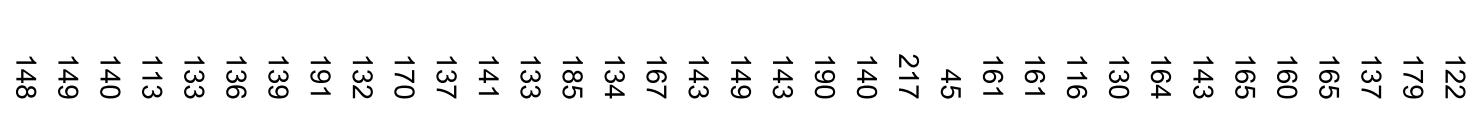

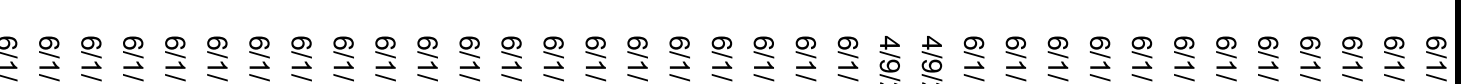




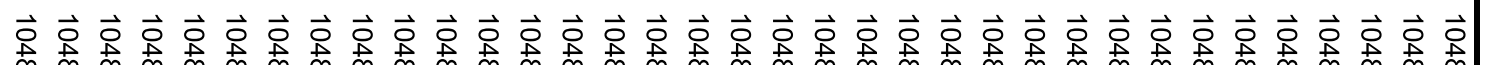

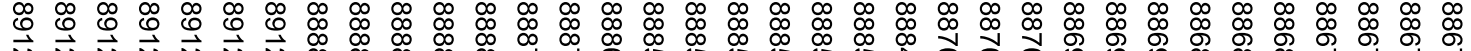

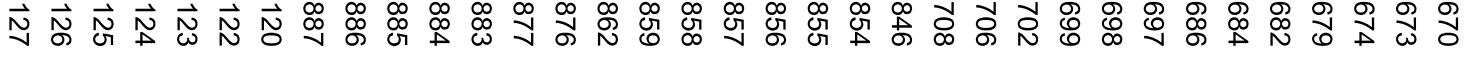

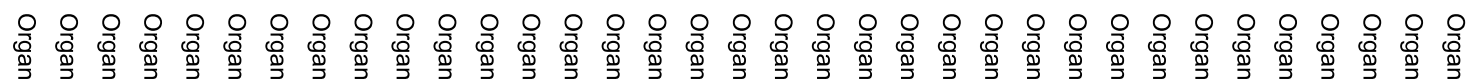

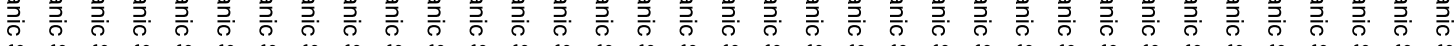

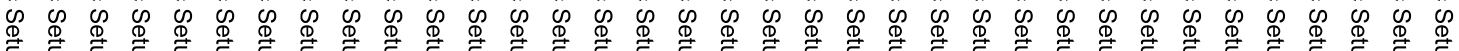

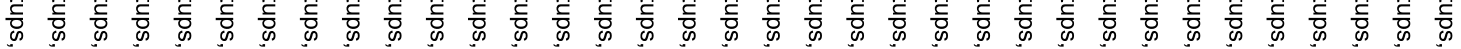

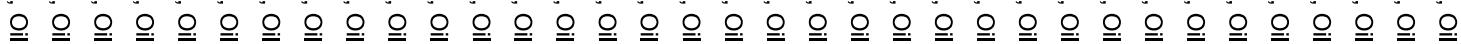

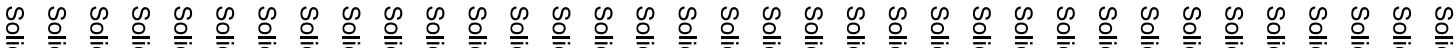

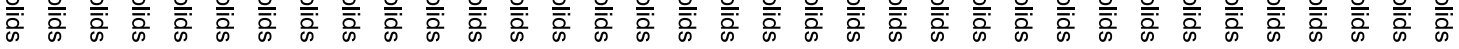

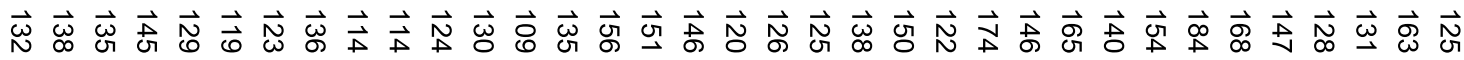




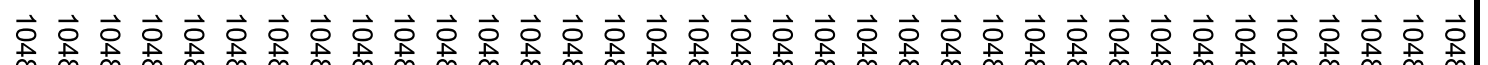

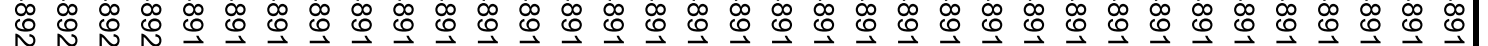

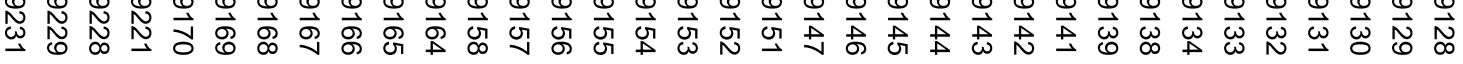

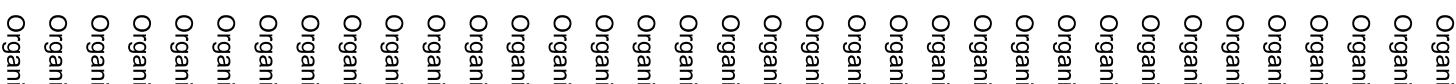

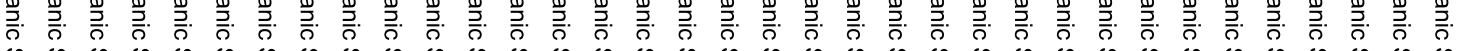

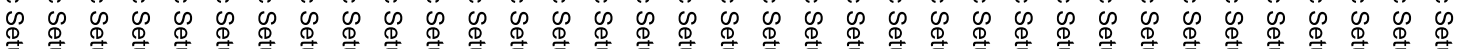

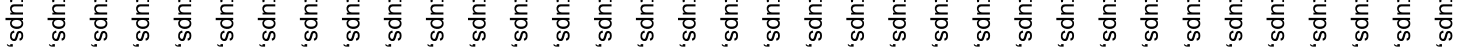

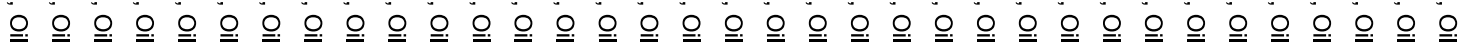

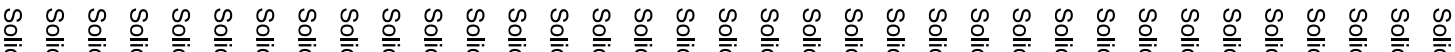

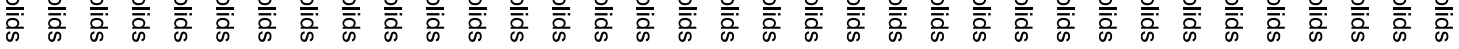

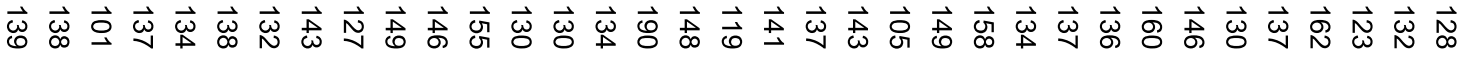




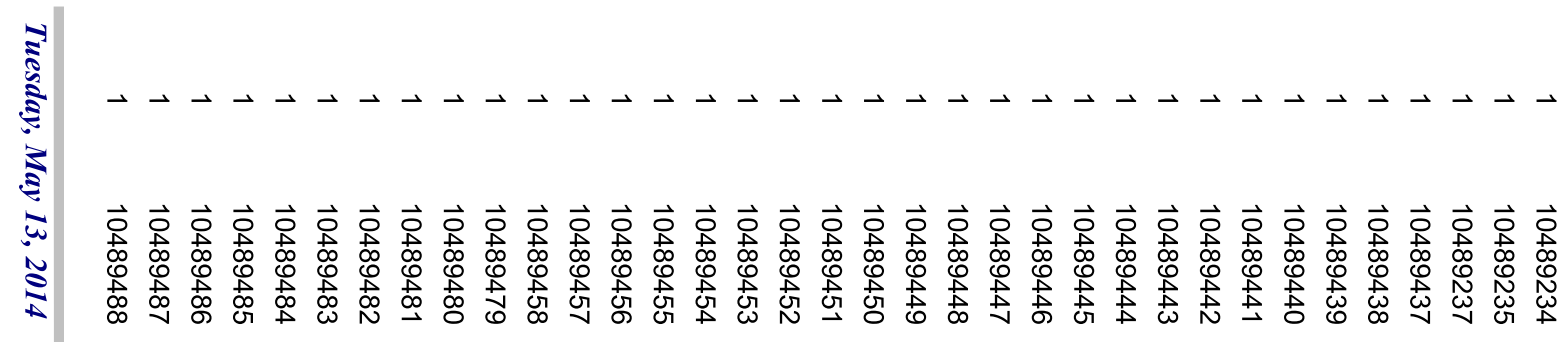

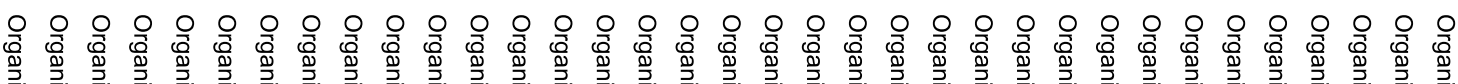
人.

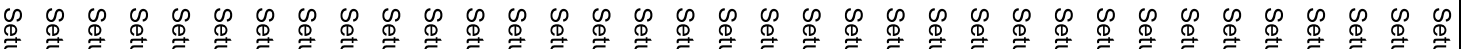
骔

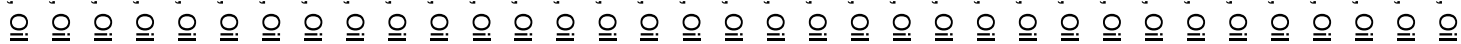

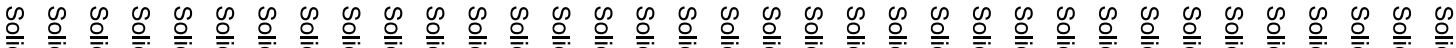

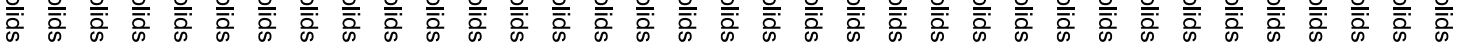

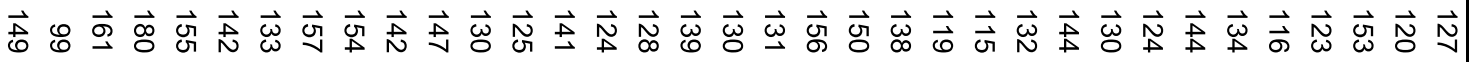

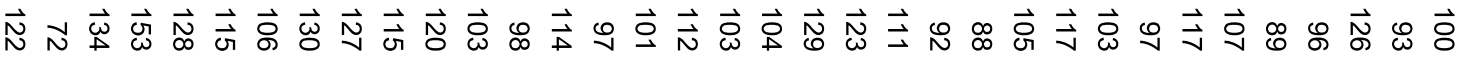

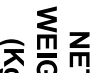
品 $\begin{aligned} & \circ \\ & \infty\end{aligned}$

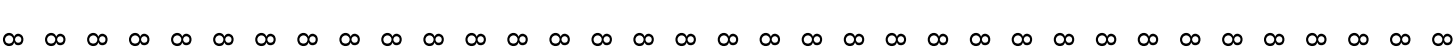




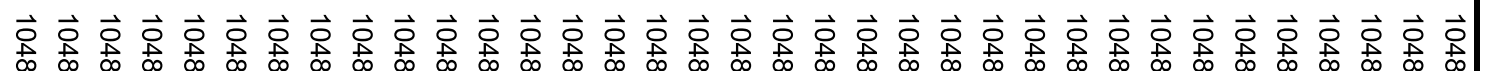
年

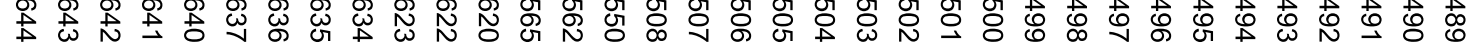

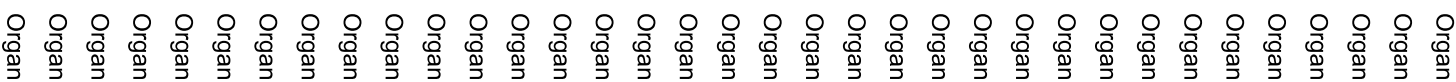

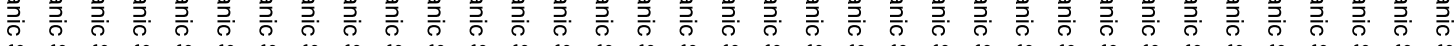
$\mathbb{W}$ W

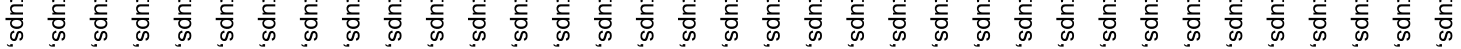

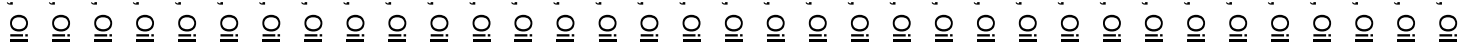

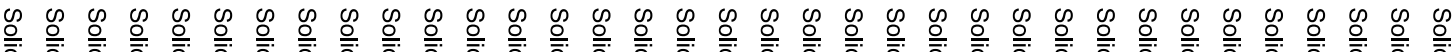

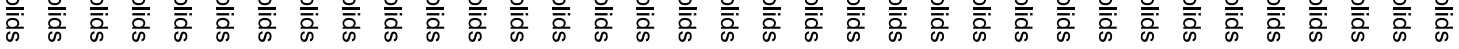

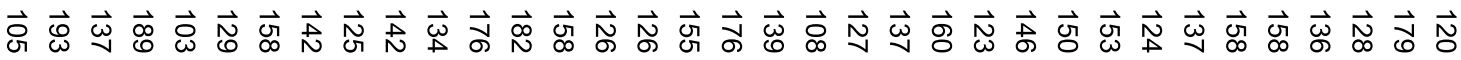




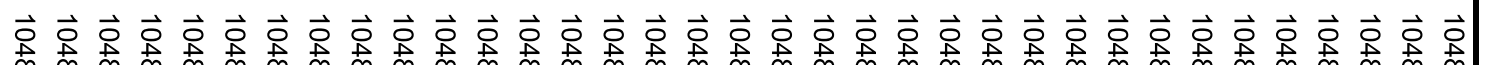

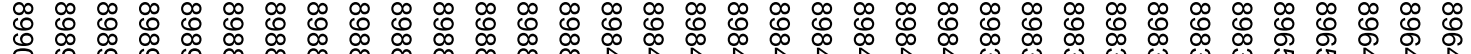

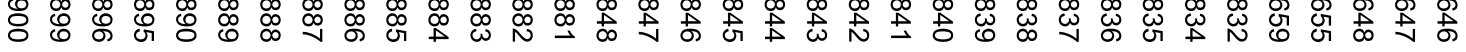

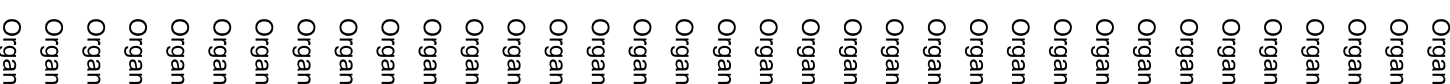

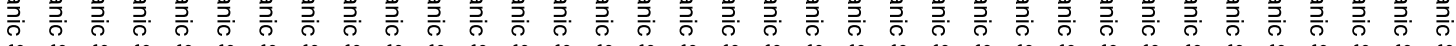

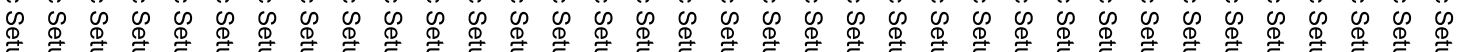
密

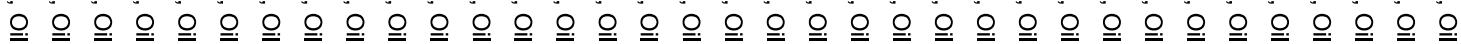

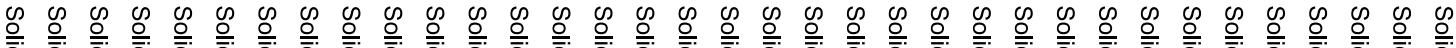

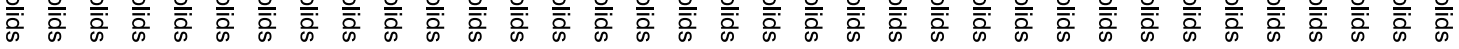

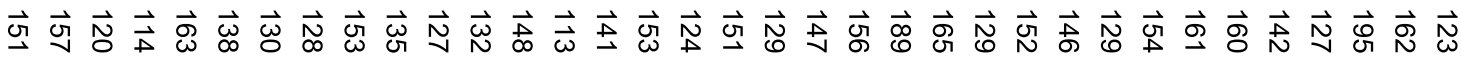




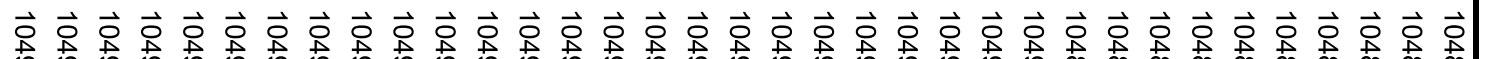

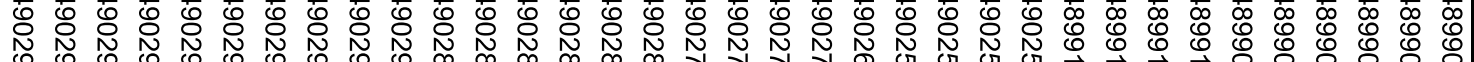
\& 0

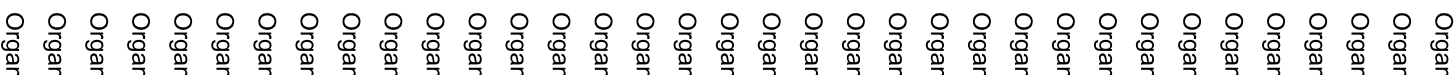

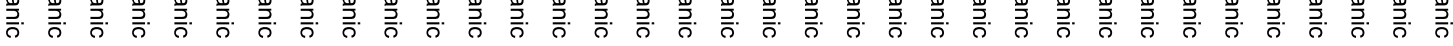

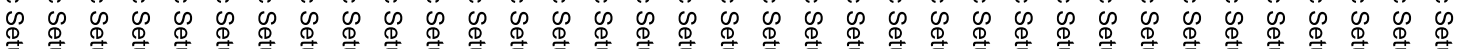
密

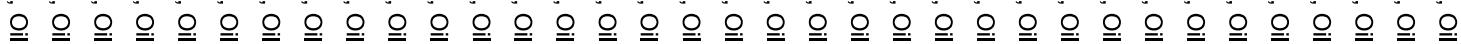

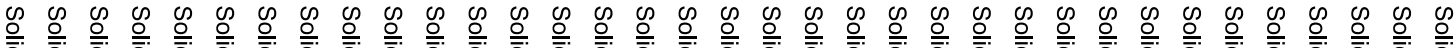

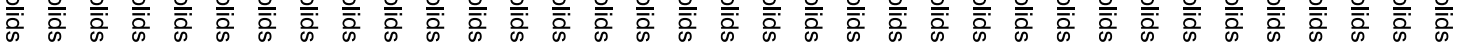

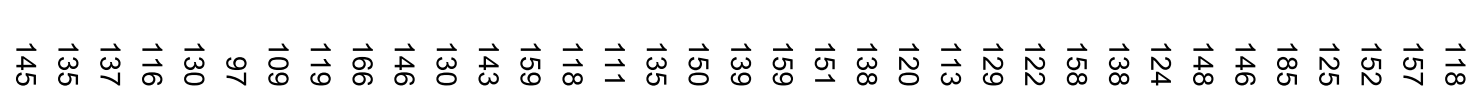




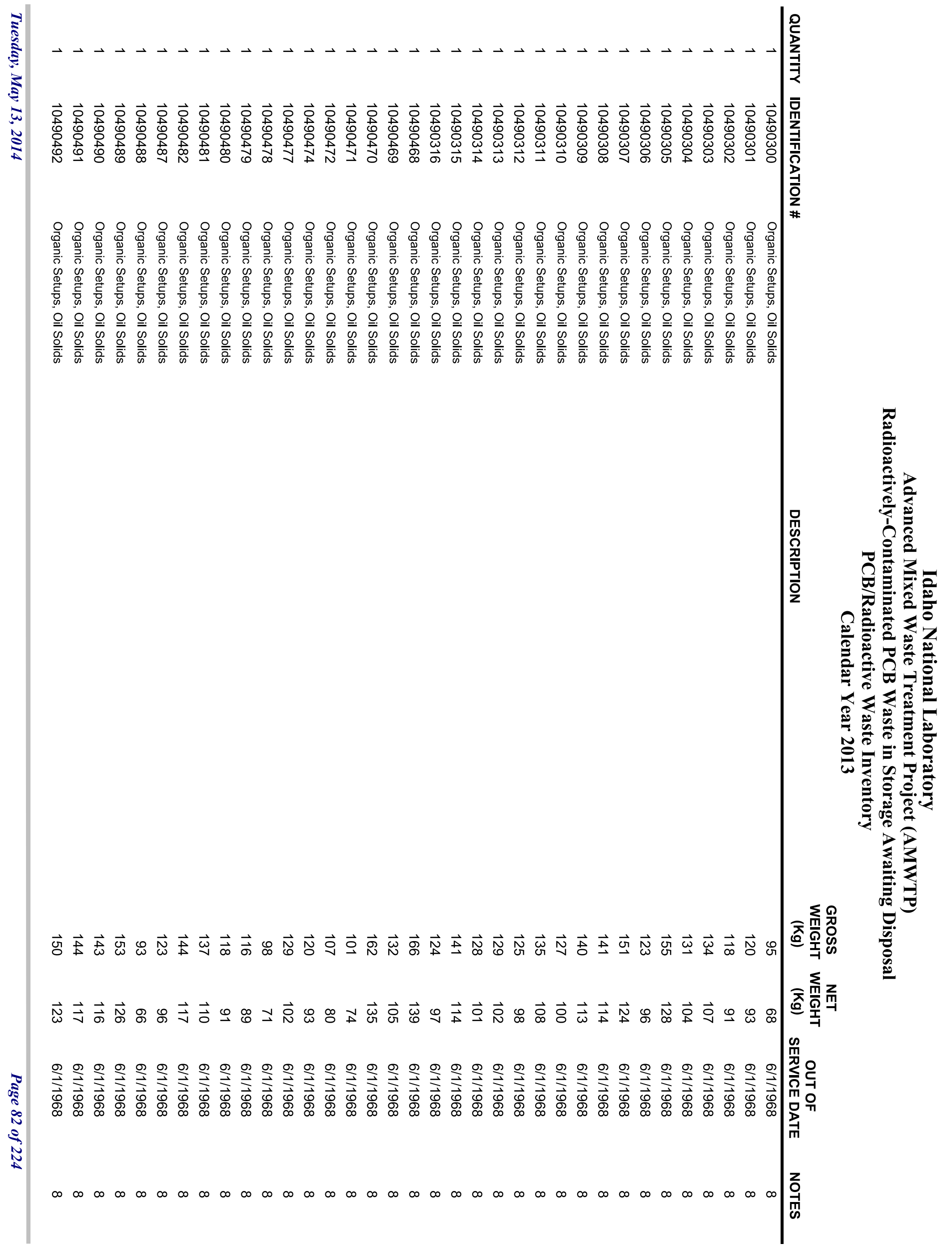




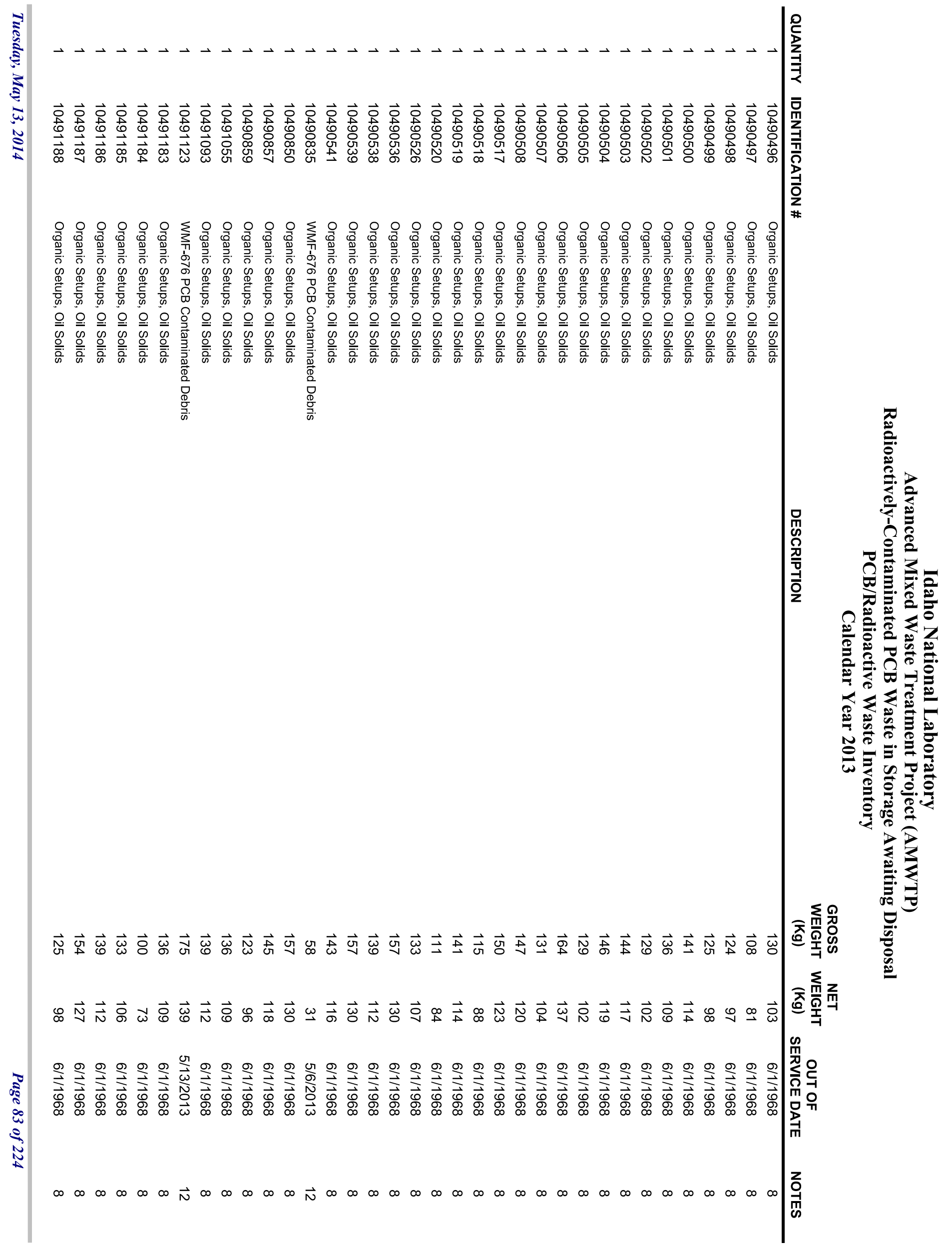




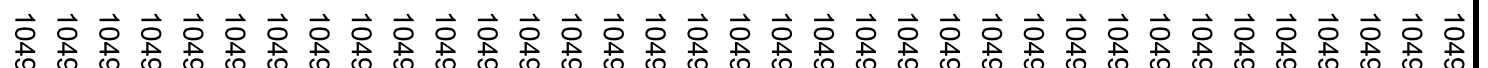

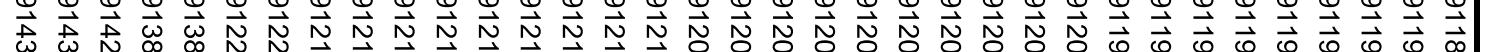

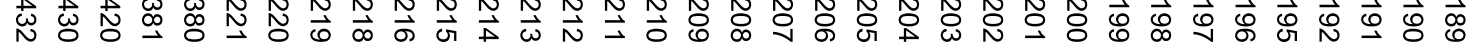

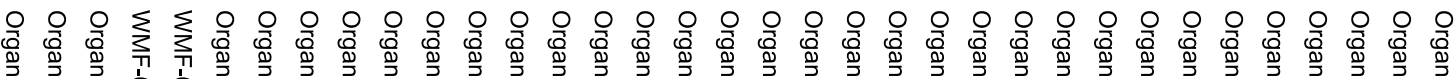

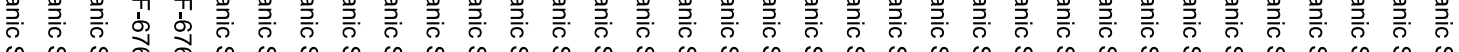

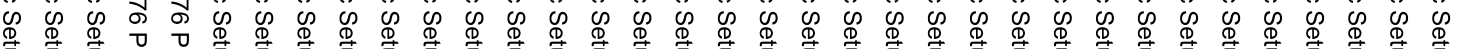

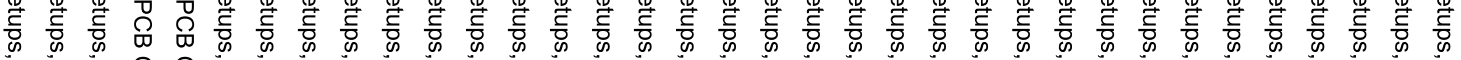

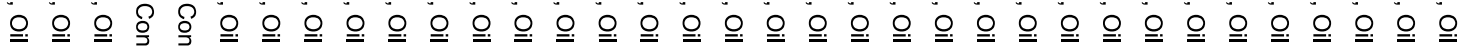
œ

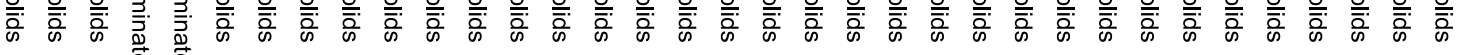
$\stackrel{\mathbb{D}}{\stackrel{\mathbb{D}}{2}}$

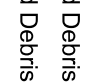

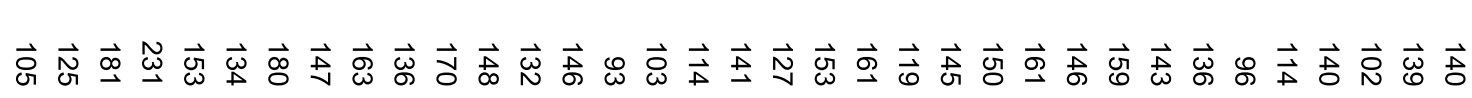




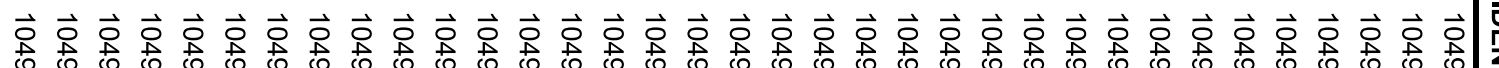
$\overrightarrow{0} \begin{gathered}\overrightarrow{0} \\ 0\end{gathered}$

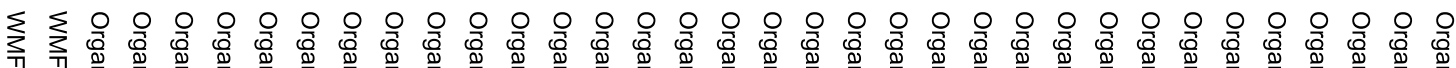

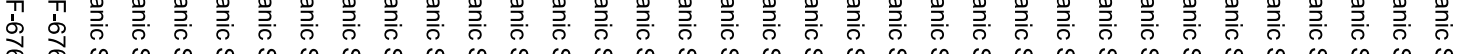

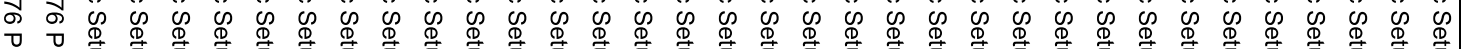

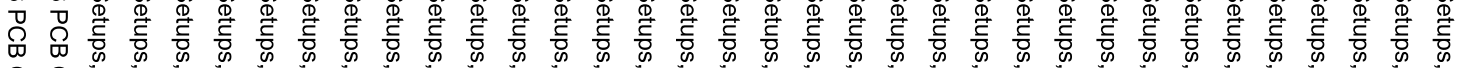

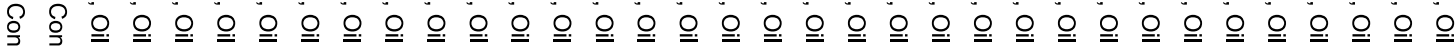

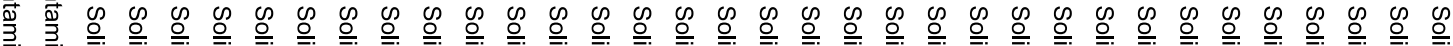

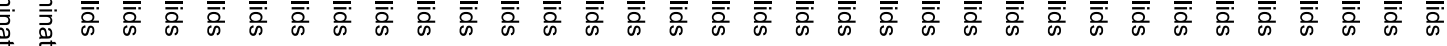
वे $\frac{\overrightarrow{0}}{9}$

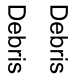

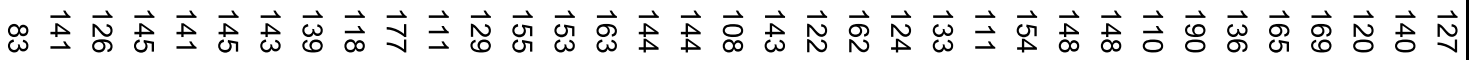

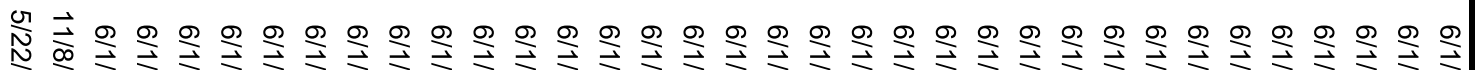




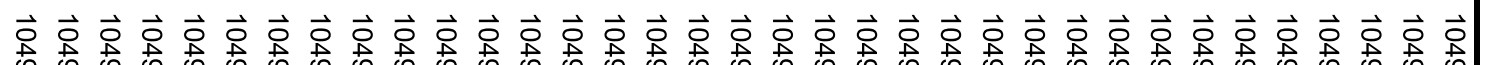

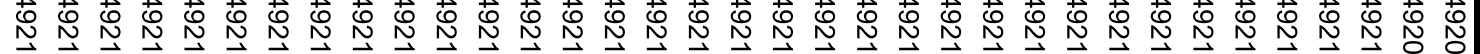

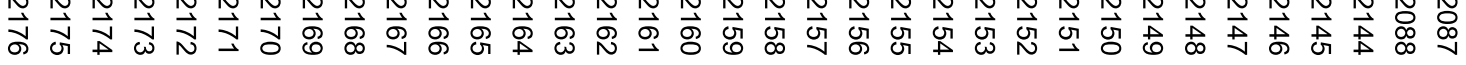

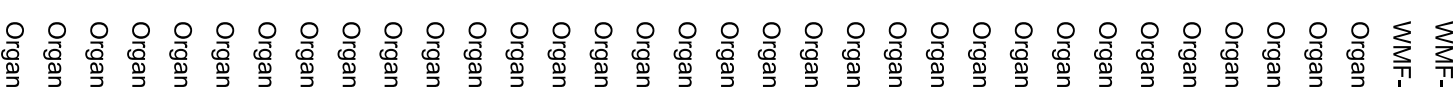

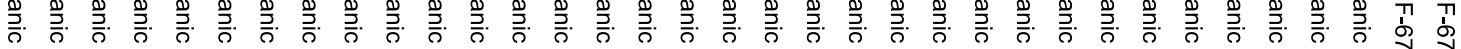

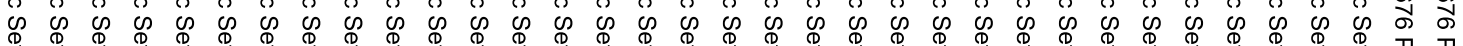

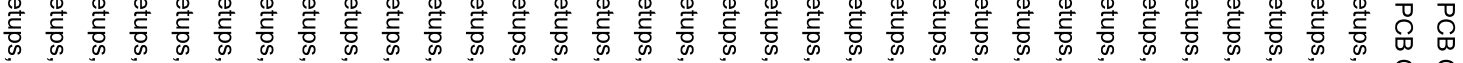

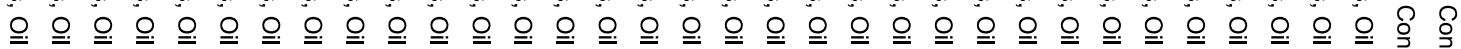

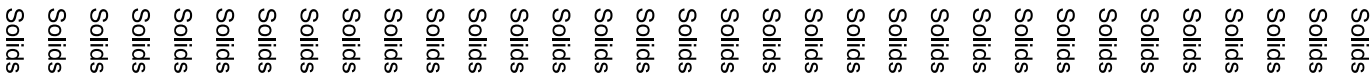

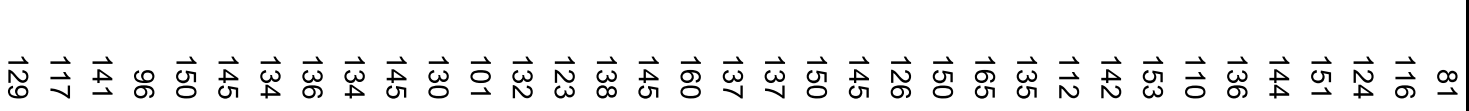

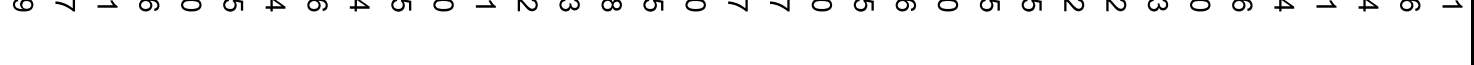

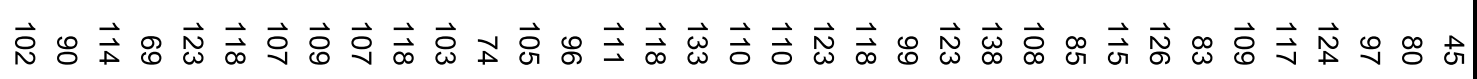




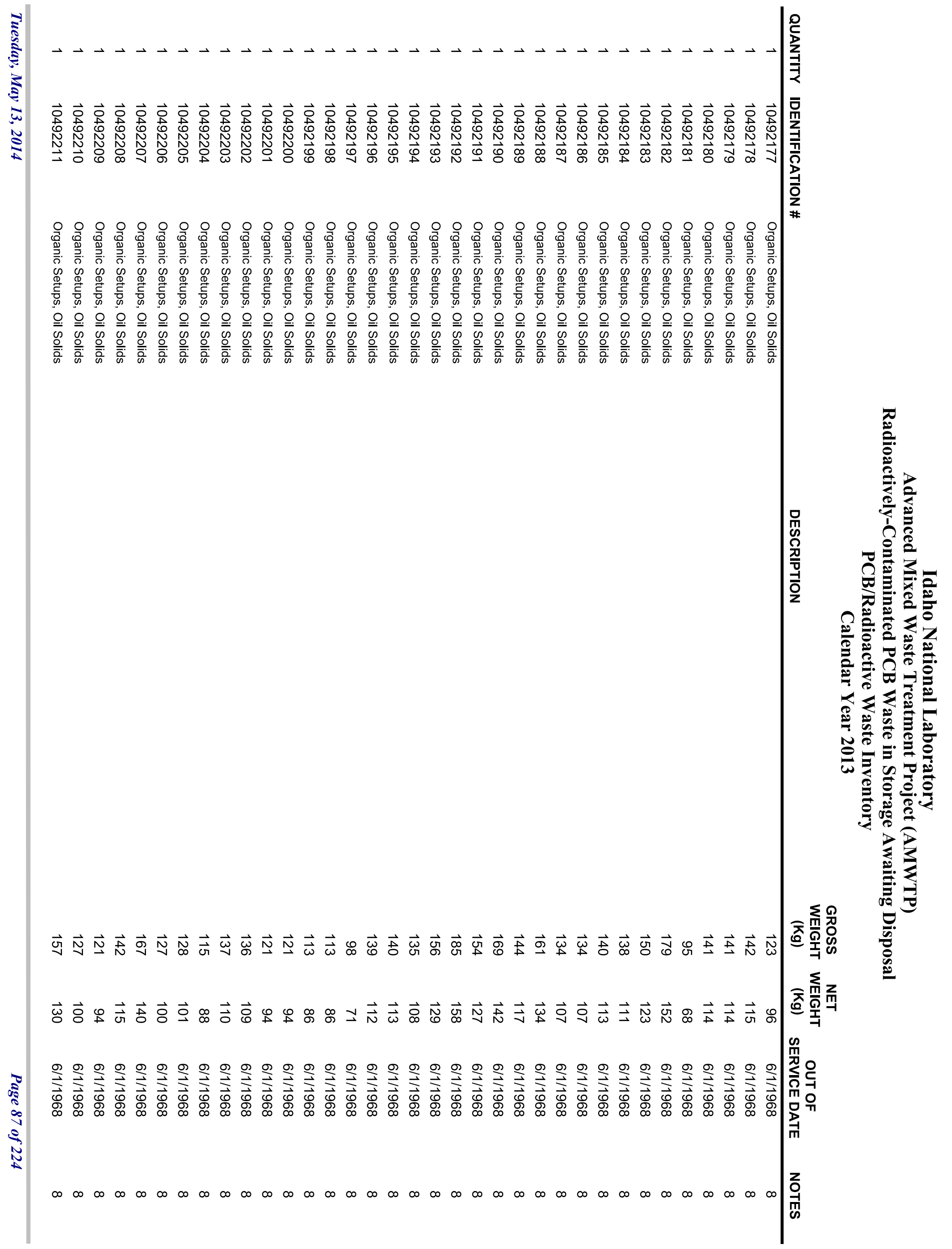




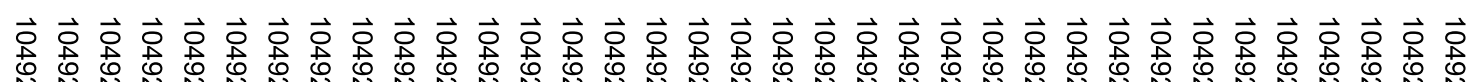

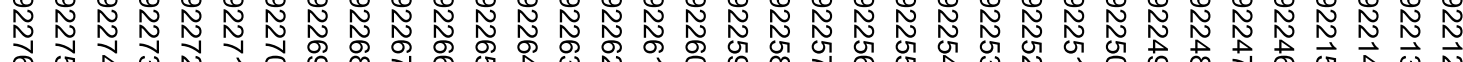

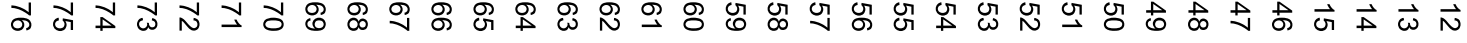

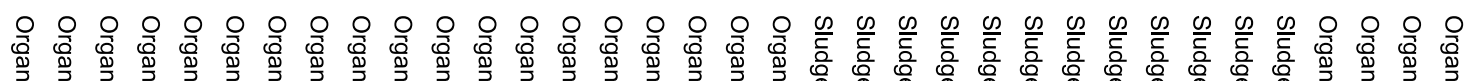

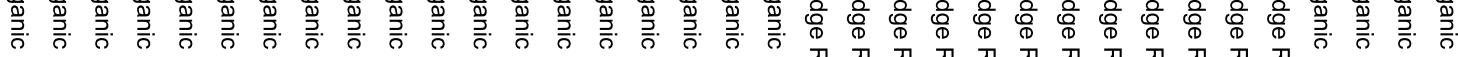

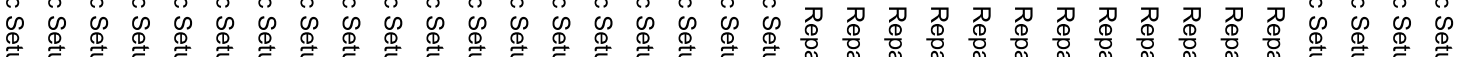

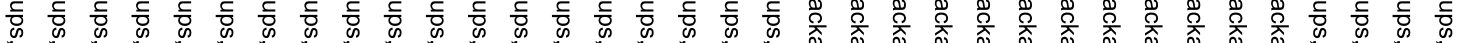

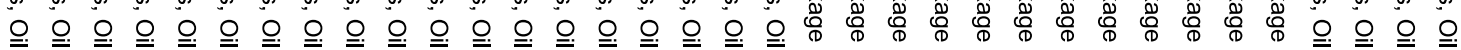

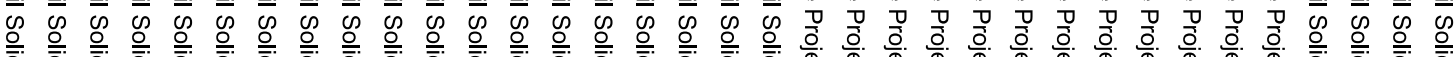

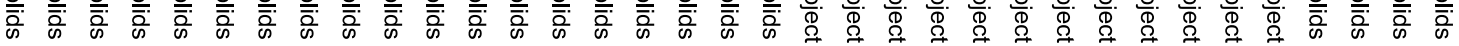

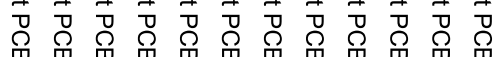

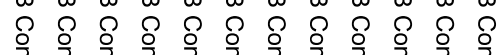

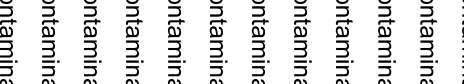

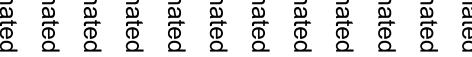

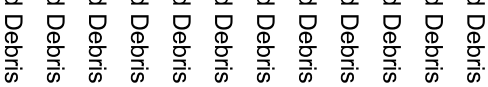

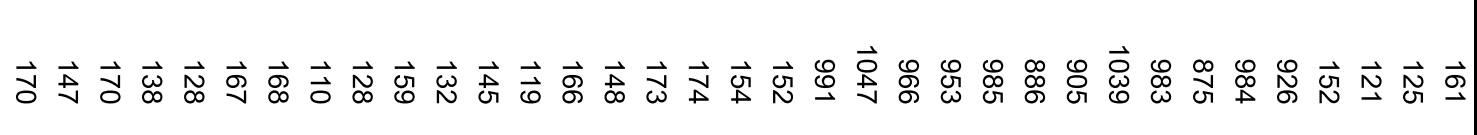

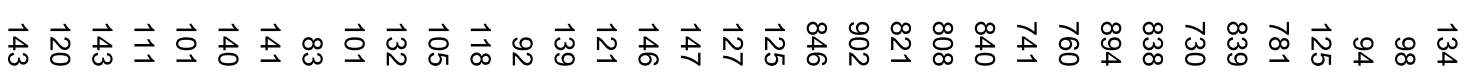
交血

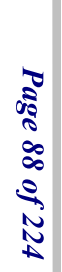

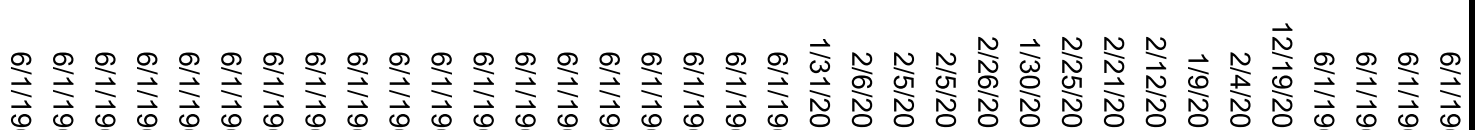
\&

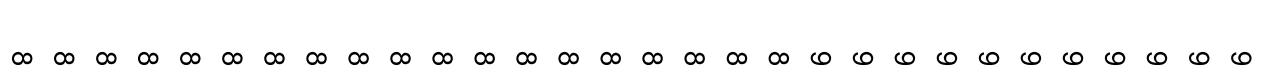
$\infty \infty \infty \infty$ 


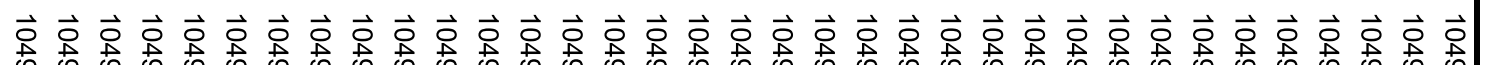

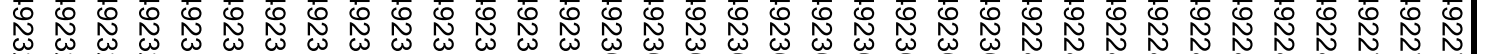

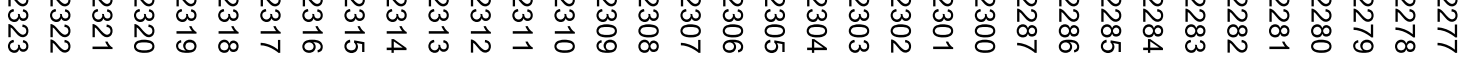

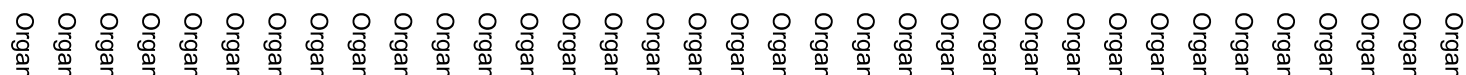

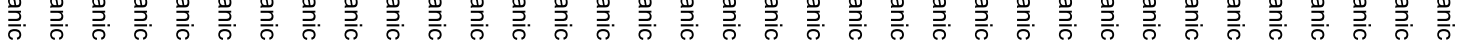

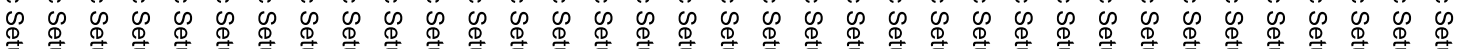

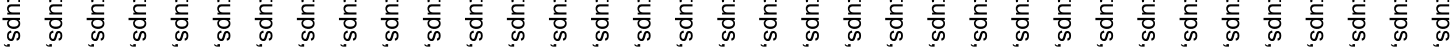

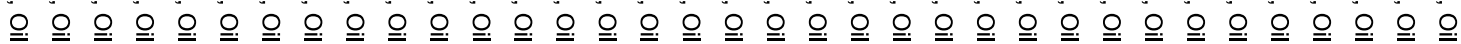

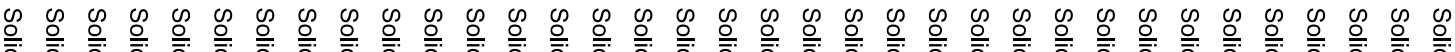

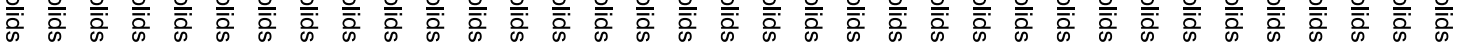

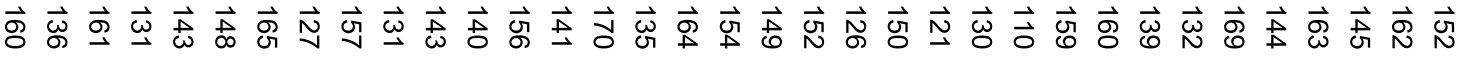




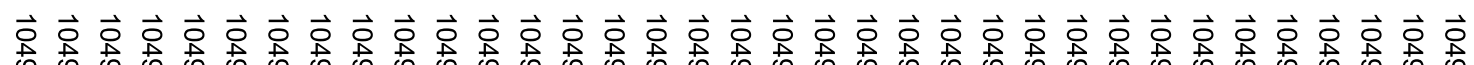

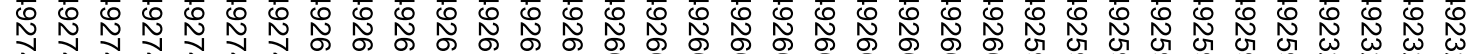

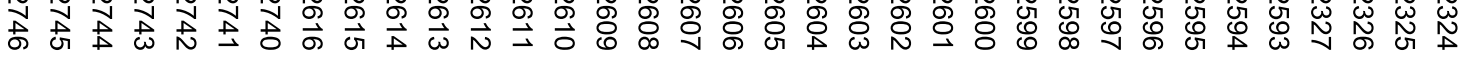

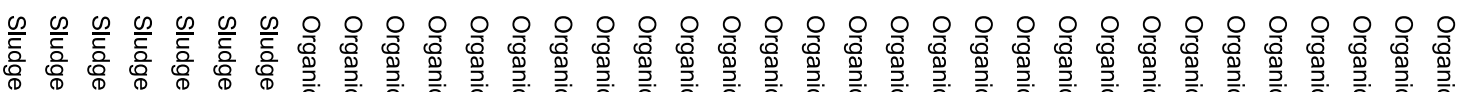
ग

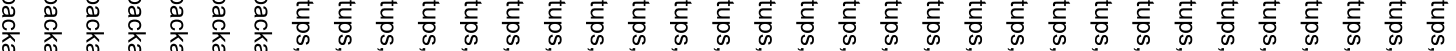
ڤ ळ

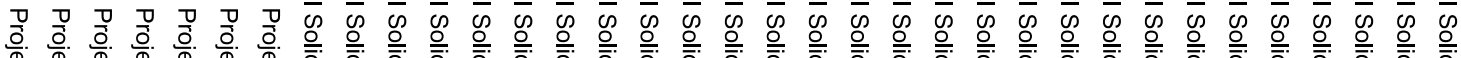

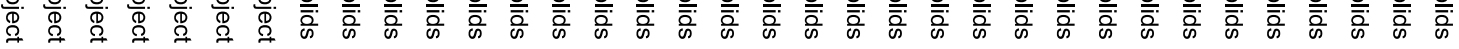
苛

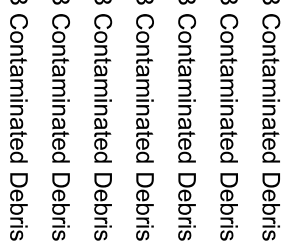

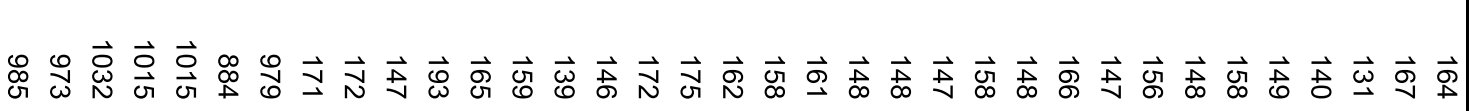

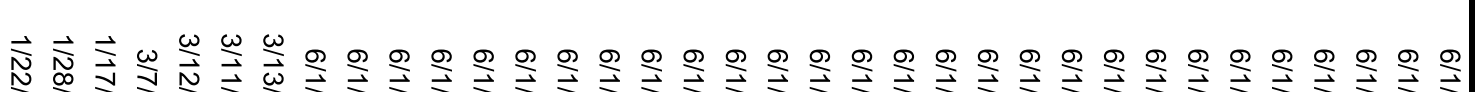

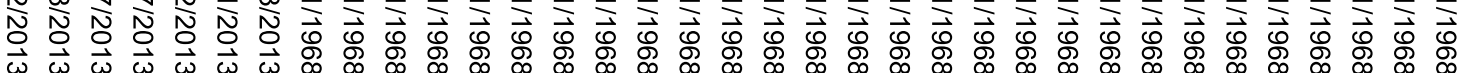

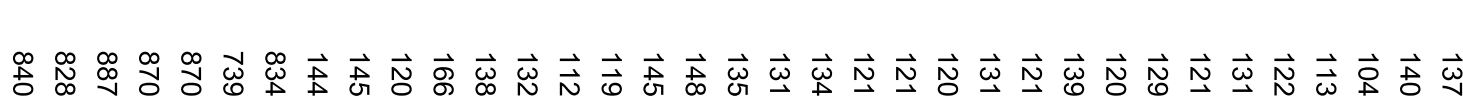
兴 
$\vec{\circ} \vec{\circ} \vec{\circ} \vec{\circ} \vec{\circ} \vec{\circ} \vec{\circ} \vec{\circ} \vec{\circ} \vec{\circ} \vec{\circ} \vec{\circ} \vec{\circ} \vec{\circ} \vec{\circ} \vec{\circ} \vec{\circ} \vec{\circ} \vec{\circ} \vec{\circ} \vec{\circ} \vec{\circ} \vec{\circ} \vec{\circ} \vec{\circ}$

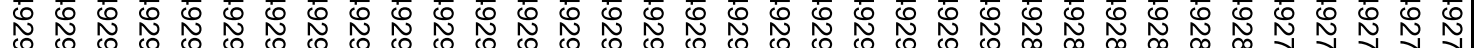
ơ जै

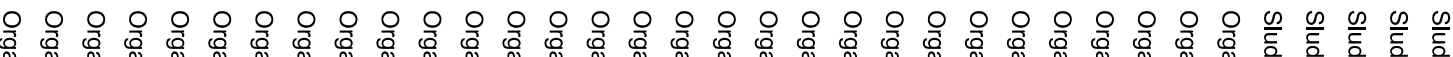

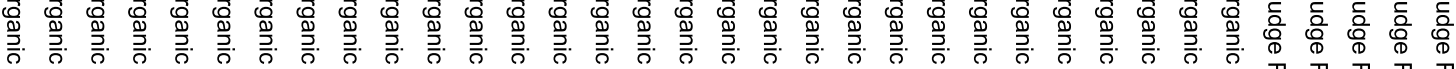

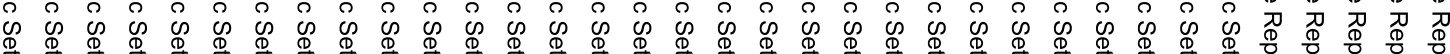

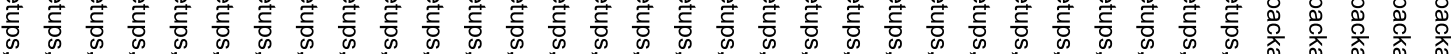

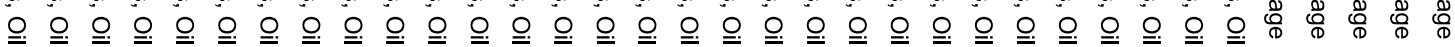

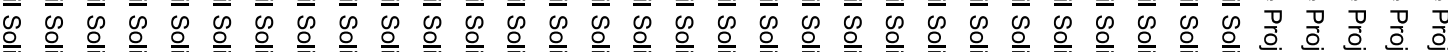

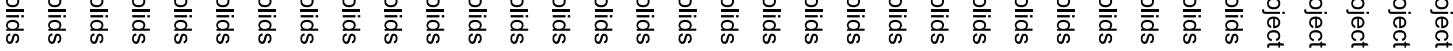

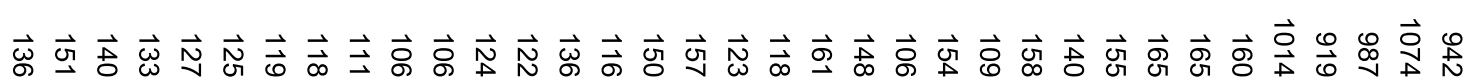

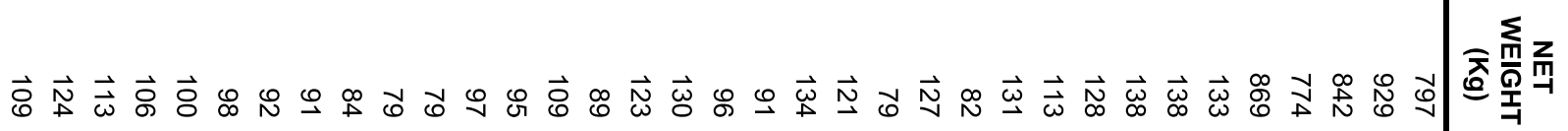




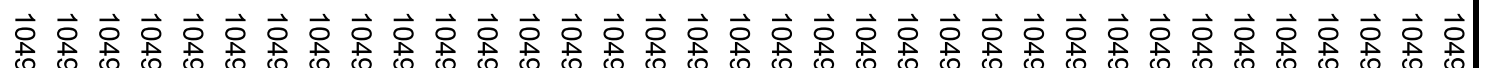

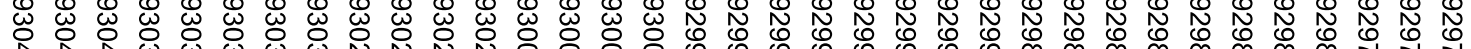

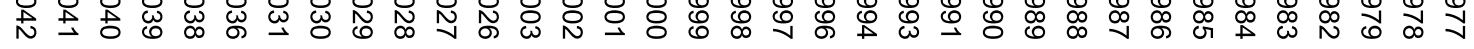

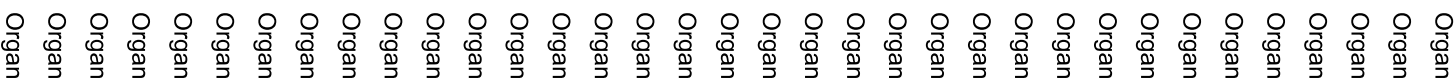

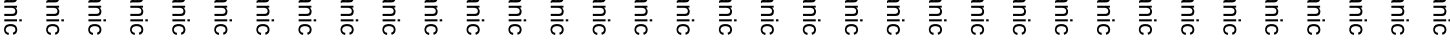

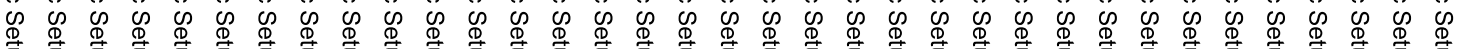
密

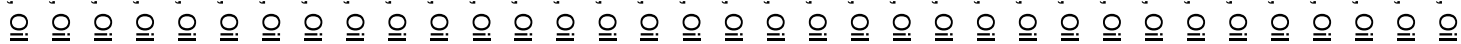

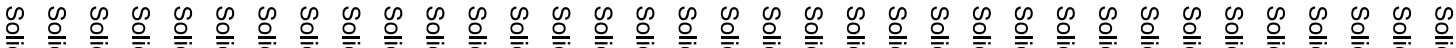

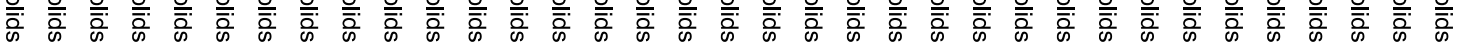

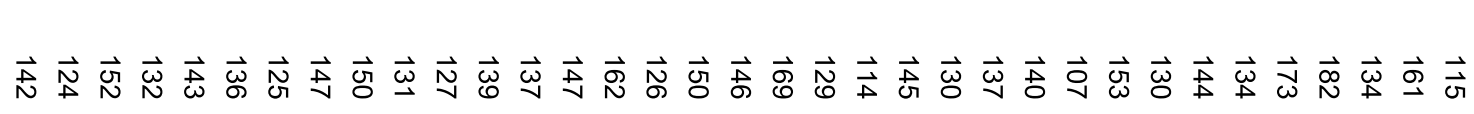




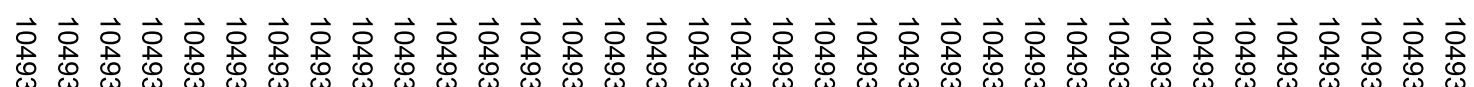

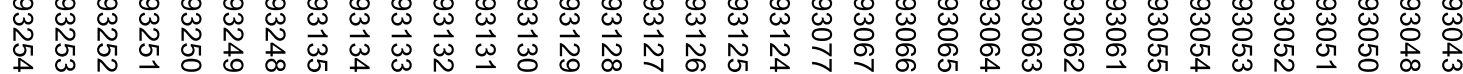

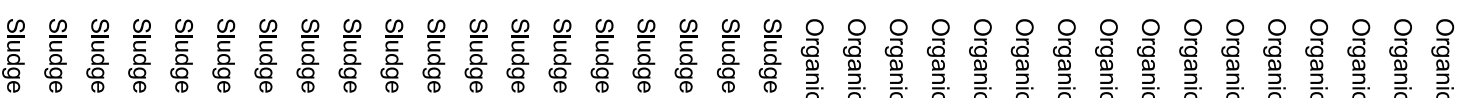

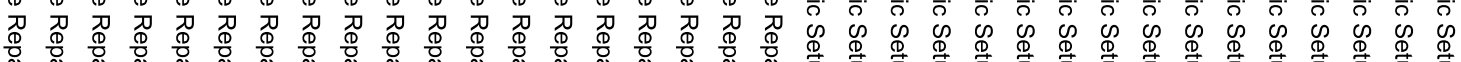

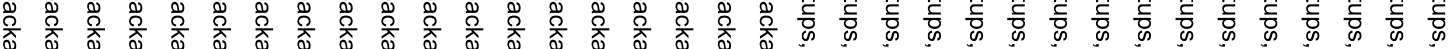

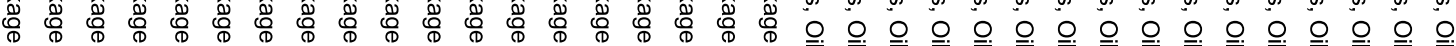

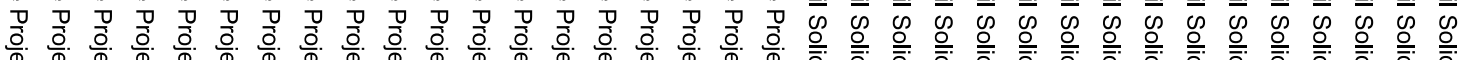

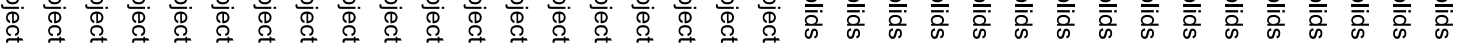

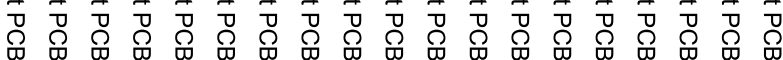

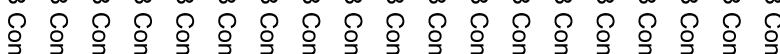

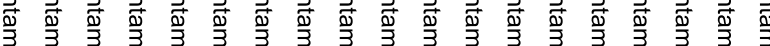

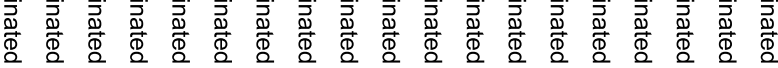

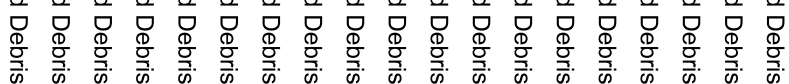

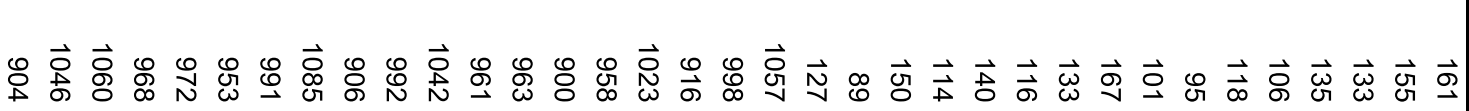

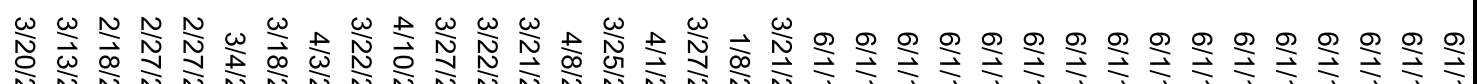

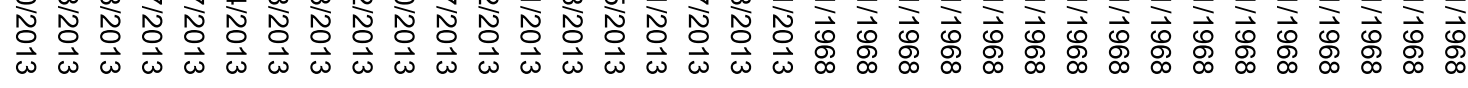

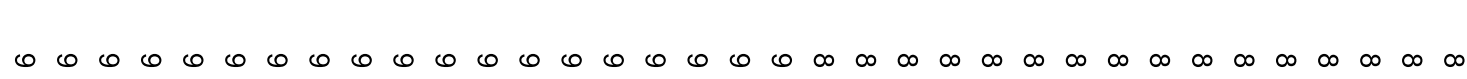




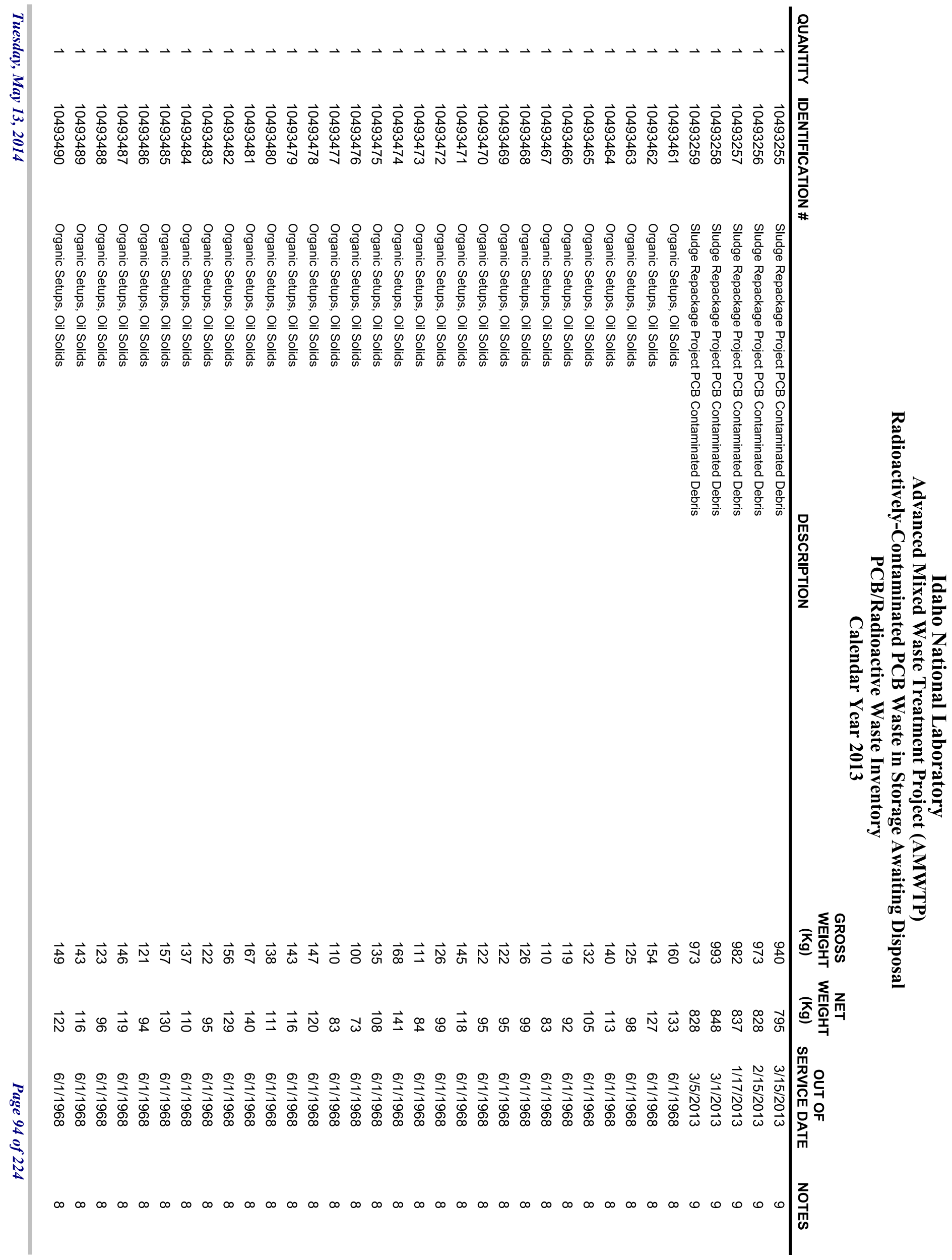




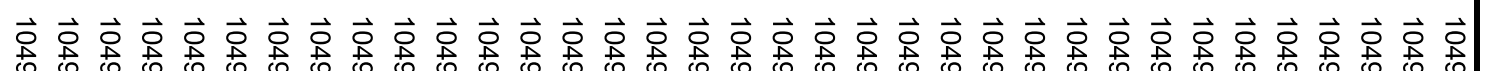

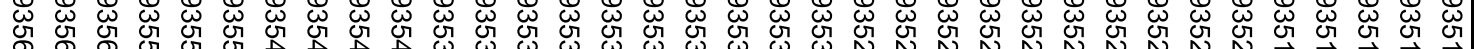

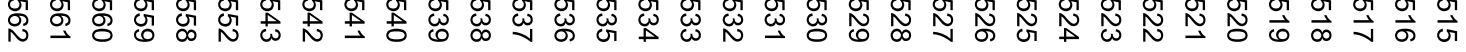

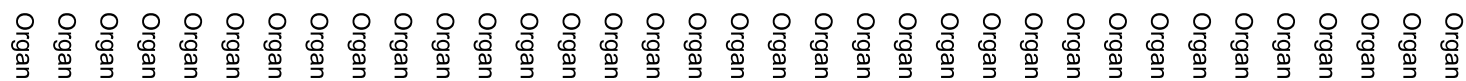

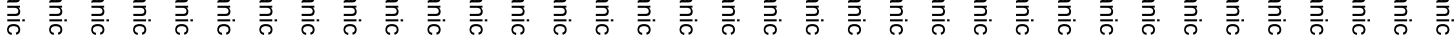

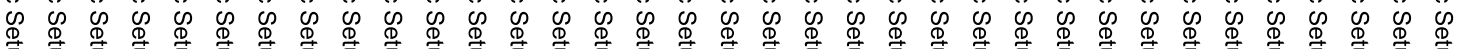
密

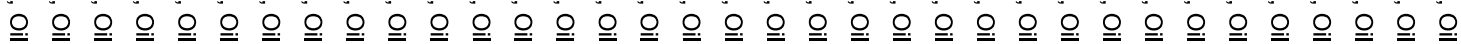

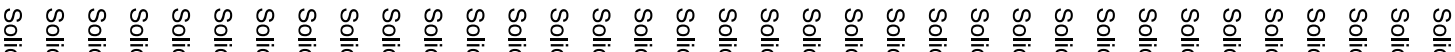

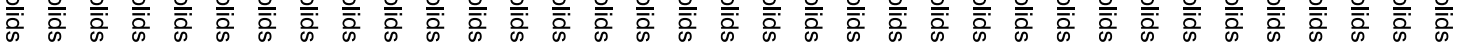

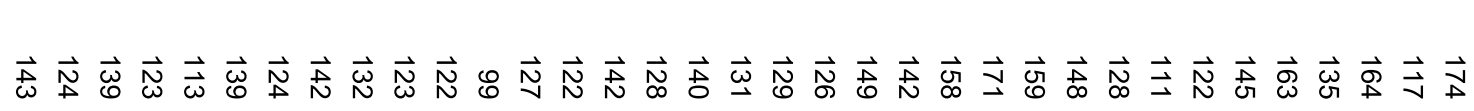




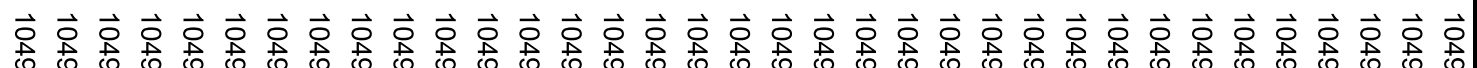
W

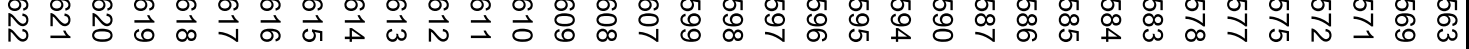

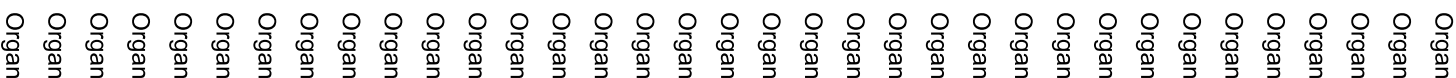

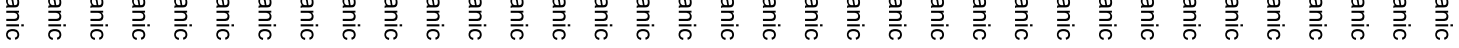

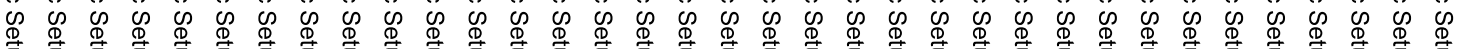

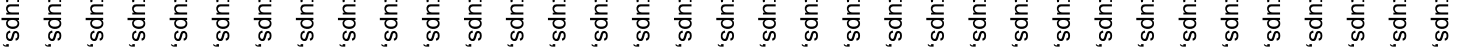

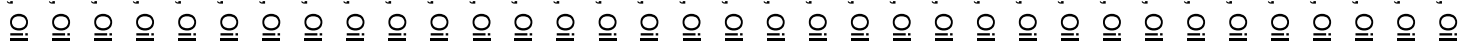

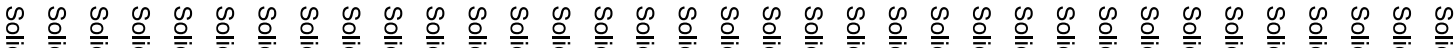

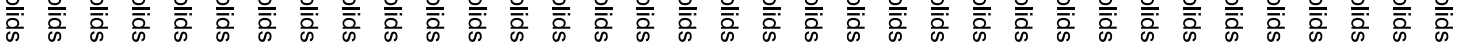

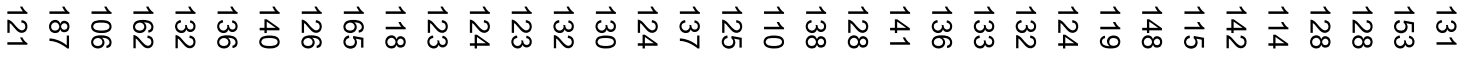

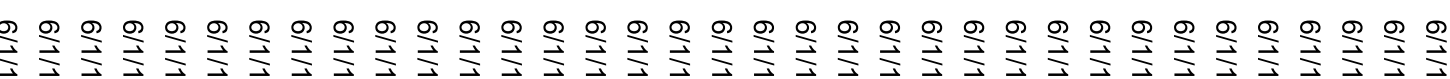
\% 


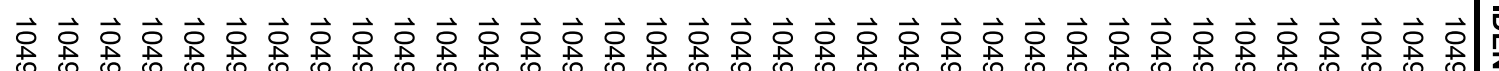

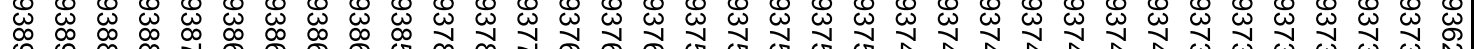
菏

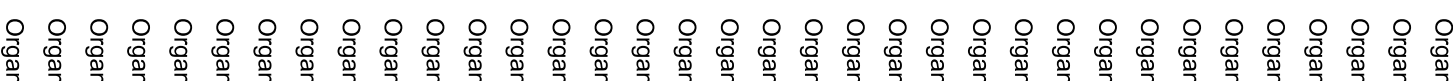

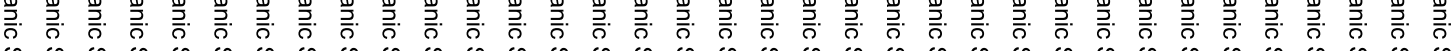

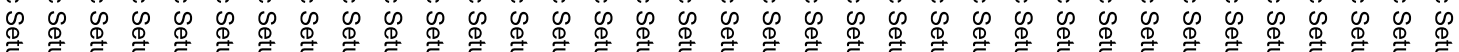
骔

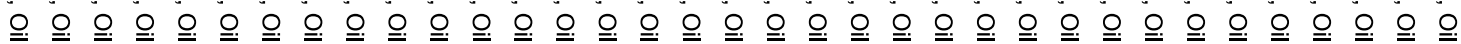

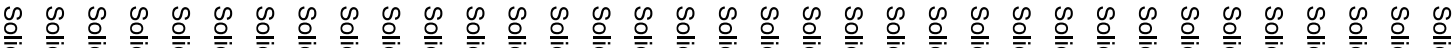

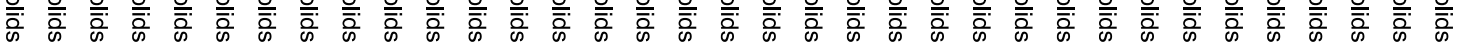

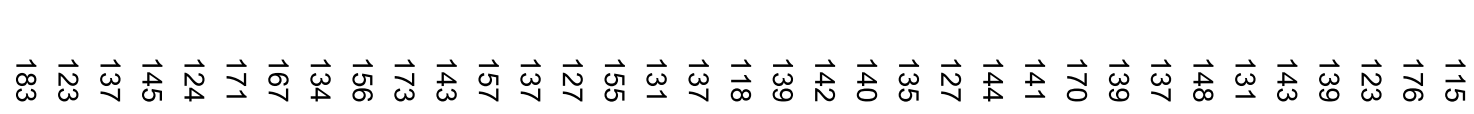




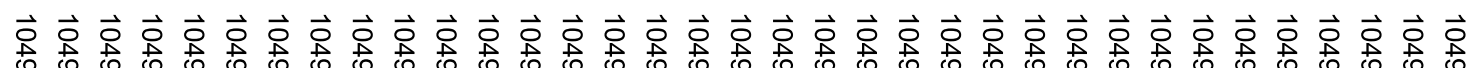
0
$\oplus$

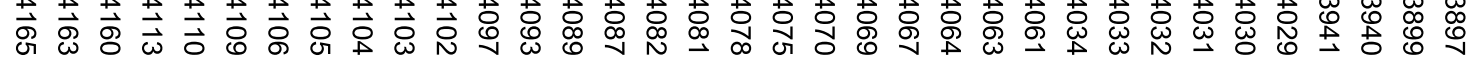

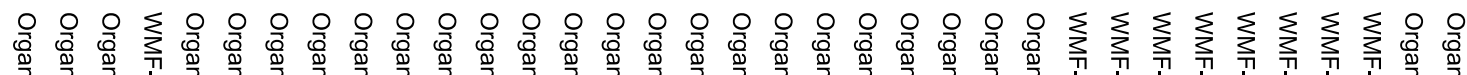

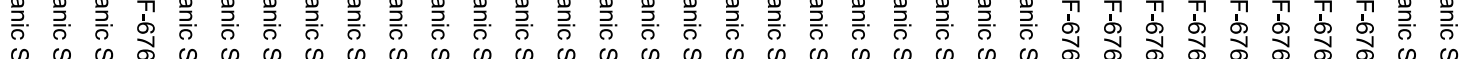
W

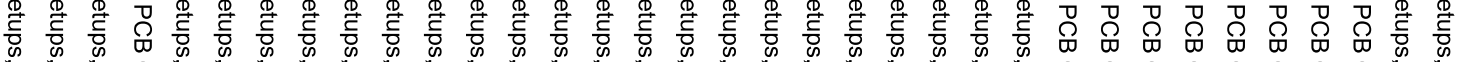

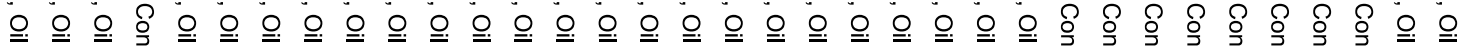

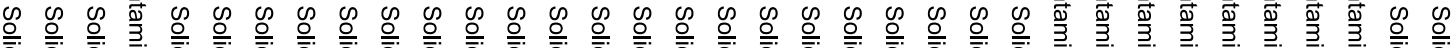

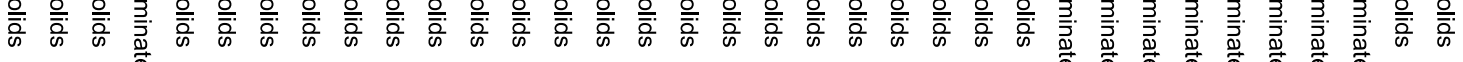

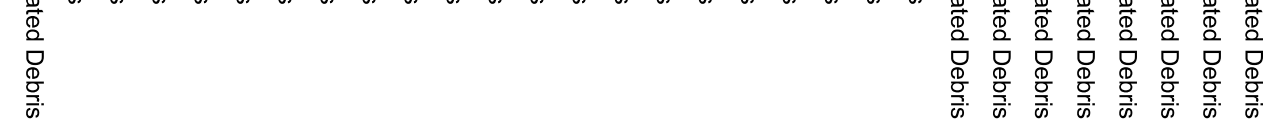

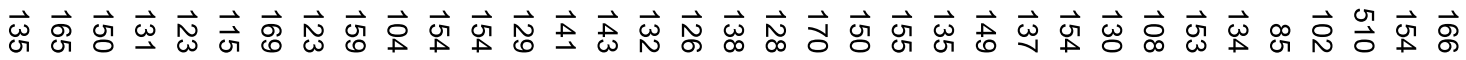

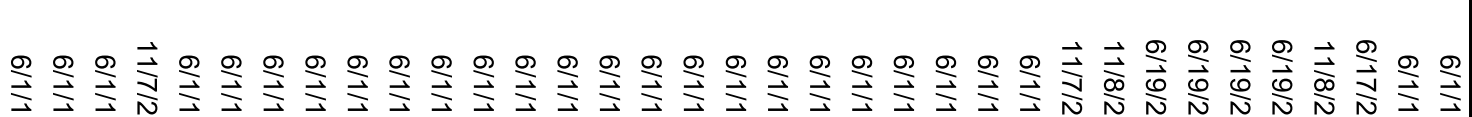

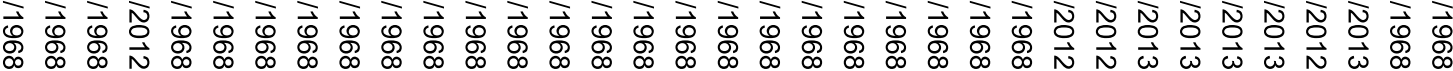

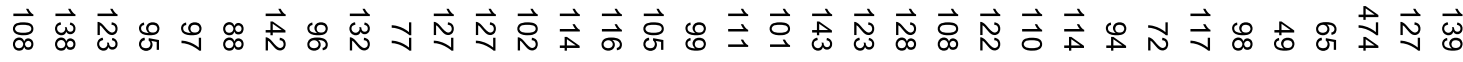
징 
$\vec{\circ} \vec{\circ} \vec{\circ} \vec{\circ} \vec{\circ} \vec{\circ} \vec{\circ} \vec{\circ} \vec{\circ} \vec{\circ} \vec{\circ} \vec{\circ} \vec{\circ} \vec{\circ} \vec{\circ} \vec{\circ} \vec{\circ} \vec{\circ} \vec{\circ} \vec{\circ} \vec{\circ} \vec{\circ} \vec{\circ} \vec{\circ} \vec{\circ} \vec{\circ}$

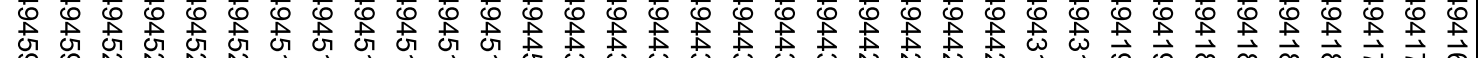

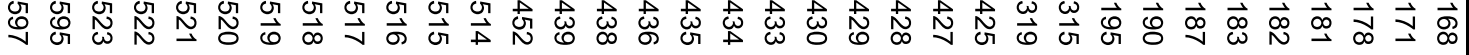

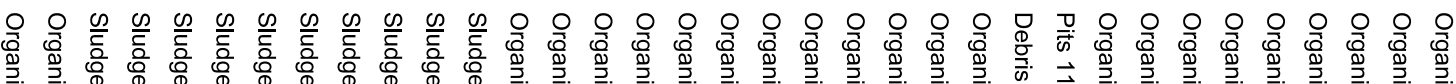

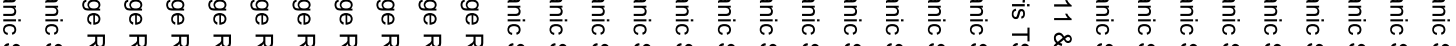
W c c 해

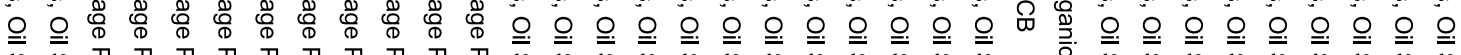
D

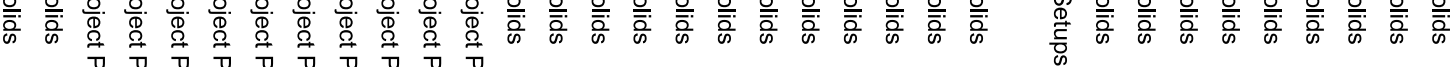

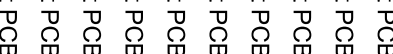

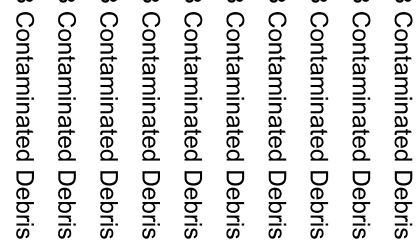

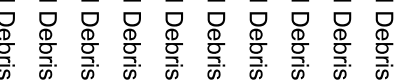

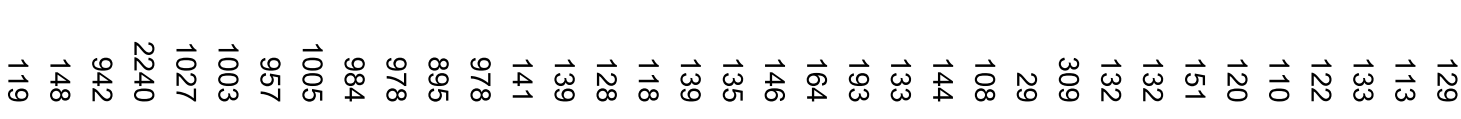

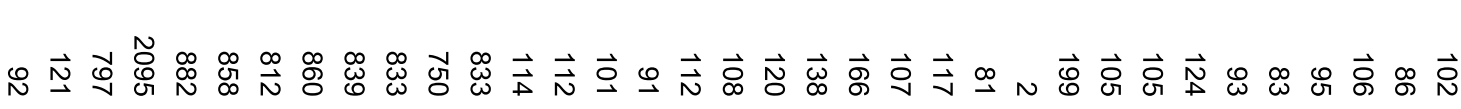




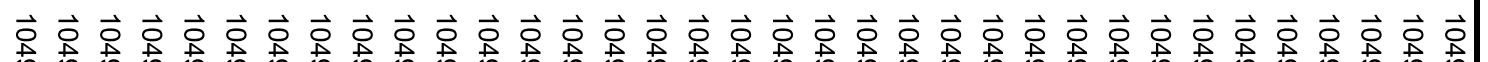
0
0 空

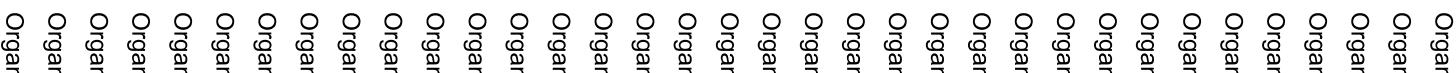

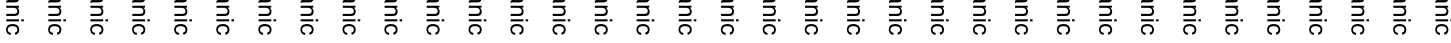

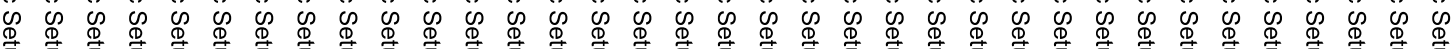
密

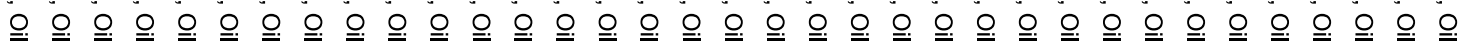

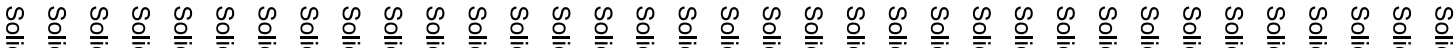

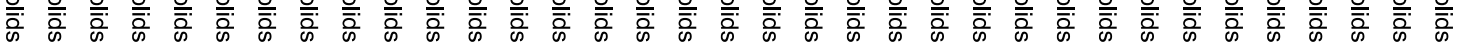

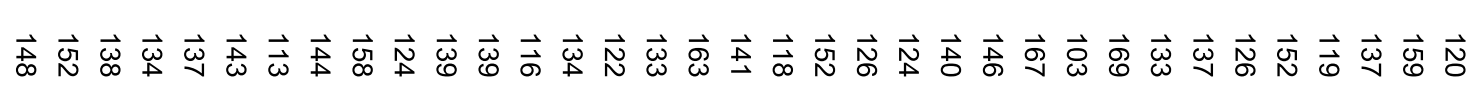


$\vec{\circ} \vec{\circ} \vec{\circ} \vec{\circ} \vec{\circ} \vec{\circ} \vec{\circ} \vec{\circ} \vec{\circ} \vec{\circ} \vec{\circ} \vec{\circ} \vec{\circ} \vec{\circ} \vec{\circ} \vec{\circ} \vec{\circ} \vec{\circ} \vec{\circ} \vec{\circ} \vec{\circ} \vec{\circ} \vec{\circ} \vec{\circ} \vec{\circ}$

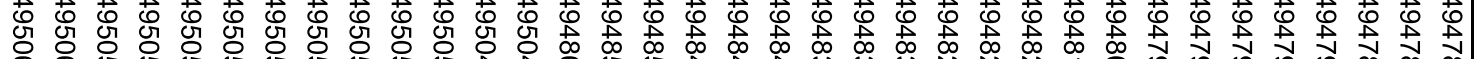

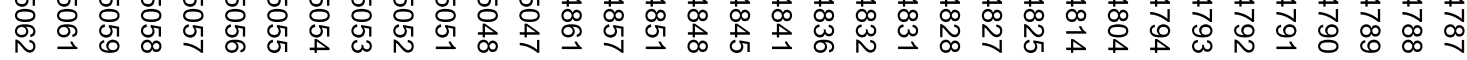

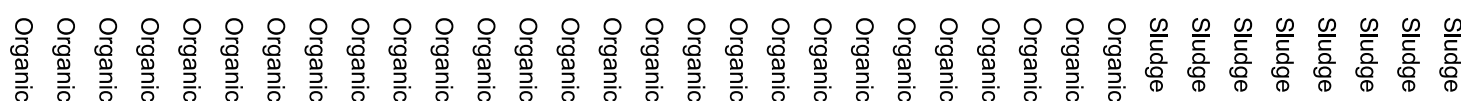

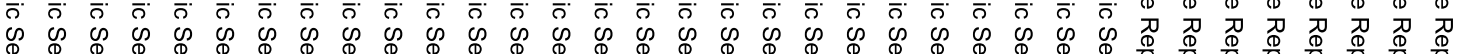

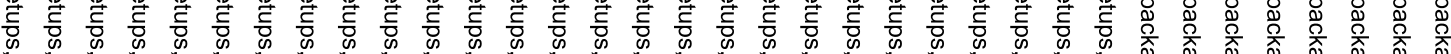

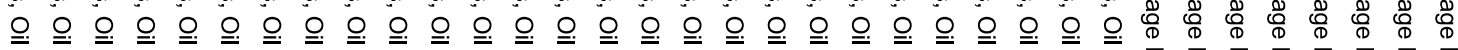
D

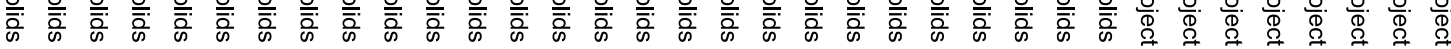

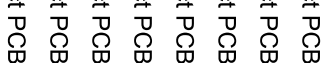

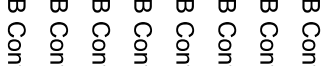

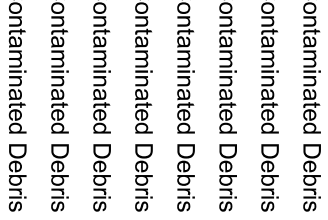

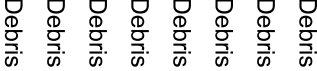

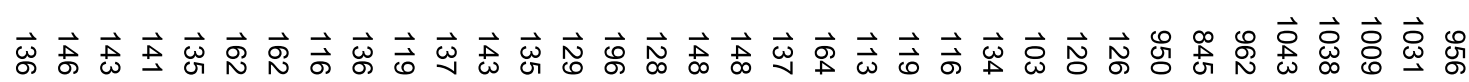

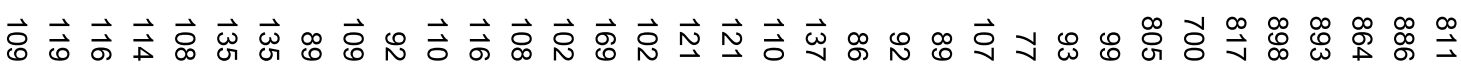
交兴

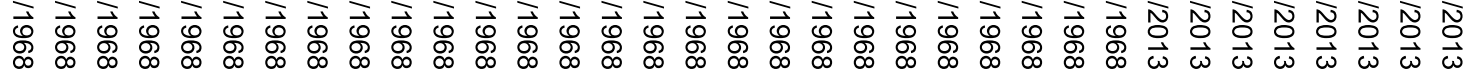


$\vec{\circ} \vec{\circ} \vec{\circ} \vec{\circ} \vec{\circ} \vec{\circ} \vec{\circ} \vec{\circ} \vec{\circ} \vec{\circ} \vec{\circ} \vec{\circ} \vec{\circ} \vec{\circ} \vec{\circ} \vec{\circ} \vec{\circ} \vec{\circ} \vec{\circ} \vec{\circ} \vec{\circ} \vec{\circ} \vec{\circ} \vec{\circ} \vec{\circ}$

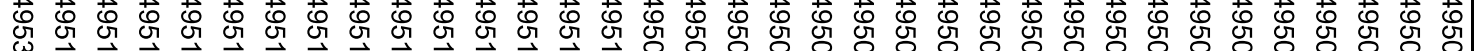

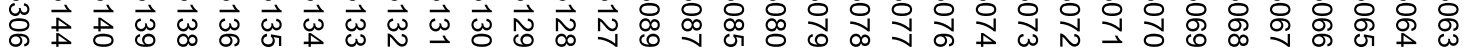

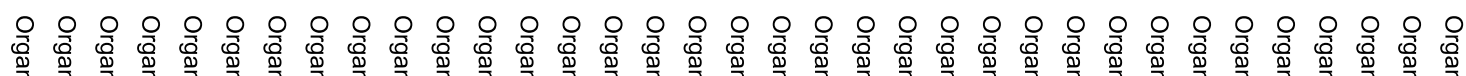

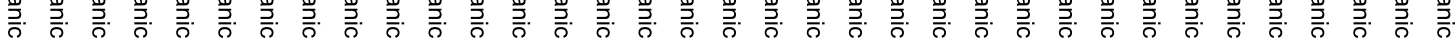

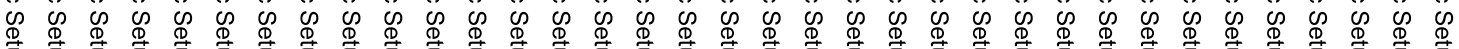
密

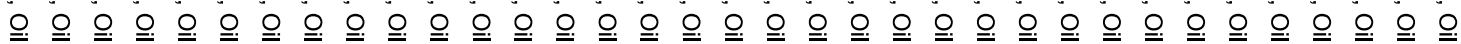

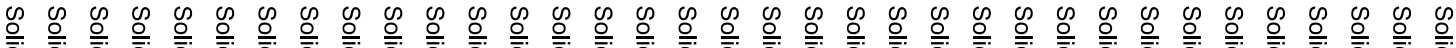

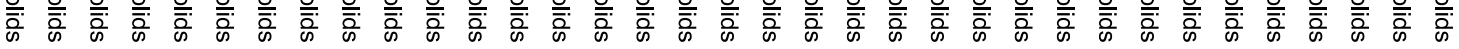

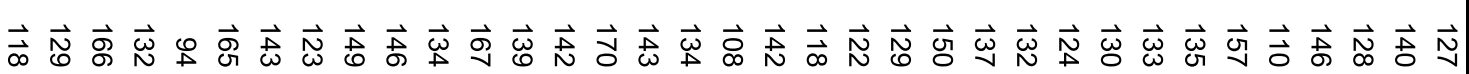

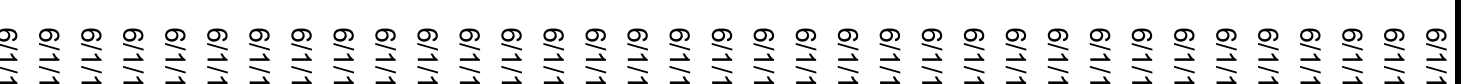

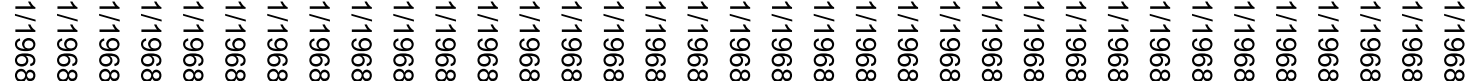


$\vec{\circ} \vec{\circ} \vec{\circ} \vec{\circ} \vec{\circ} \vec{\circ} \vec{\circ} \vec{\circ} \vec{\circ} \vec{\circ} \vec{\circ} \vec{\circ} \vec{\circ} \vec{\circ} \vec{\circ} \vec{\circ} \vec{\circ} \vec{\circ} \vec{\circ} \vec{\circ} \vec{\circ} \vec{\circ} \vec{\circ} \vec{\circ} \vec{\circ}$ 崩

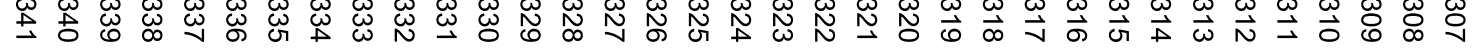

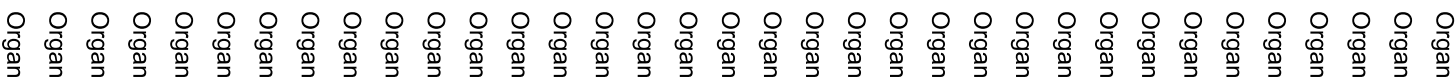

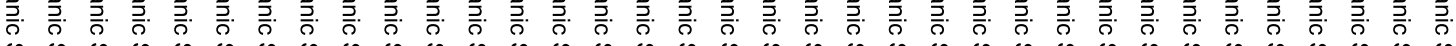
$\mathbb{W}$ W

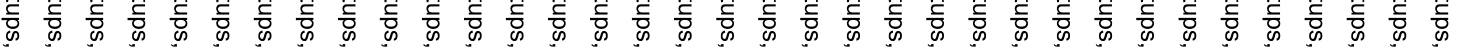

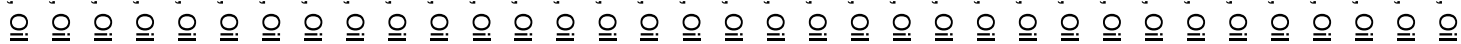

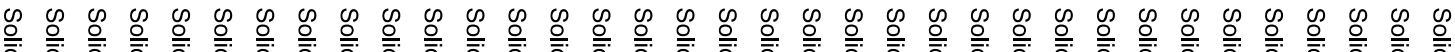

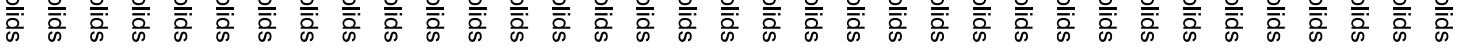

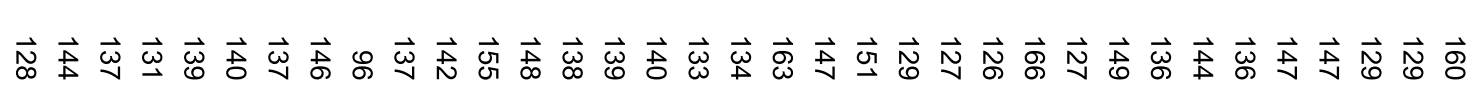




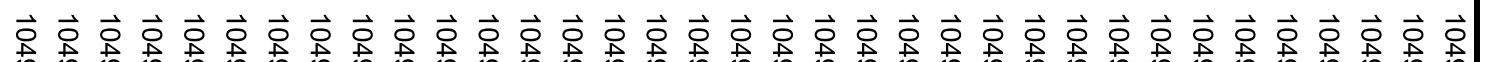

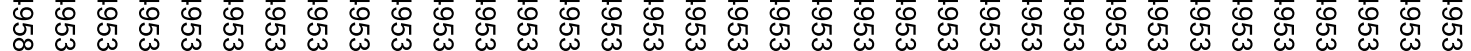

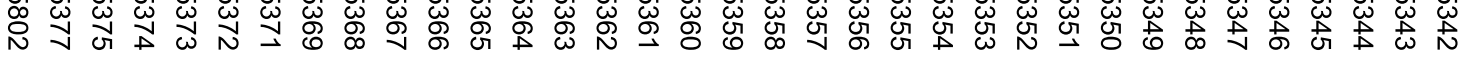

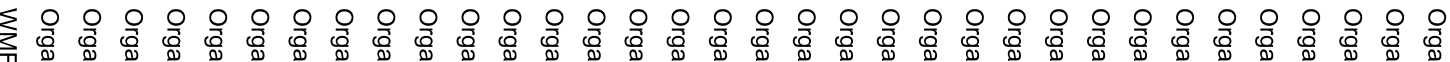

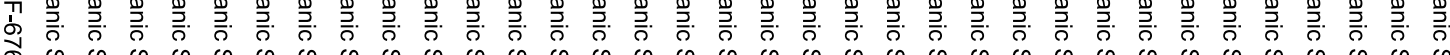

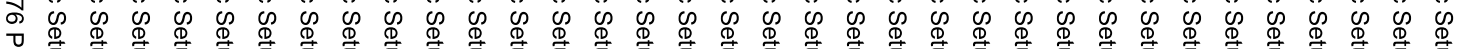

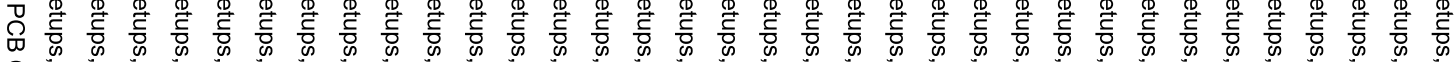

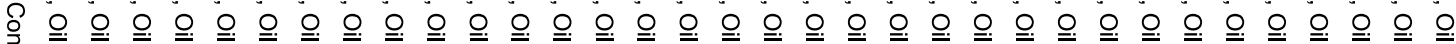

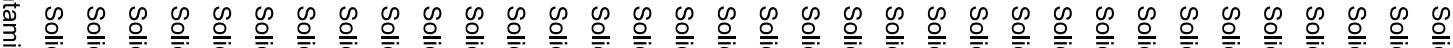

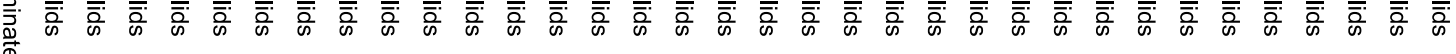
$\frac{\sqrt{0}}{\frac{D}{0}}$

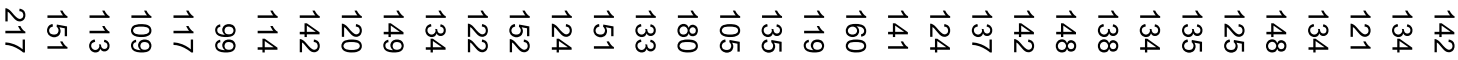

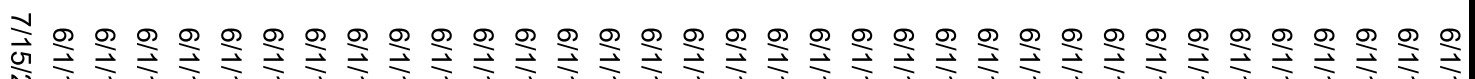
它 
$\vec{\circ} \vec{\circ} \vec{\circ} \vec{\circ} \vec{\circ} \vec{\circ} \vec{\circ} \vec{\circ} \vec{\circ} \vec{\circ} \vec{\circ} \vec{\circ} \vec{\circ} \vec{\circ} \vec{\circ} \vec{\circ} \vec{\circ} \vec{\circ} \vec{\circ} \vec{\circ} \vec{\circ} \vec{\circ} \vec{\circ} \vec{\circ} \vec{\circ} \vec{\circ} \vec{\circ}$

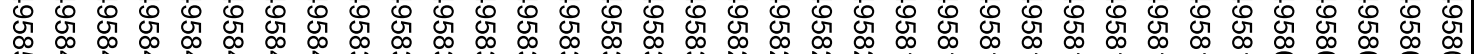

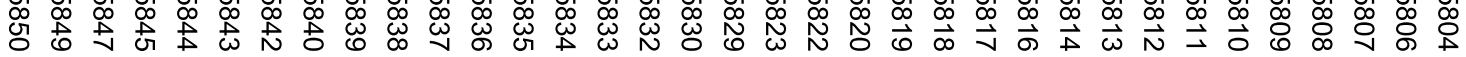

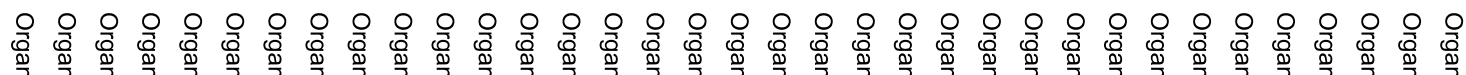

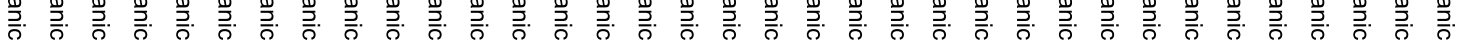

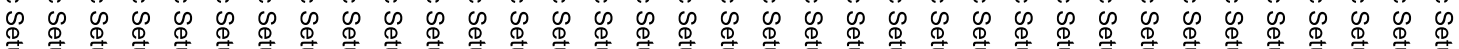

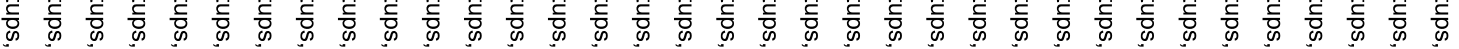

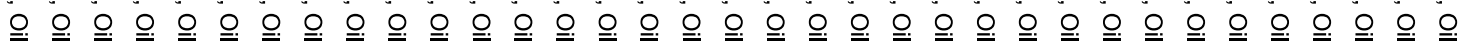

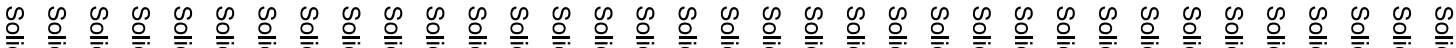

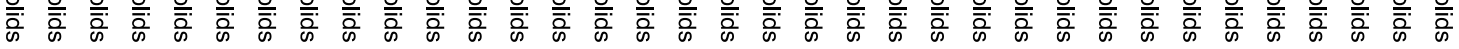

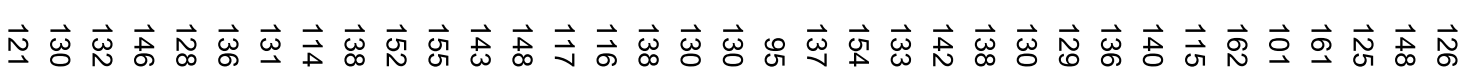




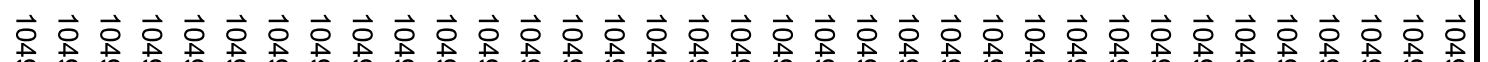

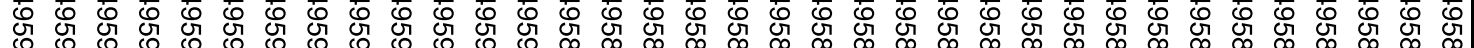

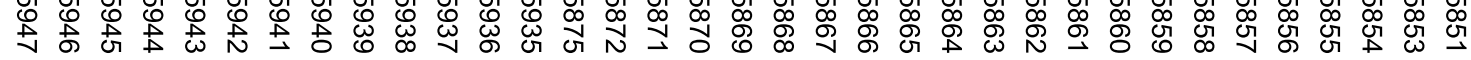

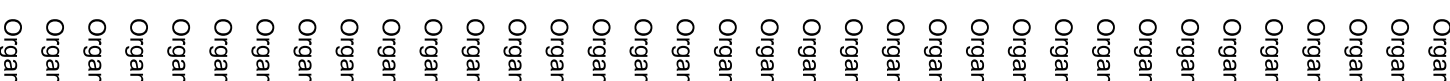

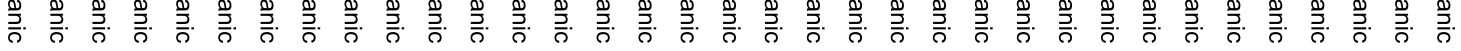

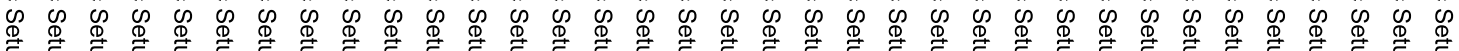

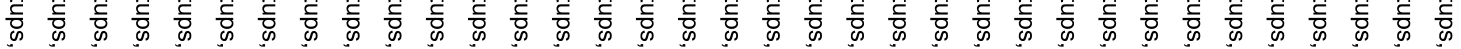

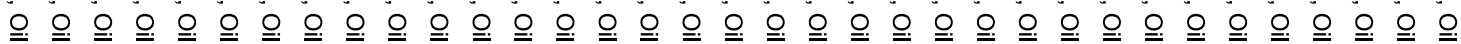

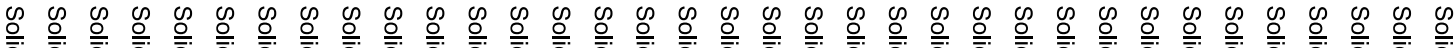

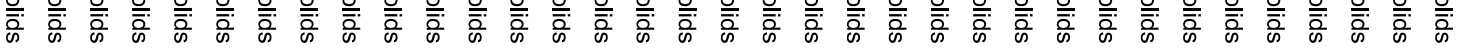

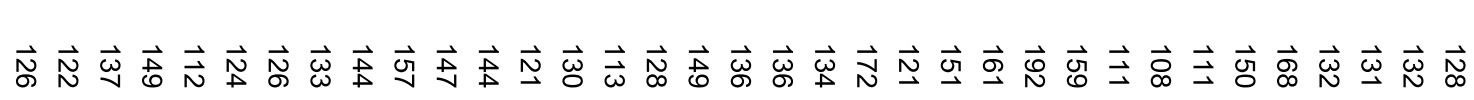

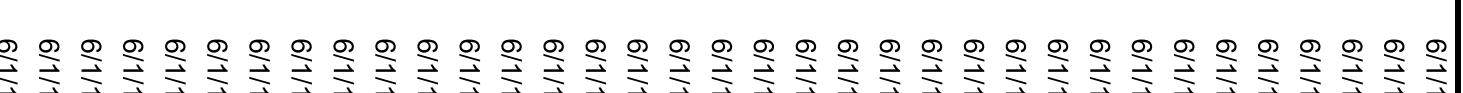




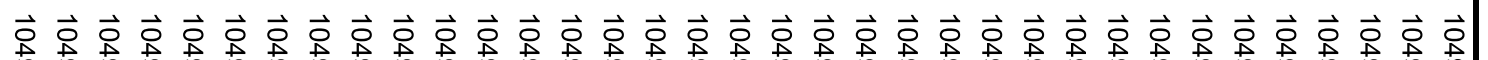
\% : $\%$ \%

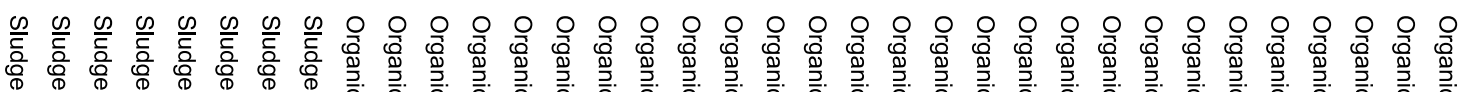

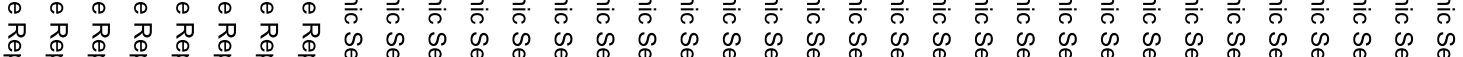

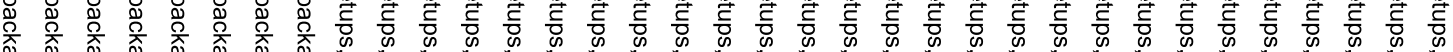
造

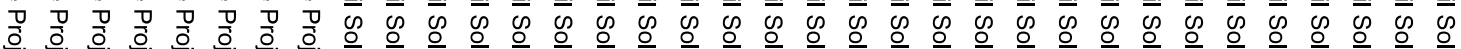

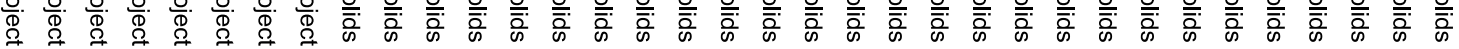

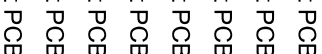

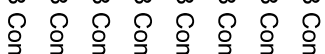

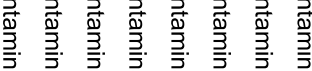

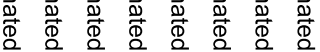

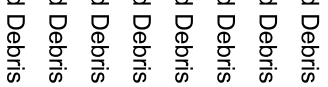

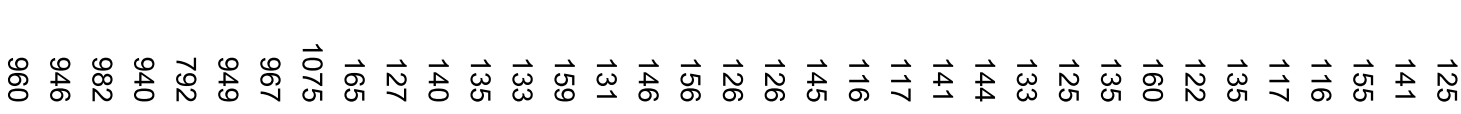

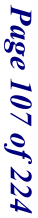

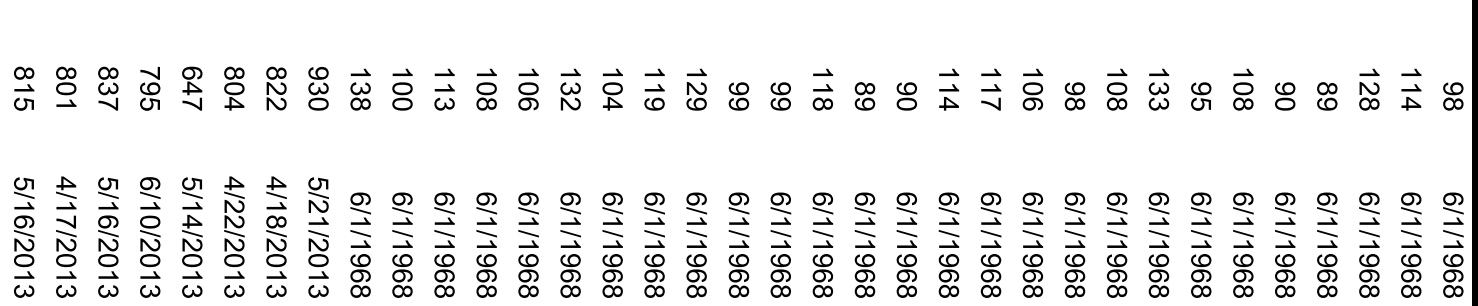

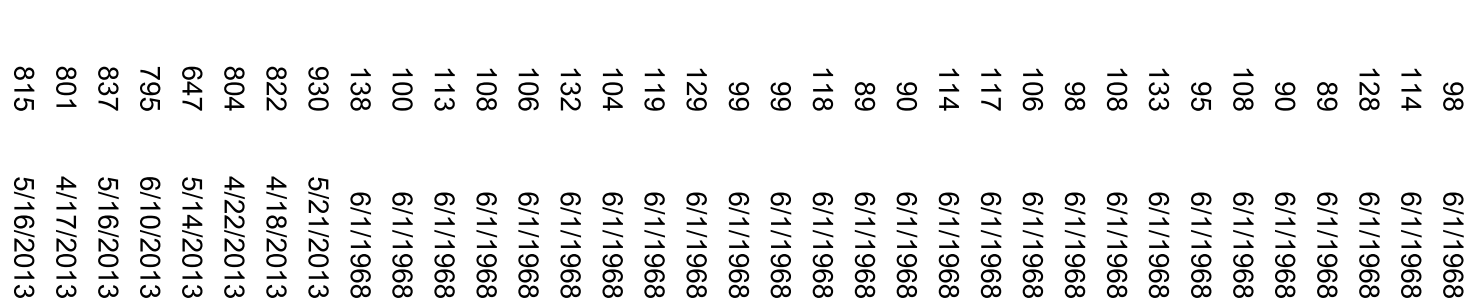

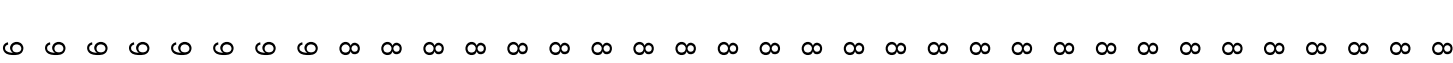


$\vec{\circ} \vec{\circ} \vec{\circ} \vec{\circ} \vec{\circ} \vec{\circ} \vec{\circ} \vec{\circ} \vec{\circ} \vec{\circ} \vec{\circ} \vec{\circ} \vec{\circ} \vec{\circ} \vec{\circ} \vec{\circ} \vec{\circ} \vec{\circ} \vec{\circ} \vec{\circ} \vec{\circ} \vec{\circ} \vec{\circ} \vec{\circ} \vec{\circ} \vec{\circ}$

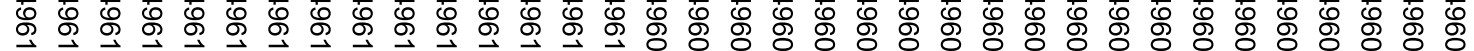

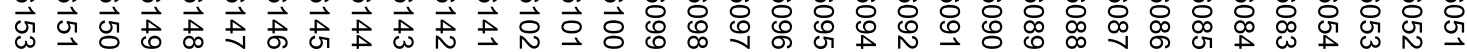

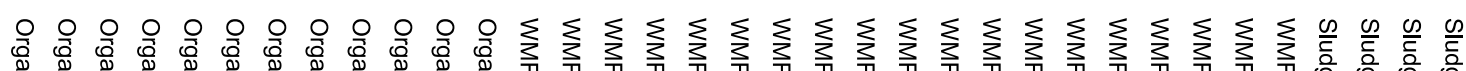

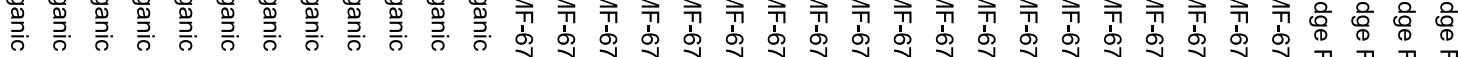

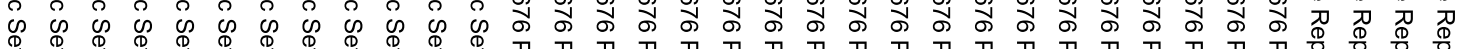

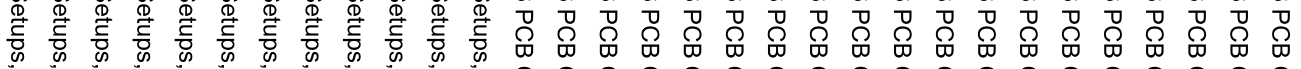

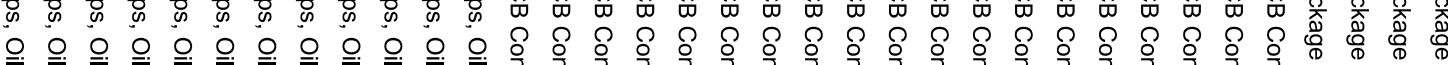

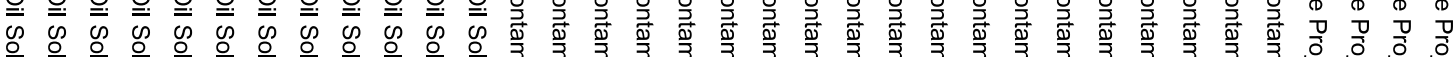

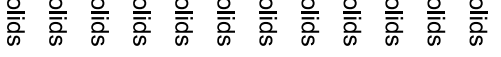

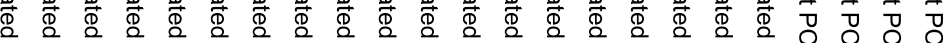

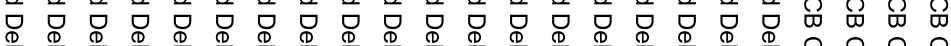

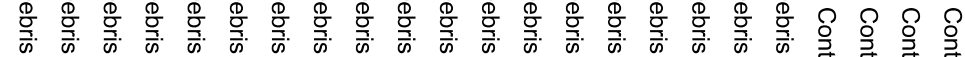

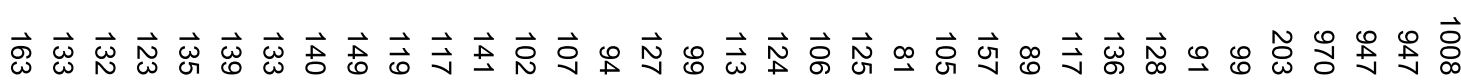

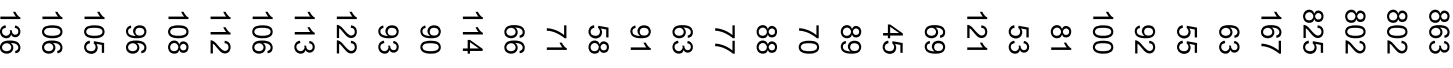


$\vec{\circ} \vec{\circ} \vec{\circ} \vec{\circ} \vec{\circ} \vec{\circ} \vec{\circ} \vec{\circ} \vec{\circ} \vec{\circ} \vec{\circ} \vec{\circ} \vec{\circ} \vec{\circ} \vec{\circ} \vec{\circ} \vec{\circ} \vec{\circ} \vec{\circ} \vec{\circ} \vec{\circ} \vec{\circ} \vec{\circ} \vec{\circ} \vec{\circ} \vec{\circ} \vec{\circ} \vec{\circ}$ ग

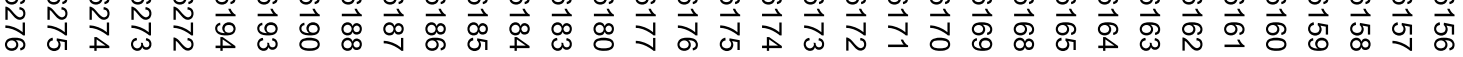

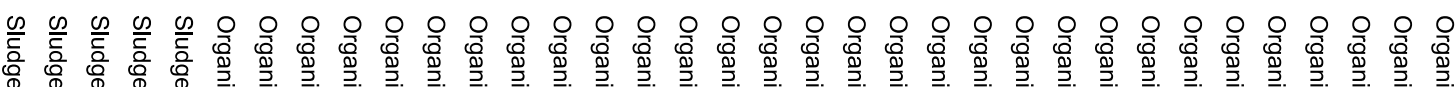

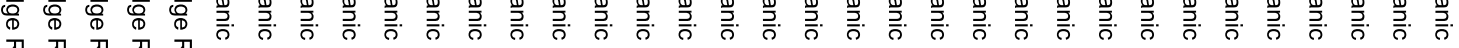

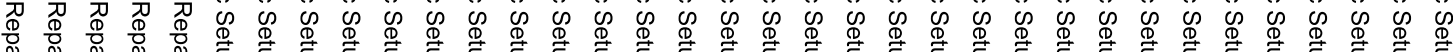

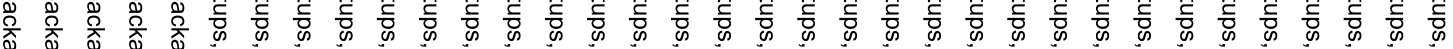

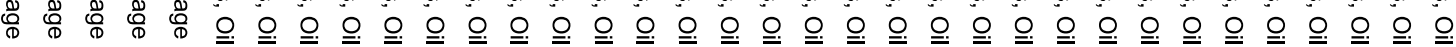

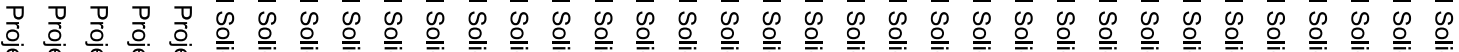

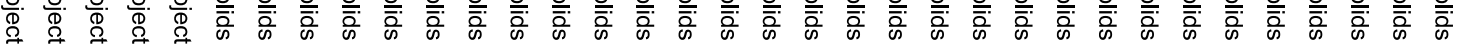
ते

$\odot \bigcirc$

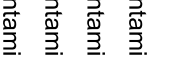

变

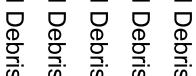

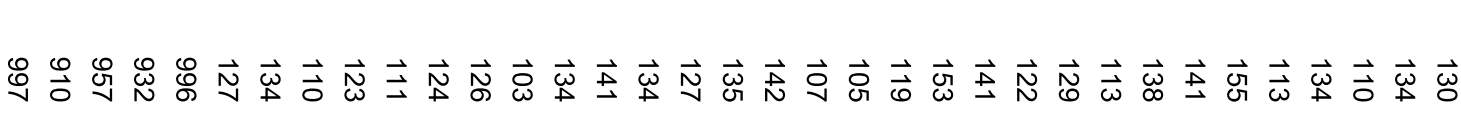

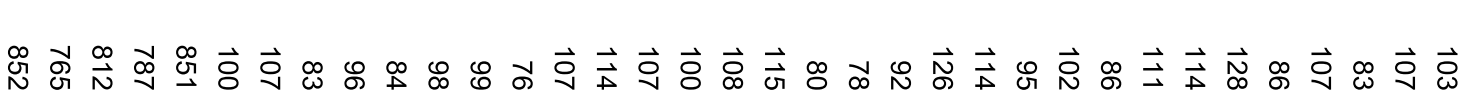

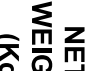

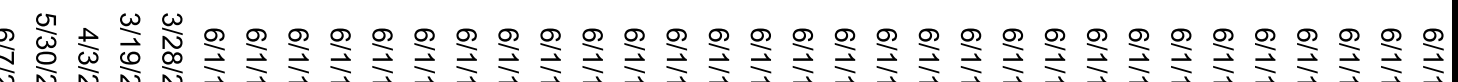
N 


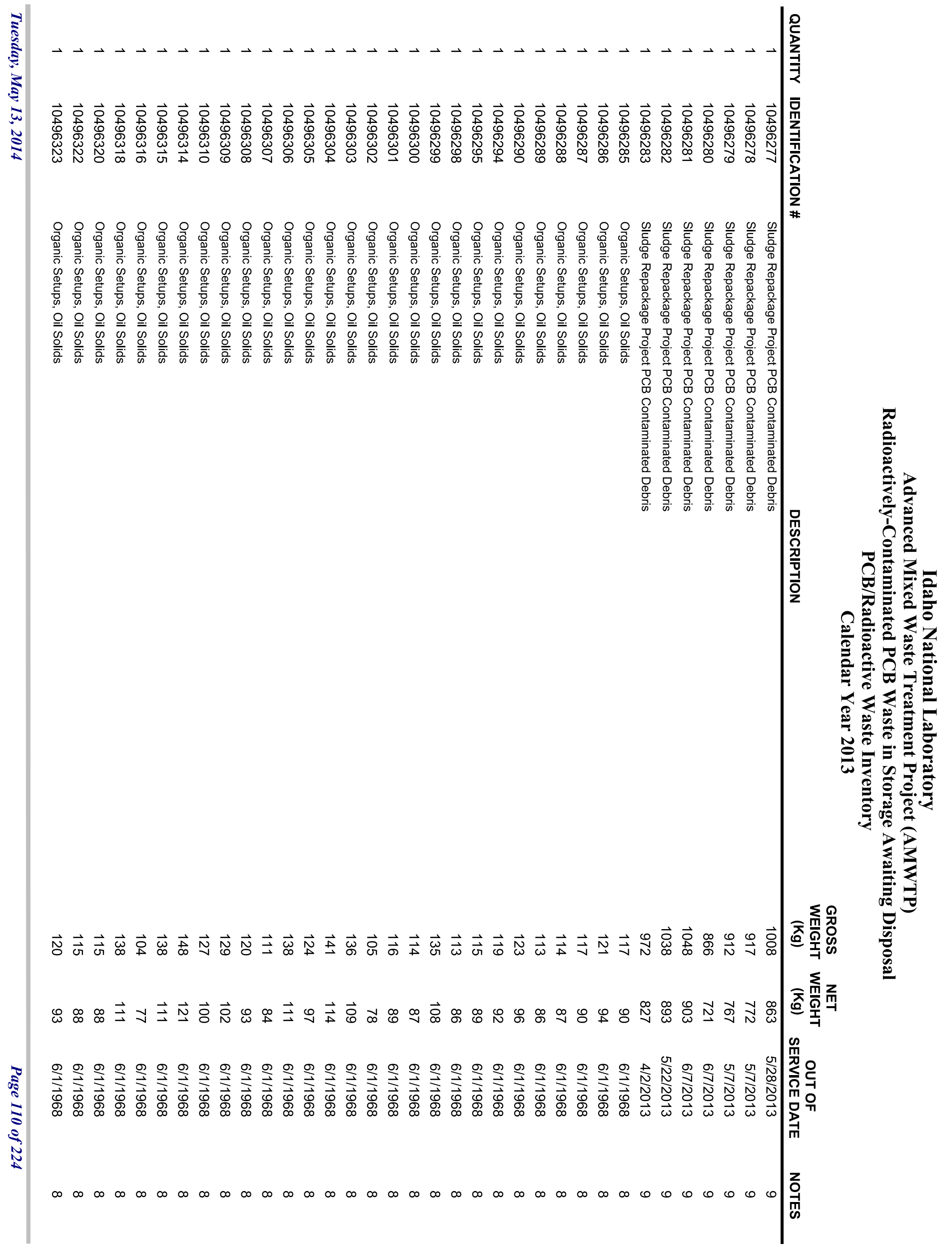




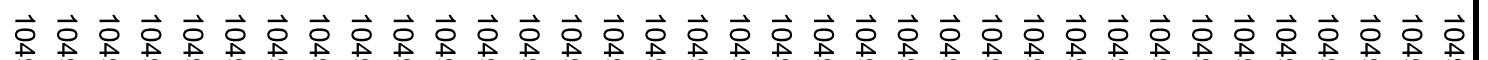

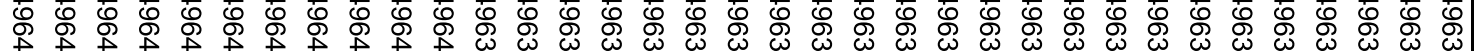

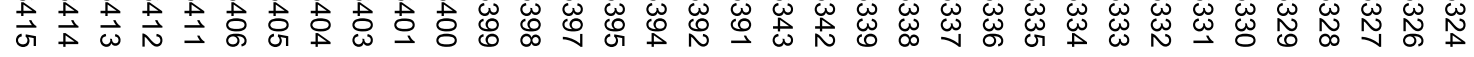

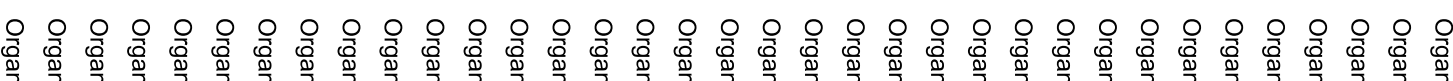

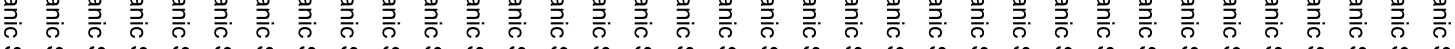

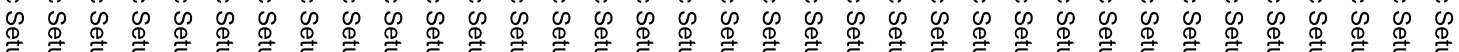
密

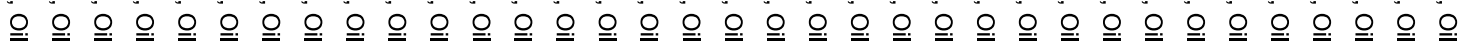

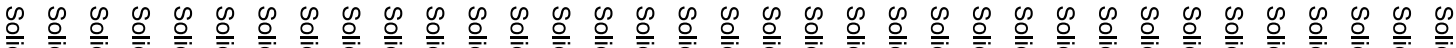

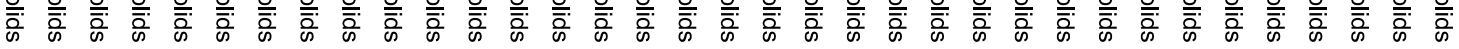

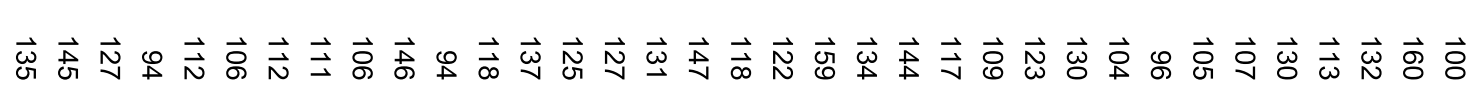

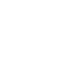


位 $\vec{\circ} \vec{\circ} \vec{\circ} \vec{\circ} \vec{\circ} \vec{\circ} \vec{\circ} \vec{\circ} \vec{\circ} \vec{\circ} \vec{\circ} \vec{\circ} \vec{\circ} \vec{\circ} \vec{\circ} \vec{\circ} \vec{\circ} \vec{\circ} \vec{\circ} \vec{\circ} \vec{\circ} \vec{\circ} \vec{\circ} \vec{\circ} \vec{\circ}$ O 00 \%

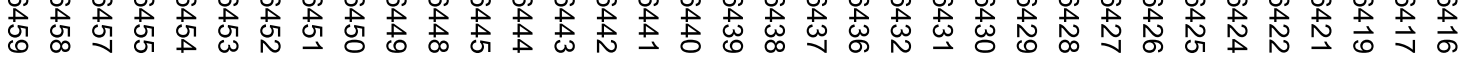

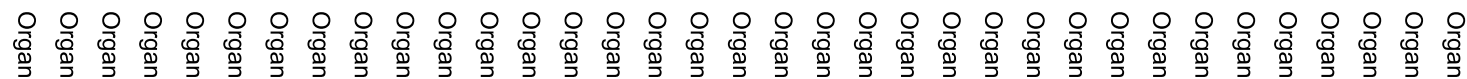

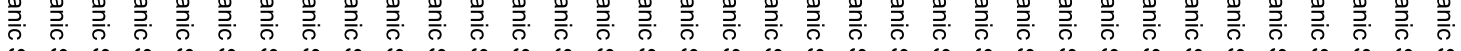

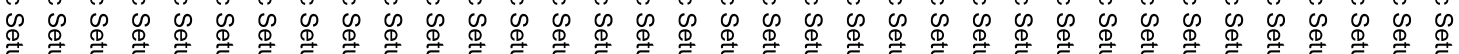

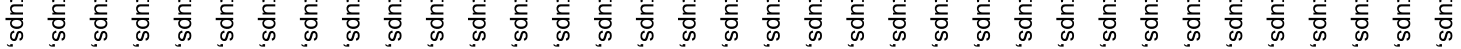

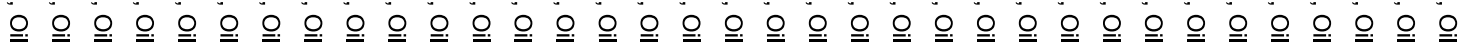

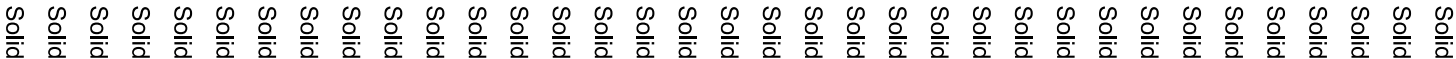

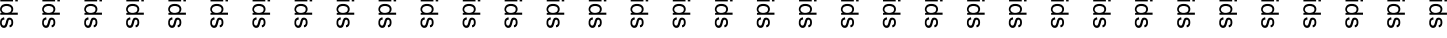

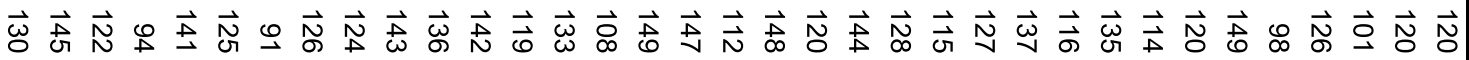


$\vec{\circ} \vec{\circ} \vec{\circ} \vec{\circ} \vec{\circ} \vec{\circ} \vec{\circ} \vec{\circ} \vec{\circ} \vec{\circ} \vec{\circ} \vec{\circ} \vec{\circ} \vec{\circ} \vec{\circ} \vec{\circ} \vec{\circ} \vec{\circ} \vec{\circ} \vec{\circ} \vec{\circ} \vec{\circ} \vec{\circ} \vec{\circ}$ 贯

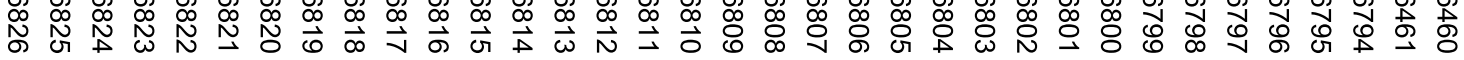

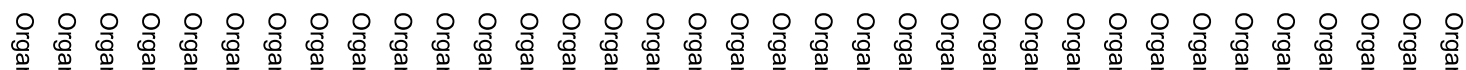

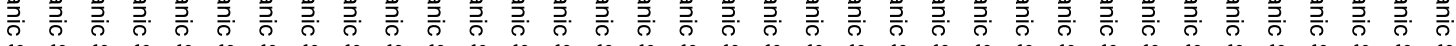

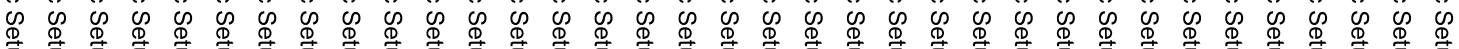
密

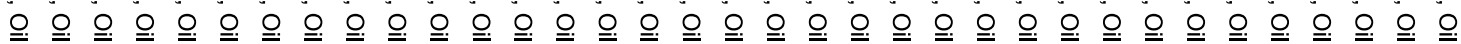

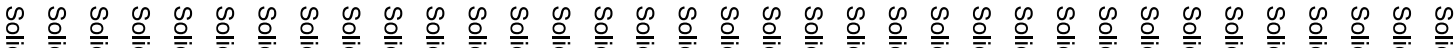

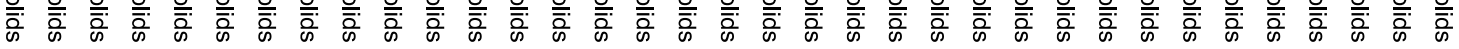

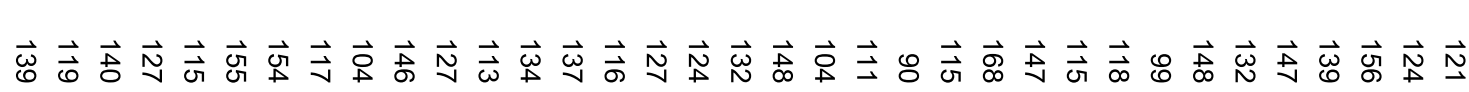




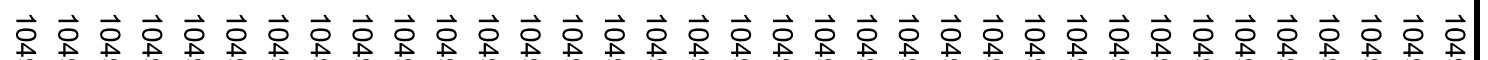

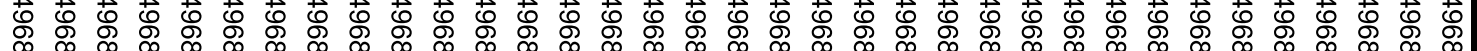

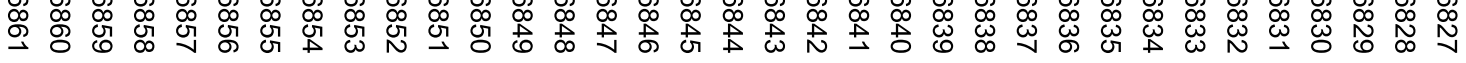

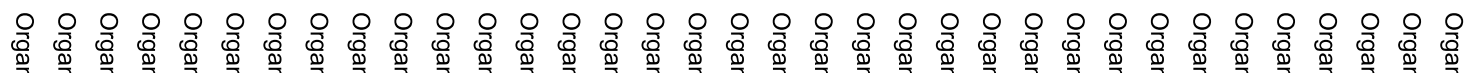

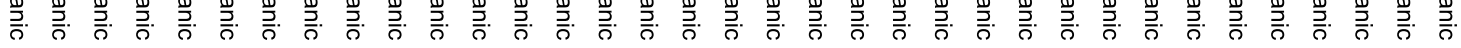

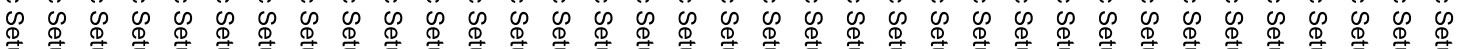
密

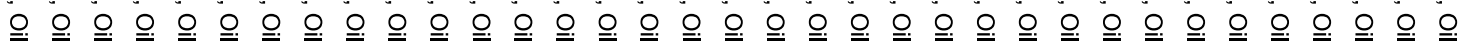

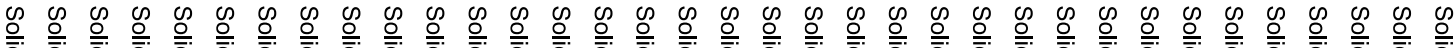

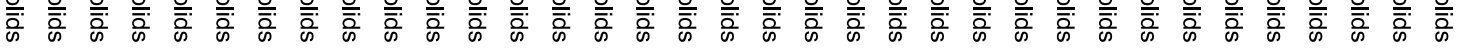

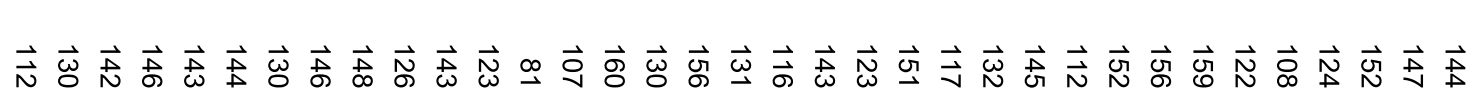




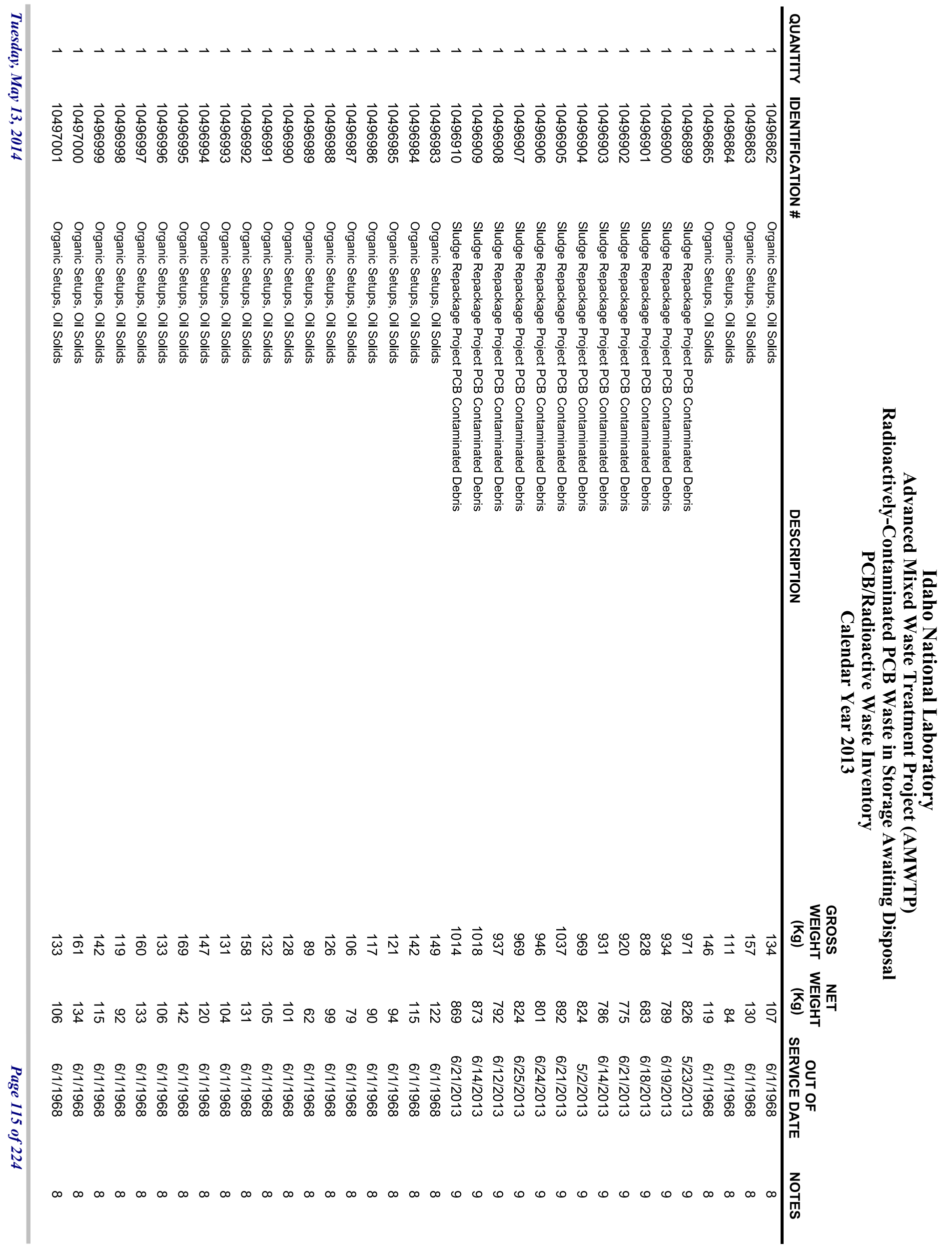




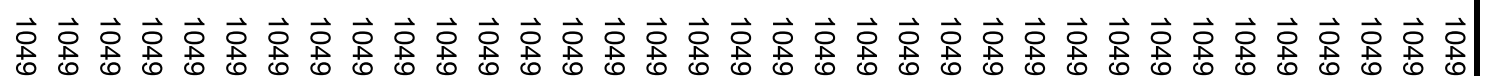

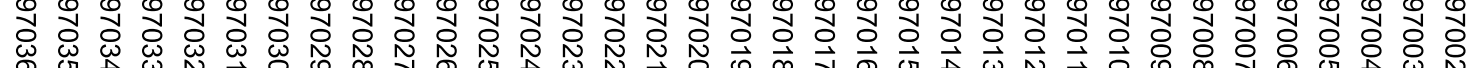

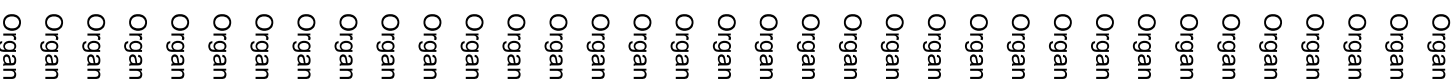

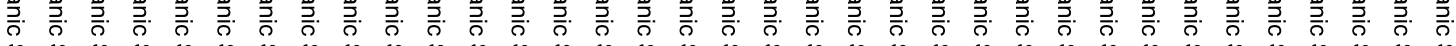

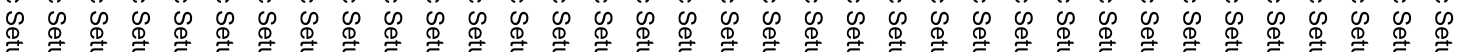
骔

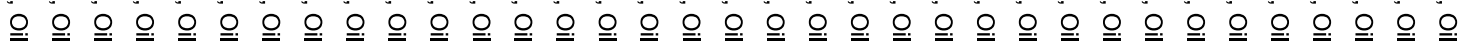

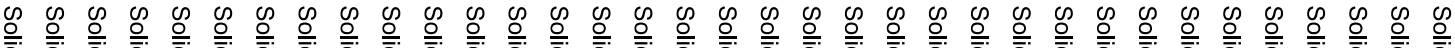

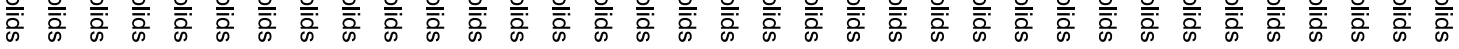

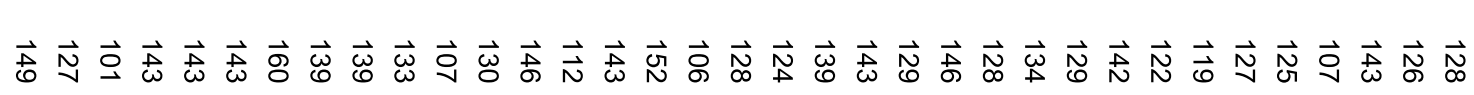




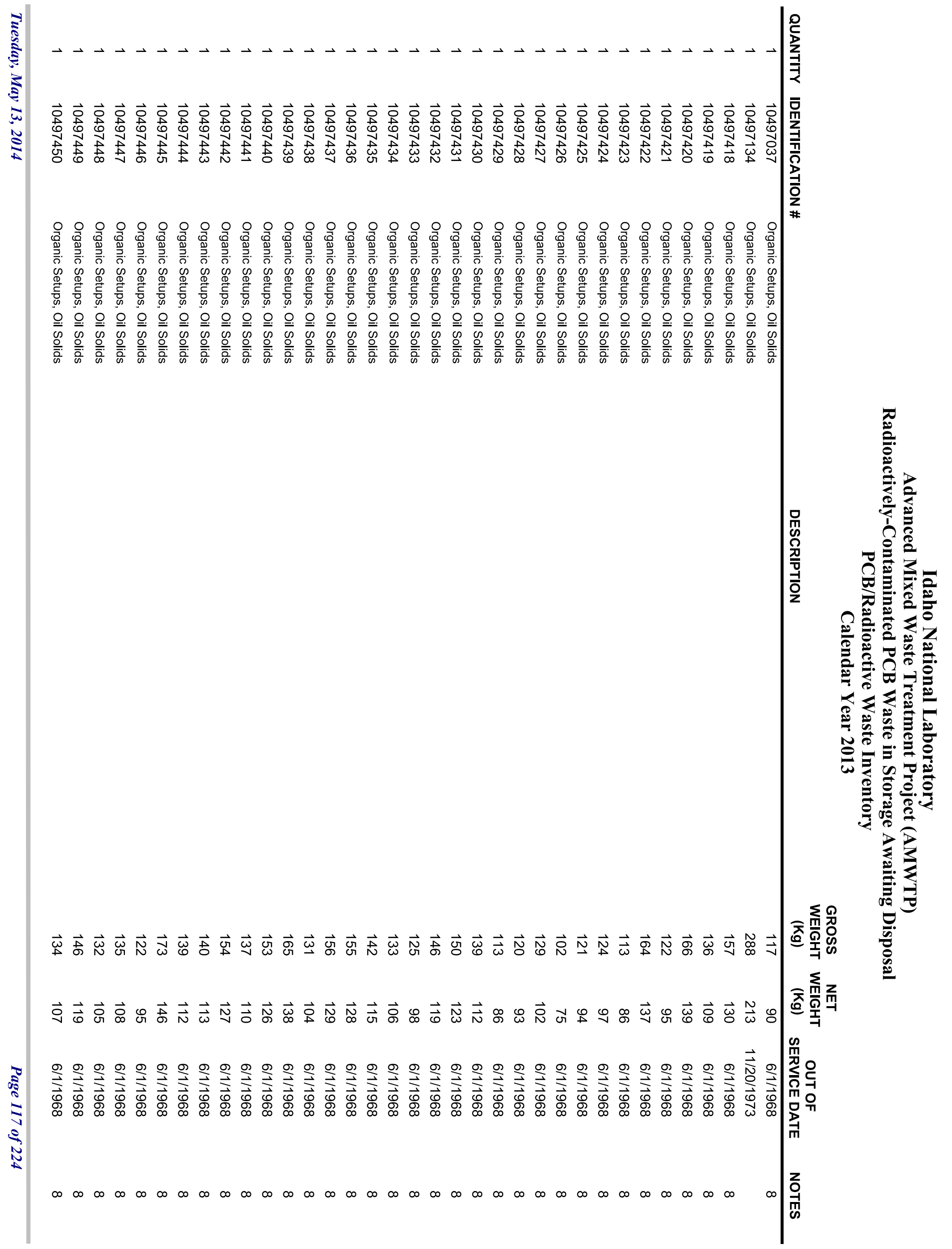




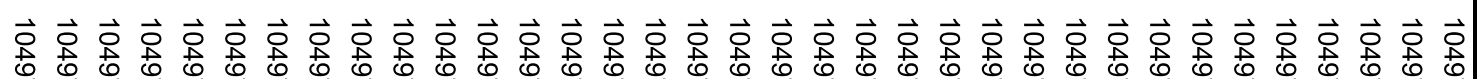
जी

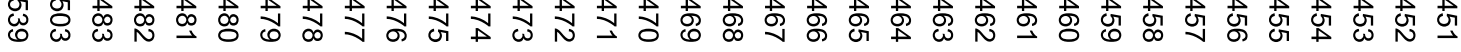

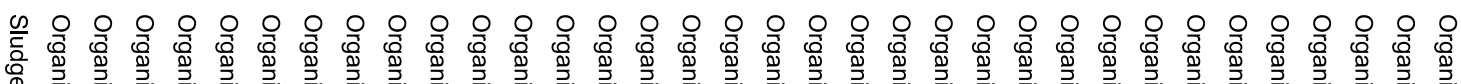

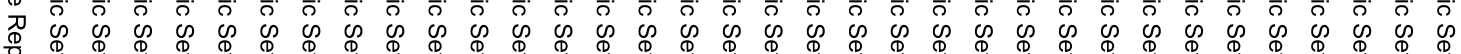

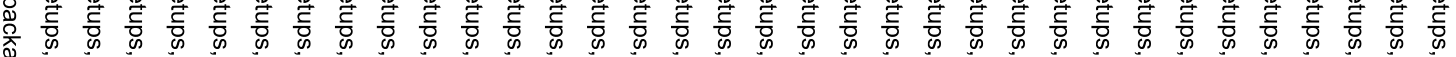

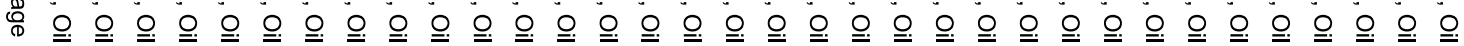

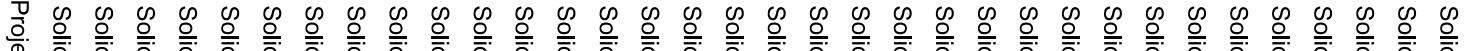

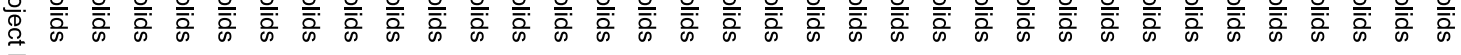
กัญ

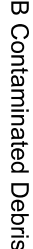

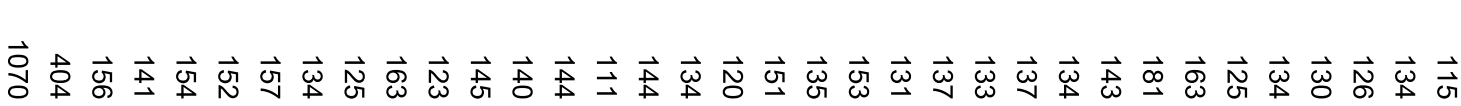

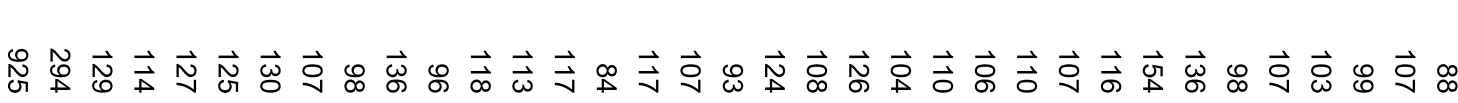




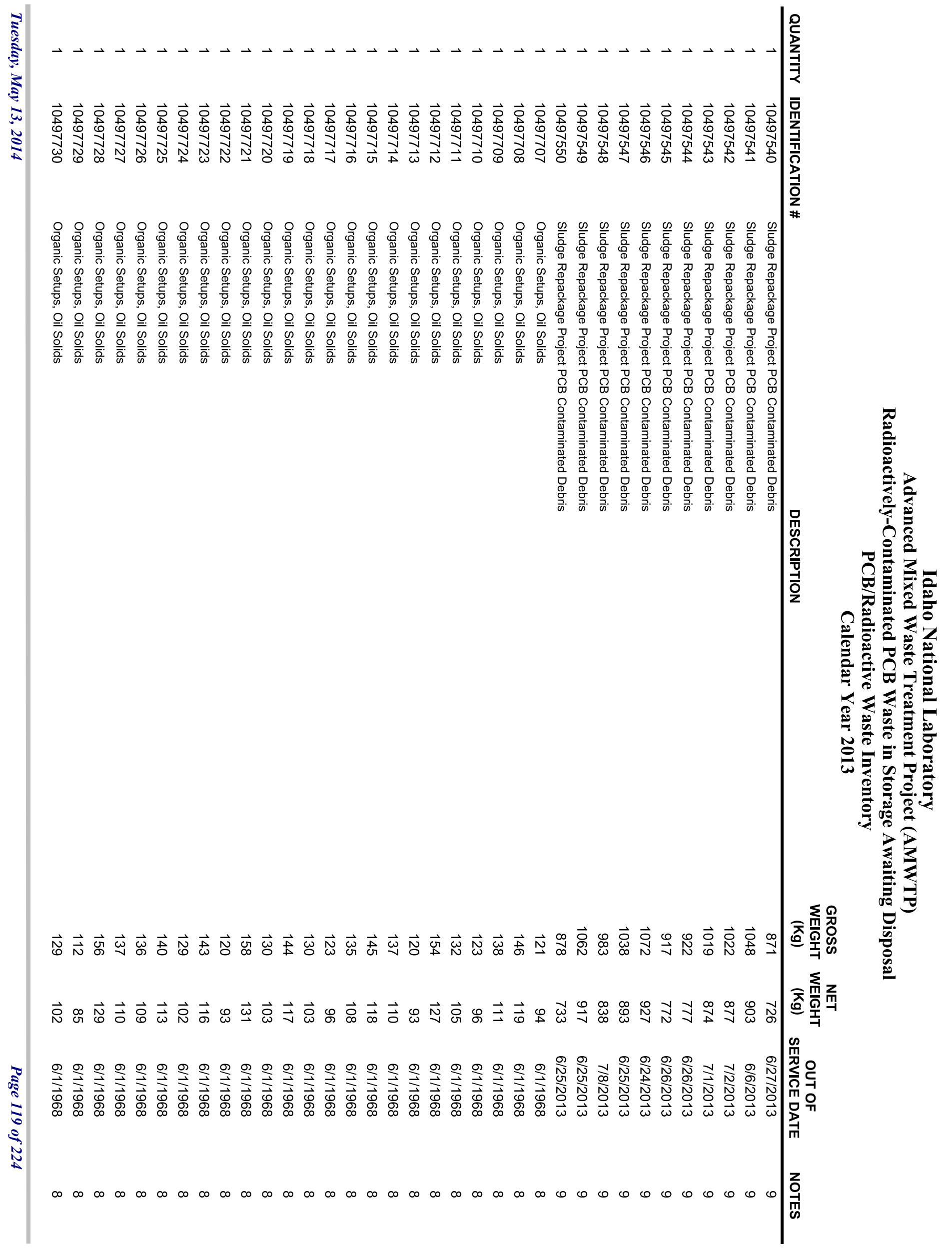




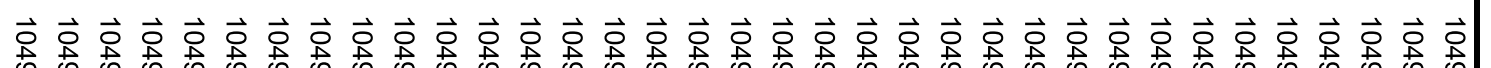

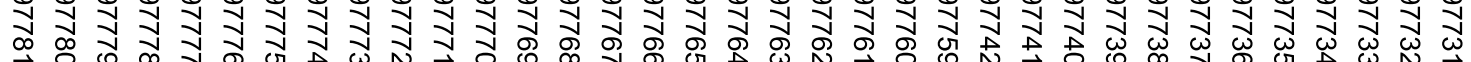

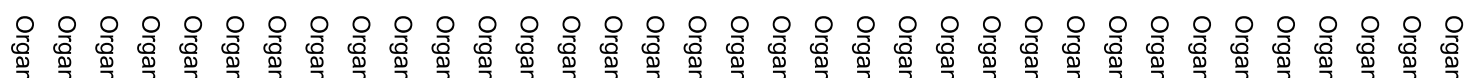

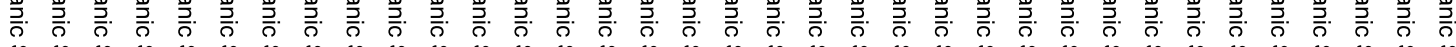

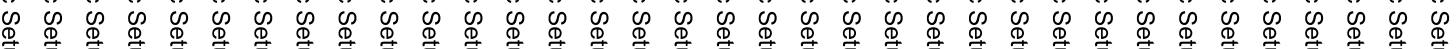
密

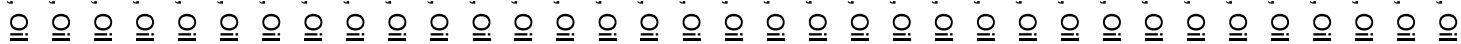

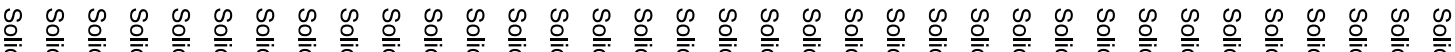

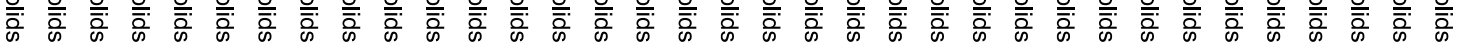

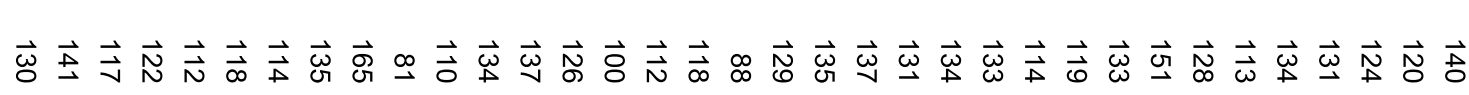

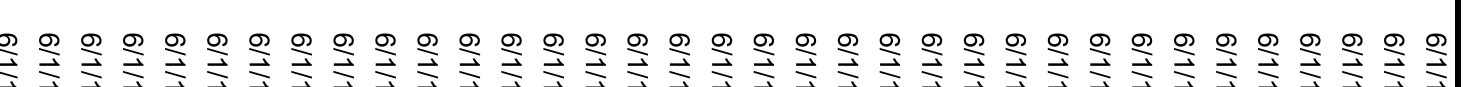

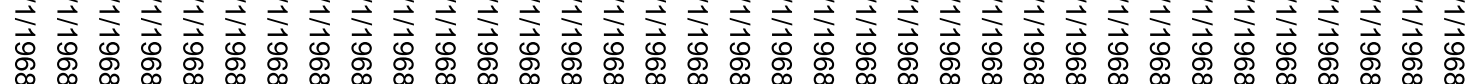




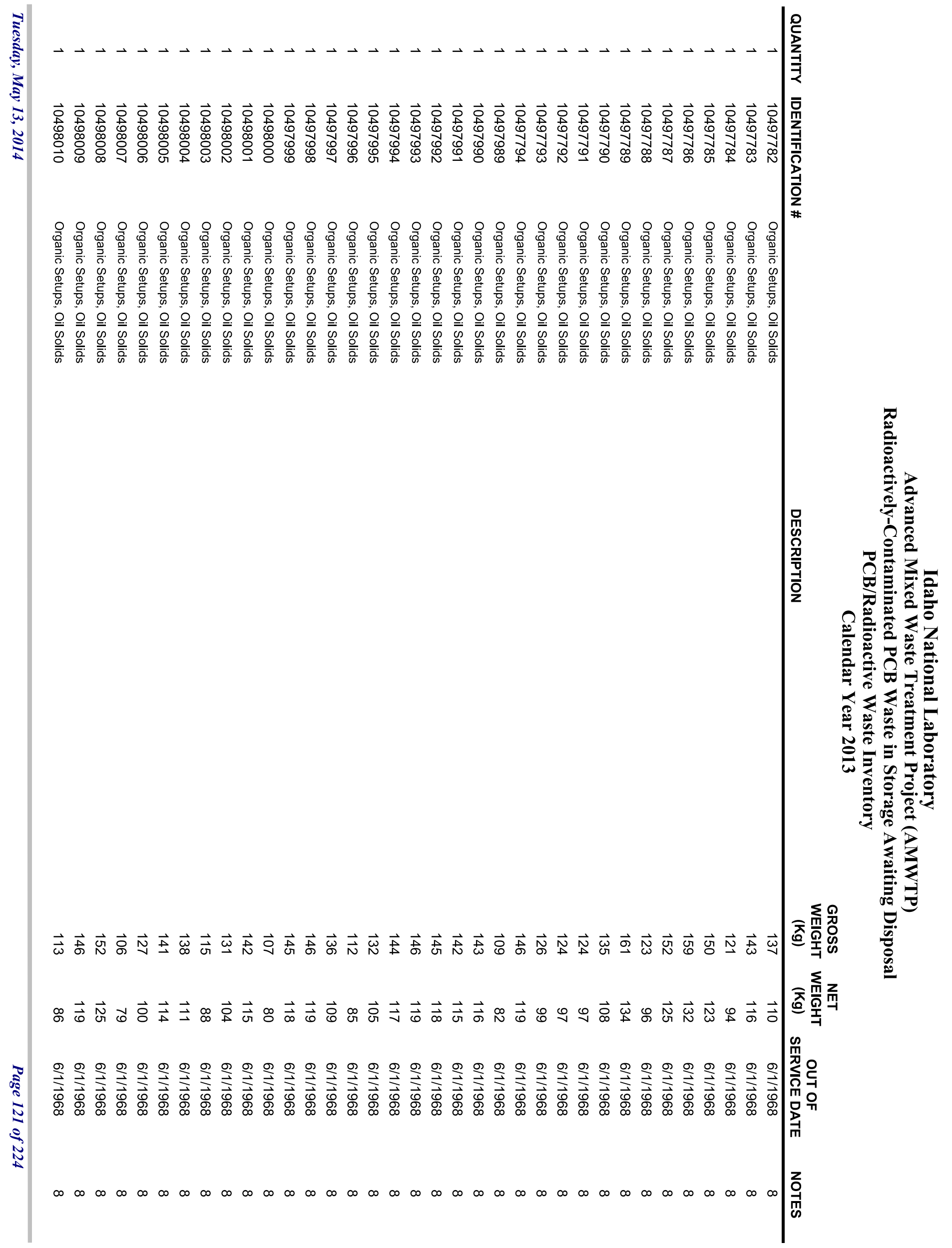


$\vec{\circ} \vec{\circ} \vec{\circ} \vec{\circ} \vec{\circ} \vec{\circ} \vec{\circ} \vec{\circ} \vec{\circ} \vec{\circ} \vec{\circ} \vec{\circ} \vec{\circ} \vec{\circ} \vec{\circ} \vec{\circ} \vec{\circ} \vec{\circ} \vec{\circ} \vec{\circ} \vec{\circ} \vec{\circ} \vec{\circ} \vec{\circ} \vec{\circ}$ $\begin{array}{llll}0 & 0 & 0 & 0\end{array}$

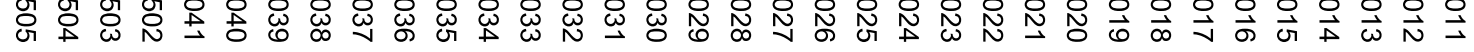

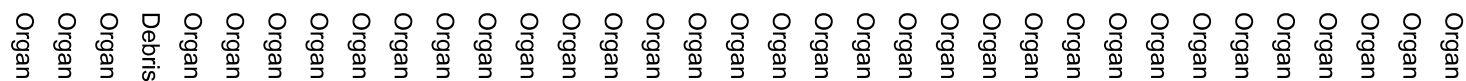

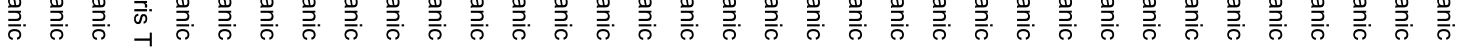

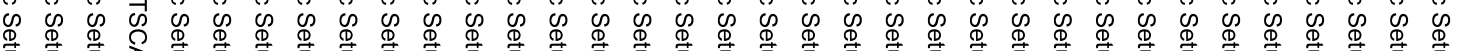
部安

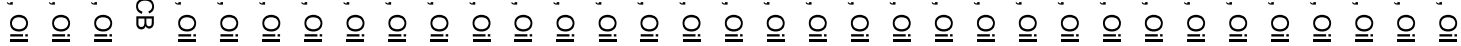

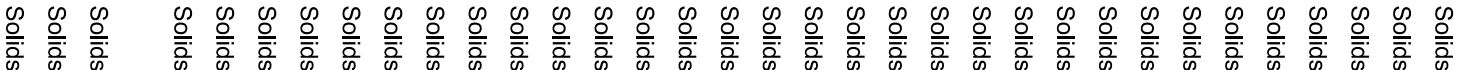

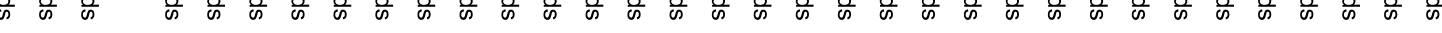

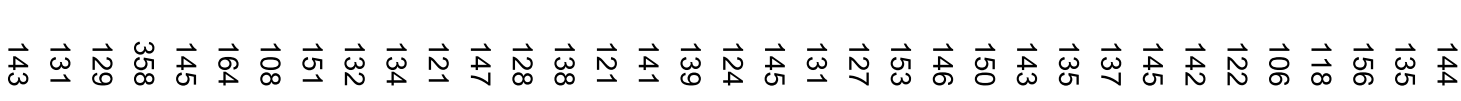




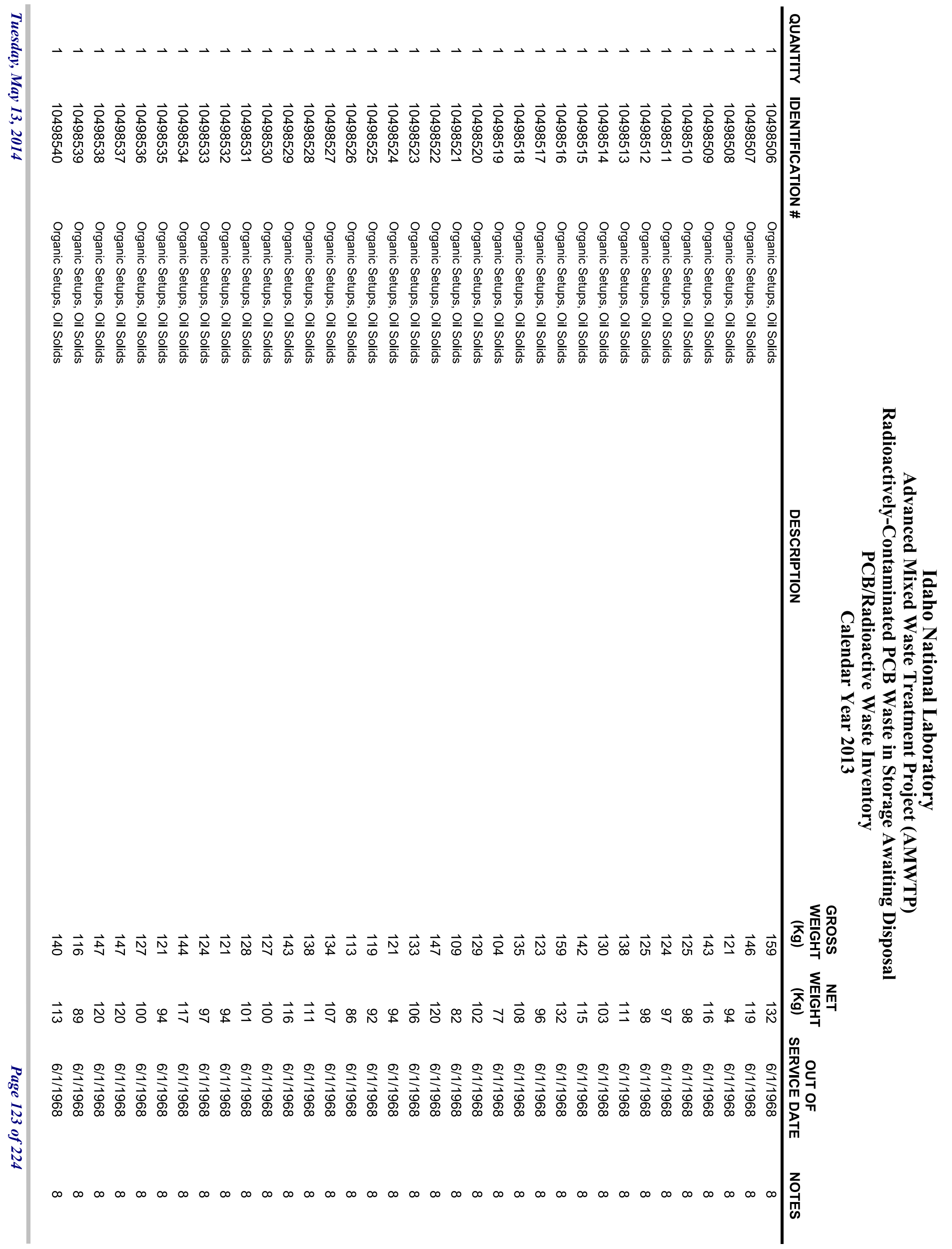




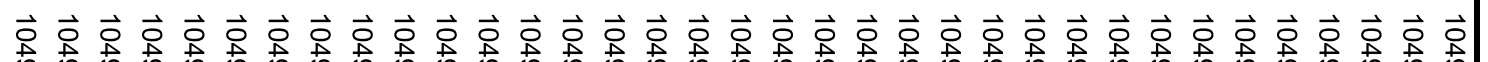

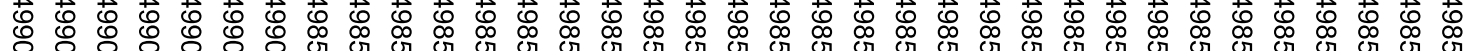

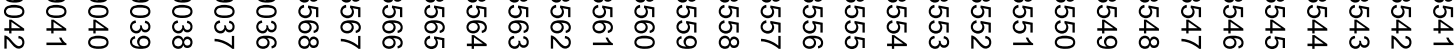

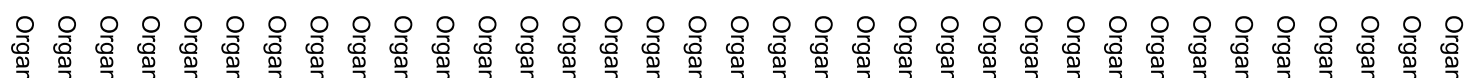

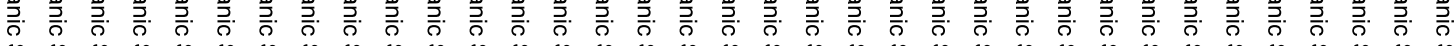

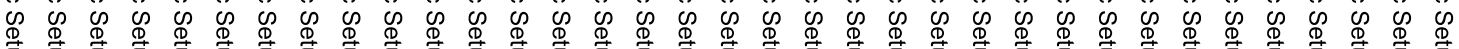

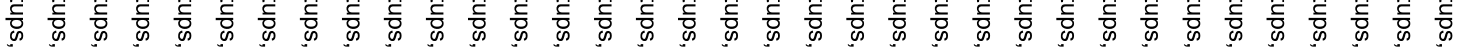

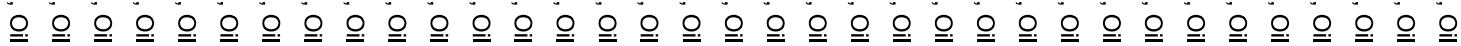

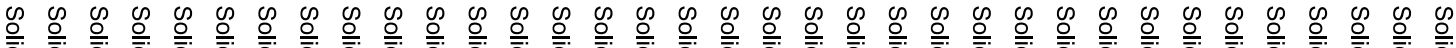

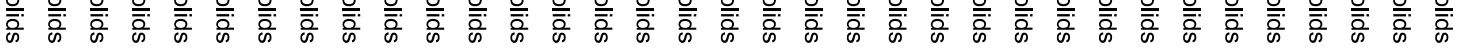

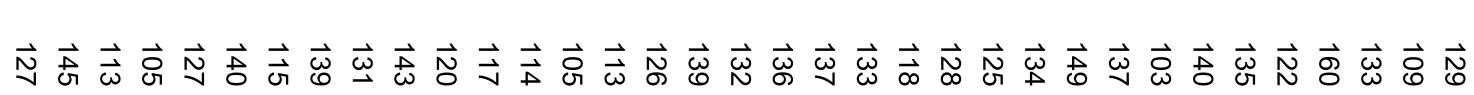




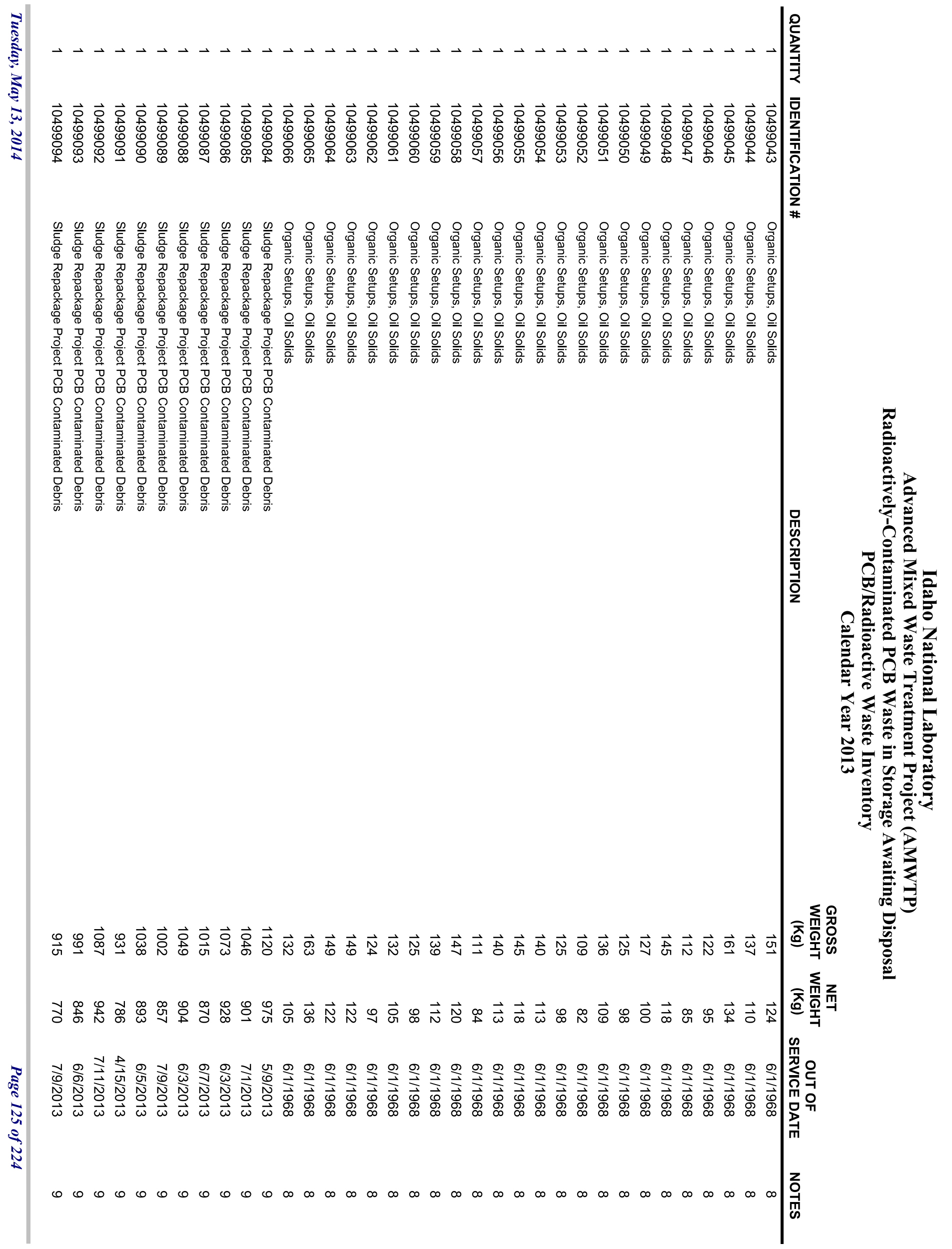


$\vec{\circ} \vec{\circ} \vec{\circ} \vec{\circ} \vec{\circ} \vec{\circ} \vec{\circ} \vec{\circ} \vec{\circ} \vec{\circ} \vec{\circ} \vec{\circ} \vec{\circ} \vec{\circ} \vec{\circ} \vec{\circ} \vec{\circ} \vec{\circ} \vec{\circ} \vec{\circ} \vec{\circ} \vec{\circ} \vec{\circ} \vec{\circ} \vec{\circ} \vec{\circ} \vec{\circ} \vec{\circ}$

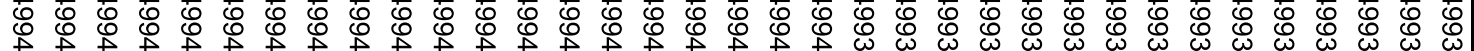

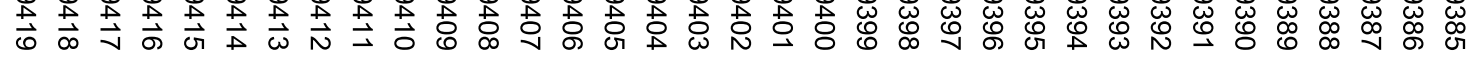

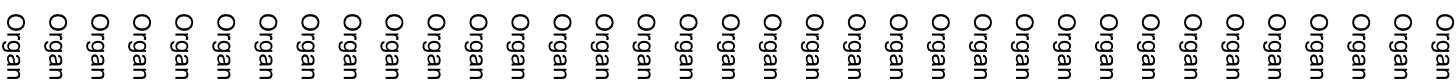

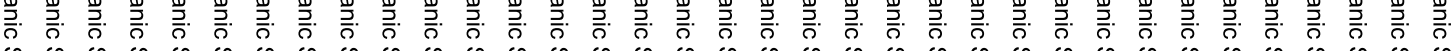

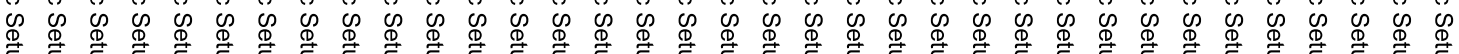

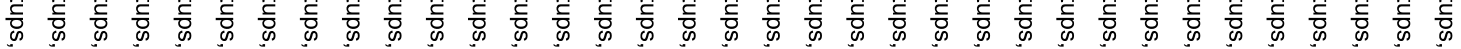

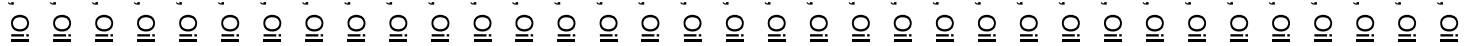

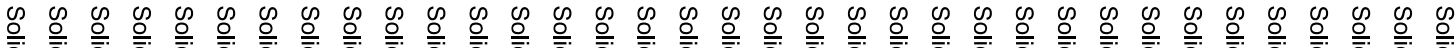

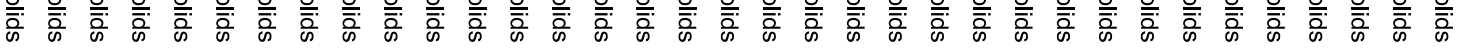

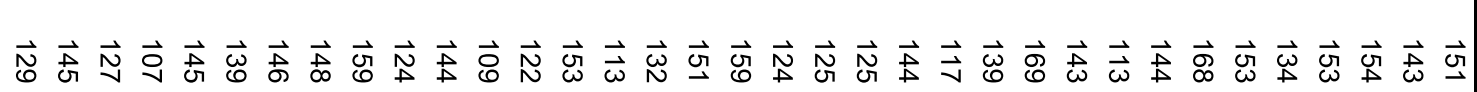

ॠ艹ّ 


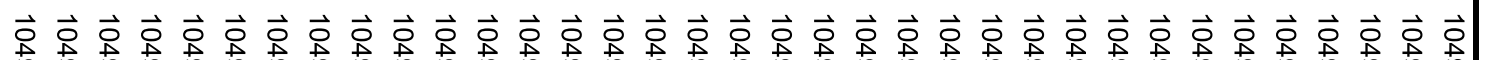

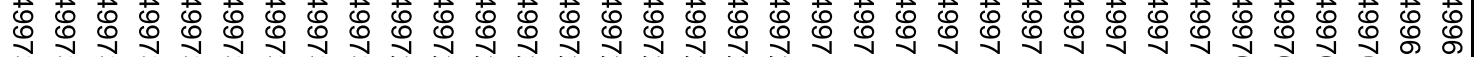

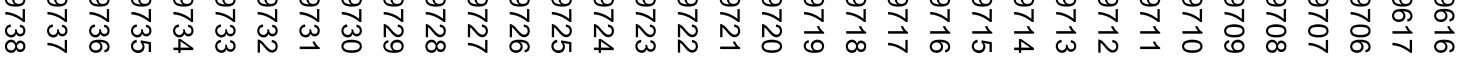

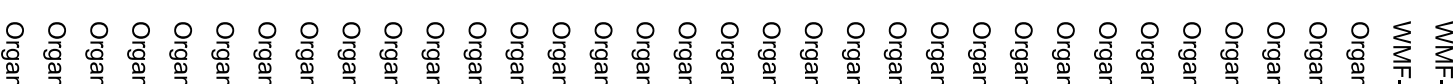

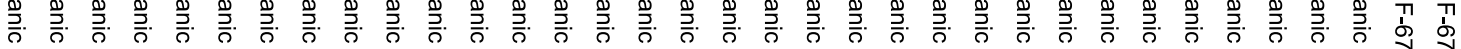

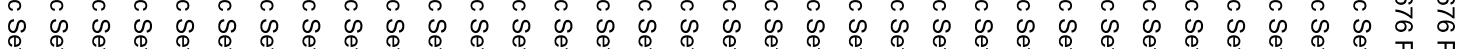

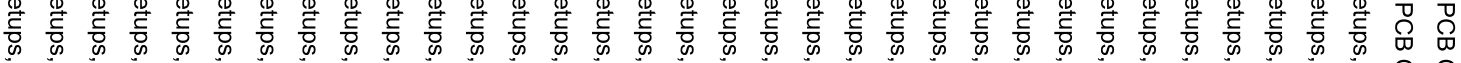

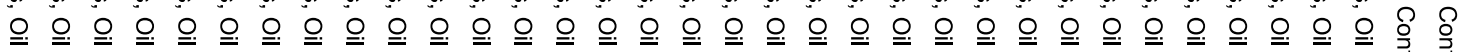

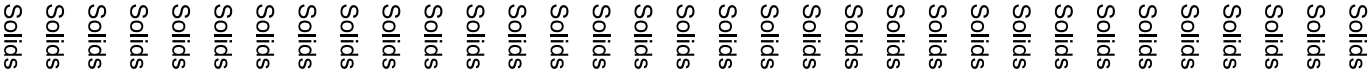

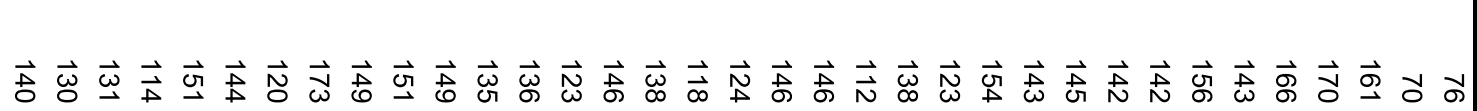


$\vec{\circ} \vec{\circ} \vec{\circ} \vec{\circ} \vec{\circ} \vec{\circ} \vec{\circ} \vec{\circ} \vec{\circ} \vec{\circ} \vec{\circ} \vec{\circ} \vec{\circ} \vec{\circ} \vec{\circ} \vec{\circ} \vec{\circ} \vec{\circ} \vec{\circ} \vec{\circ} \vec{\circ} \vec{\circ} \vec{\circ} \vec{\circ} \vec{\circ} \vec{\circ}$ \& 4000

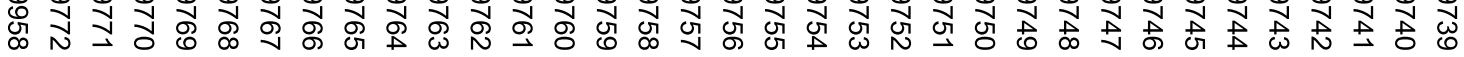

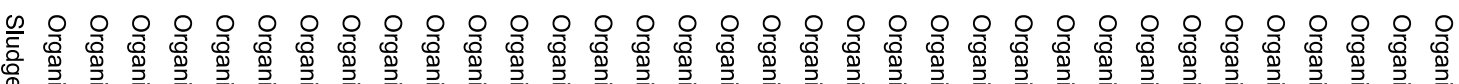

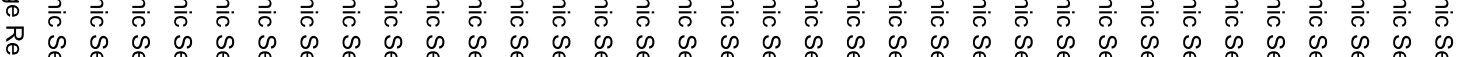

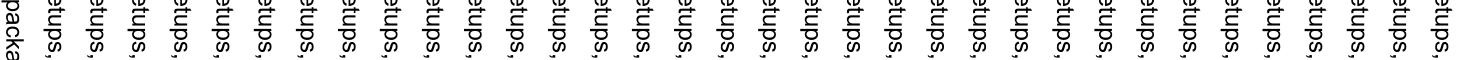

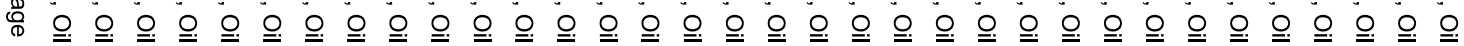

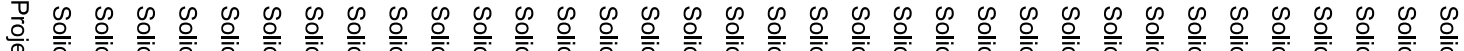

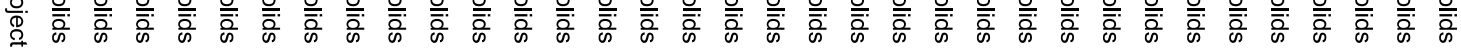
กัญ

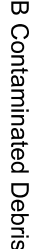

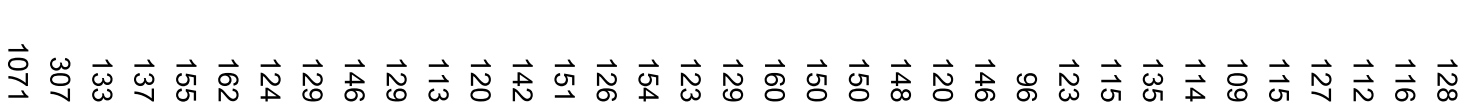

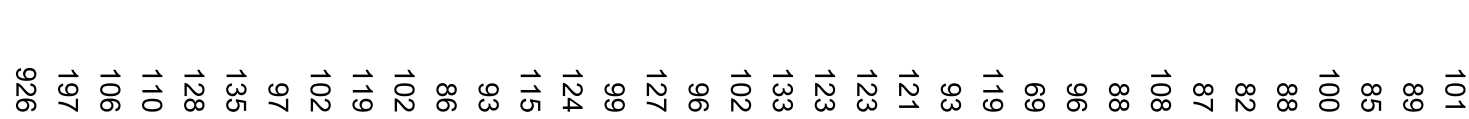
囬 $z$

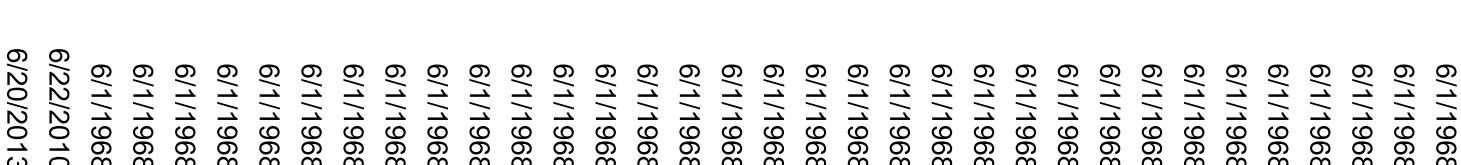
喟 


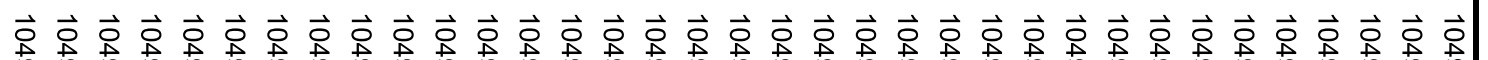

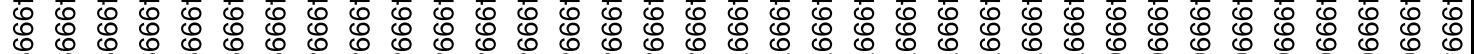
o

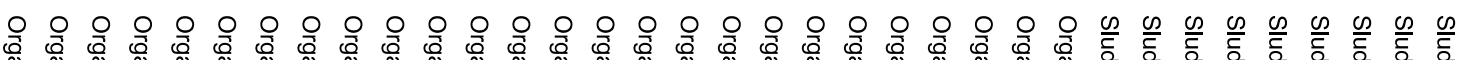

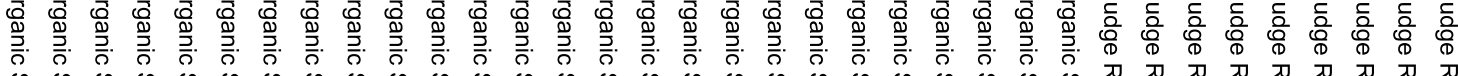

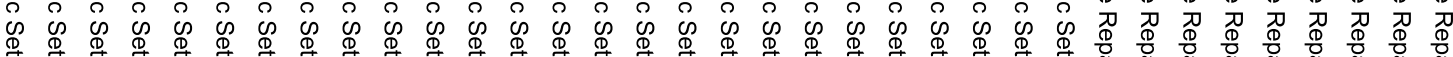

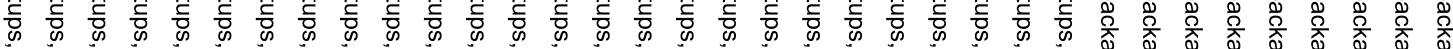

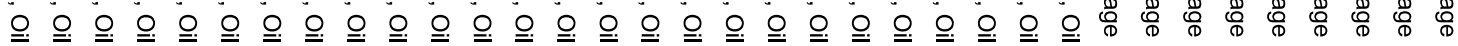

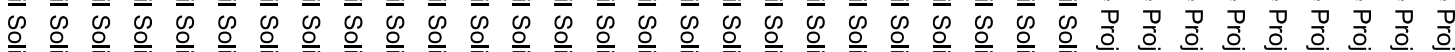

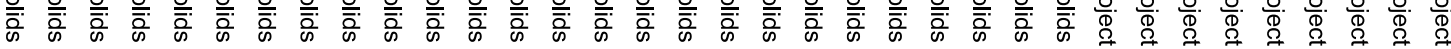

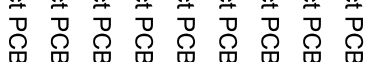

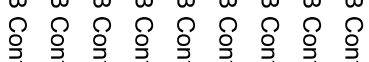

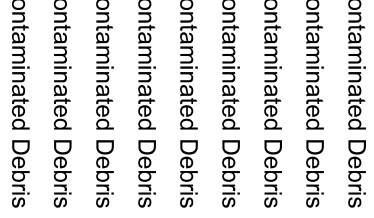

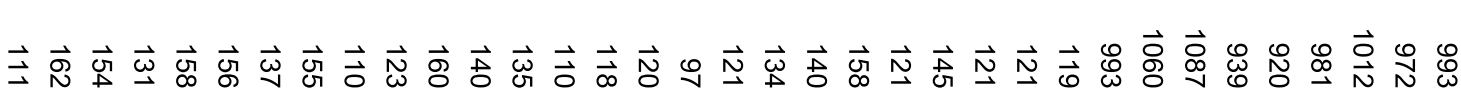

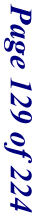

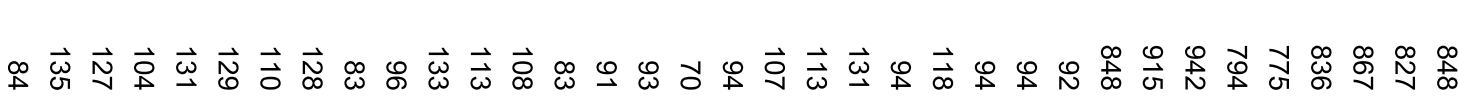
즈음 


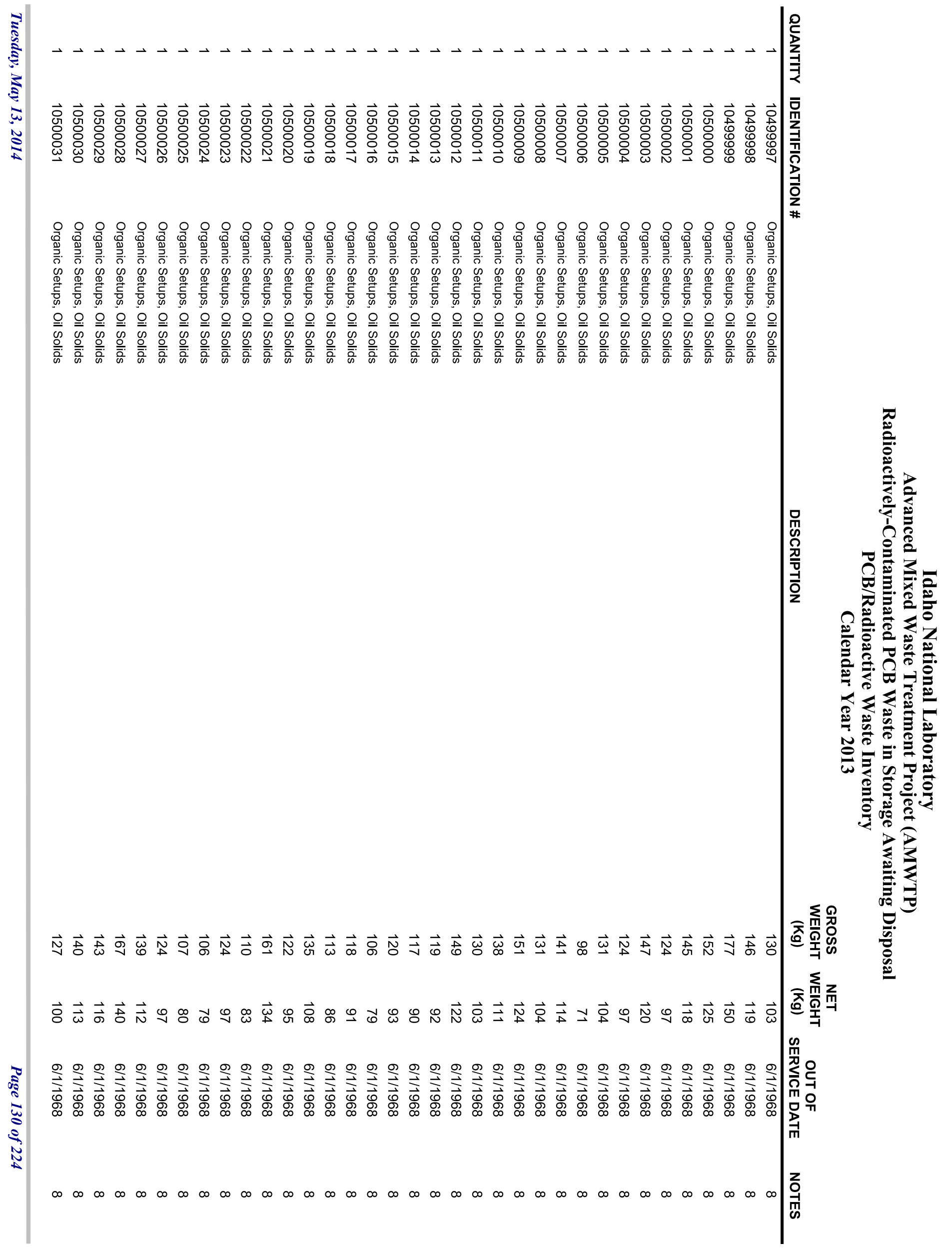




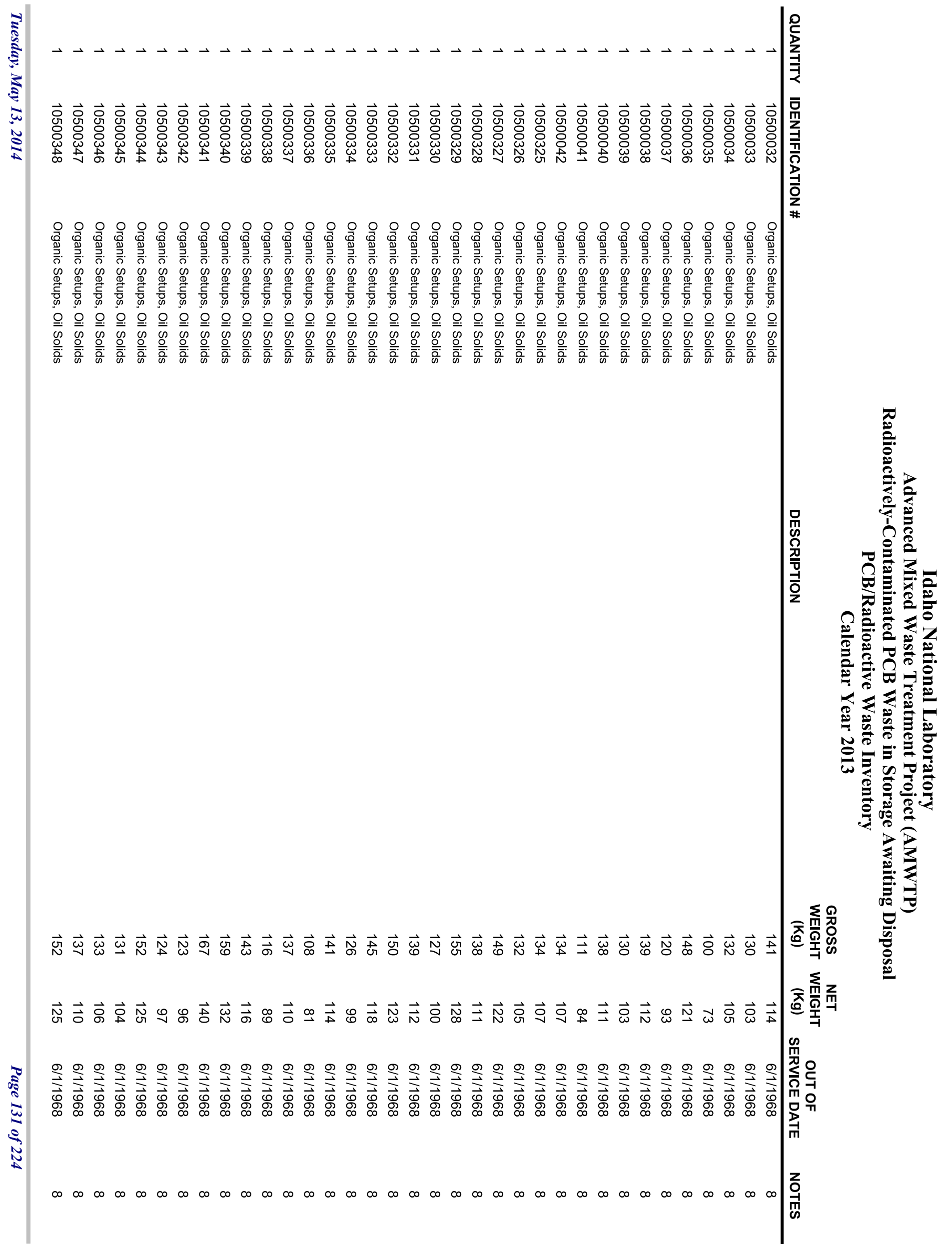




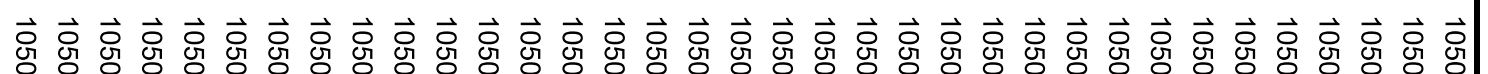

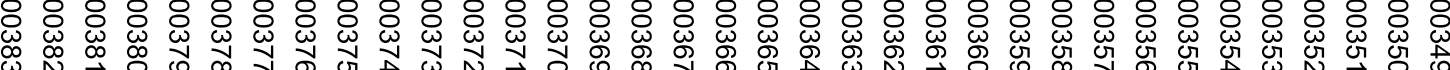

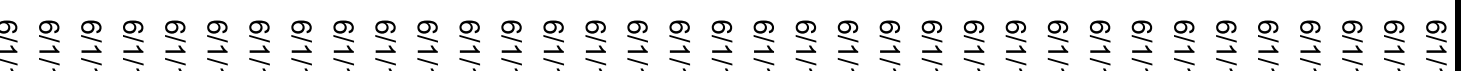




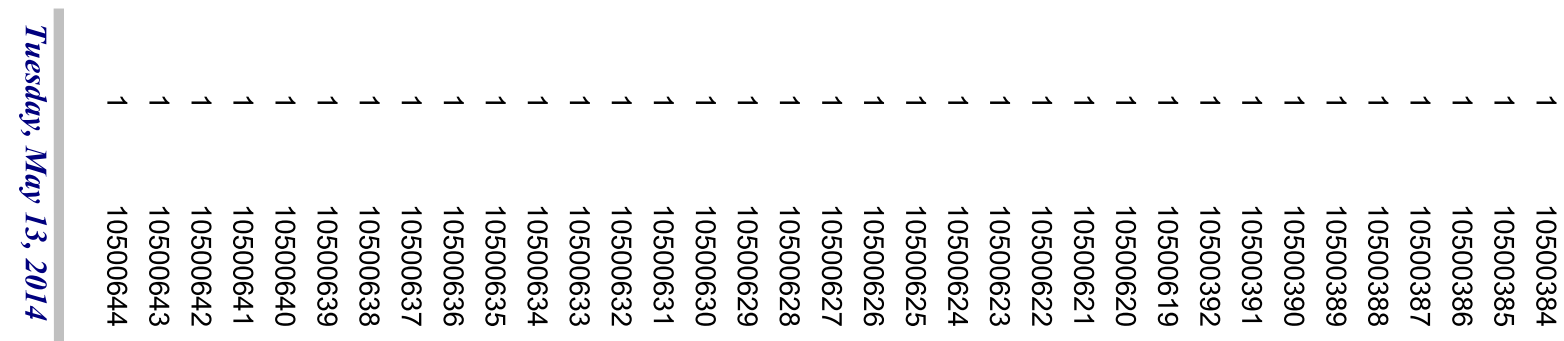

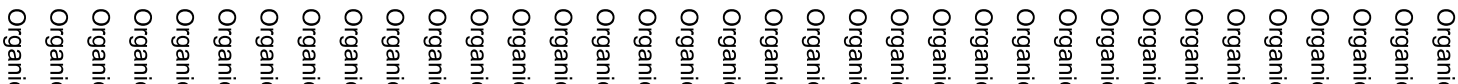

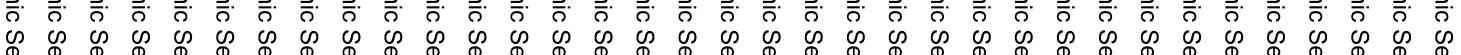

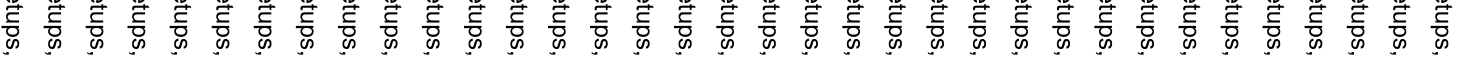

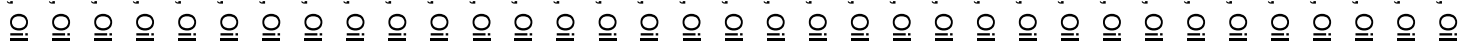

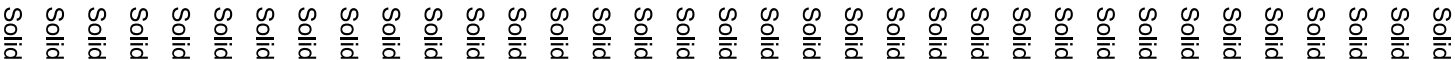

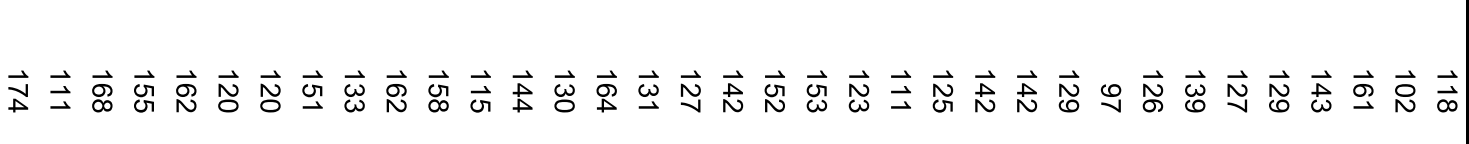

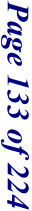

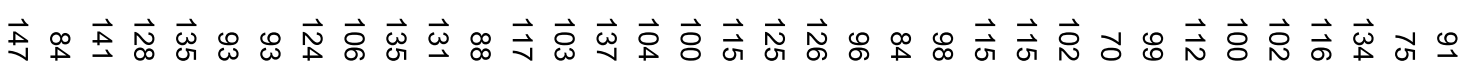
지음

?ำ 可.

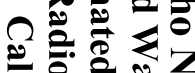

क 产

.

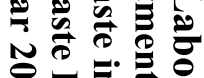




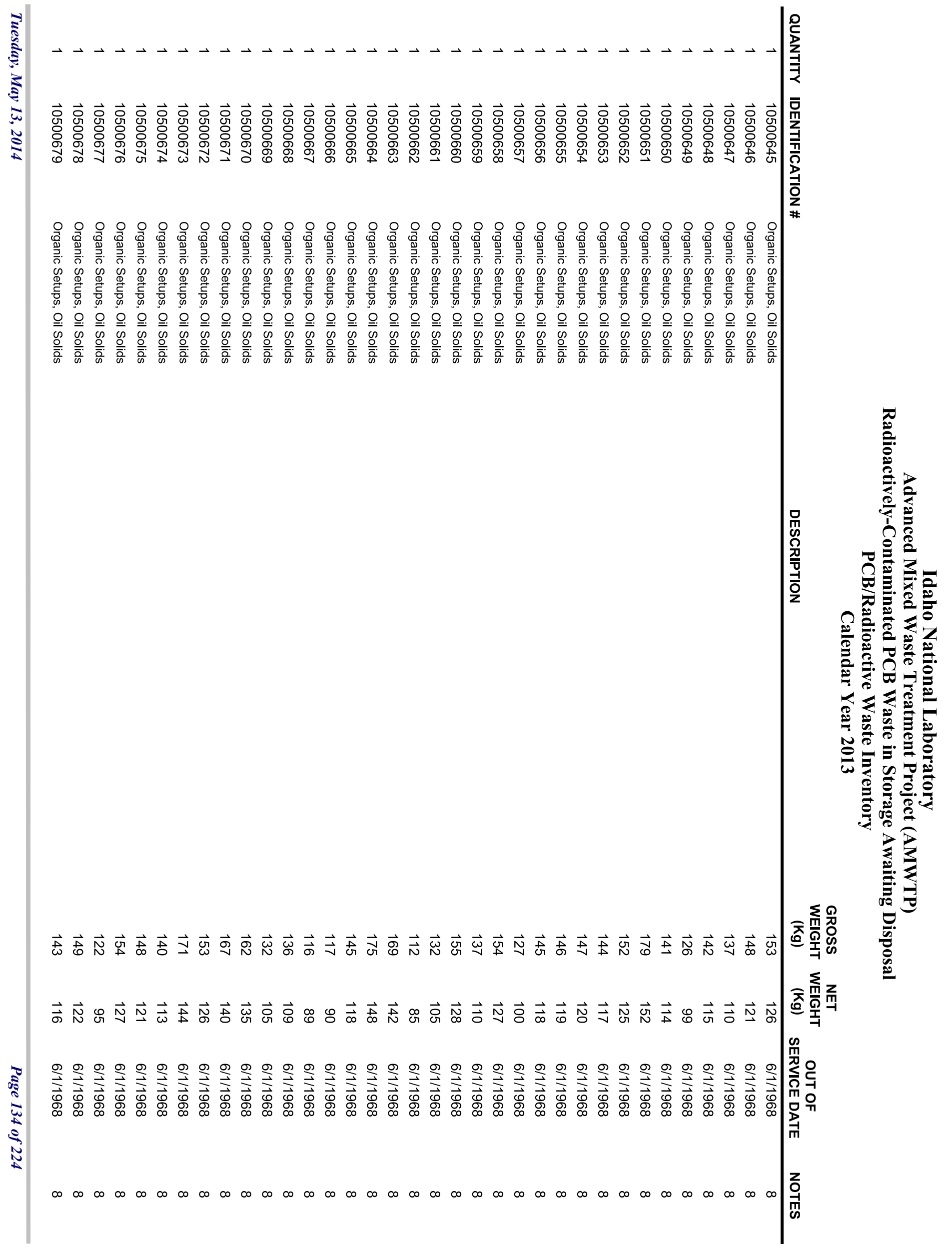




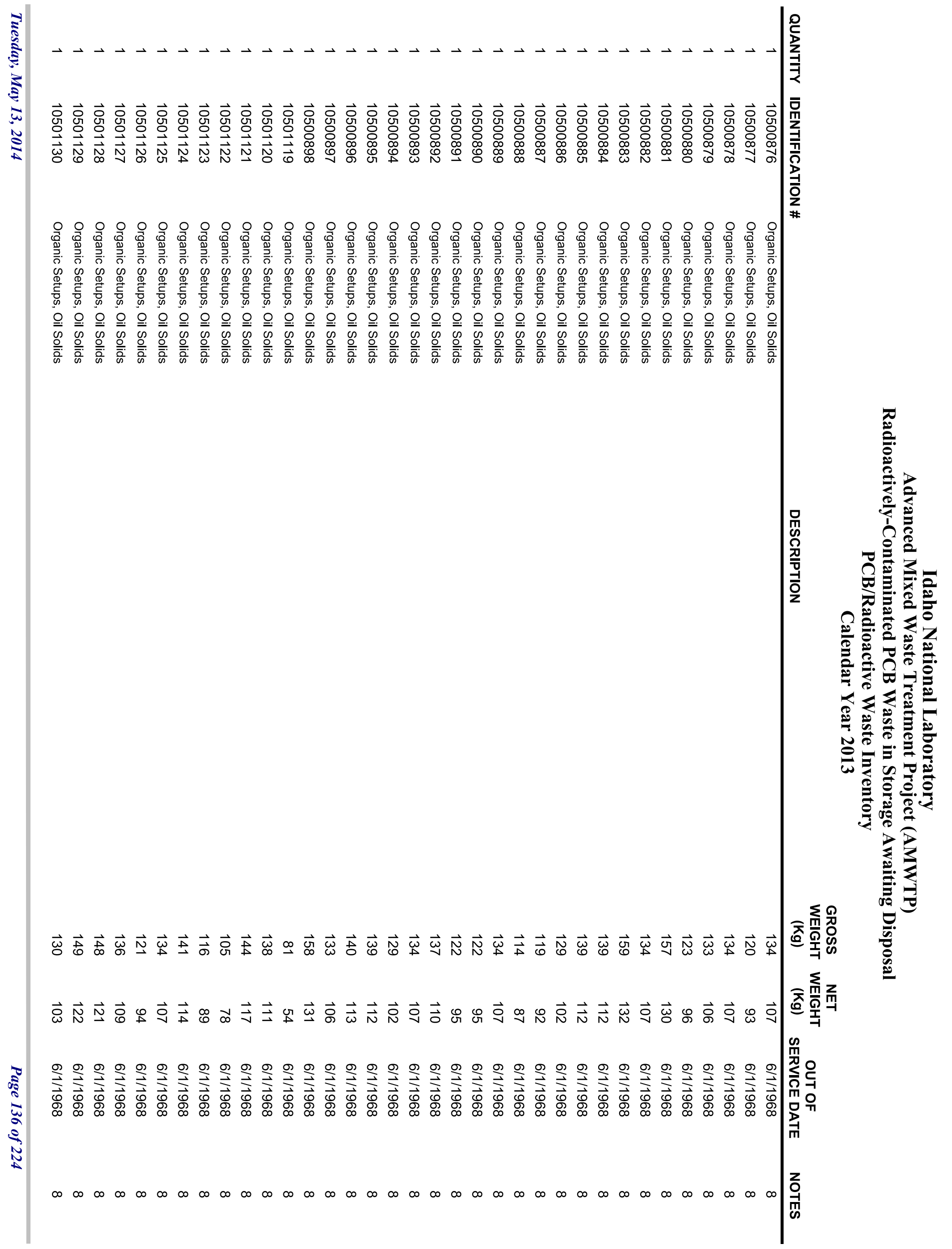




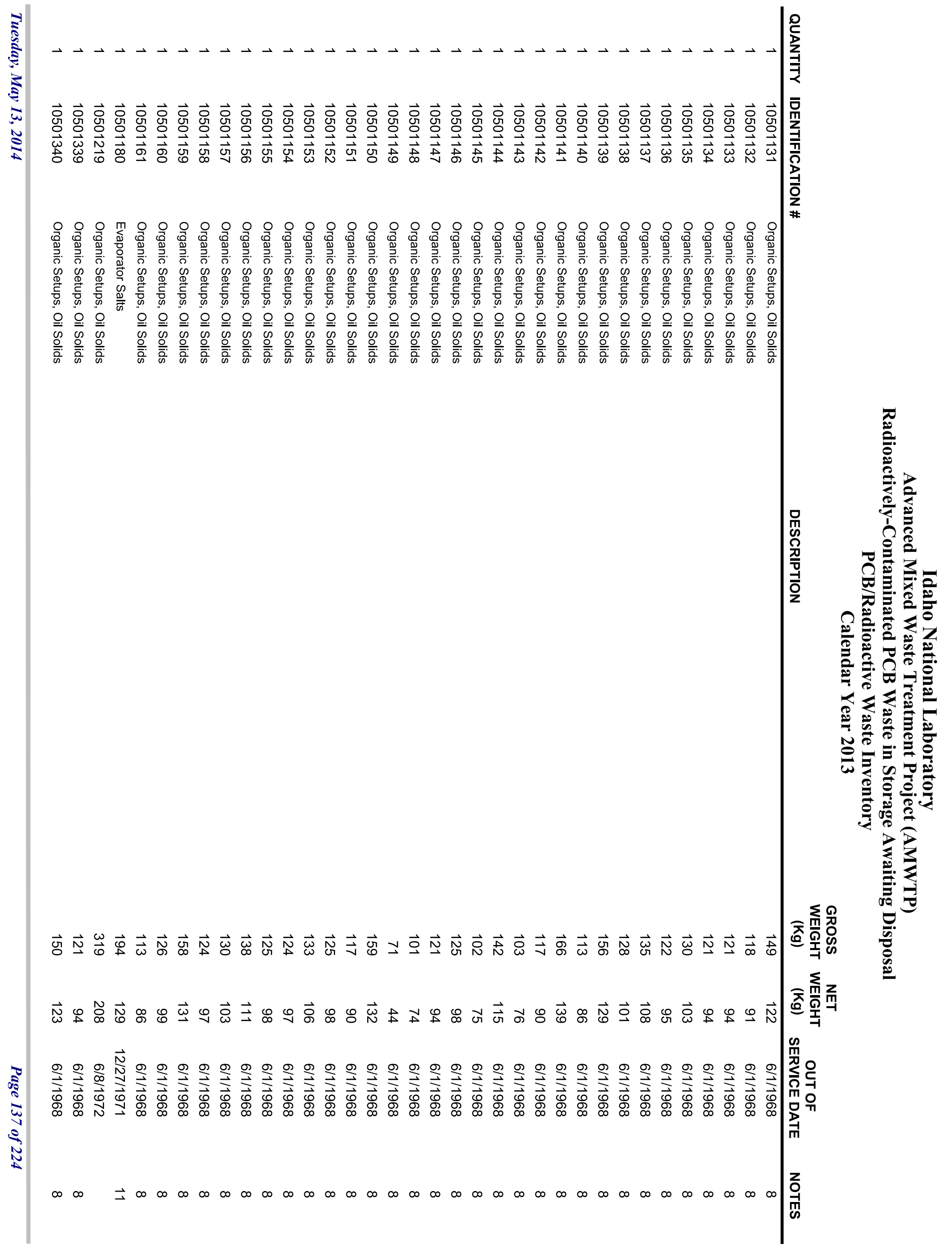




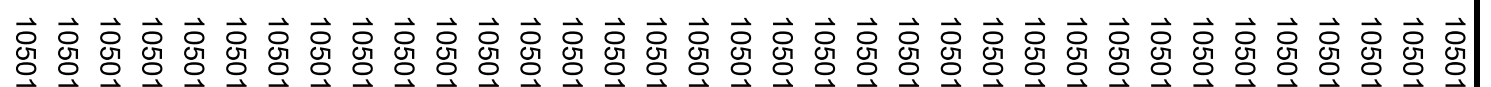

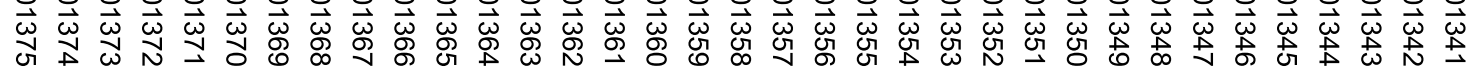

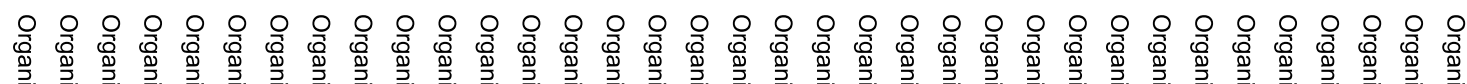

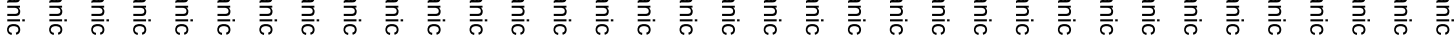

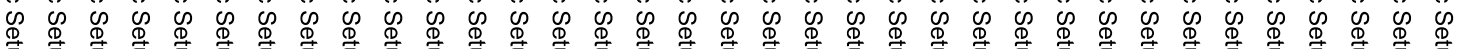

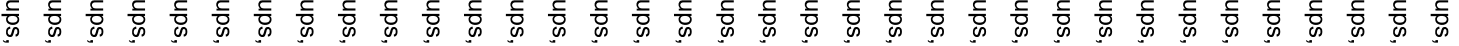

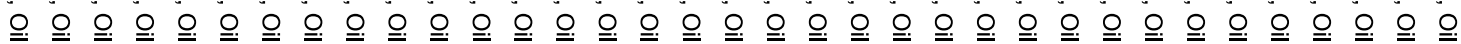

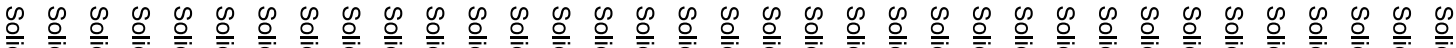

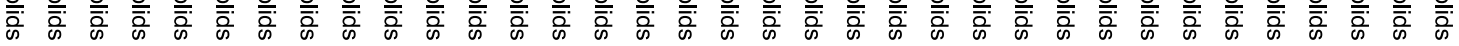

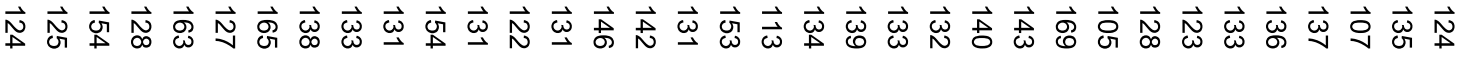

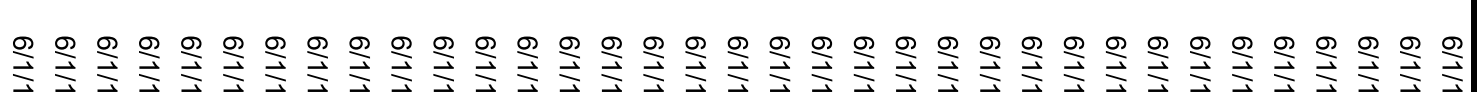
唐 


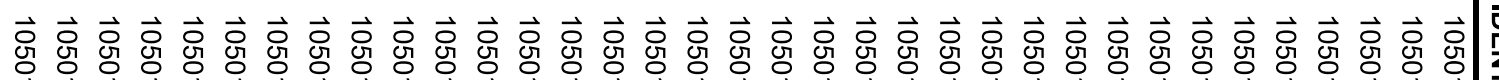

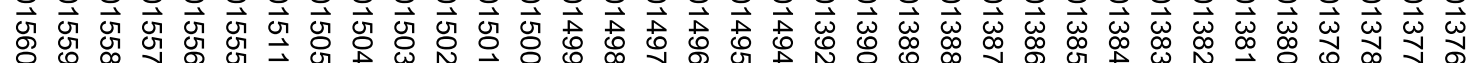

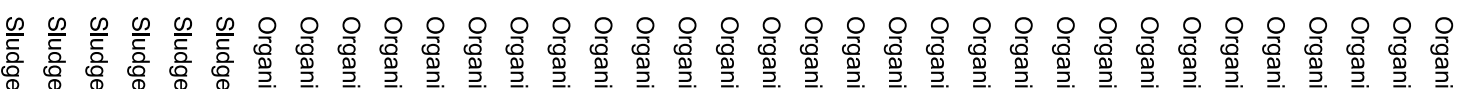

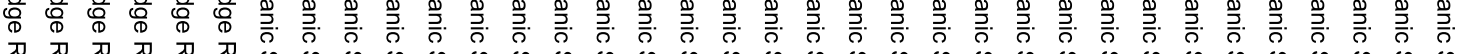

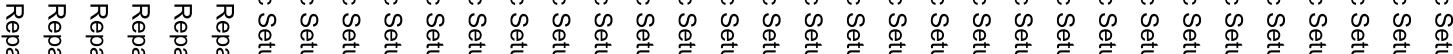

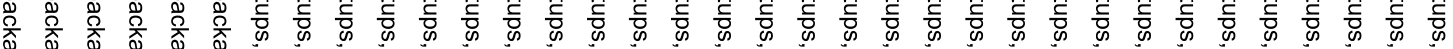

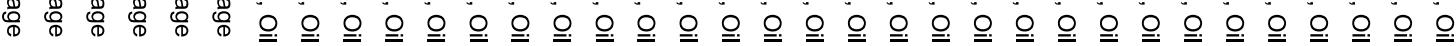
뭉 뭉 뭉 뭉 ग0

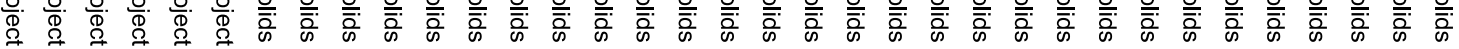
苛

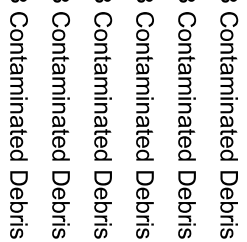

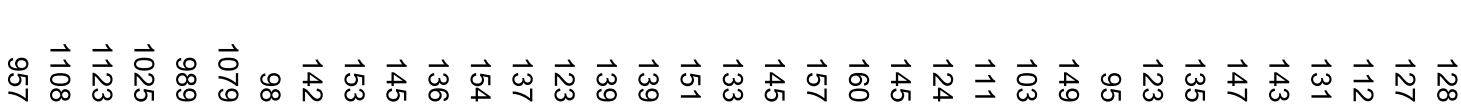

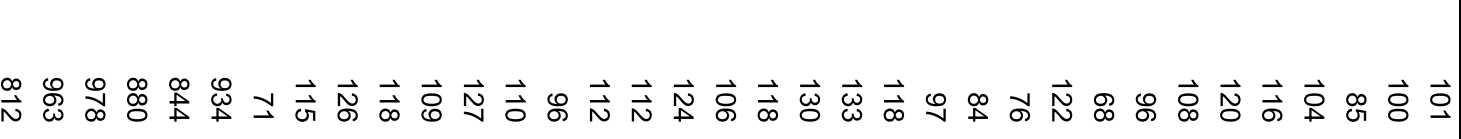
血

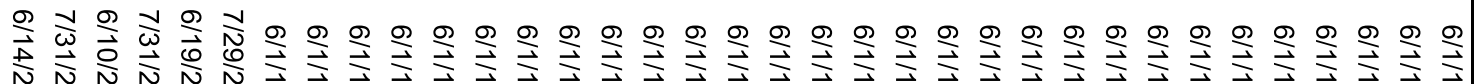
N N 


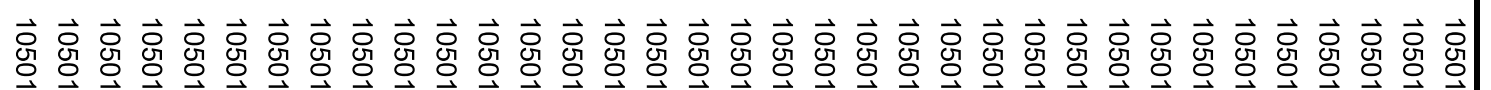

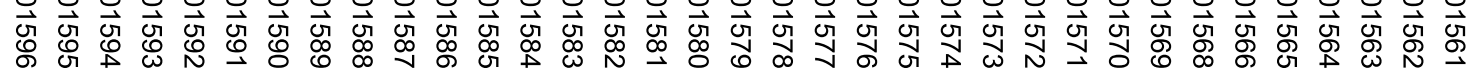

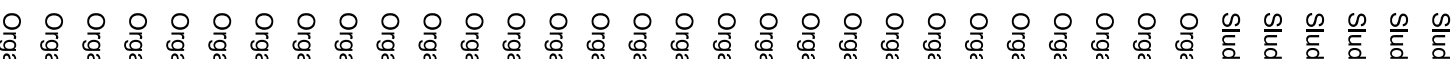

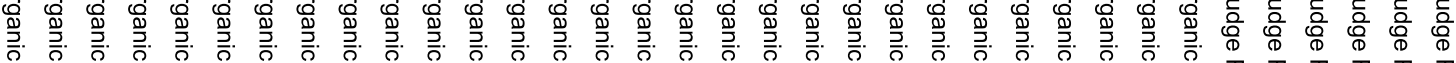

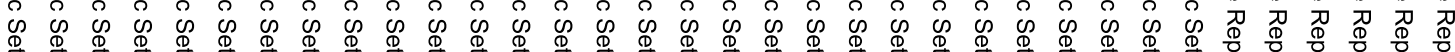

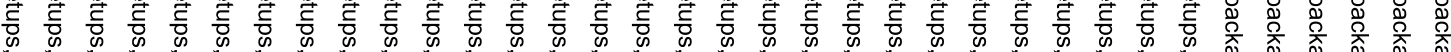

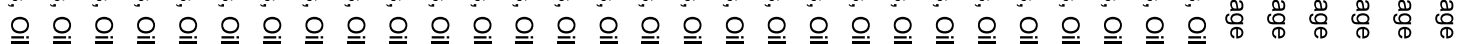

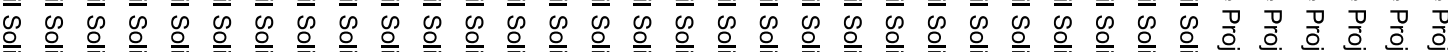

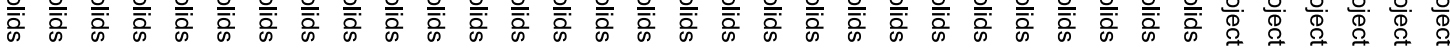

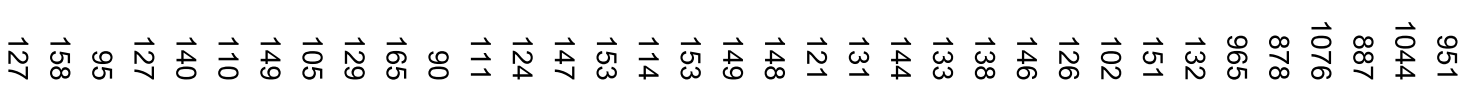

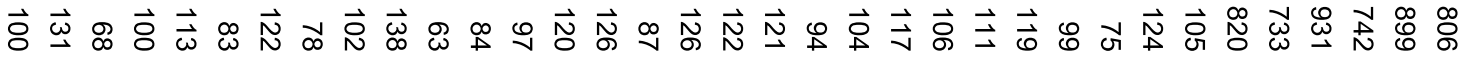
囬z

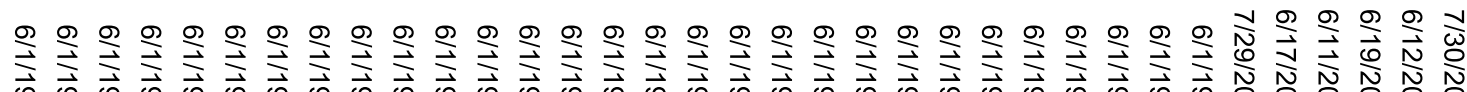

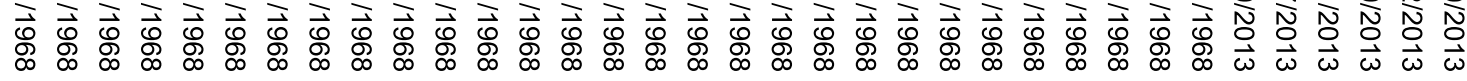




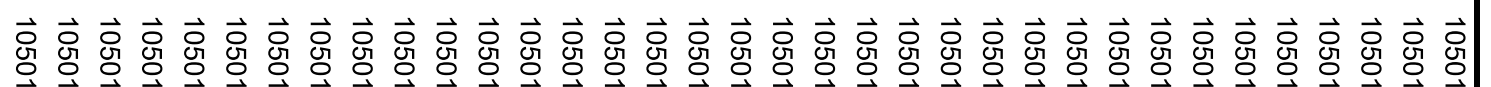

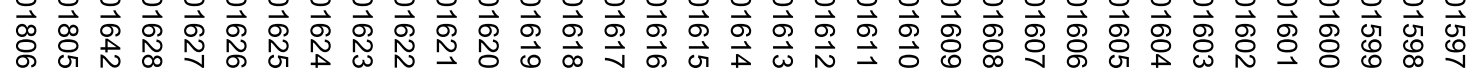

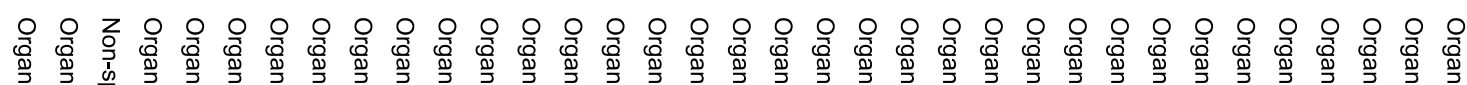

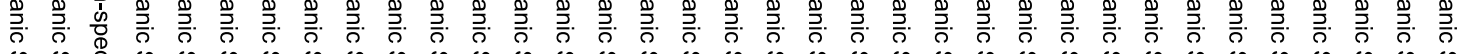

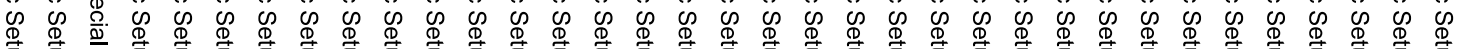

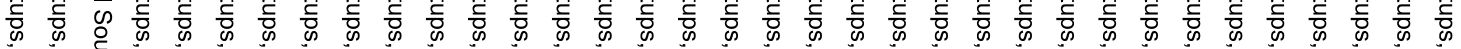

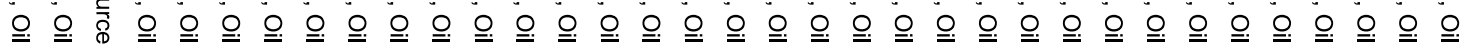
๗

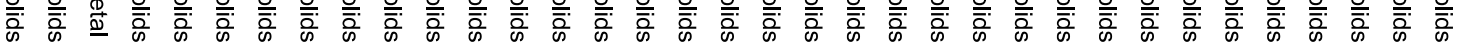

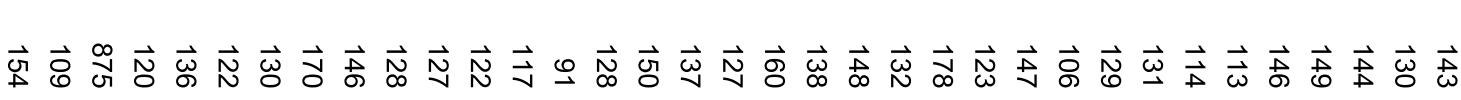

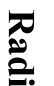




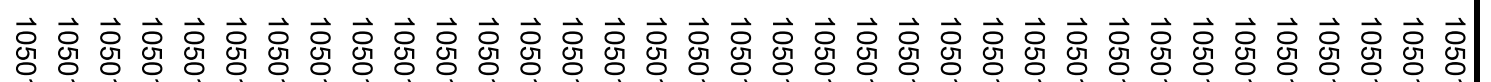

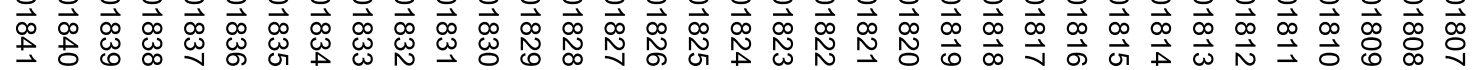

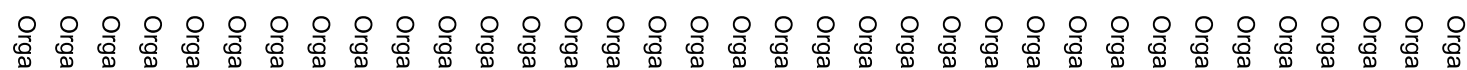

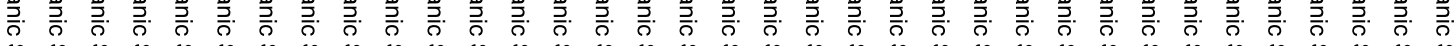

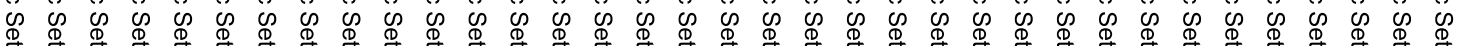

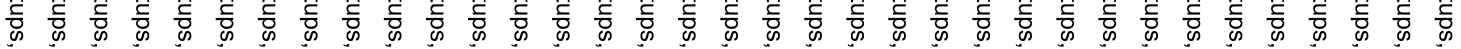

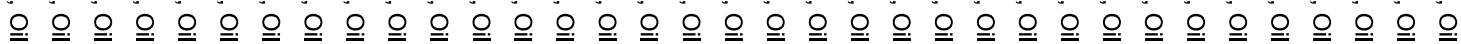

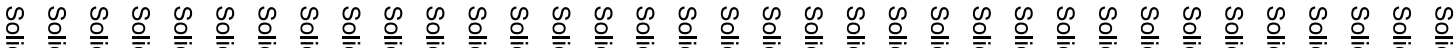

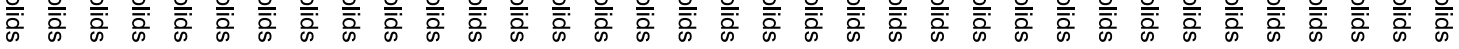

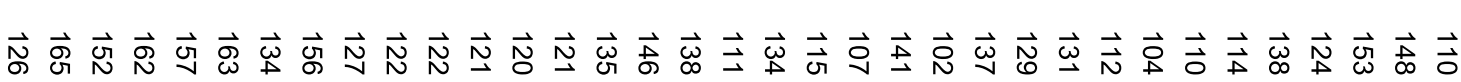




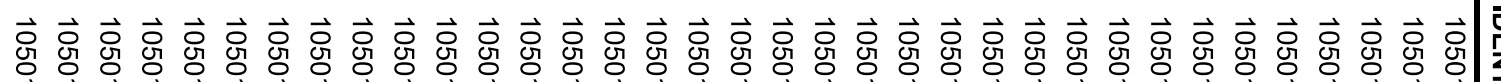

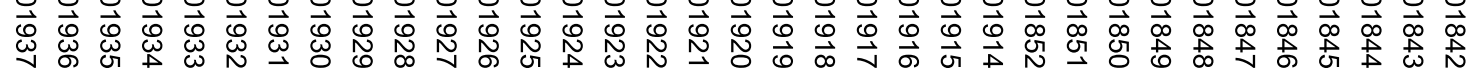

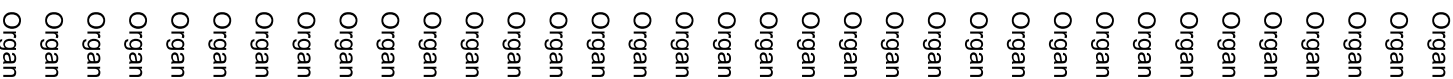

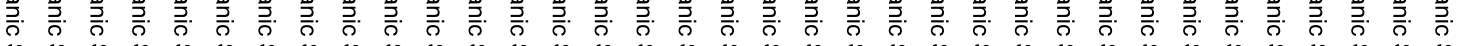

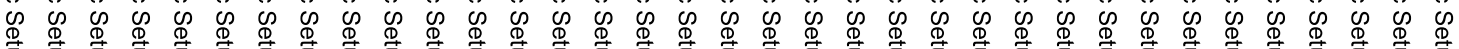

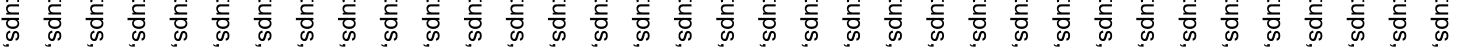

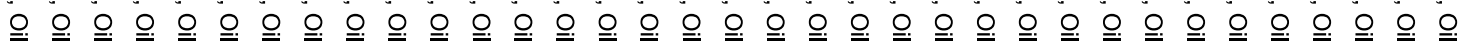

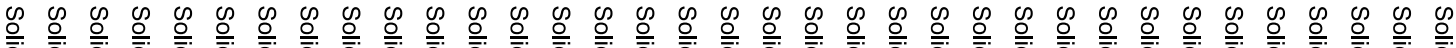

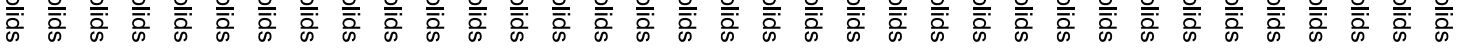

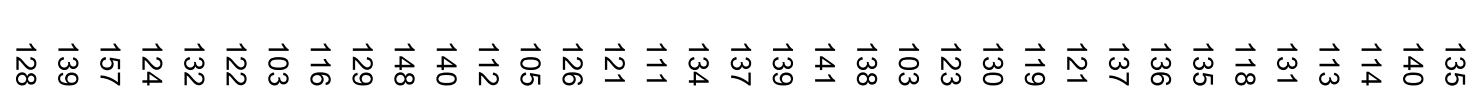




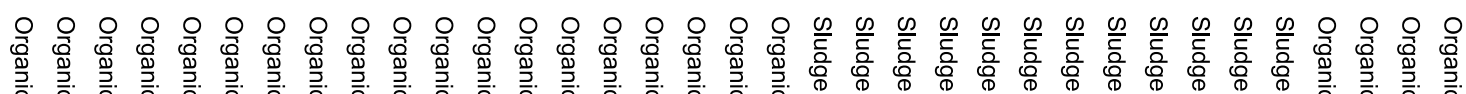

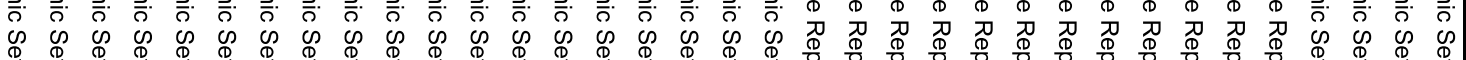

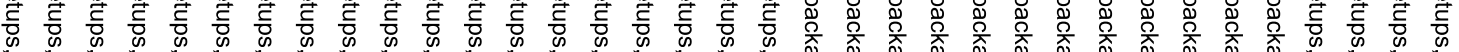

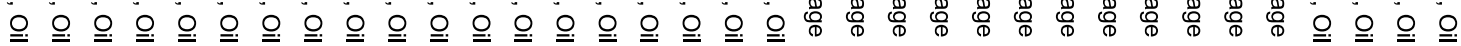

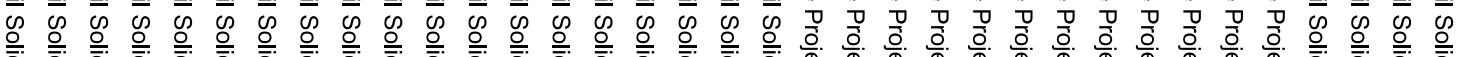

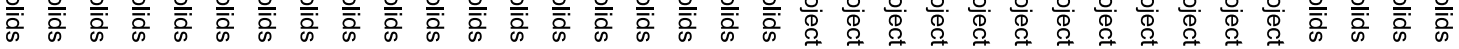

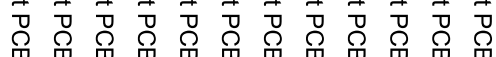

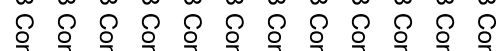

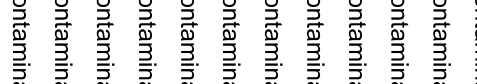

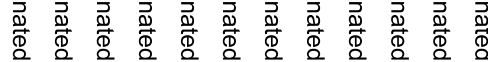

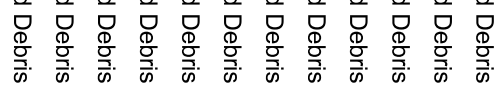

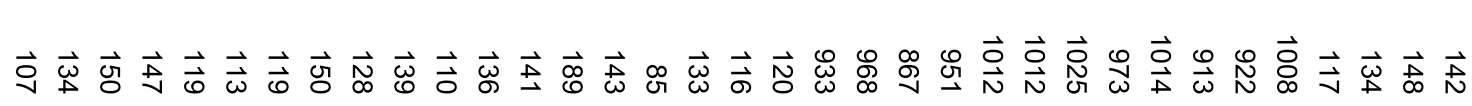

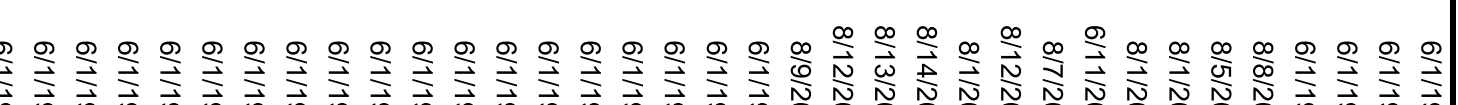

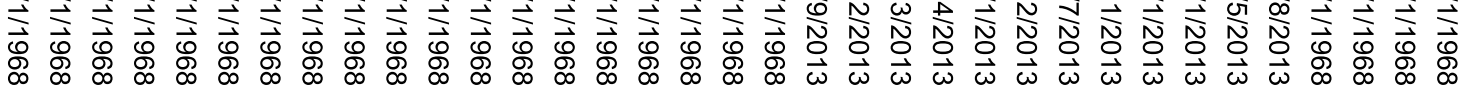




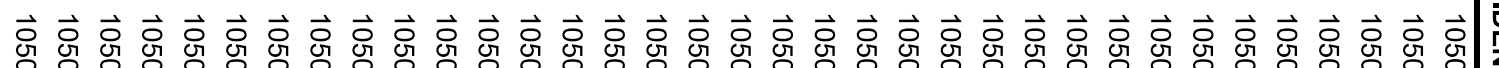
N N N N N N N N N N N N N N N N N N N N N N N N N N N N N N N N N N N N N N N N N N N N N N N N N N N N N

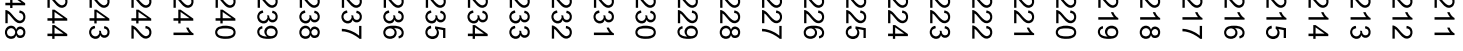

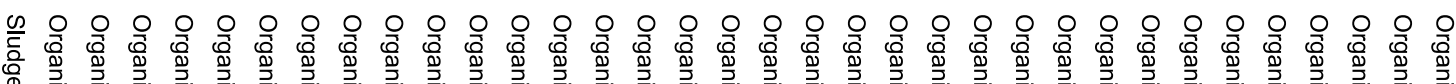

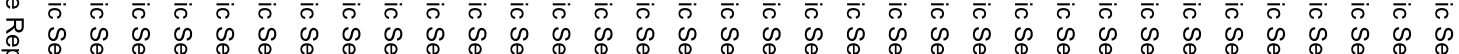

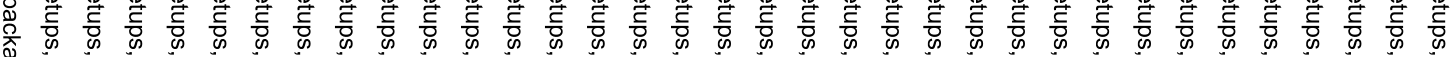
চ

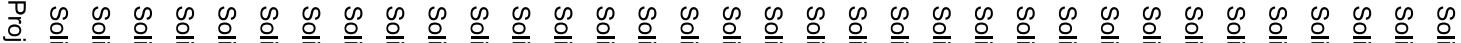

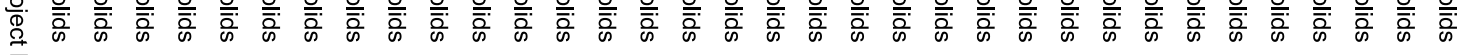
艿

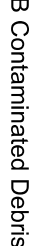

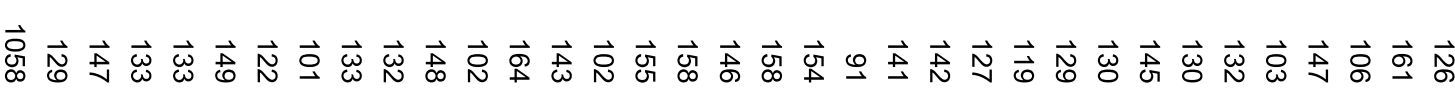

2
8
0
0
0
0
0

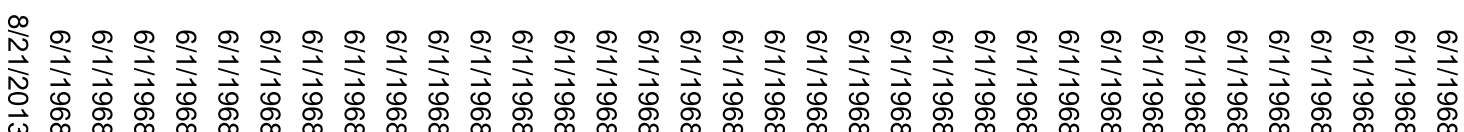

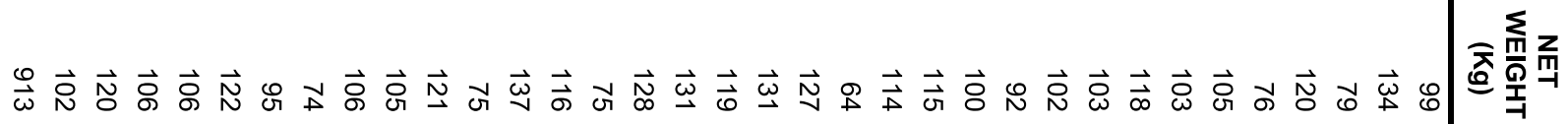

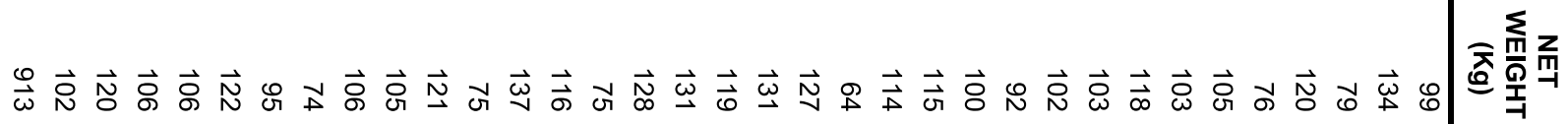
监 


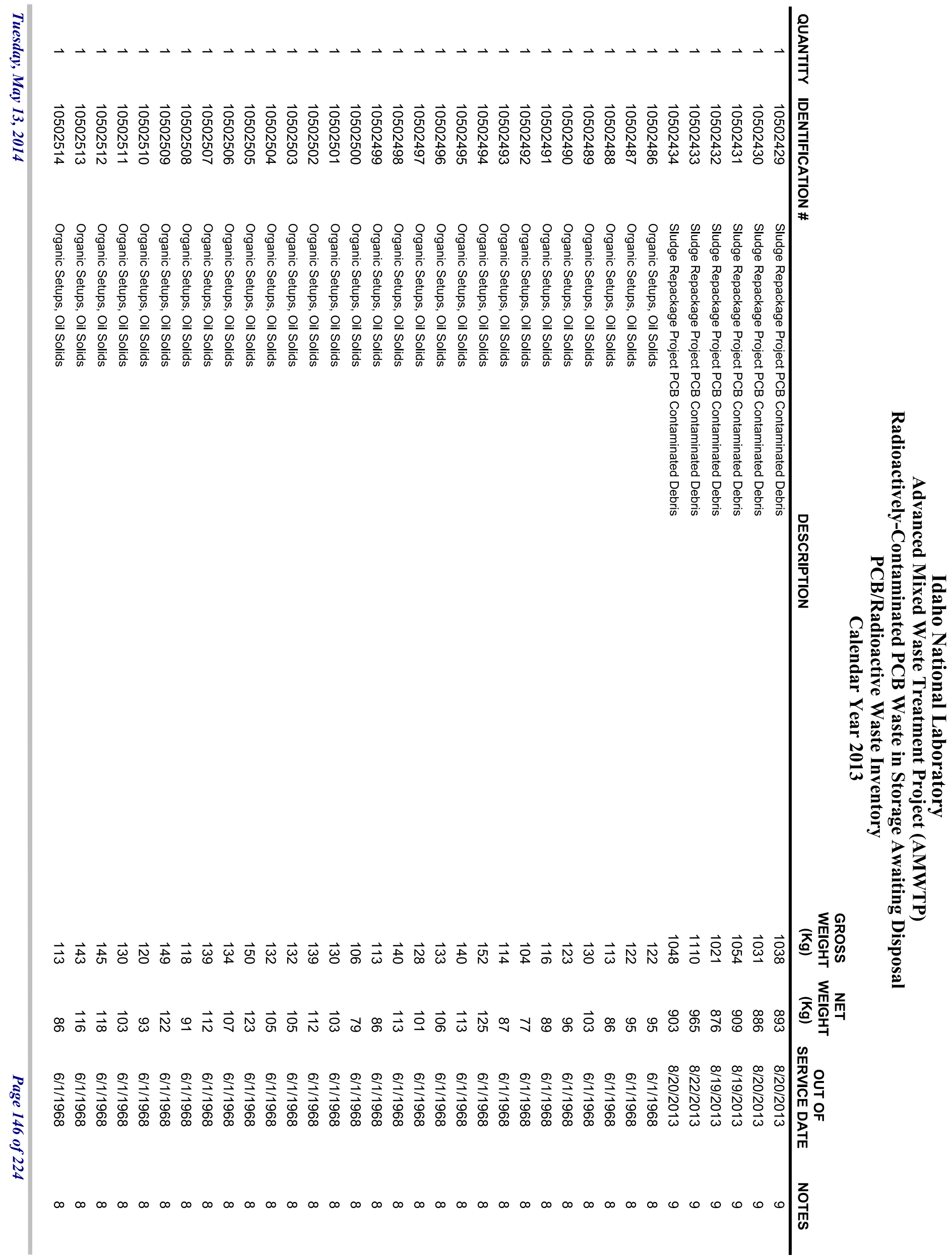




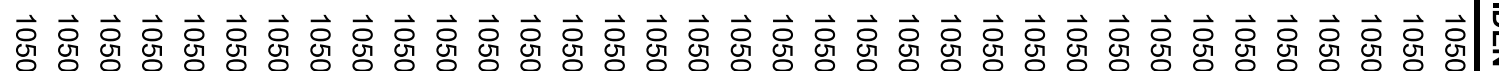
代出N N

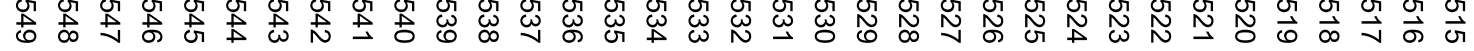

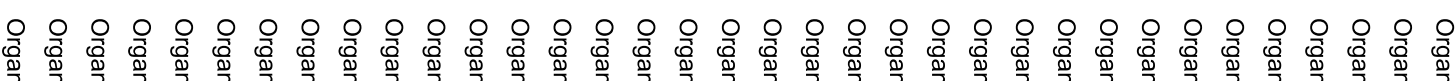

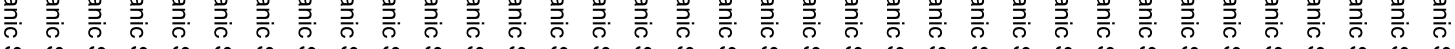

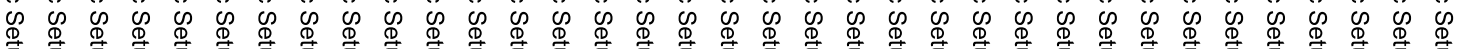

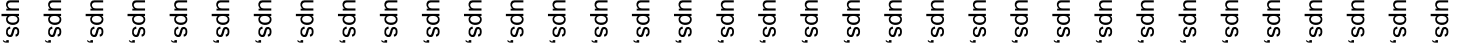

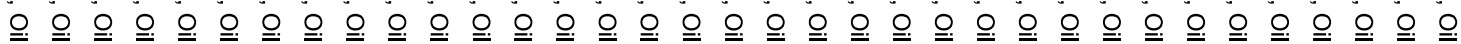

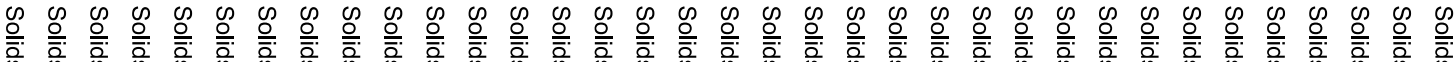

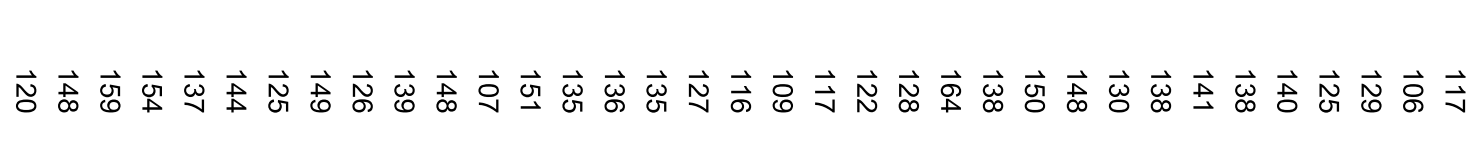

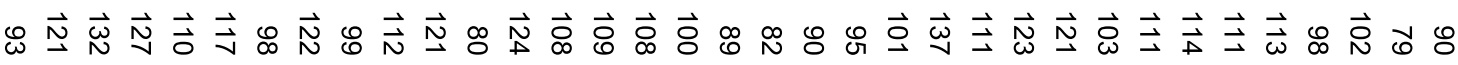




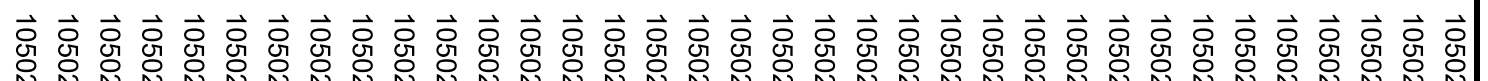

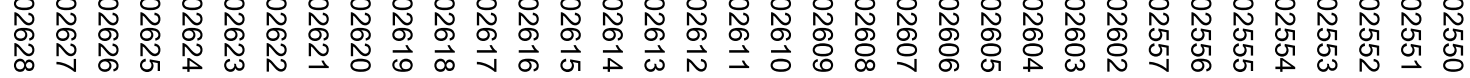

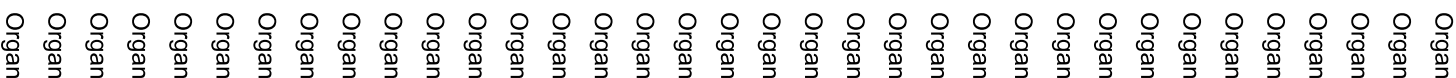

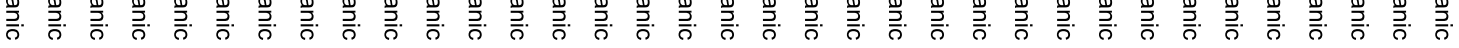

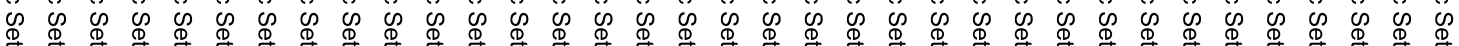

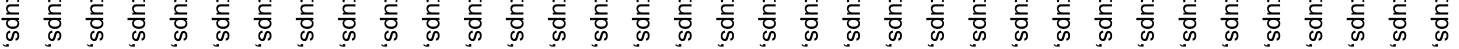

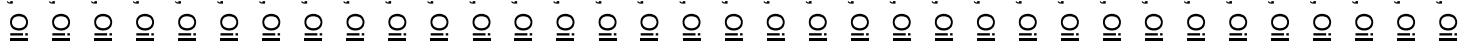

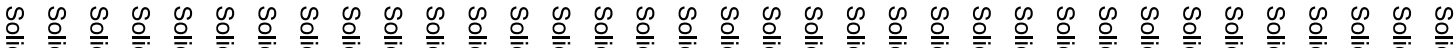

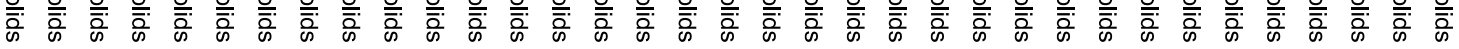

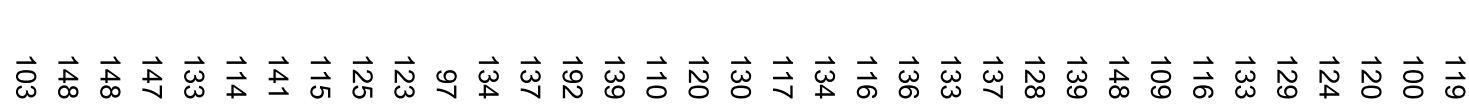

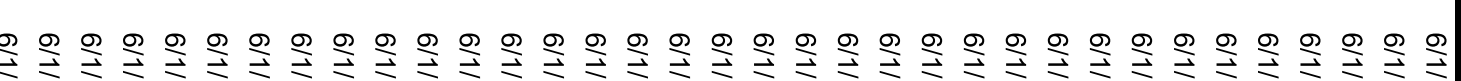




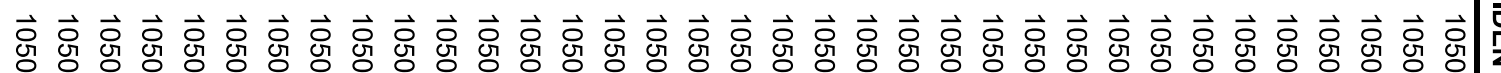

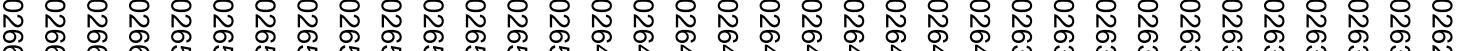

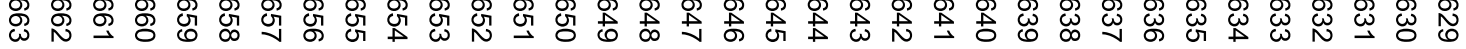

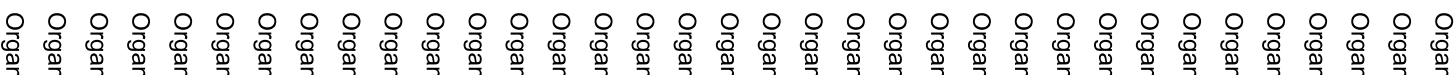

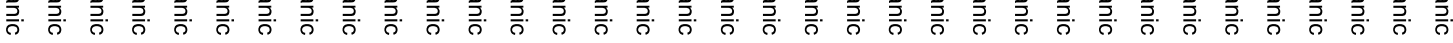

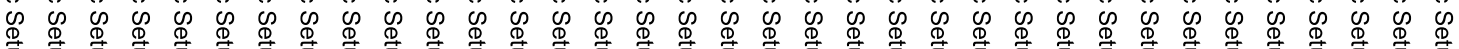
密

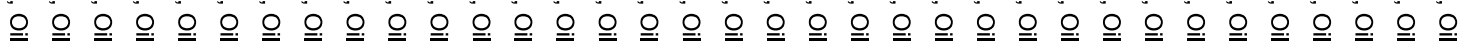

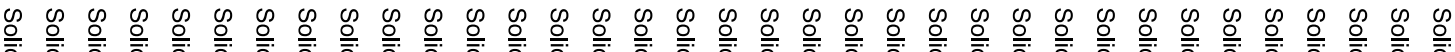

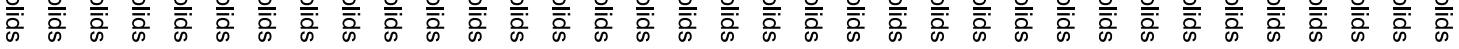

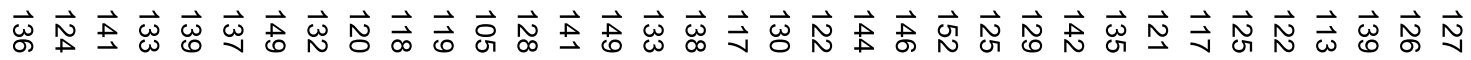

है

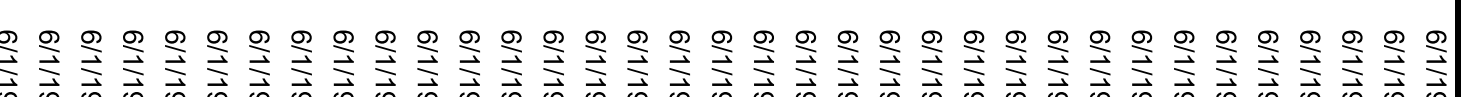

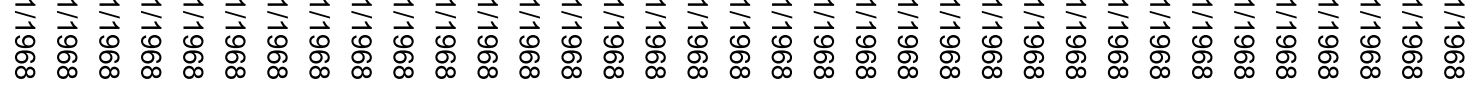




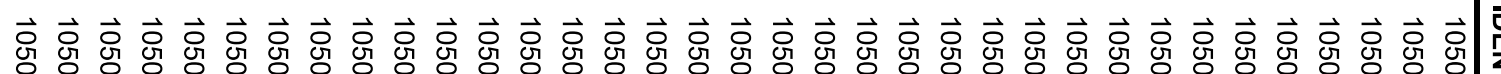

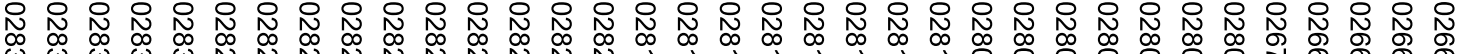

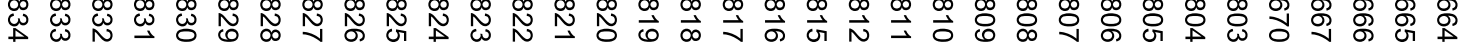

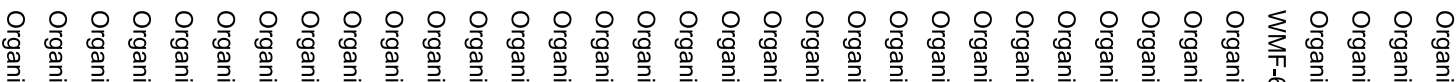

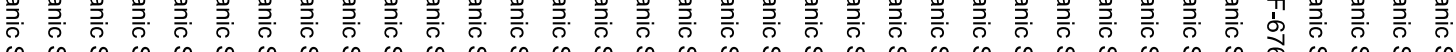

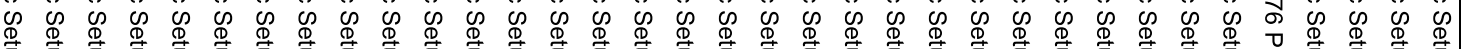

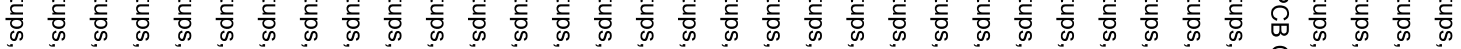

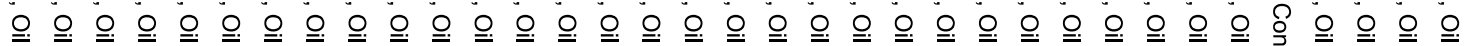
W

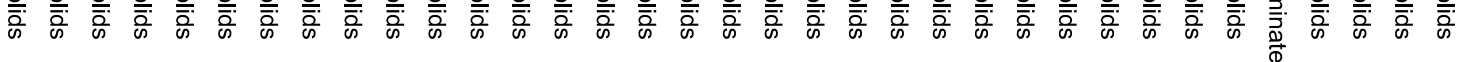

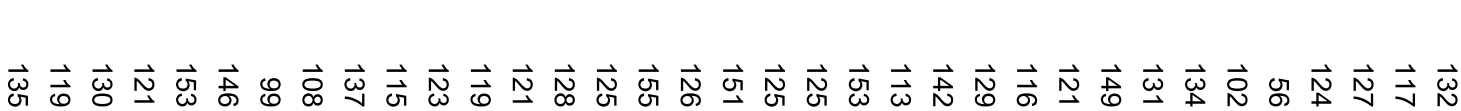




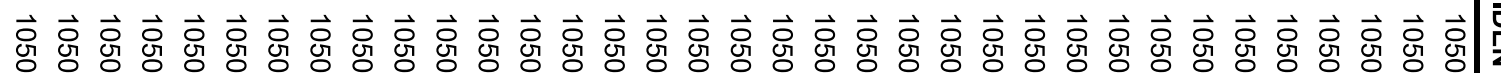

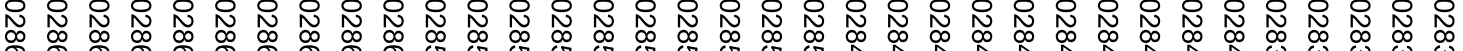

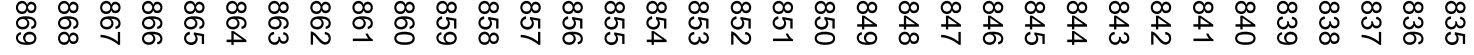

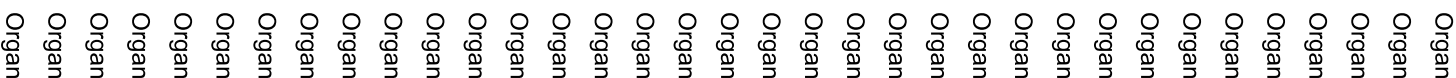

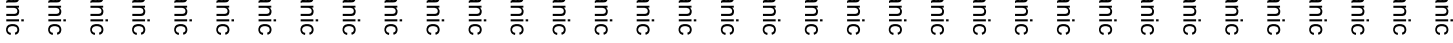

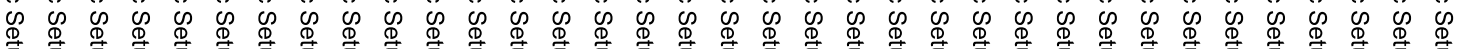
密

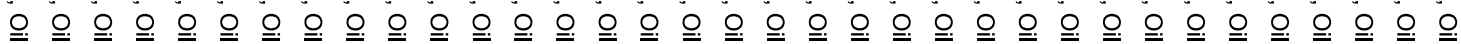

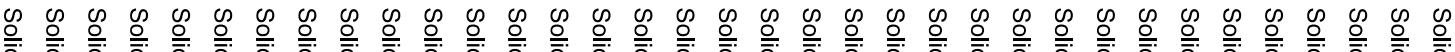

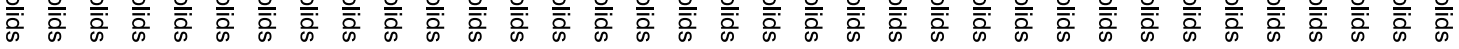

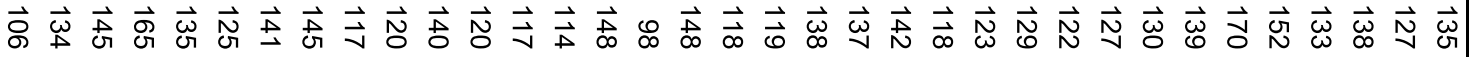




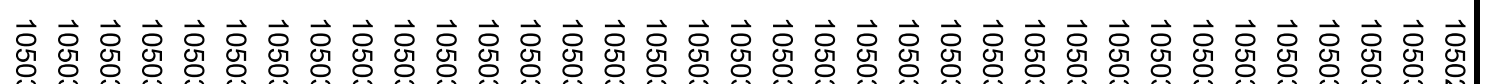

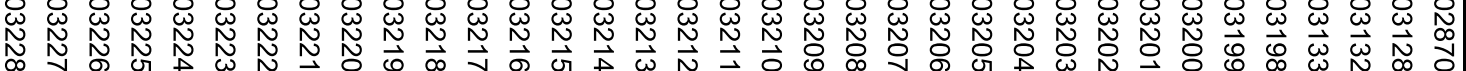

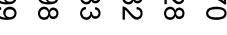

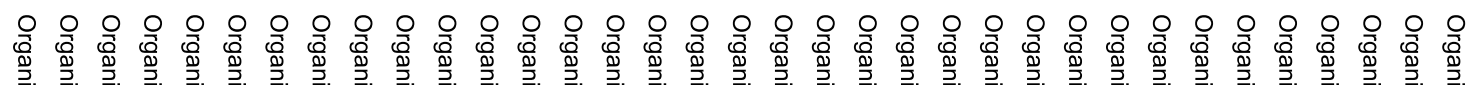

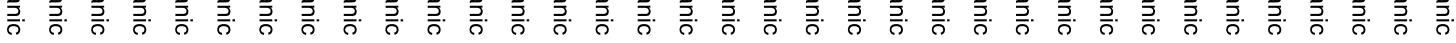

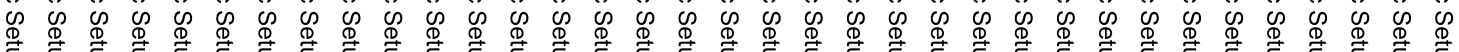

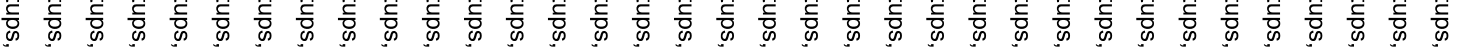

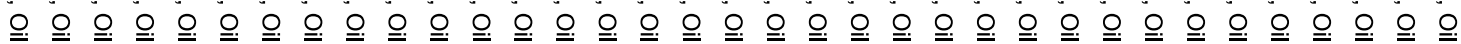

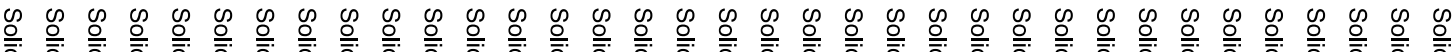

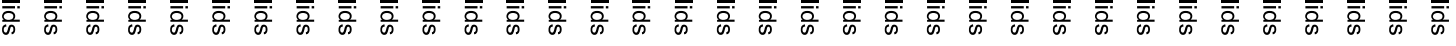

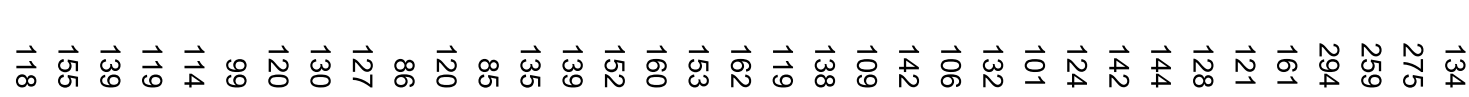

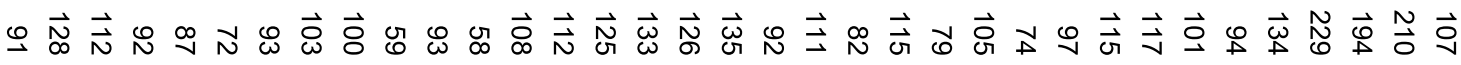
囬而

高

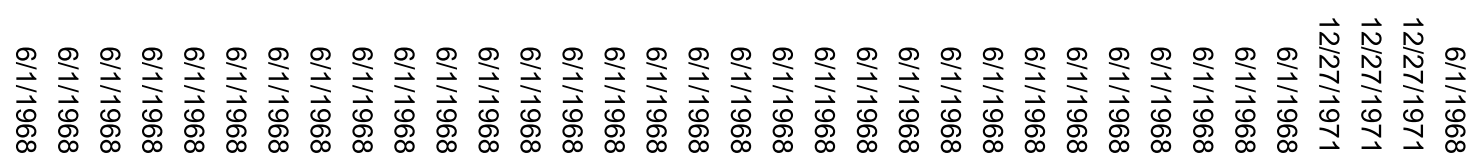




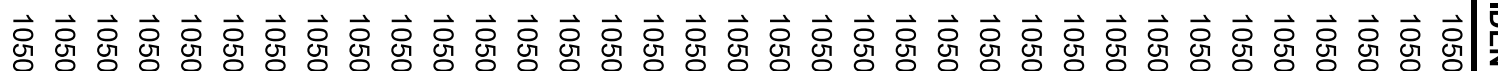

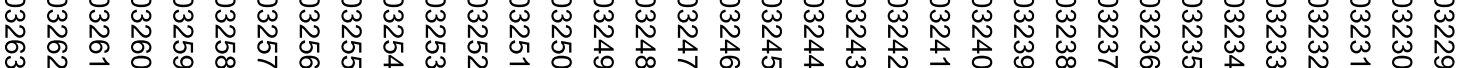

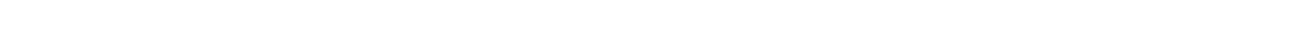

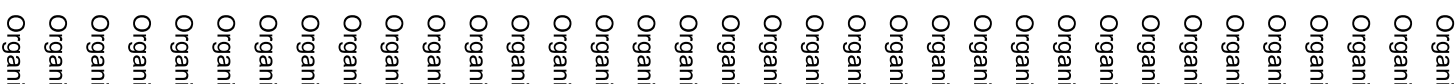

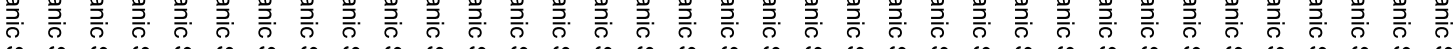

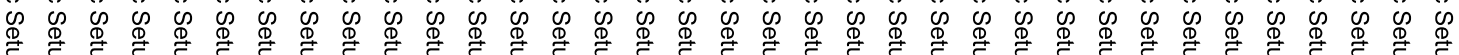

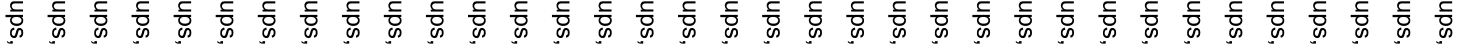

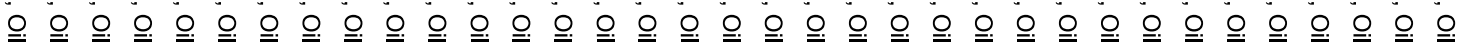

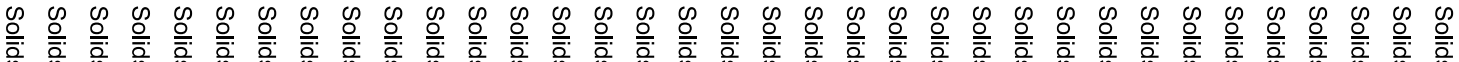

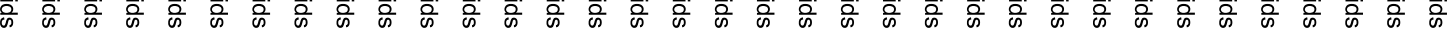

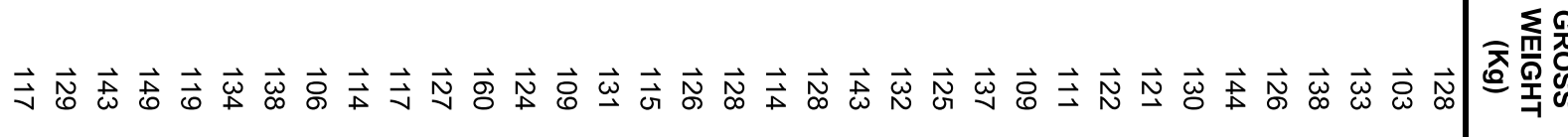

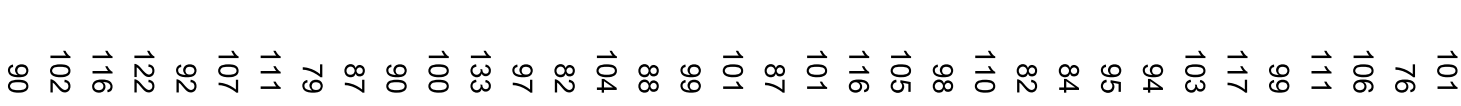




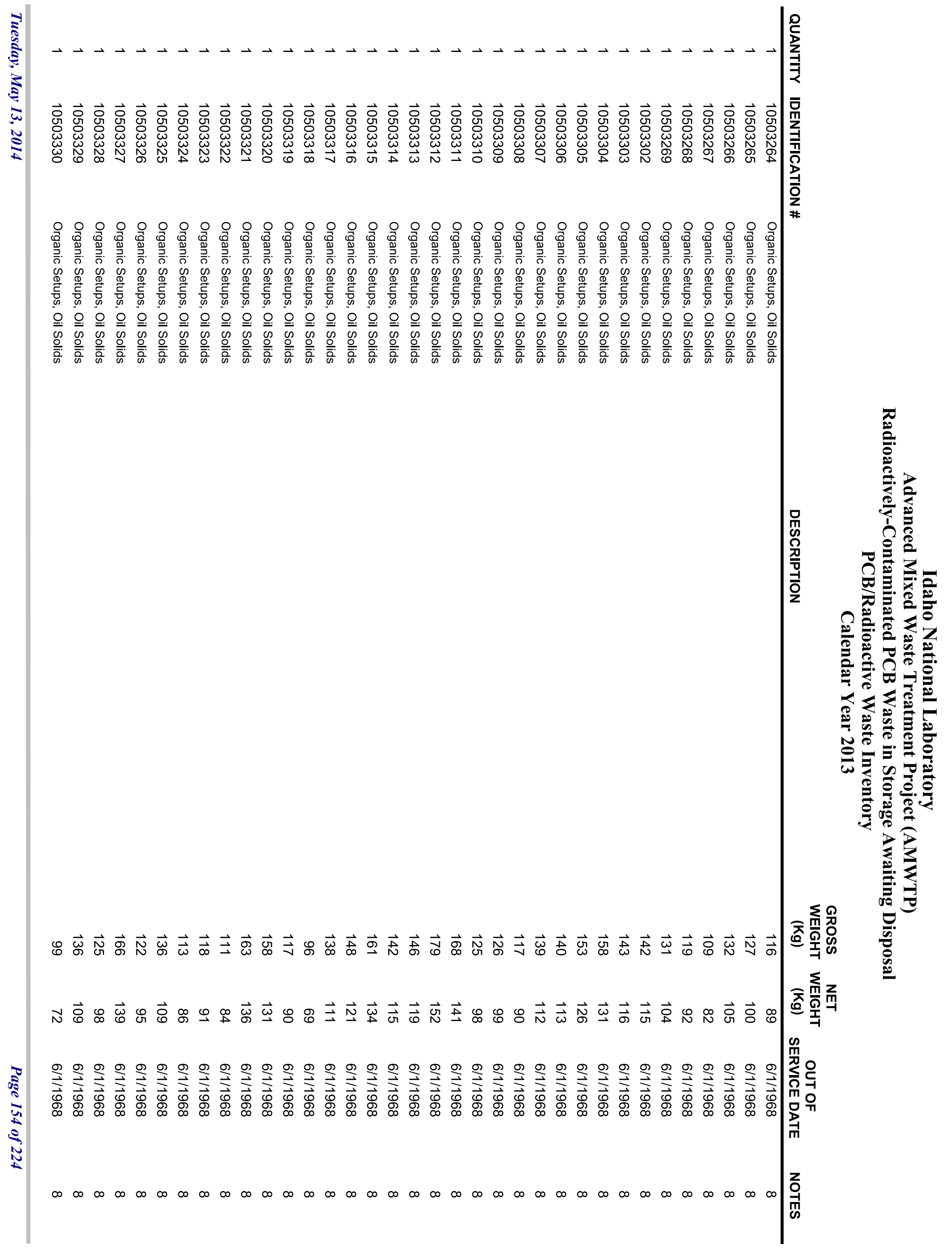




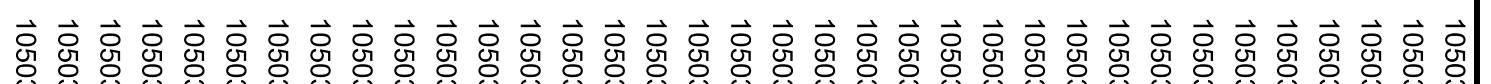

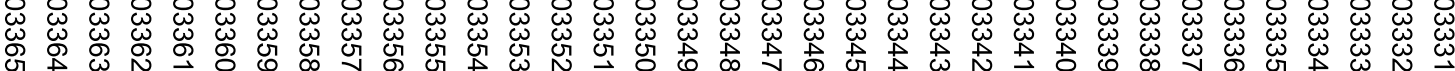

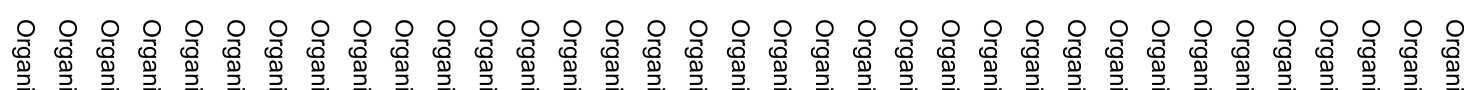

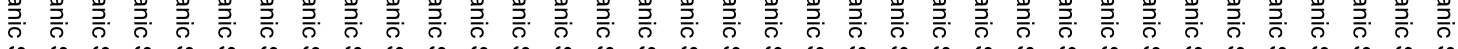

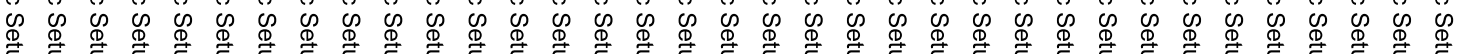

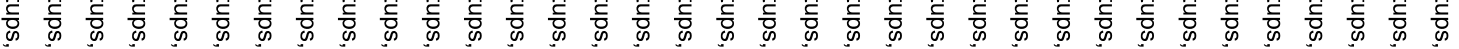

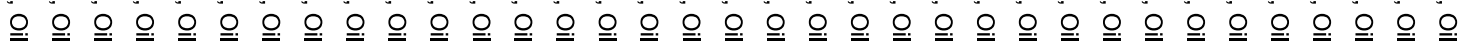

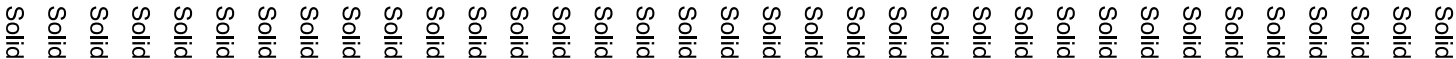

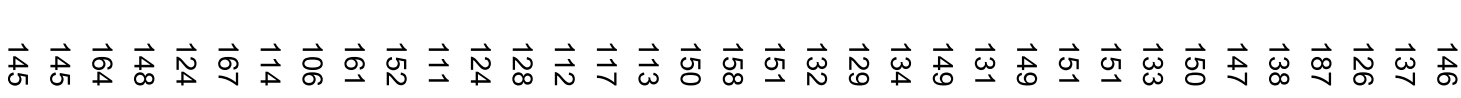


융 융 융 융 융 융 융 융 융 융 융 융 융 융 융 융 융 융 융 융 융 융 융 융 융 융 융 융 잉

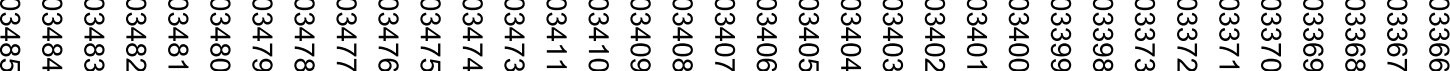

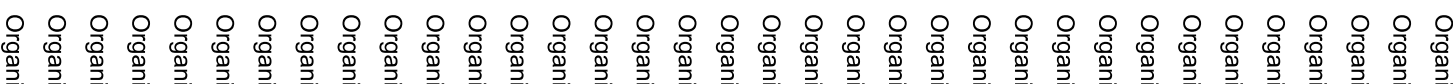

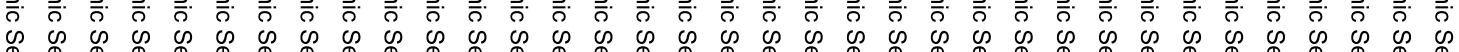

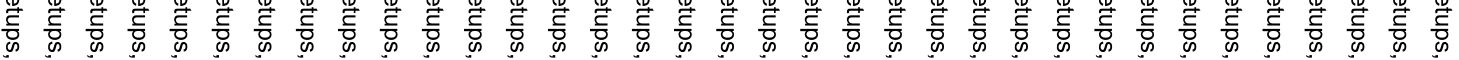

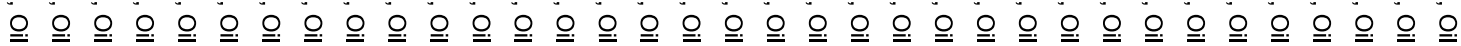

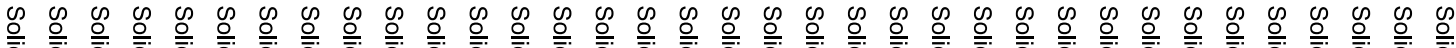

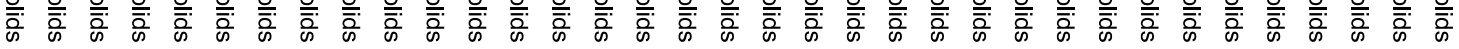

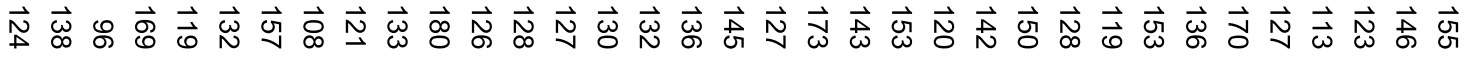




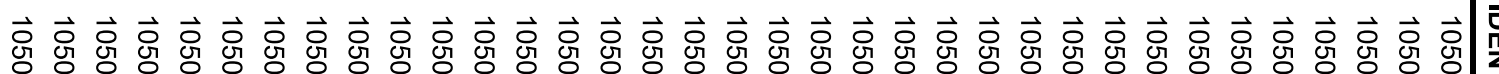

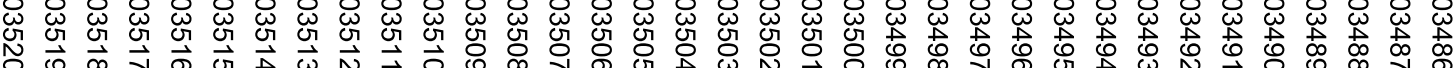

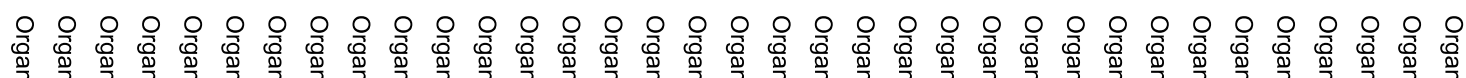

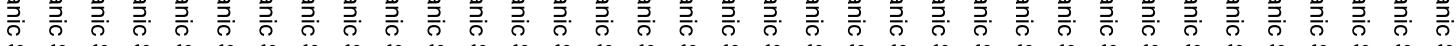

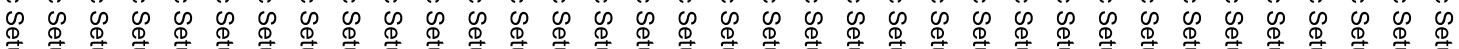
密

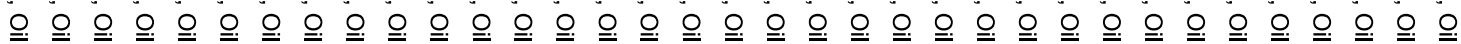

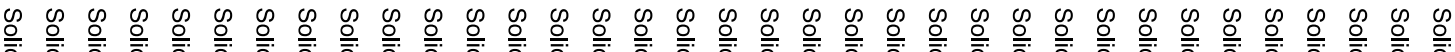

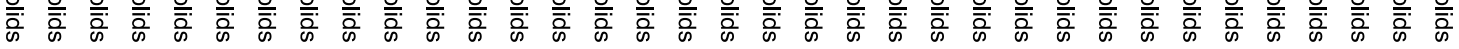

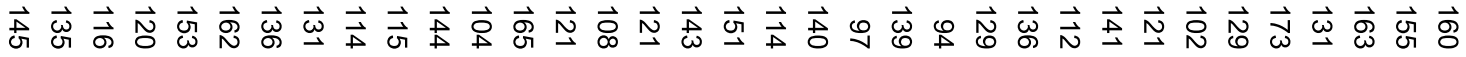

줄

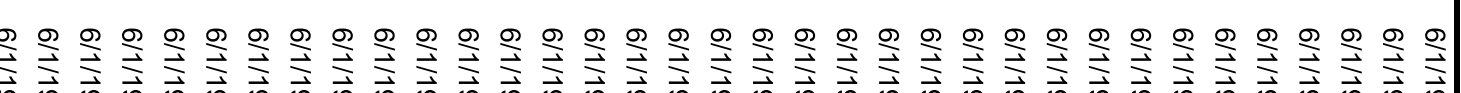

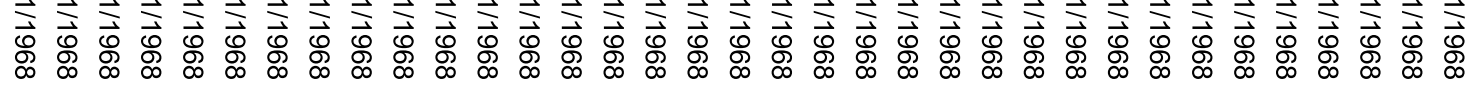


융 융 융 융 융 융 융 융 융 융 융 융 융 융 융 융 융 융 융 융 융 융 융 융 융 융 융 융 융 융 융 융 융 융 융

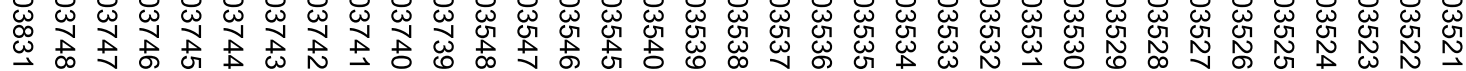

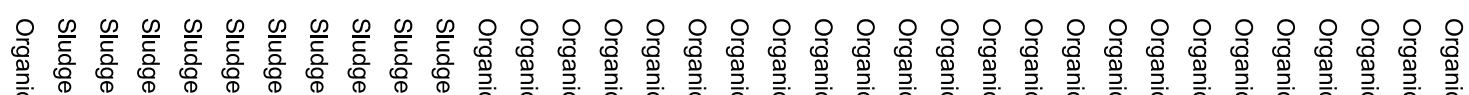
न 0 d

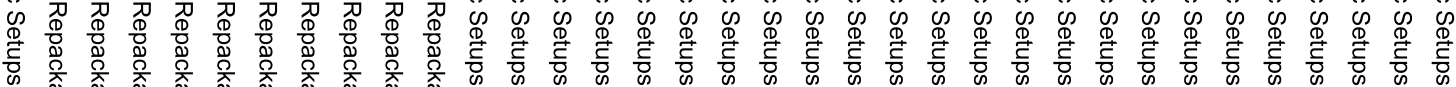

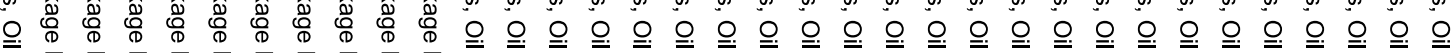

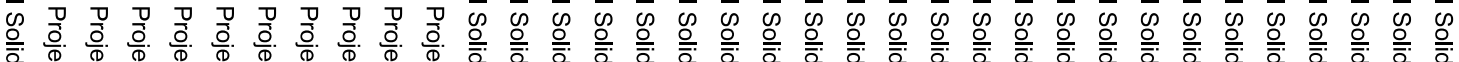

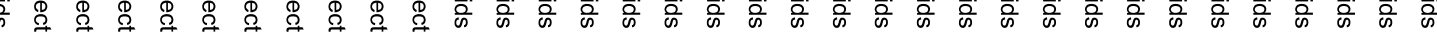

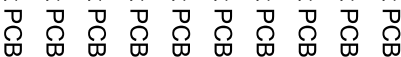

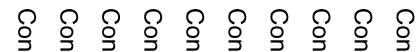

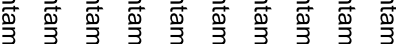




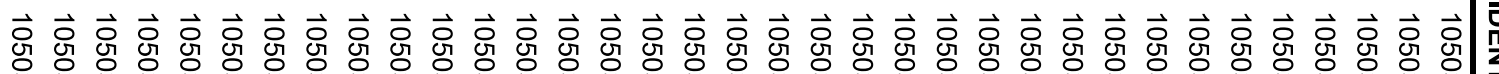

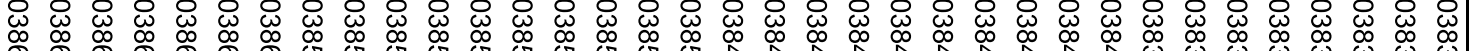

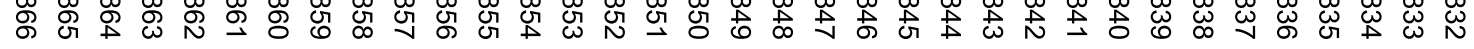

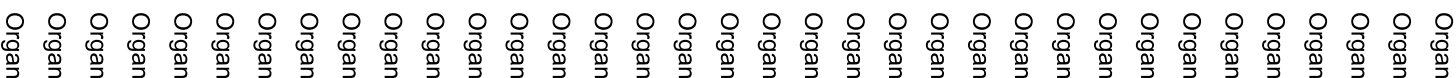

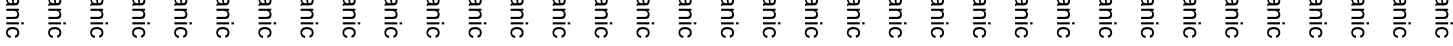

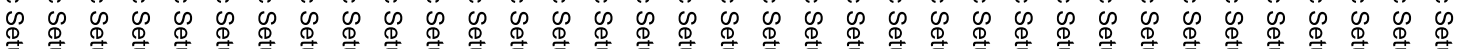
密

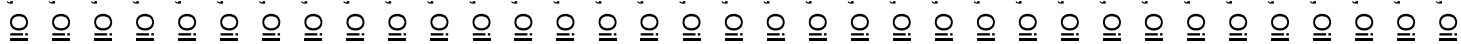

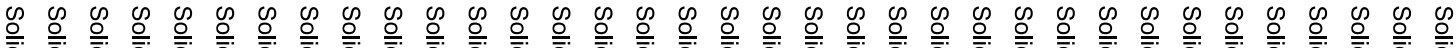

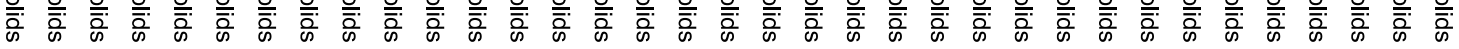

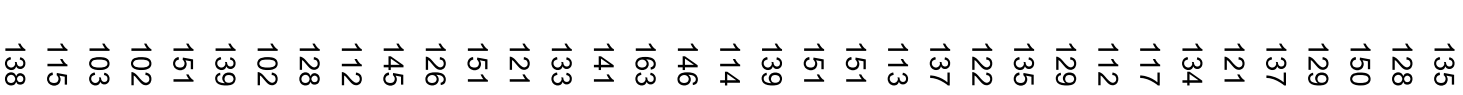

줄 


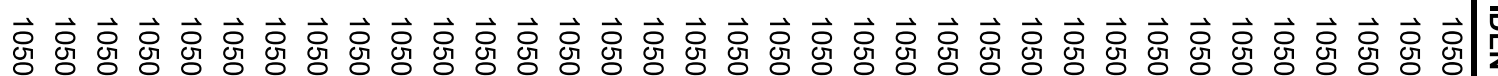

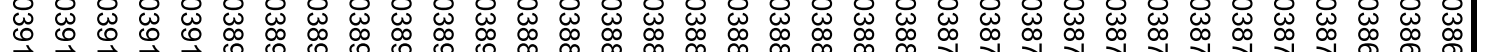

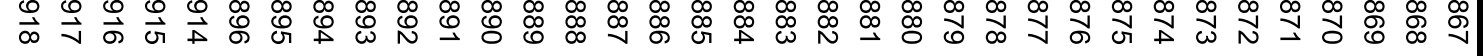

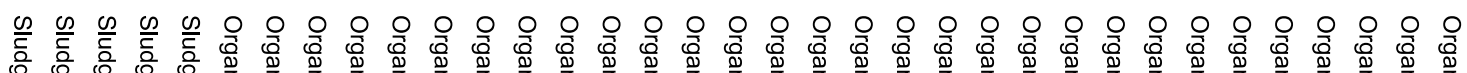

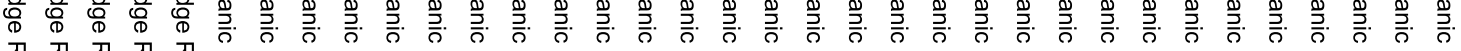

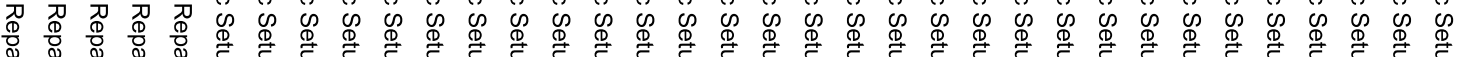

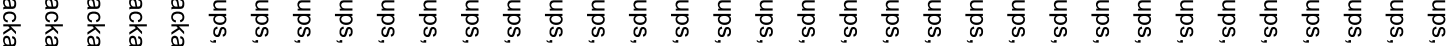
б

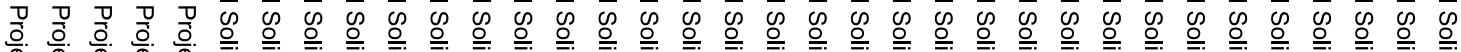

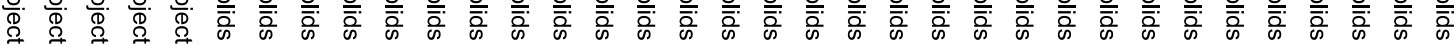

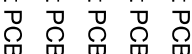

$\circ \odot$

类

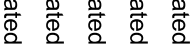

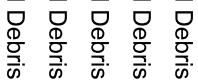

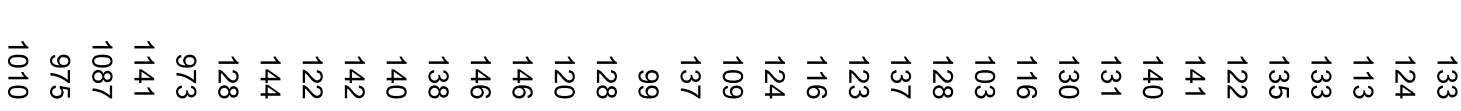

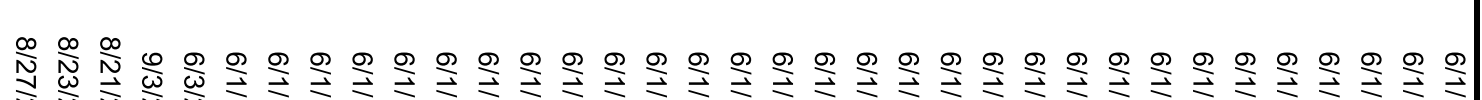

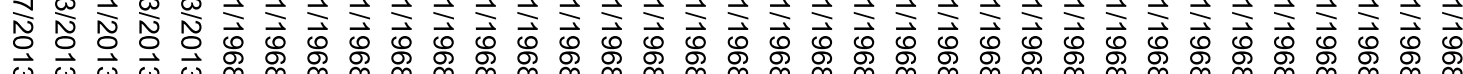




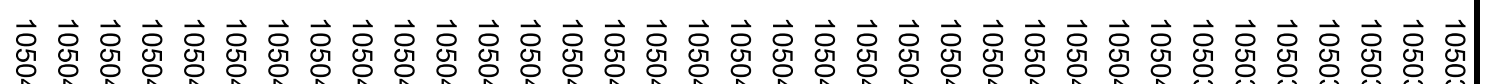

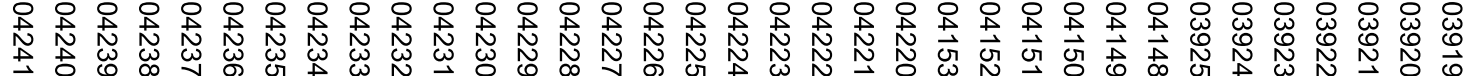

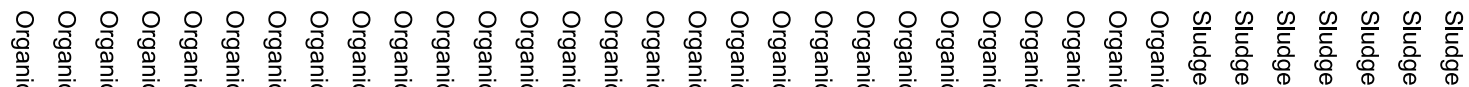

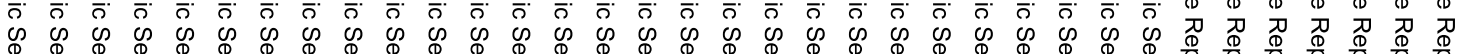

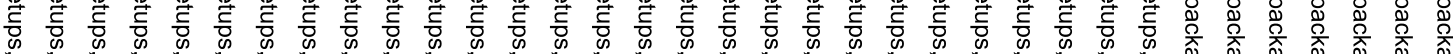

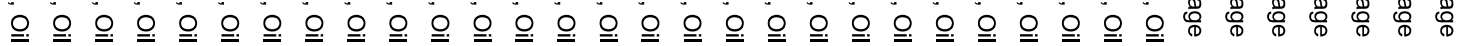

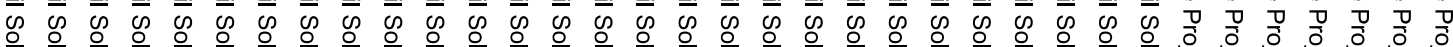

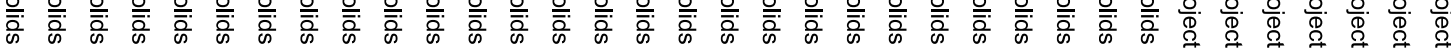

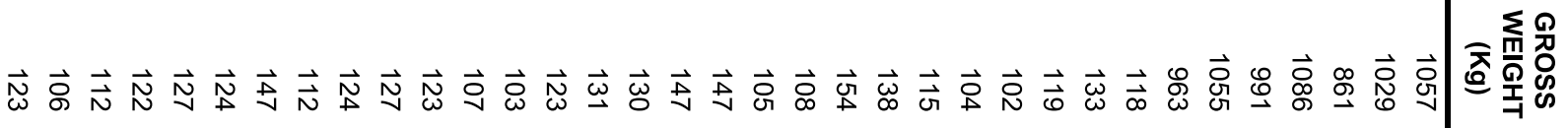
\& ర위 兴血 


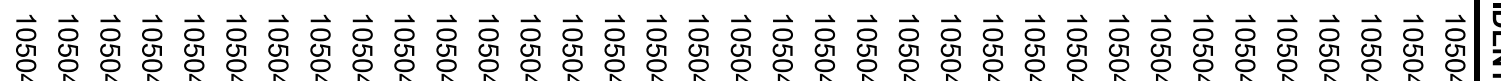

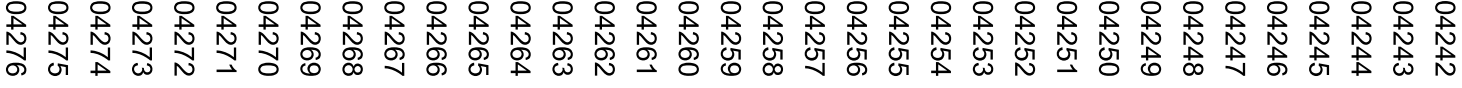

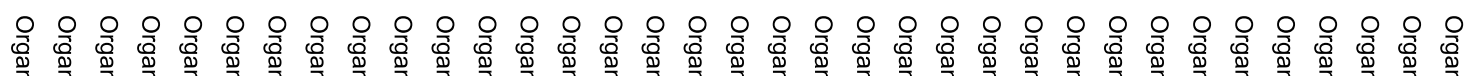

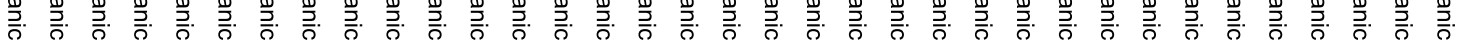

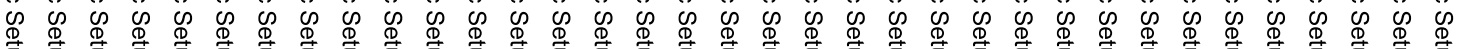

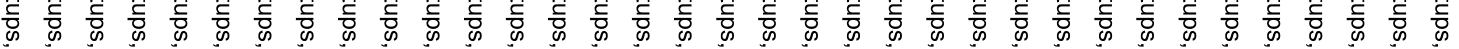

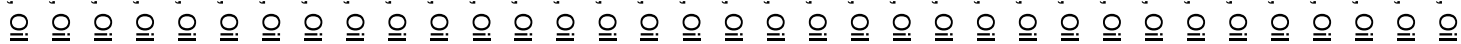

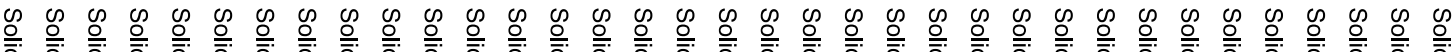

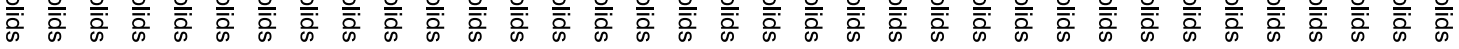

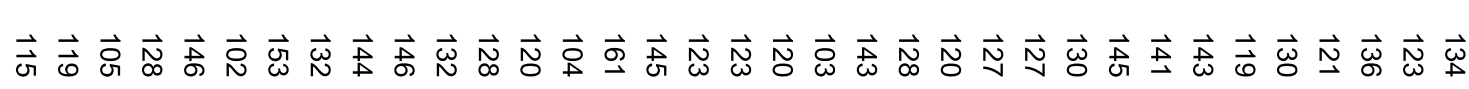

줄 


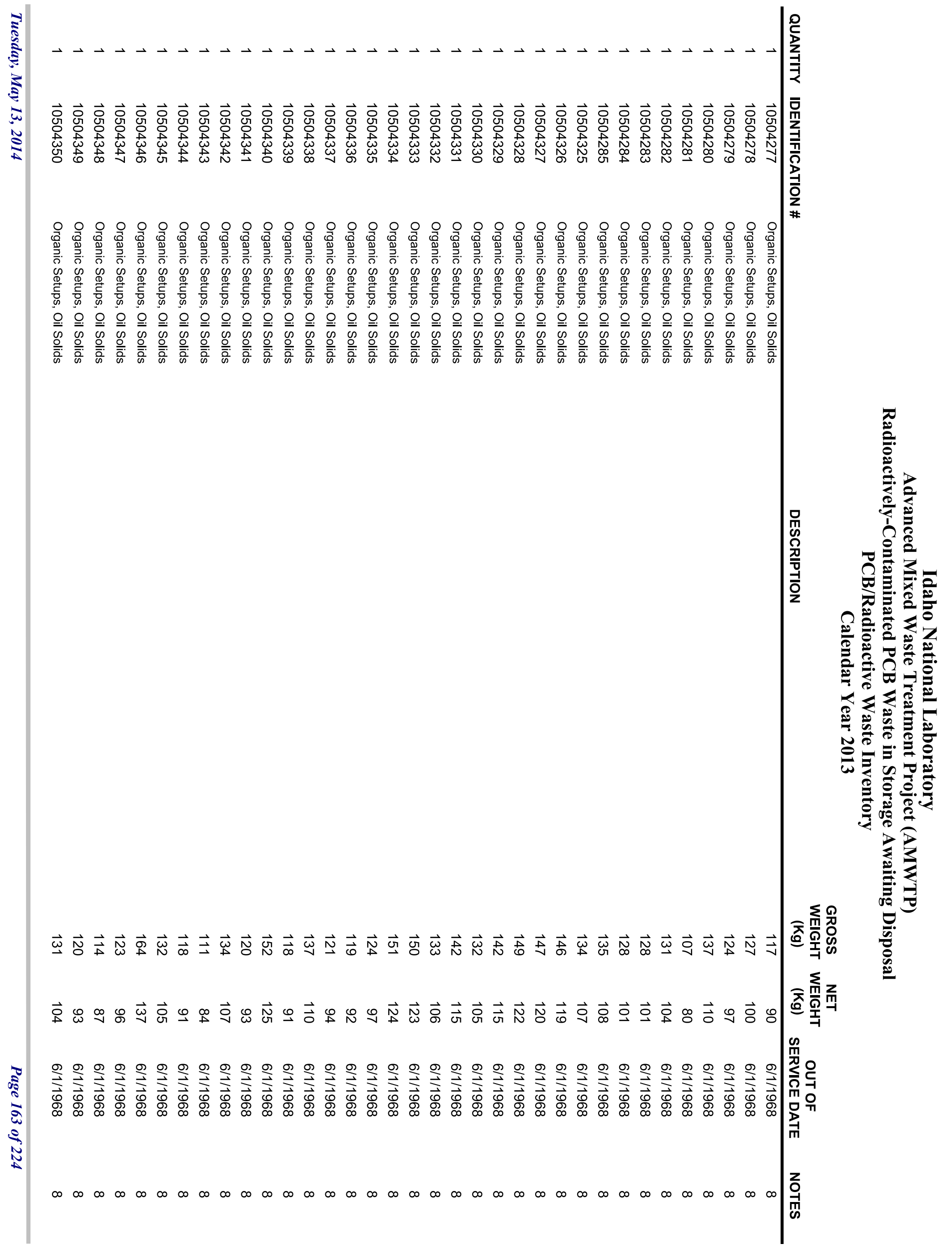


융 융 융 융 융 융 융 융 융 융 융 융 융 융 융 융 융 융 융 융 융 융 융 융 융 융 융 융 융 융 융 융 융 잉

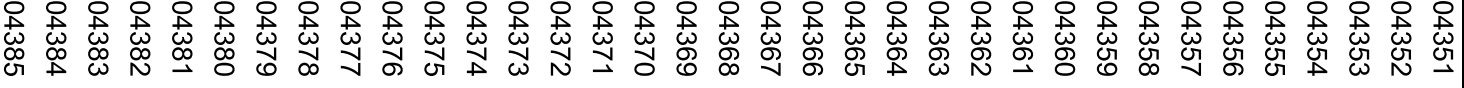

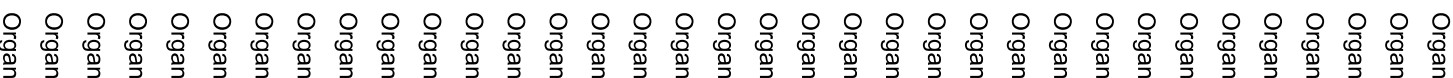

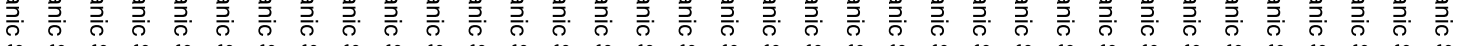

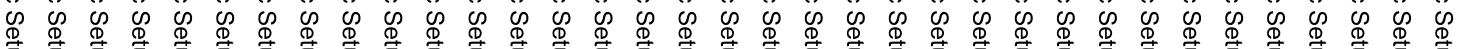

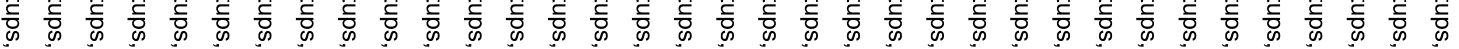

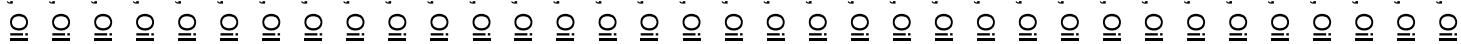

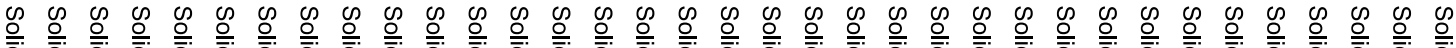

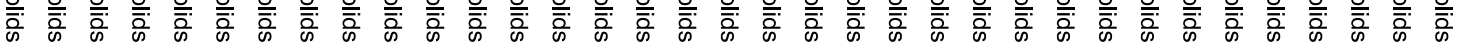

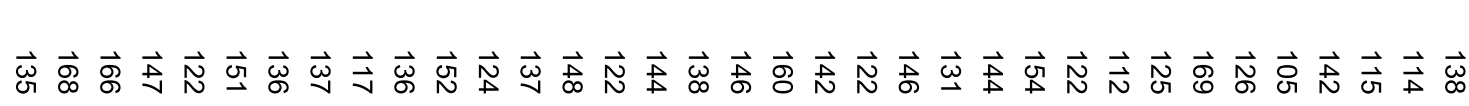

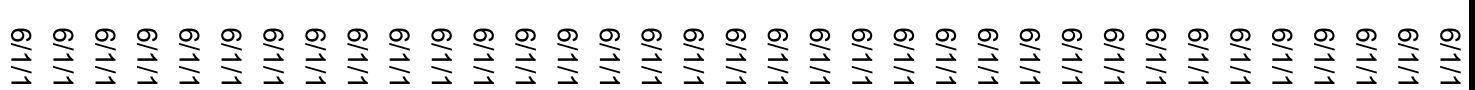

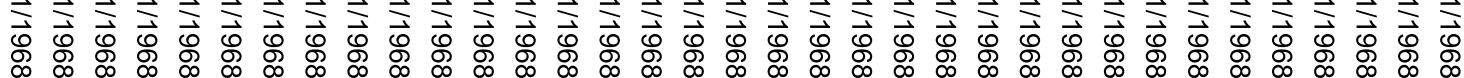




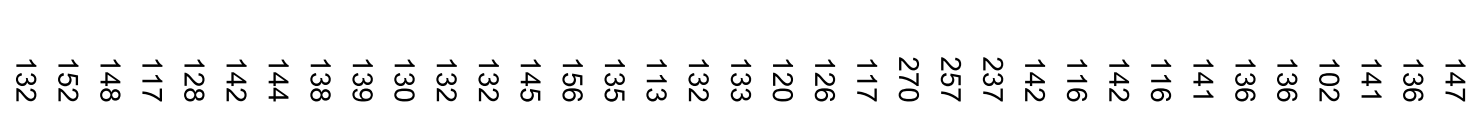

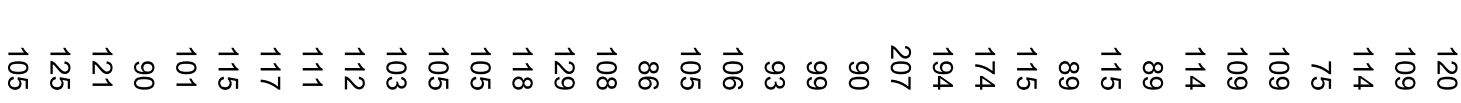
亩兴

\section{$\vec{N} \vec{N} \vec{N}$}


융 융 융 융 융 융 융 융 융 융 융 융 융 융 융 융 융 융 융 융 융 융 융 융 융 융 융 융 융 융 융 융 융 융 잉

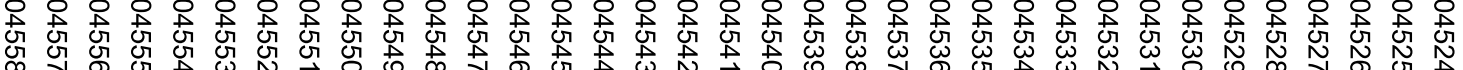

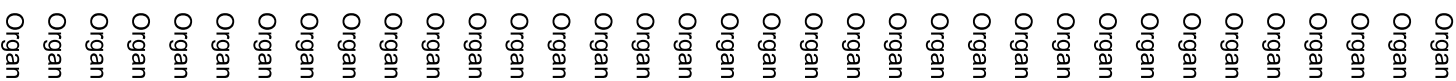

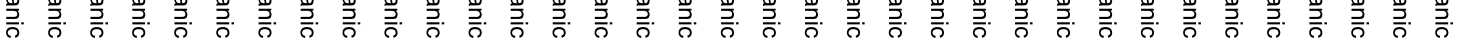

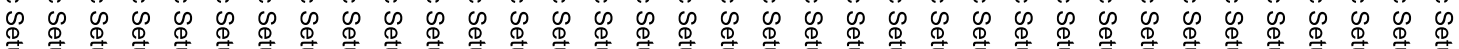

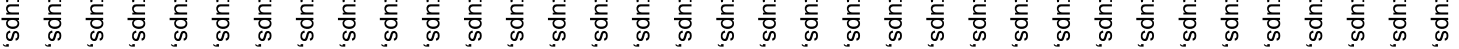

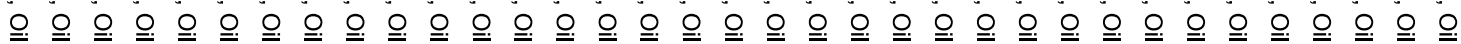

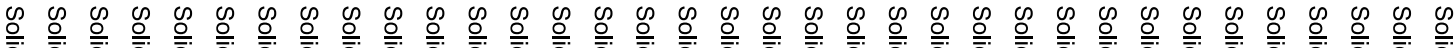

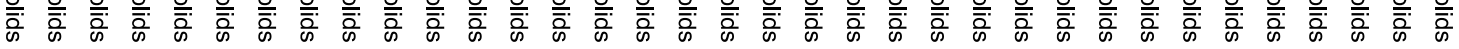

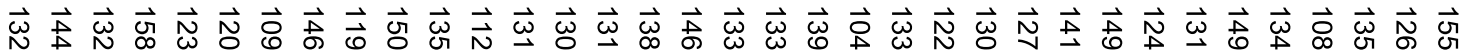




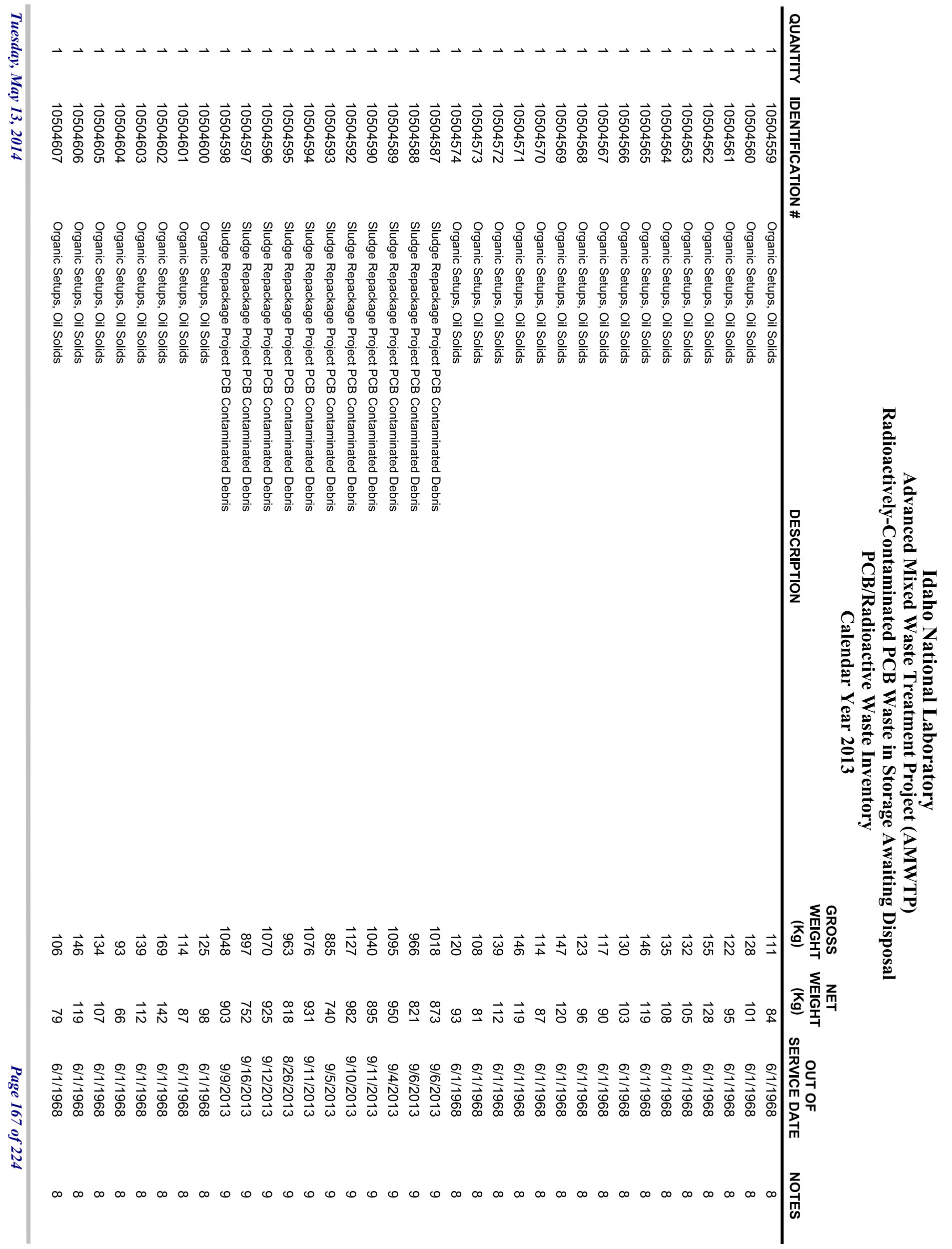




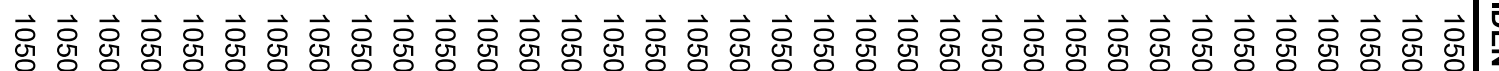

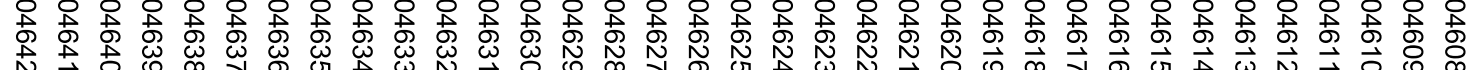

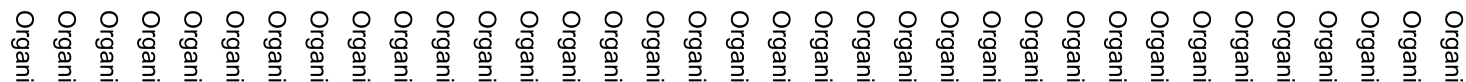

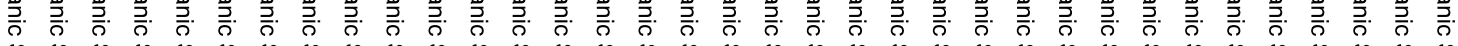

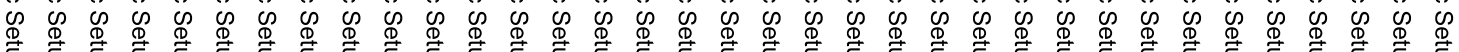
骔

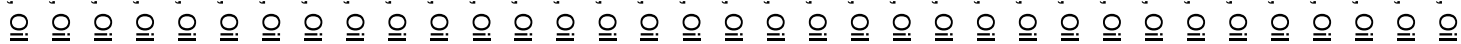

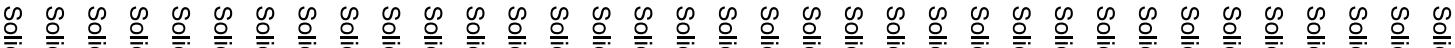

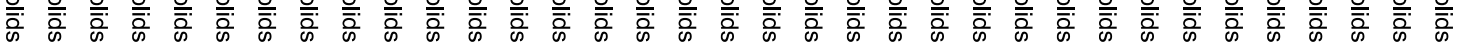

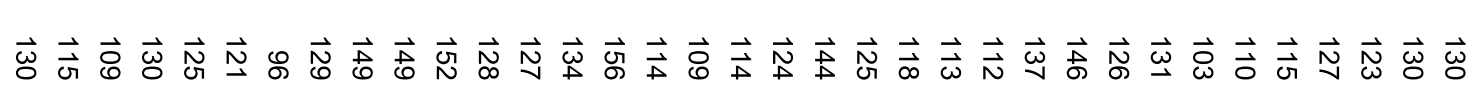

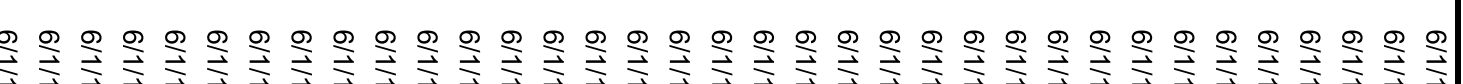

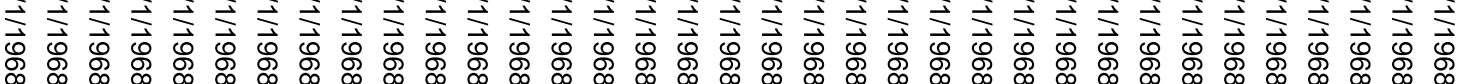




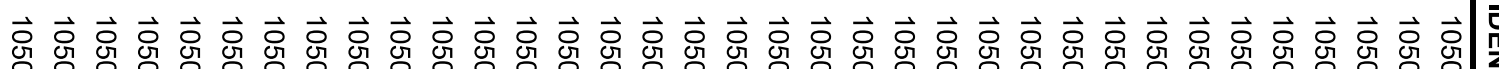

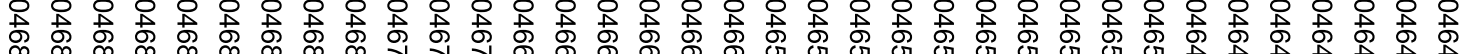
冓

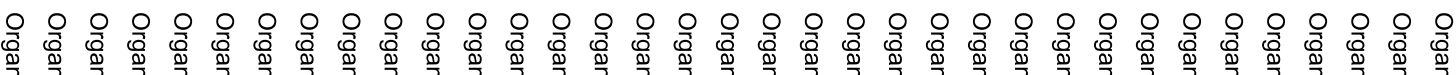

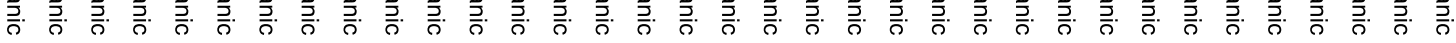

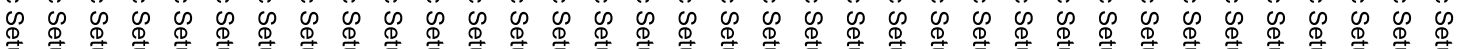
密

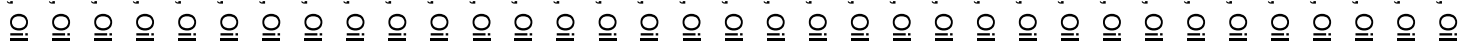

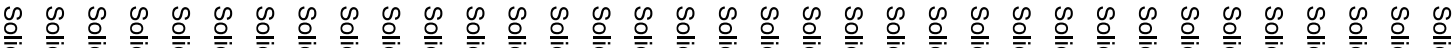

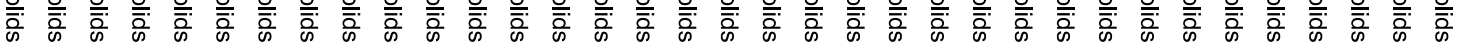

7
8
8
0
0
0

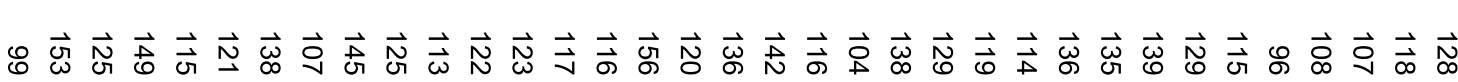

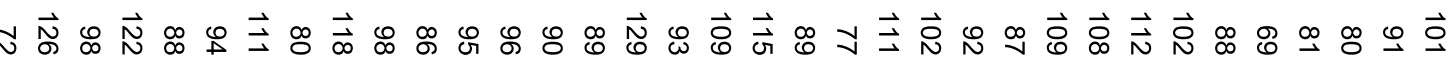
交血

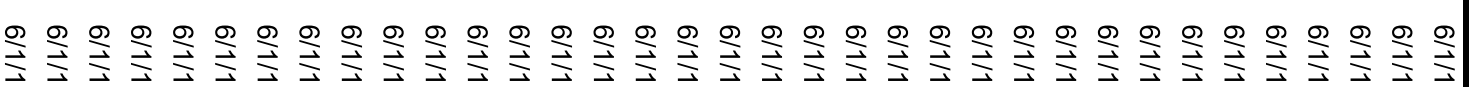
o 


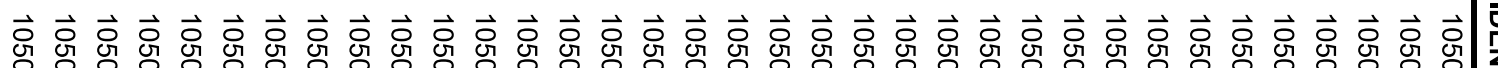

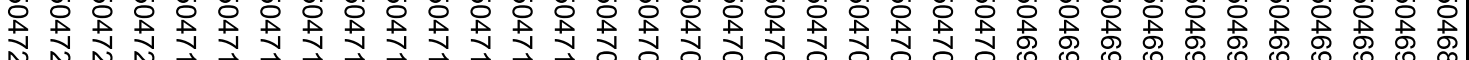

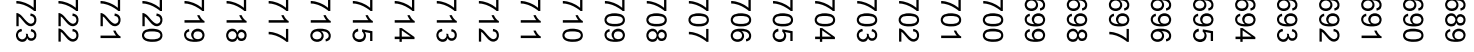

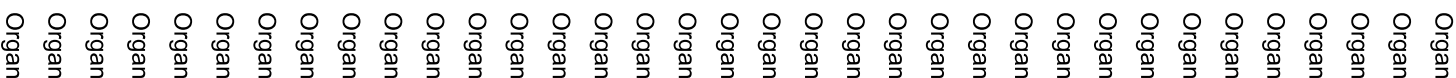

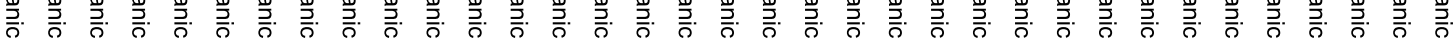

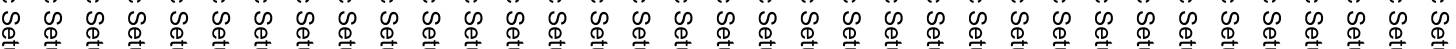
密

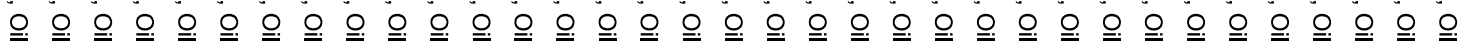

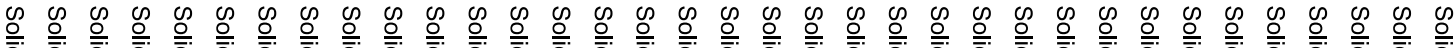

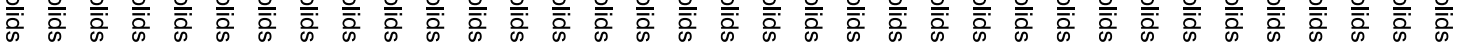

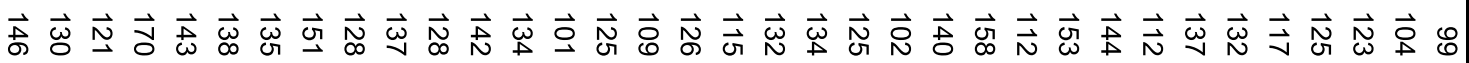




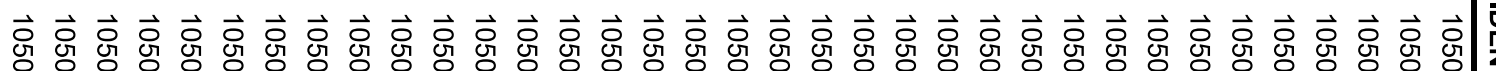

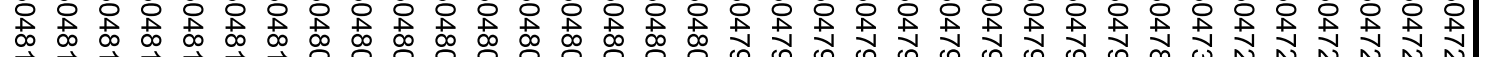

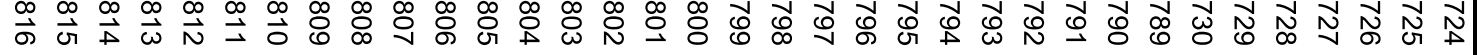

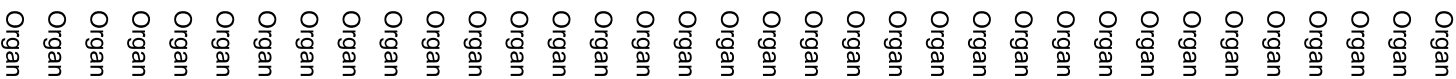

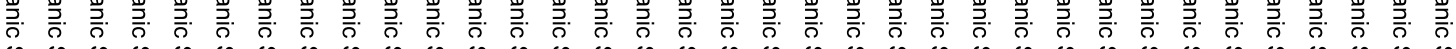

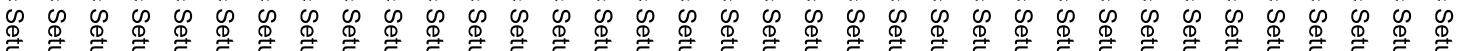
骔

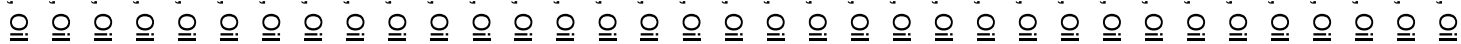

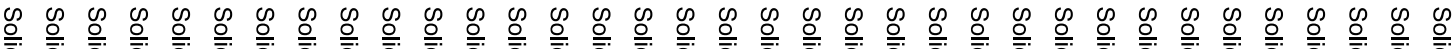

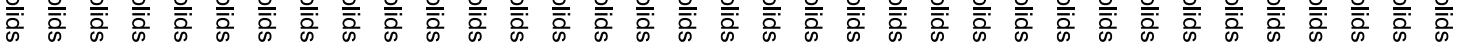

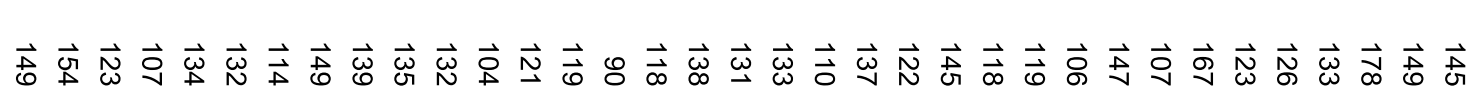




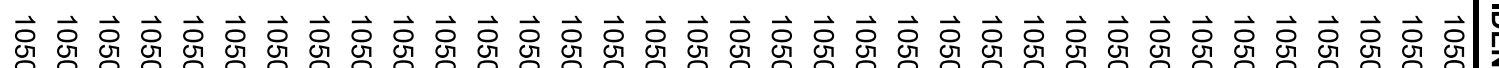

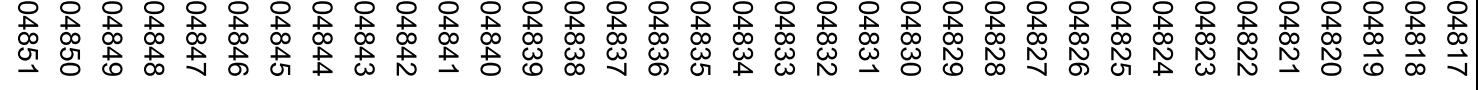

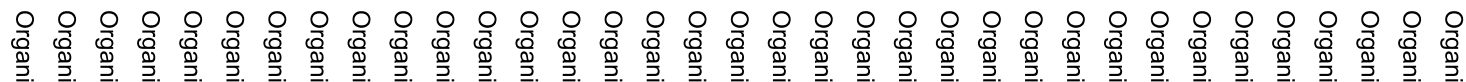

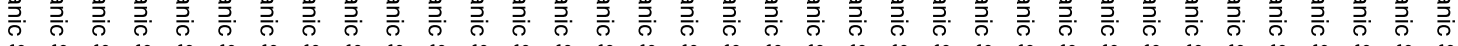

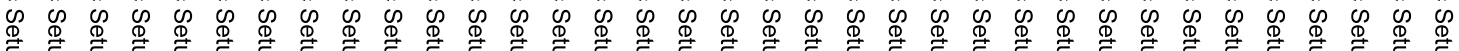
骔

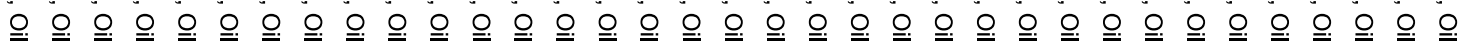

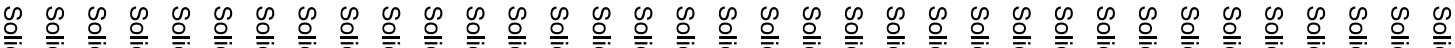

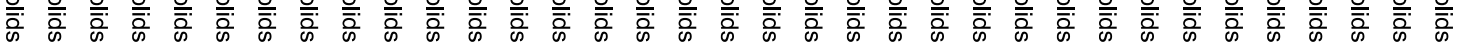

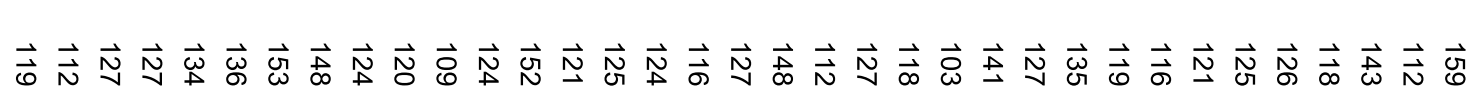

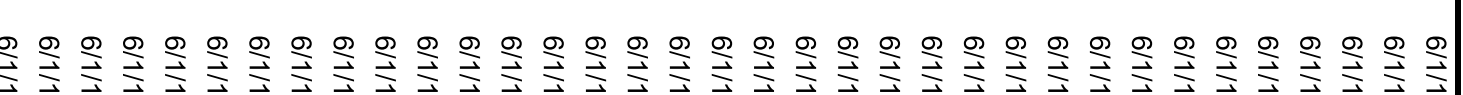

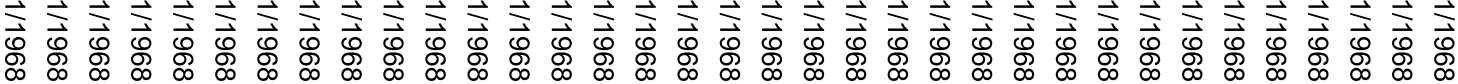




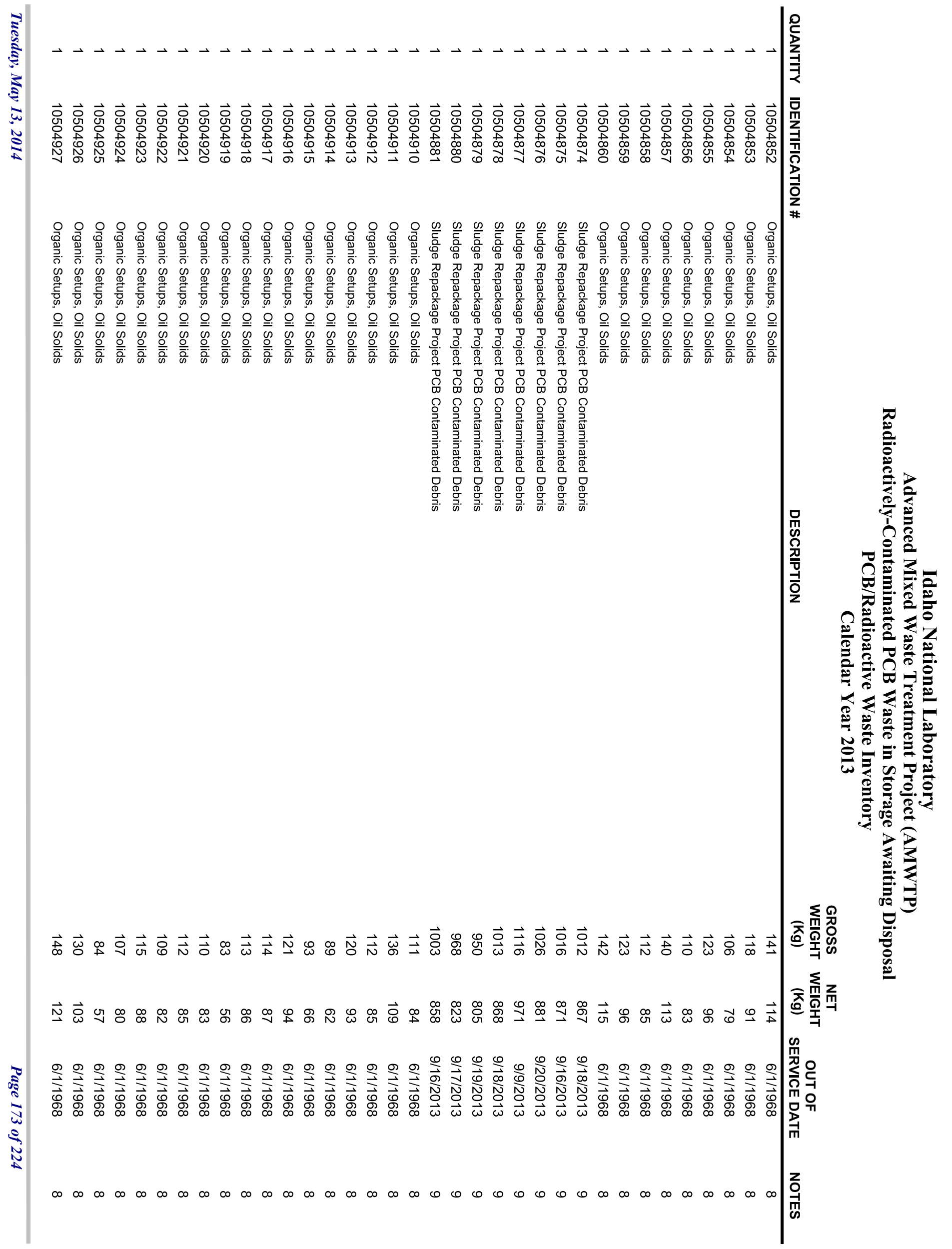




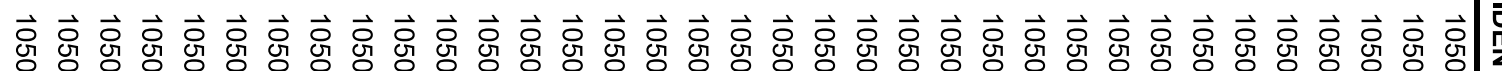

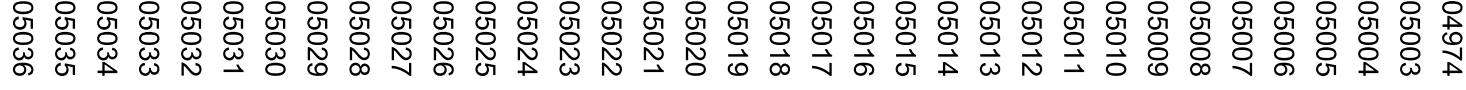

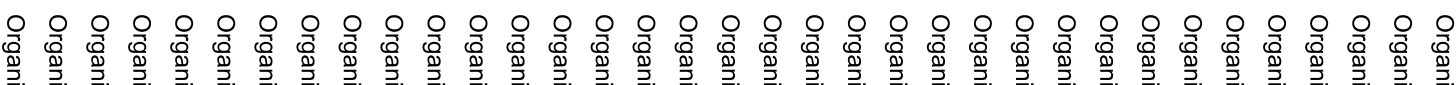

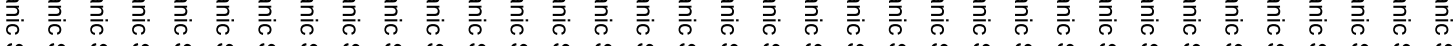

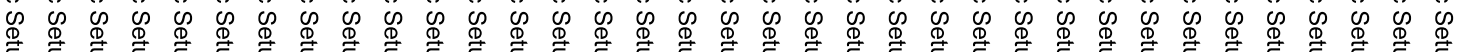
密

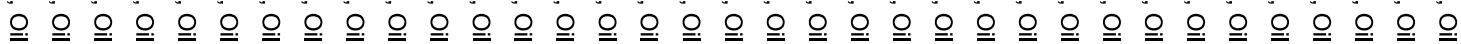

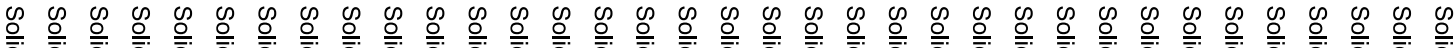

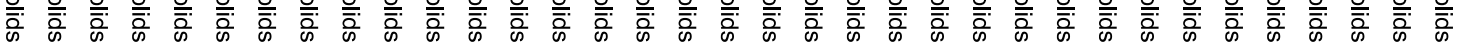

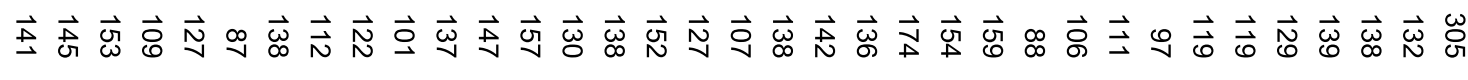

$$
\text { ore }
$$

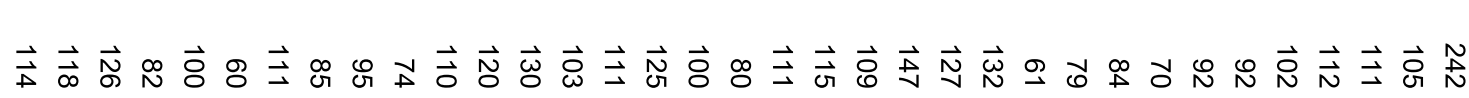
囬而 


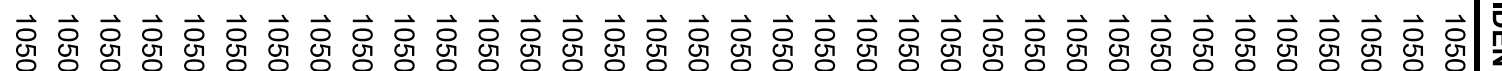

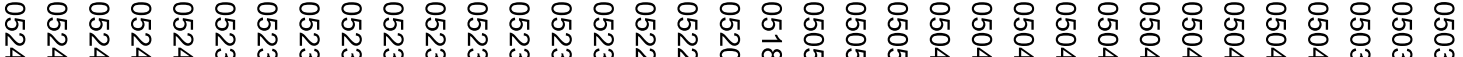

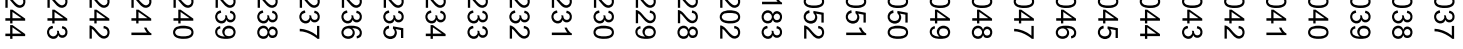

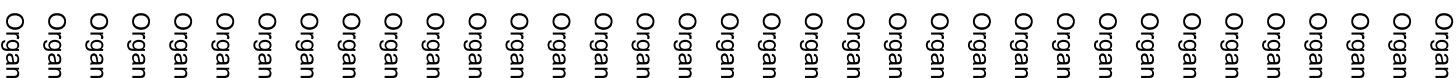

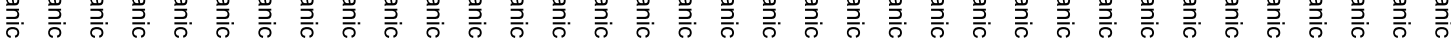

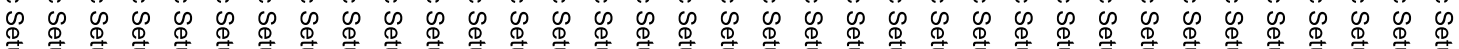
密

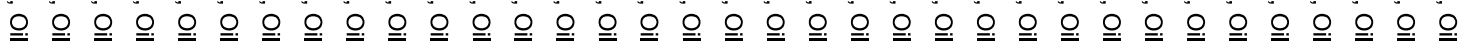

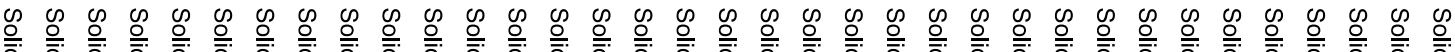

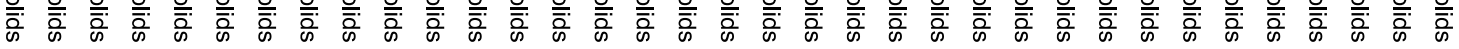

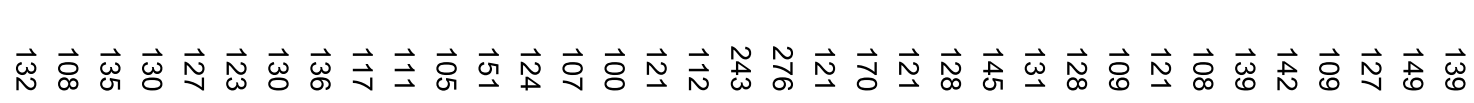

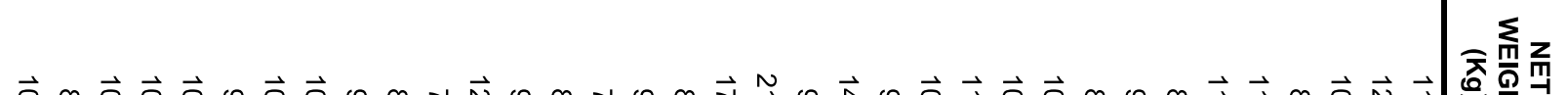




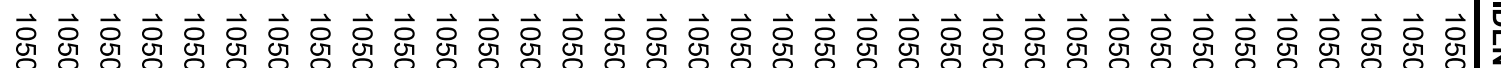

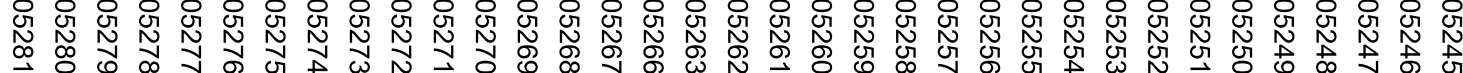

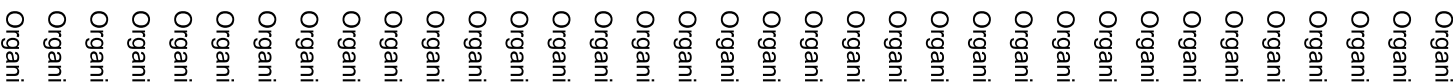

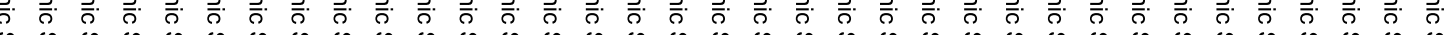
W

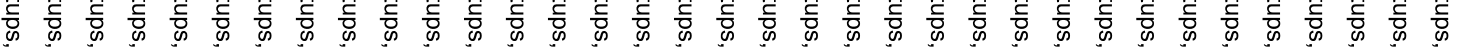

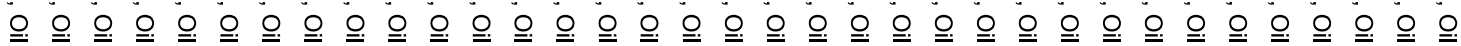
œ a वे के के

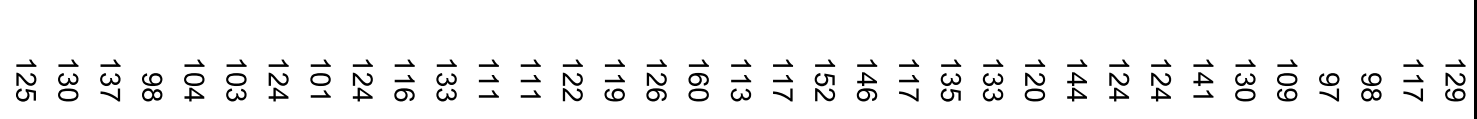




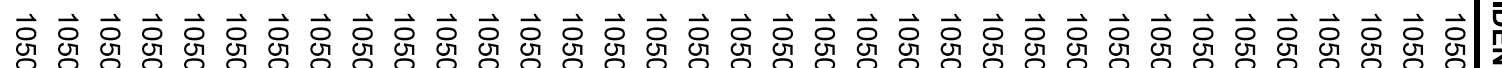

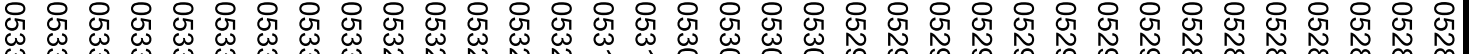

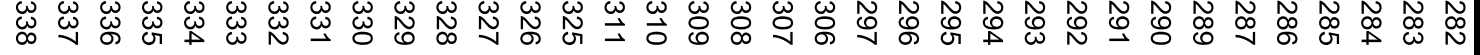

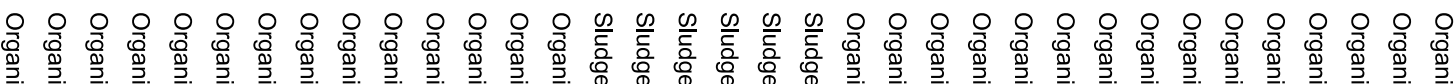

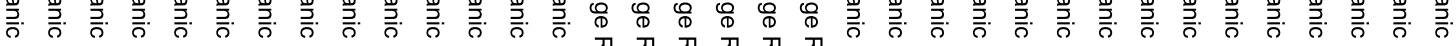

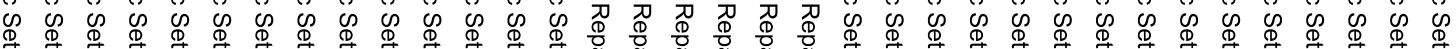

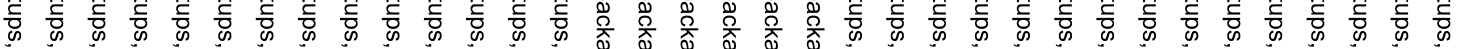

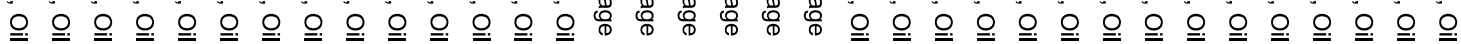

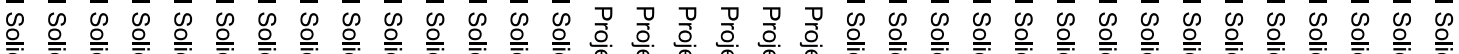

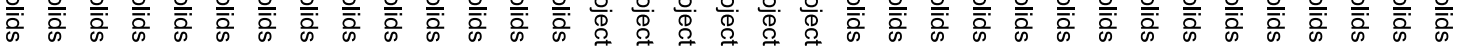

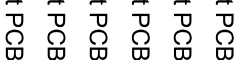

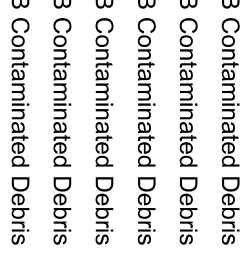

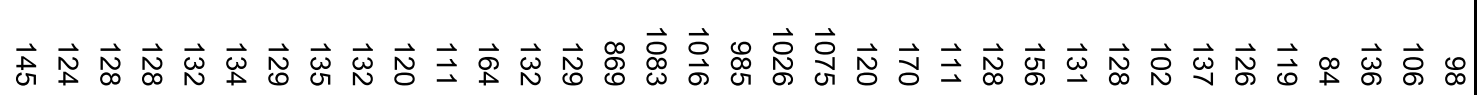

A

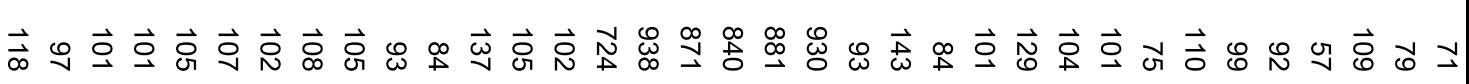
交而 


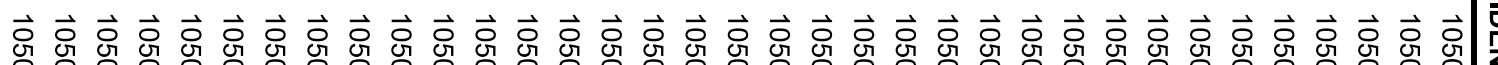

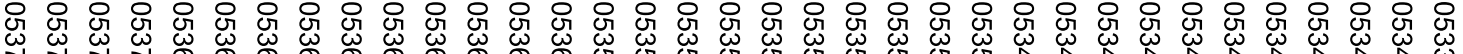

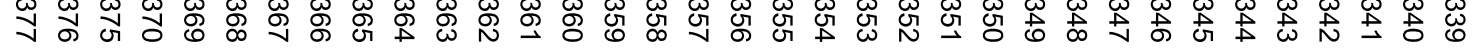

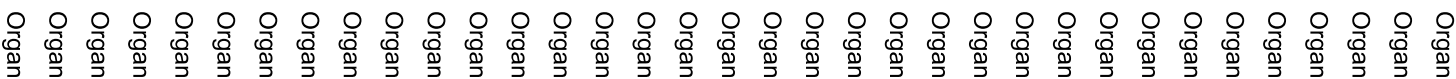

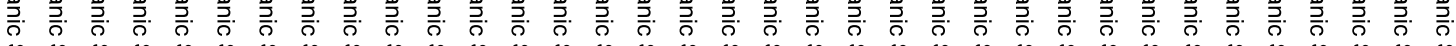

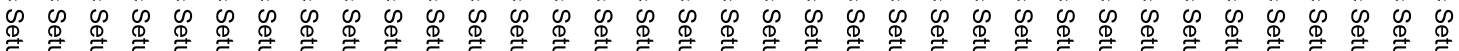
密

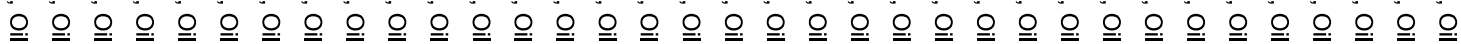

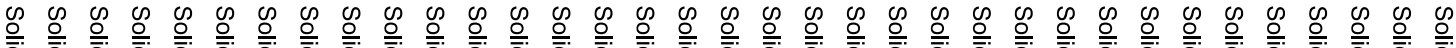

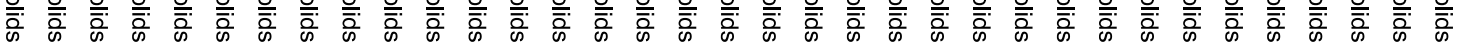

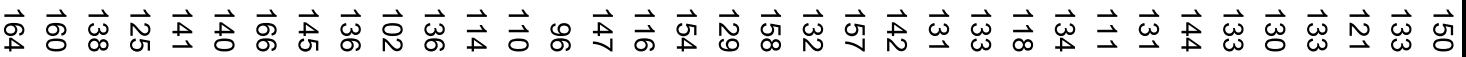




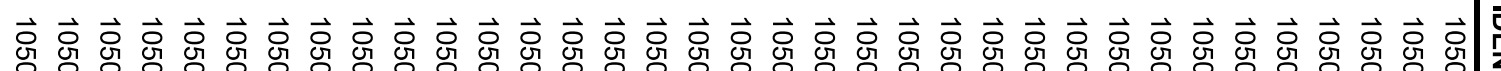

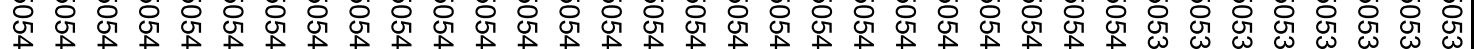

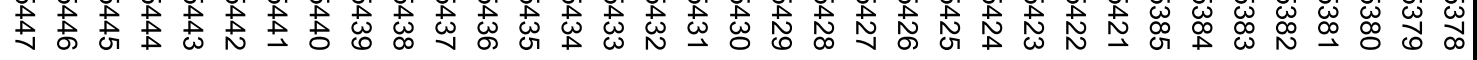

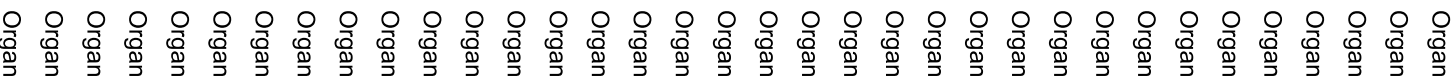

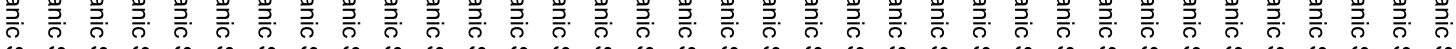

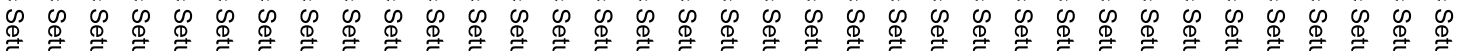
密

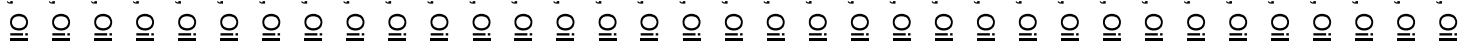

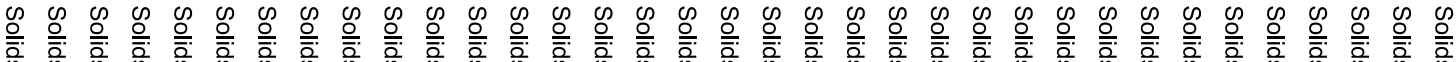

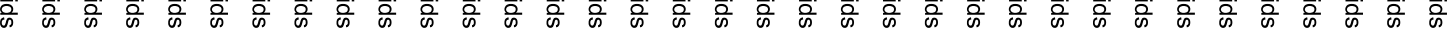

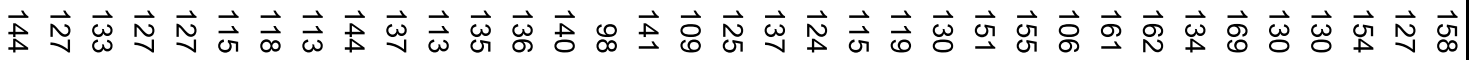

줄 


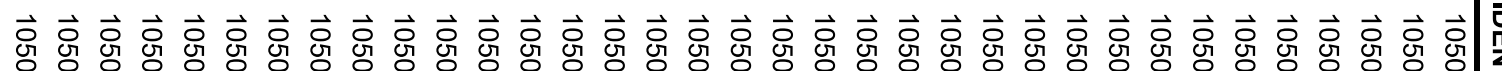
贸

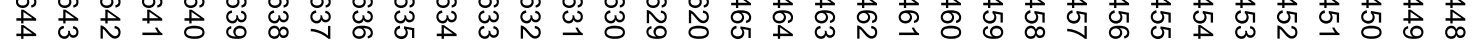

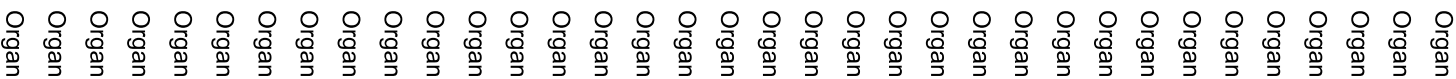

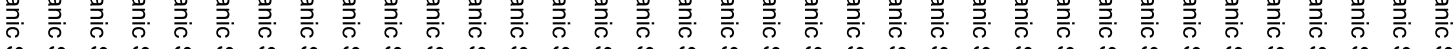

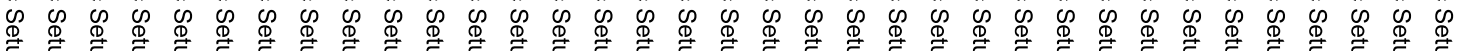
骔

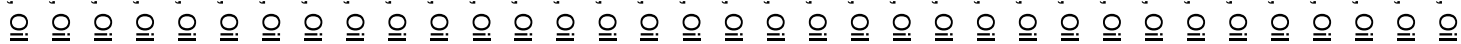

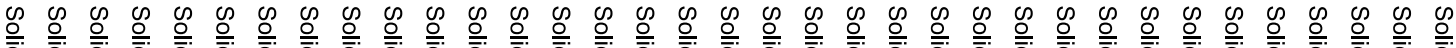

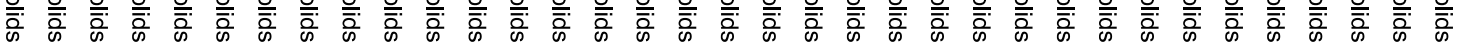

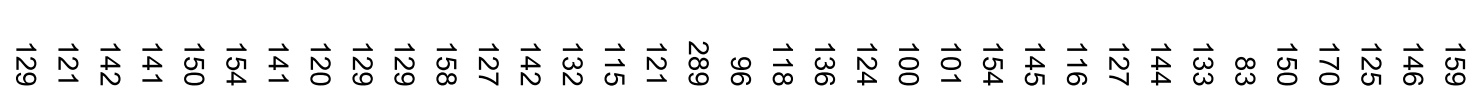

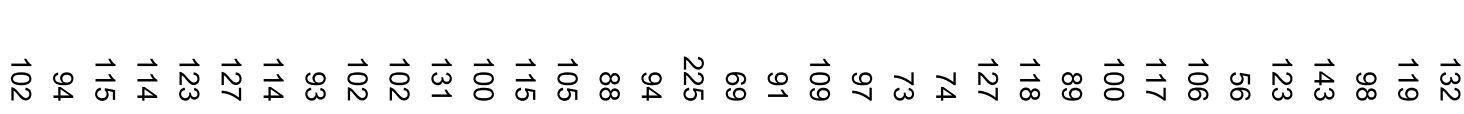
兴

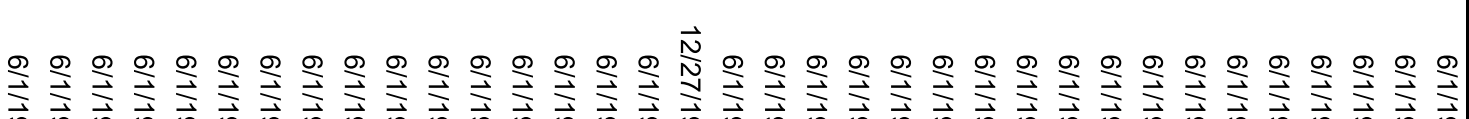

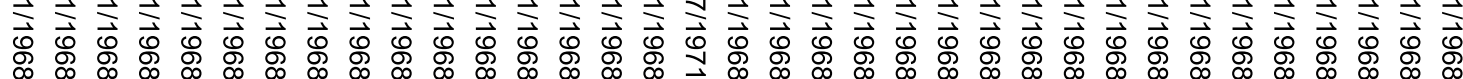




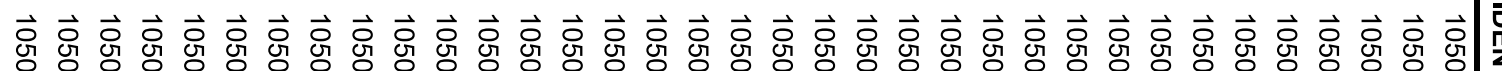

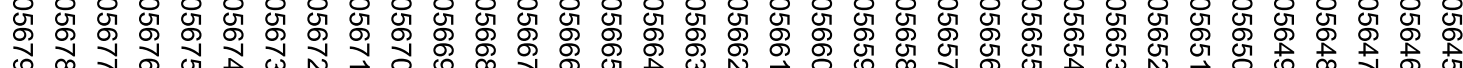

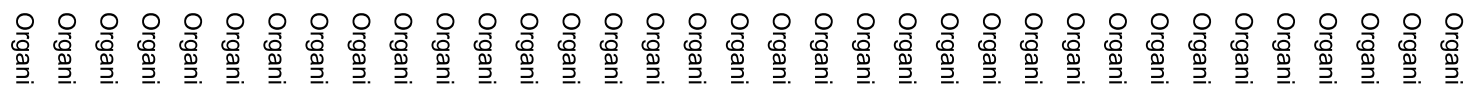
人

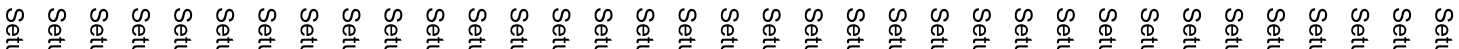
密

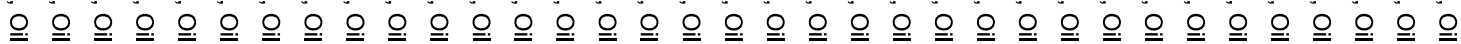

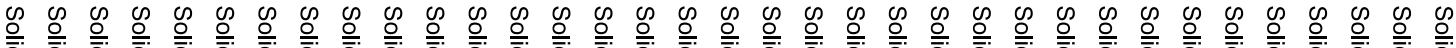

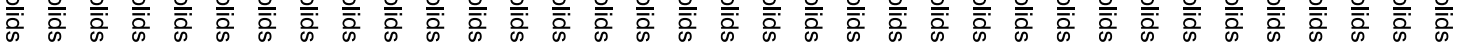

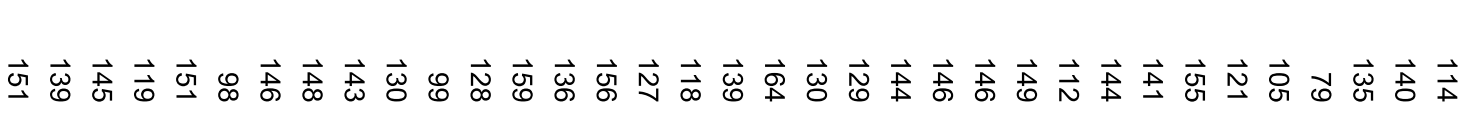




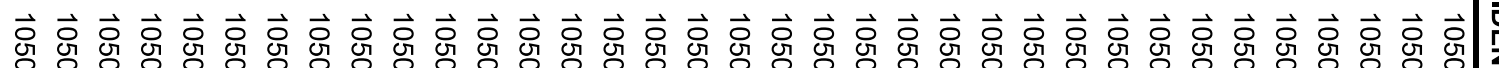

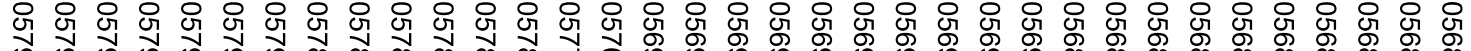
○

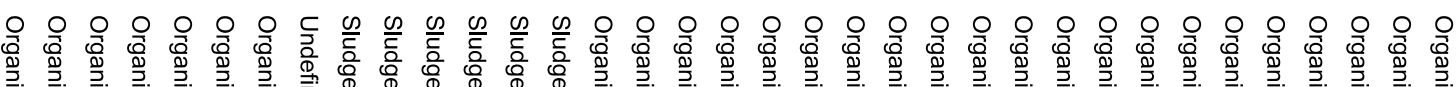

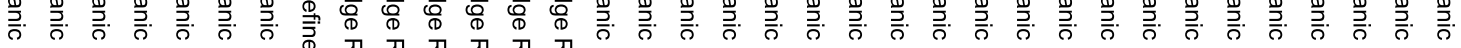

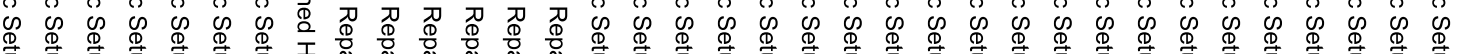

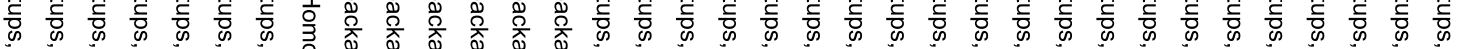

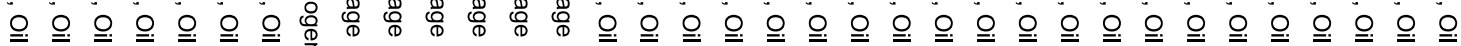

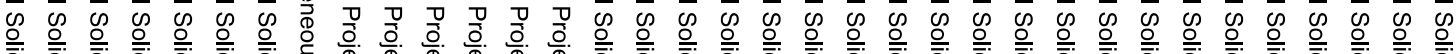

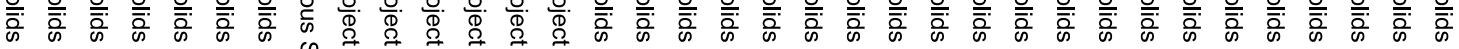

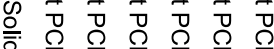

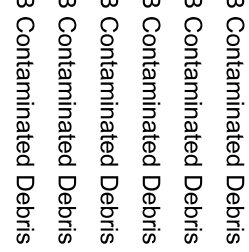

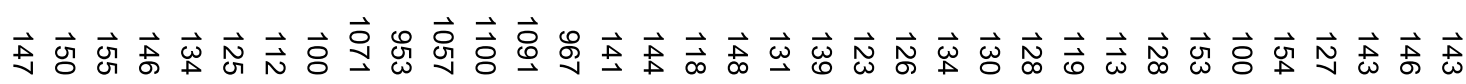

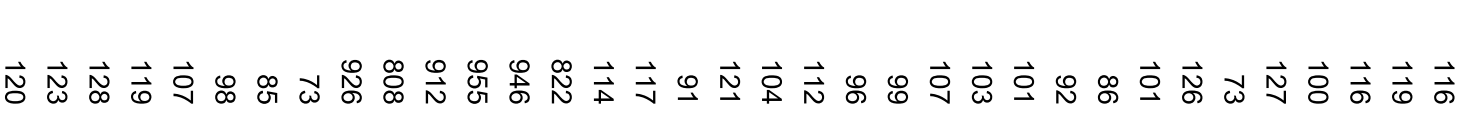
짐 


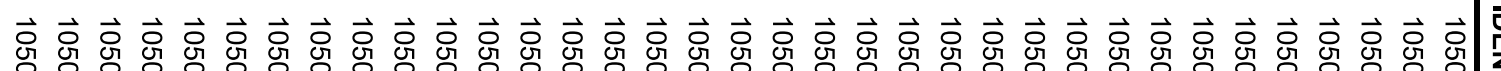

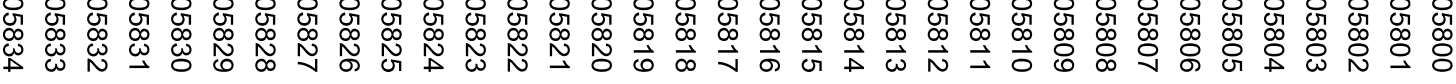

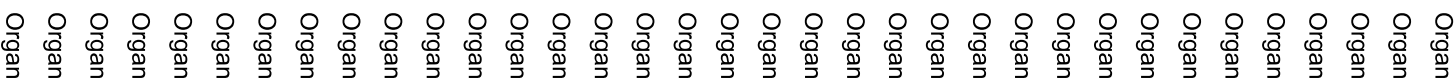

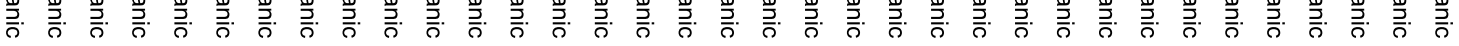

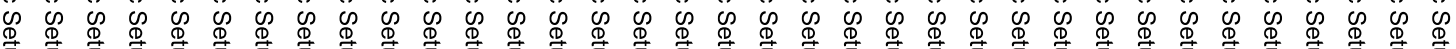

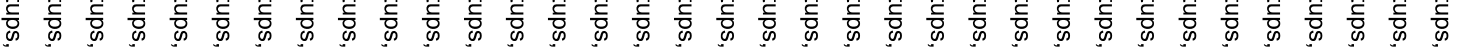

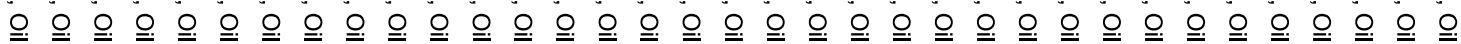

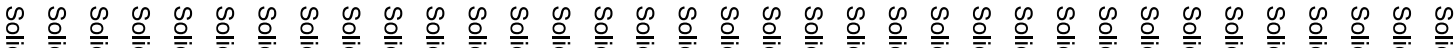

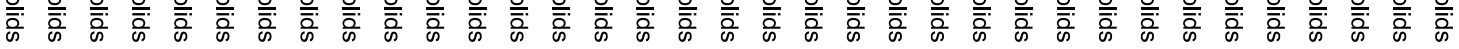

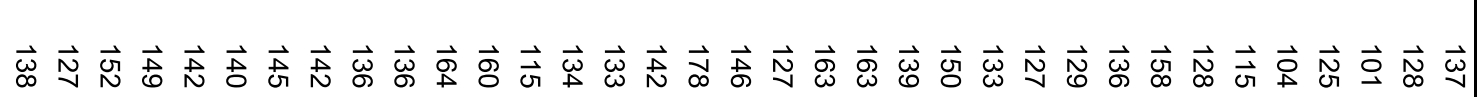

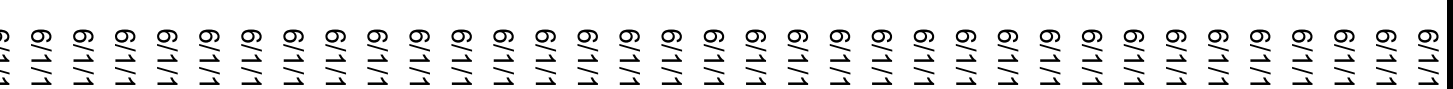

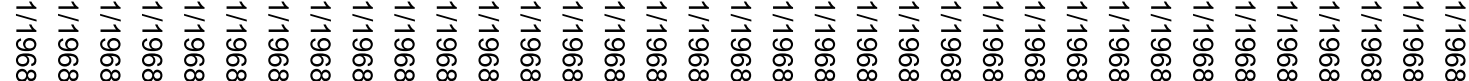




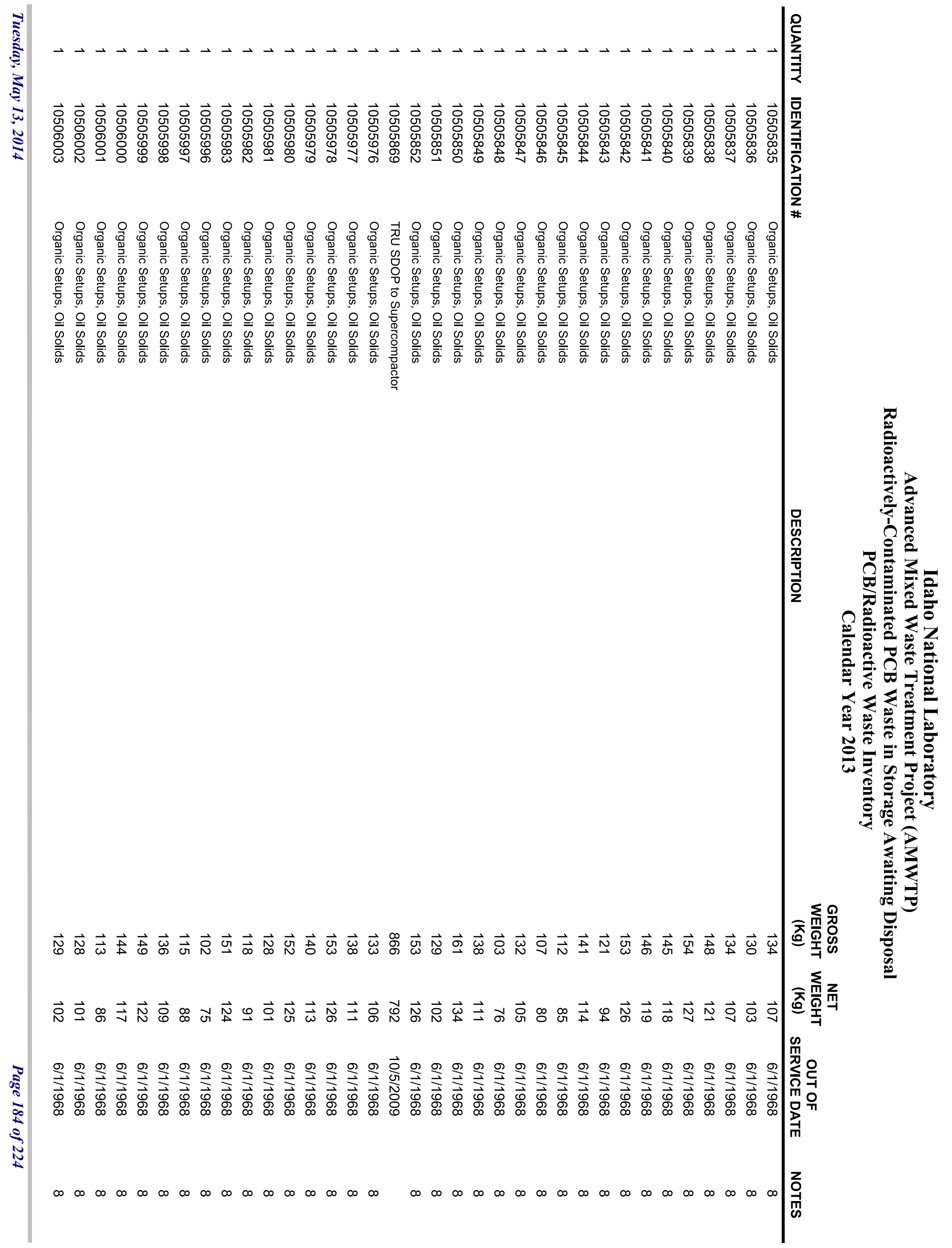




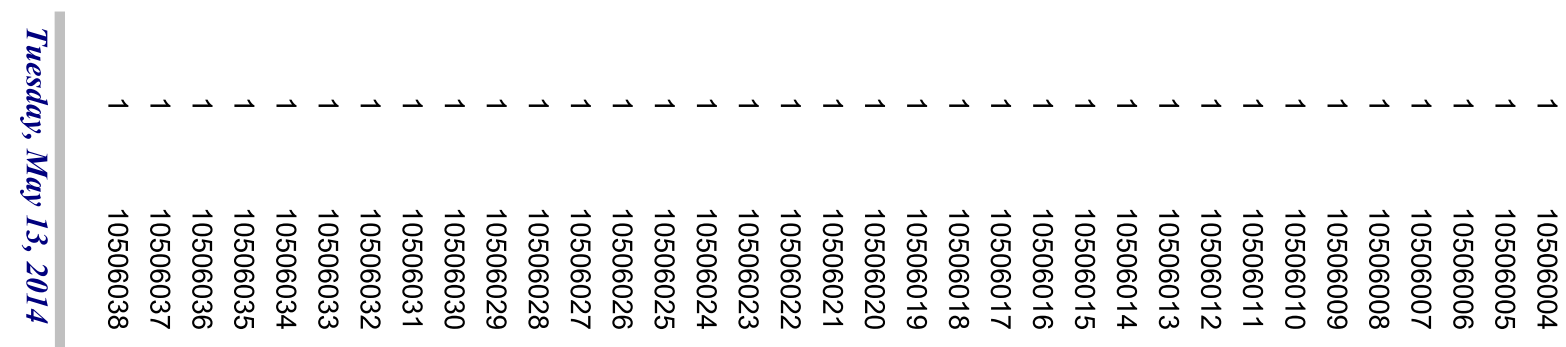

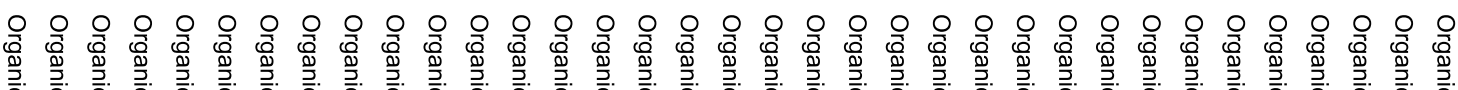

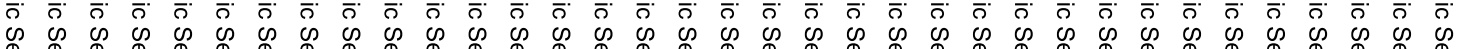

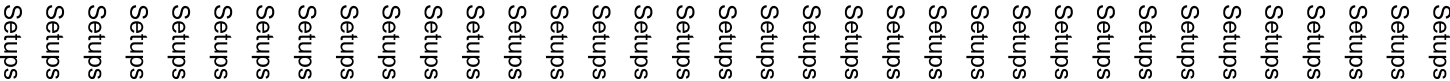

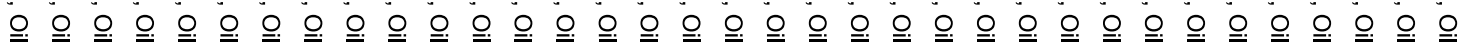

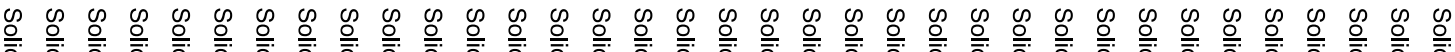

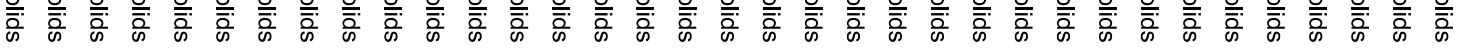

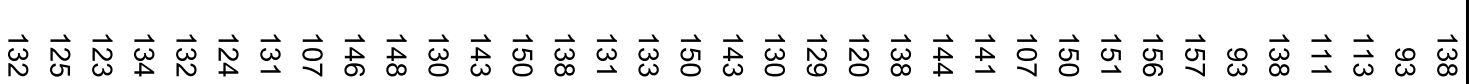




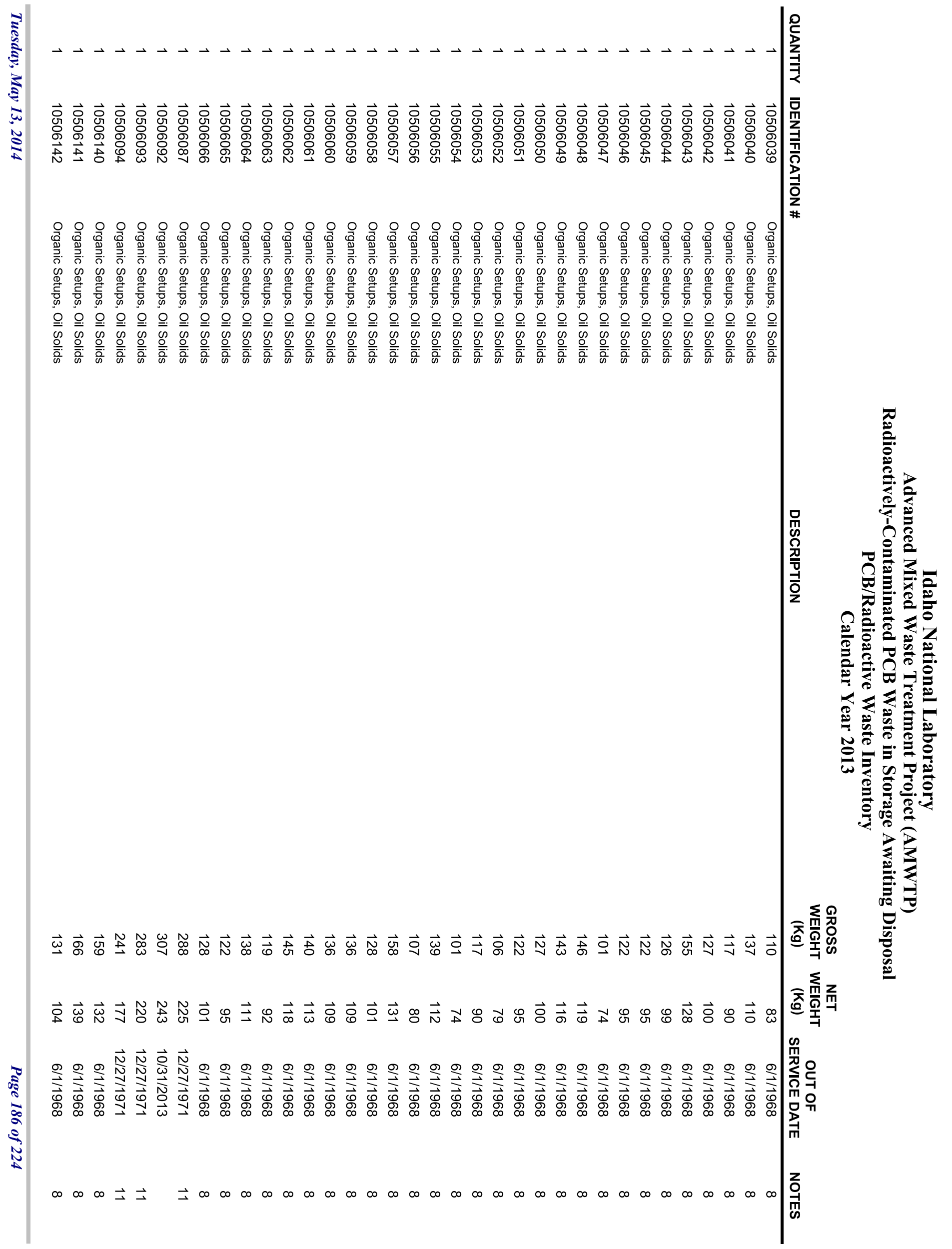




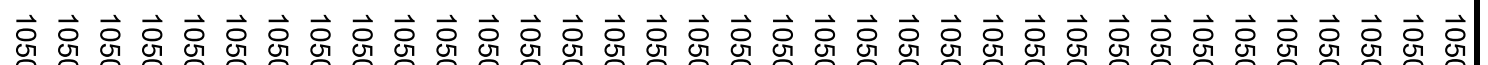

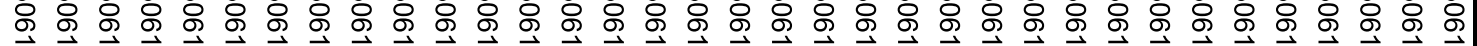

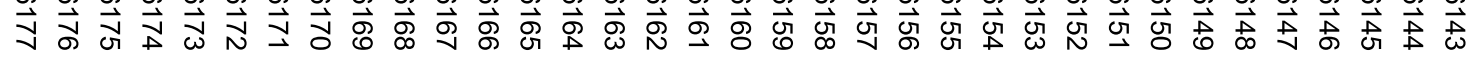

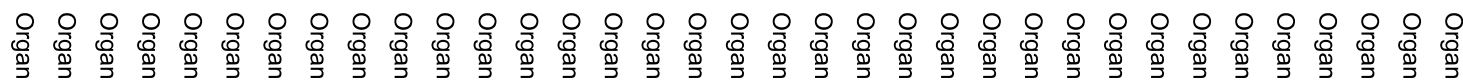

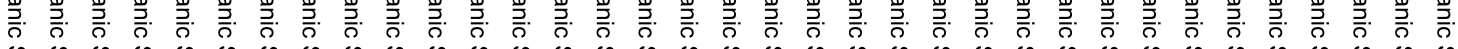

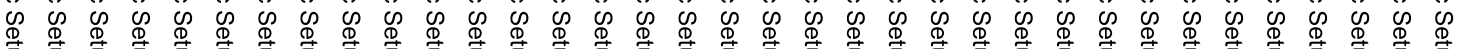

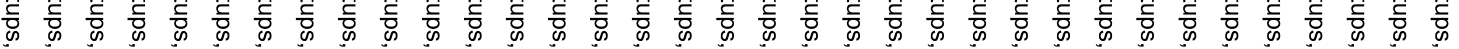

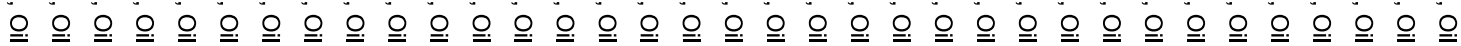

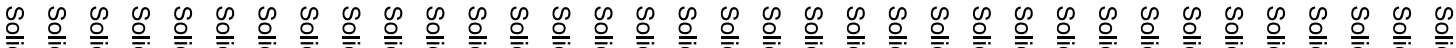

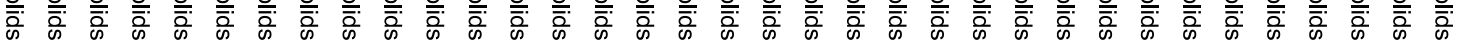

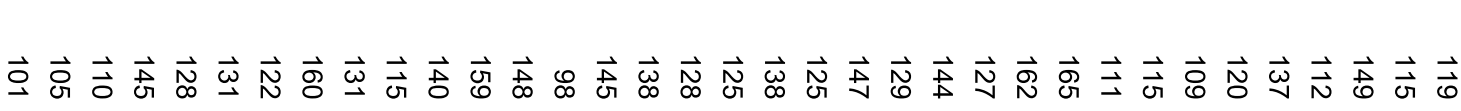

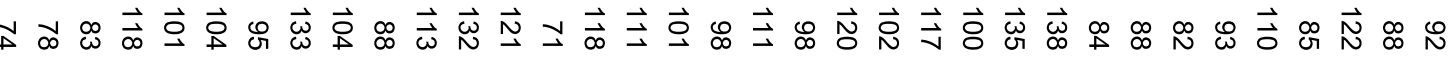
交兴

7
0
0
0
0
0

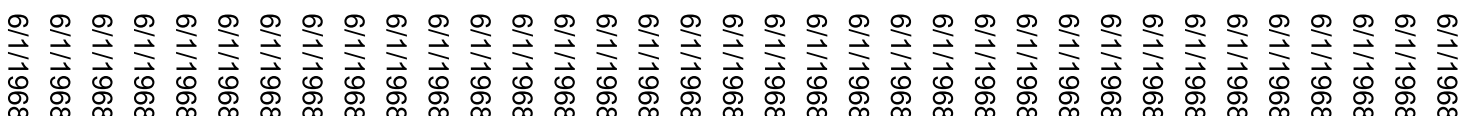




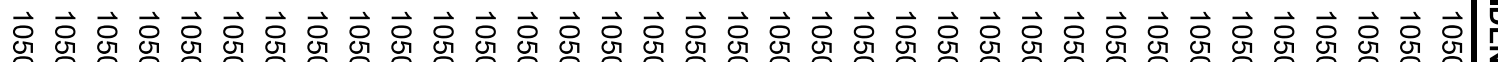

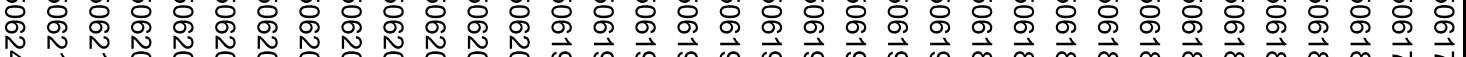

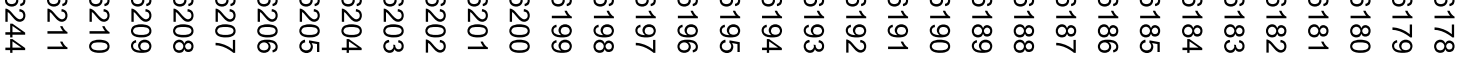

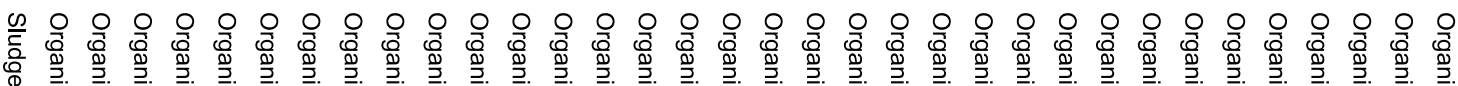

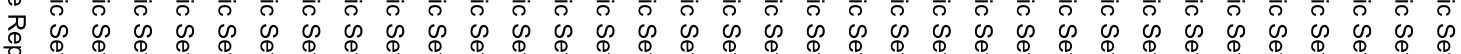

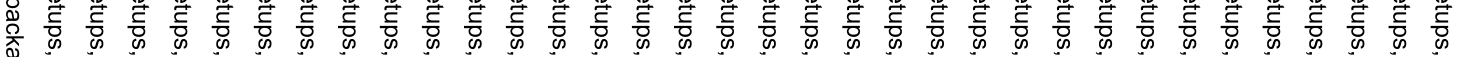

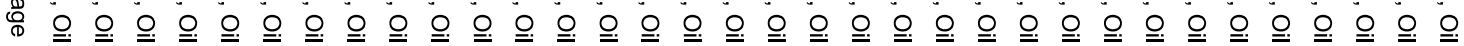

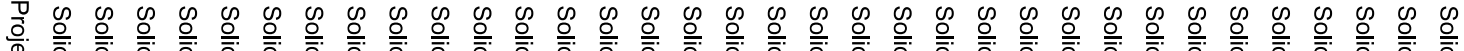

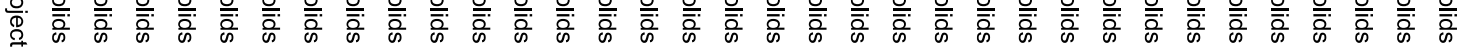
กัญ

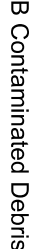

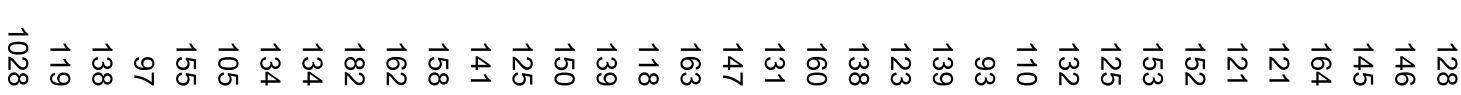

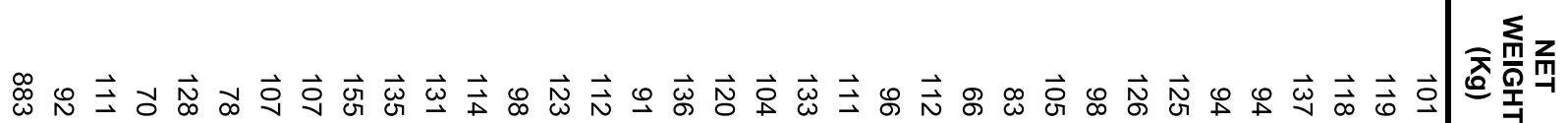




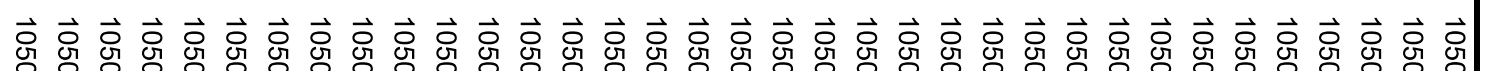

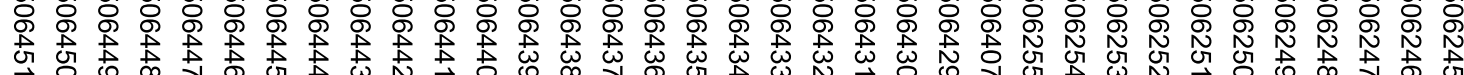

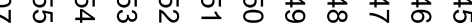

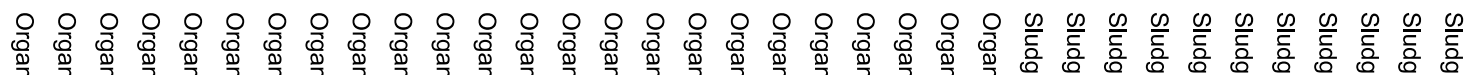

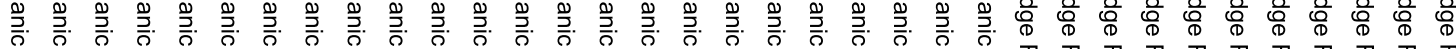

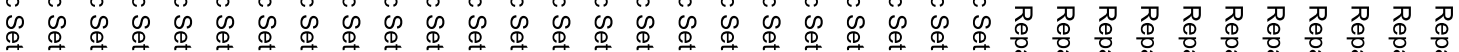

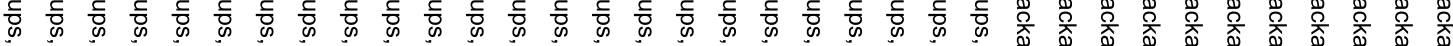

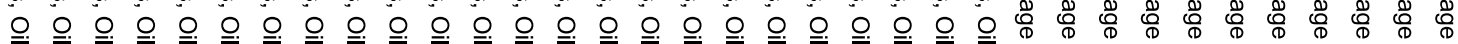
œ

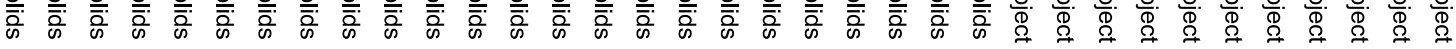

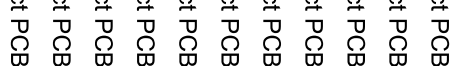

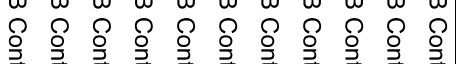

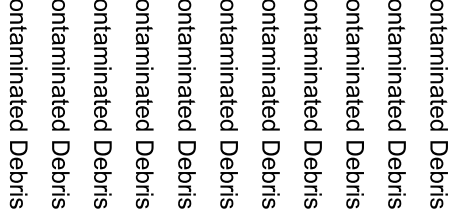

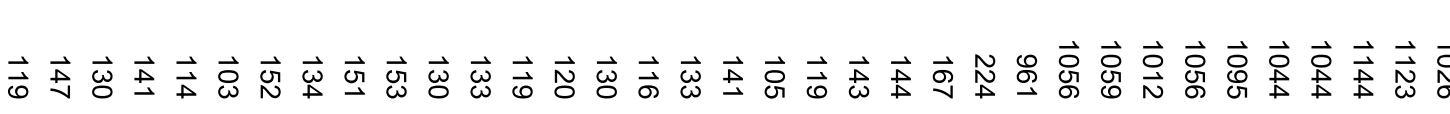

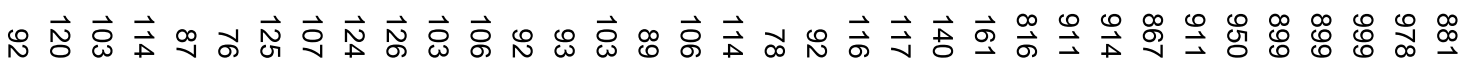
亩兴

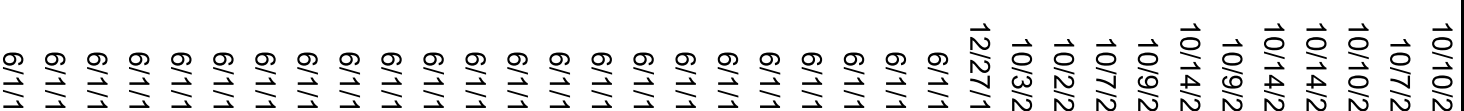

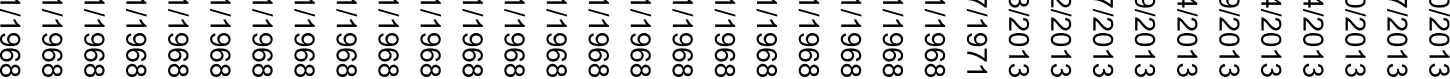

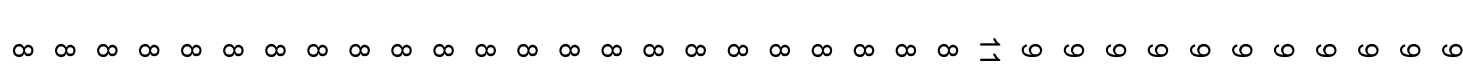




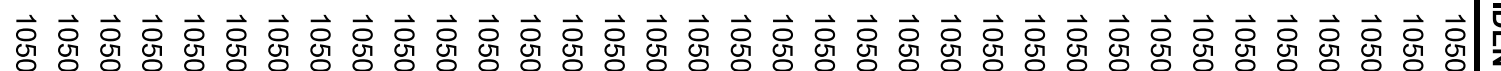

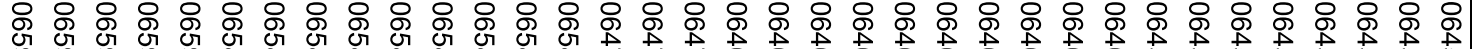

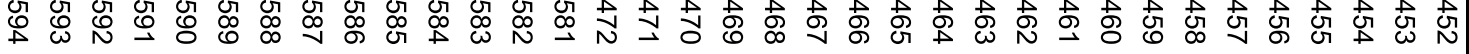

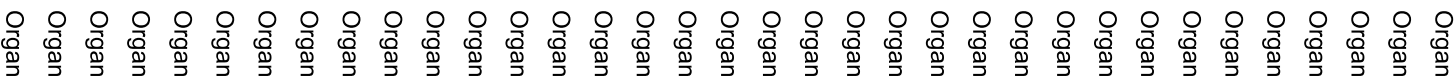

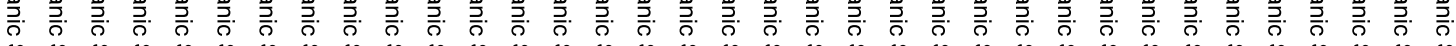

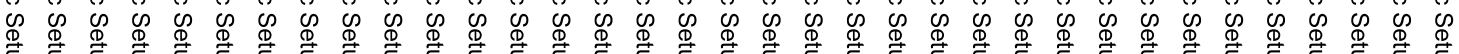
密

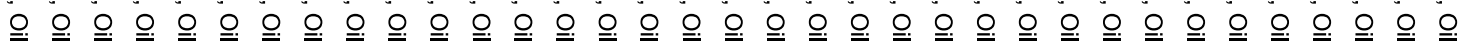

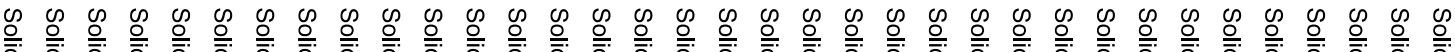

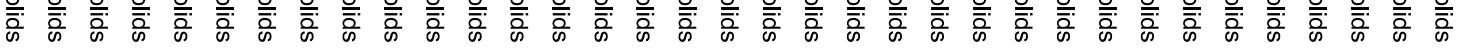

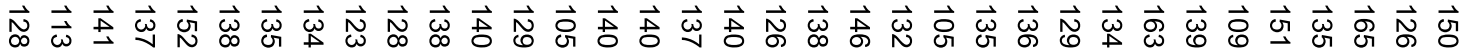




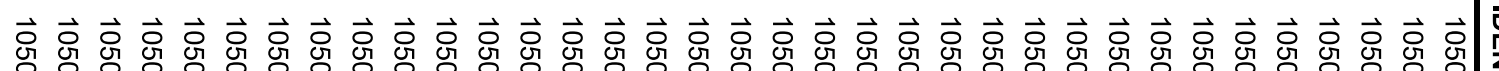
务

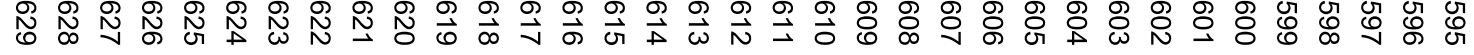

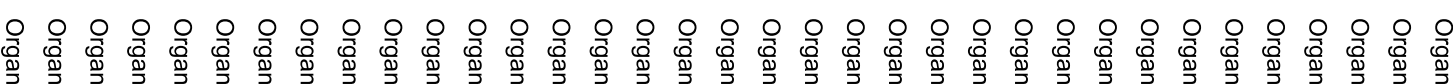

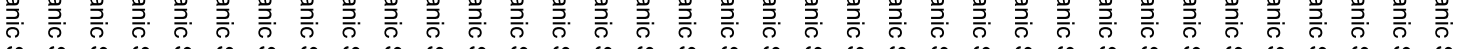

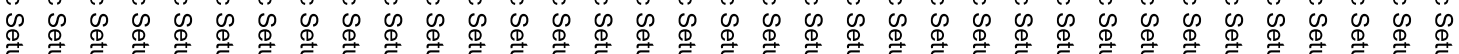
密

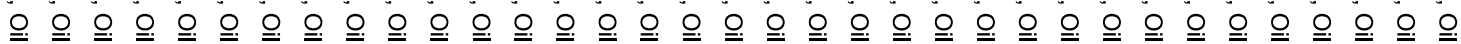

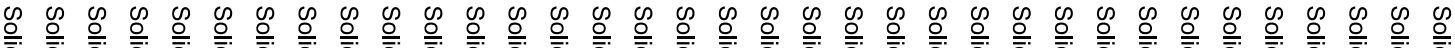

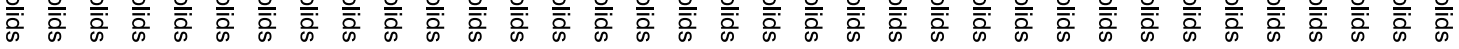

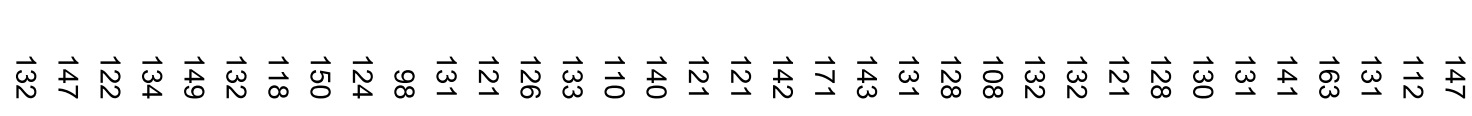




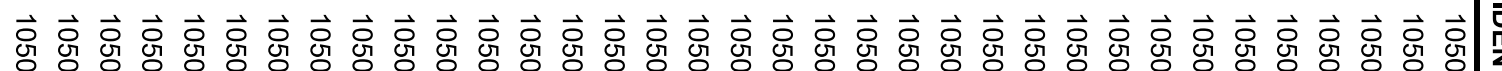

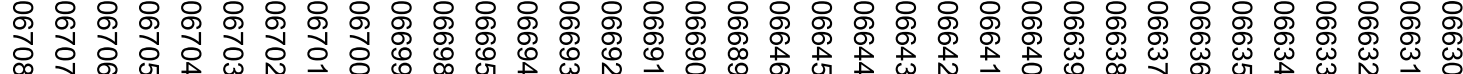

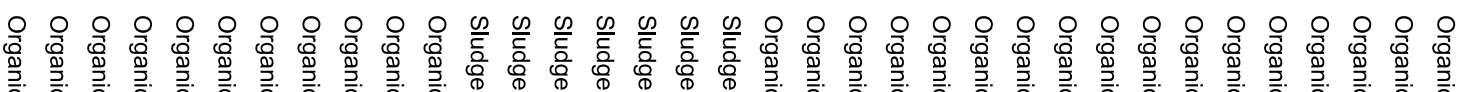

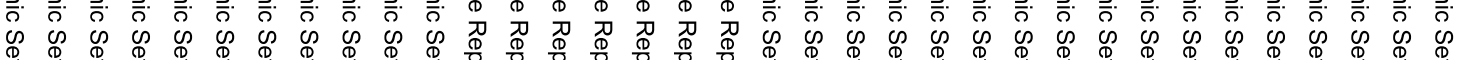

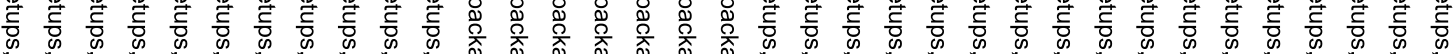

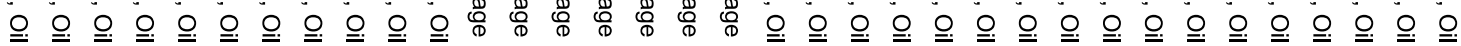

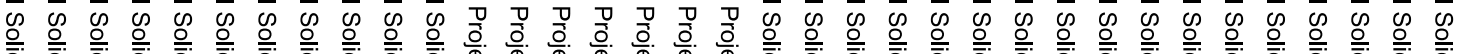

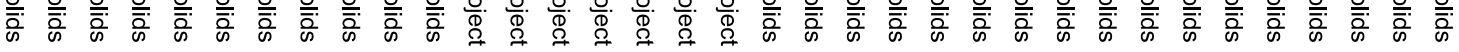
苛苛苛

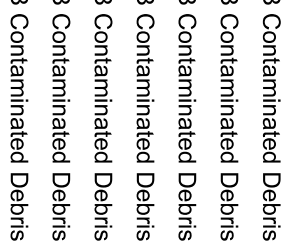

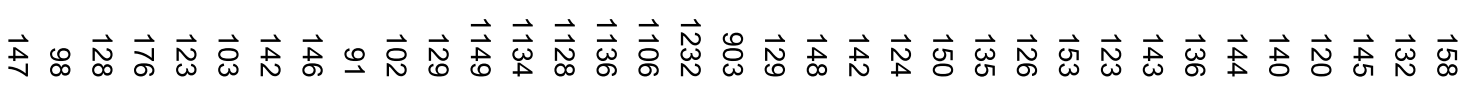

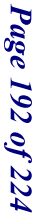

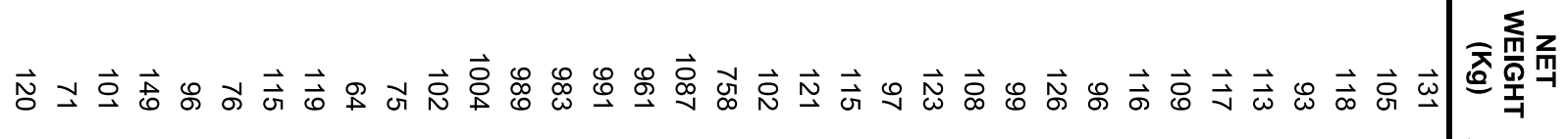

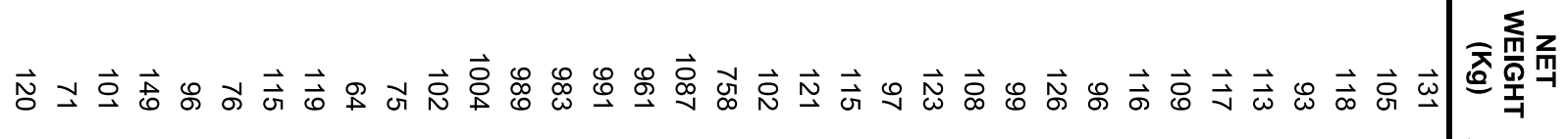

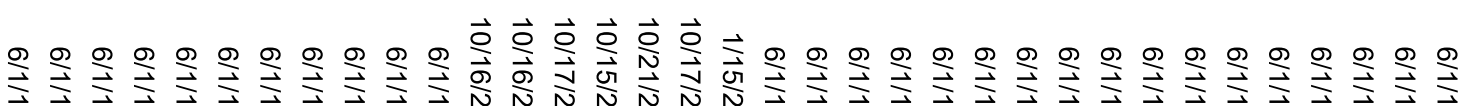
篮

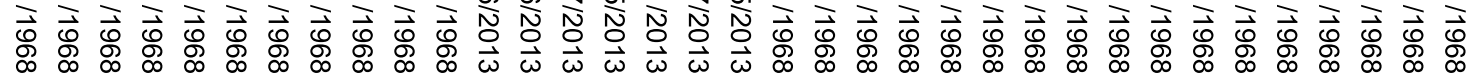




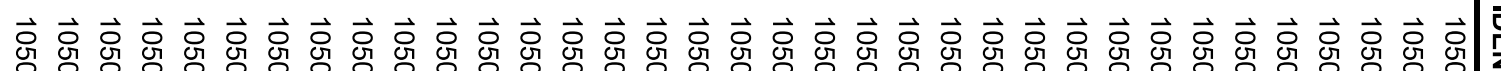
০০

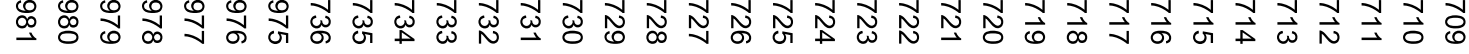

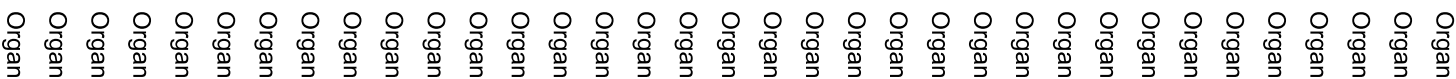

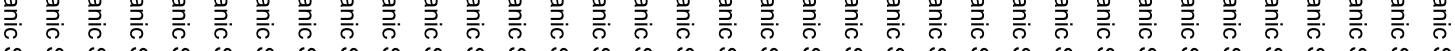

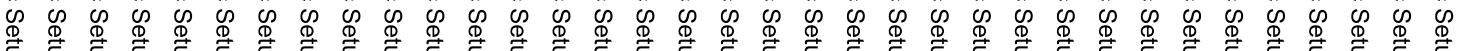

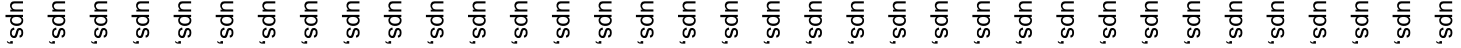

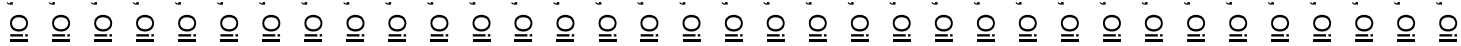

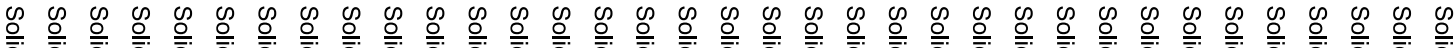

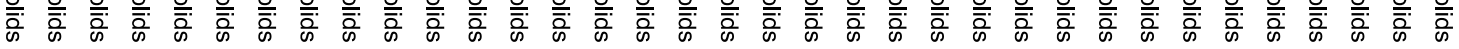

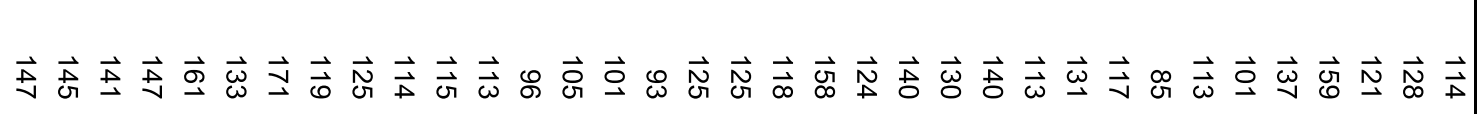

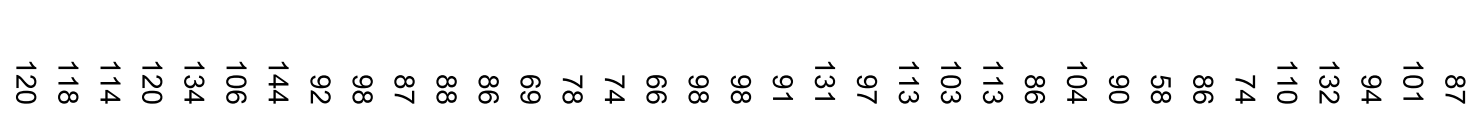
交而

$\Omega$ 늘 


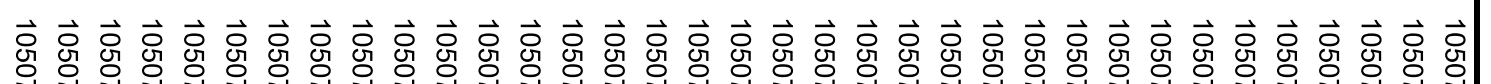

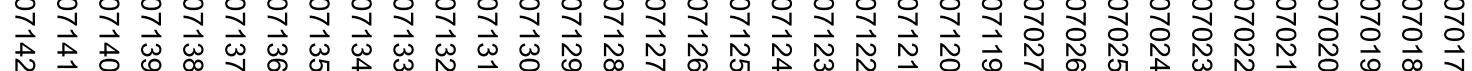

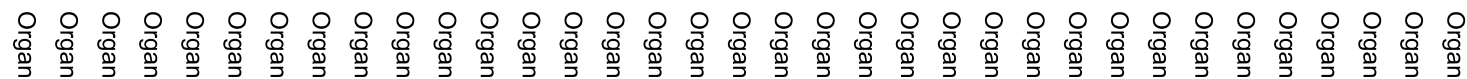

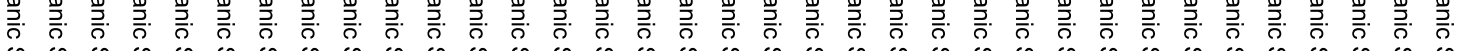

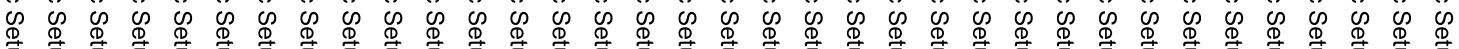

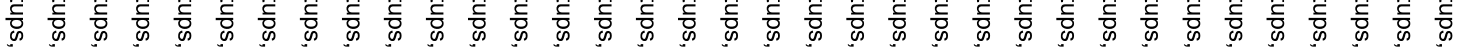

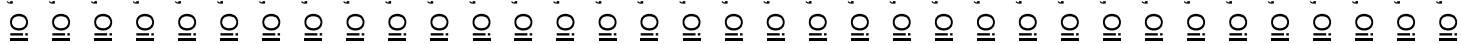

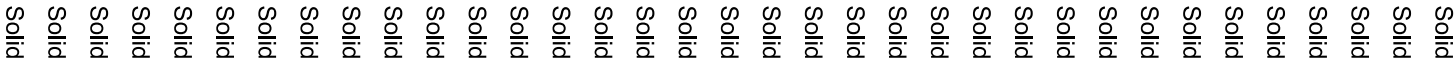

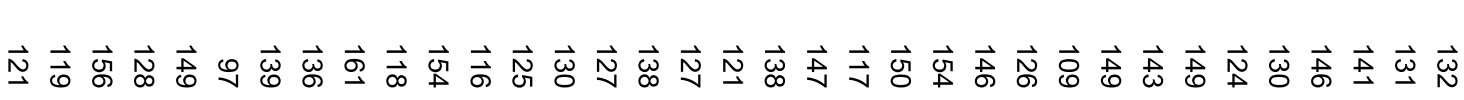




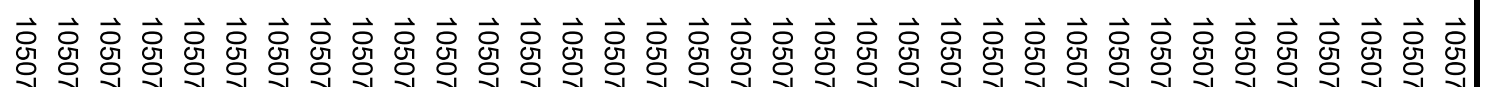

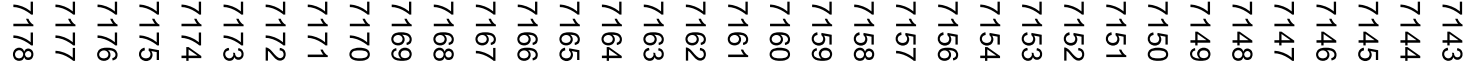

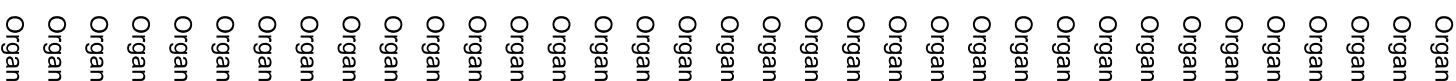

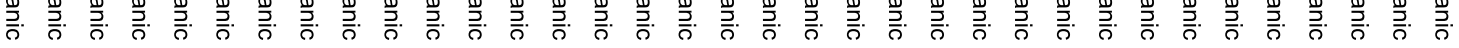

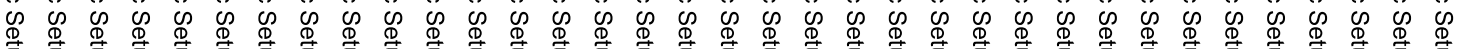

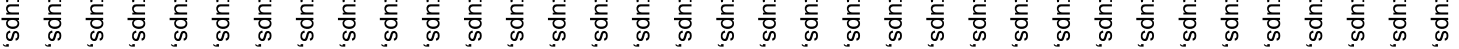

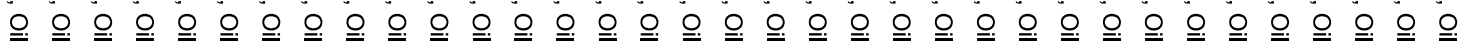

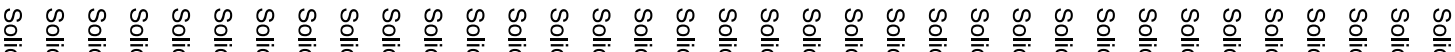

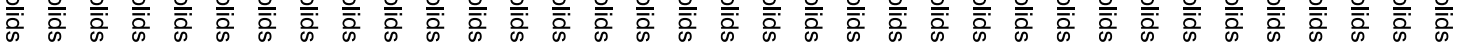

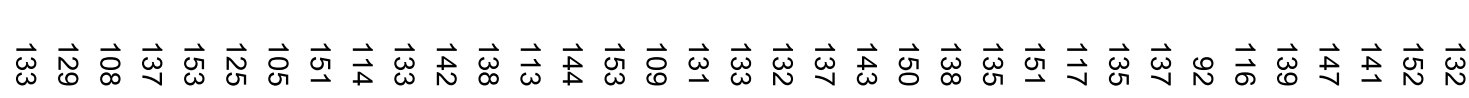




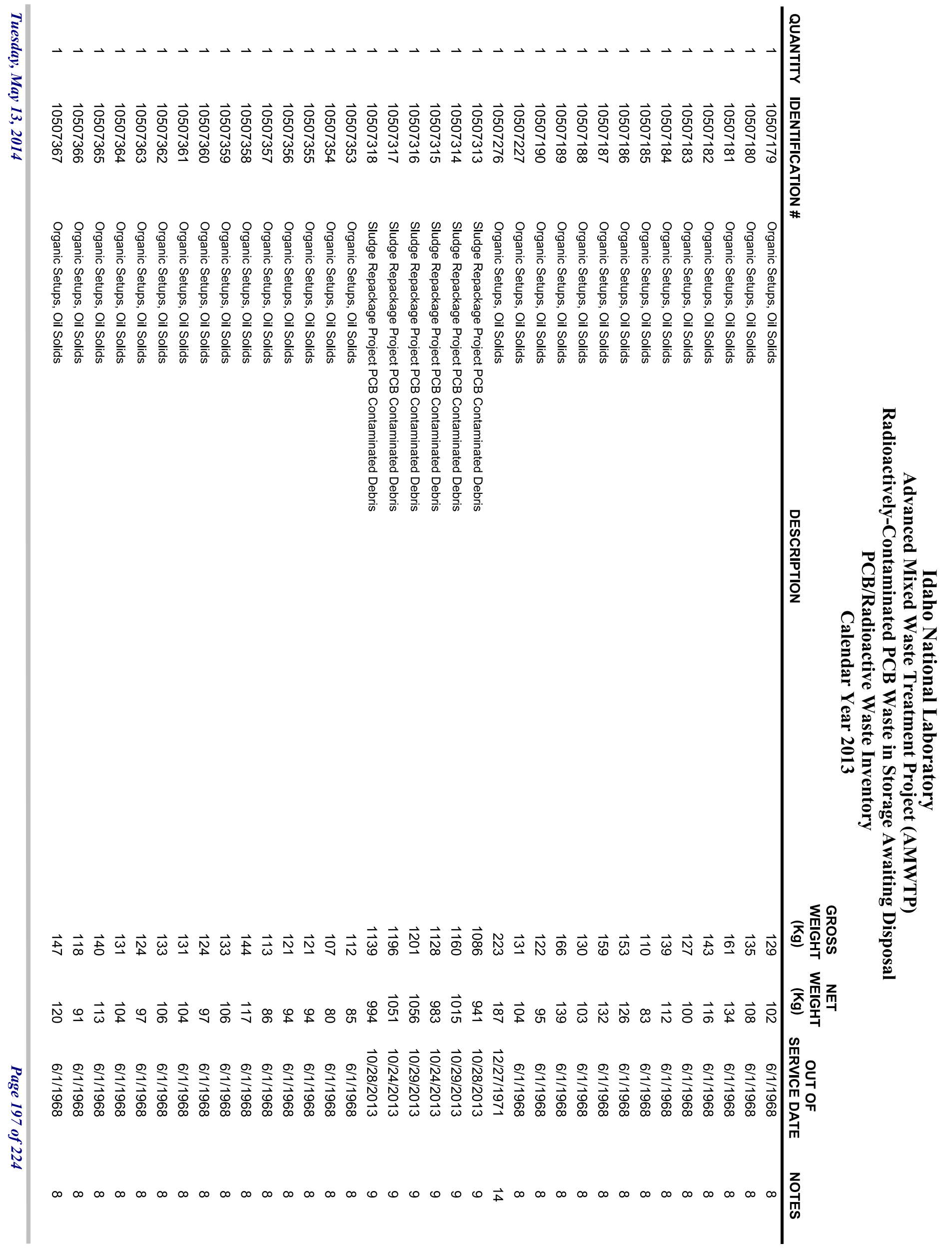




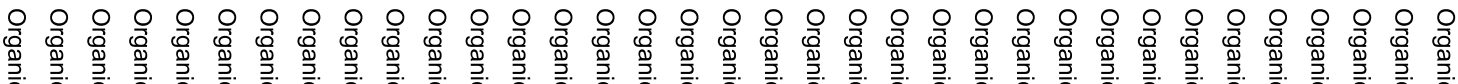

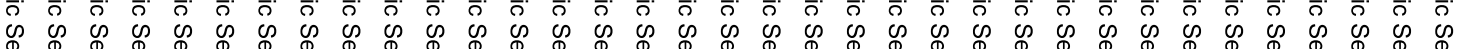

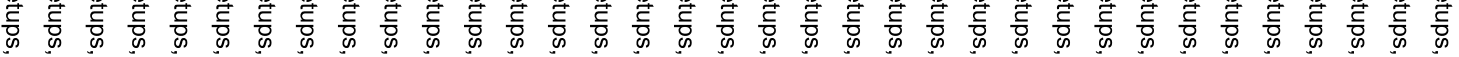

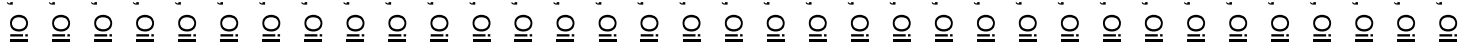

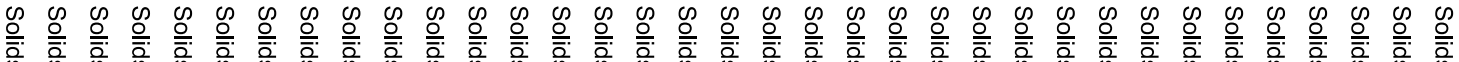

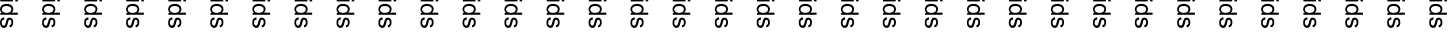

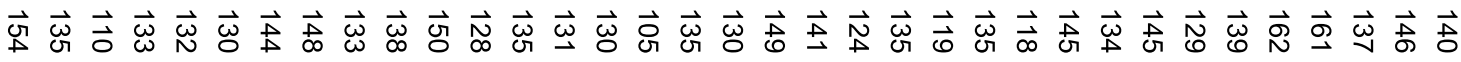


융 융 융 융 융 융 융 융 융 융 융 융 융 융 융 융 융 융 융 융 융 융 융 융 융 융 융 융 융 융 융 융 융 융 잉

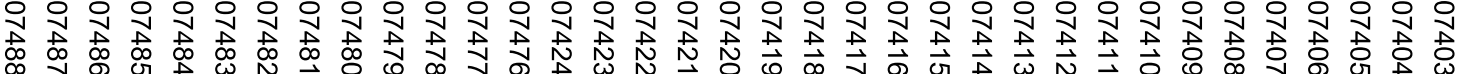

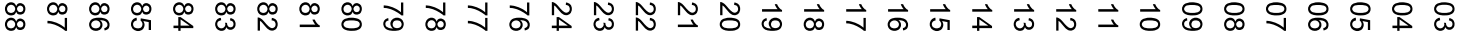

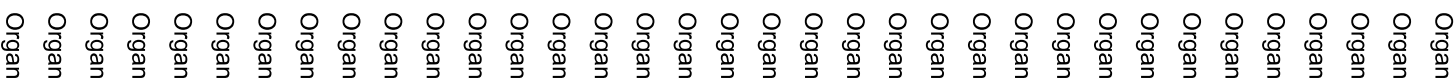

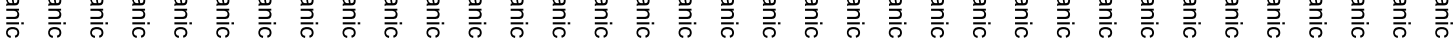

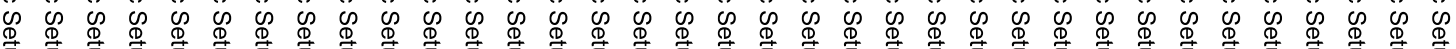

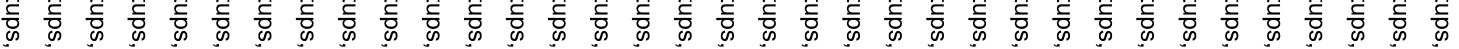

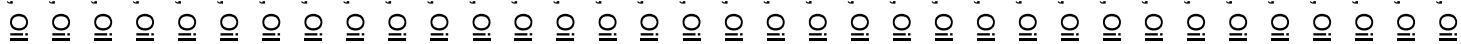

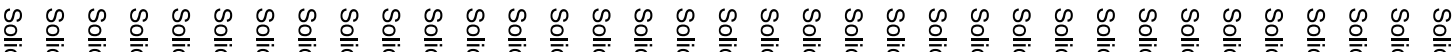

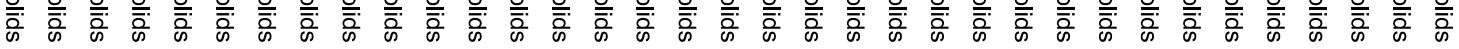

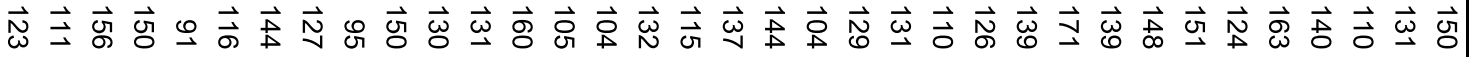




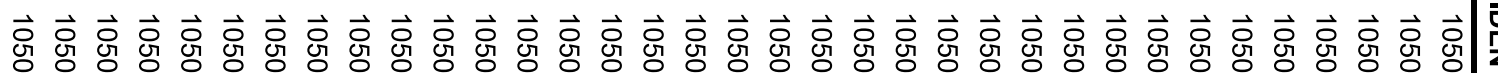

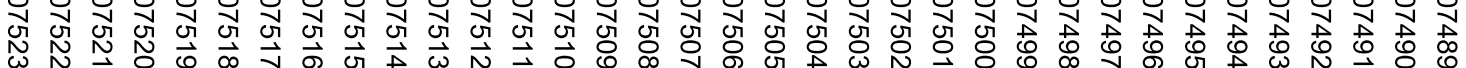

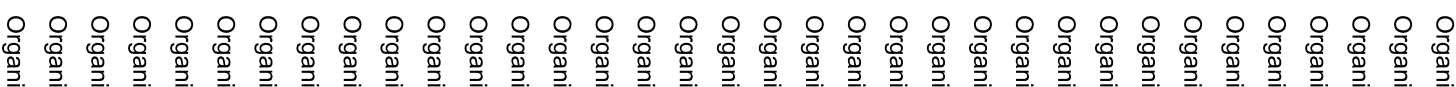

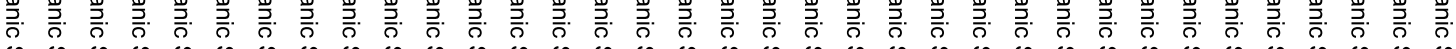

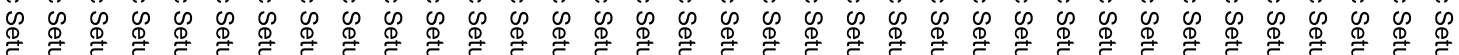

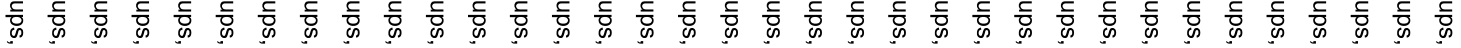

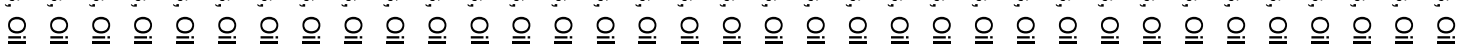

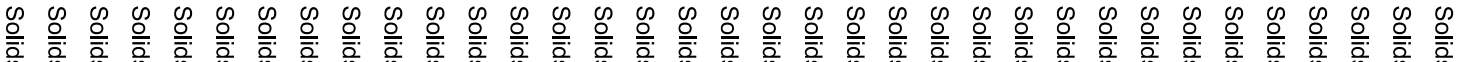

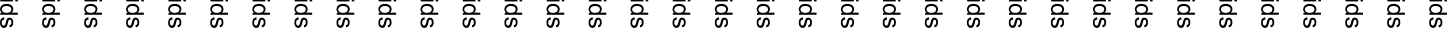

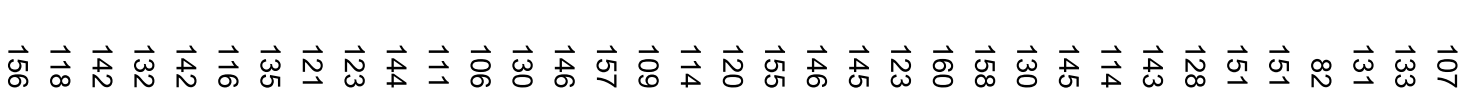


융 융 융 융 융 융 융 융 융 융 융 융 융 융 융 융 융 융 융 융 융 융 융 융 융 융 융 융 융 융 융 융 융 융 잉

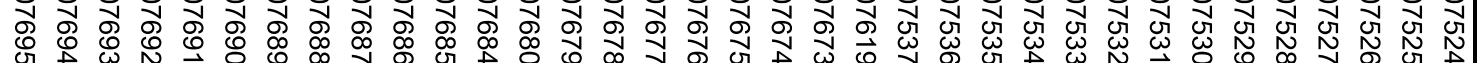
A

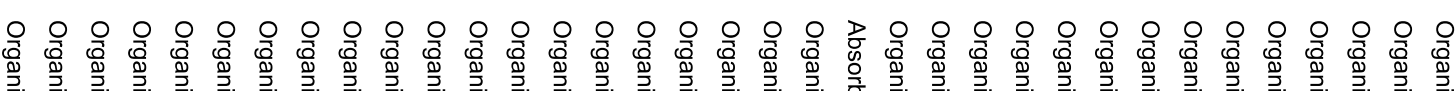

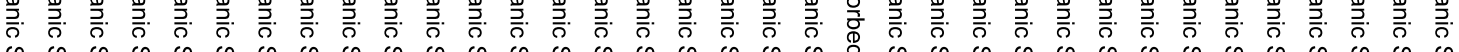

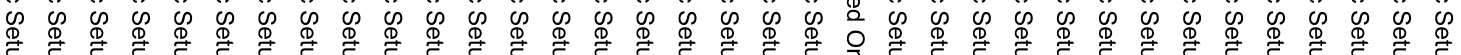

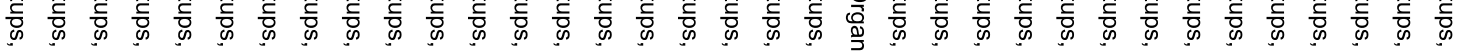

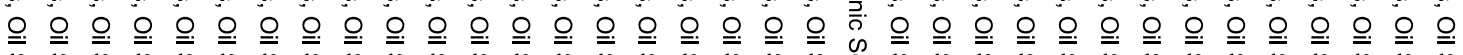

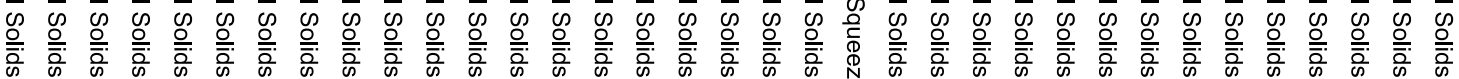

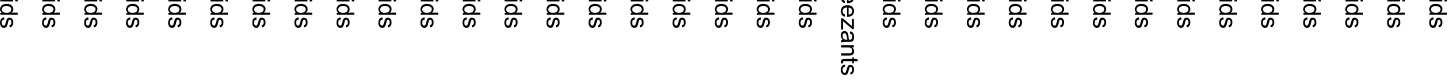

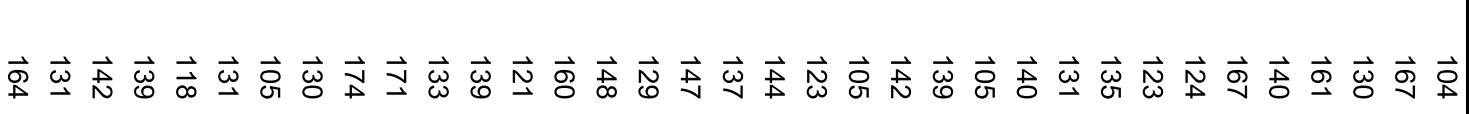




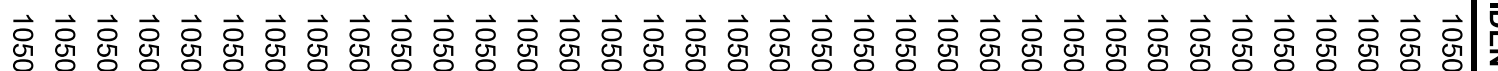

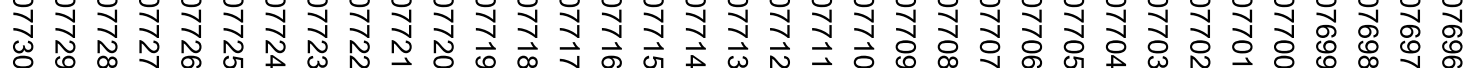

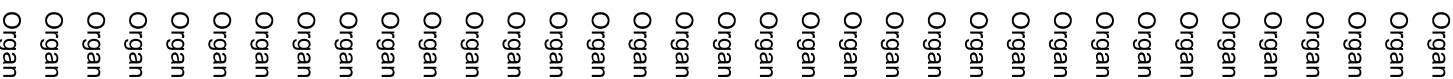

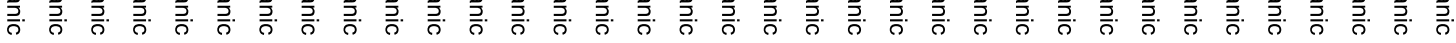

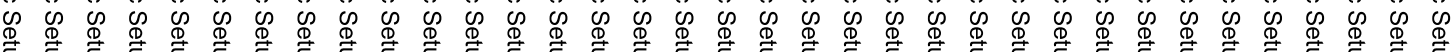
骔

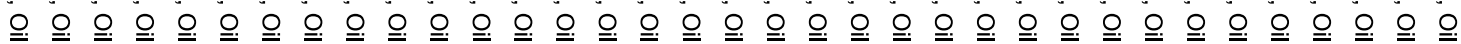

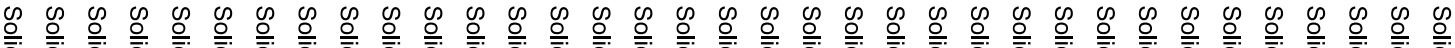

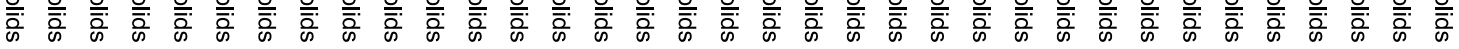

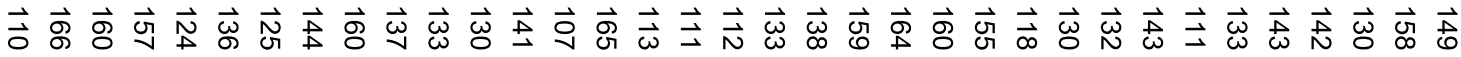

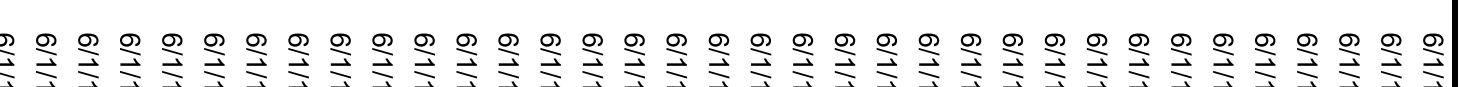

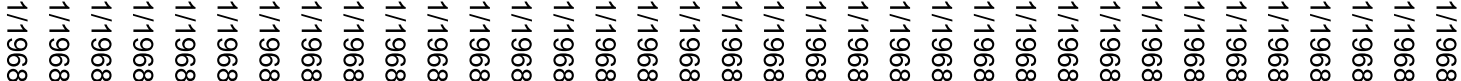




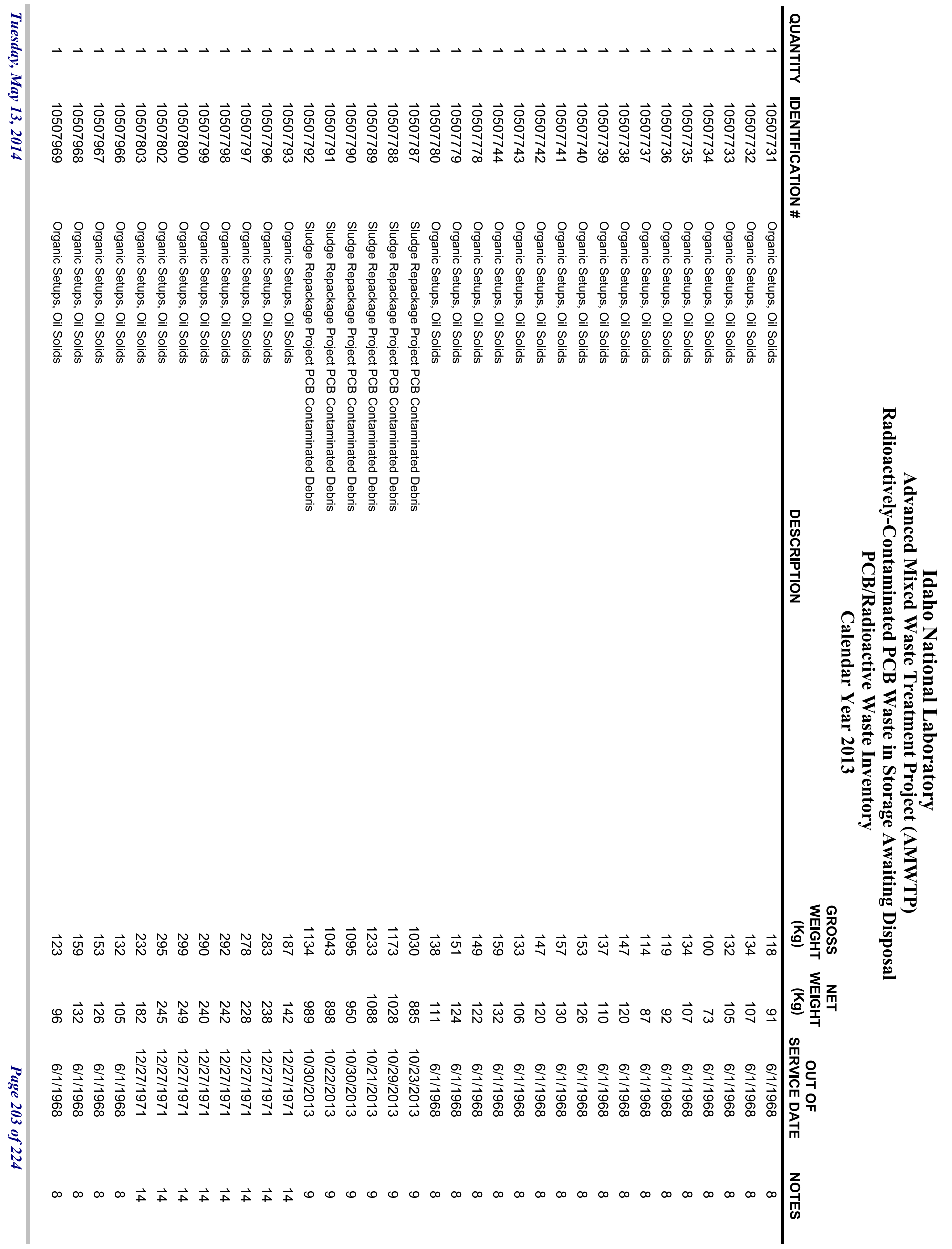




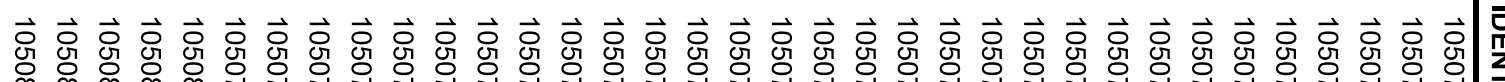

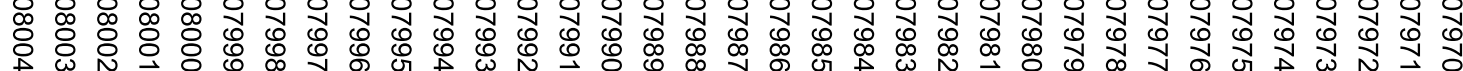

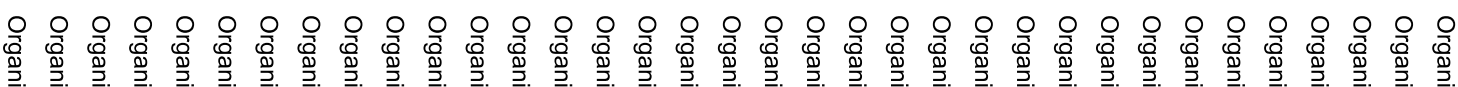

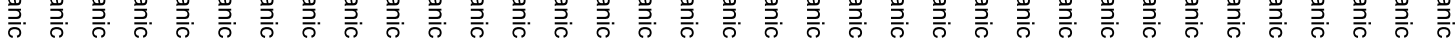

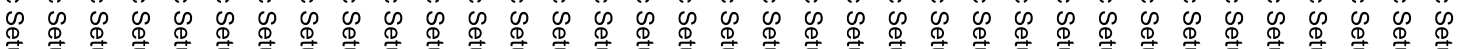

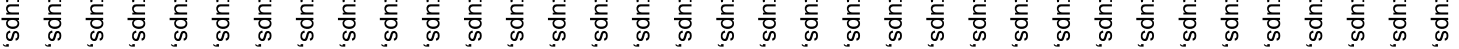

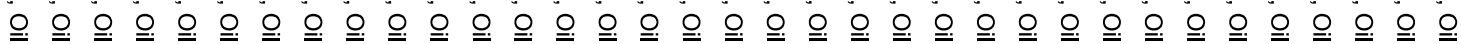

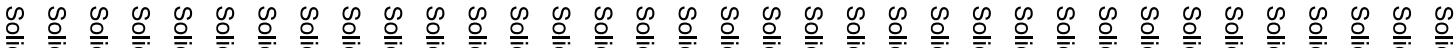

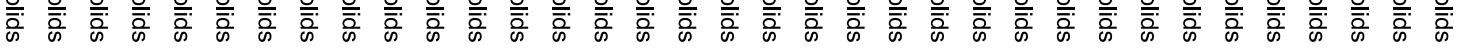

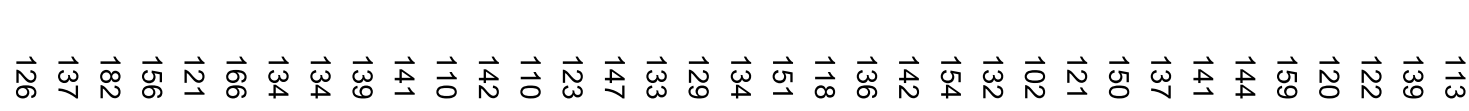




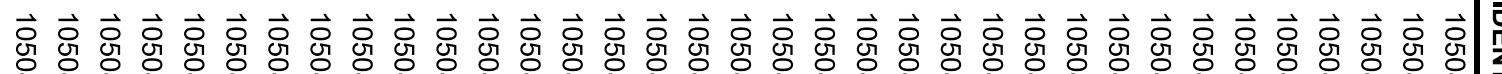
$\infty$

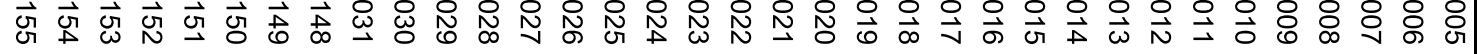

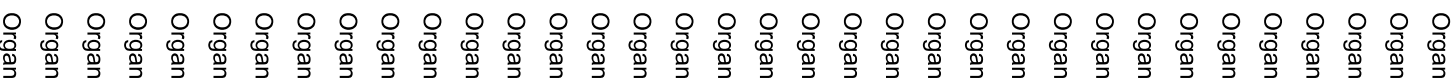

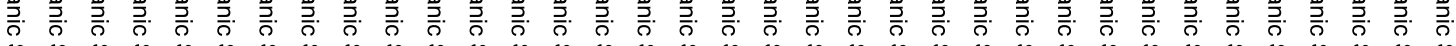
$\mathbb{W}$ W

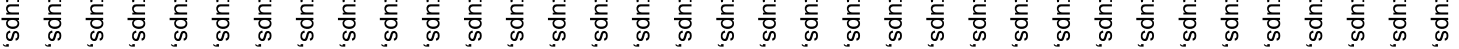

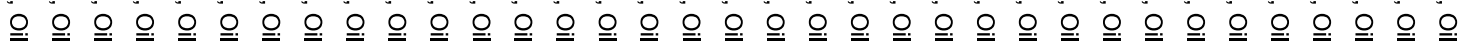

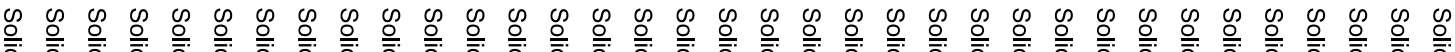

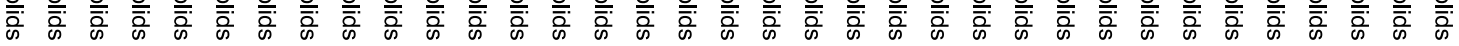

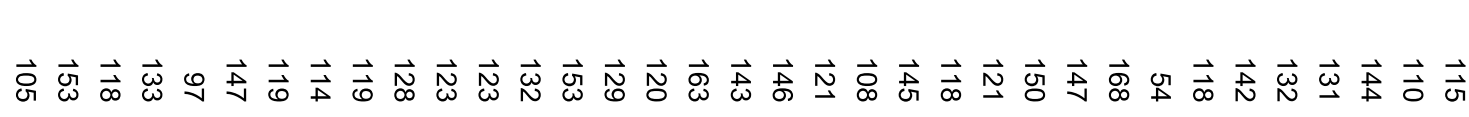

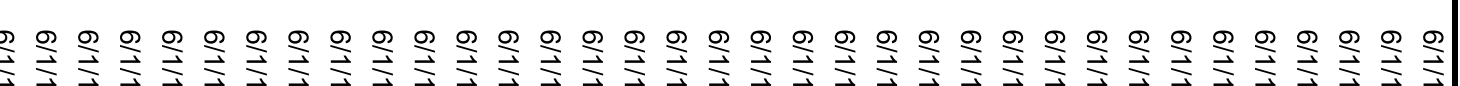

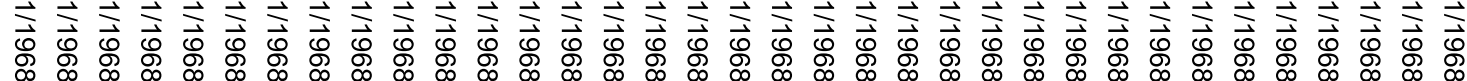




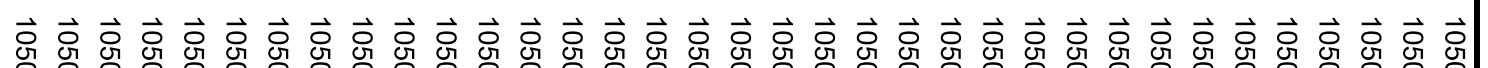
品

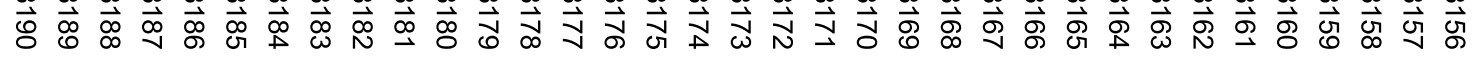

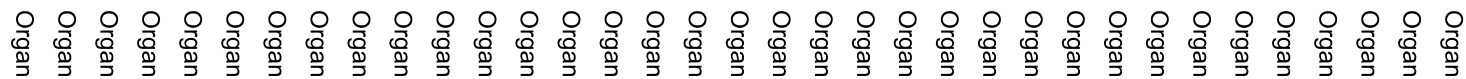

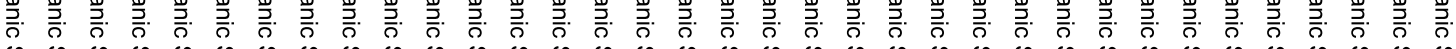

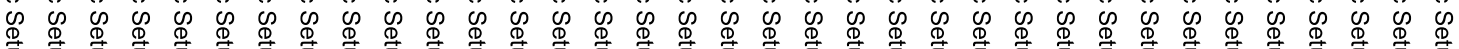

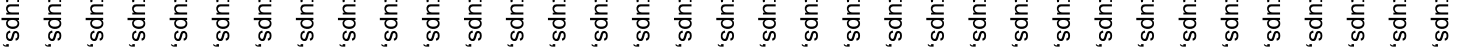

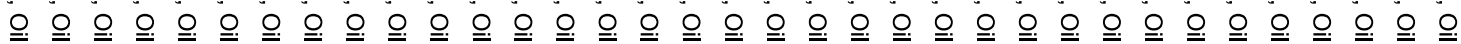

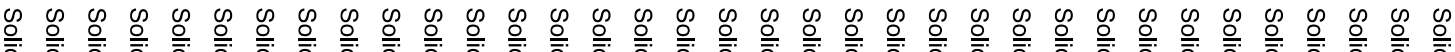

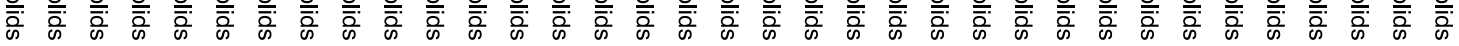

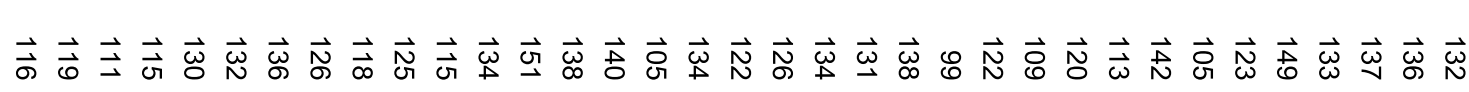

Q

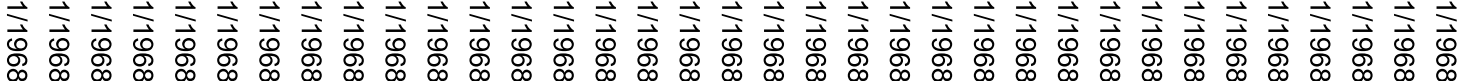




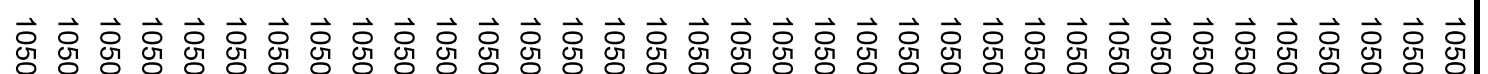

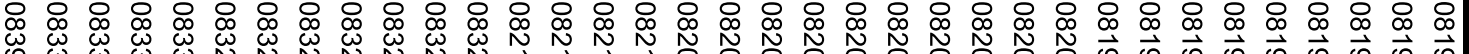

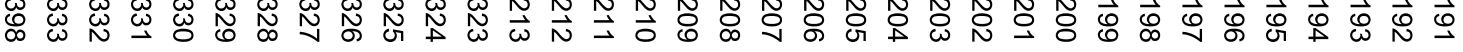

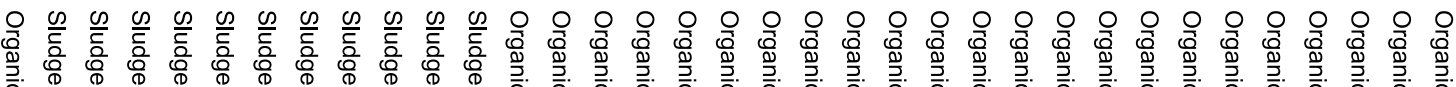
人. W

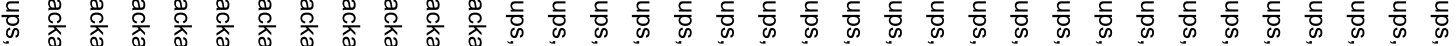
유

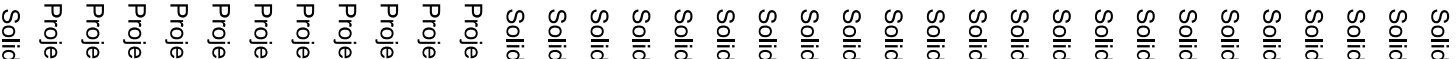

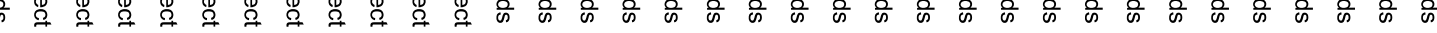

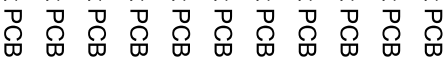

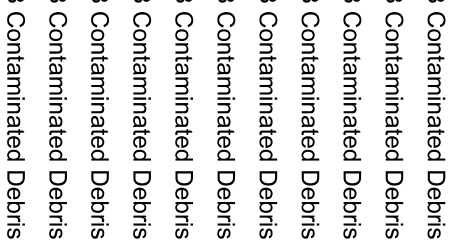

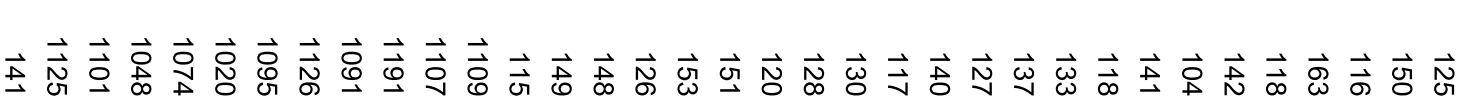


융 융 융 융 융 융 융 융 융 융 융 융 융 융 융 융 융 융 융 융 융 융 융 융 융 융 융 융 융 잉

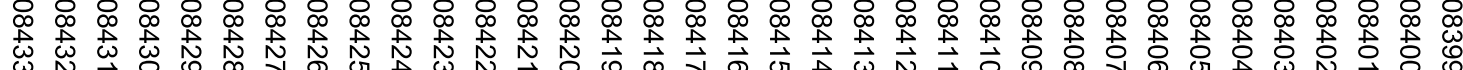

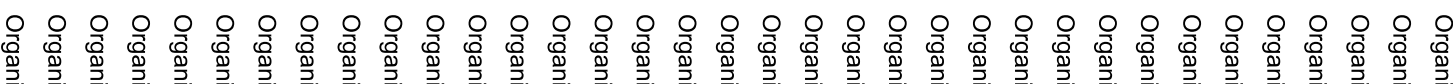

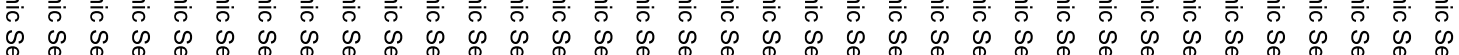

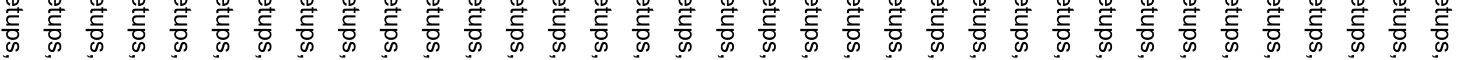

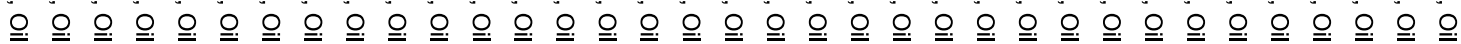

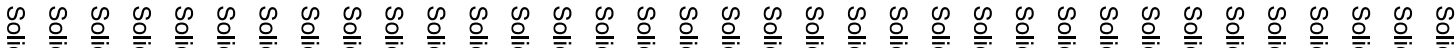

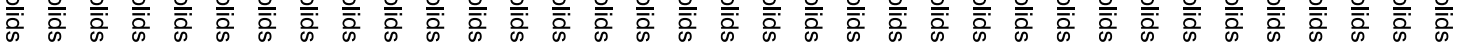

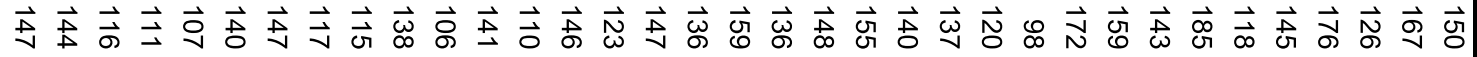

q

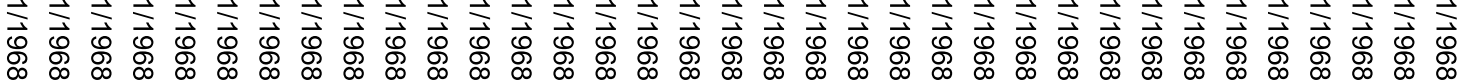


융 융 융 융 융 융 융 융 융 융 융 융 융 융 융 융 융 융 융 융 융 융 융 융 융 융 융 융 융 융 융 융 융 융 잉

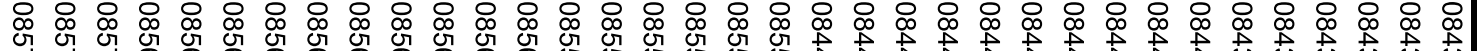
N J J 0 .

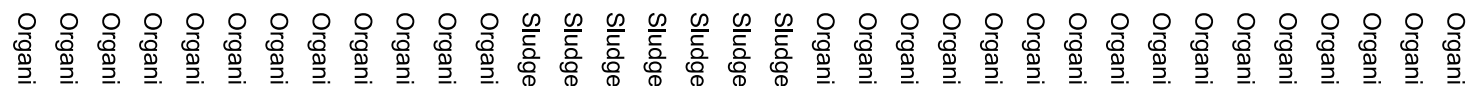

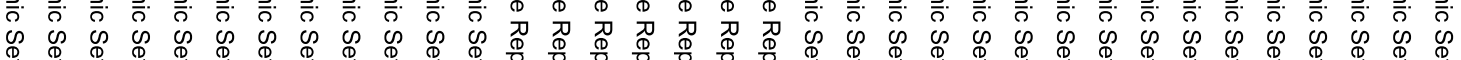

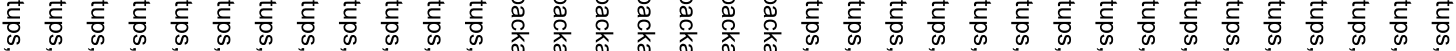

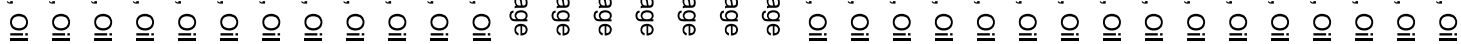

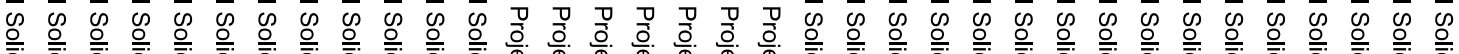

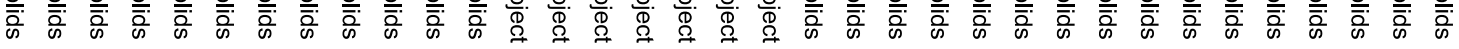

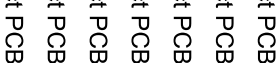

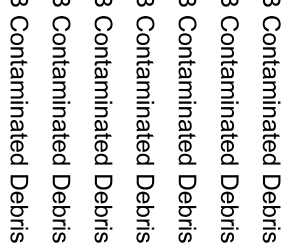

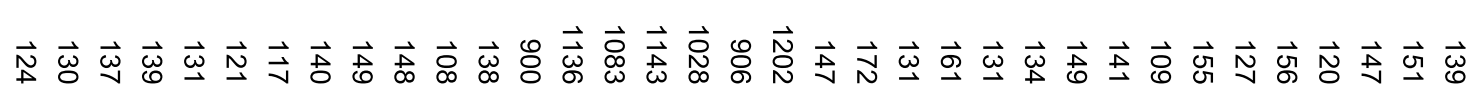

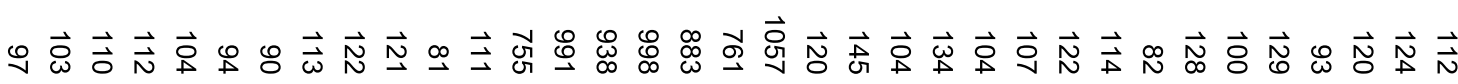
入血而
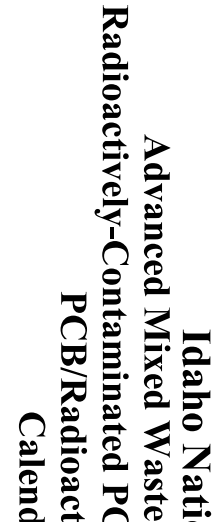

을

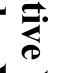

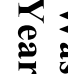

要 를

E.

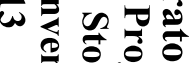




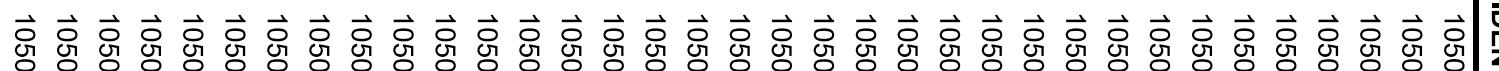
o ○ ᄋ 마

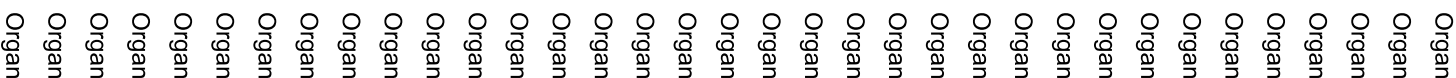

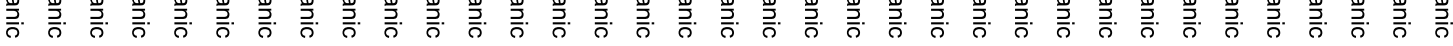

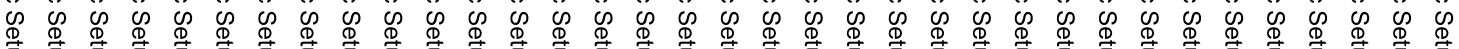
密

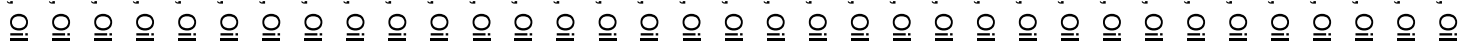

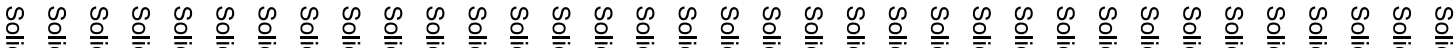

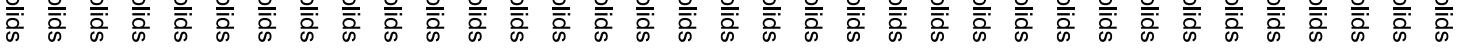

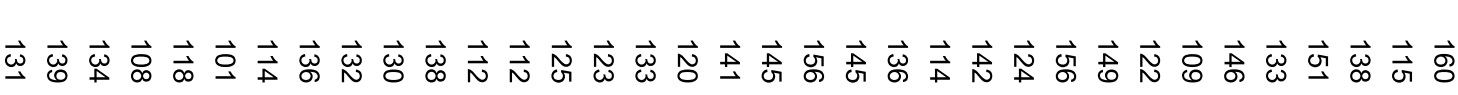

ॠँّ 


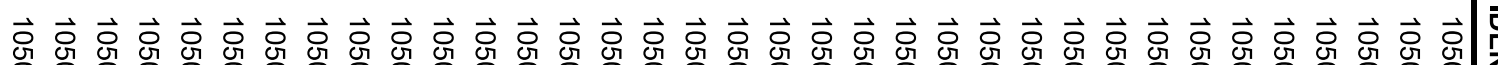
品

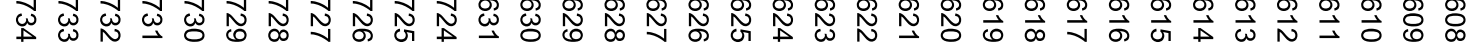

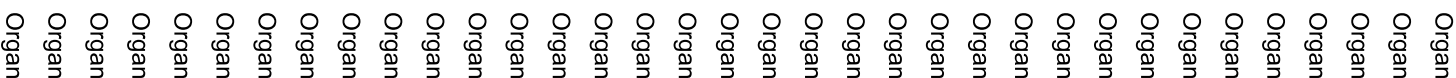

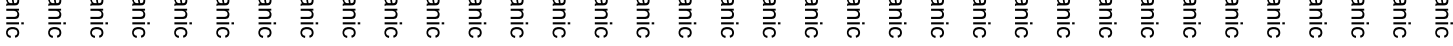

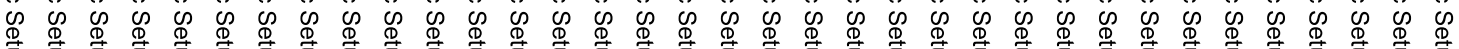
密

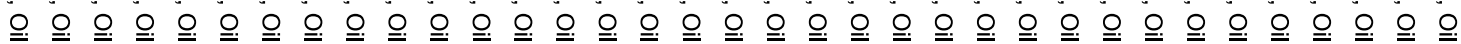

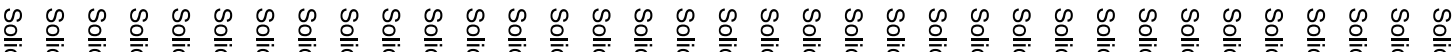

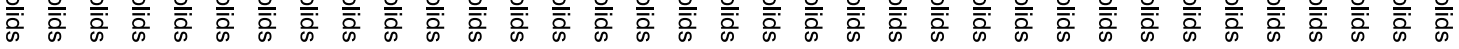

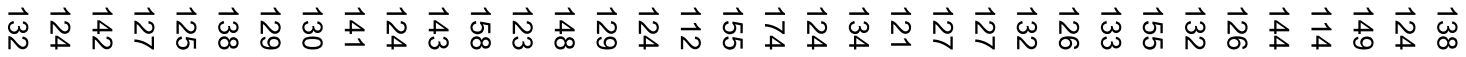

ॠ艹ّ 


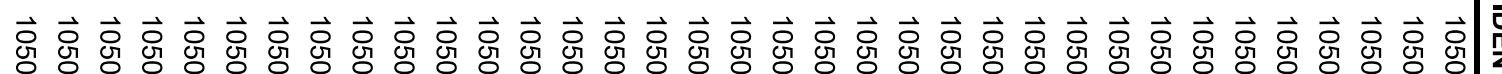

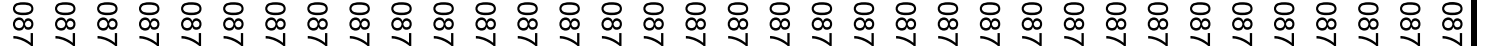

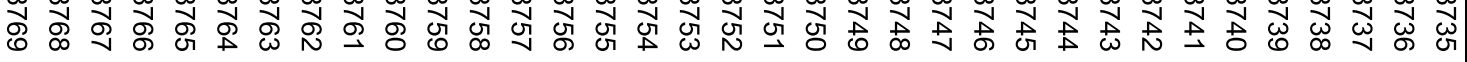

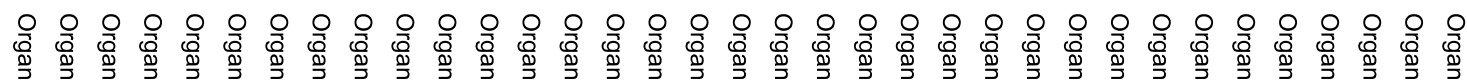

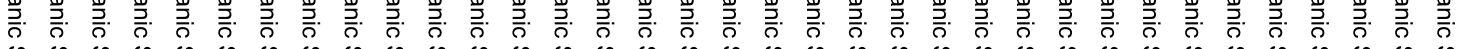

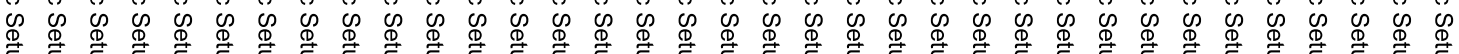
密

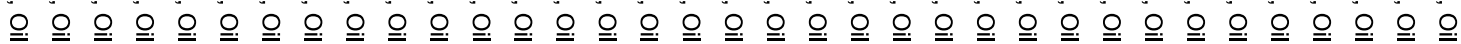

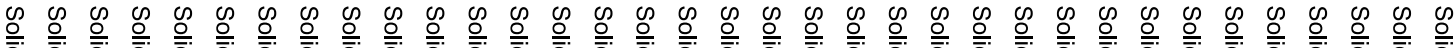

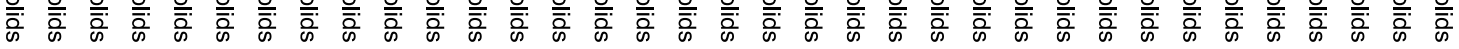

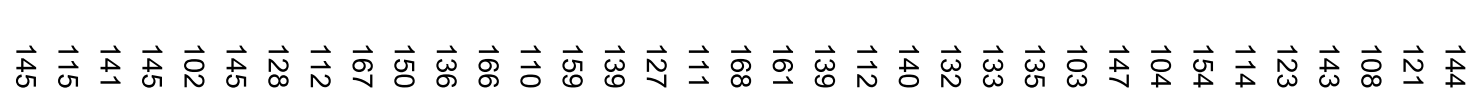




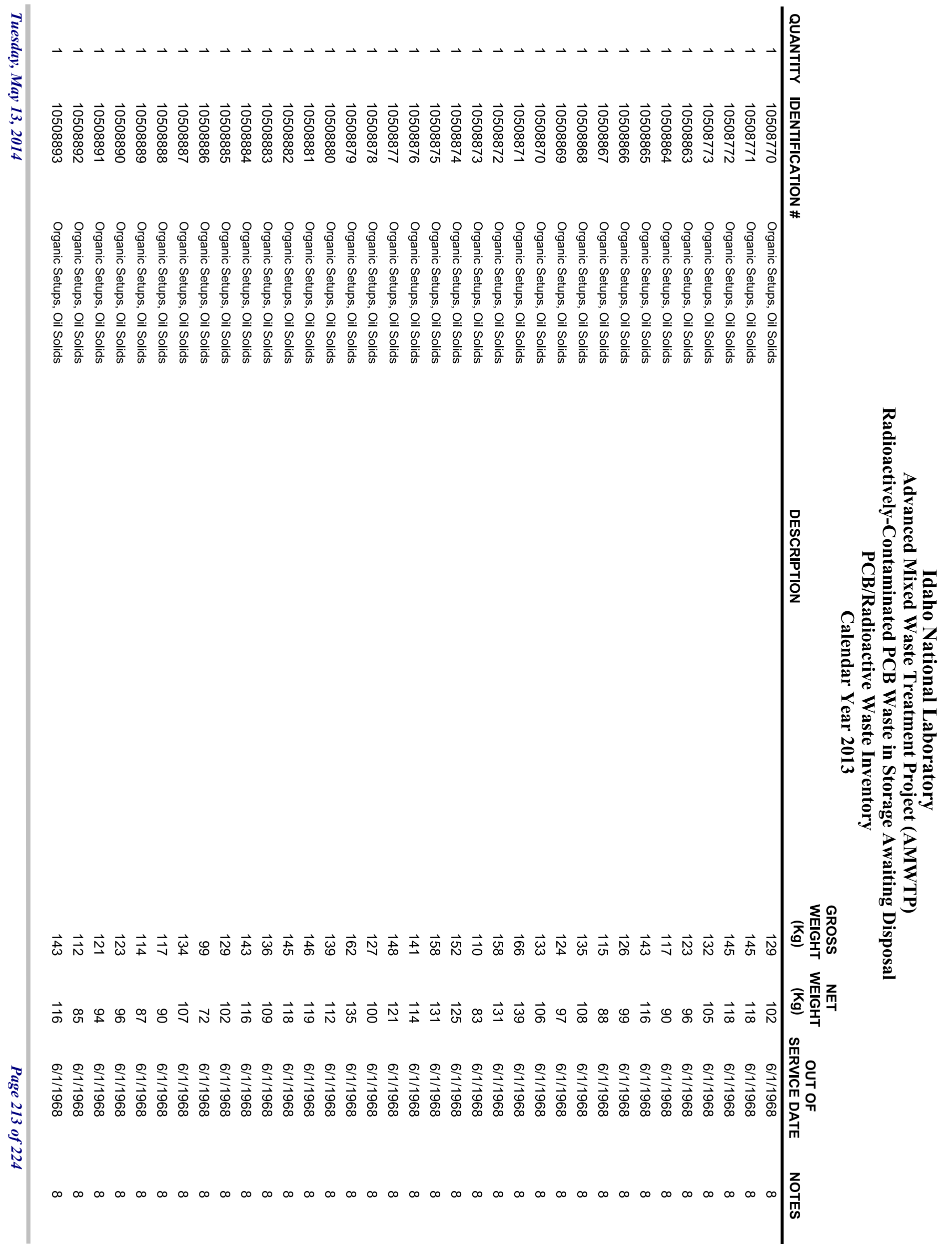




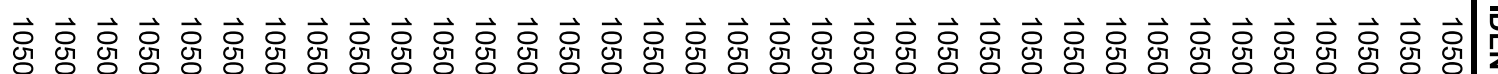

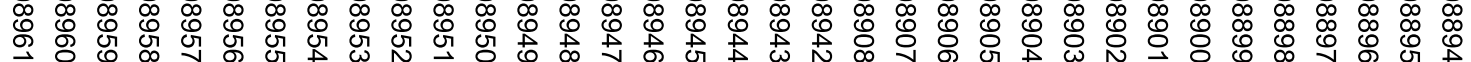

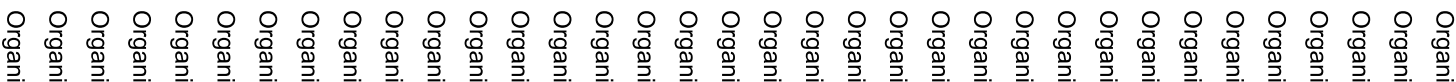

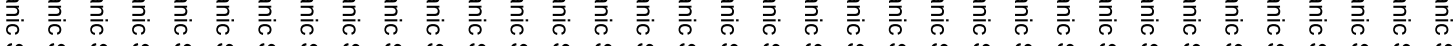

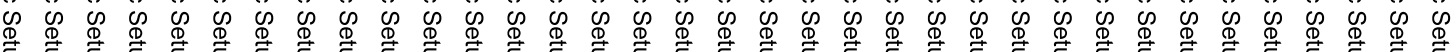
骔

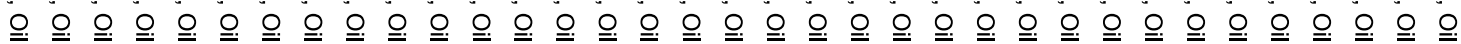

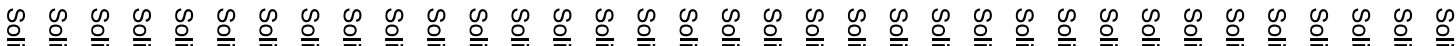

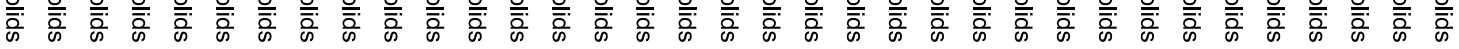

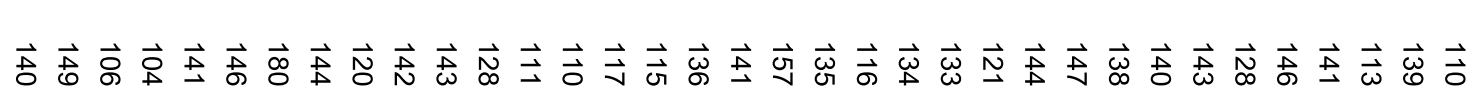




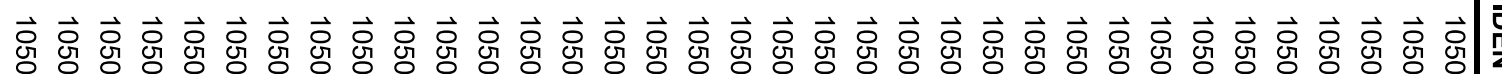
o 0

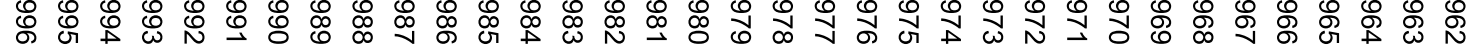

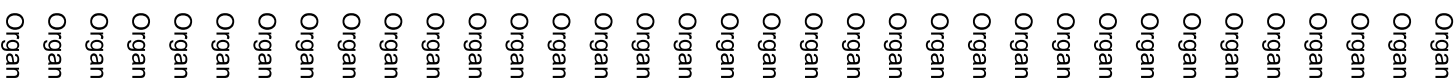

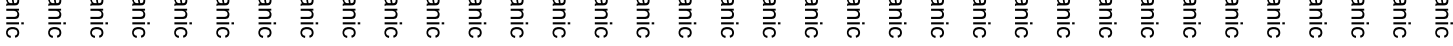

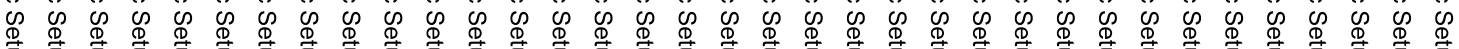
密

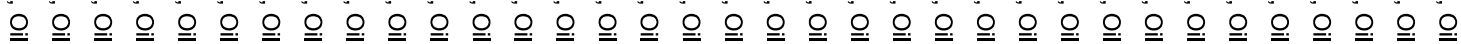

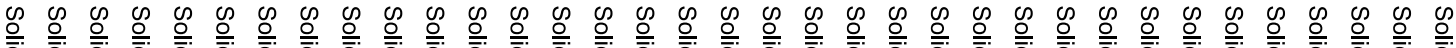

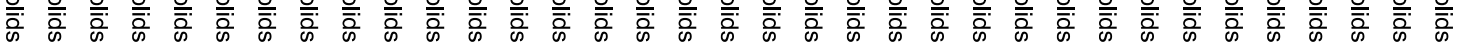

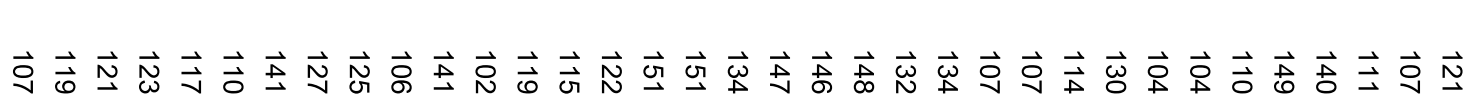

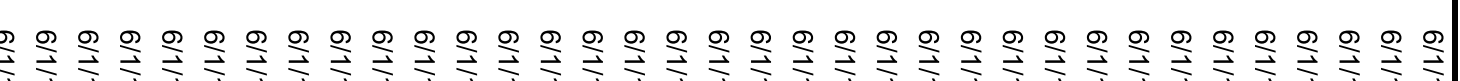




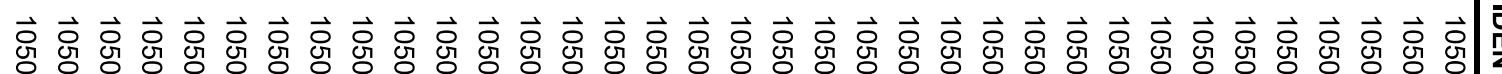
\&

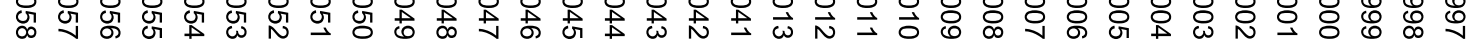

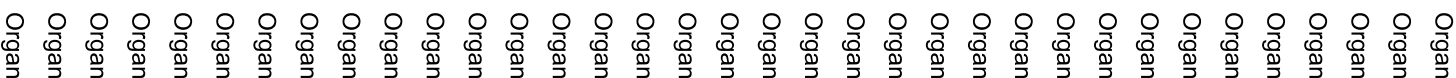

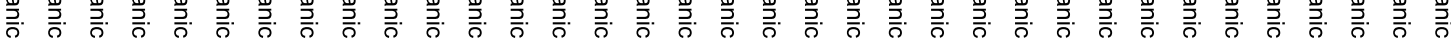

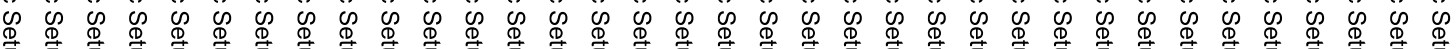
密

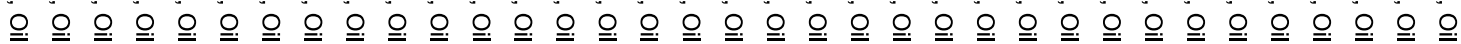

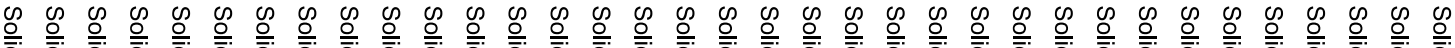

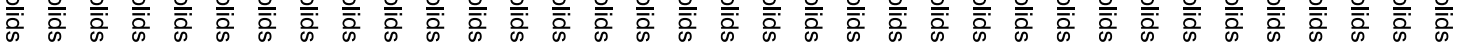

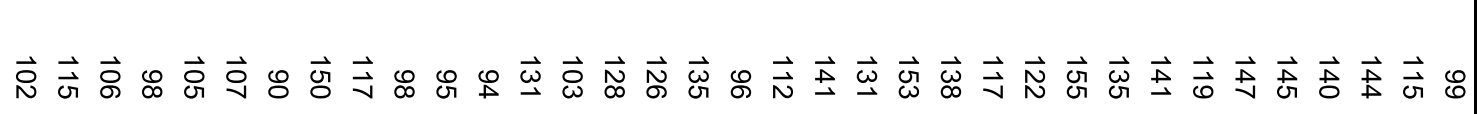




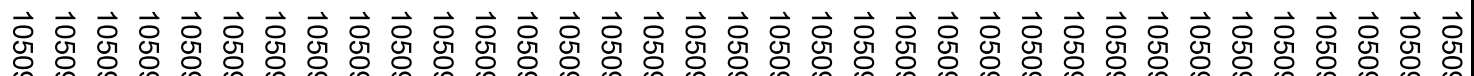

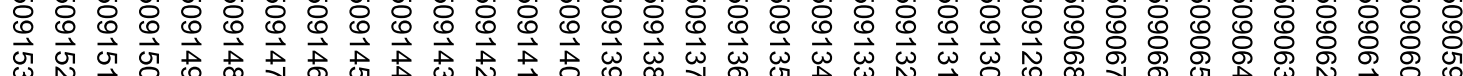

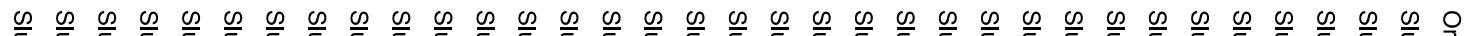

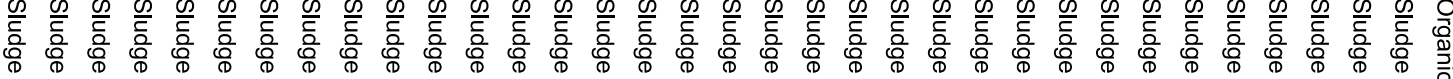
否 슨 商 总造

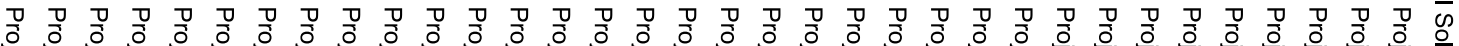

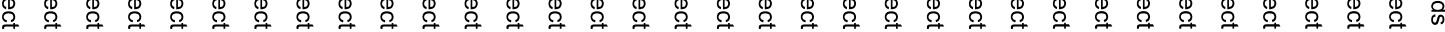

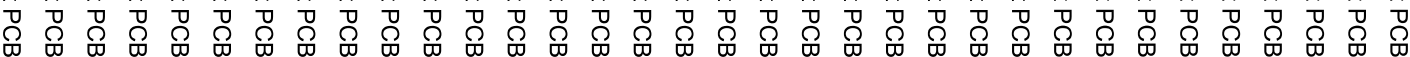

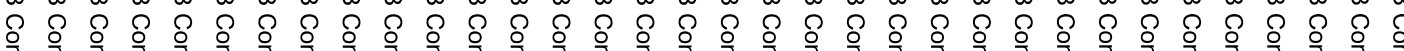
का

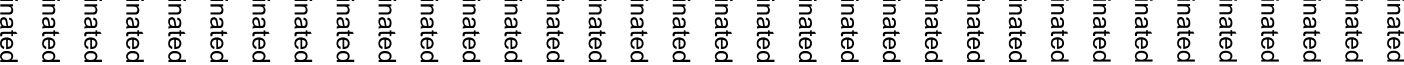

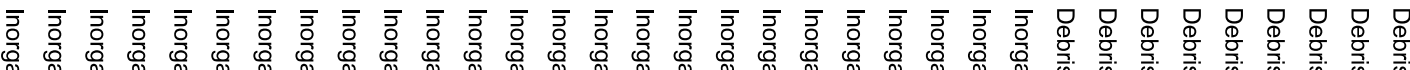

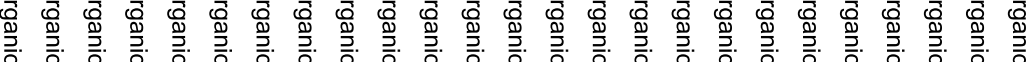

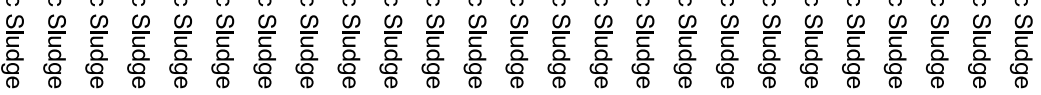

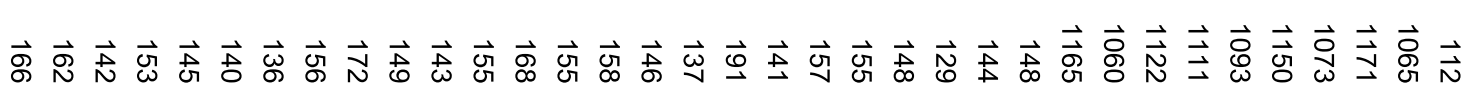

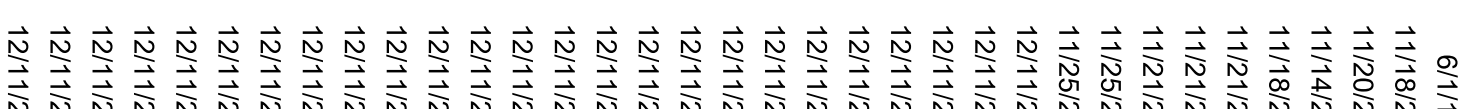

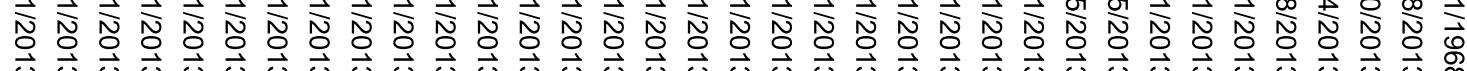
$\vec{\omega} \vec{\omega} \vec{\omega} \vec{\omega} \vec{\omega} \vec{\omega} \vec{\omega} \vec{\omega} \vec{\omega} \vec{\omega} \vec{\omega} \vec{\omega} \vec{\omega} \vec{\omega} \vec{\omega} \vec{\omega} \vec{\omega} \vec{\omega} \vec{\omega} \vec{\omega} \vec{\omega} \vec{\omega} \vec{\omega} \vec{\omega} \vec{\omega} \vec{\omega} \vec{\omega} \vec{\omega} \vec{\omega} \vec{\omega} \vec{\omega} \vec{\omega} \vec{\omega}$ \& $\overrightarrow{0} \overrightarrow{0} \overrightarrow{0} \overrightarrow{0} \overrightarrow{0} \overrightarrow{0} \overrightarrow{0} \overrightarrow{0} \overrightarrow{0} \overrightarrow{0} \overrightarrow{0} \overrightarrow{0} \overrightarrow{0} \overrightarrow{0} \overrightarrow{0} \overrightarrow{0} \overrightarrow{0} \overrightarrow{0} \overrightarrow{0} \overrightarrow{0} \overrightarrow{0} \overrightarrow{0} 0000000000$ 


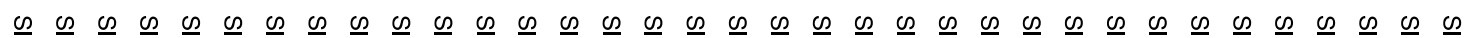

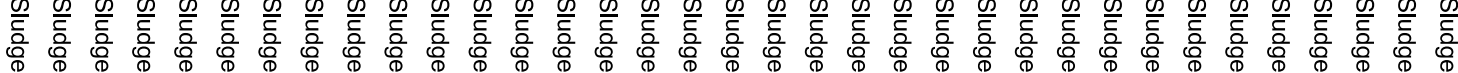

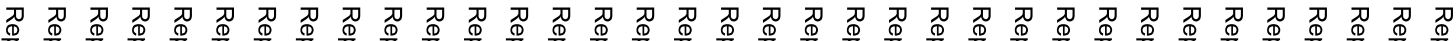

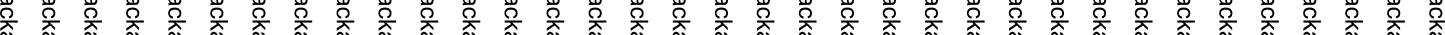

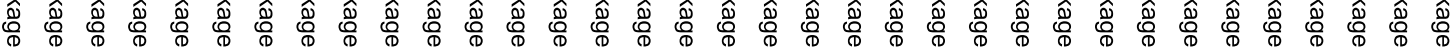

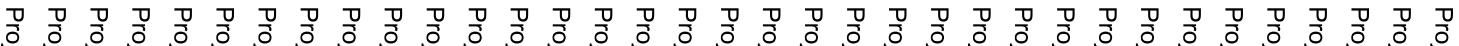

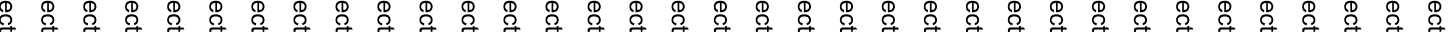

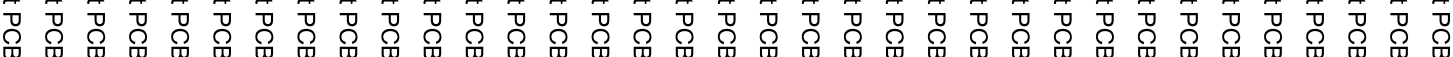

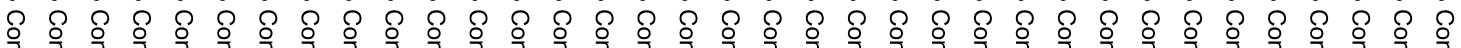

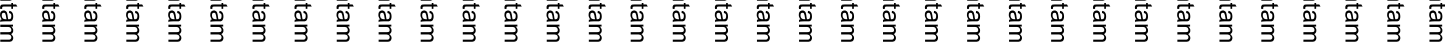

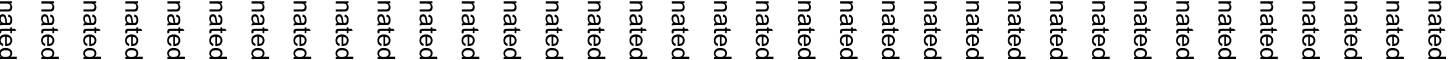

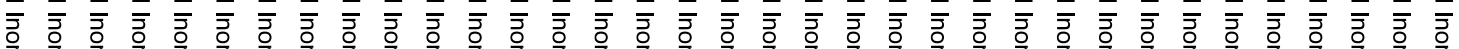

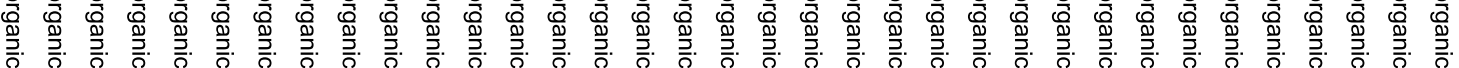

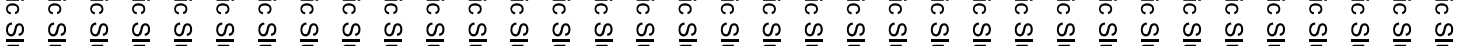

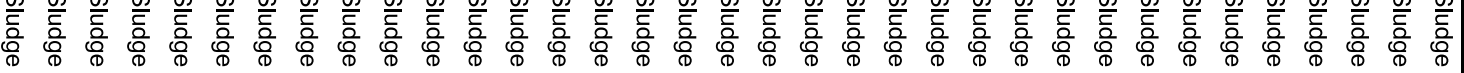

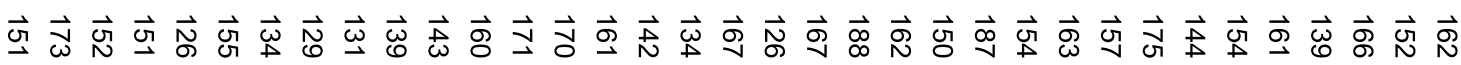

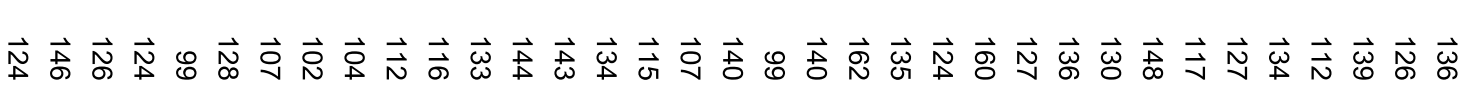
즈음

党

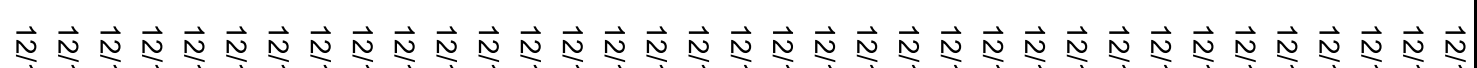

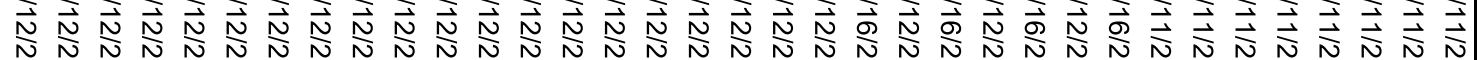

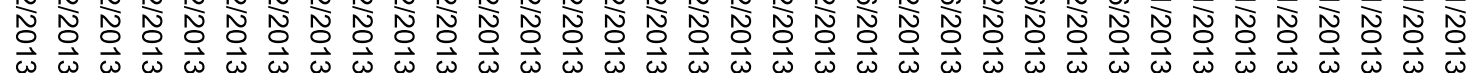




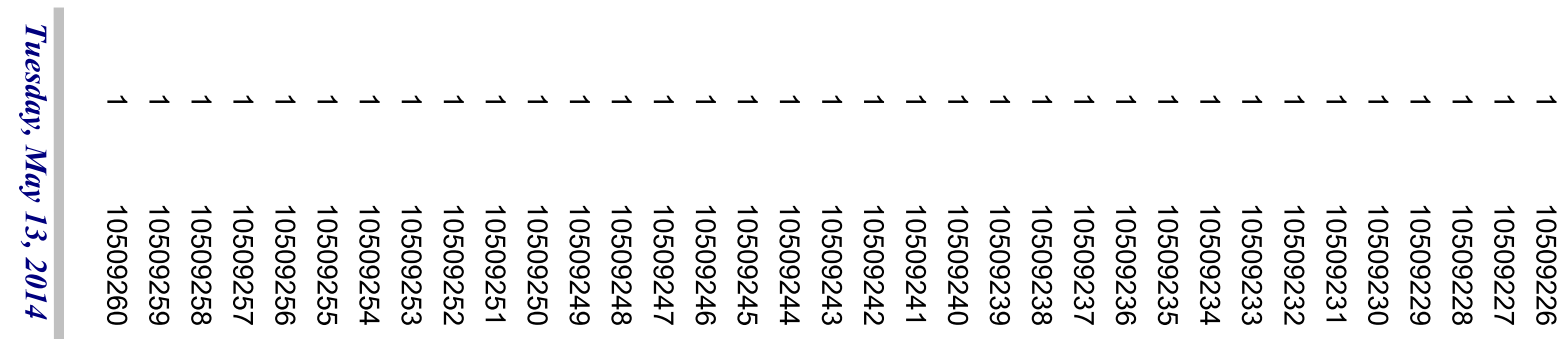

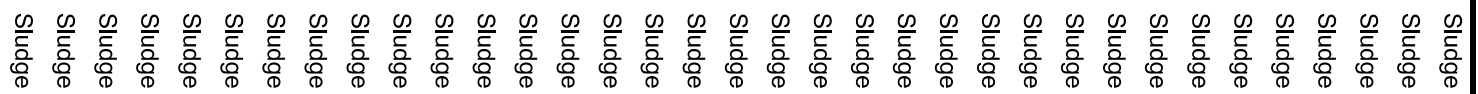

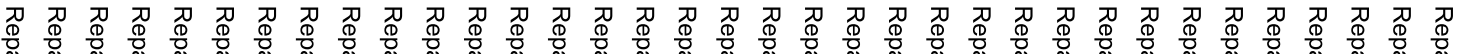

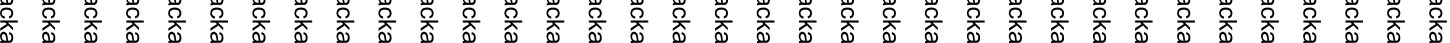
商 总造

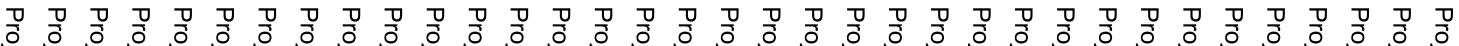

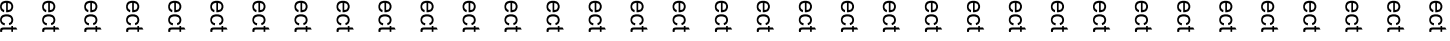

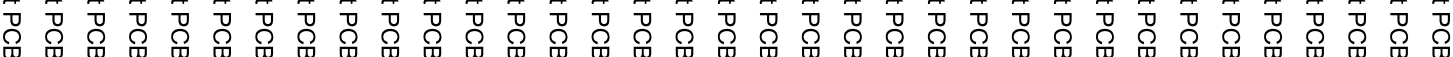

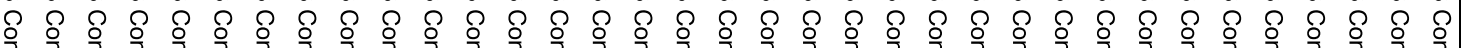

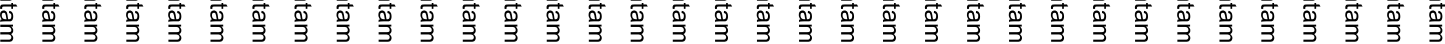

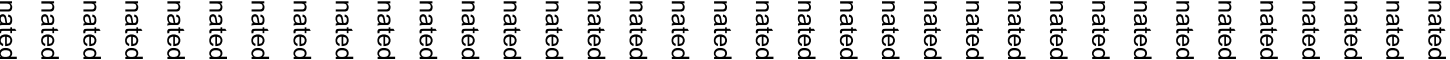

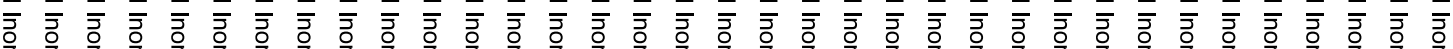

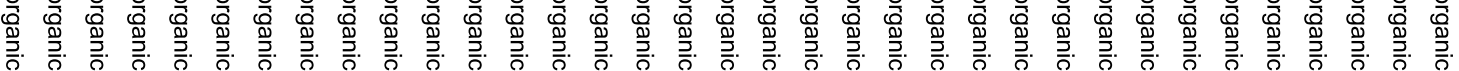

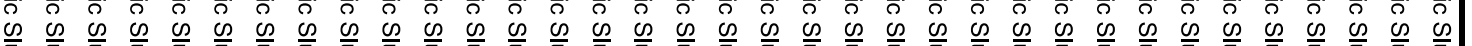

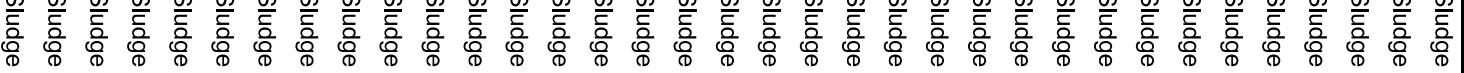

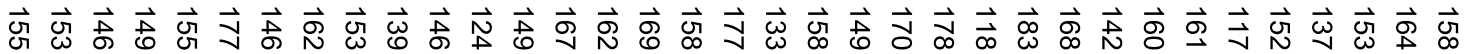

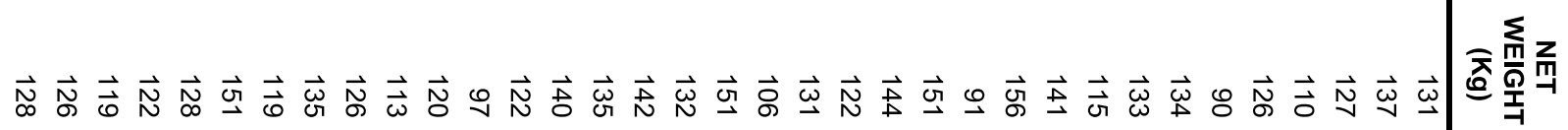

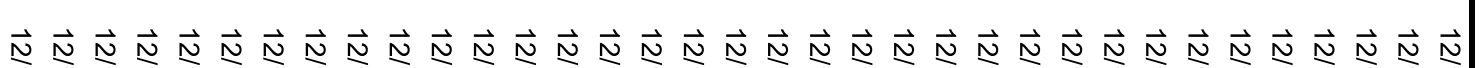
金

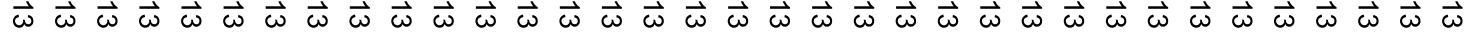
$\overrightarrow{0} \overrightarrow{0} \overrightarrow{0} \overrightarrow{0} \overrightarrow{0} \overrightarrow{0} \overrightarrow{0} \overrightarrow{0} \overrightarrow{0} \overrightarrow{0} \overrightarrow{0} \overrightarrow{0} \overrightarrow{0} \overrightarrow{0} \overrightarrow{0} \overrightarrow{0} \overrightarrow{0} \overrightarrow{0} \overrightarrow{0} \overrightarrow{0} \overrightarrow{0} \overrightarrow{0} \overrightarrow{0} \overrightarrow{0} \overrightarrow{0} \overrightarrow{0} \overrightarrow{0} \overrightarrow{0} \overrightarrow{0} \overrightarrow{0}$ 


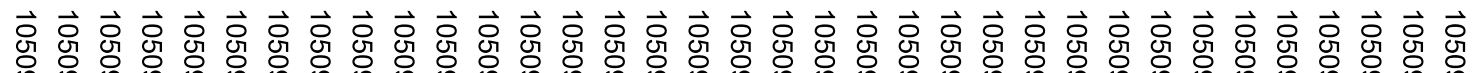

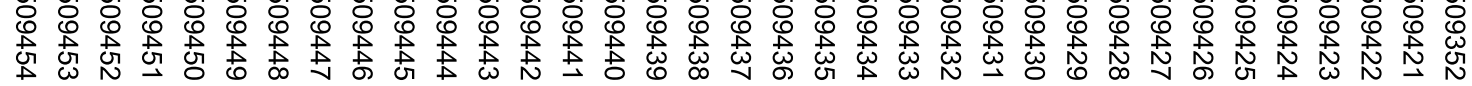

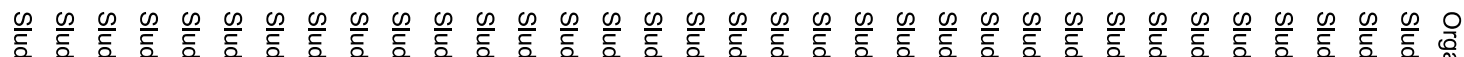
言 音 歪 要

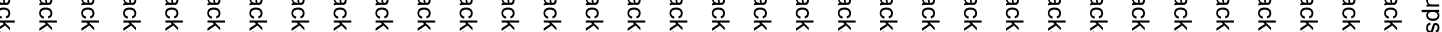

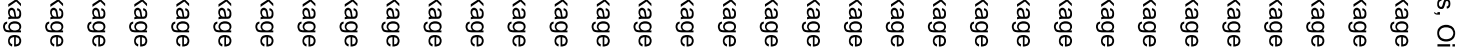

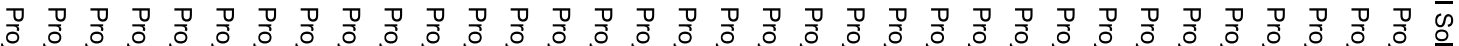

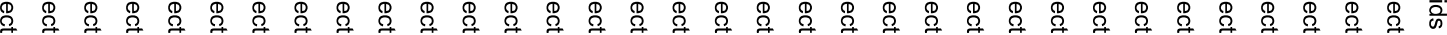

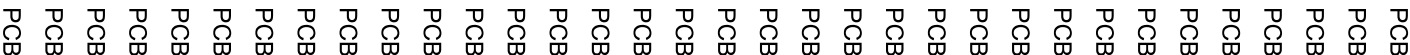

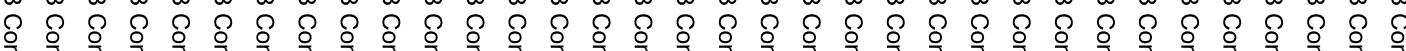

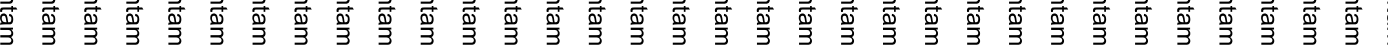

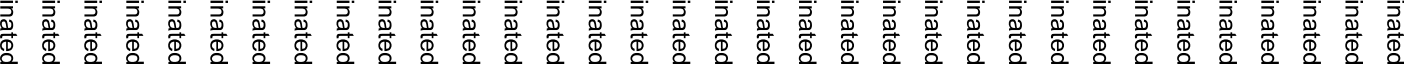

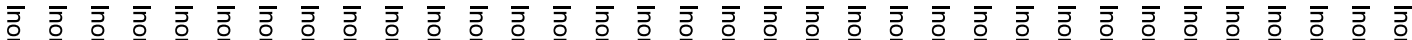

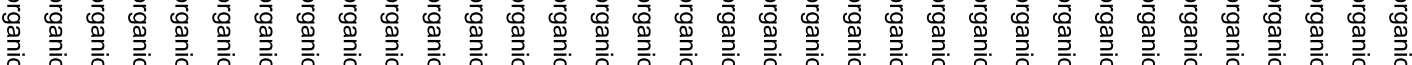

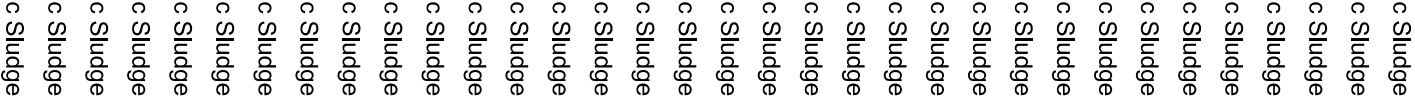

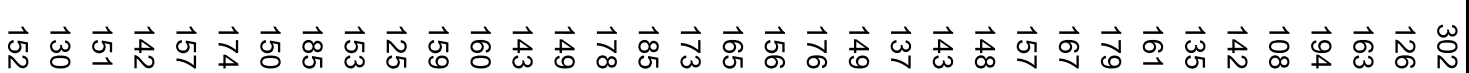

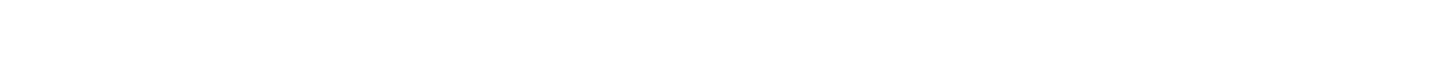

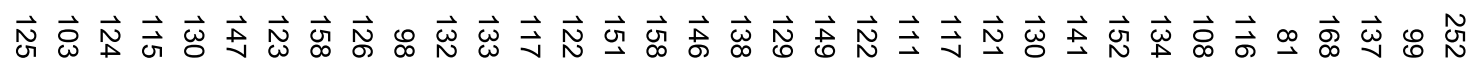

$\vec{N} \vec{N} \vec{N} \vec{N} \vec{N} \vec{N} \vec{N} \vec{N} \vec{N} \vec{N} \vec{N} \vec{N} \vec{N} \vec{N} \vec{N} \vec{N} \vec{N} \vec{N} \vec{N} \vec{N} \vec{N} \vec{N} \vec{N} \vec{N} \vec{N} \vec{N} \vec{N} \vec{N} \vec{N} \vec{N}$

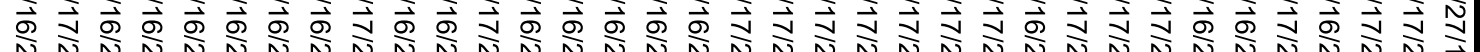

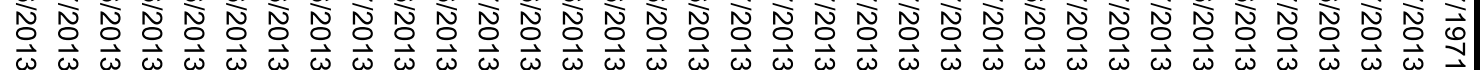
(1)

$\overrightarrow{0} \overrightarrow{0} \overrightarrow{0} \overrightarrow{0} \overrightarrow{0} \overrightarrow{0} \overrightarrow{0} \overrightarrow{0} \overrightarrow{0} \overrightarrow{0} \overrightarrow{0} \overrightarrow{0} \overrightarrow{0} \overrightarrow{0} \overrightarrow{0} \overrightarrow{0} \overrightarrow{0} \overrightarrow{0} \overrightarrow{0} \overrightarrow{0} \overrightarrow{0} \overrightarrow{0} \overrightarrow{0} \overrightarrow{0} \overrightarrow{0} \overrightarrow{0} \overrightarrow{0} \overrightarrow{0} \vec{f}$ 


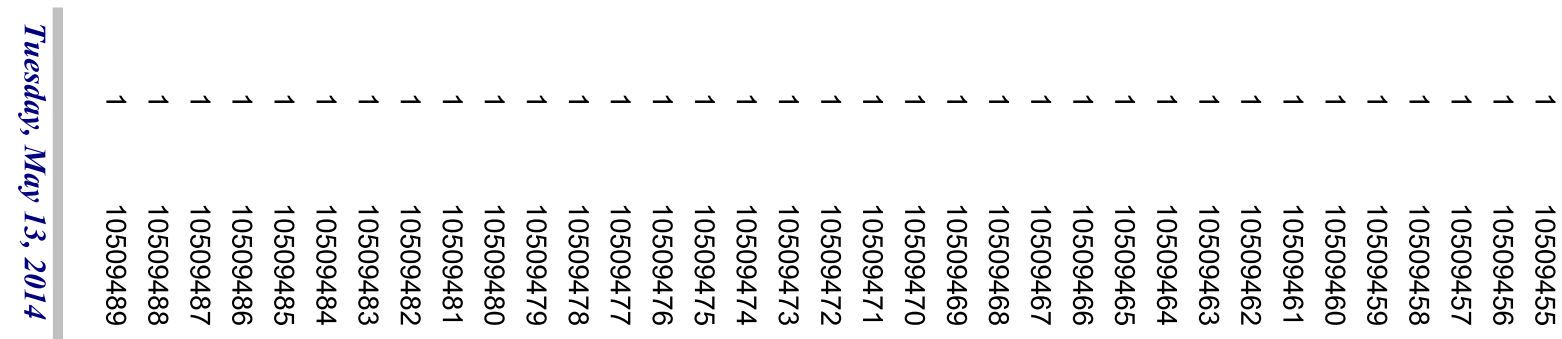

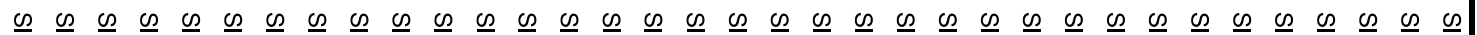

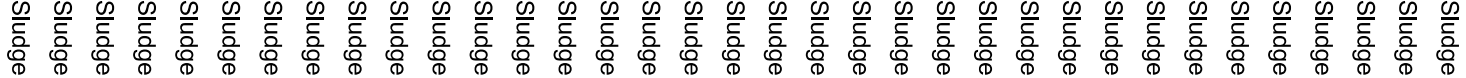

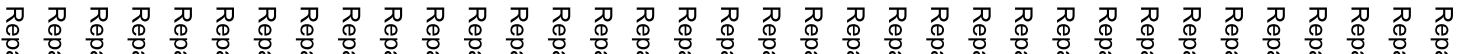

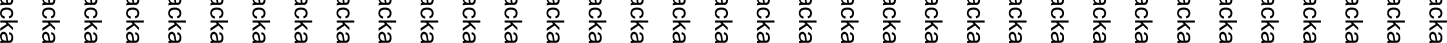

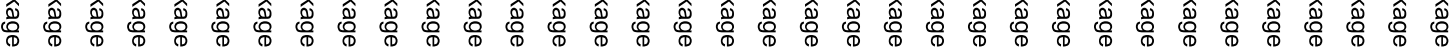

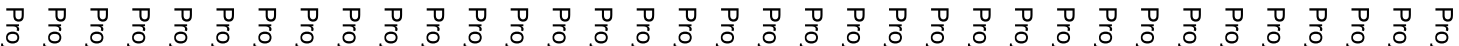

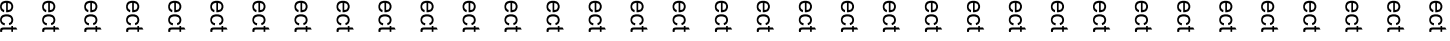

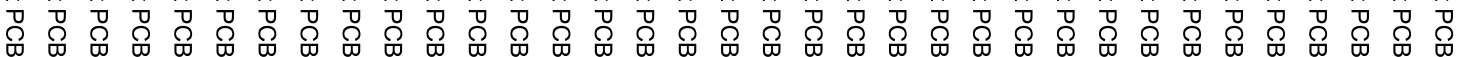

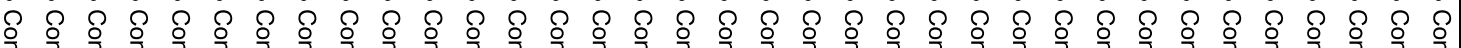

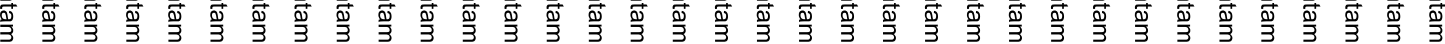

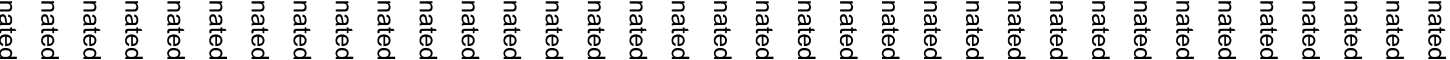

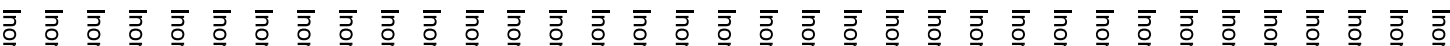

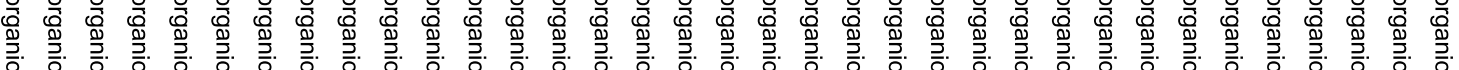

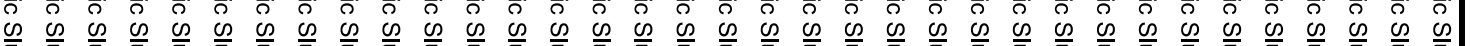

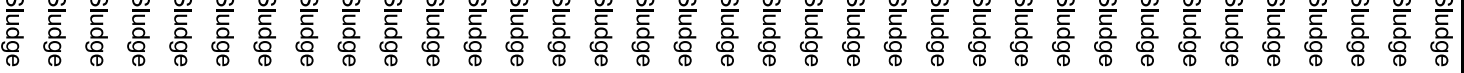

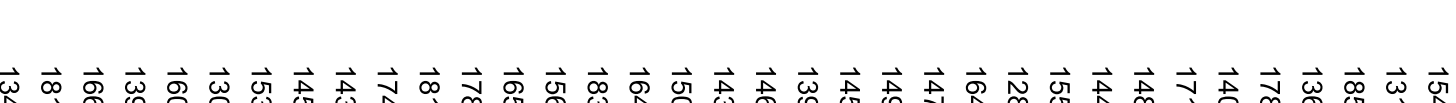

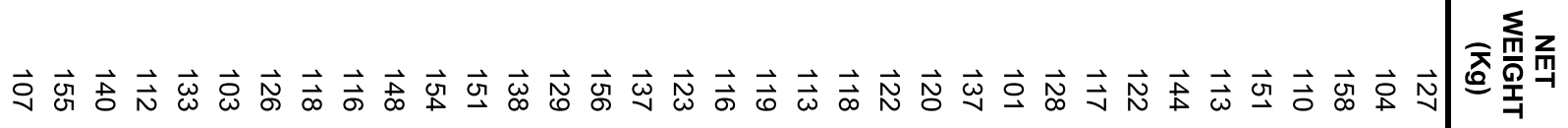

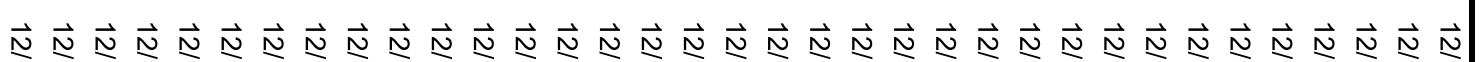

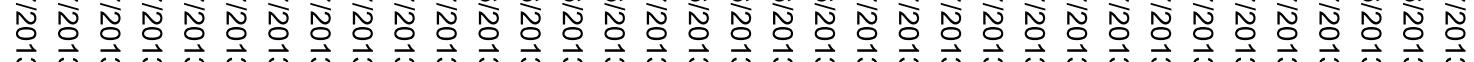

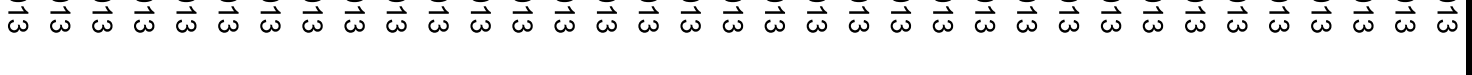
$\overrightarrow{0} \overrightarrow{0} \overrightarrow{0} \overrightarrow{0} \overrightarrow{0} \overrightarrow{0} \overrightarrow{0} \overrightarrow{0} \overrightarrow{0} \overrightarrow{0} \overrightarrow{0} \overrightarrow{0} \overrightarrow{0} \overrightarrow{0} \overrightarrow{0} \overrightarrow{0} \overrightarrow{0} \overrightarrow{0} \overrightarrow{0} \overrightarrow{0} \overrightarrow{0} \overrightarrow{0} \overrightarrow{0} \overrightarrow{0} \overrightarrow{0} \overrightarrow{0} \overrightarrow{0} \overrightarrow{0}$ 


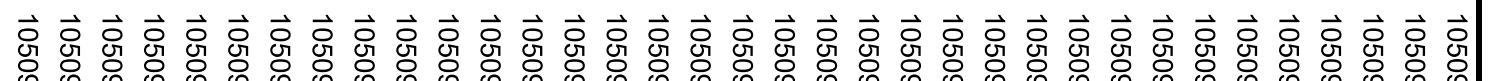

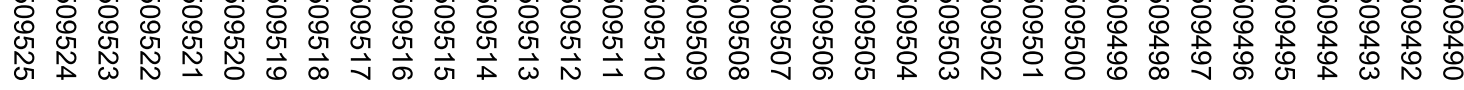

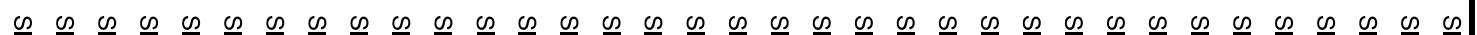

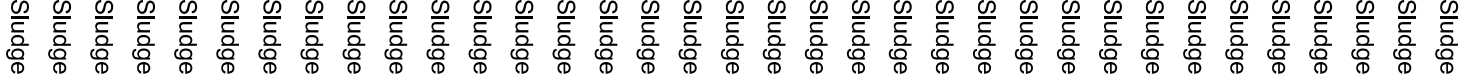

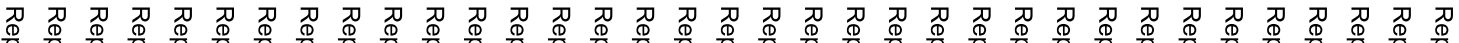

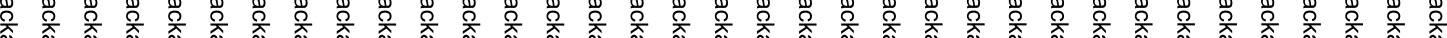
产會

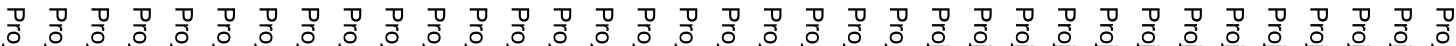

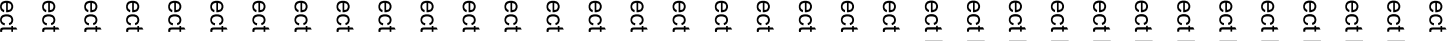

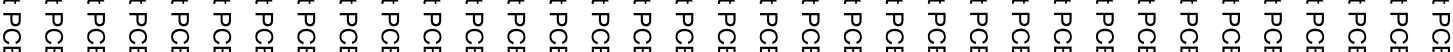

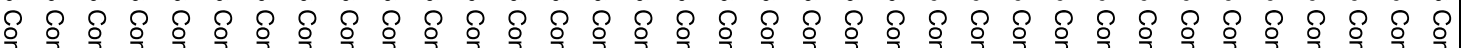

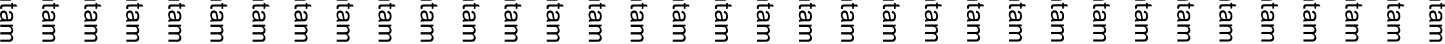

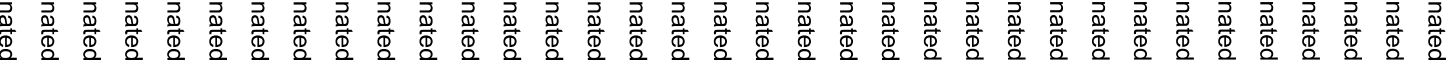

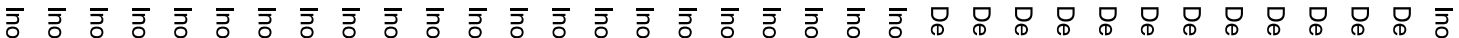

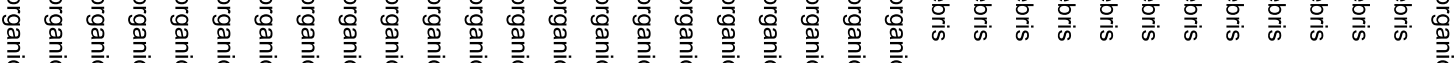

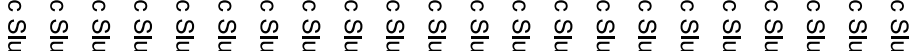

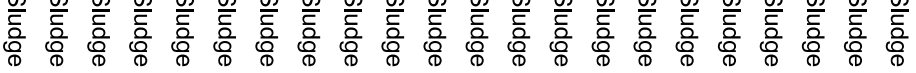

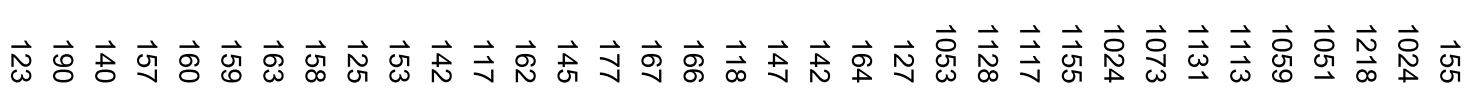

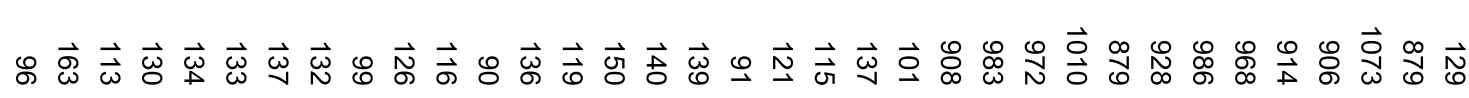
층

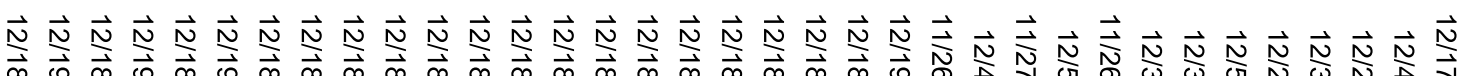

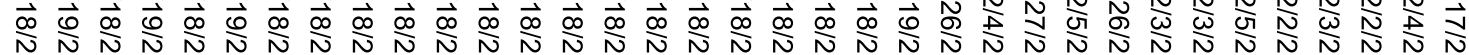

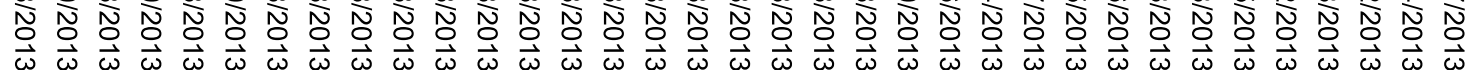

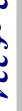
$\overrightarrow{0} \overrightarrow{0} \overrightarrow{0} \overrightarrow{0} \overrightarrow{0} \overrightarrow{0} \overrightarrow{0} \overrightarrow{0} \overrightarrow{0} \overrightarrow{0} \overrightarrow{0} \overrightarrow{0} \overrightarrow{0} \overrightarrow{0} \overrightarrow{0} \overrightarrow{0} \overrightarrow{0} \overrightarrow{0} \overrightarrow{0} 000000000000 \overrightarrow{0}$ 


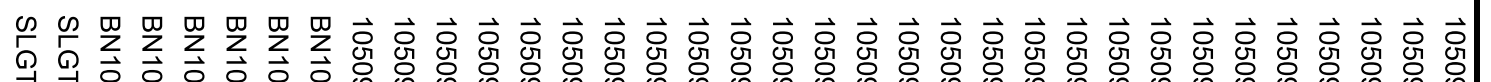

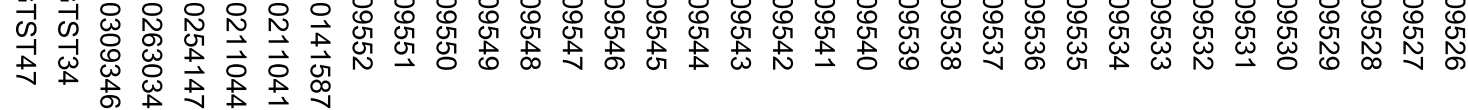

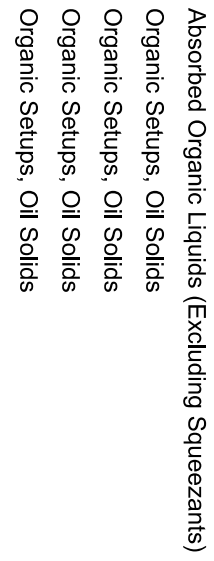

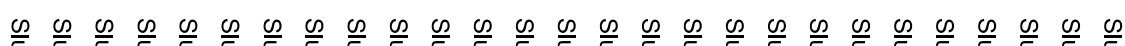

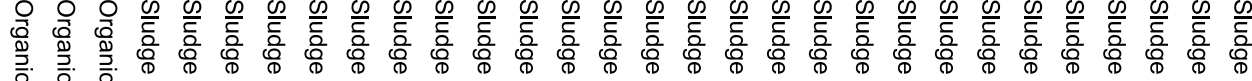
$\begin{array}{llll} & \\ 0 & 0 & 0 & 0\end{array}$

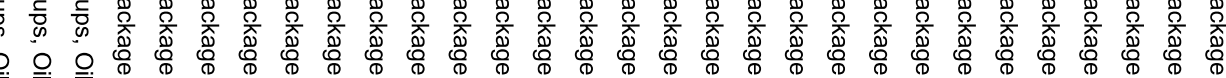
舟

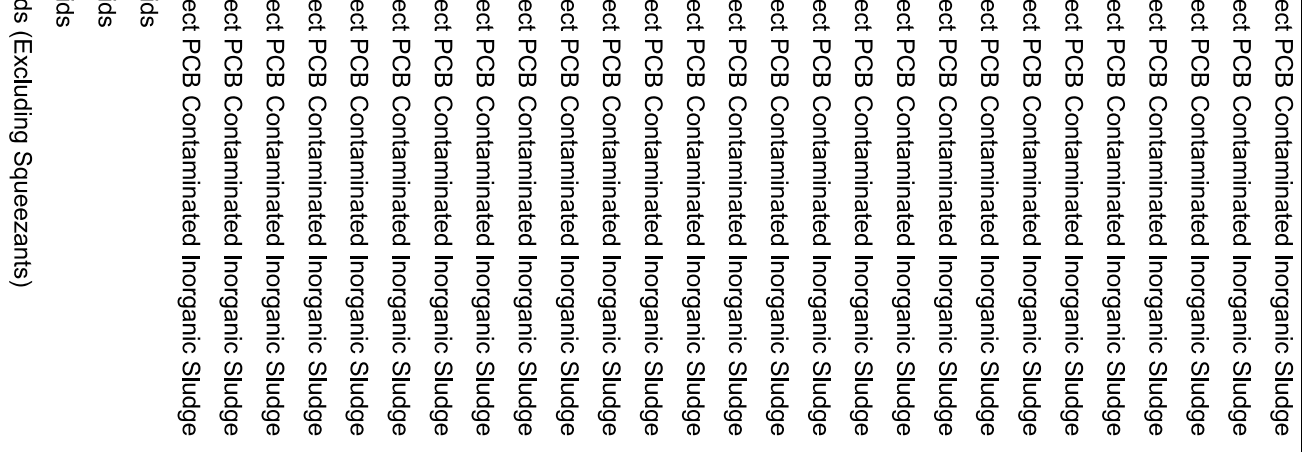

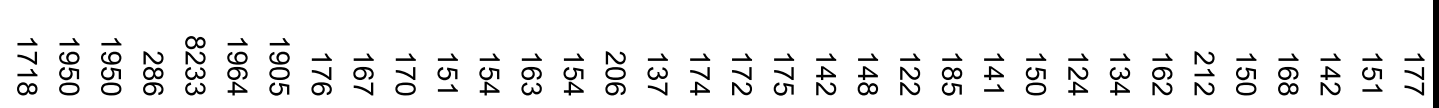

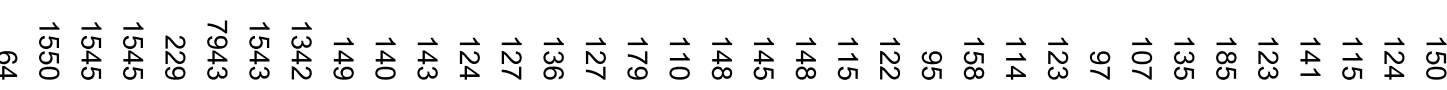
交血

\section{2}

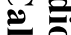

हैं.

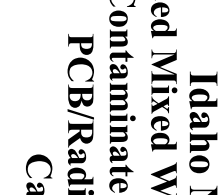

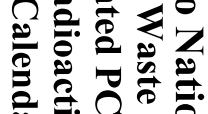

을

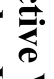

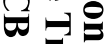

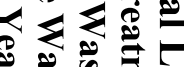

กิ宀

急要

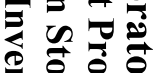

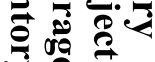

2

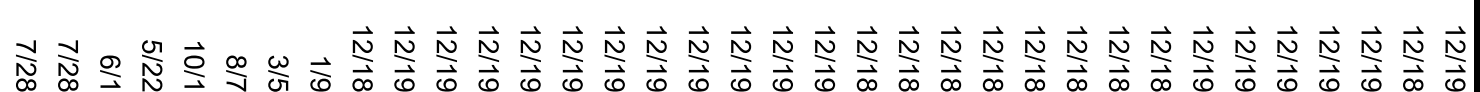

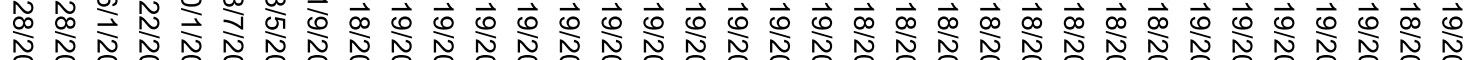

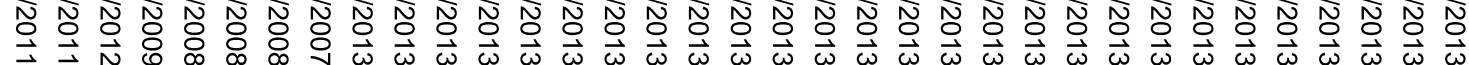




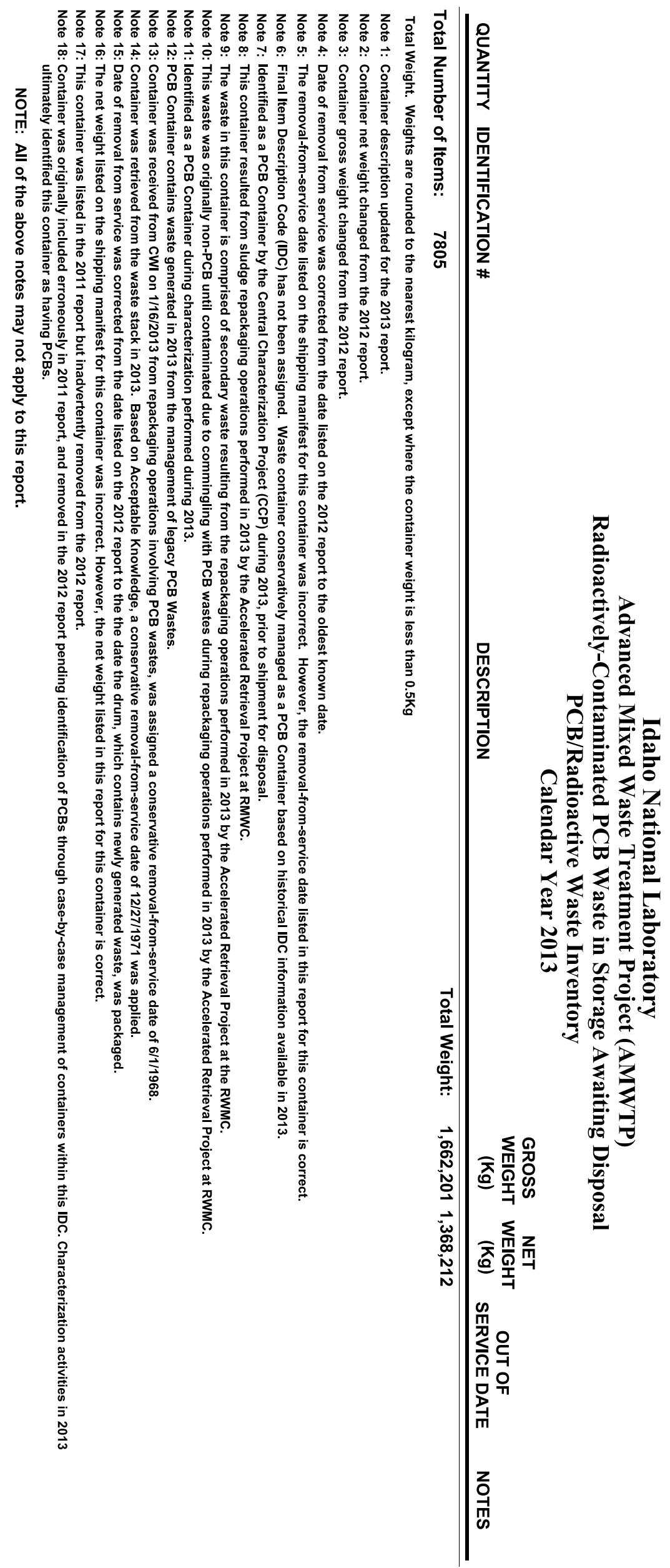


6.0 AMWTP RADIOACTIVELY-CONTAMINATED PCB WASTE REMOVED FROM SERVICE, SHIPPED AND/OR DISPOSED DURING CALENDAR YEAR 2013 


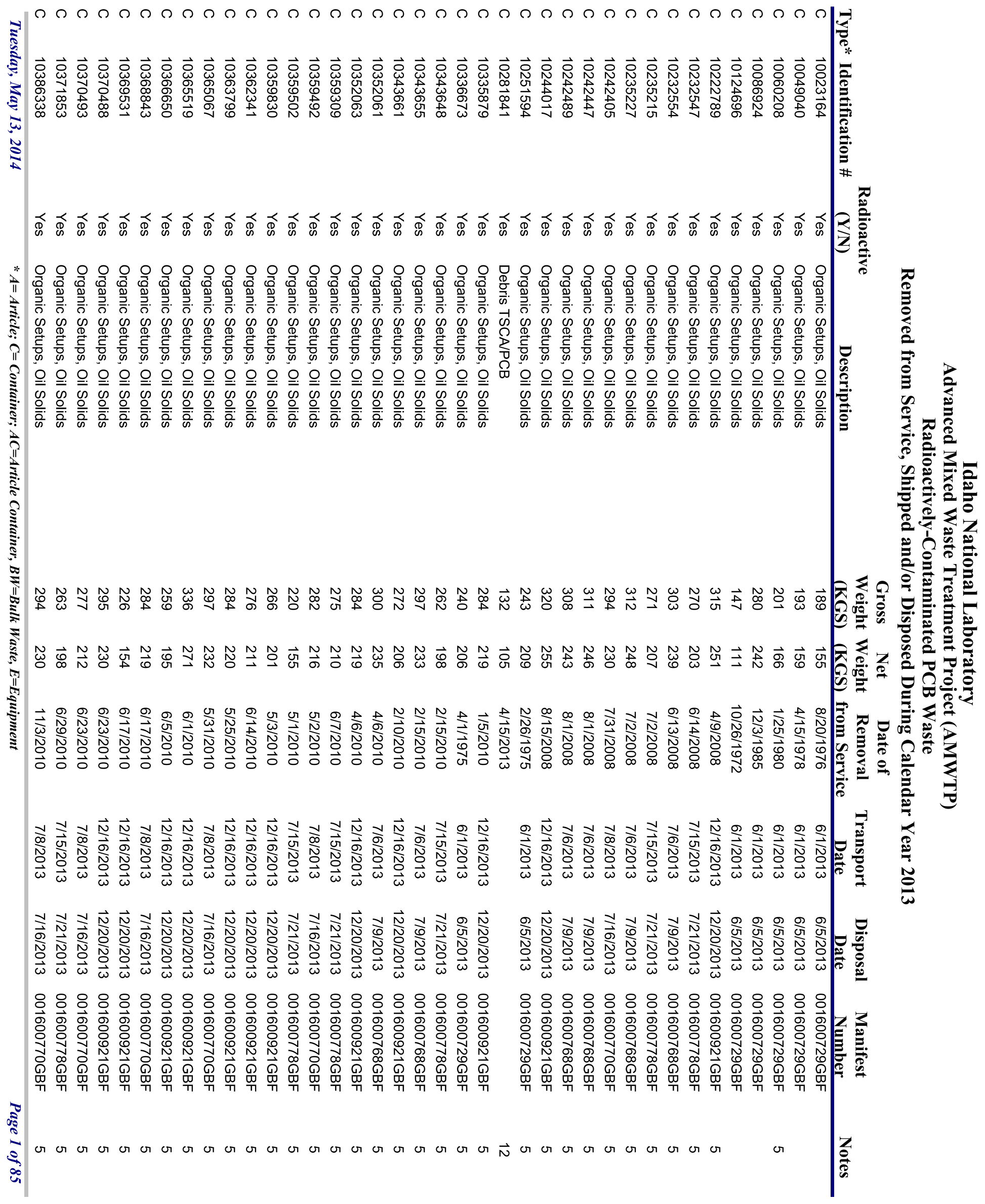




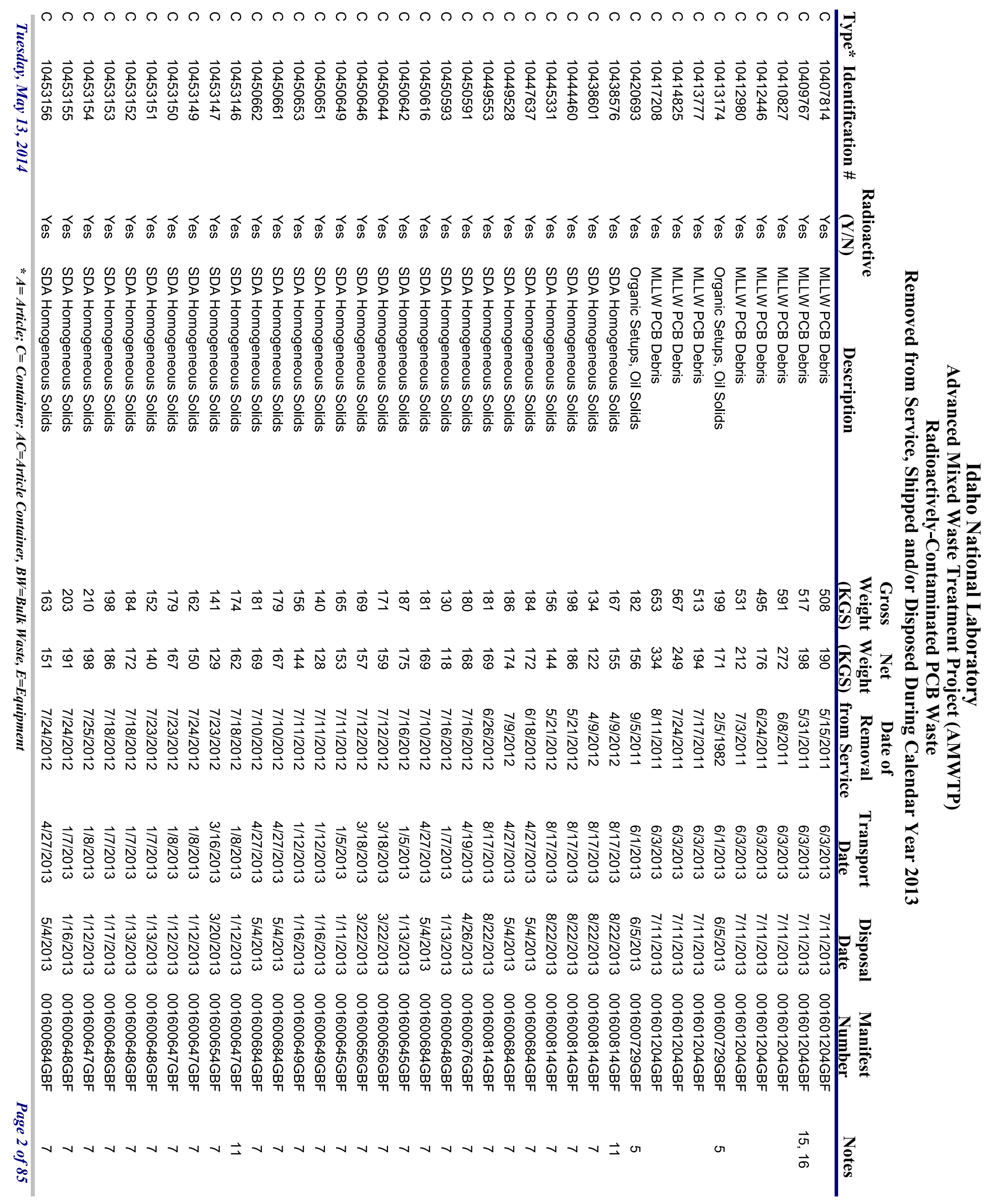




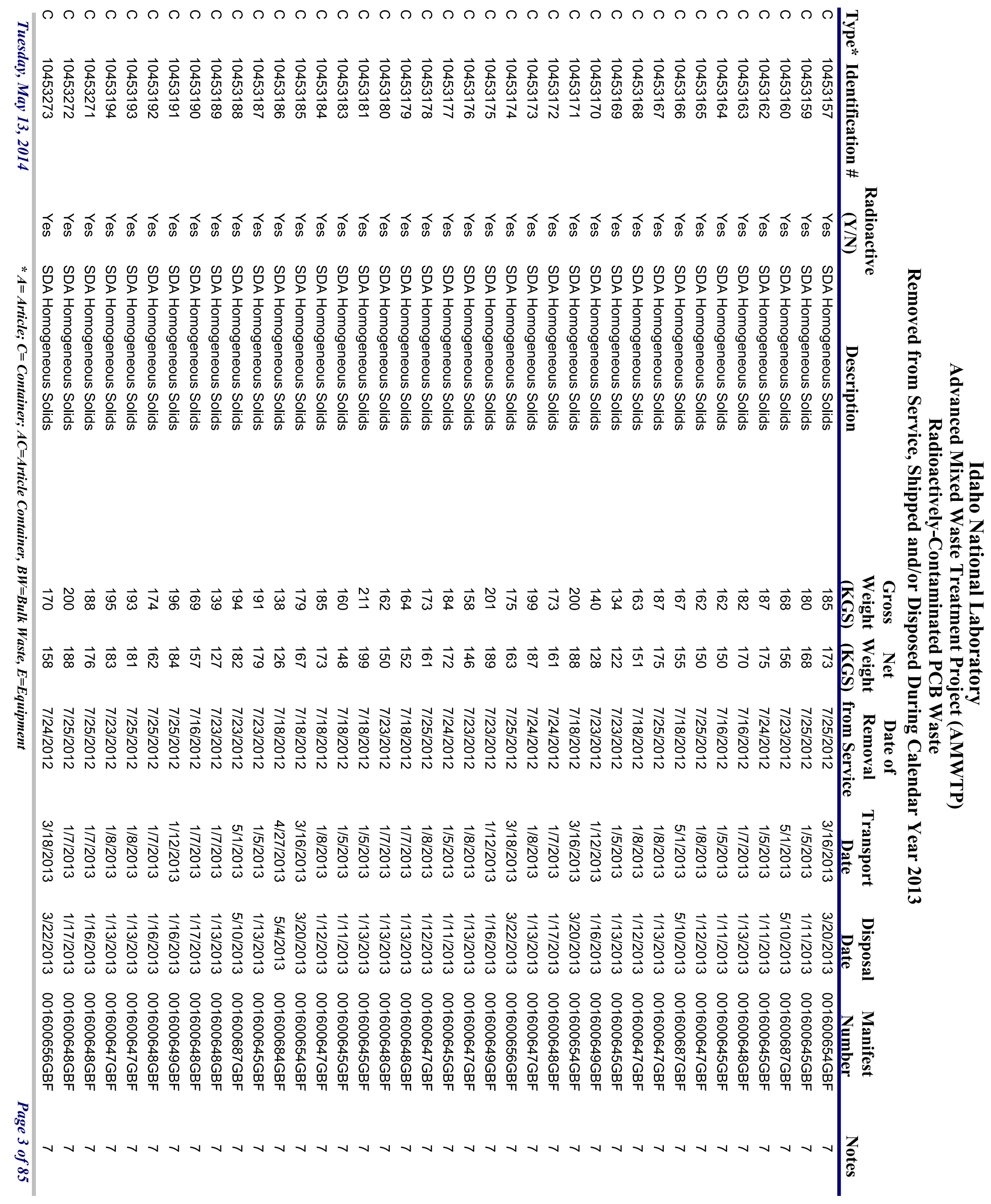




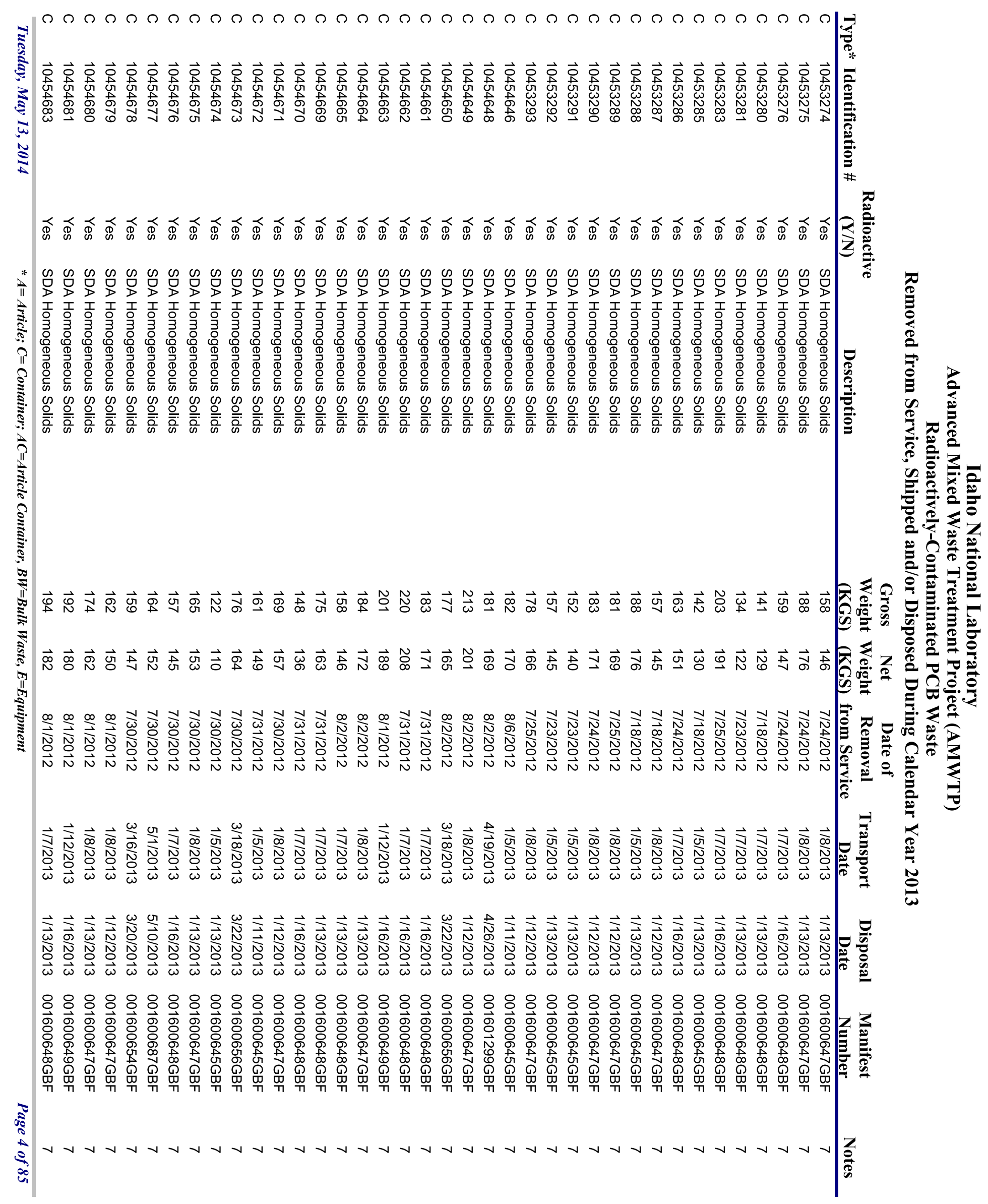




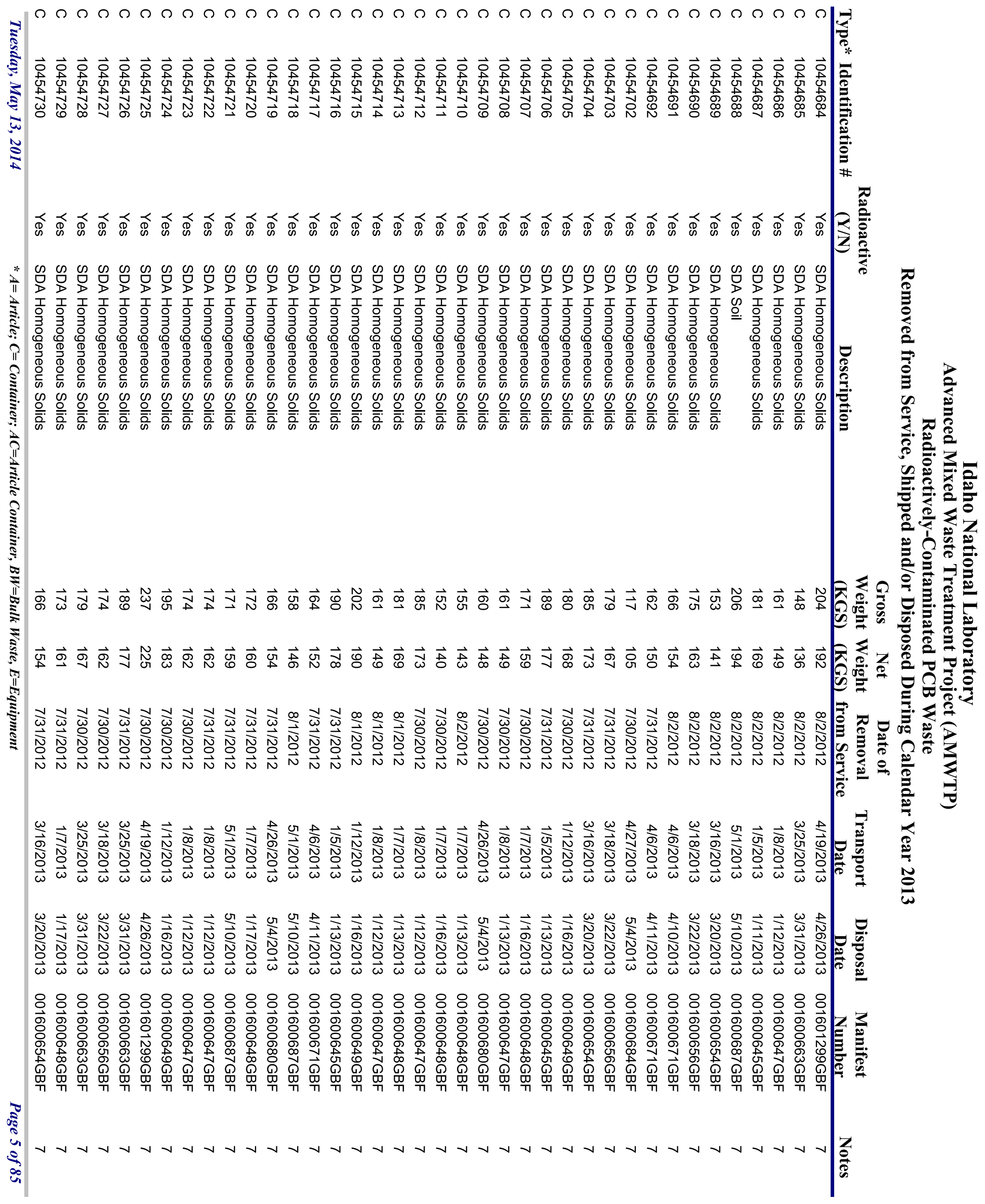




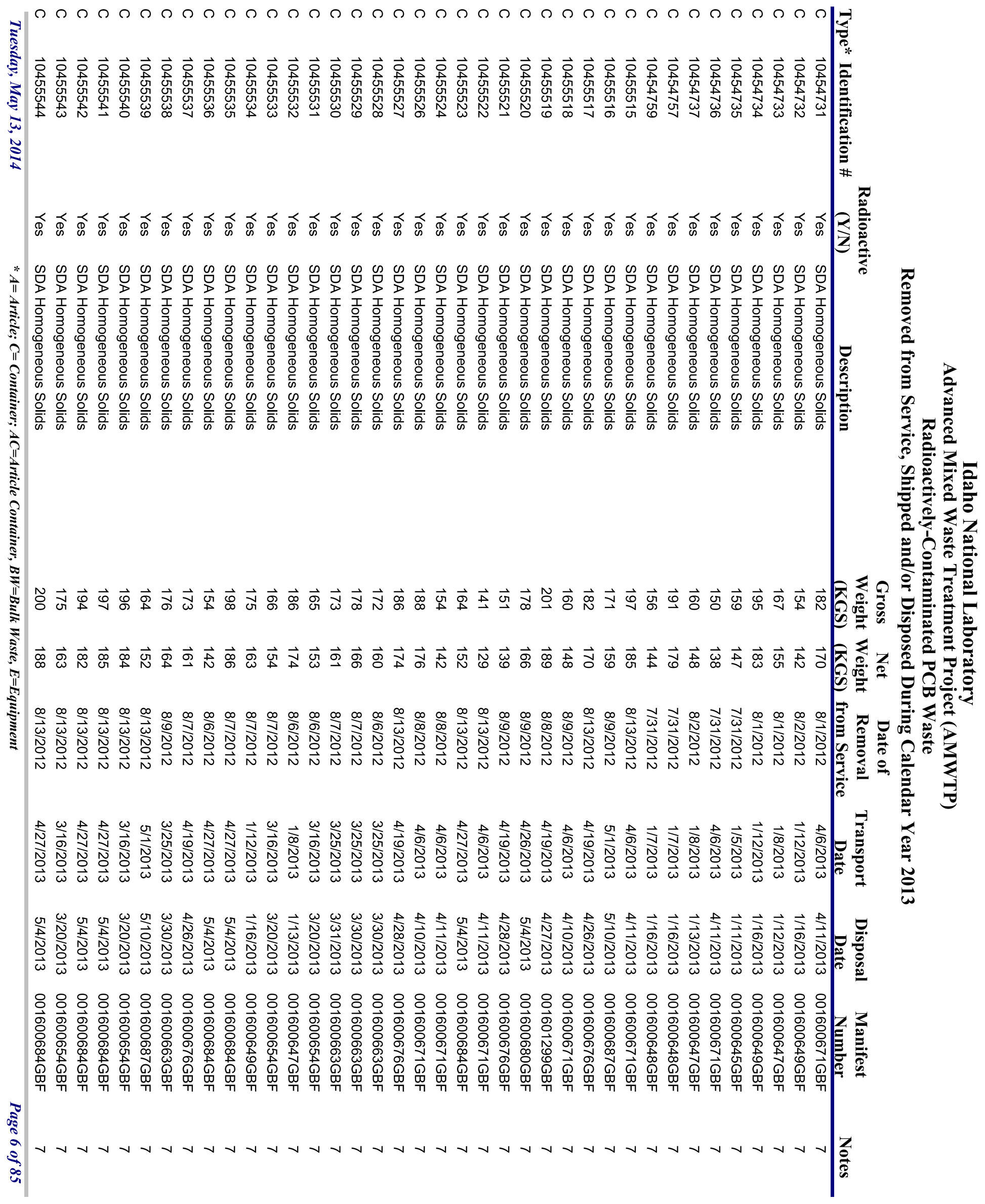




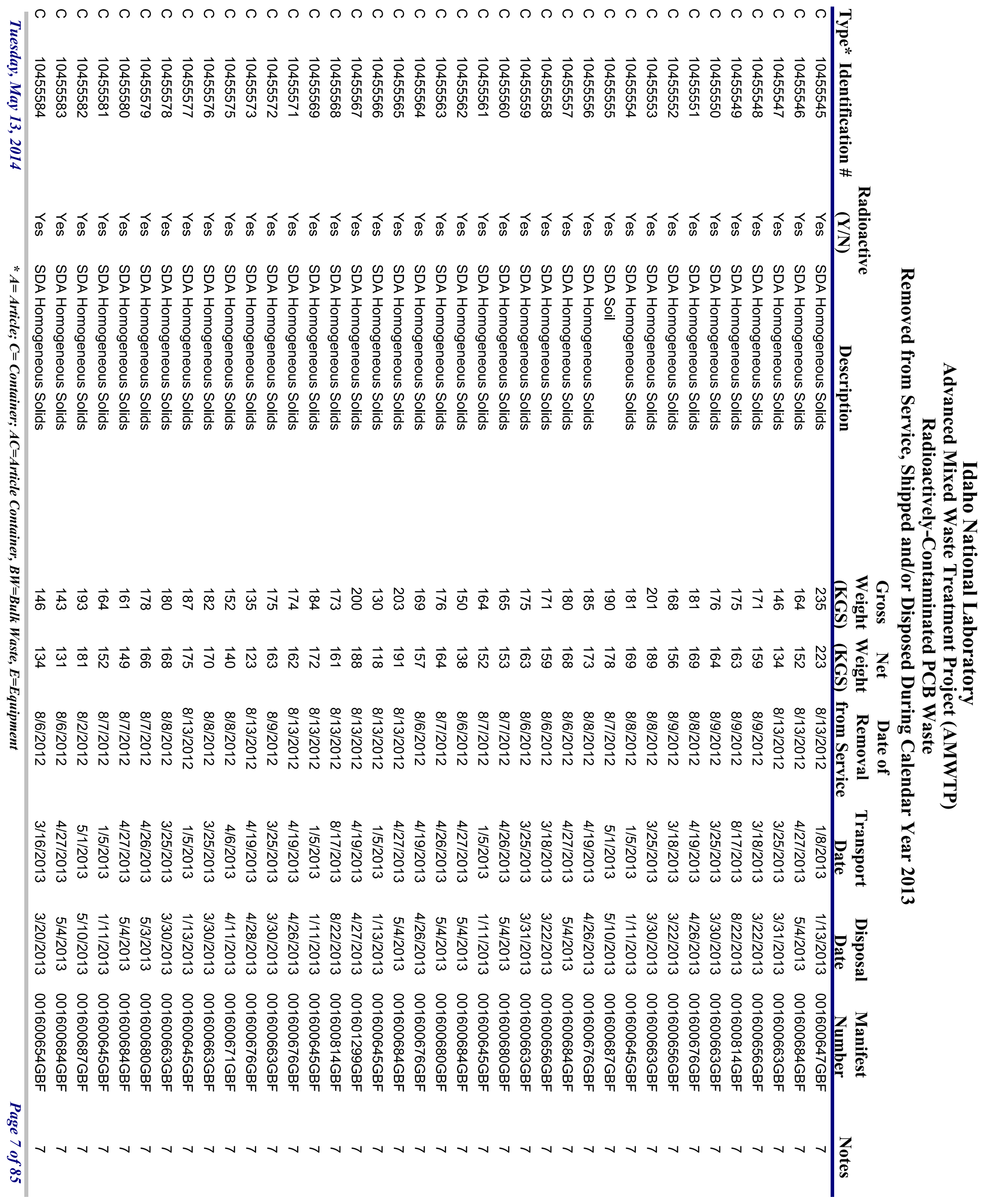




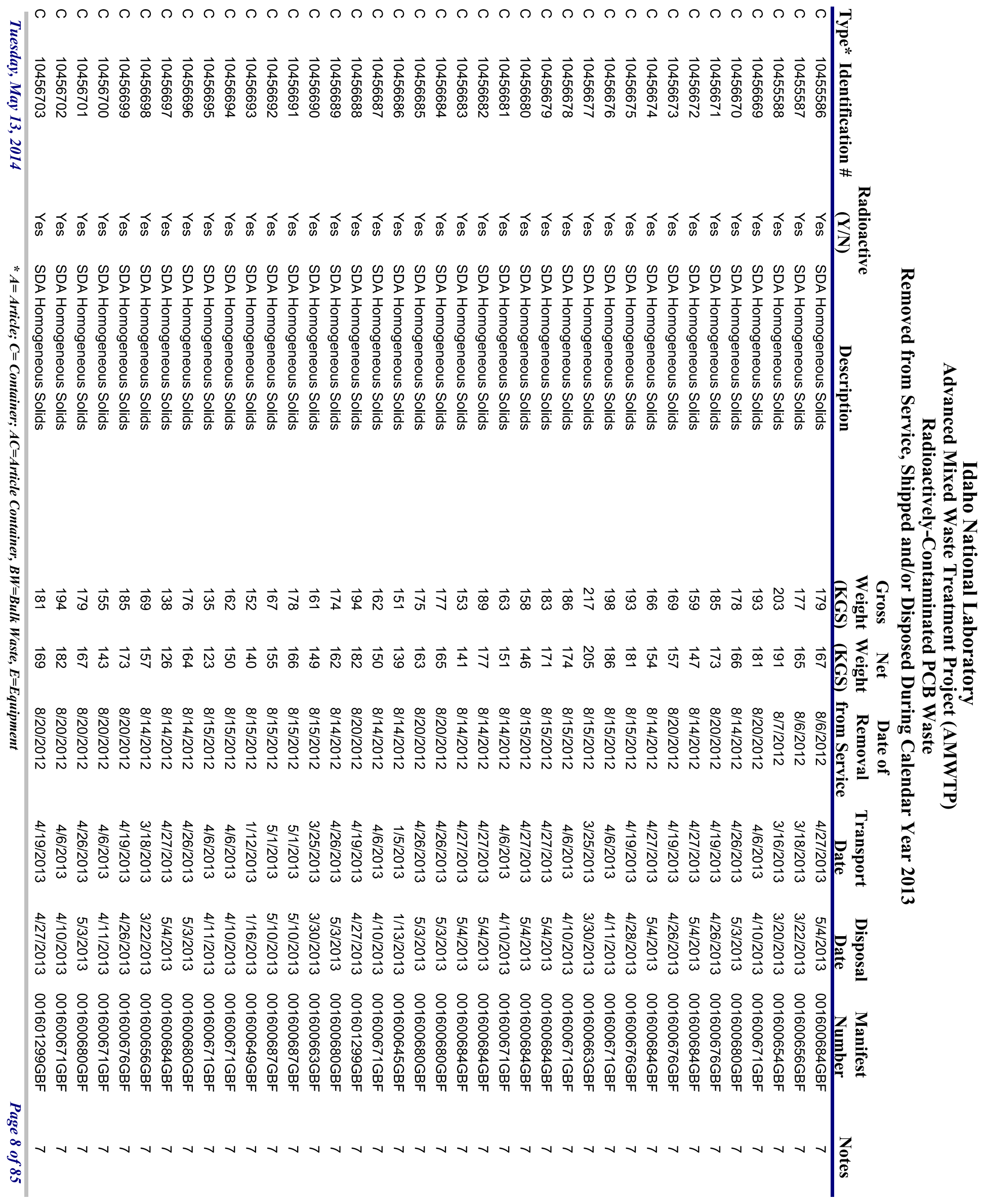




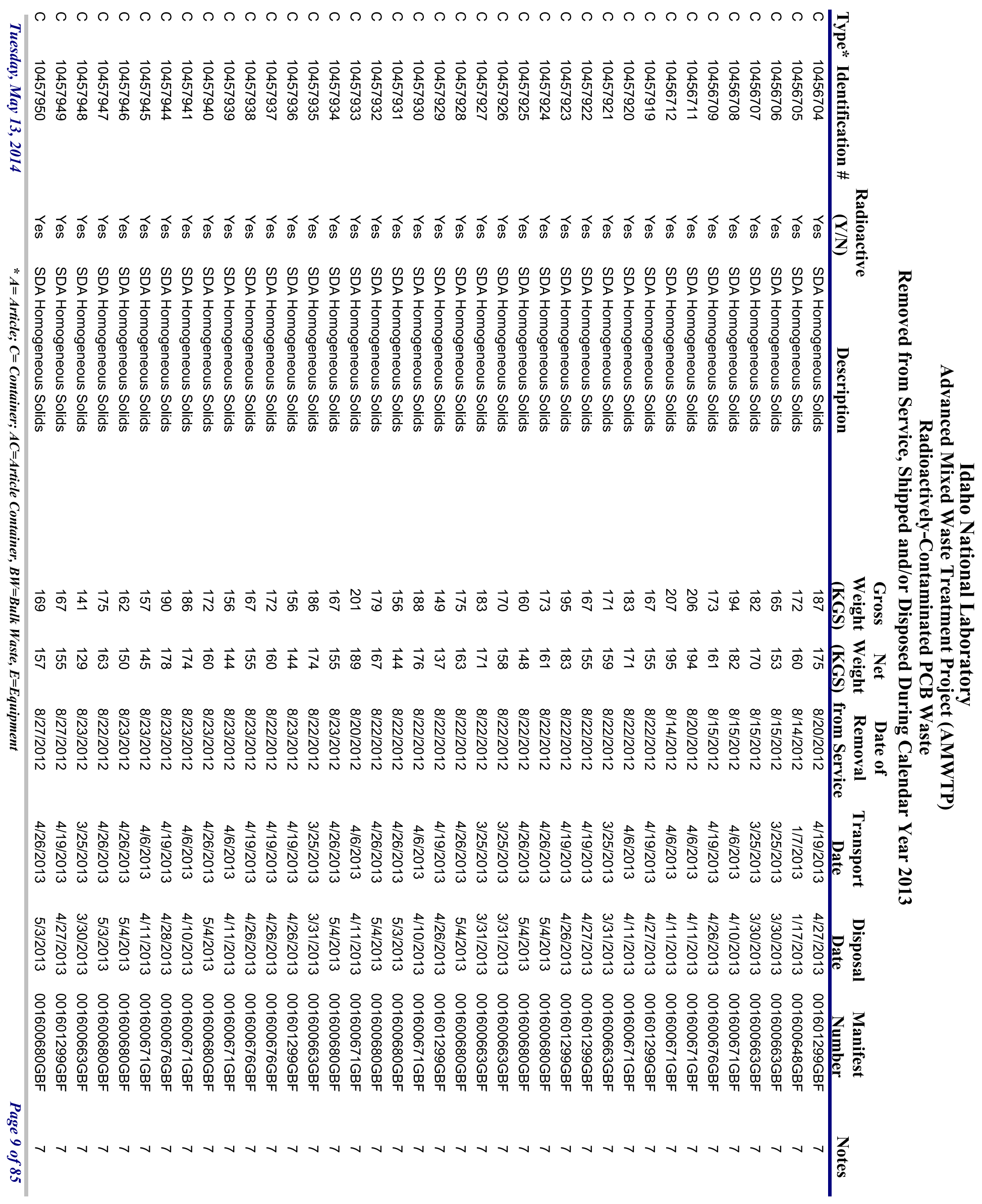




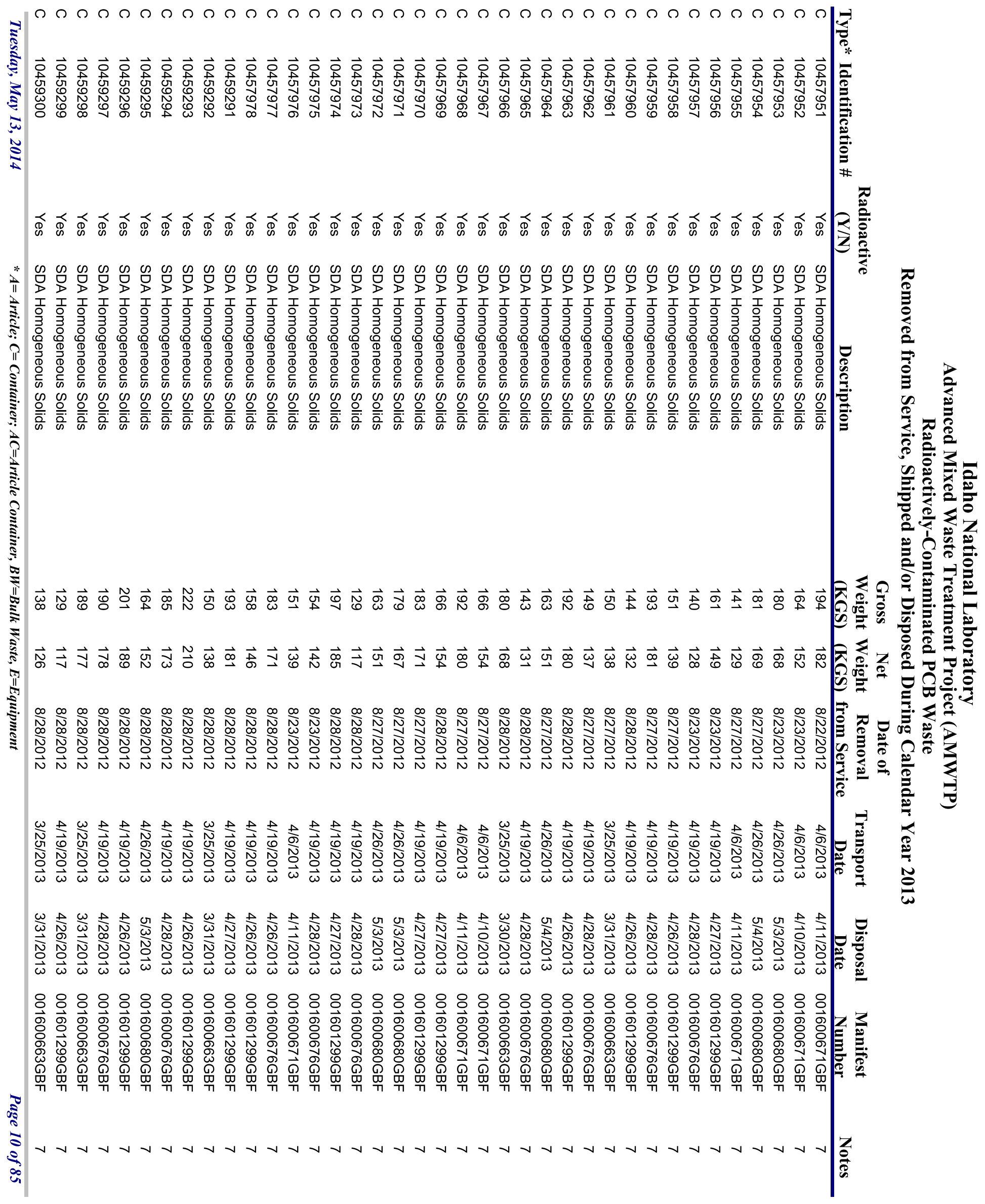




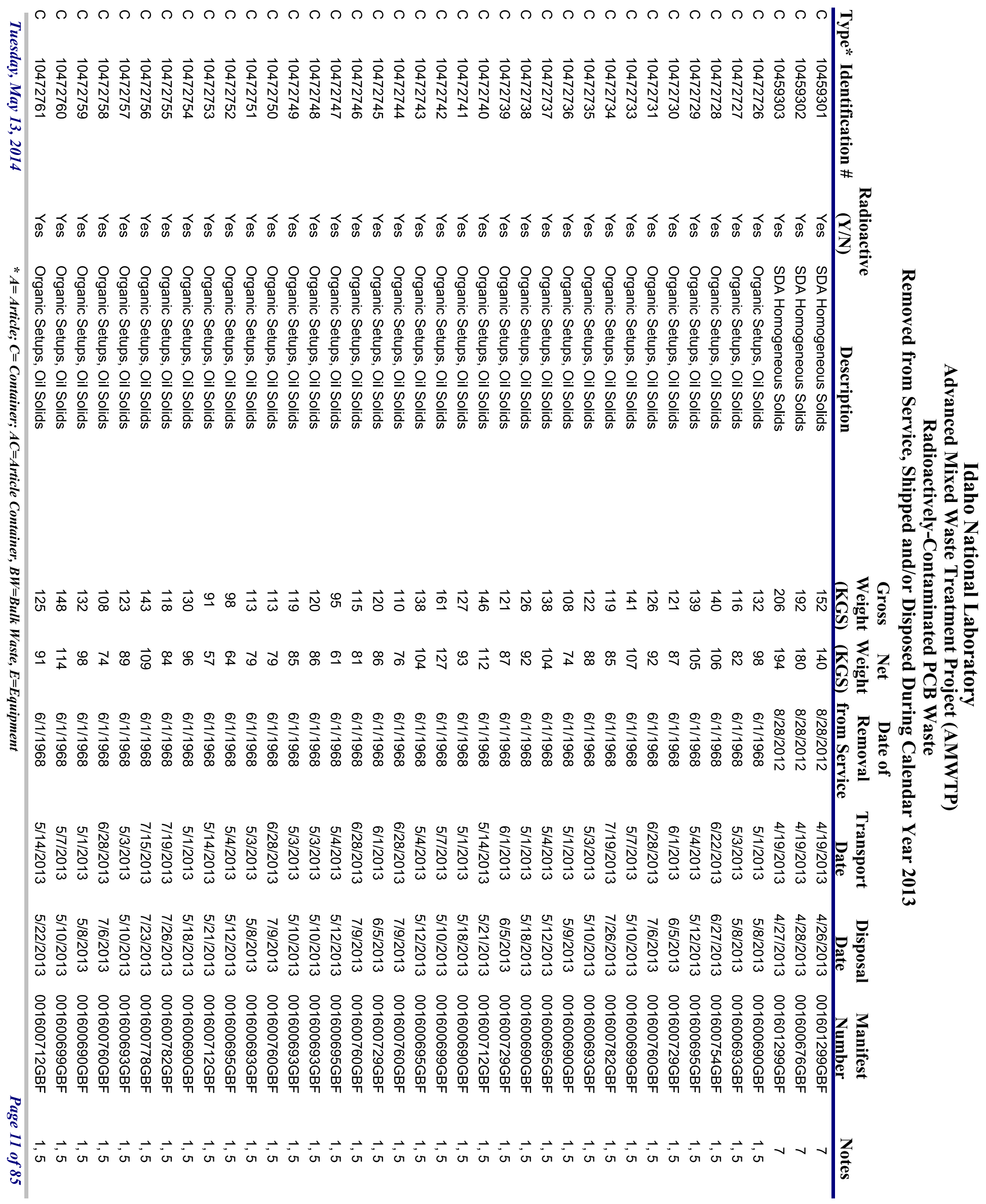




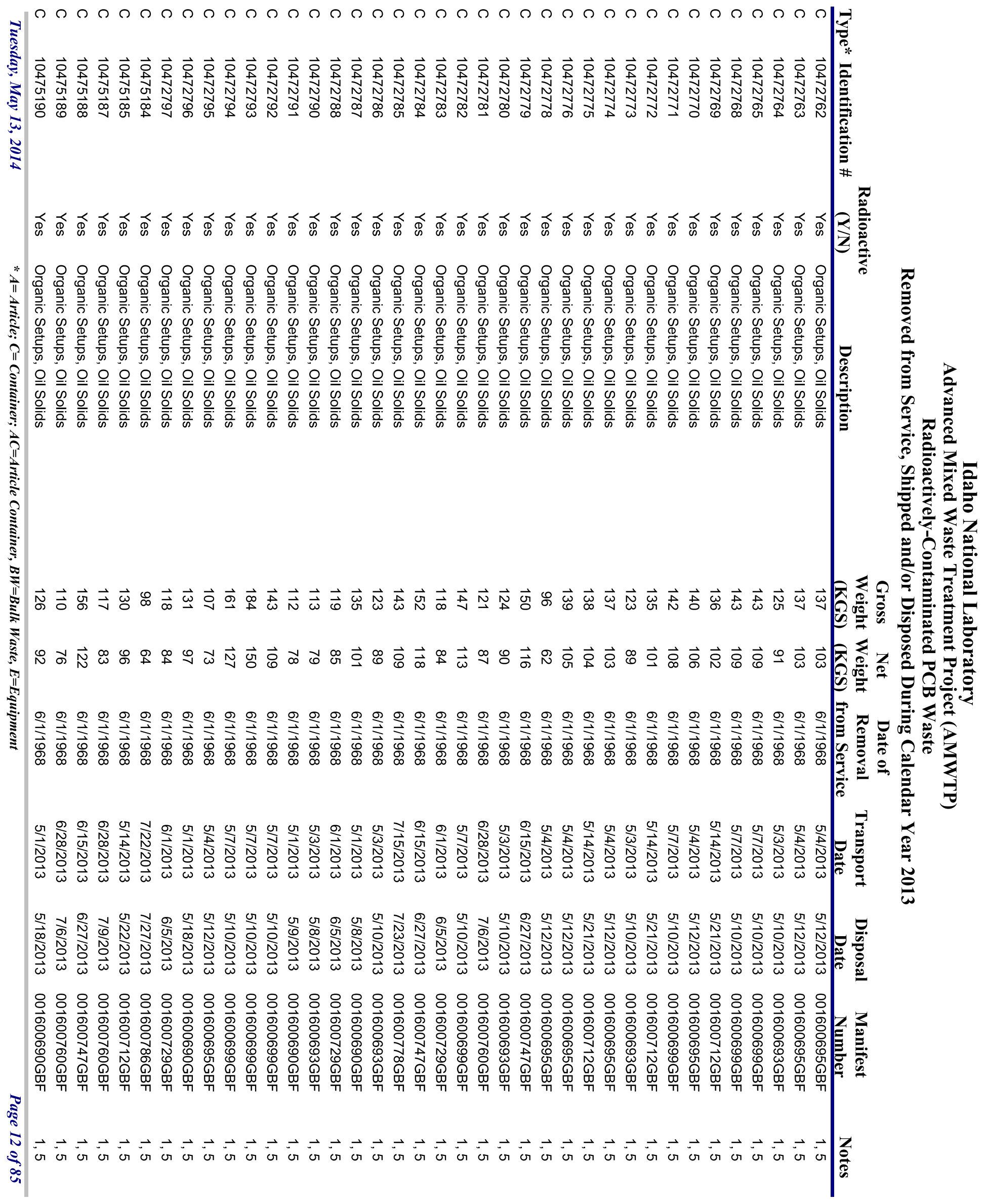




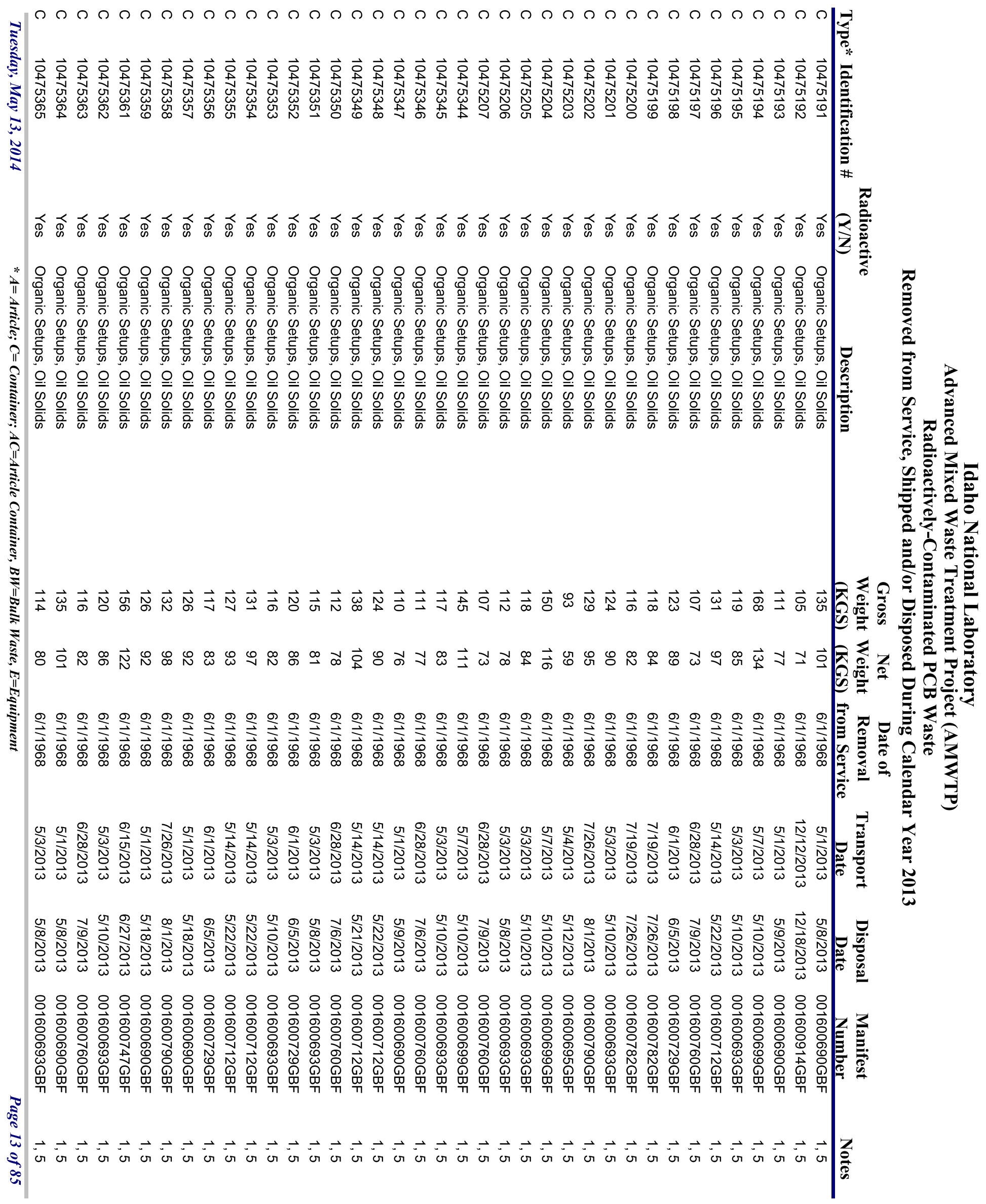




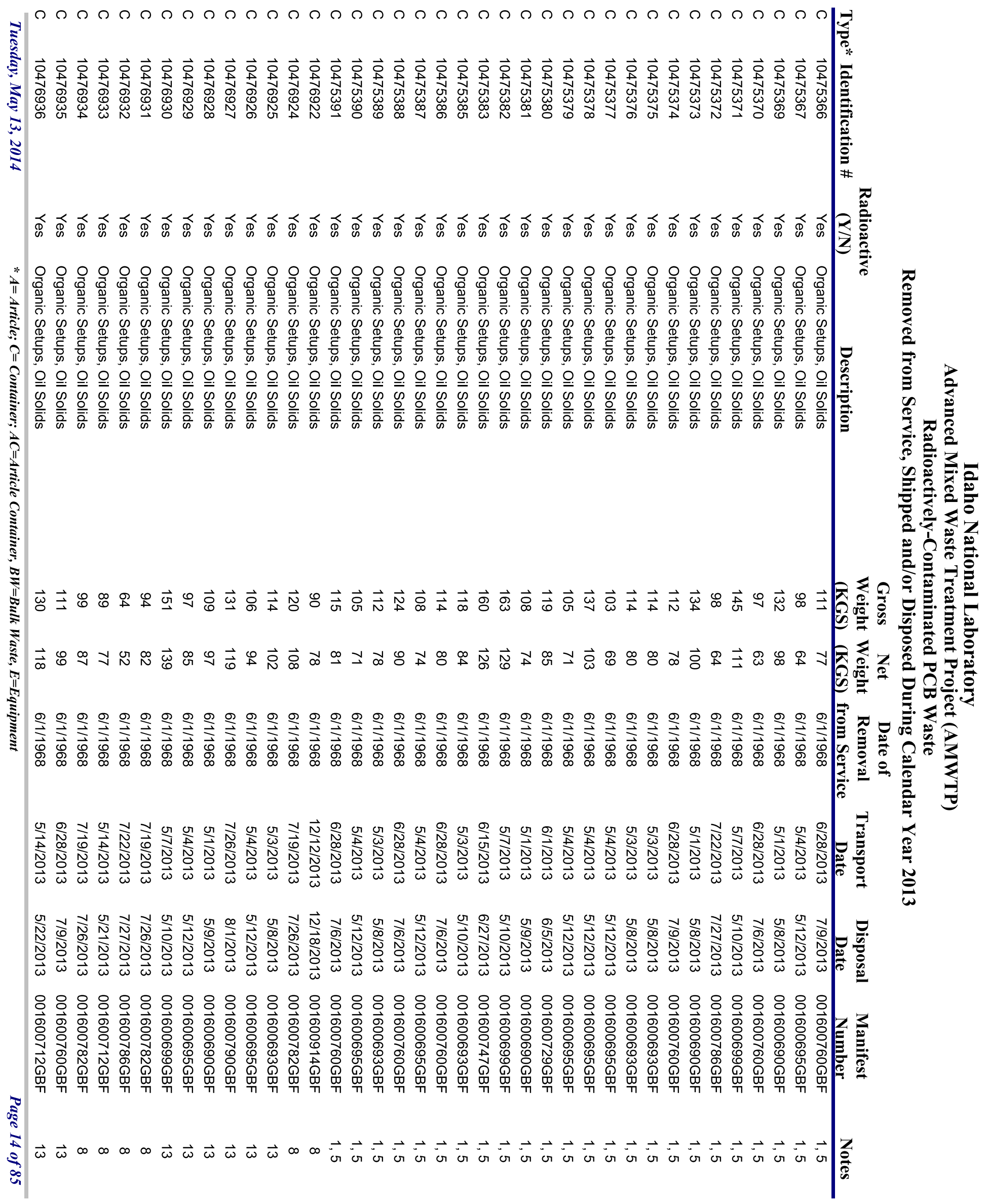




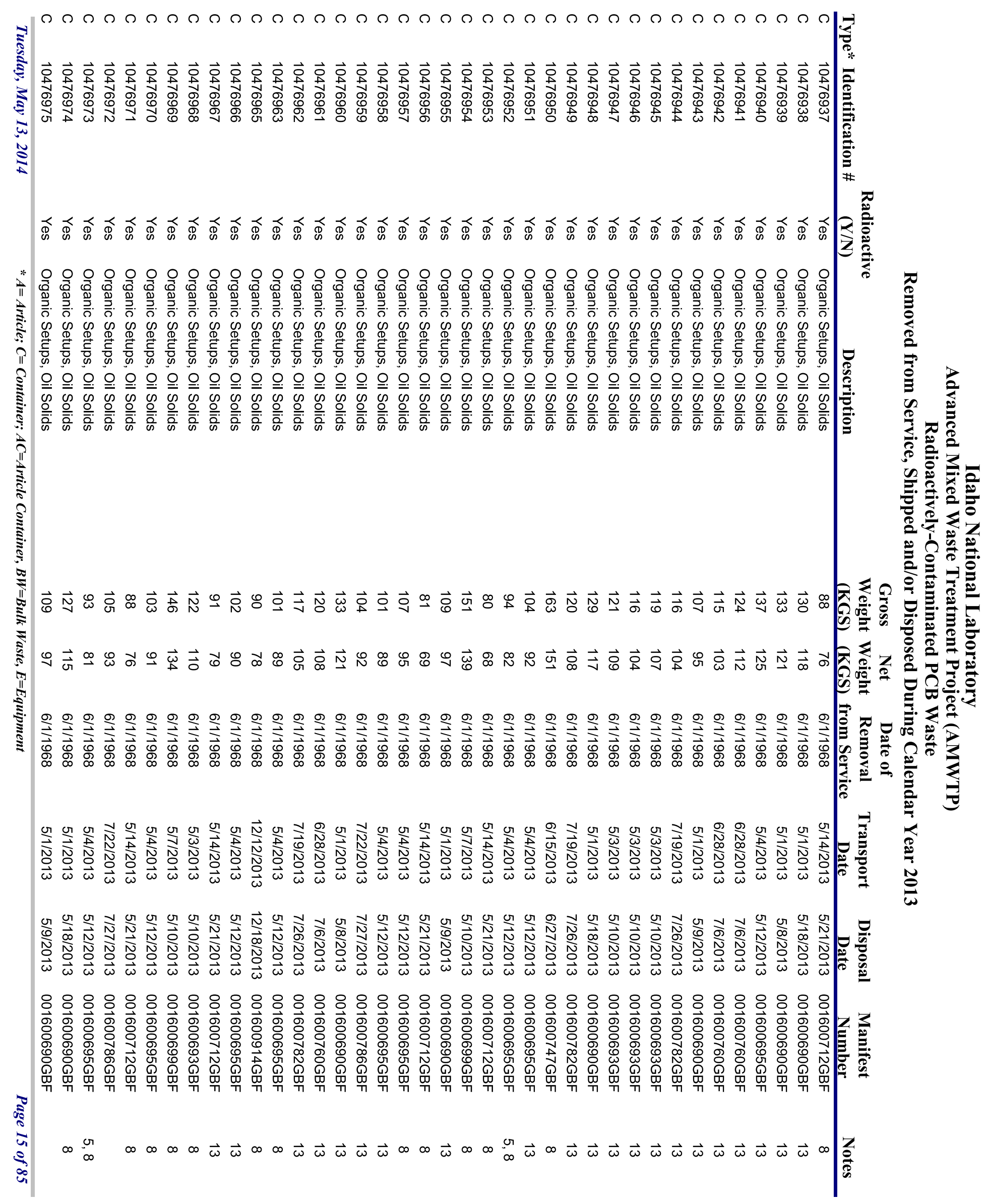




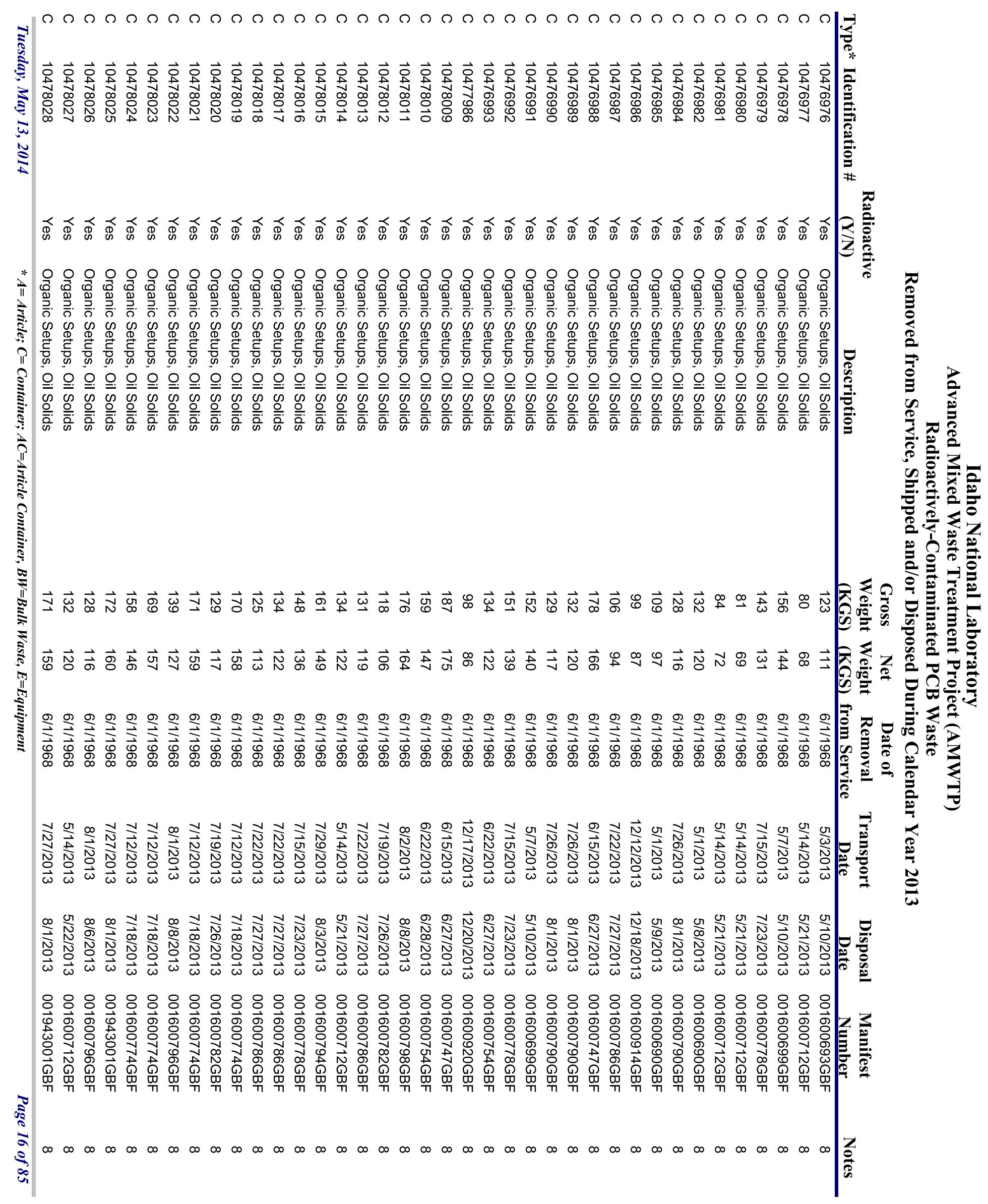




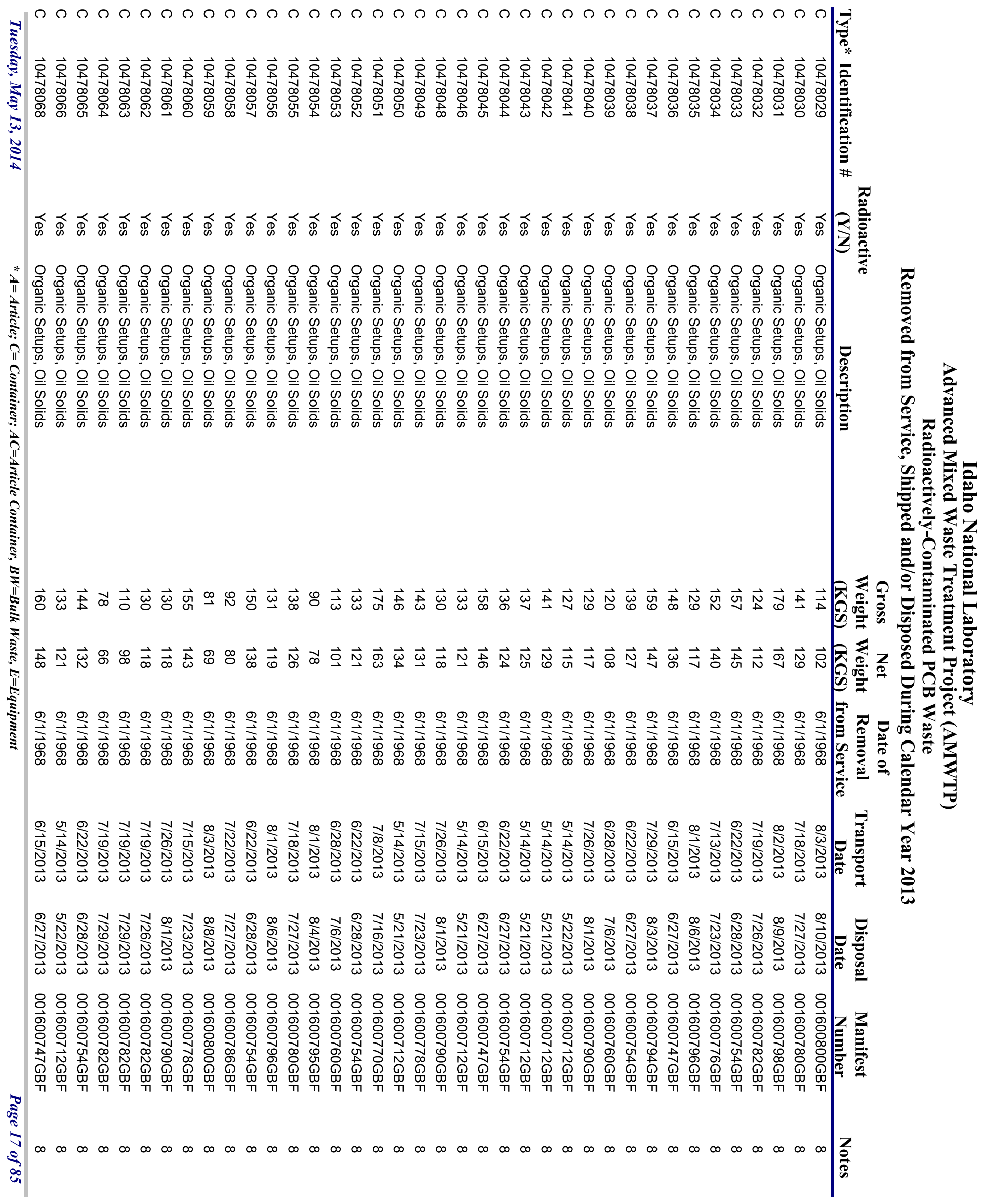




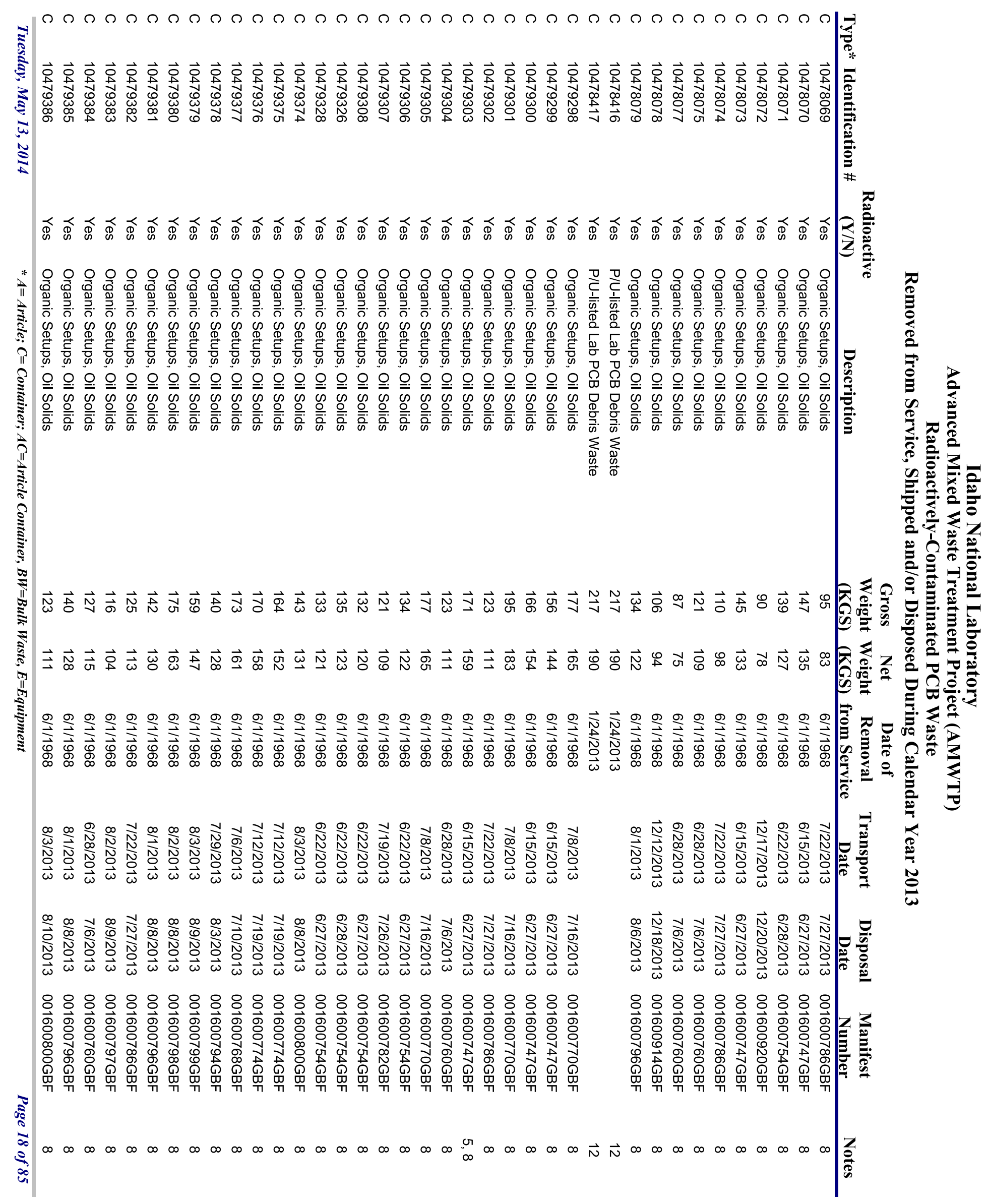




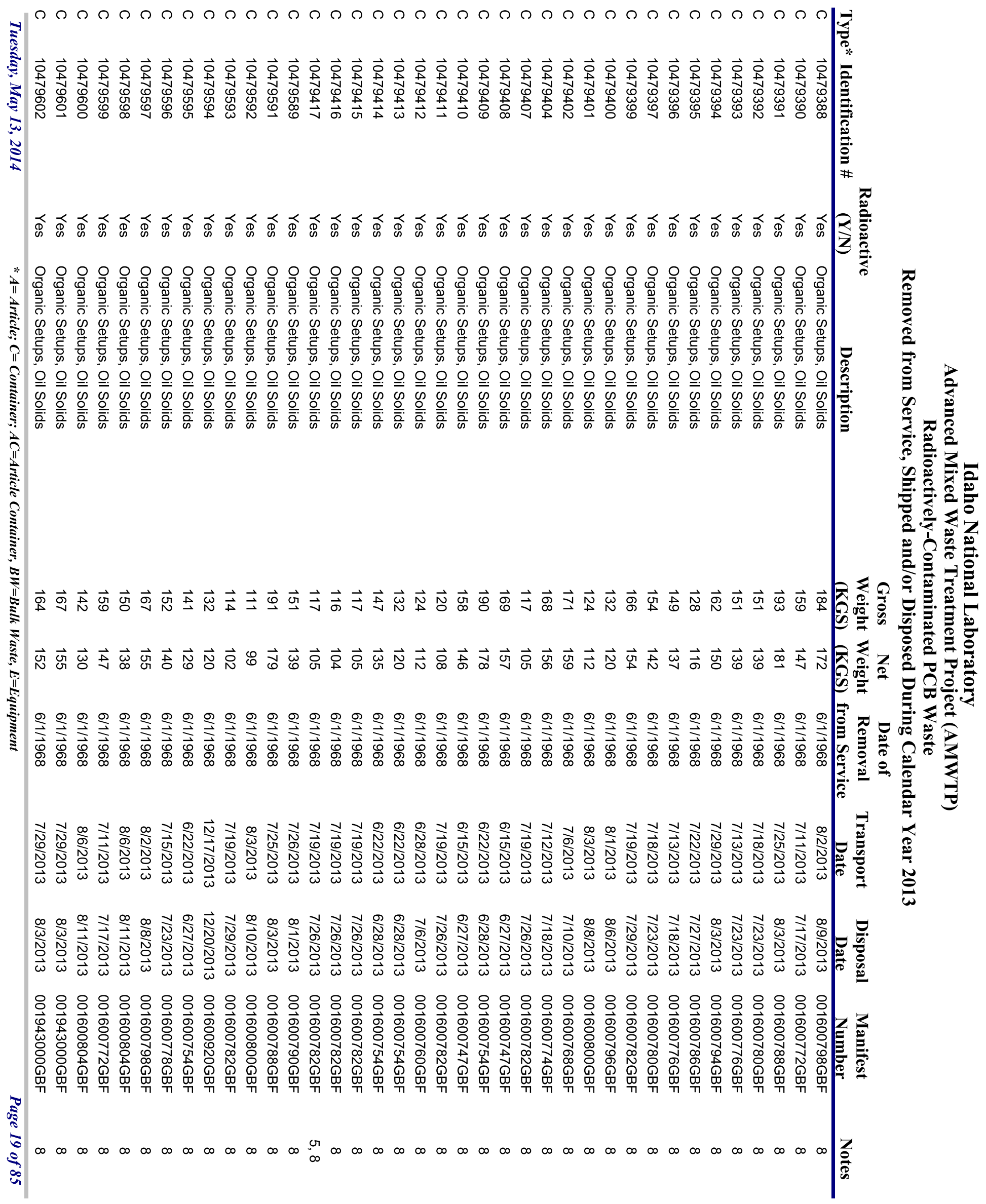




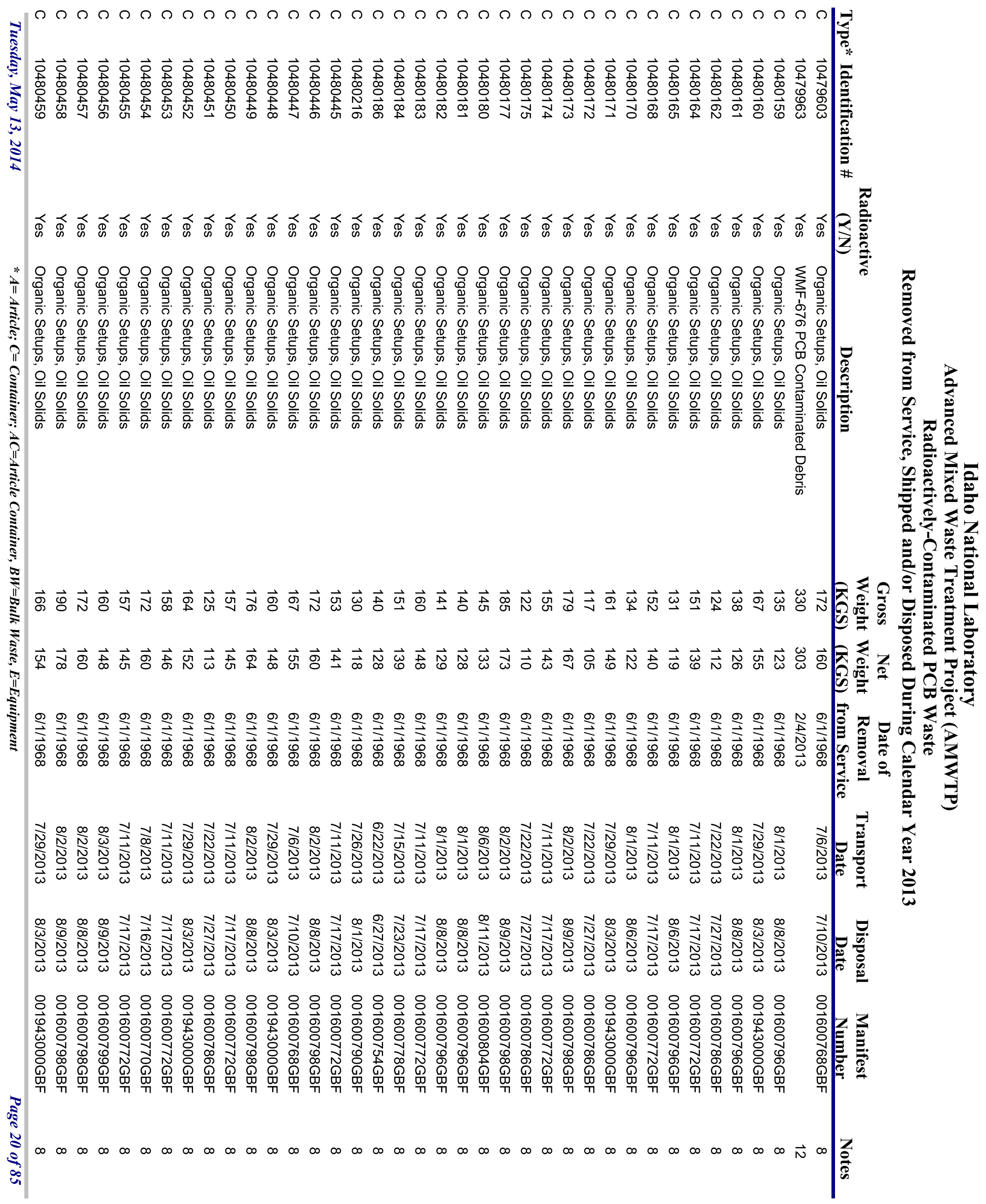




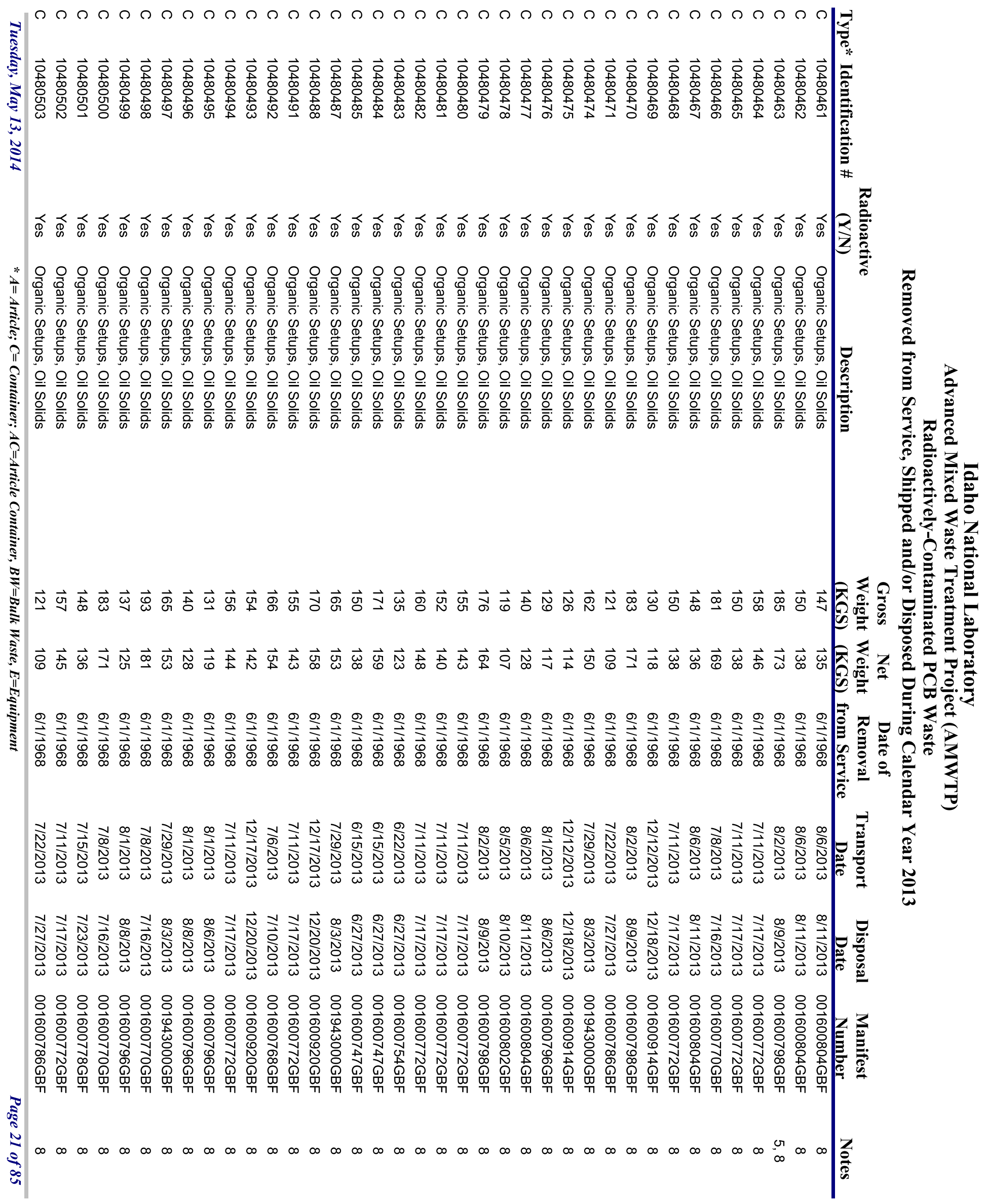




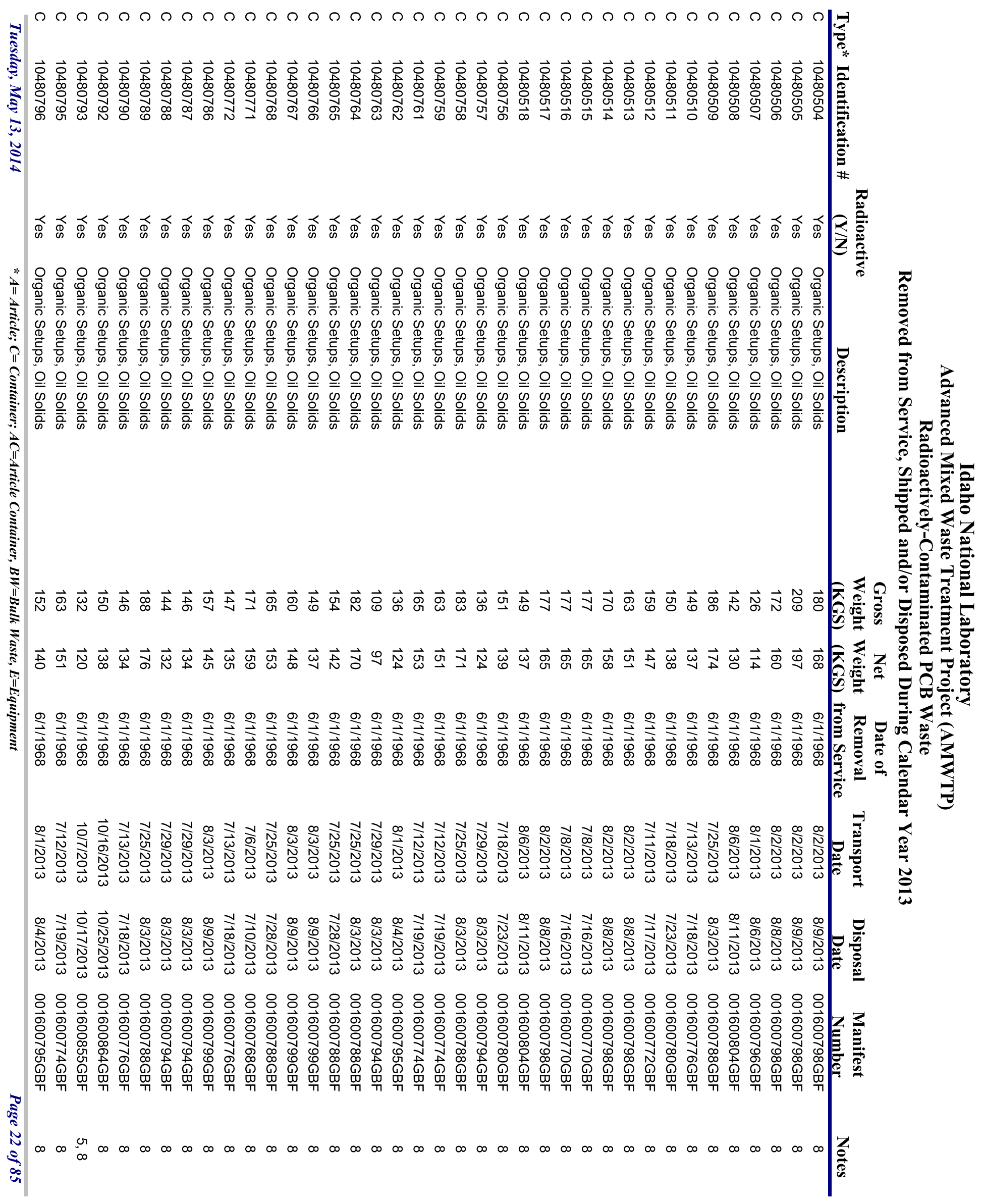




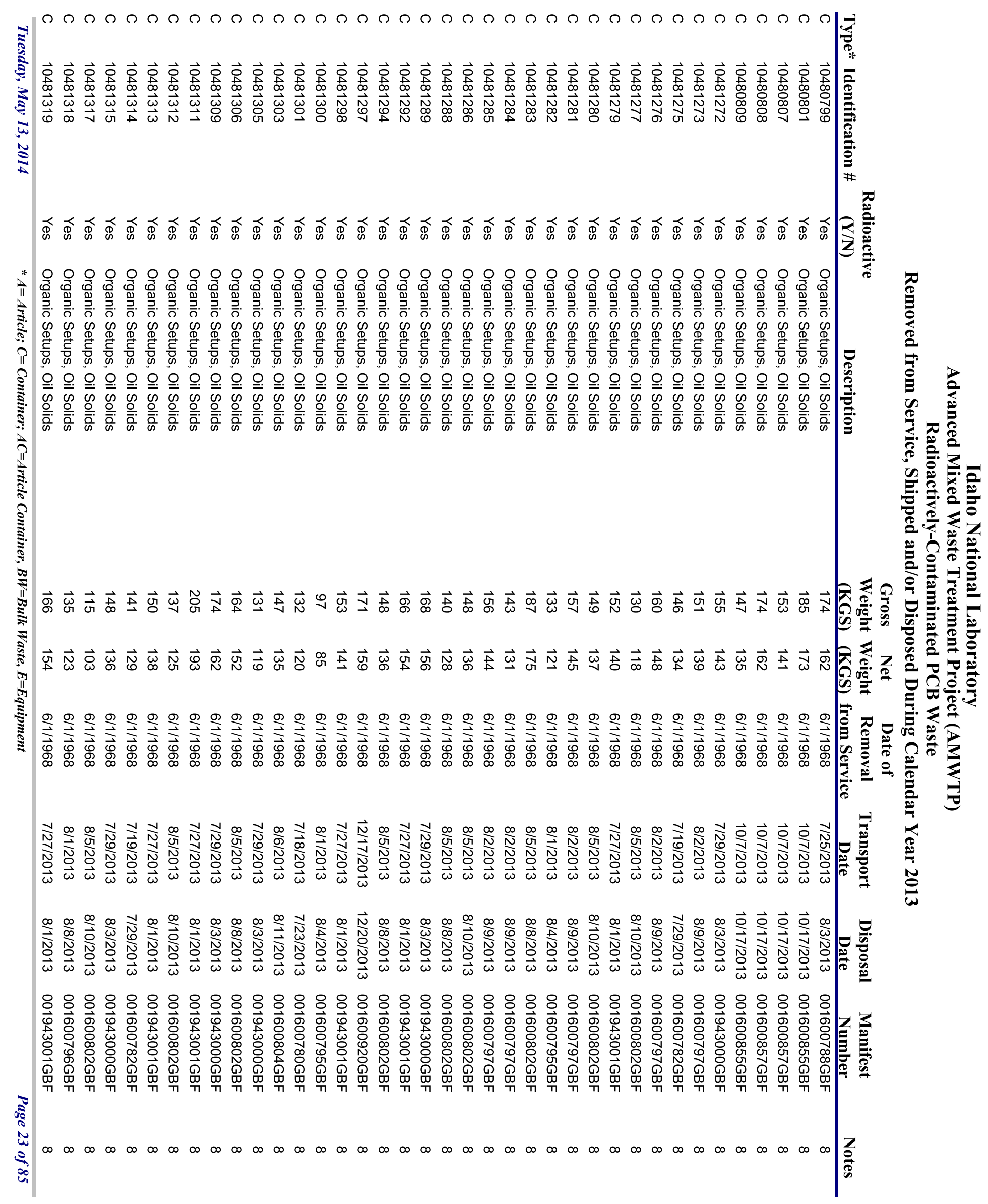




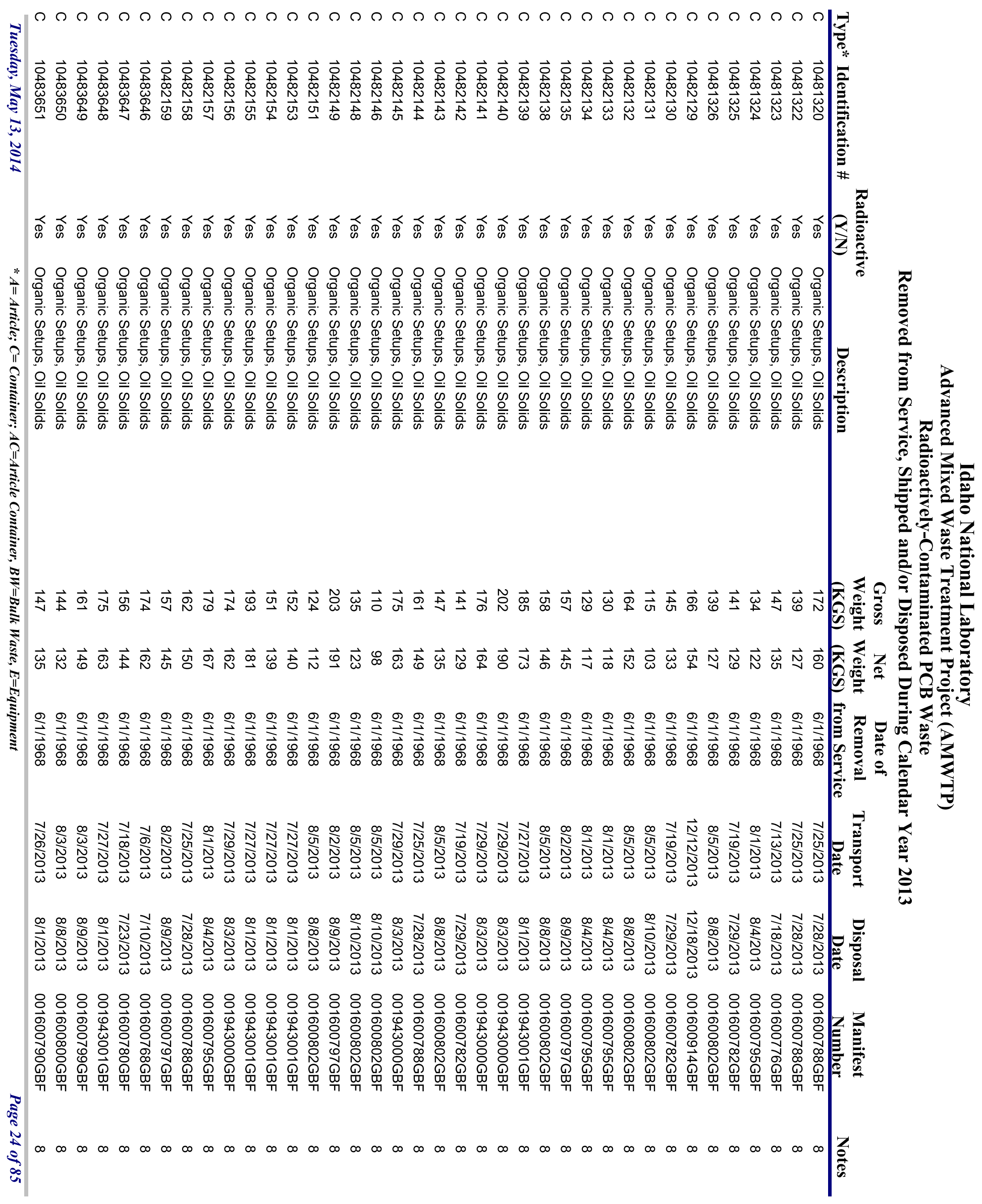




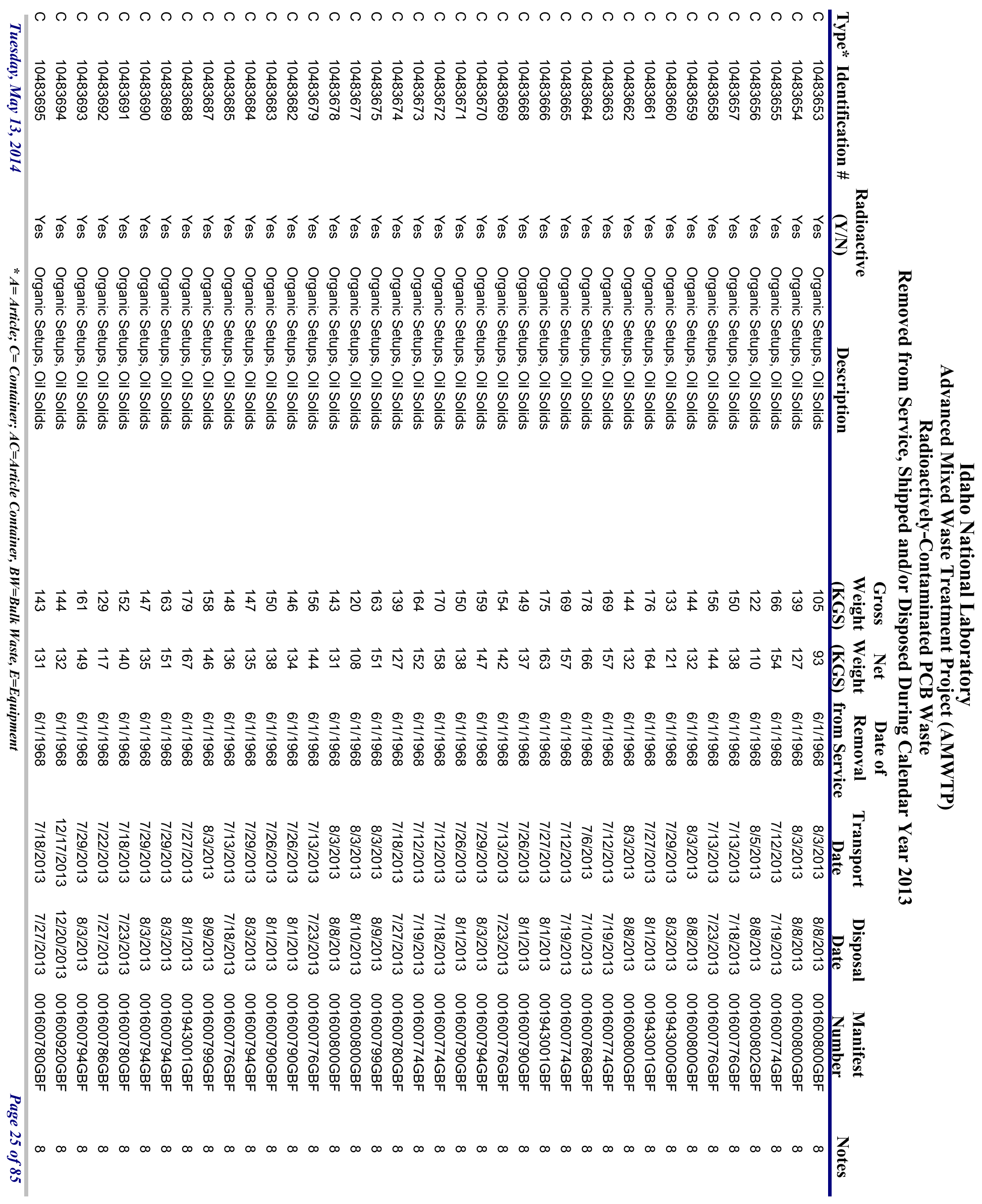




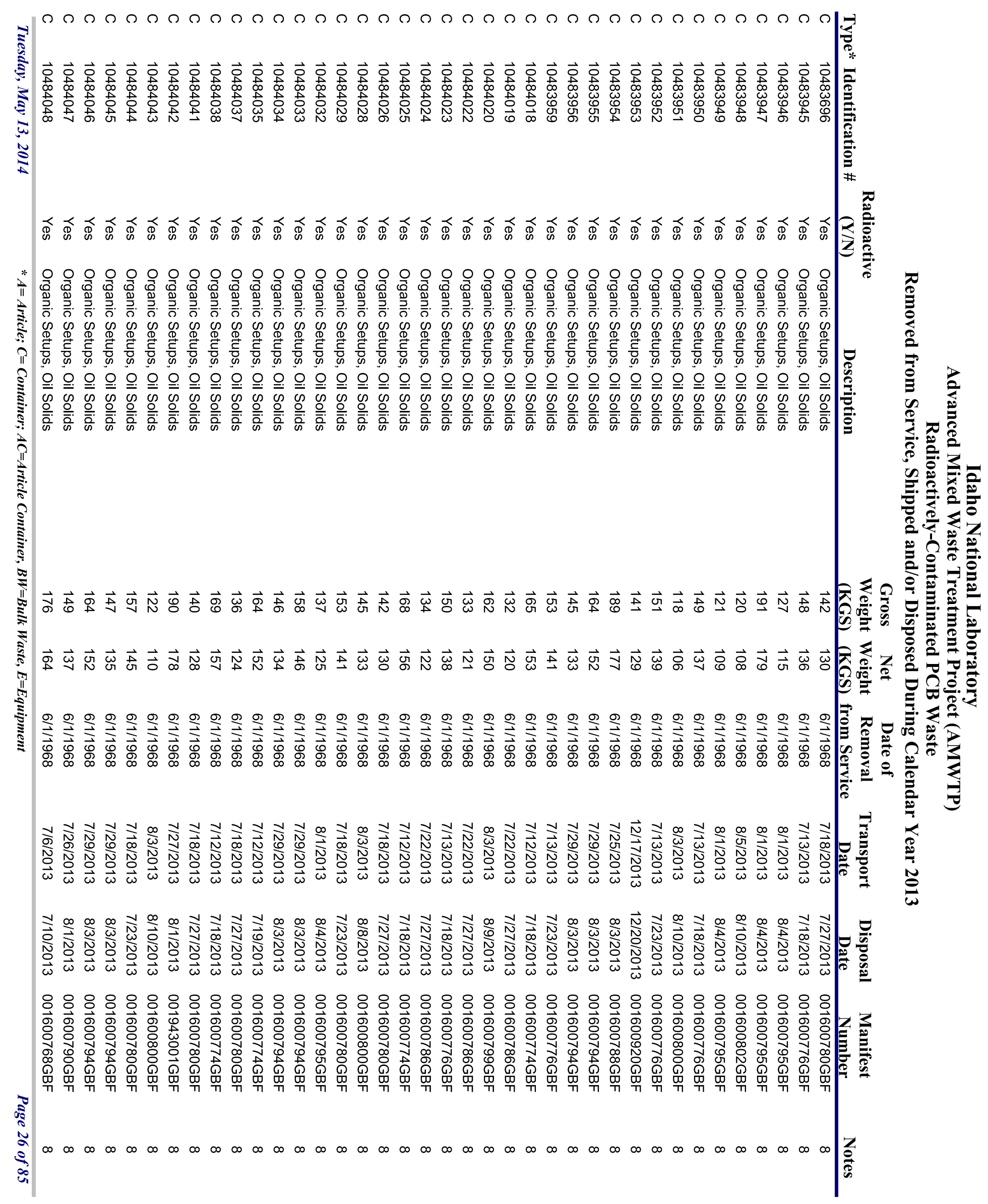




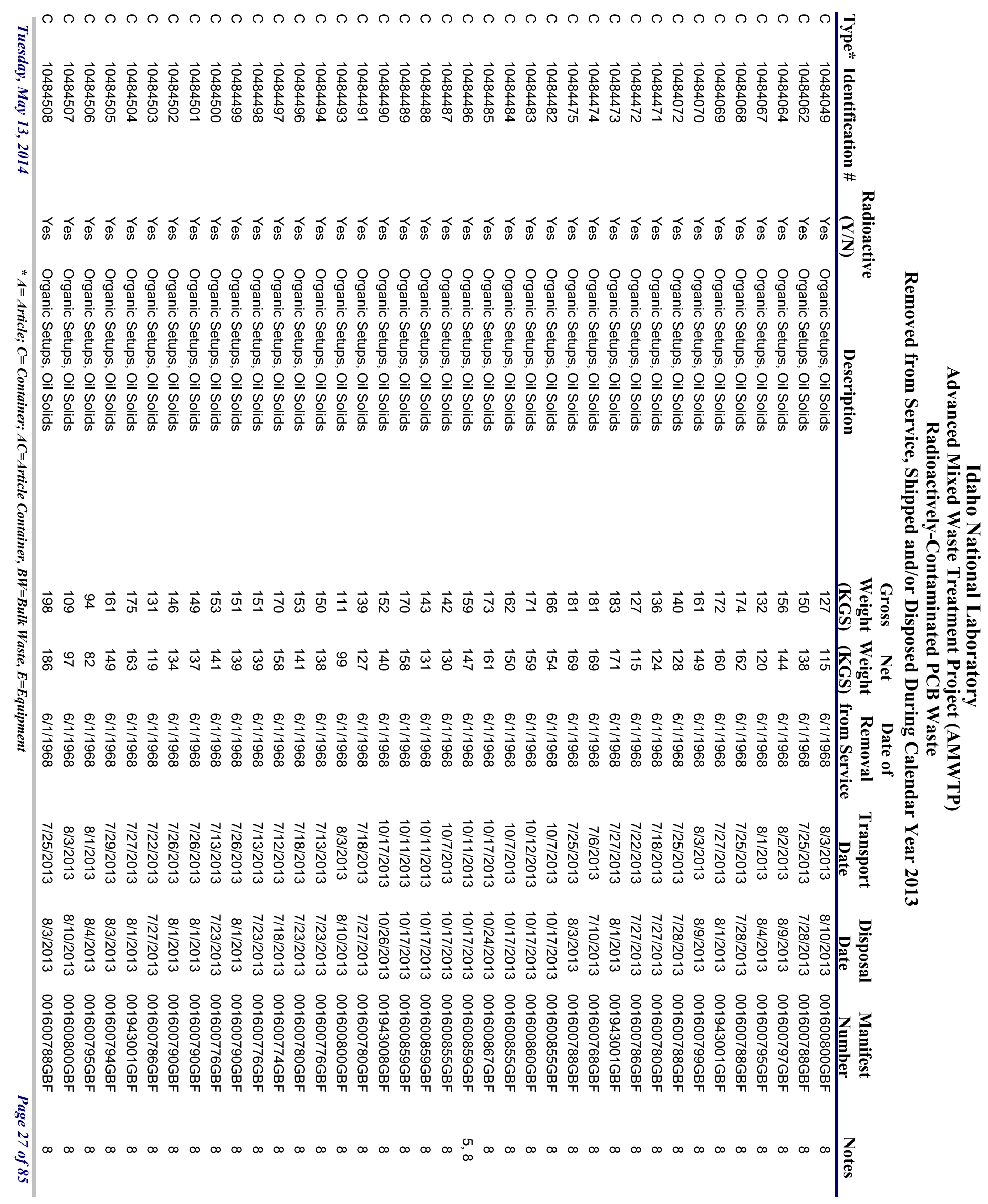




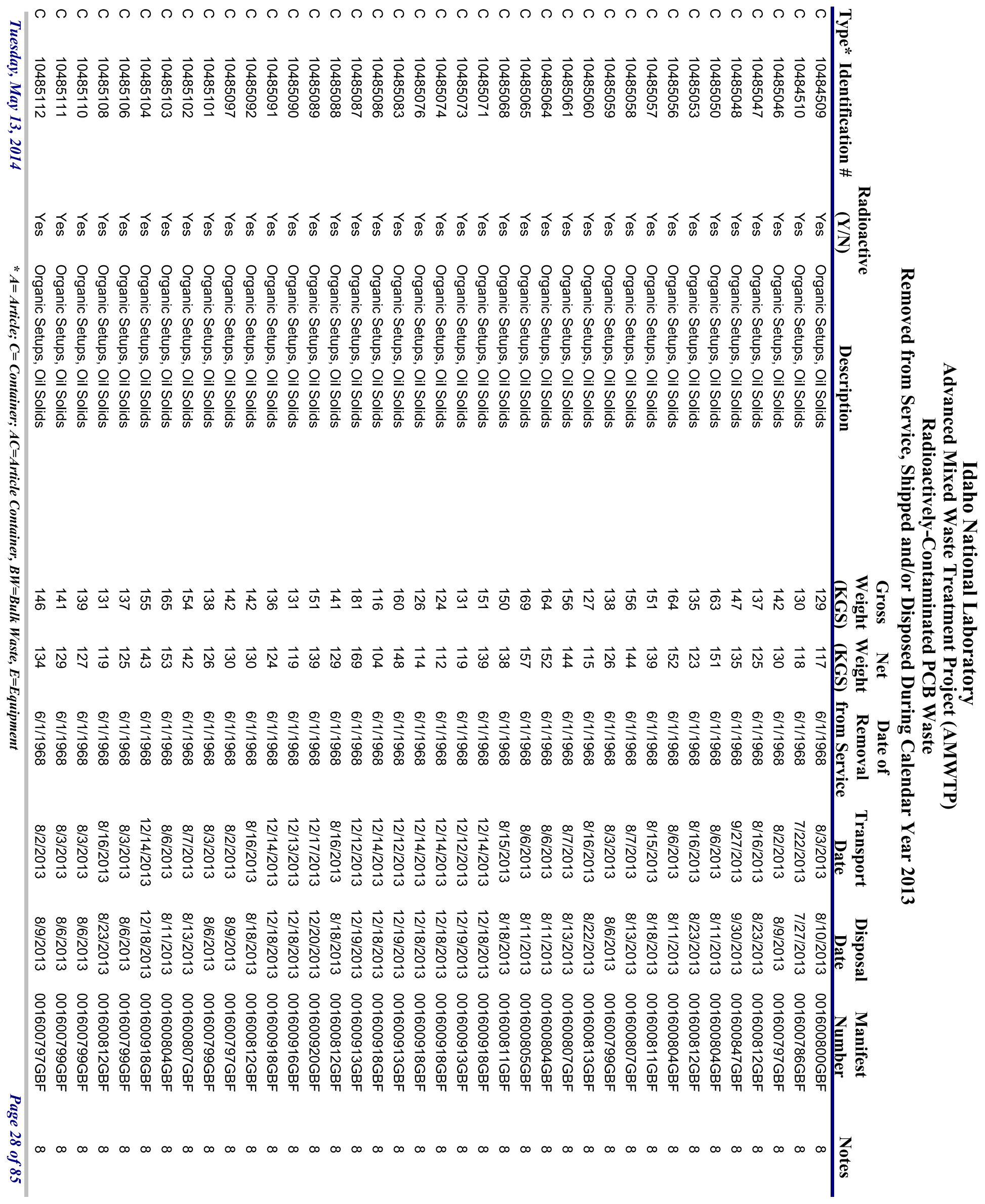




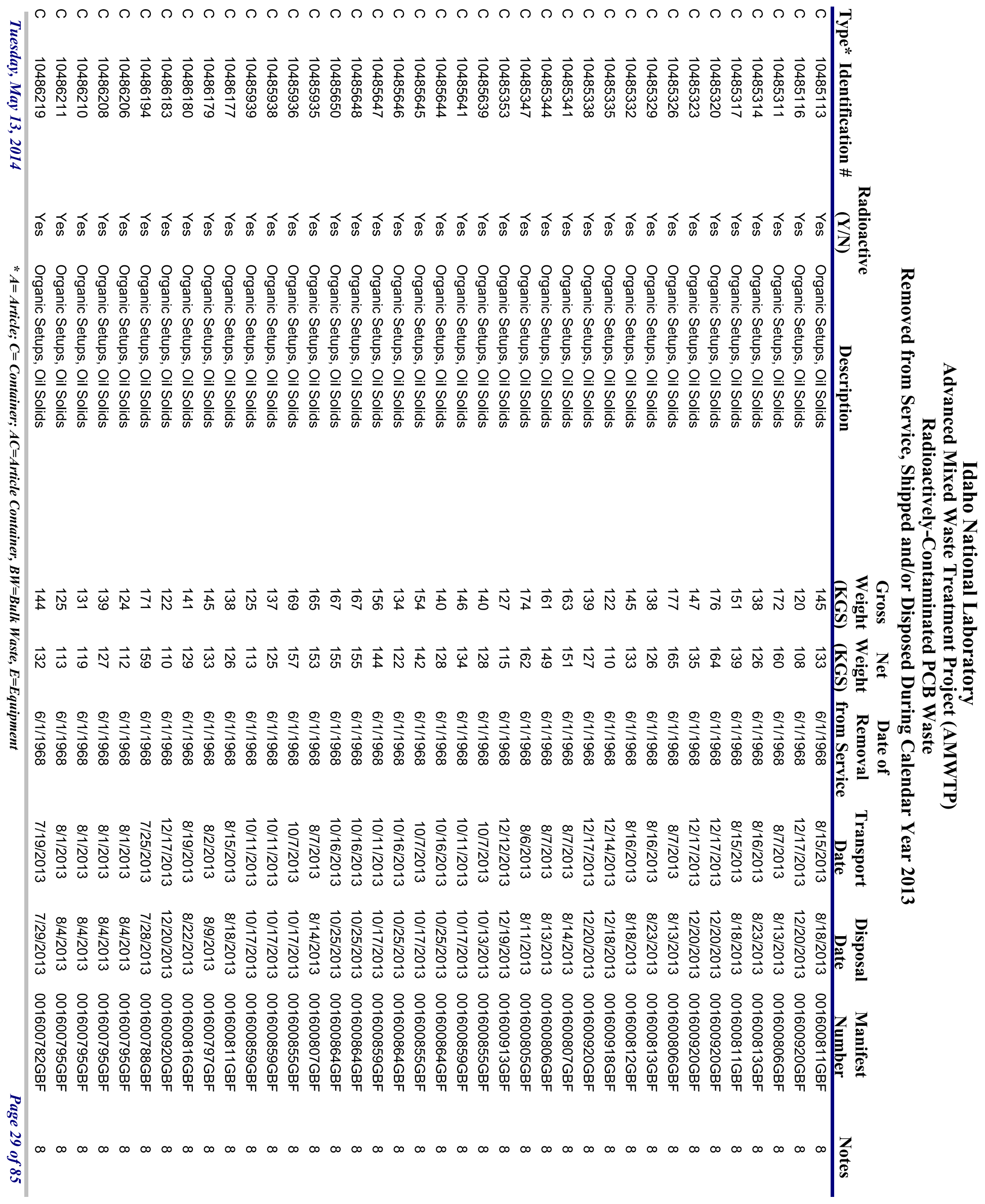




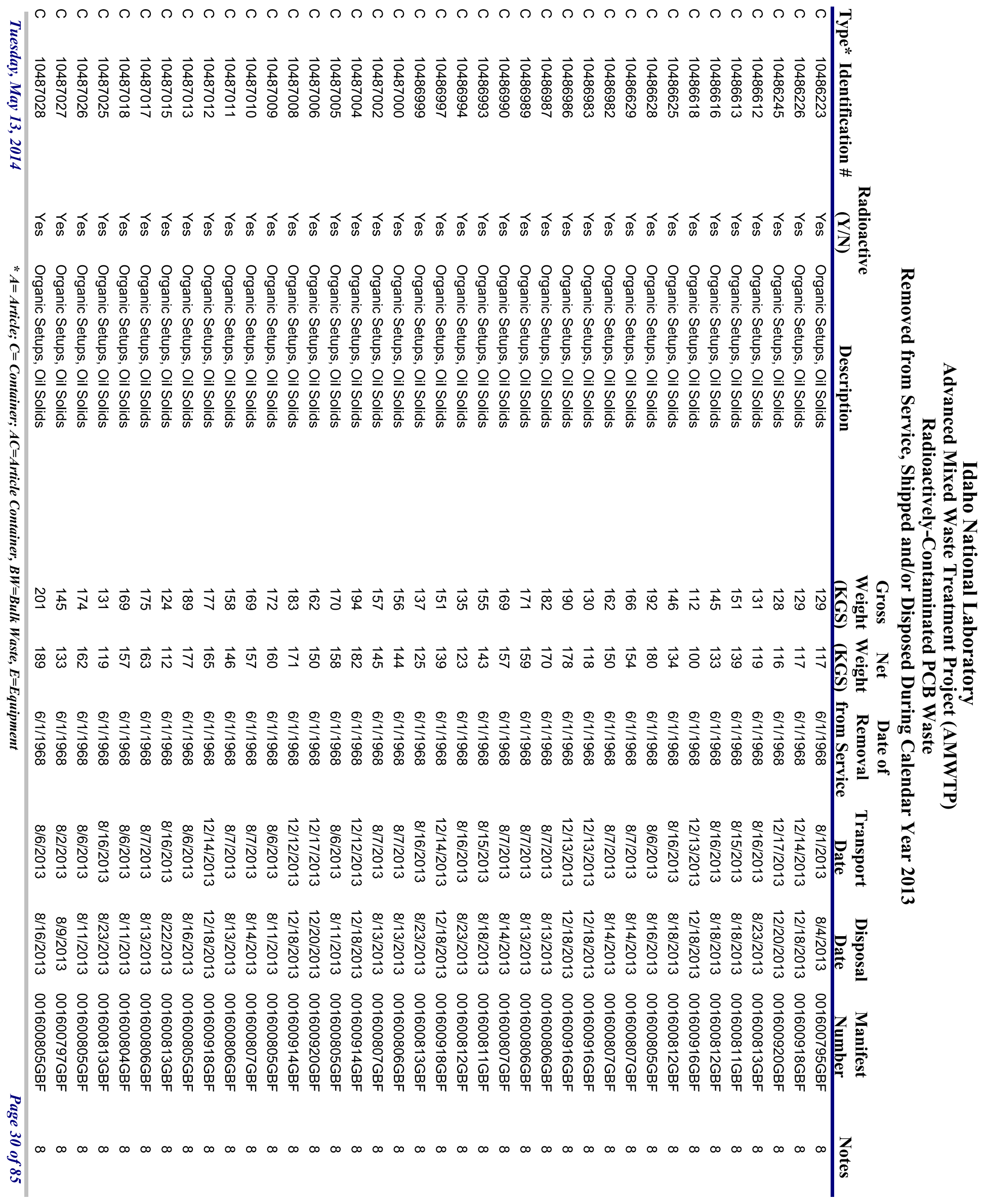




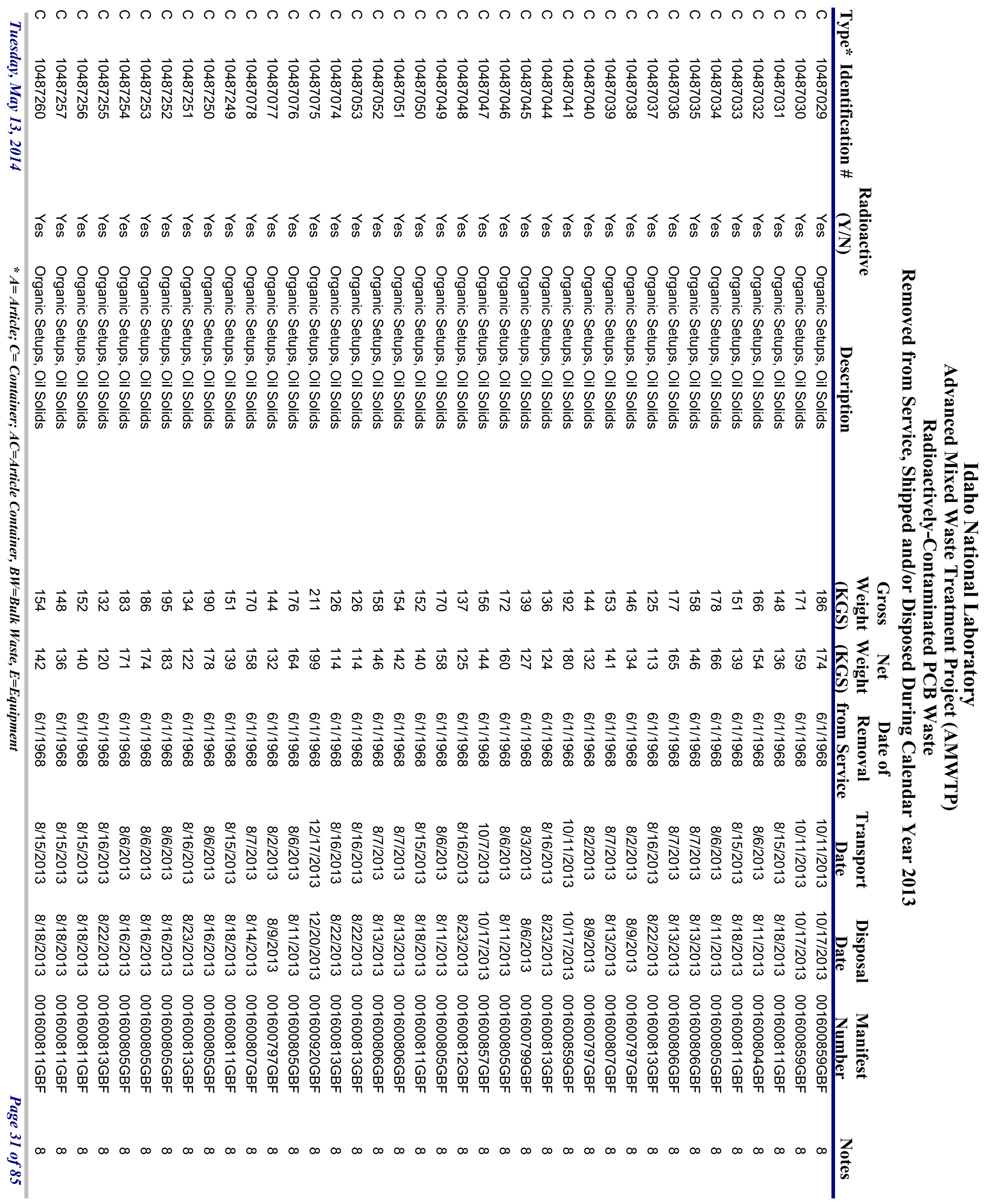




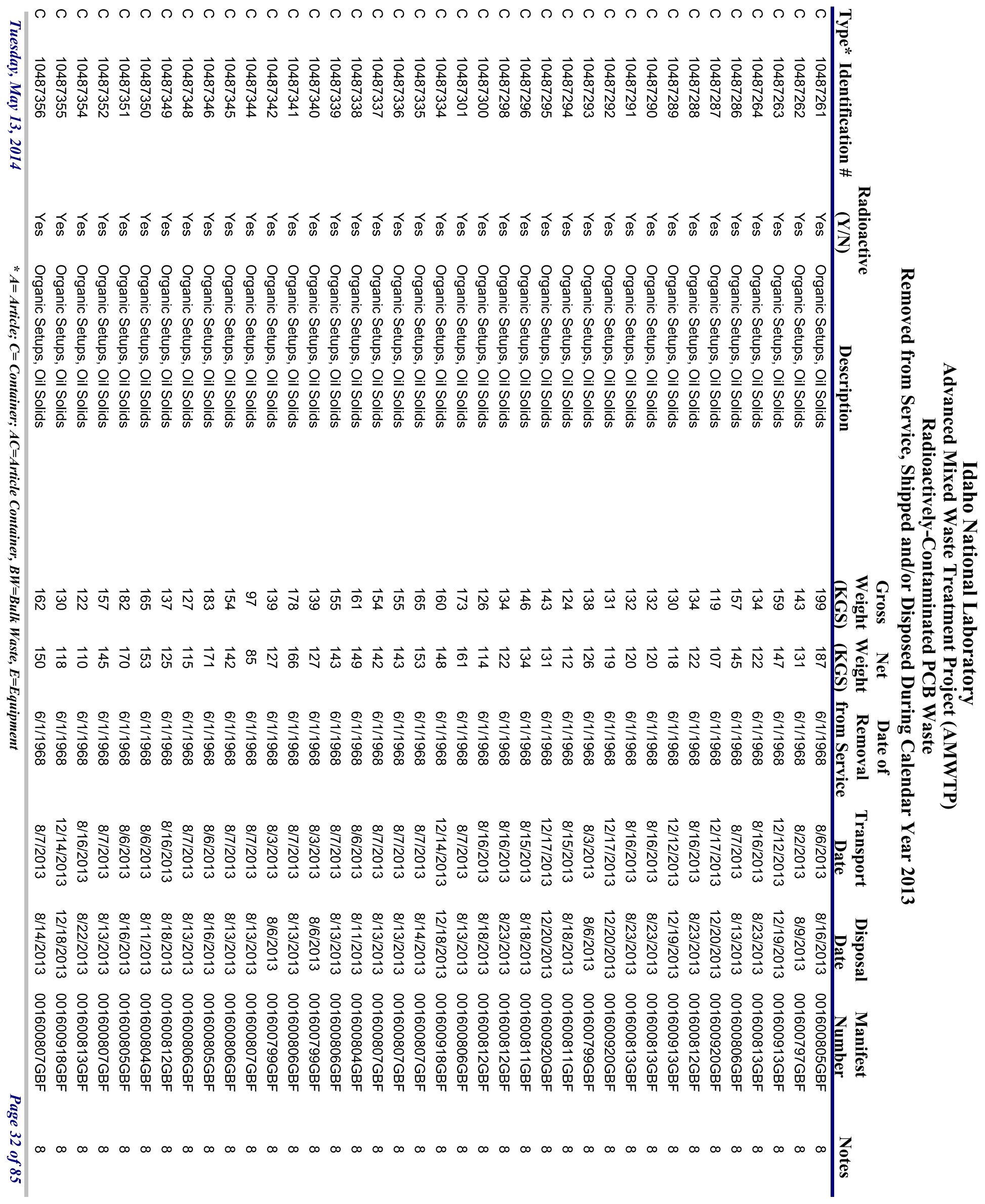




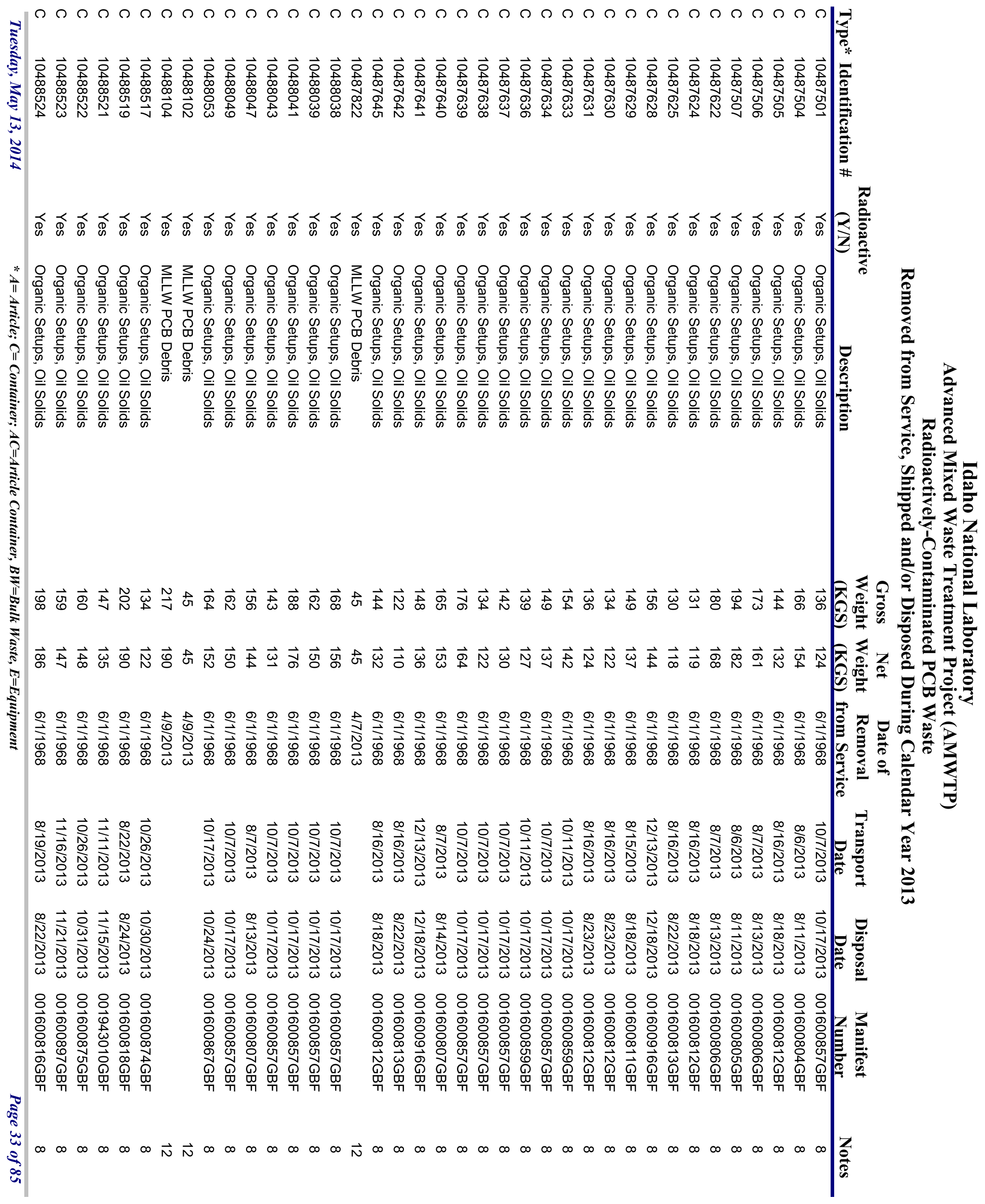




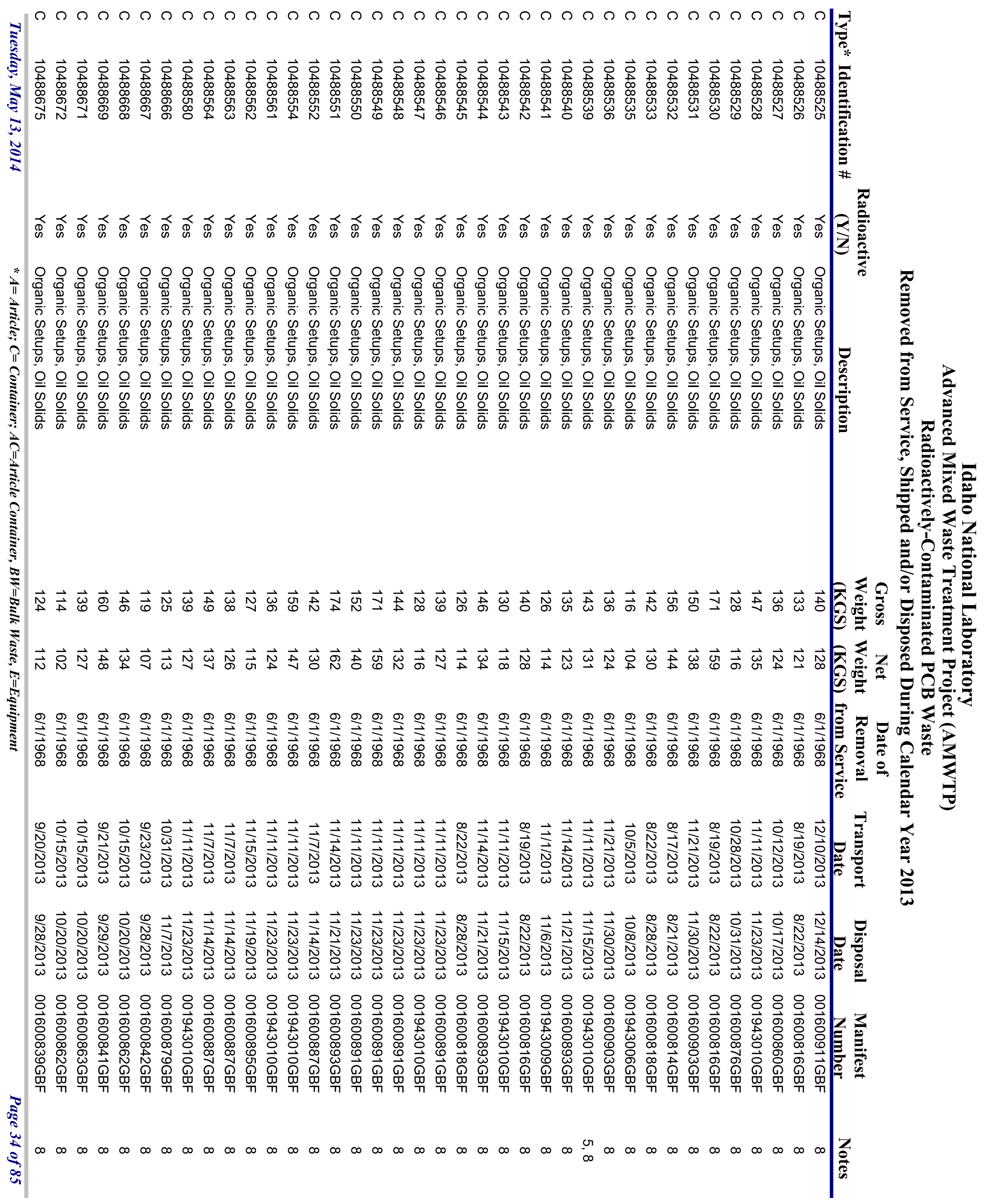




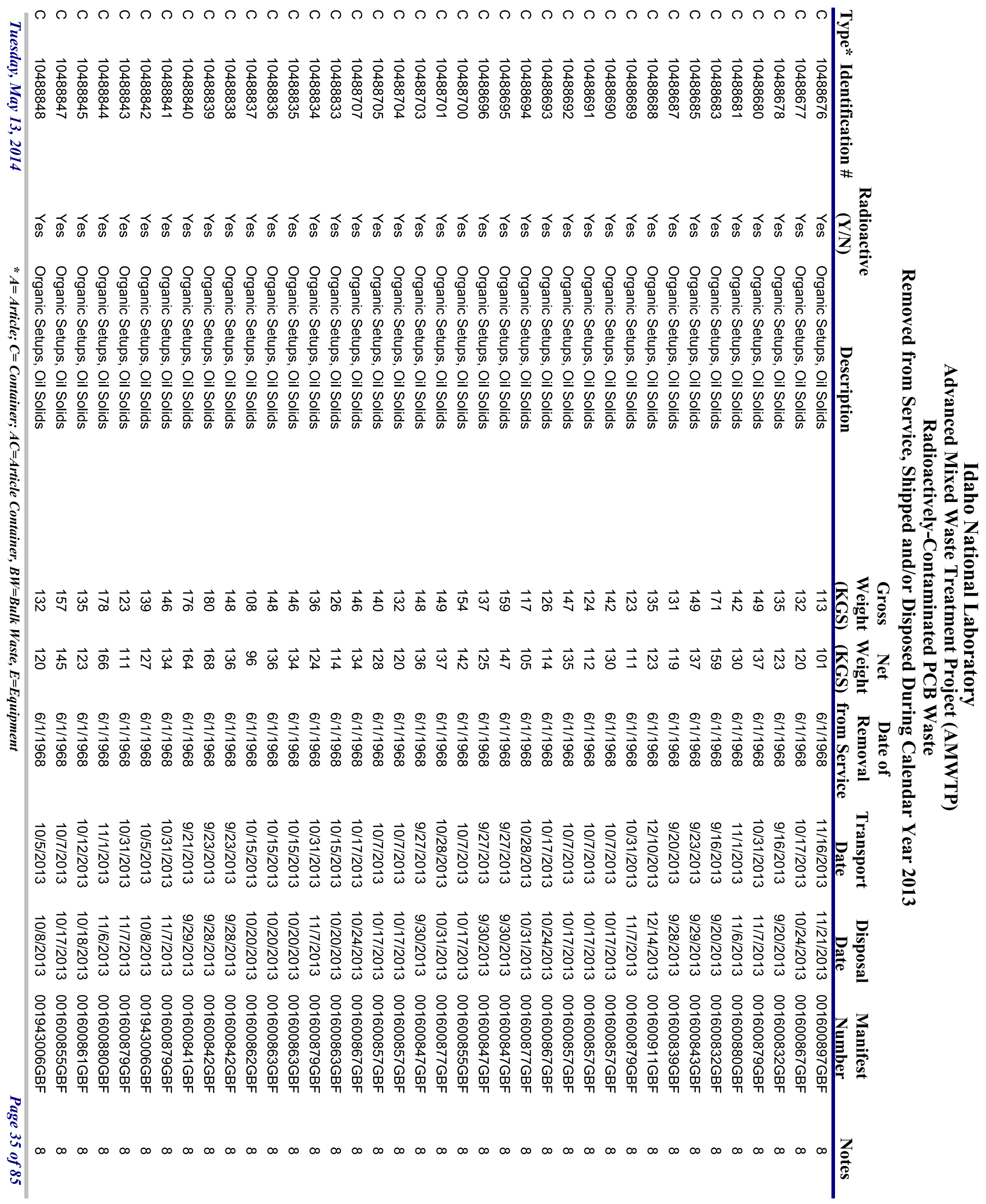




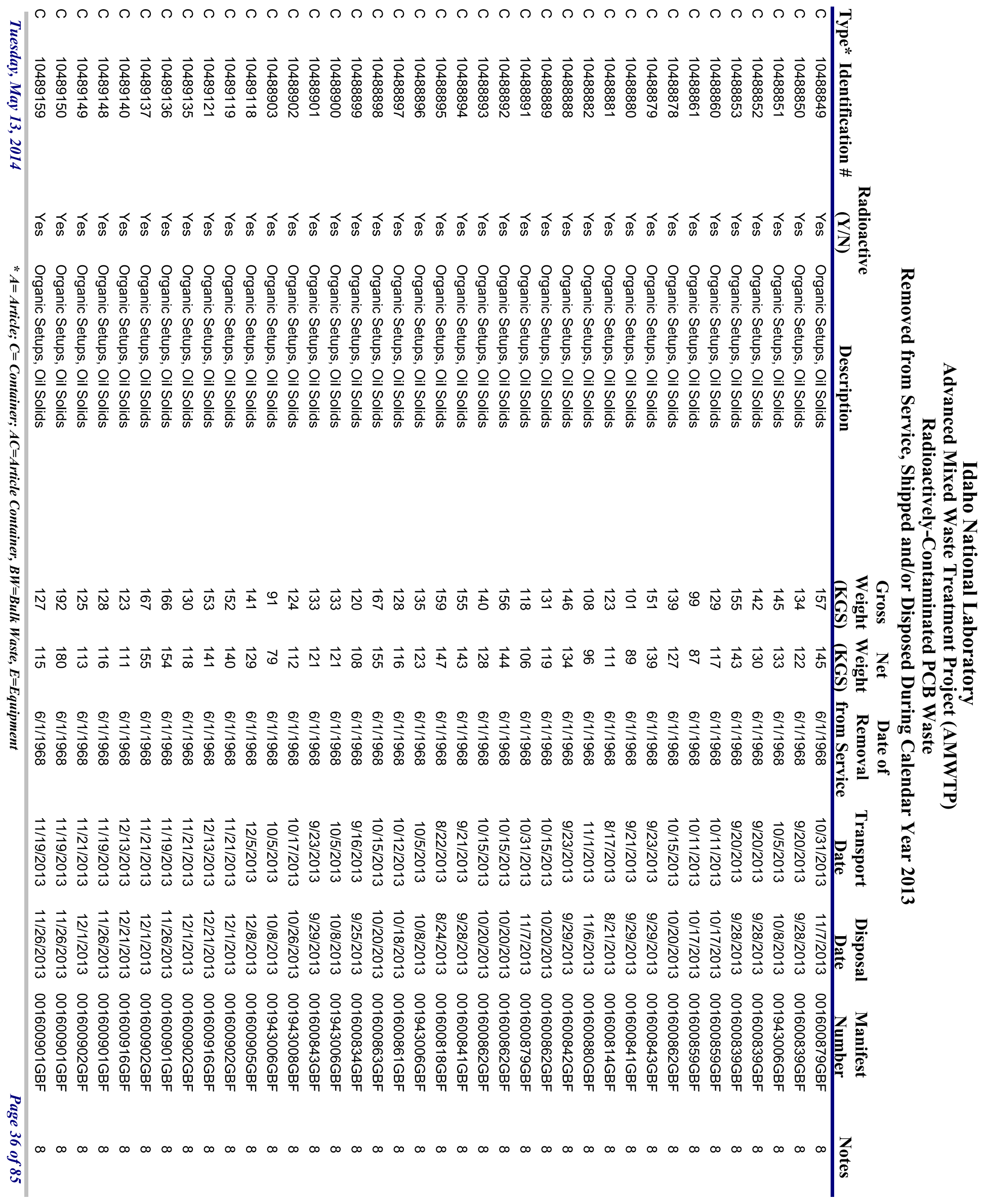




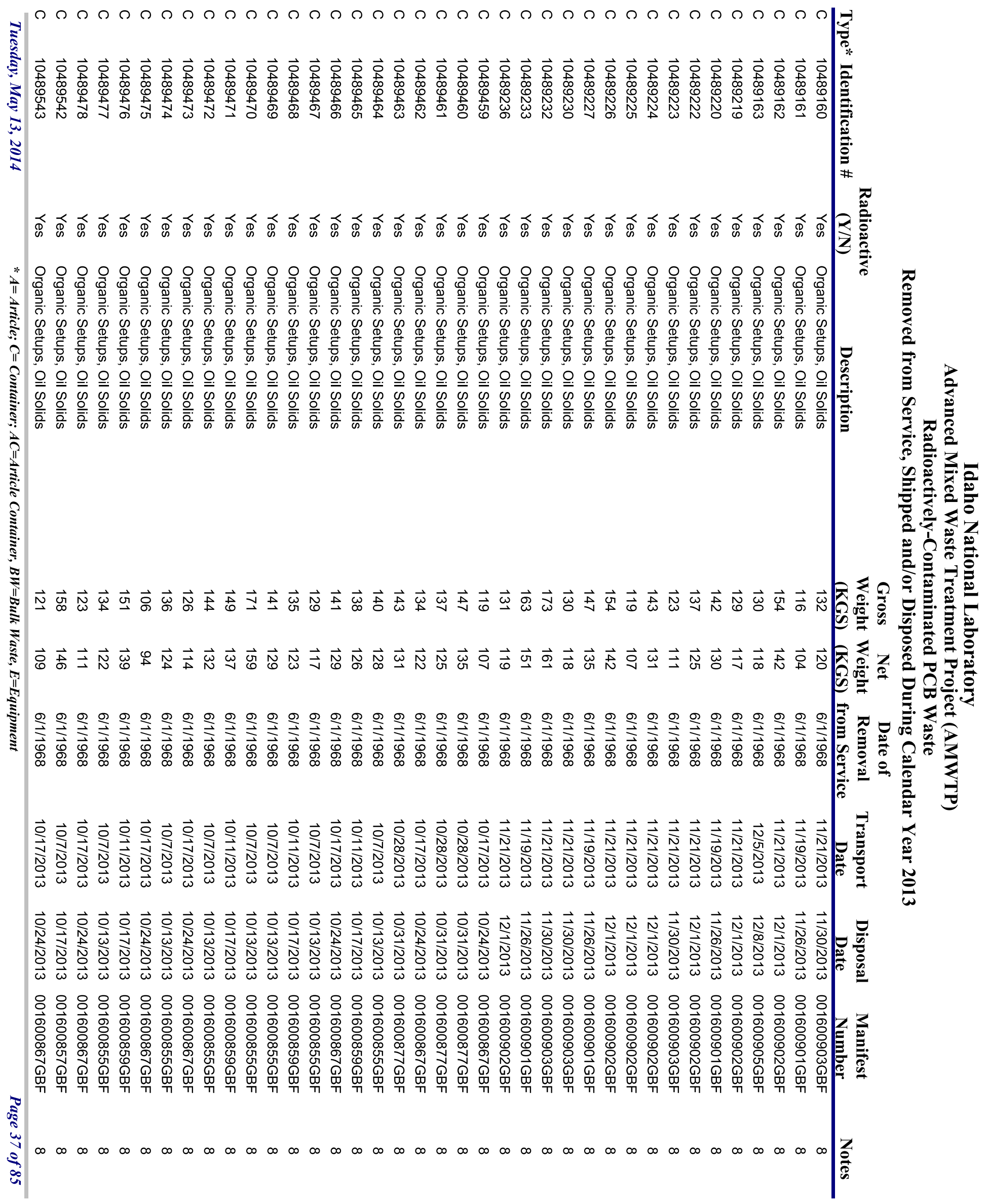




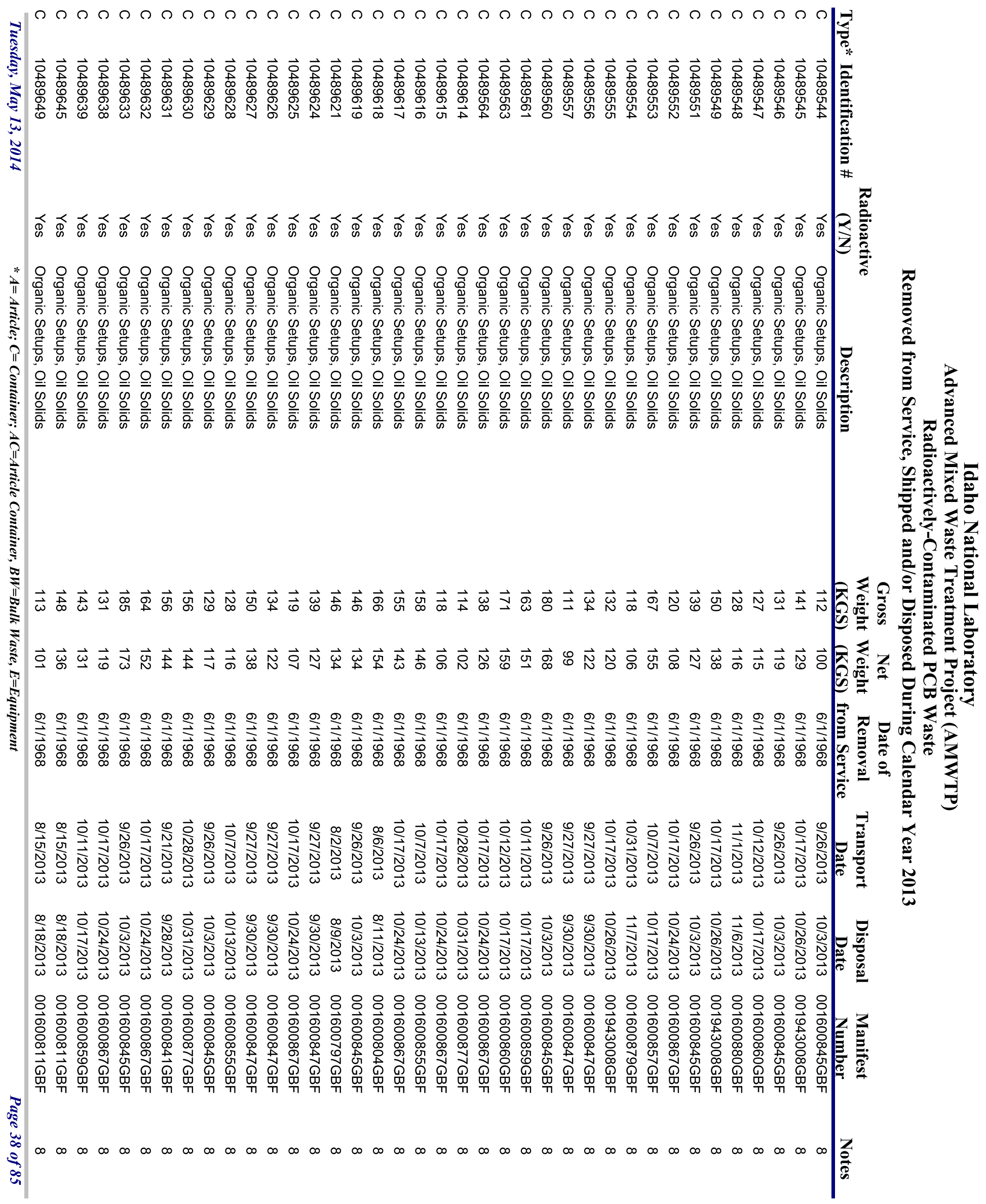




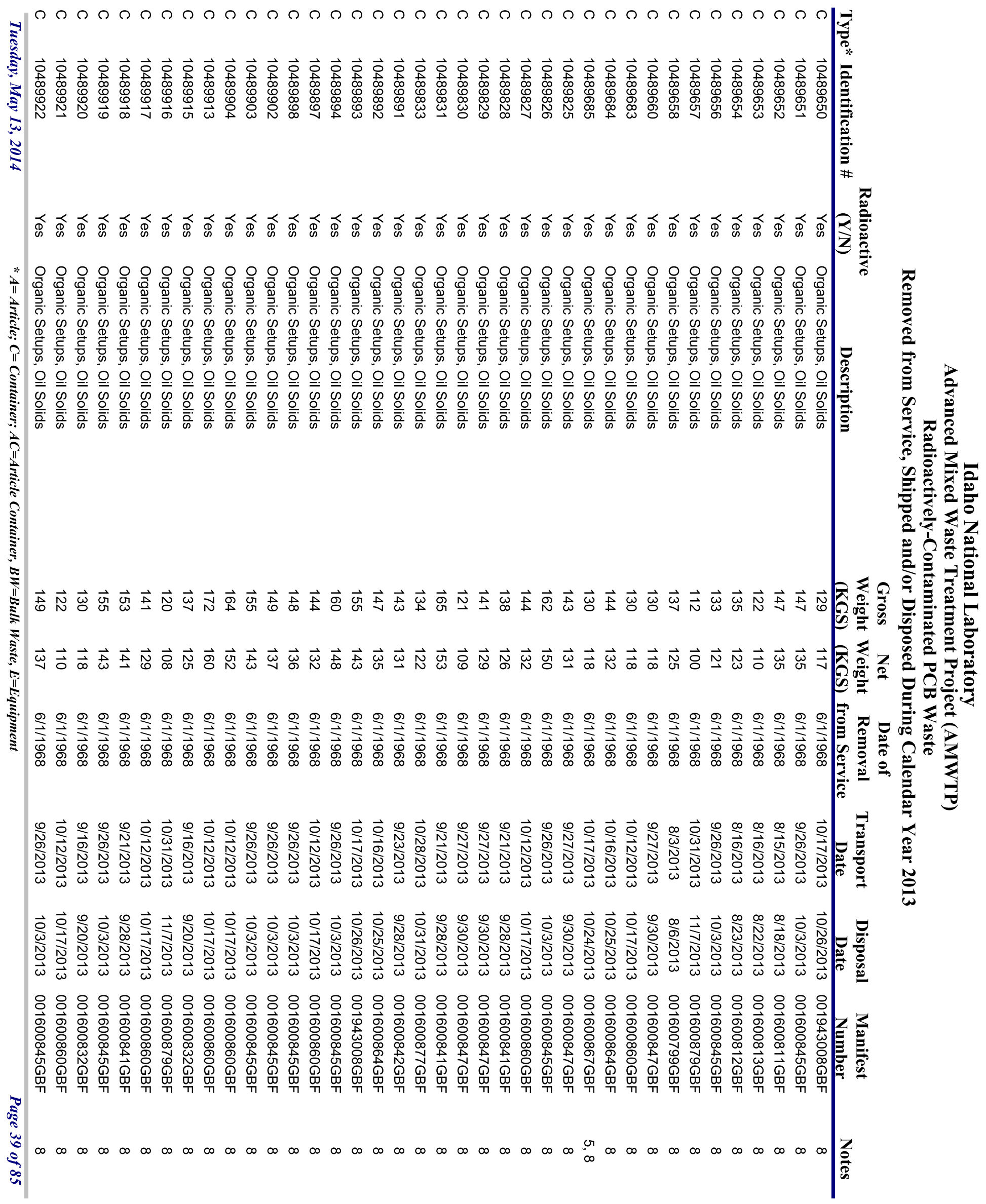




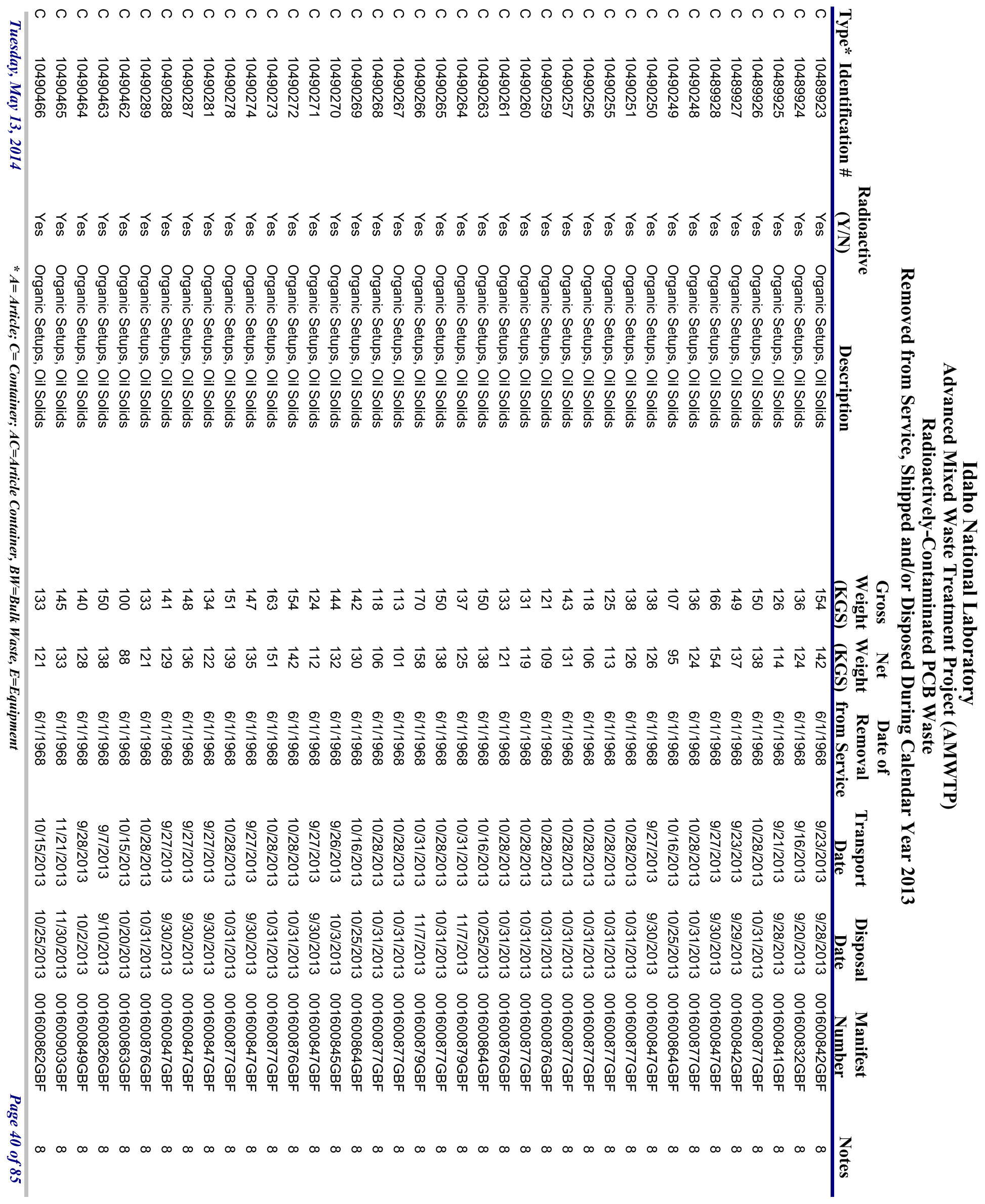




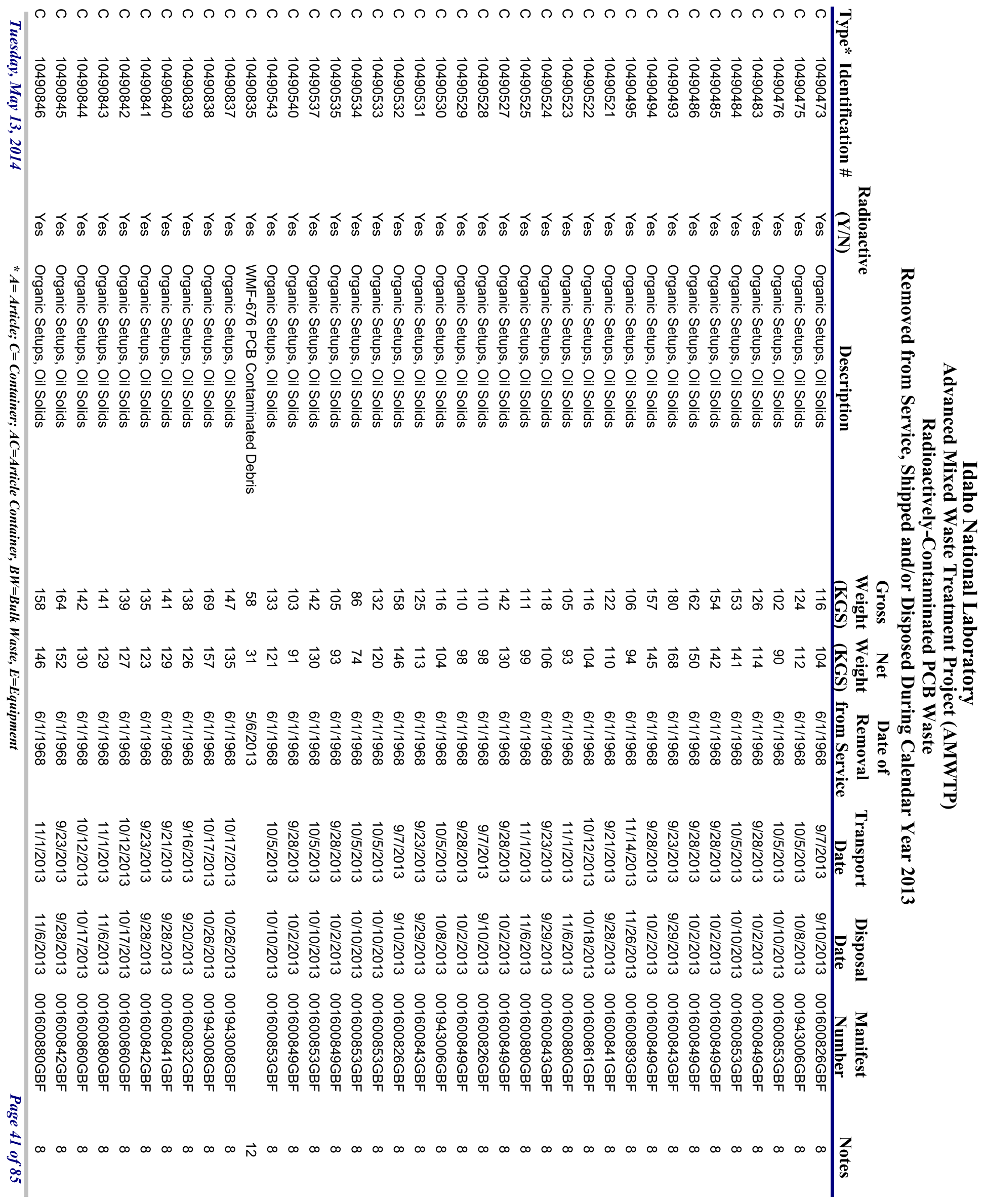




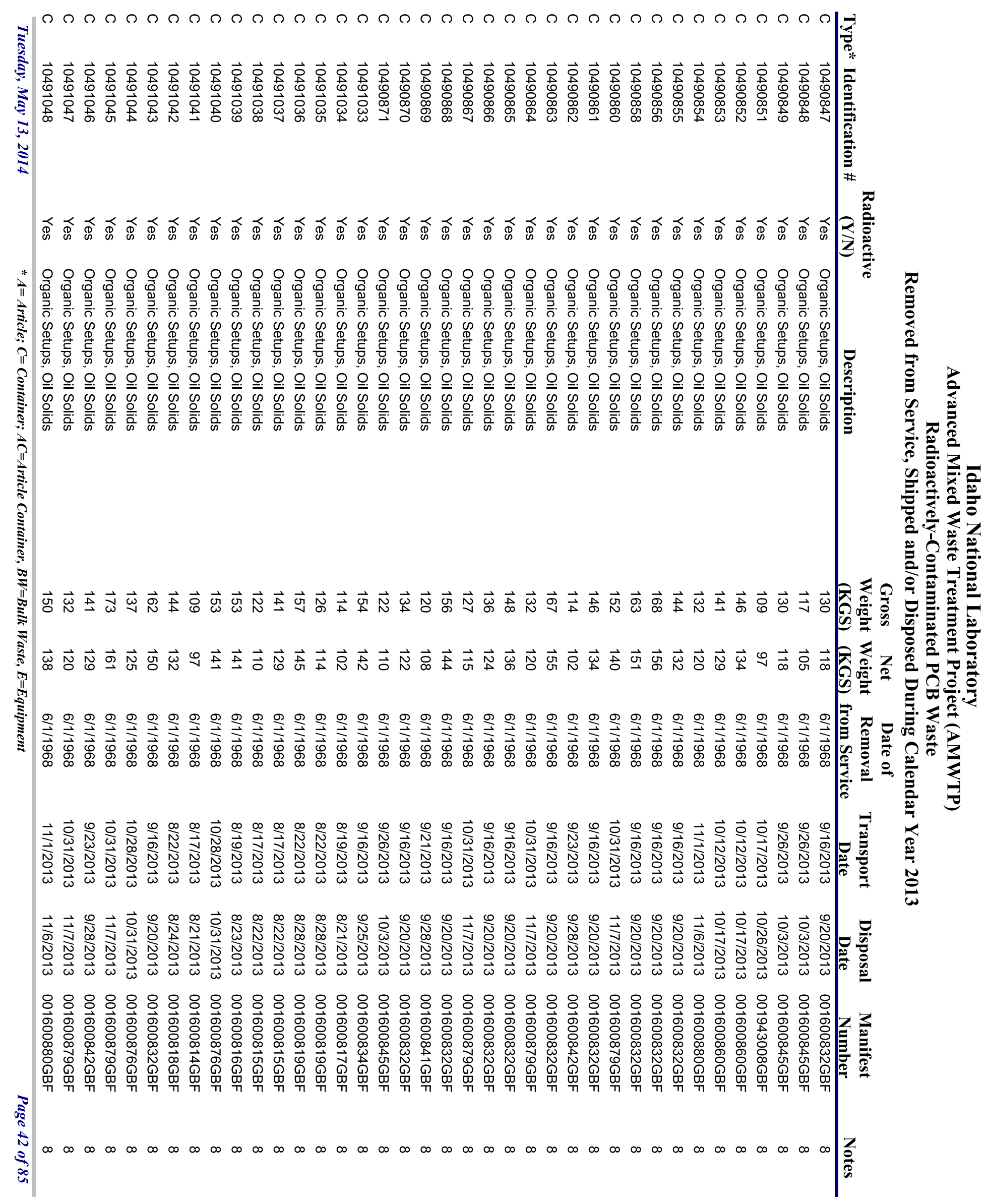




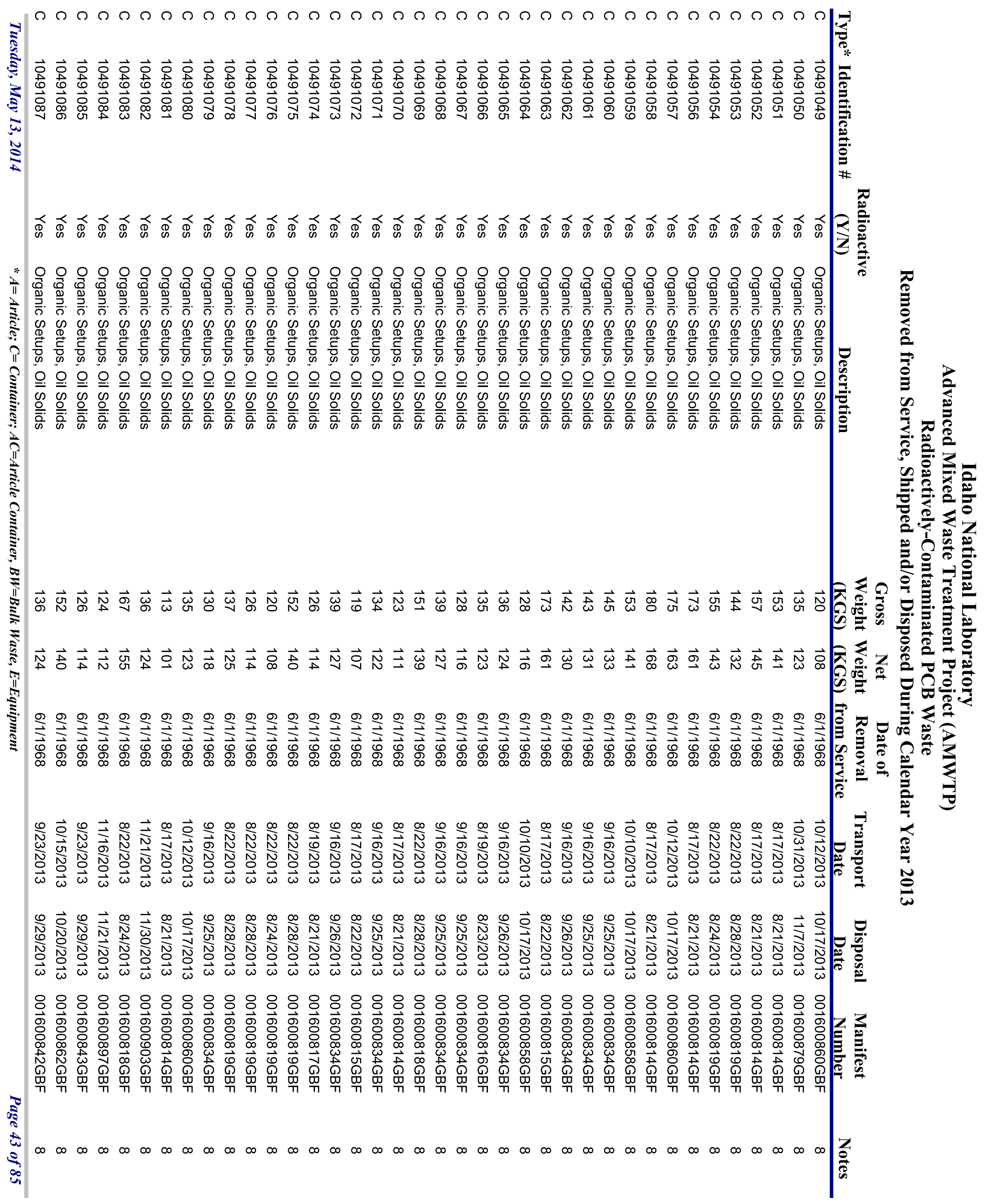




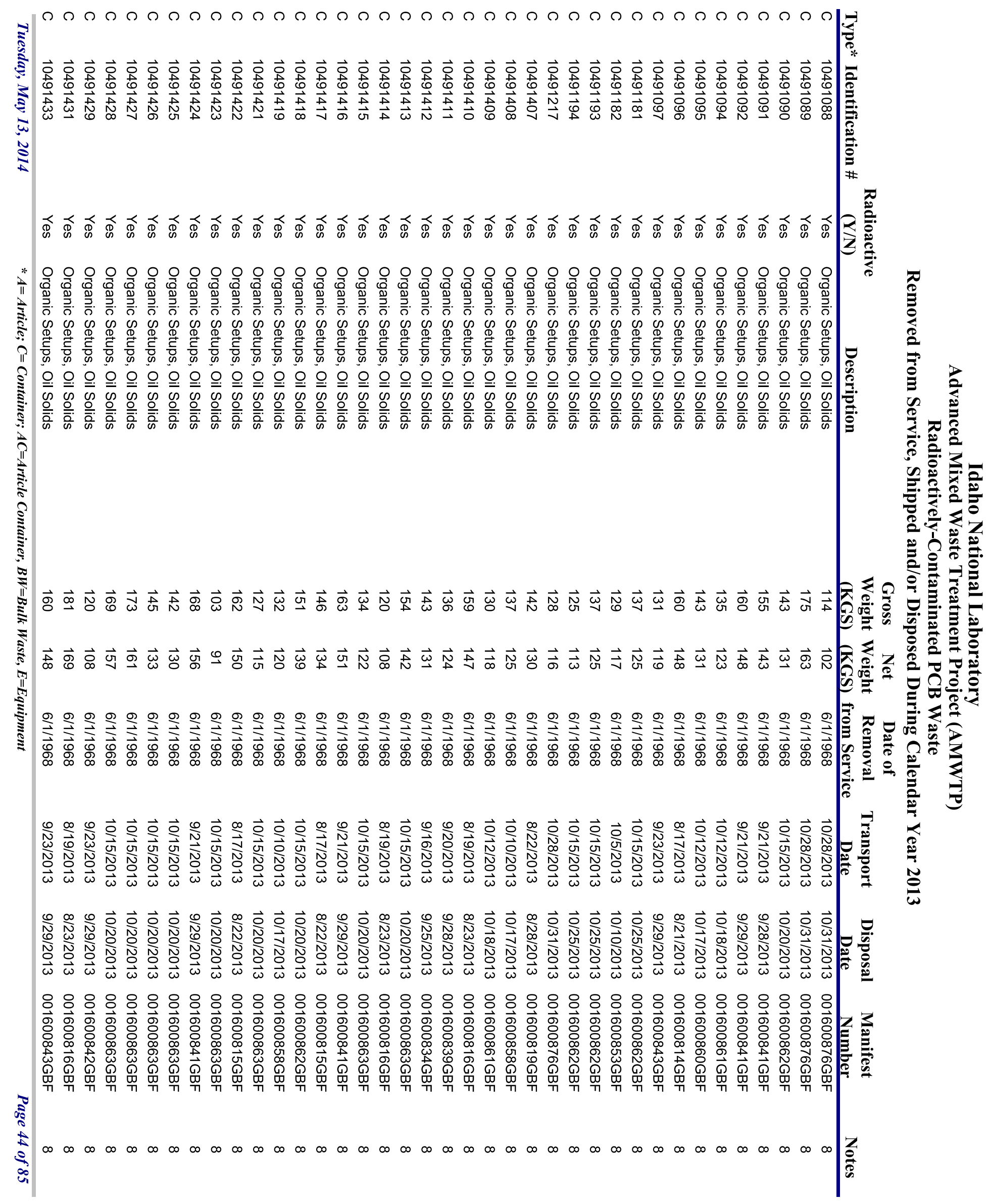




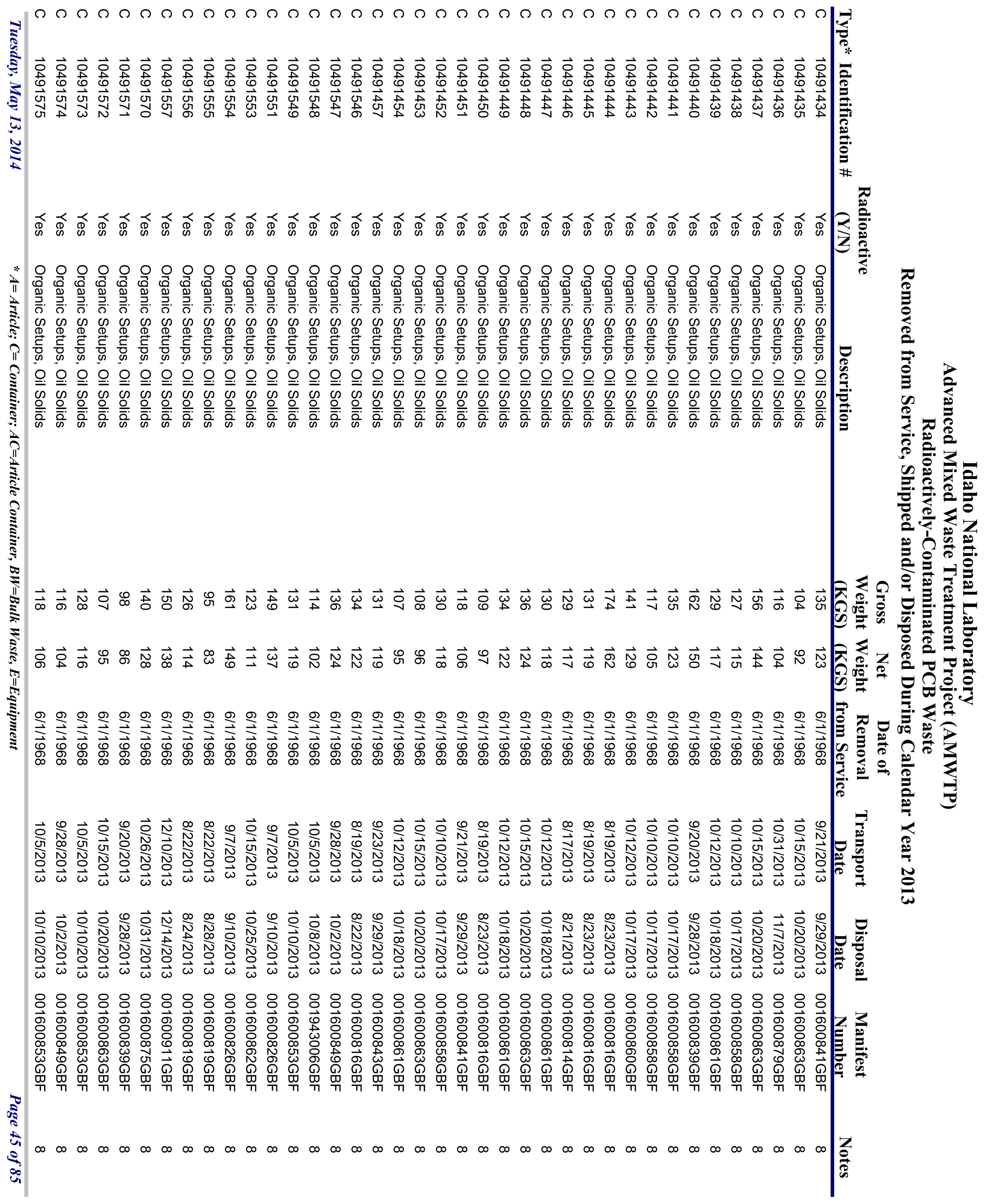




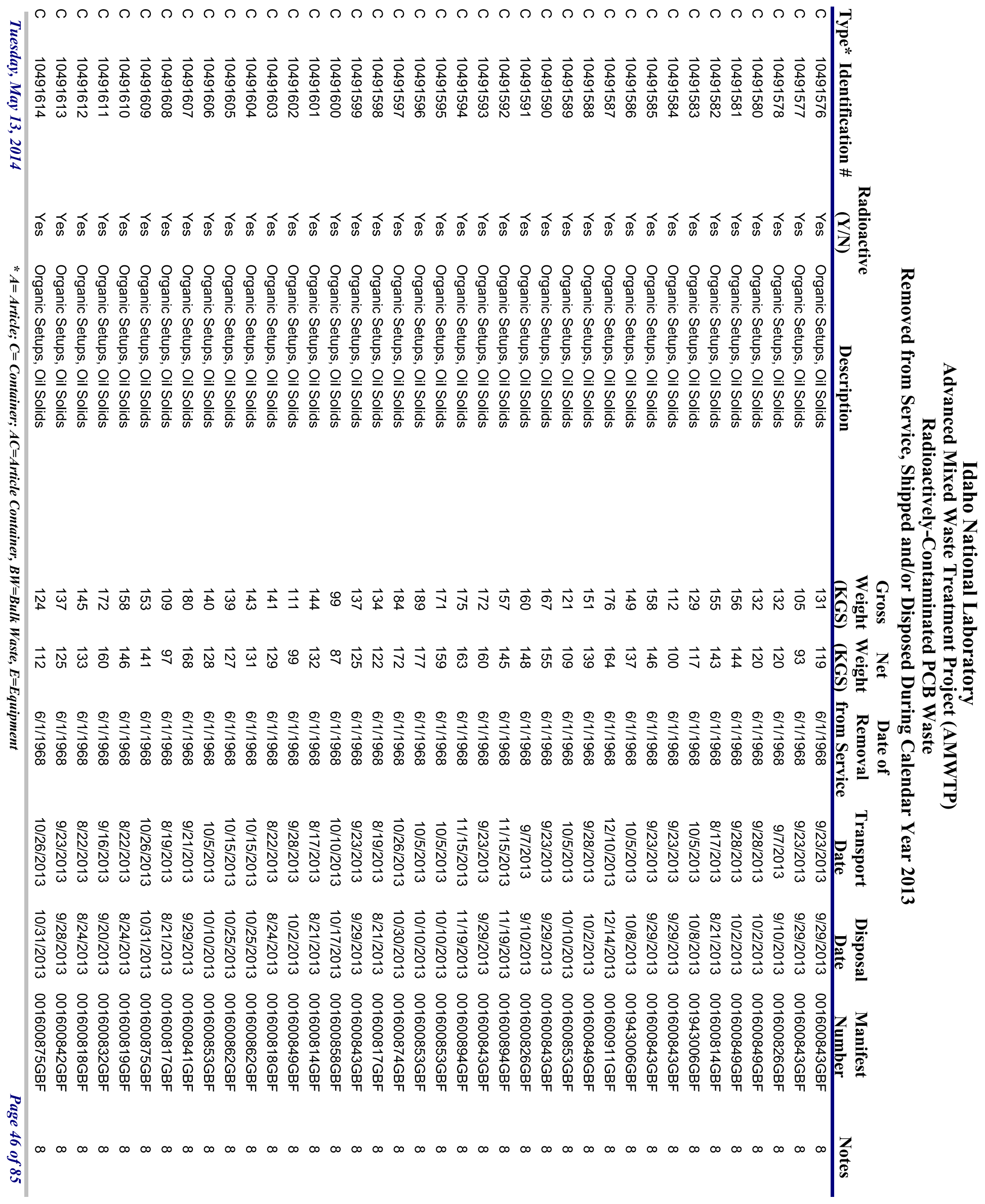




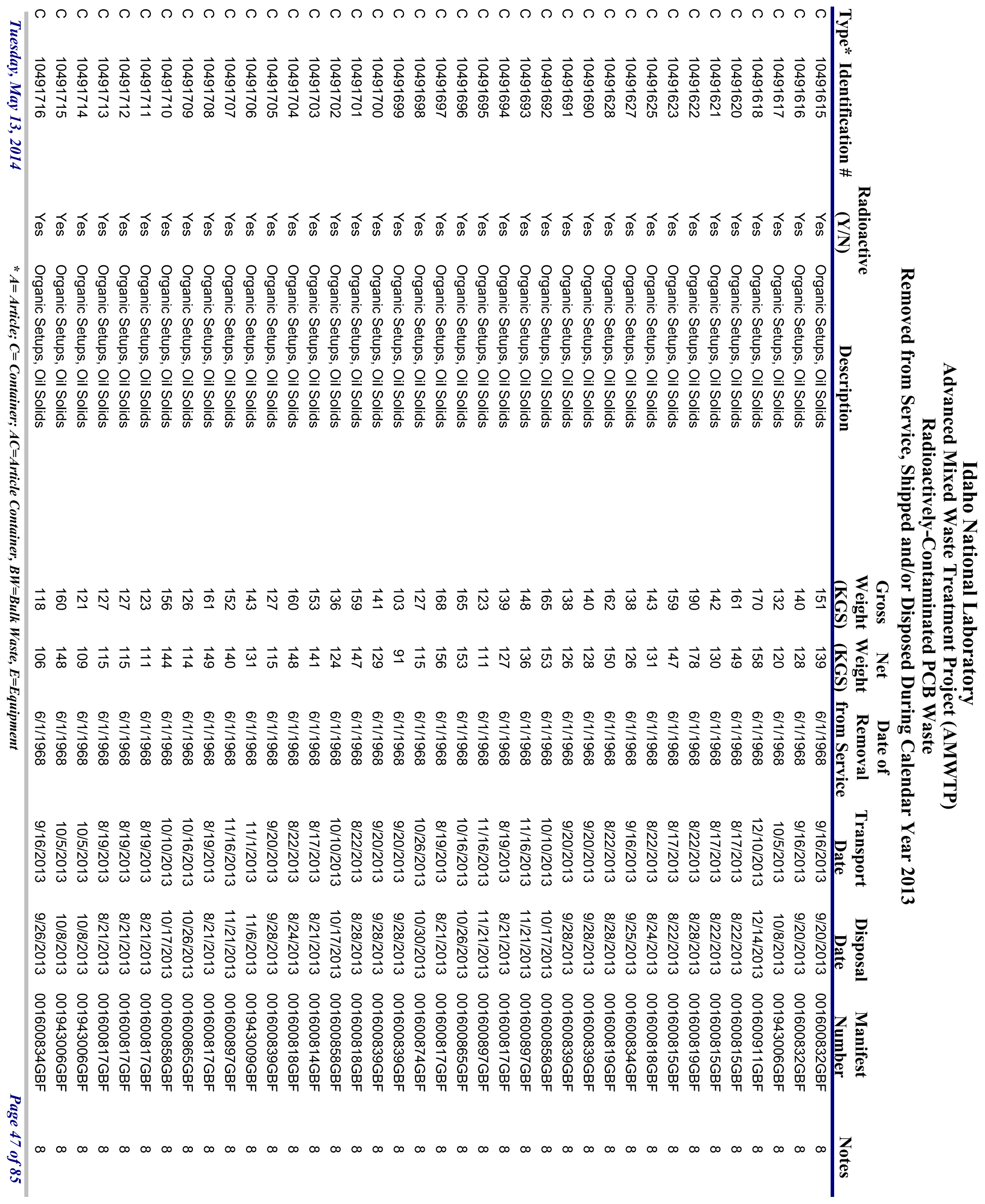




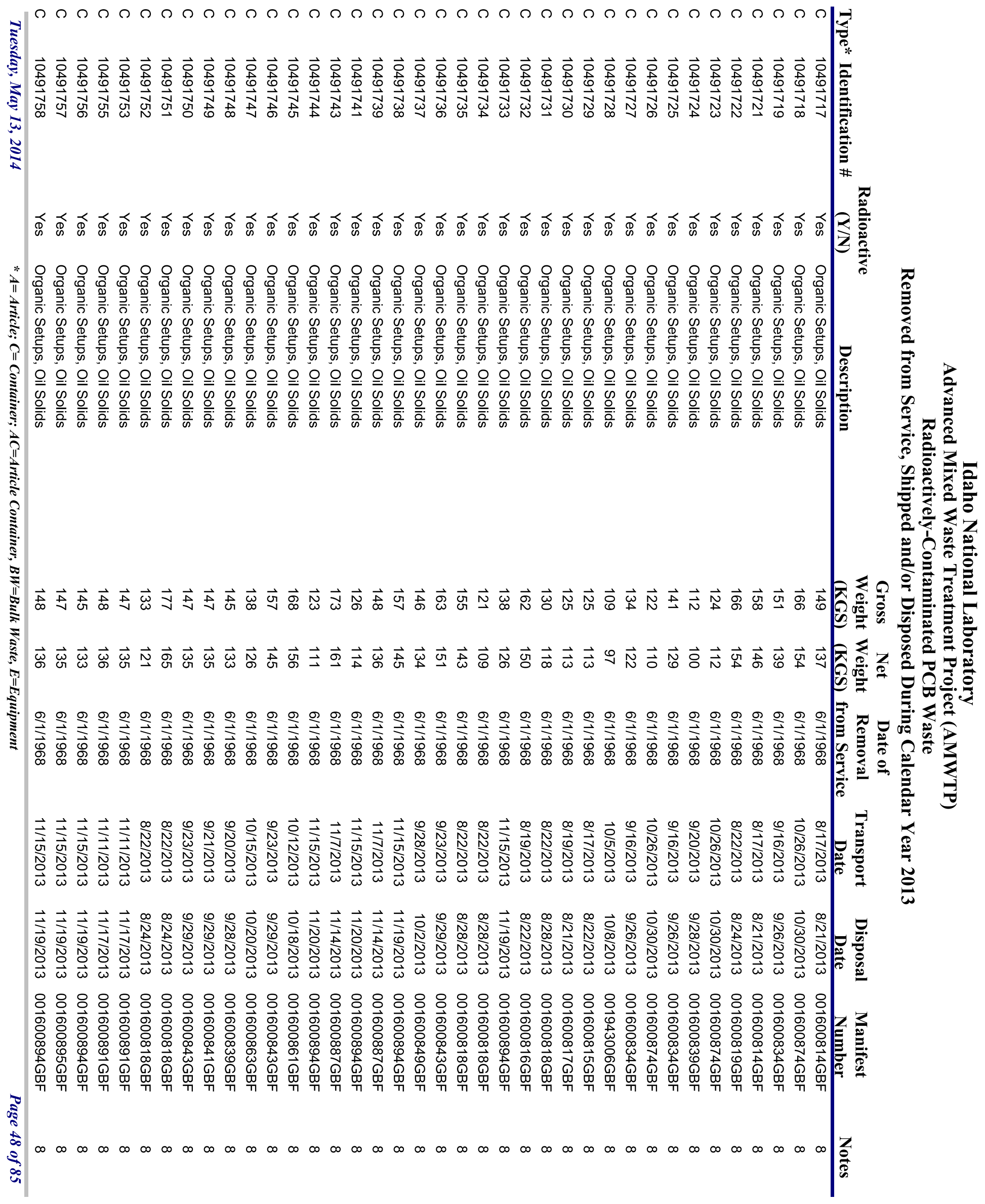




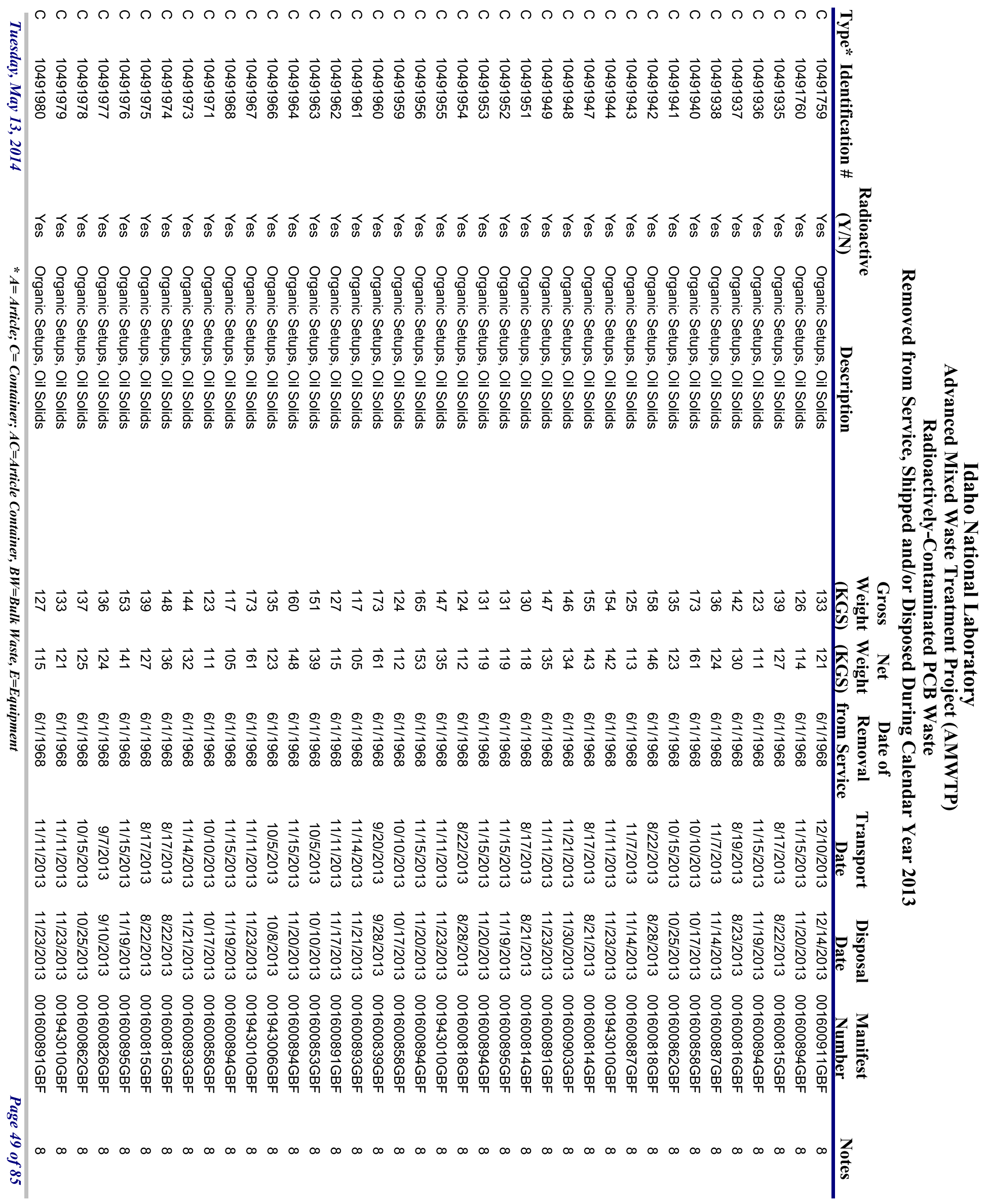




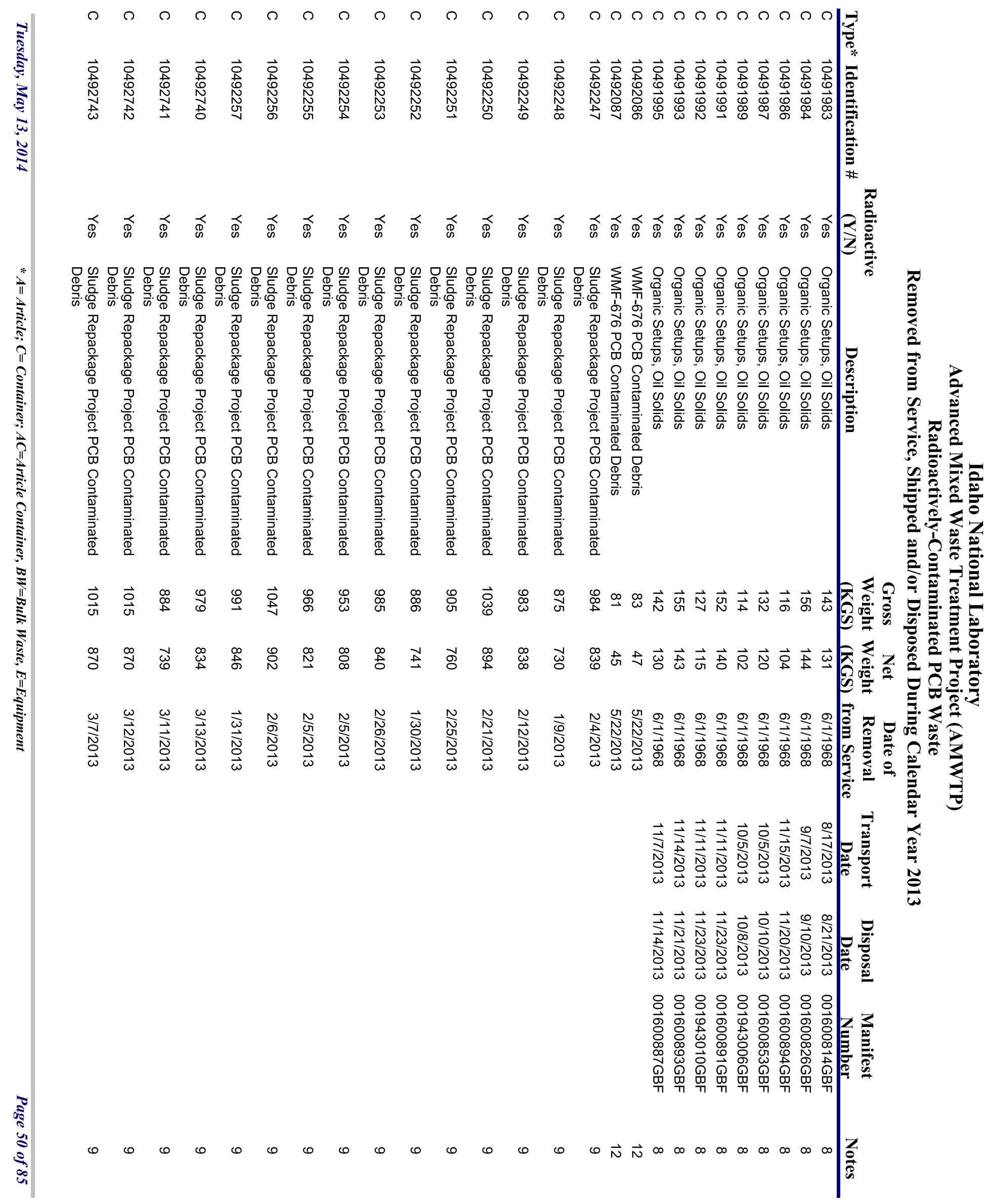




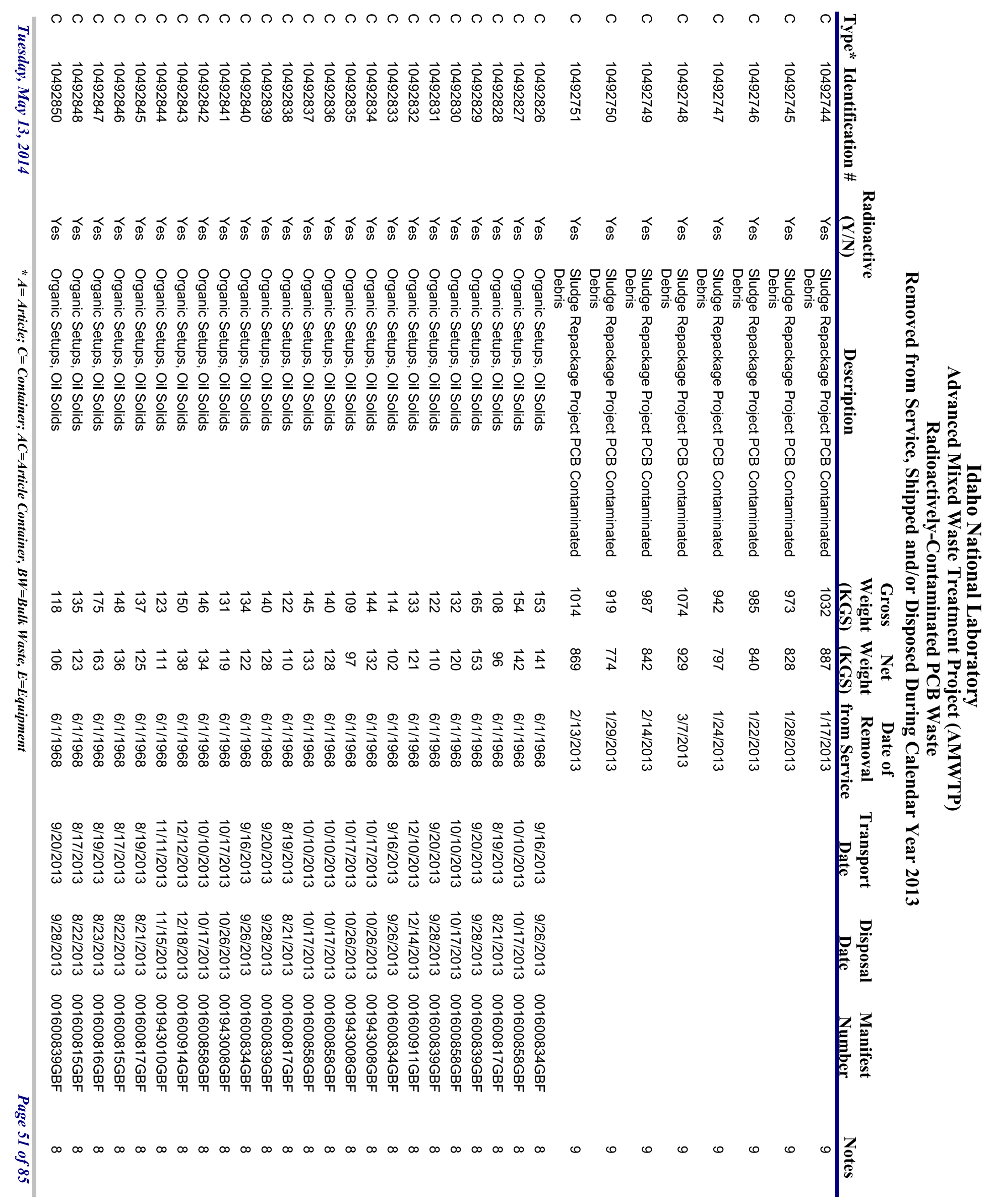




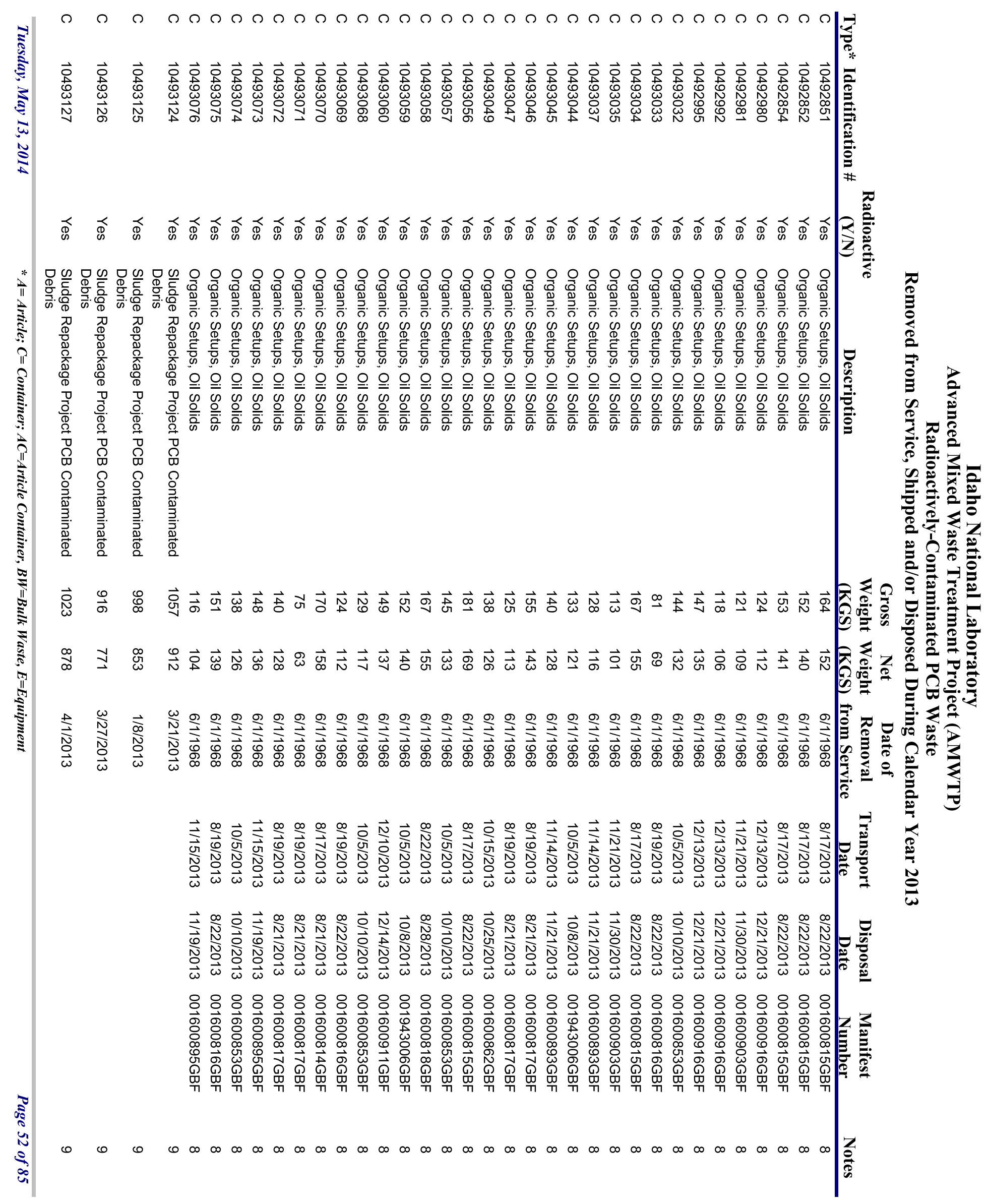




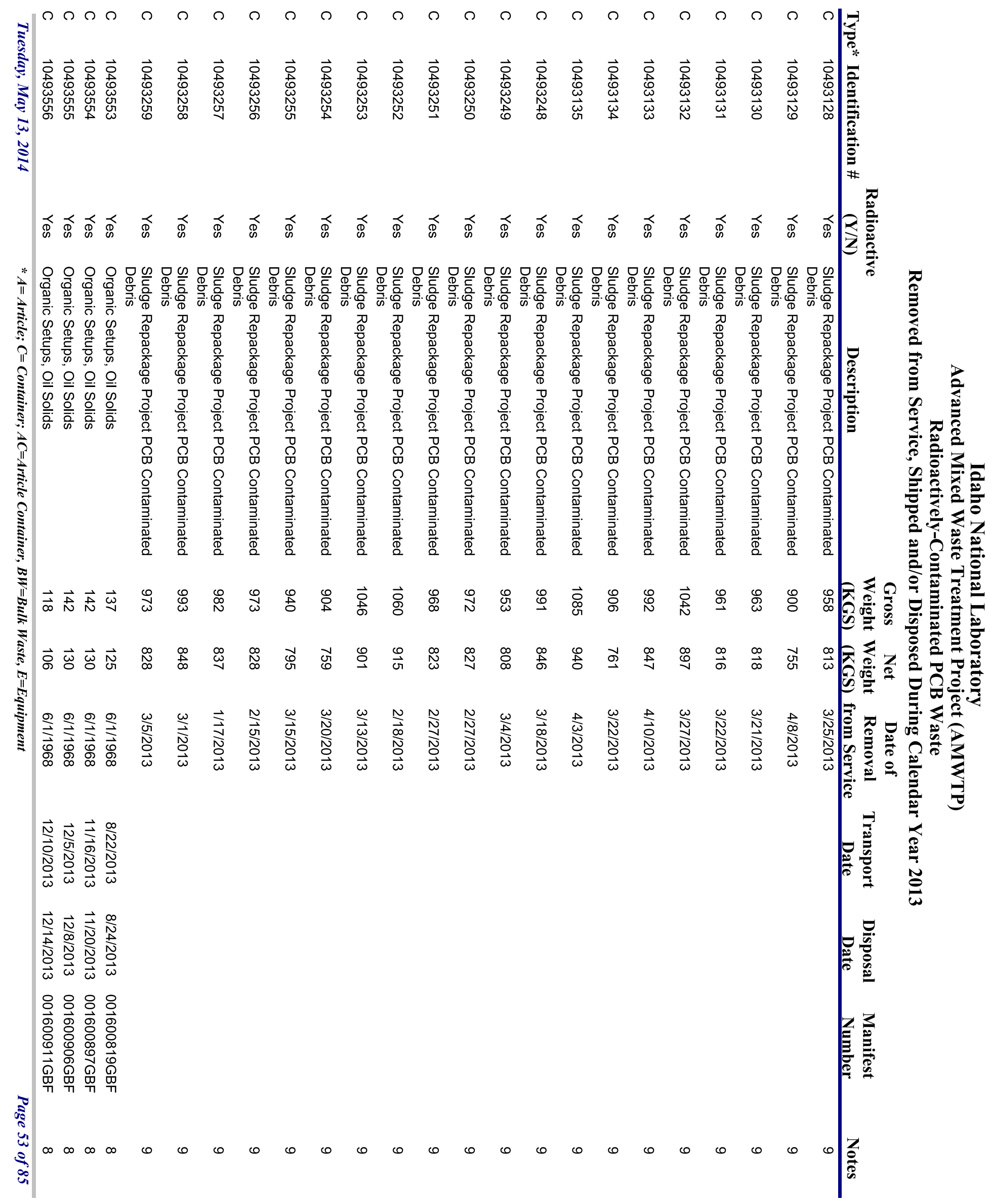




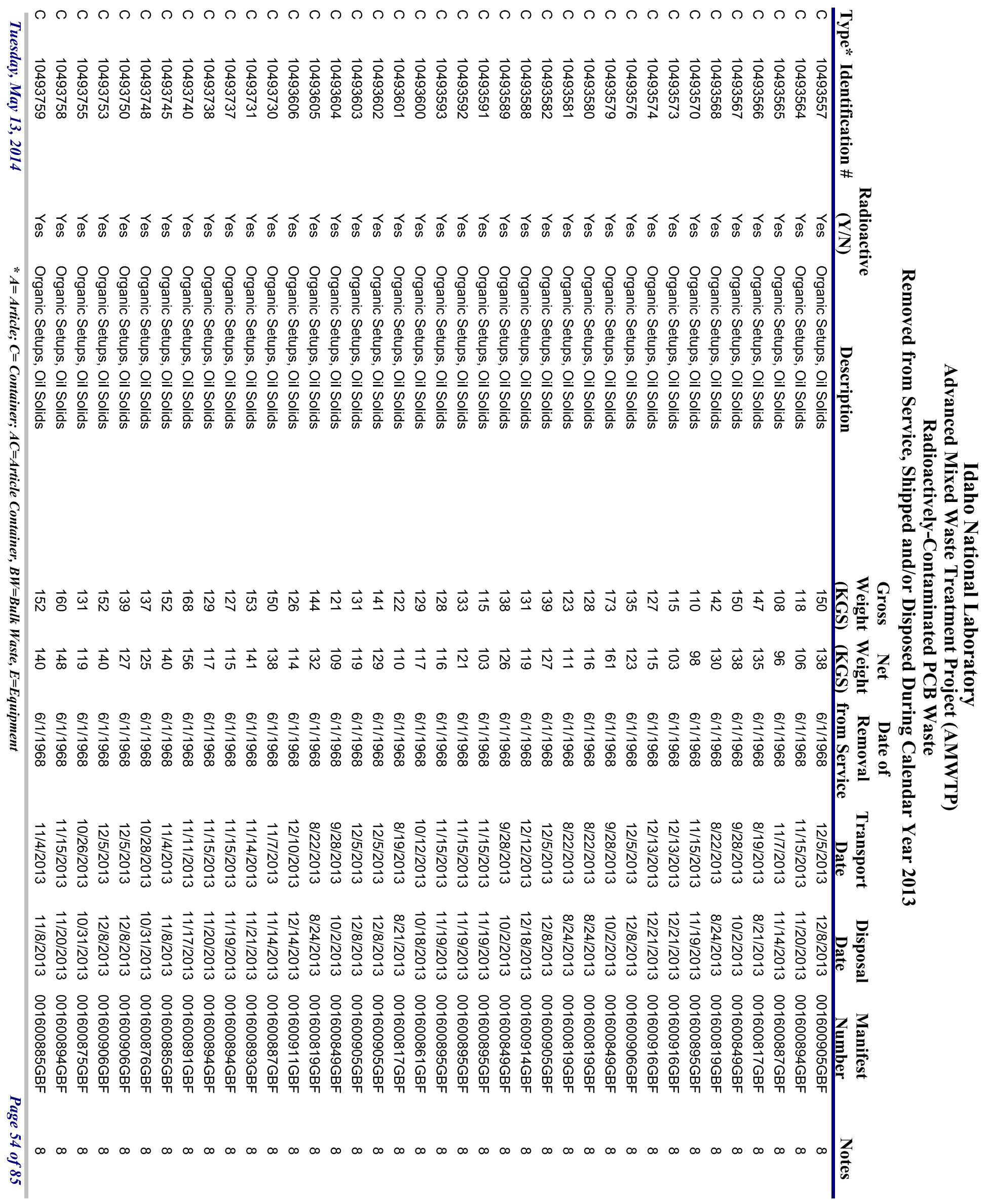




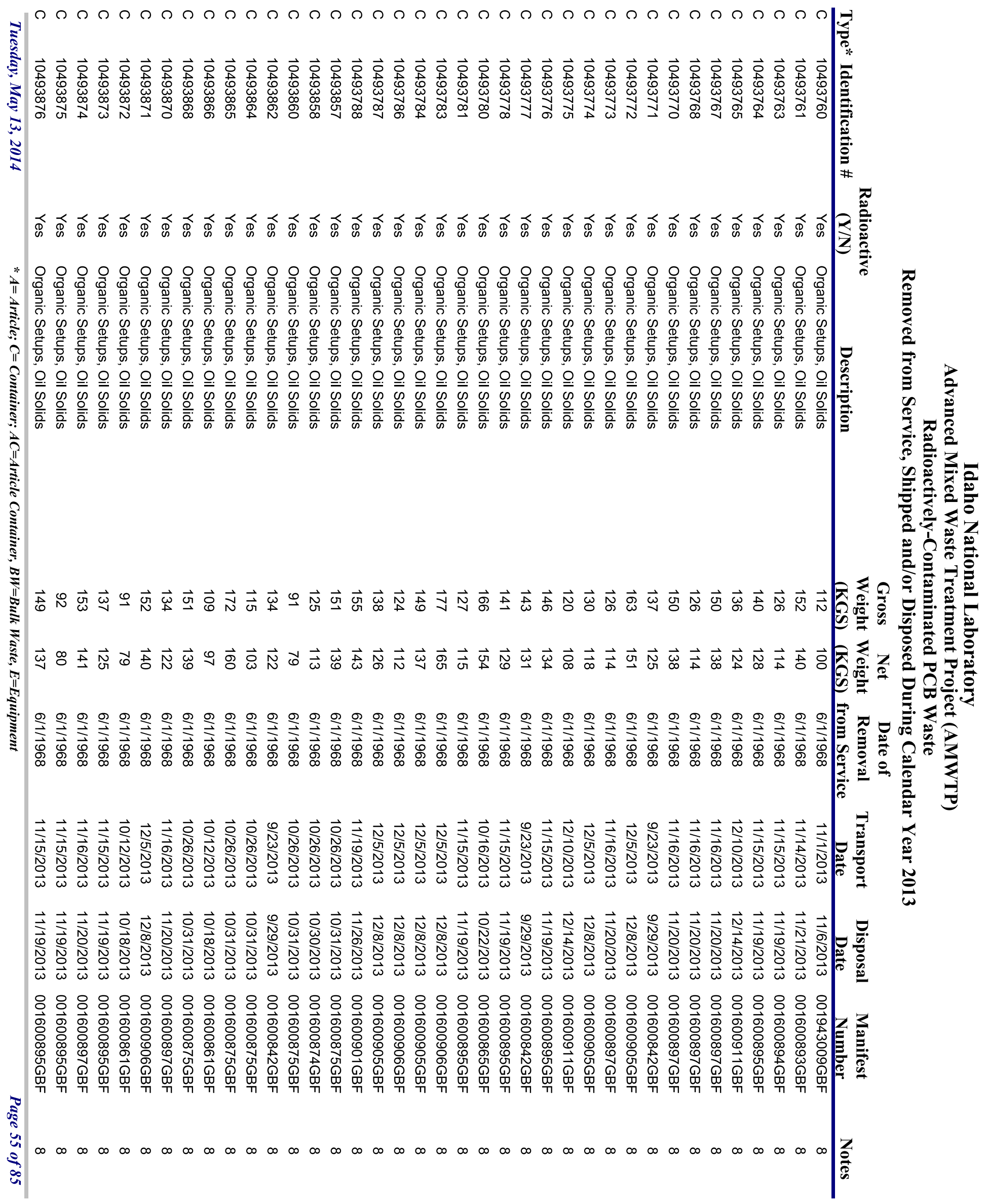




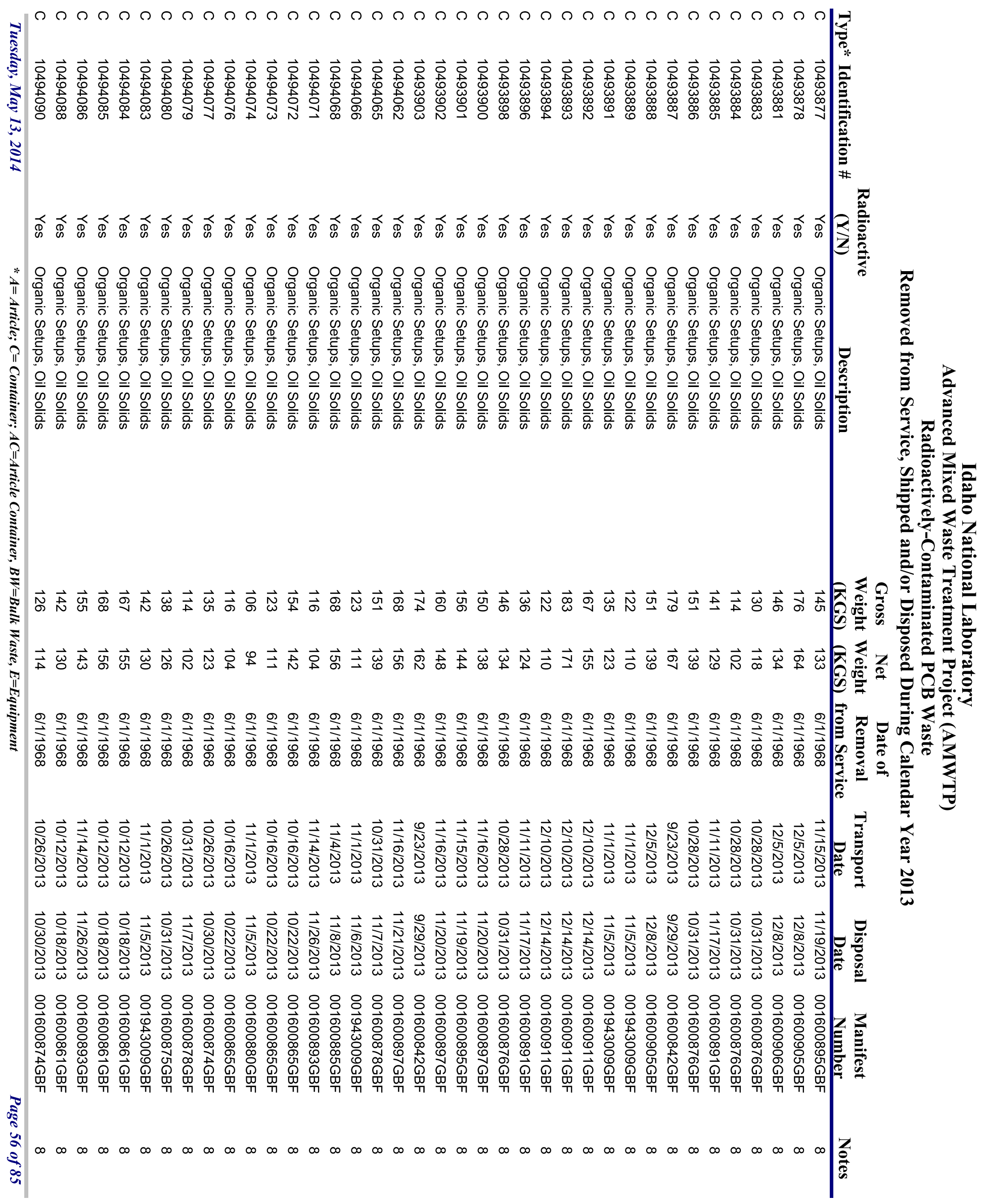




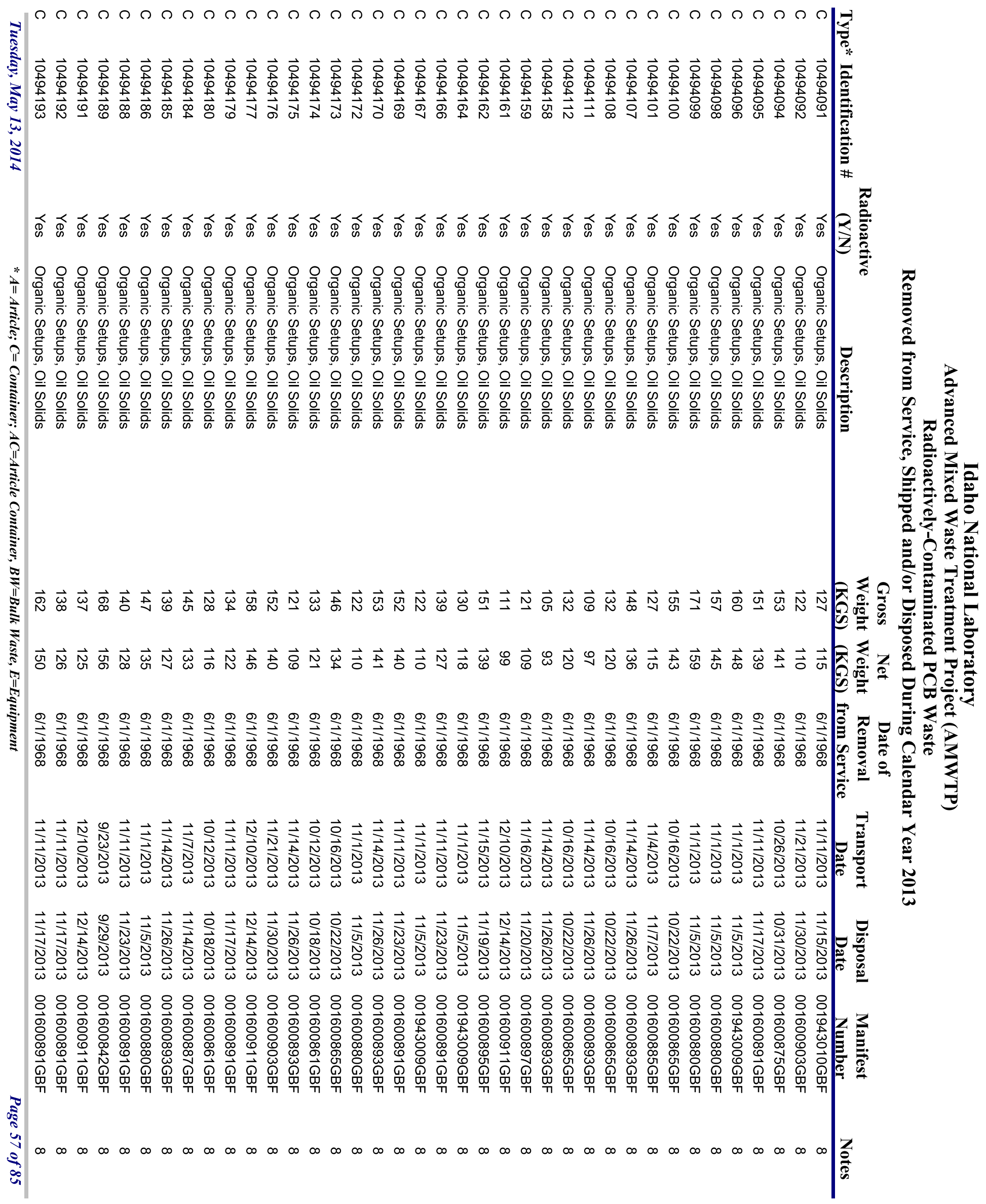




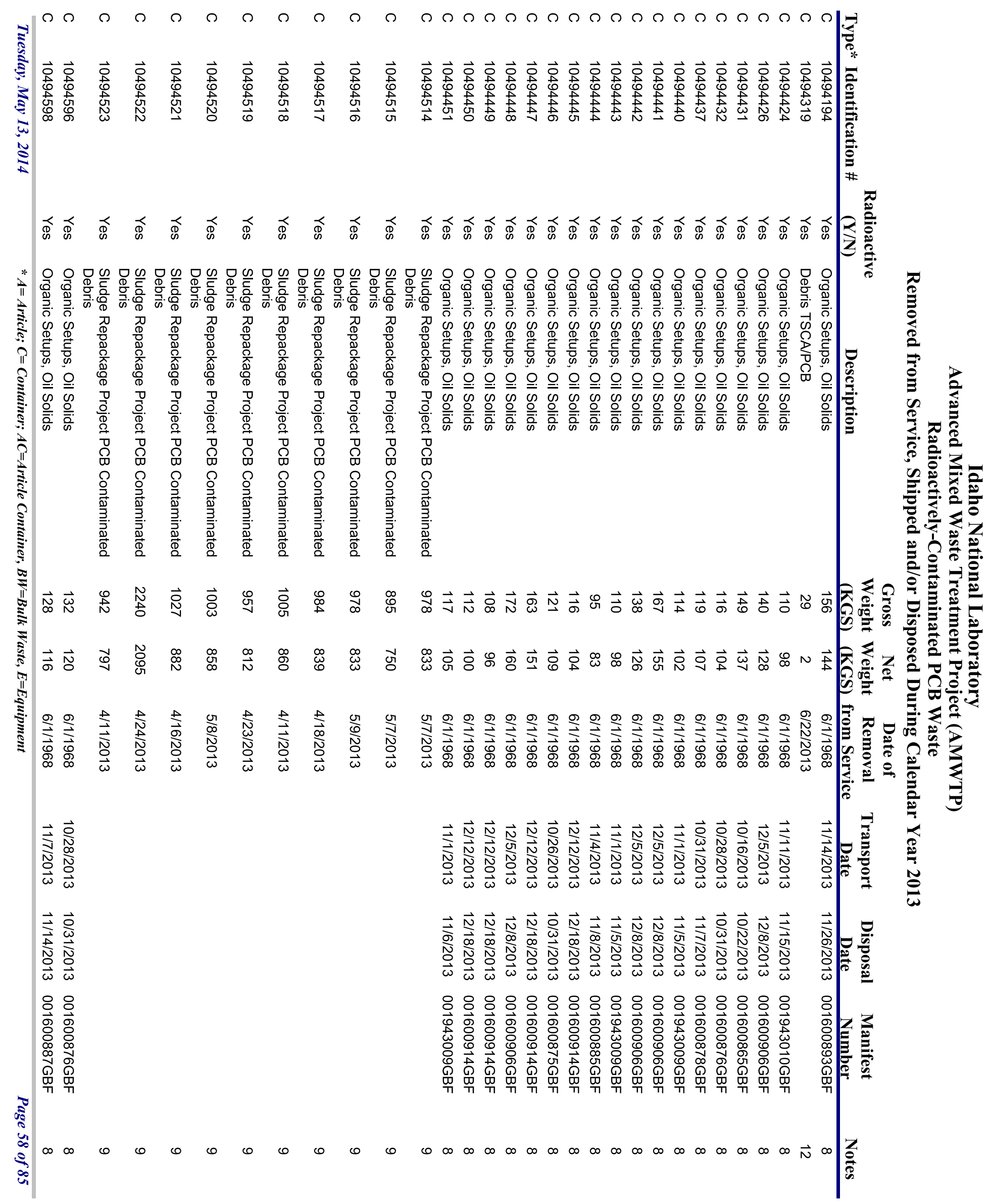


$\vec{\circ} \vec{\circ} \vec{\circ} \vec{\circ} \vec{\circ} \vec{\circ} \vec{\circ} \vec{\circ} \vec{\circ} \vec{\circ} \vec{\circ} \vec{\circ} \vec{\circ} \vec{\circ} \vec{\circ} \vec{\circ} \vec{\circ} \vec{\circ} \vec{\circ} \vec{\circ} \vec{\circ} \vec{\circ} \vec{\circ} \vec{\circ} \vec{\circ} \vec{\circ}$

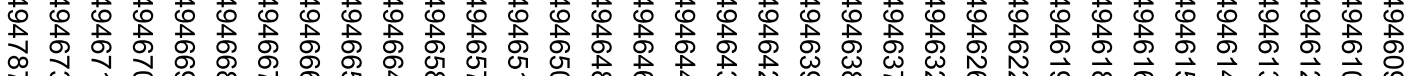

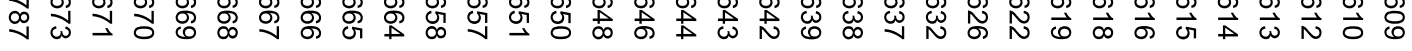

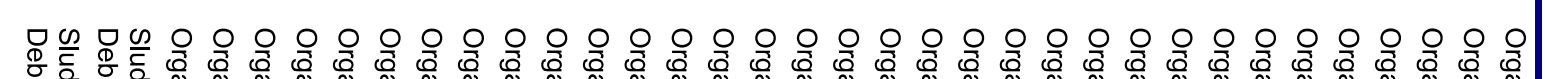

小

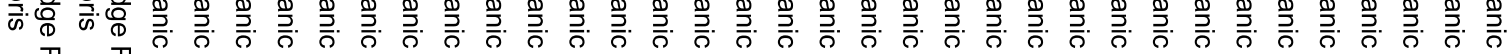

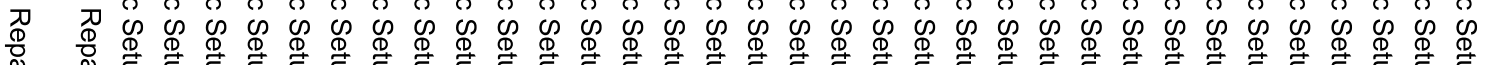

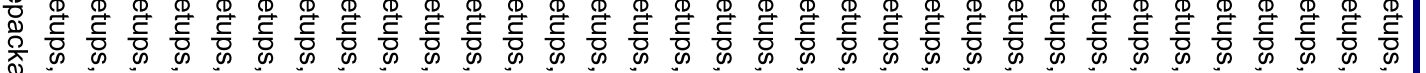

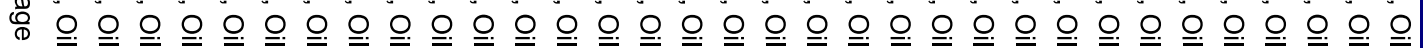

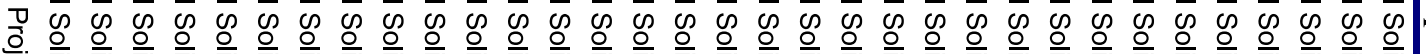

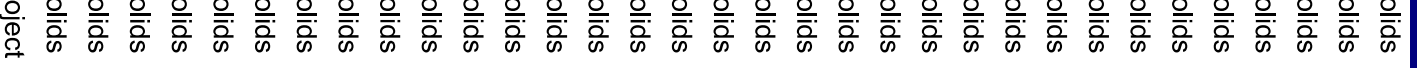
吕

๓

○

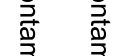

竞.

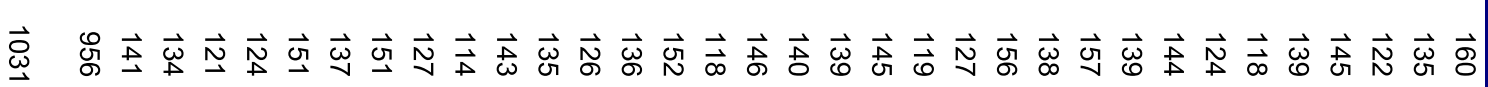

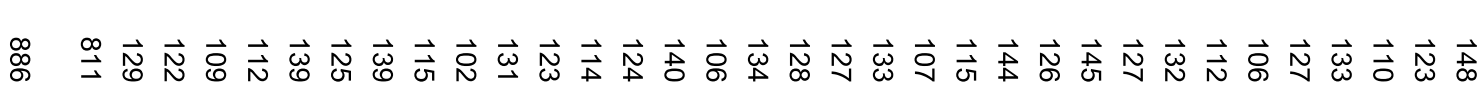

$\frac{\substack{\infty \\ \frac{D}{\omega}}}{\frac{\vec{J}}{\omega}}$

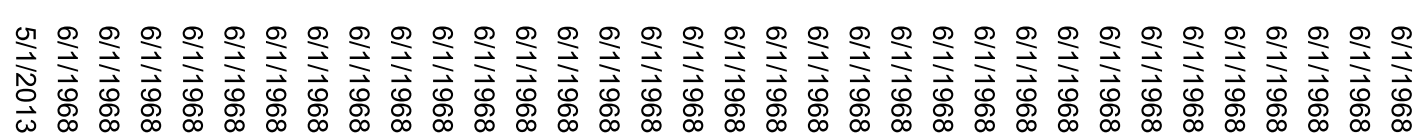

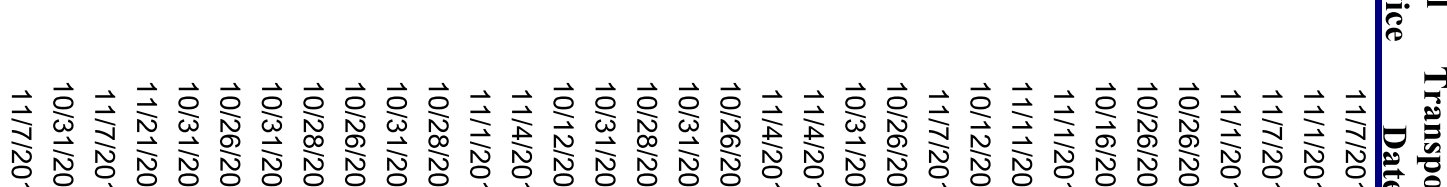

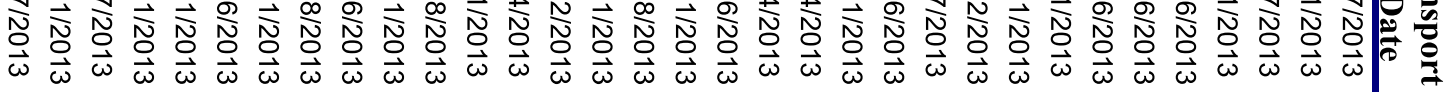

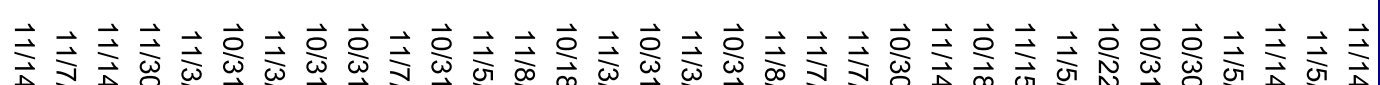

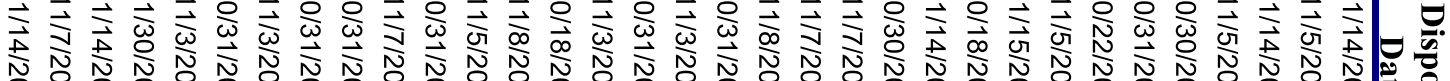
N

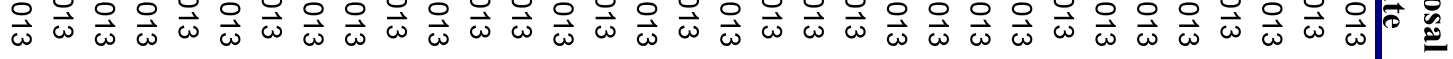

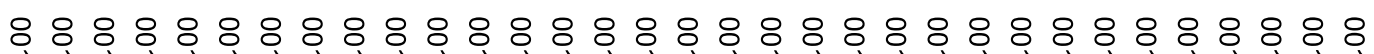

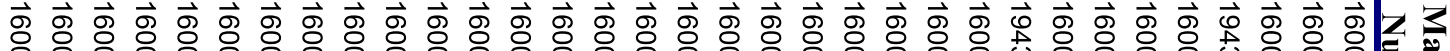

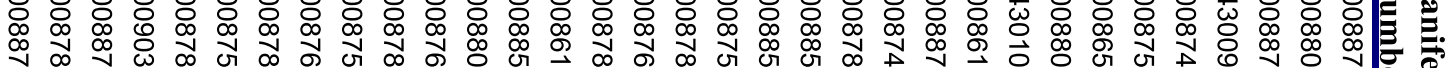

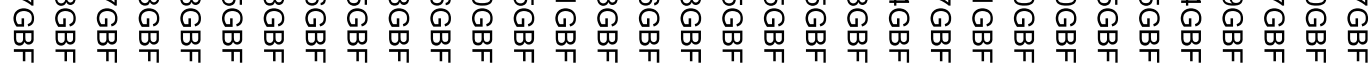

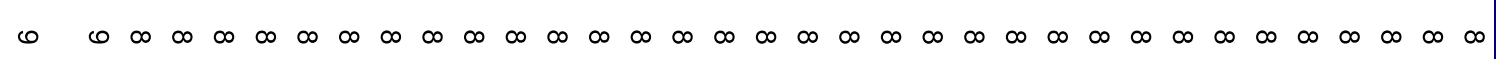




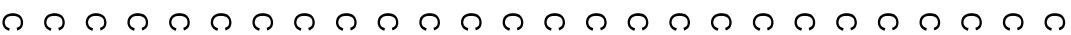

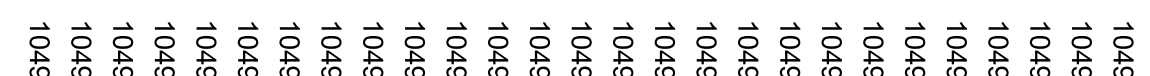

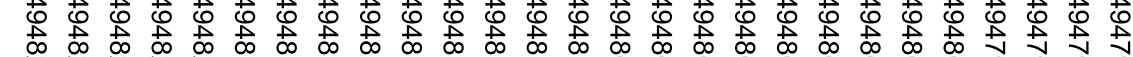

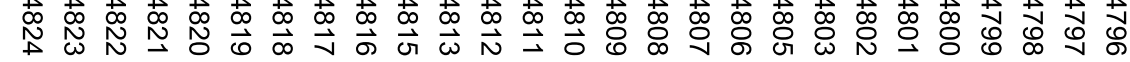

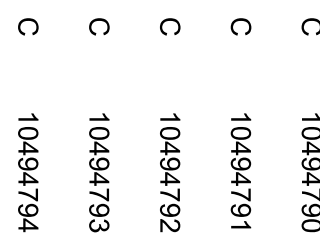

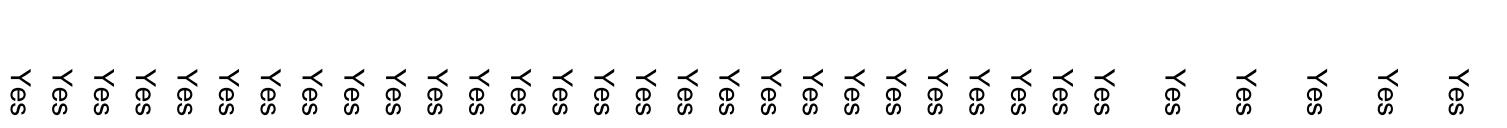

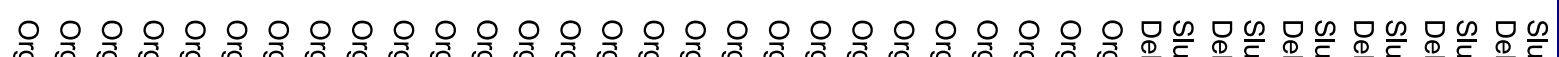

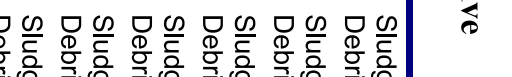

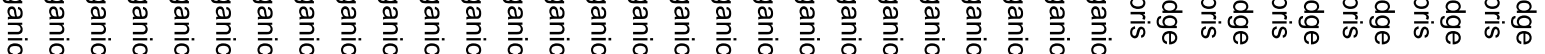

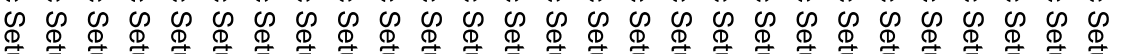

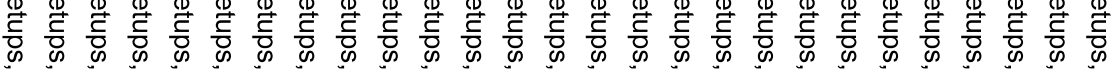

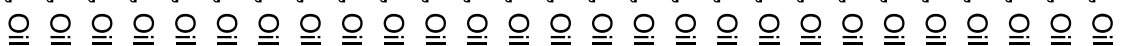

W

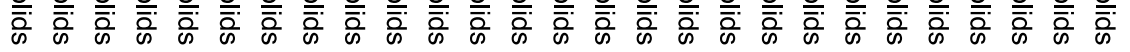

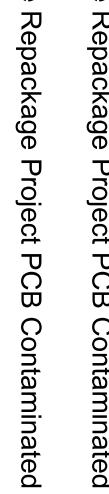

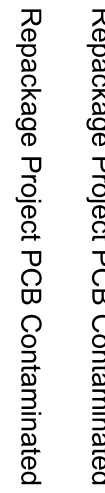

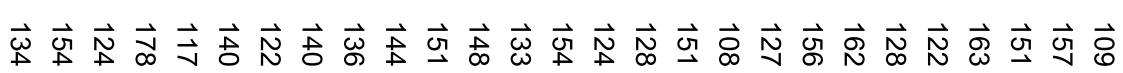

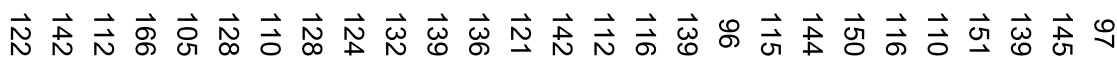

○

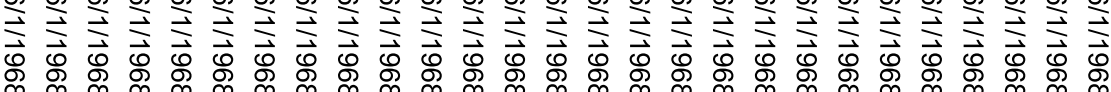

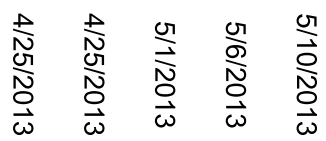

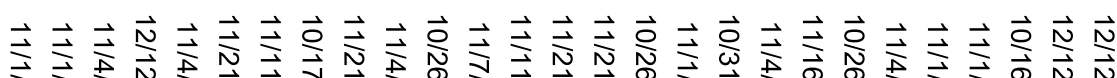

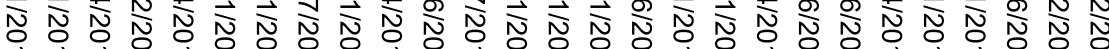

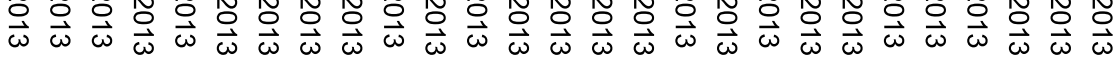

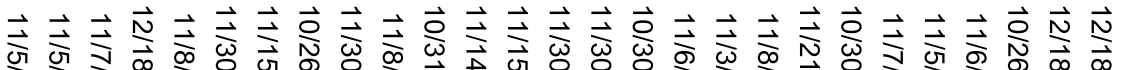
N N N N N N N N N N N N N N N N N N N N N N N N N N N N N N N N N N N N N N N N

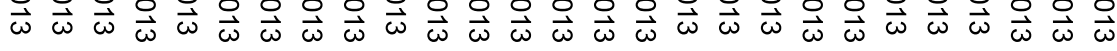

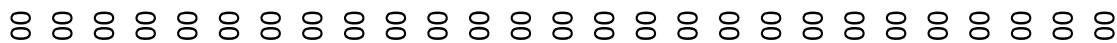

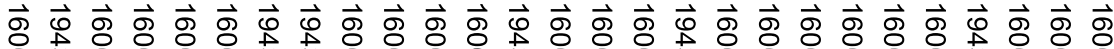
o

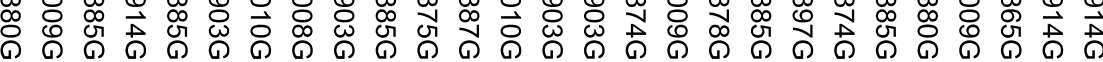

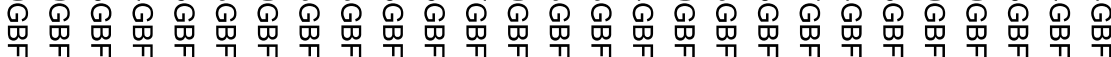

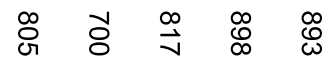




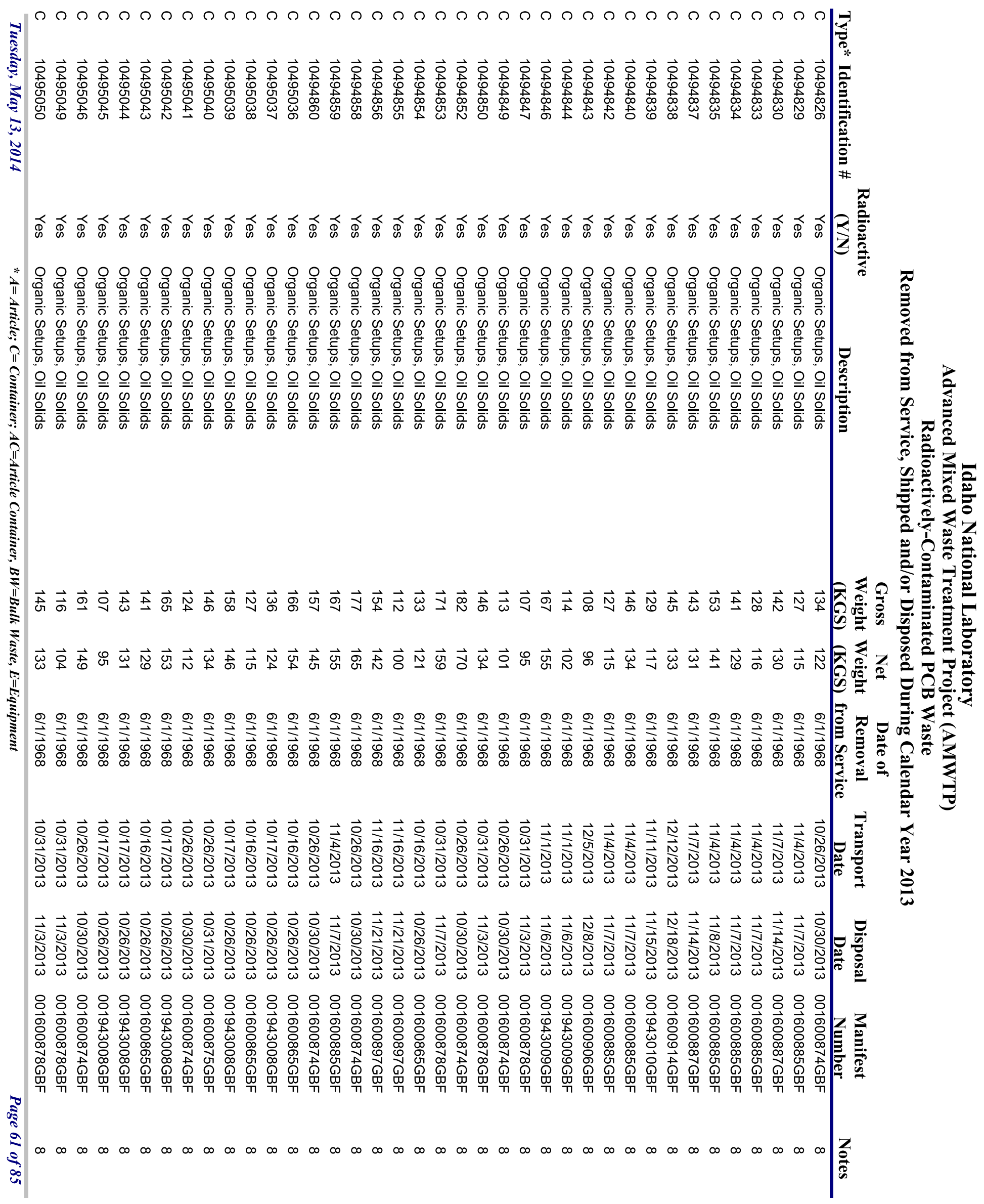


0

$\vec{\circ} \vec{\circ} \vec{\circ} \vec{\circ} \vec{\circ} \vec{\circ} \vec{\circ} \vec{\circ} \vec{\circ} \vec{\circ} \vec{\circ} \vec{\circ} \vec{\circ} \vec{\circ} \vec{\circ} \vec{\circ} \vec{\circ} \vec{\circ} \vec{\circ} \vec{\circ} \vec{\circ} \vec{\circ} \vec{\circ} \vec{\circ} \vec{\circ} \vec{\circ} \vec{\circ}$ 罂 它

ఏ

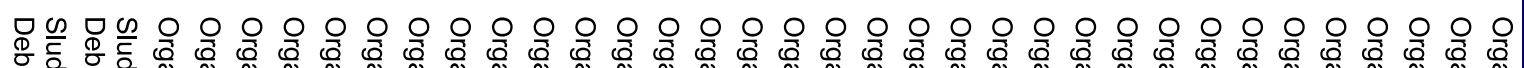

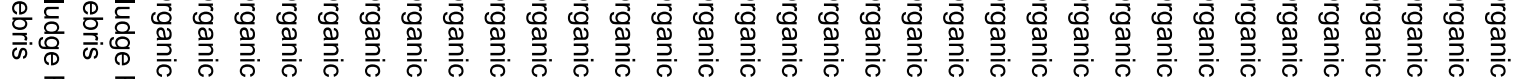

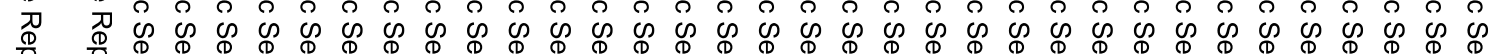

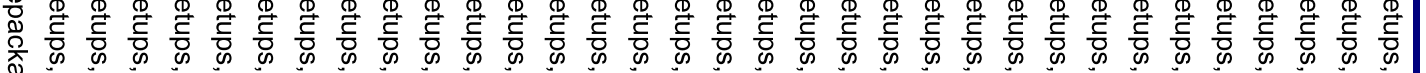

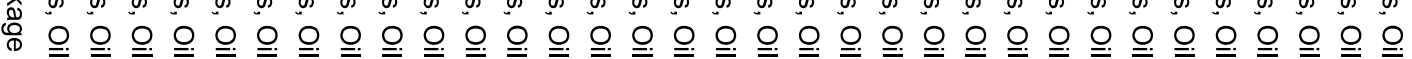

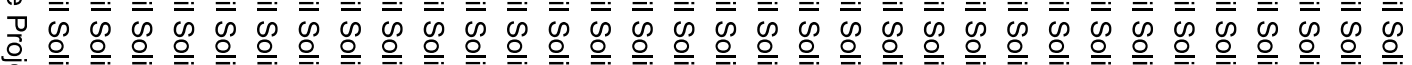

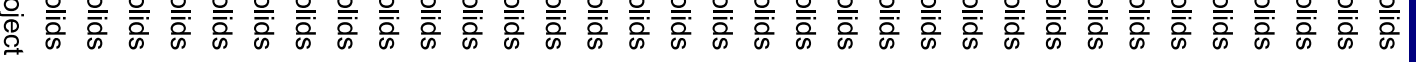
吕

๘

$\stackrel{\circ}{\circ}$

$\stackrel{\sqrt[3]{3}}{\frac{3}{3}}$

童.

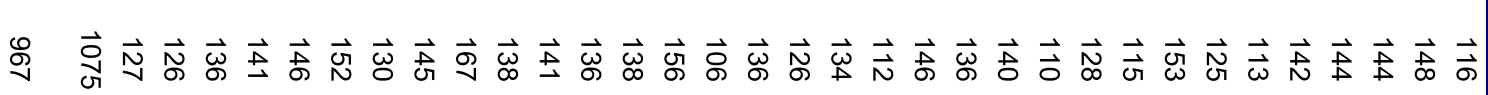

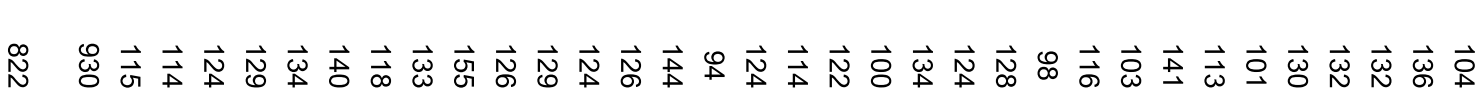

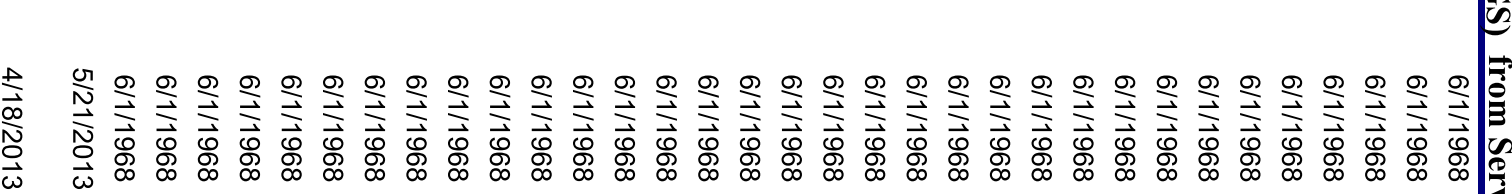

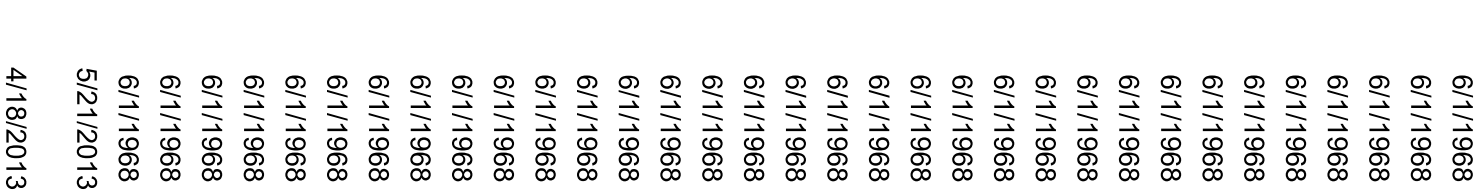

$\vec{P} \vec{O} \vec{P} \vec{N} \vec{N} \vec{N} \vec{N} \vec{N} \vec{N} \vec{N} \vec{N} \vec{N} \vec{N} \vec{N} \vec{N} \vec{N} \vec{N} \vec{N} \vec{N} \vec{N} \vec{N} \vec{O} \vec{N} \overrightarrow{0} \overrightarrow{0} \overrightarrow{0} \overrightarrow{0} \vec{N} \overrightarrow{0}$

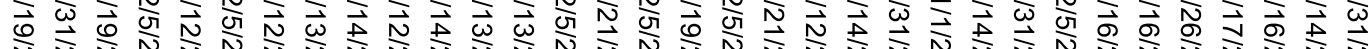

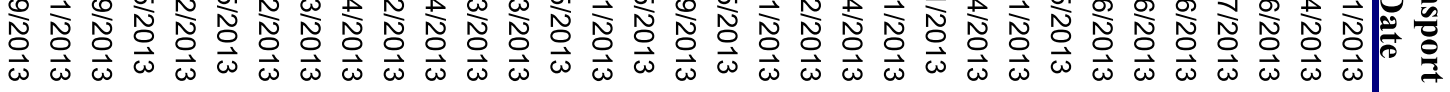

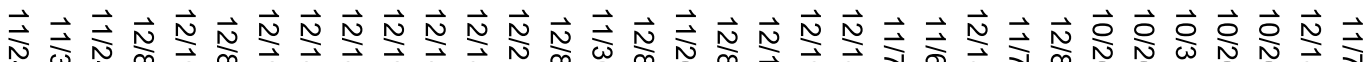

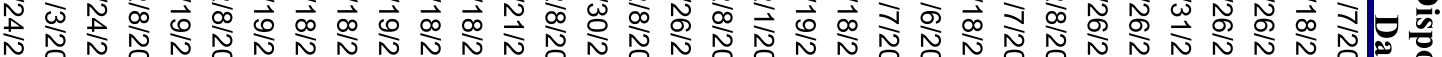
N $\vec{\omega} \omega \vec{\omega} \omega \vec{\omega} \omega \vec{\omega} \vec{\omega} \vec{\omega} \vec{\omega} \vec{\omega} \omega \vec{\omega} \omega \vec{\omega} \omega \omega \vec{\omega} \omega \omega \vec{\omega} \frac{\vec{\omega}}{\omega} \vec{\omega} \vec{\omega} \vec{\omega} \vec{\omega} \vec{\omega}$

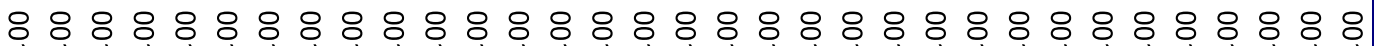

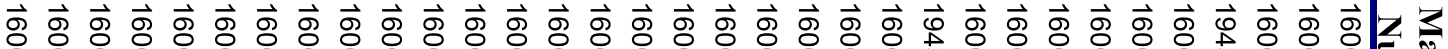

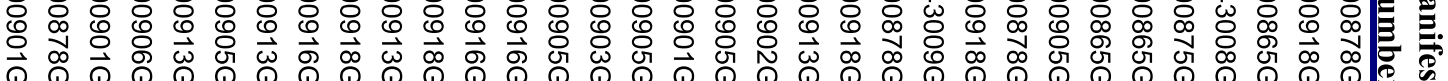




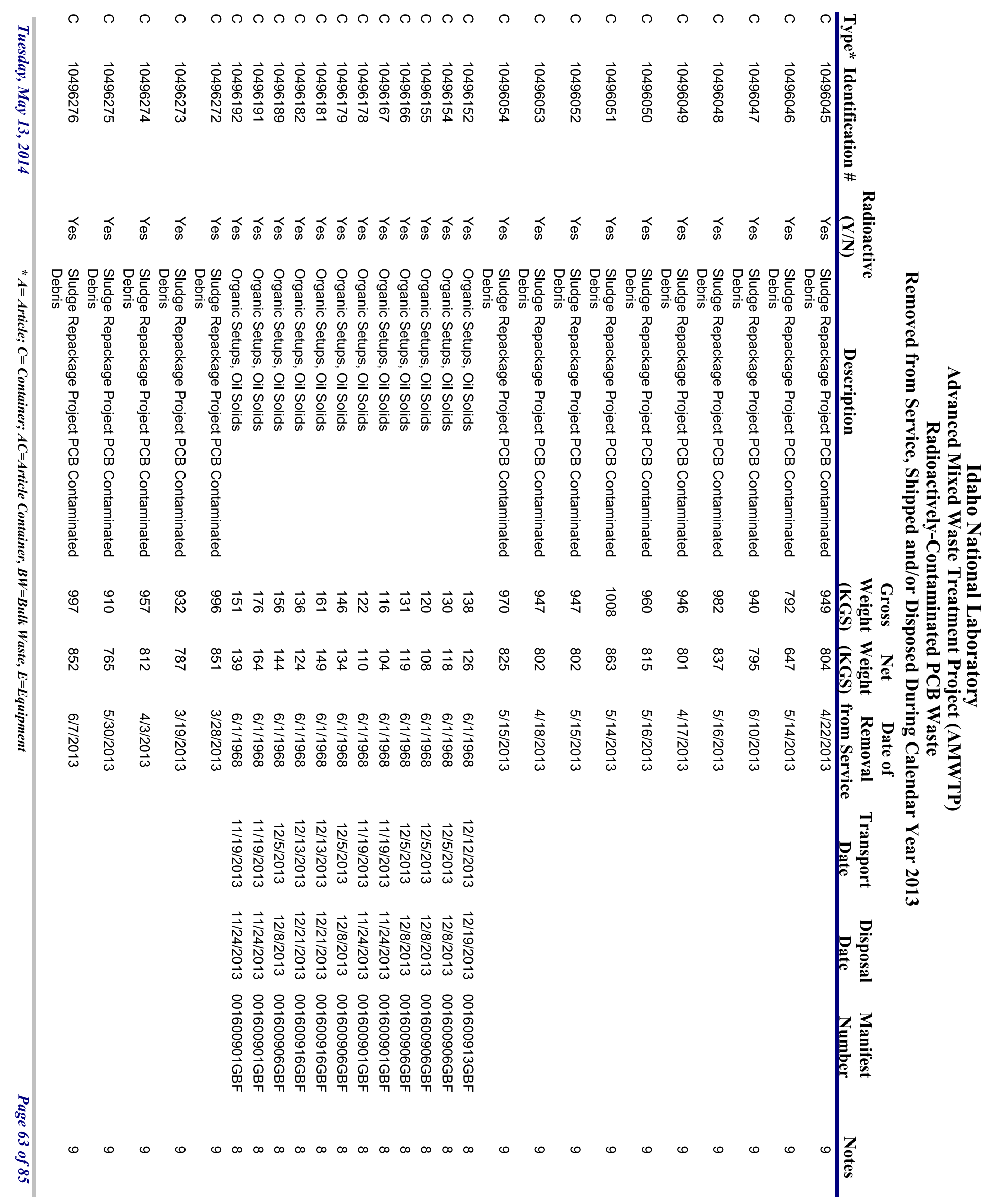




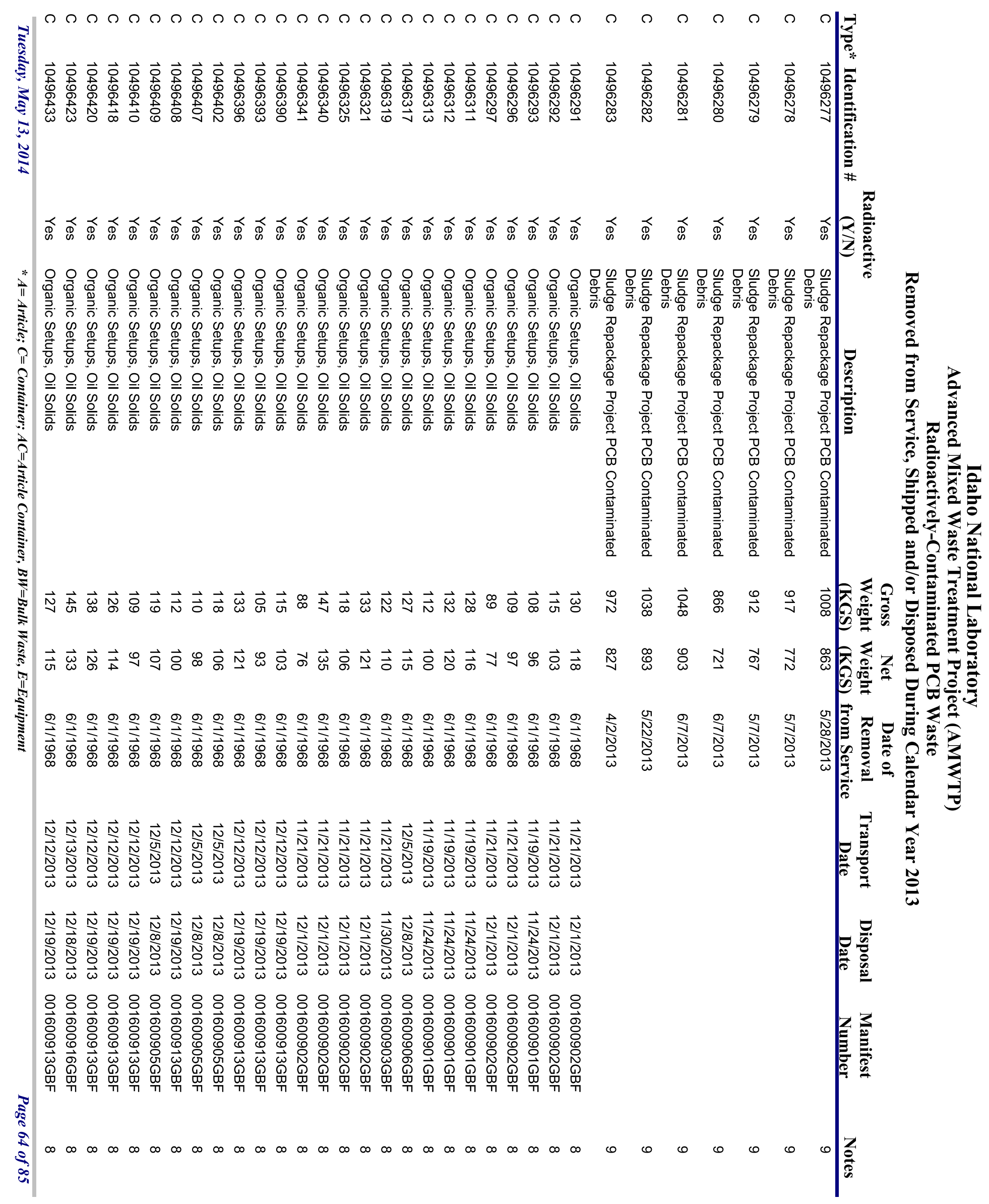




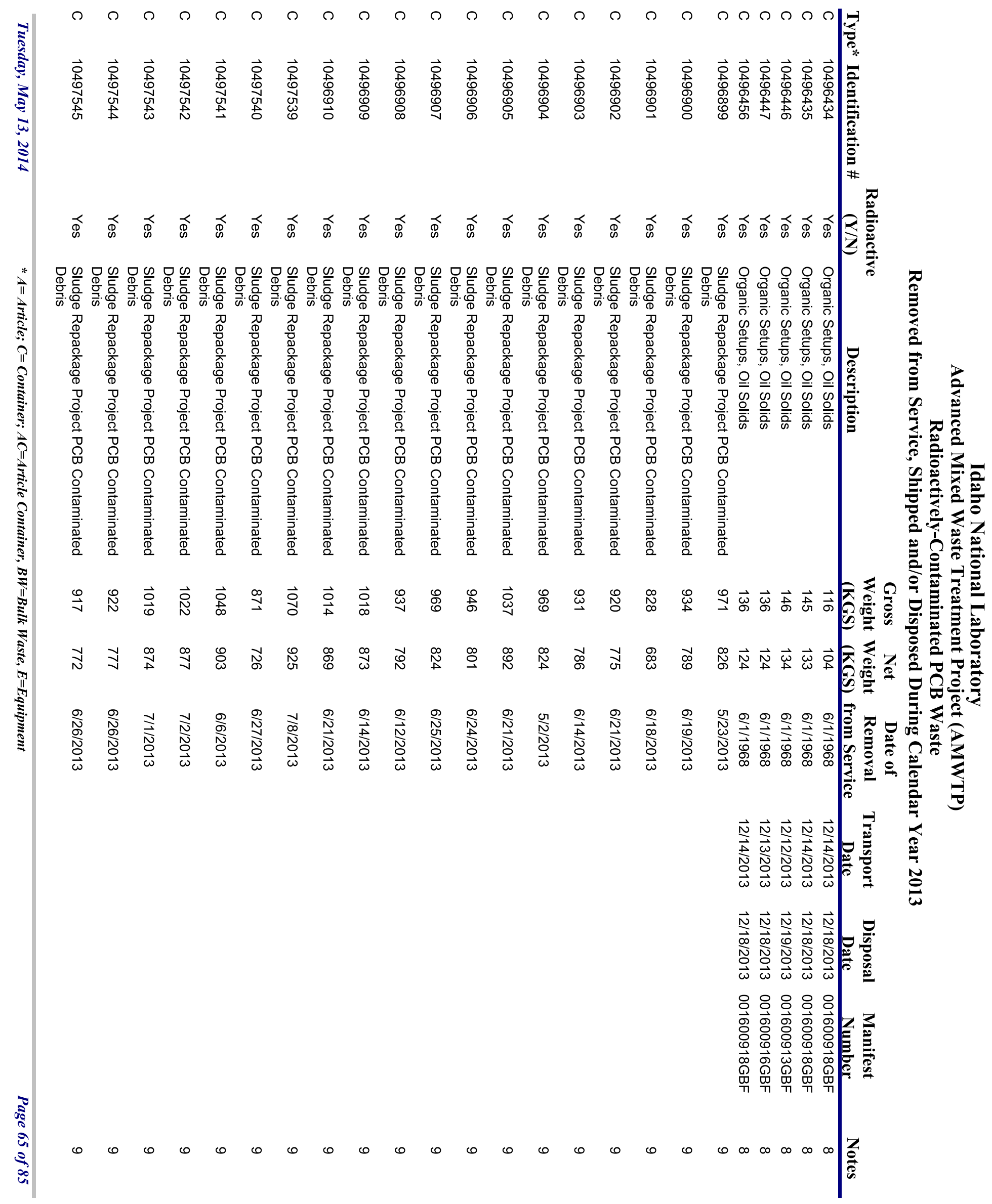




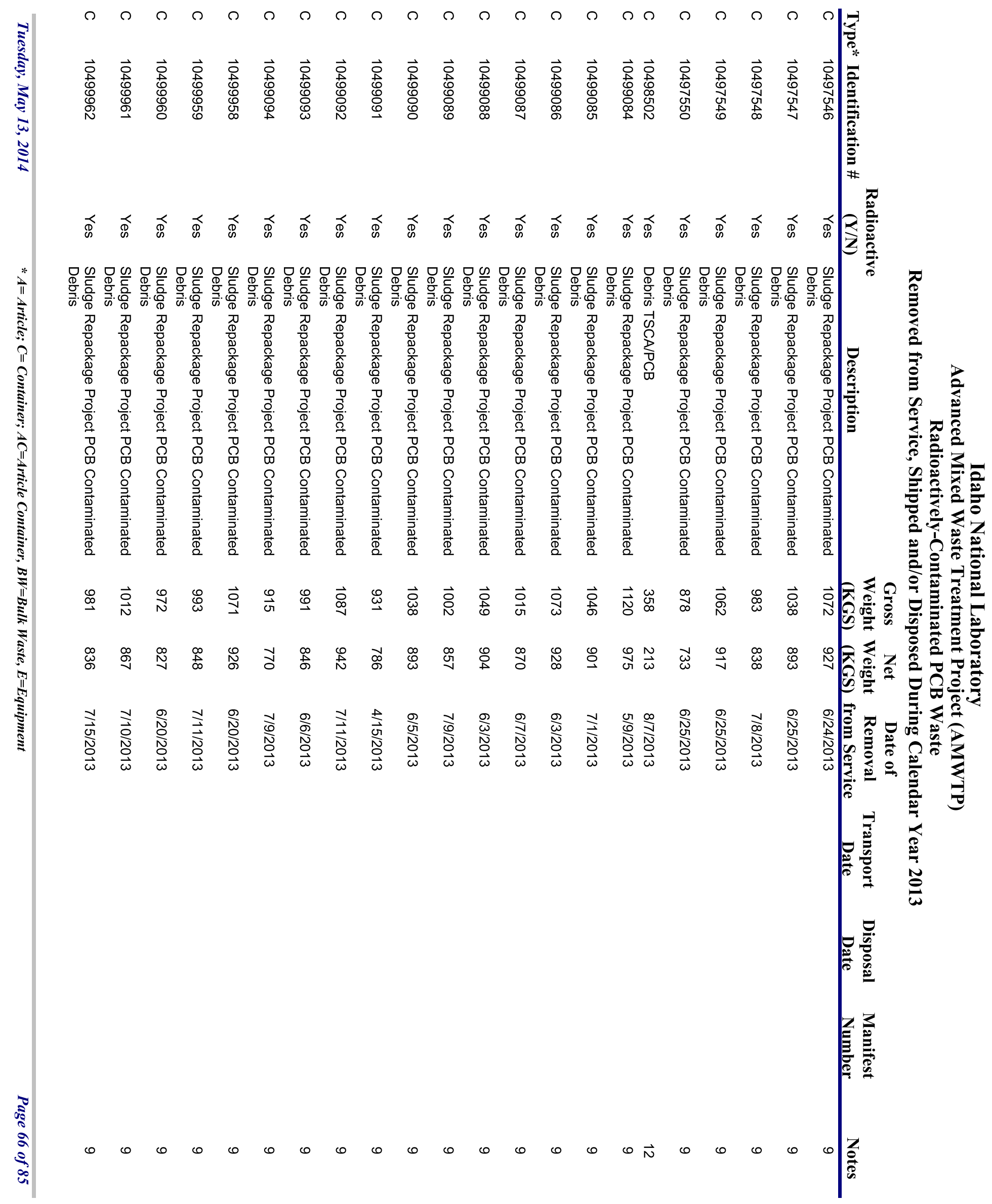




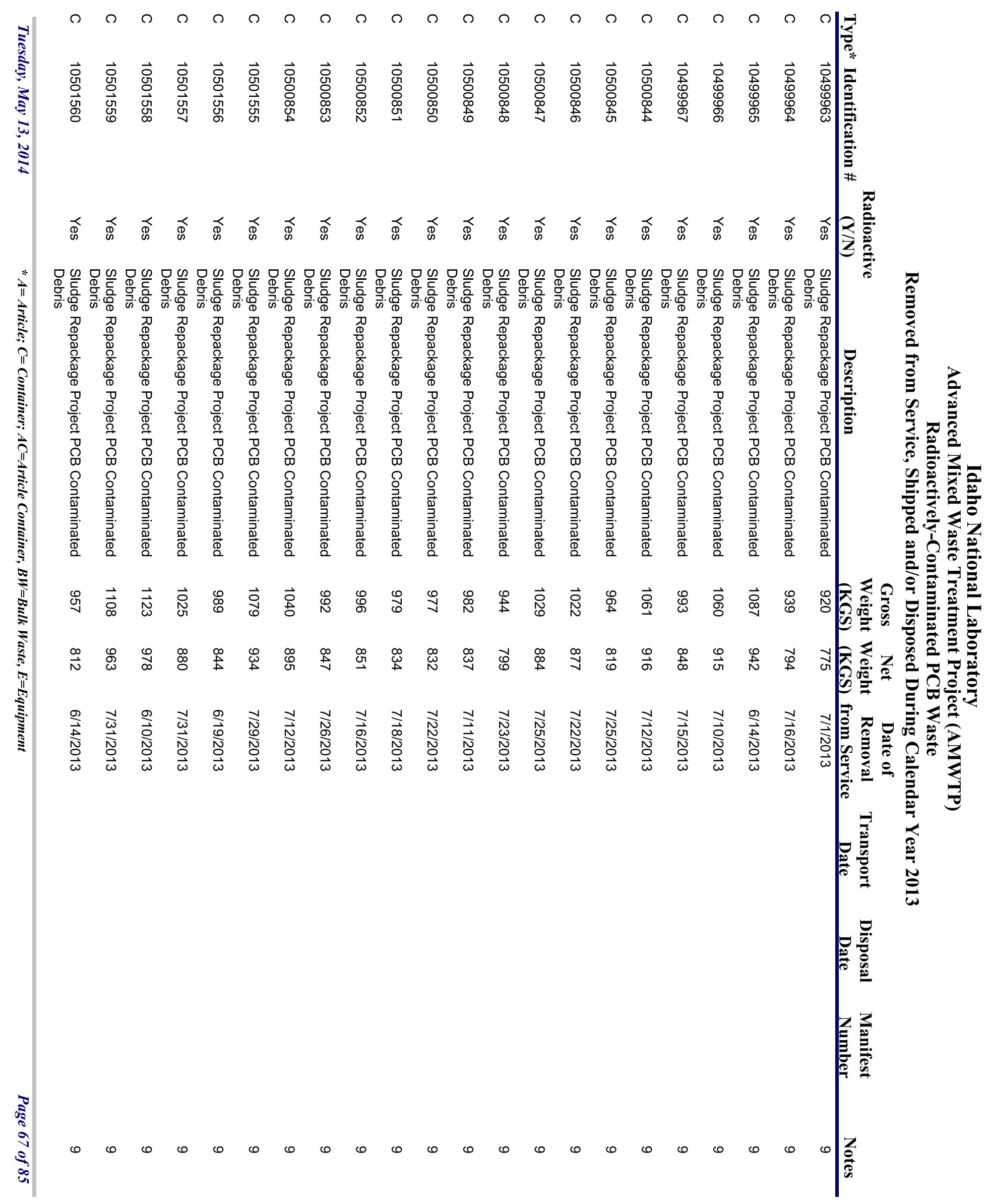




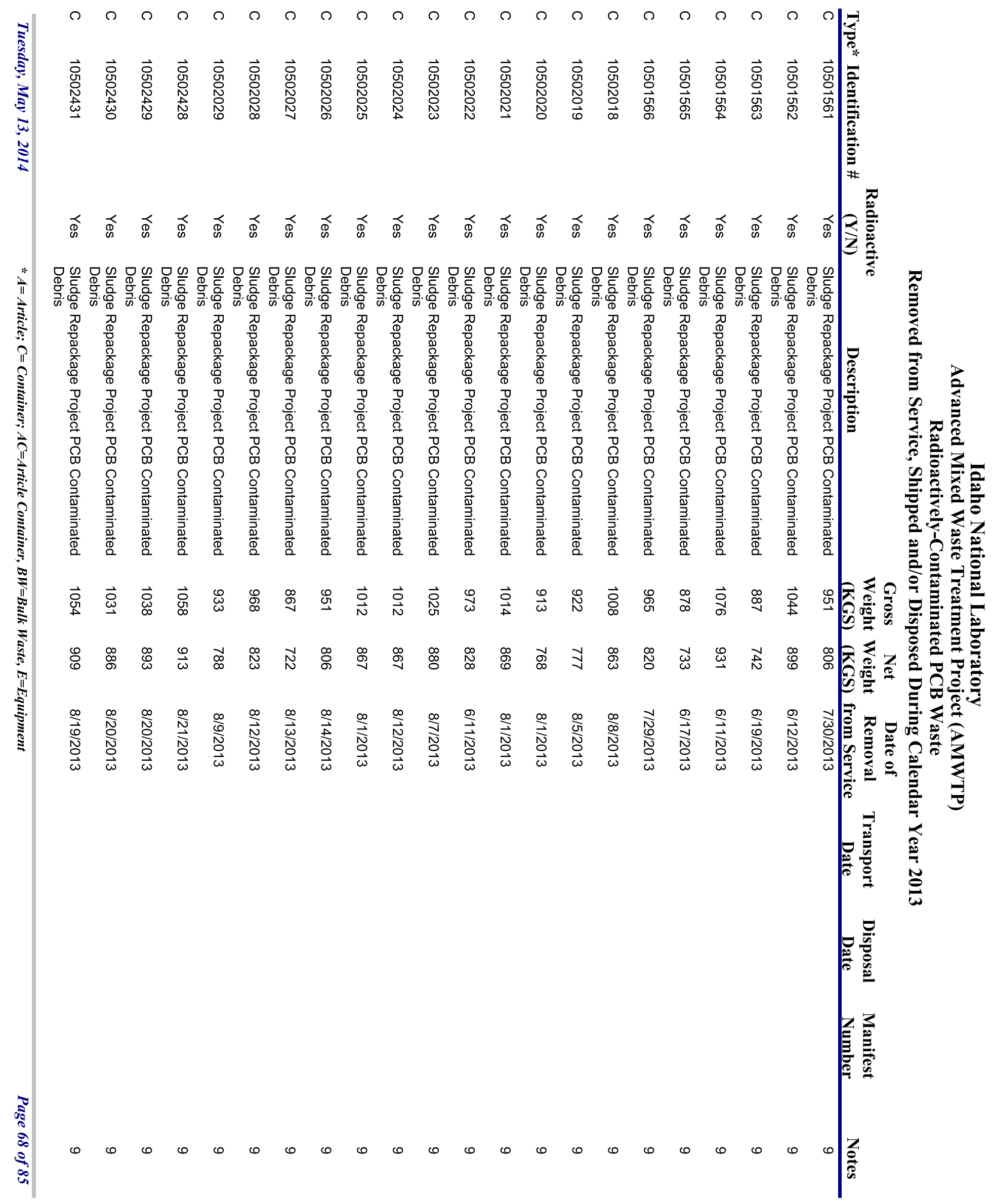




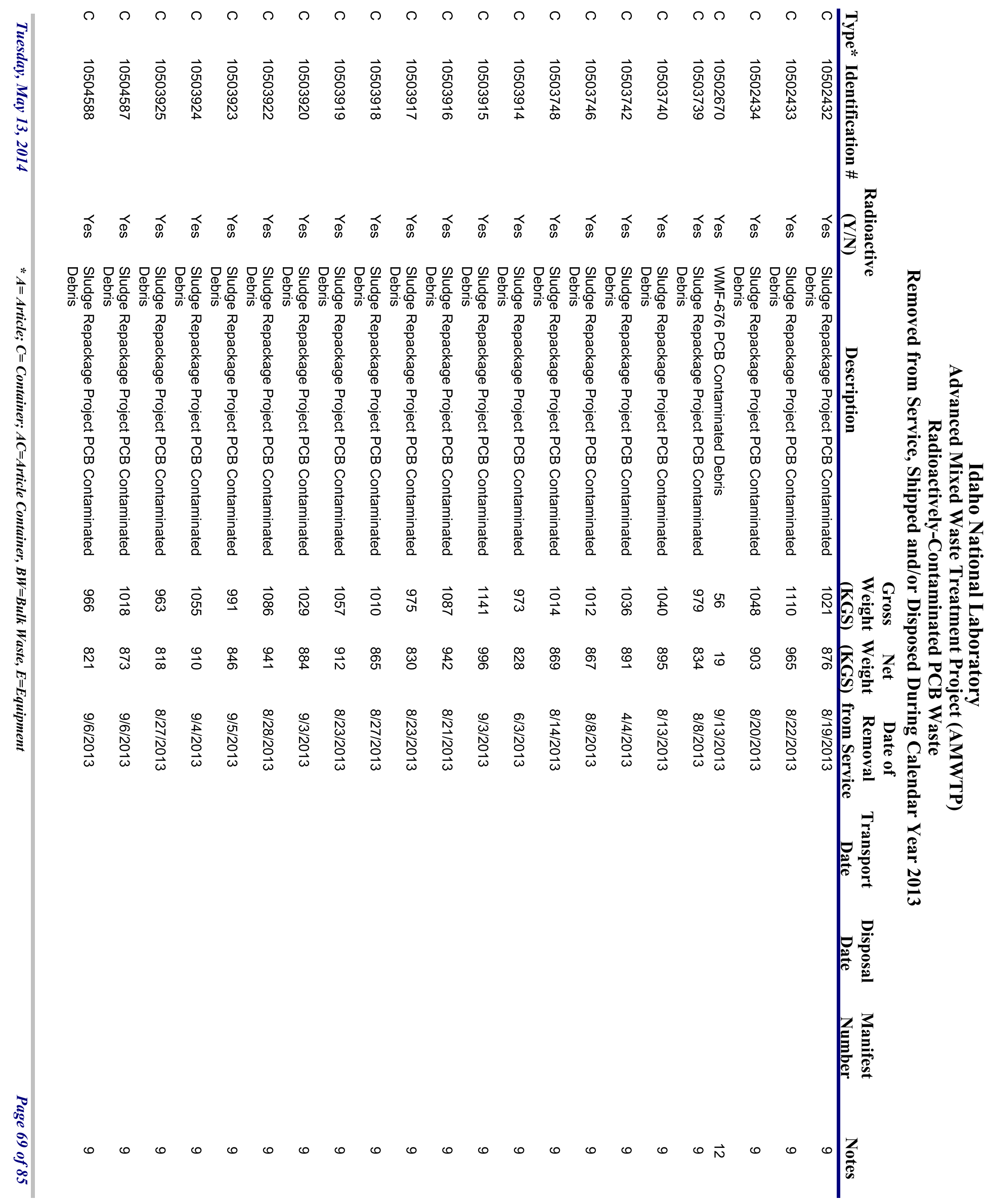




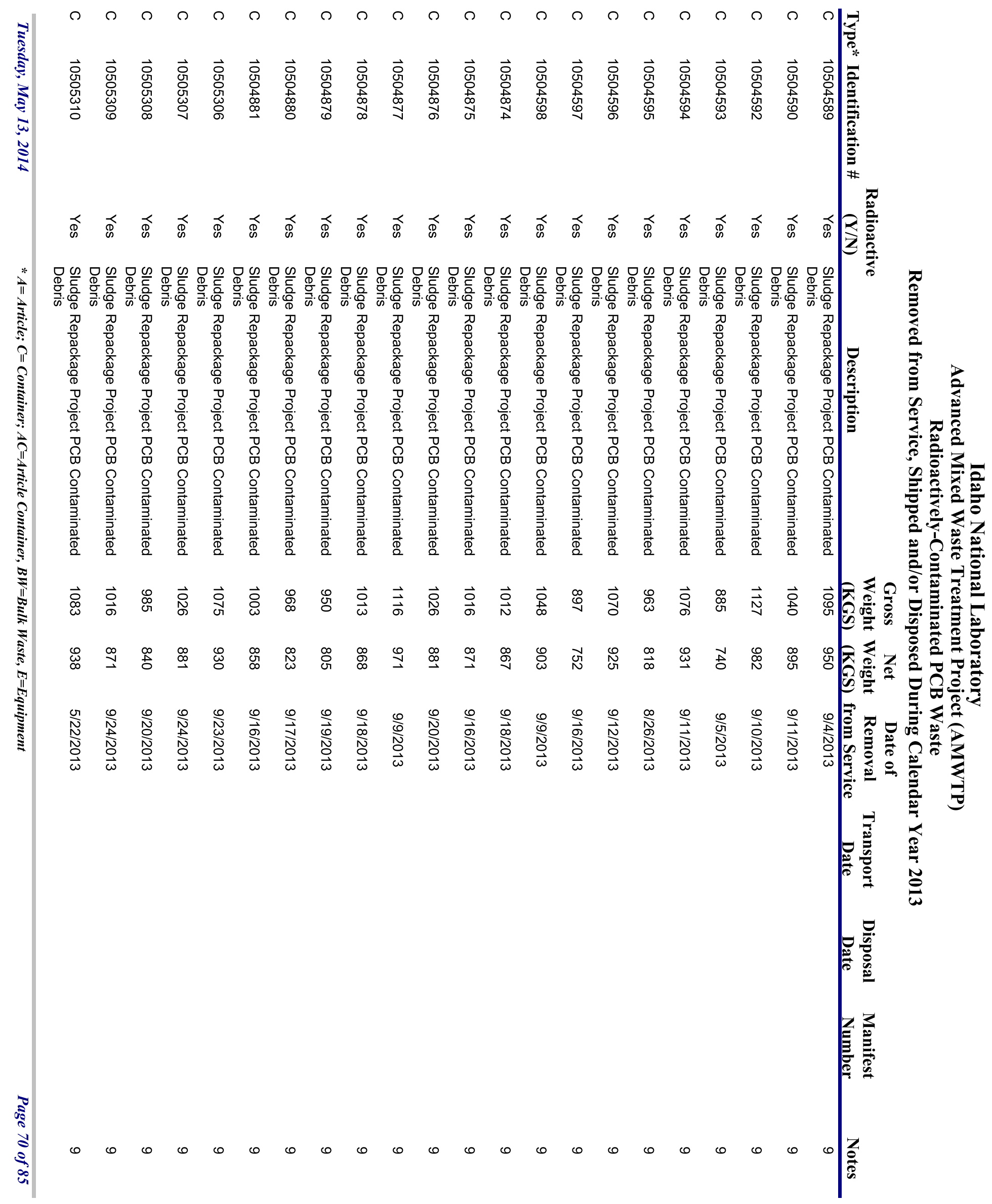




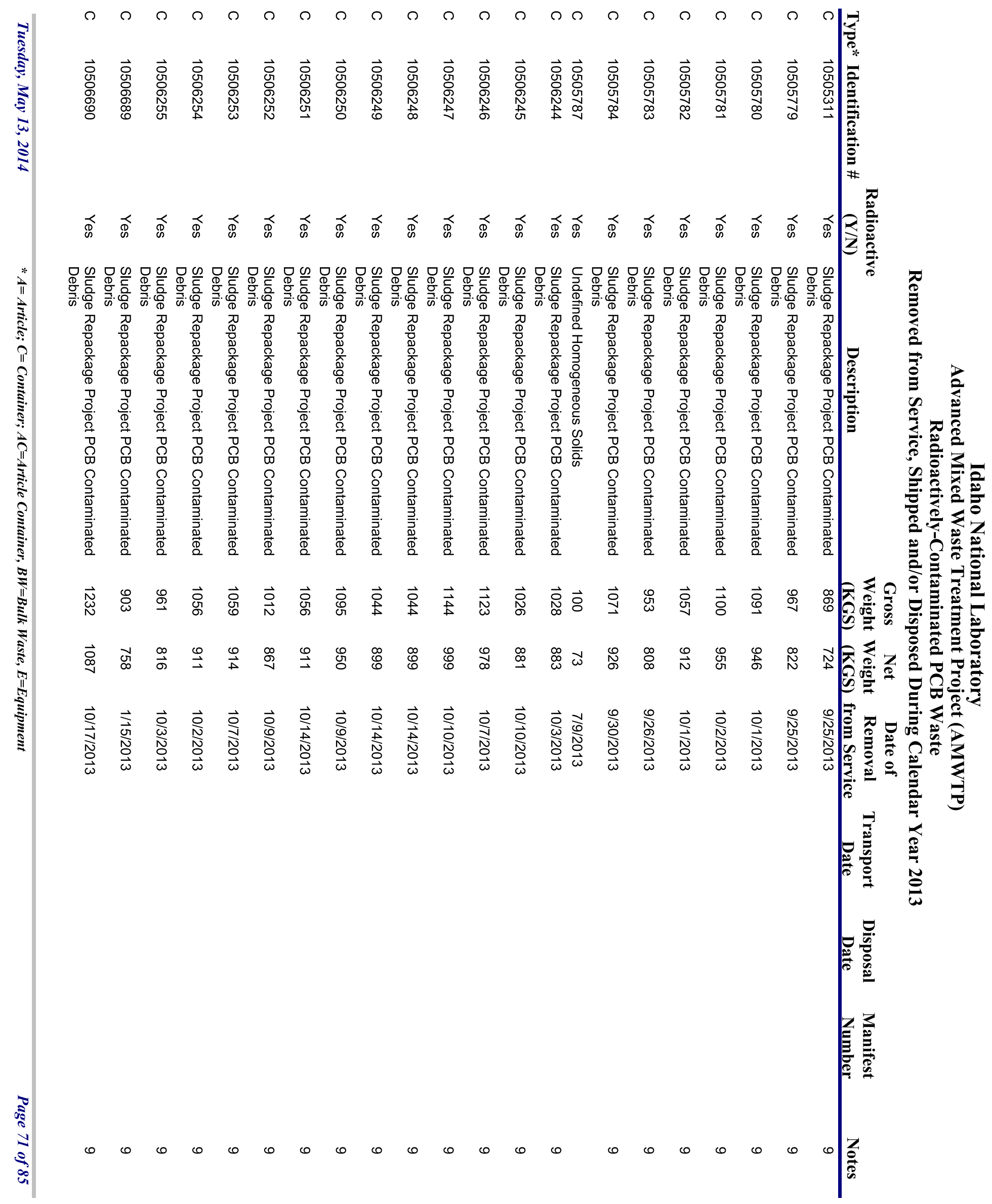




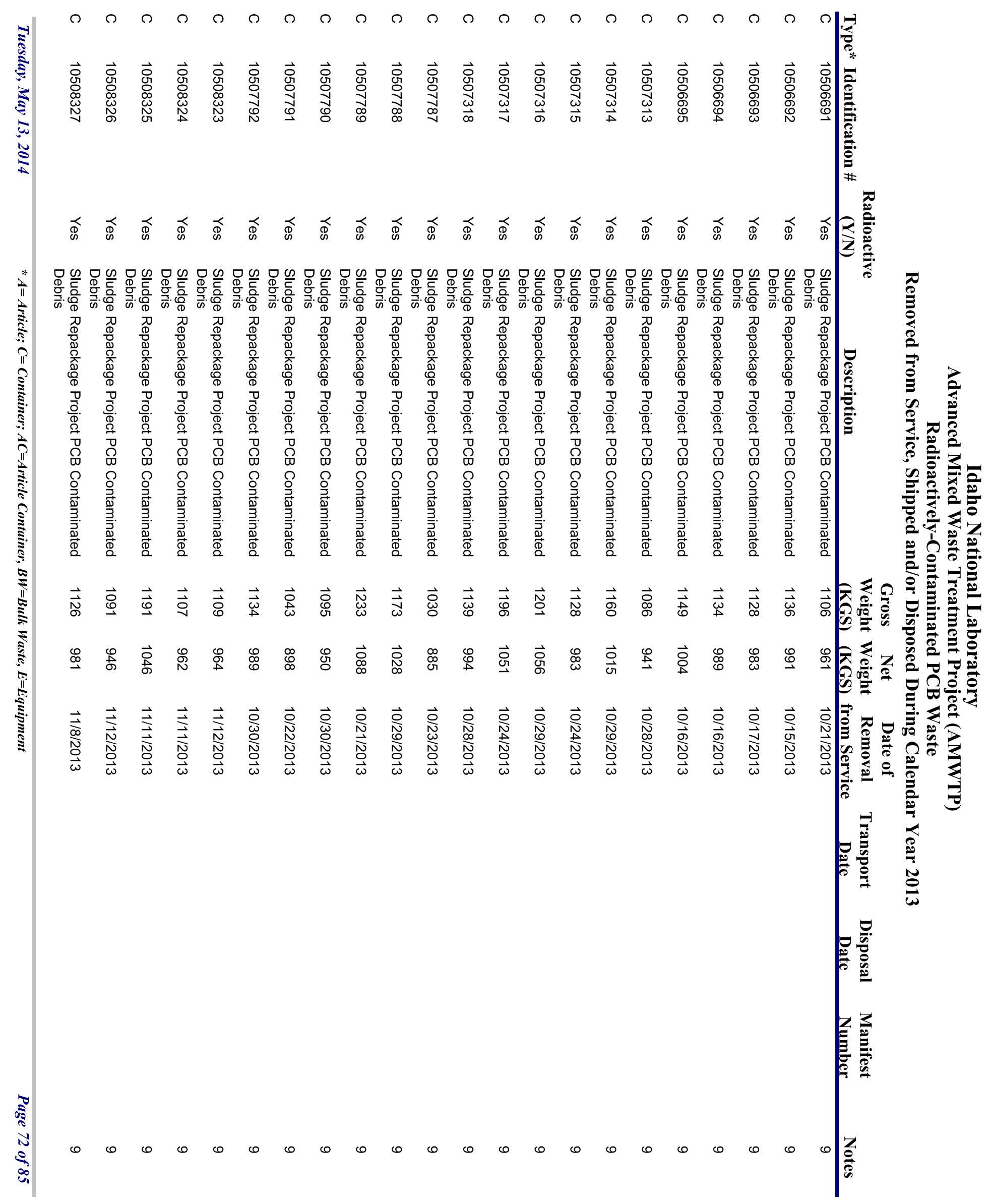




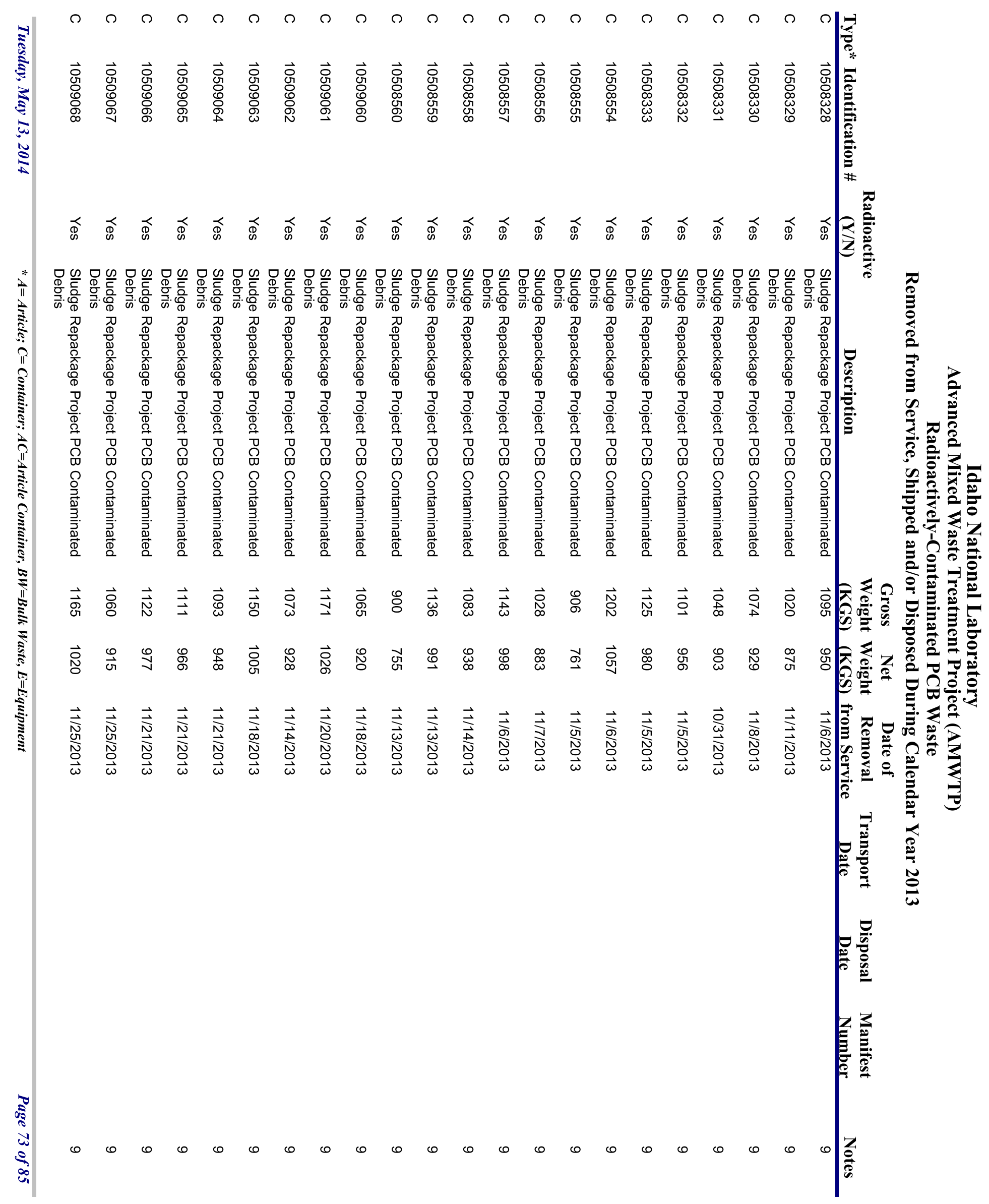




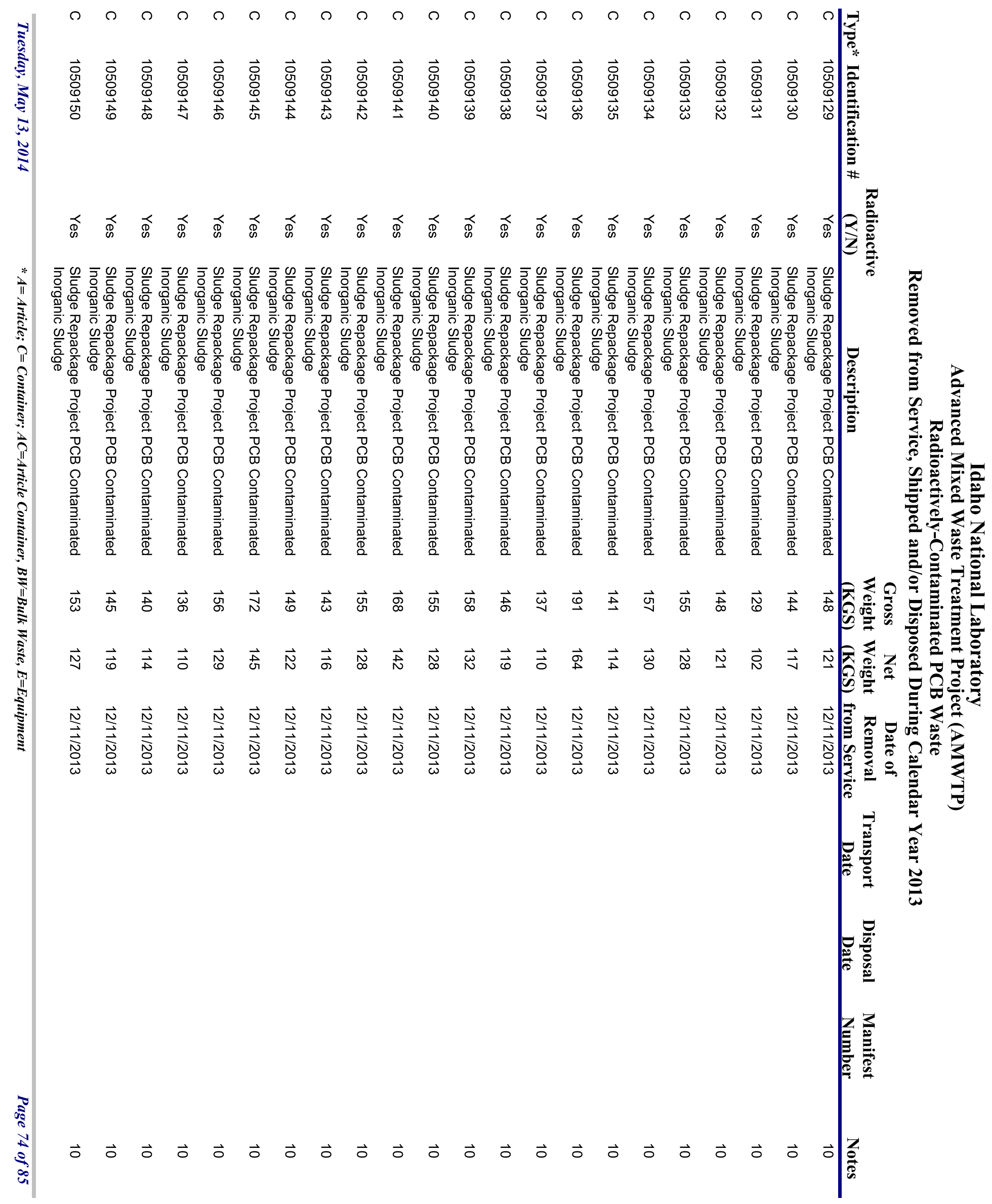




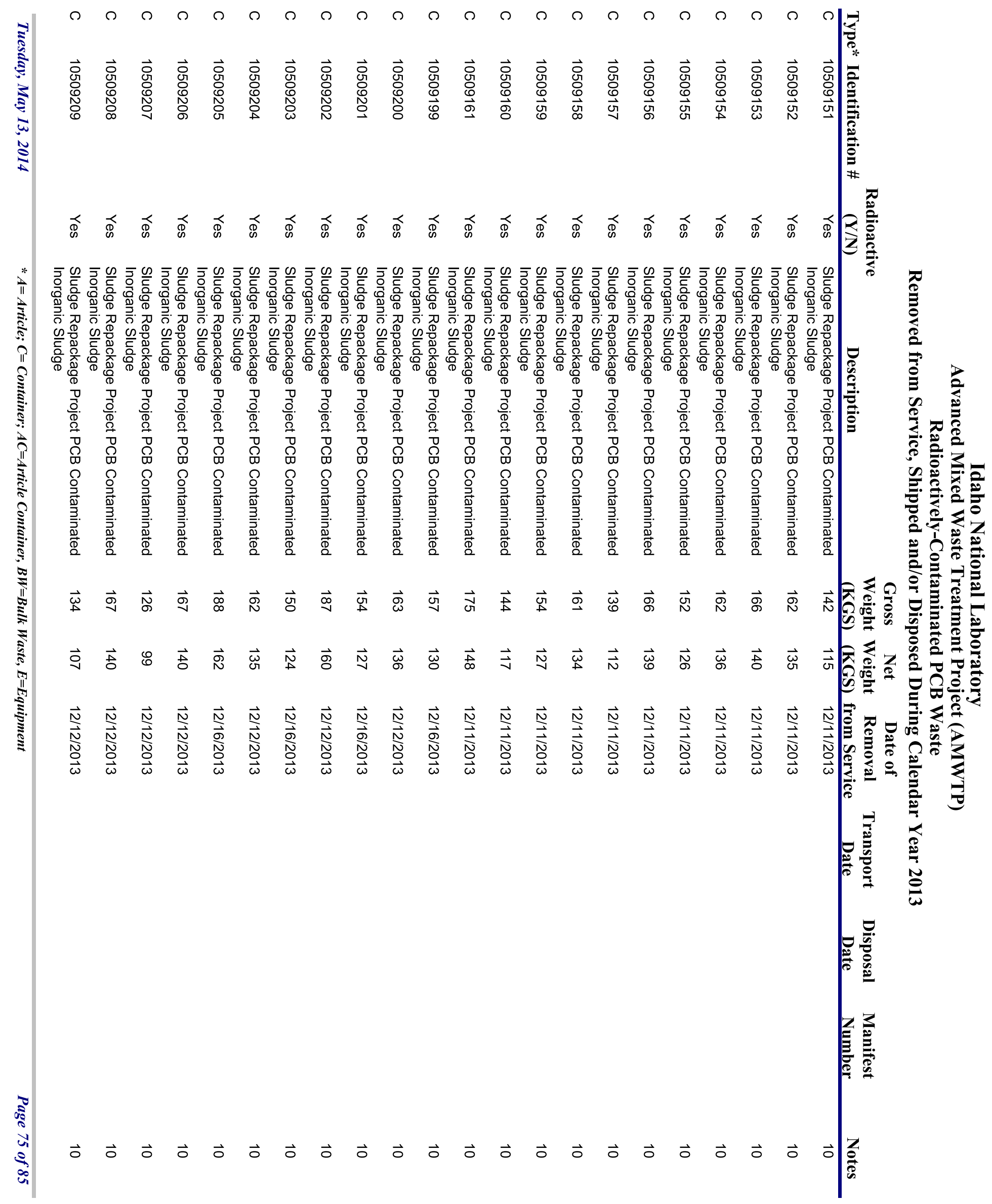




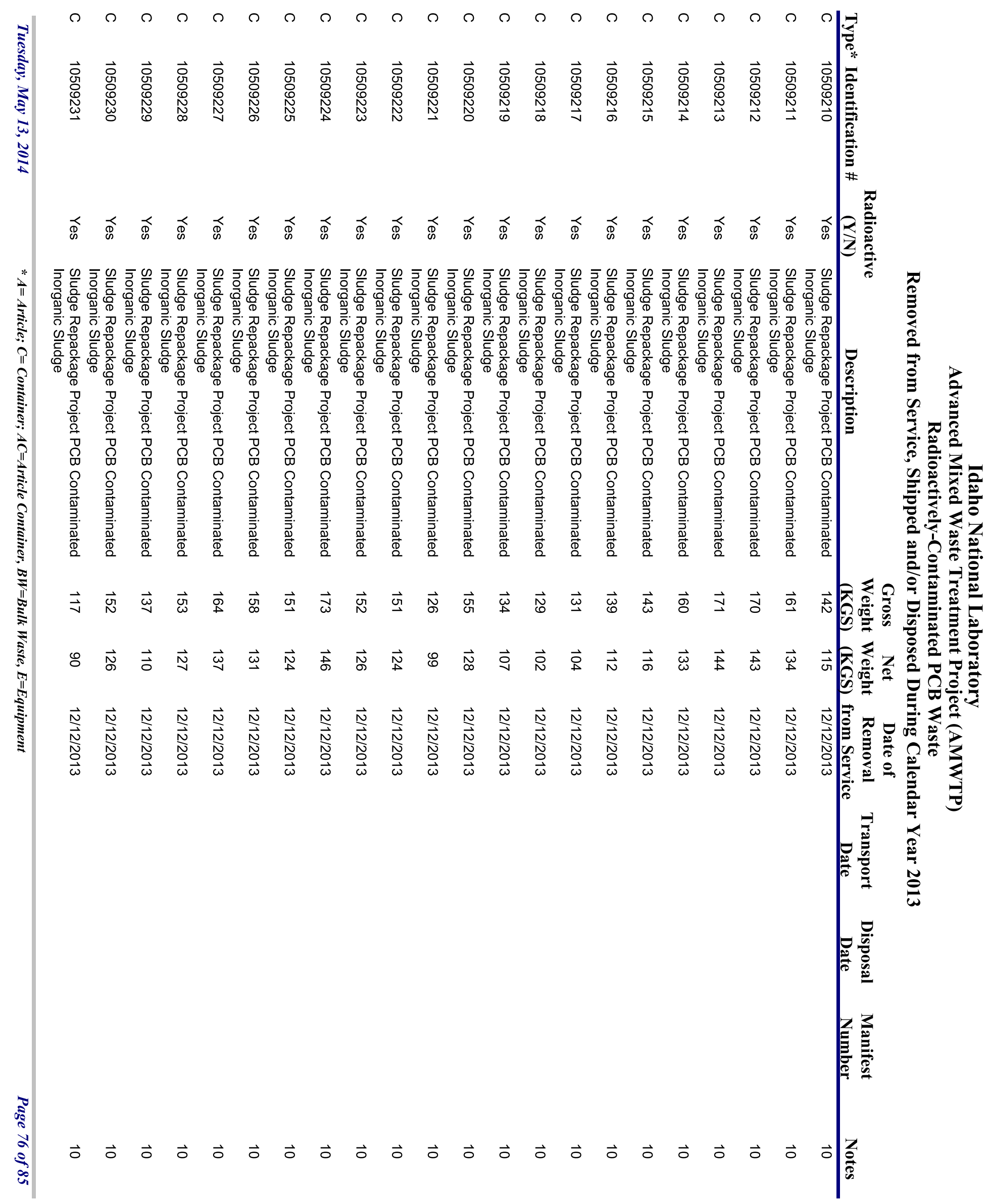




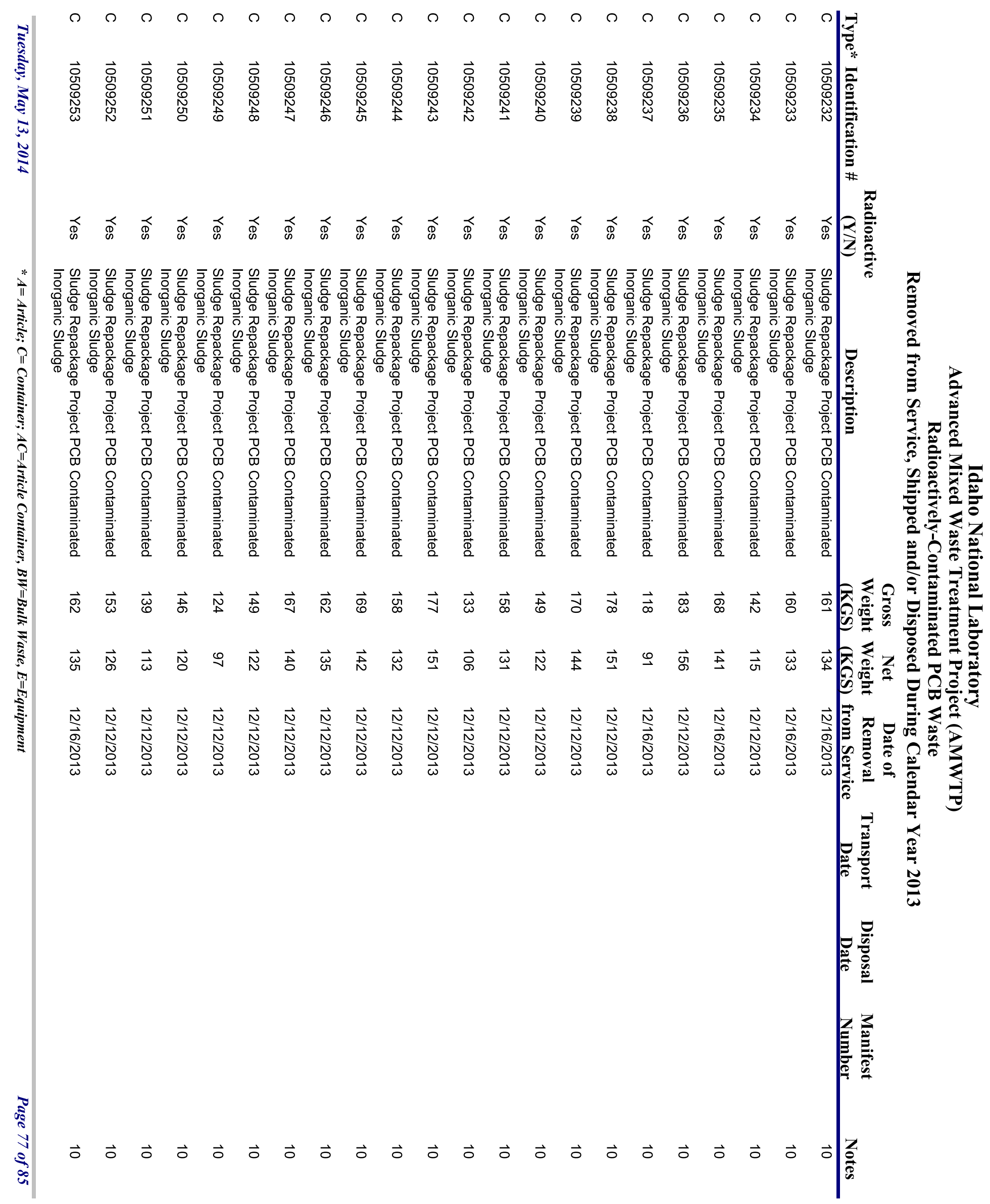




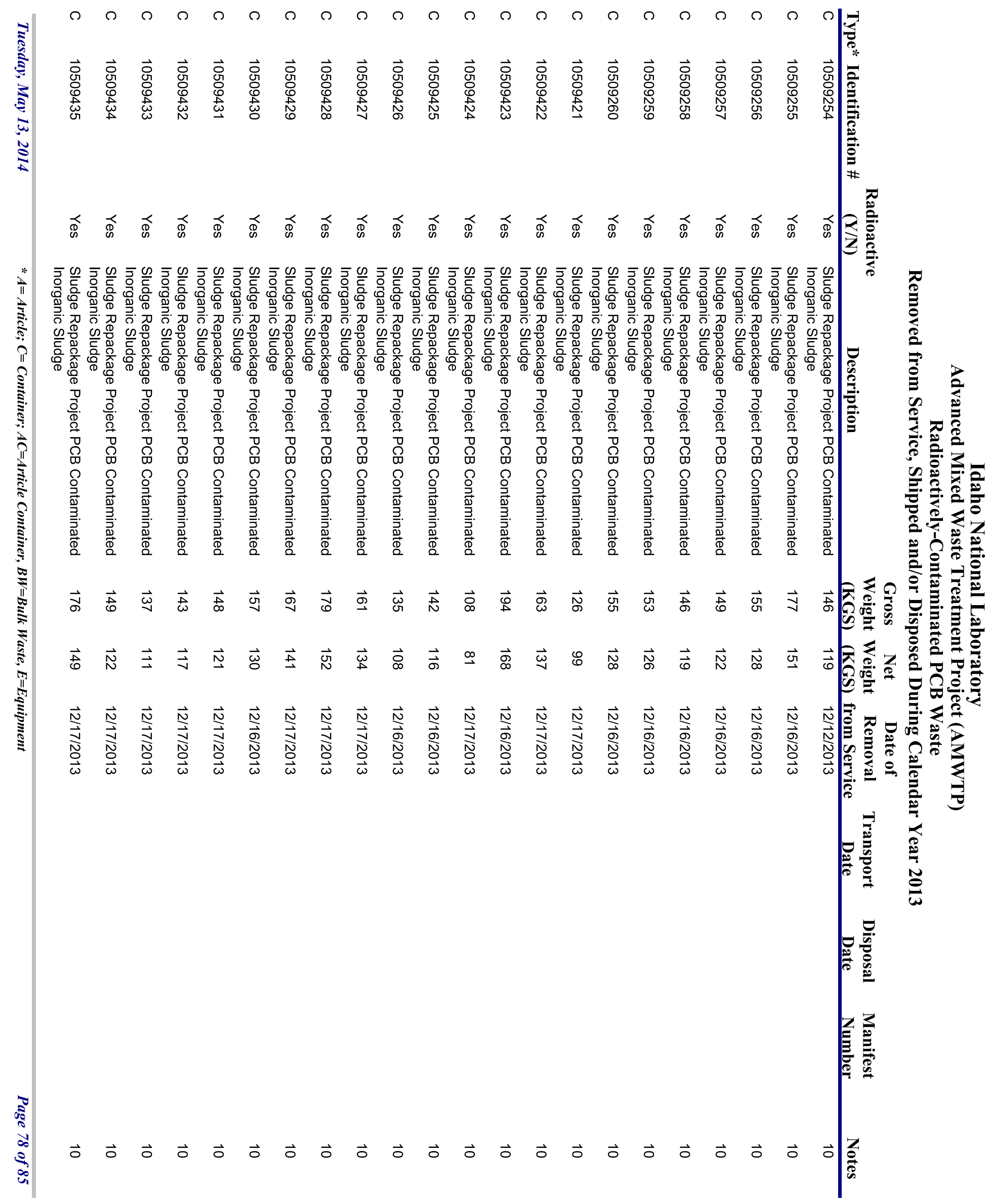




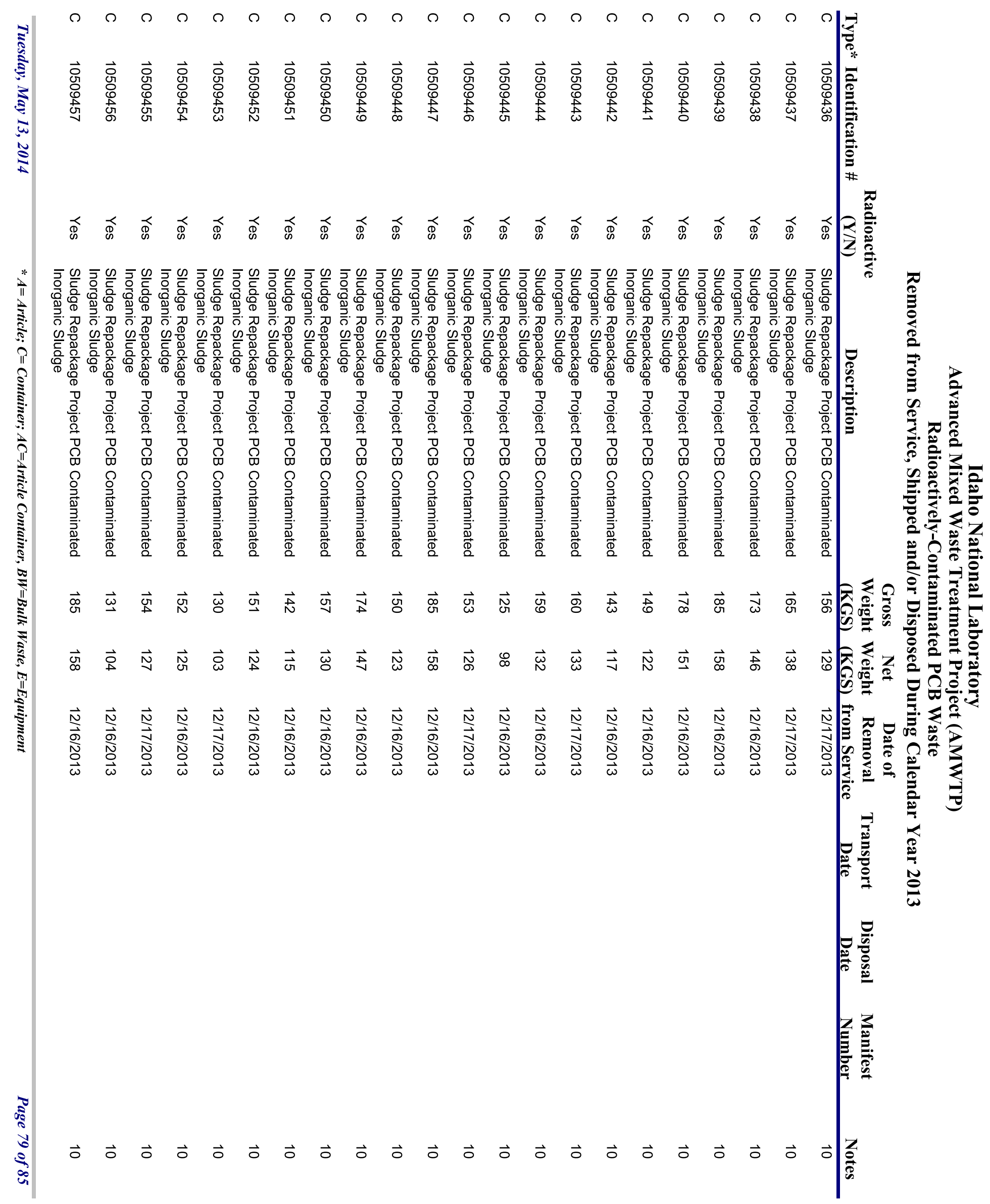




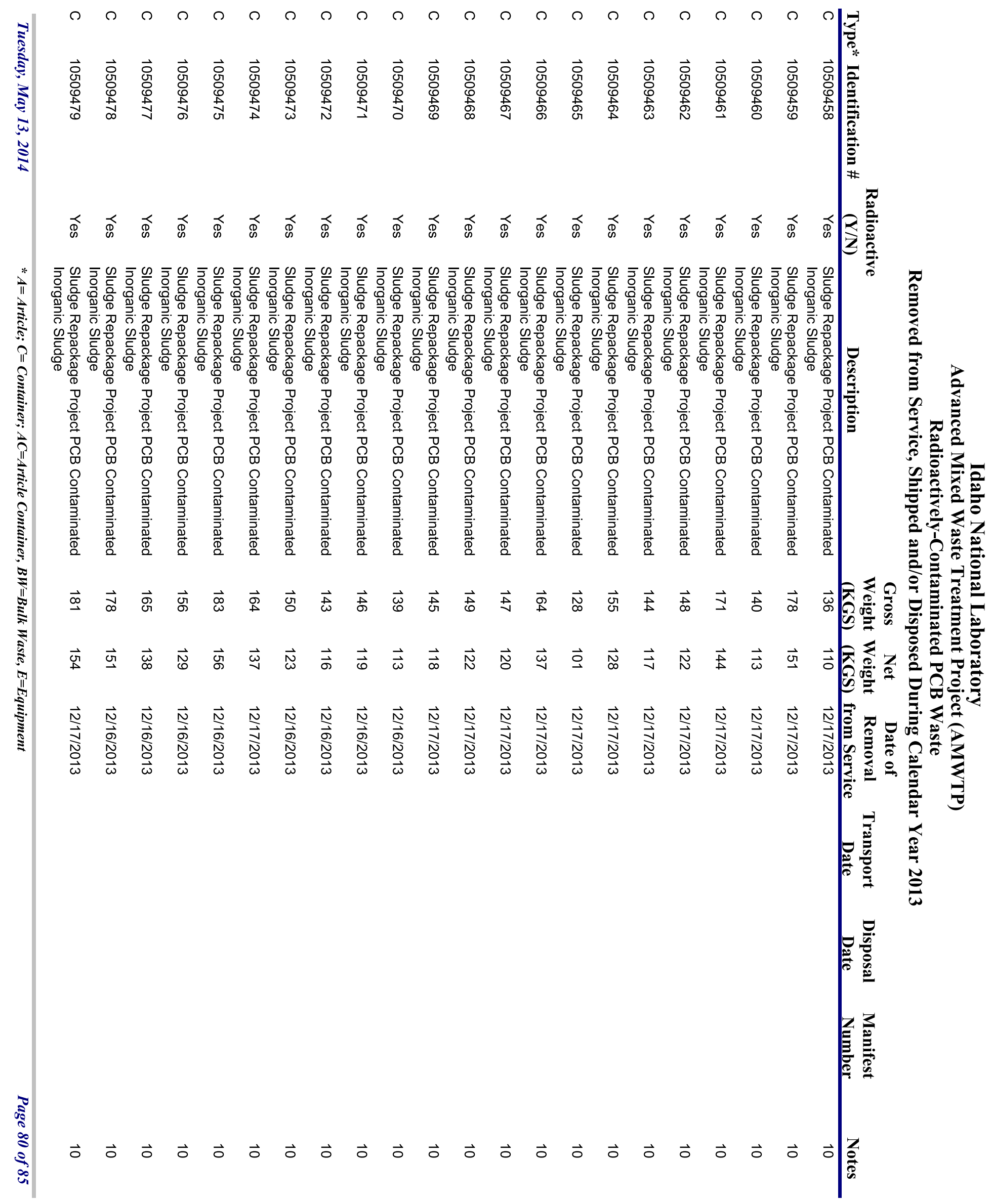




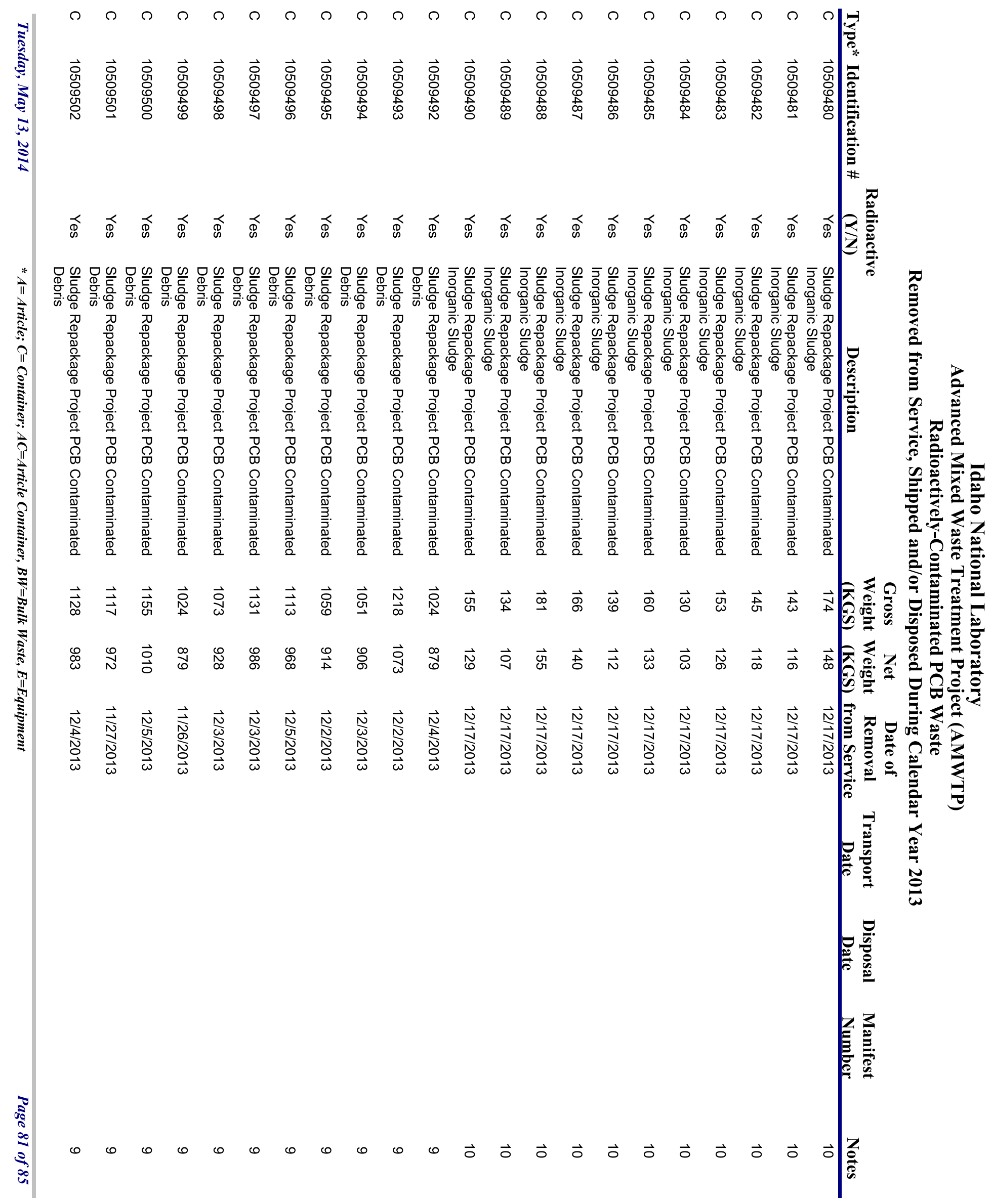




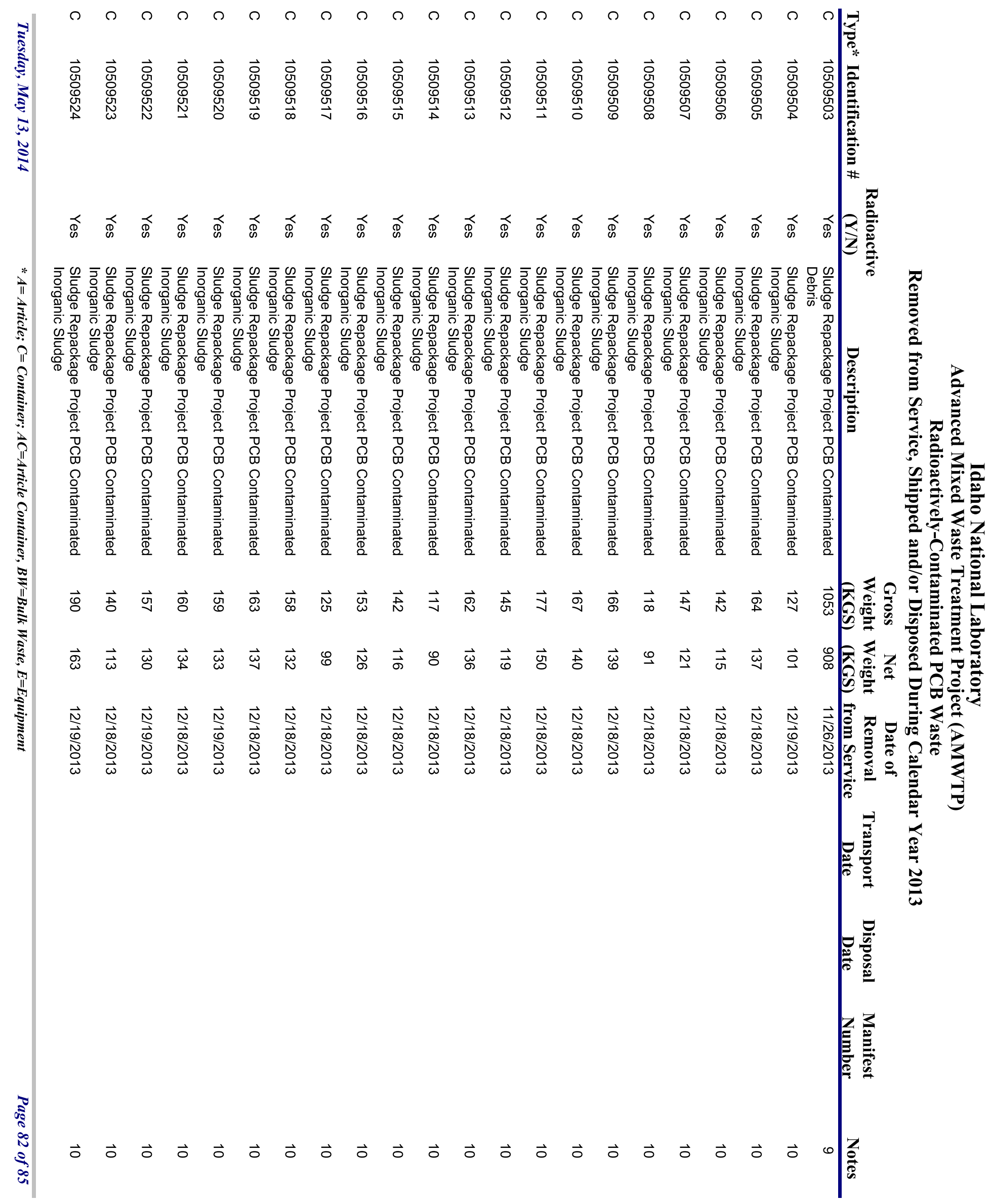




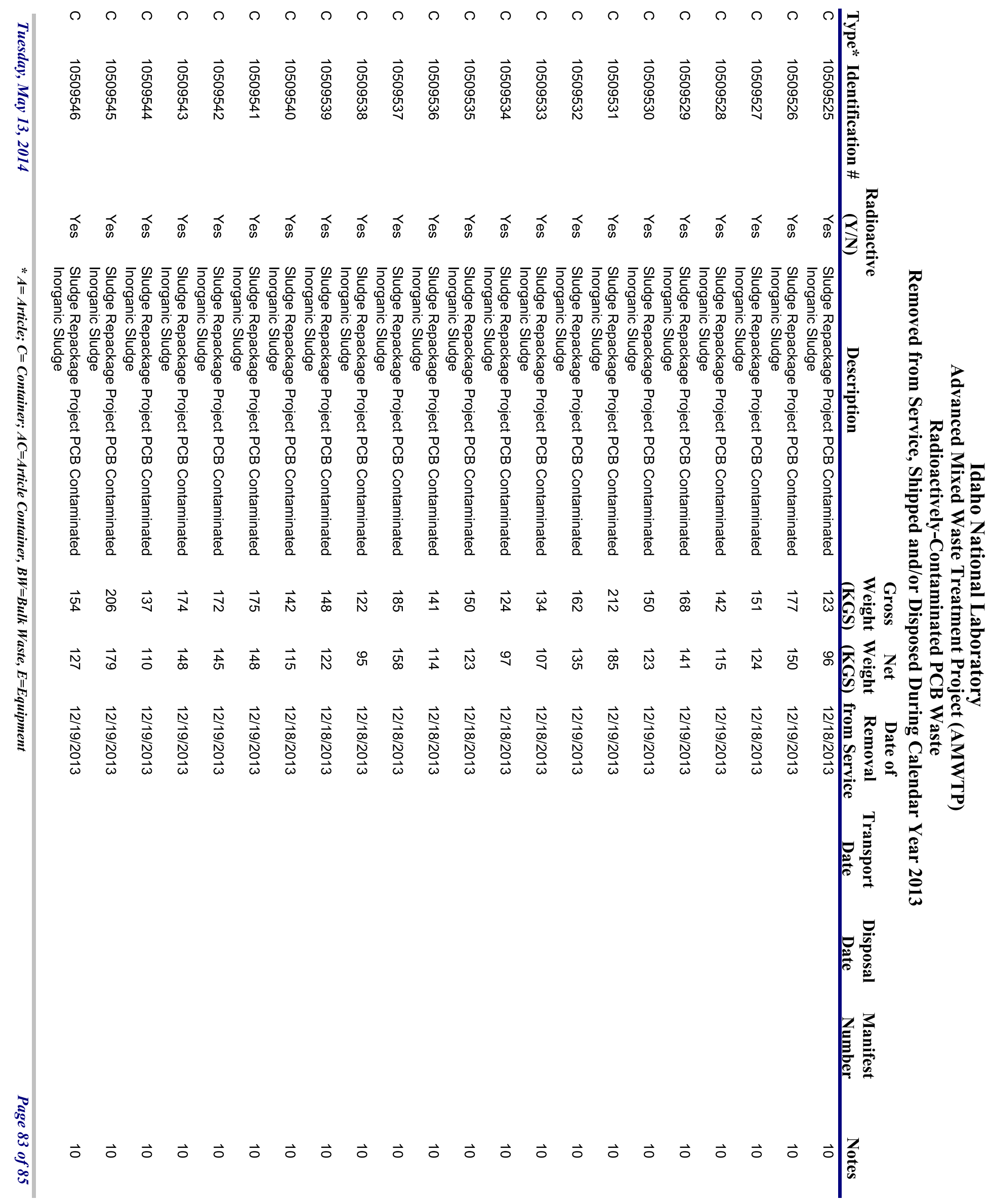




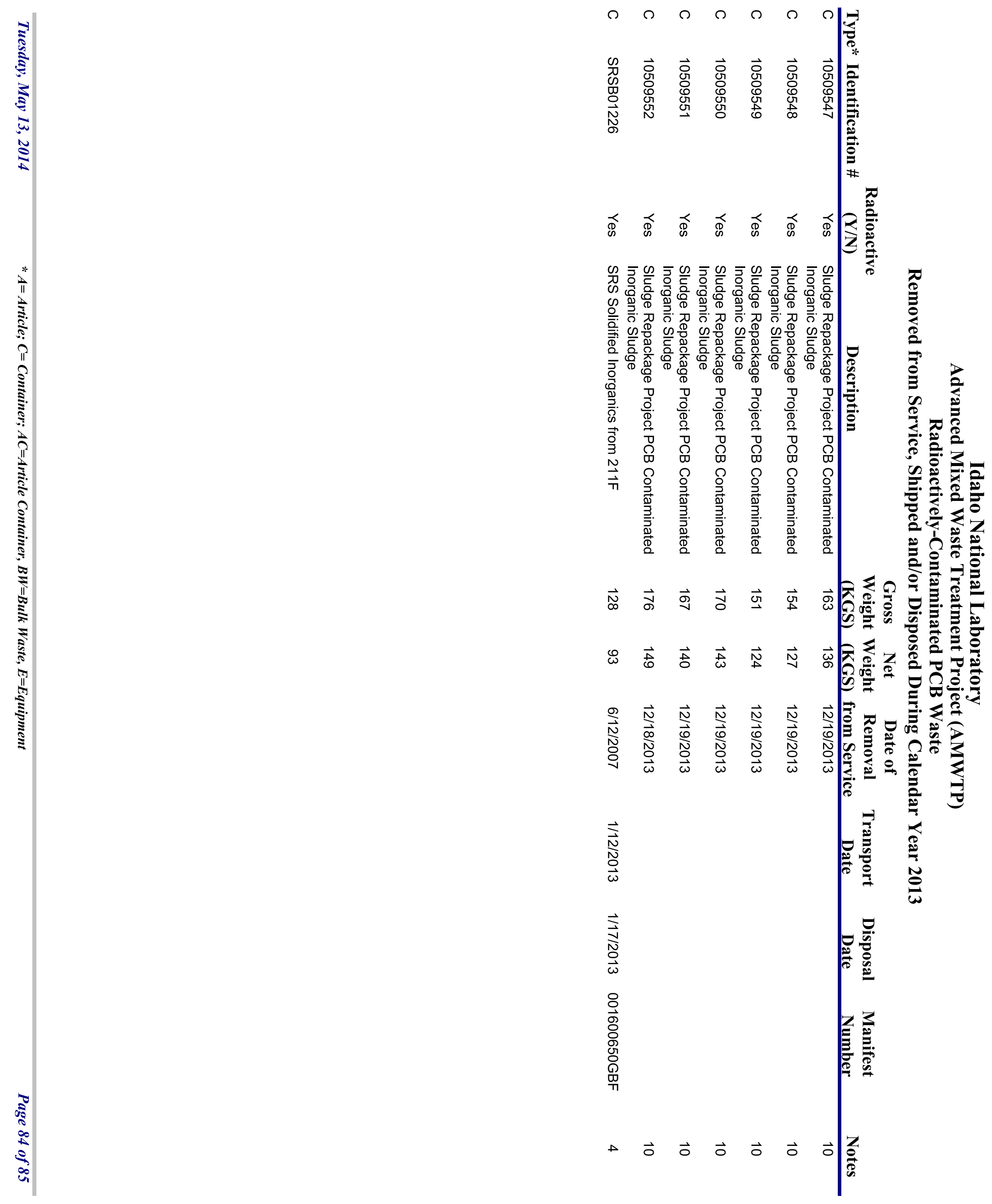




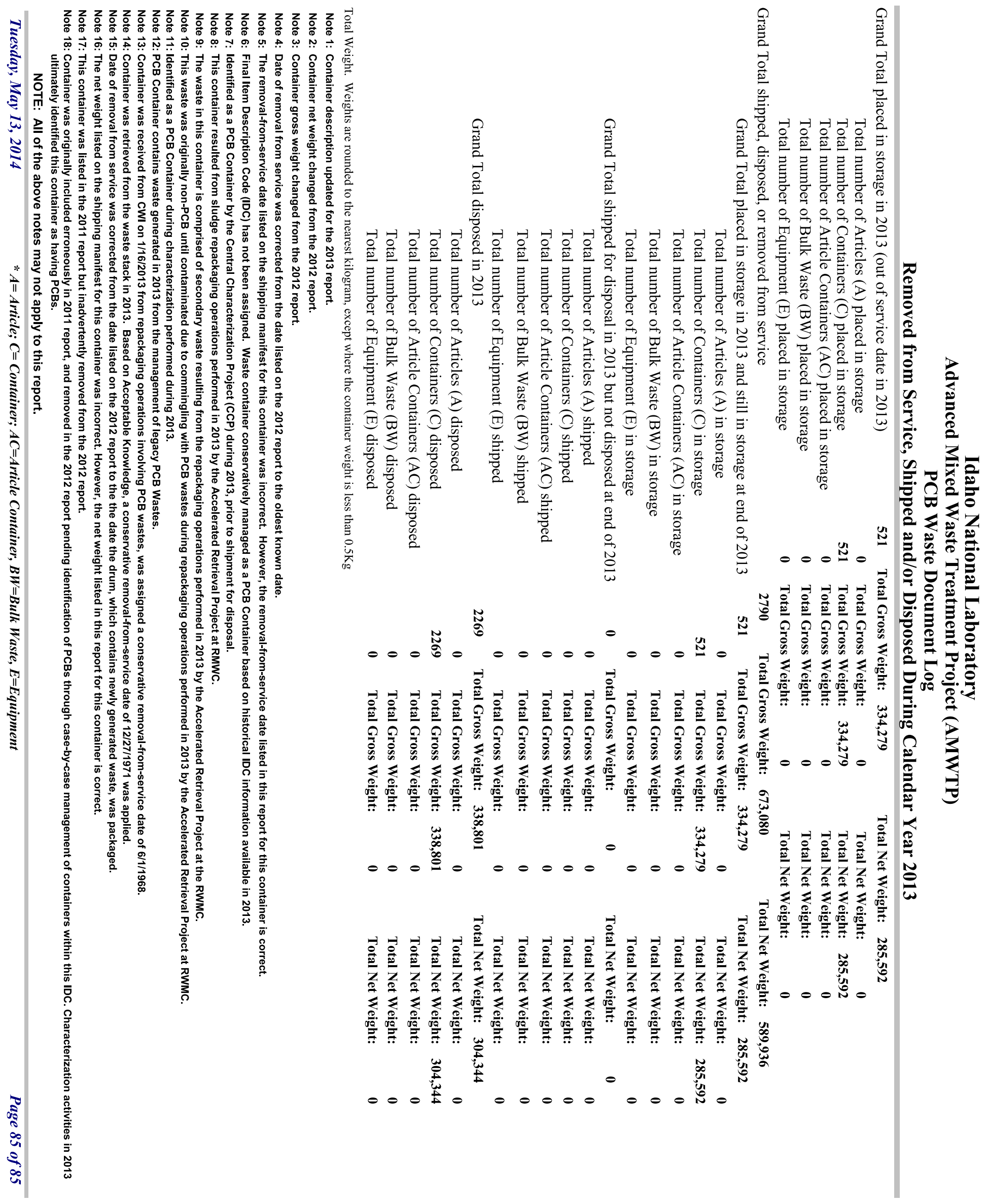


7.0 RADIOACTIVELY-CONTAMINATED PCB WASTE REPACKAGED DURING CALENDAR YEAR 2013 


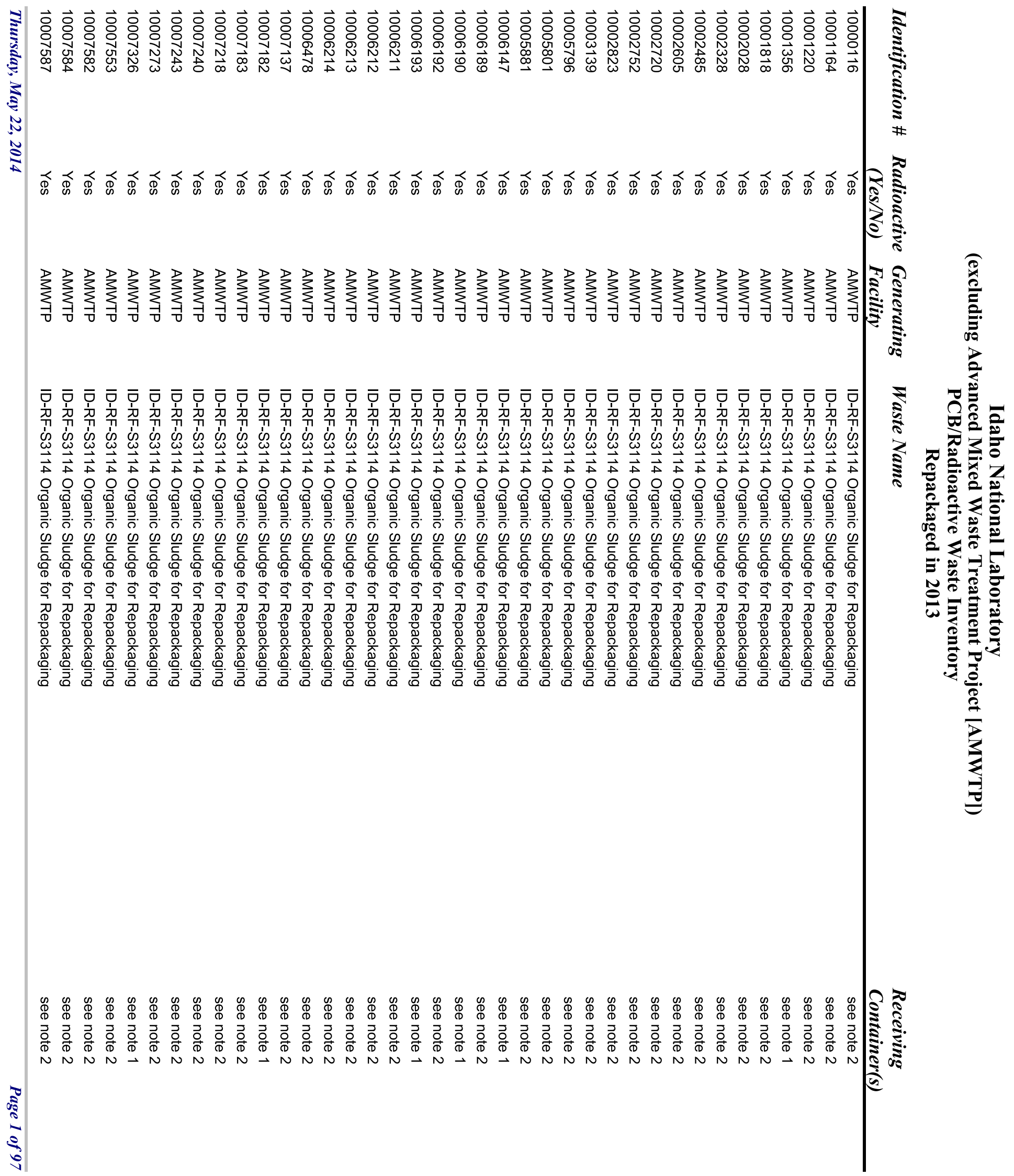




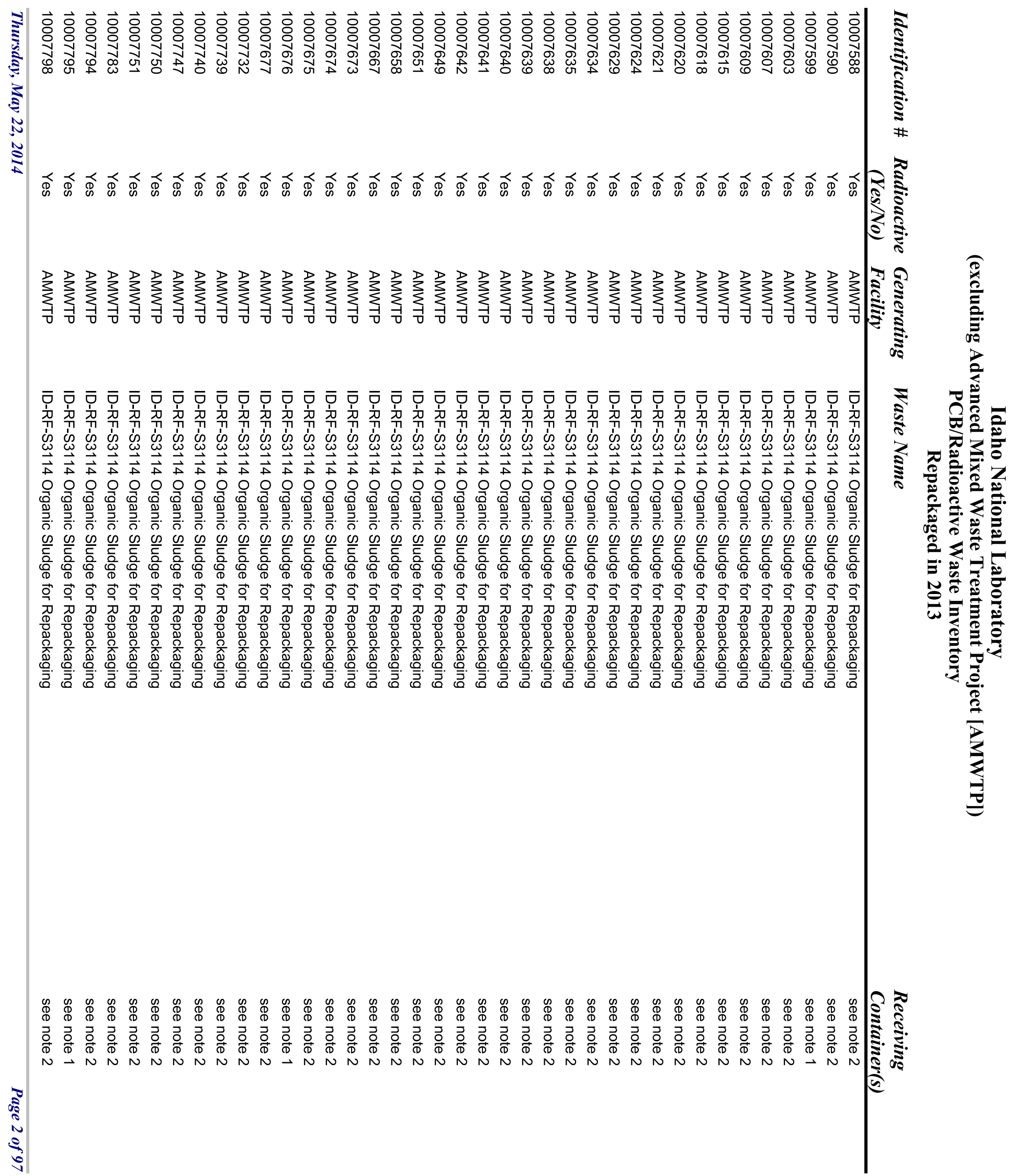




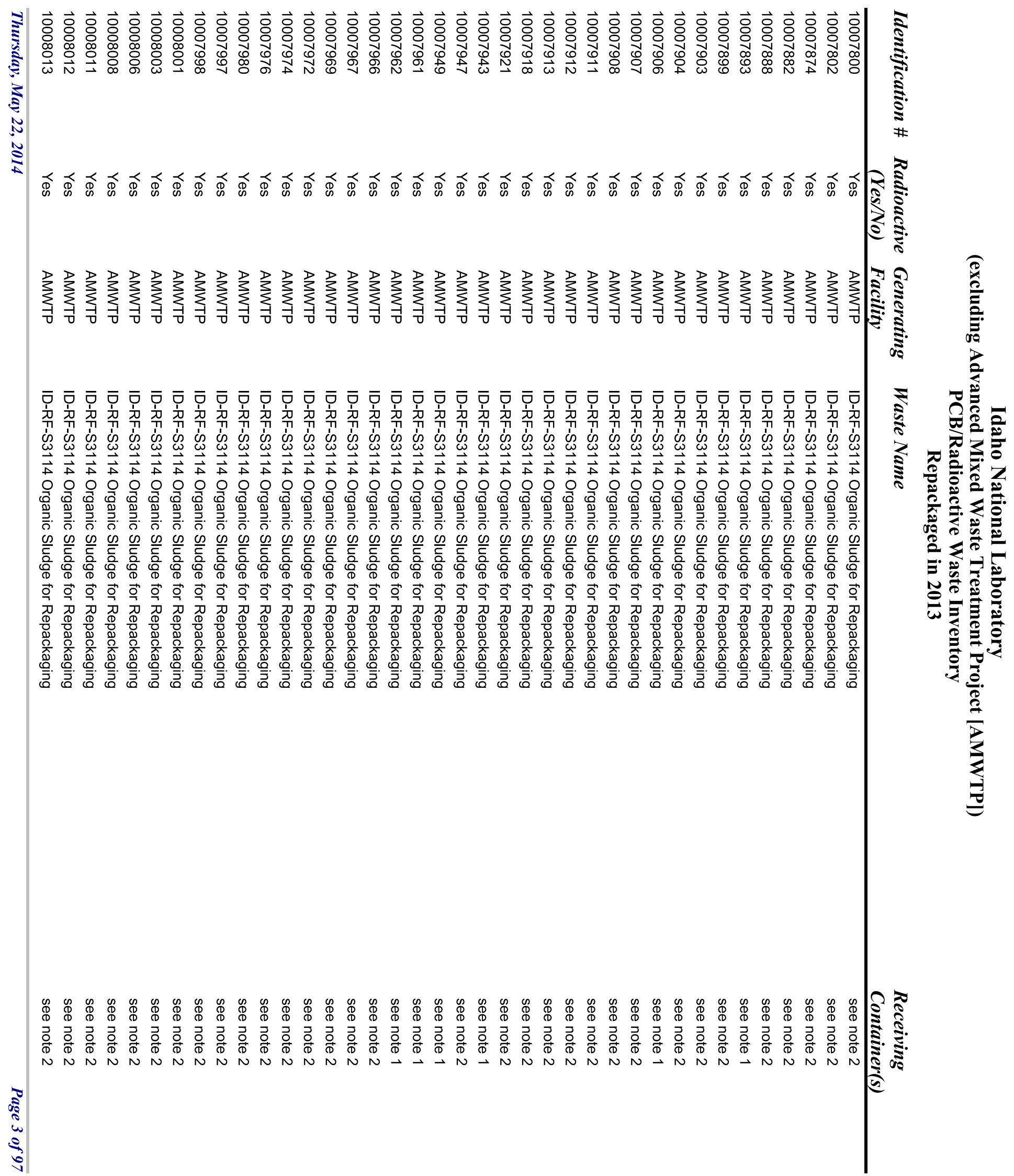




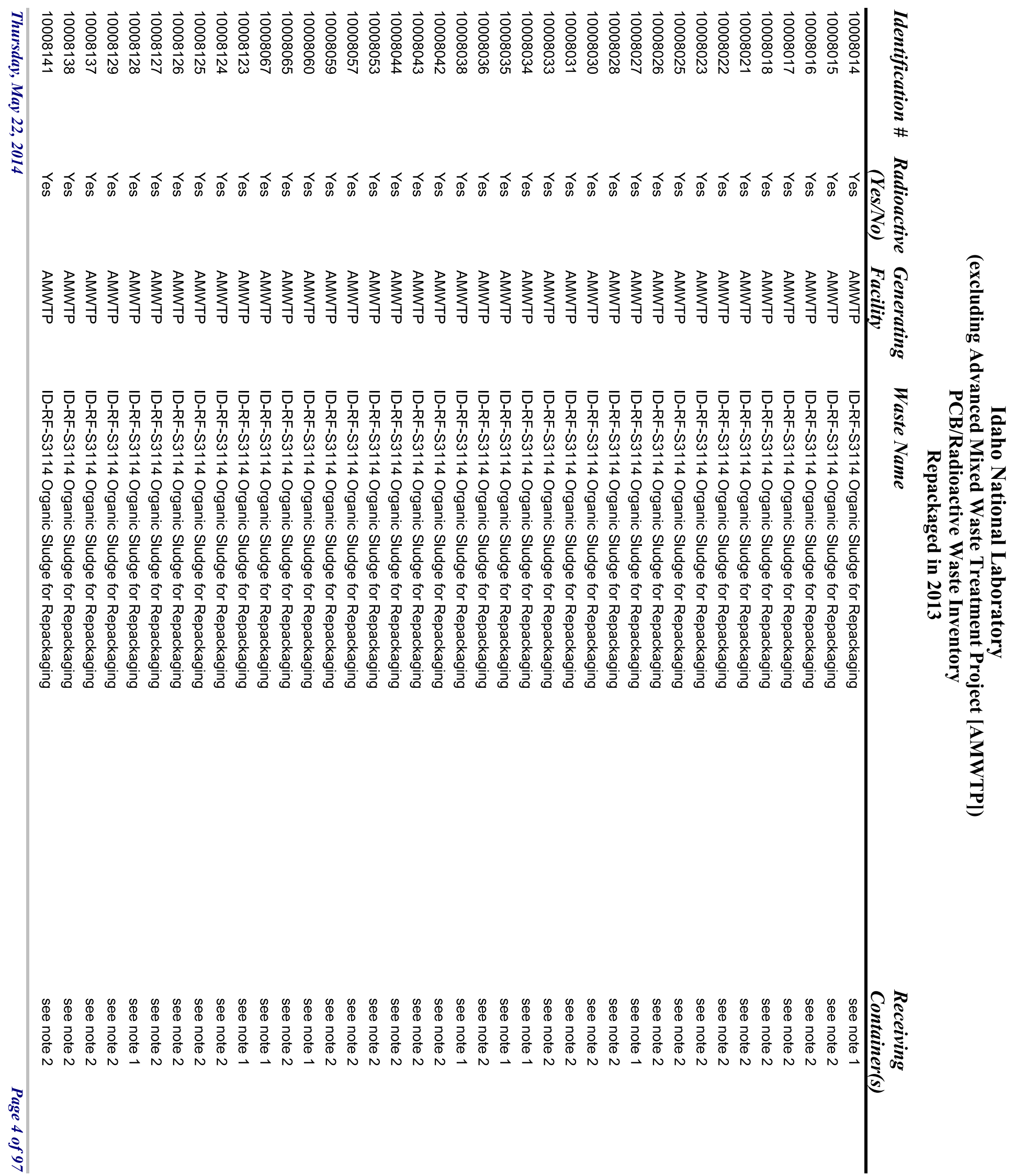




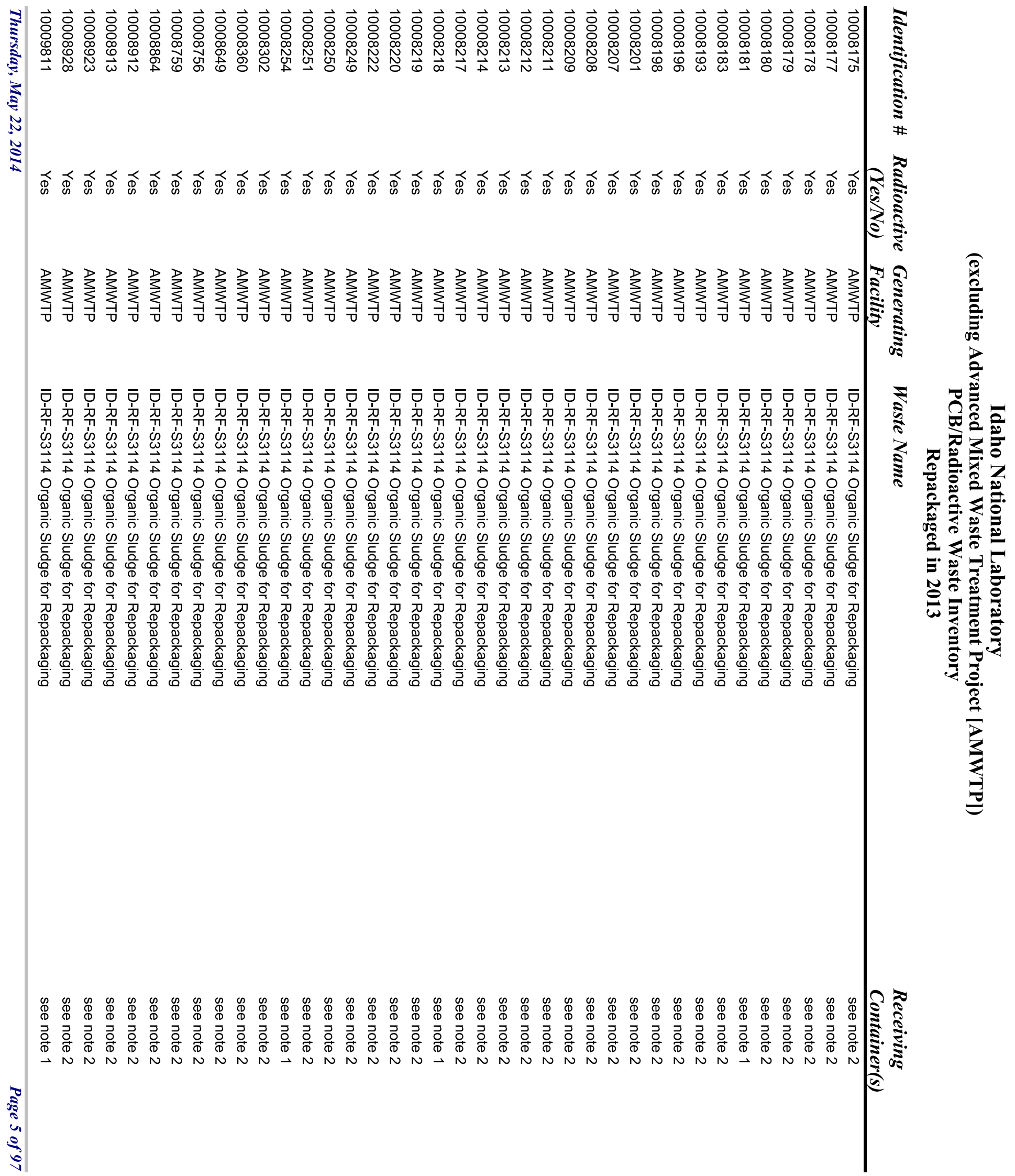




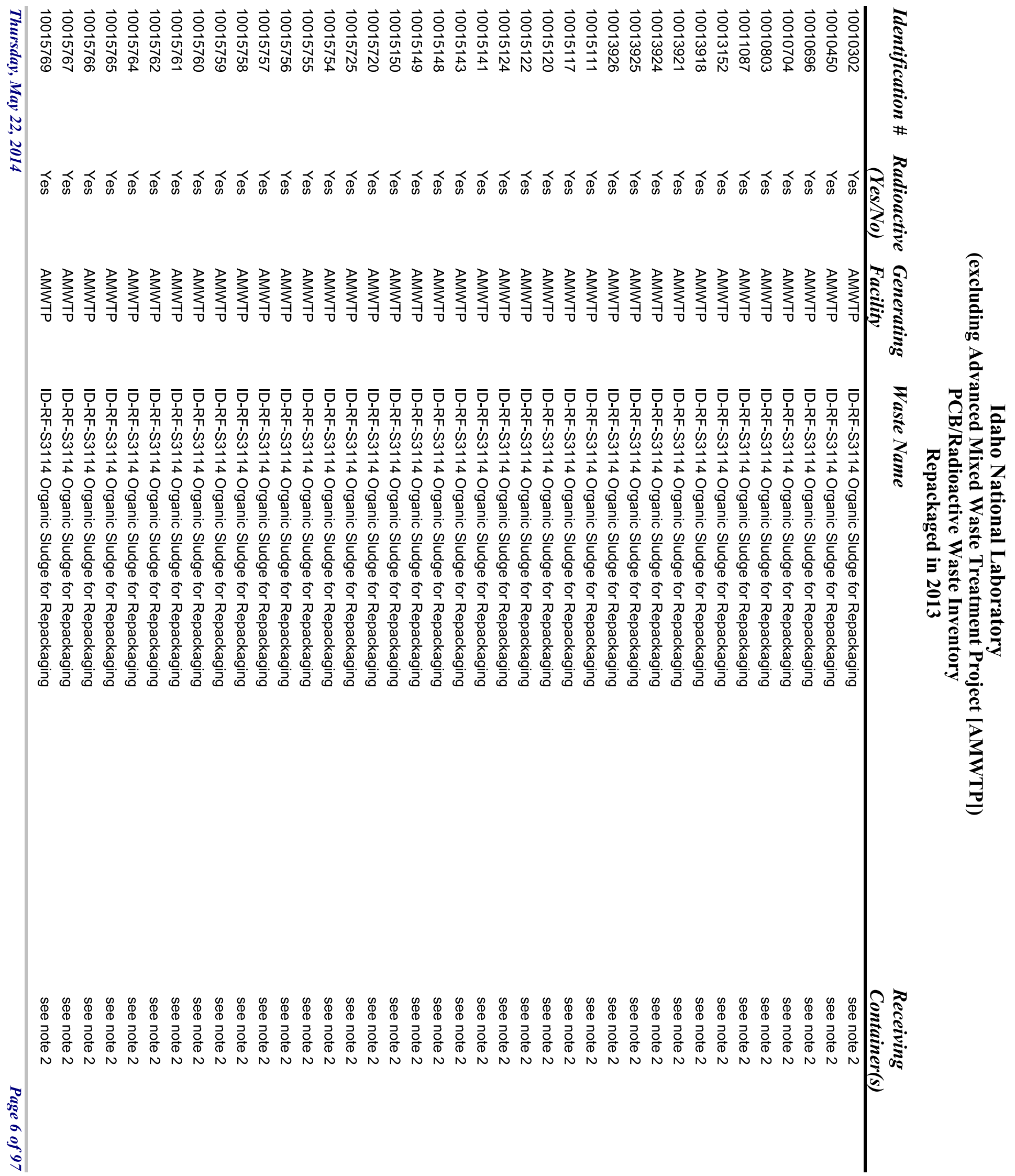




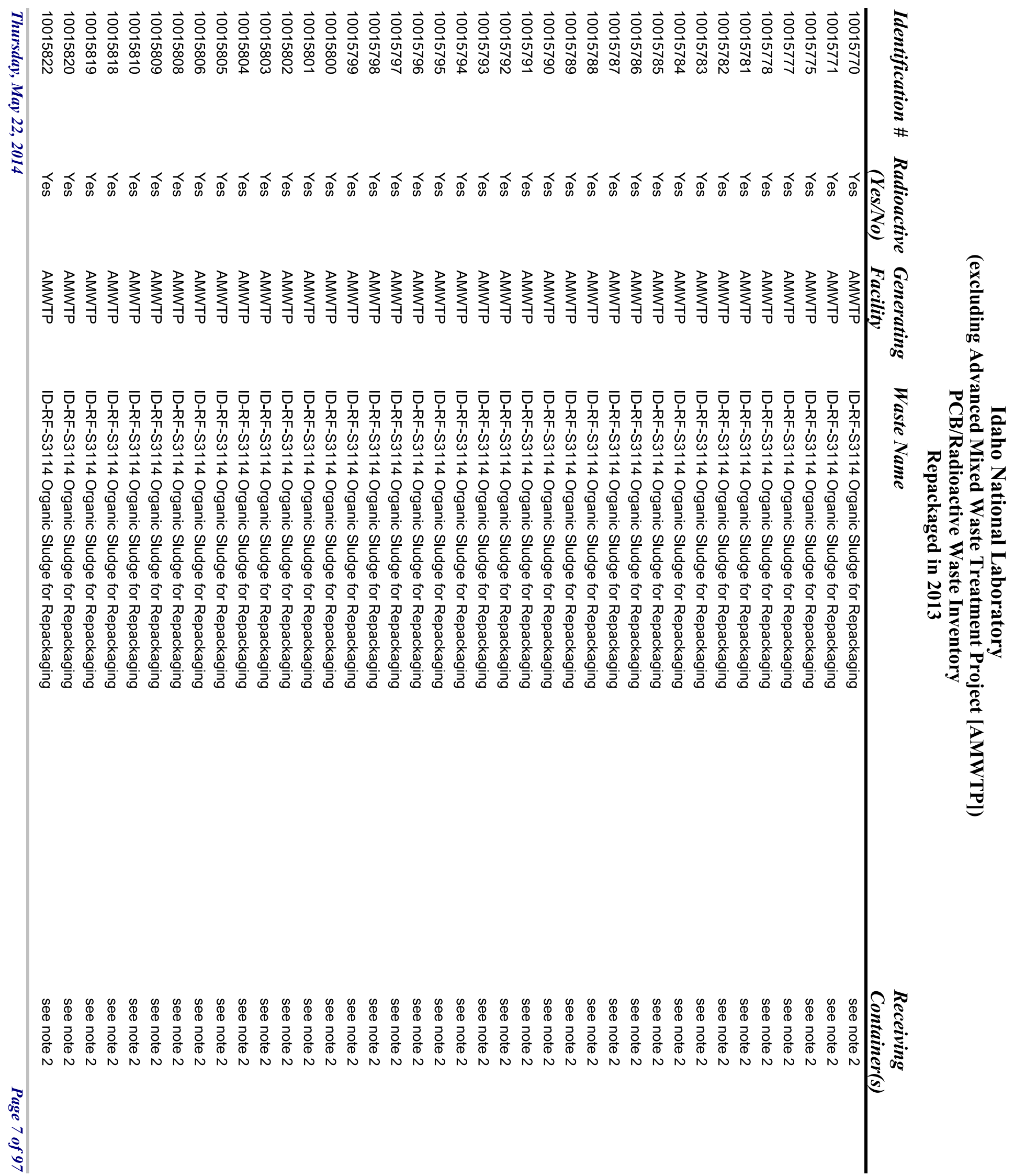




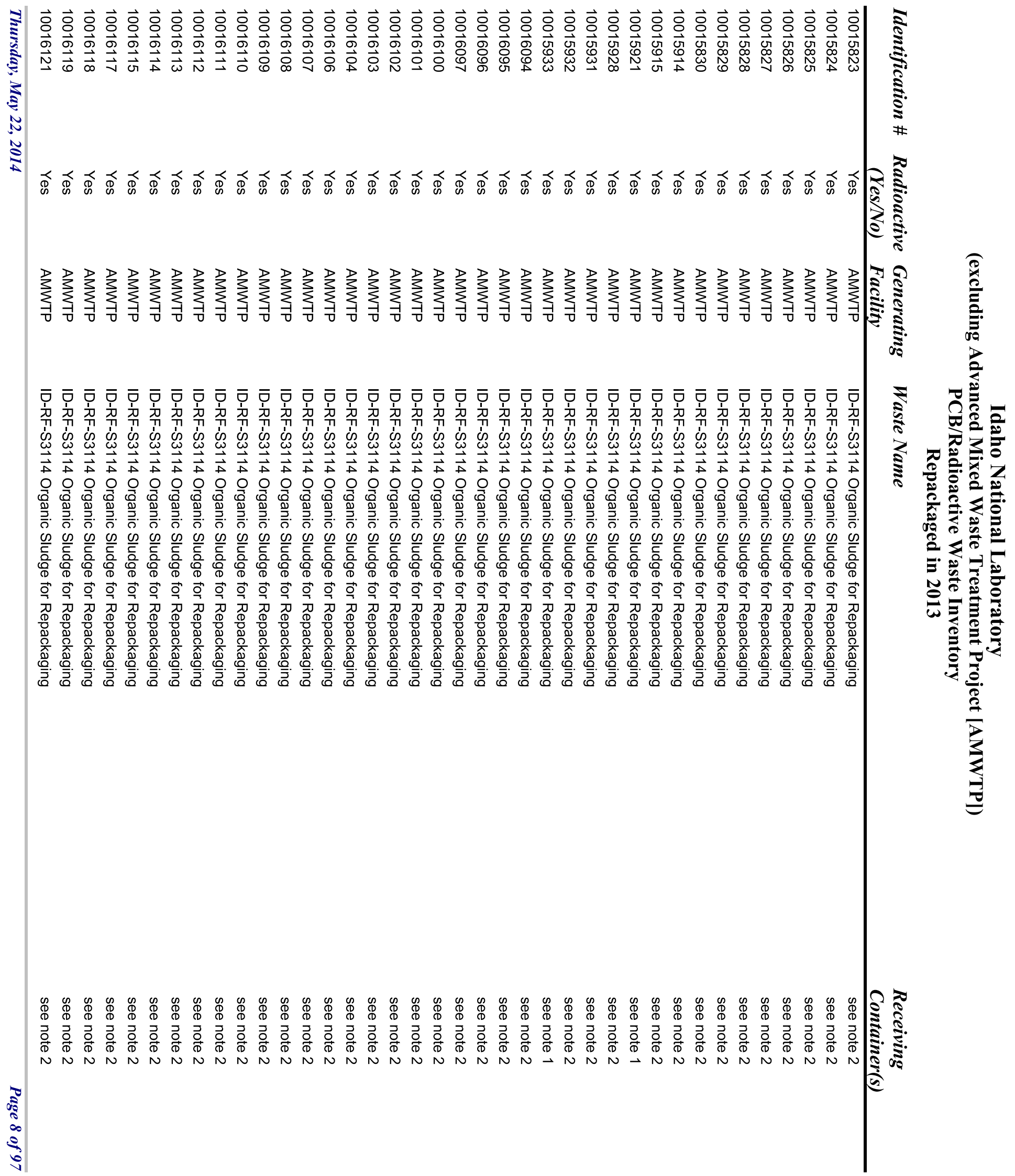




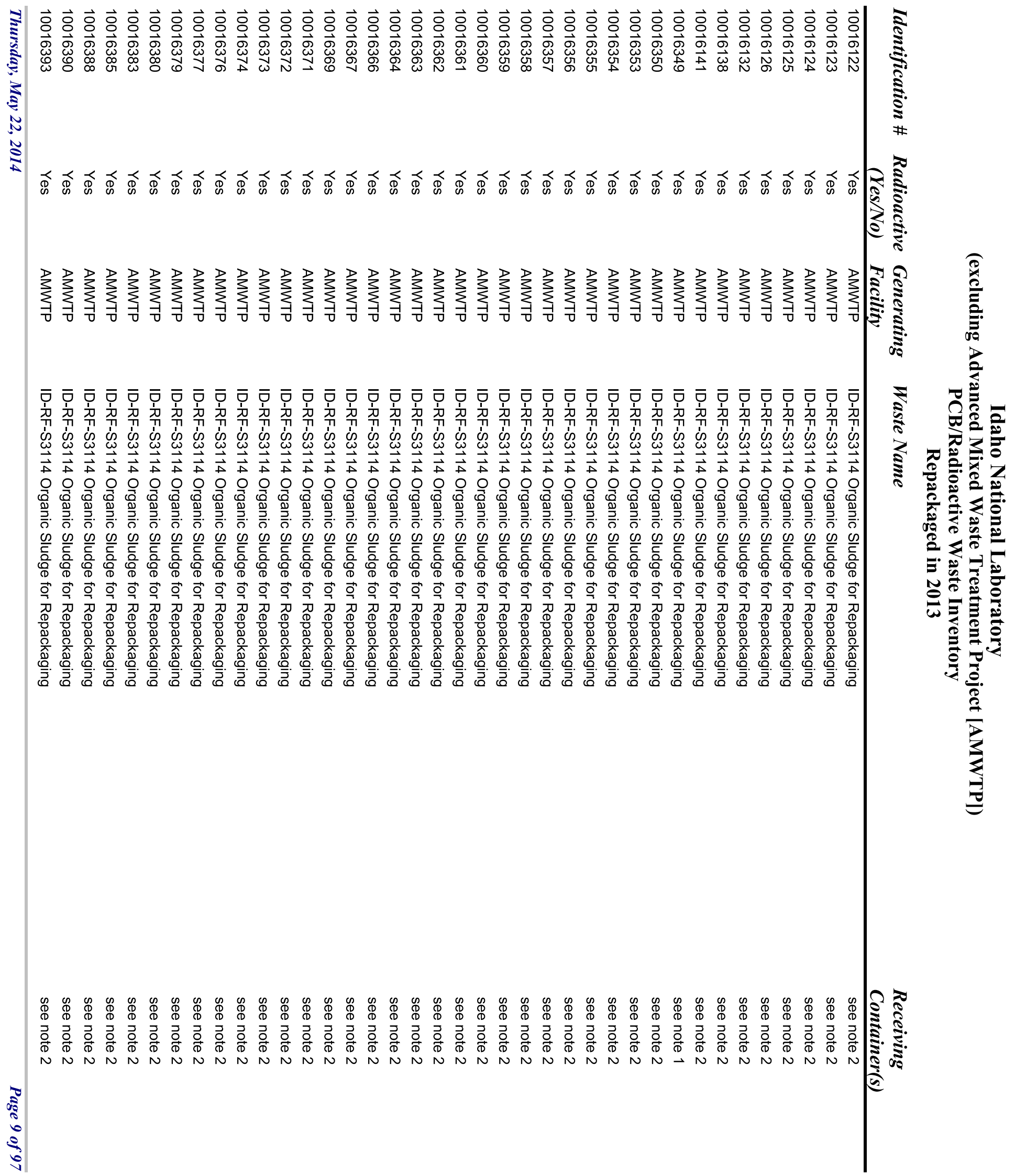




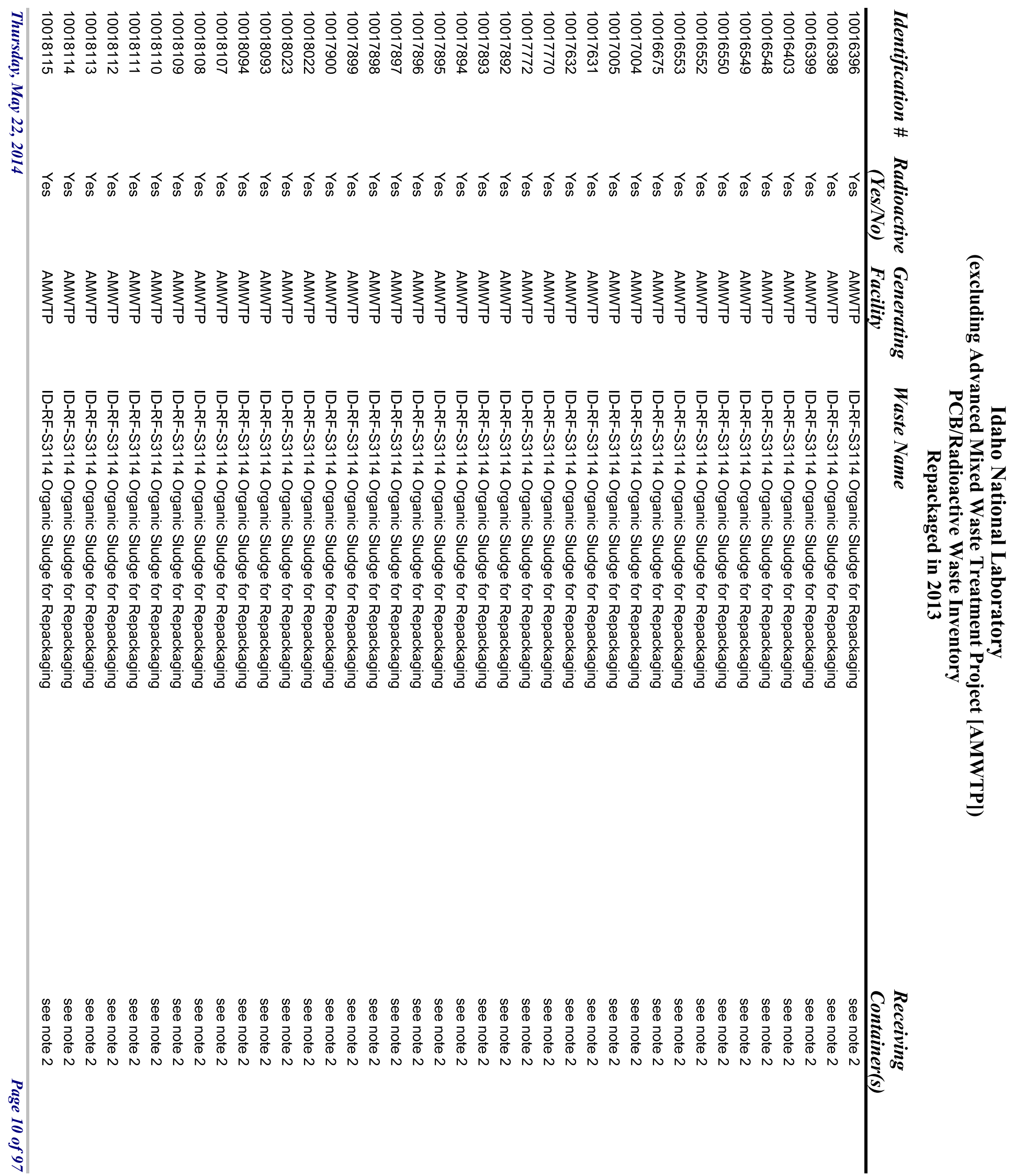




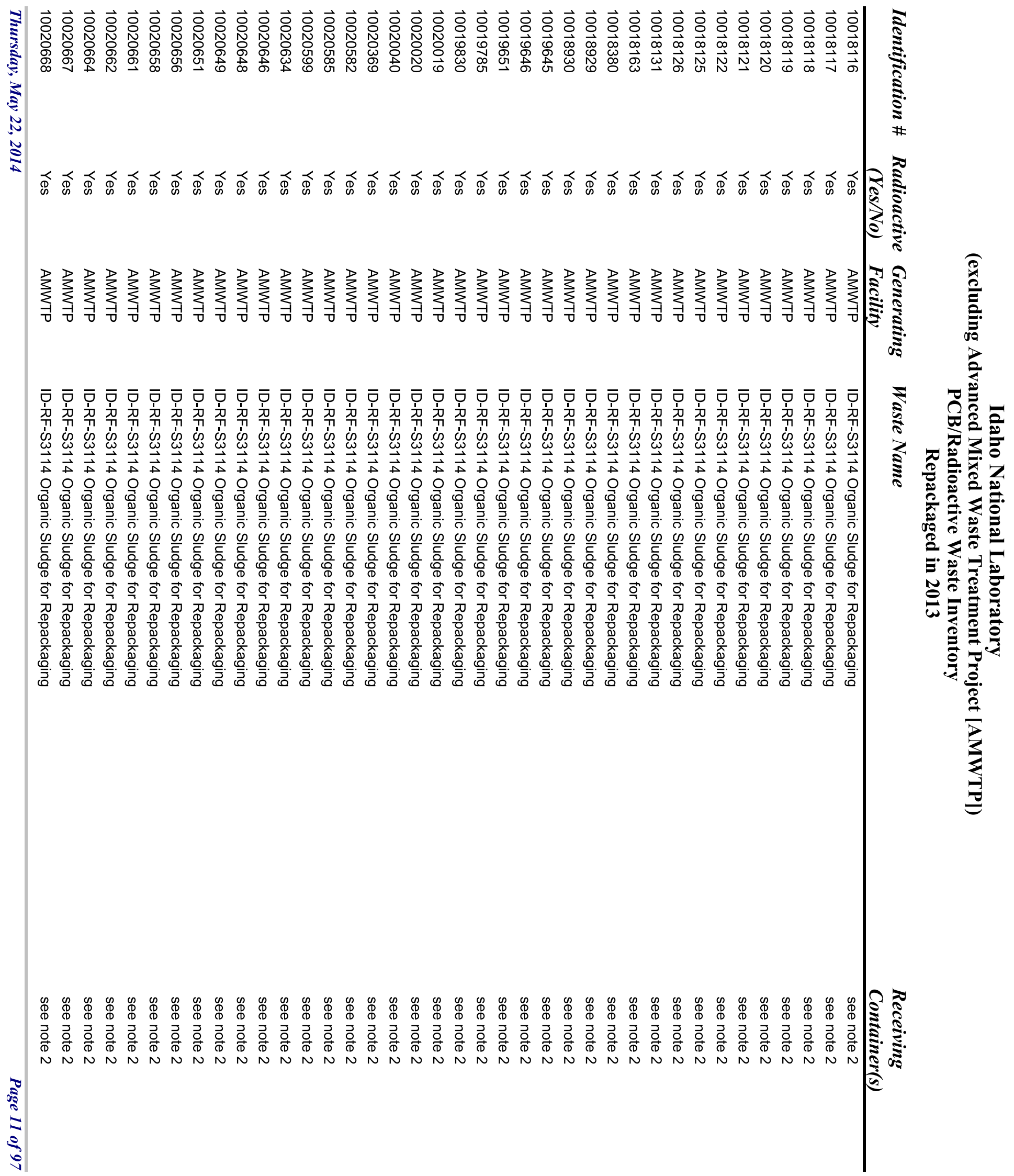




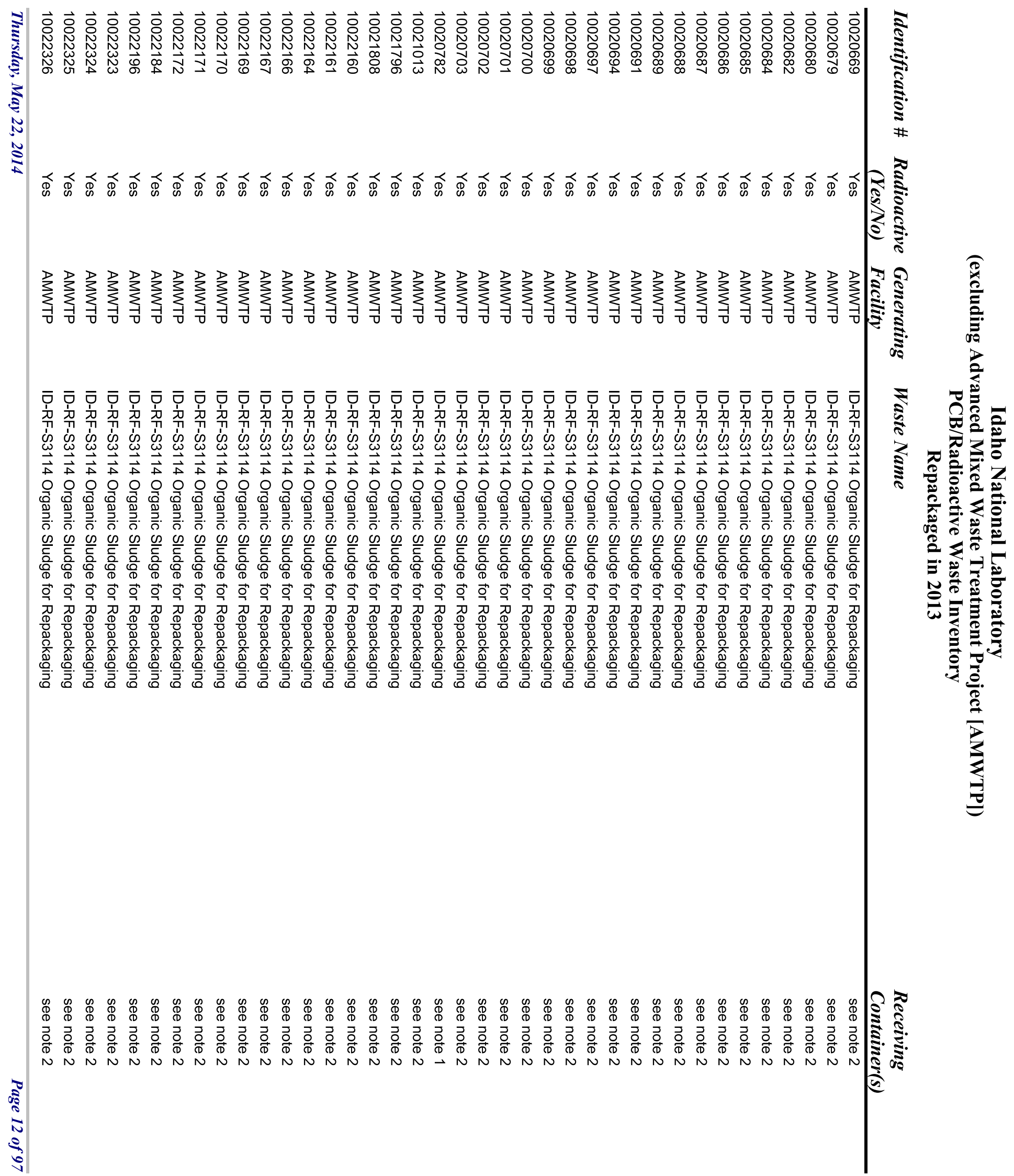




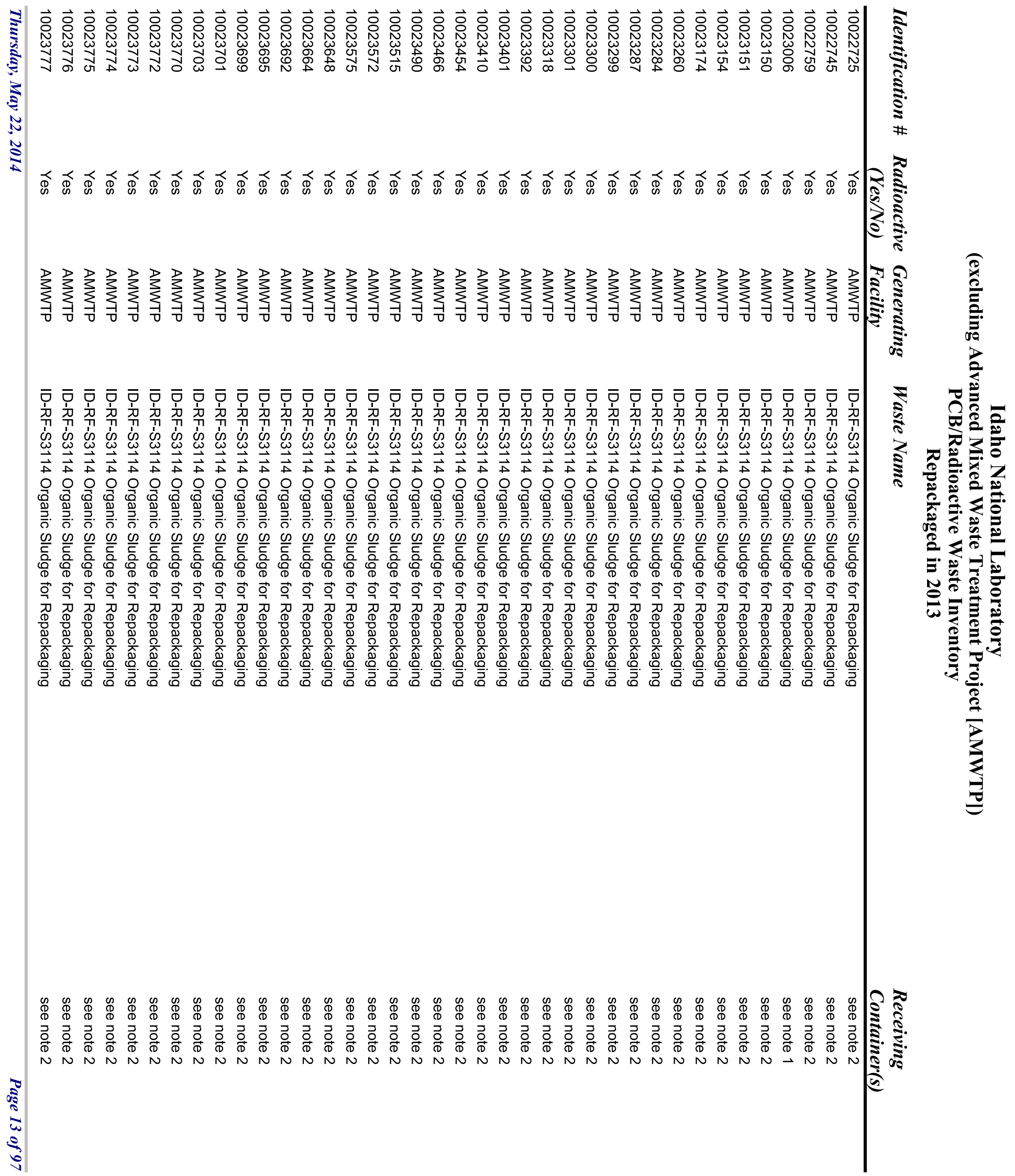




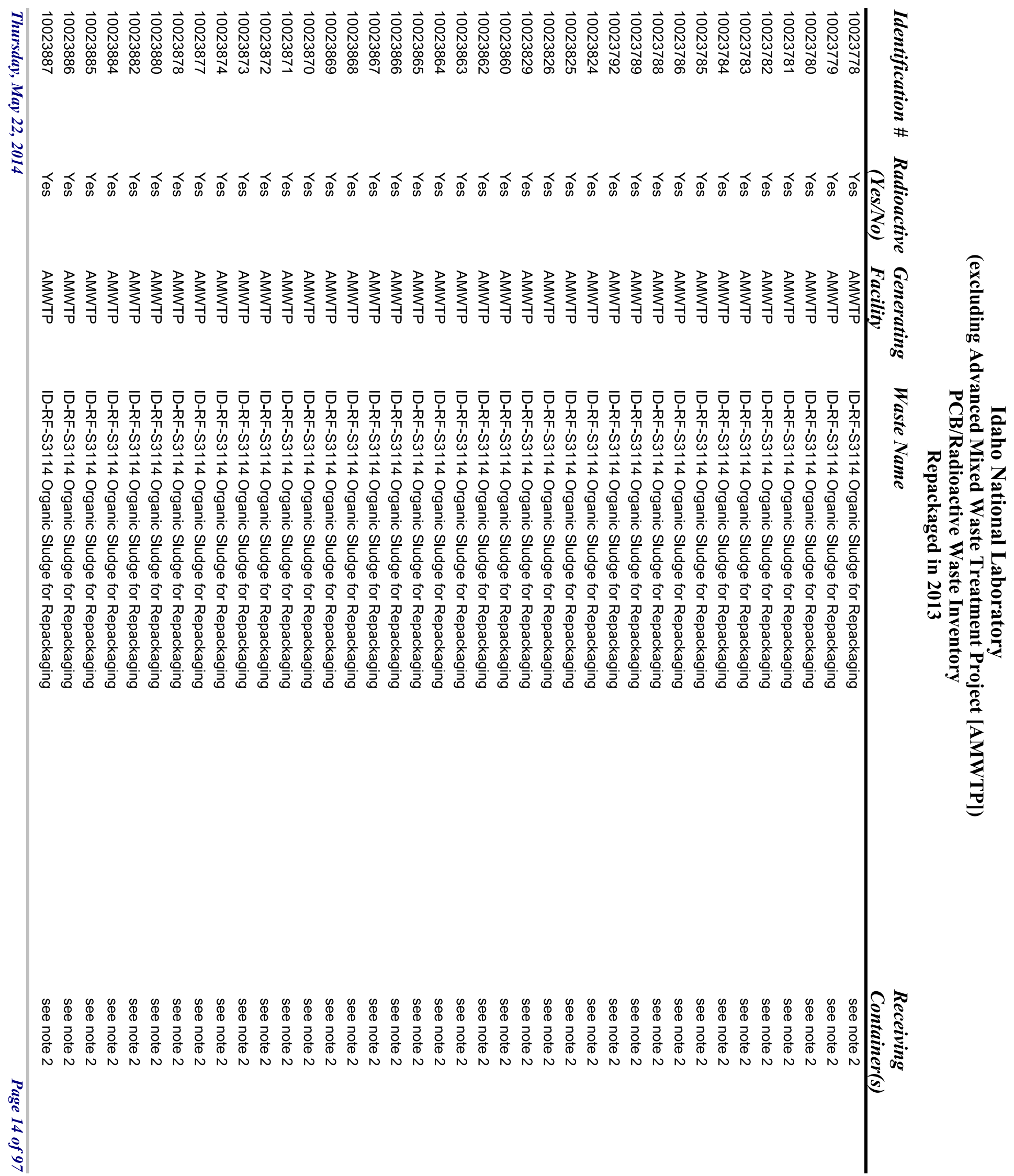




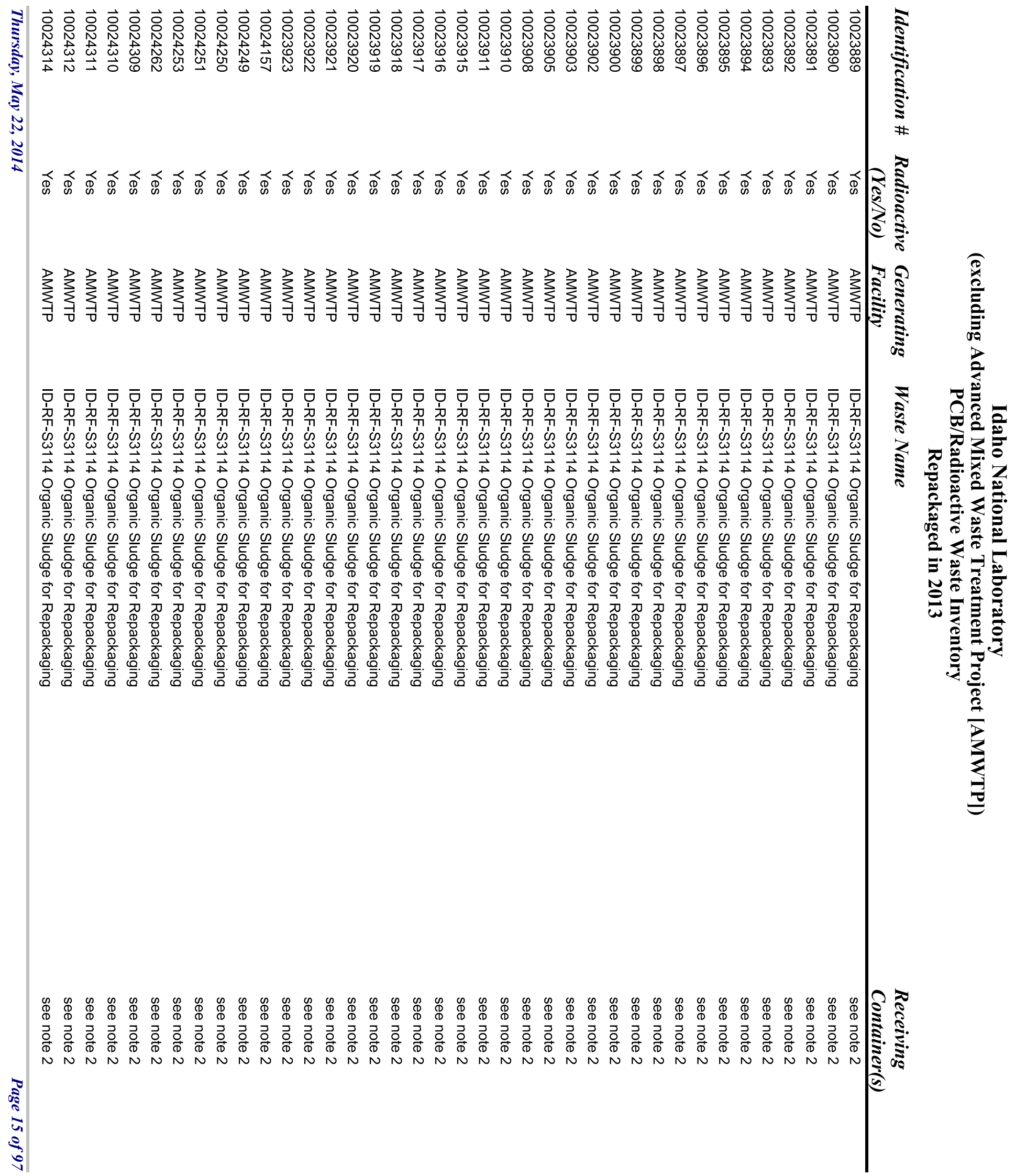




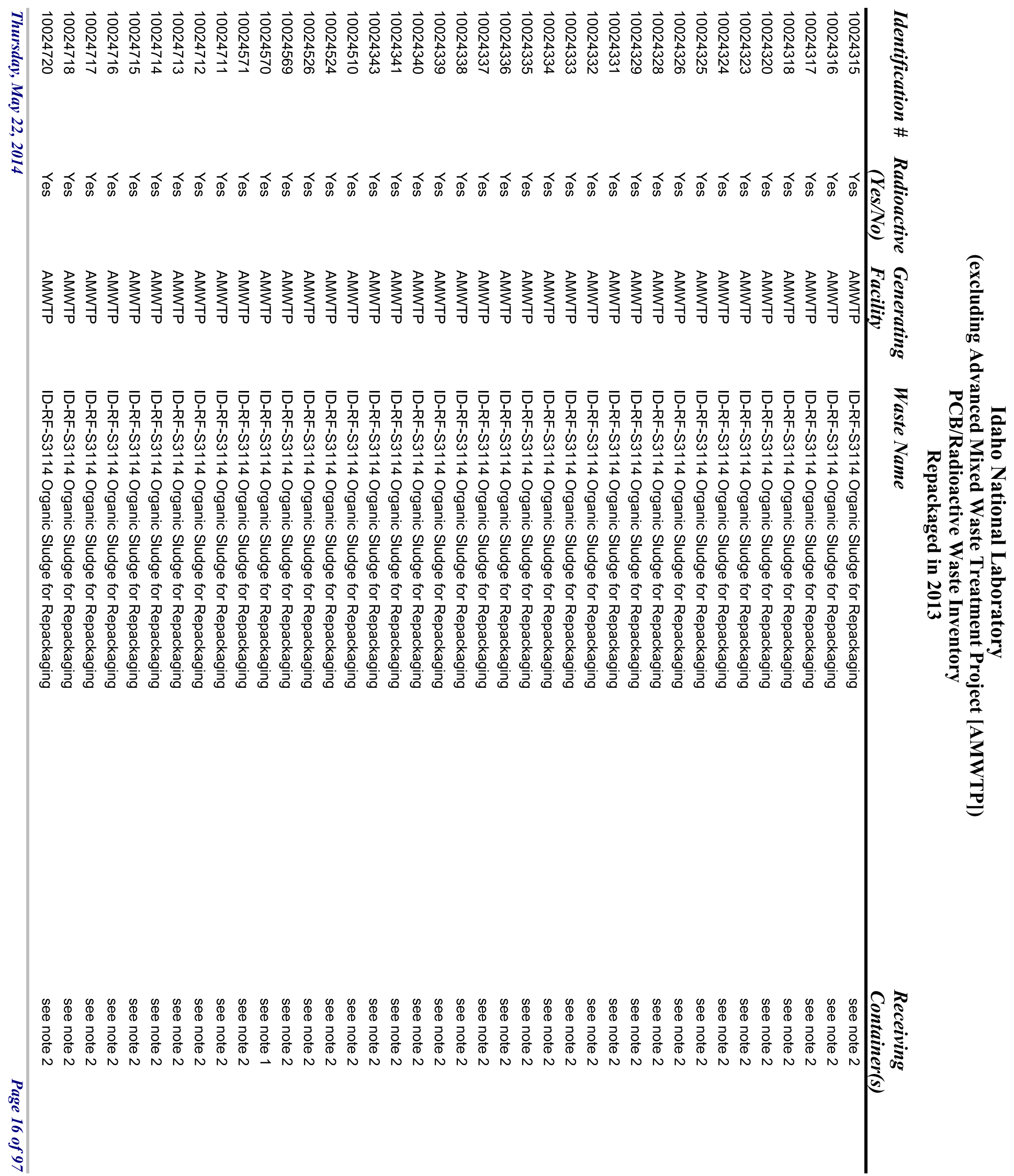




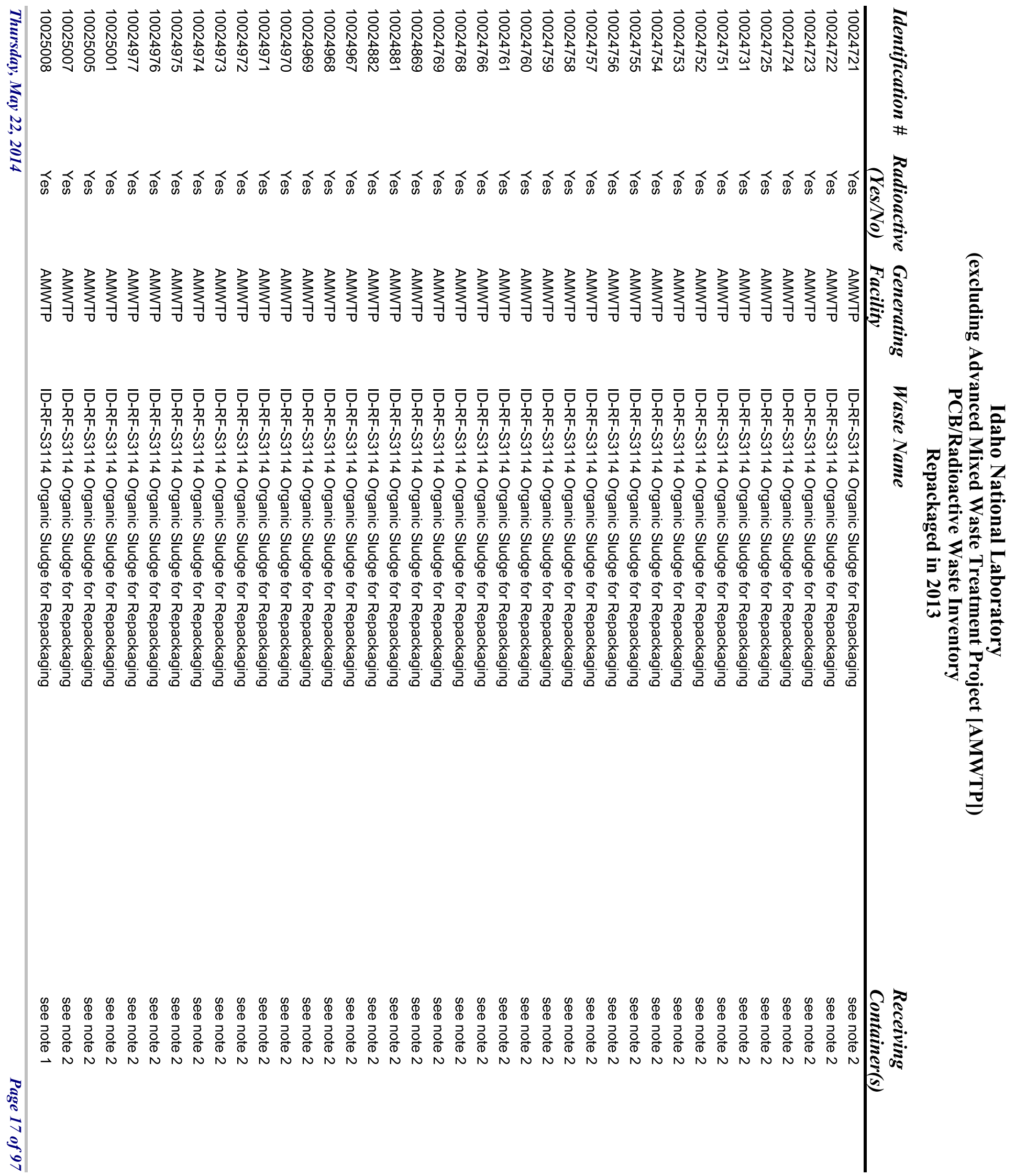




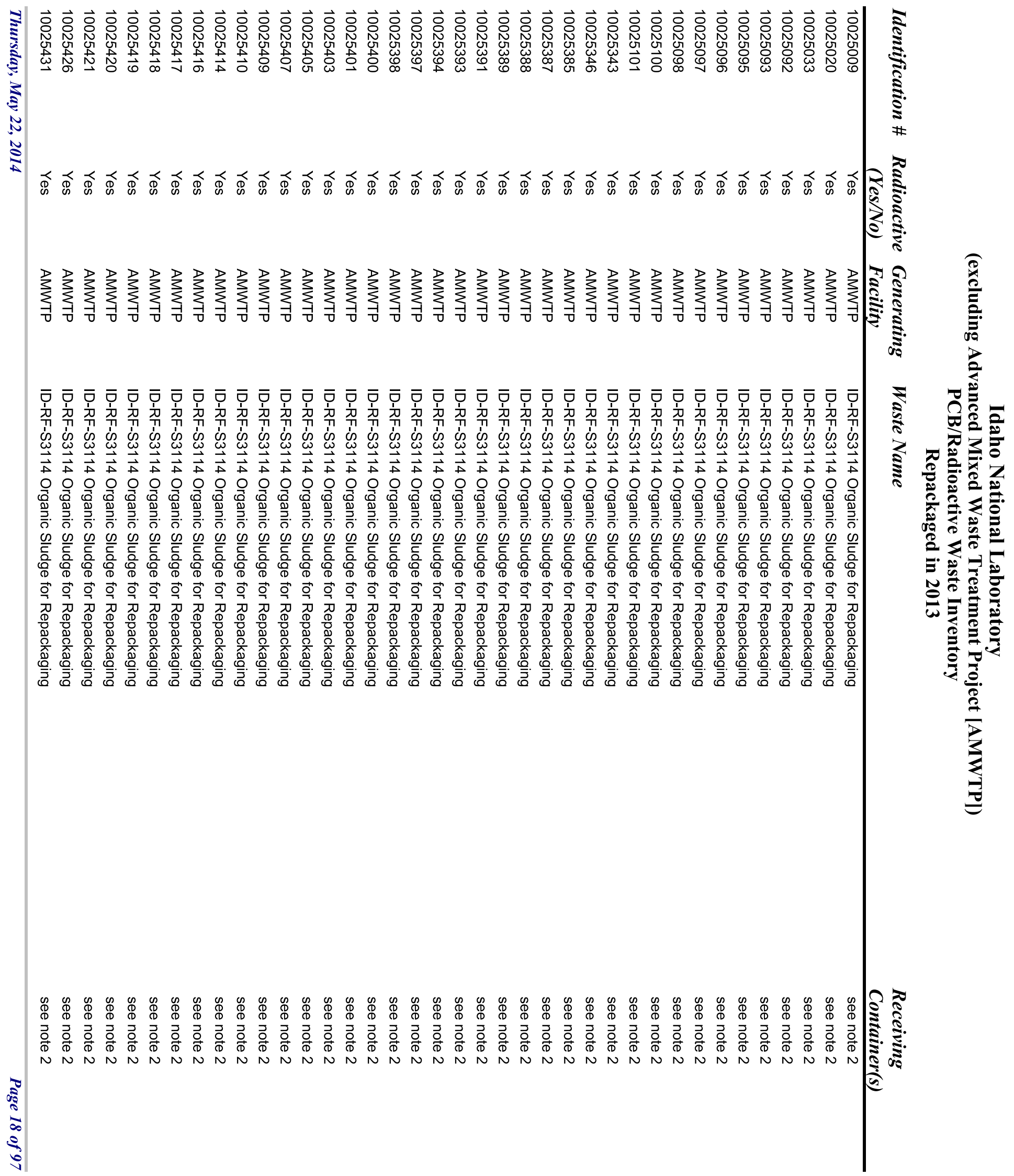




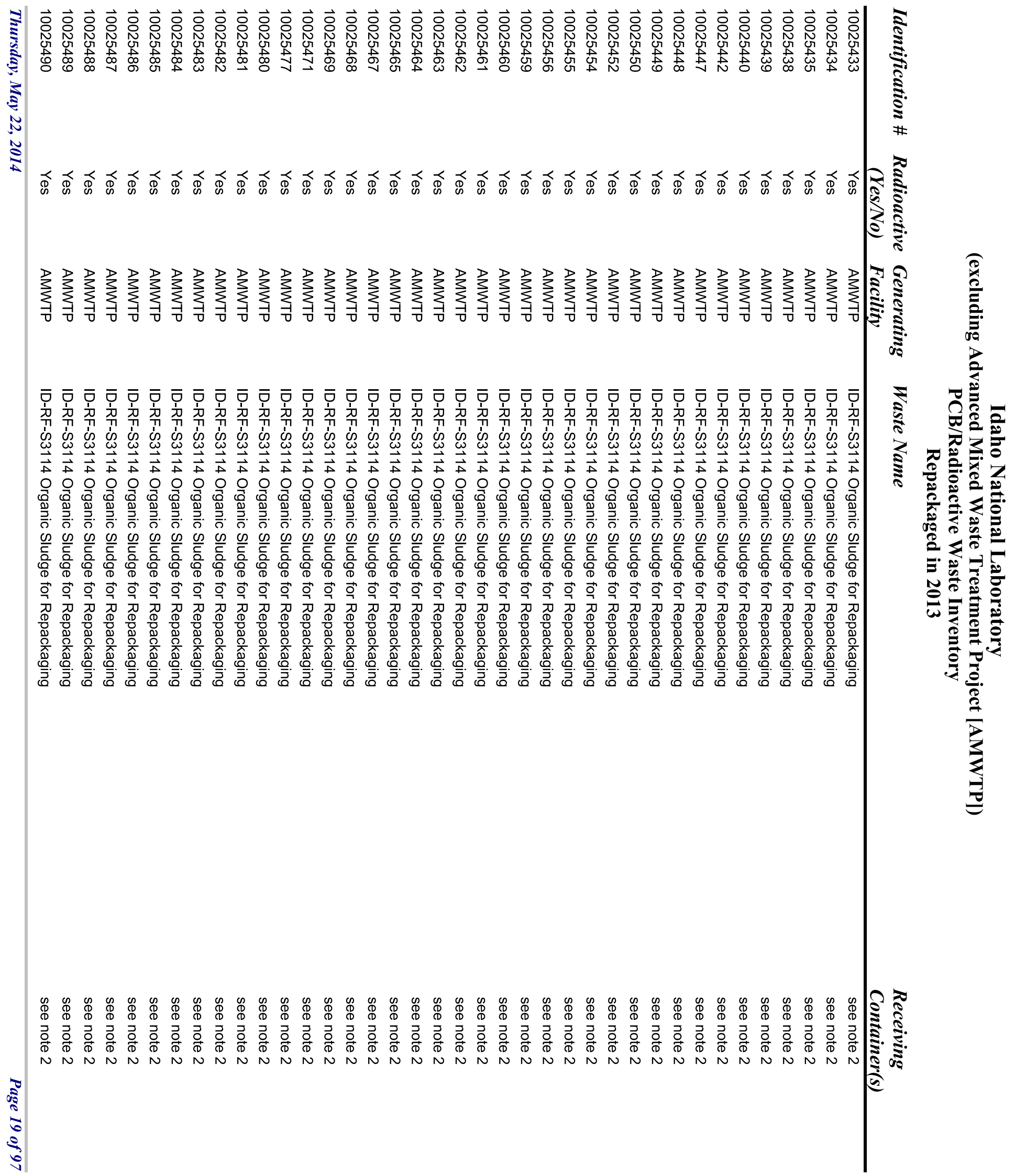




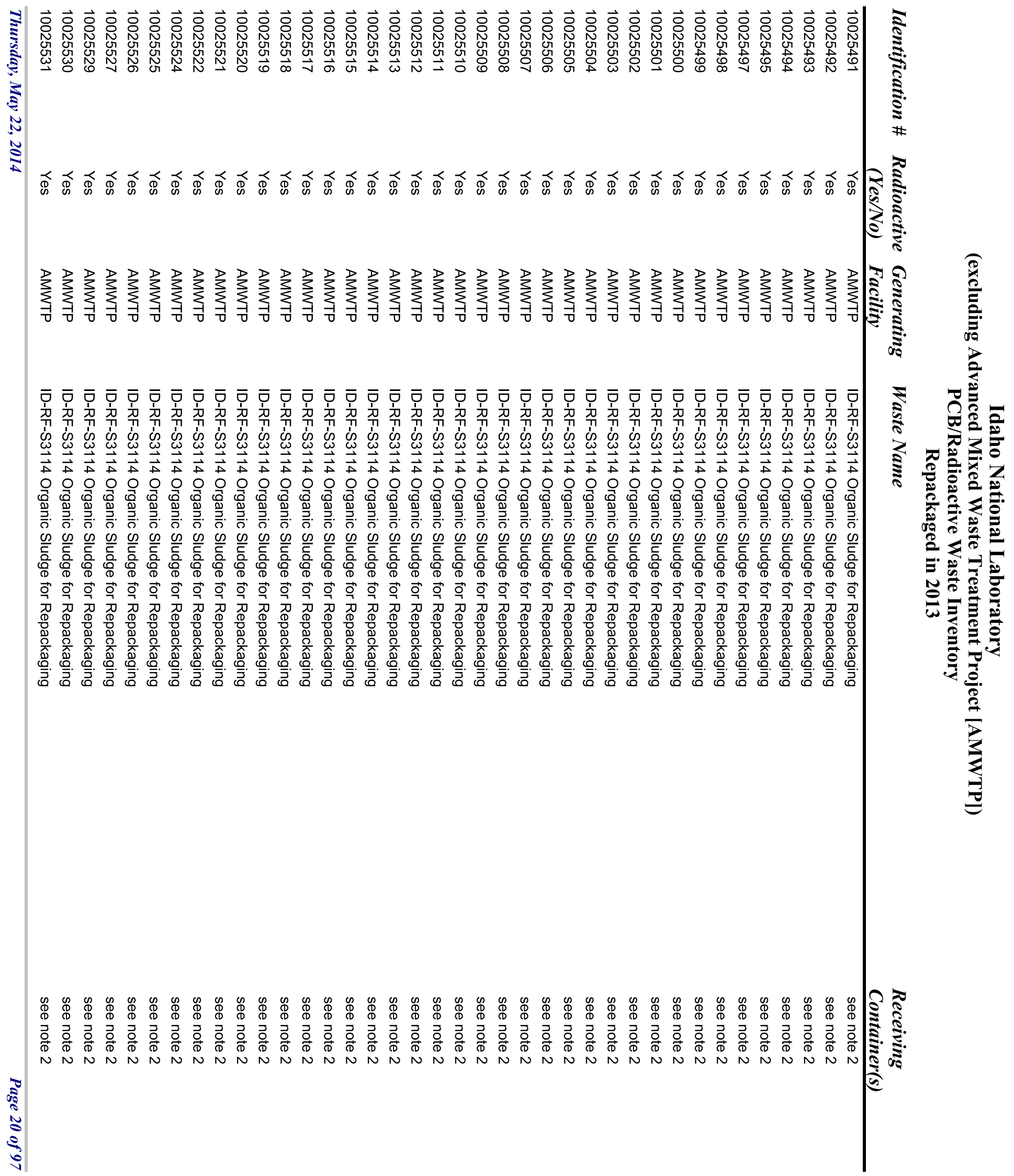




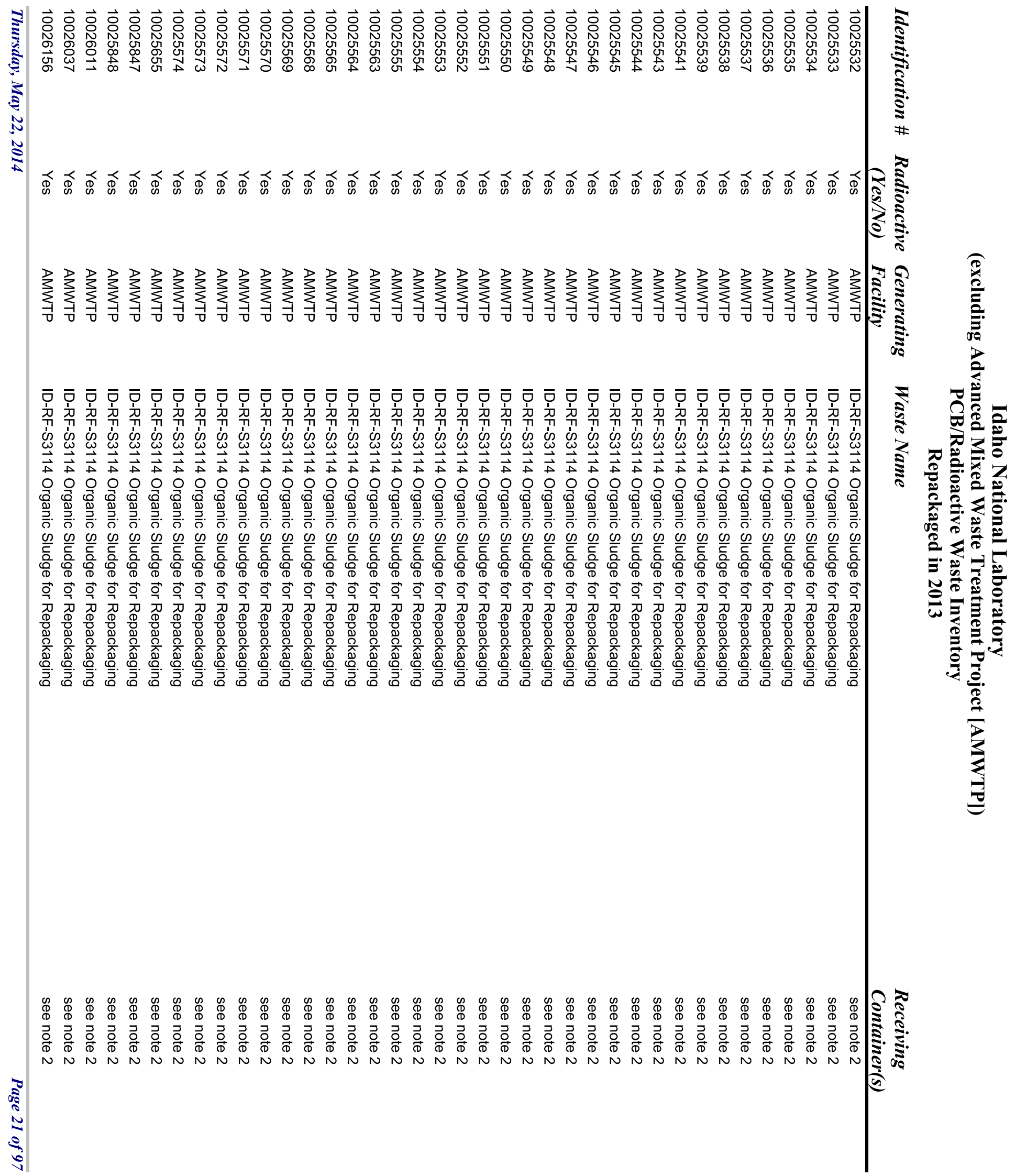




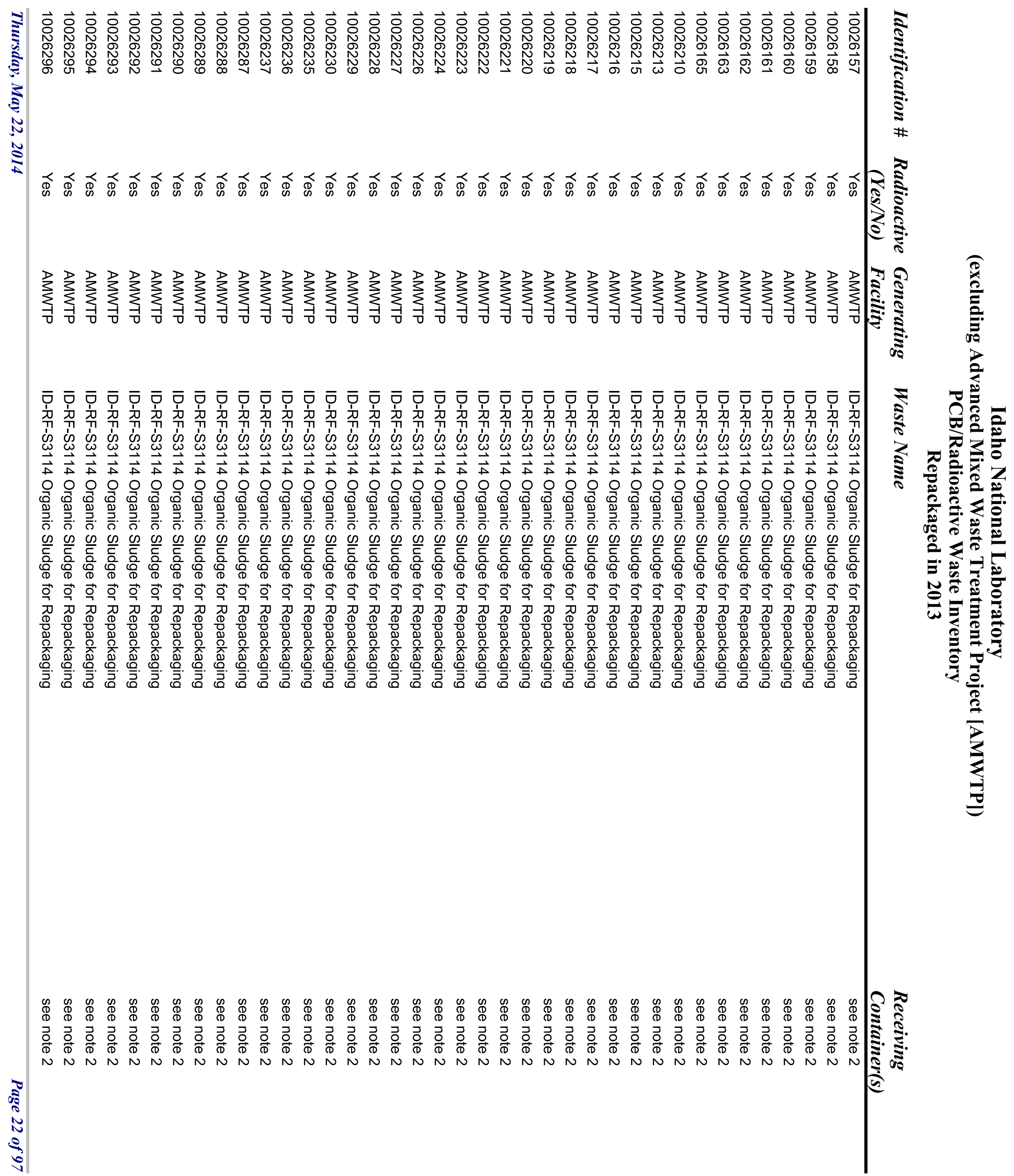




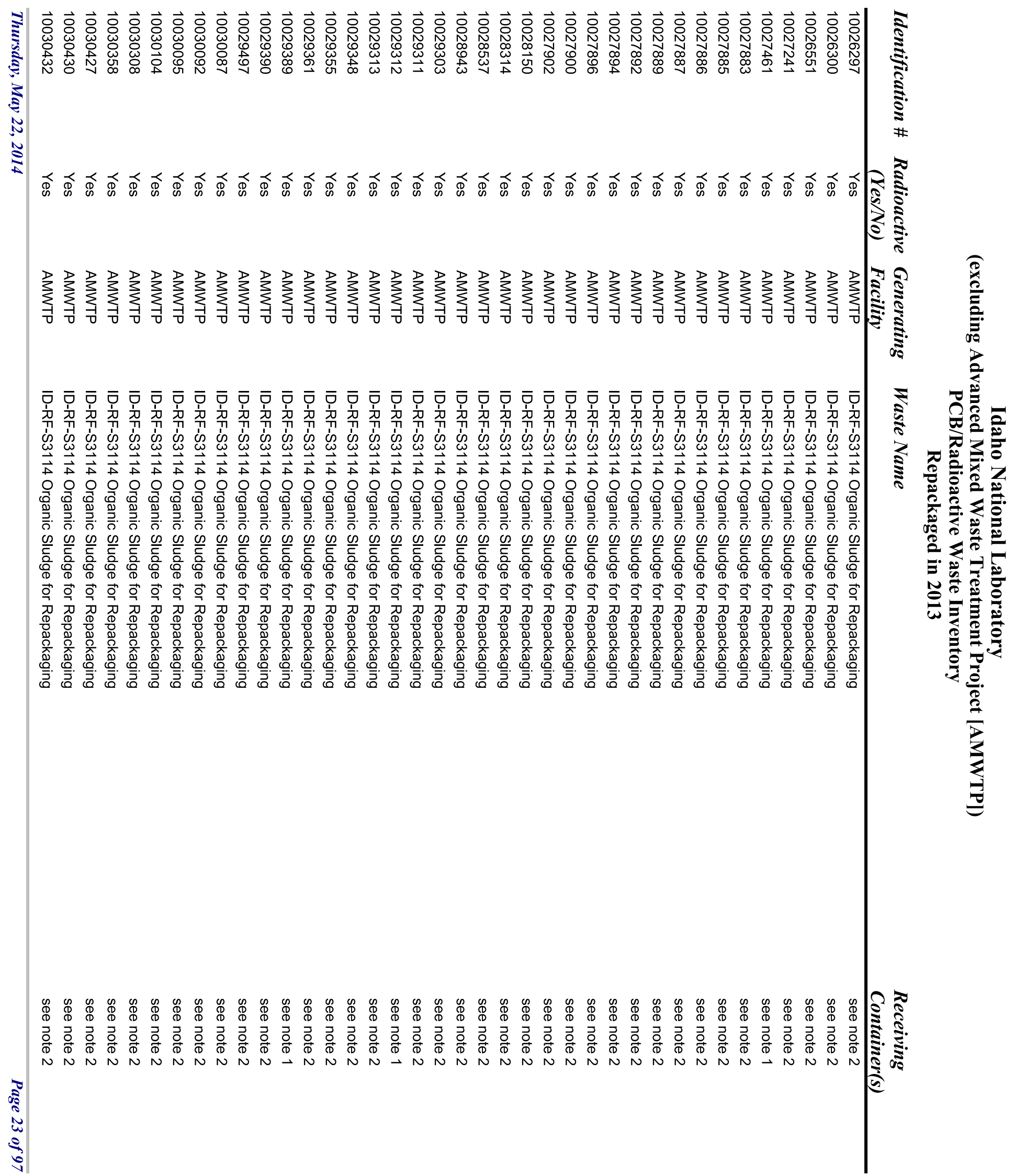




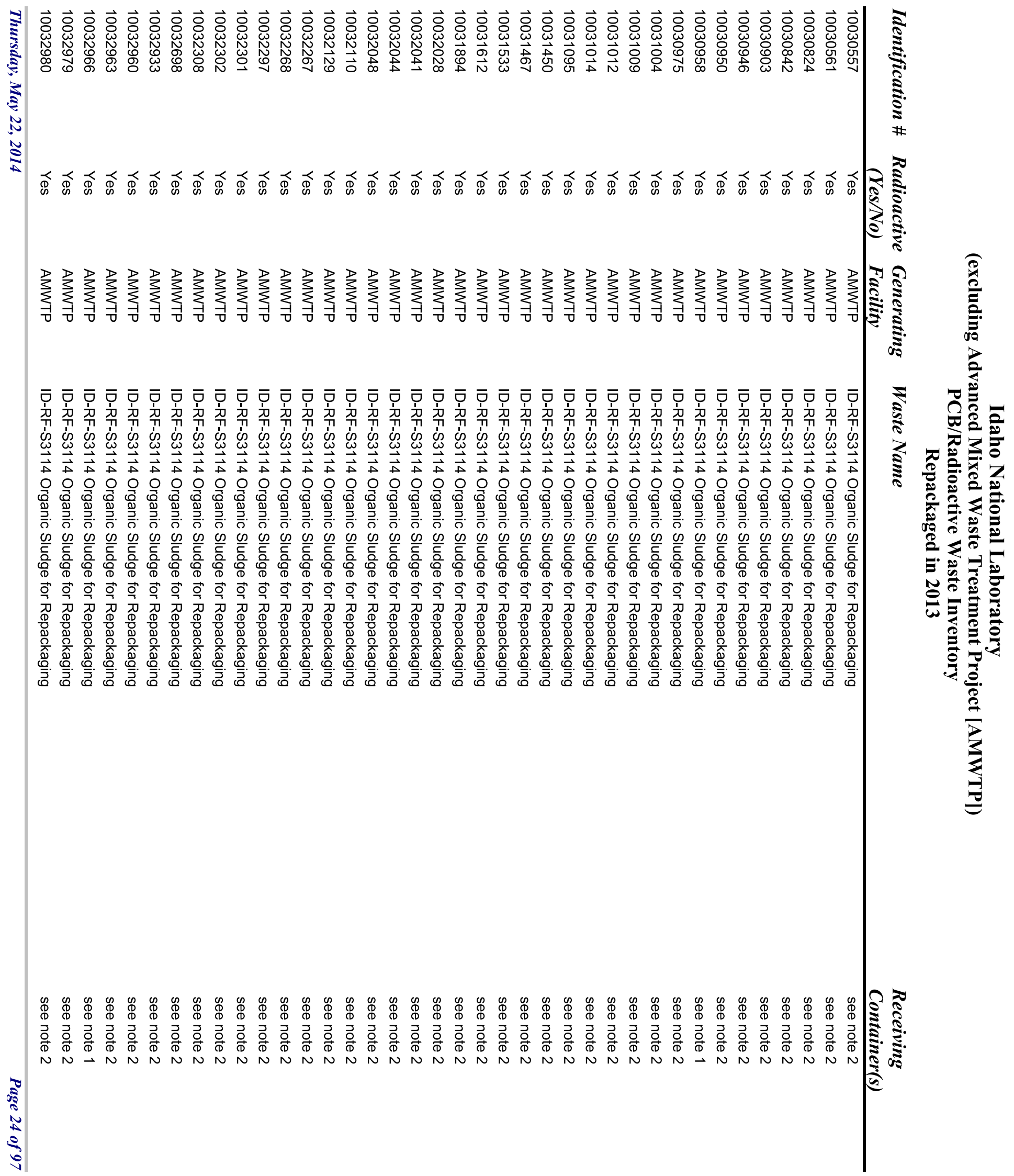




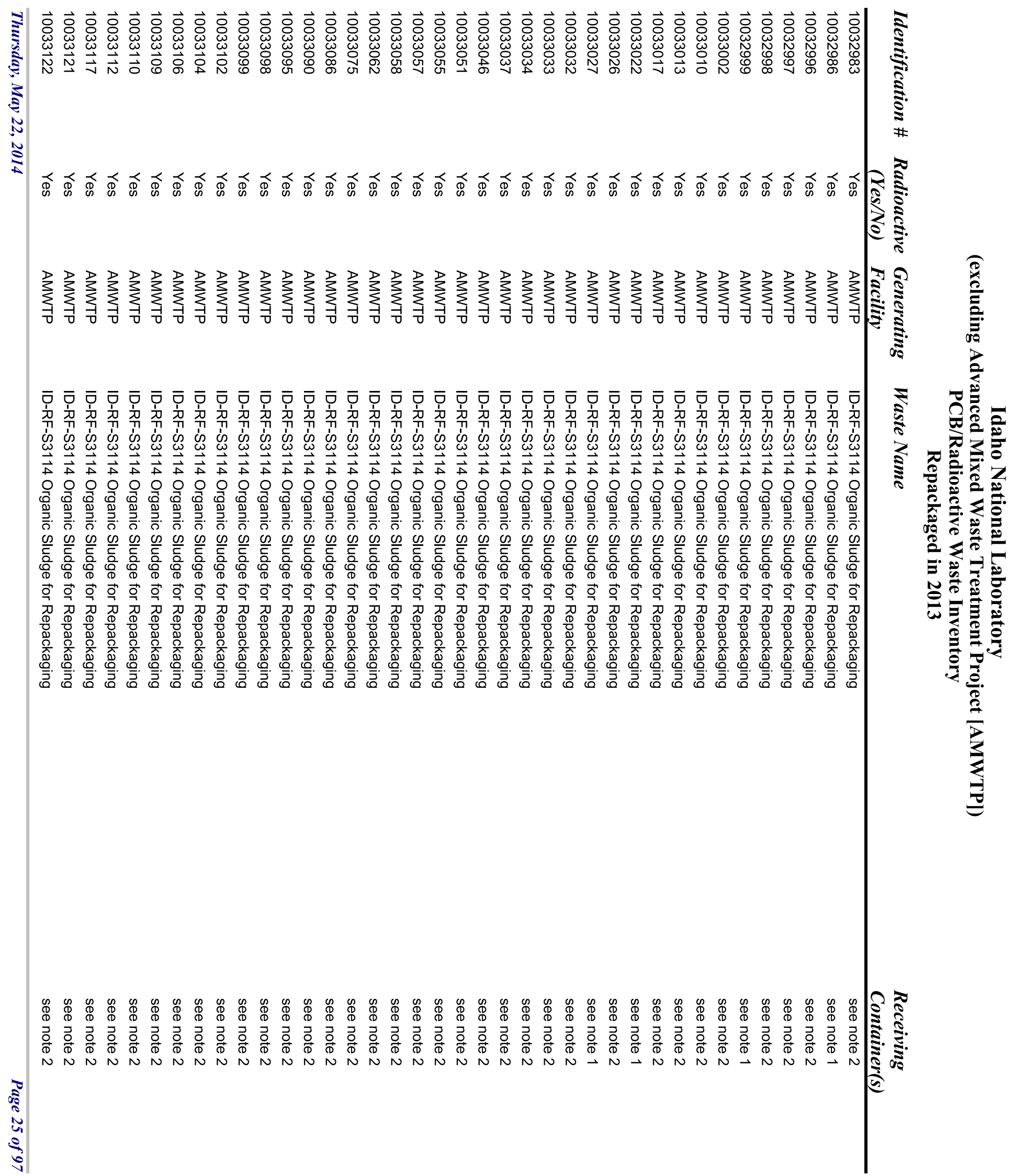




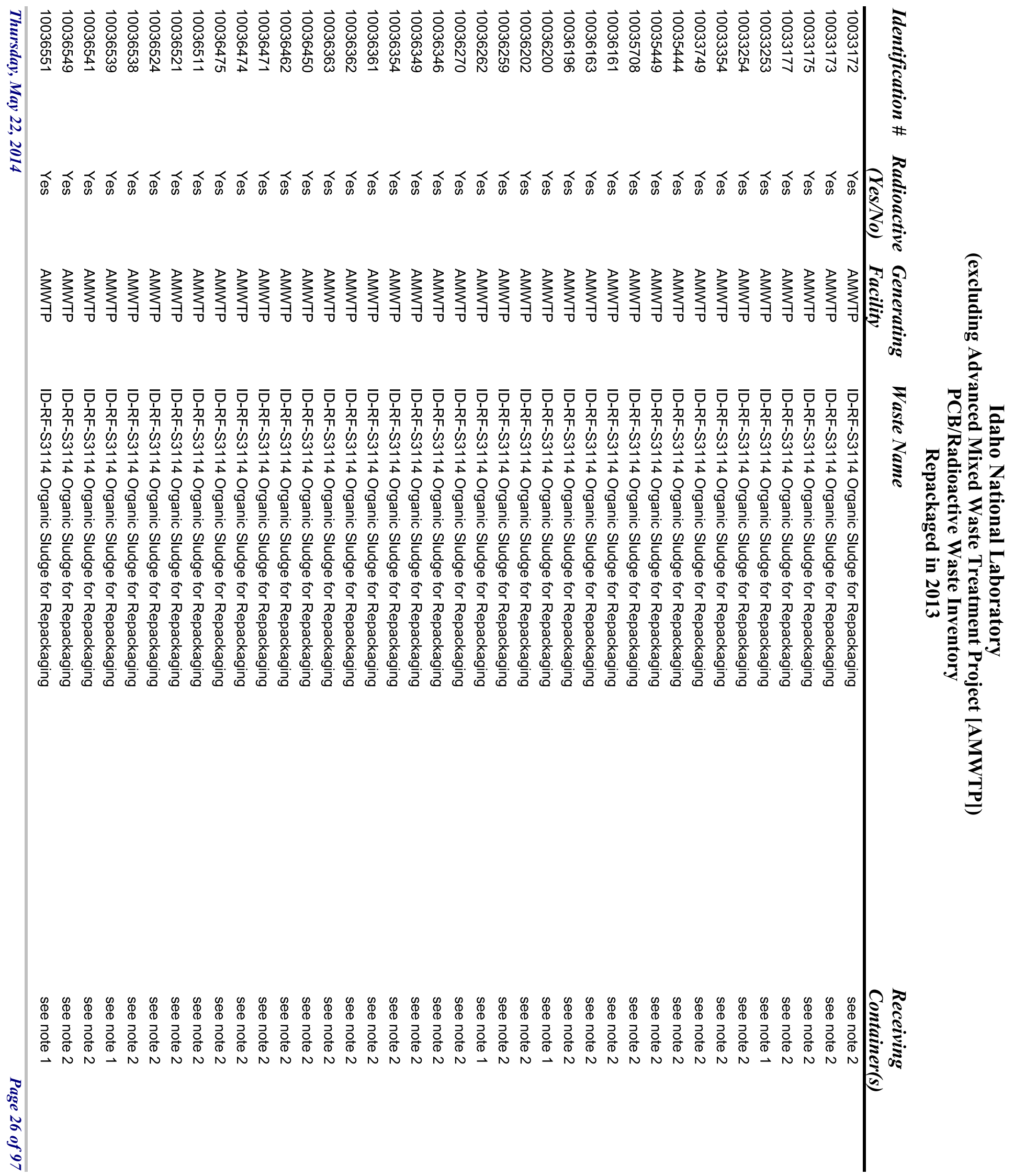




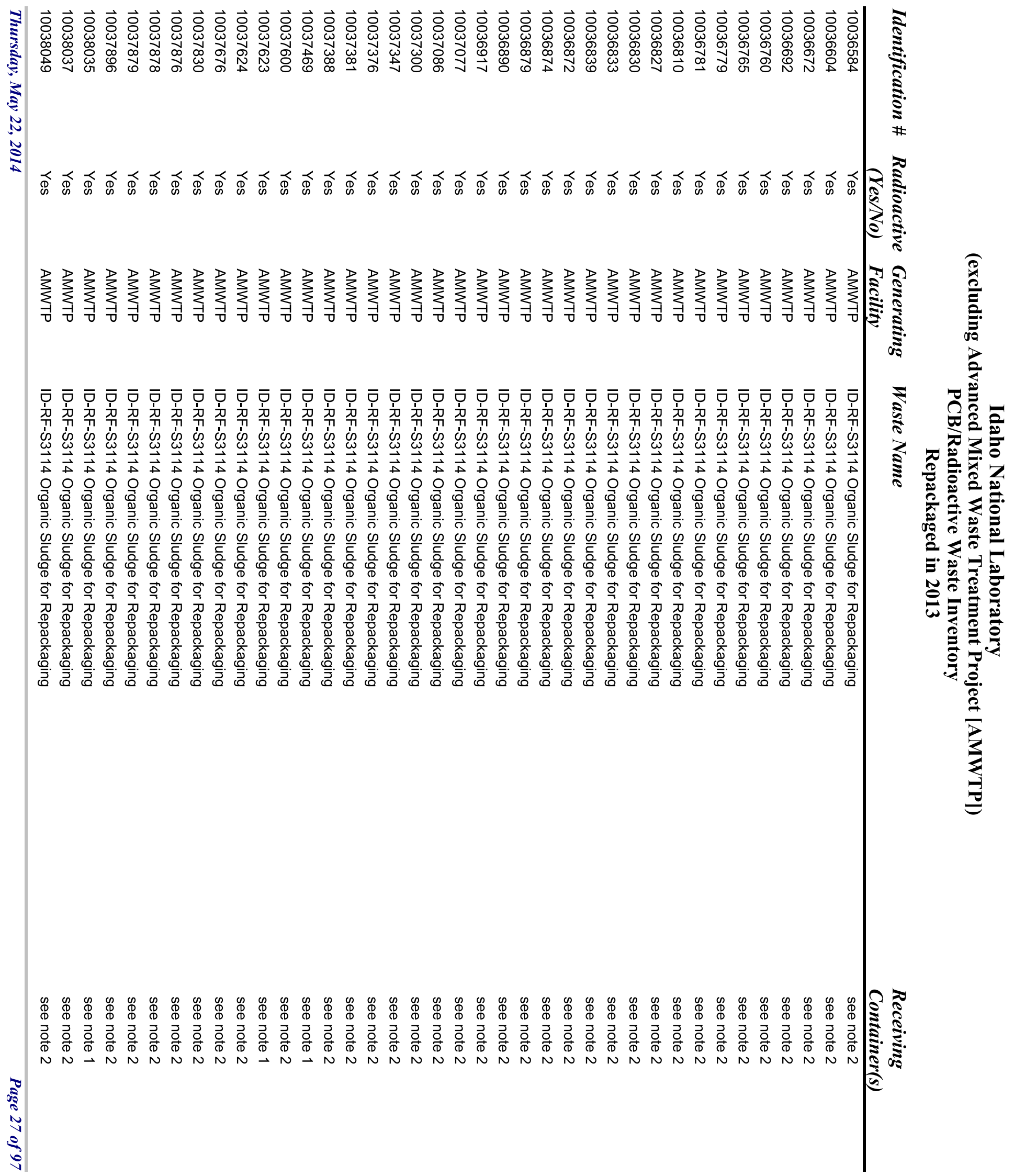




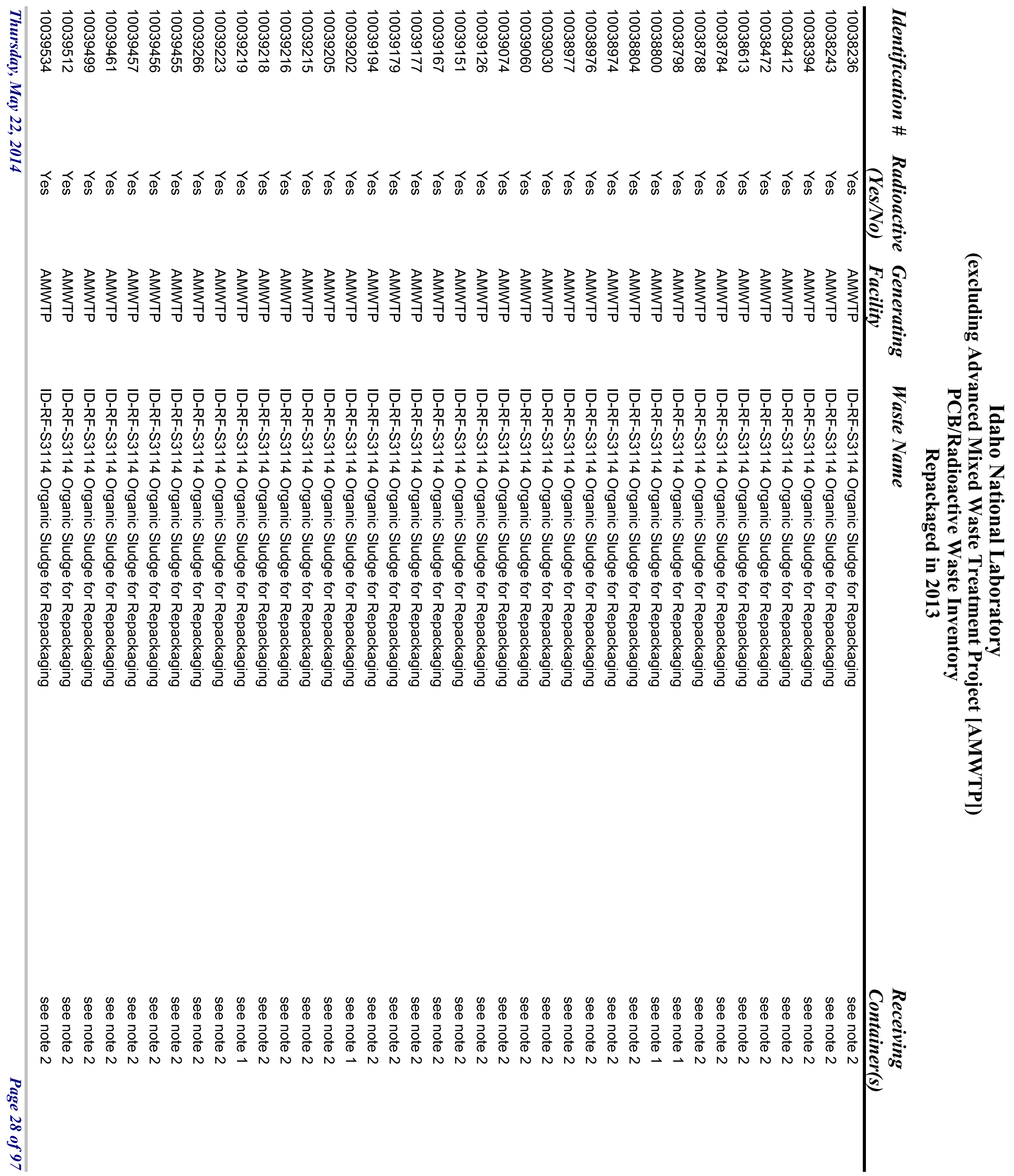




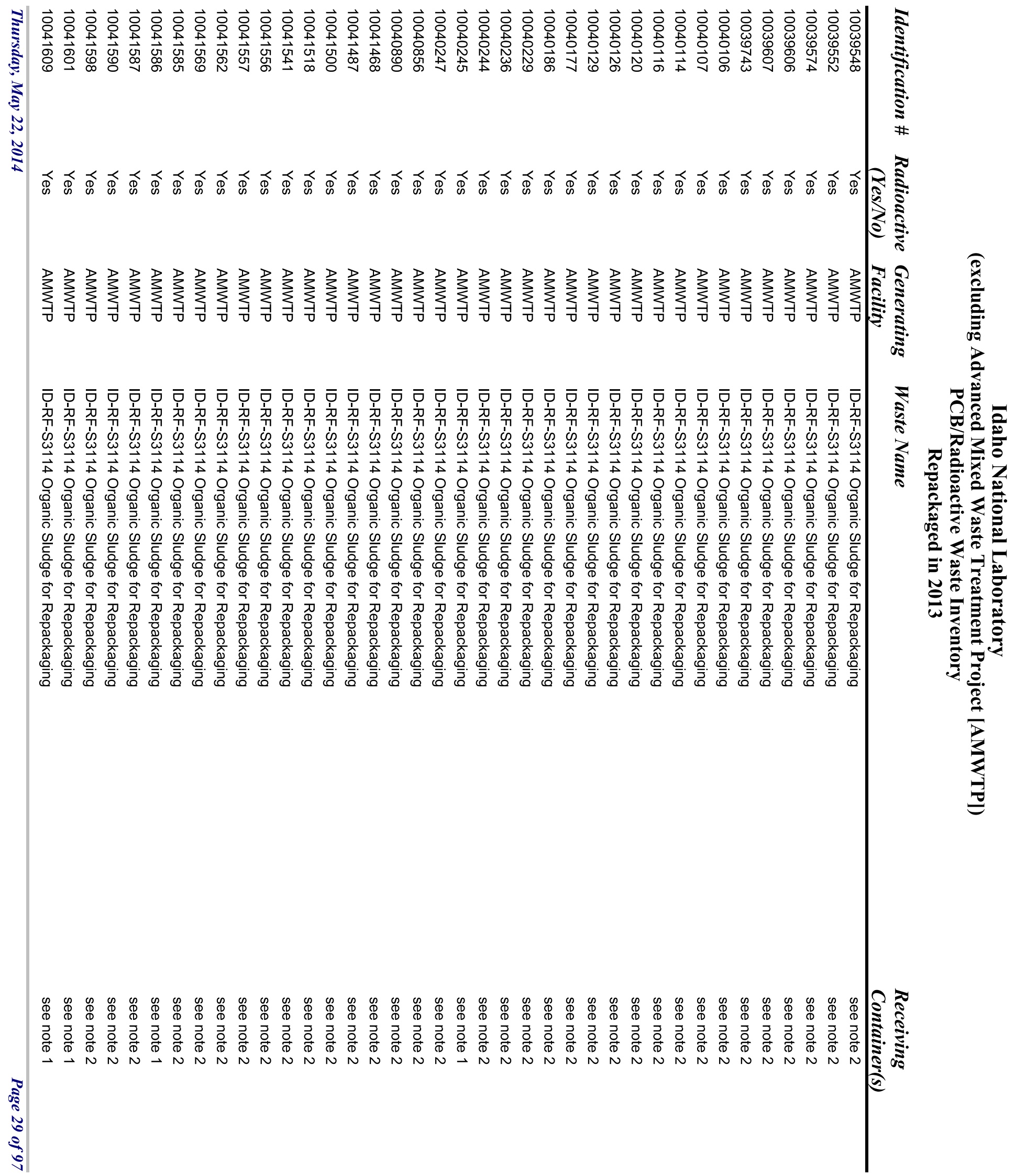




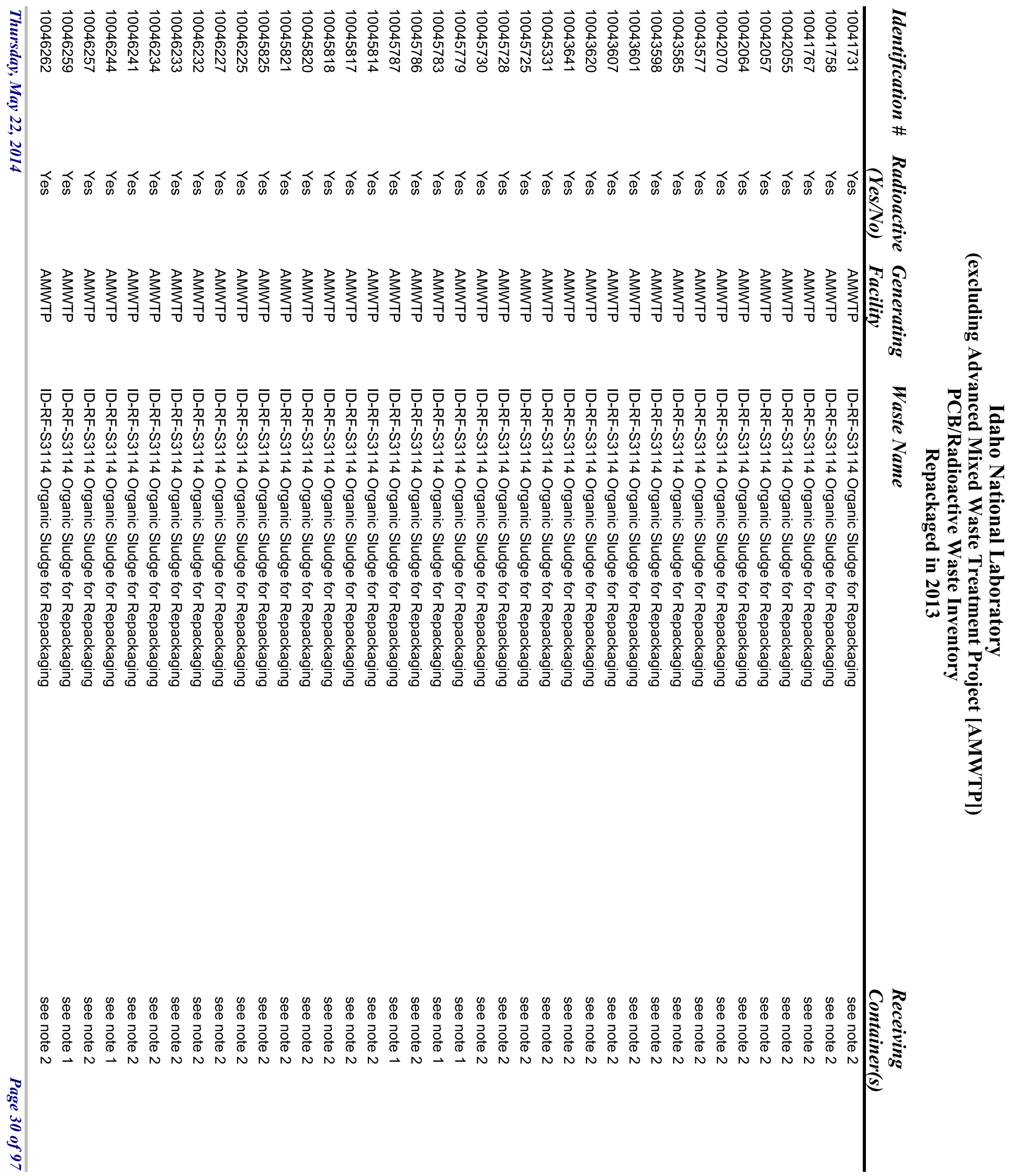




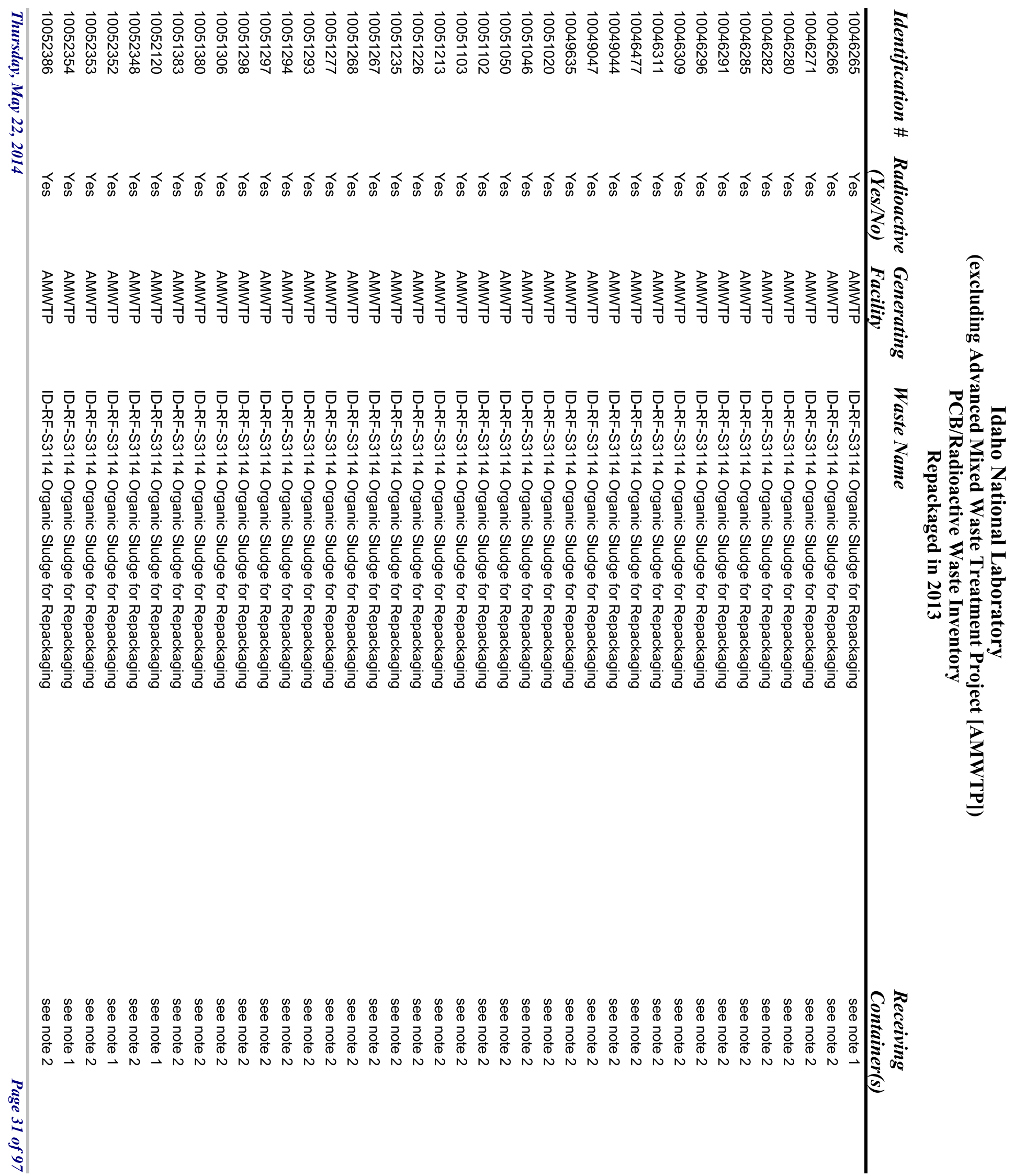




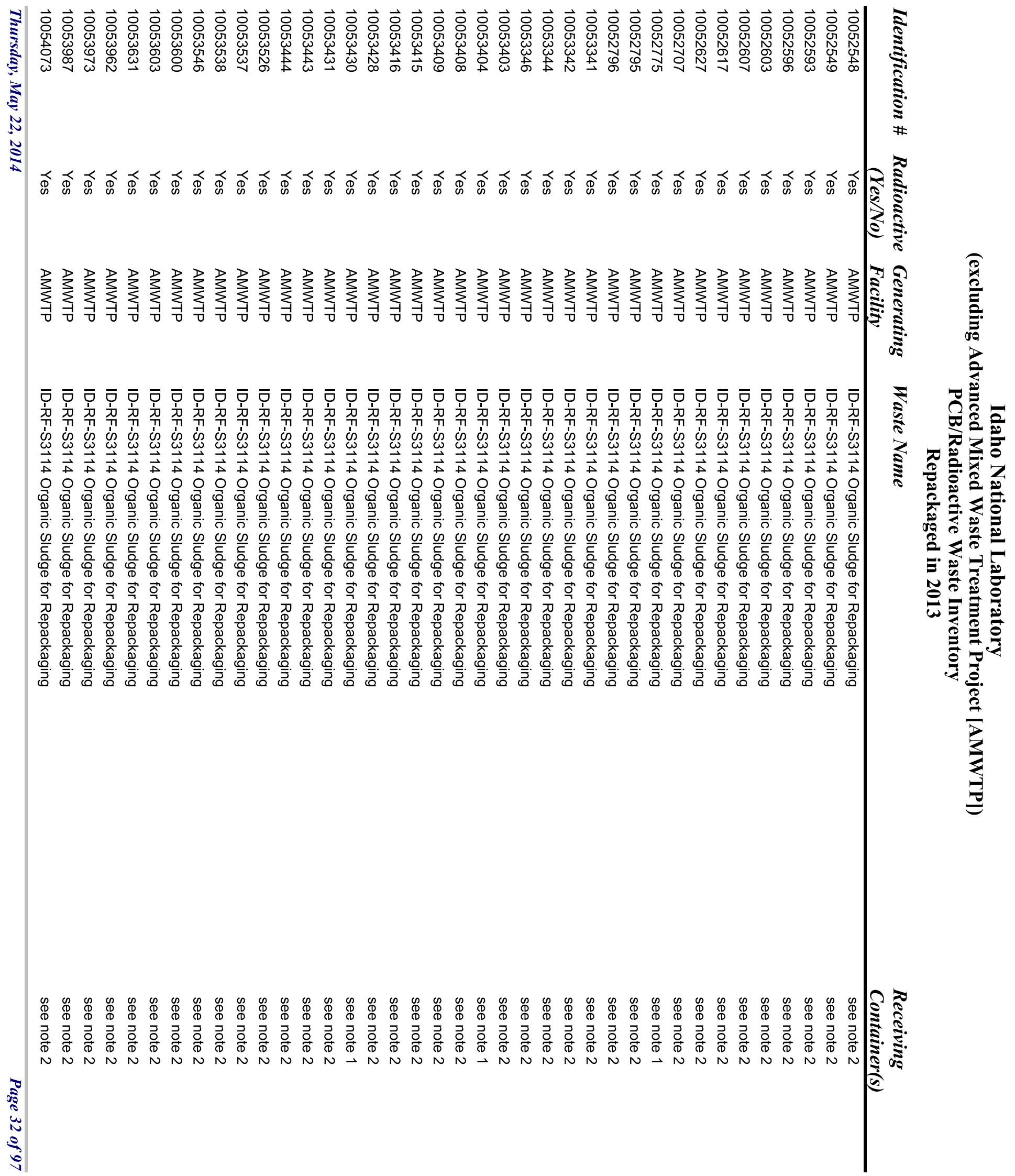




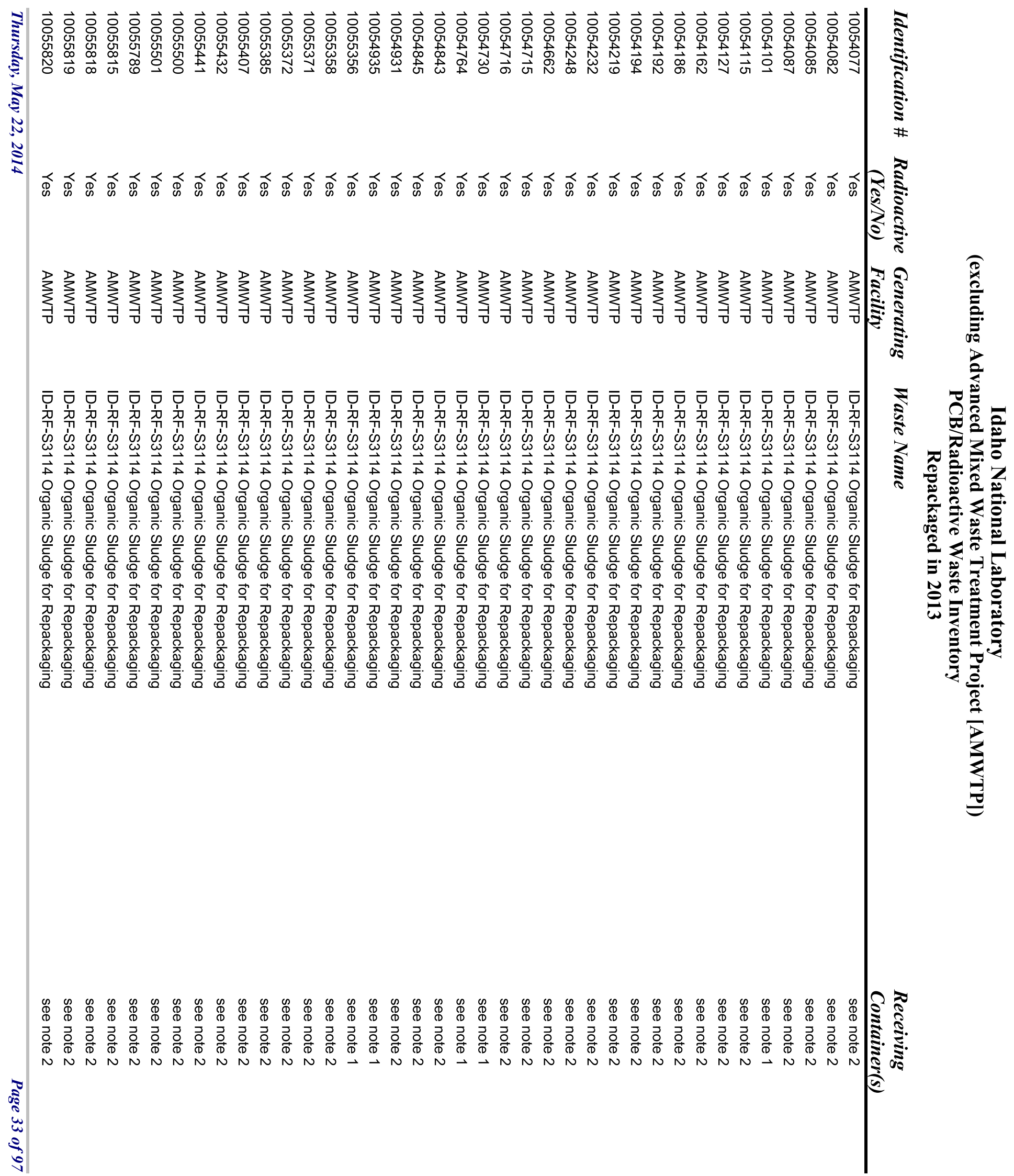




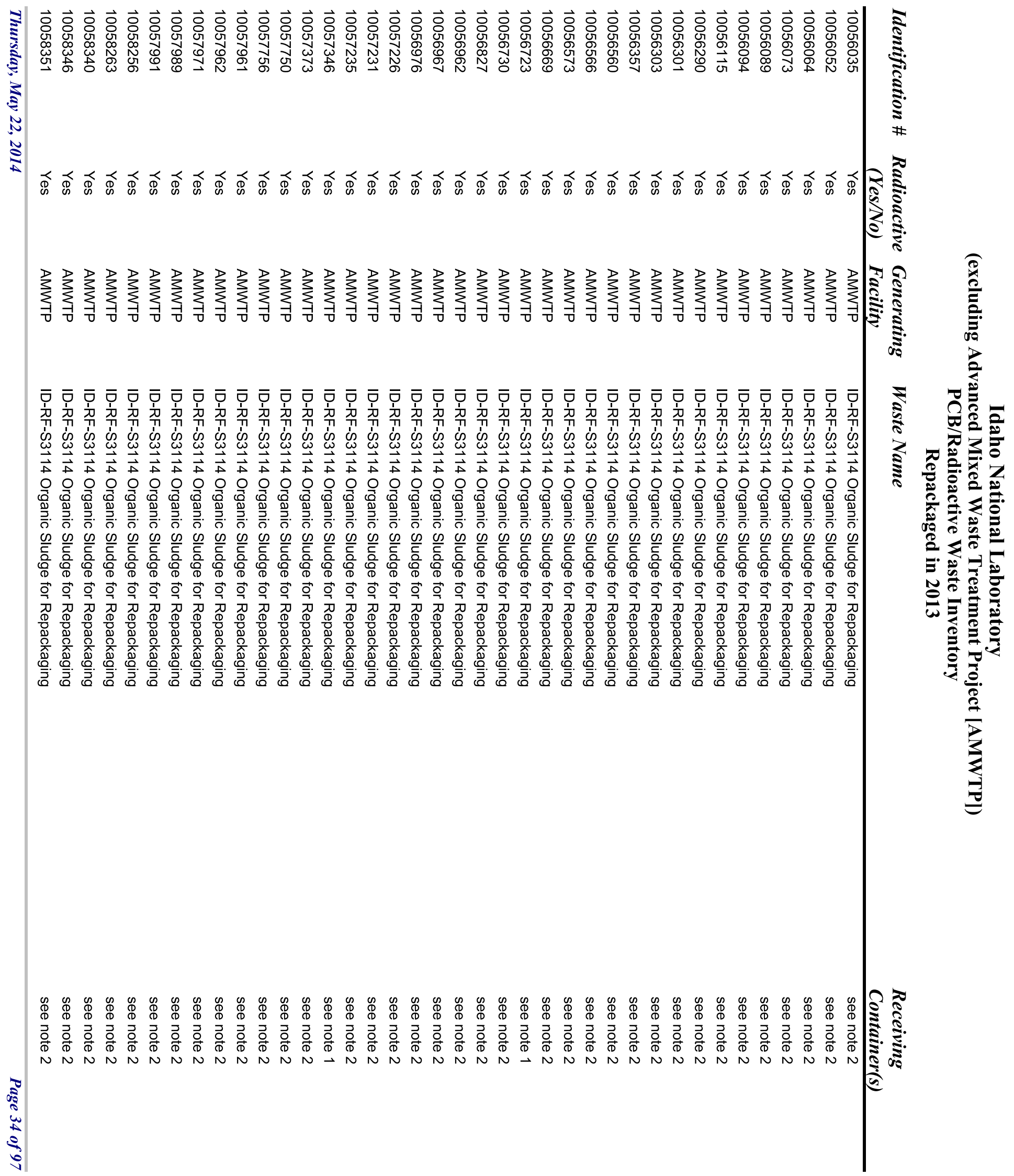




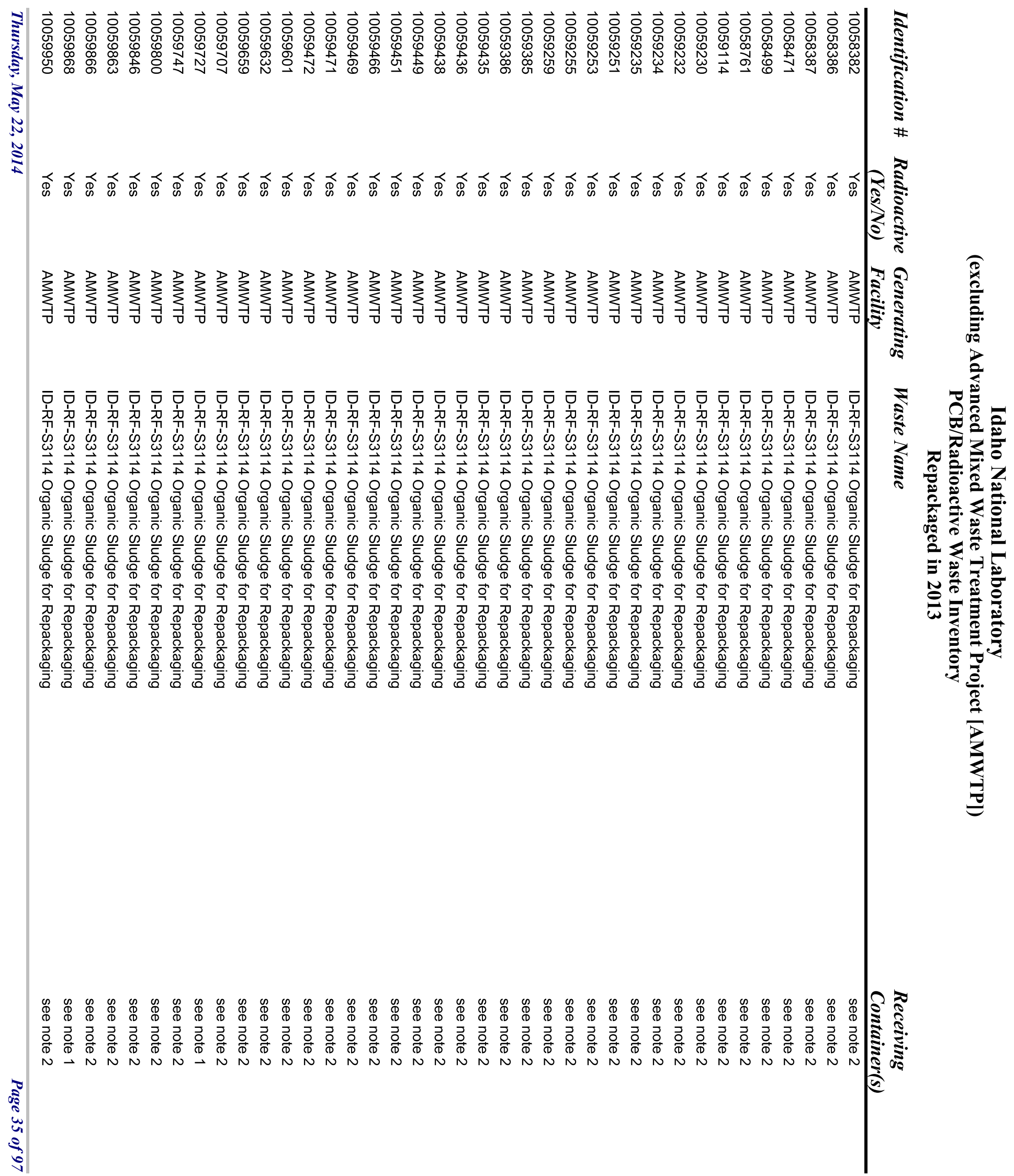




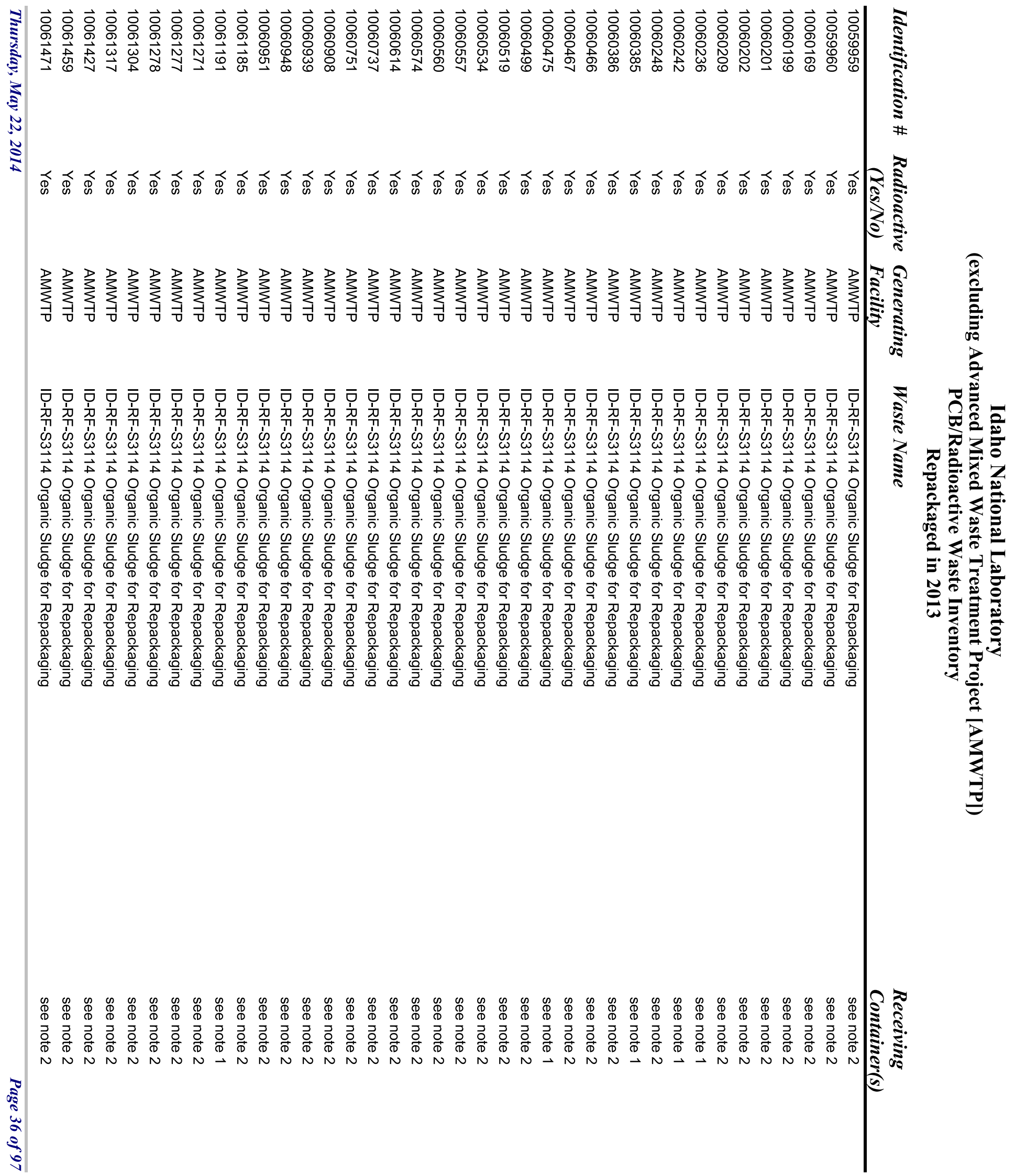




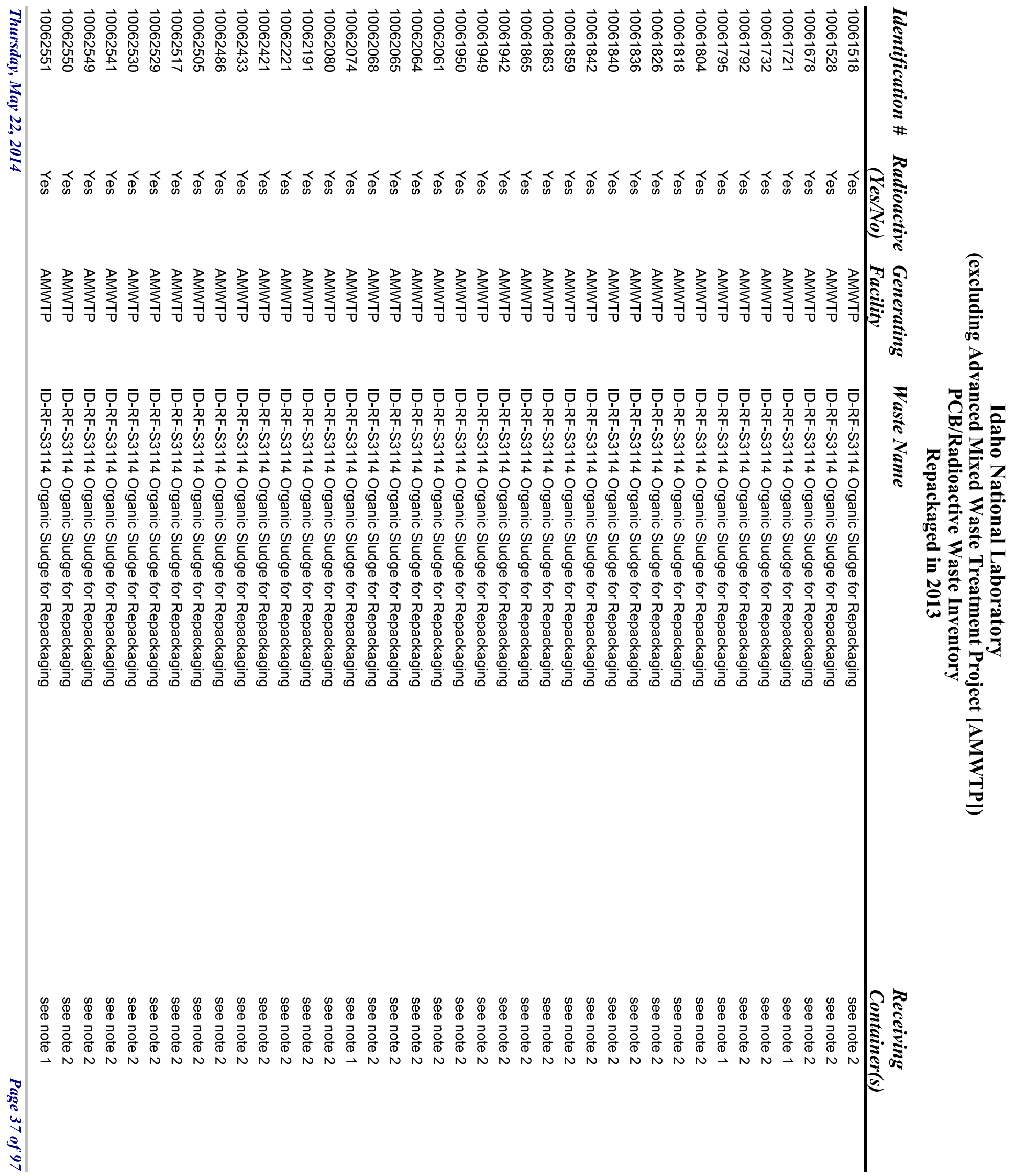




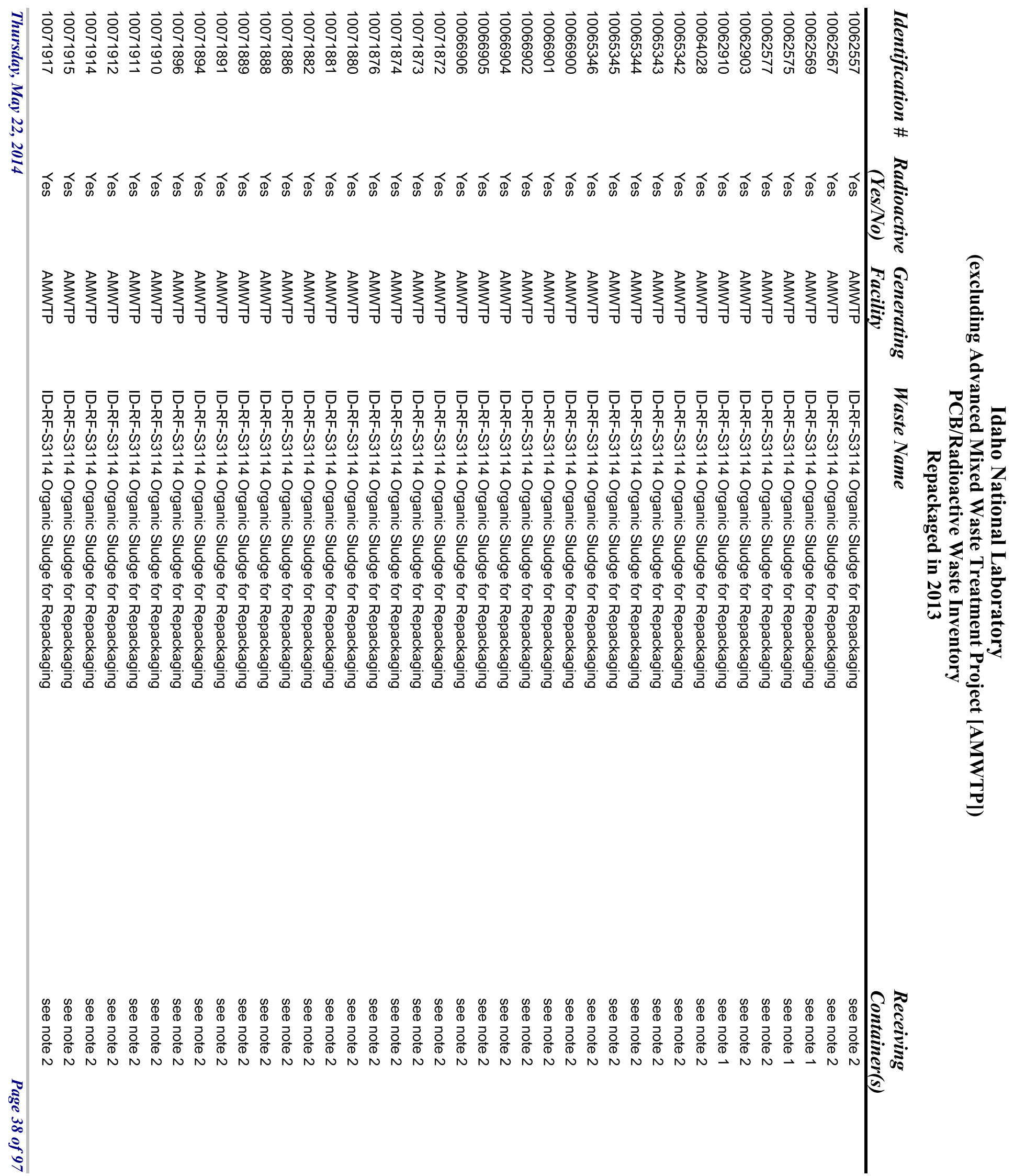




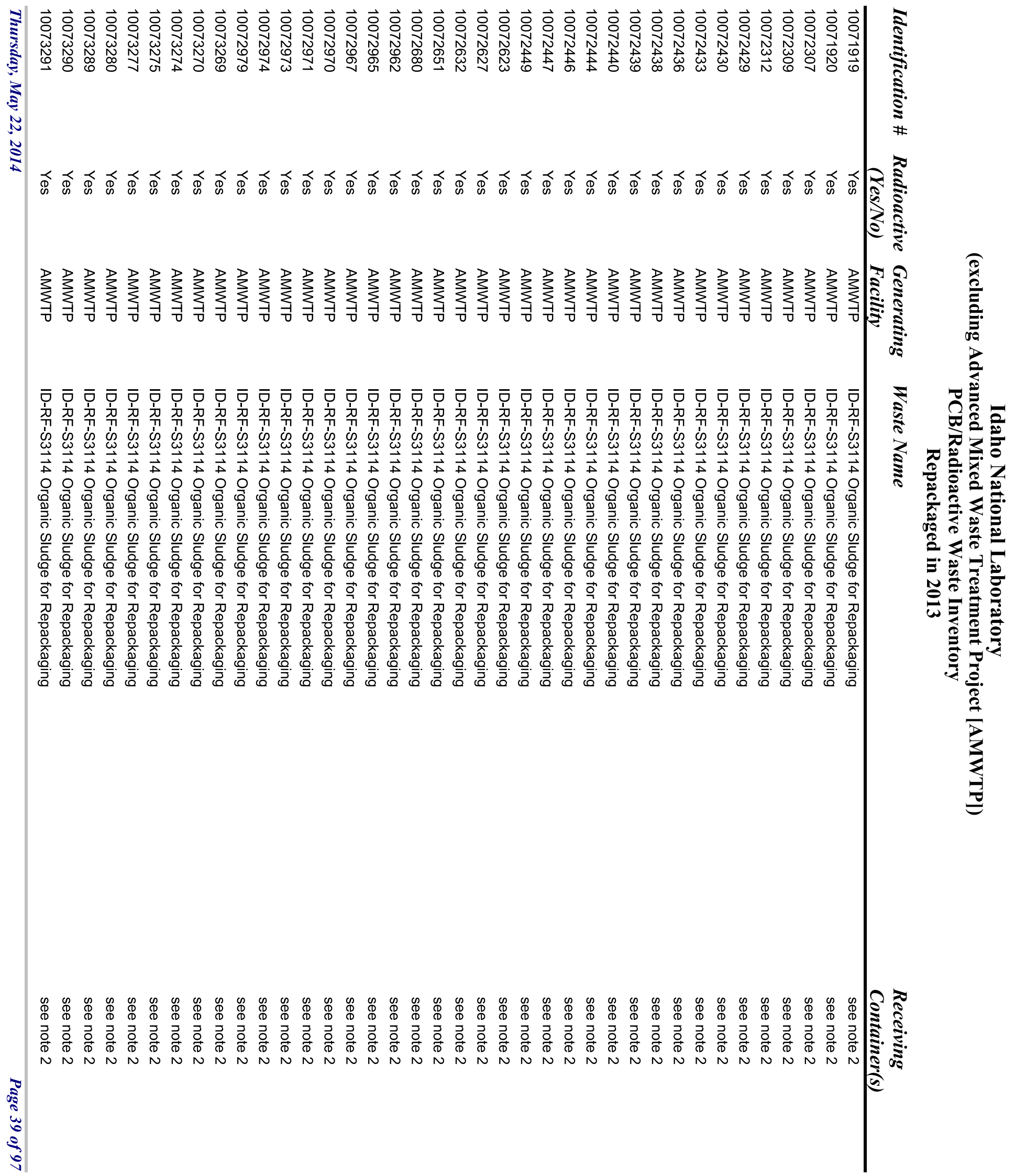




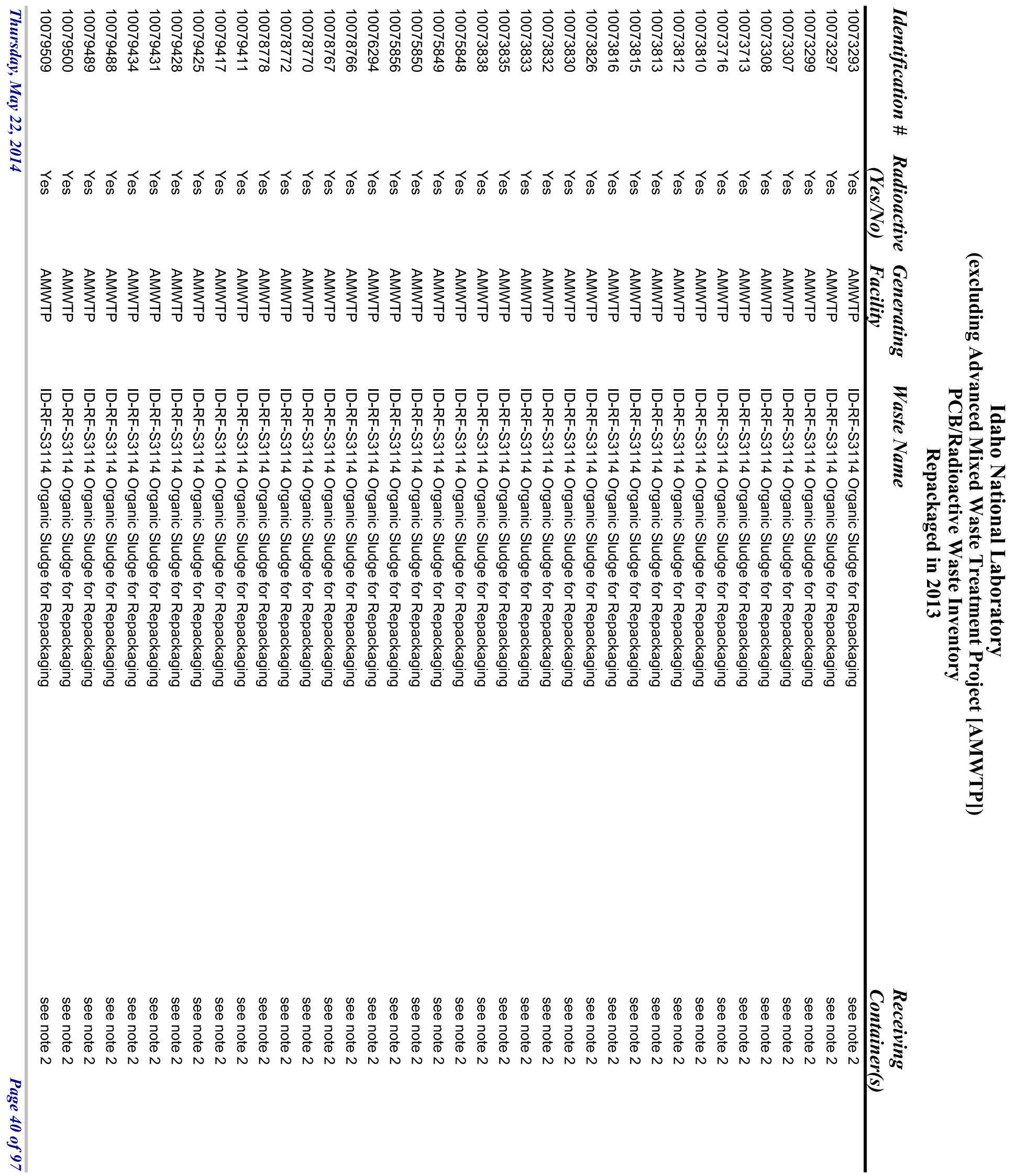




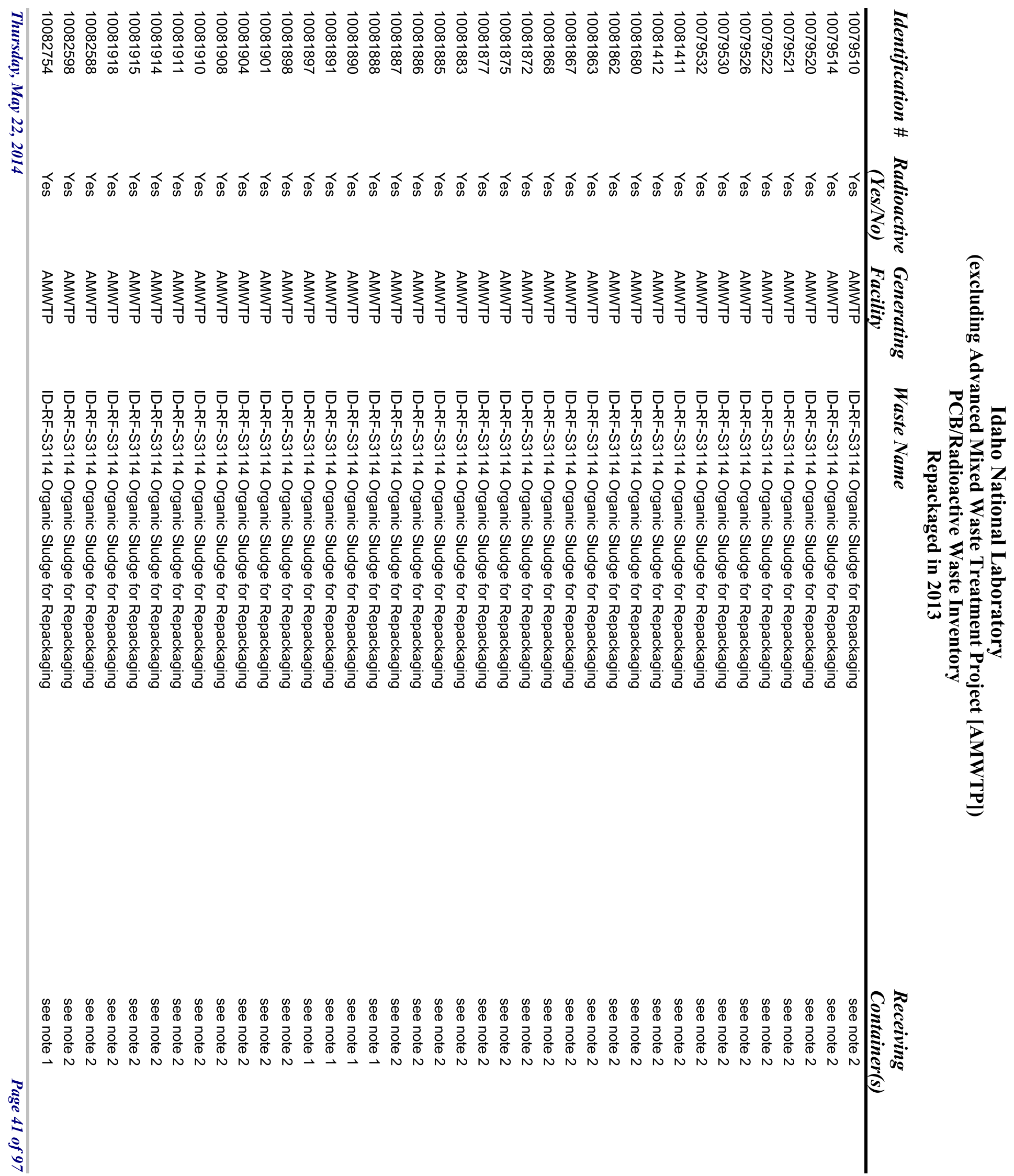




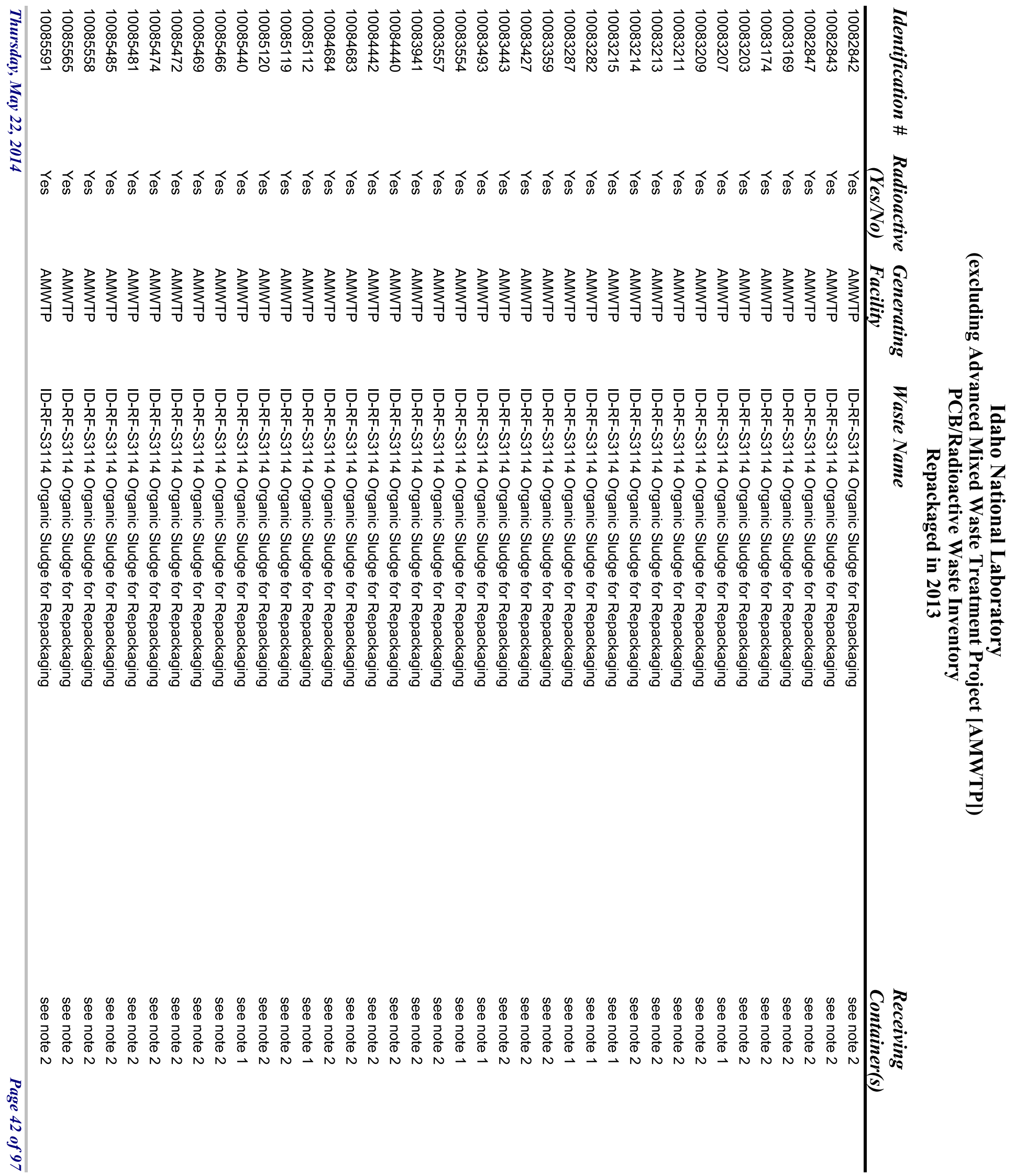




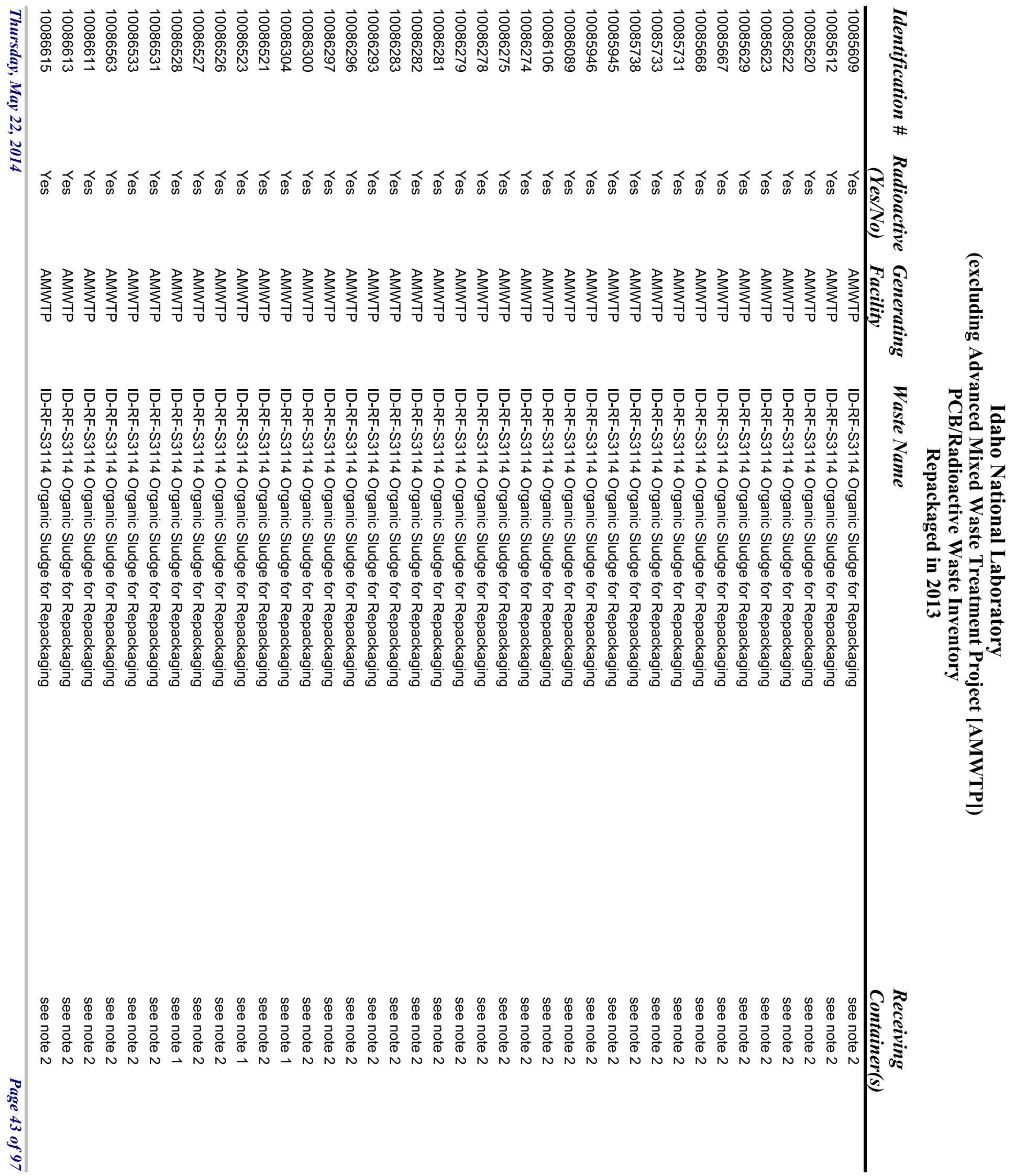




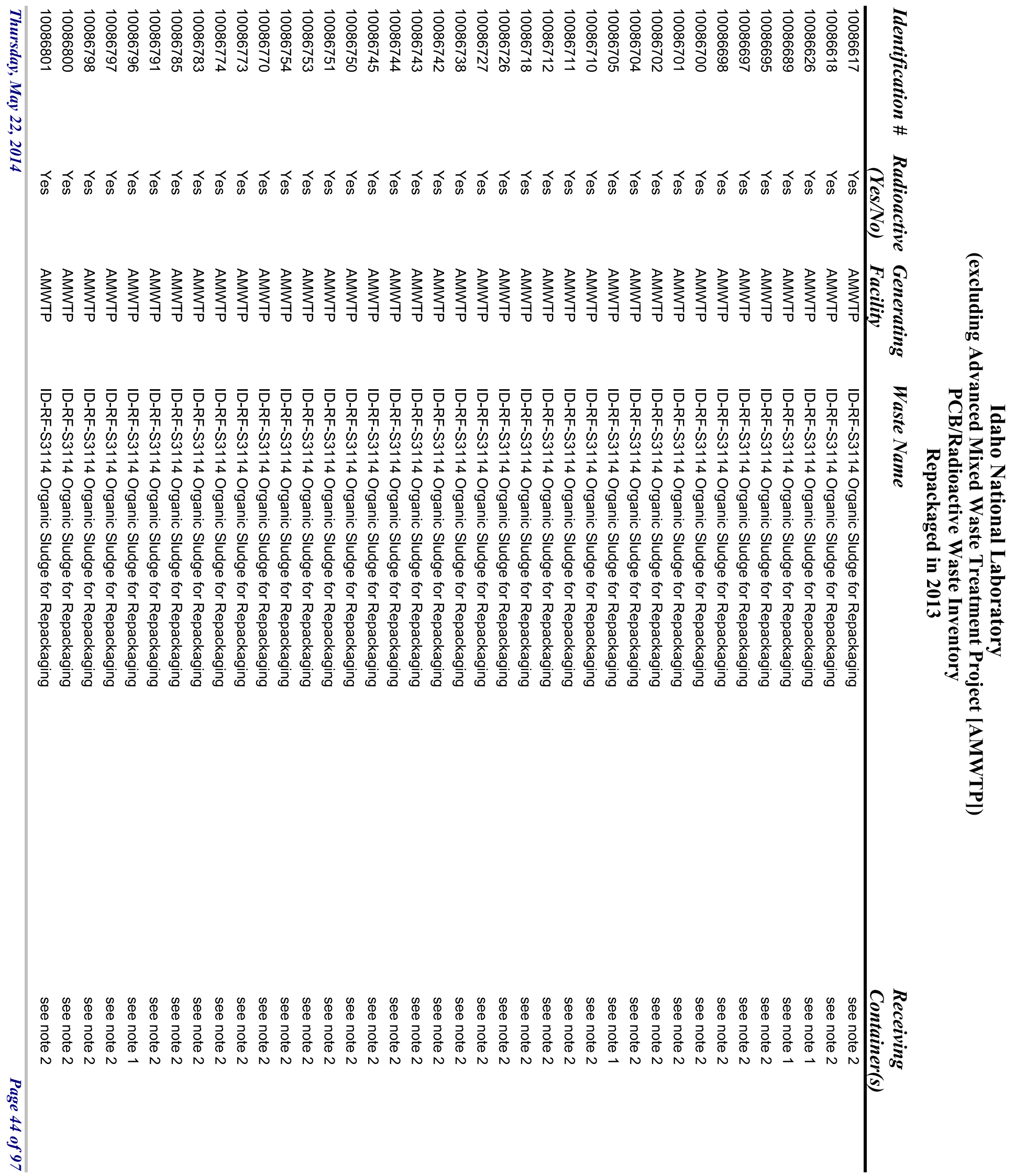




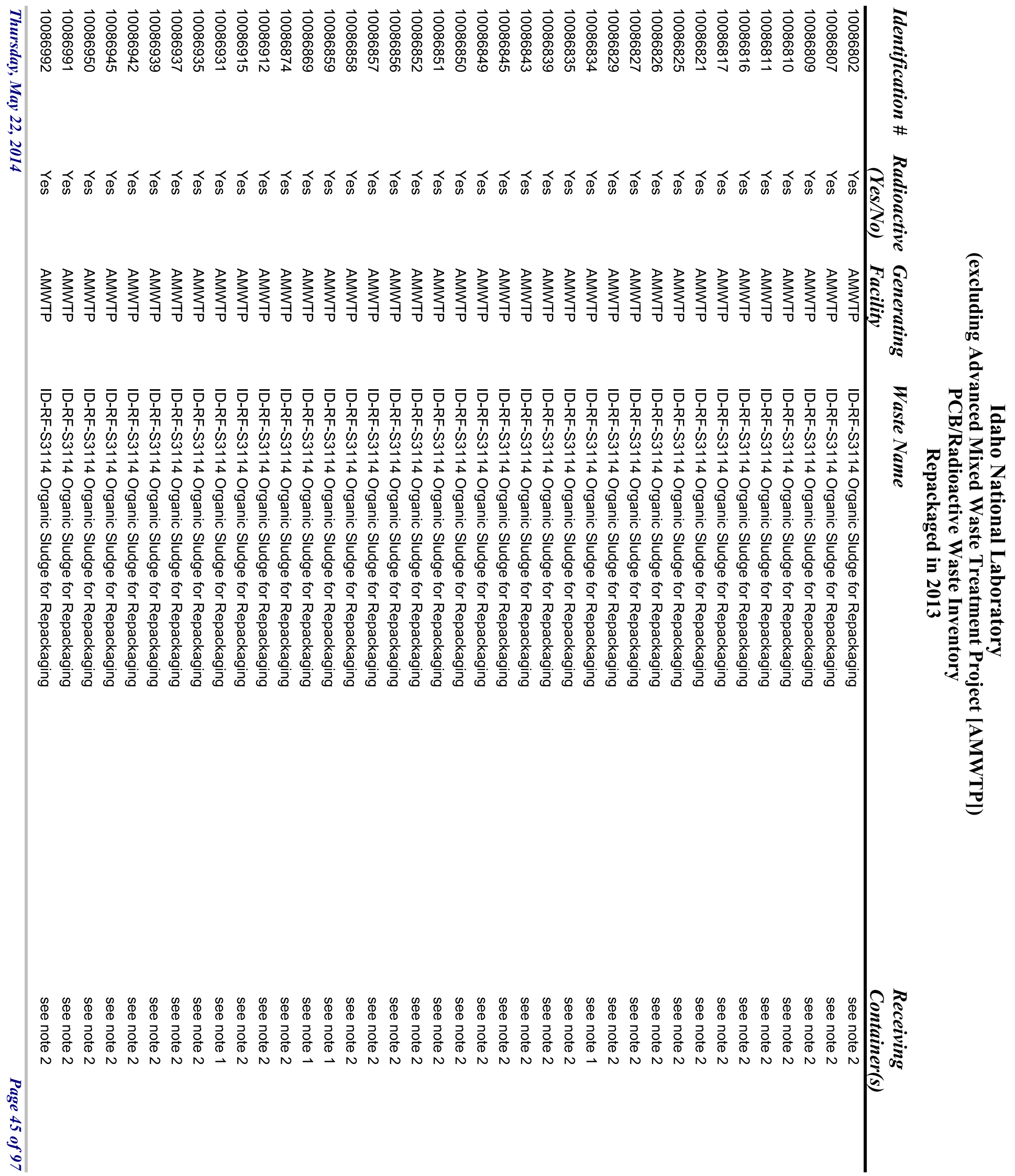




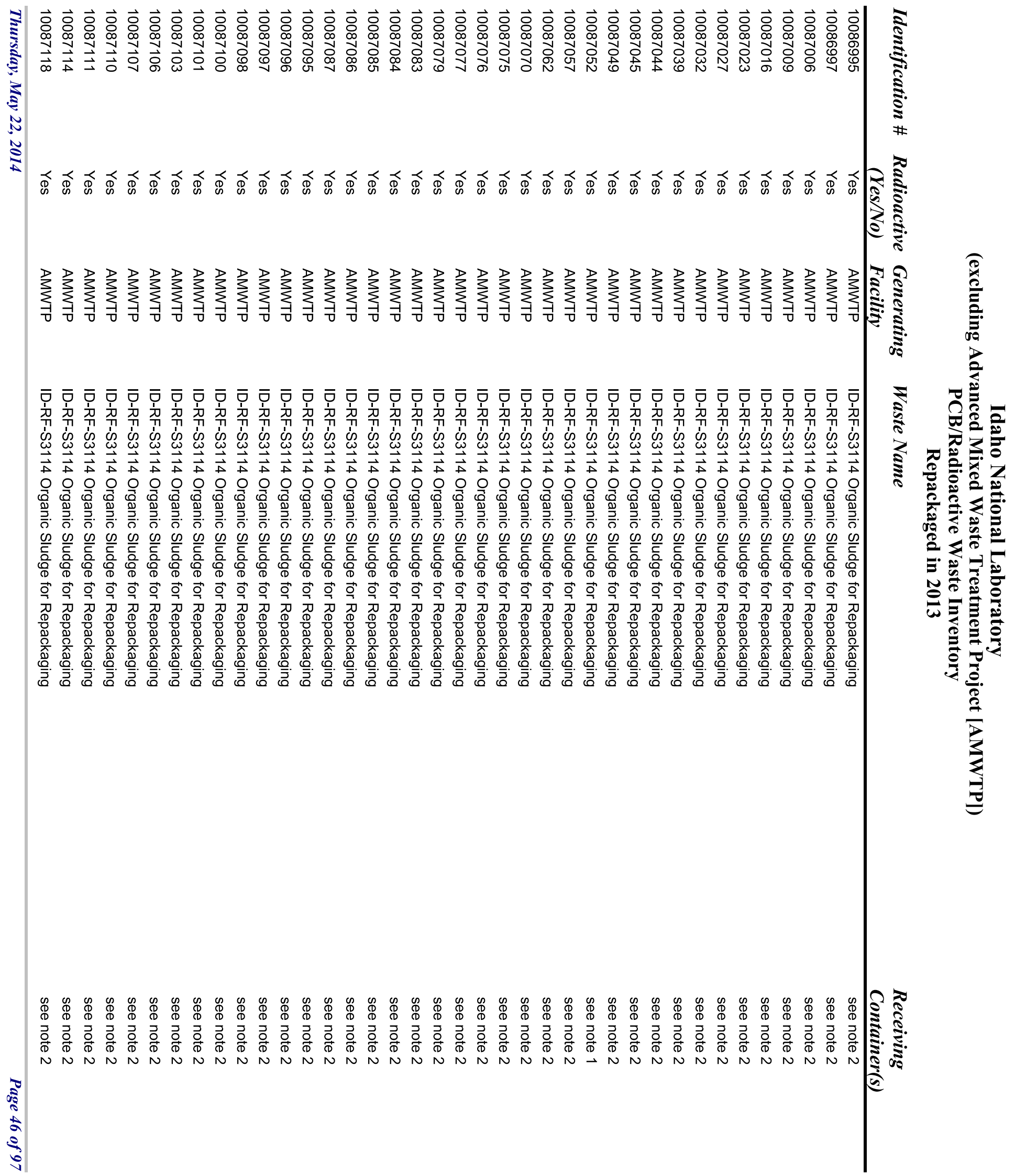




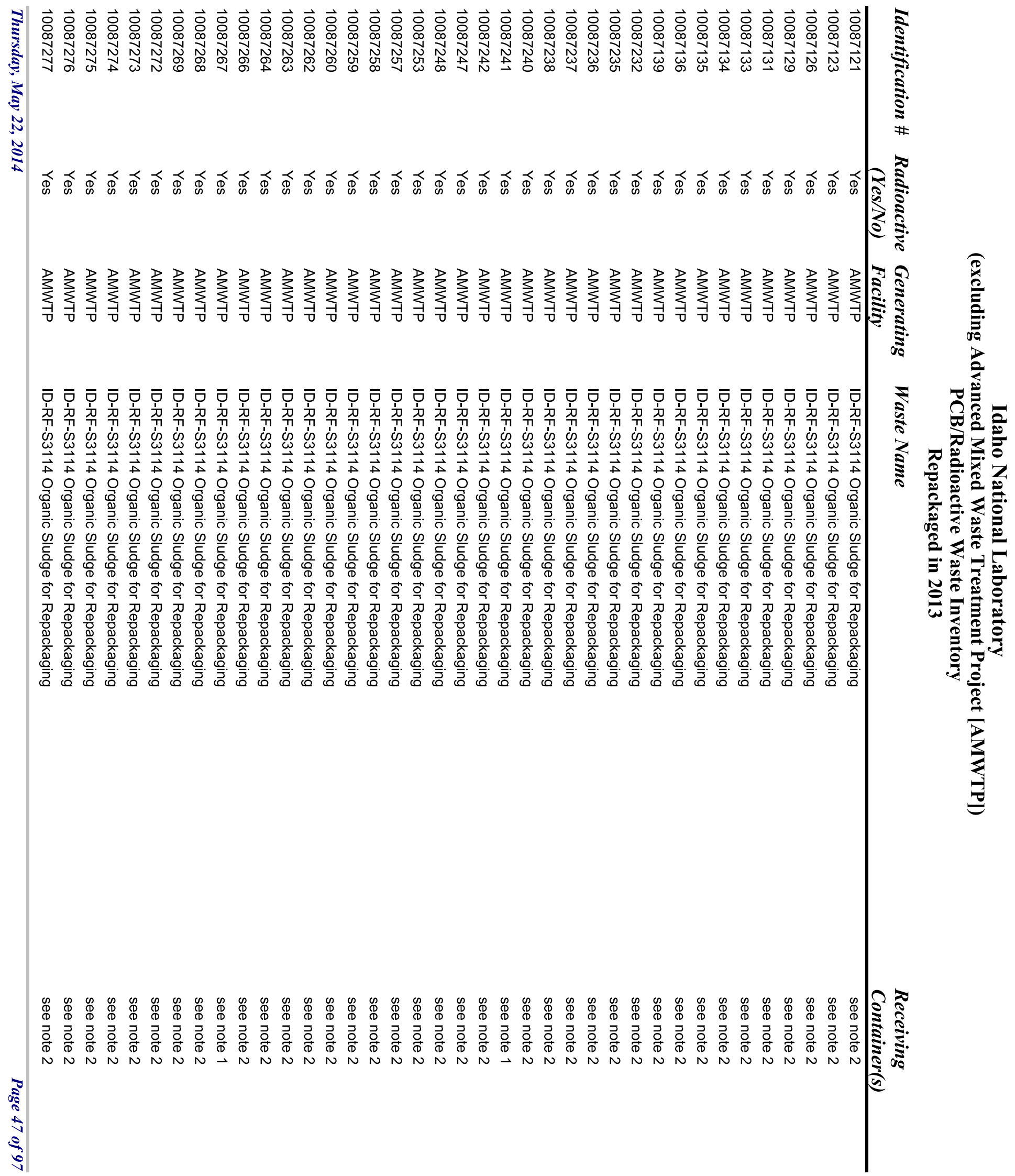




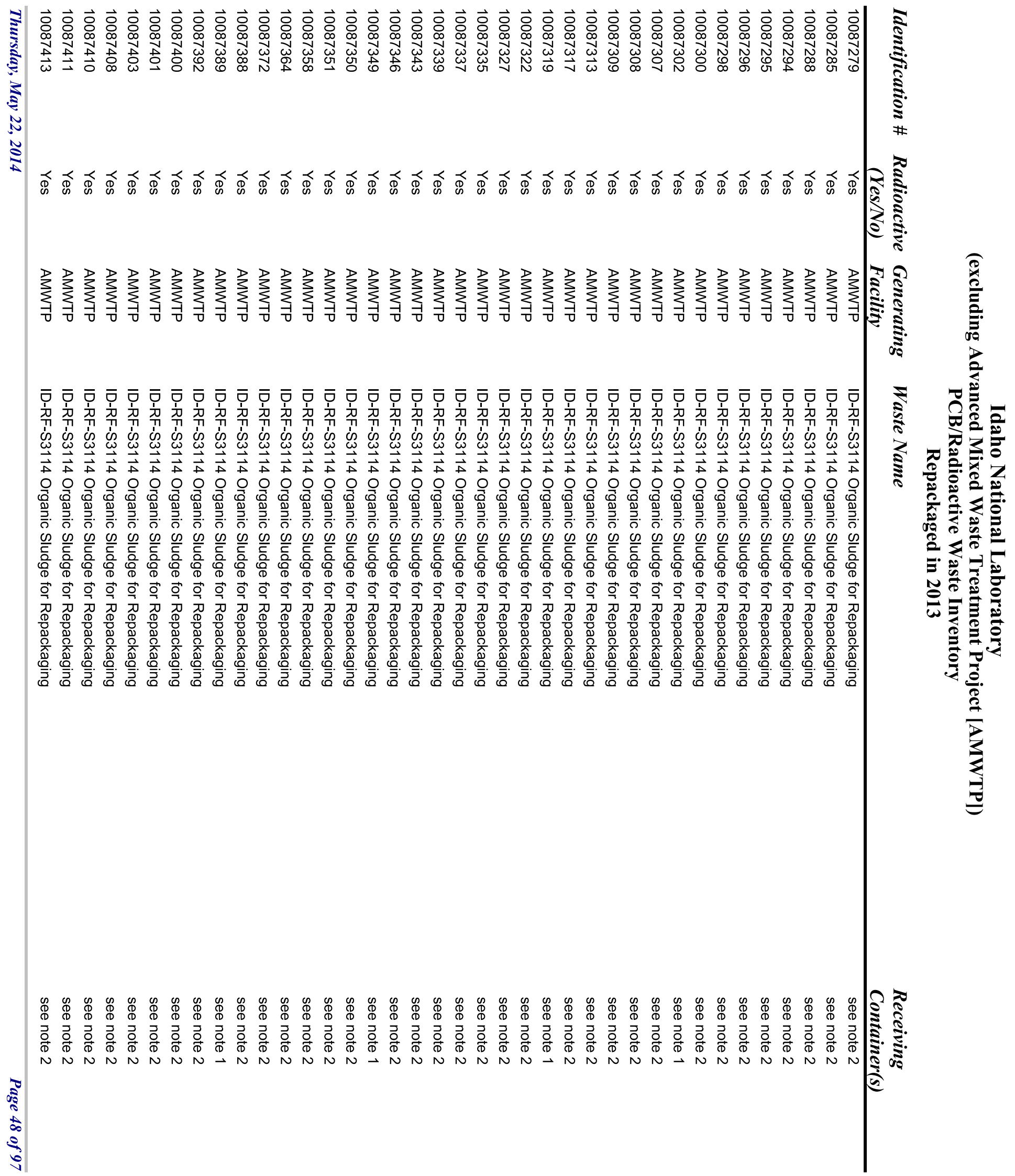




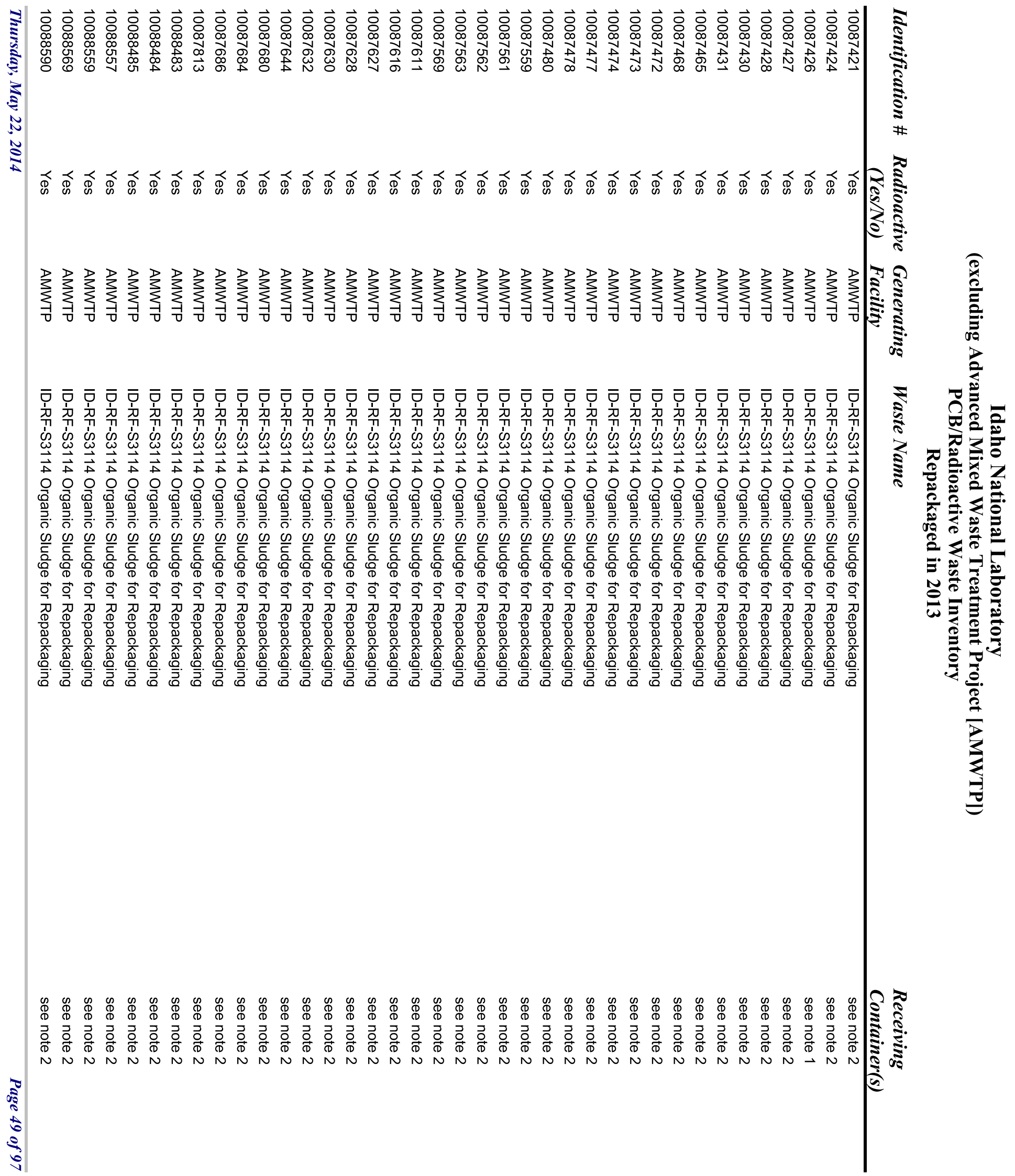




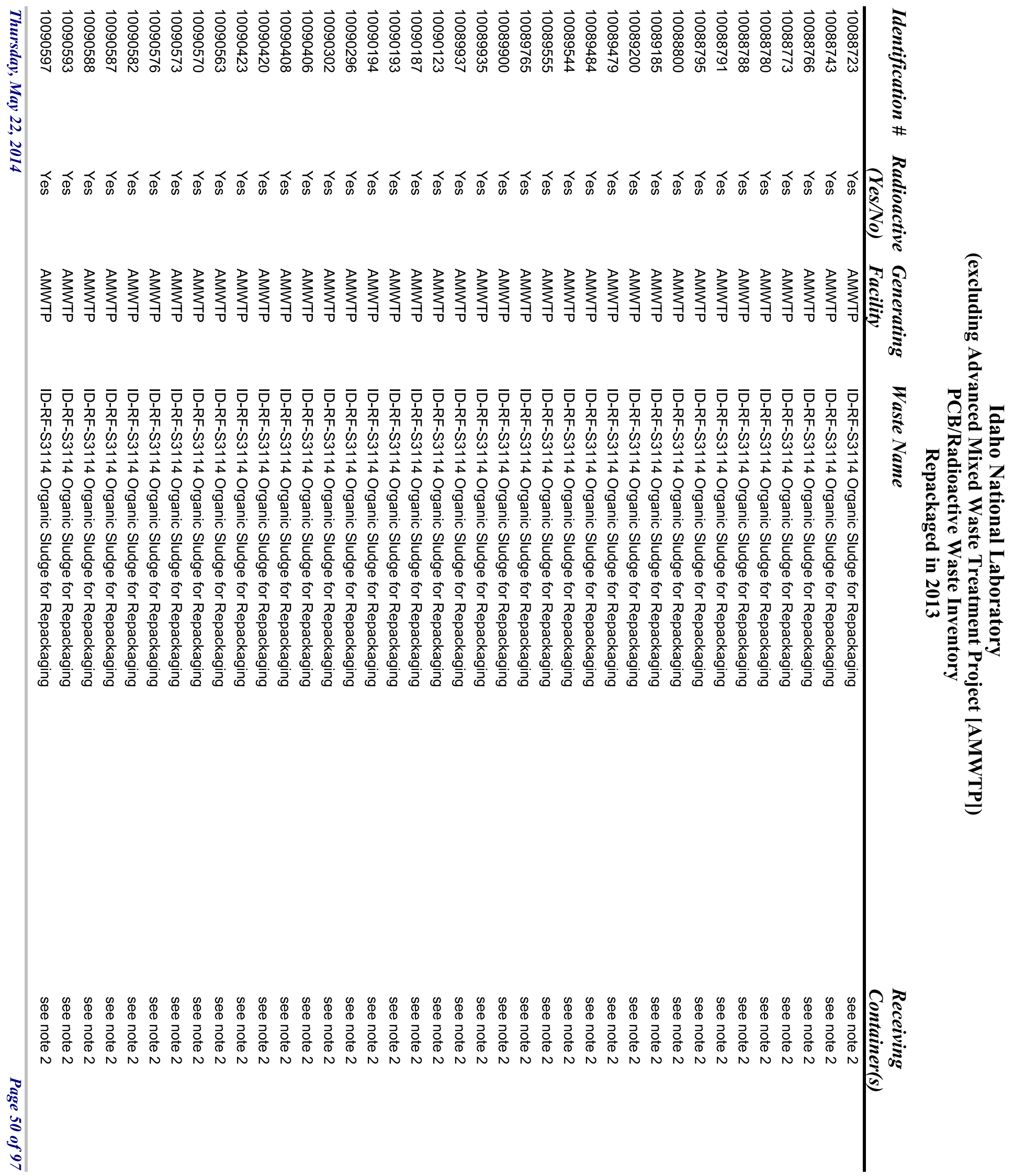




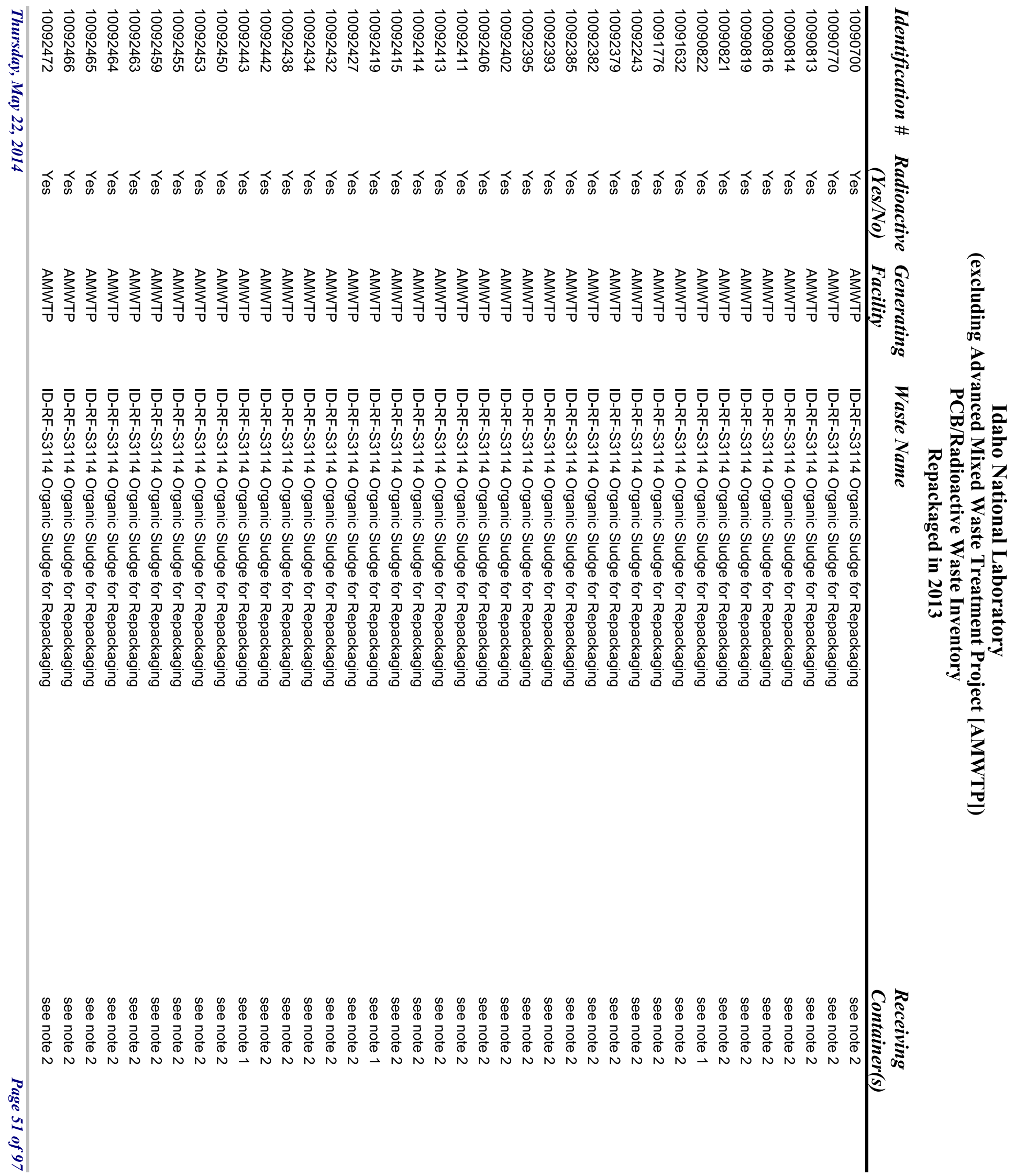




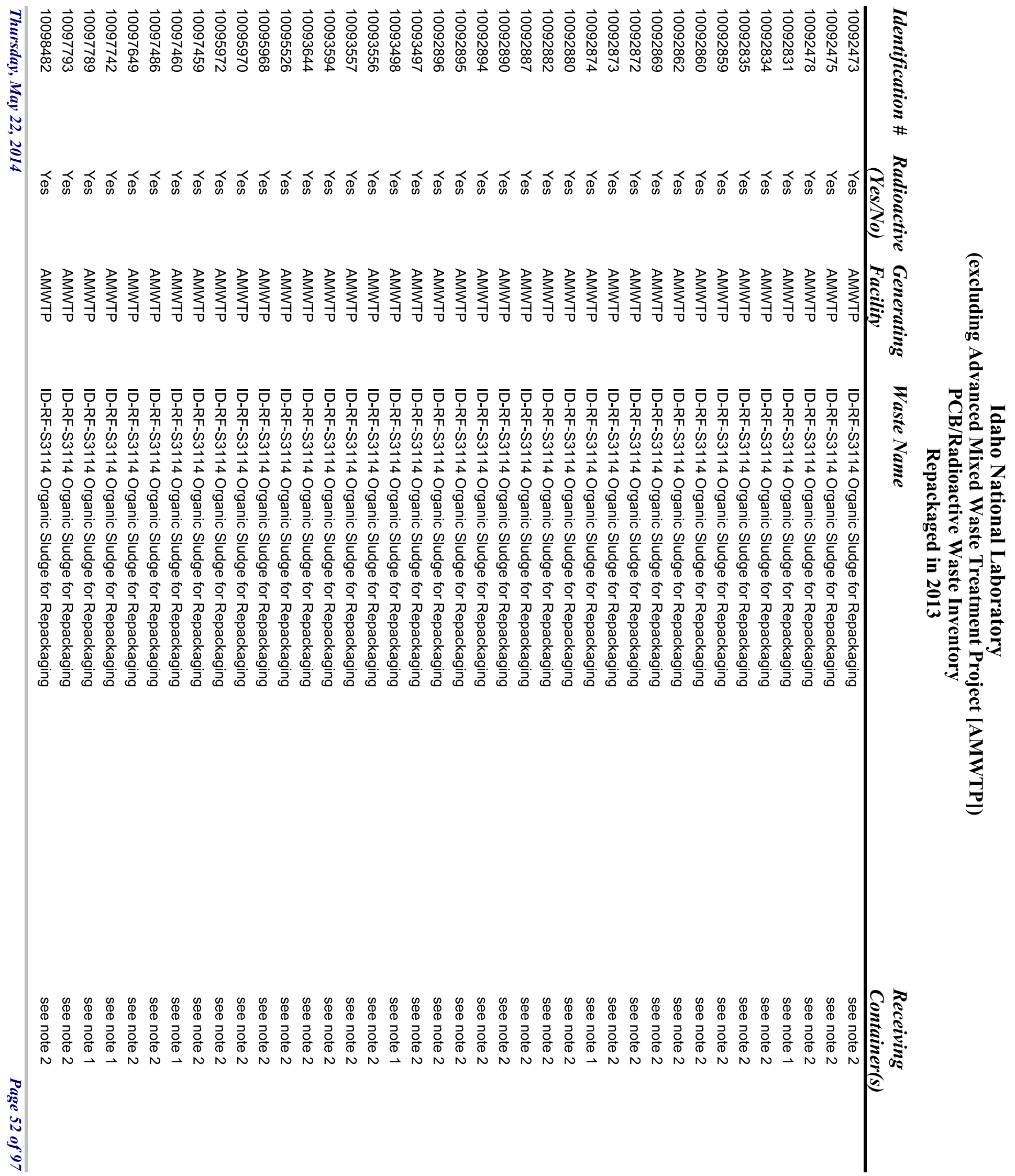




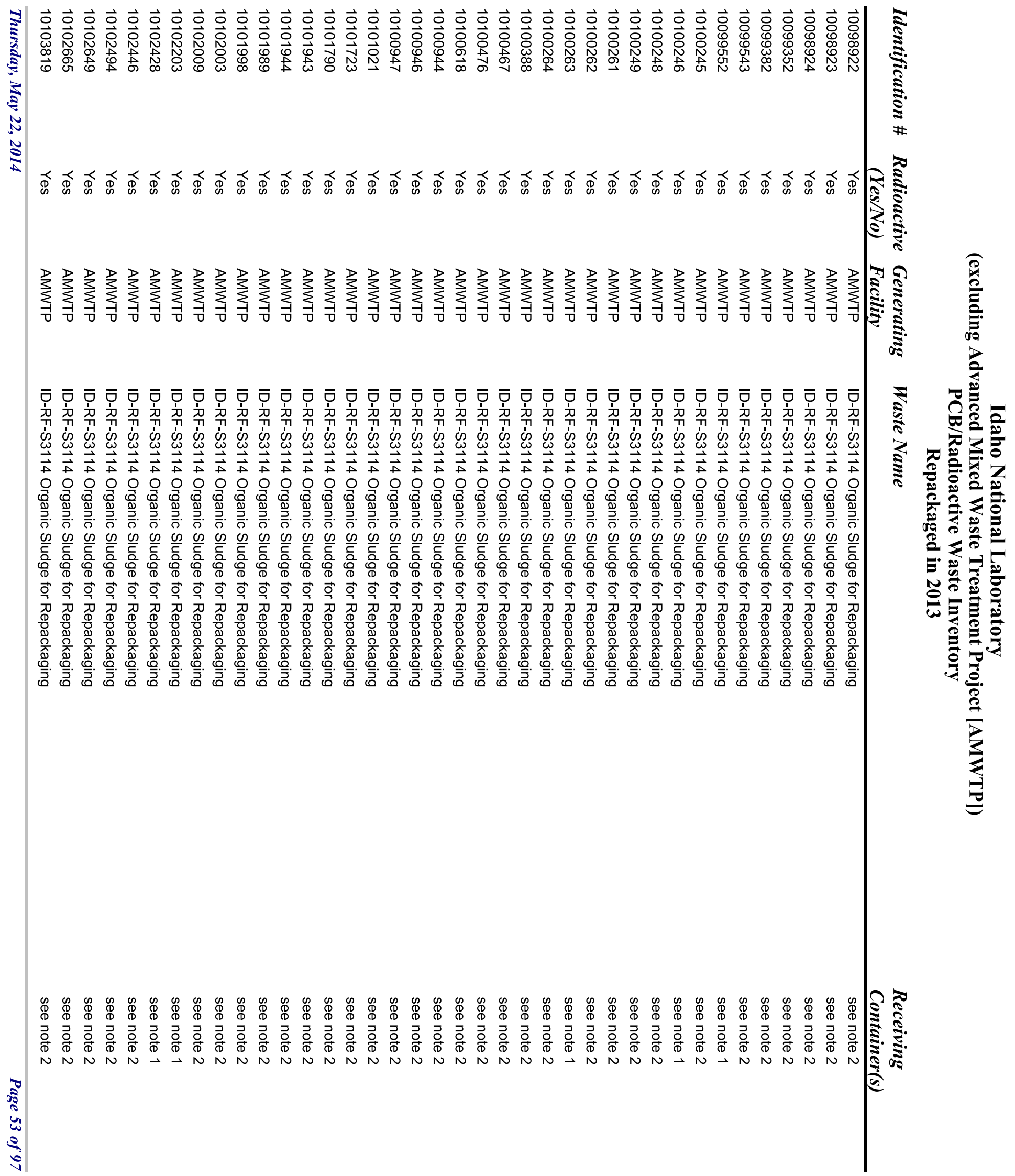




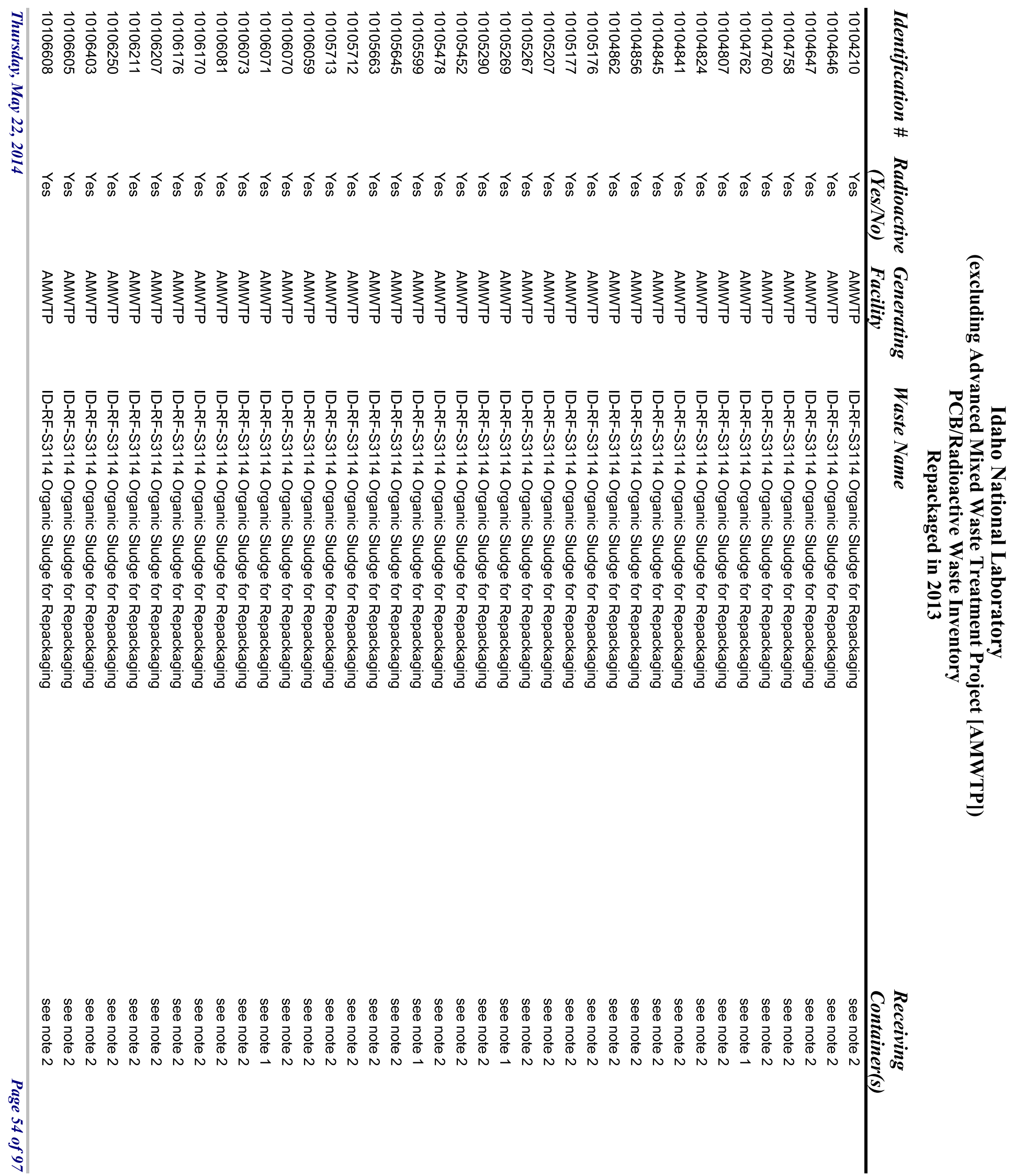




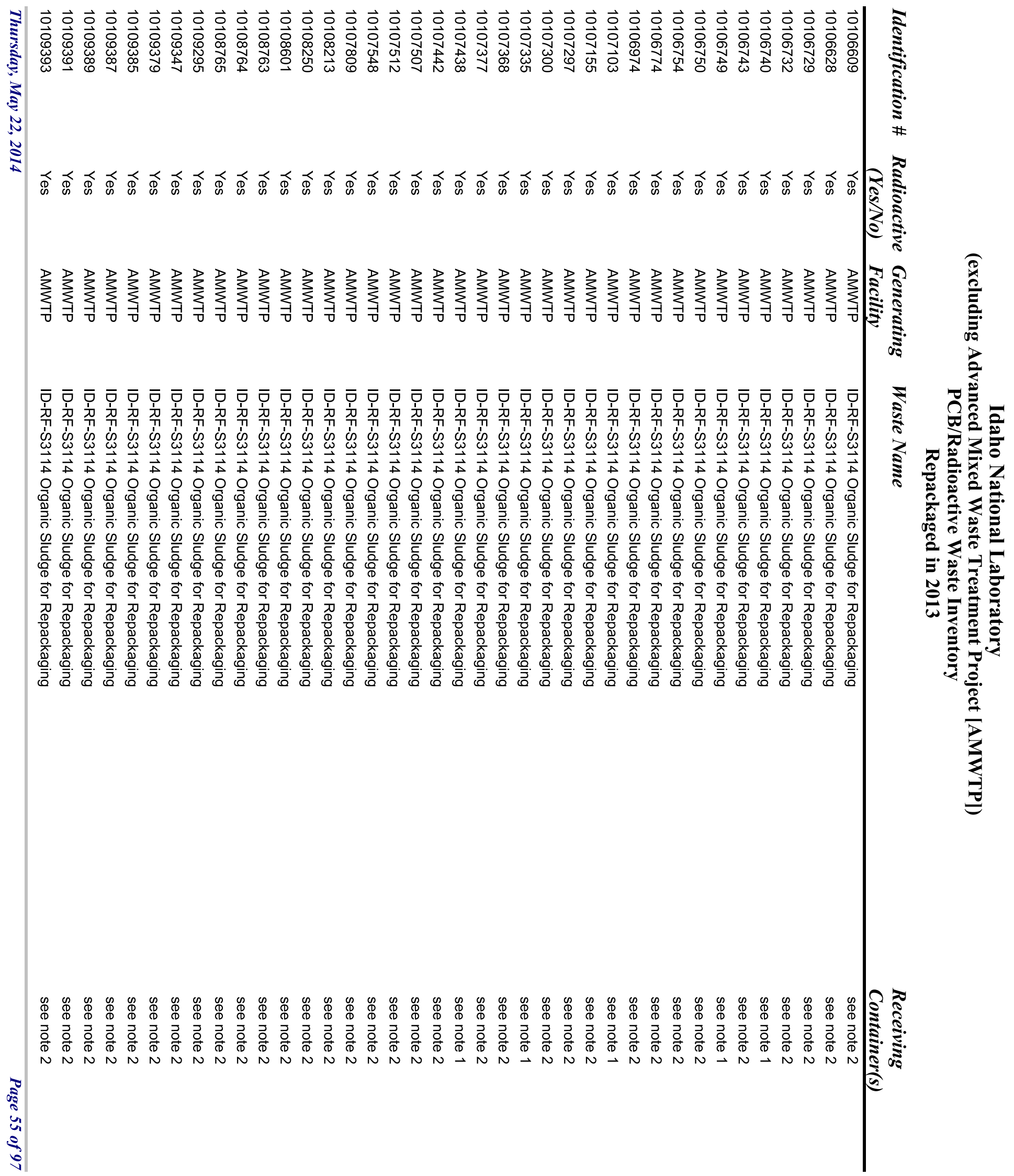




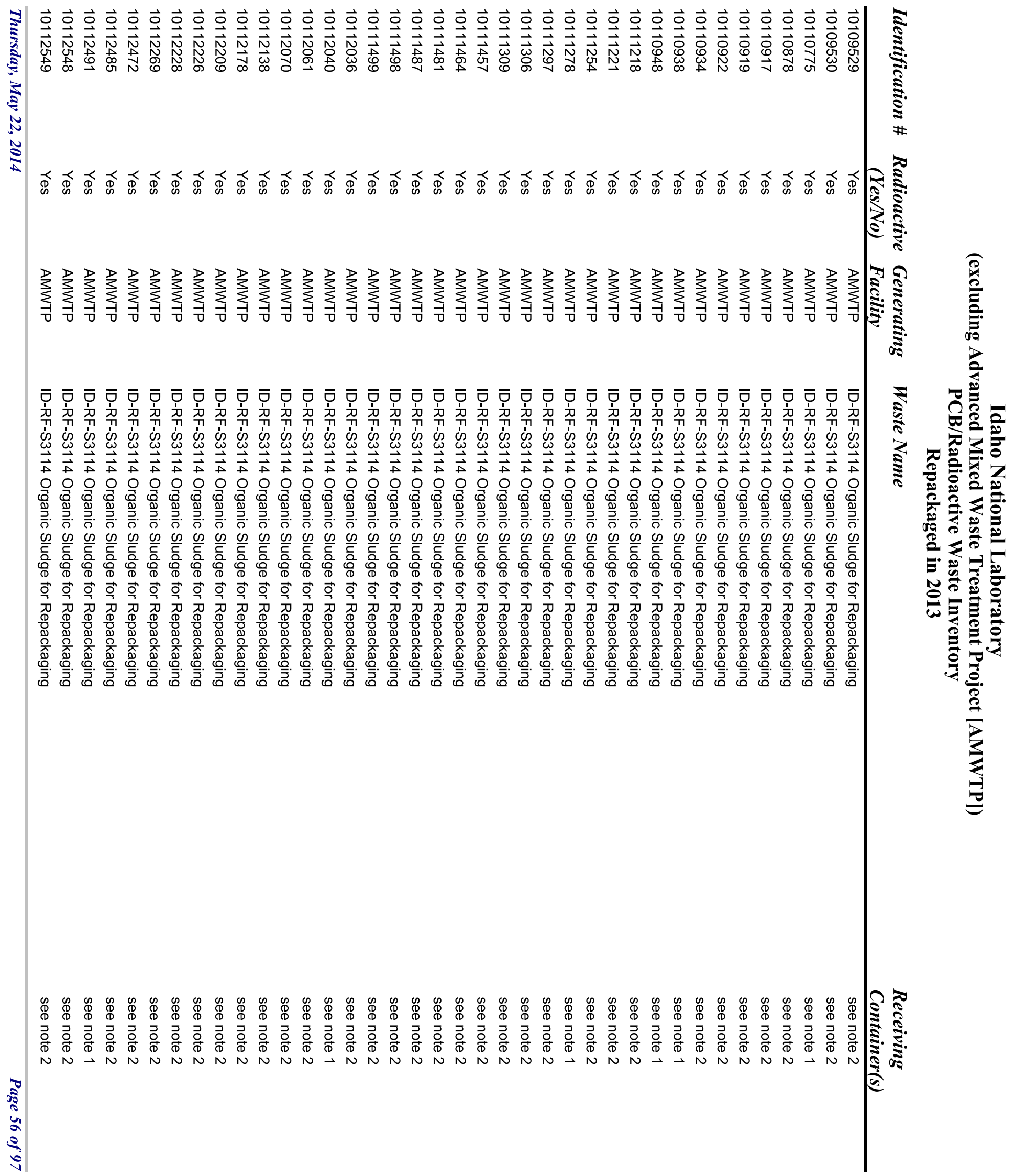




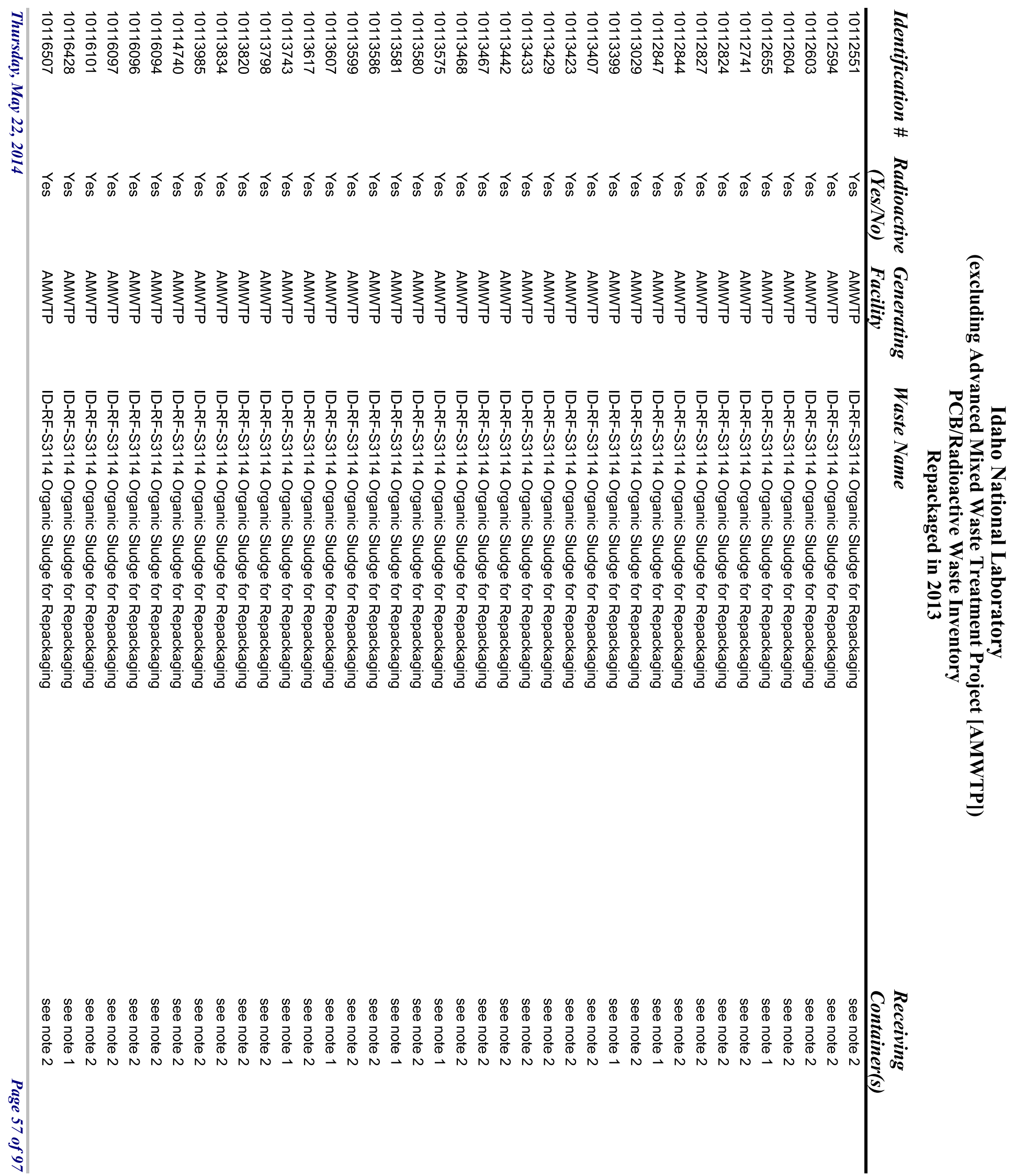




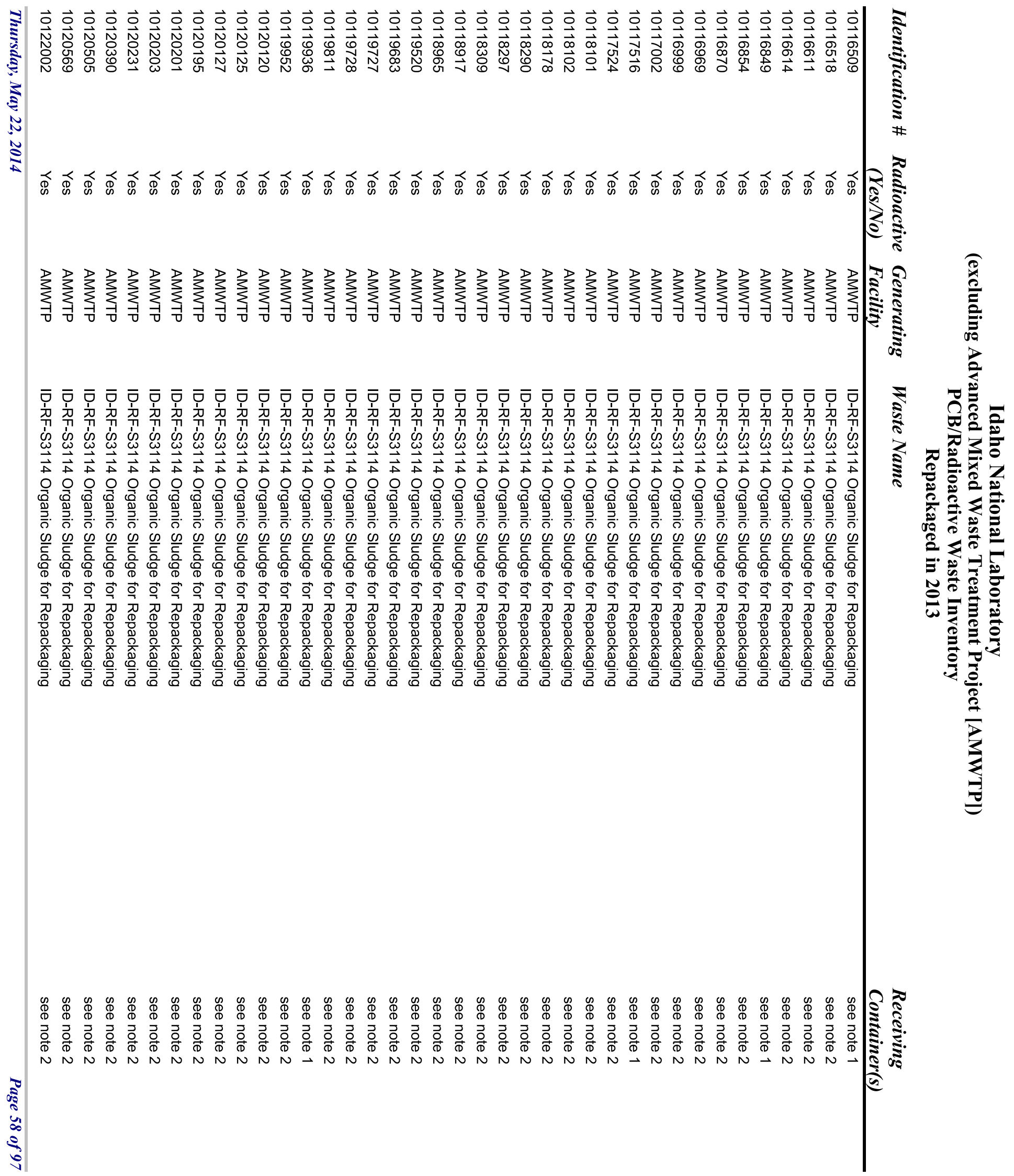




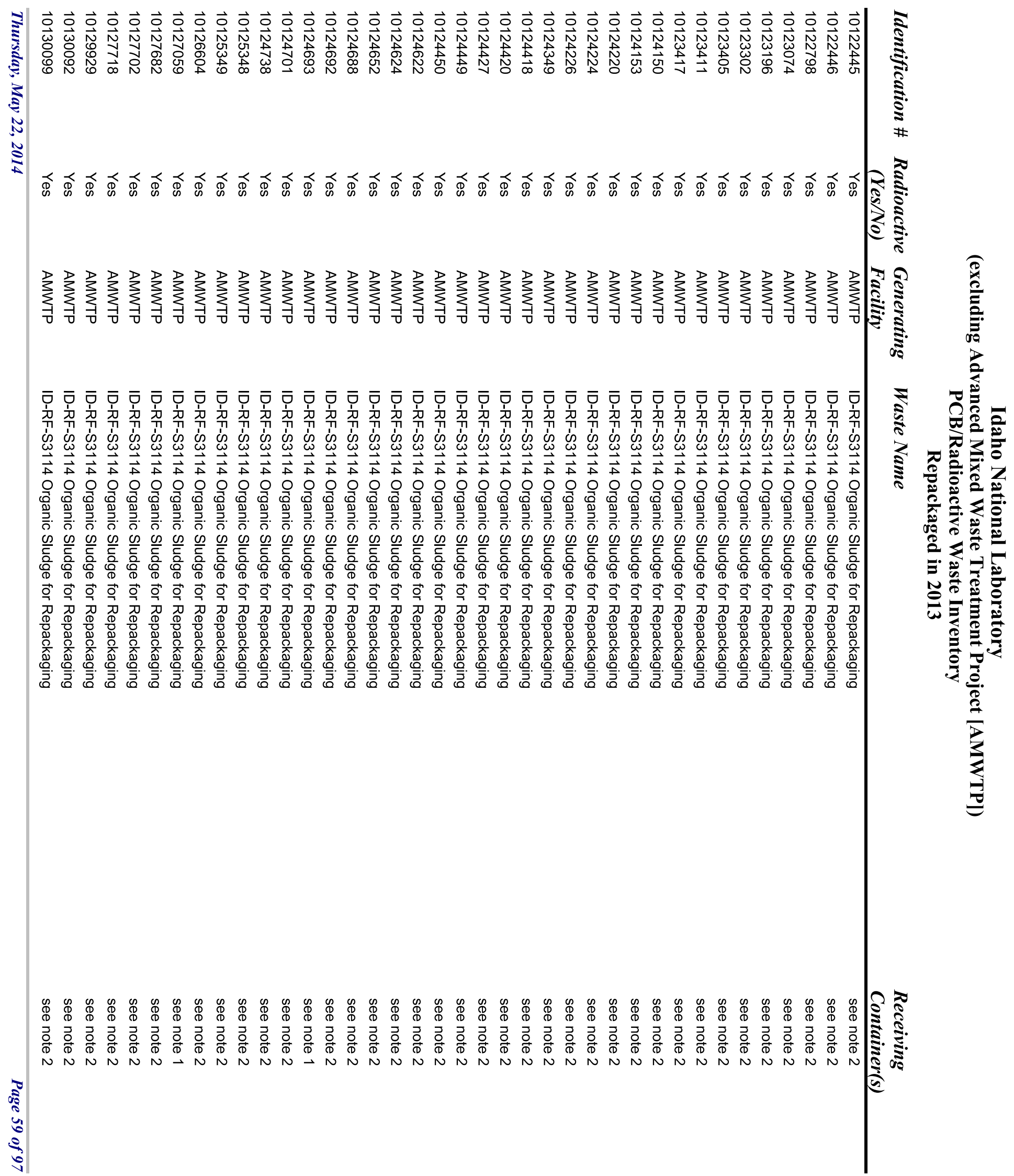




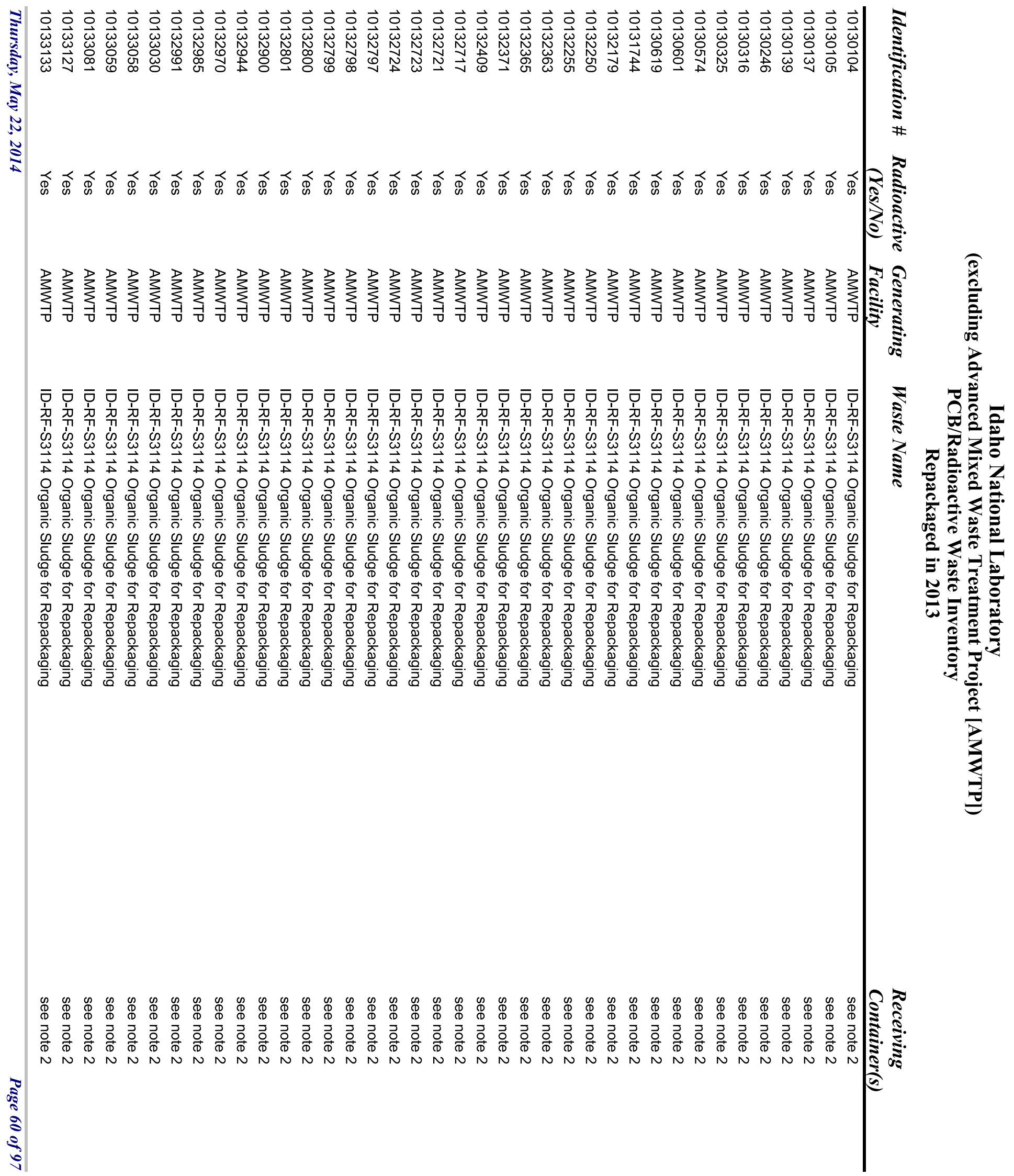




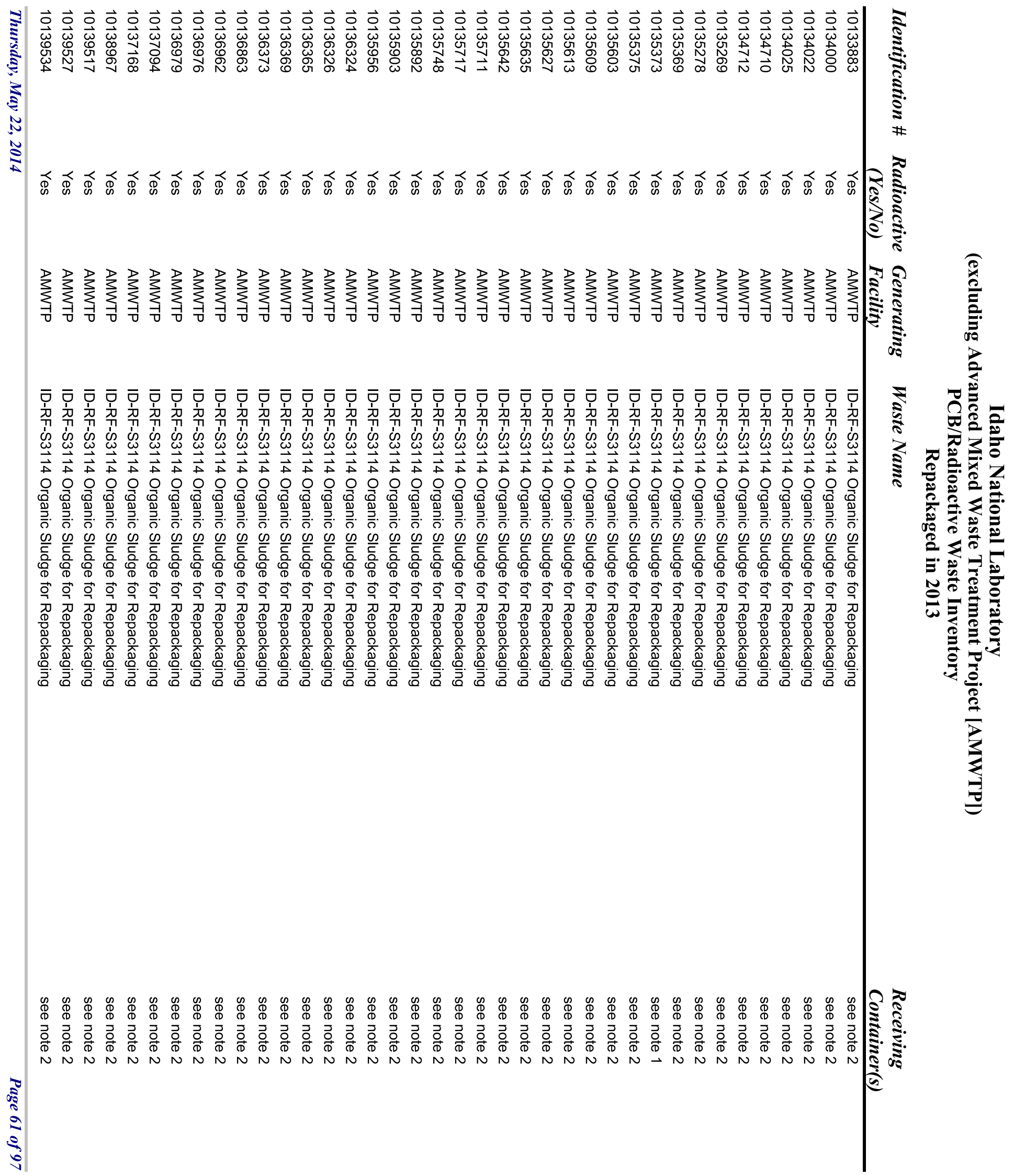




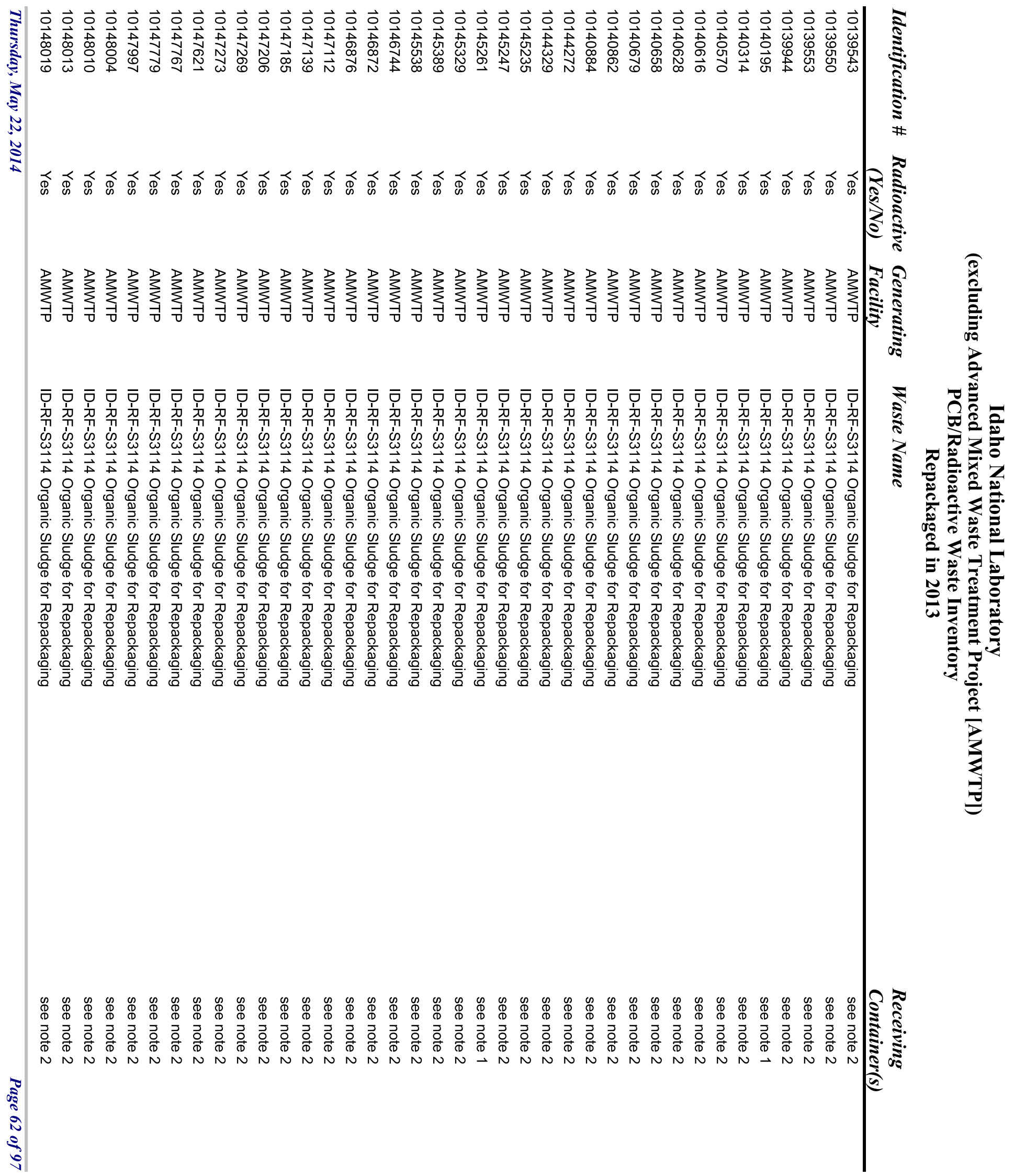




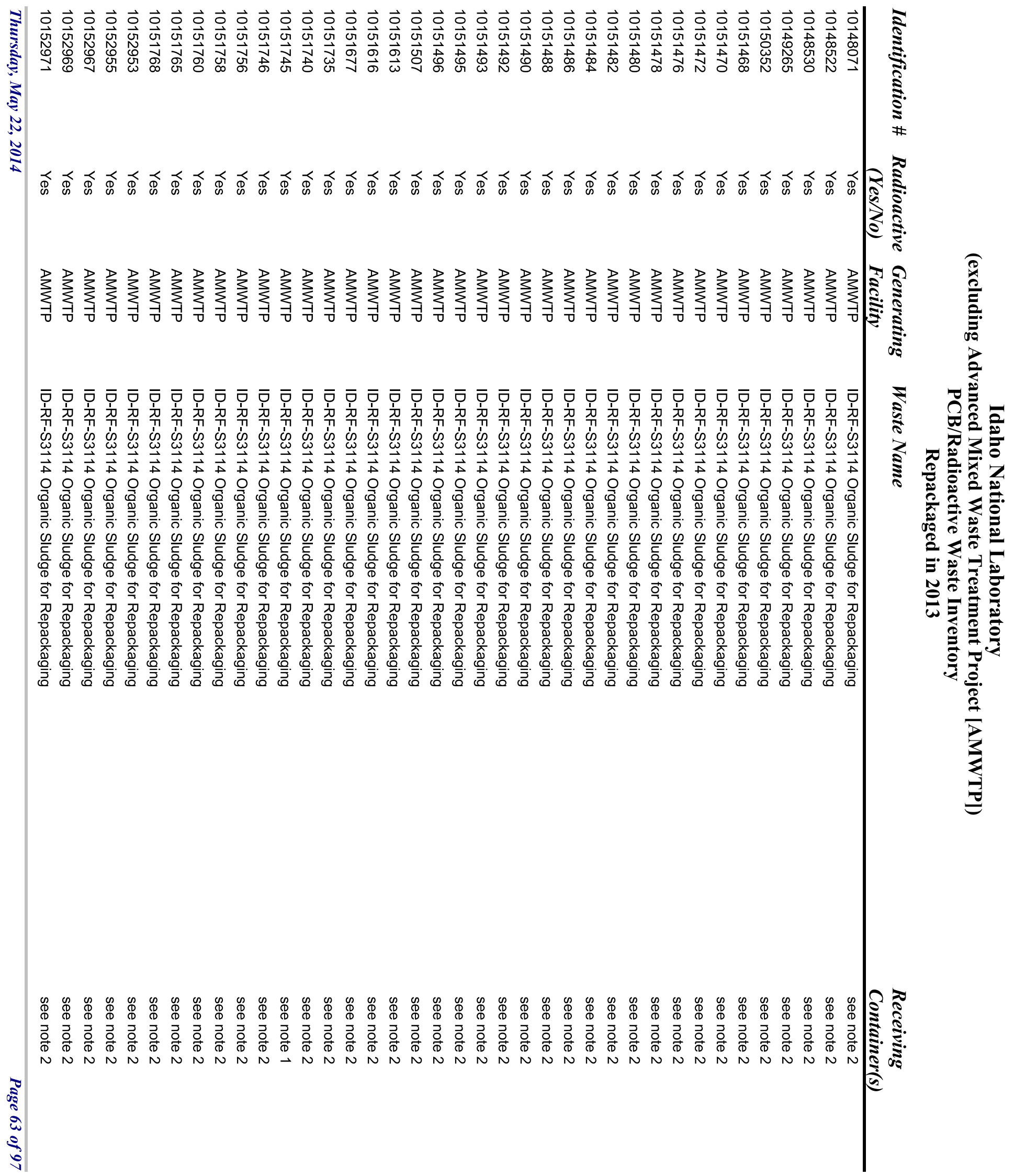




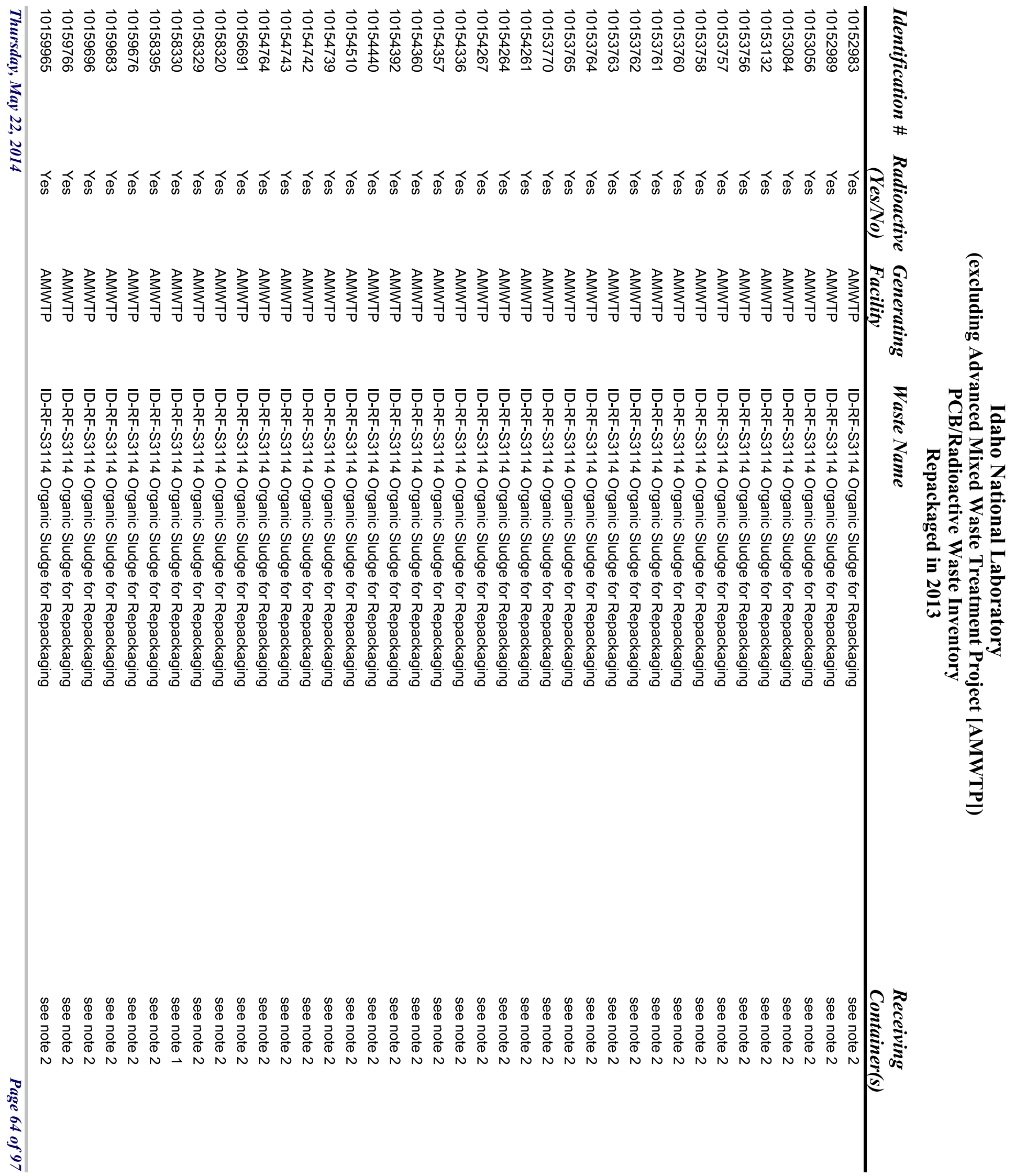




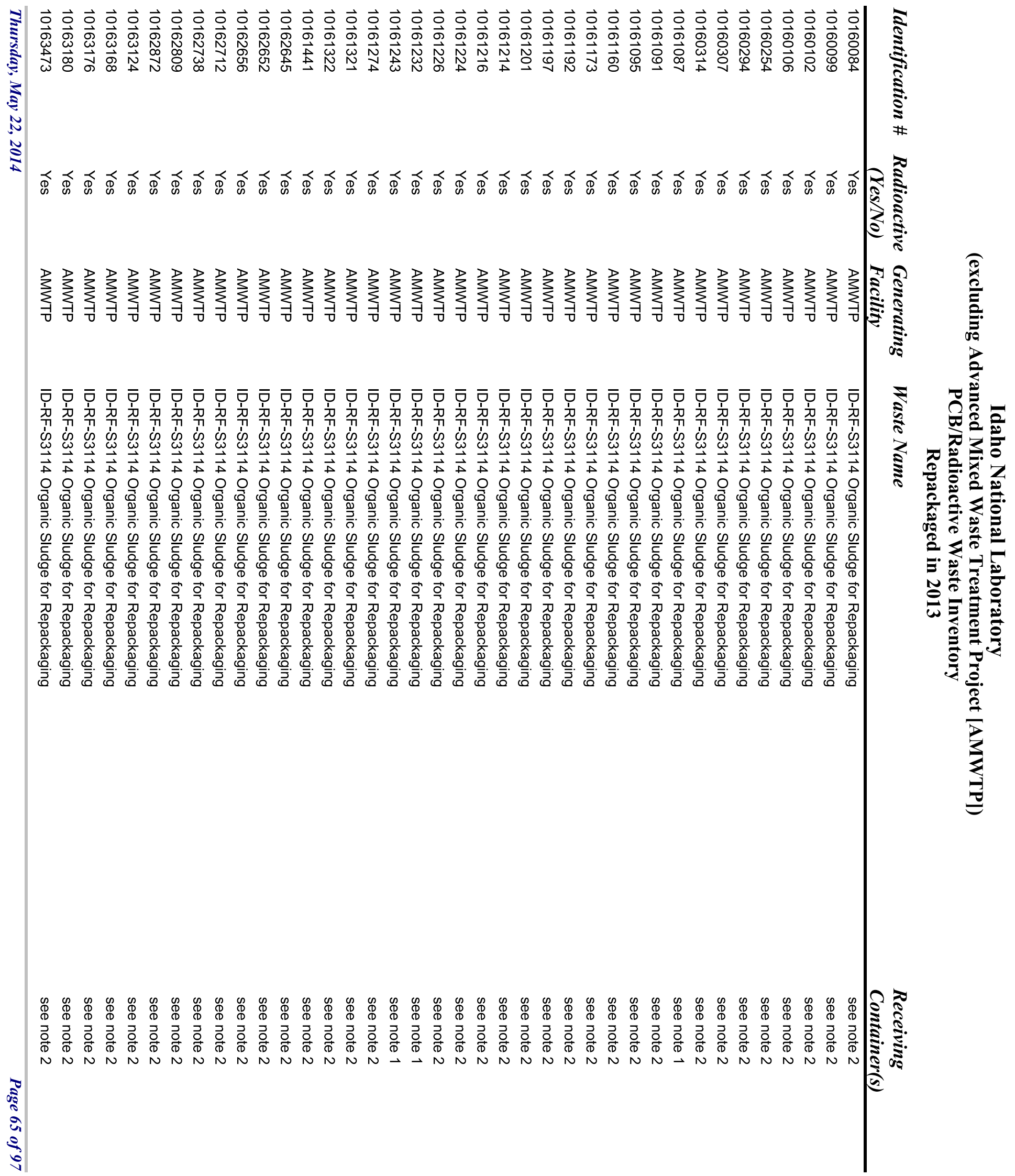




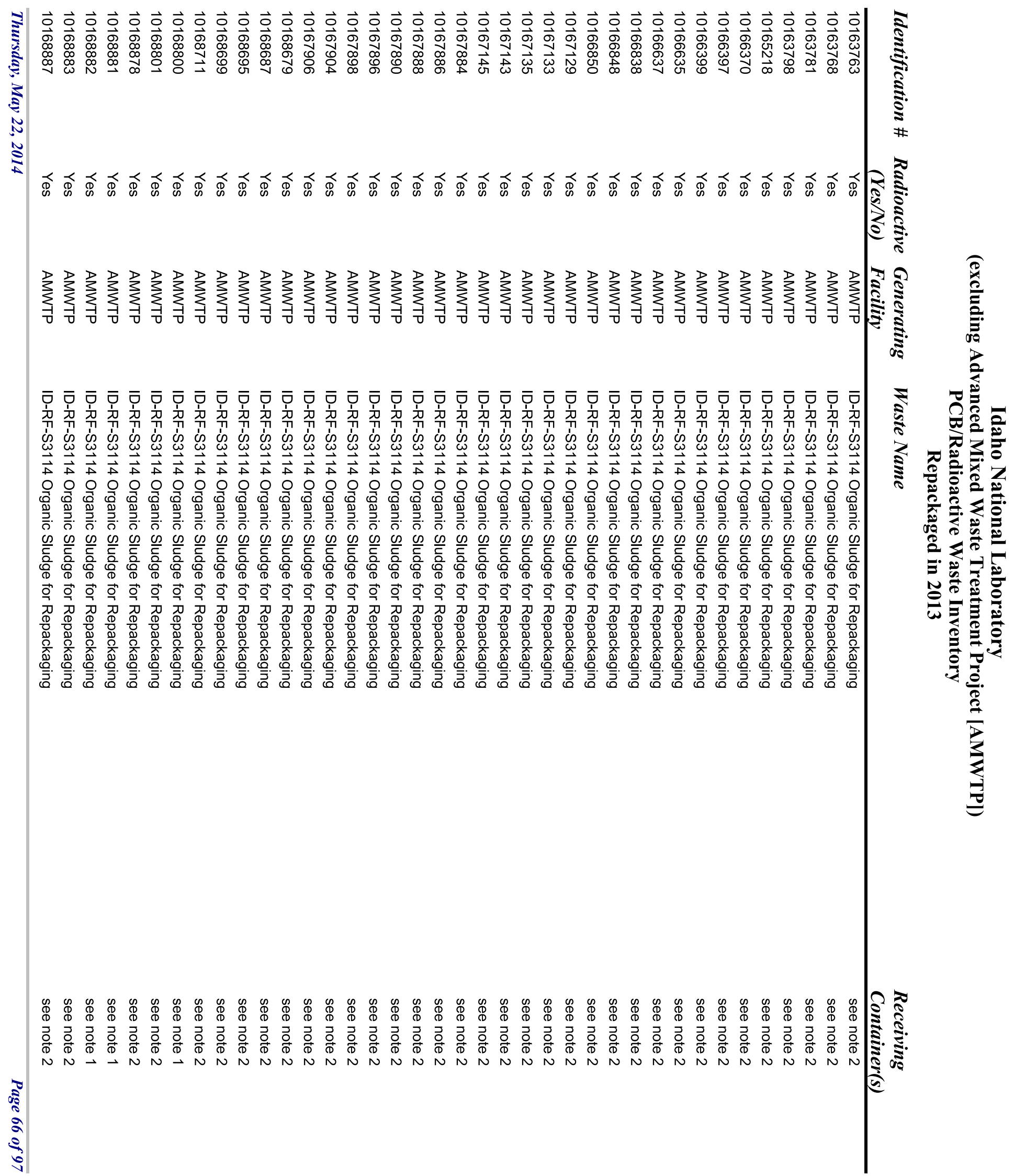




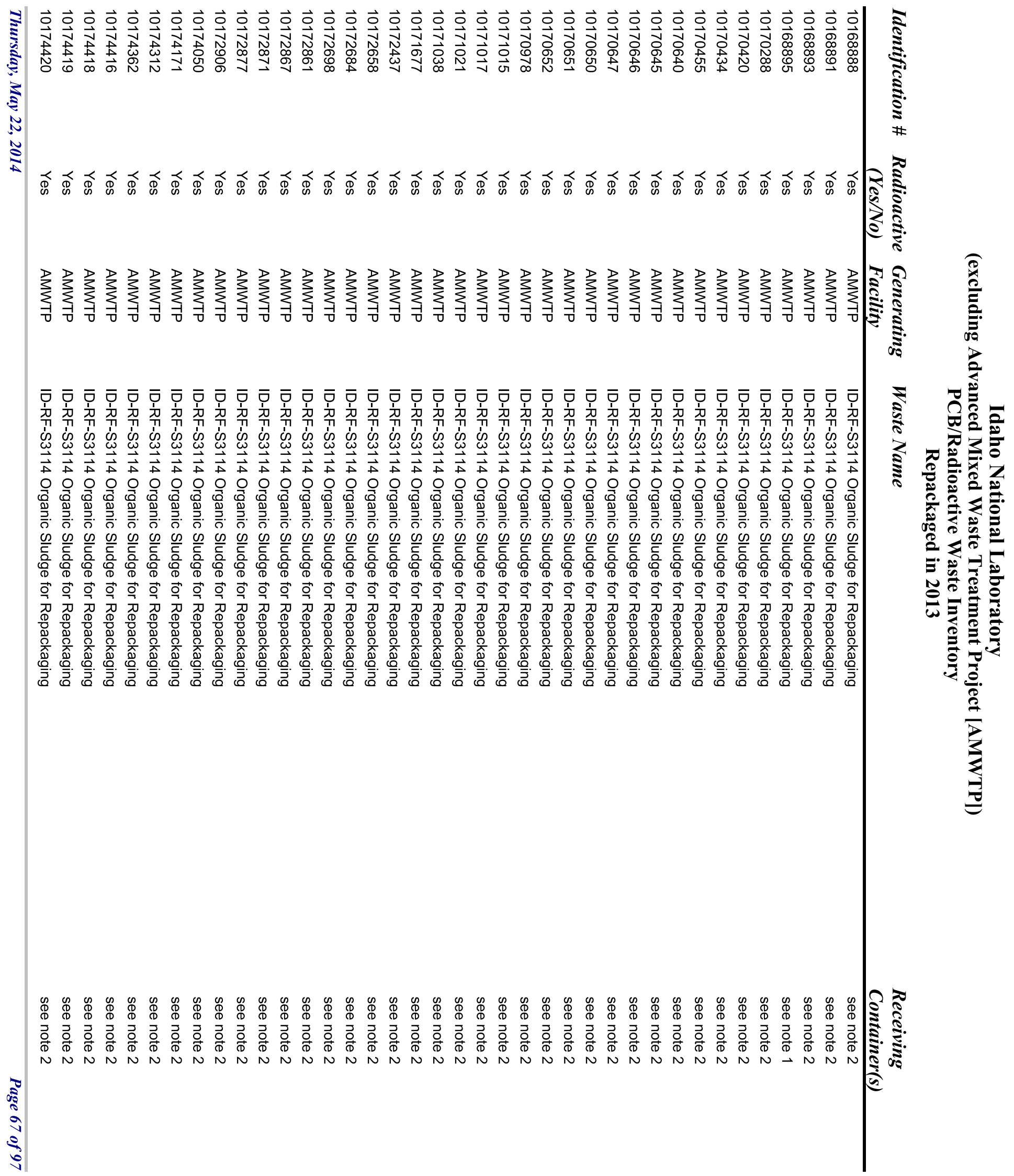




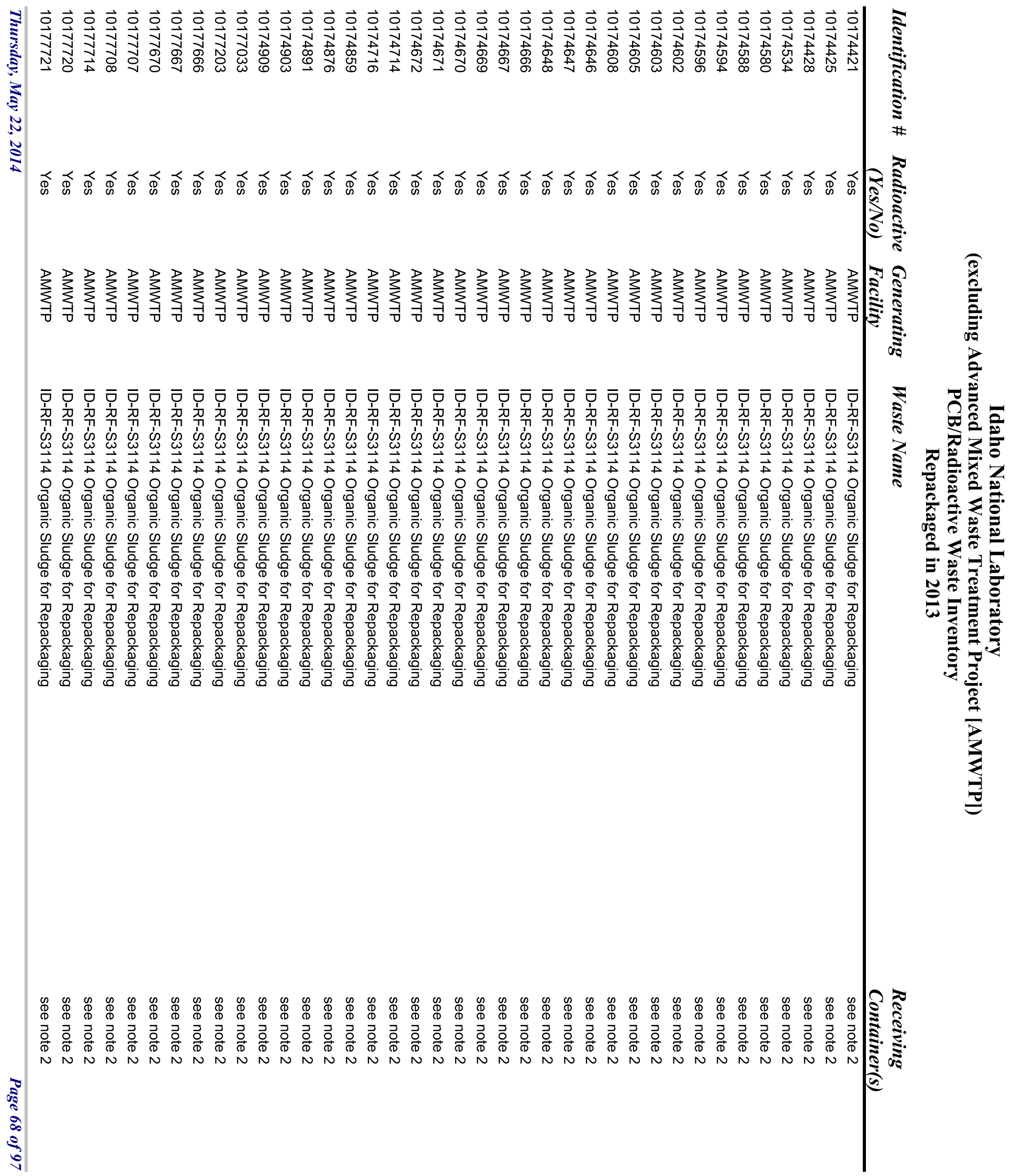




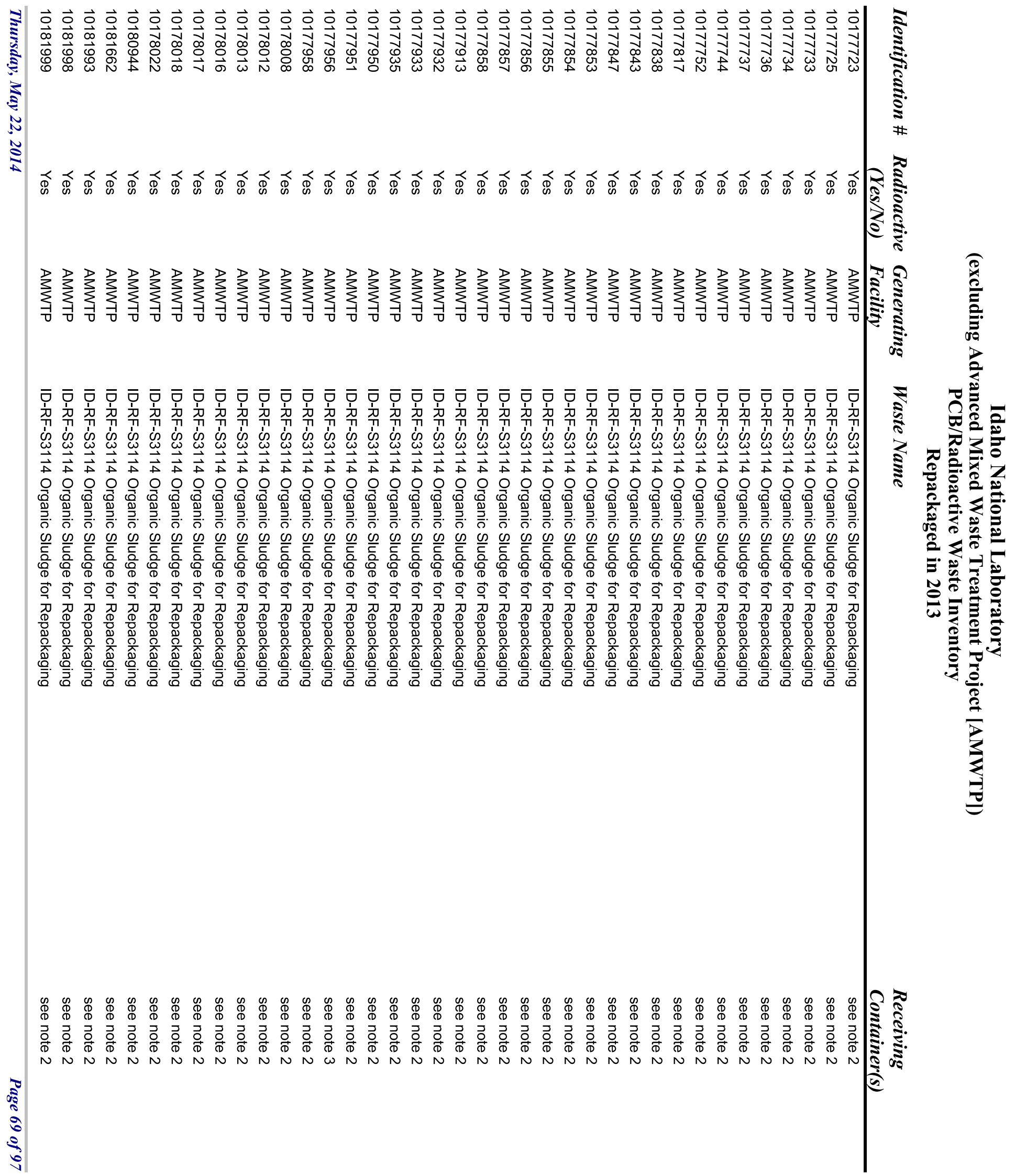




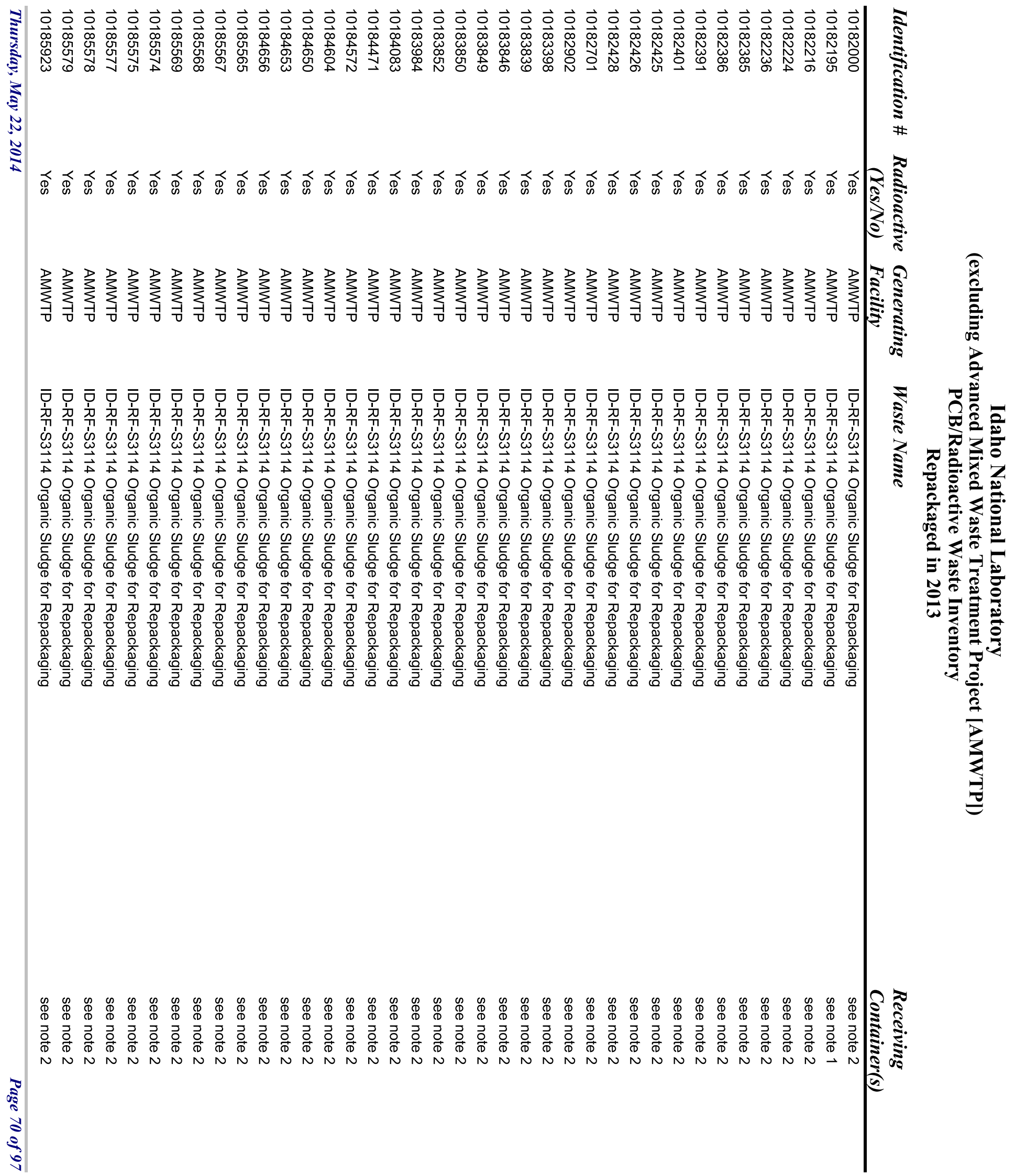




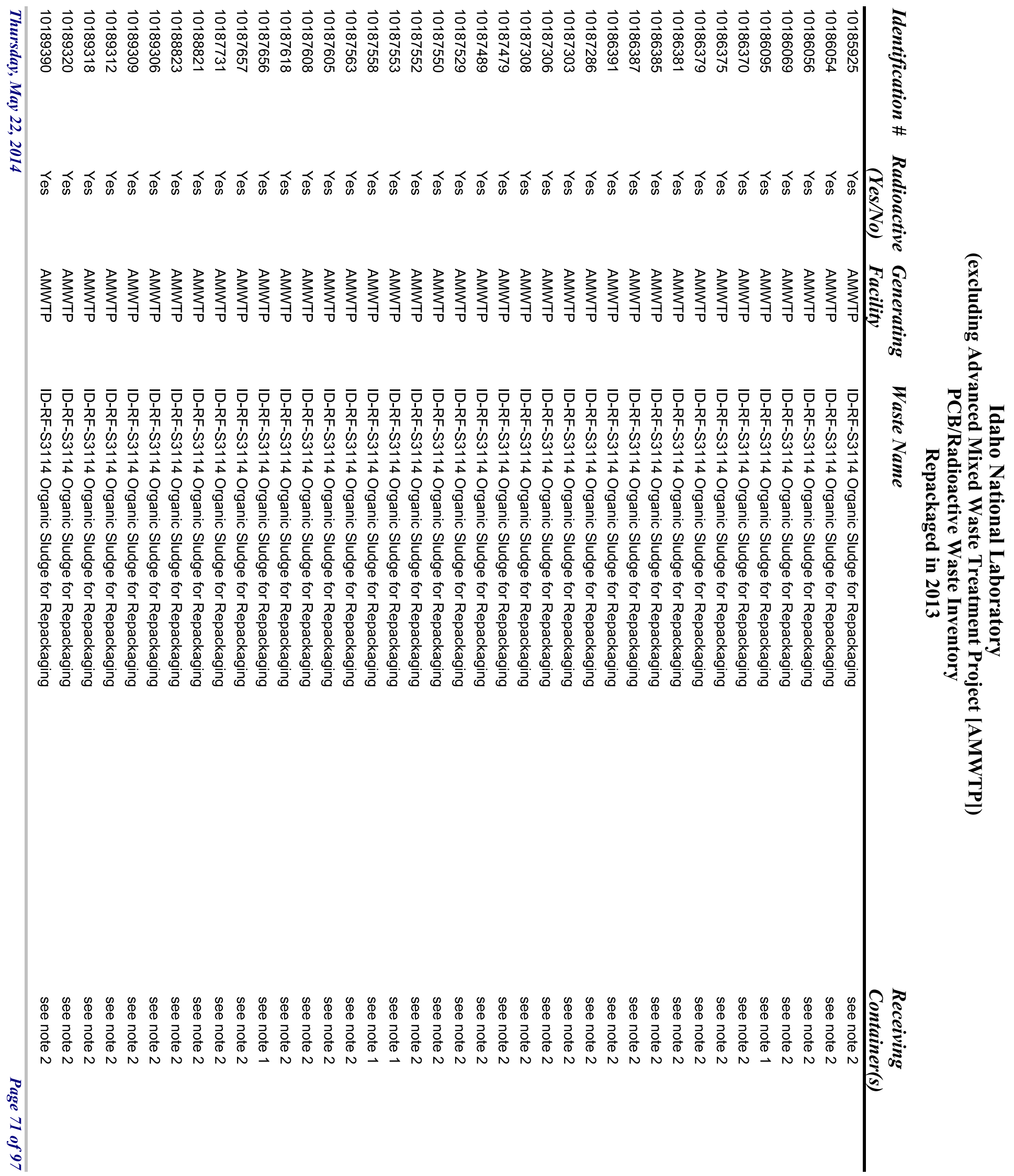




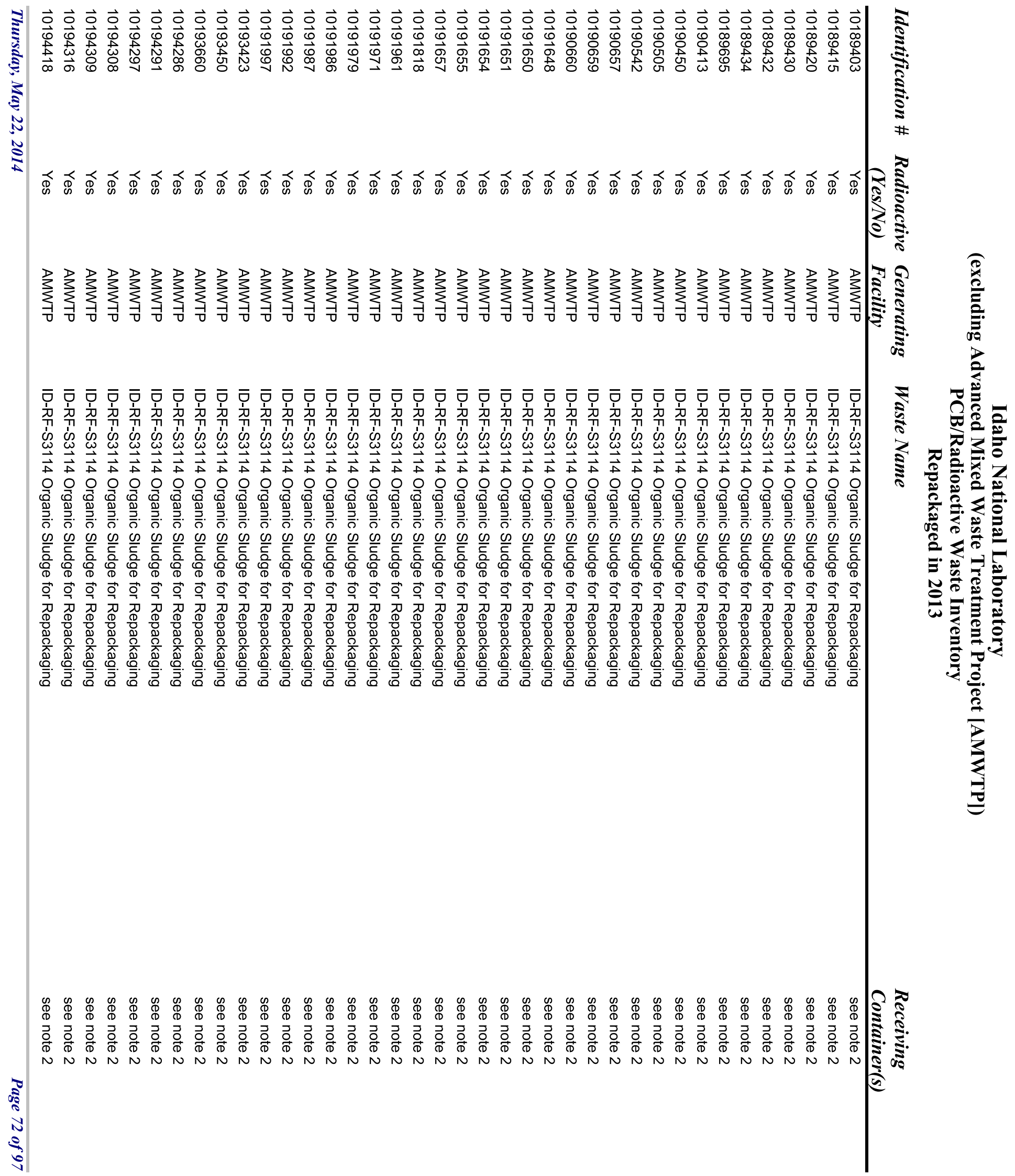




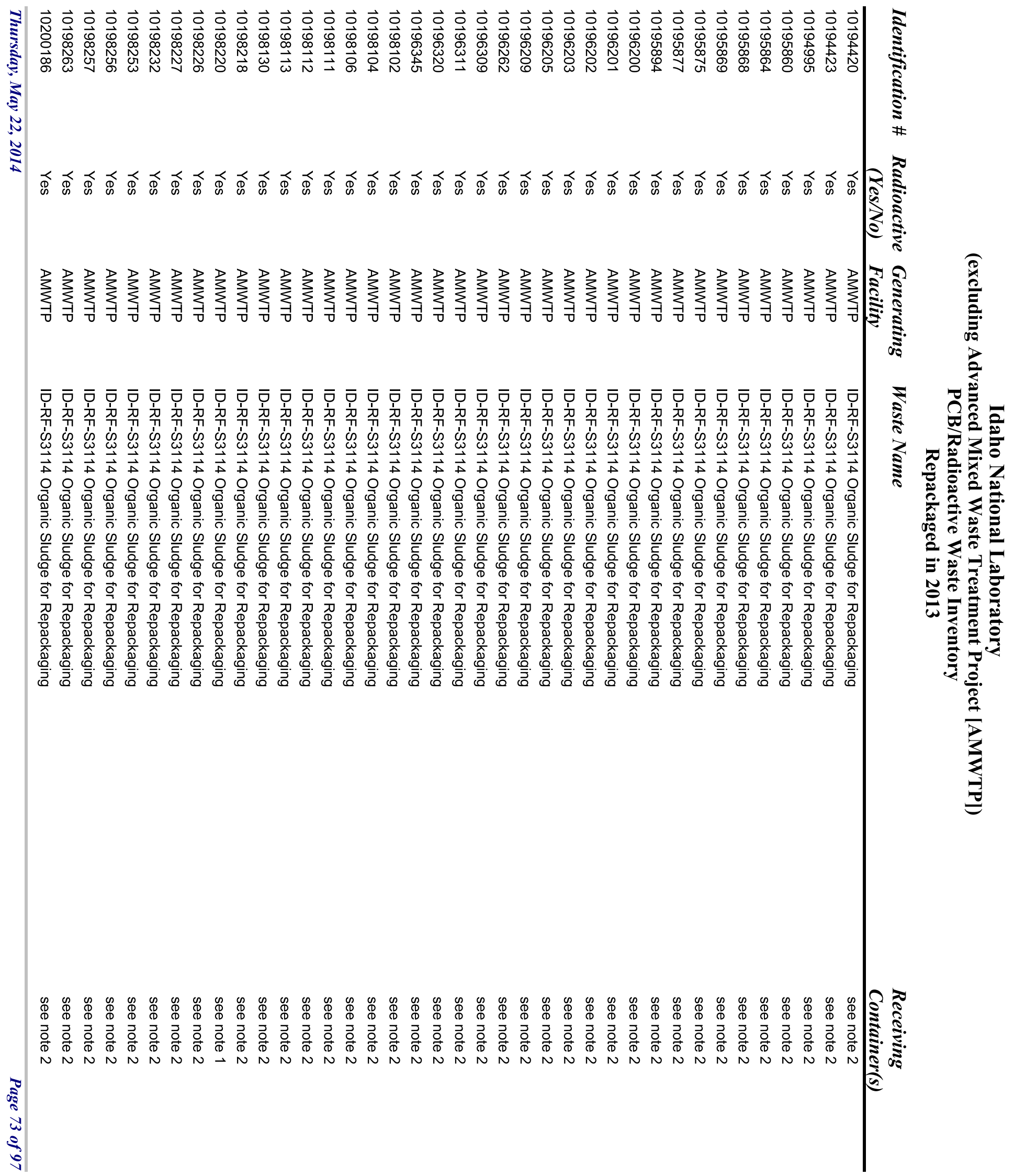




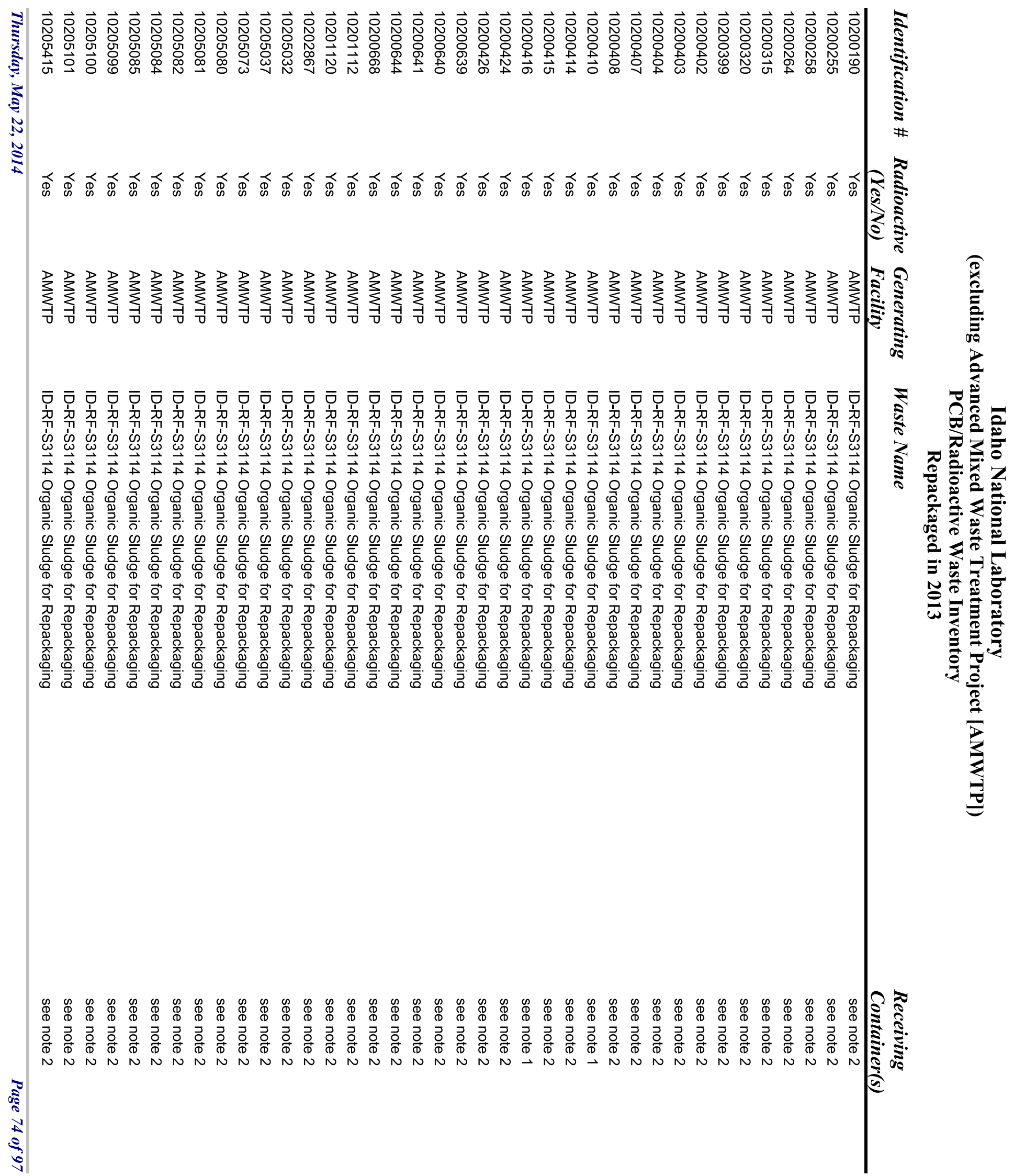




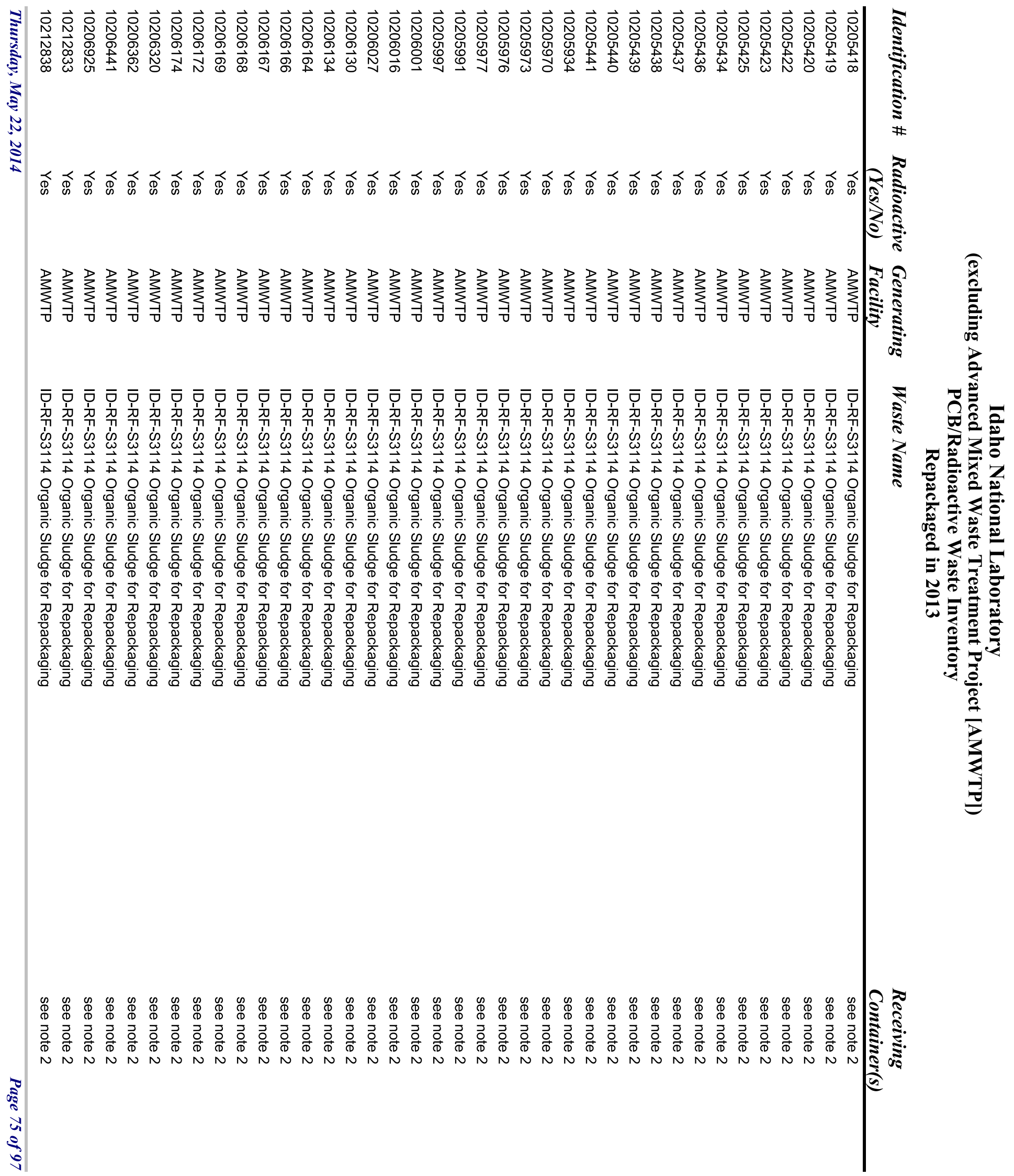




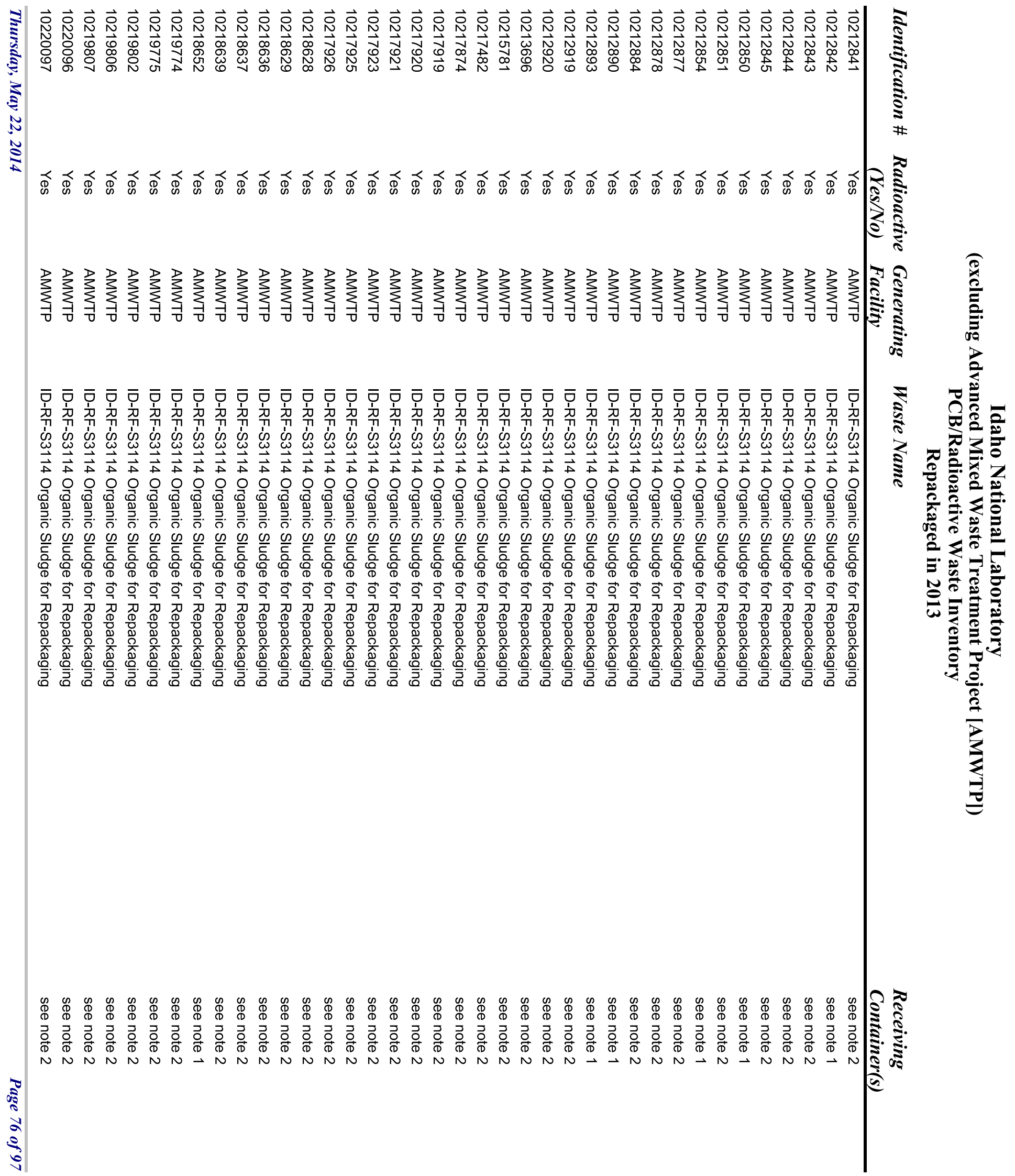




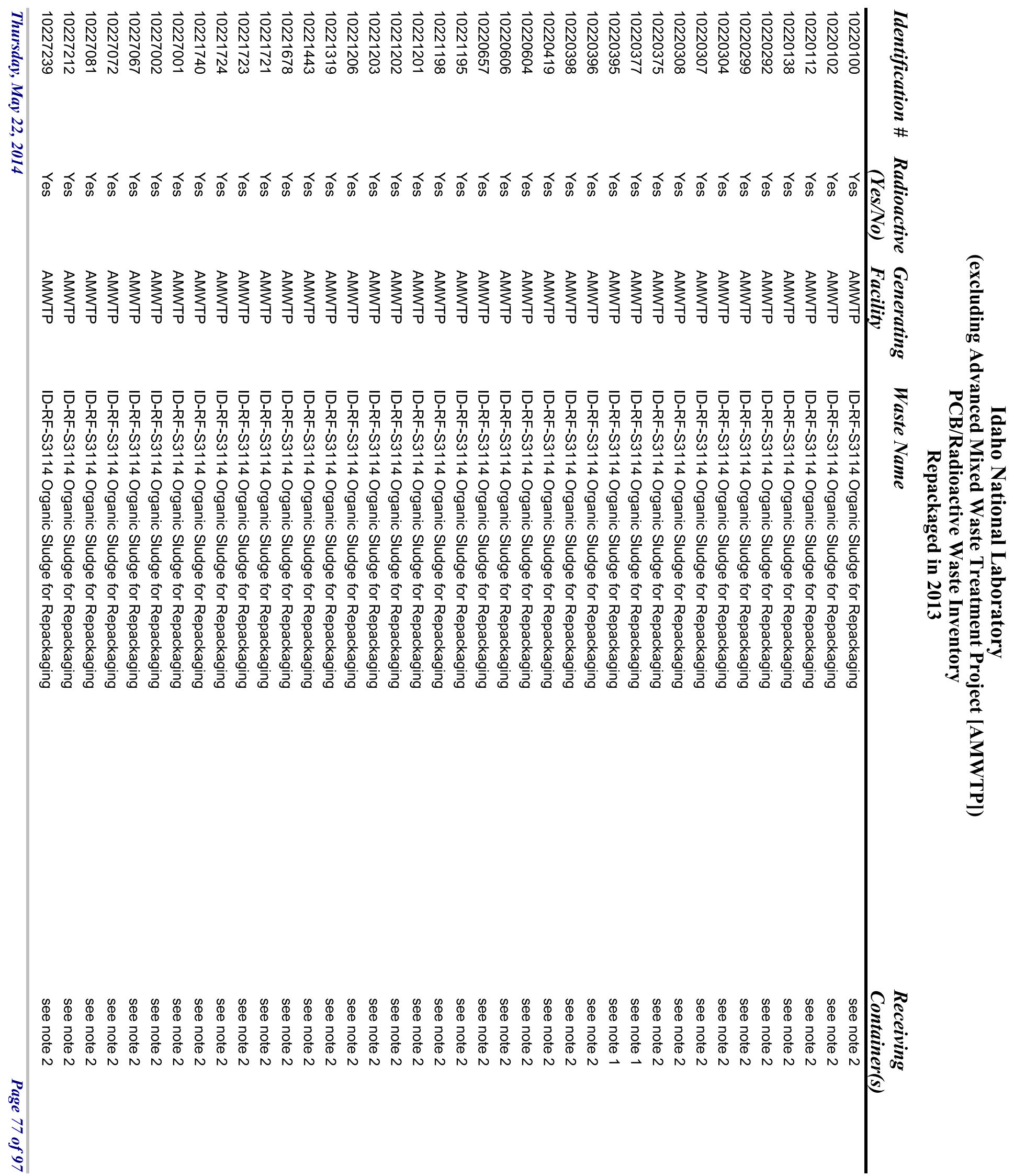




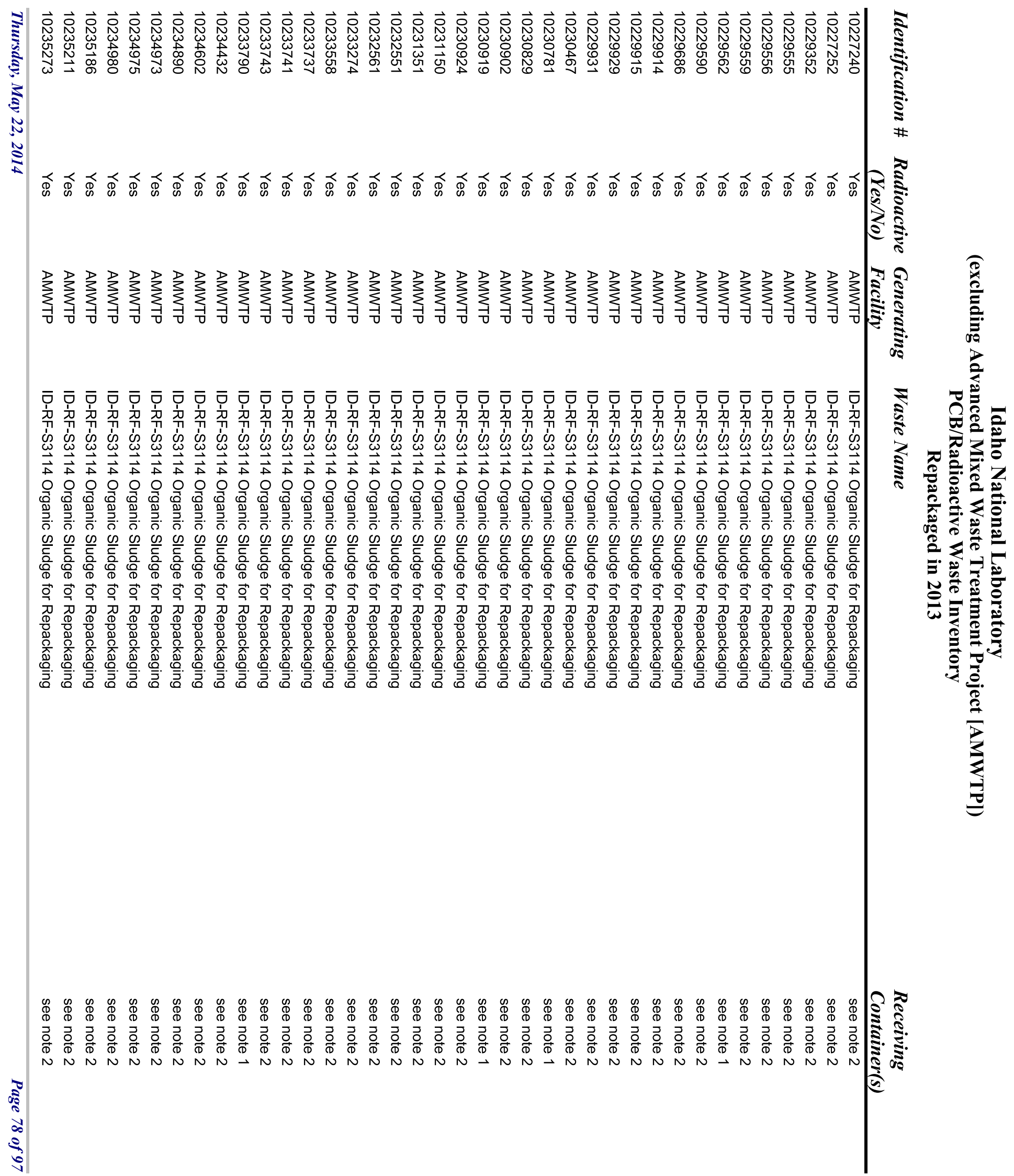




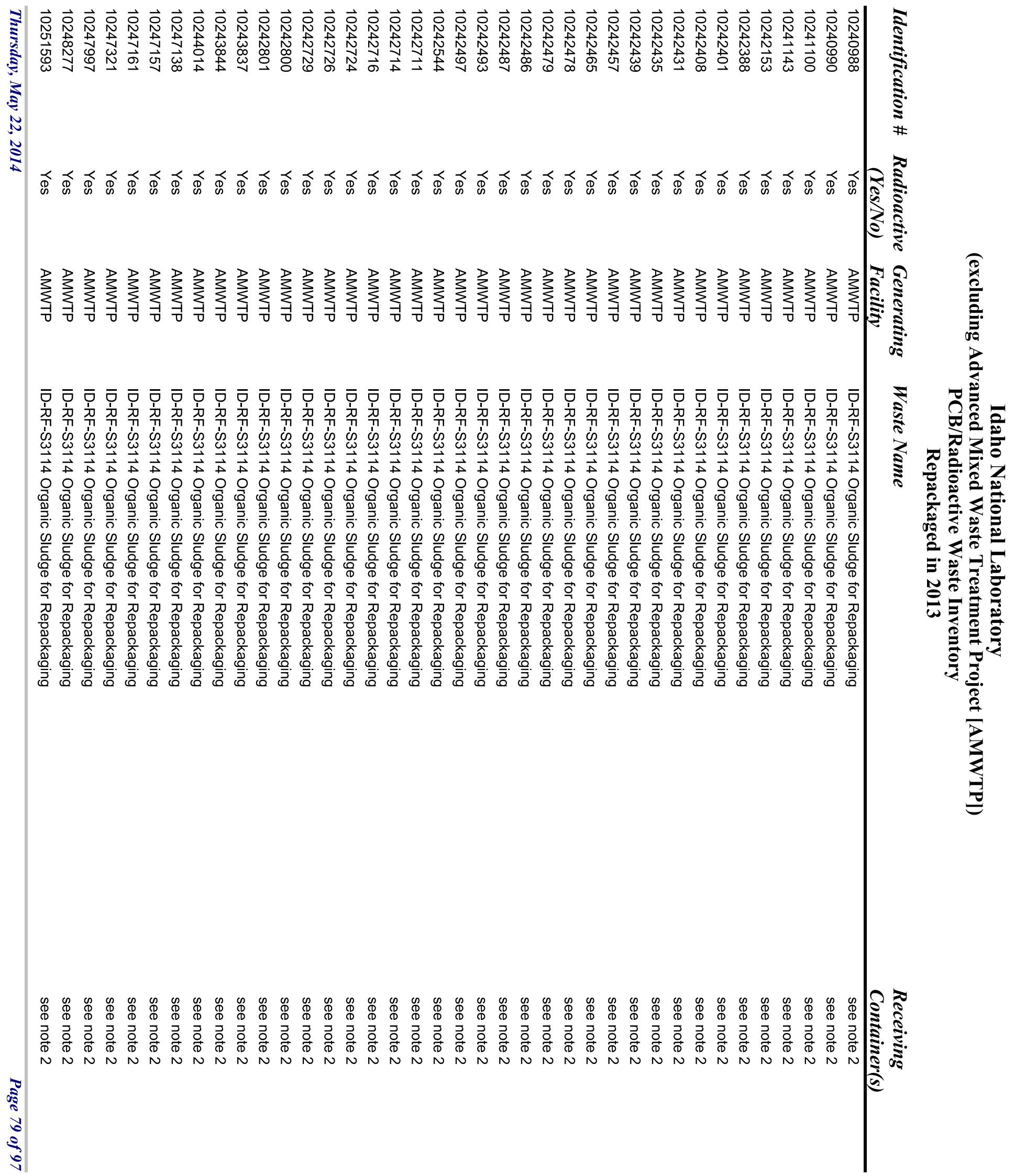




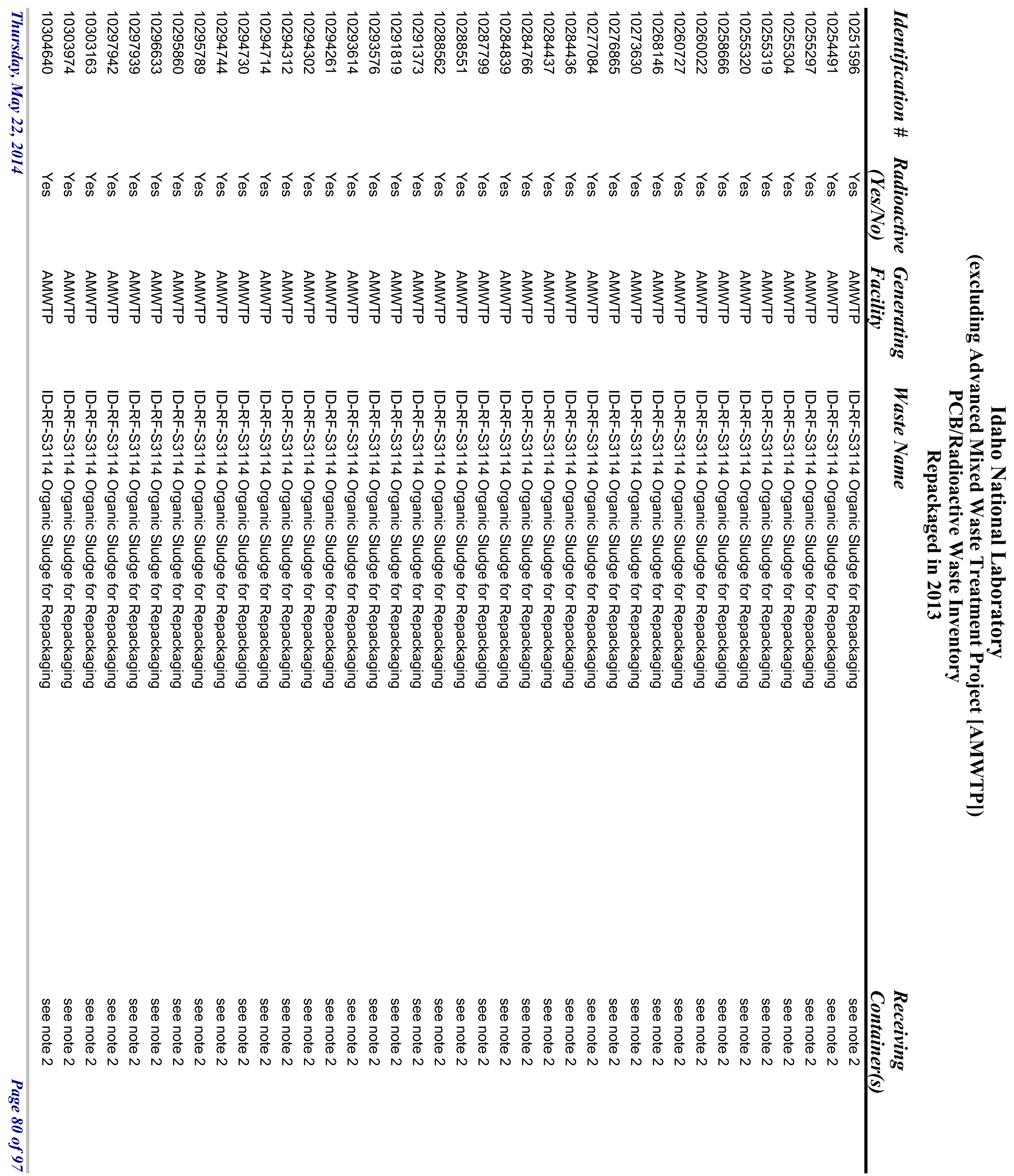




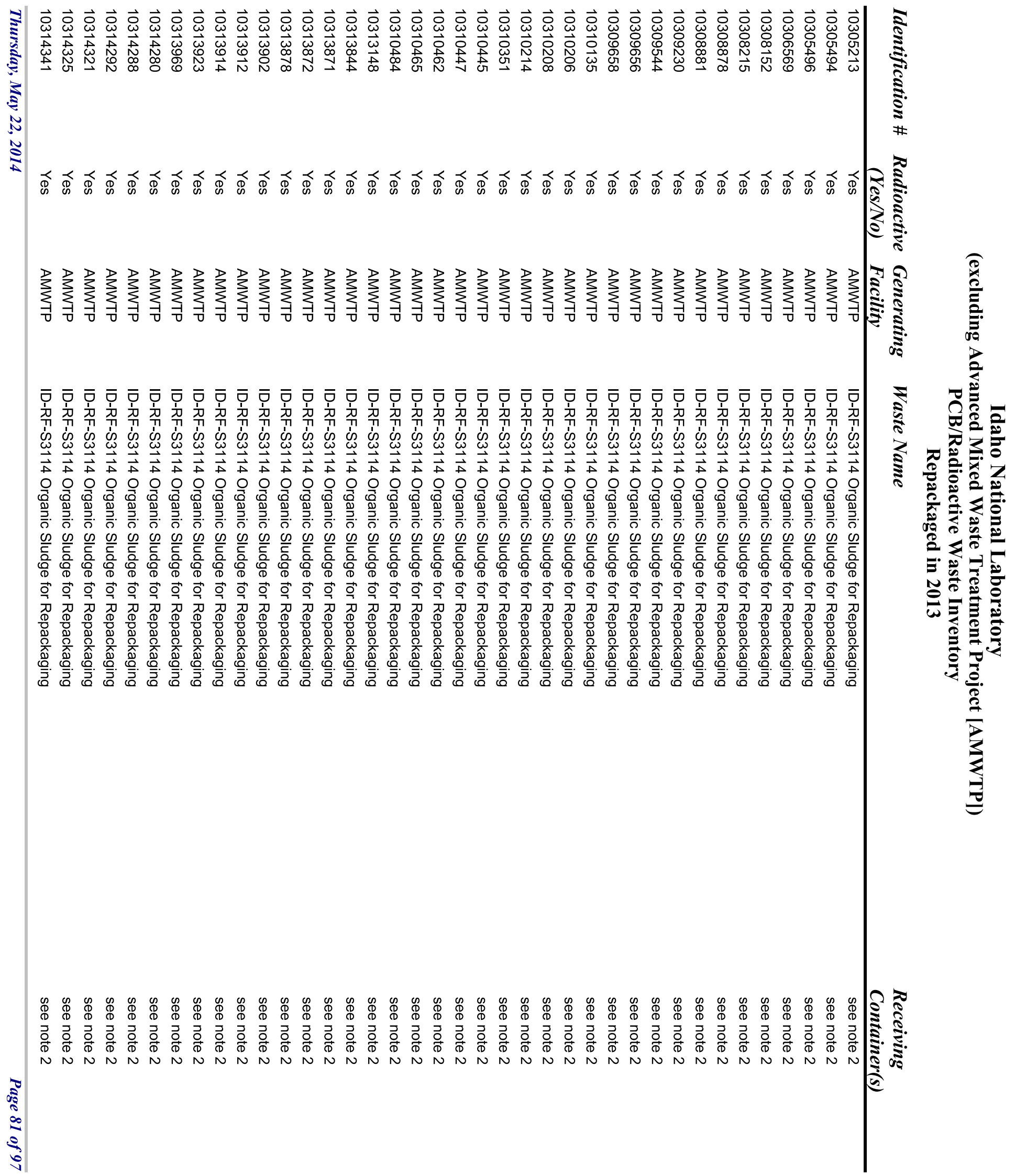




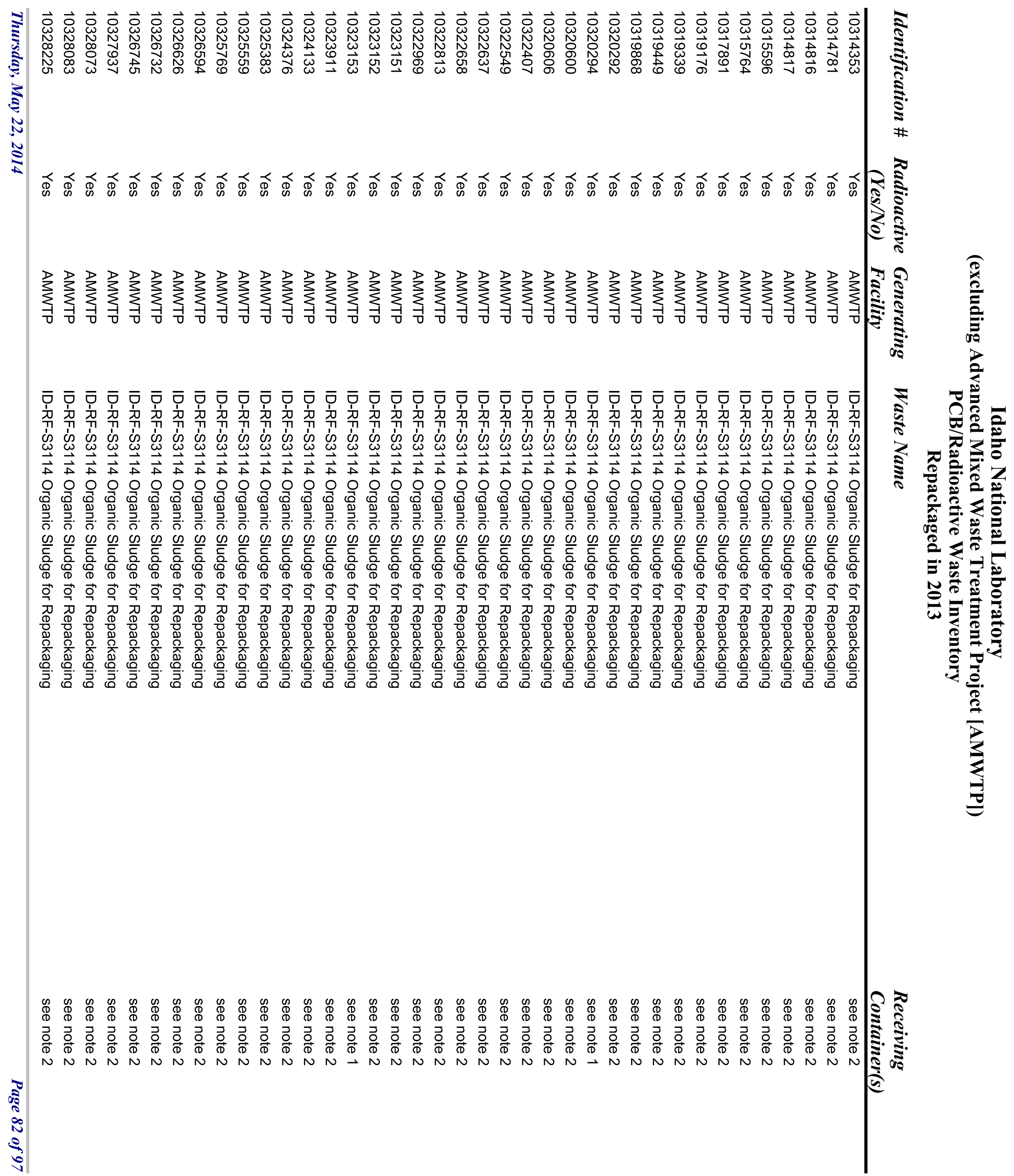




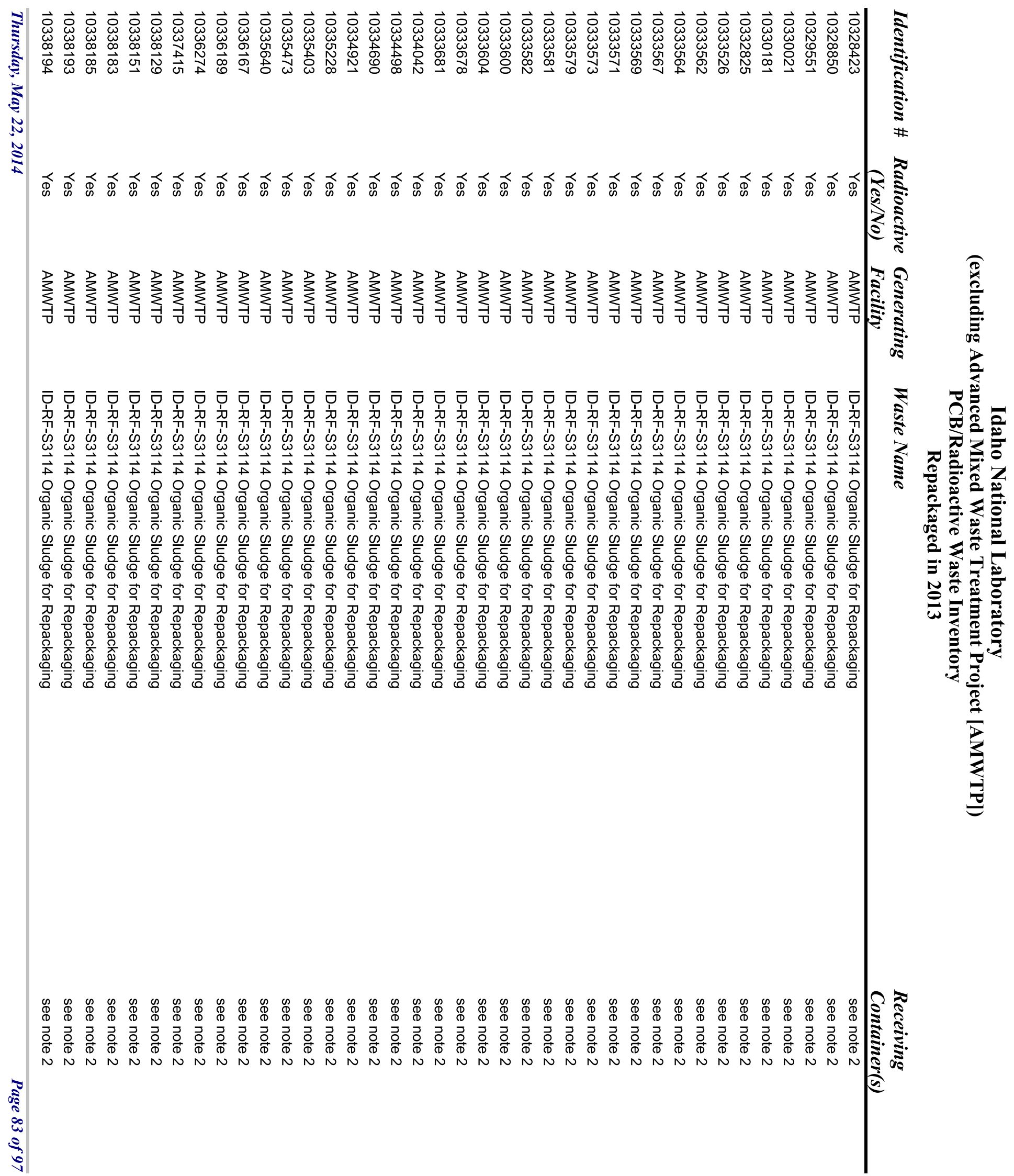




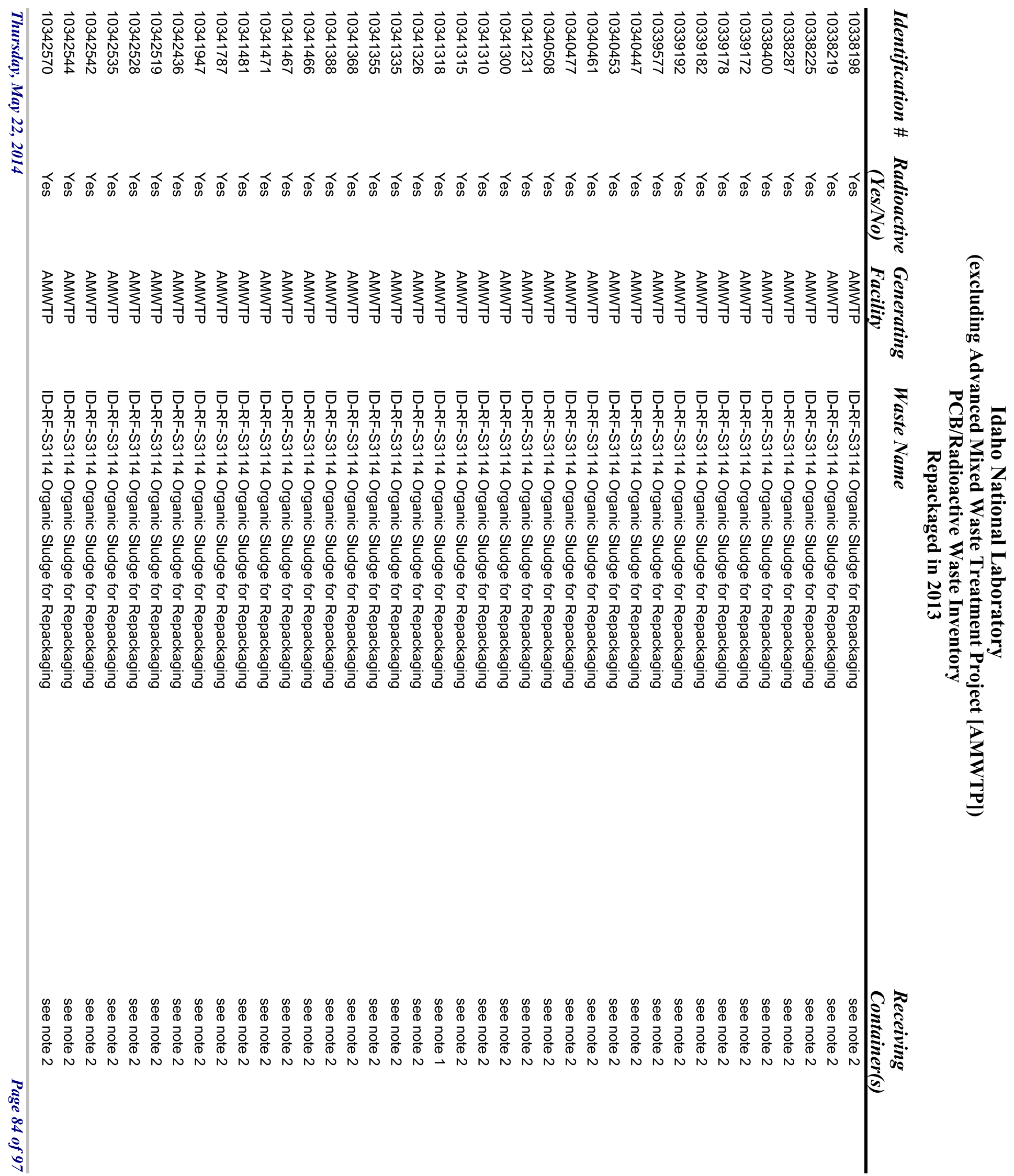




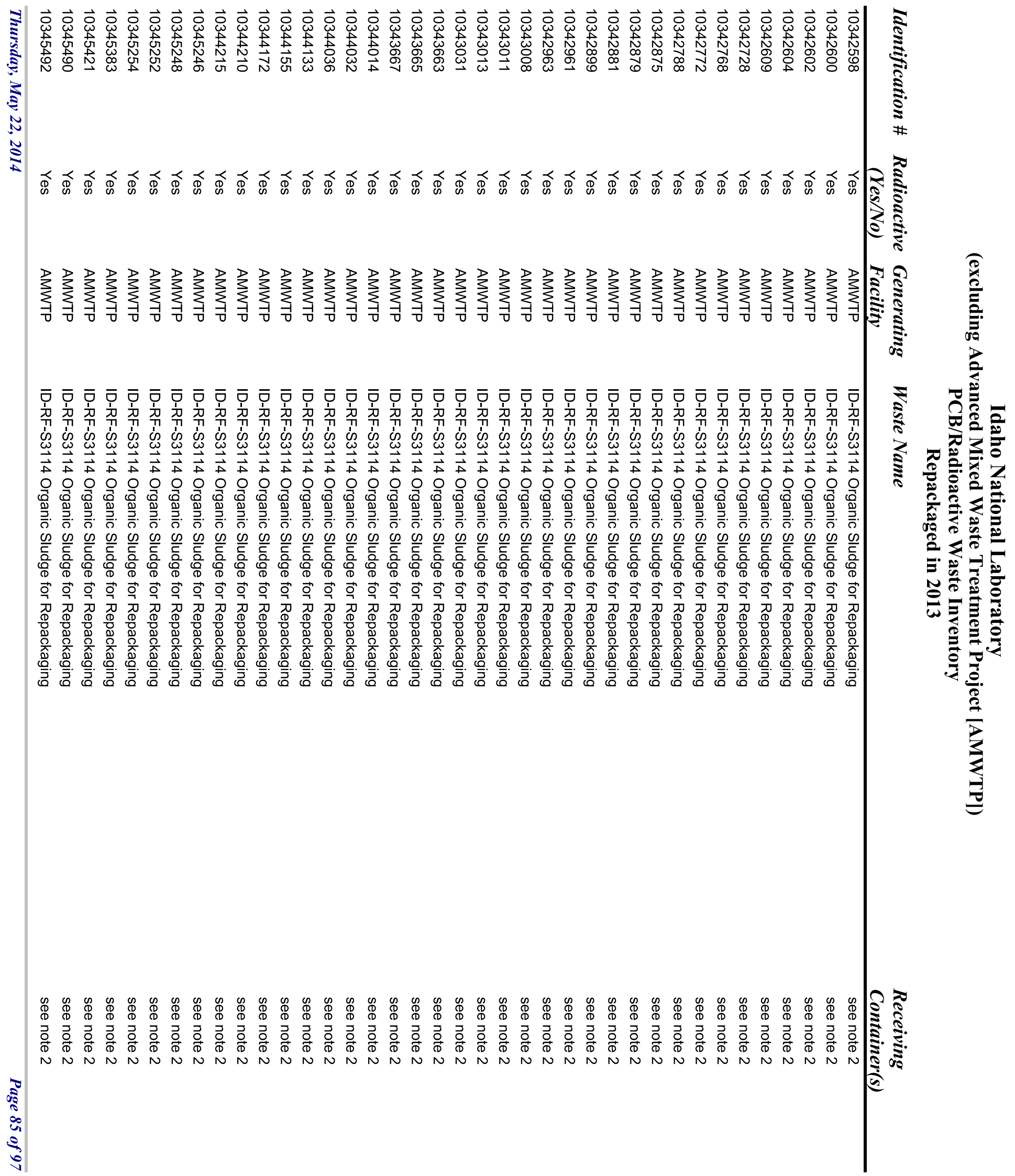




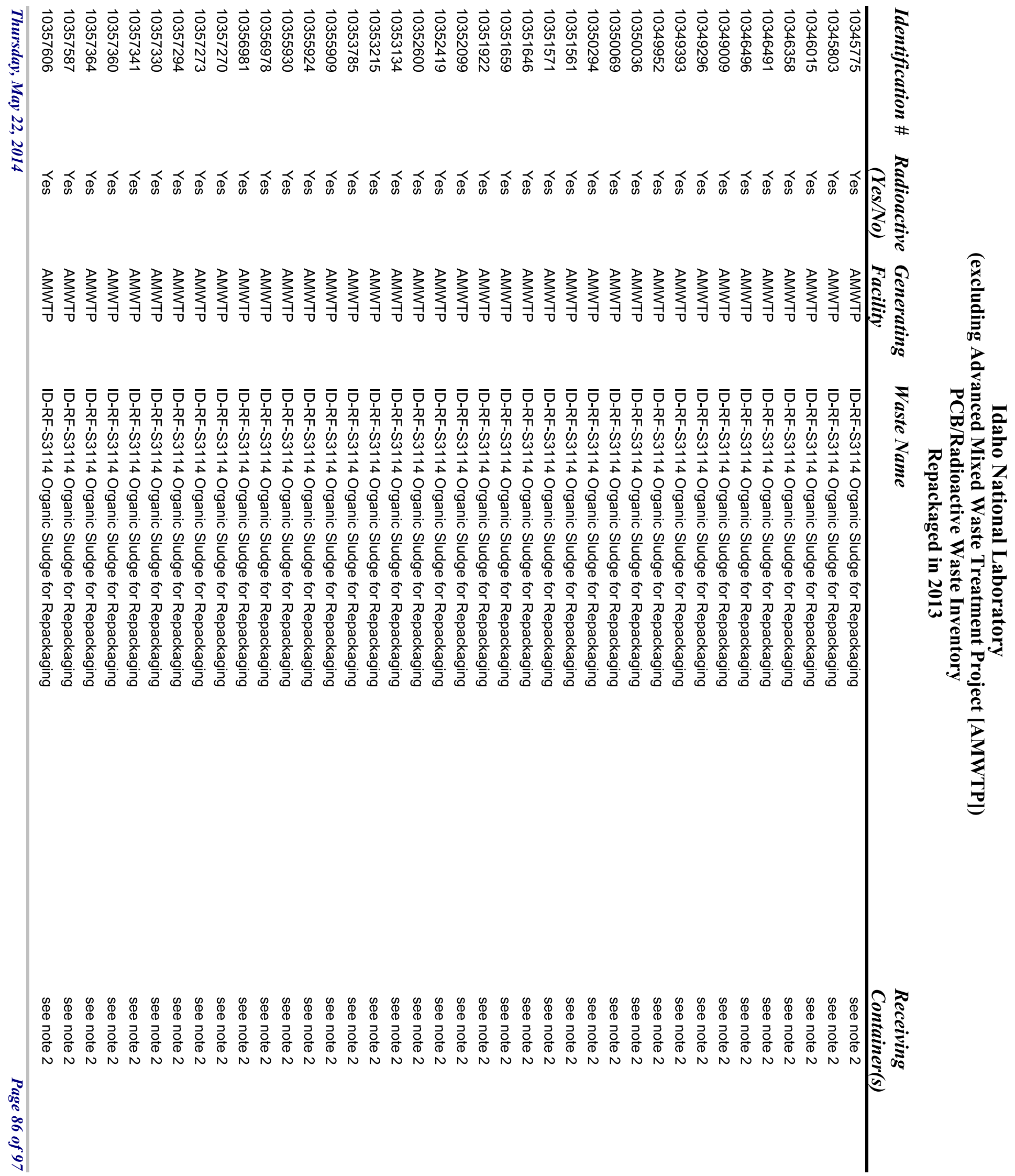




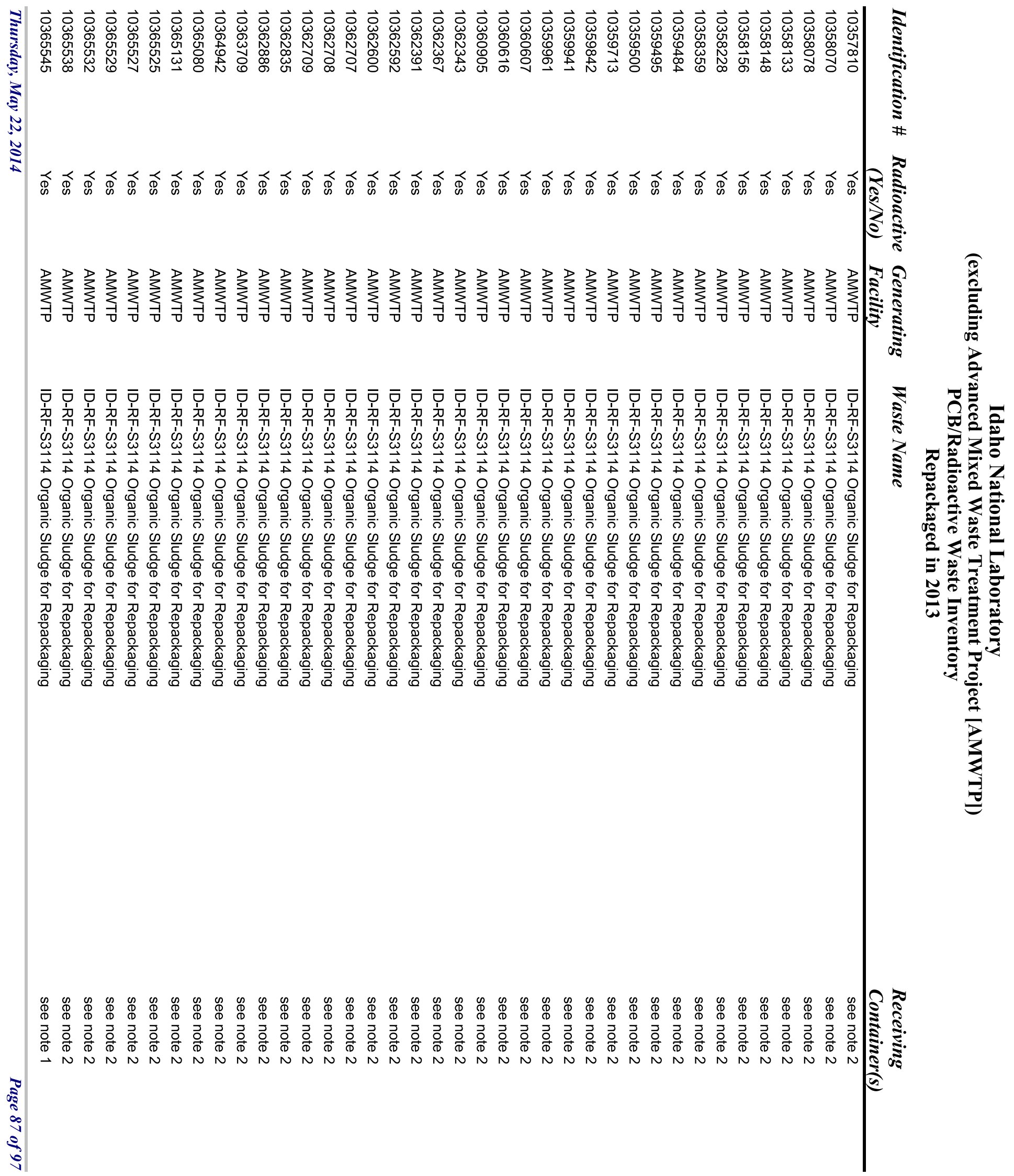




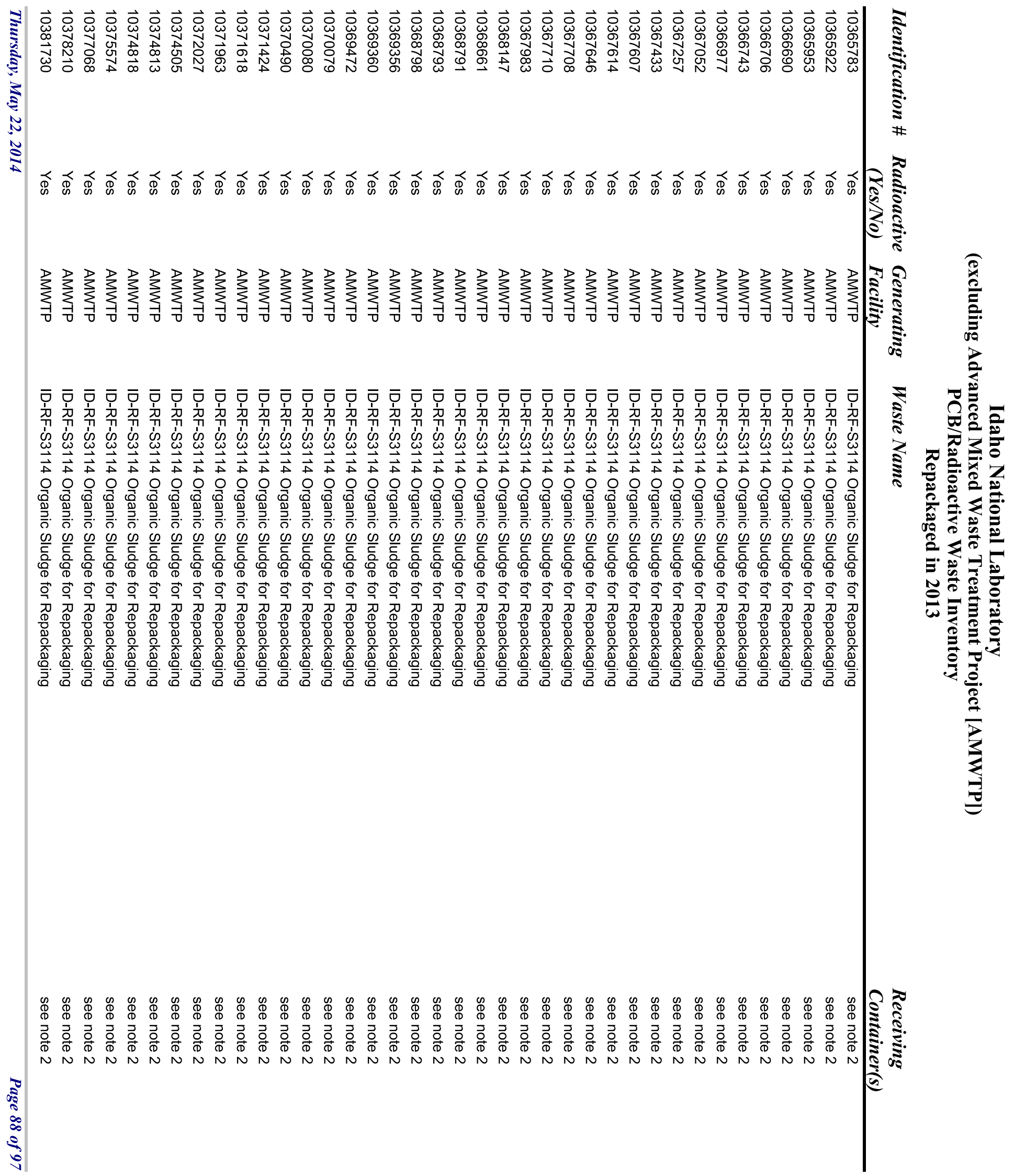




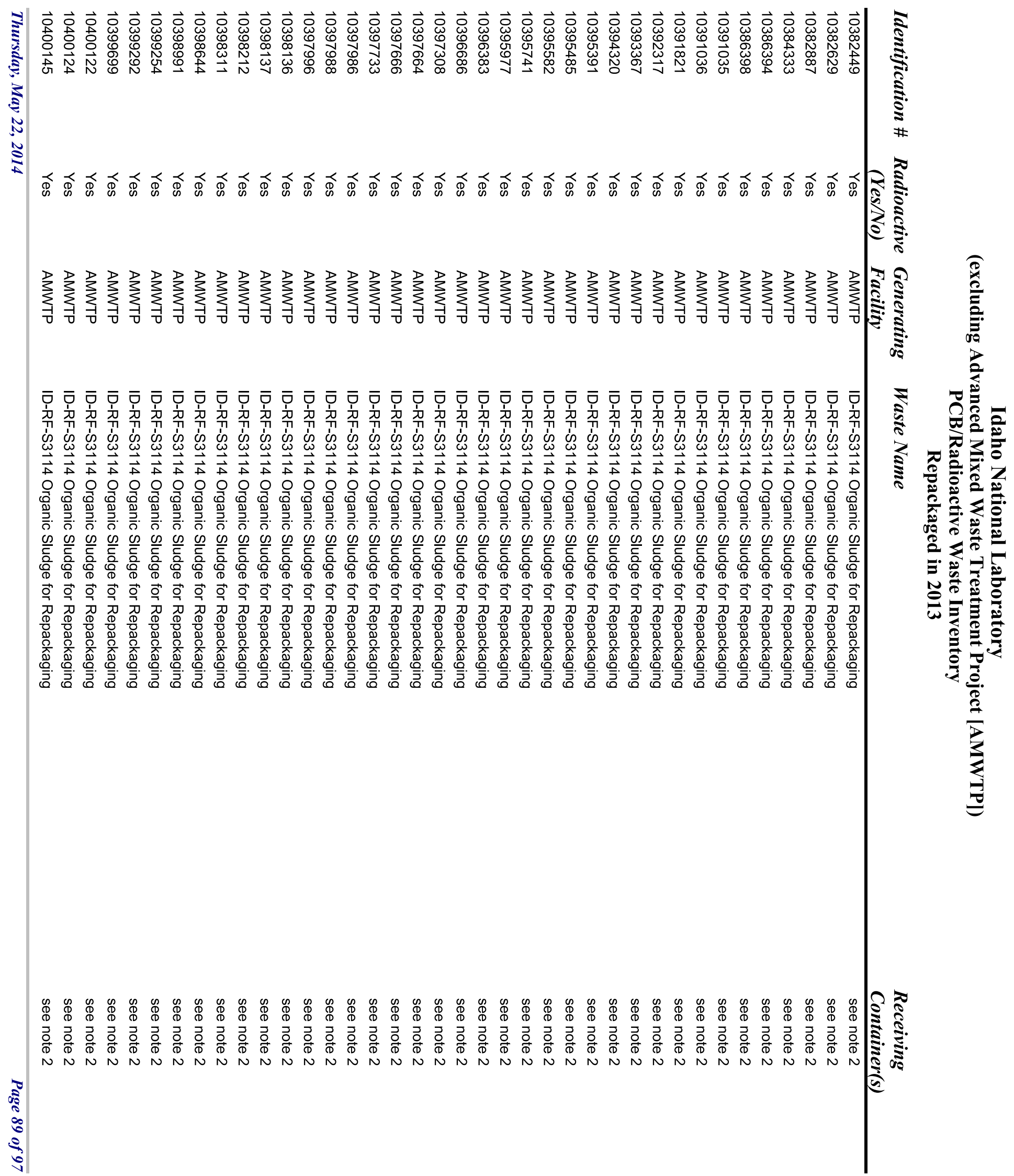




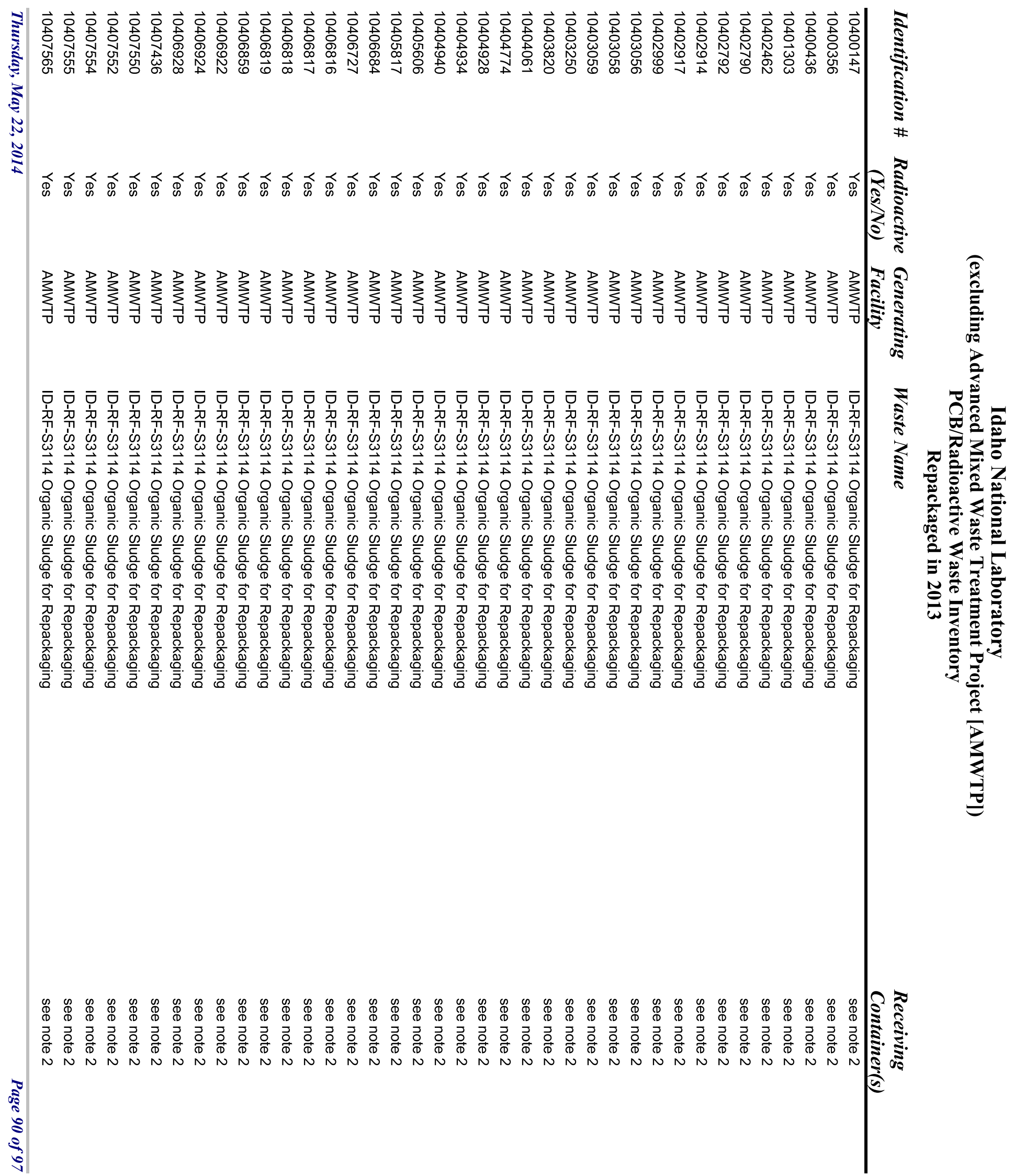




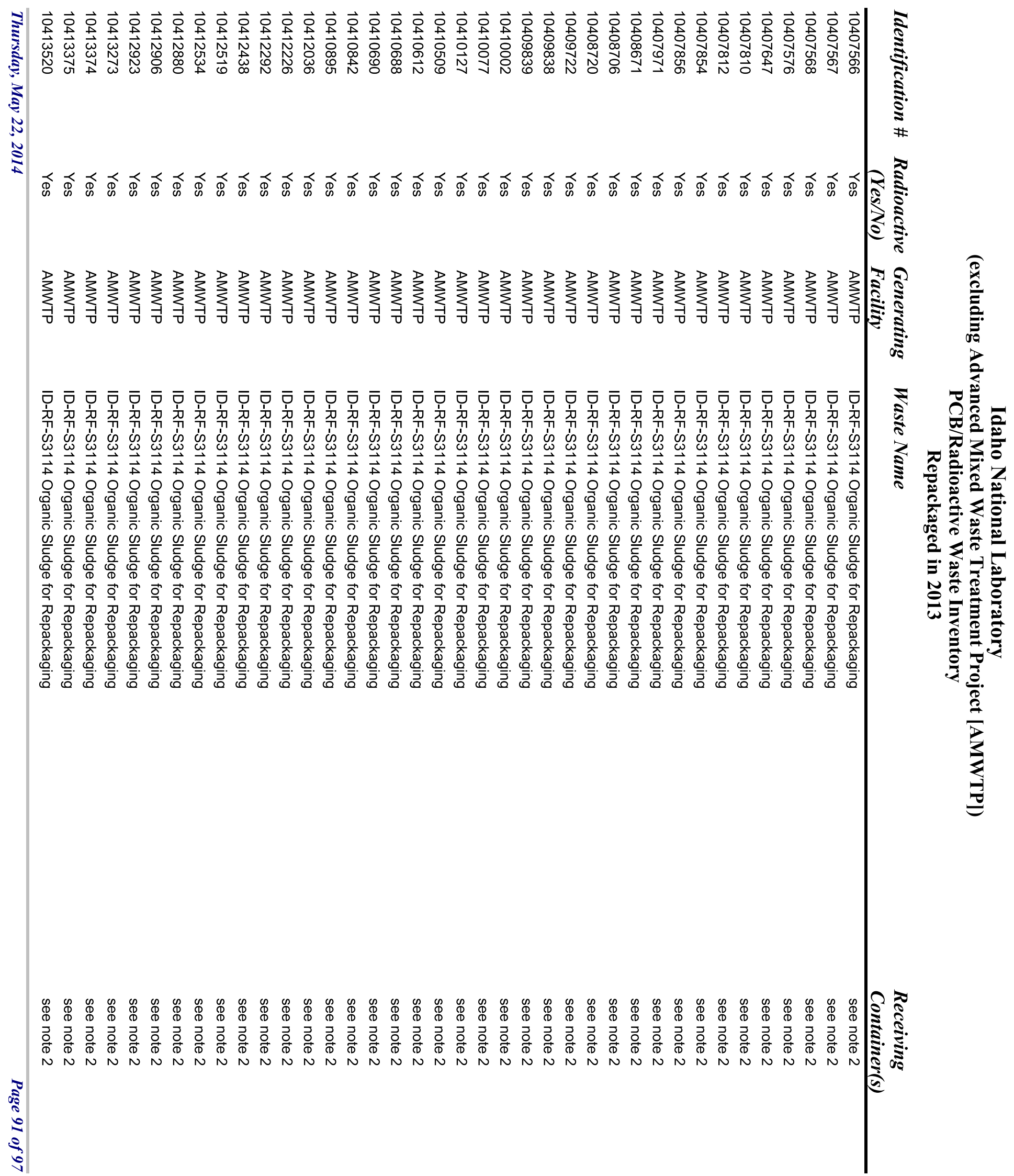




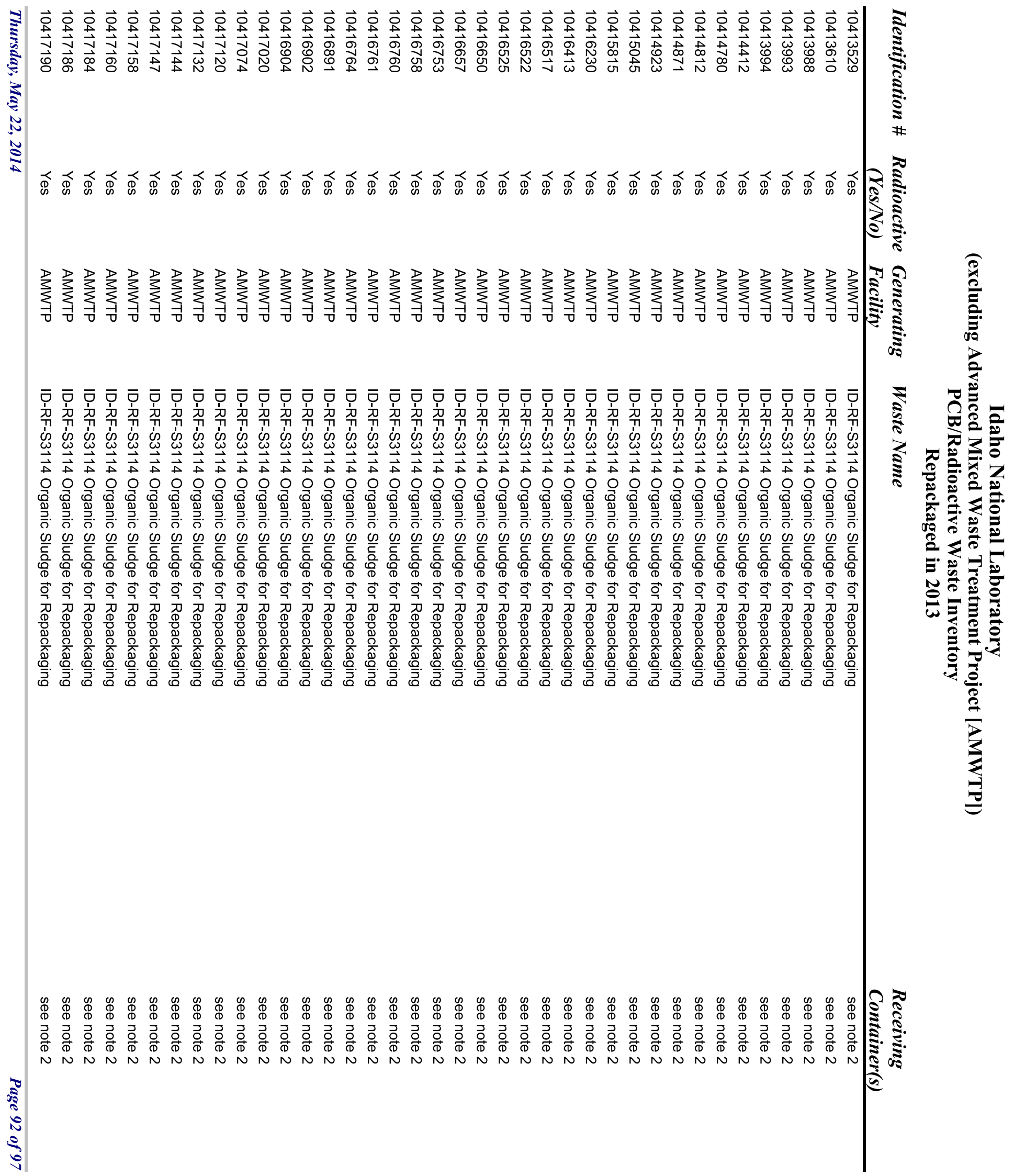




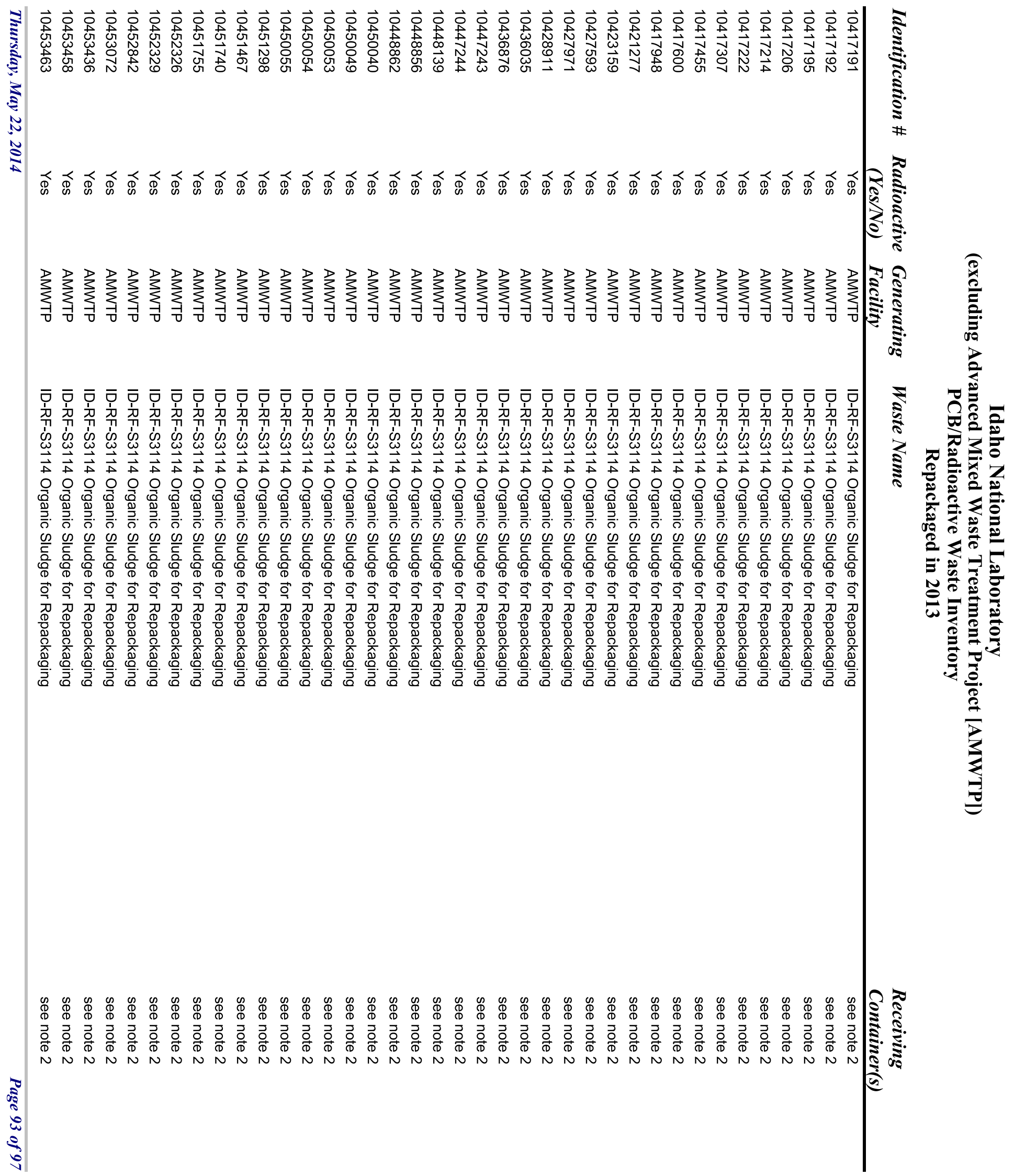




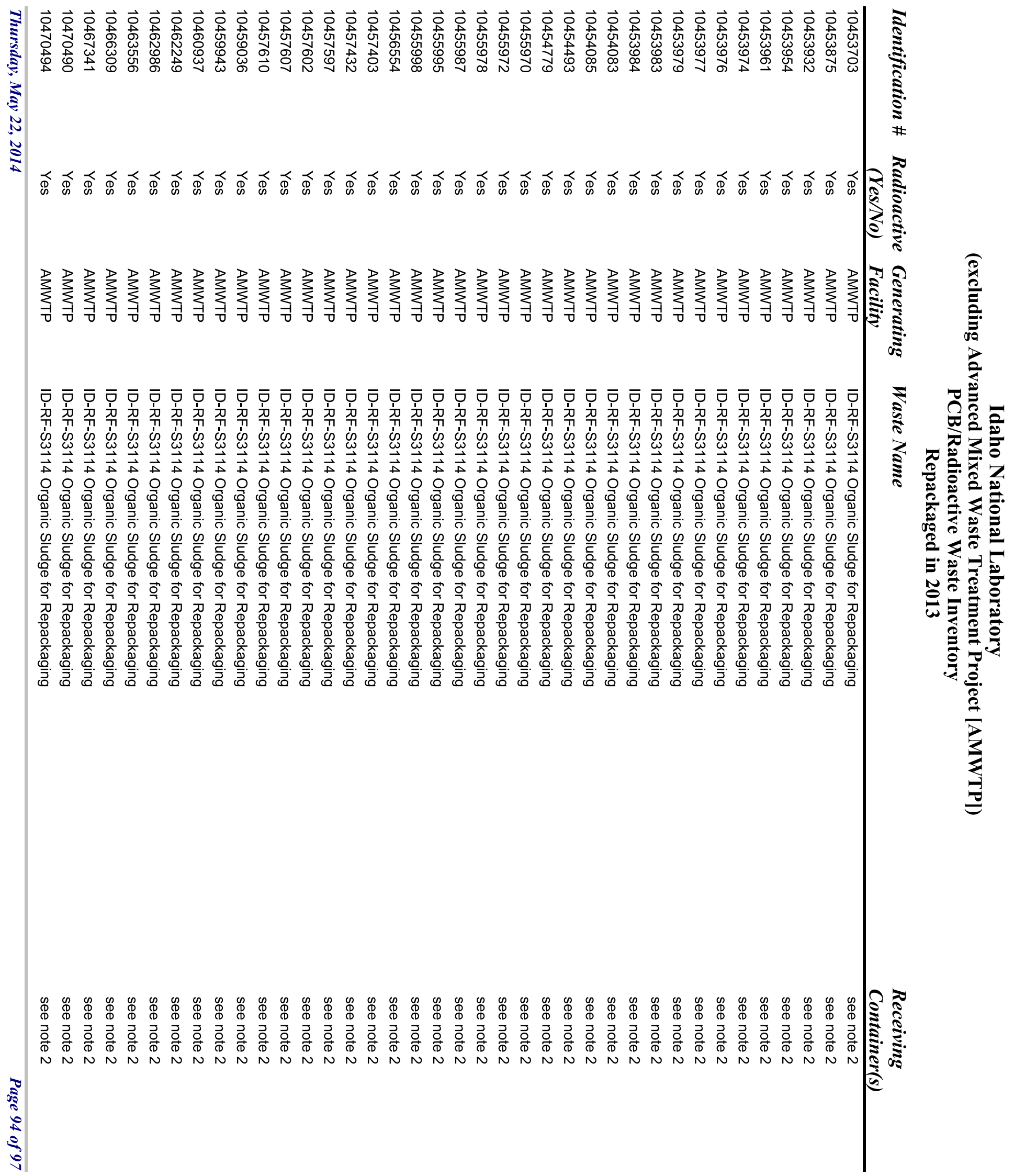




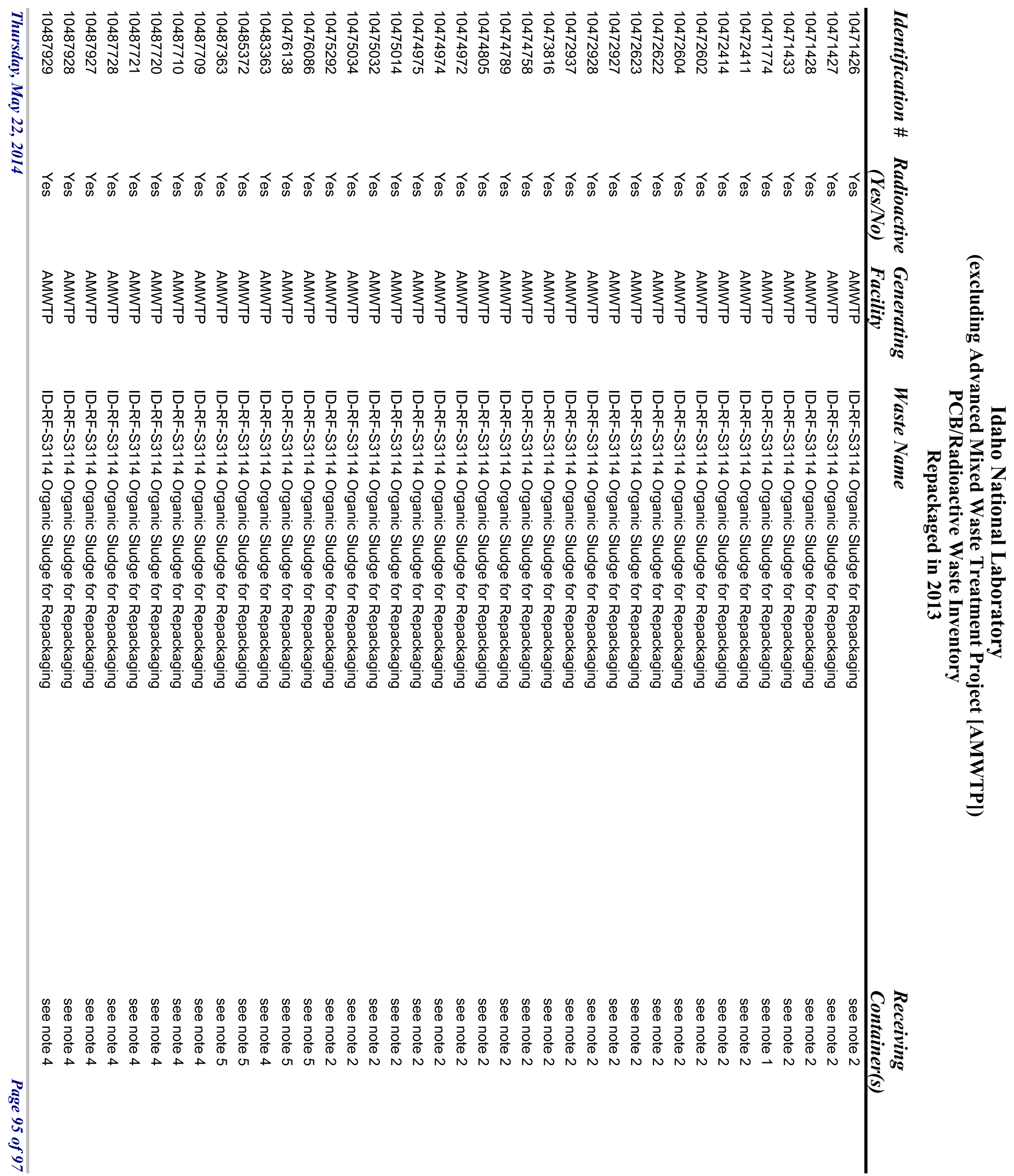




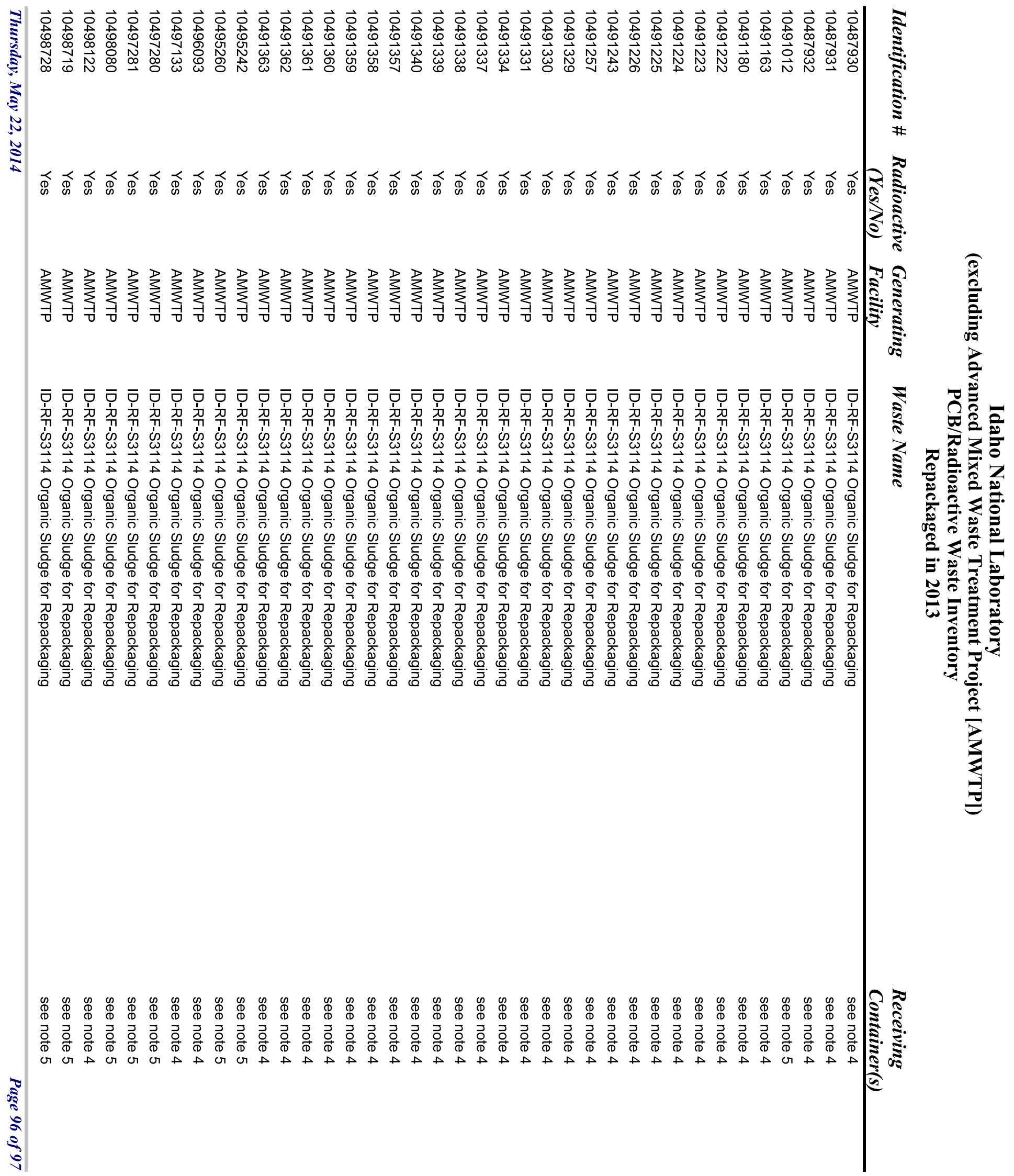



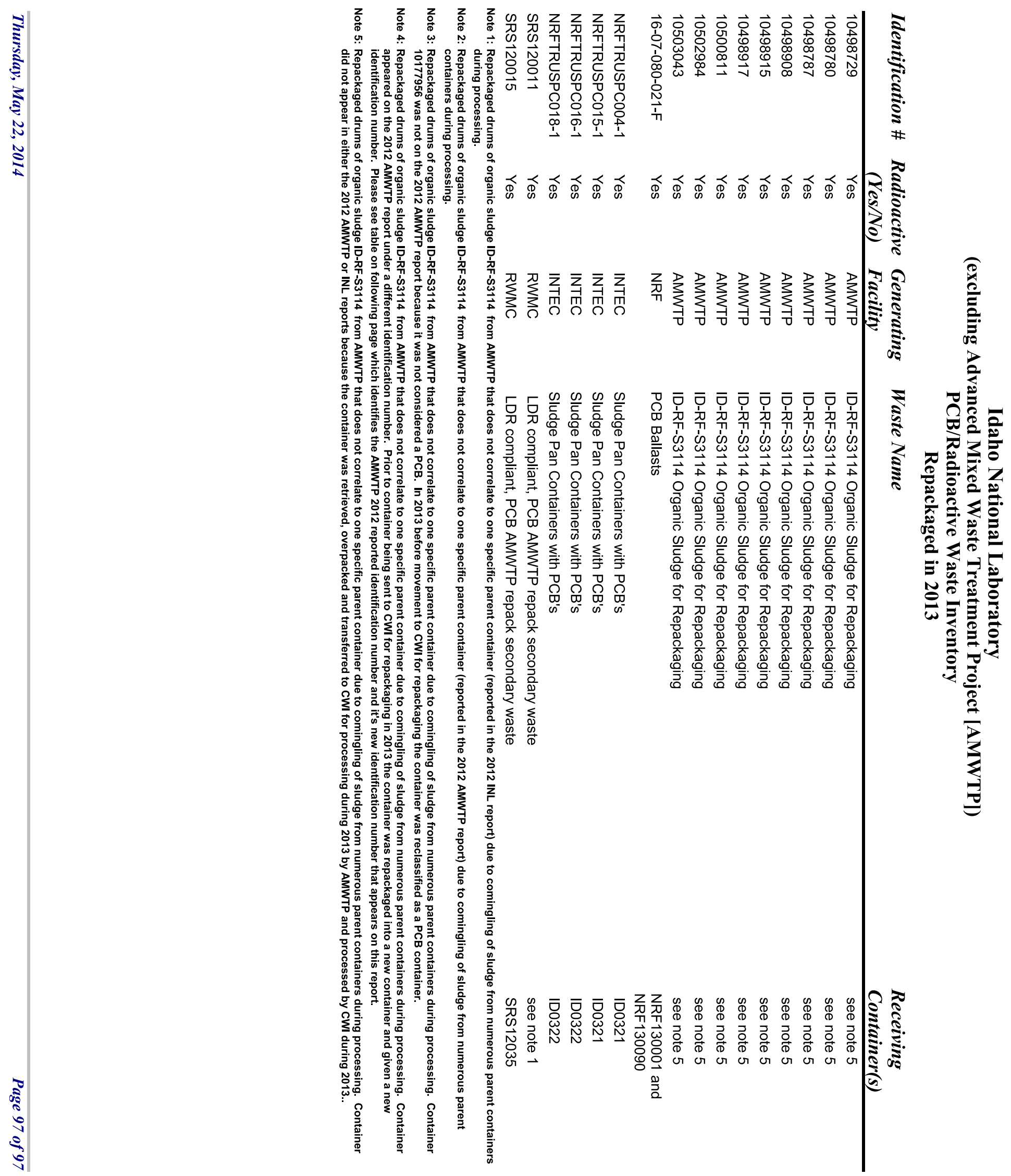


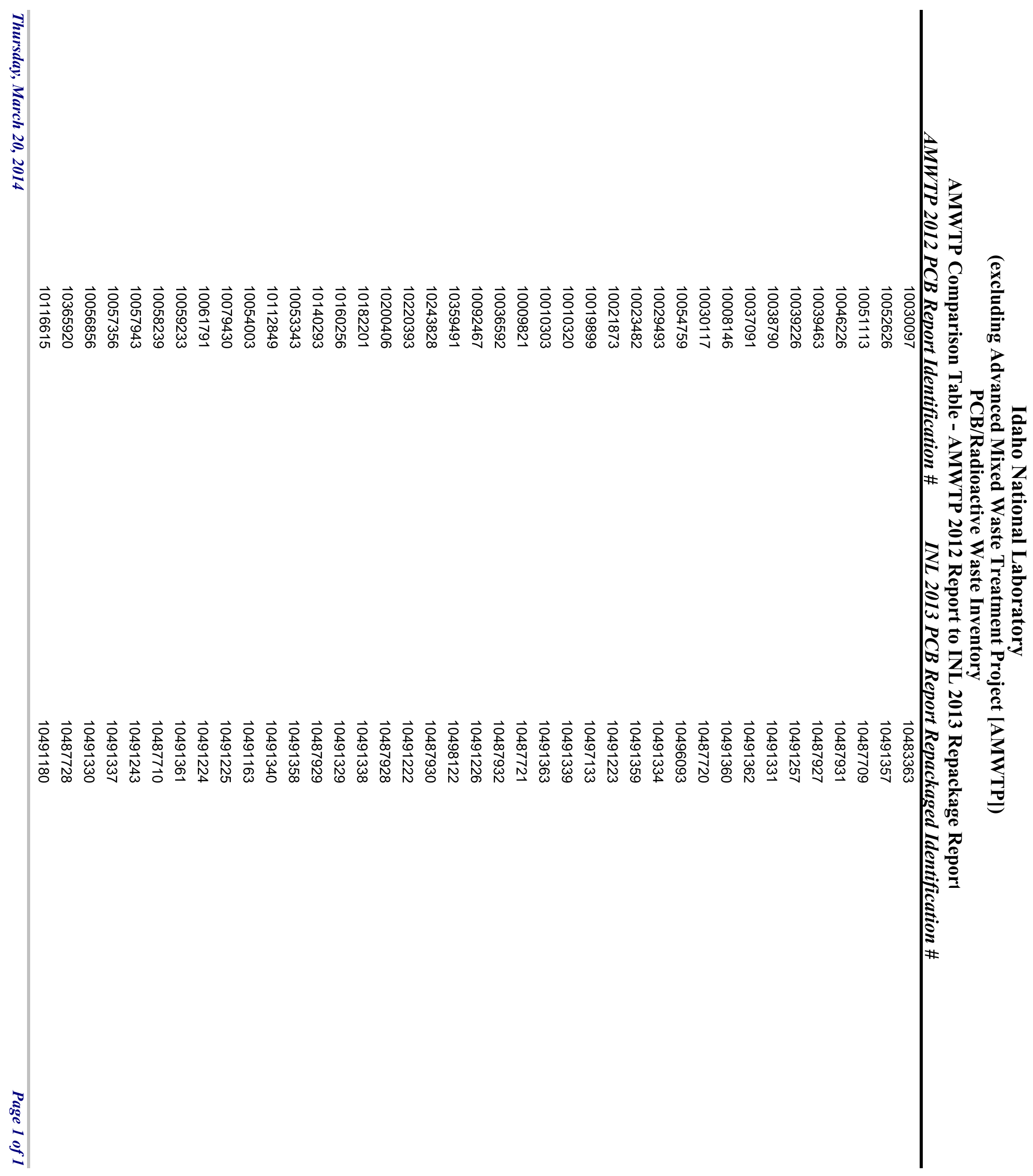




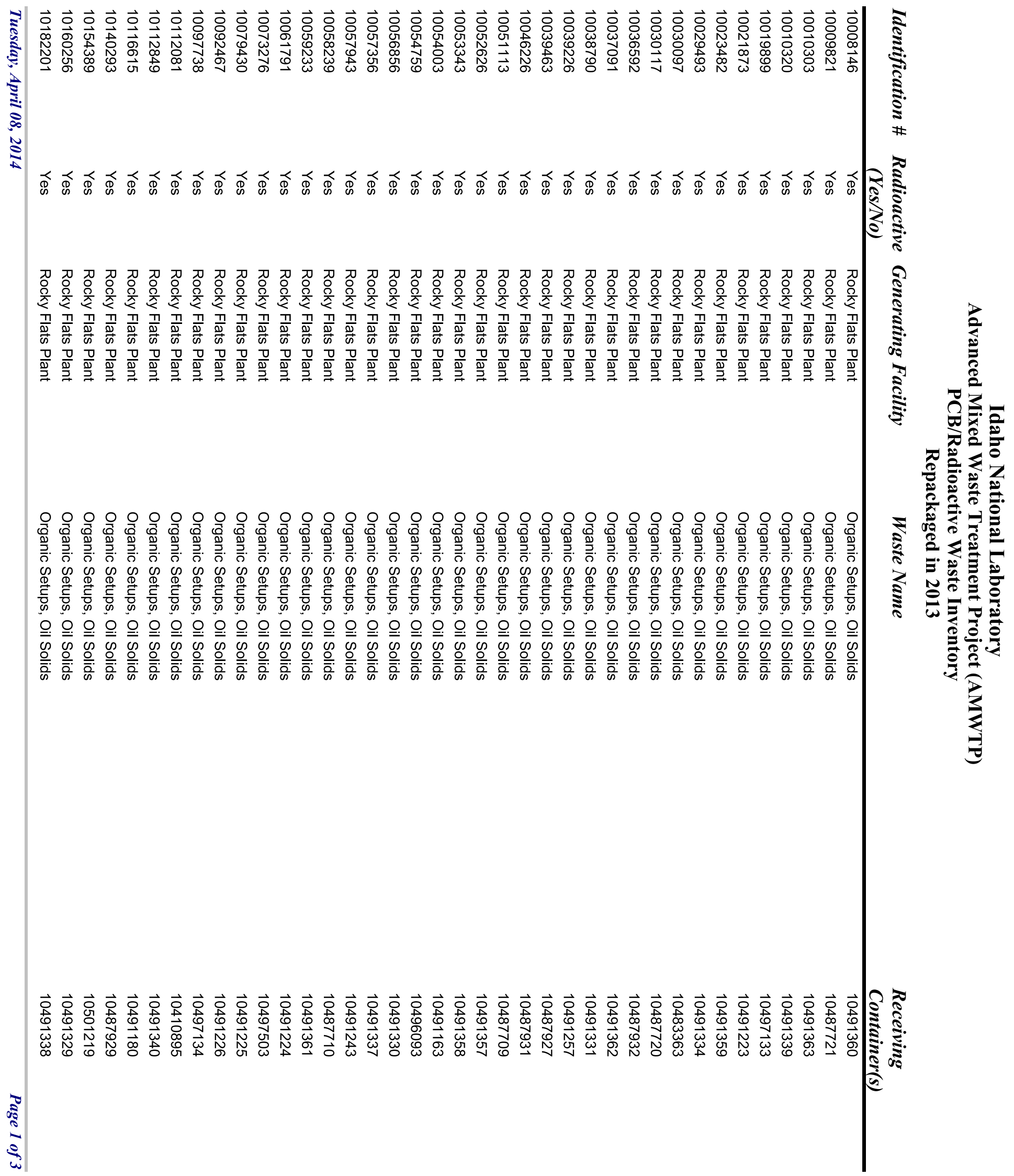




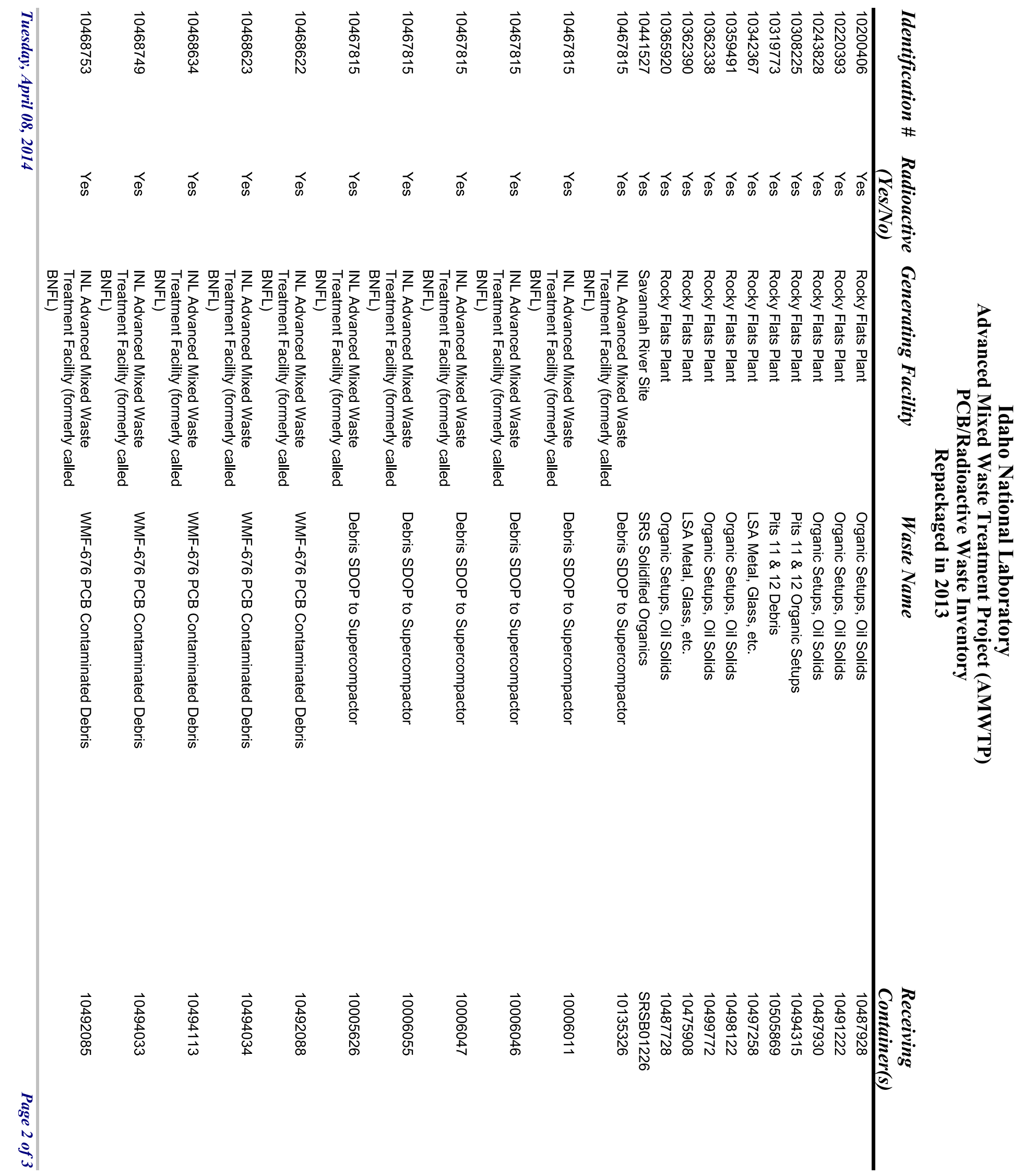



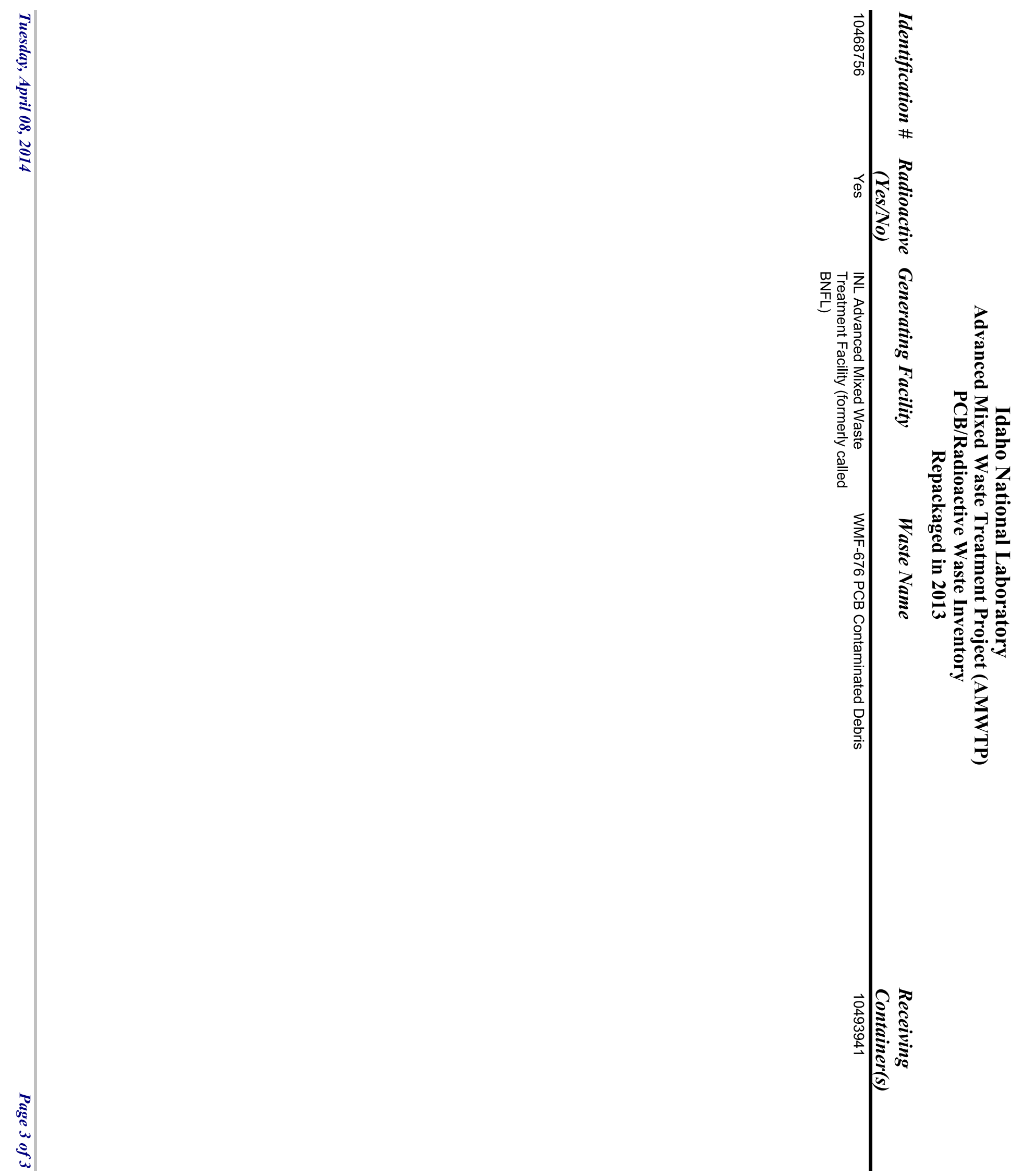
8.0 NOTES ON 2013 REPORT 


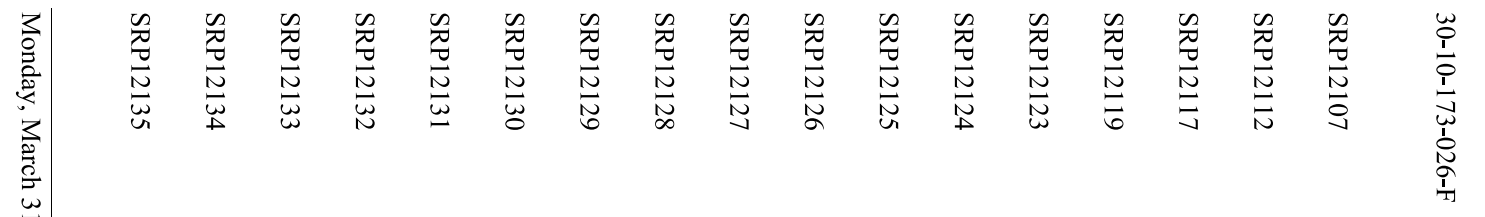

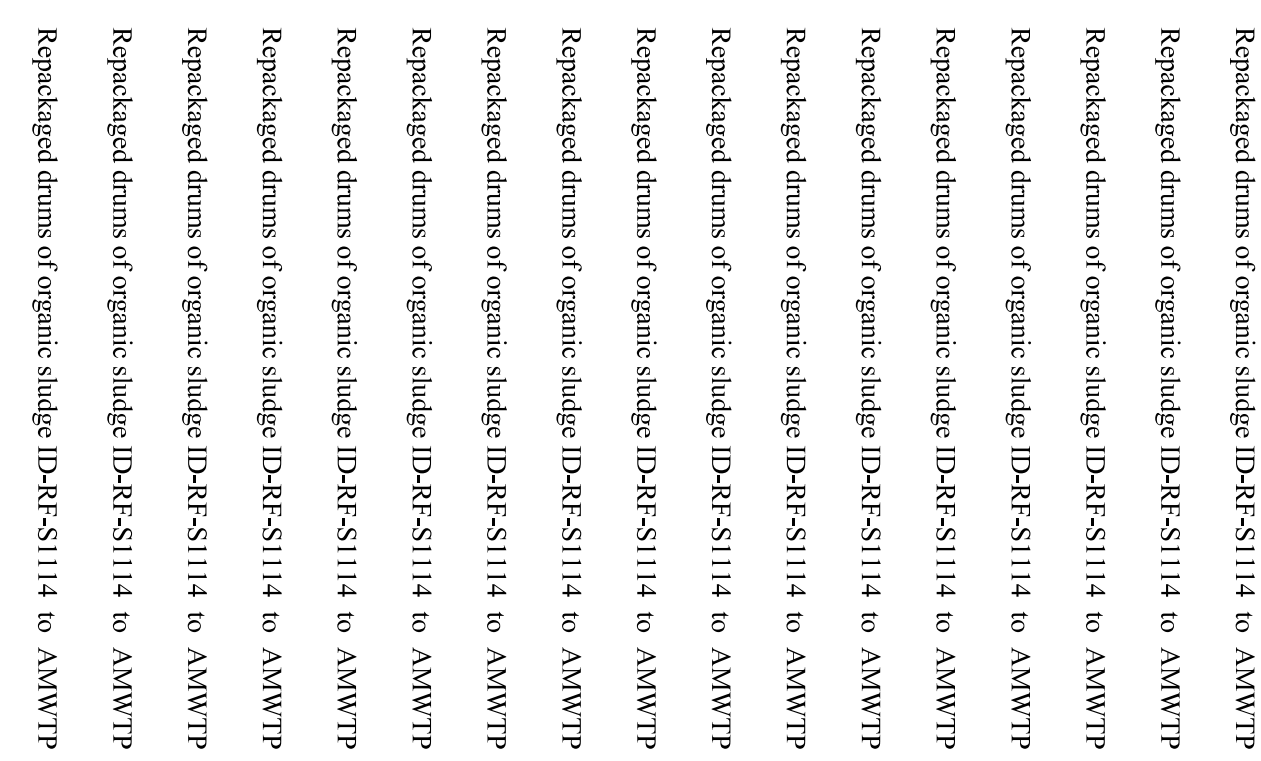

㟧

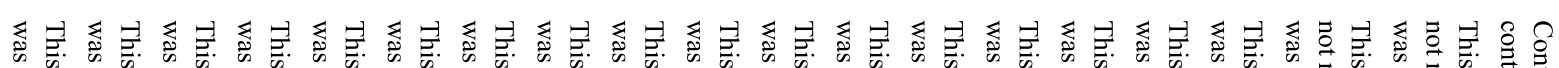

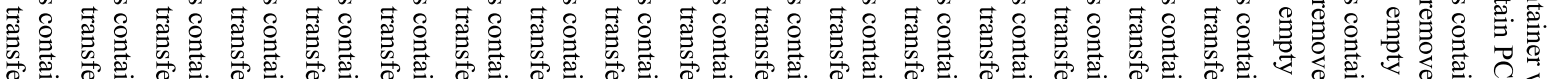

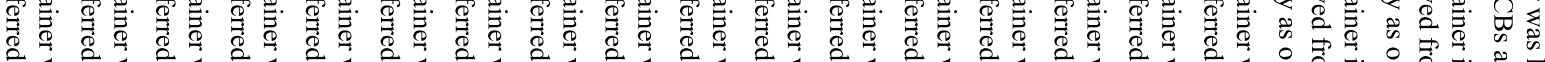

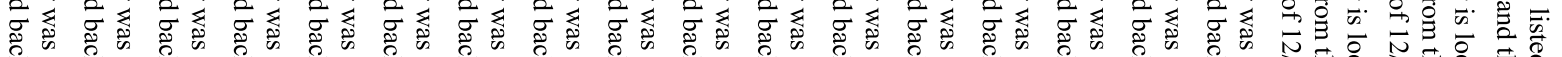

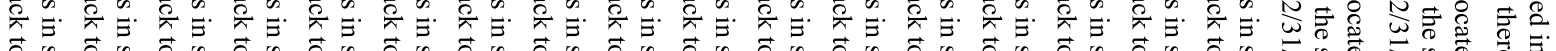

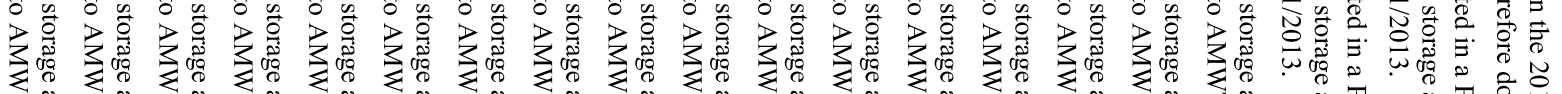

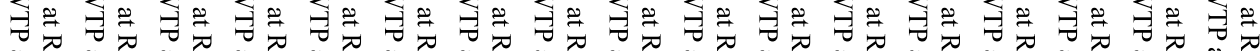

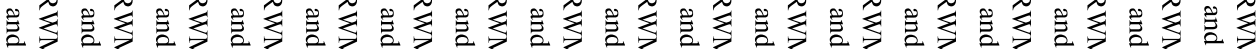

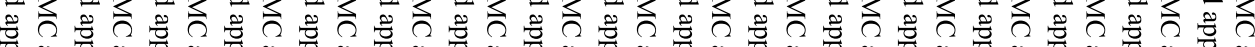

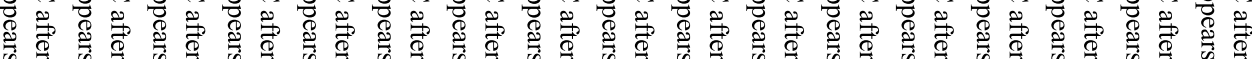

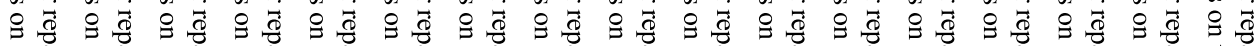

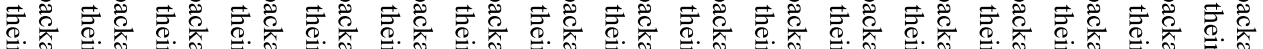

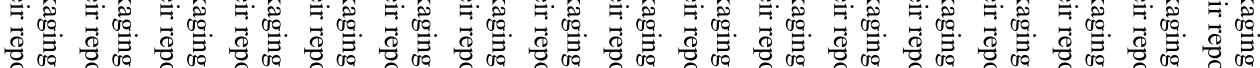

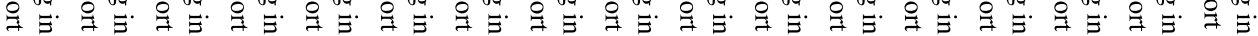

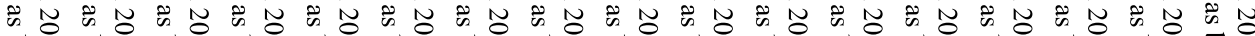

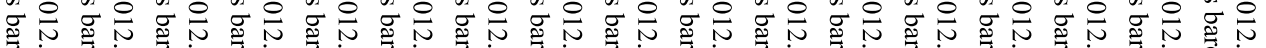

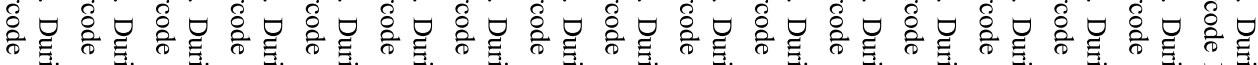

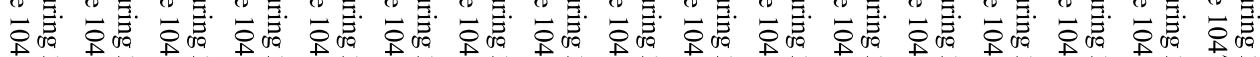

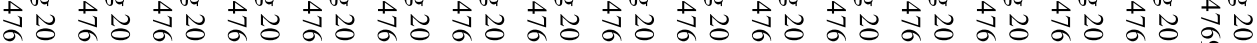

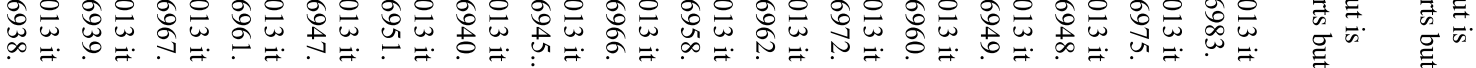

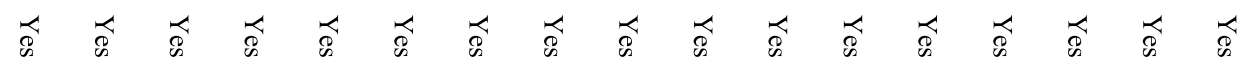




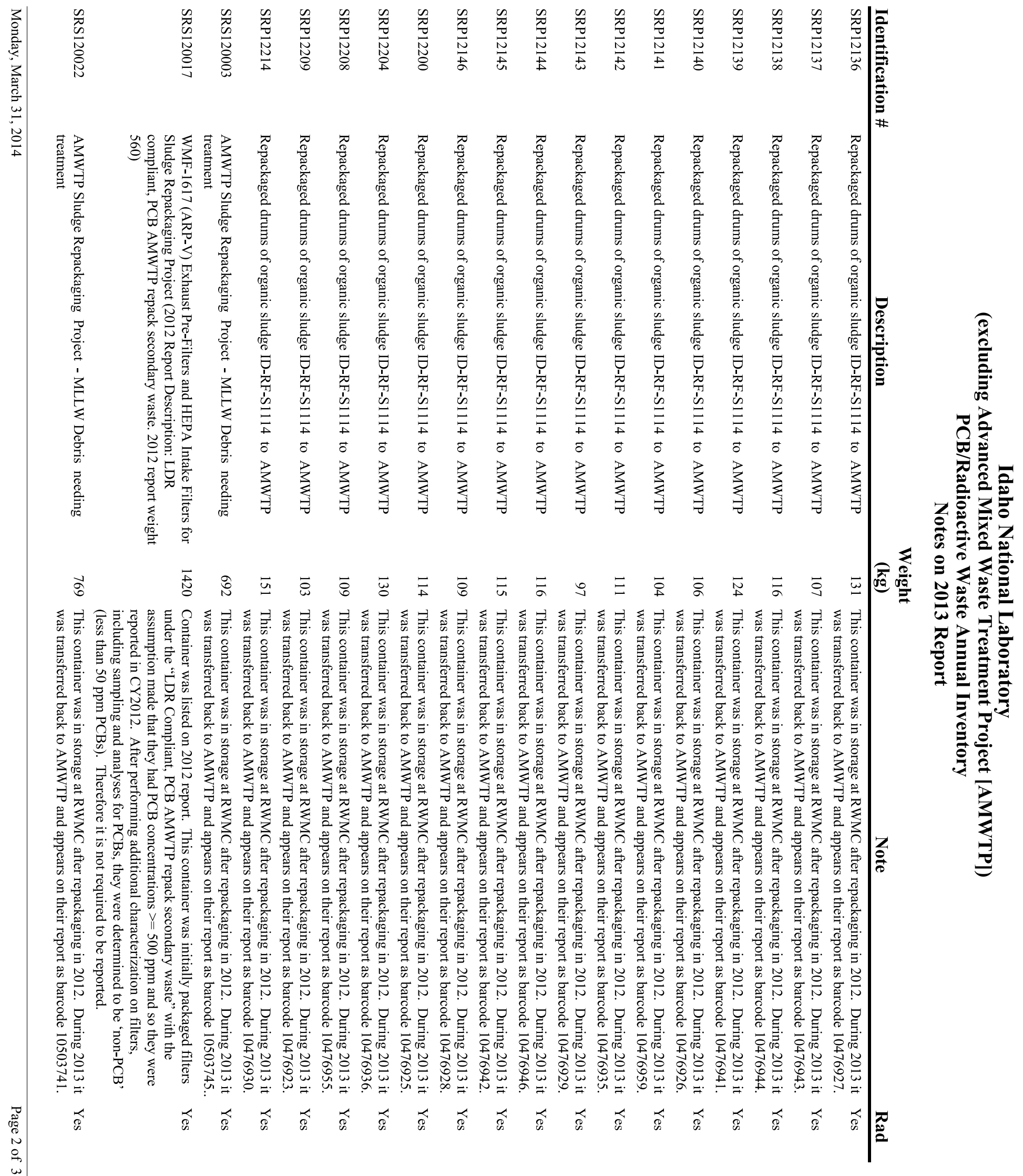



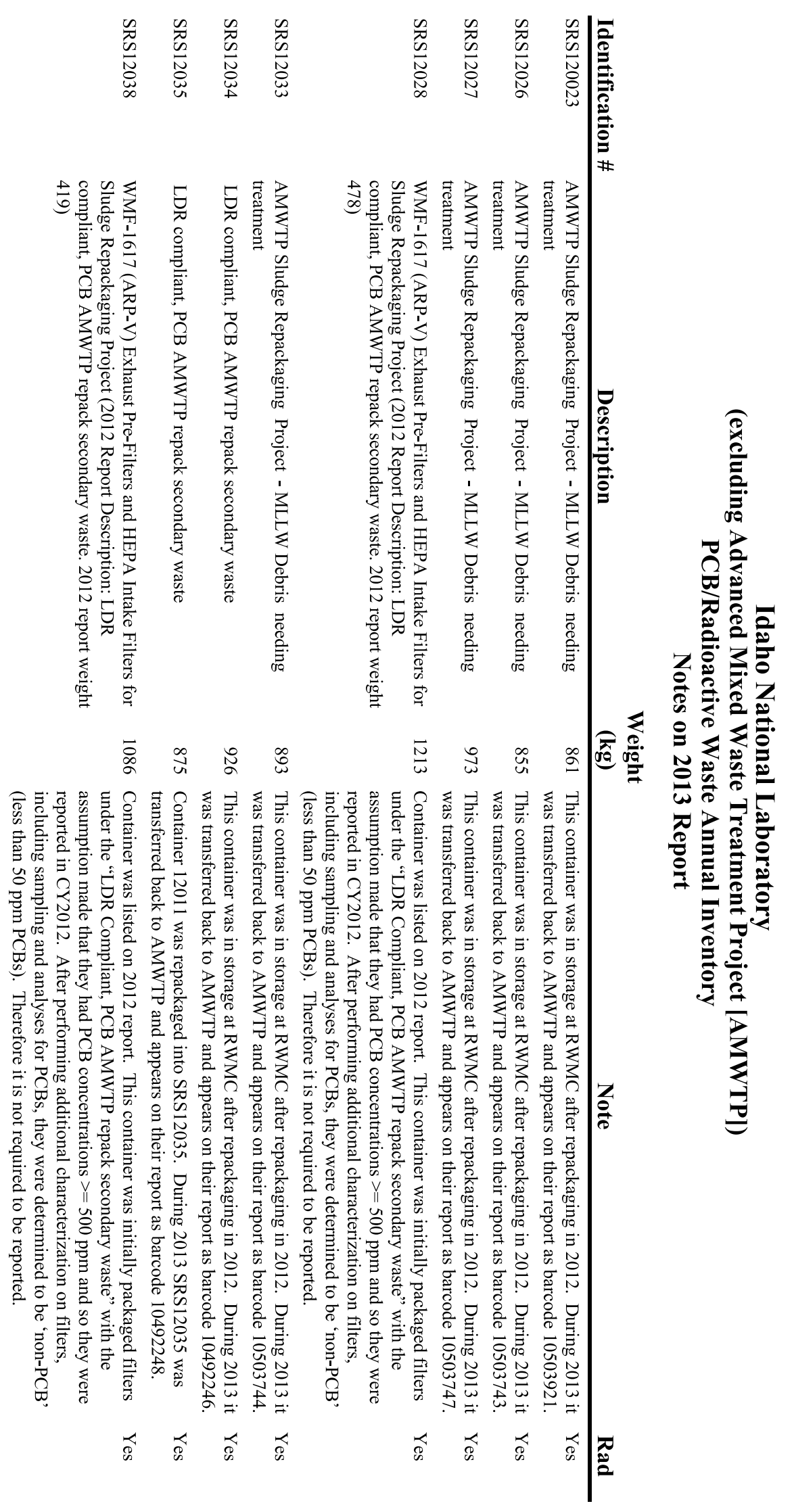


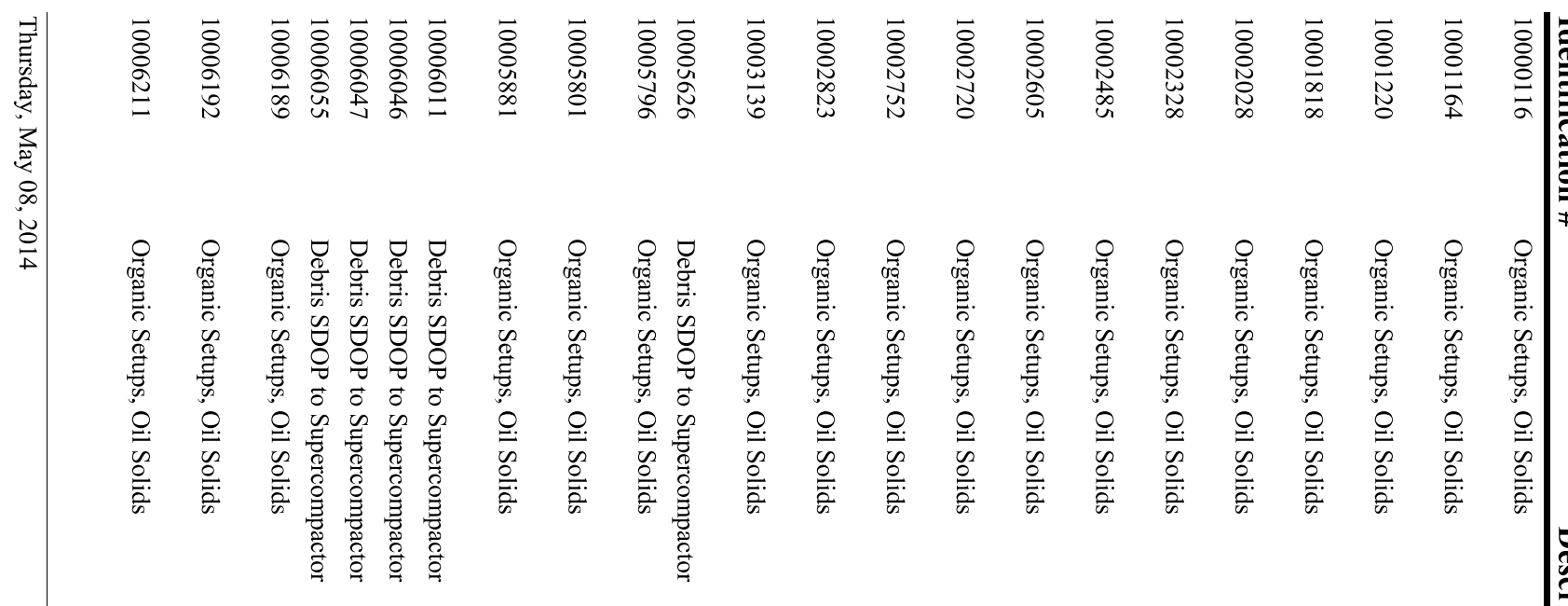

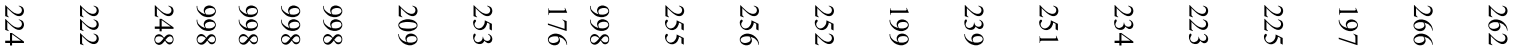

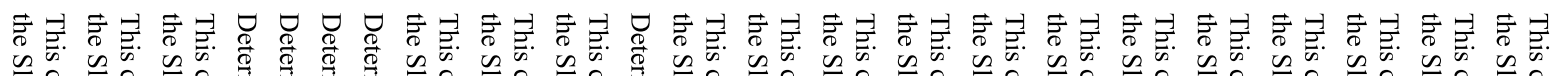

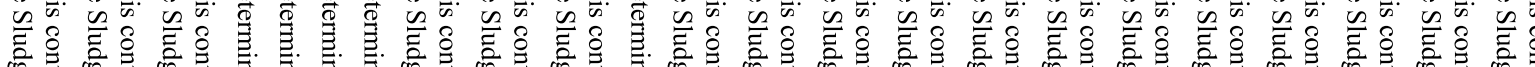

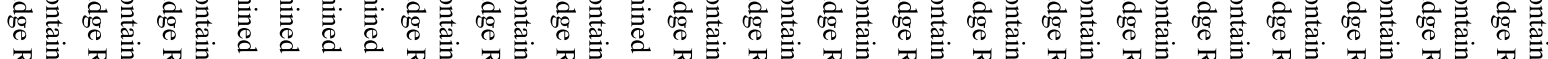

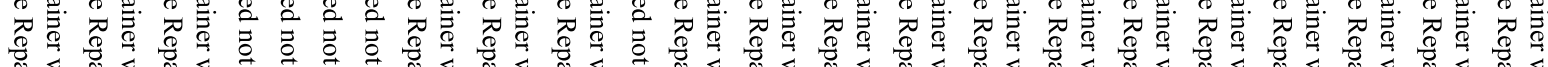

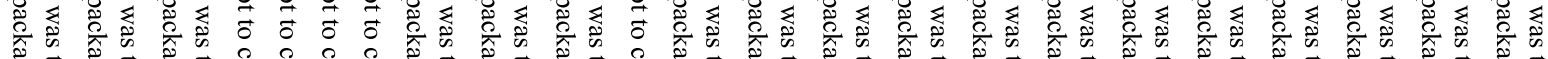

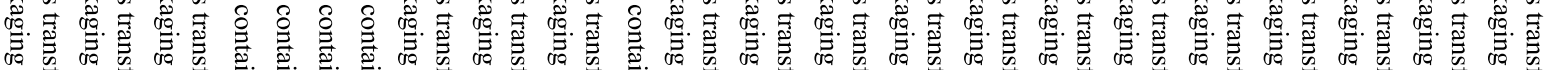

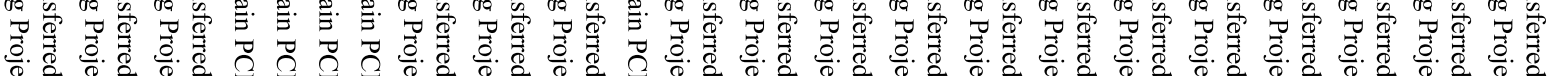

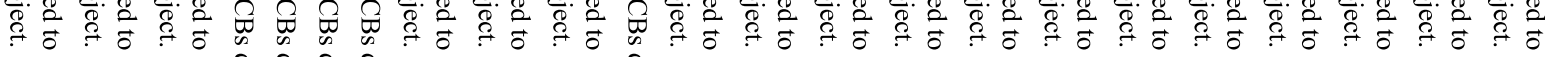

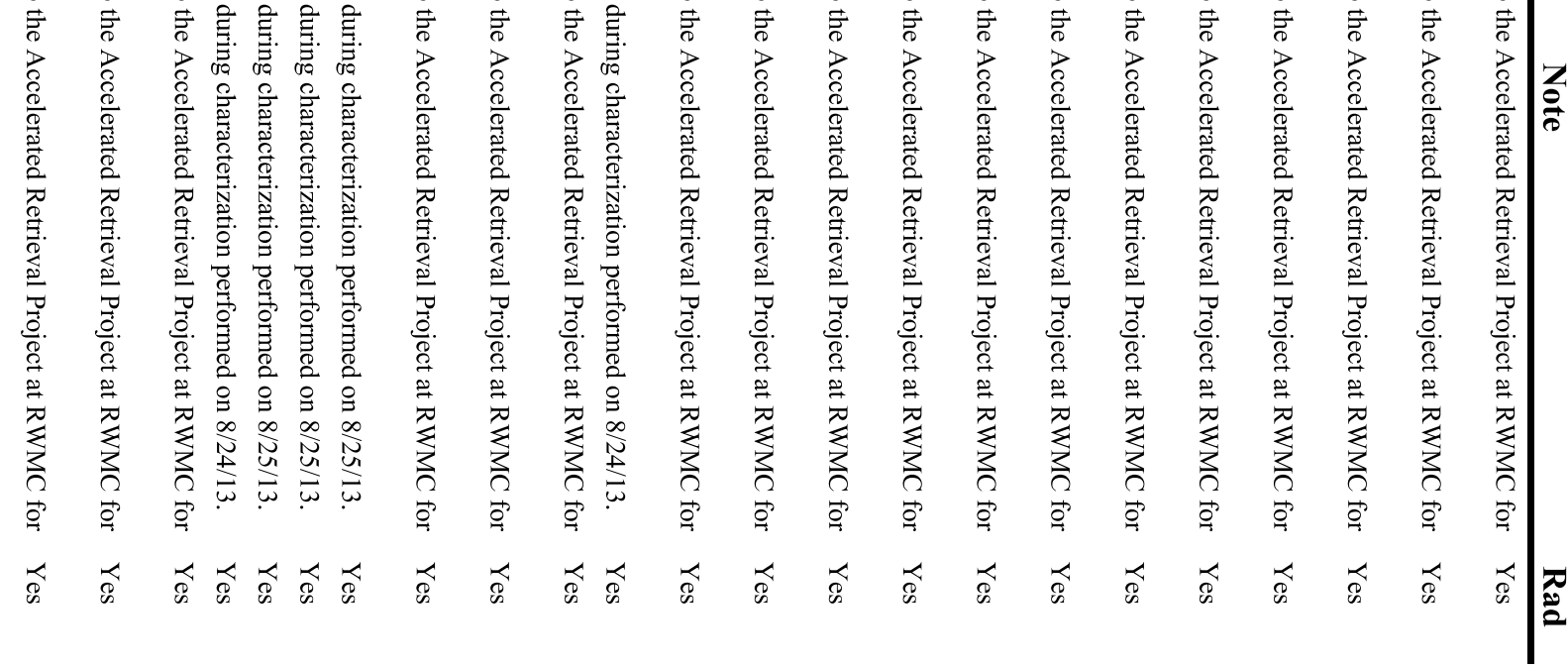




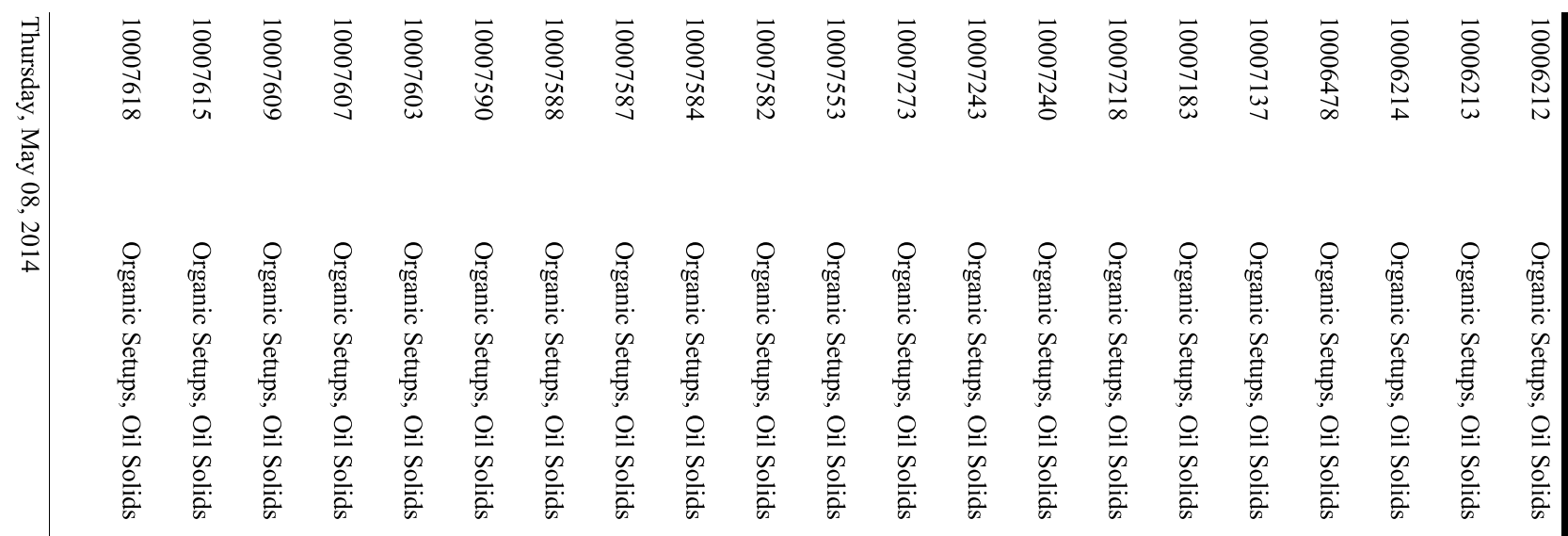

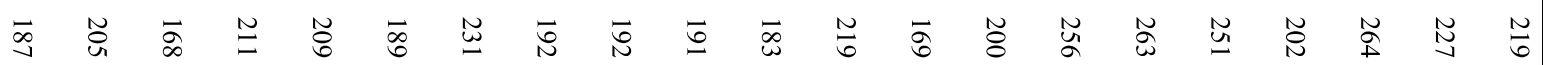

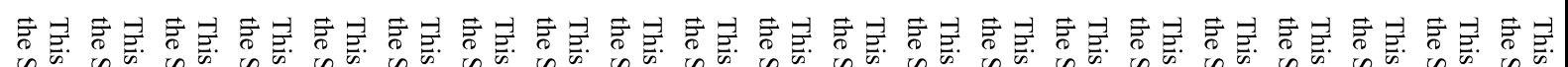

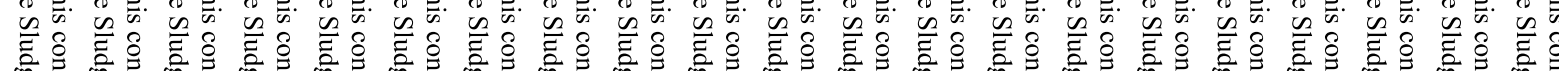

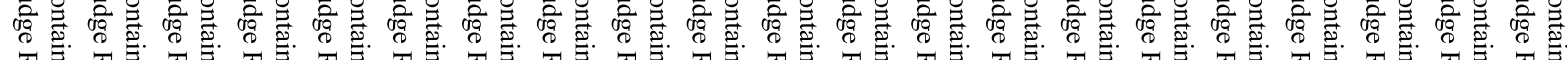
不

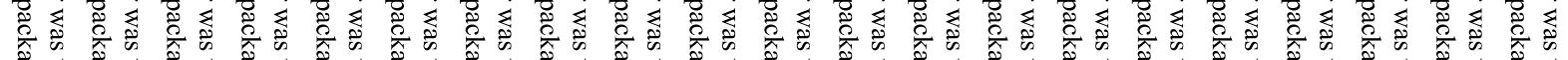

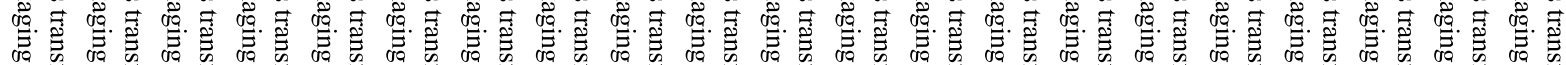

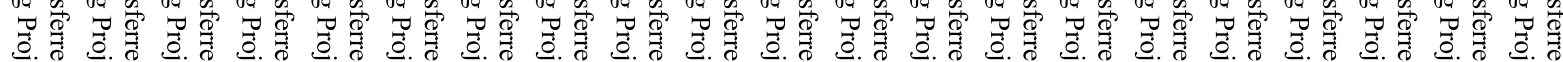

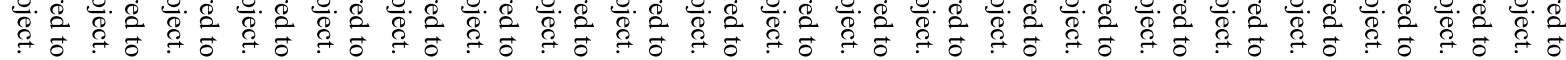

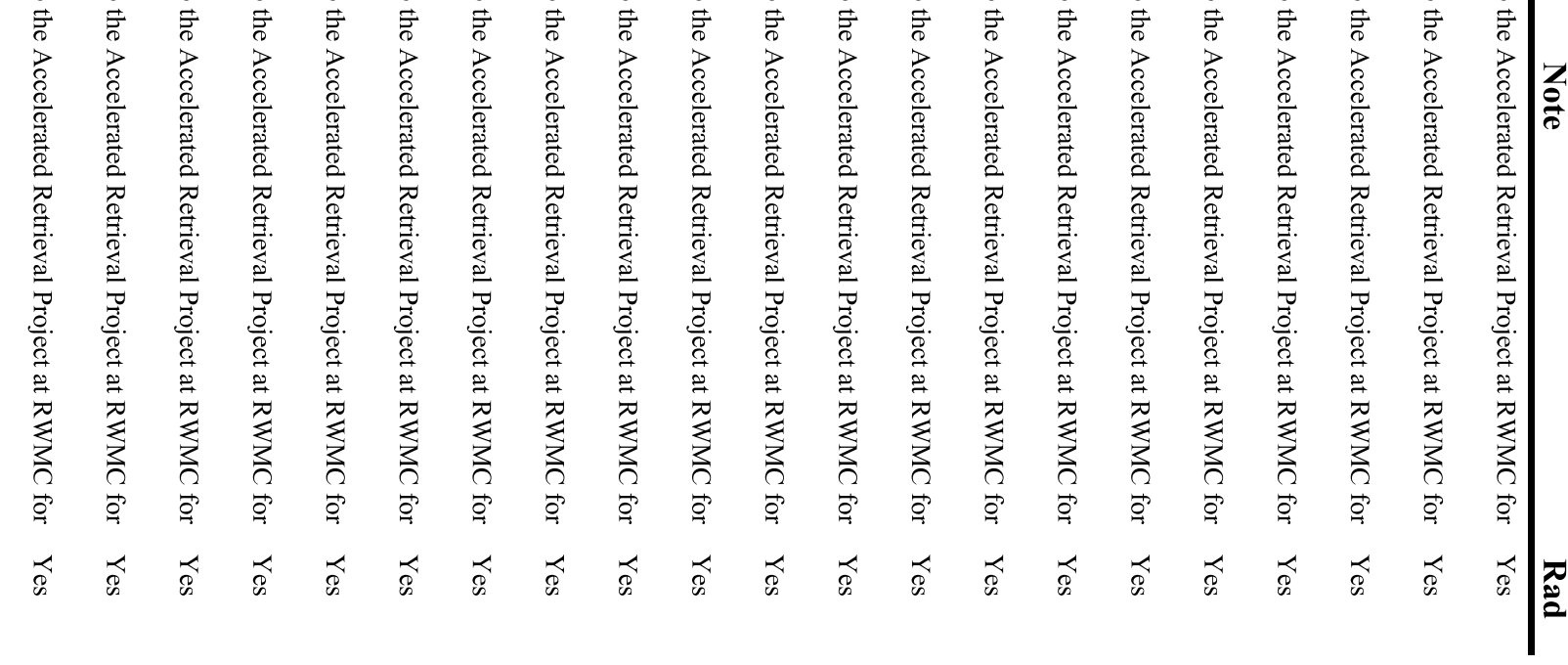




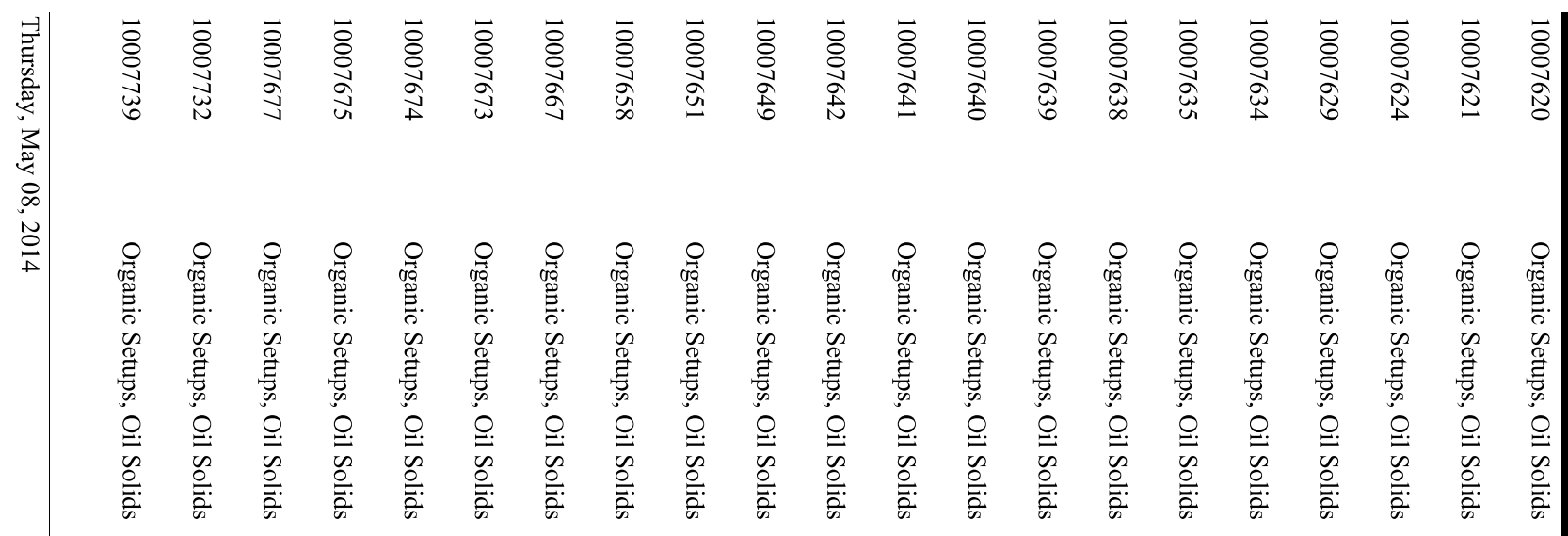

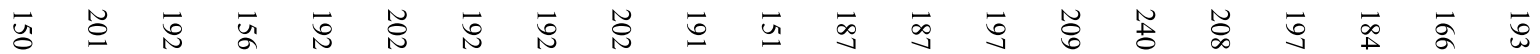

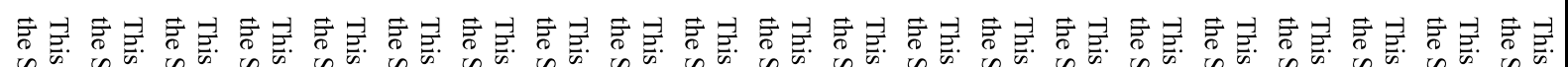

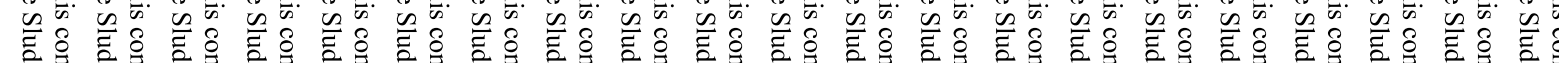

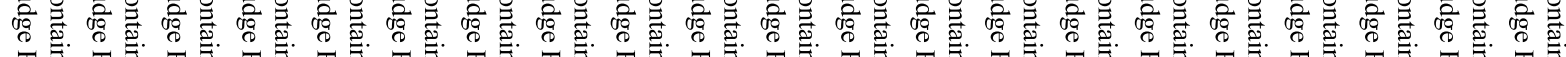
不

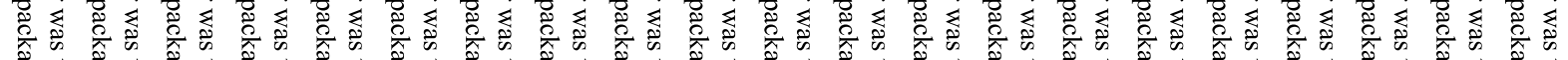

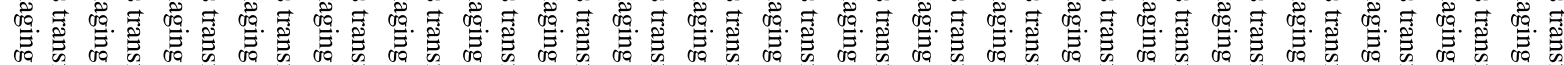

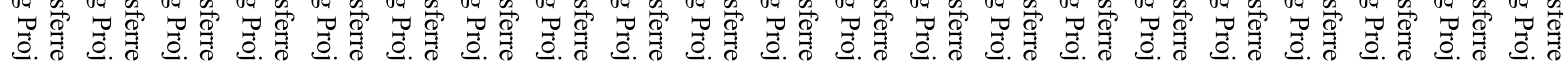

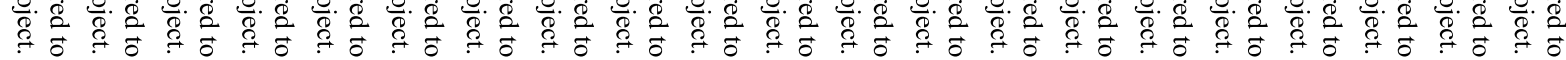

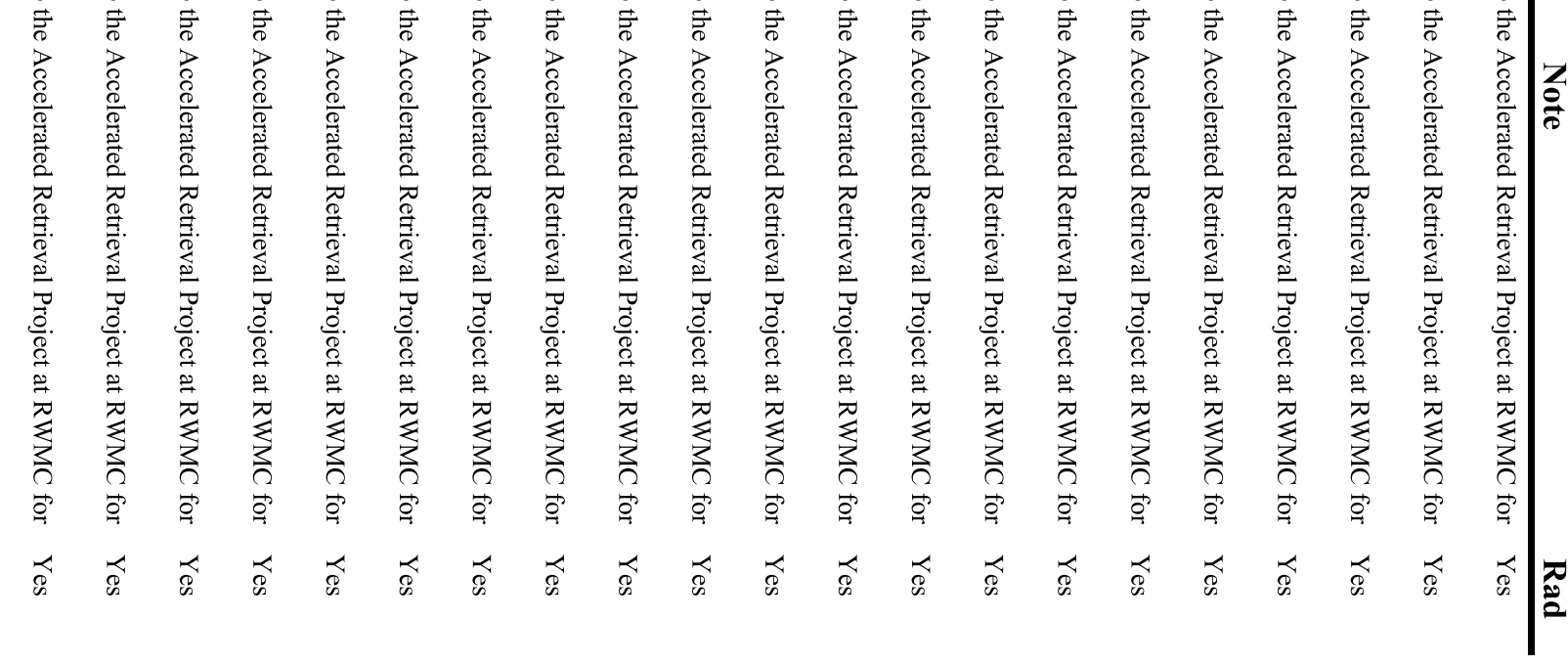




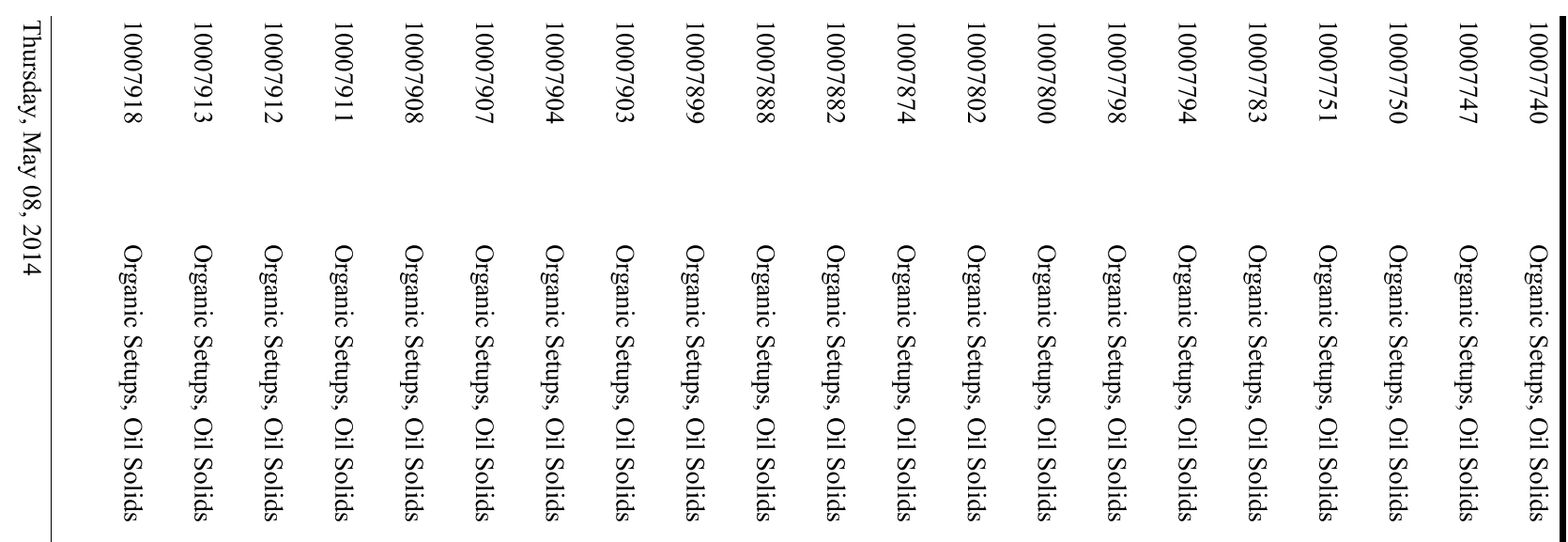

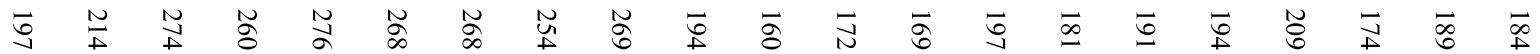

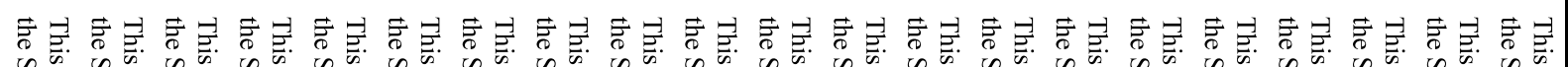

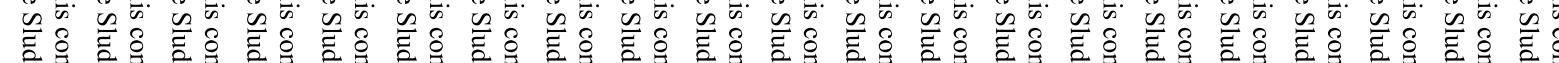

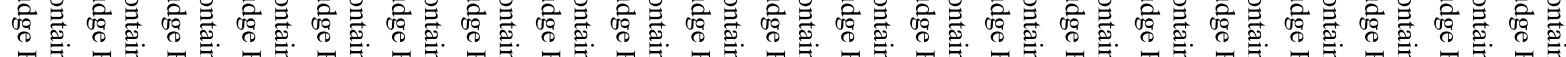
不

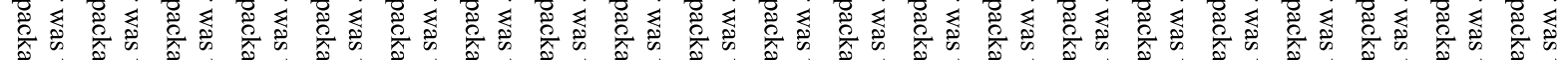

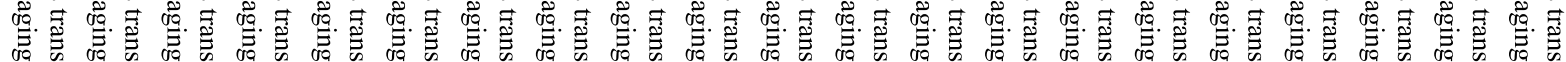

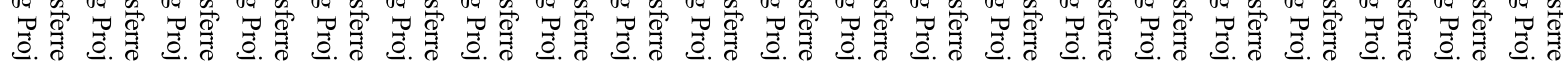

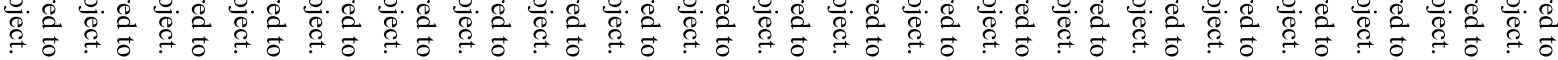

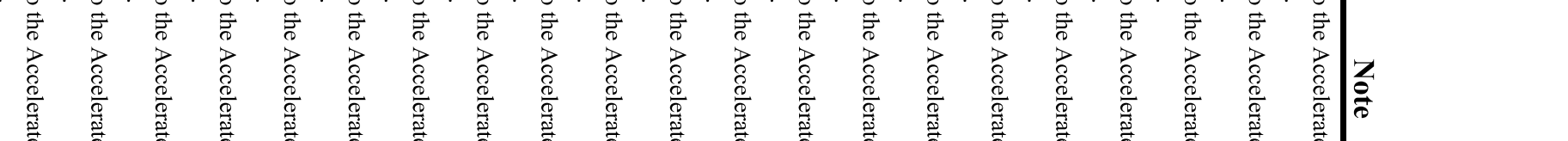




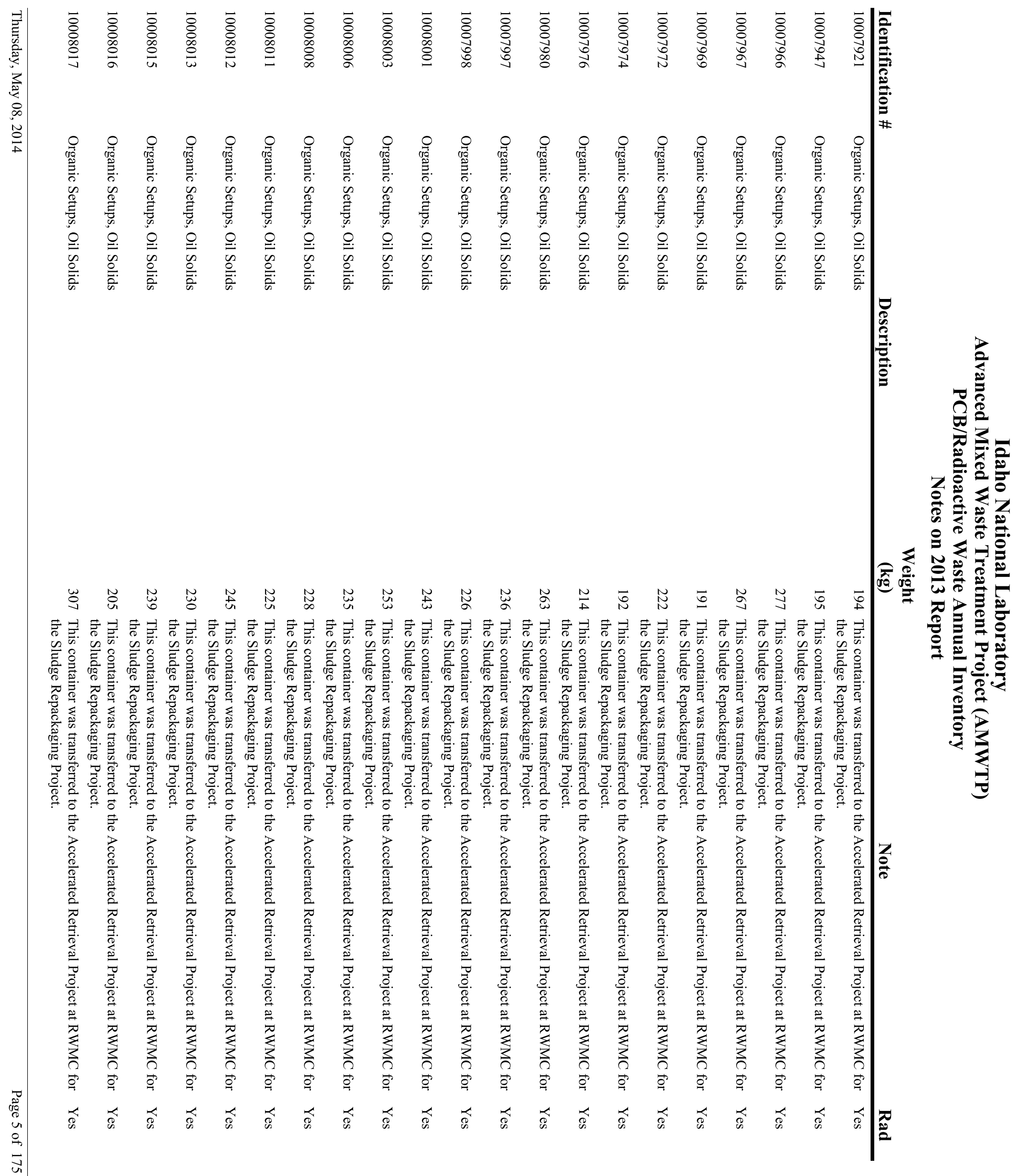




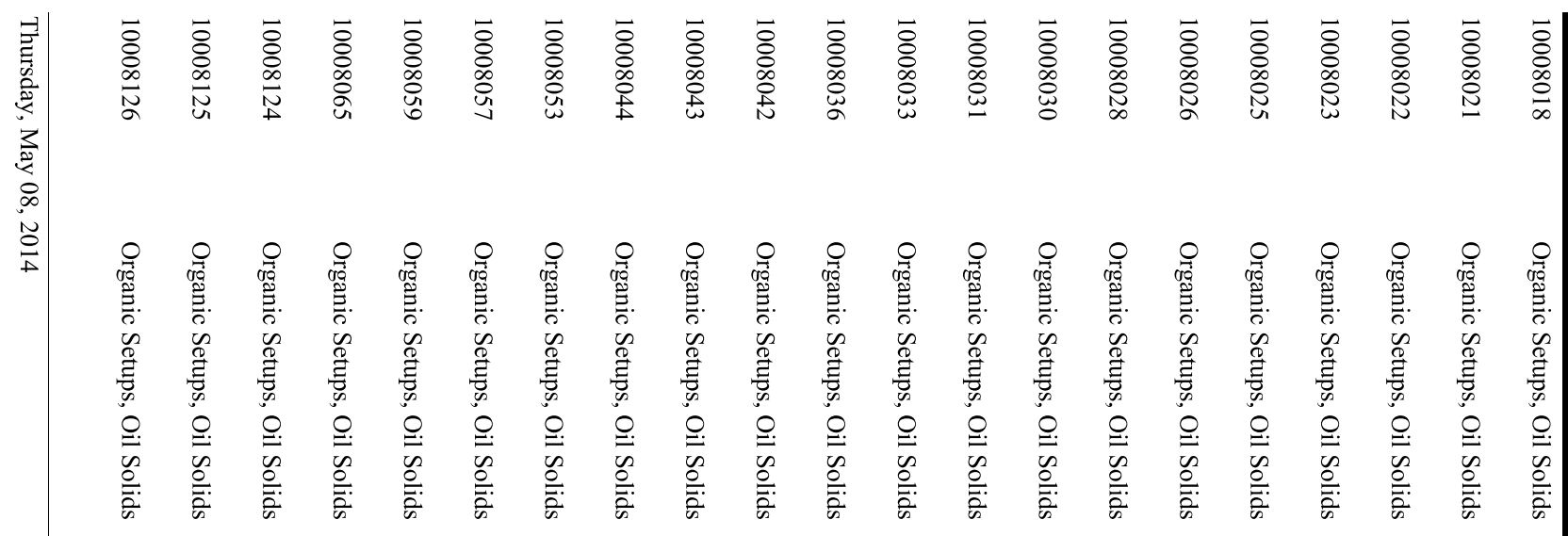

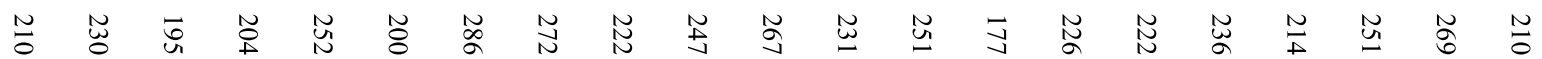

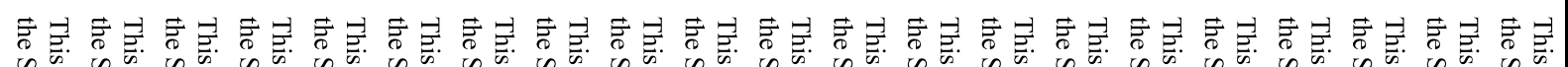

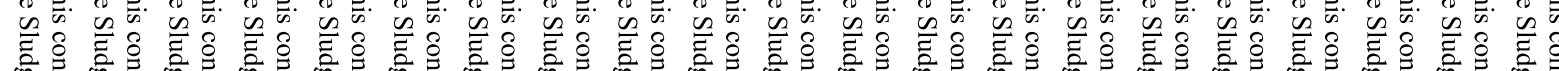

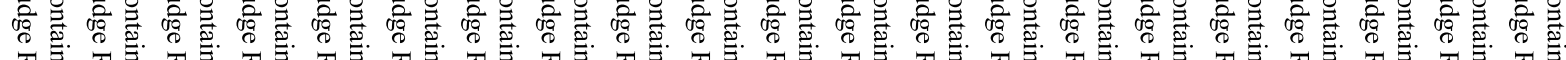

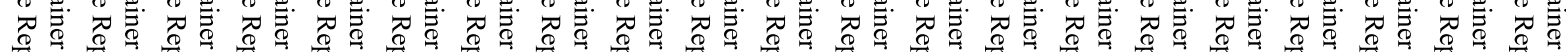

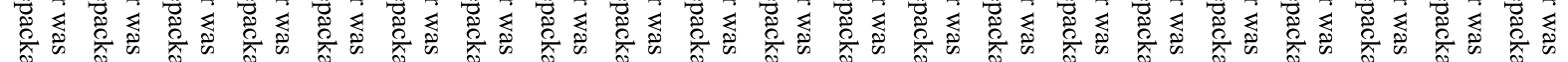

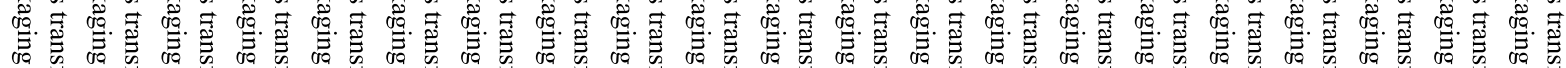

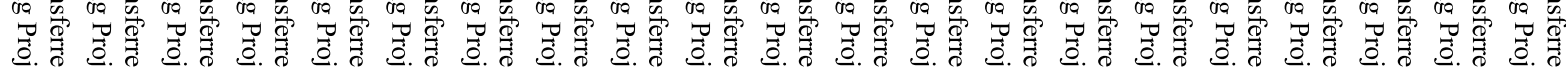

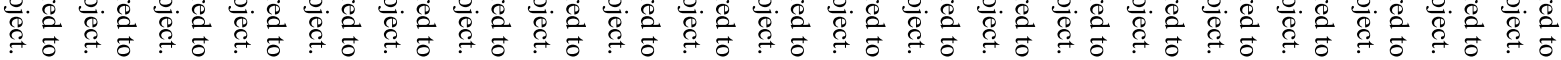

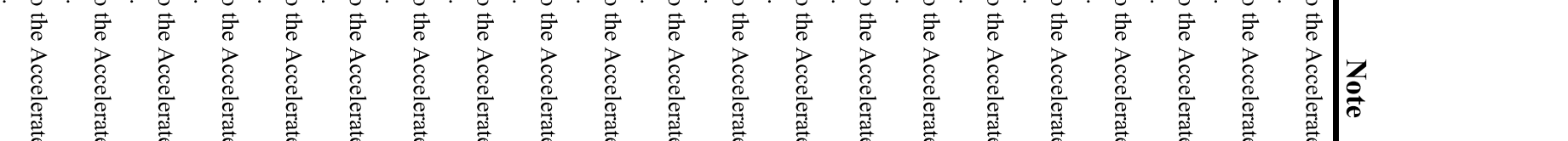




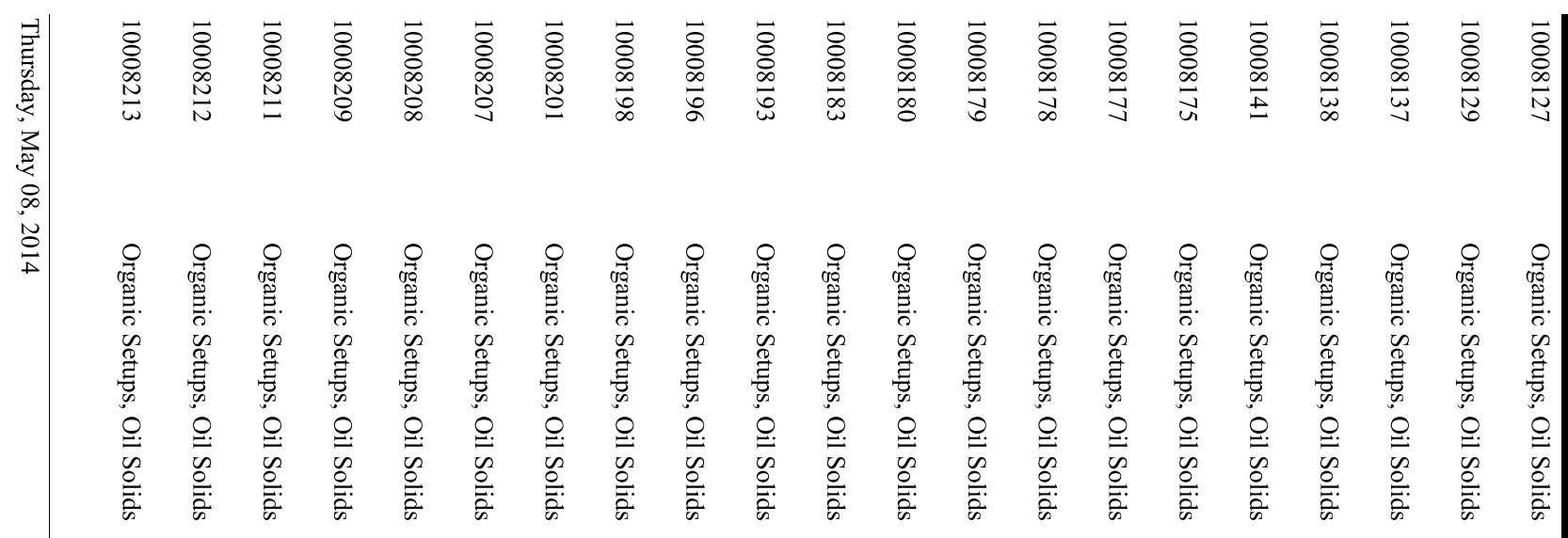

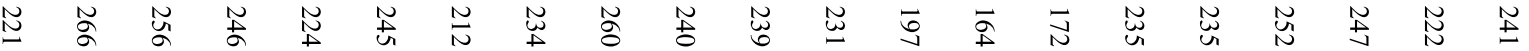

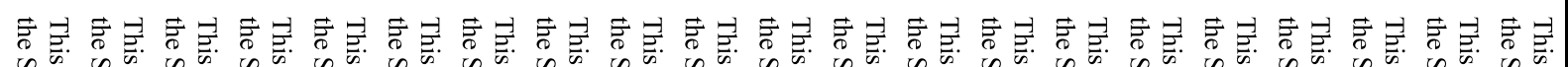

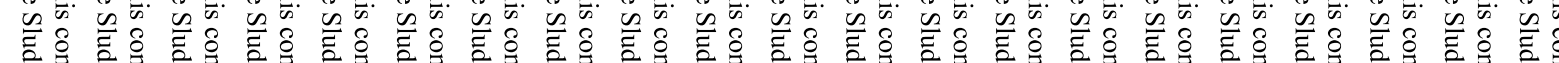

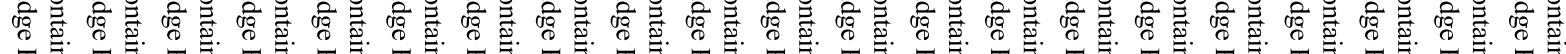
不

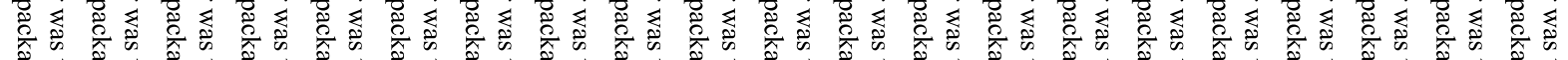

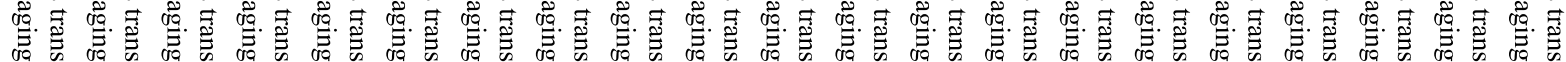

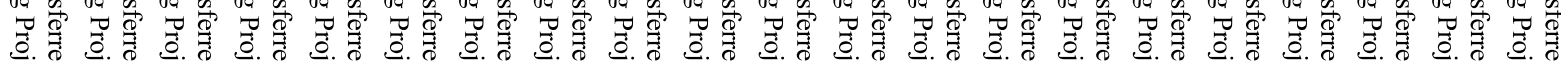

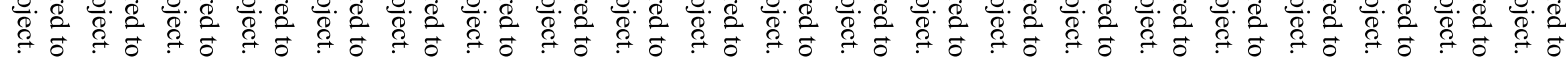

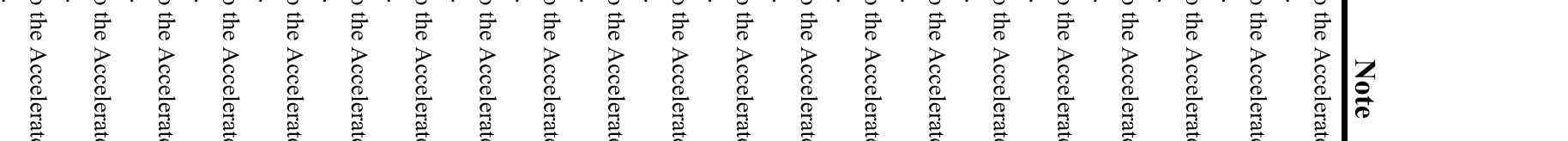




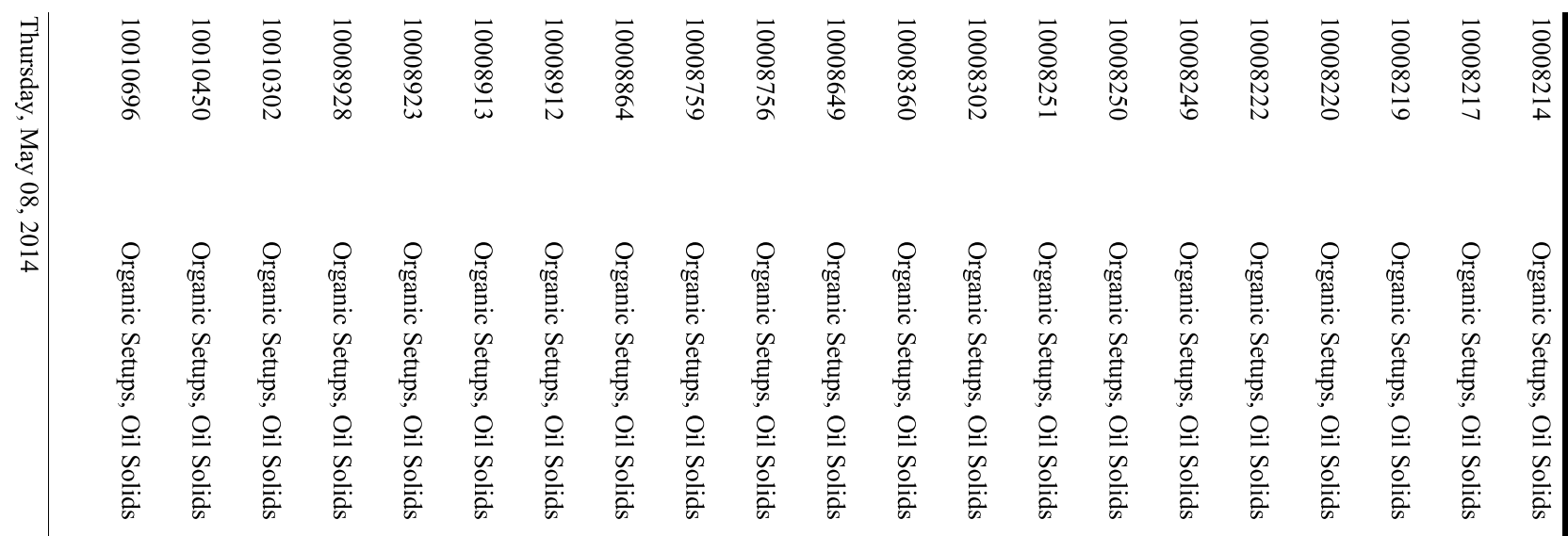

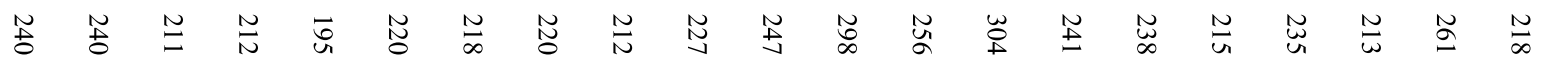

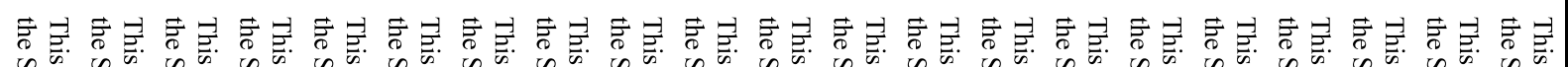

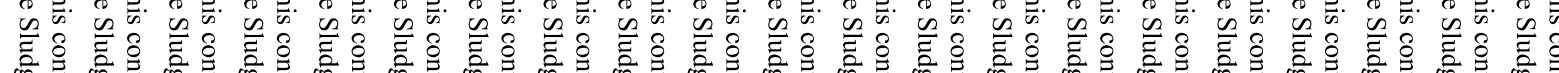

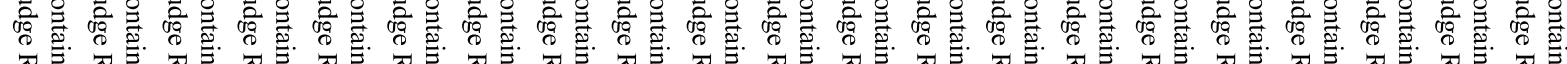

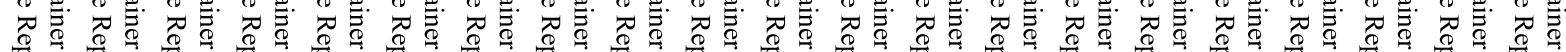

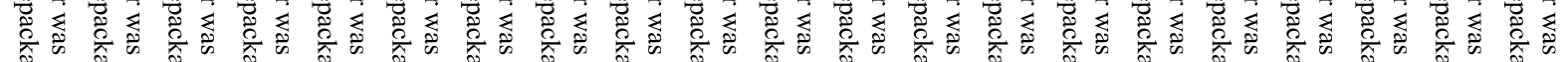

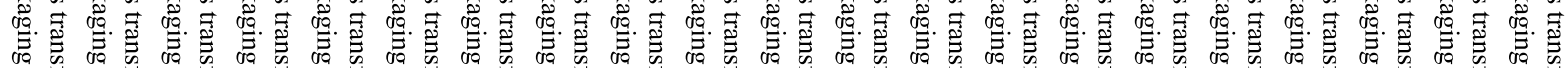

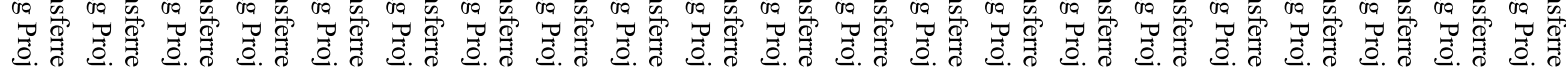

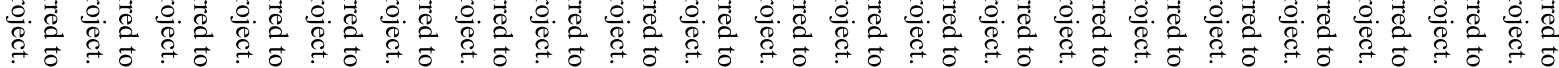

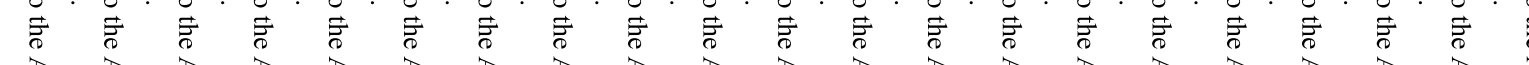

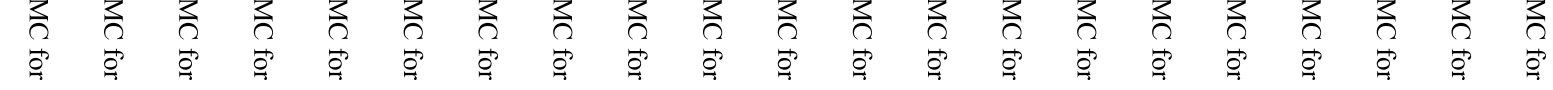

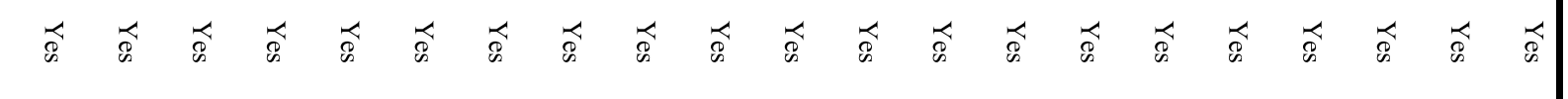




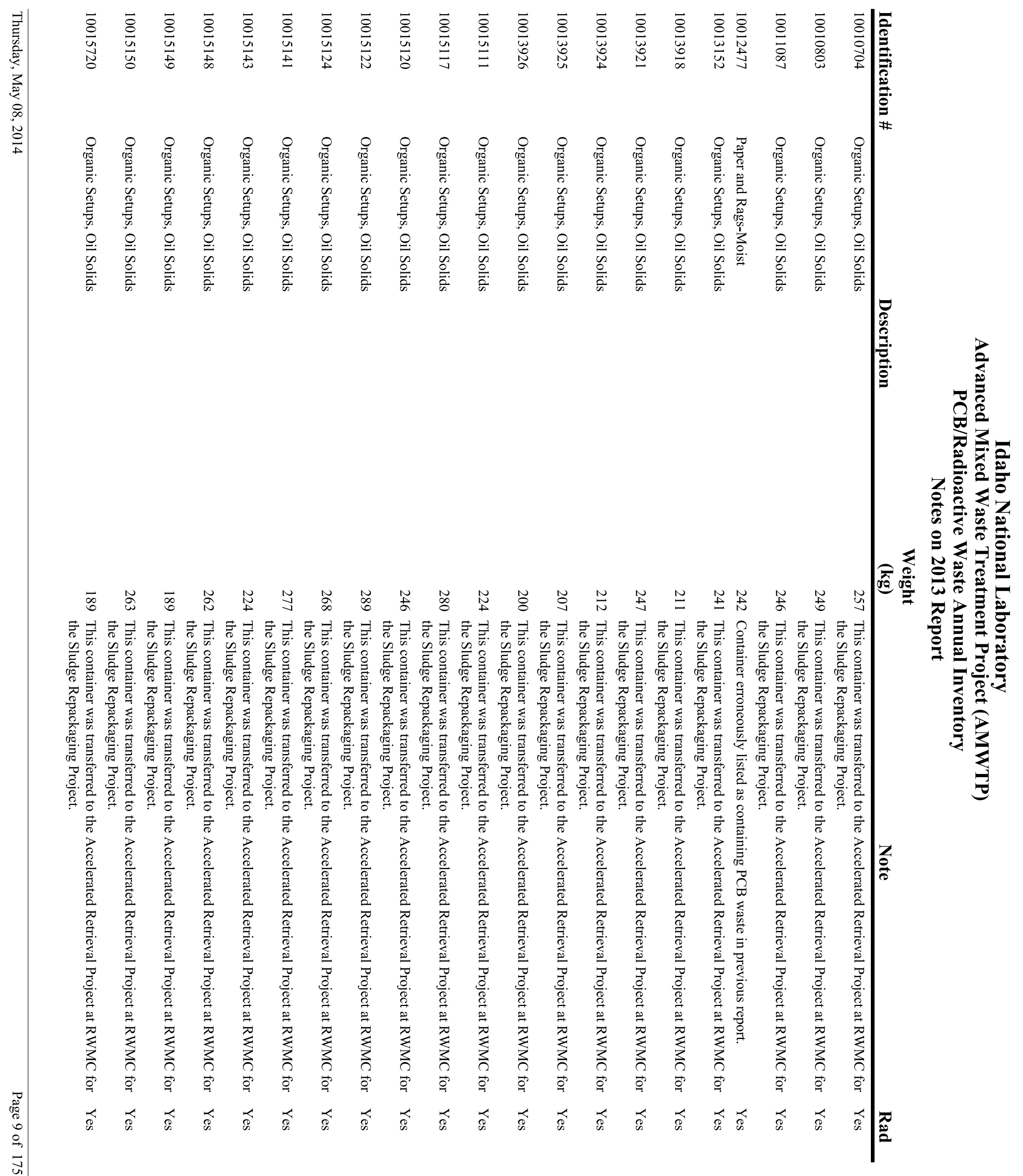




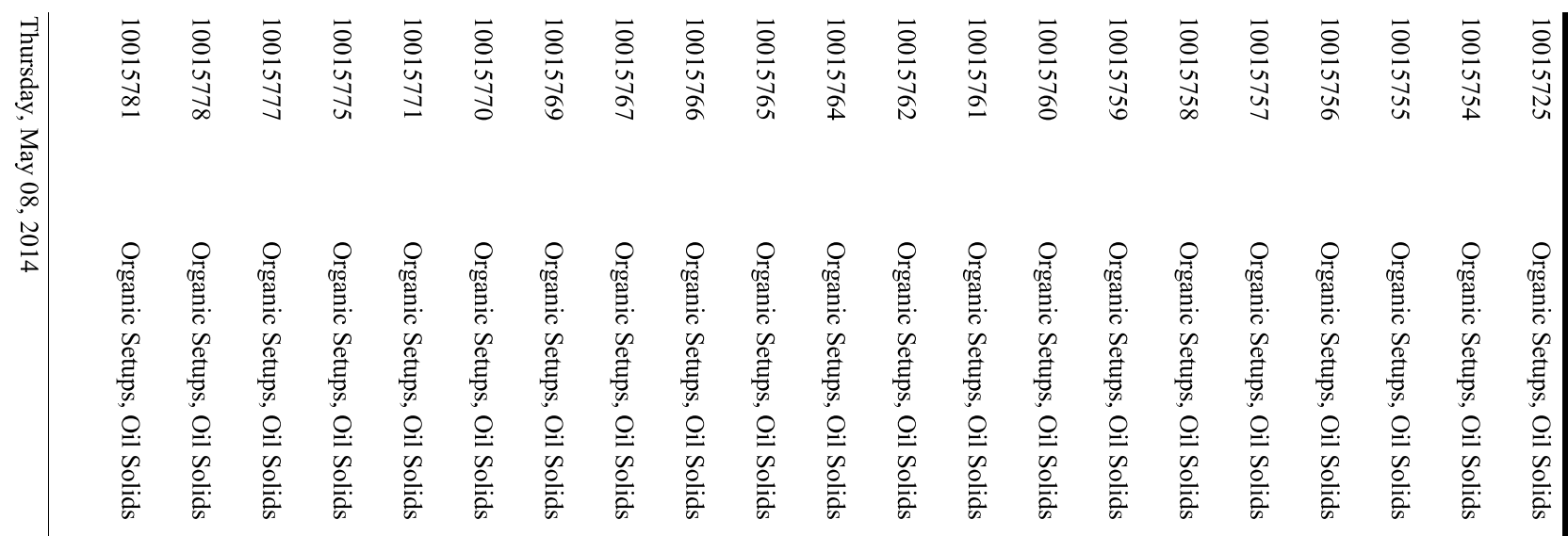

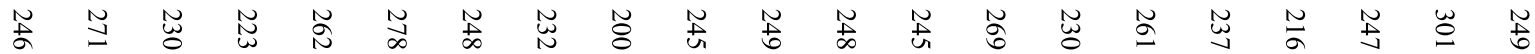

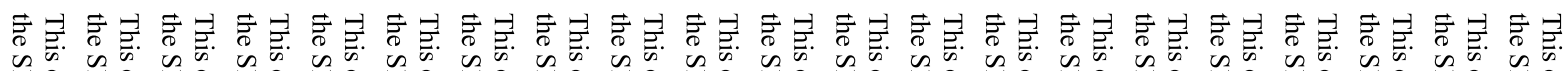

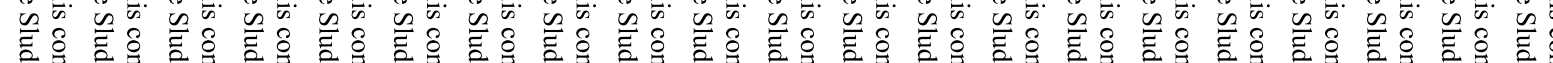

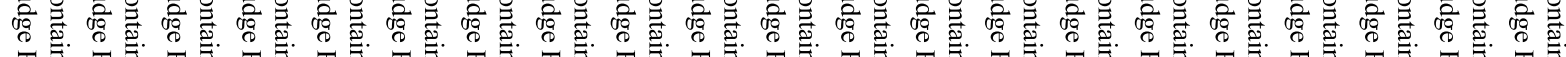

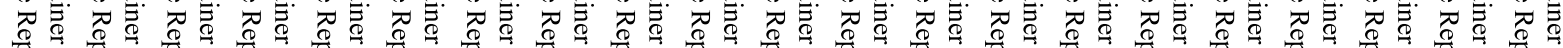

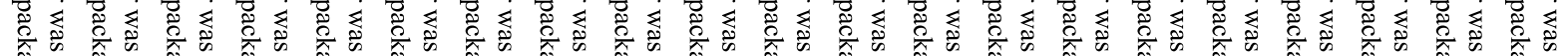

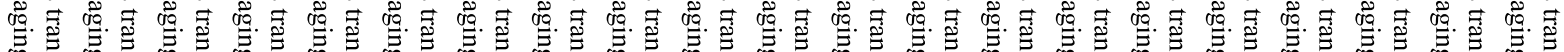

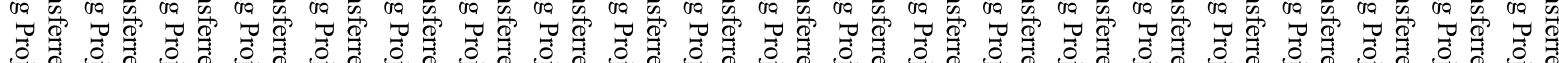

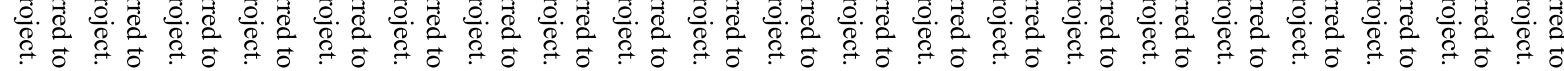

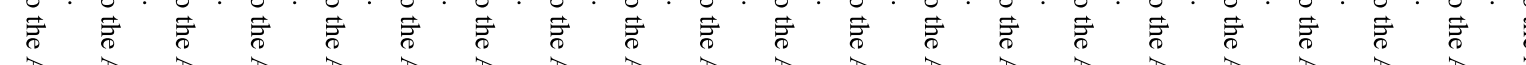




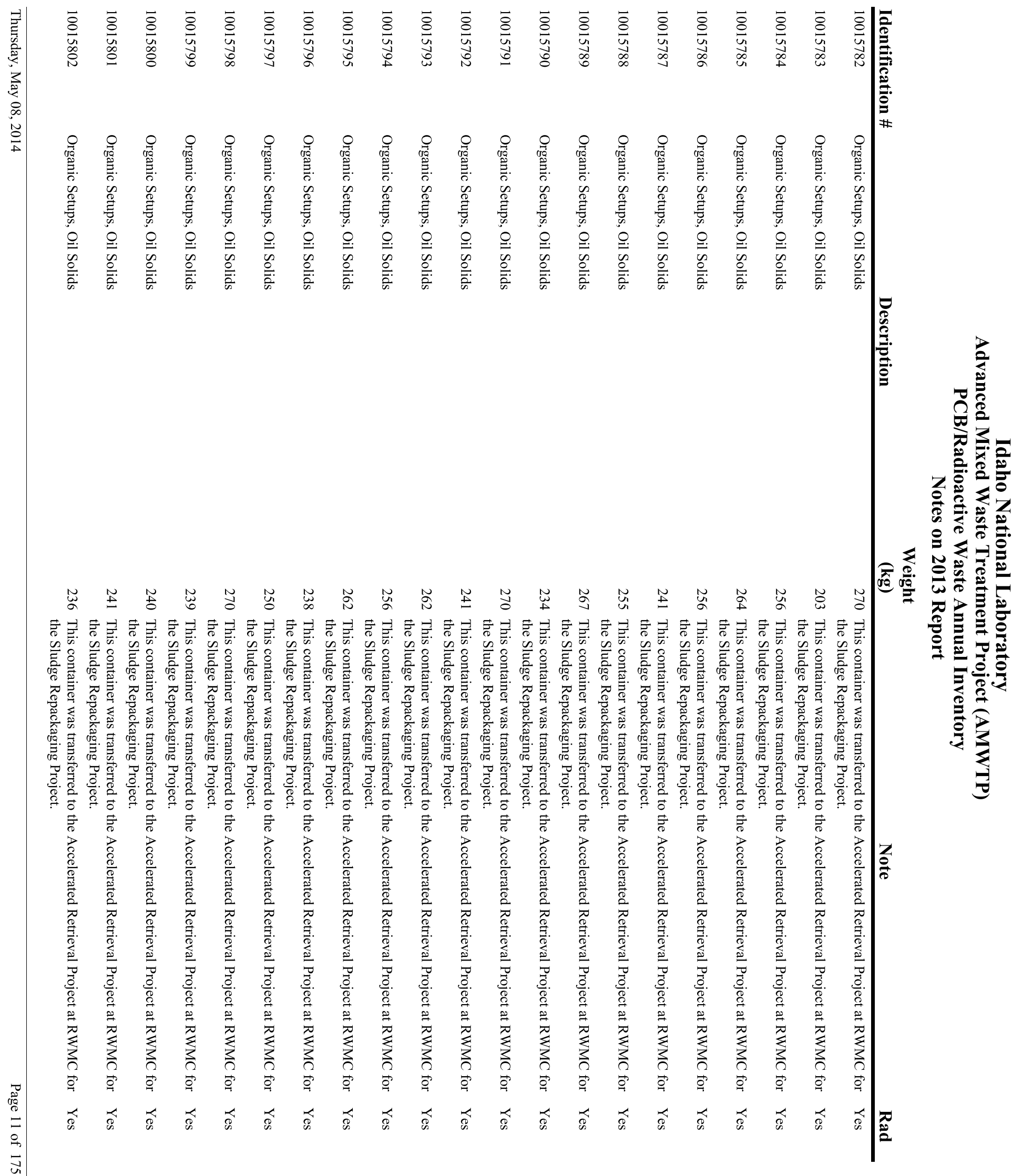




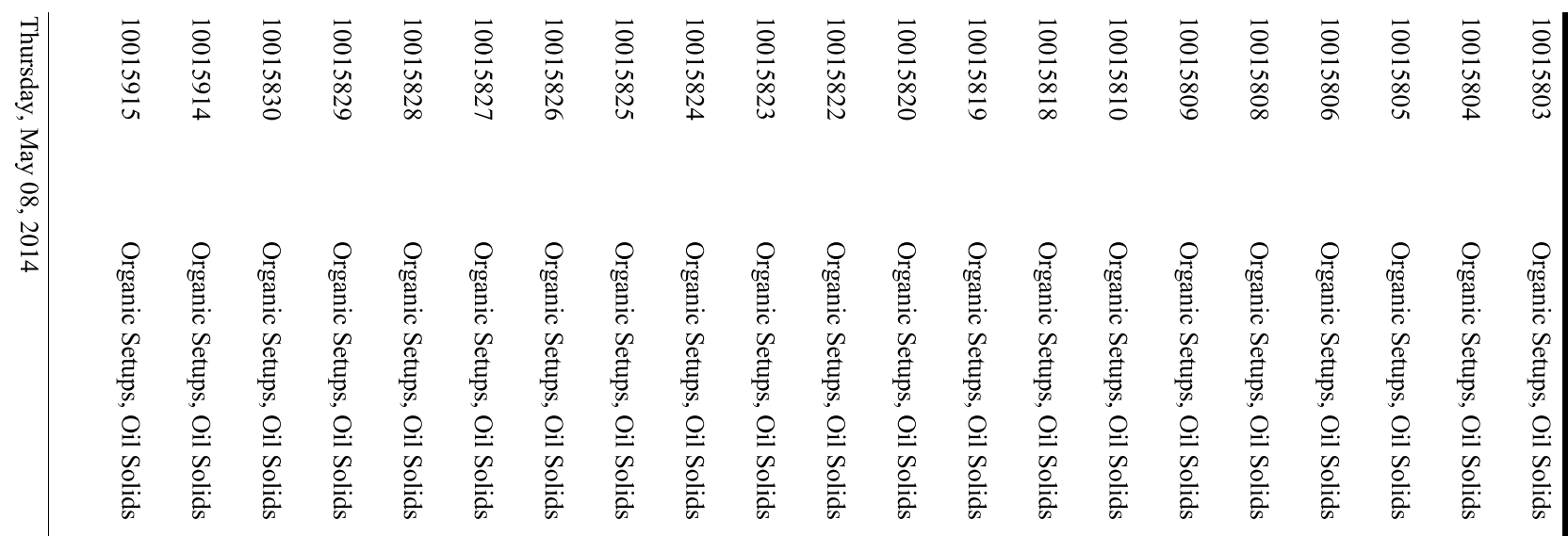

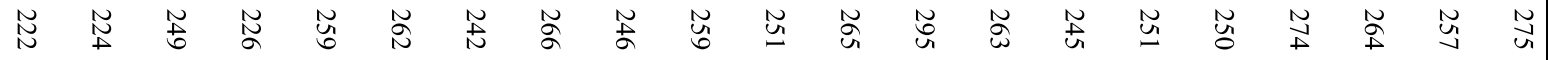

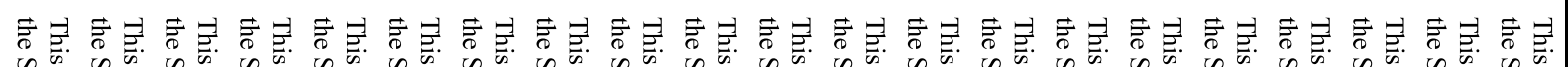

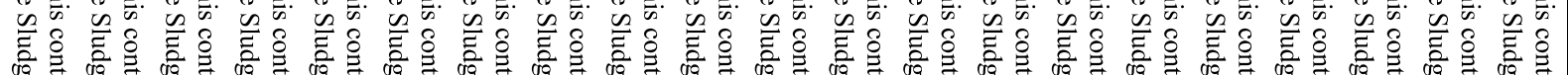

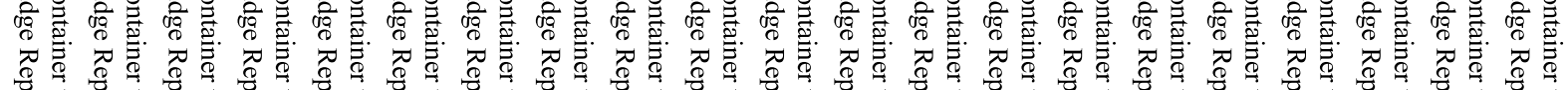

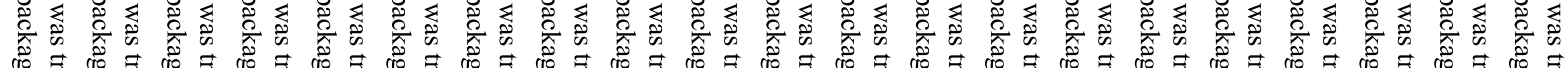

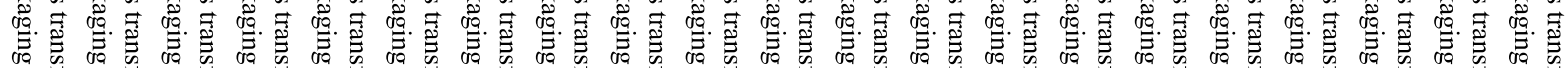

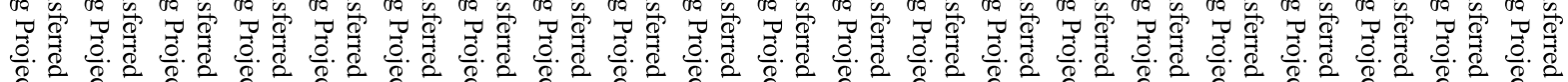

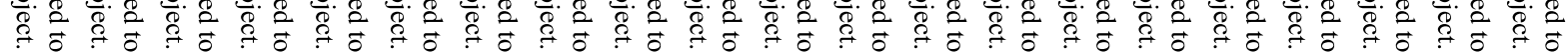

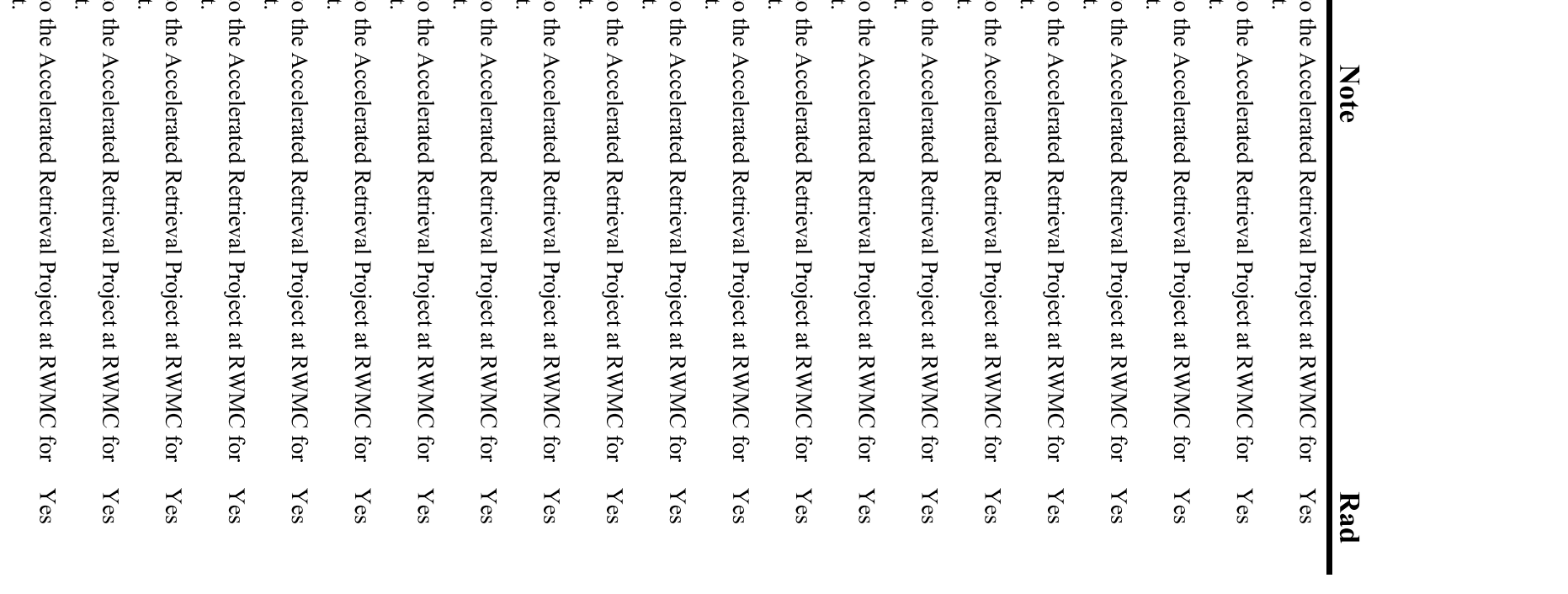




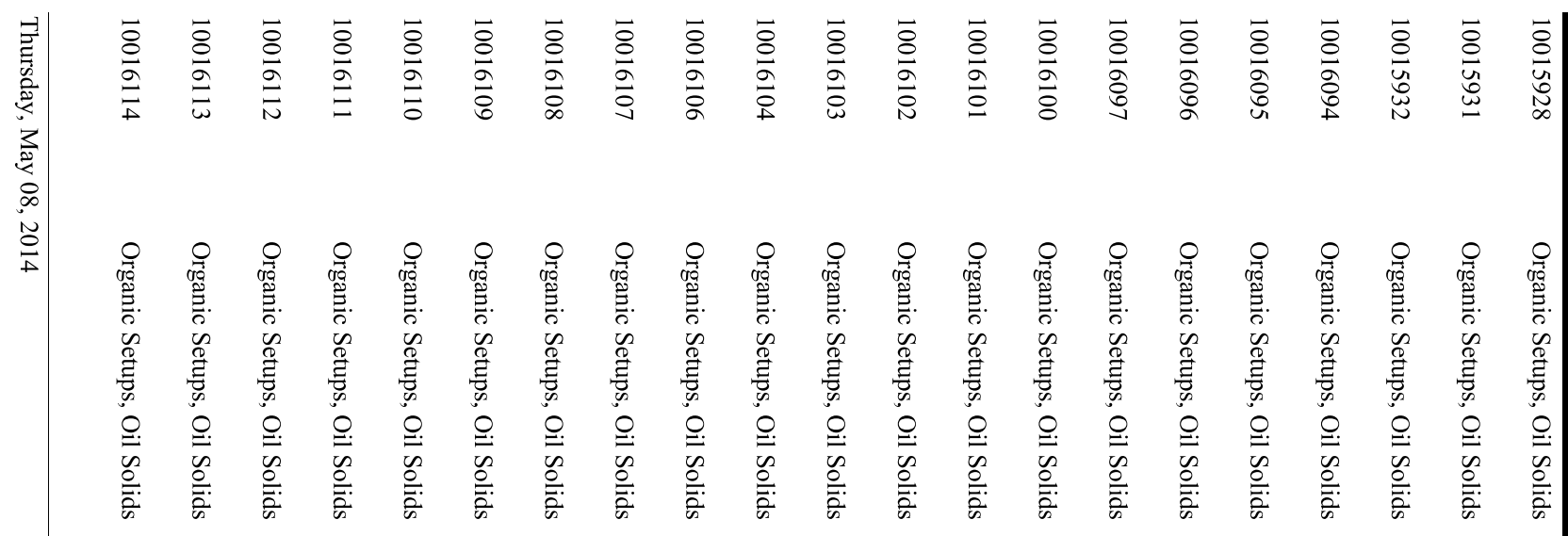

设

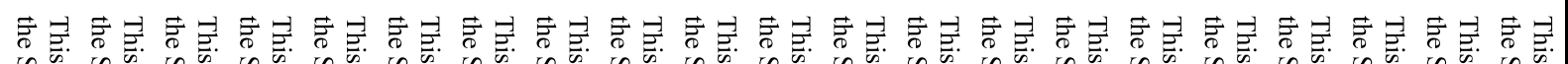

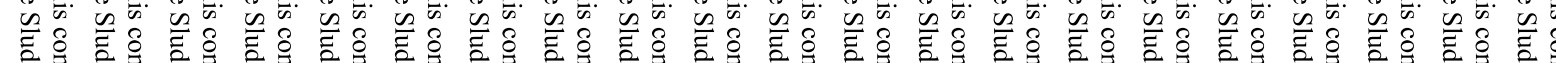

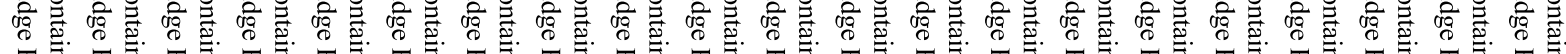

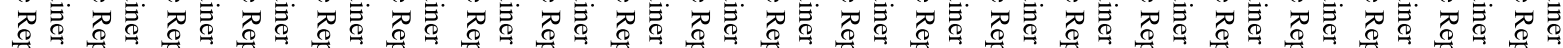

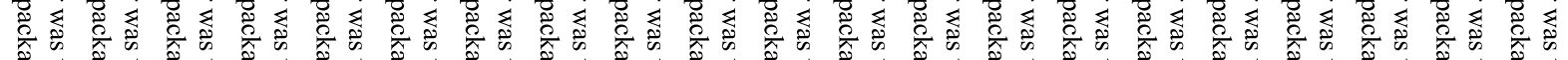

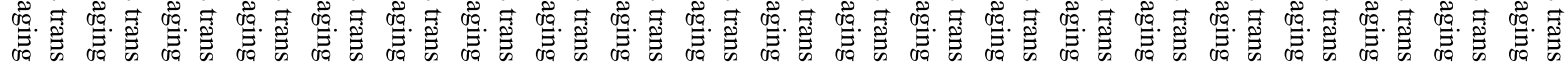

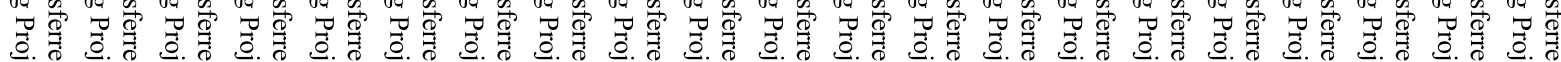

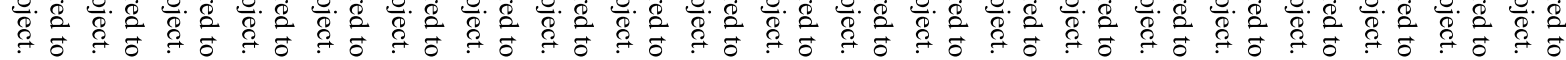

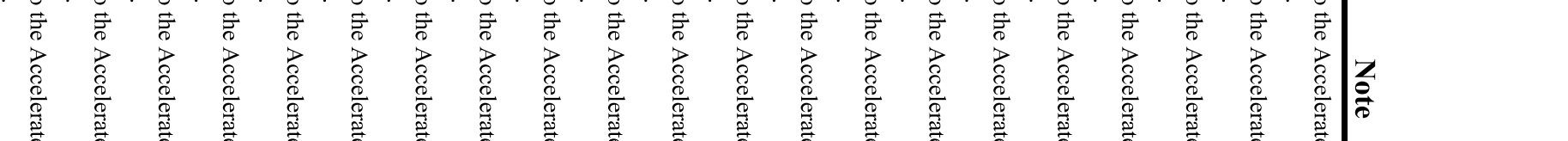




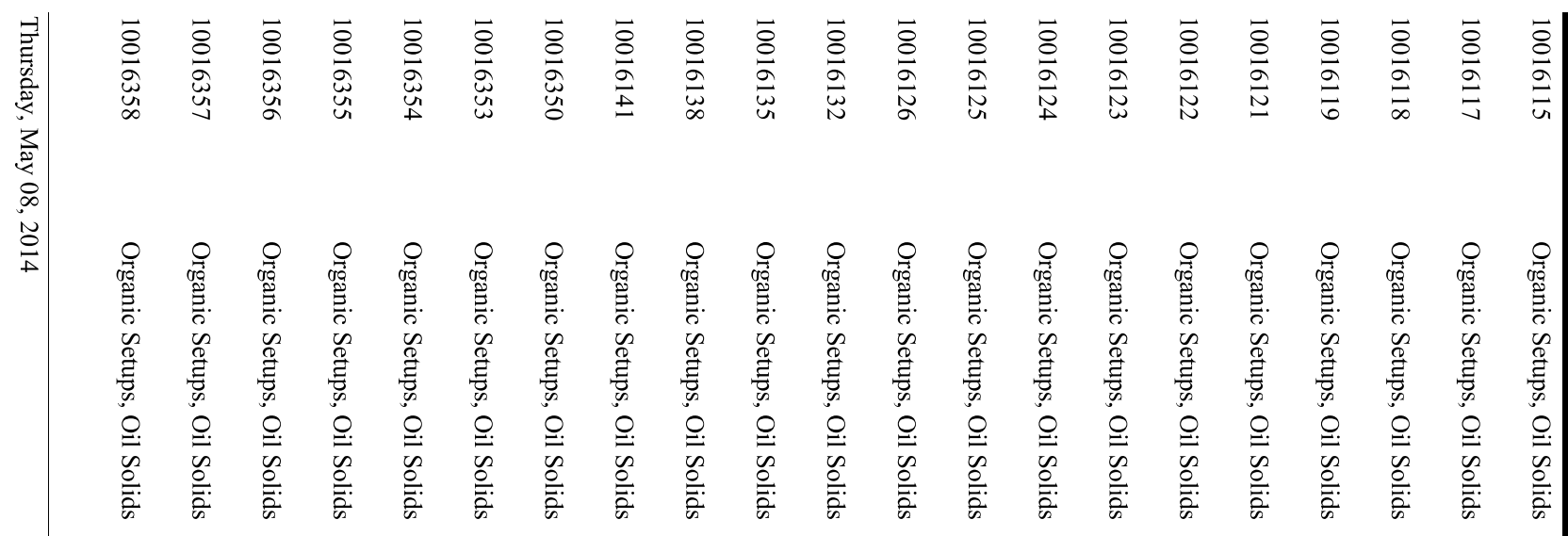

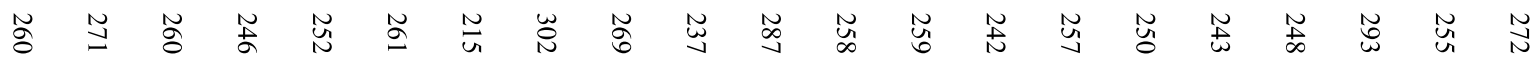

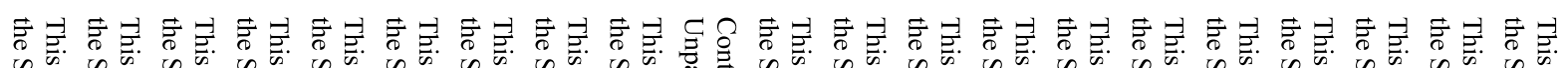

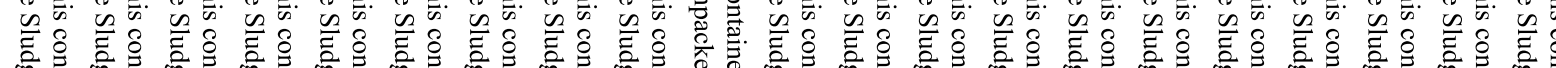

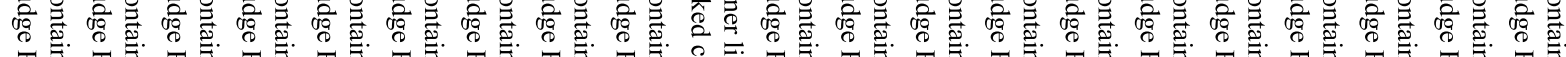

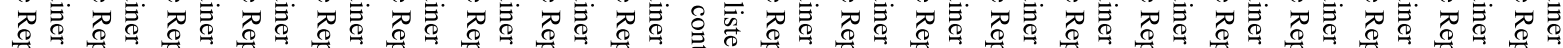

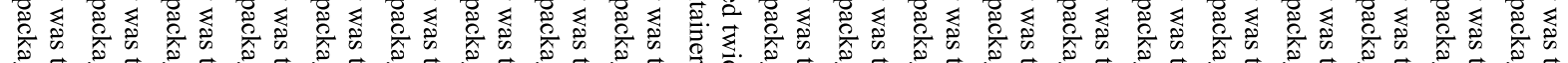

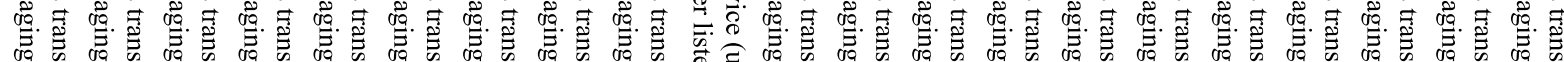

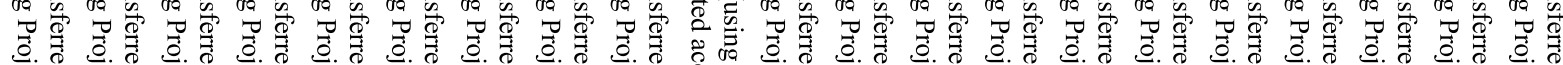

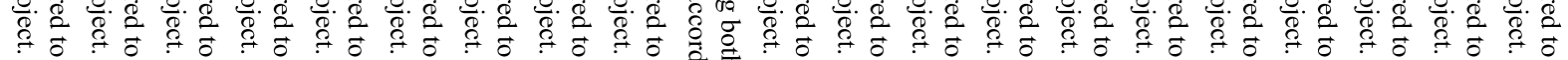

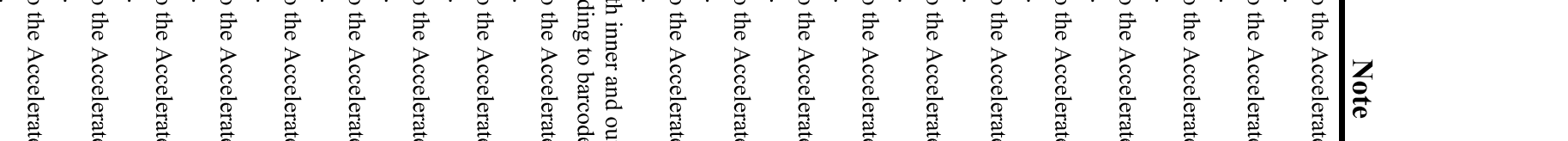

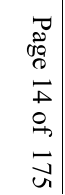




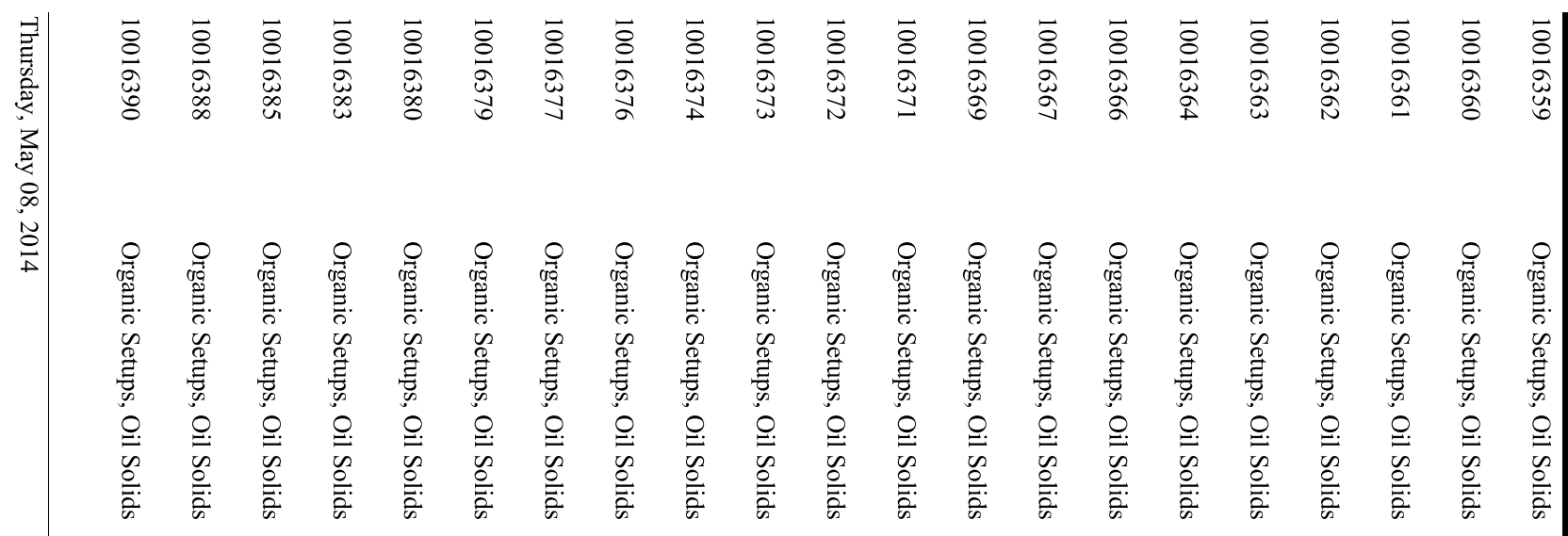

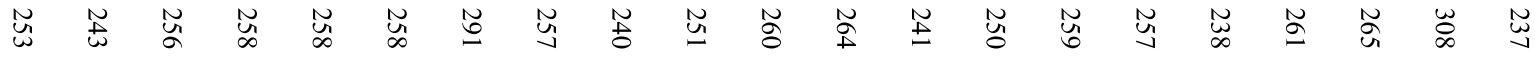

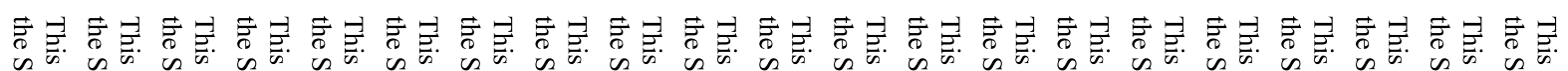

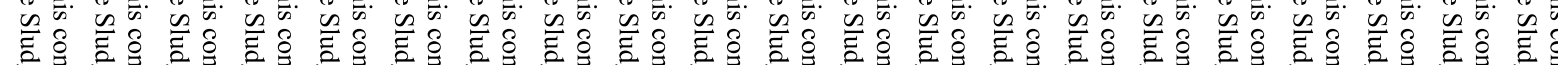

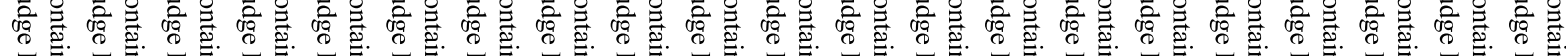
不

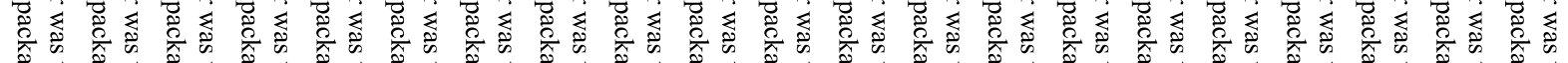

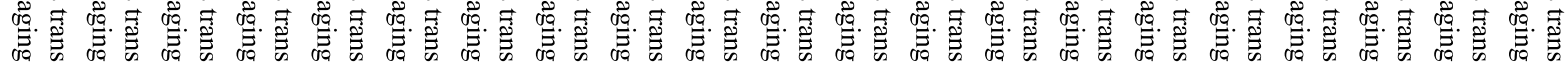

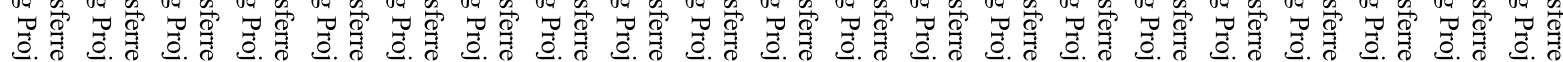

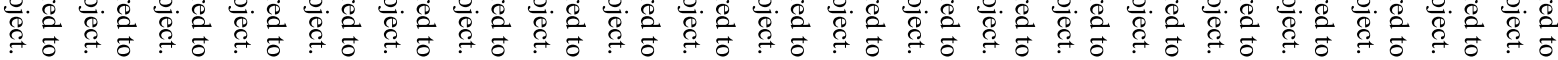

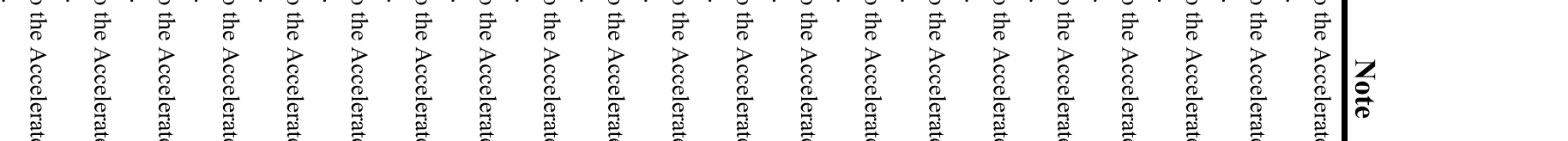




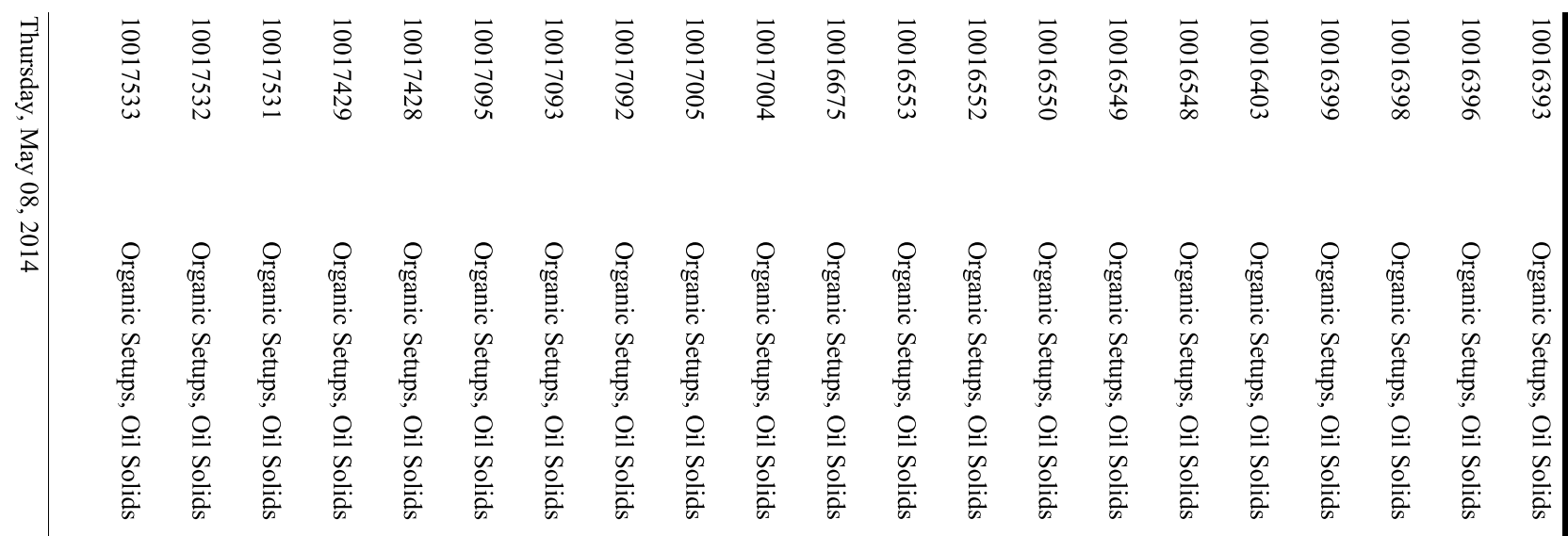

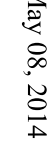

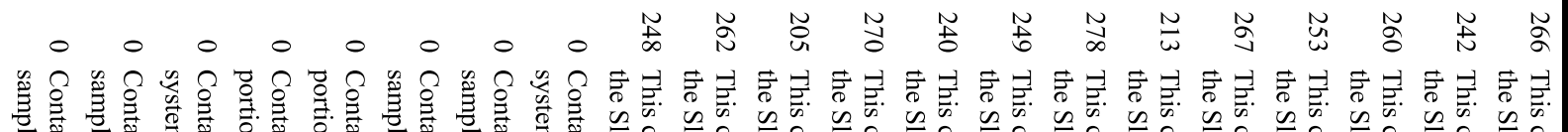

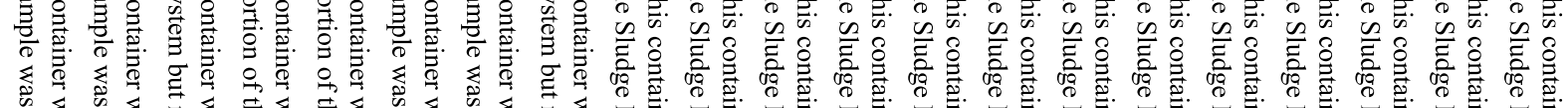

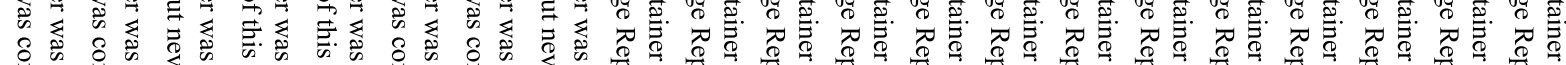

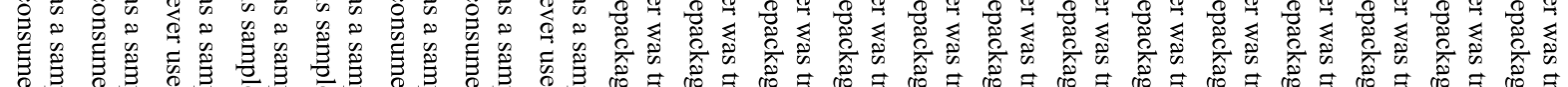

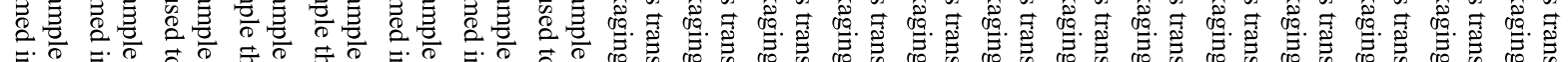

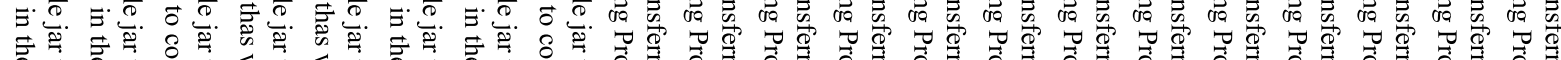

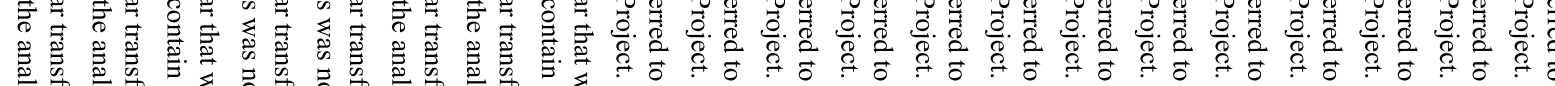

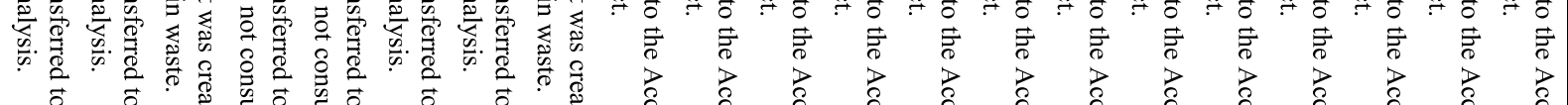

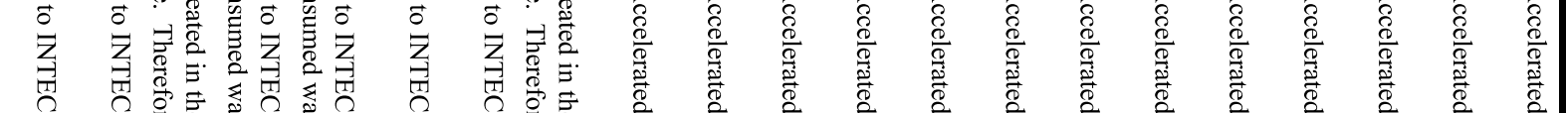
(2) 它

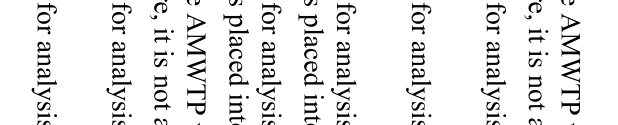

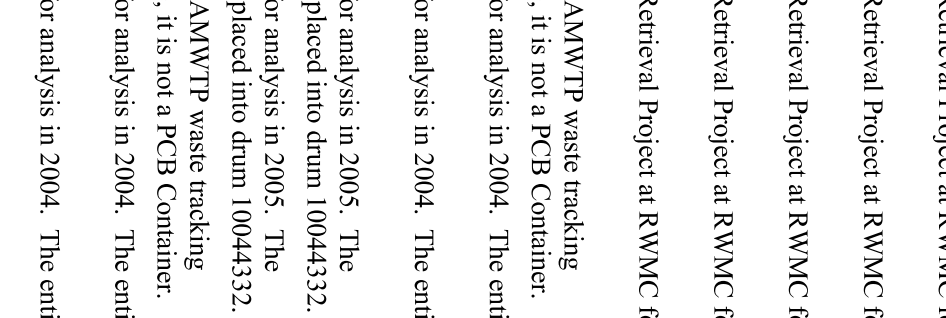

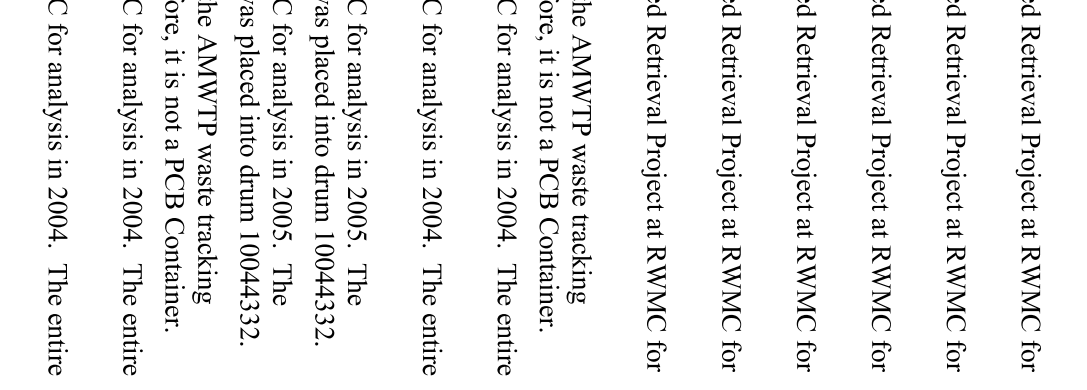

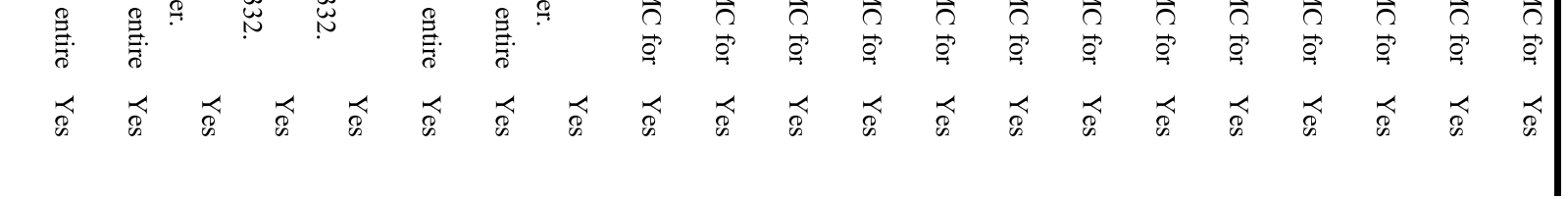




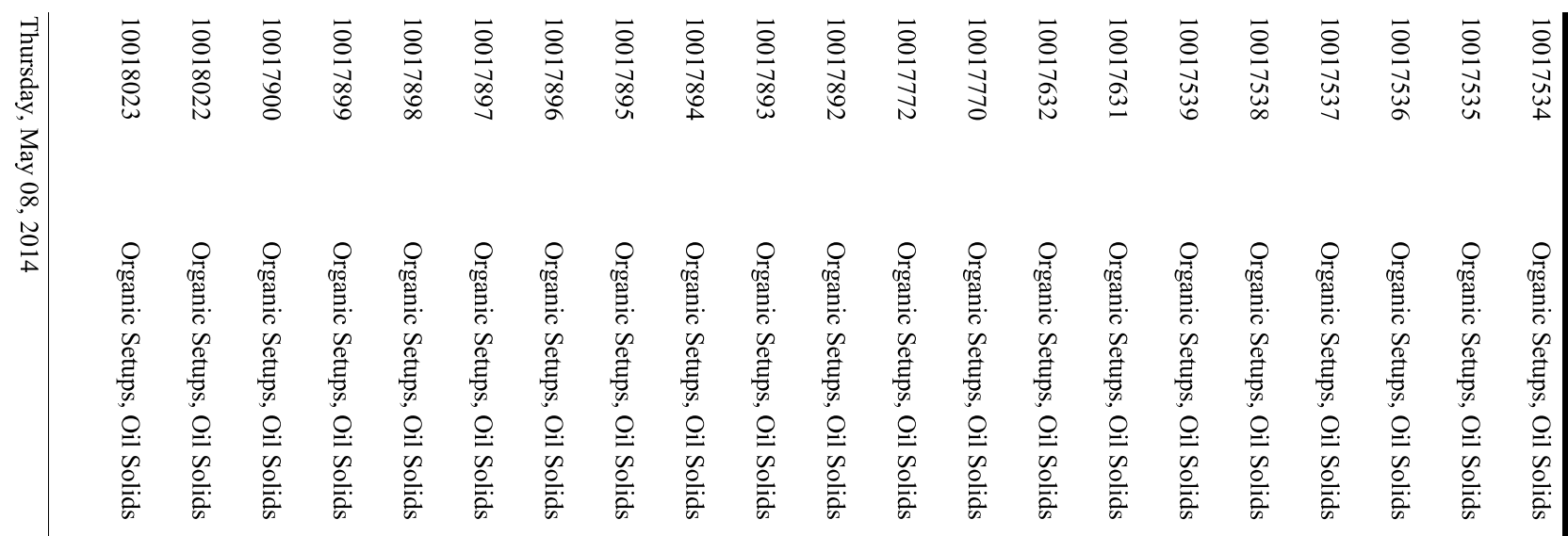

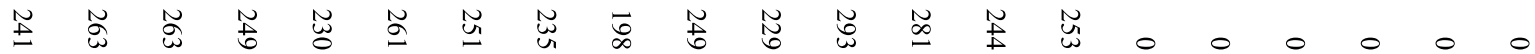

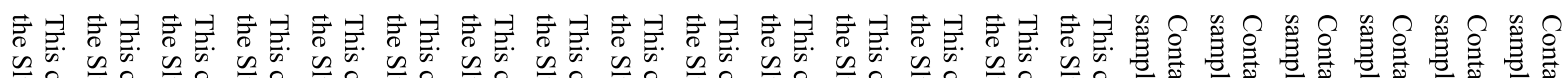

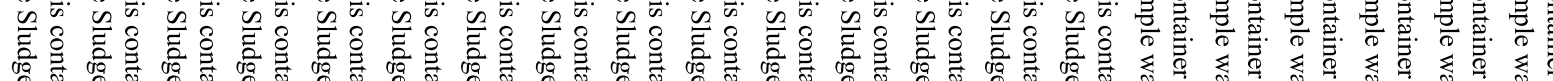

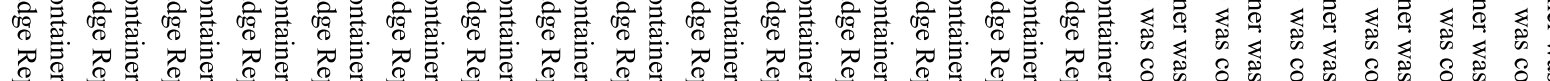

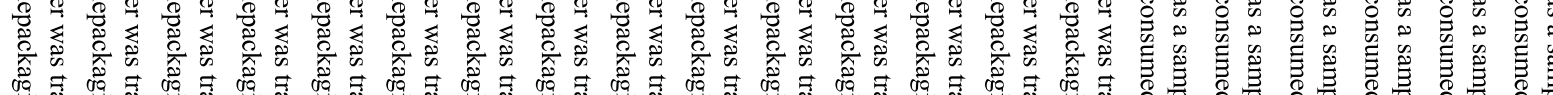

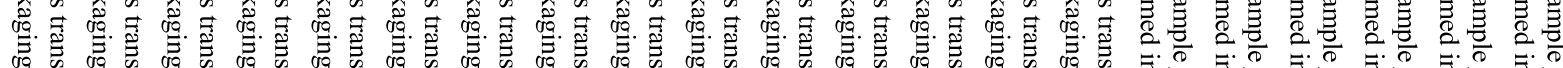

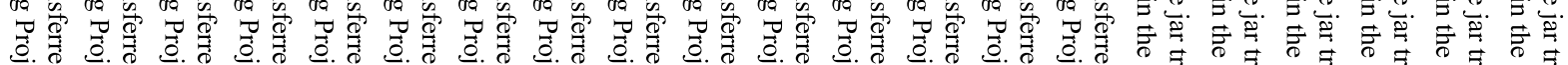

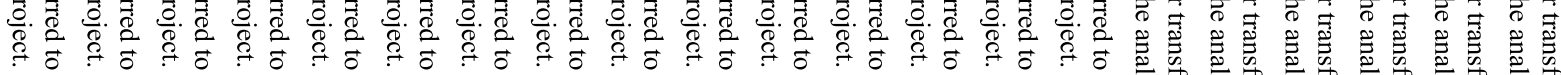

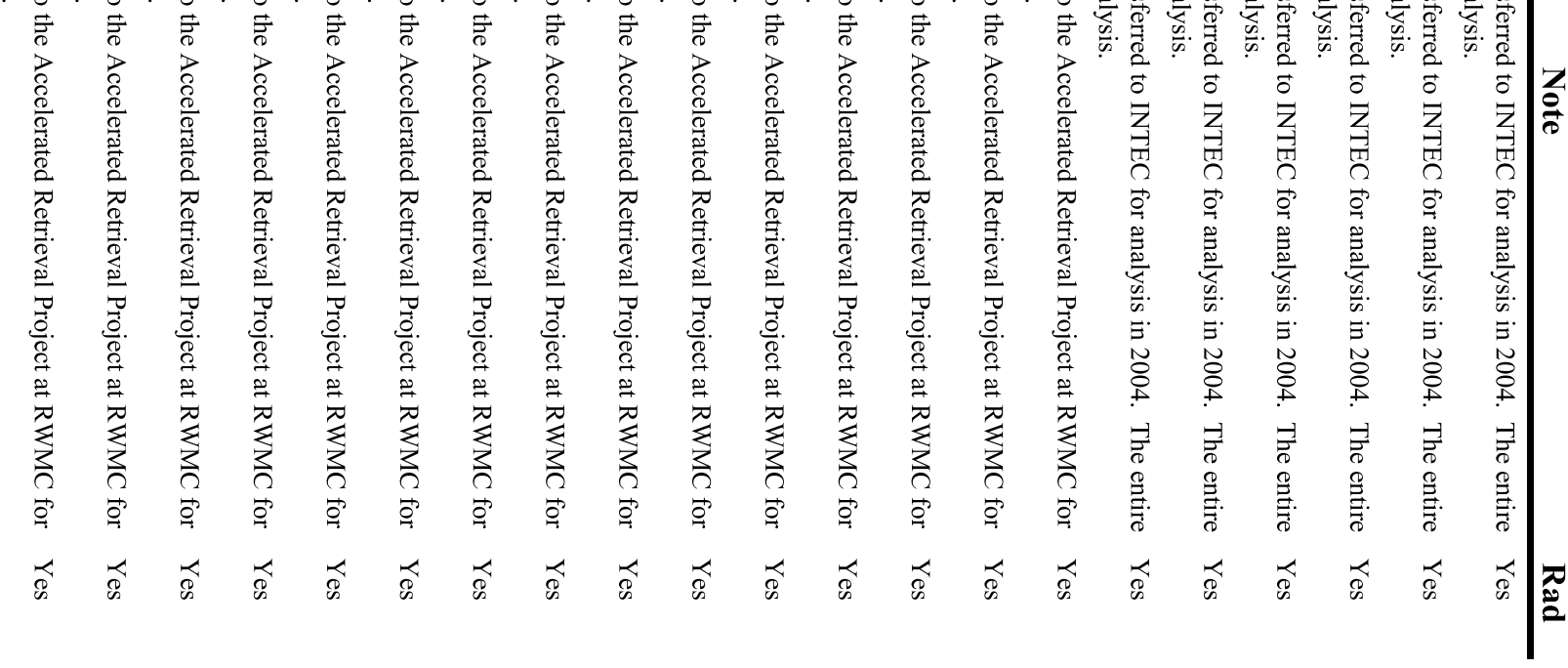




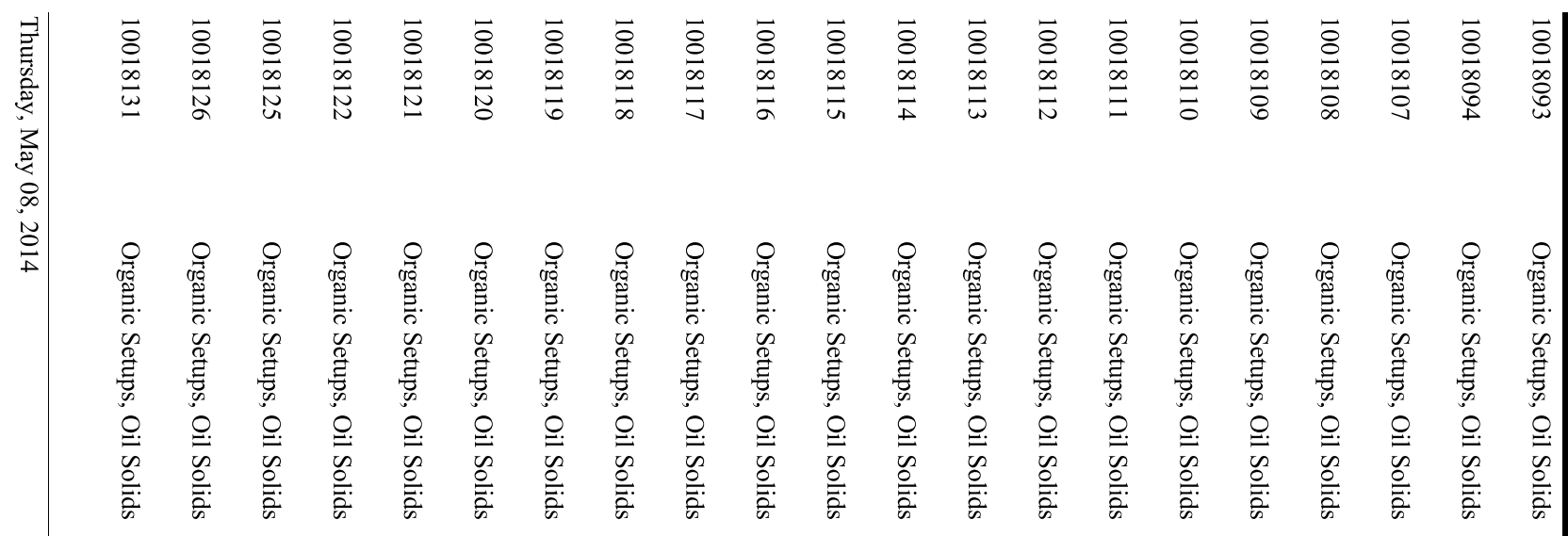

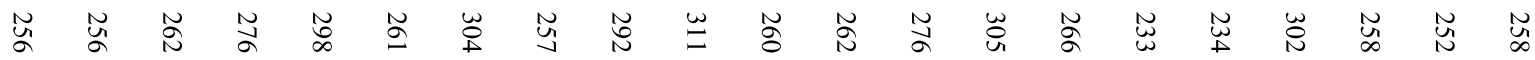

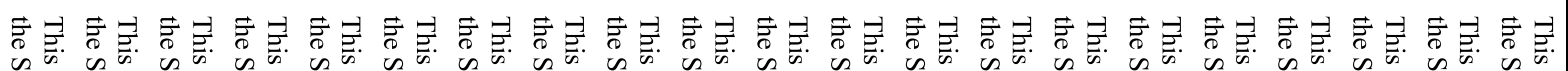

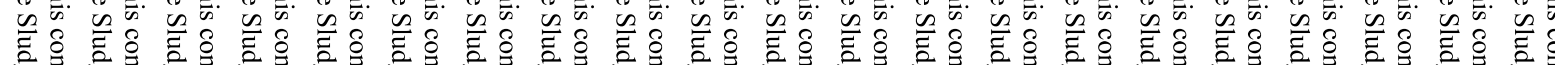

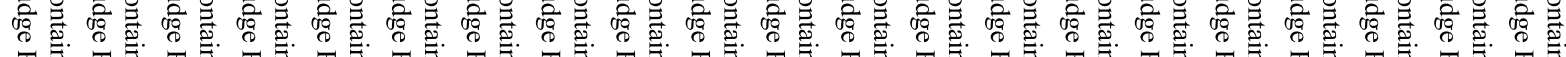
不

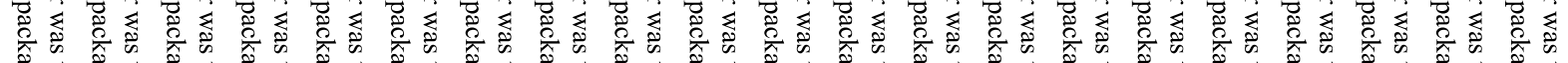

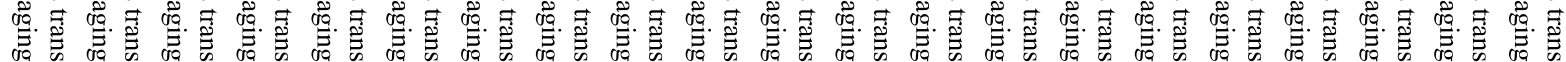

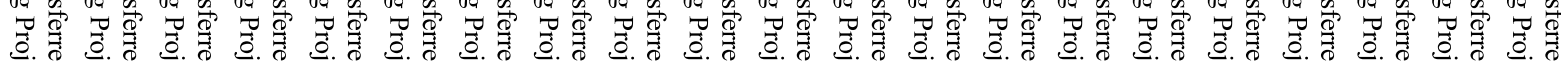

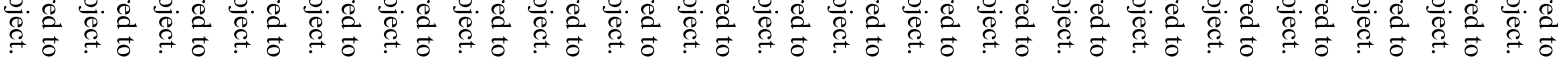

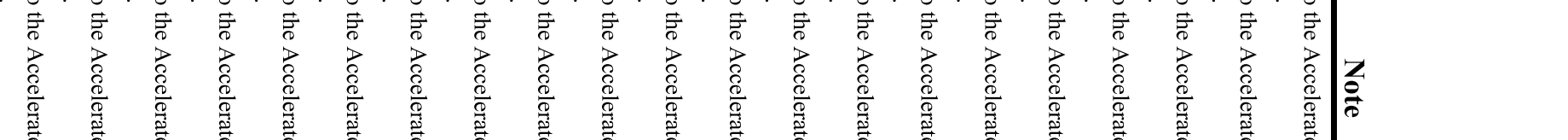




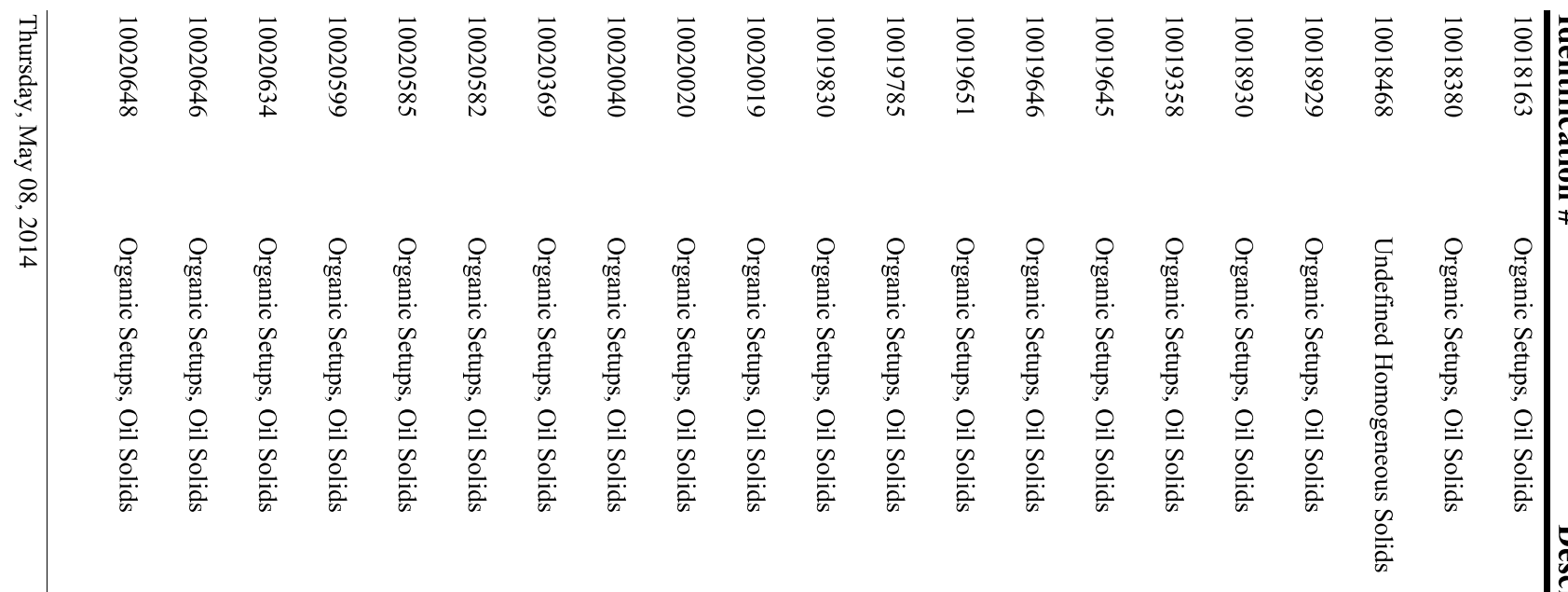

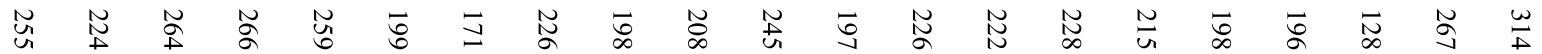

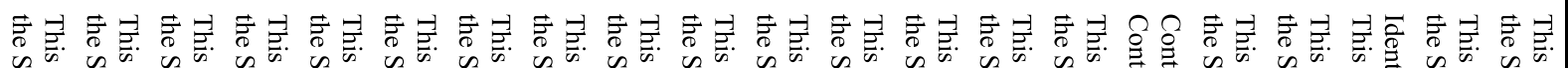

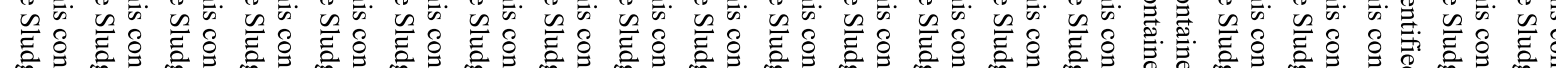

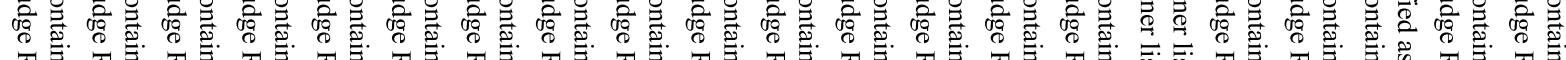

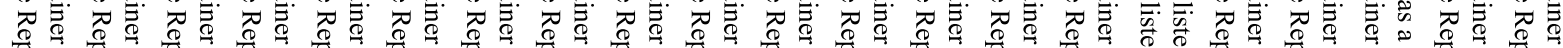

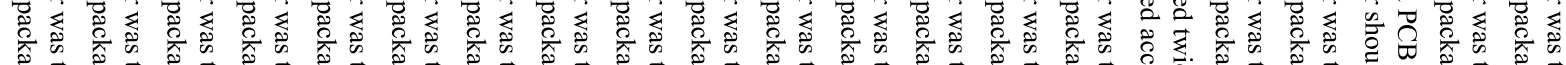

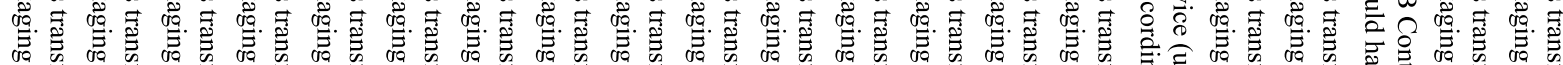

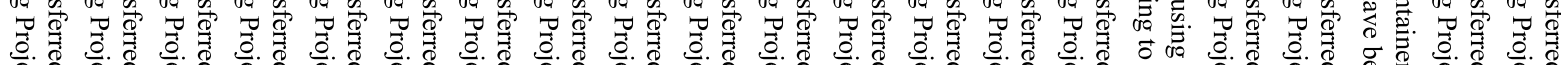

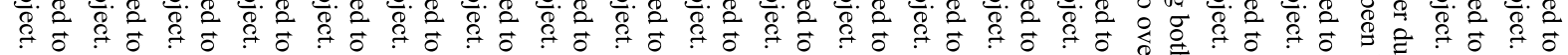




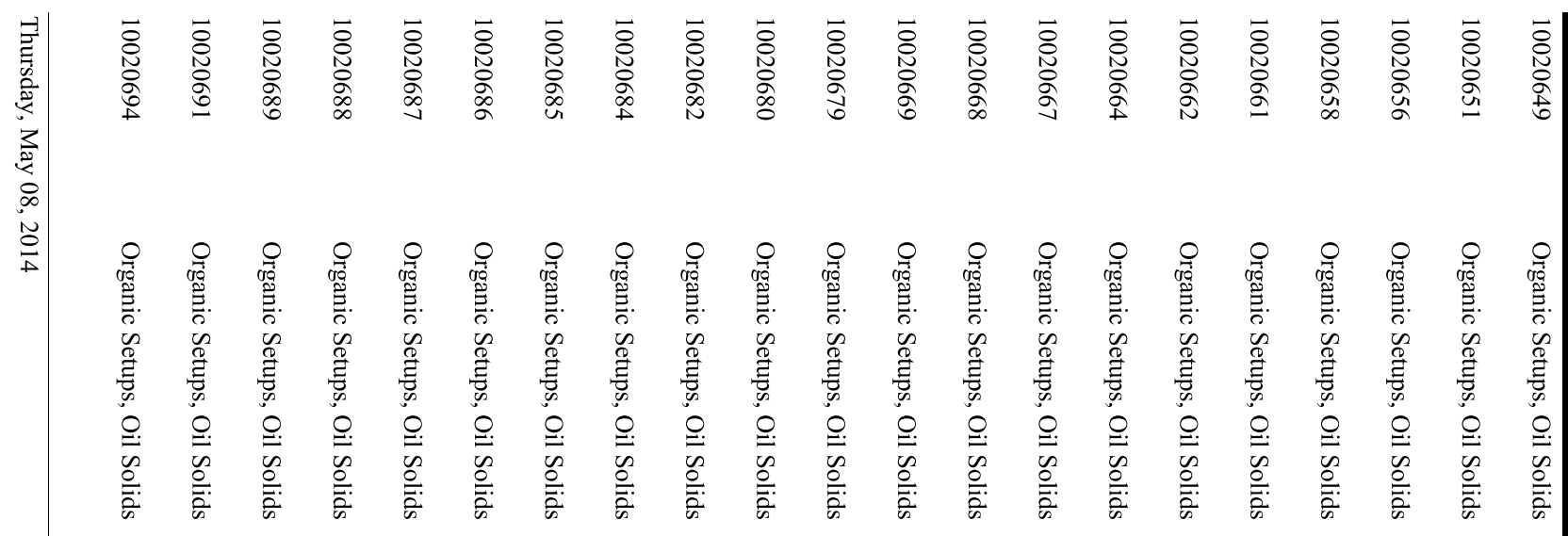

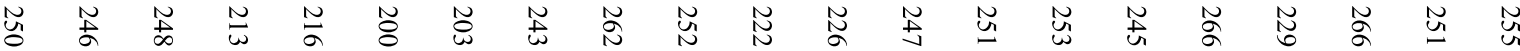

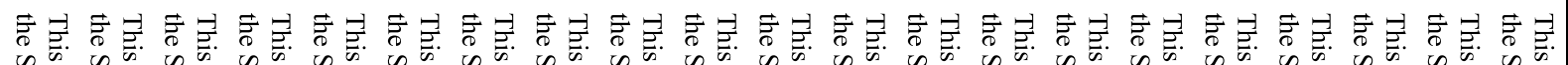

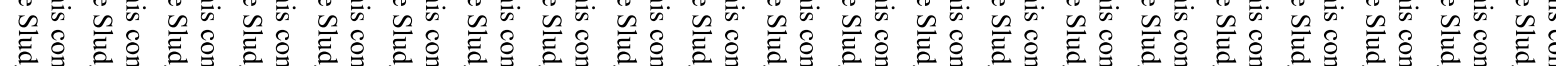

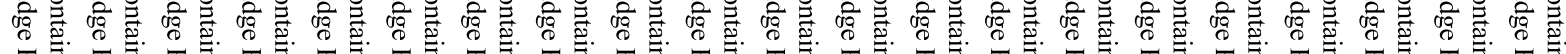
不

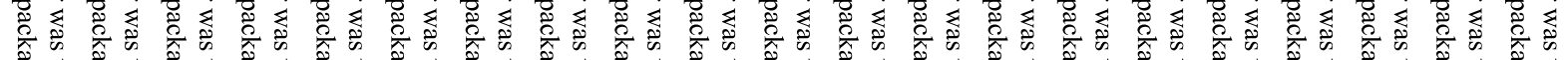

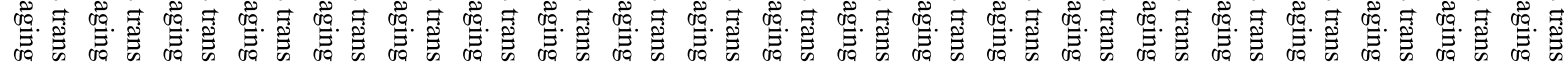

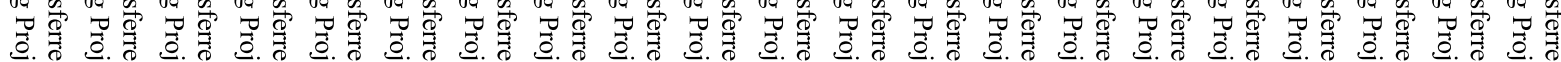

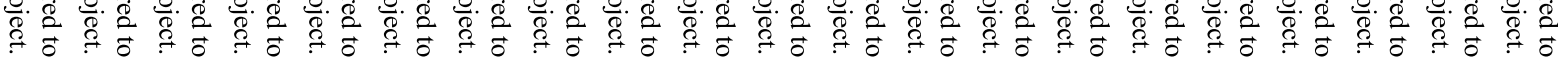

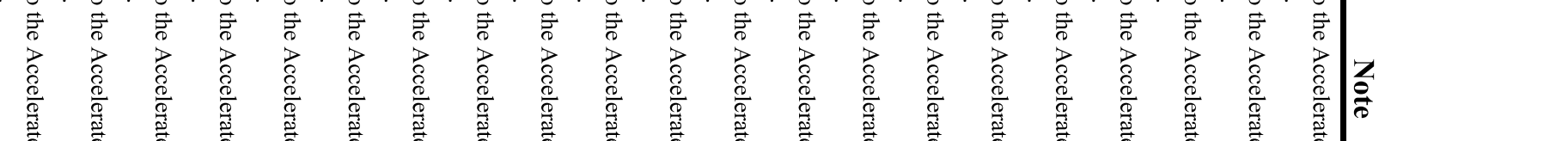




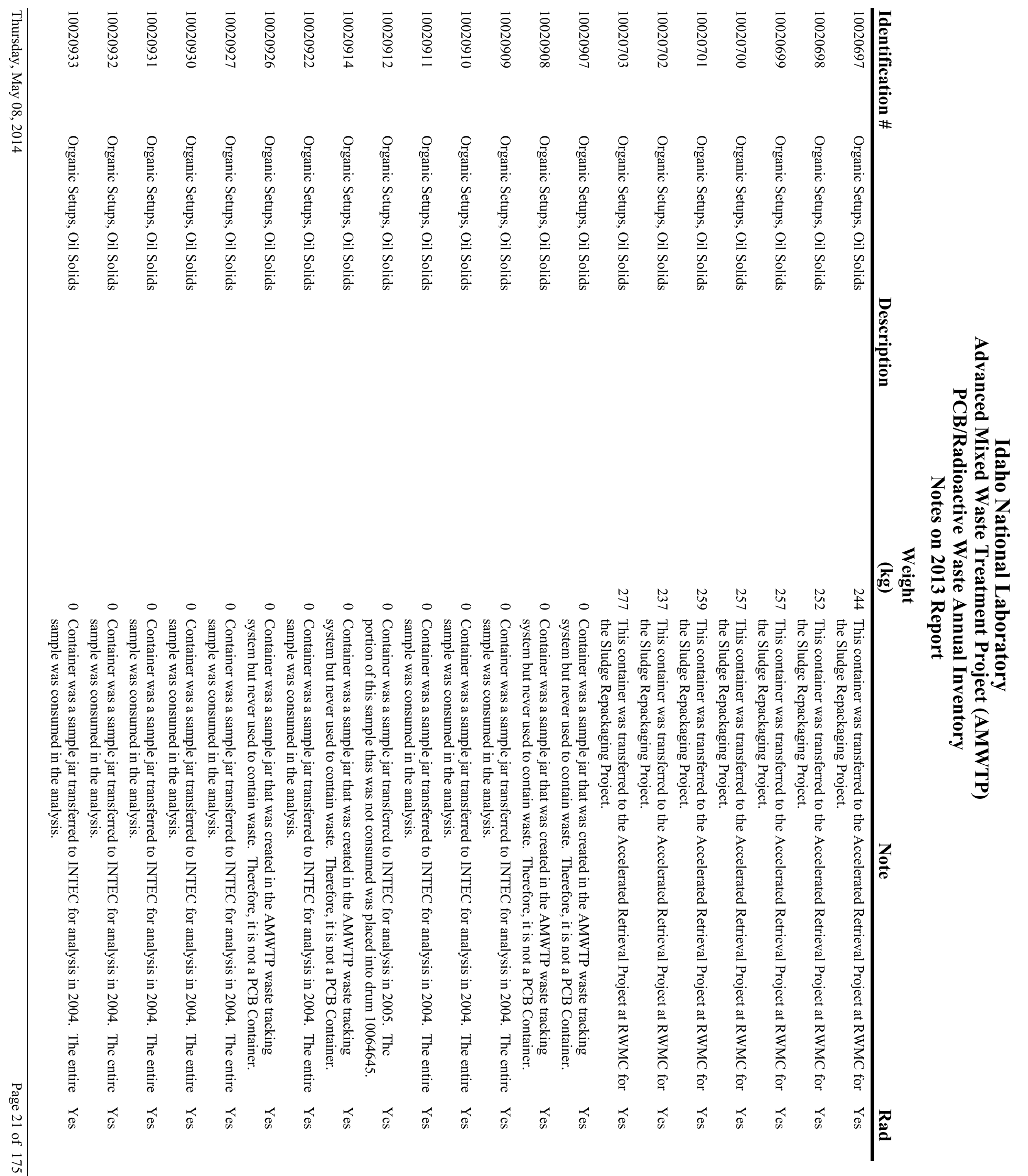




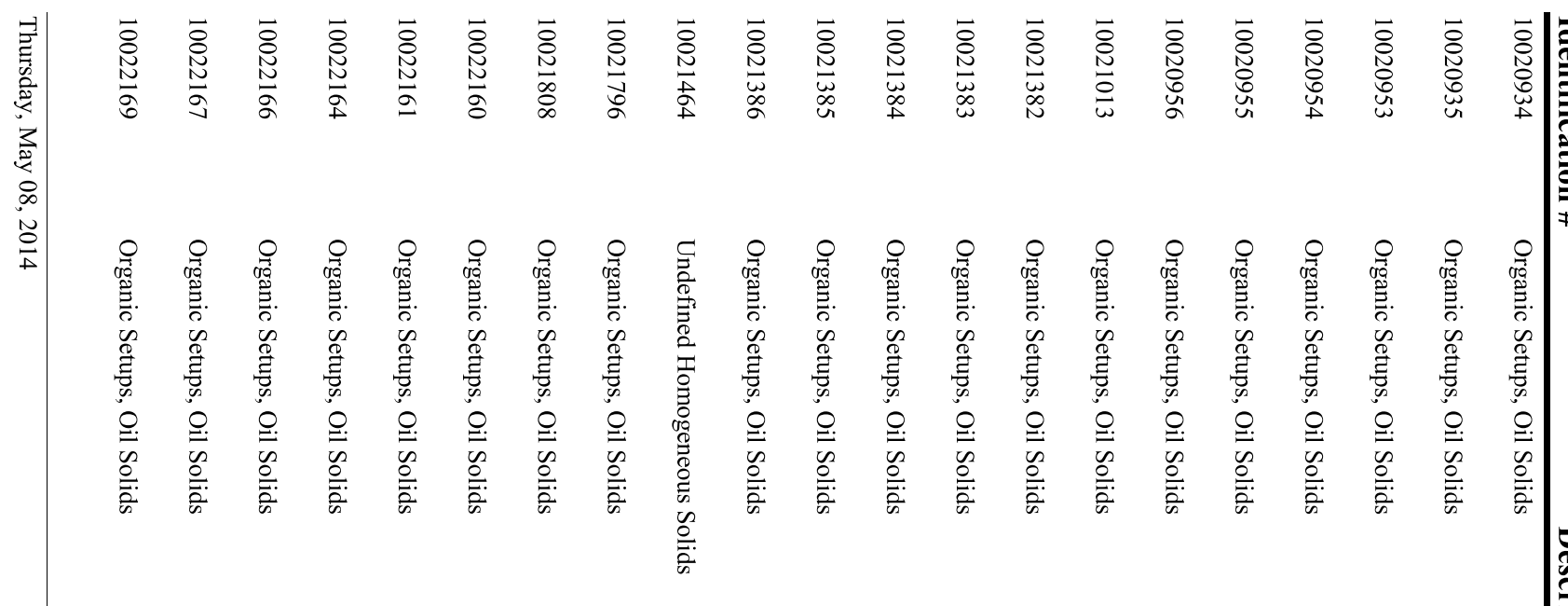

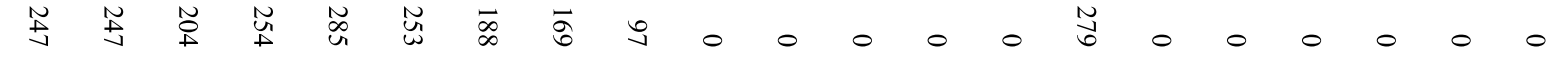

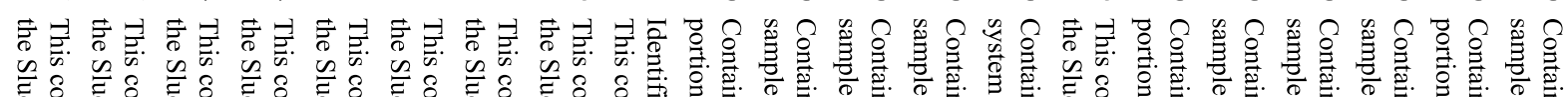

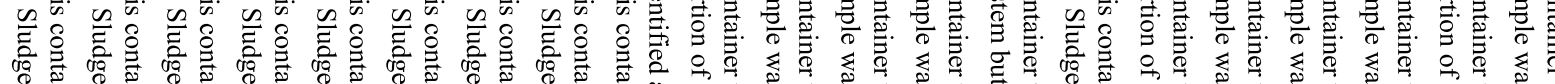

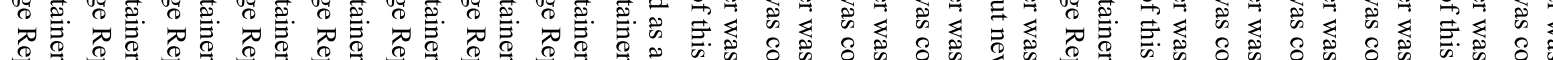

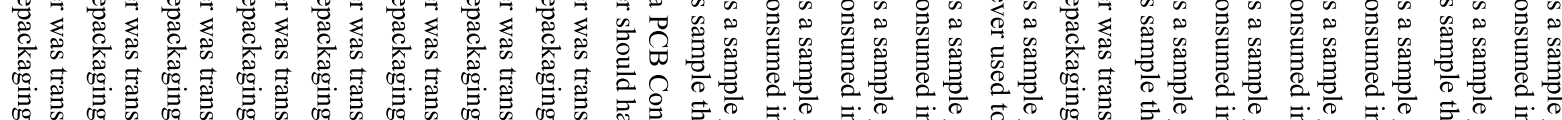

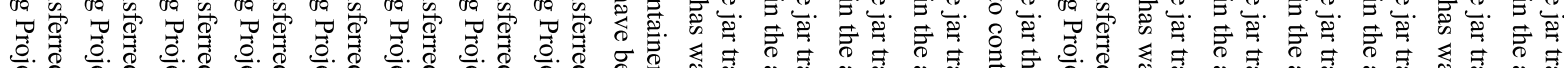

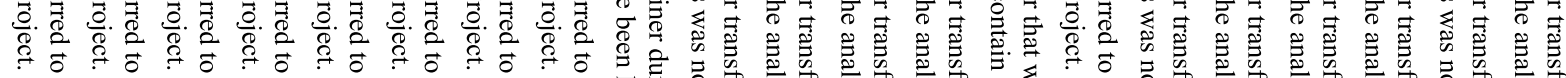

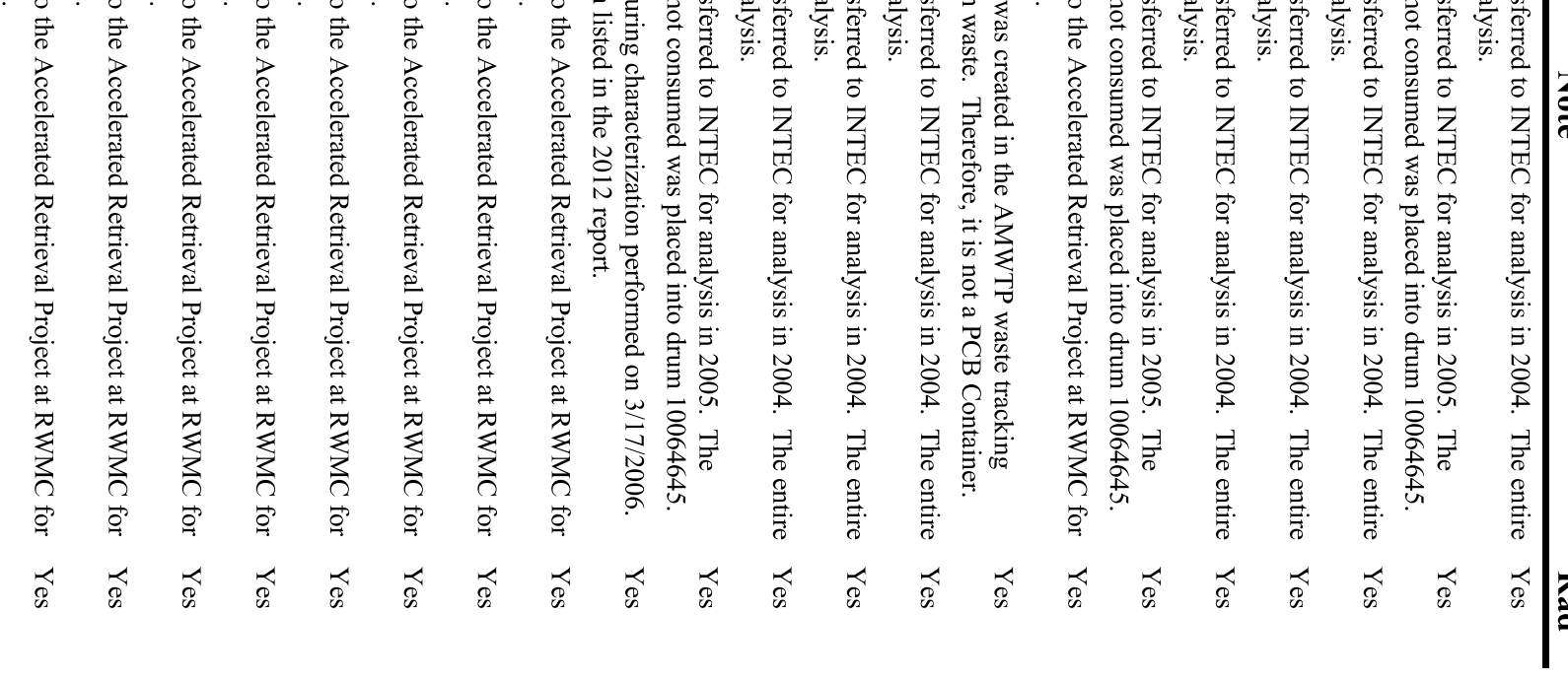



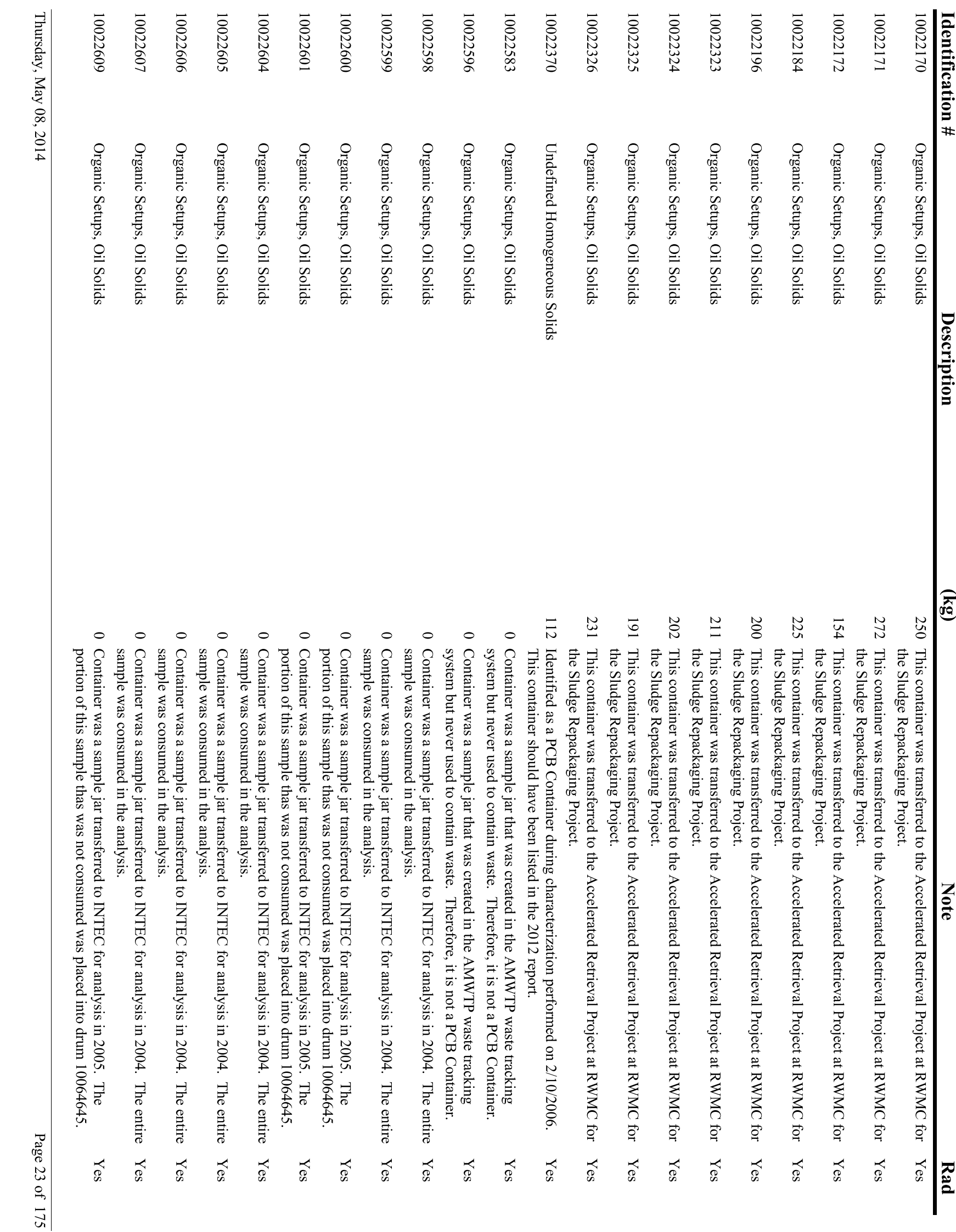


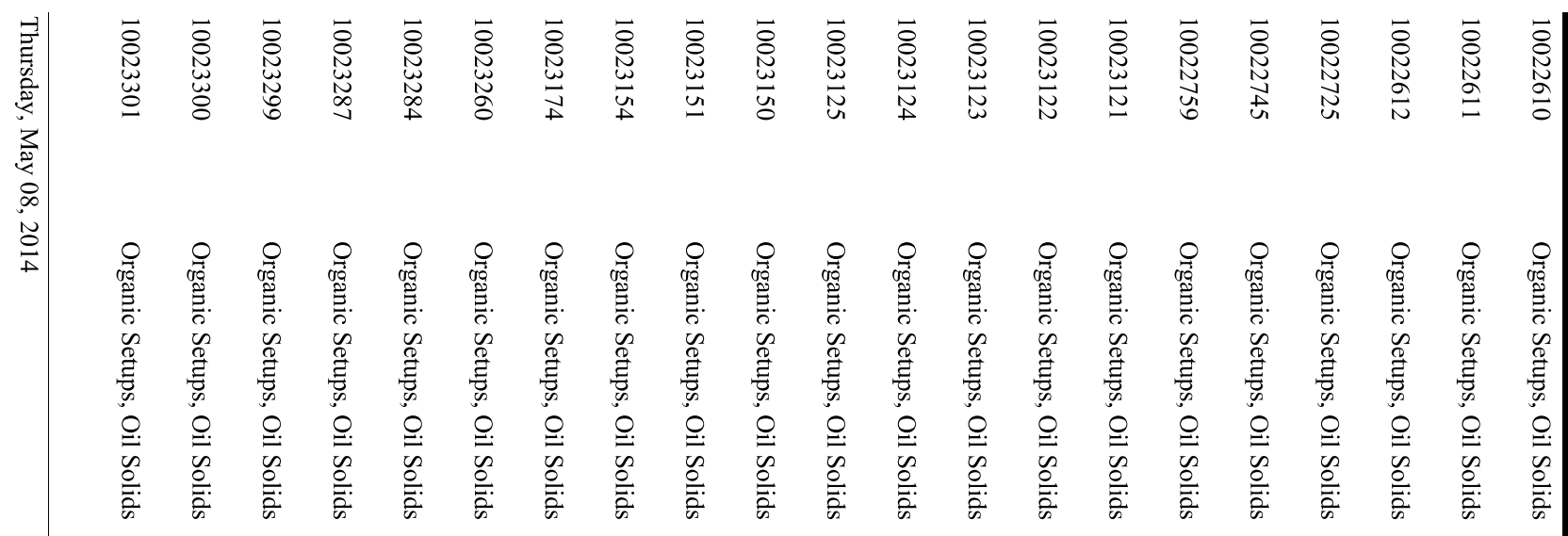

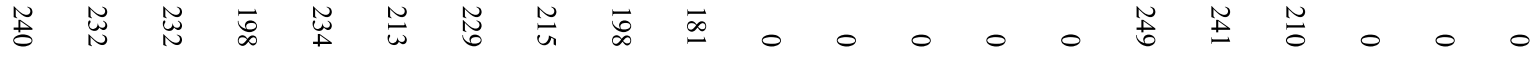

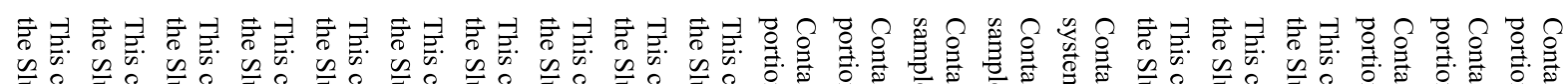

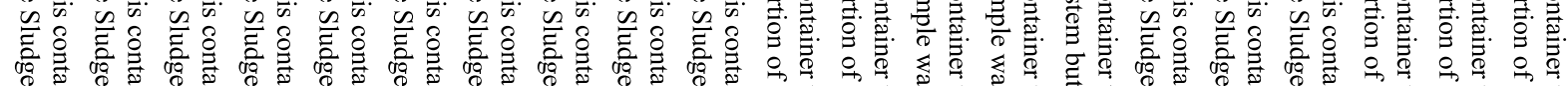

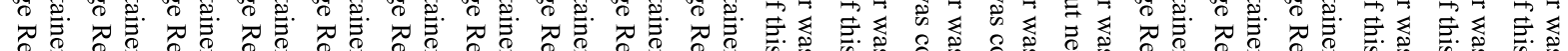

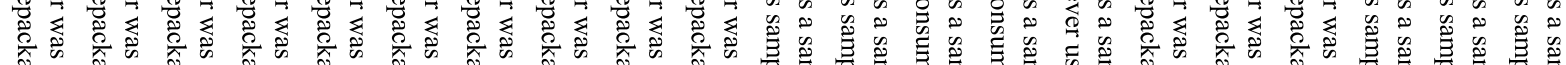

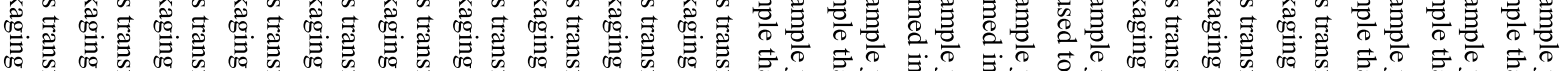

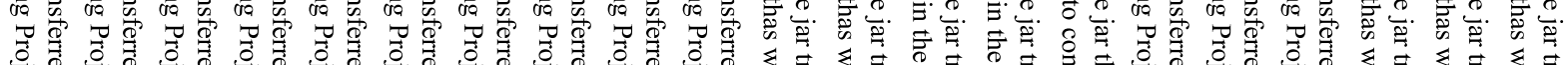

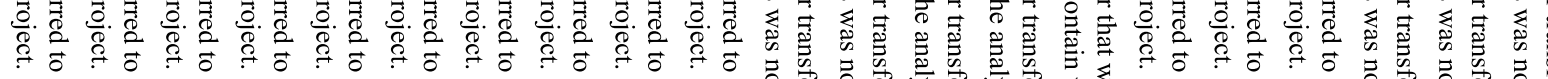

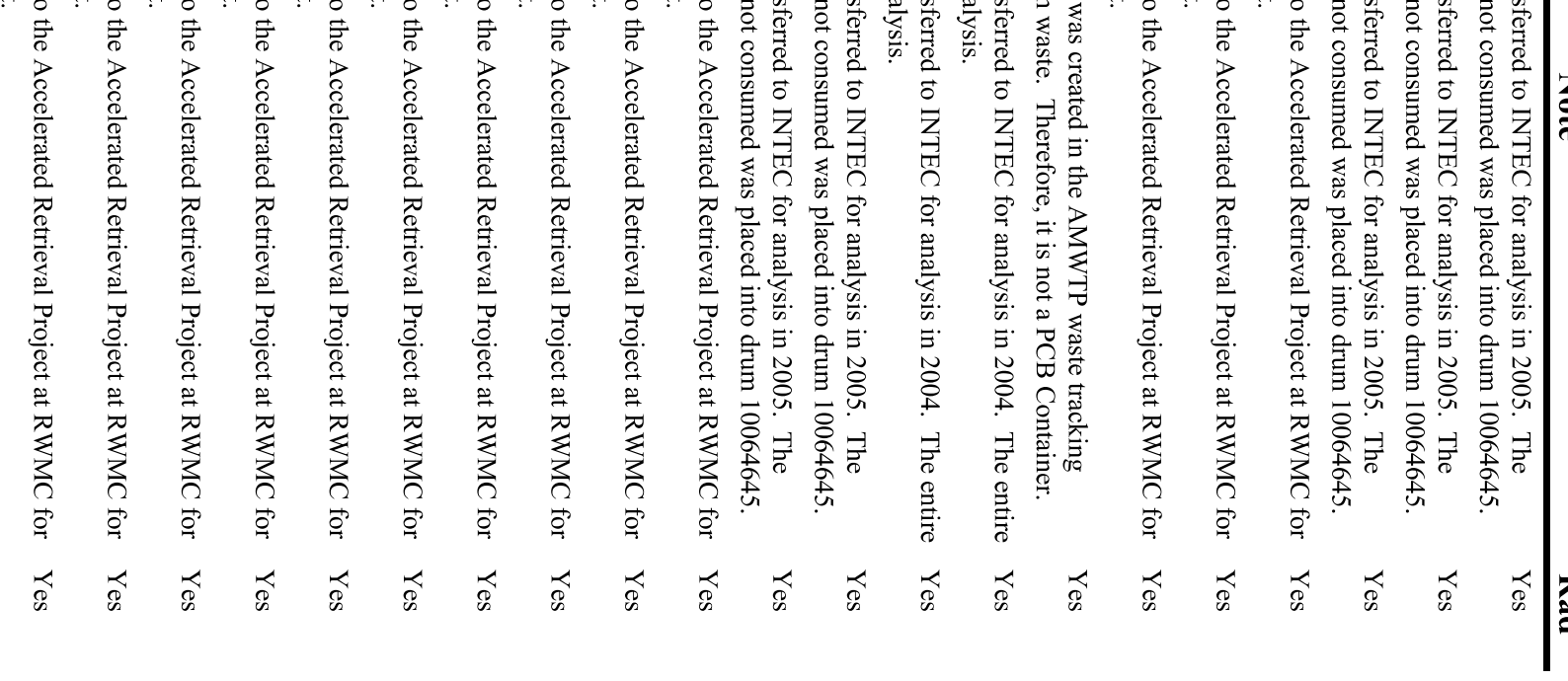




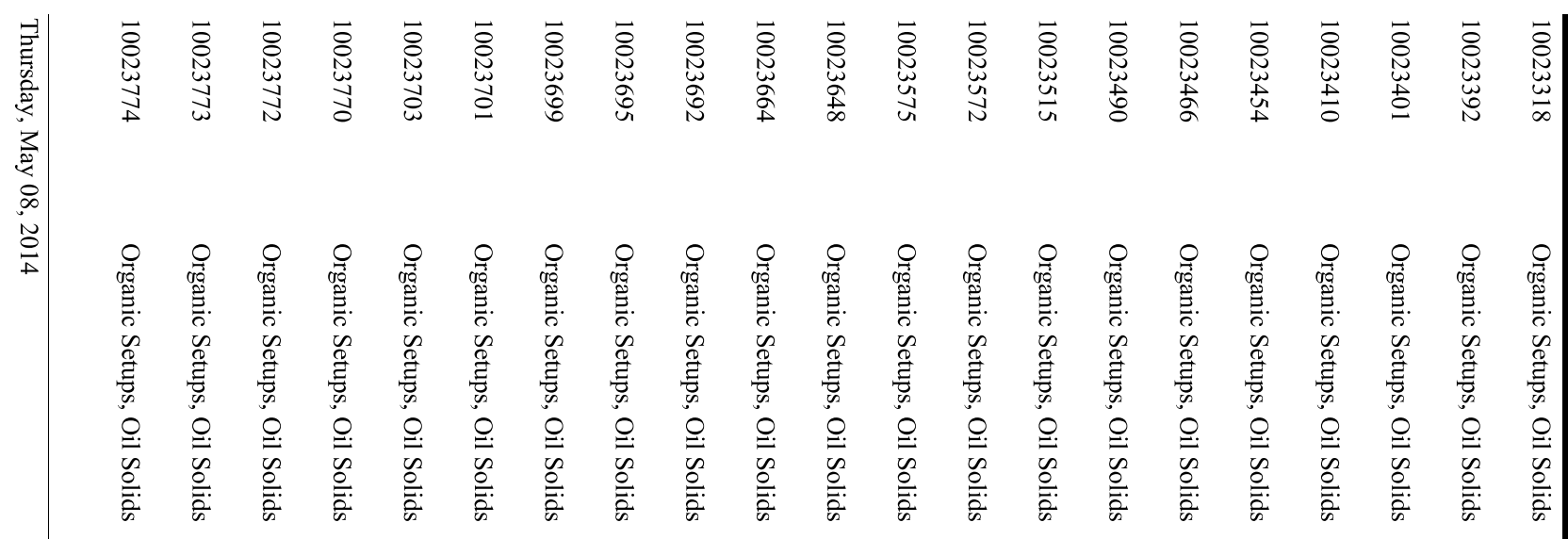

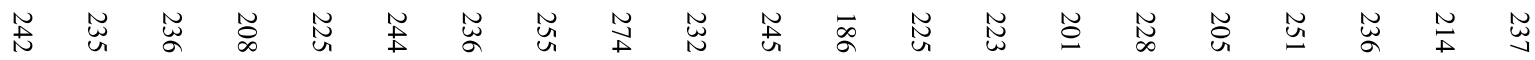

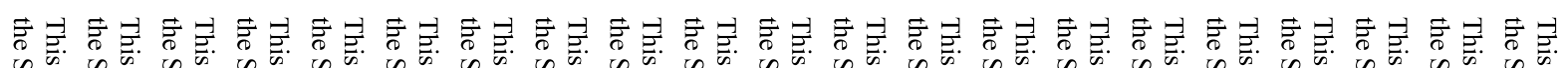

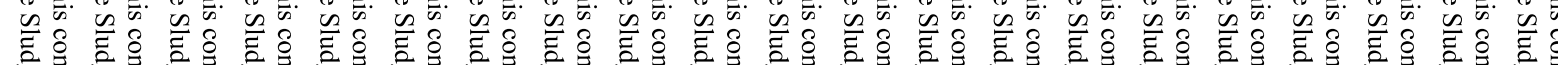

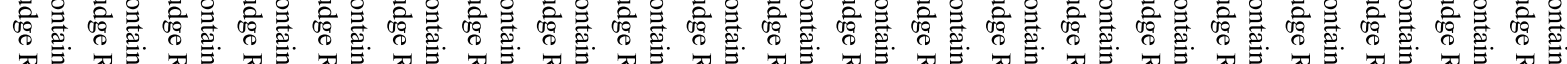

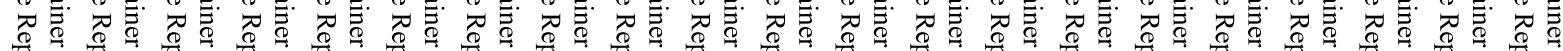

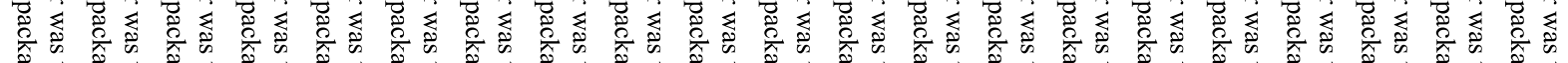

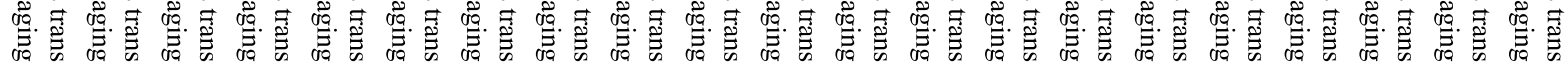

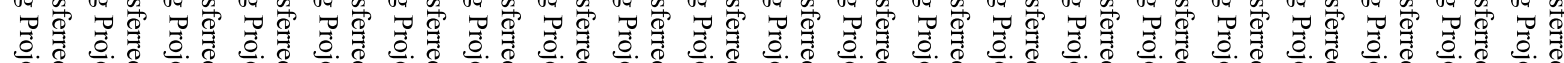

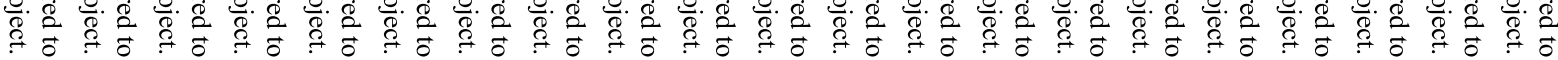

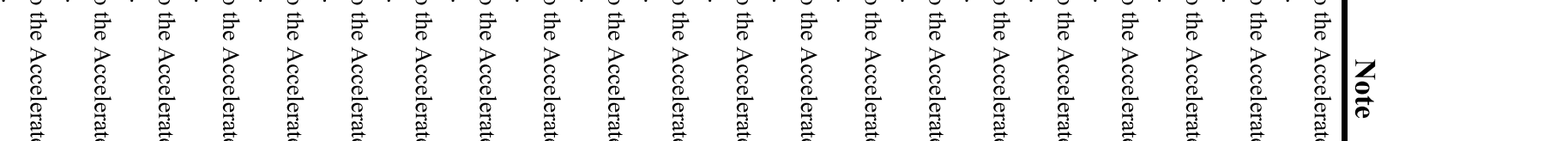




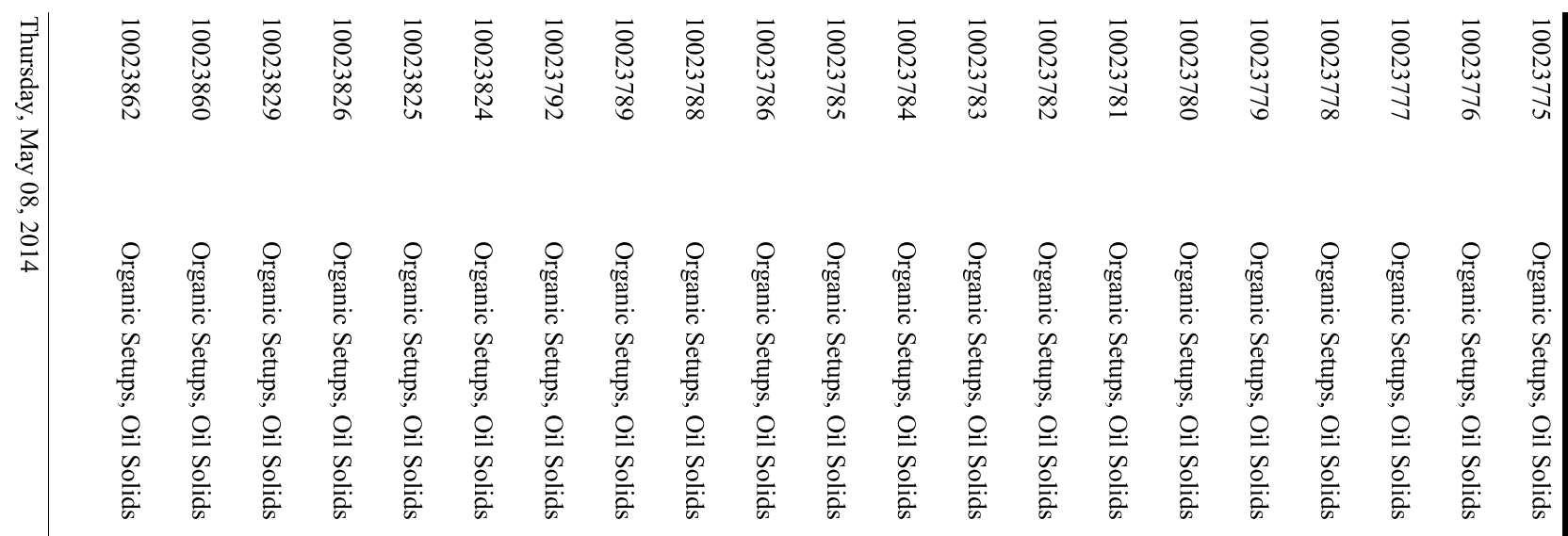

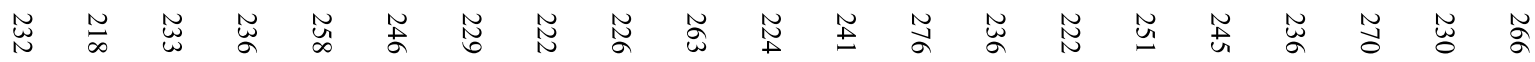

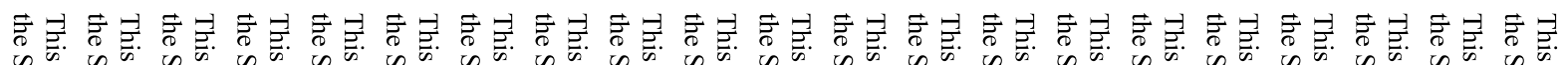

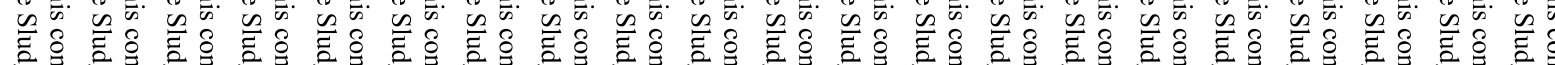

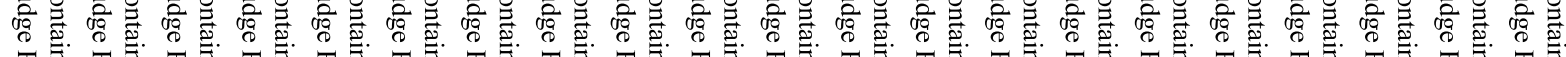

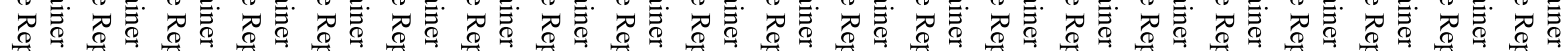

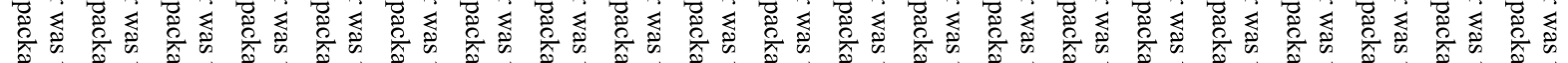

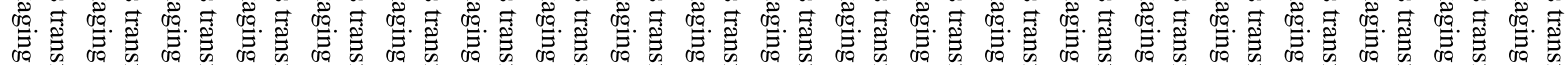

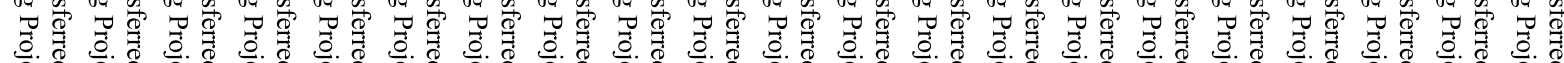

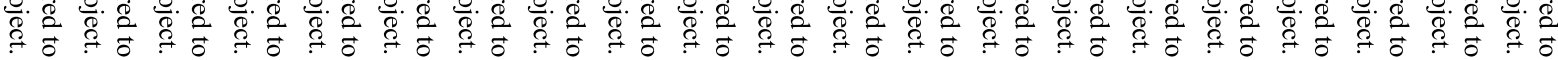

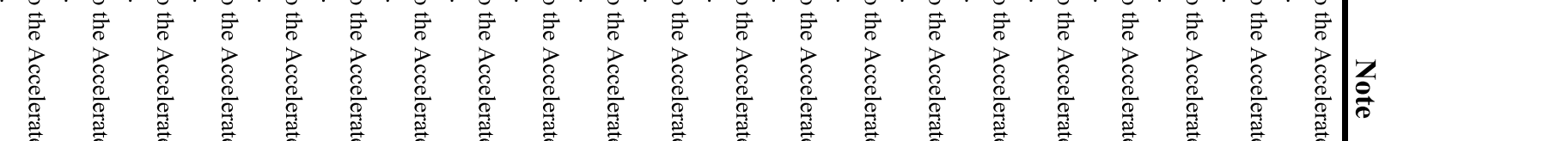




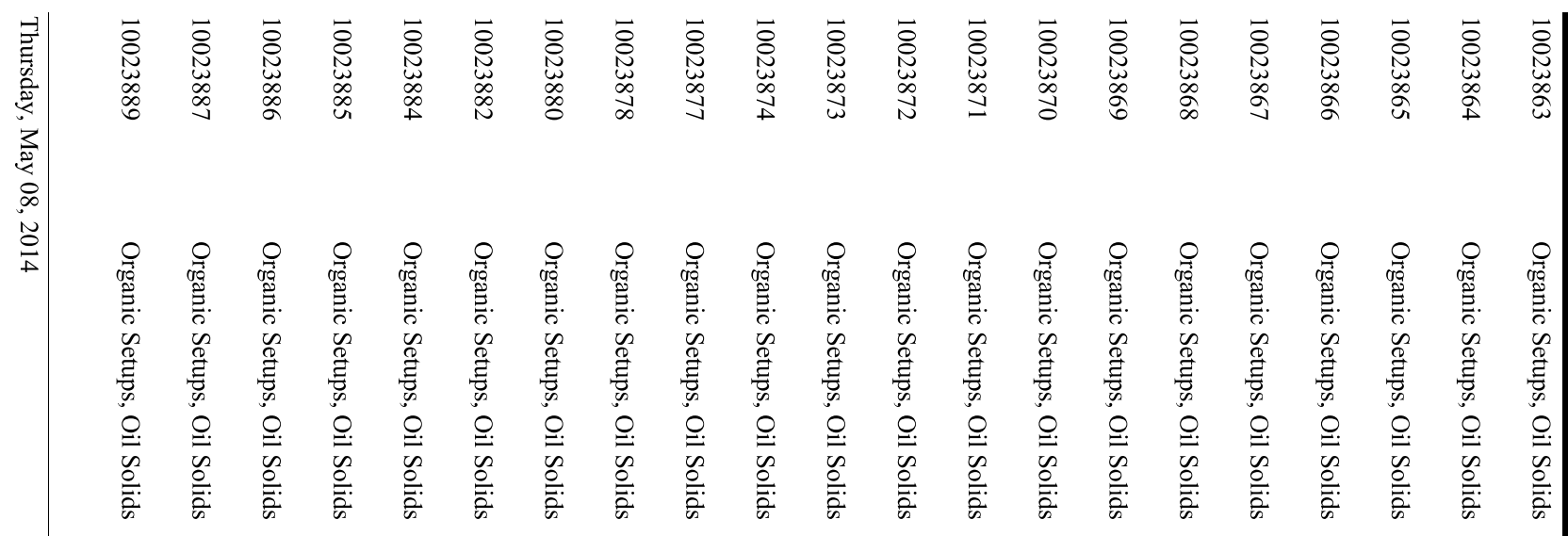

笀 N

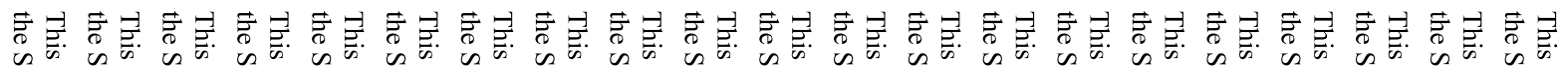

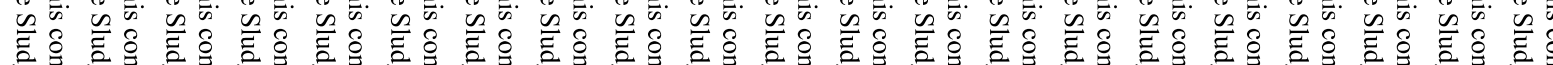

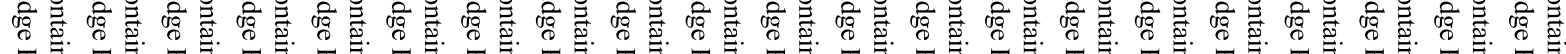
不

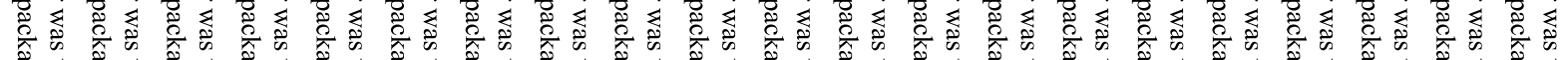

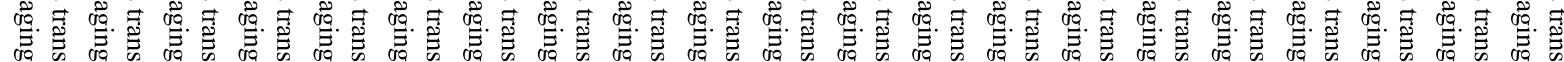

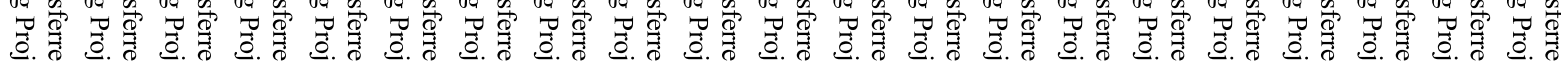

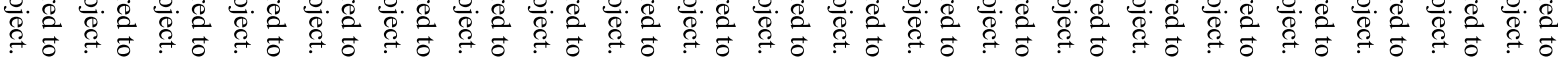

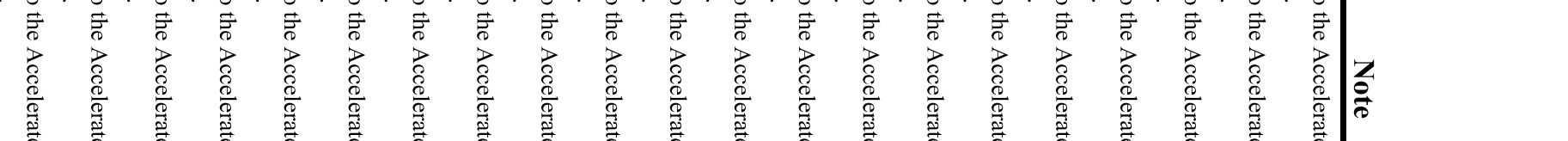




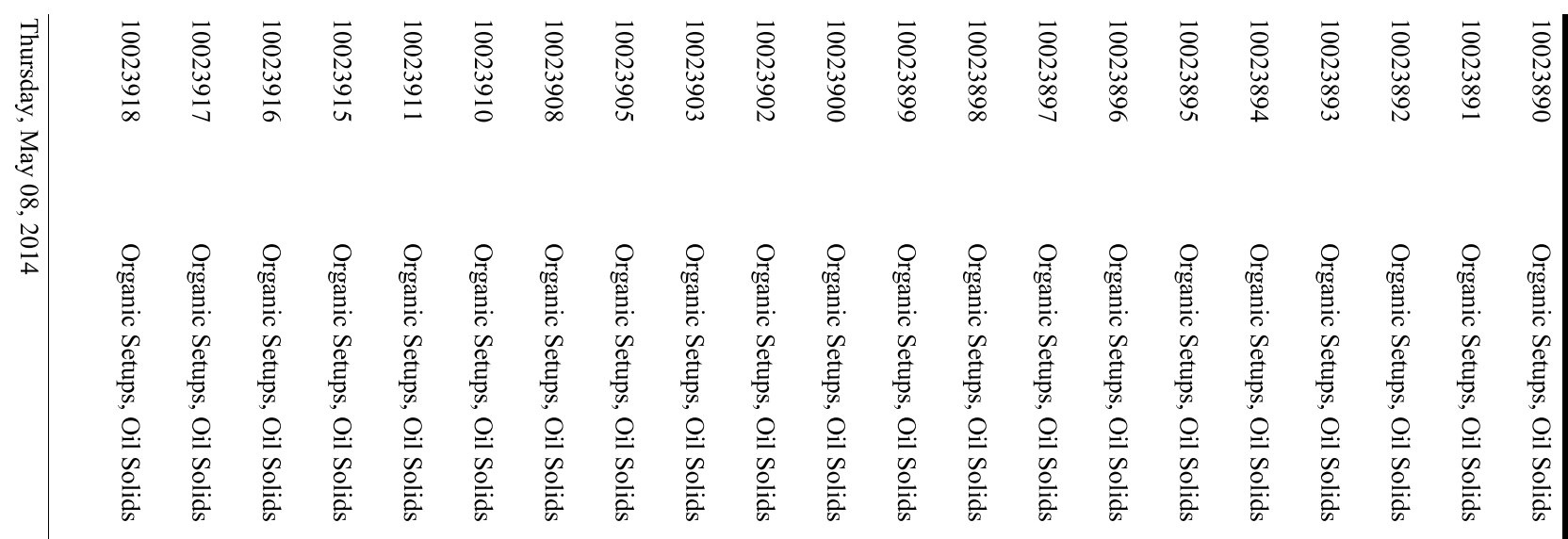

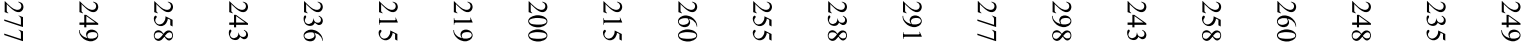

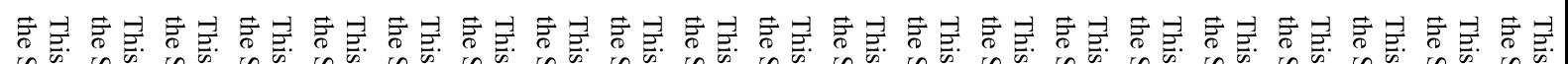

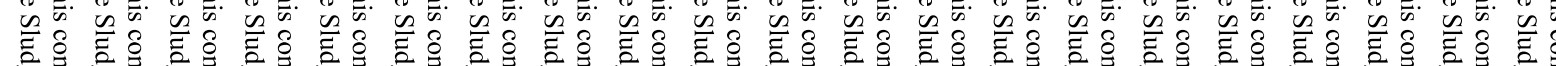

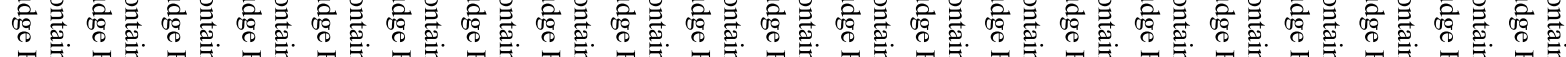

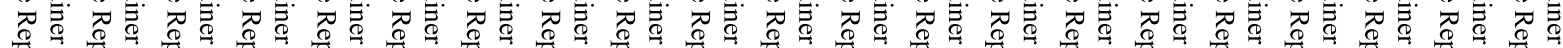

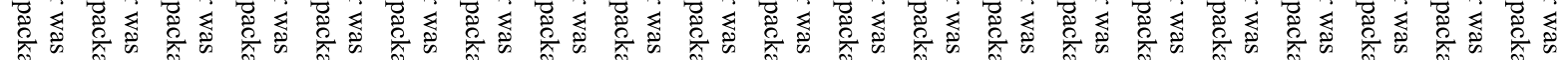

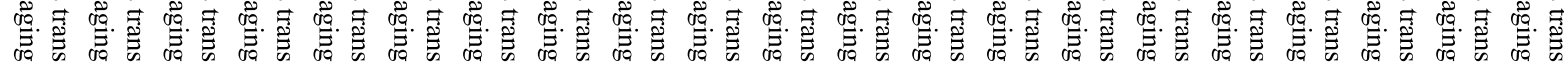

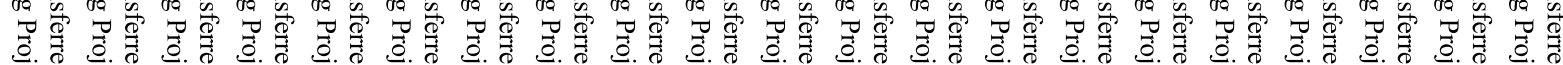

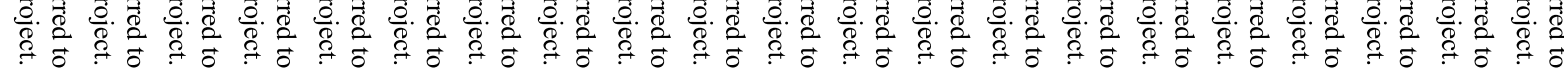

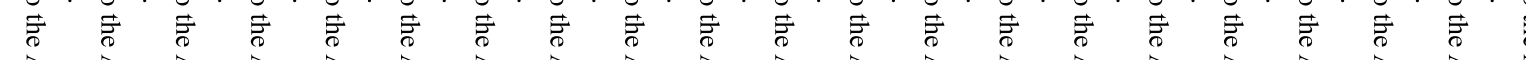

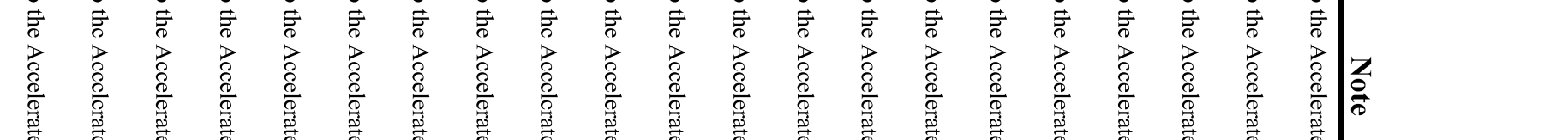

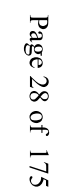




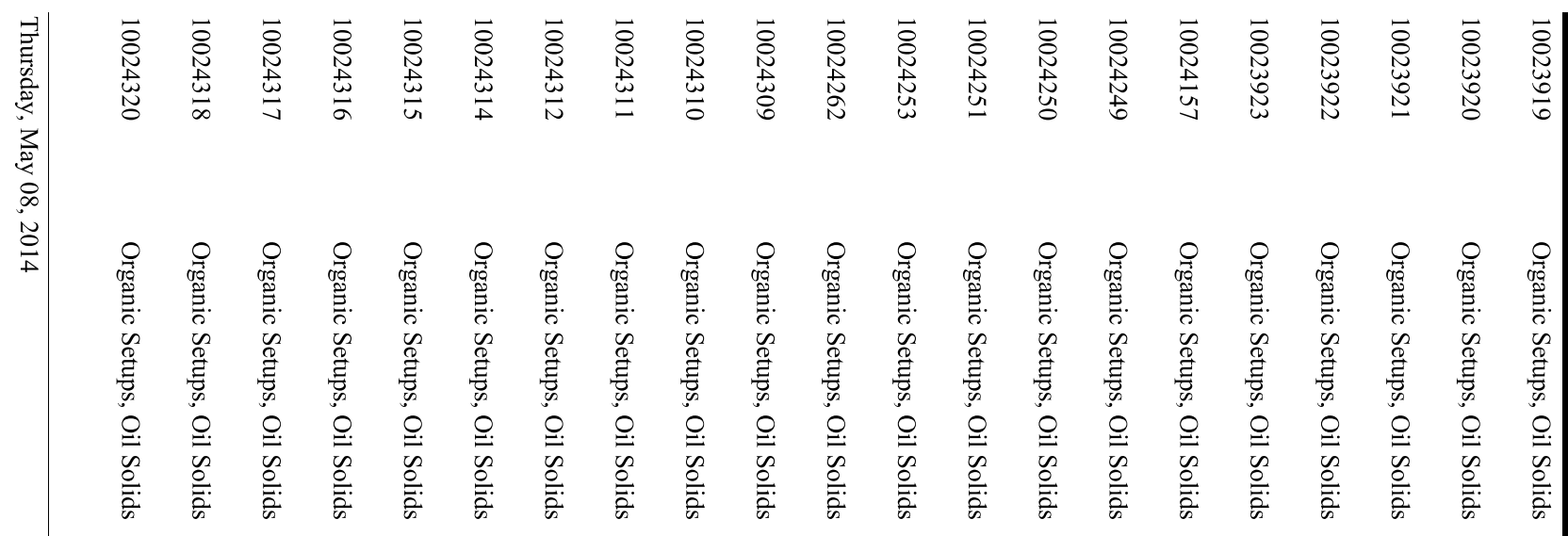

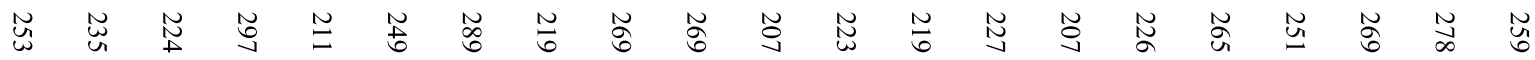

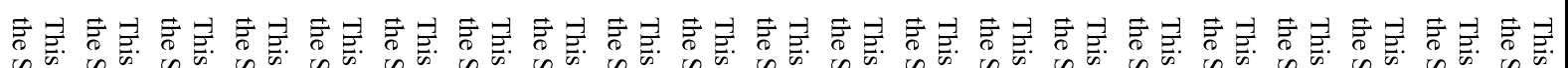

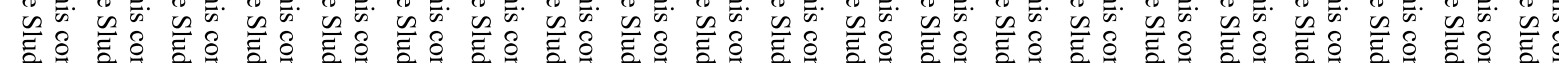

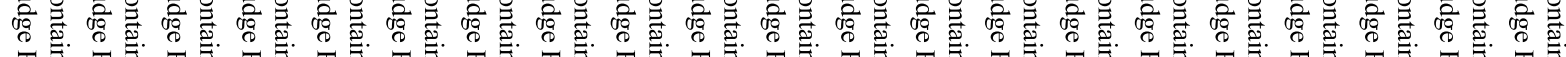
不

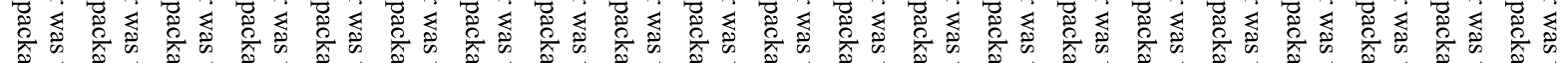

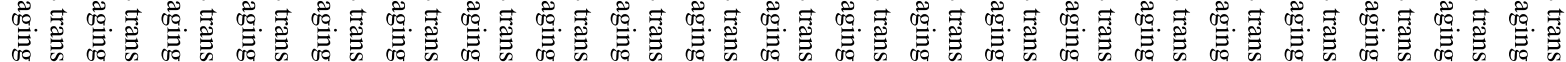

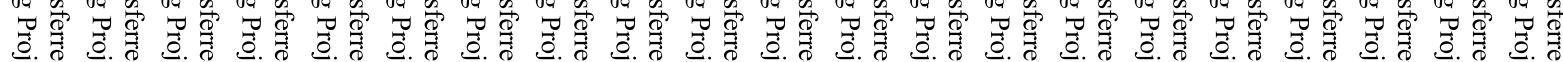

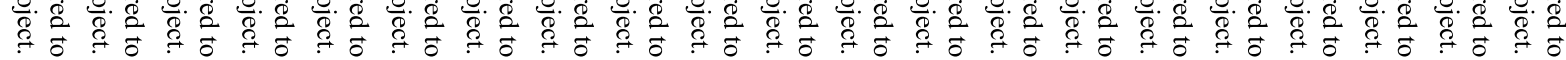

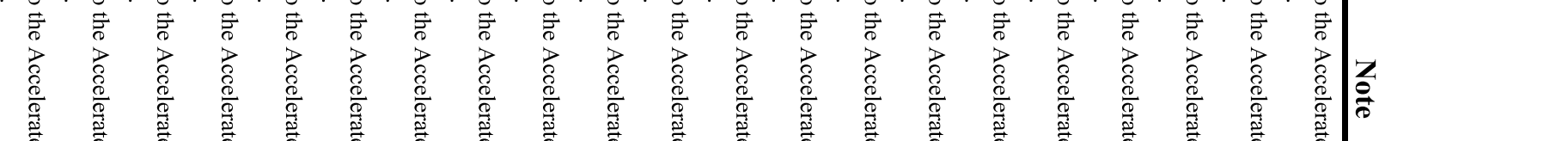




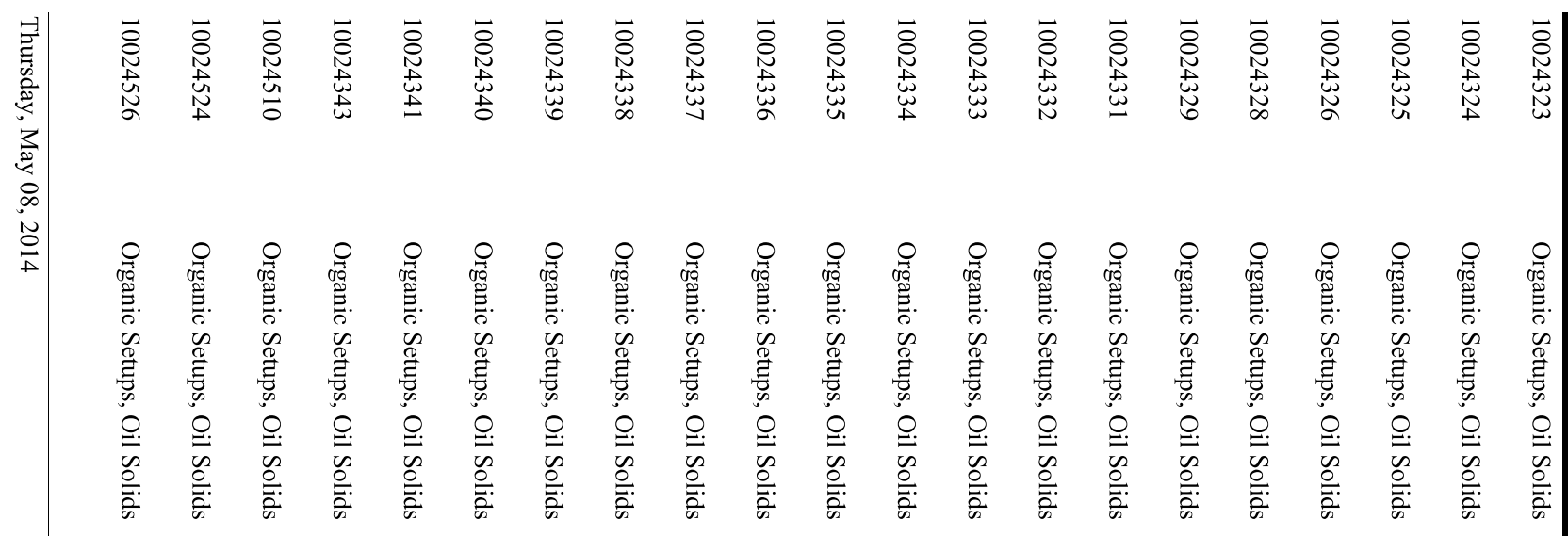

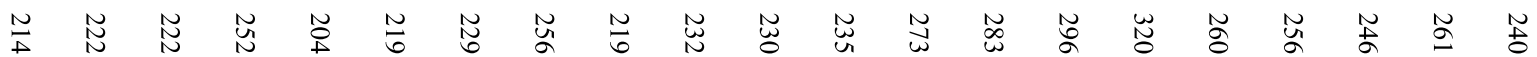

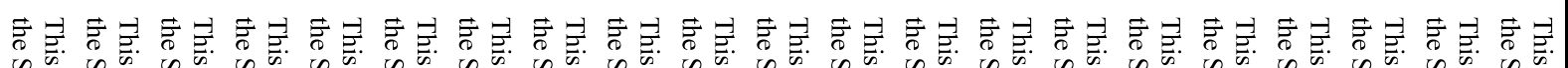

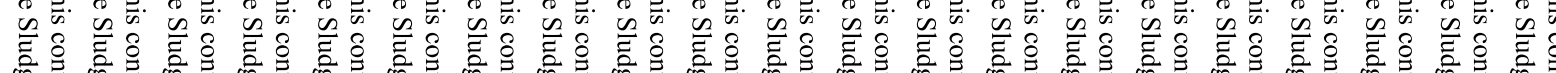

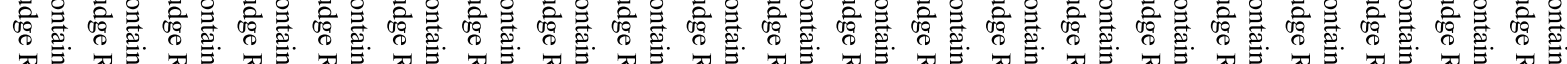

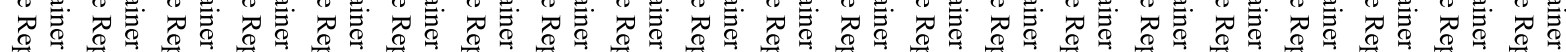

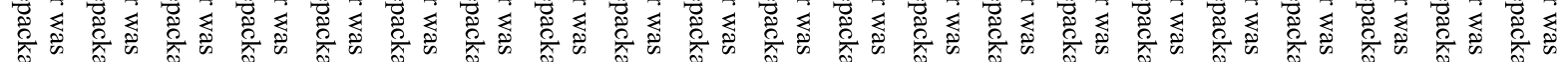

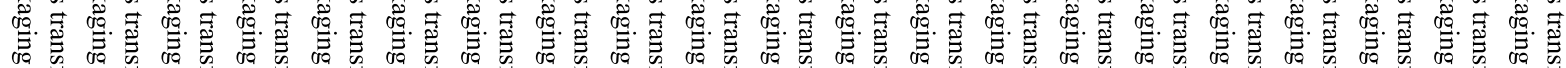

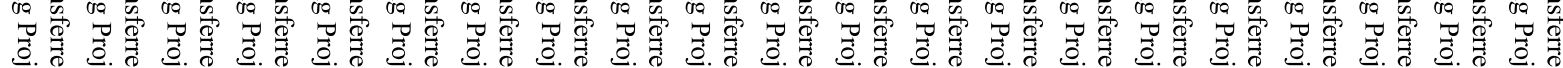

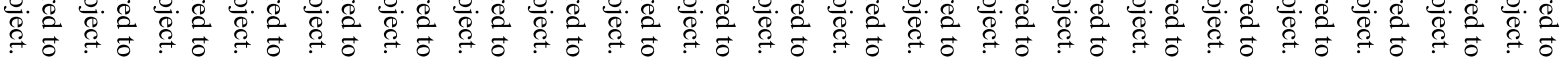

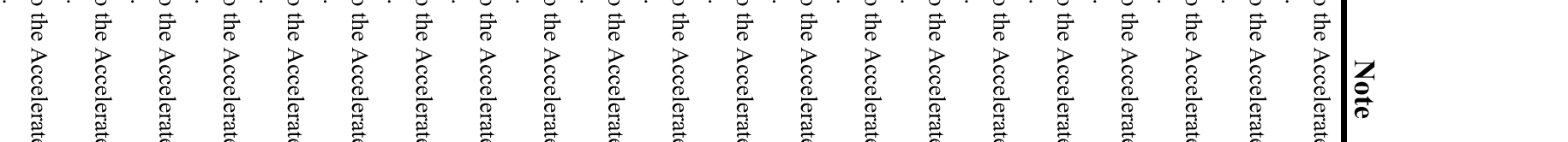




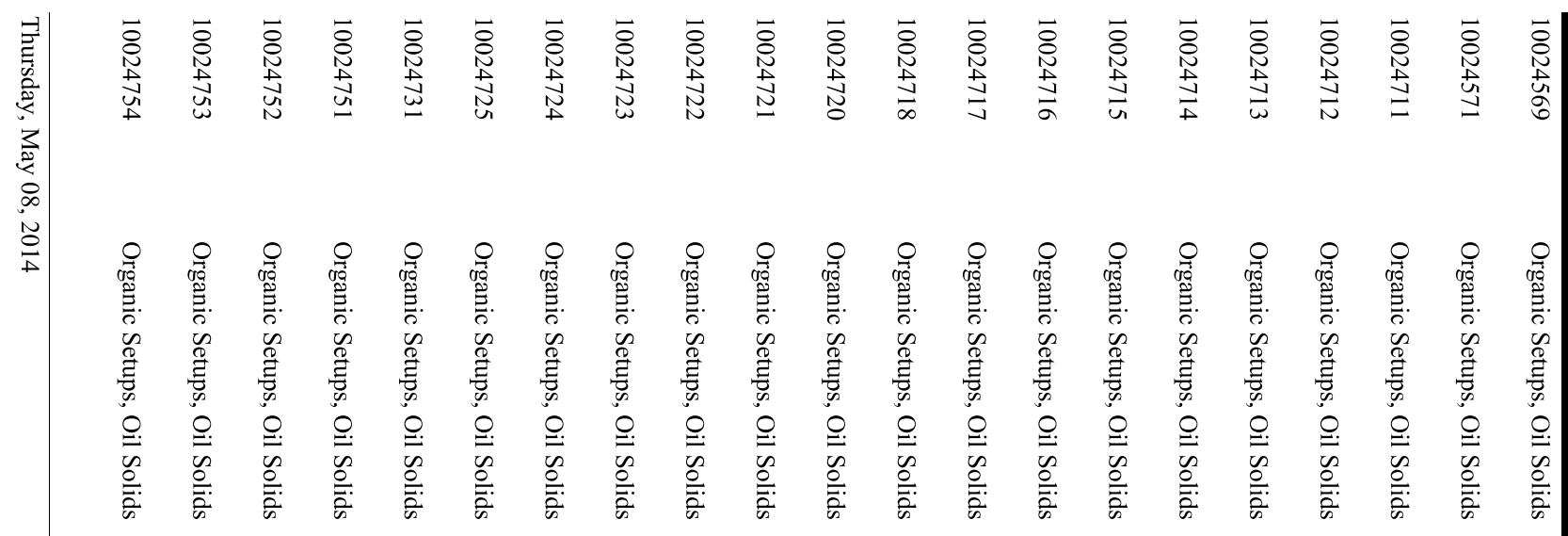

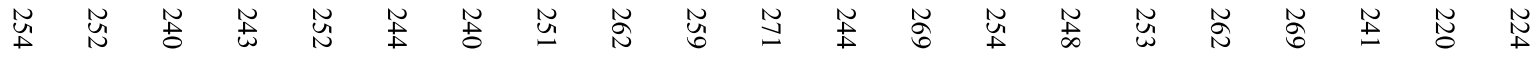

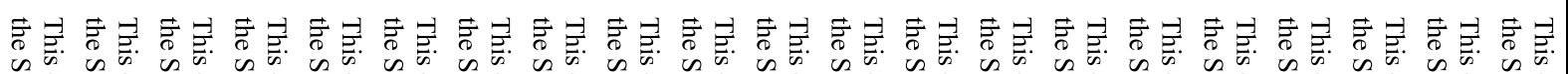

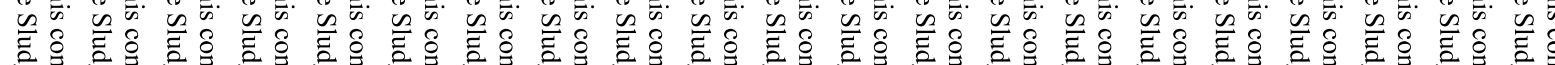

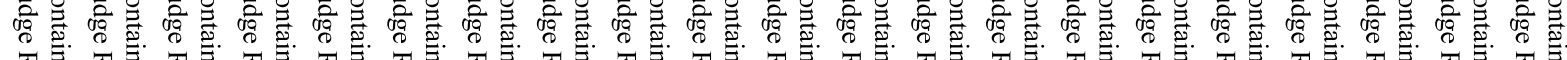
不

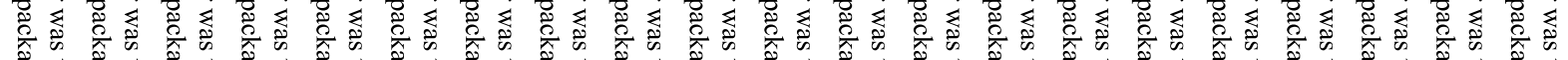

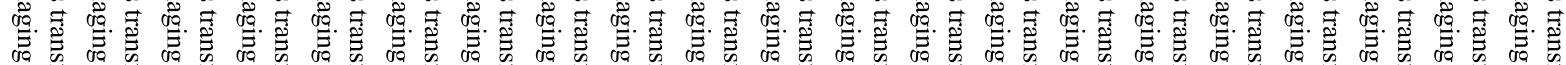

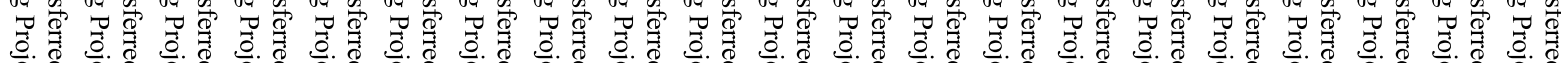

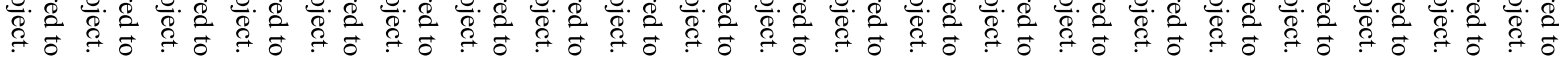

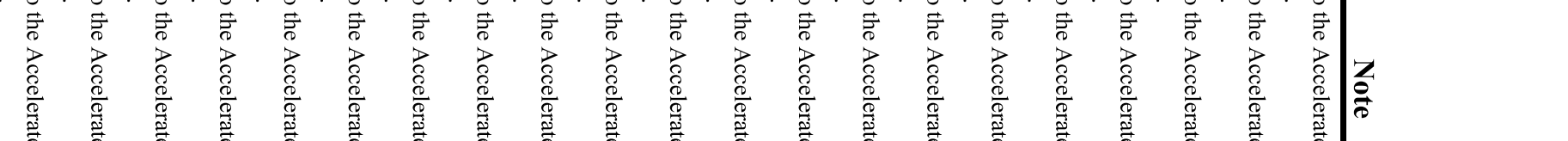




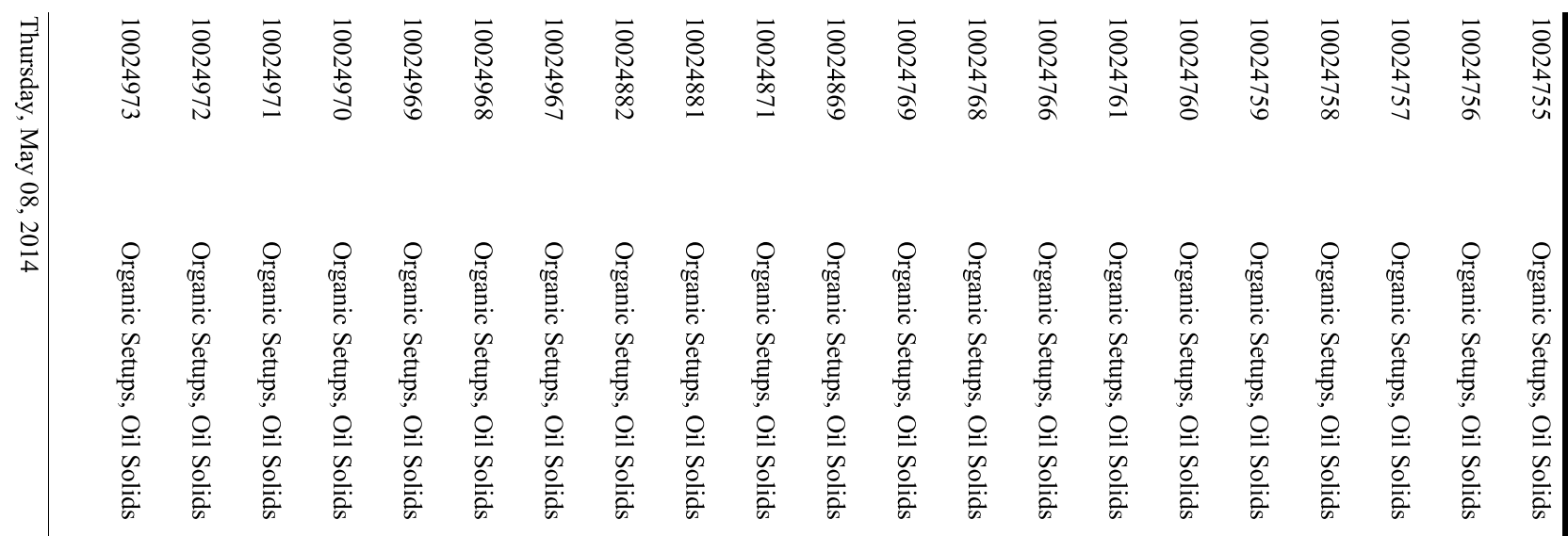

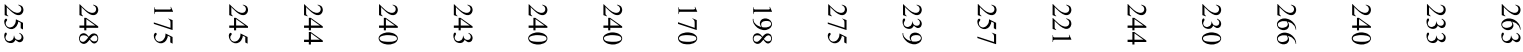

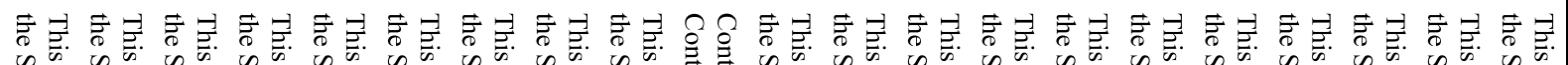

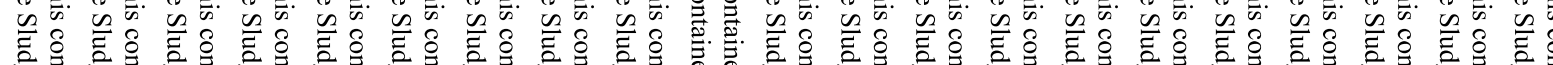

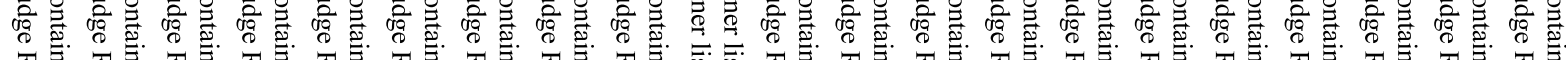
不

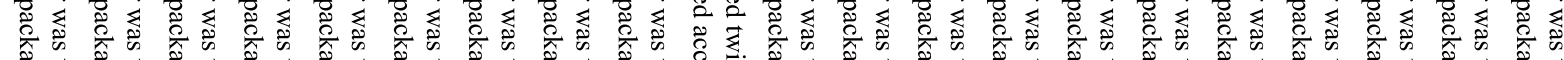

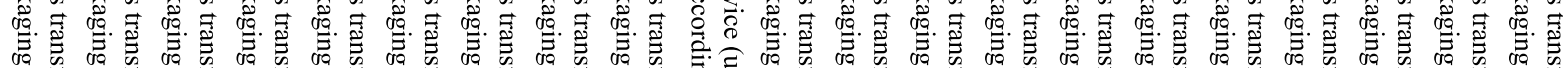

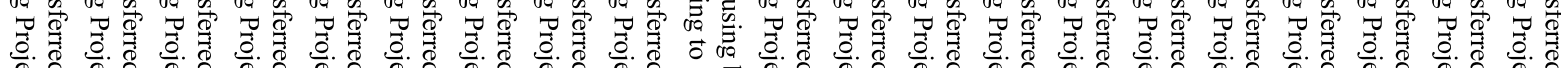

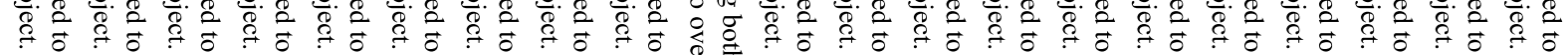

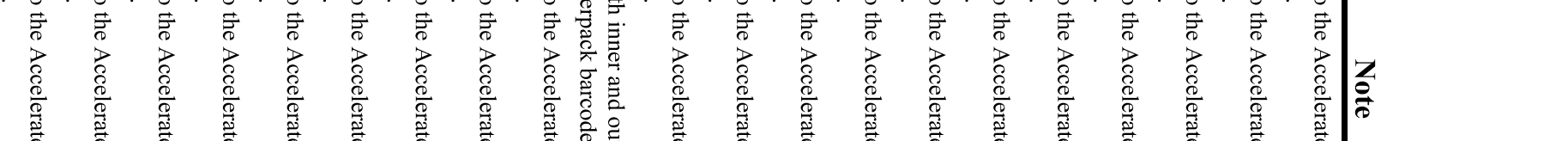




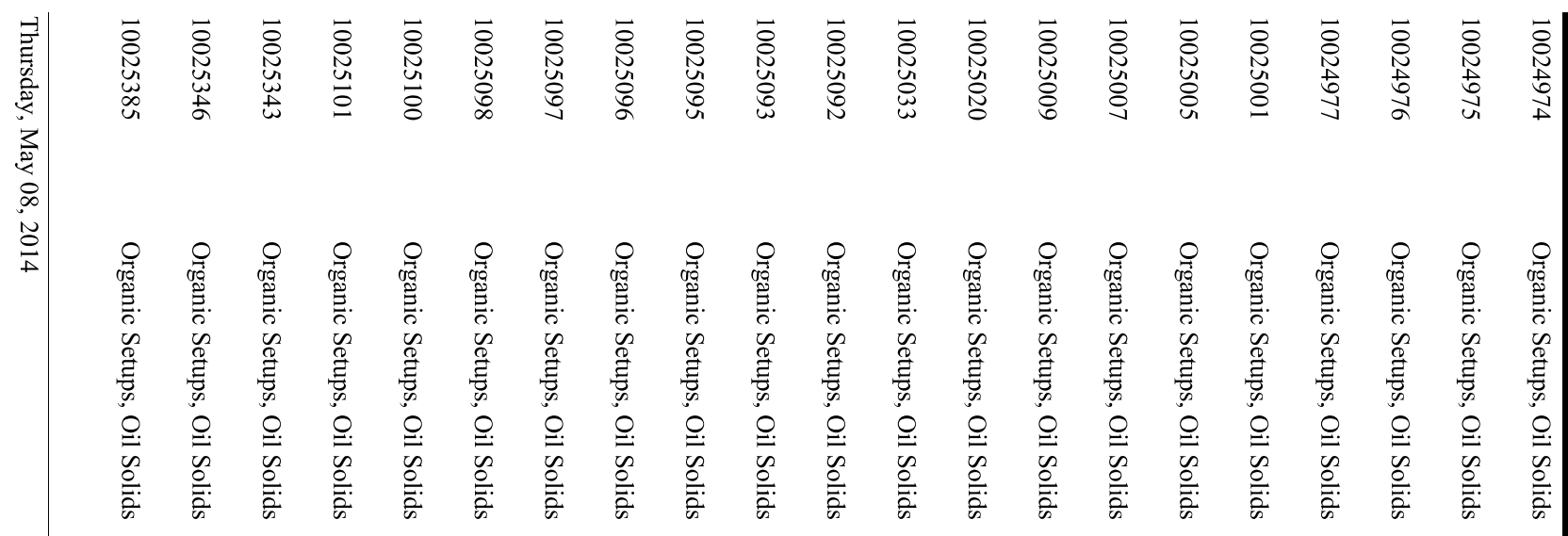

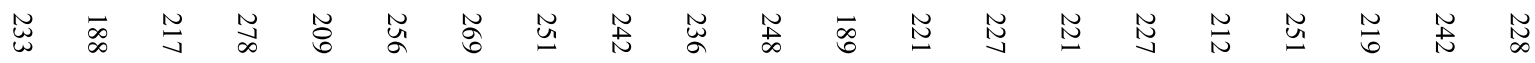

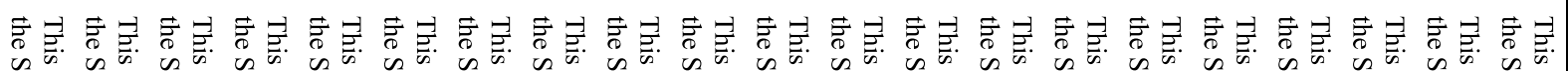

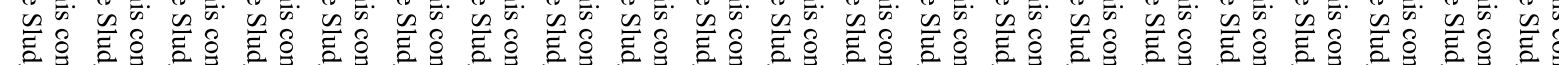

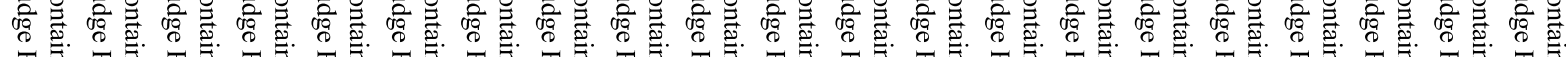

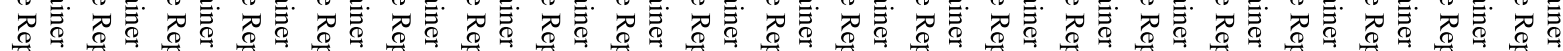

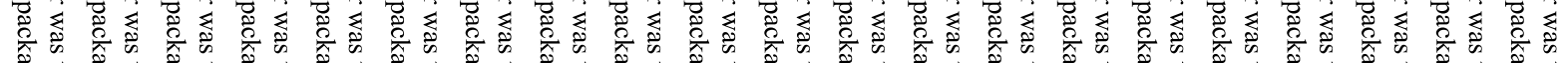

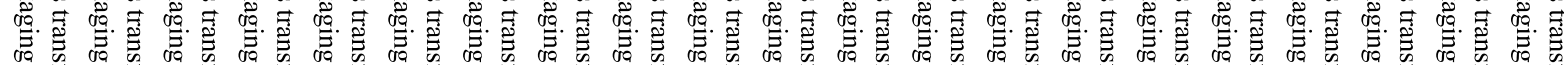

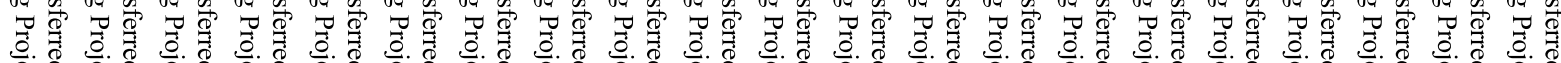

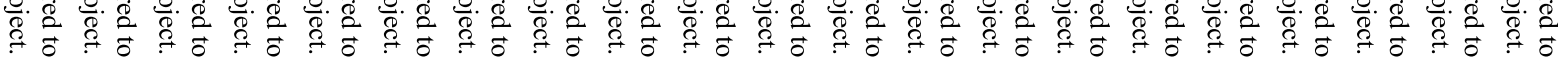

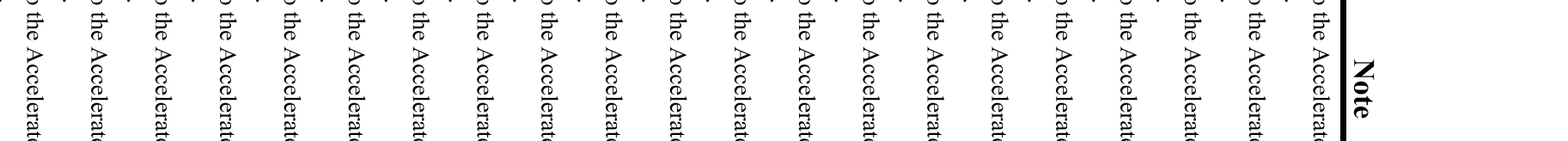




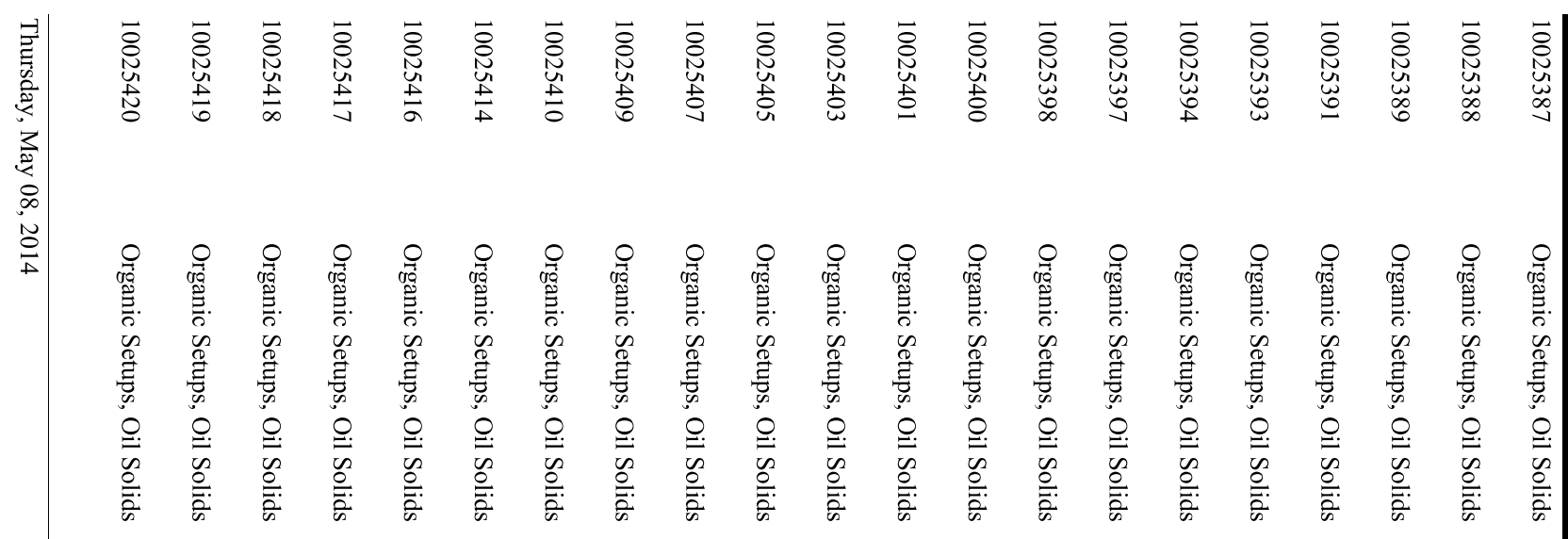

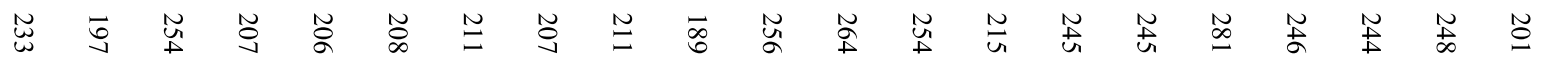

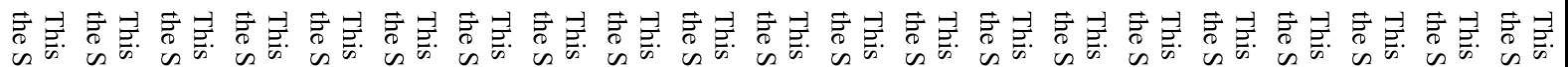

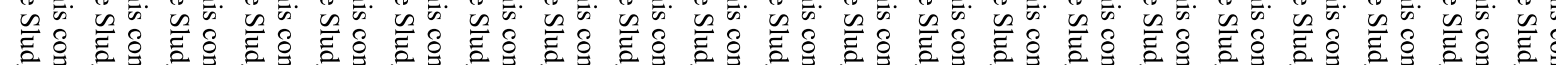

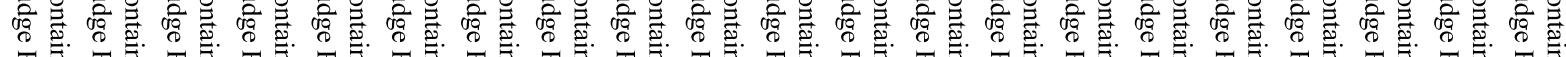
不

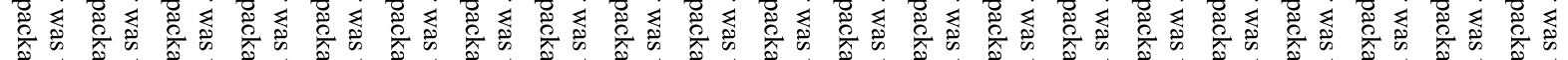

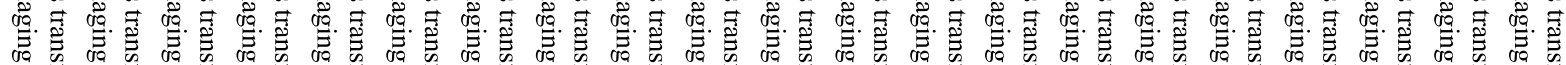

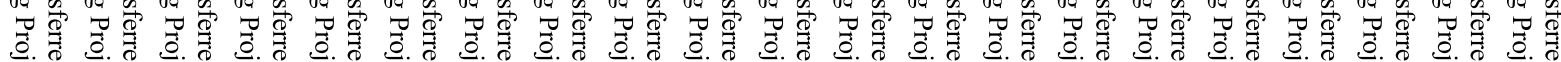

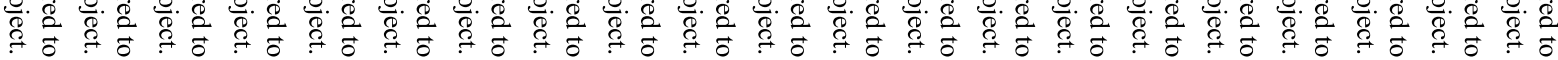

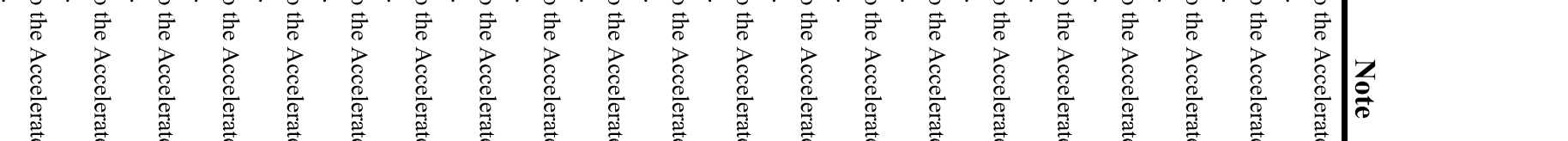




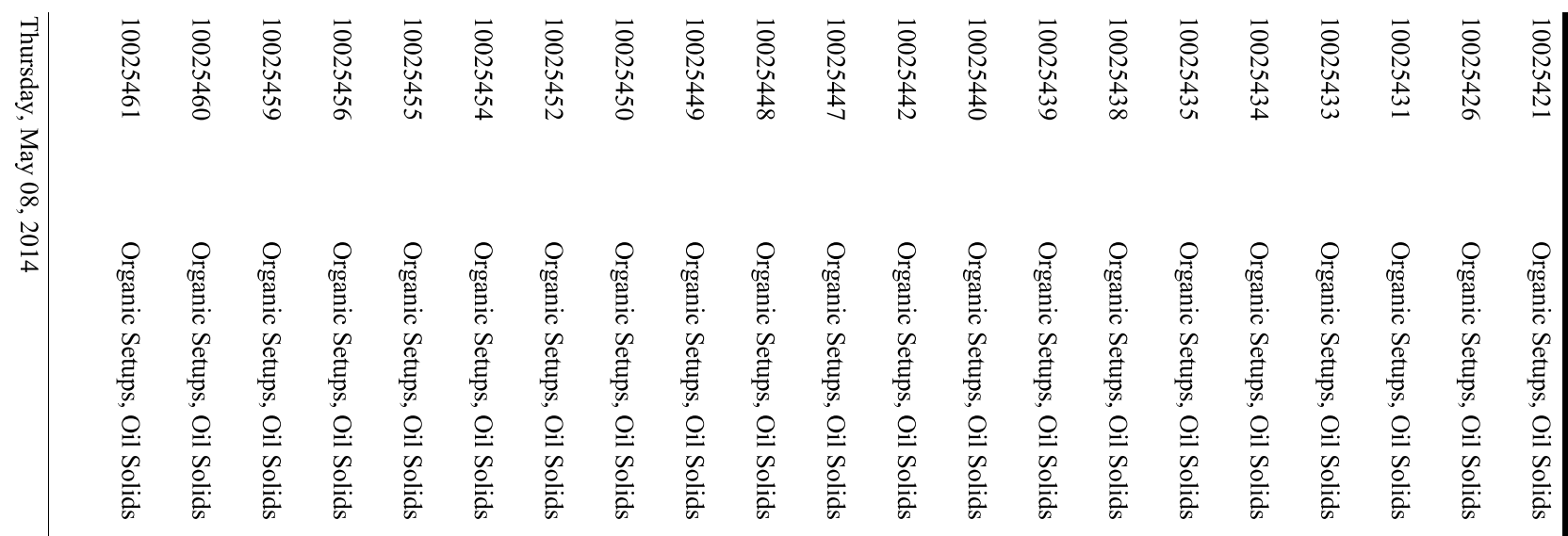

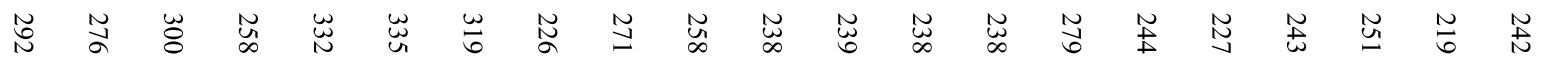

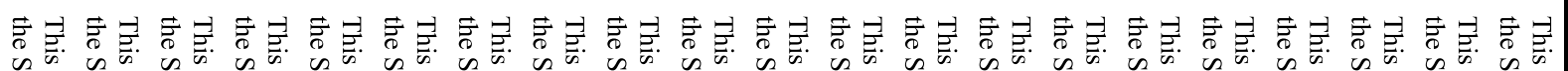

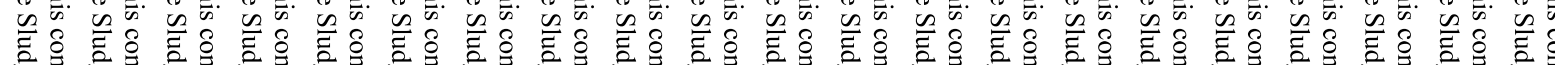

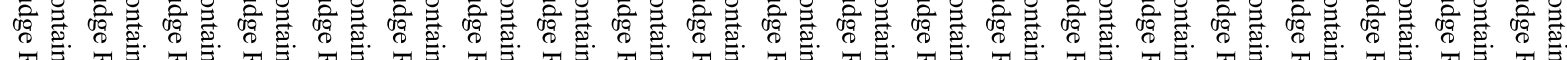
不

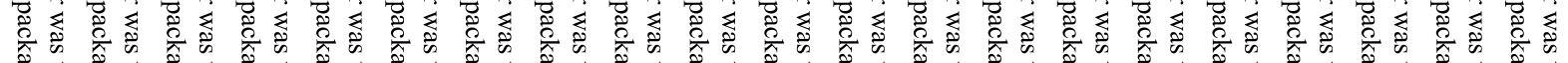

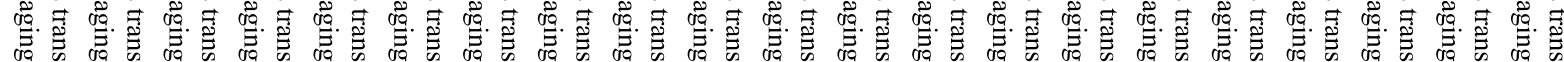

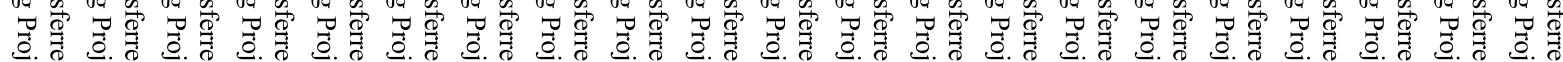

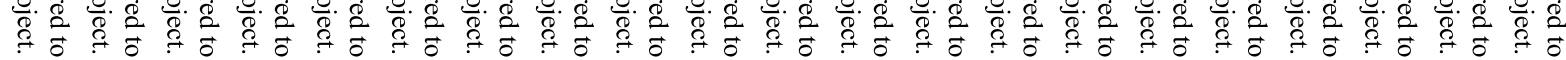

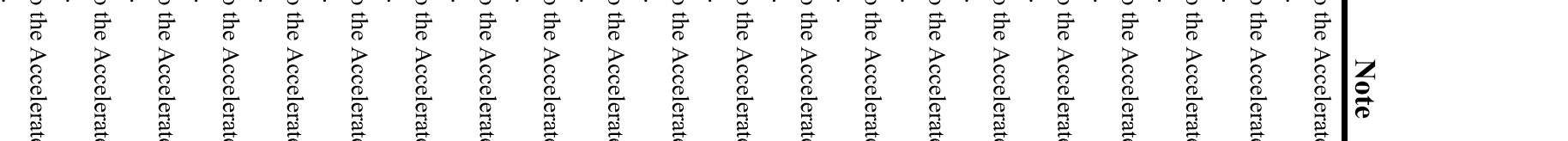




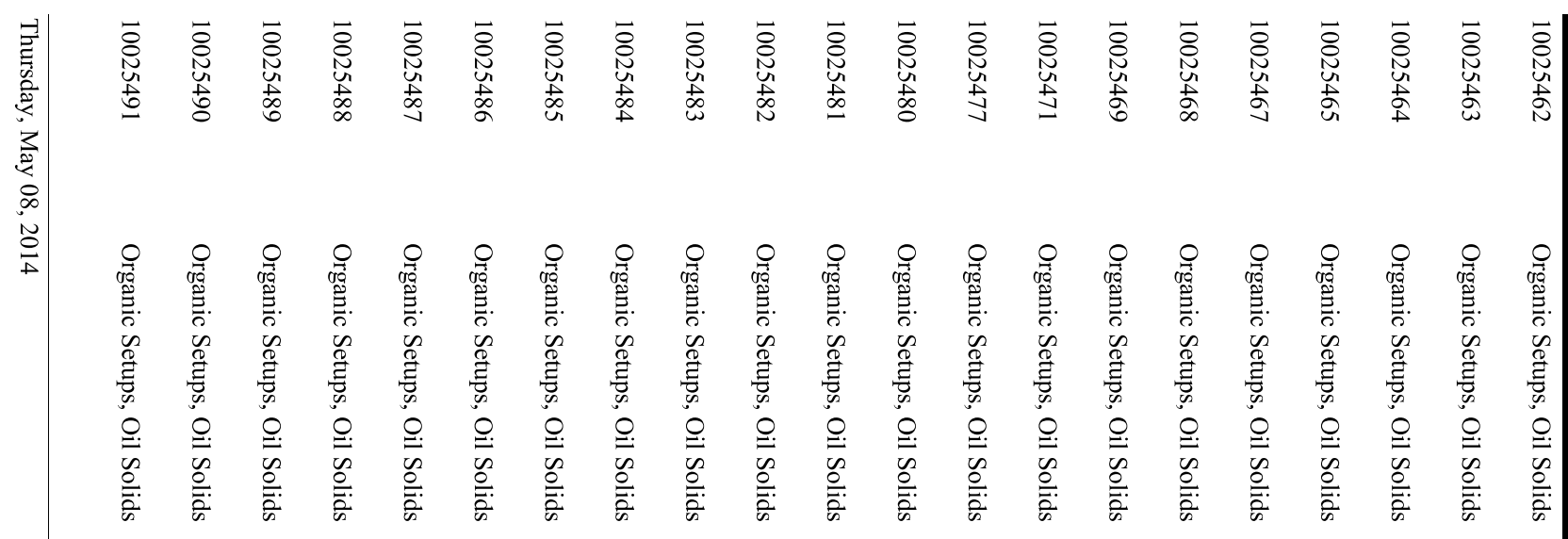

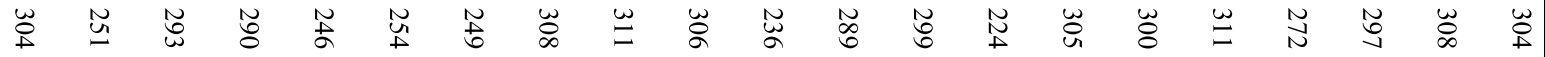

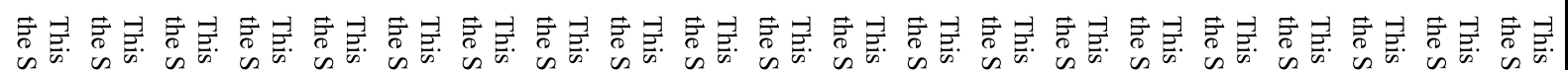

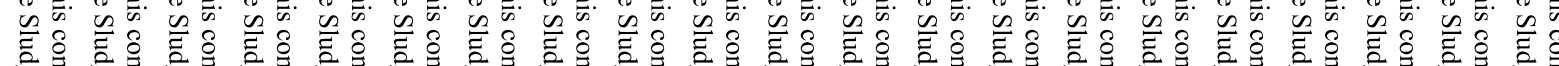

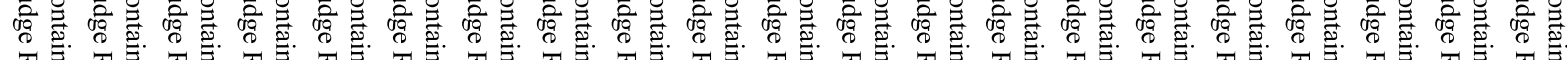
不

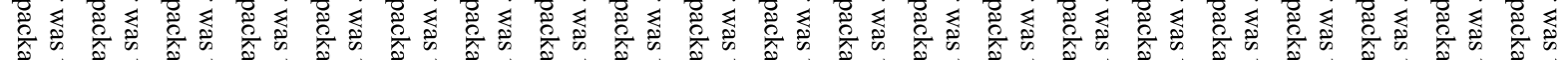

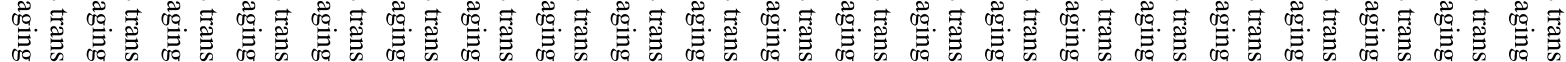

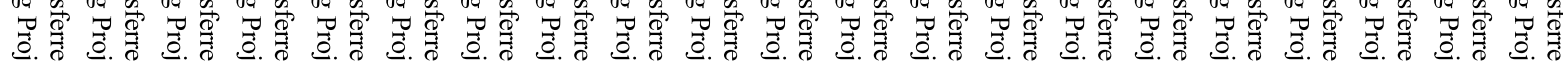

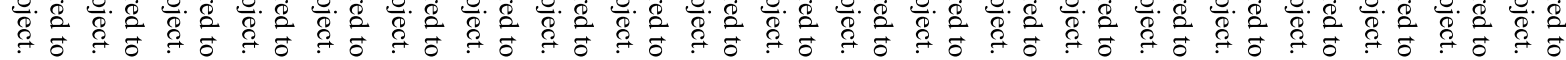

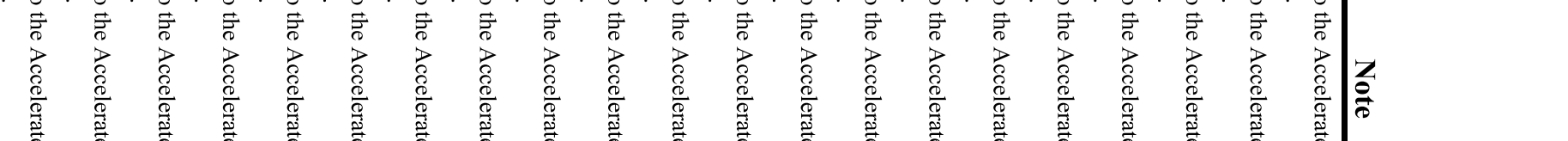




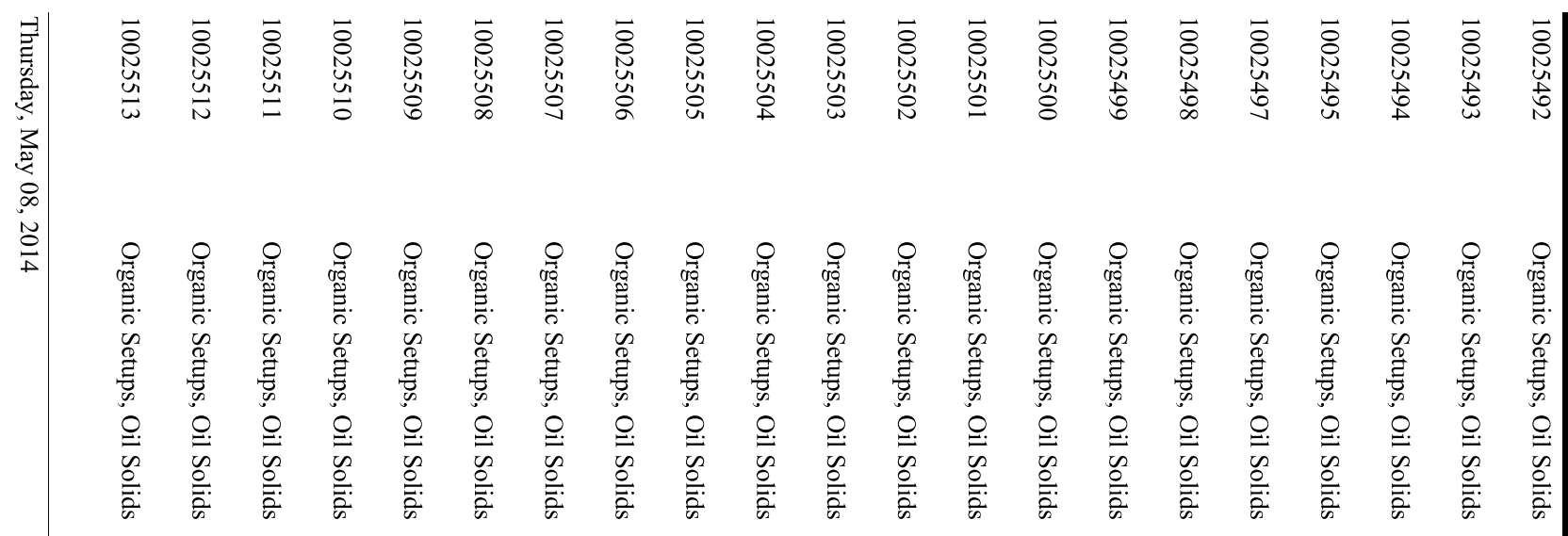

㣢

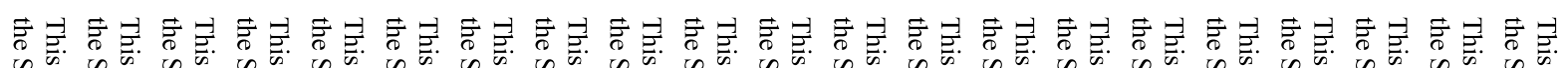

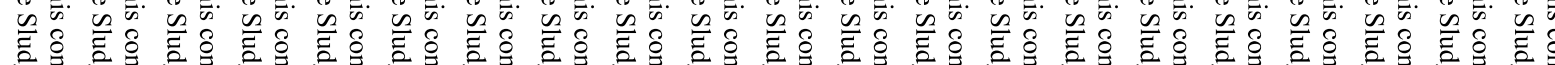

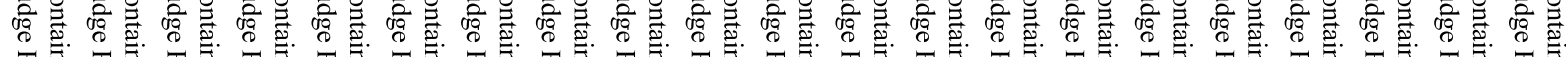
不

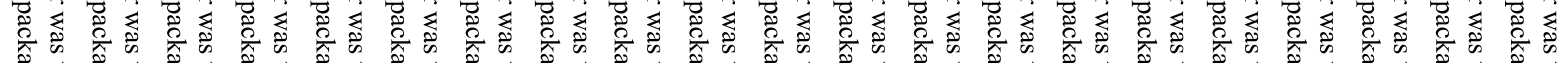

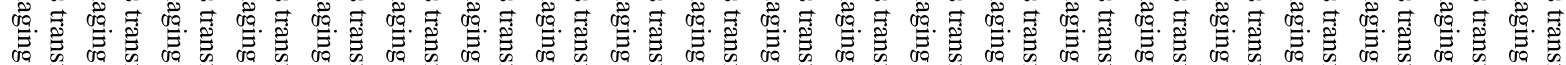

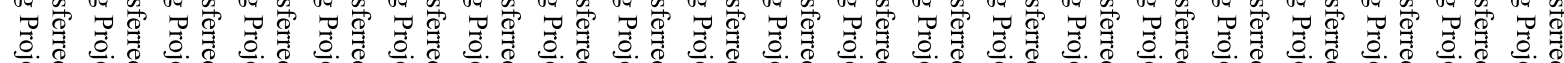

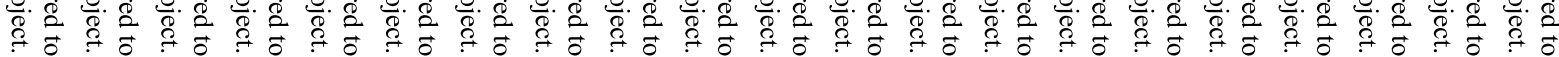

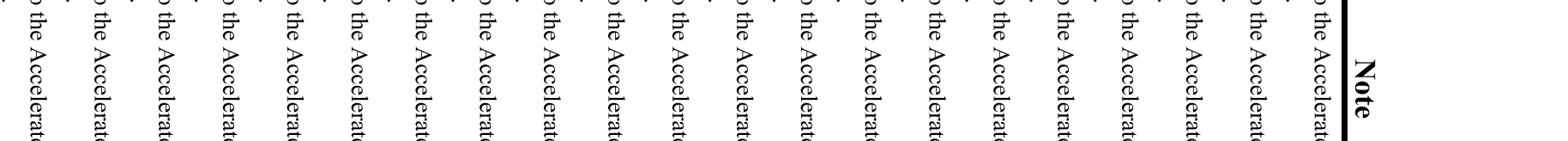




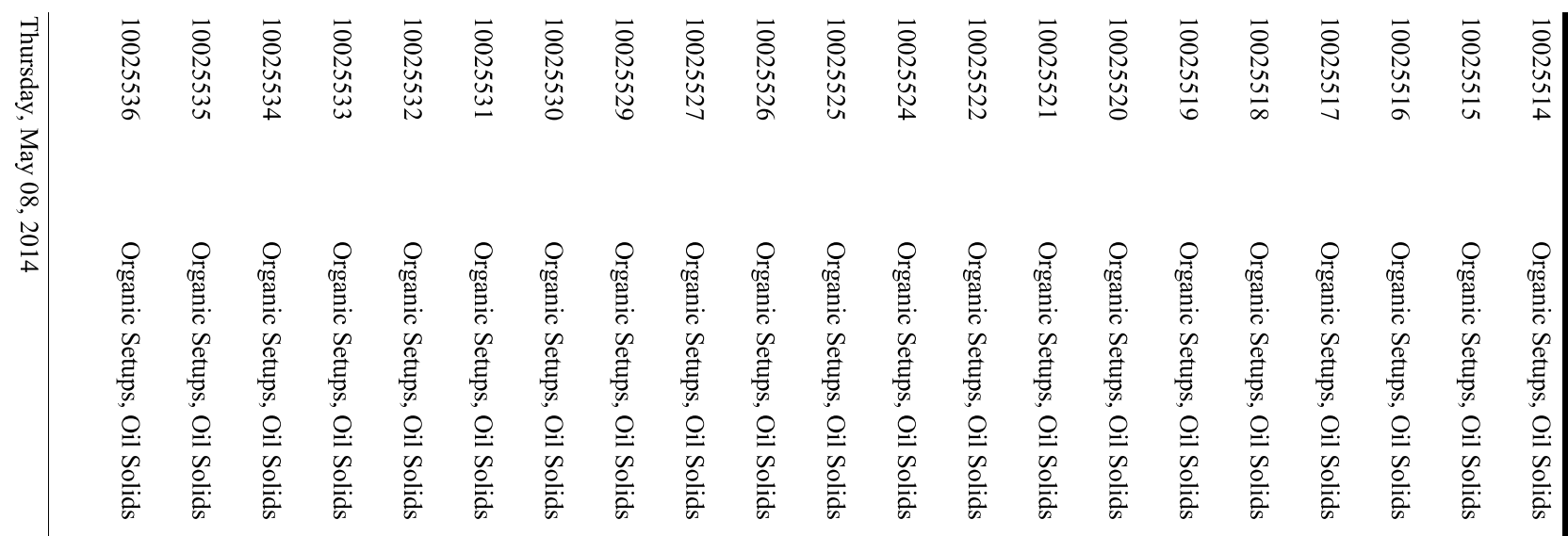

జ

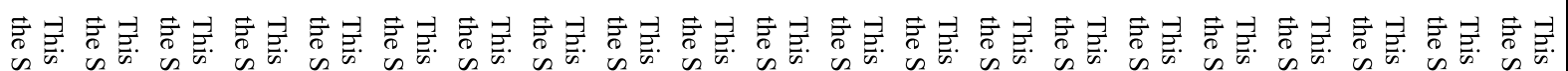

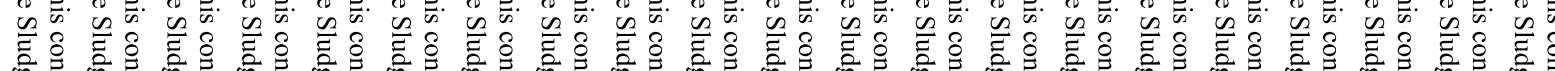

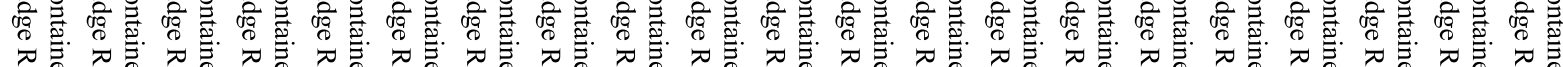
중 説

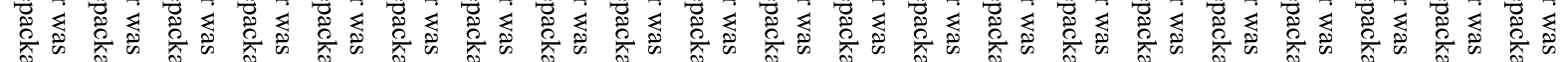

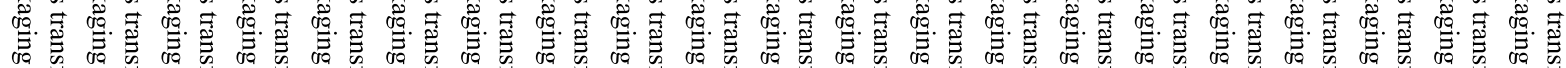

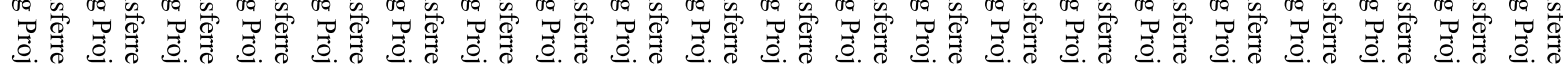

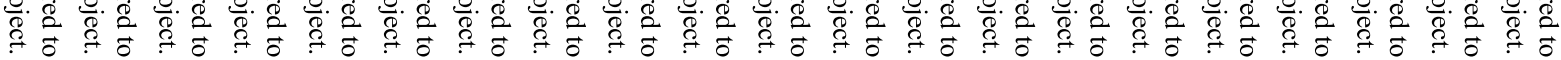

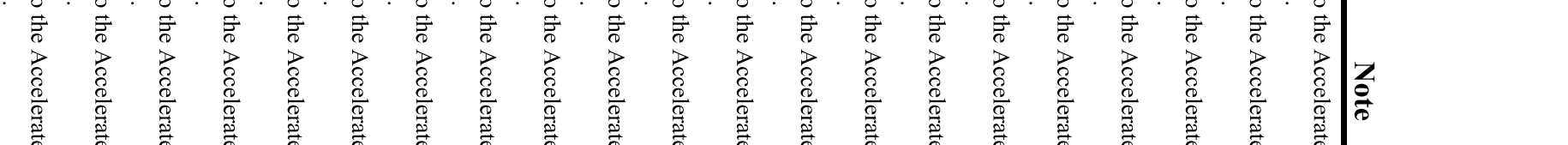




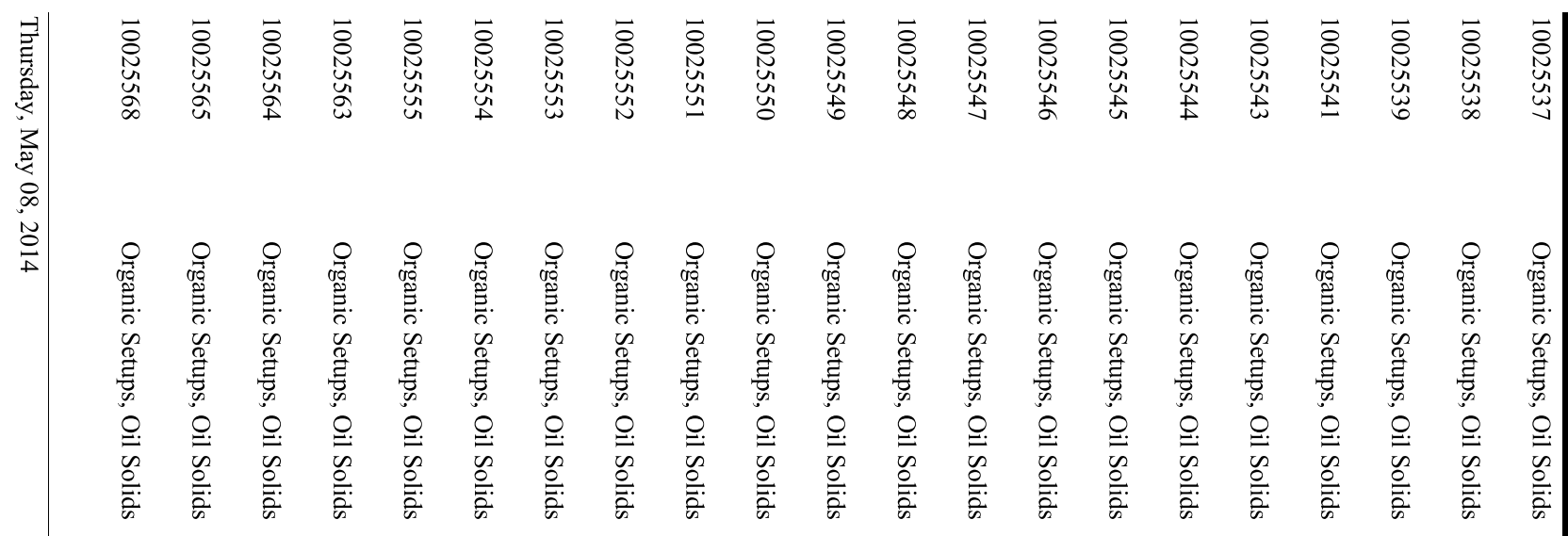

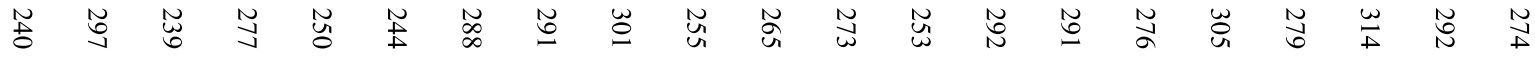

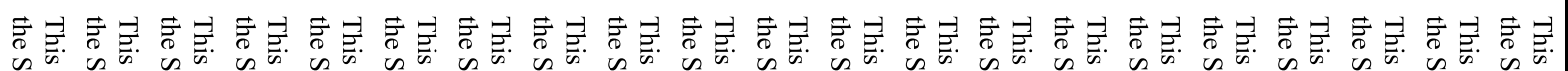

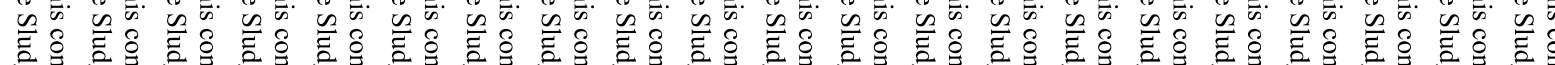

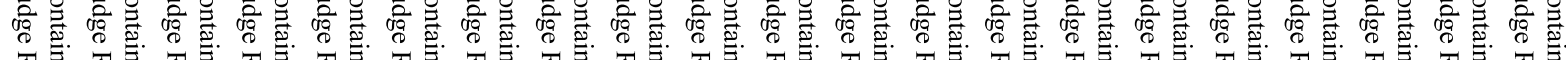
元

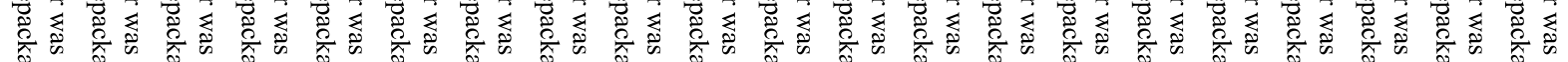

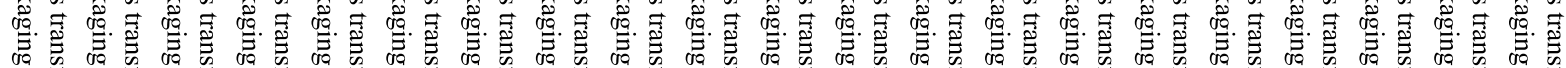

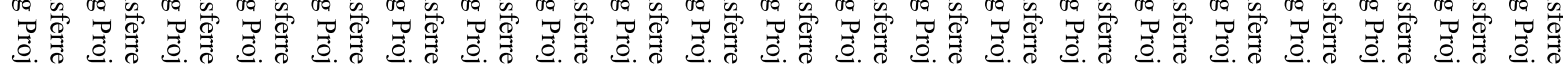

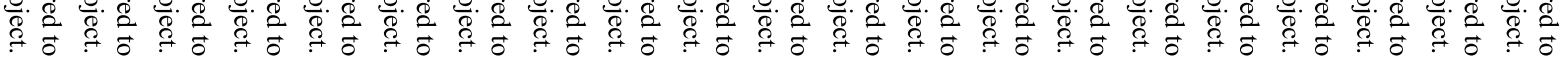

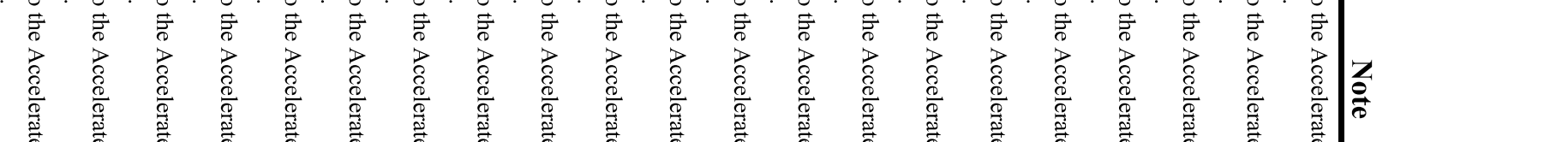




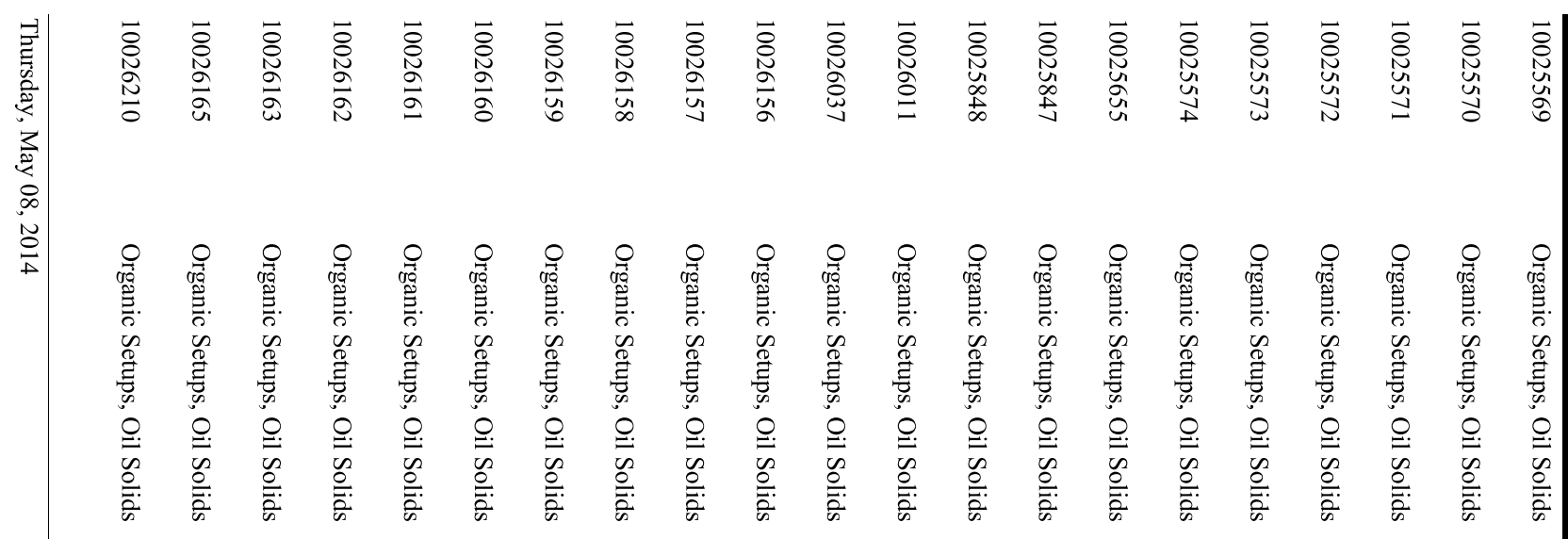

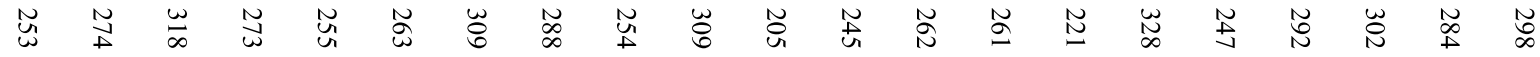

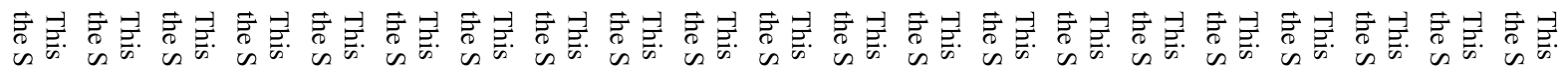

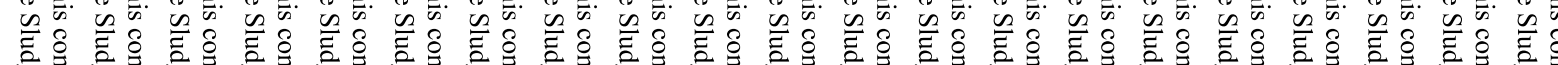

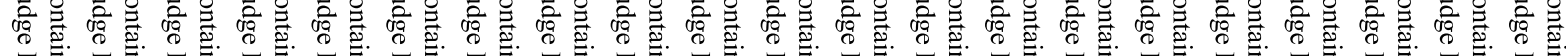

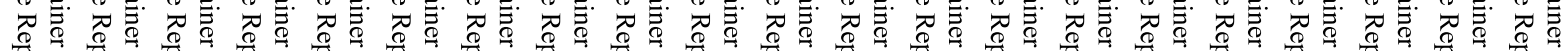

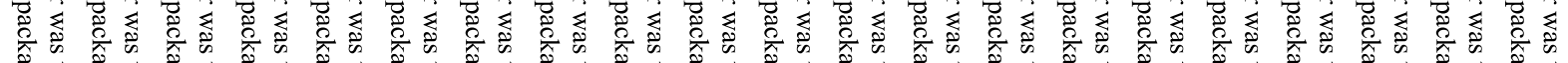

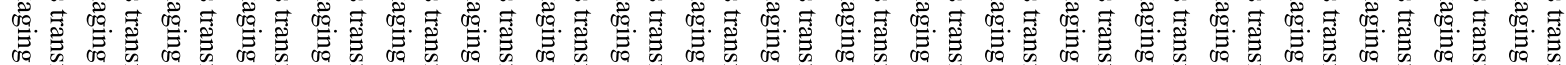

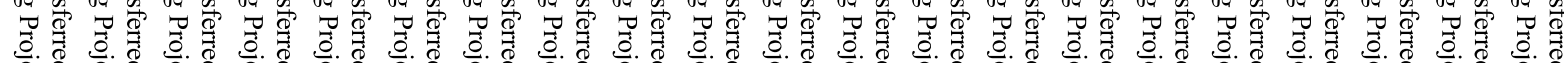

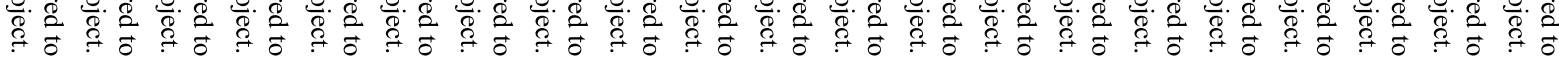

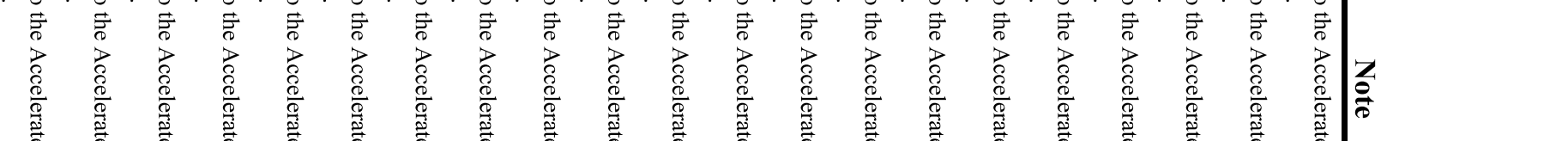




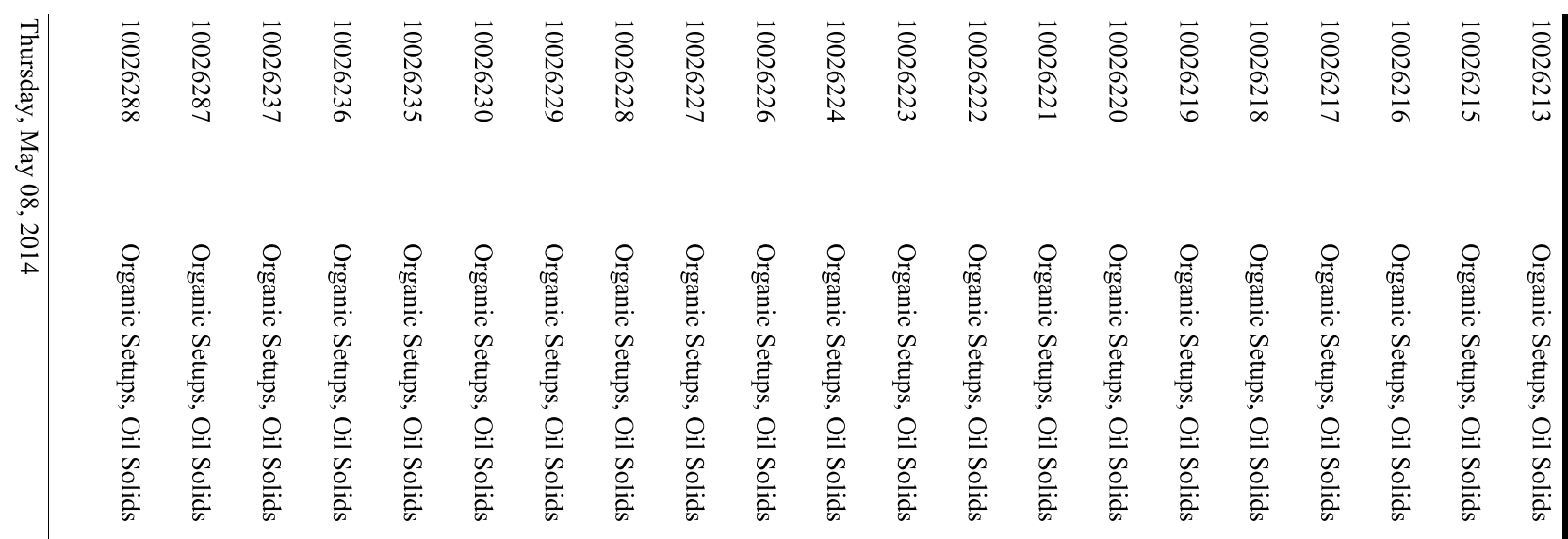

芯 雚芯 芯

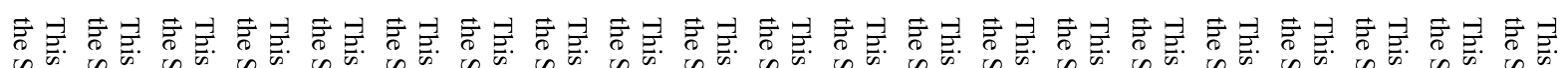

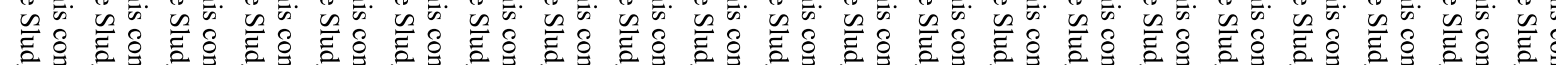

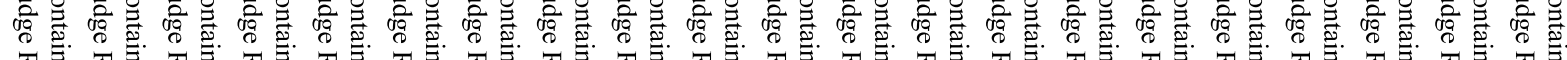
不

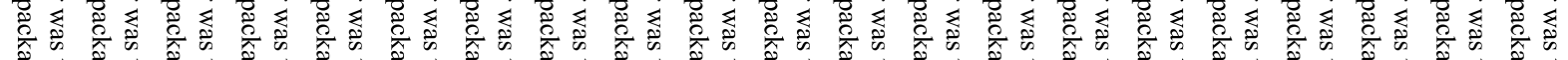

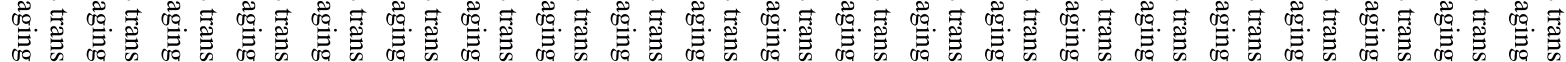

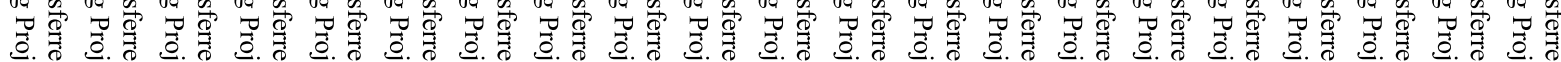

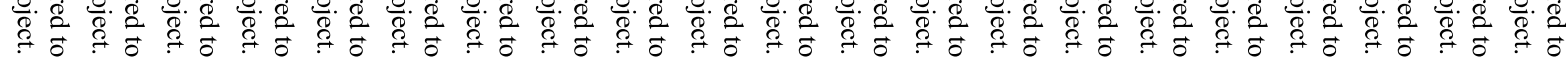

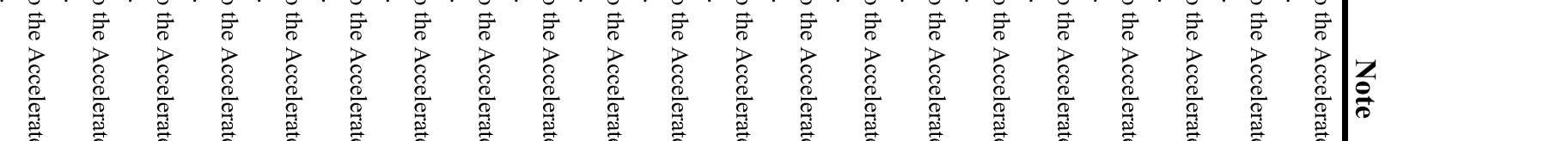




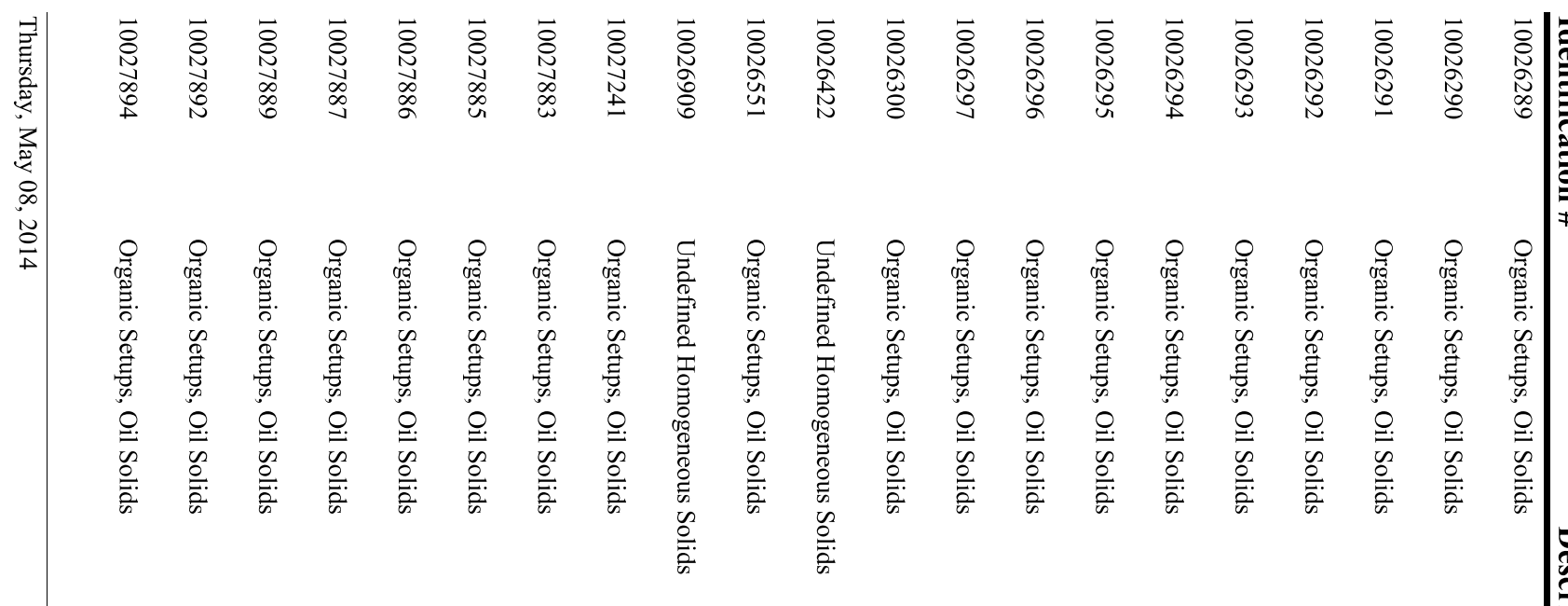

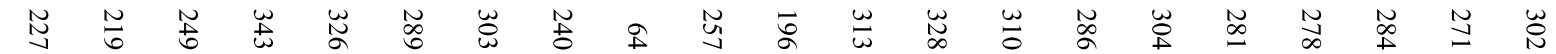

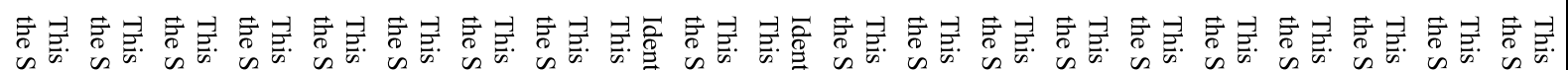

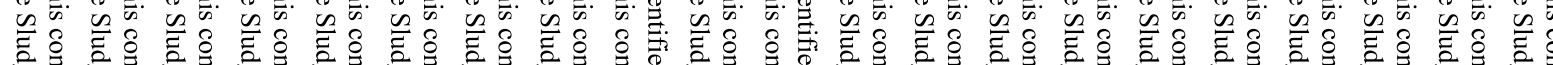

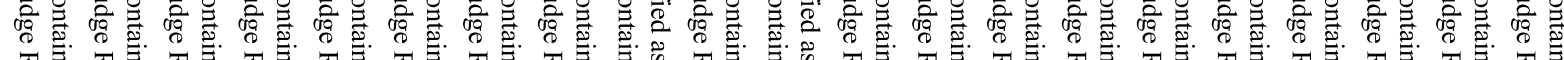

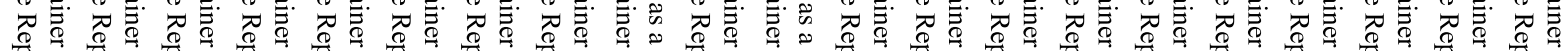

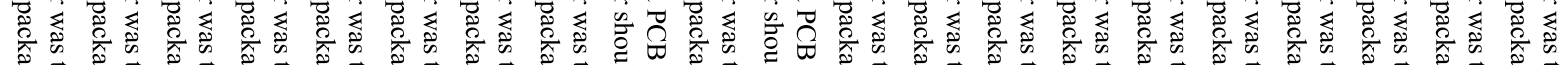

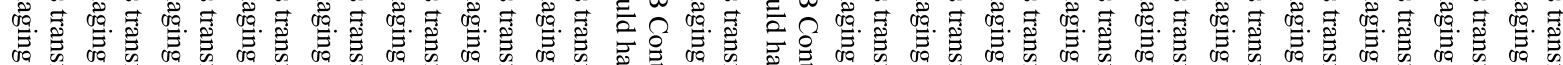

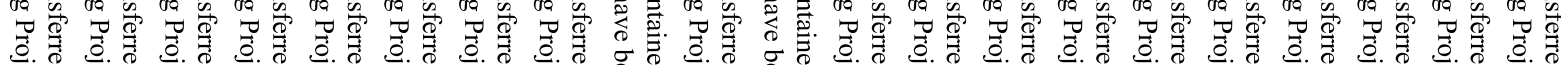

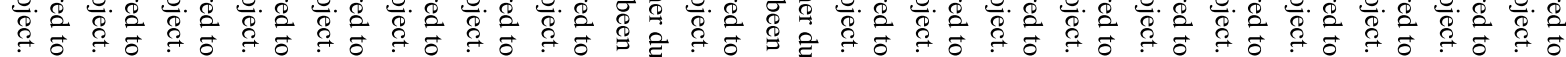

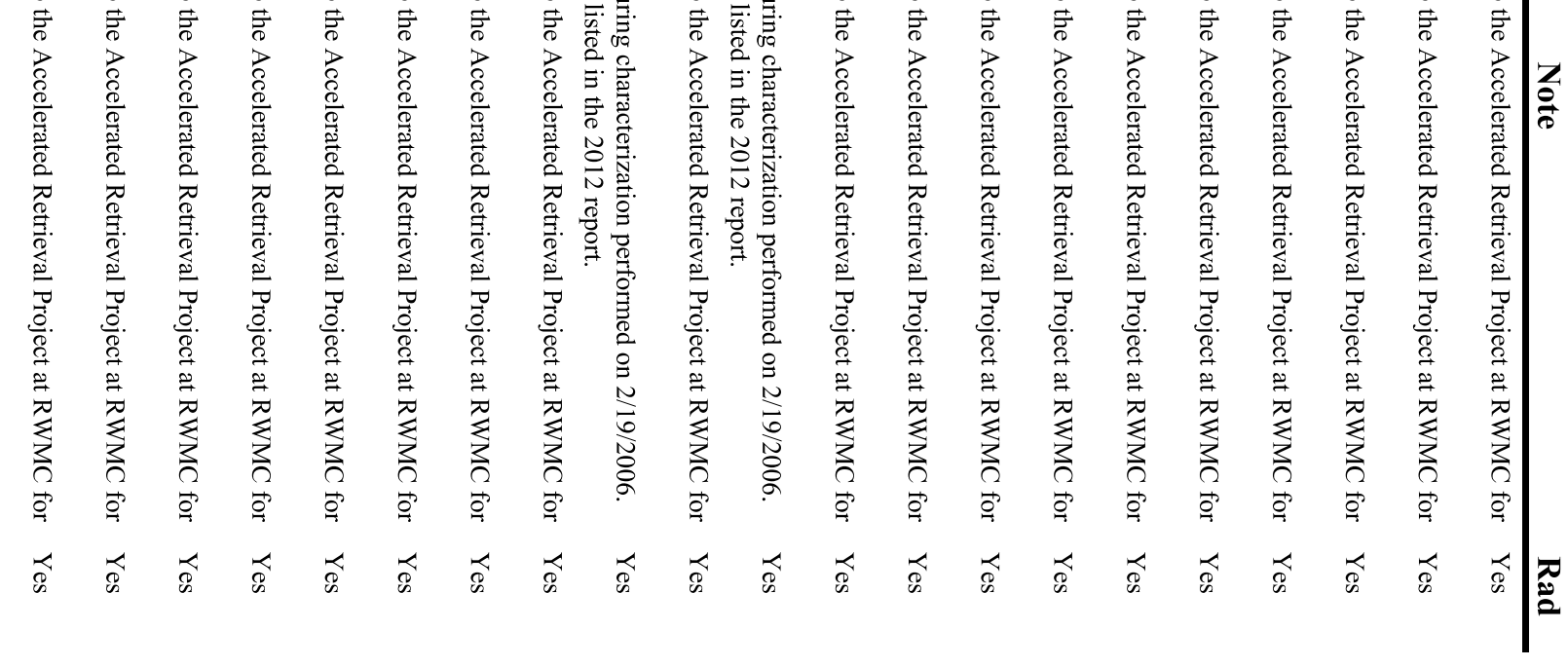




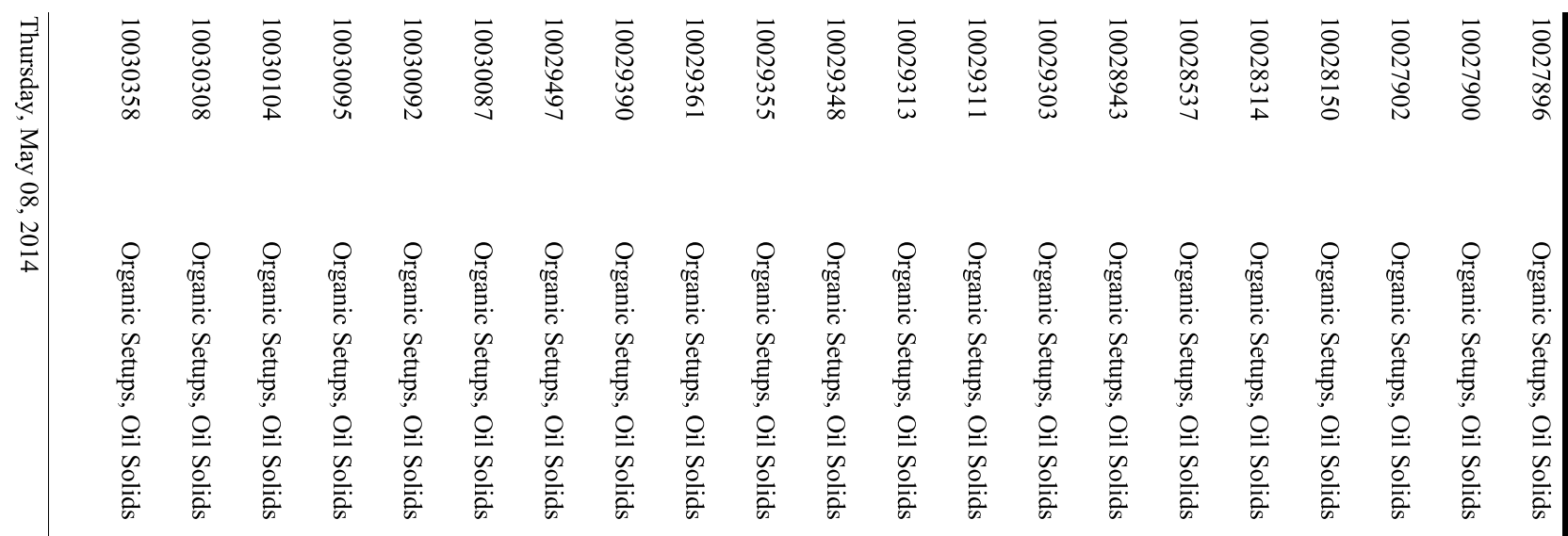

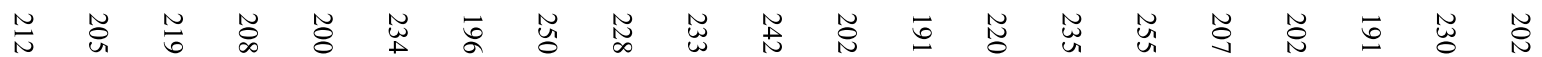

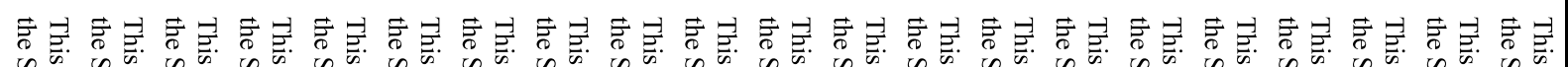

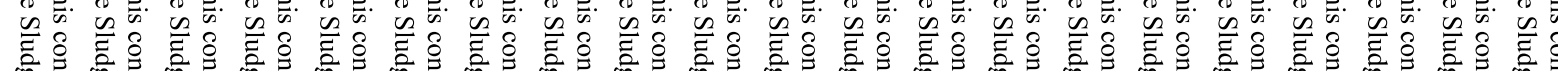

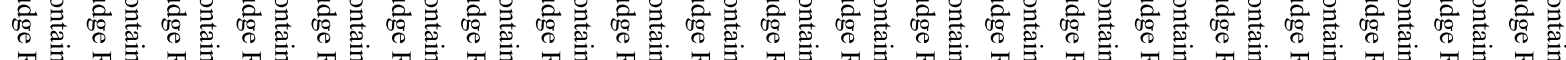
元

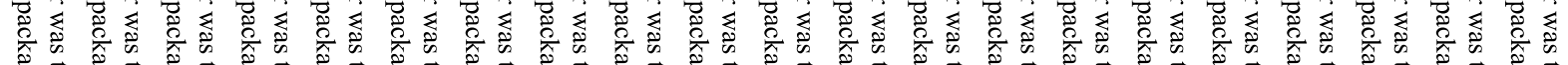

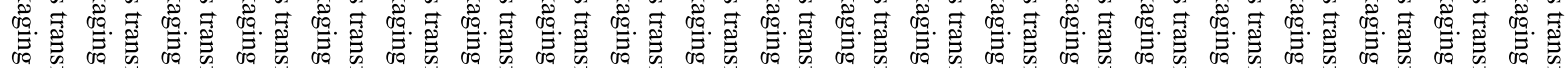

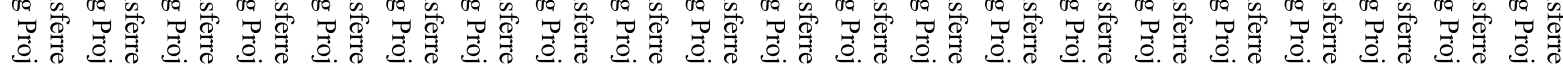

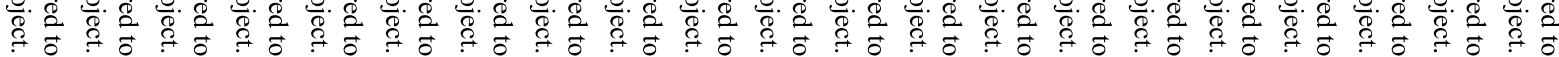

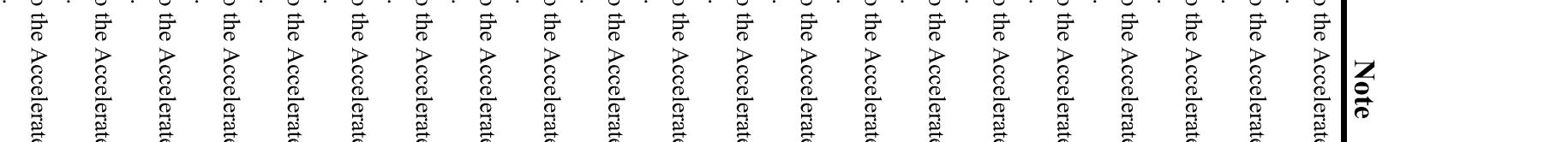




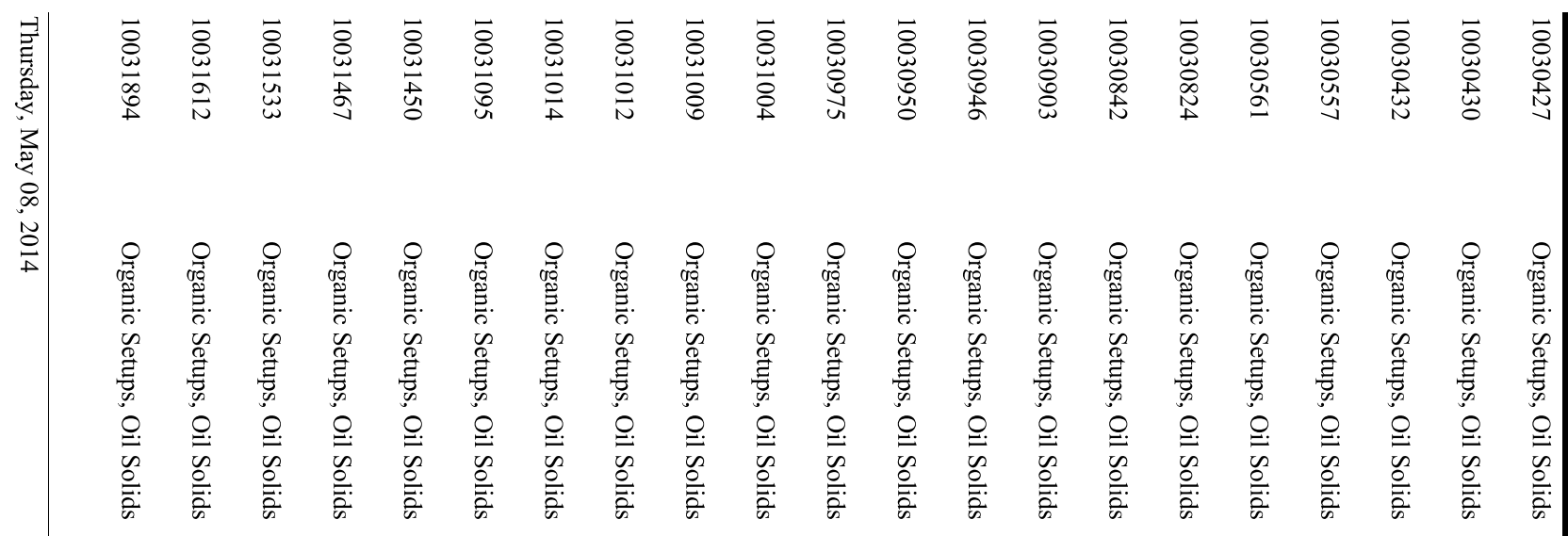

N

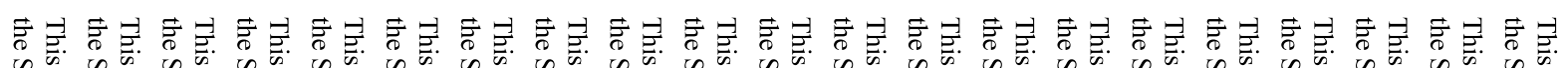

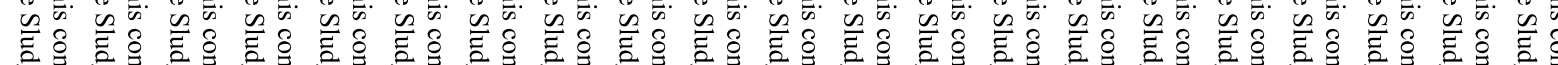

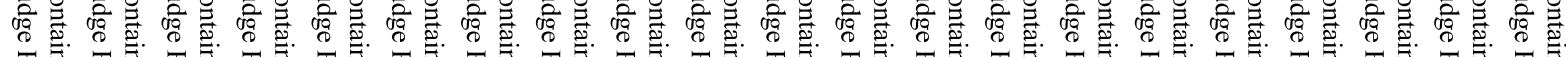
不

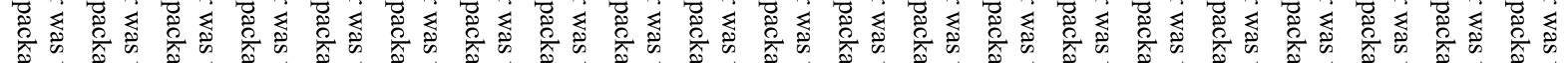

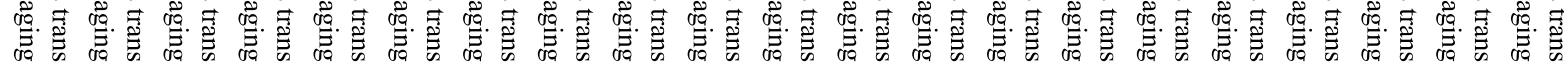

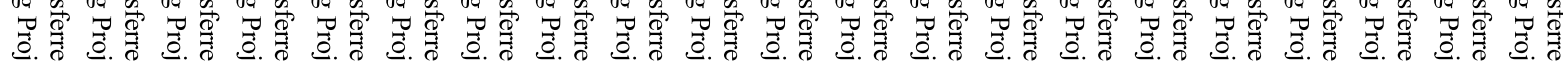

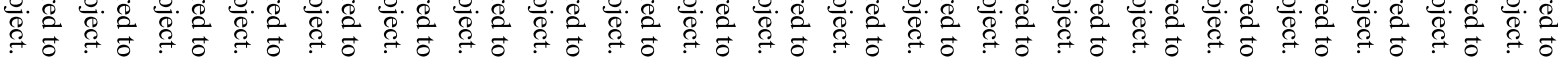

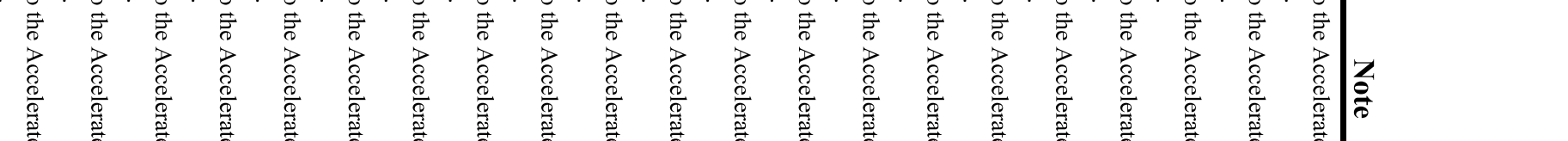




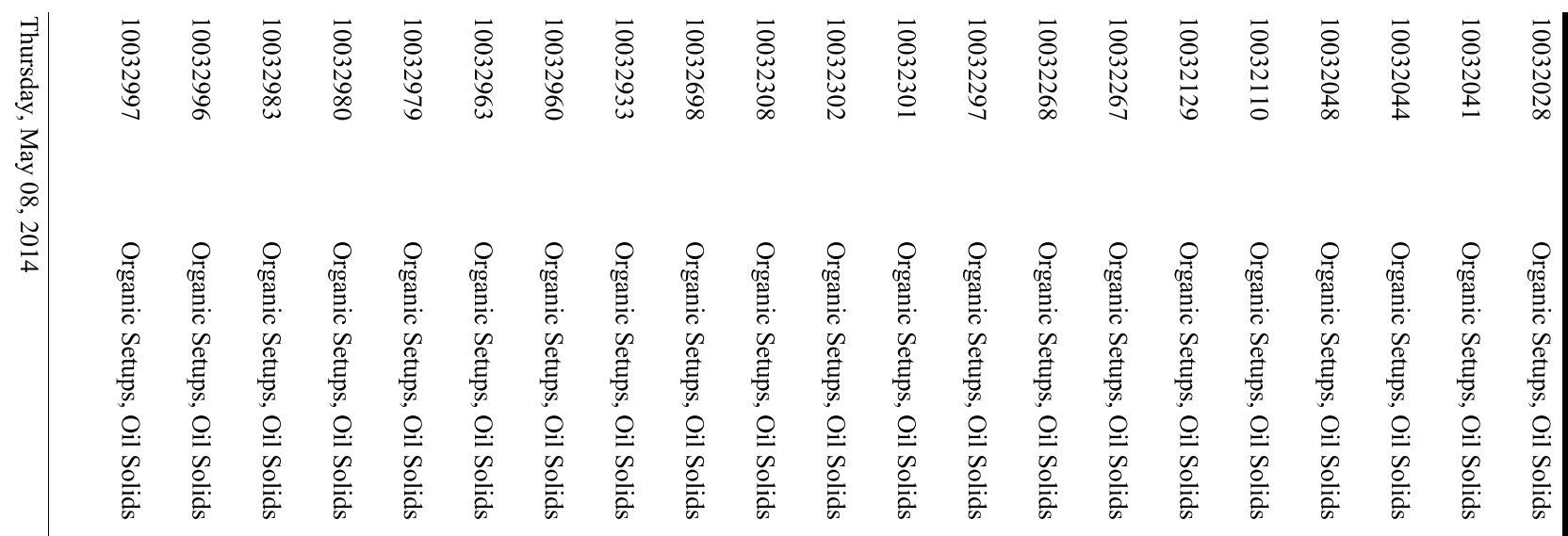

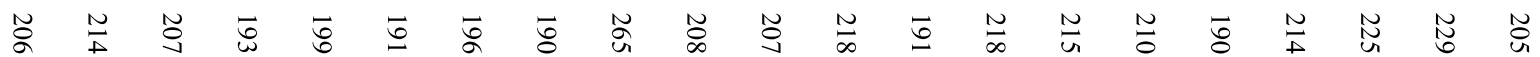

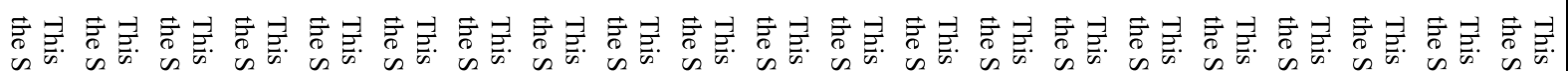

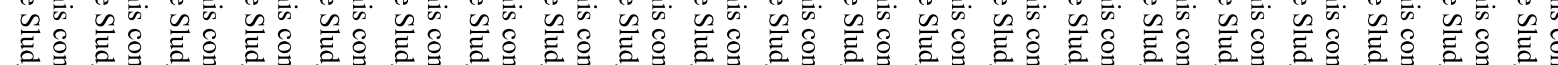

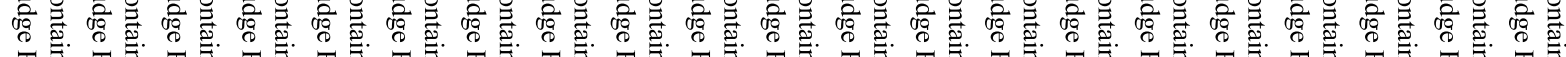
不

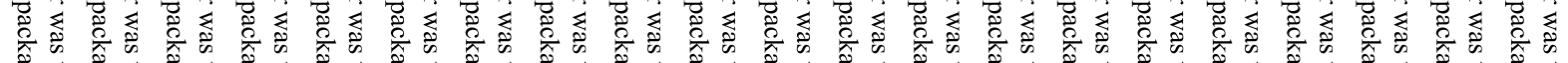

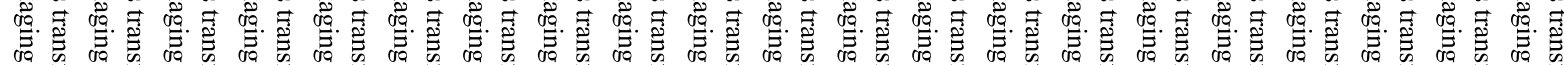

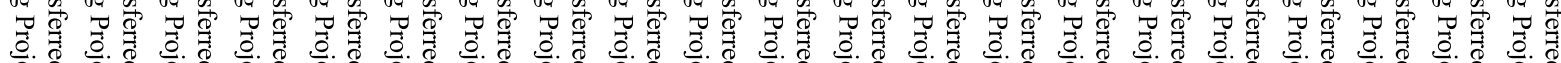

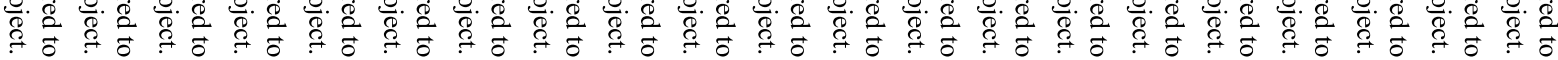

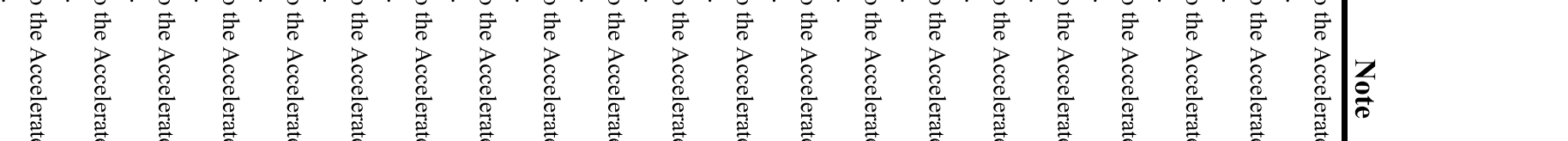




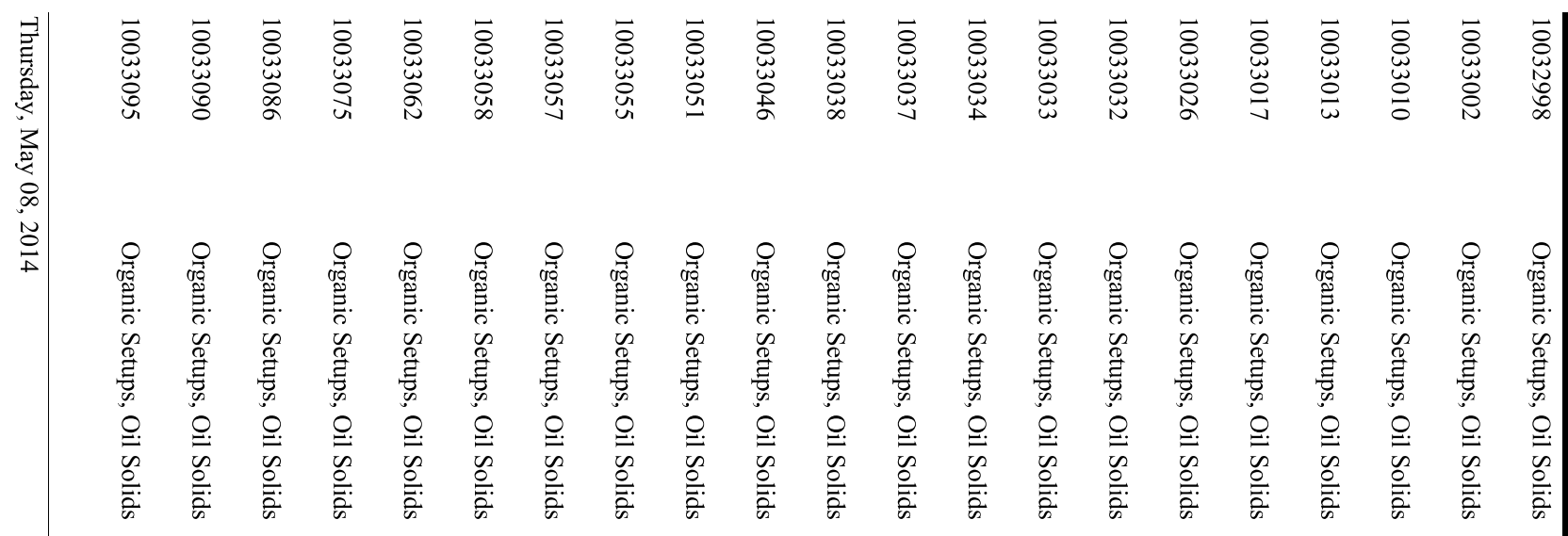

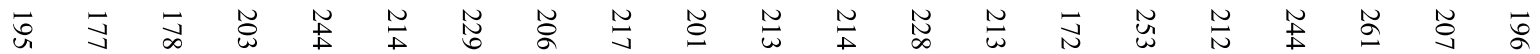

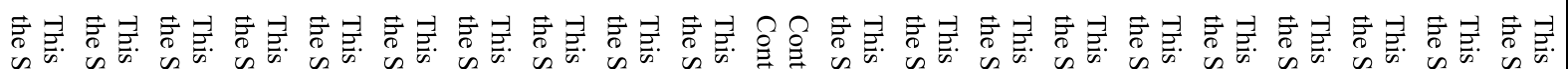

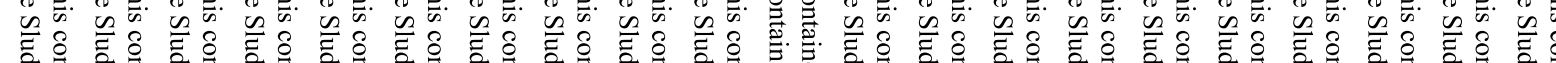

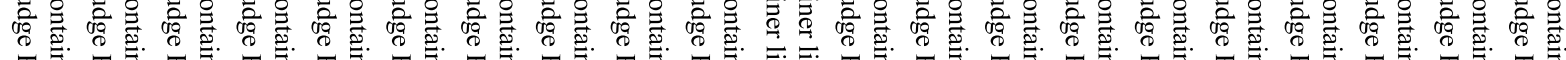
不

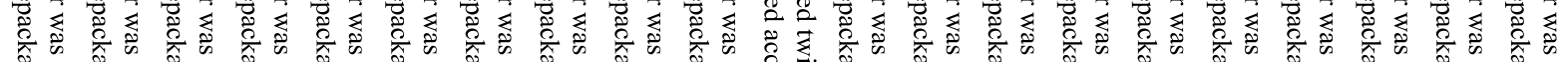

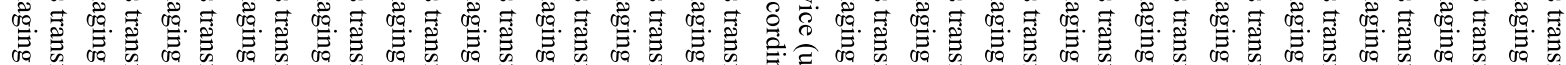

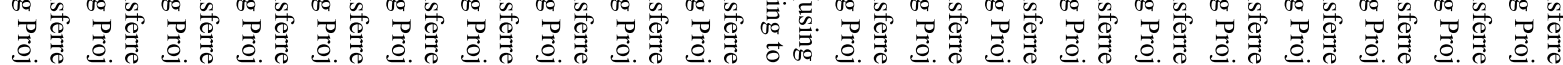

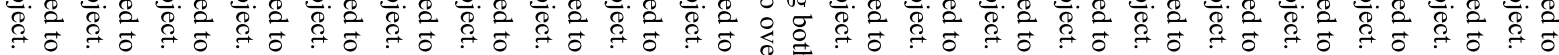

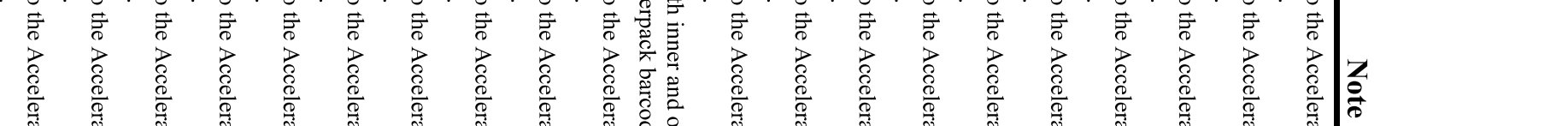




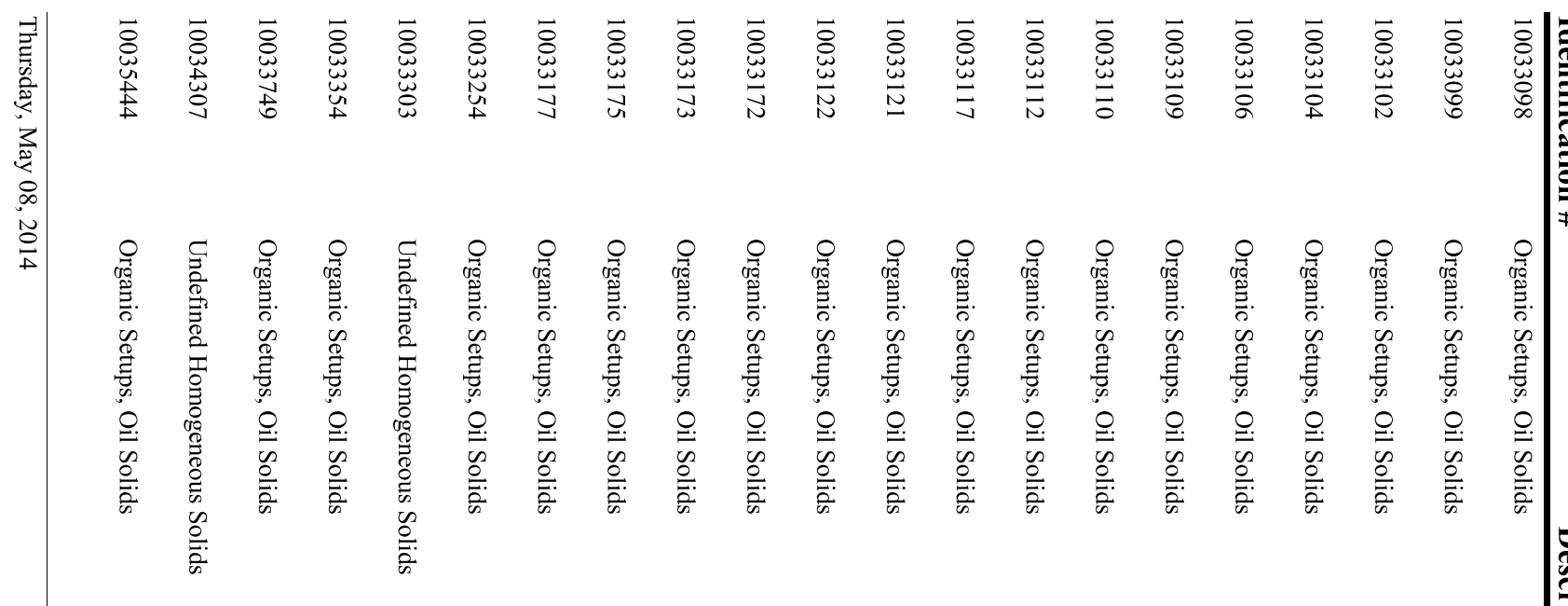

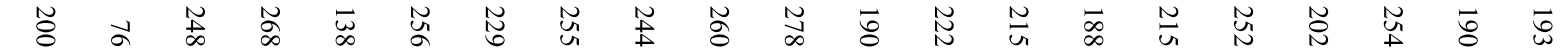

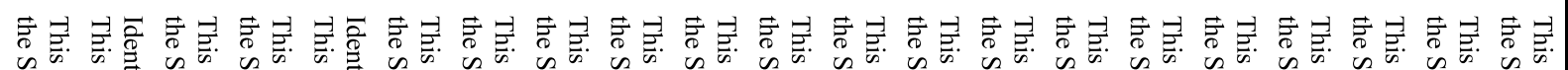

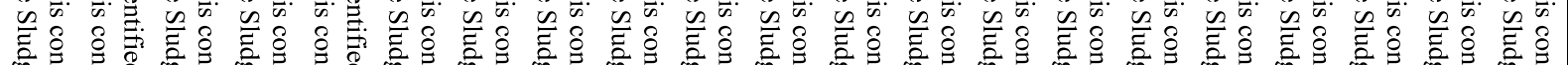

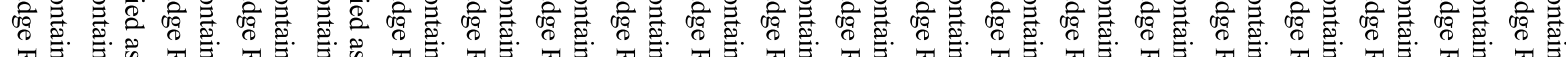

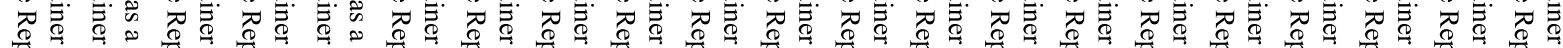

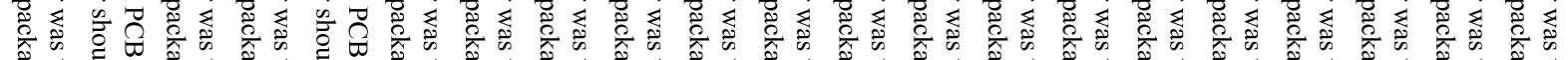

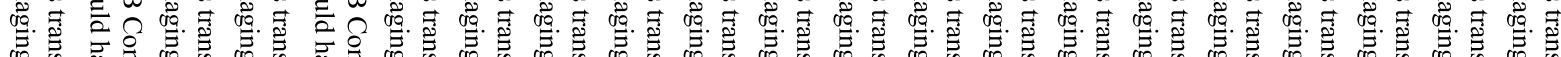

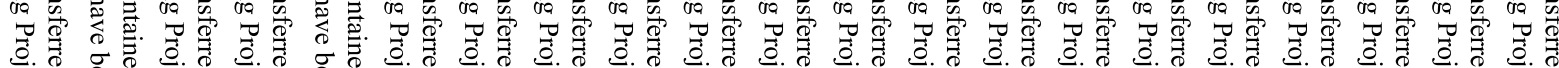

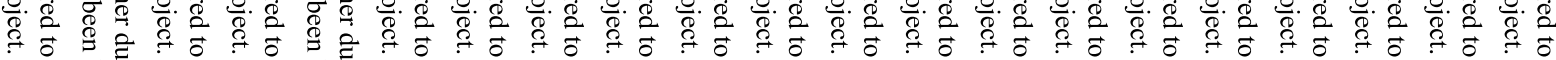

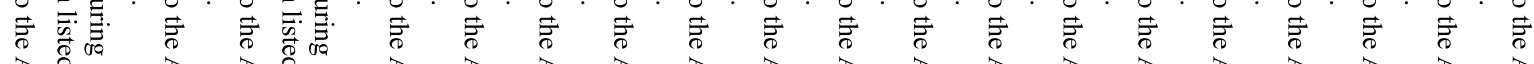

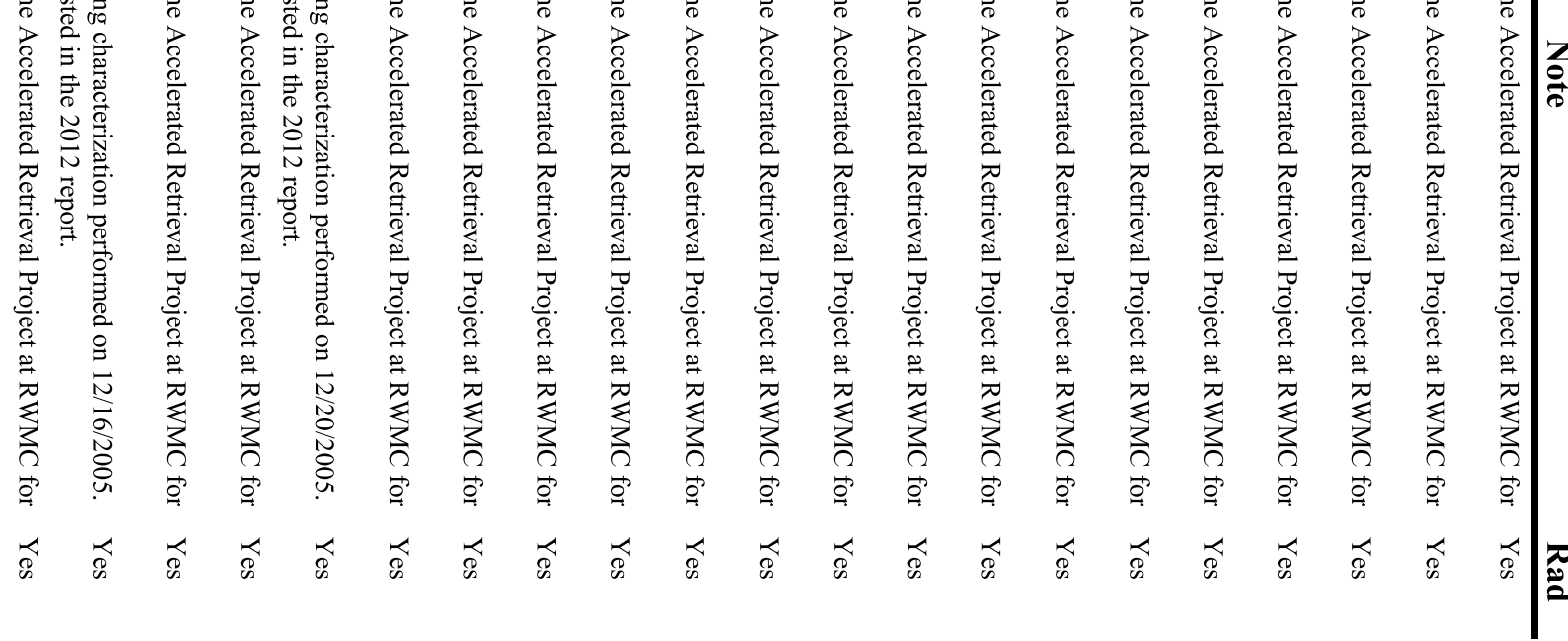




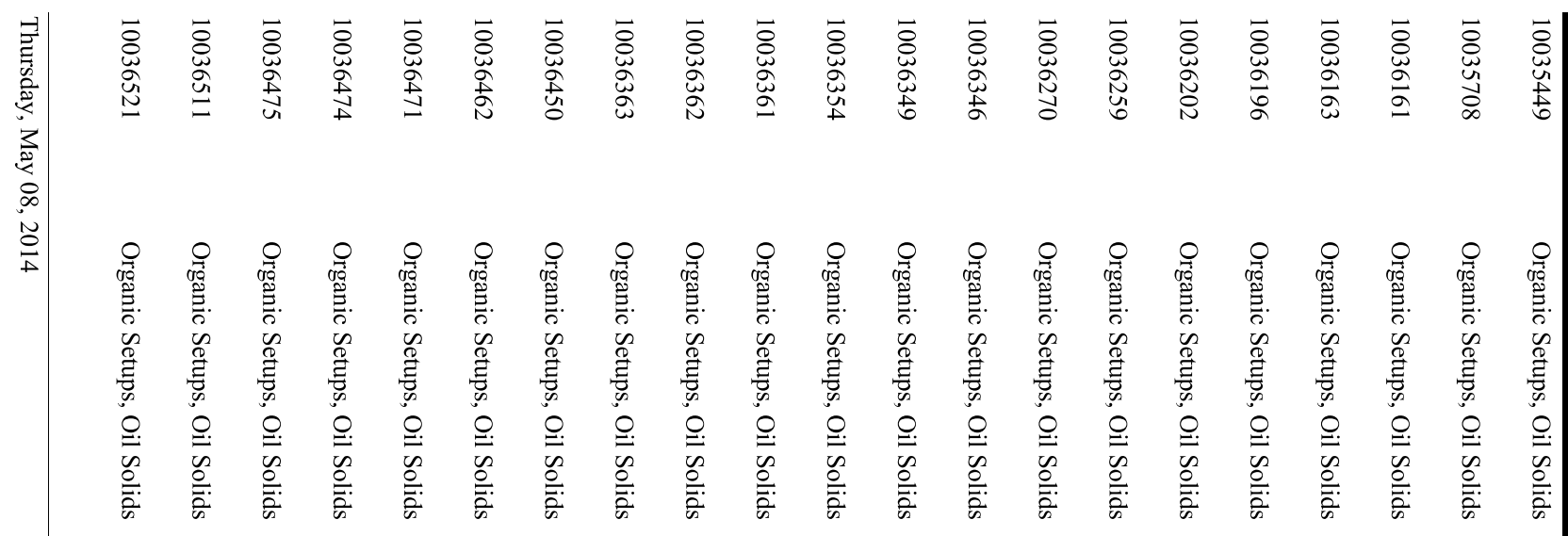

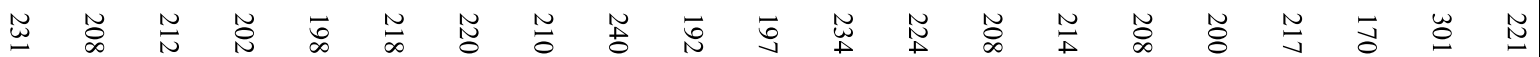

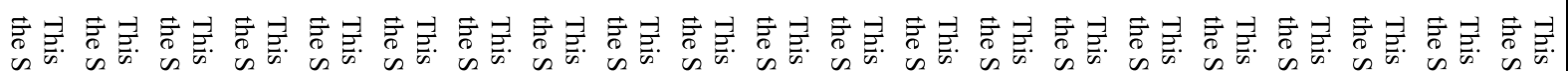

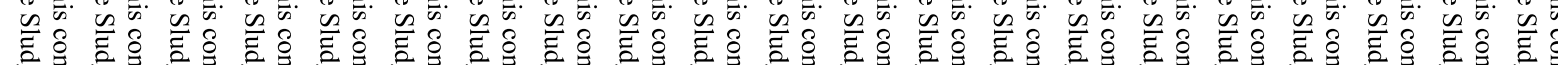

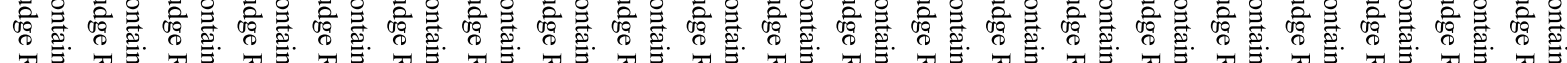
不

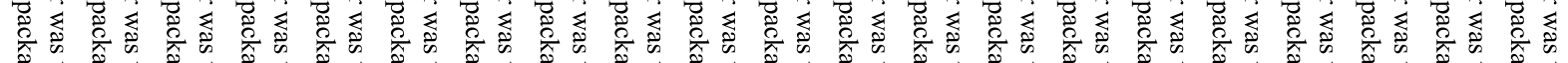

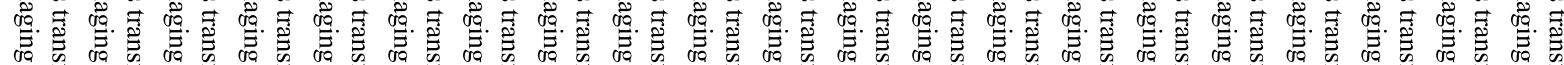

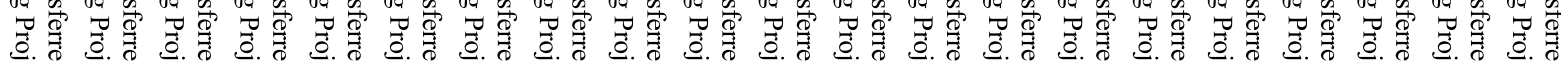

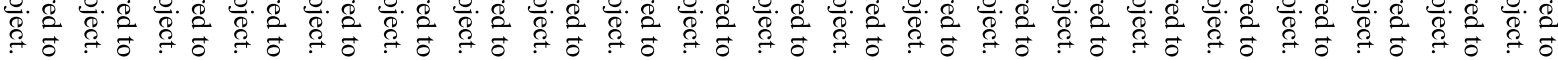

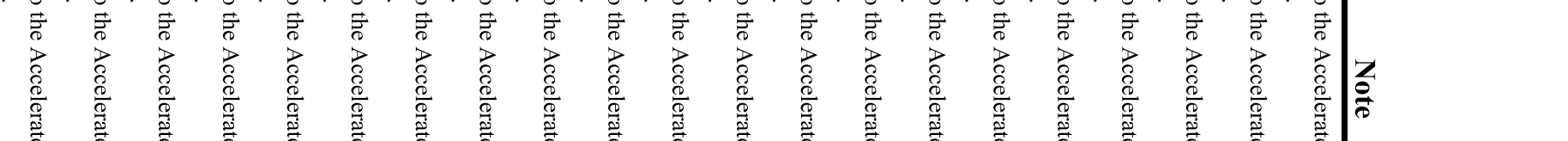




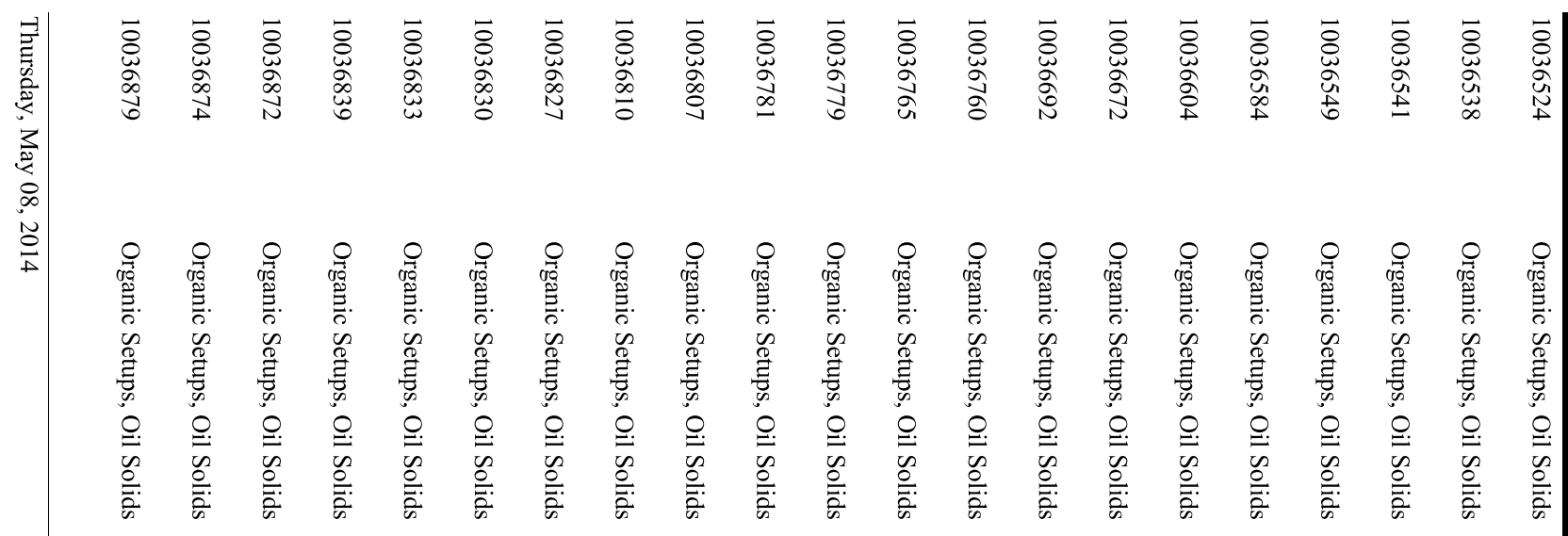

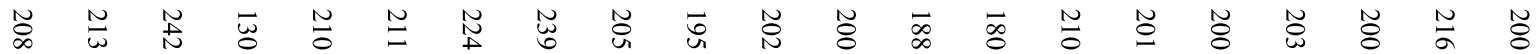

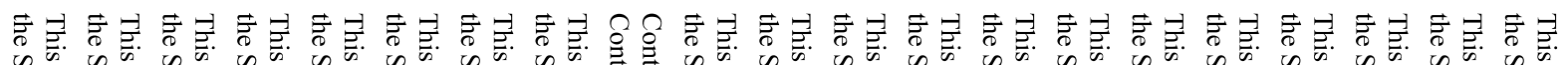

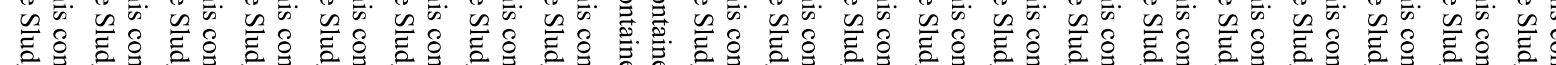

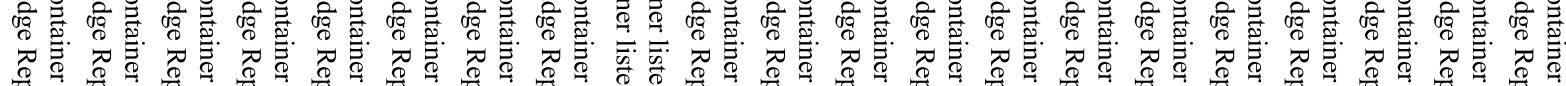

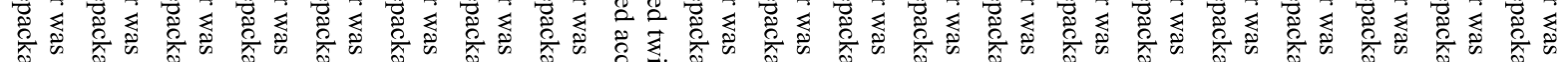

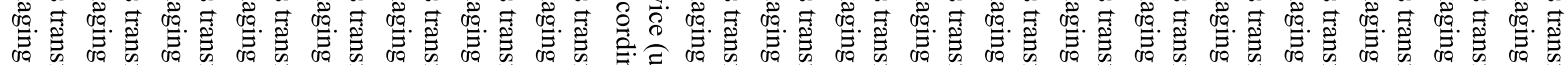

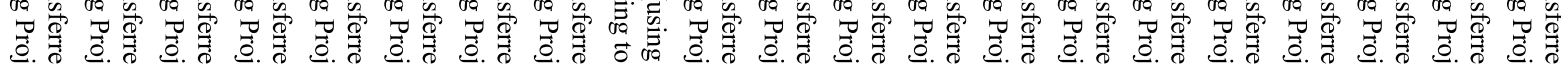

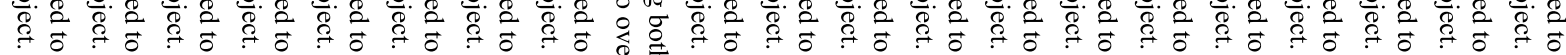

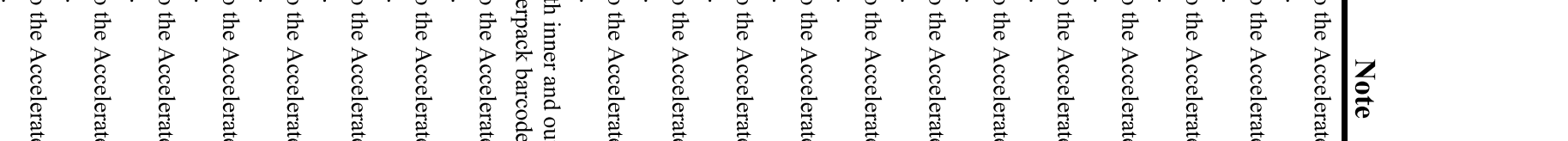




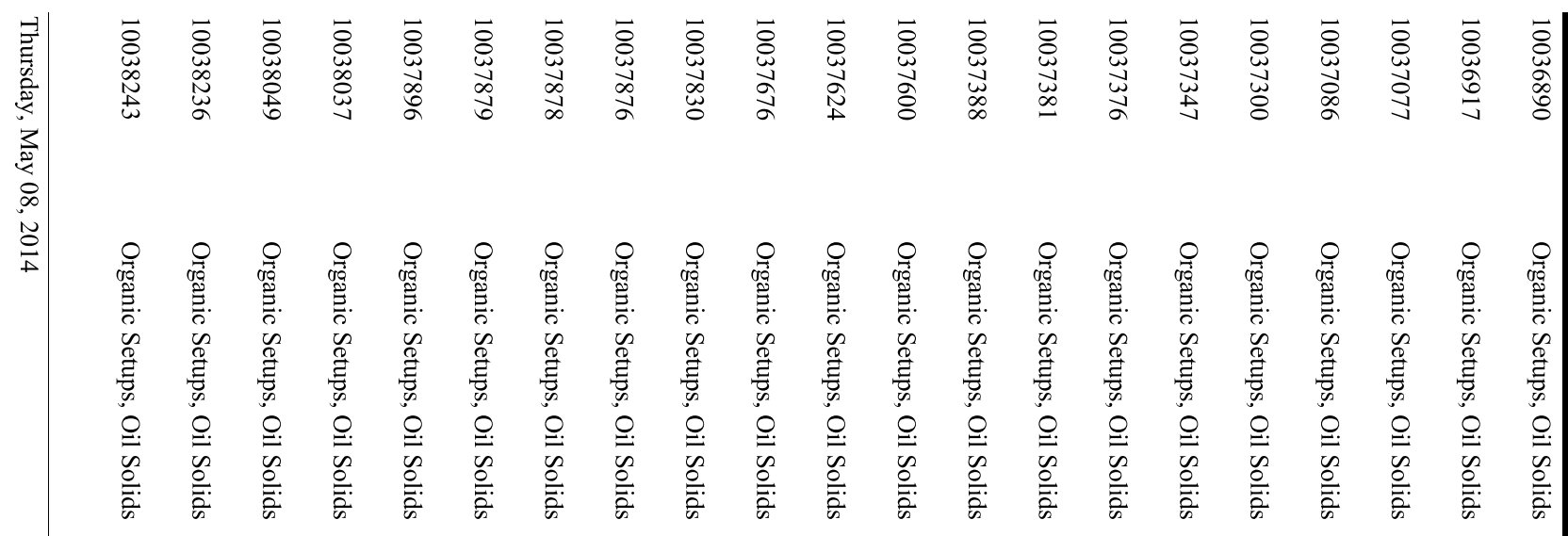

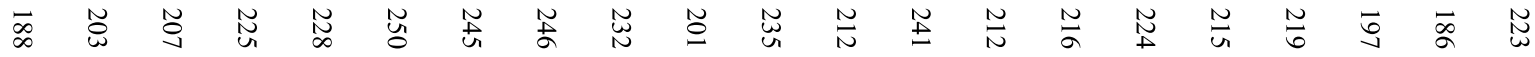

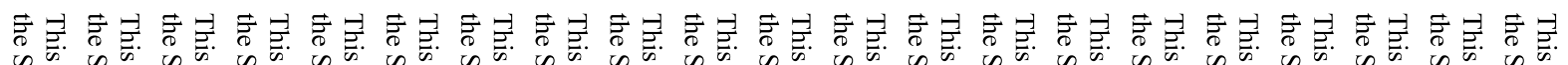

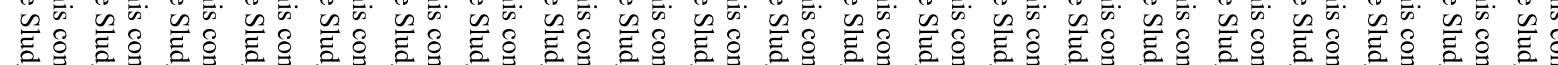

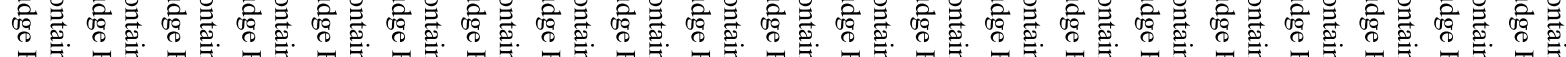
不

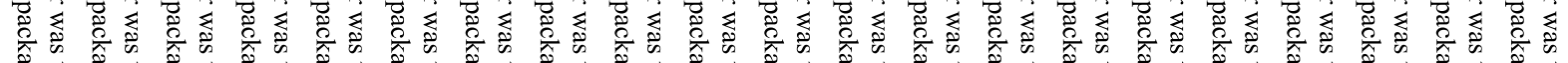

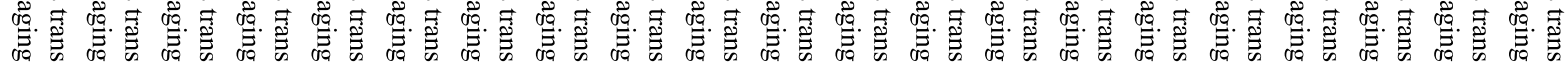

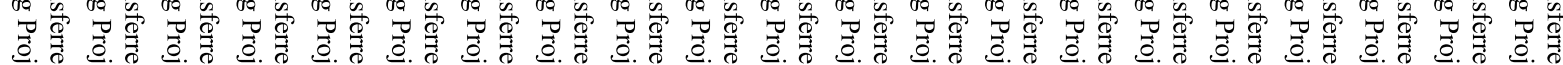

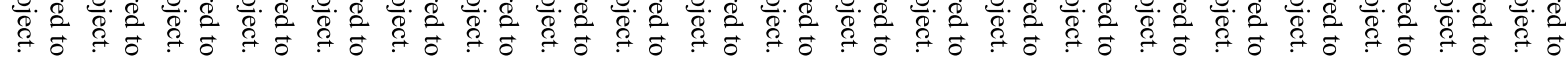

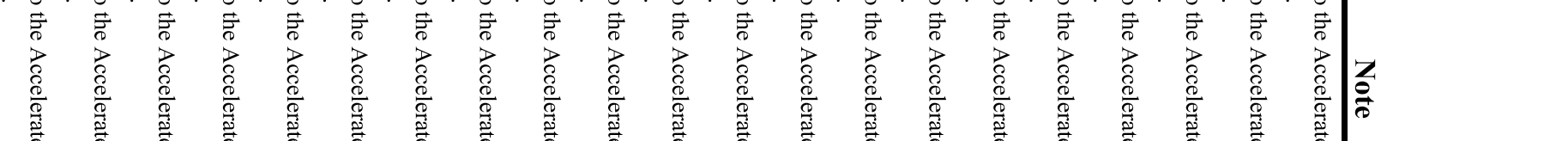




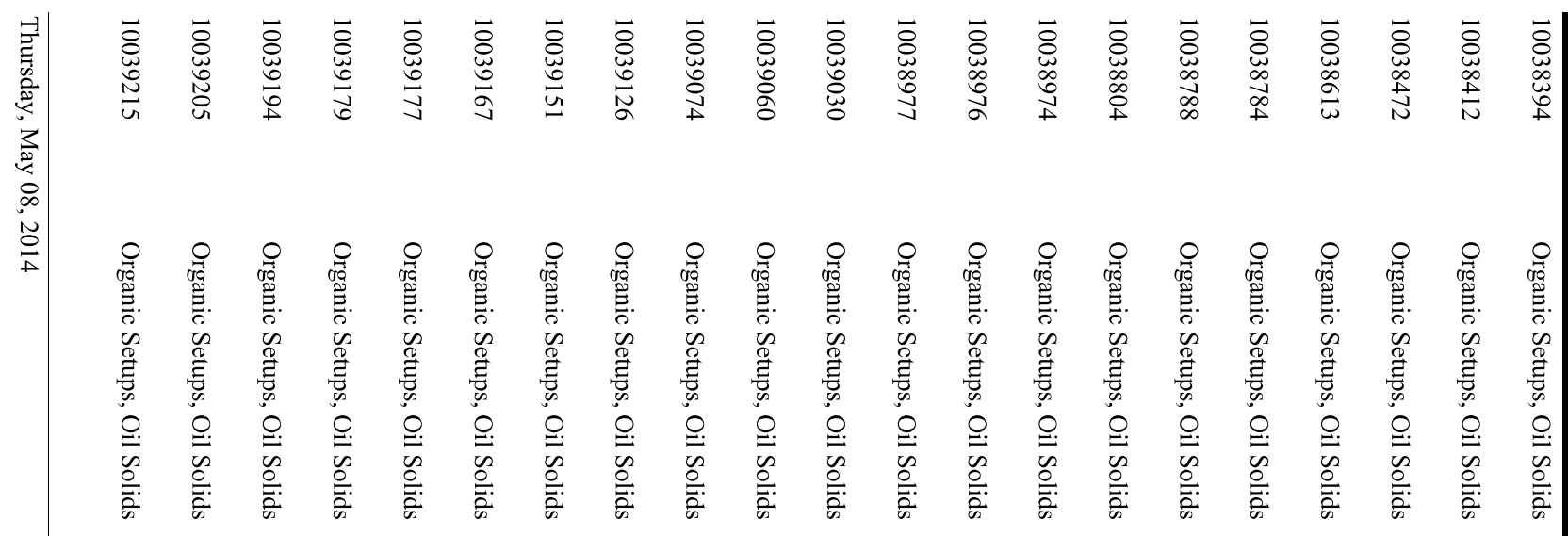

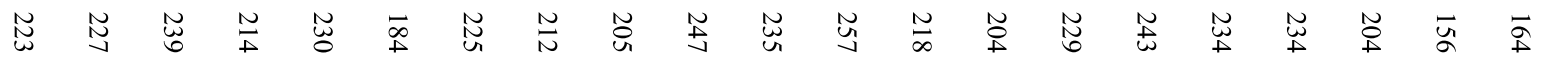

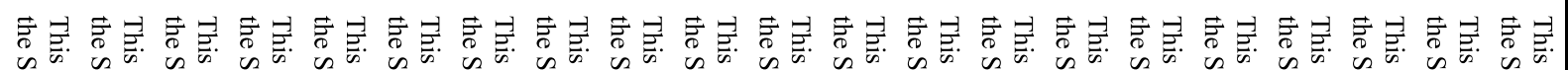

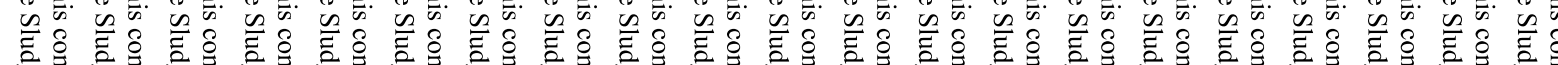

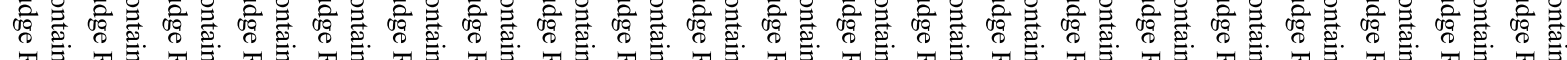
不

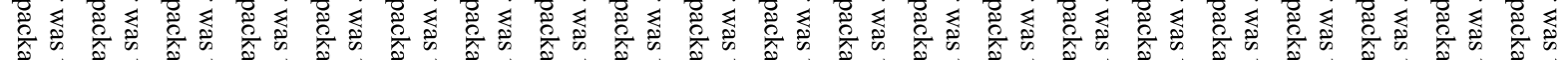

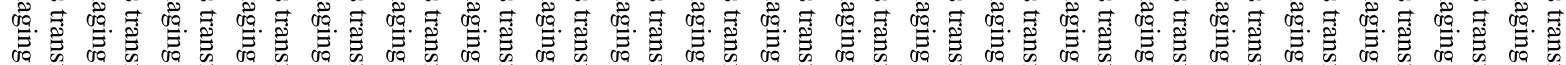

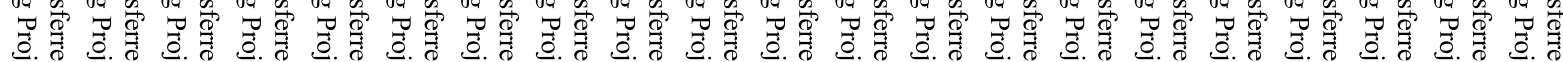

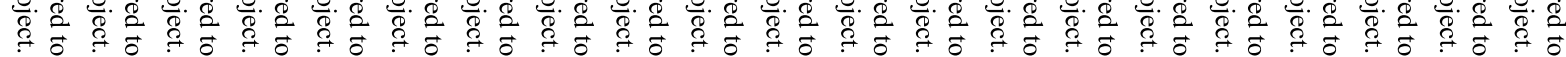

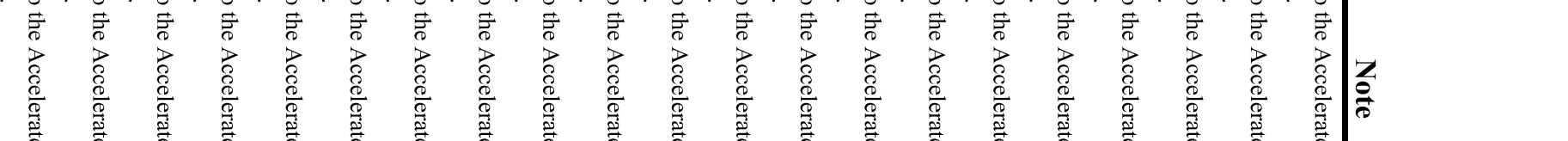




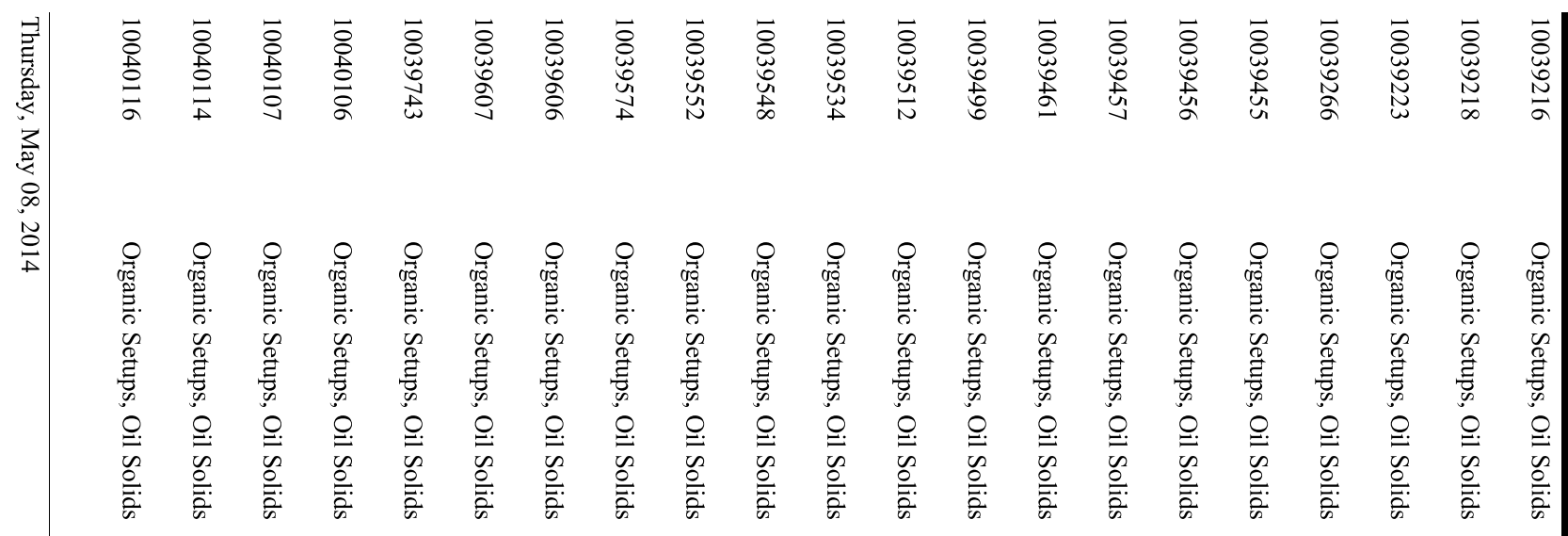

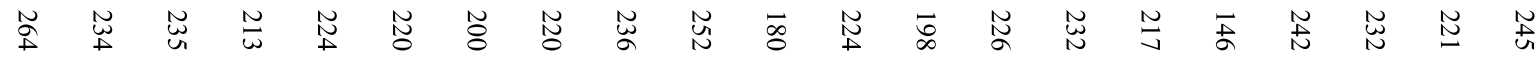

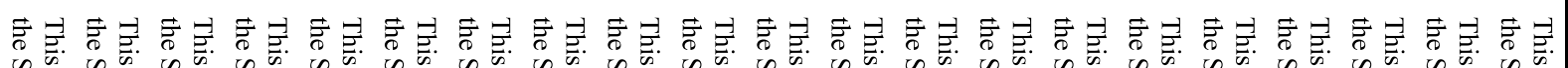

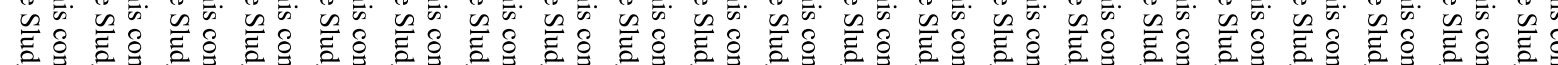

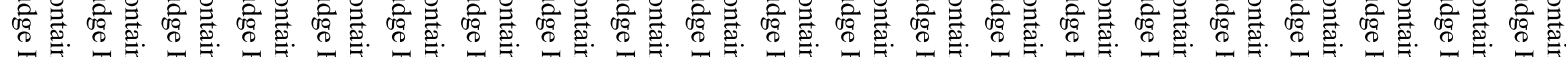
不

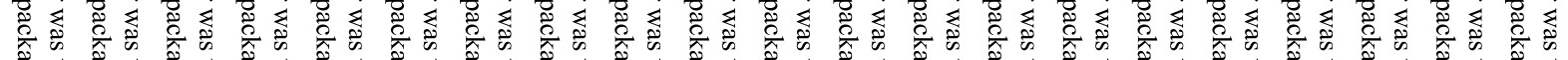

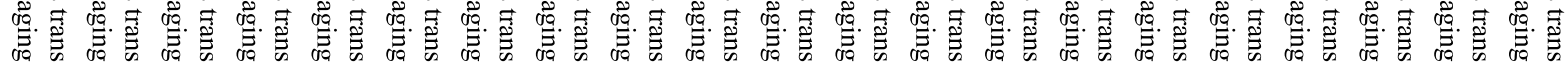

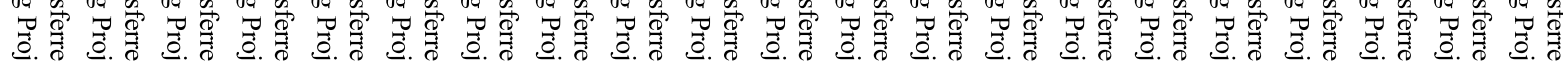

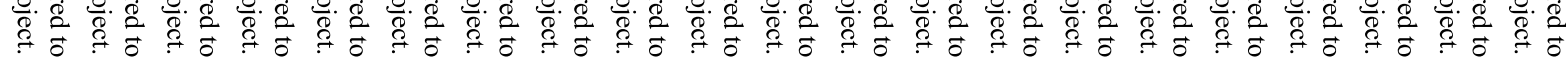

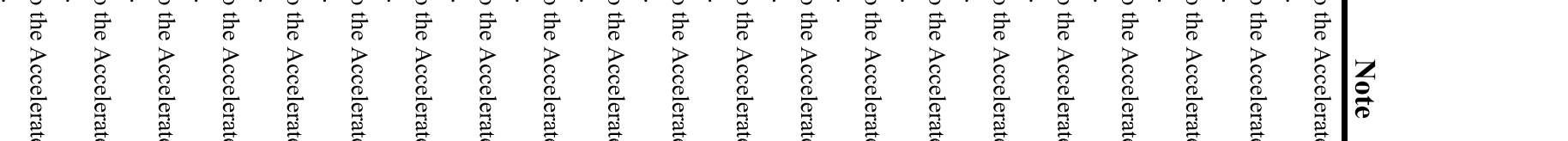




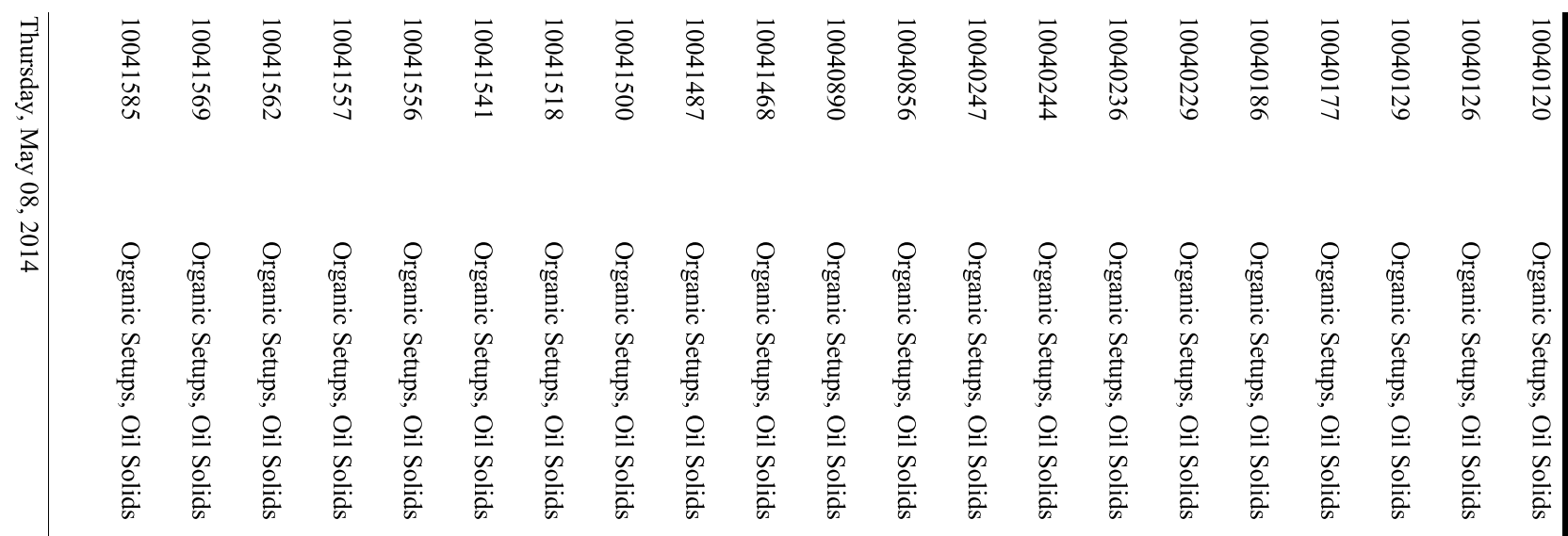

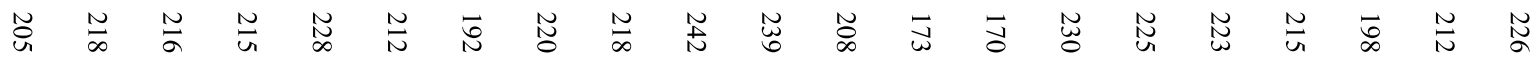

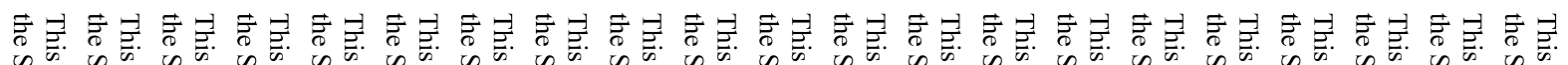

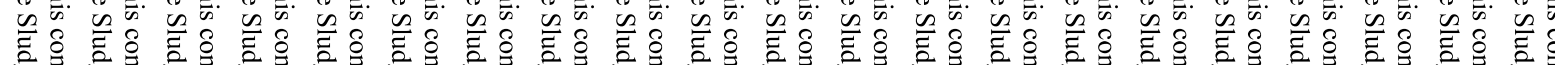

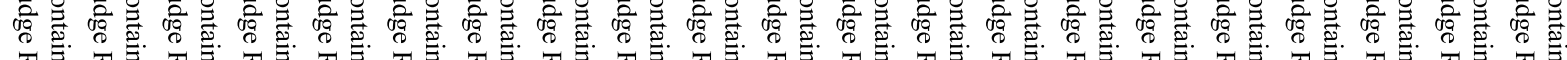
不

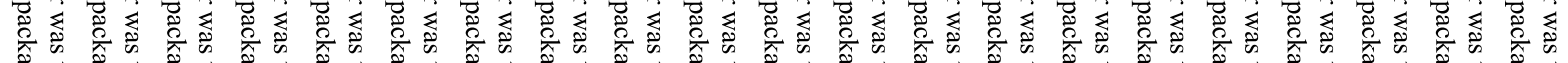

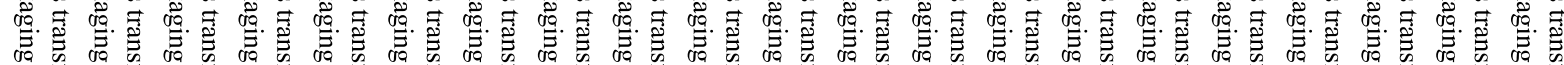

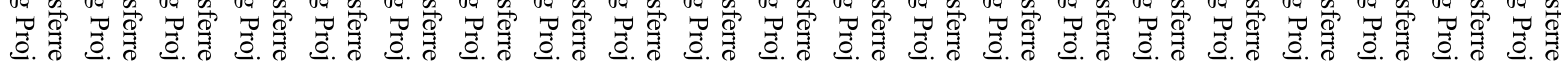

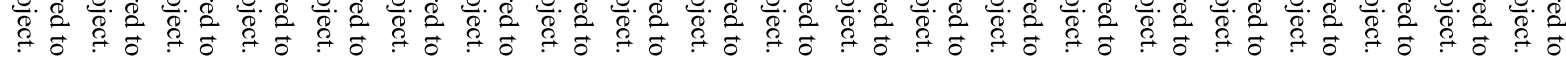

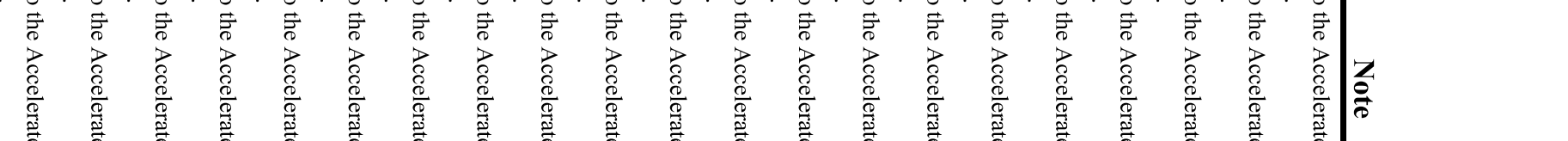




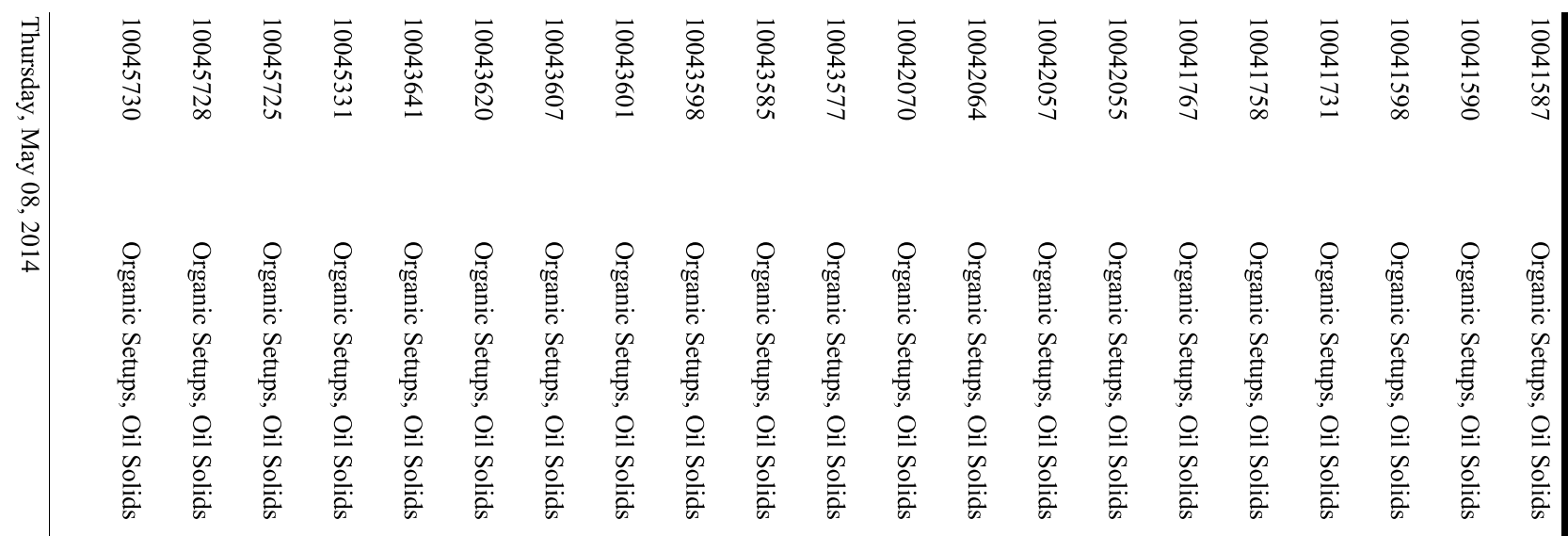

范

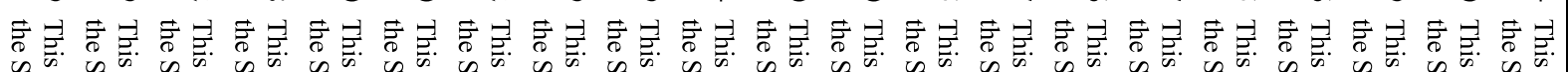

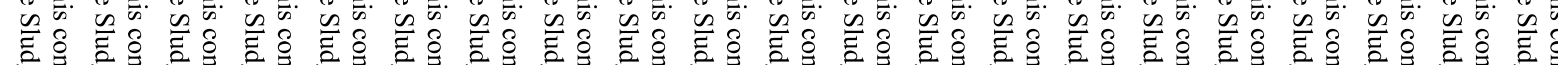

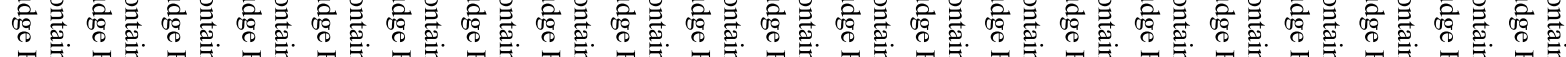
不

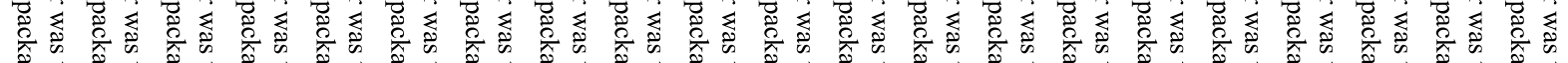

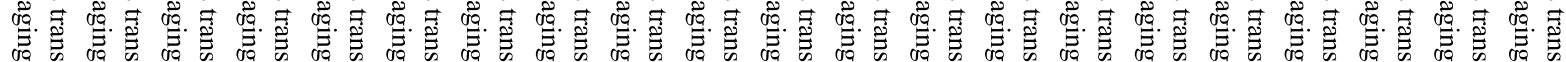

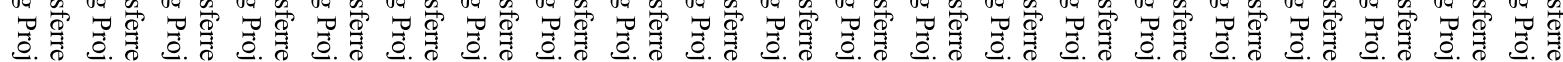

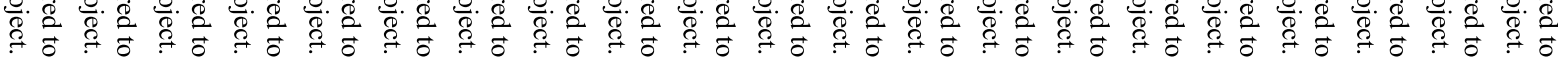

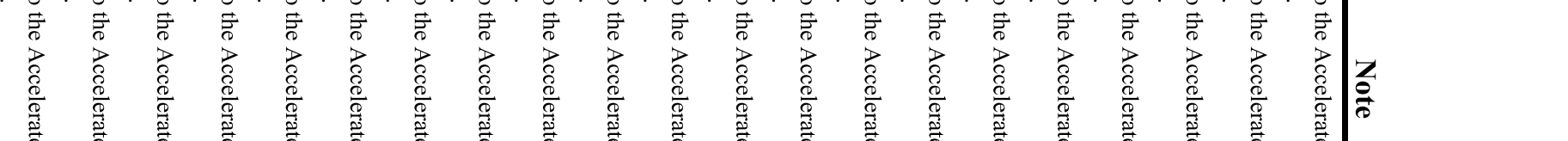




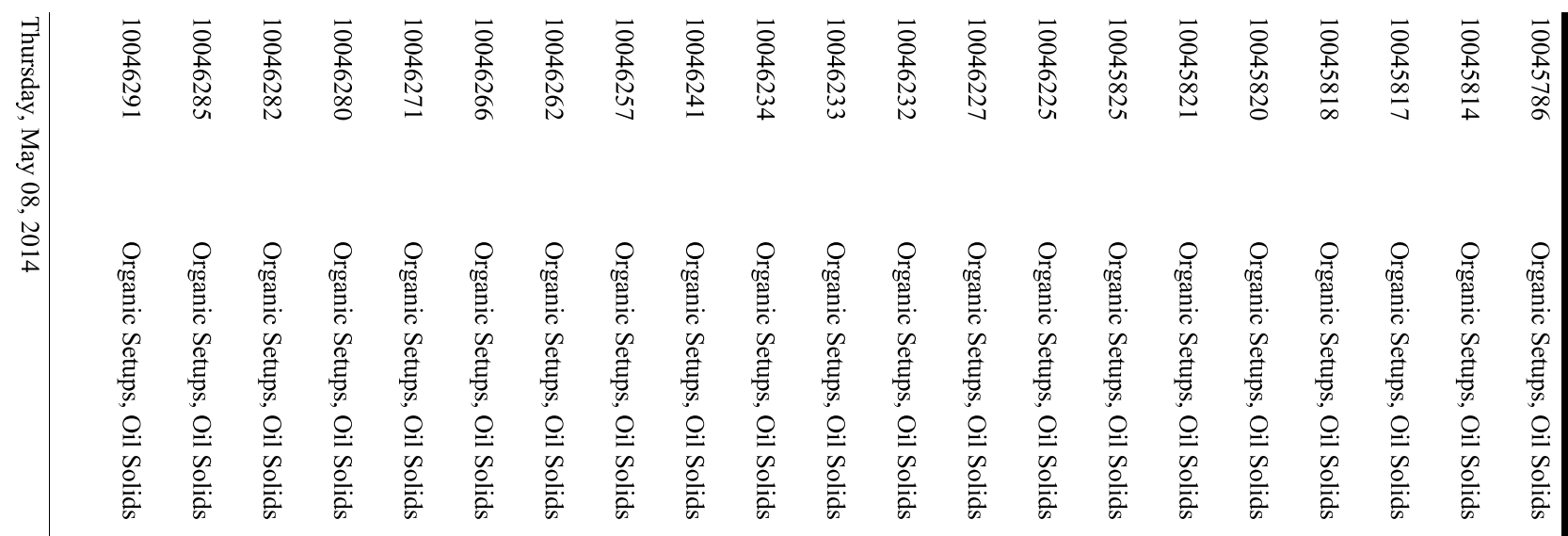

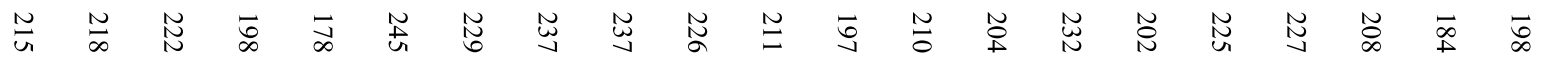

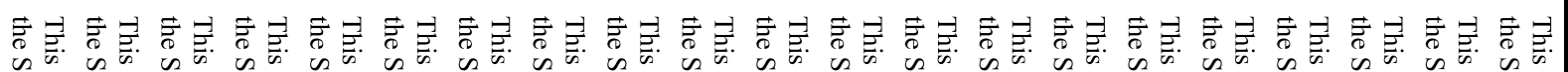

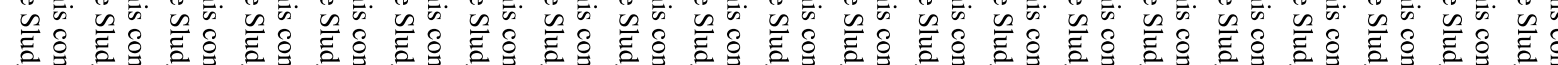

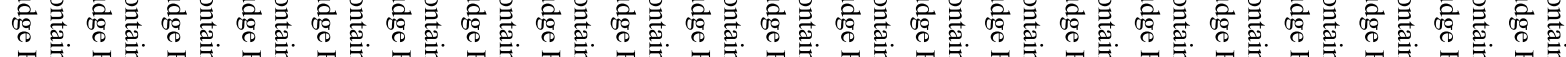
不

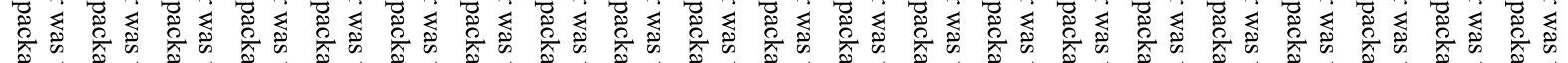

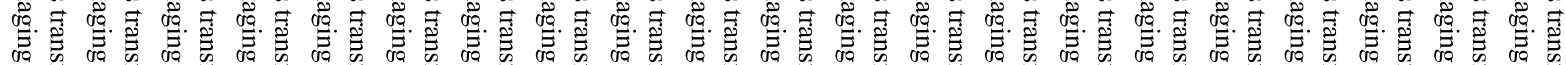

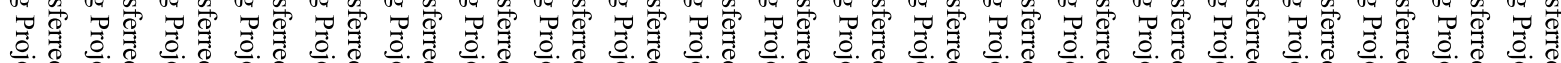

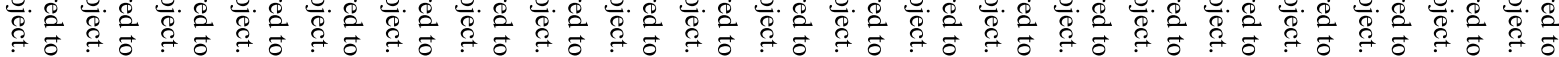

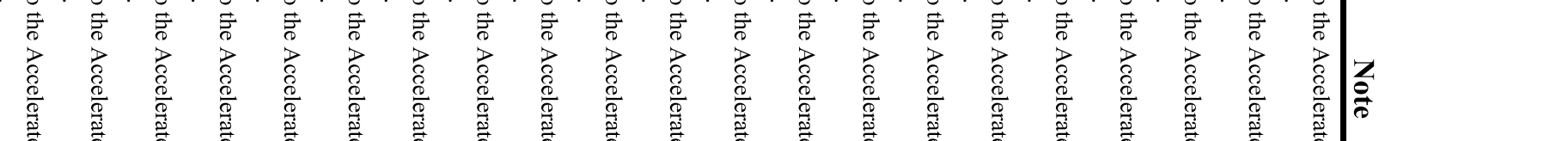




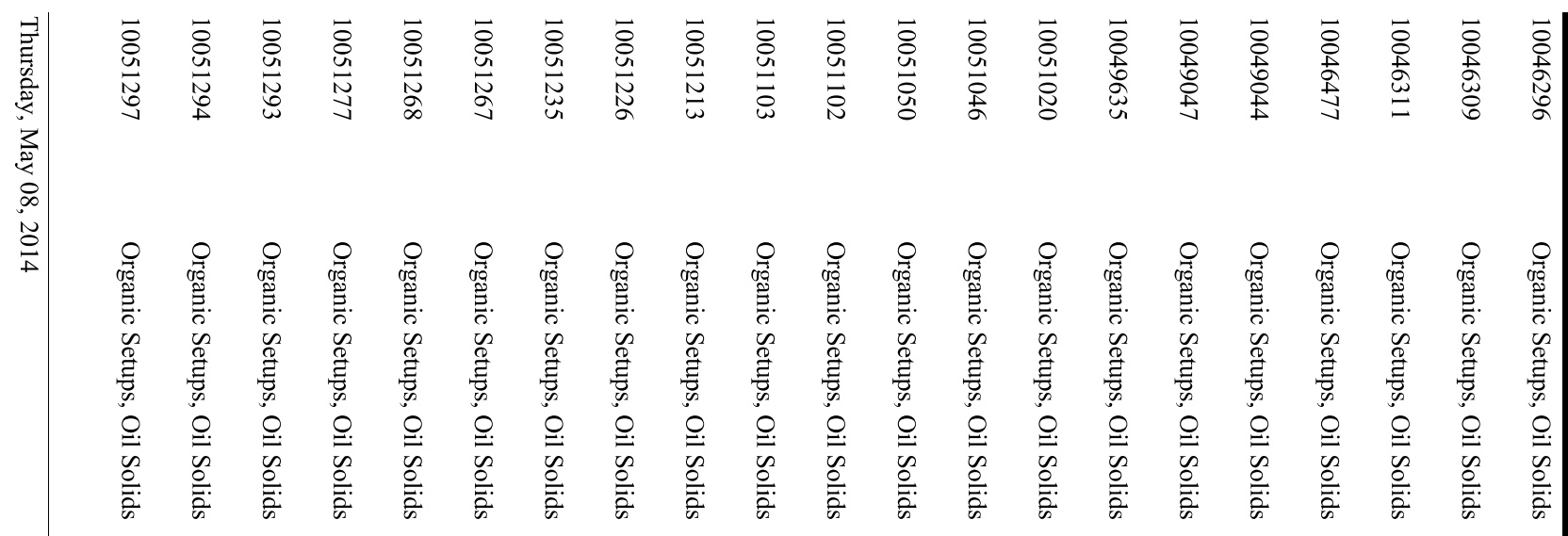

N

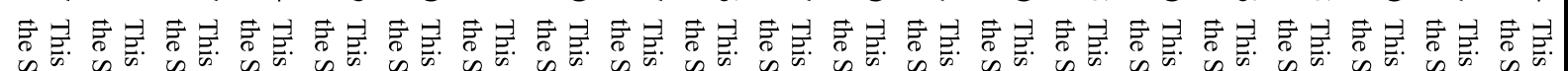

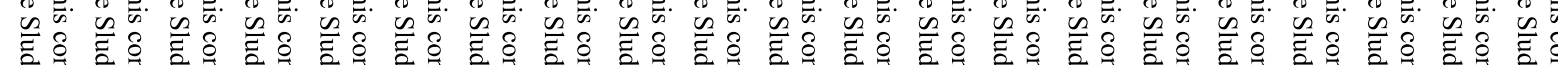

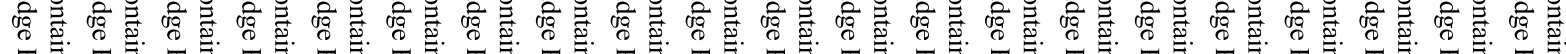

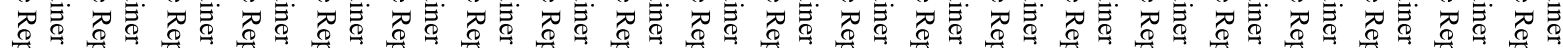

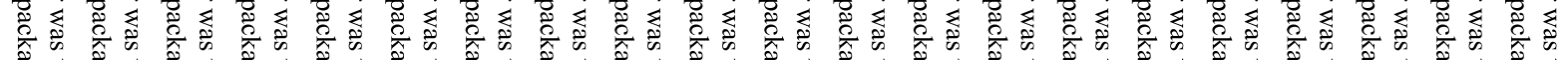

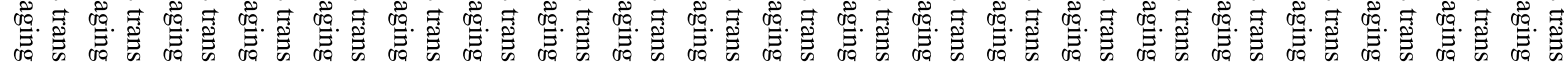

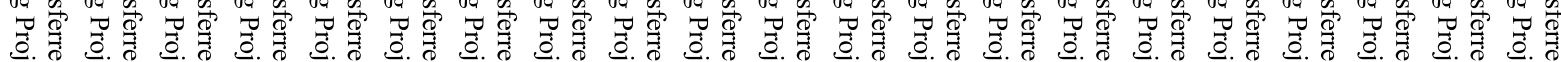

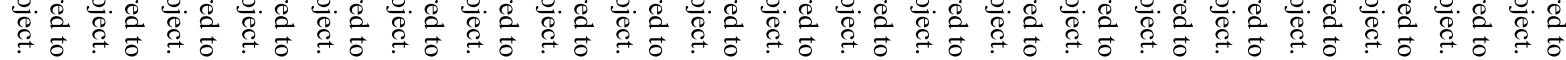

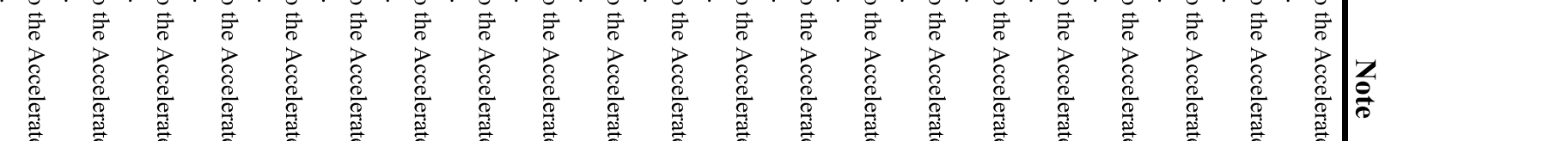




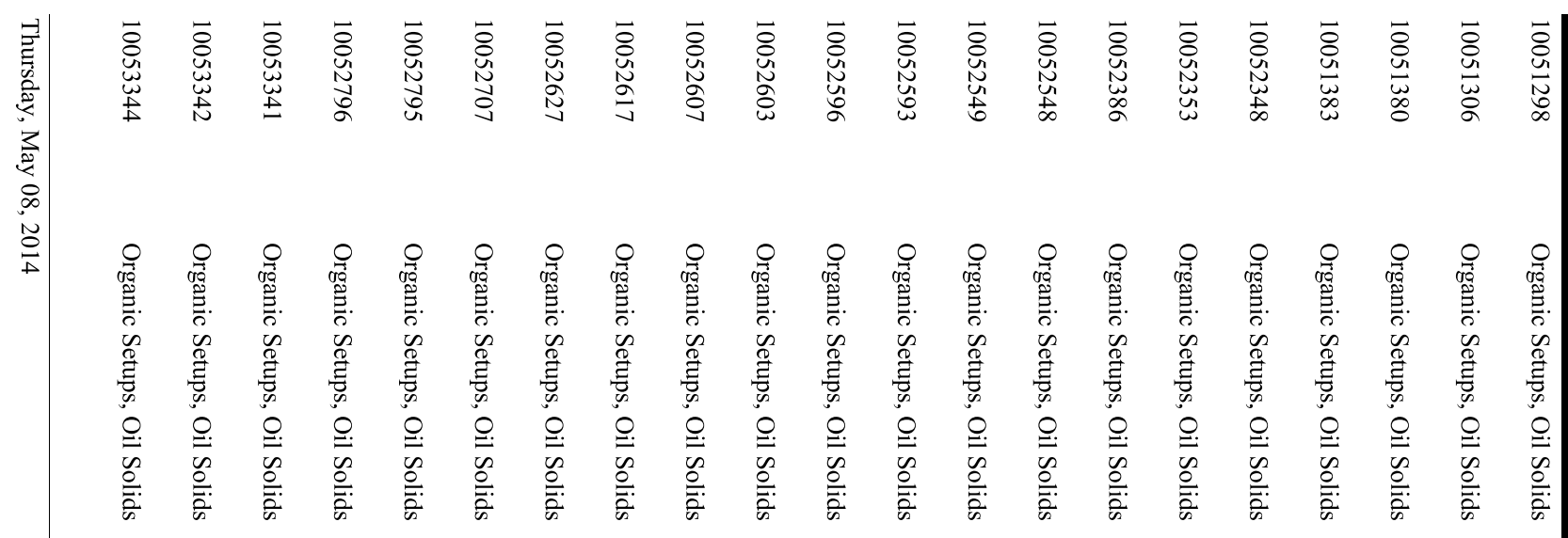

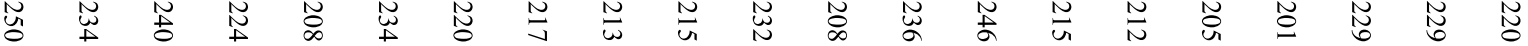

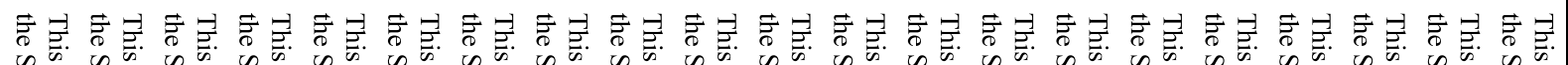

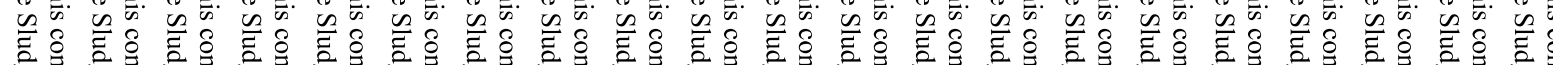

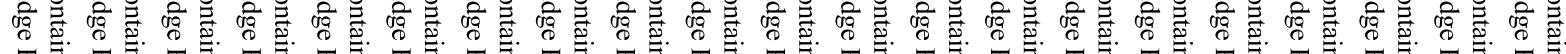
不

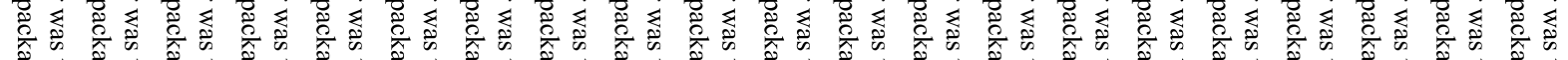

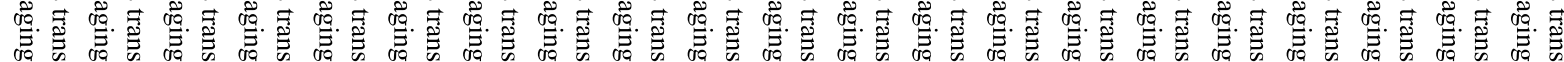

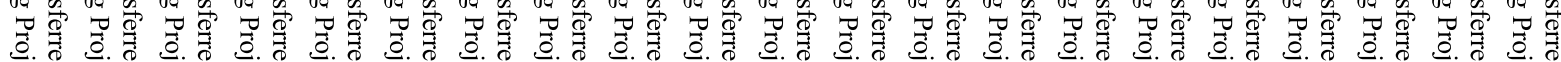

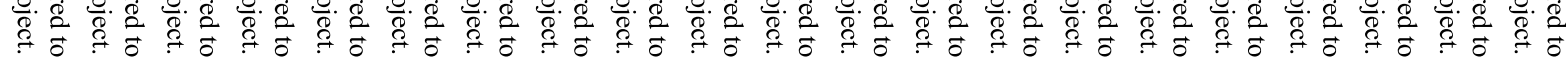

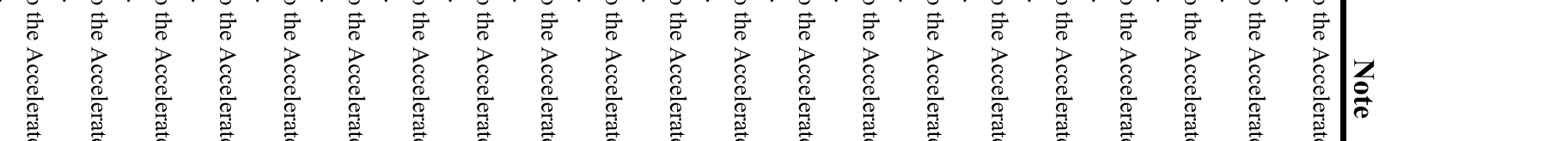




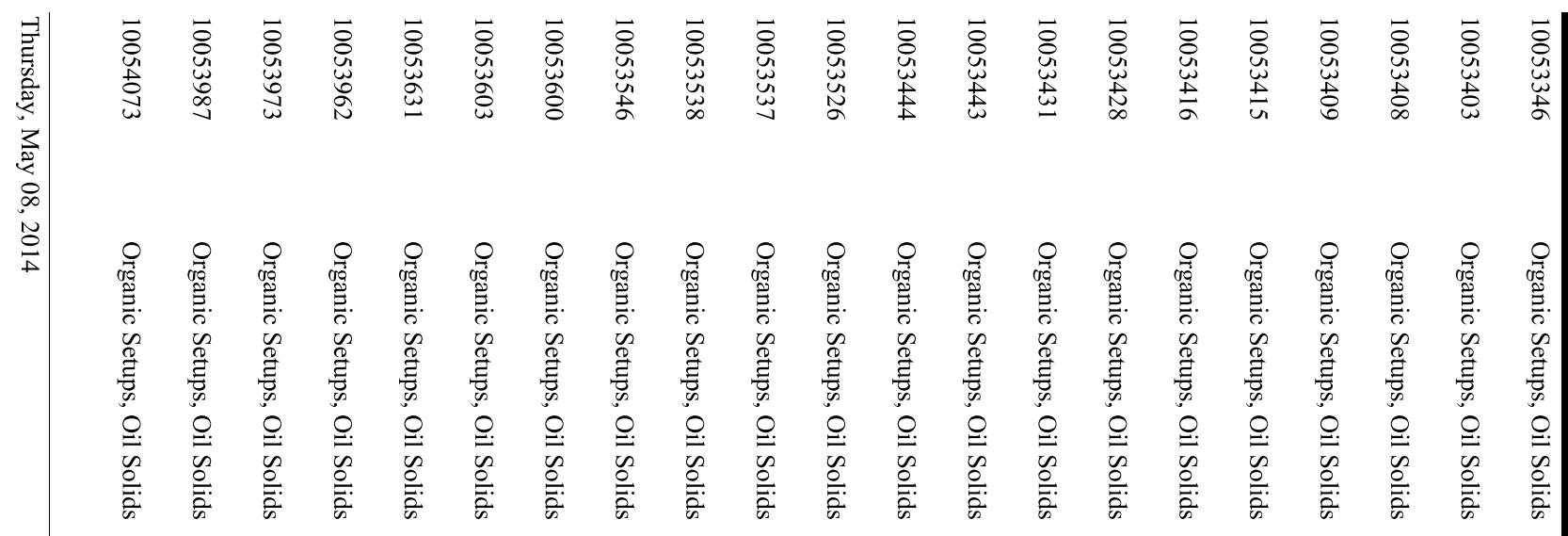

孞

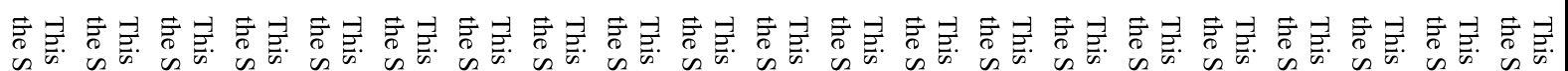

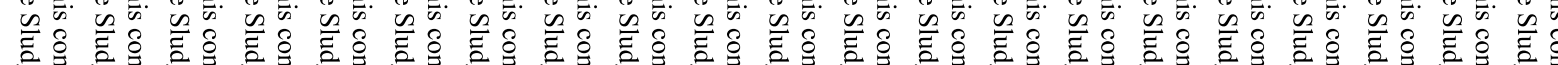

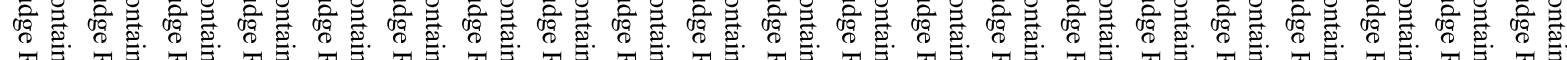
不

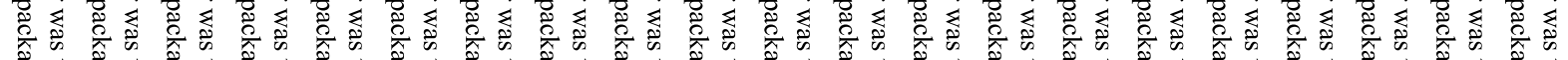

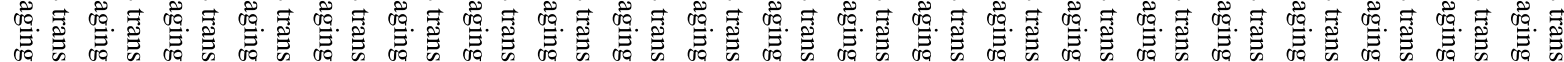

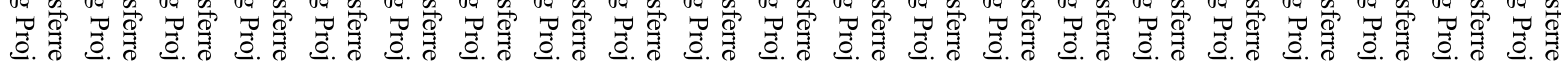

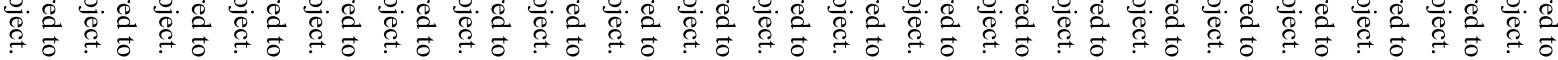

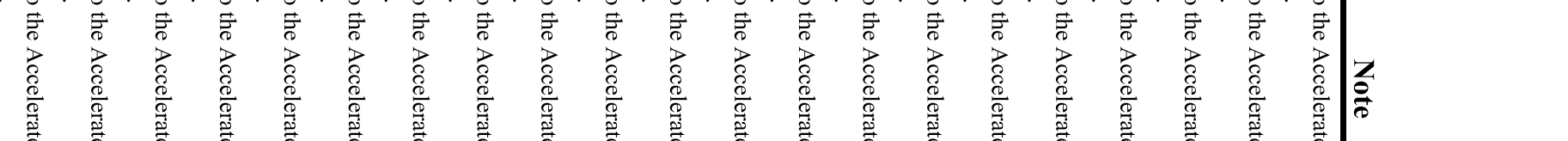




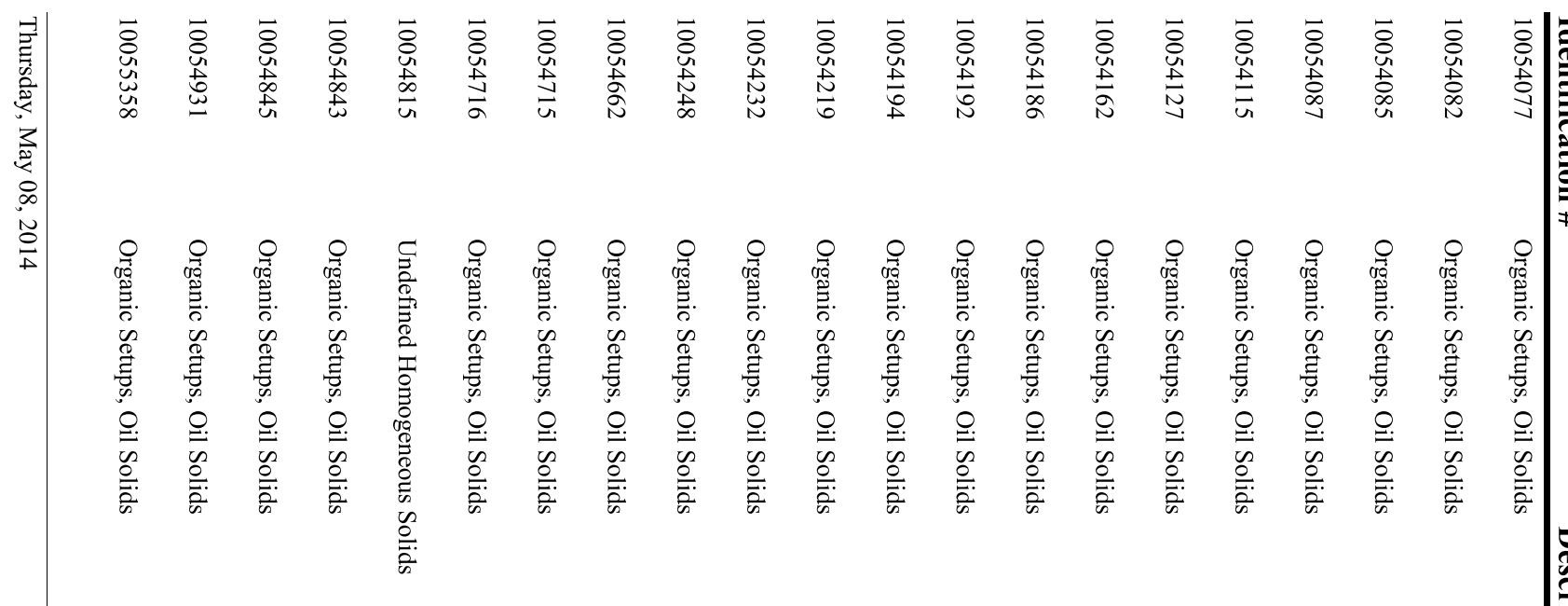

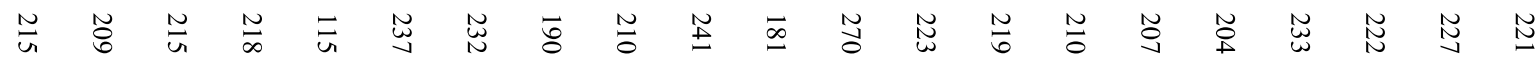

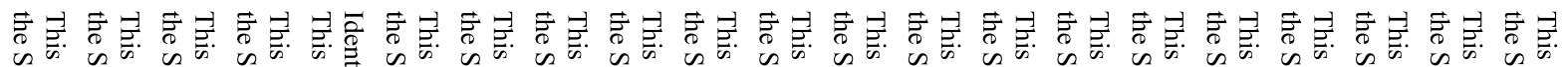

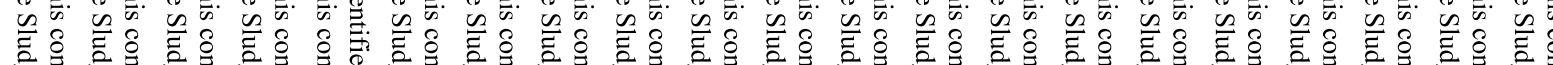

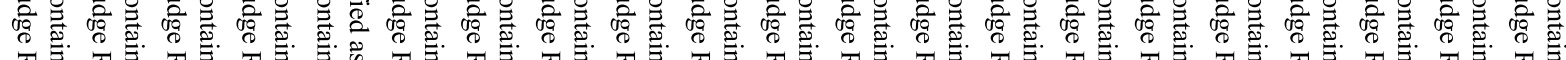
不

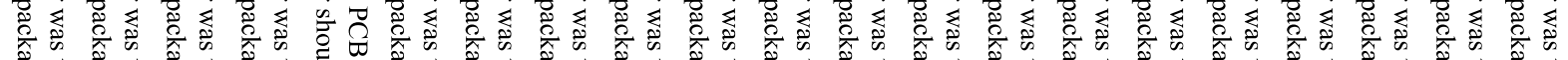

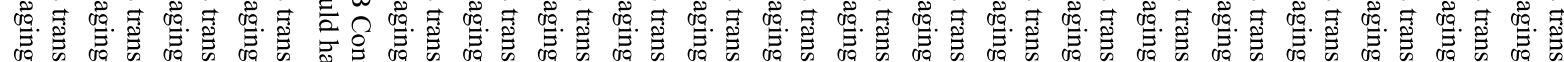

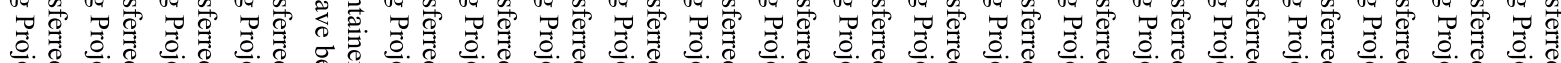

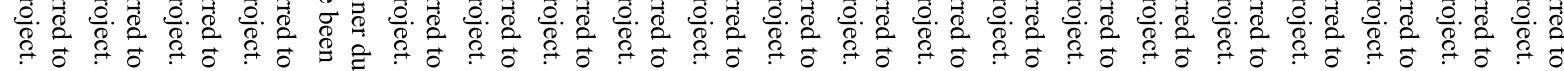

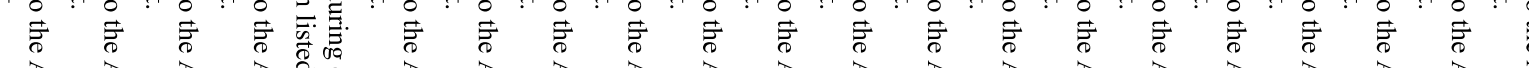




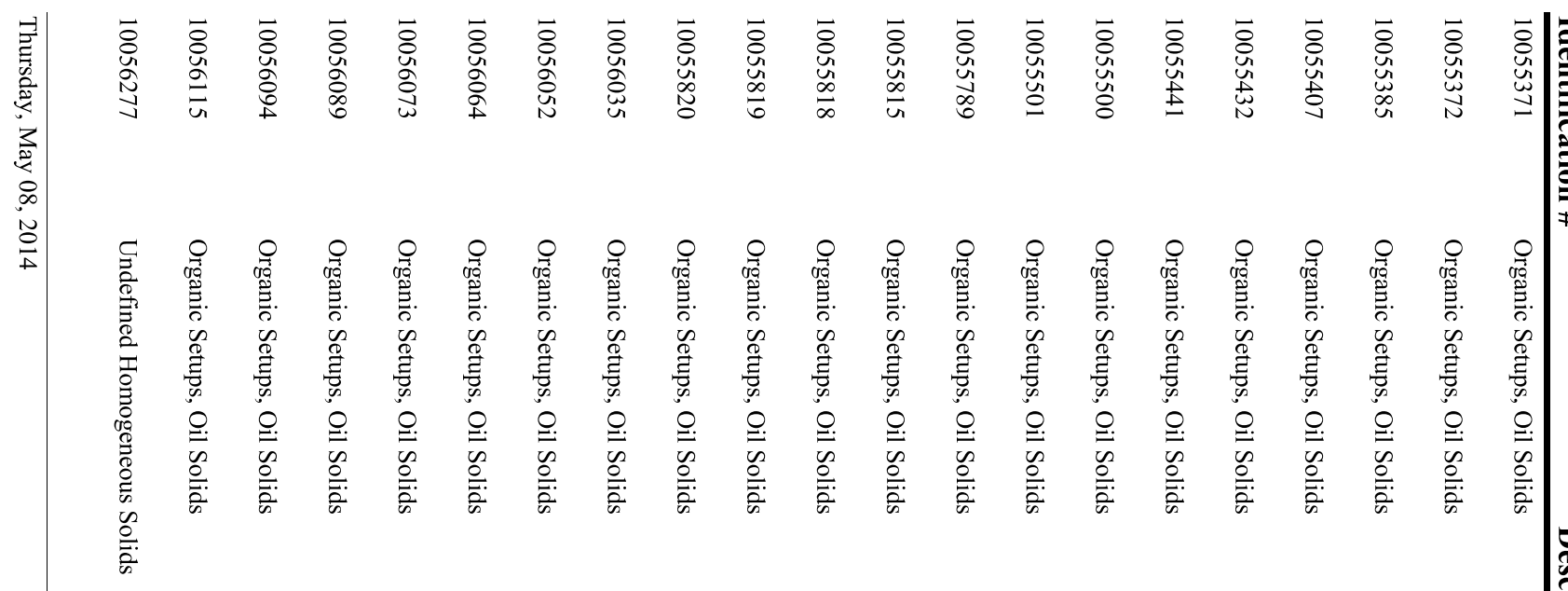

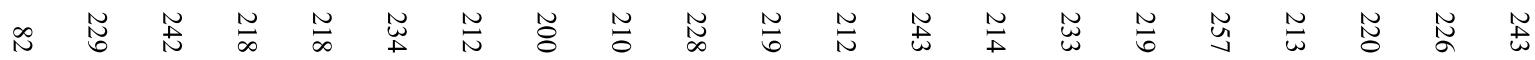

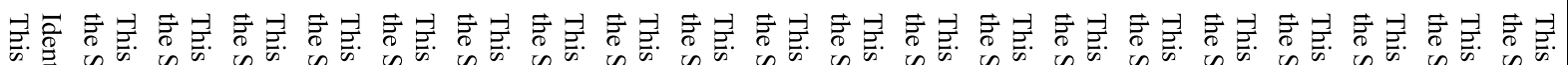

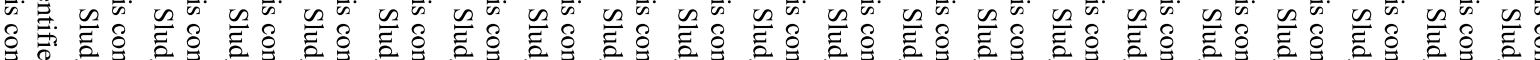

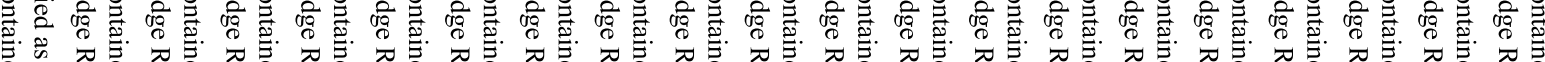

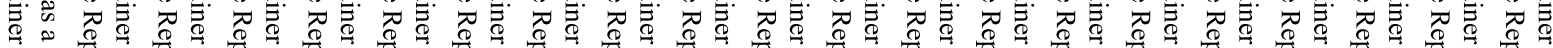

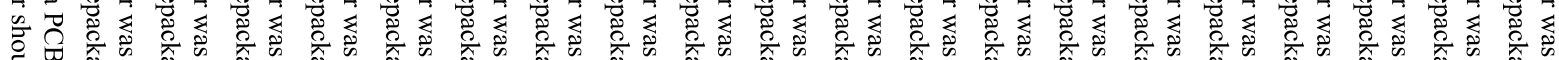

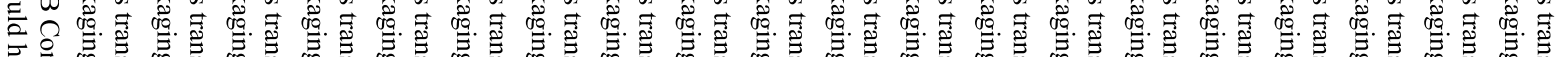

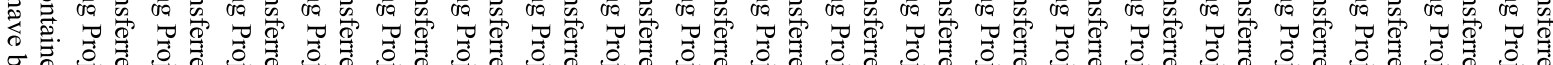

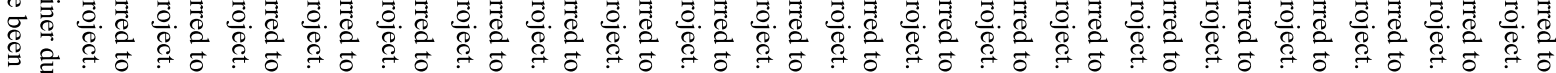

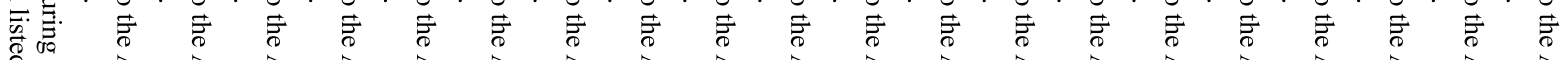

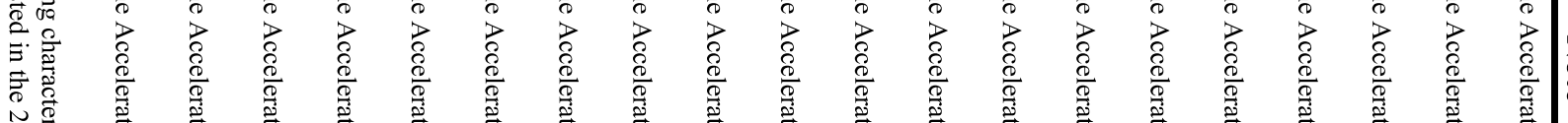

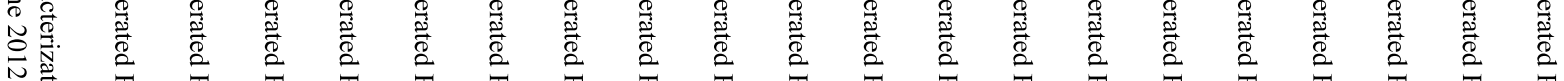

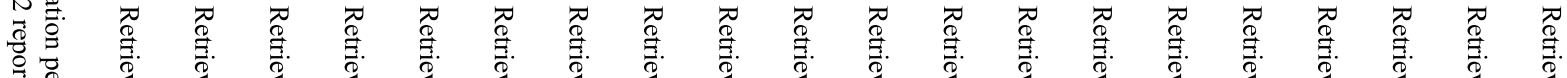
$\stackrel{\circ}{?}$ 


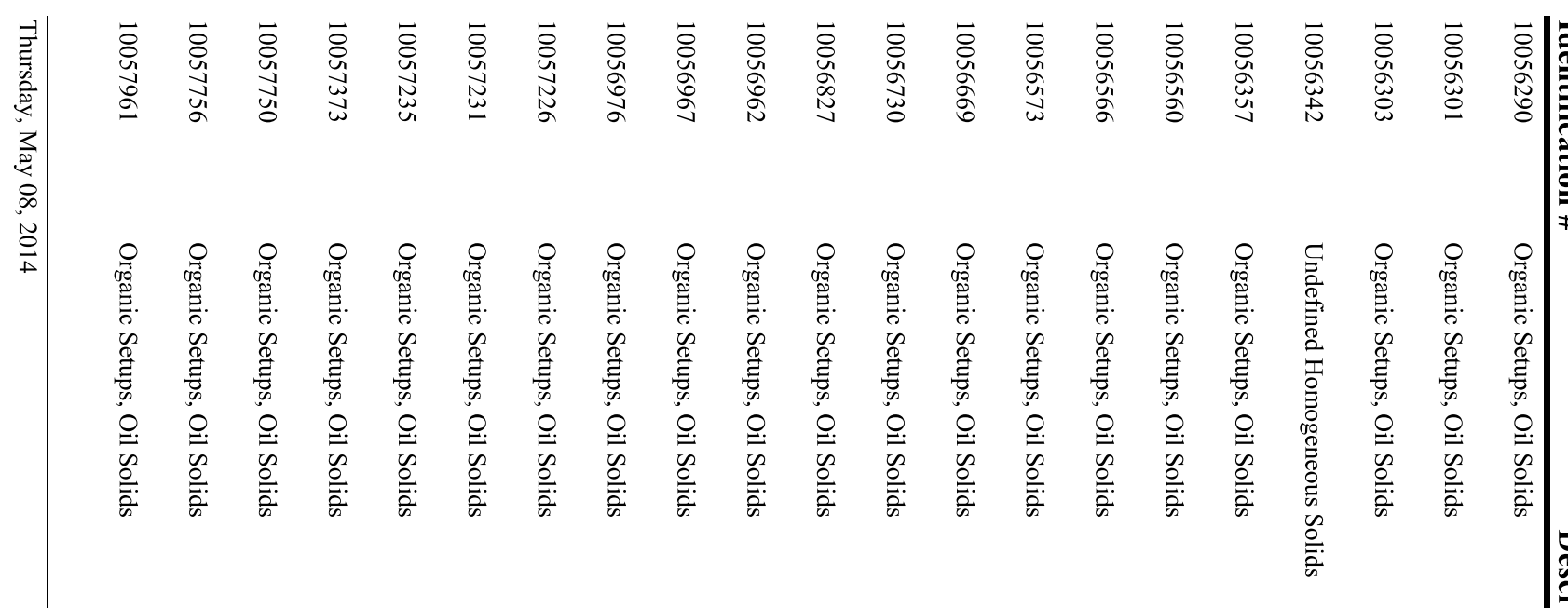

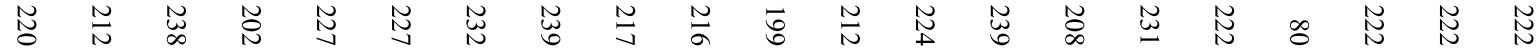

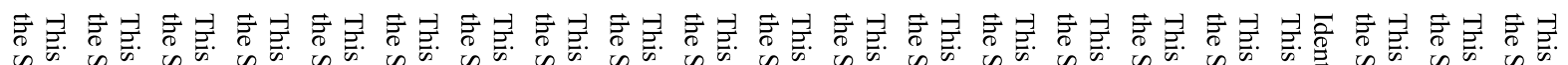

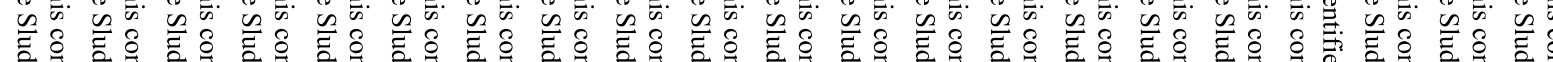

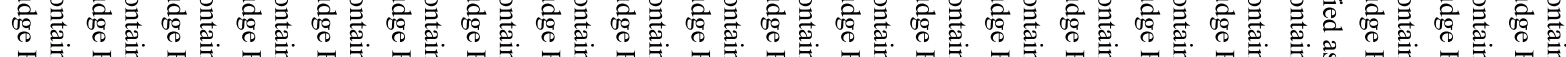

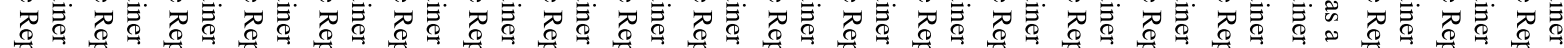

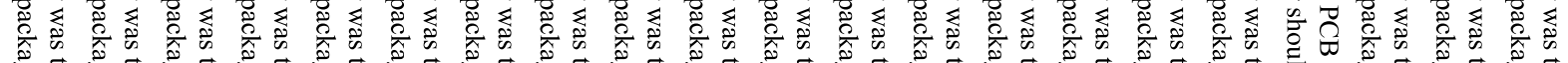

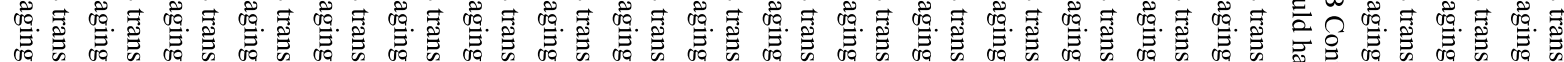

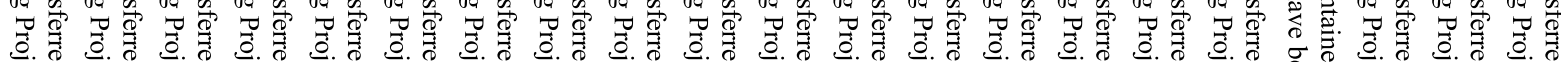

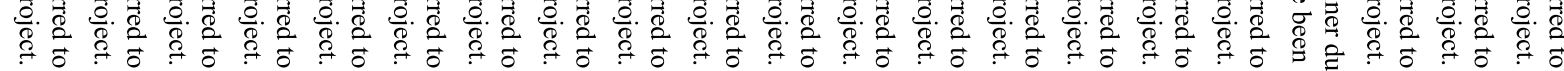

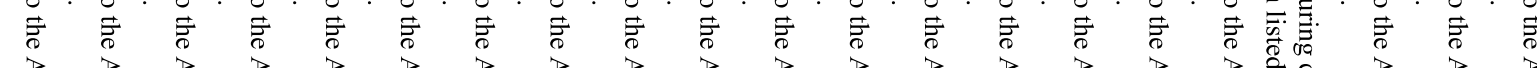

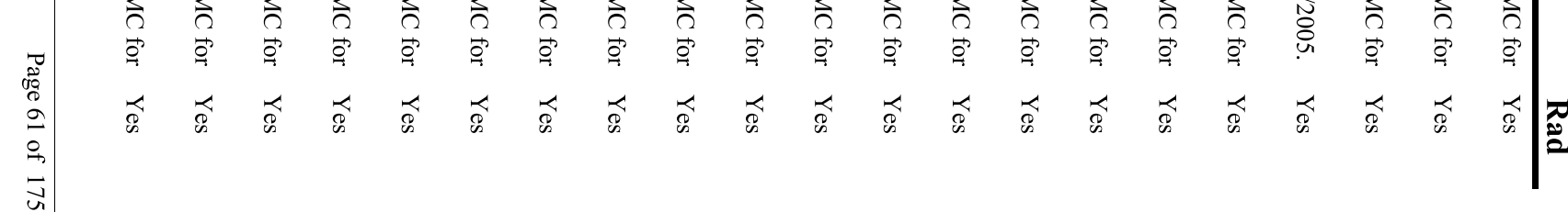

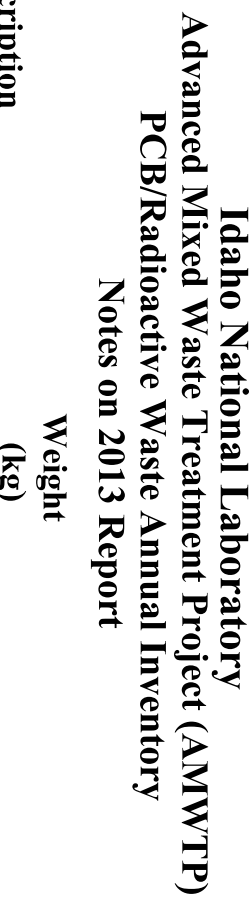




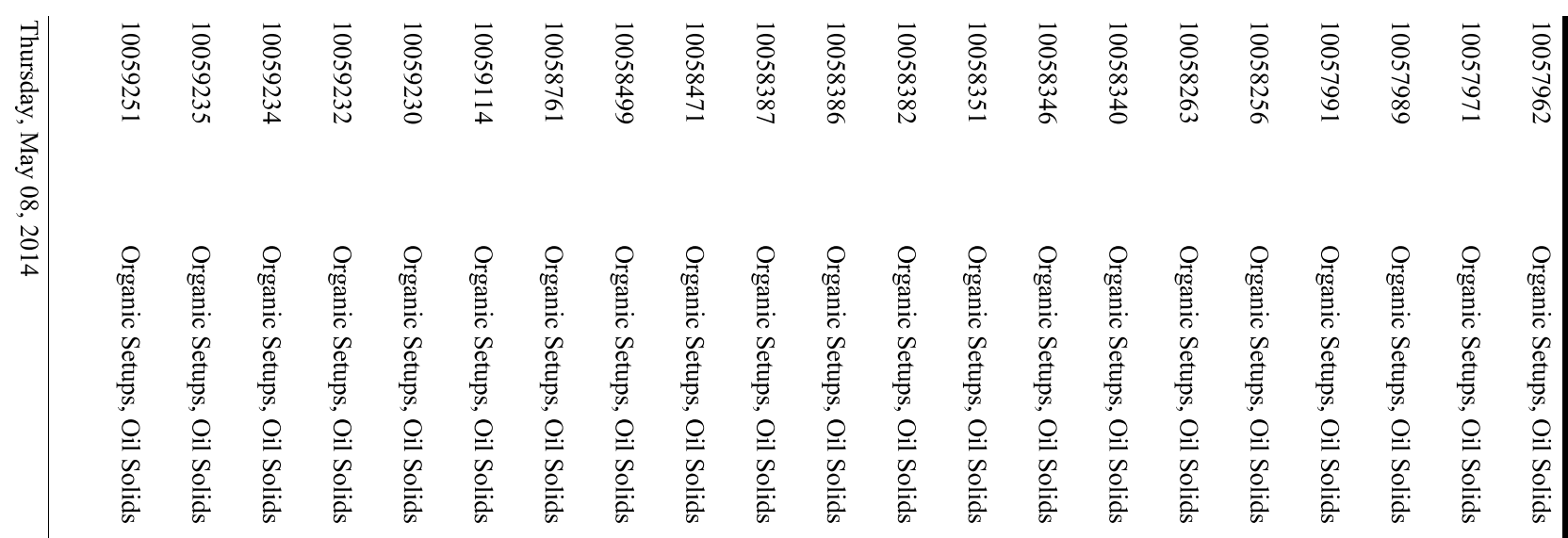

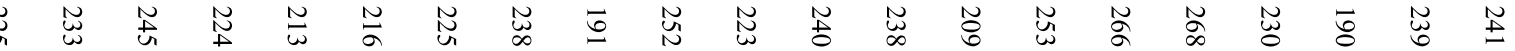

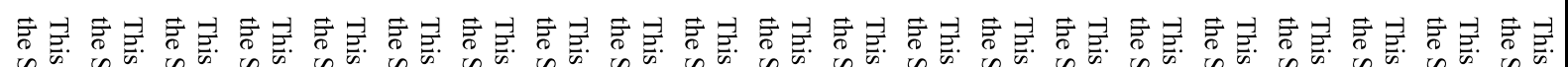

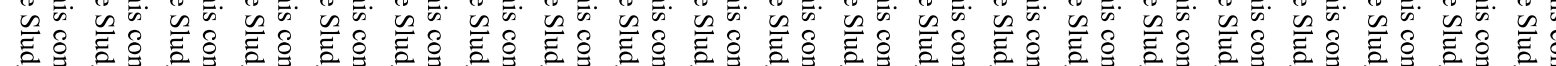

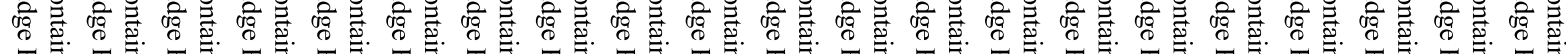

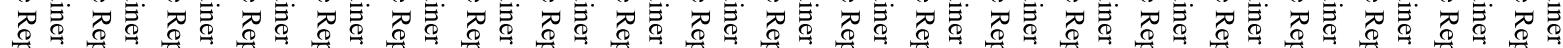

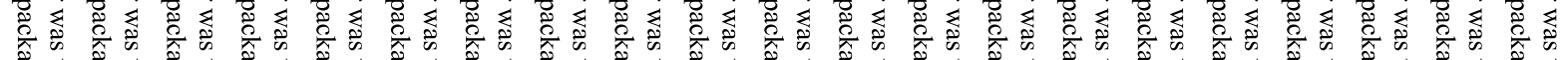

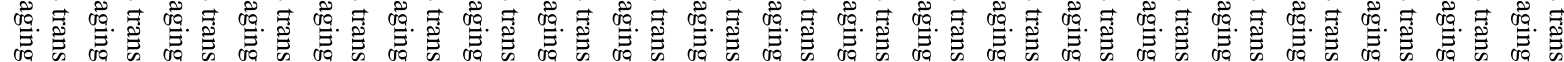

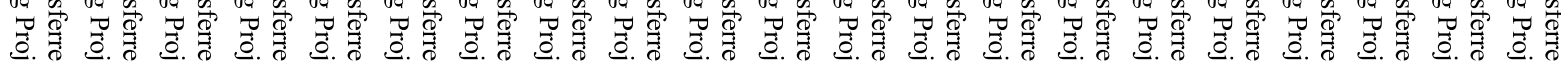

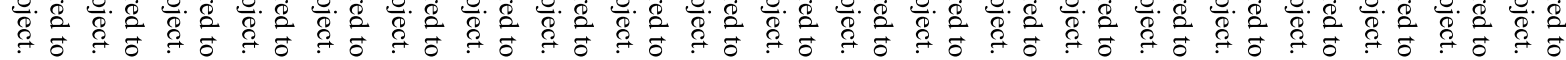

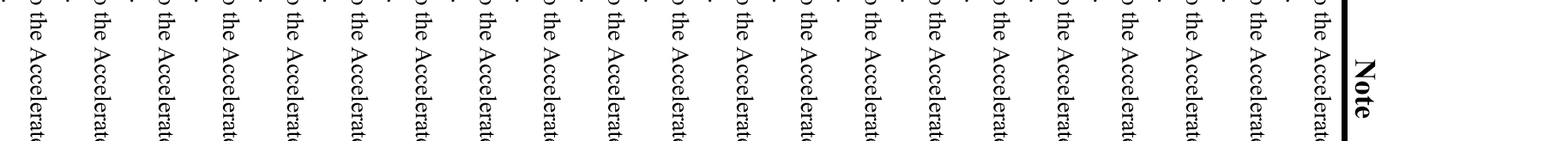




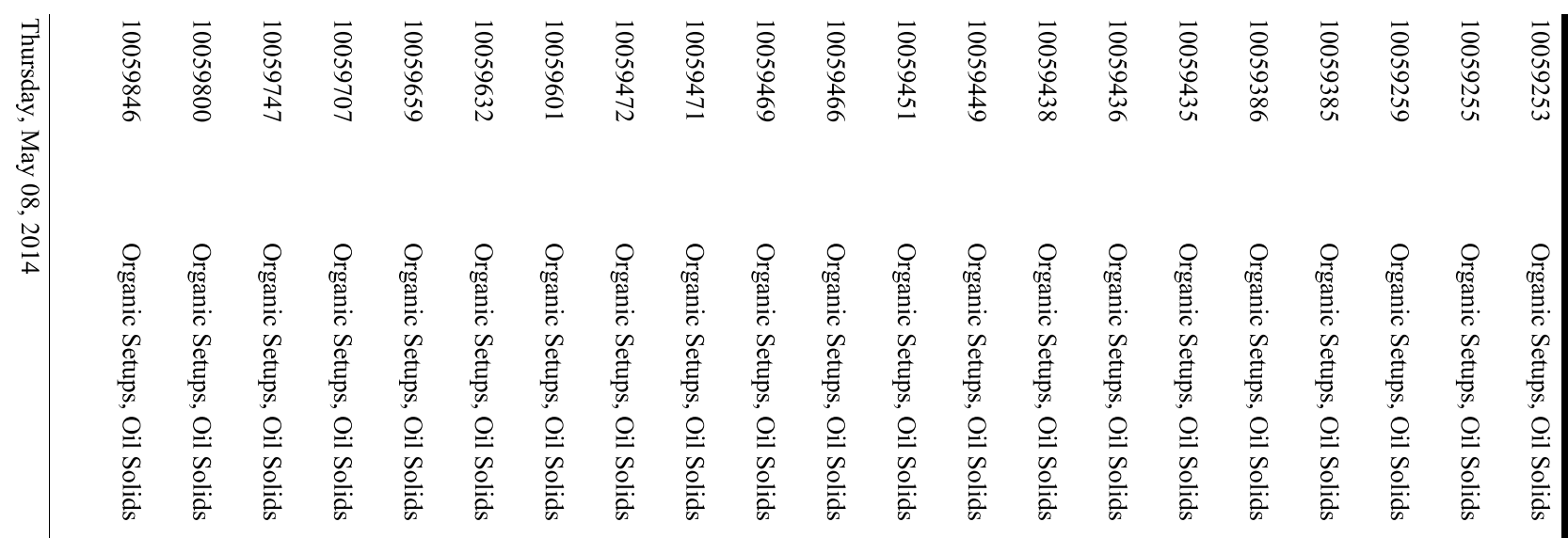

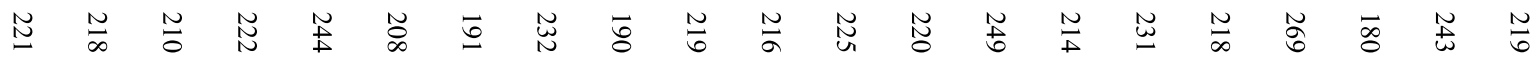

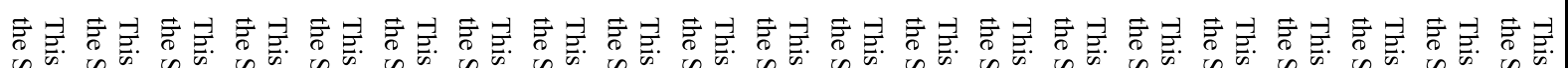

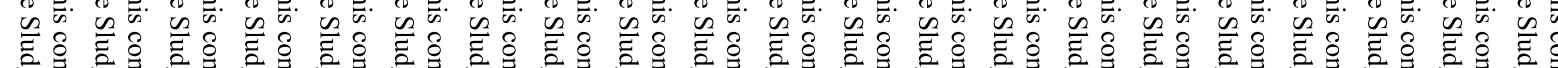

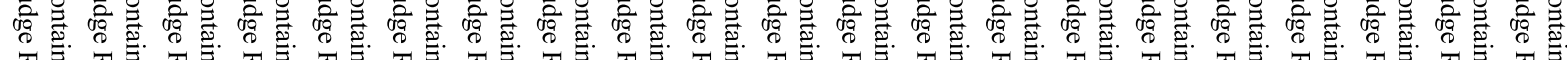
不

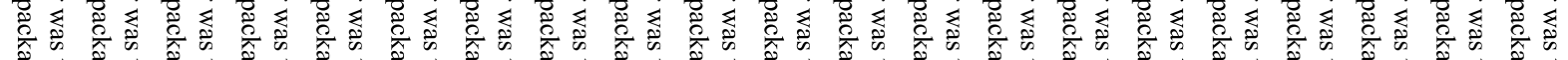

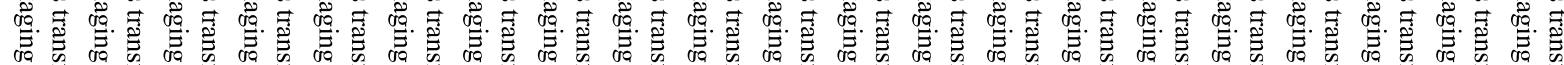

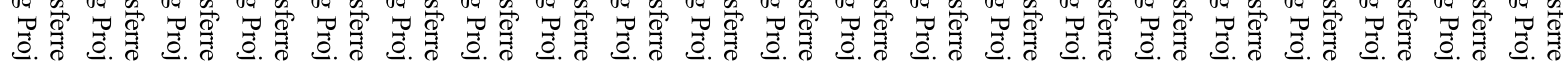

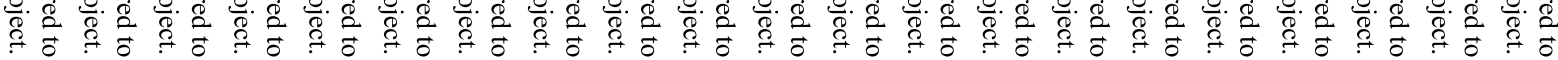

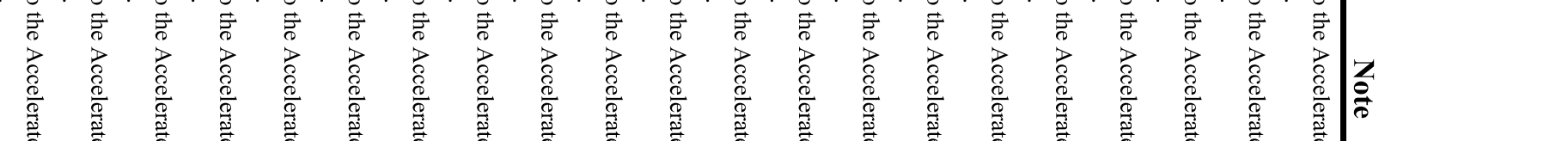




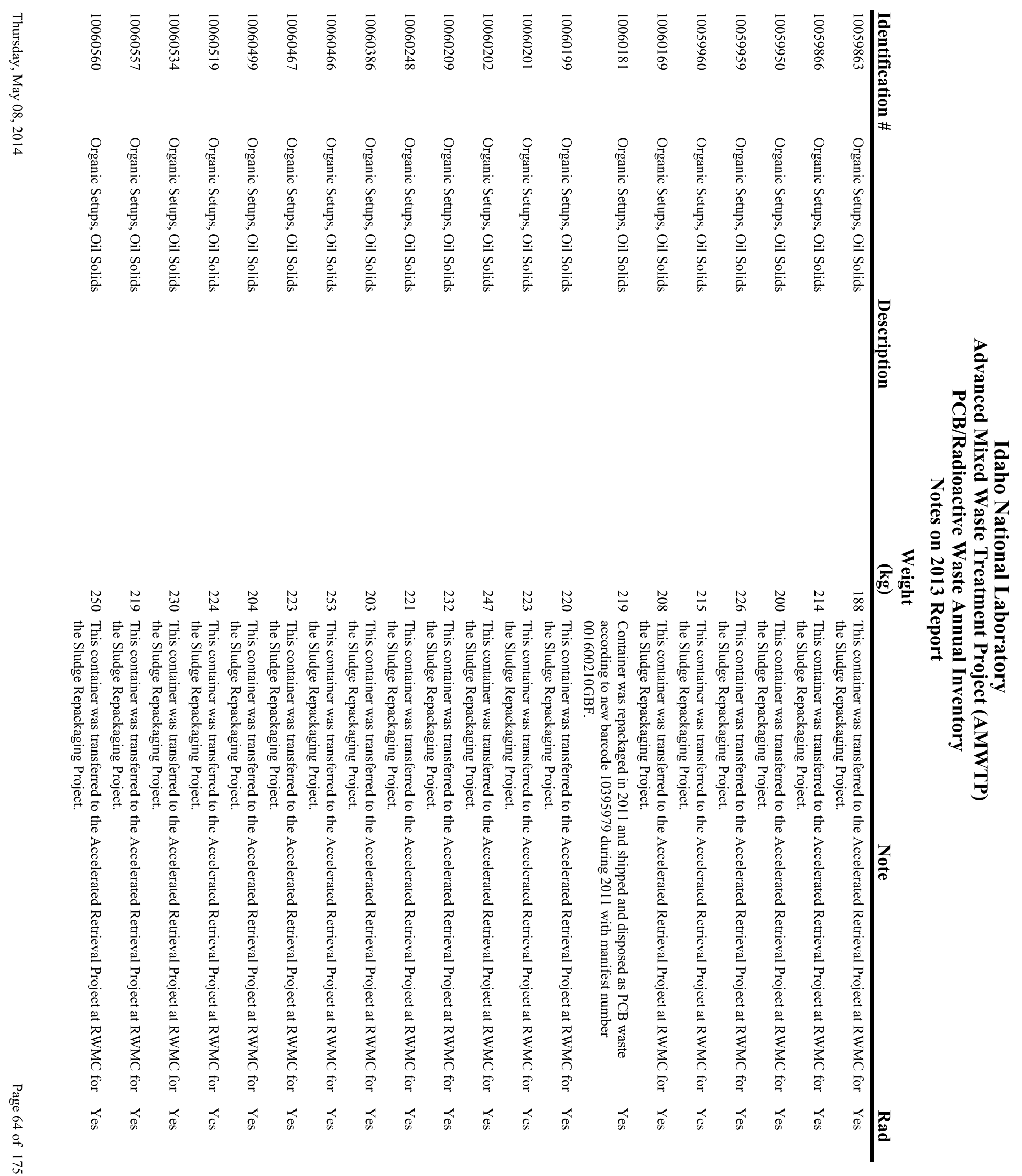




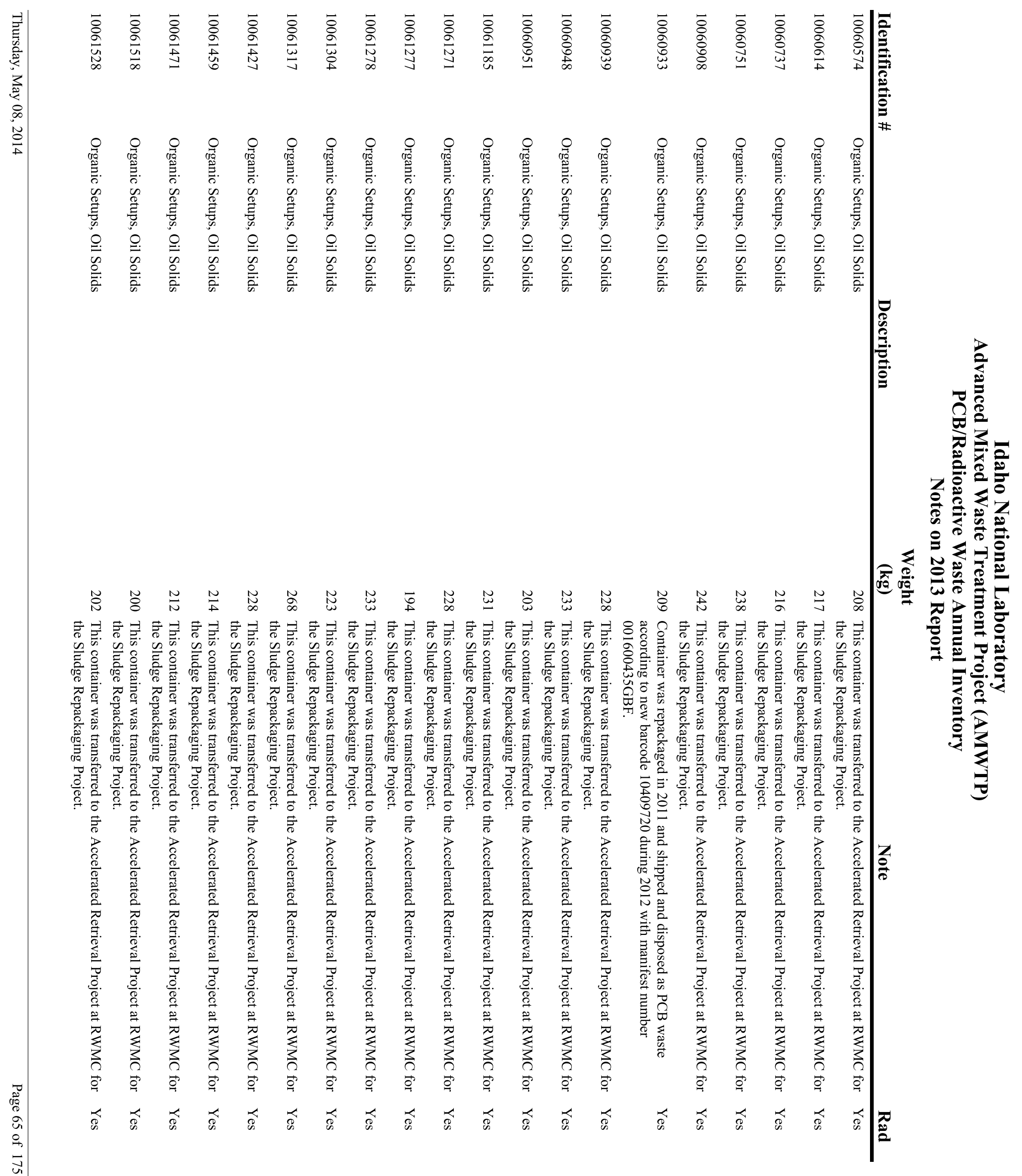




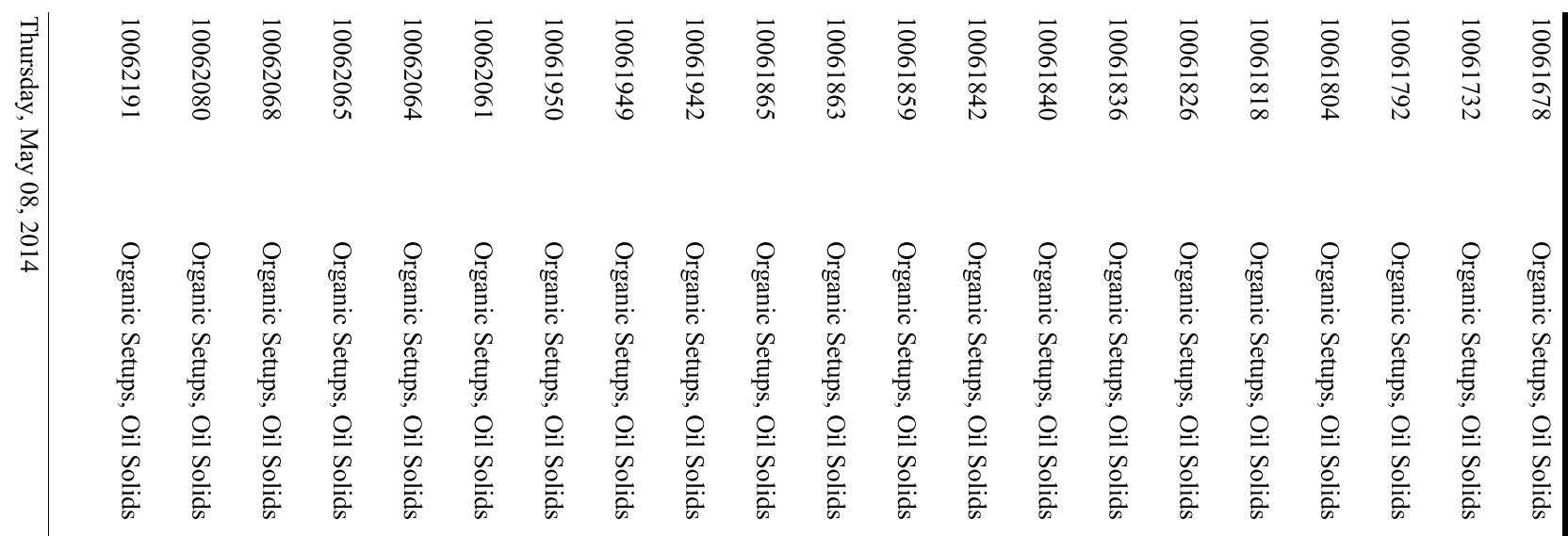

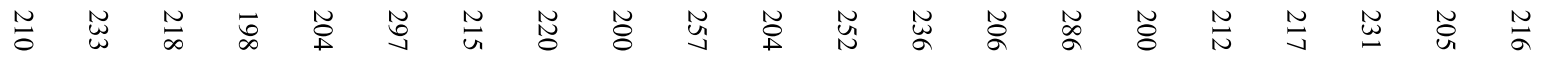

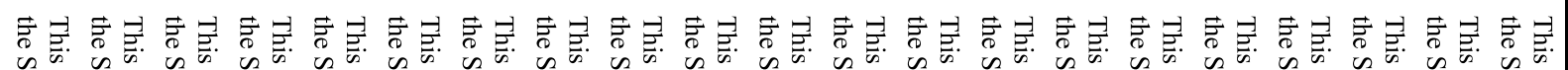

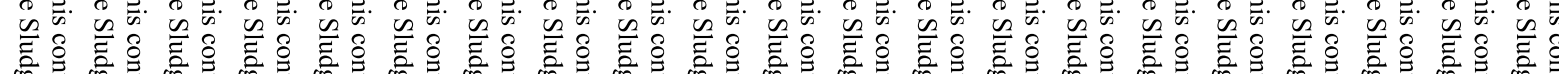

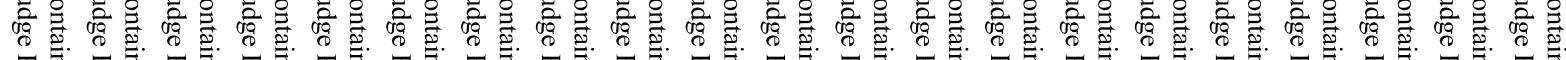

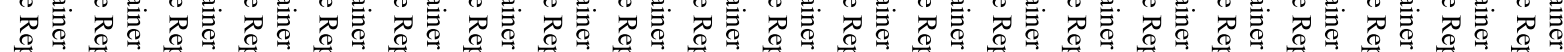

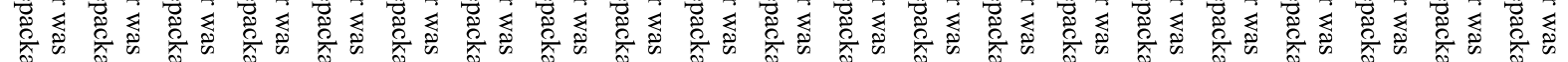

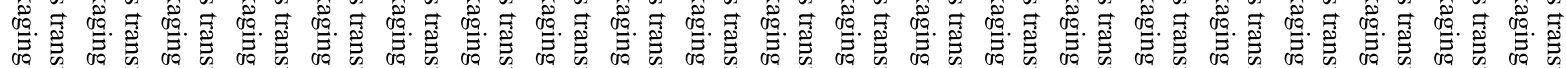

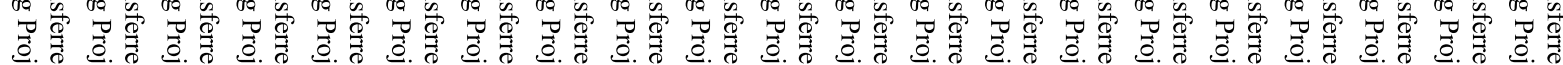

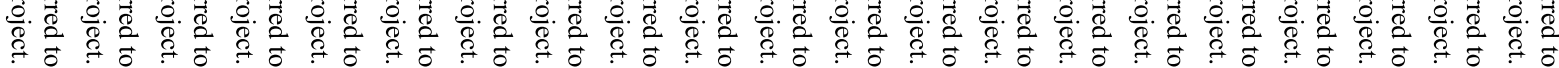

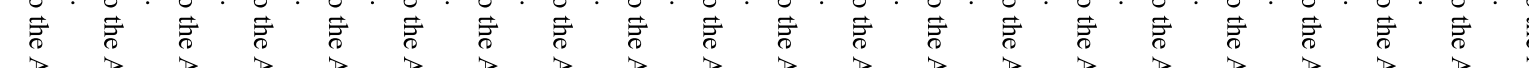




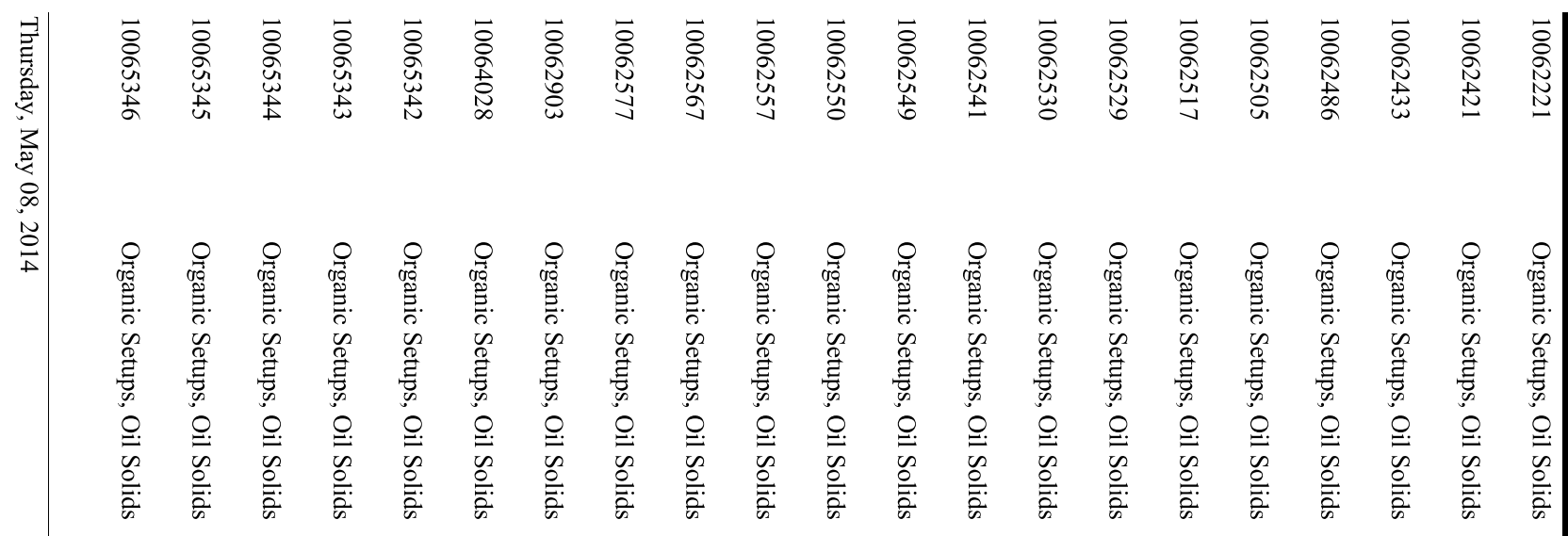

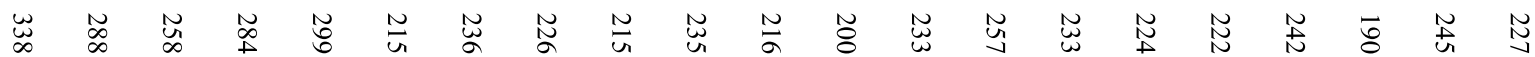

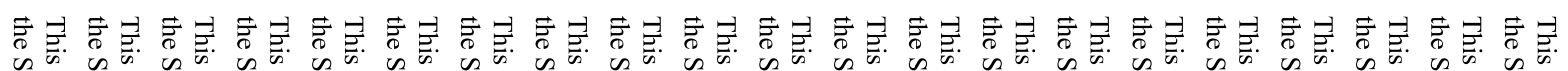

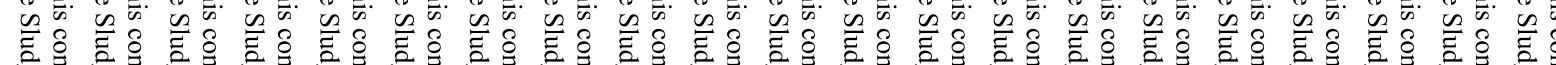

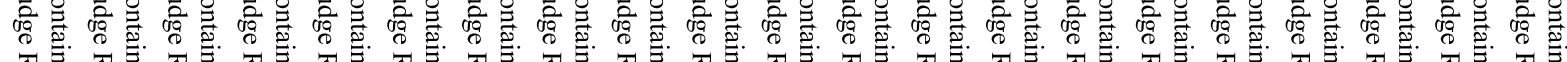
不

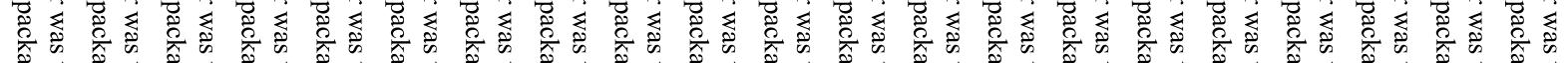

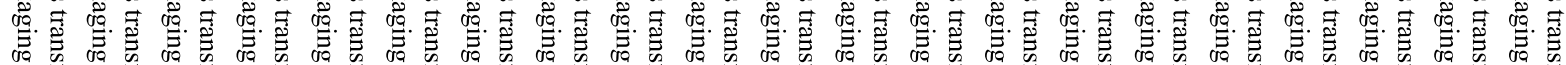

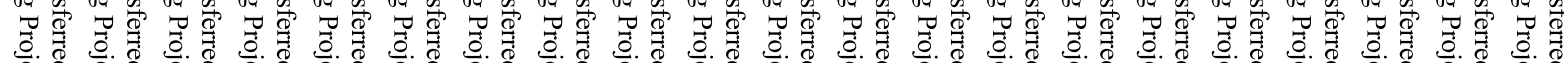

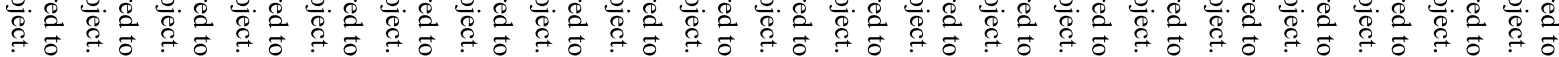

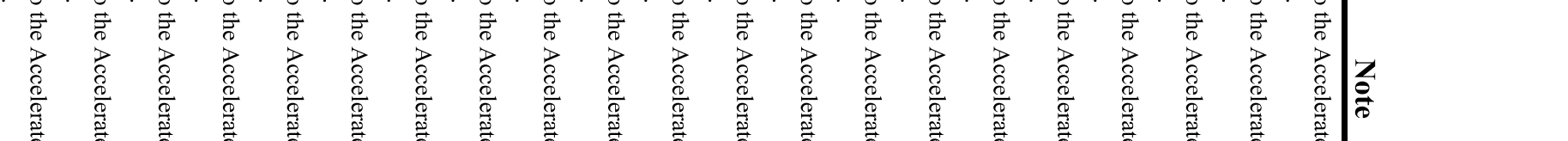




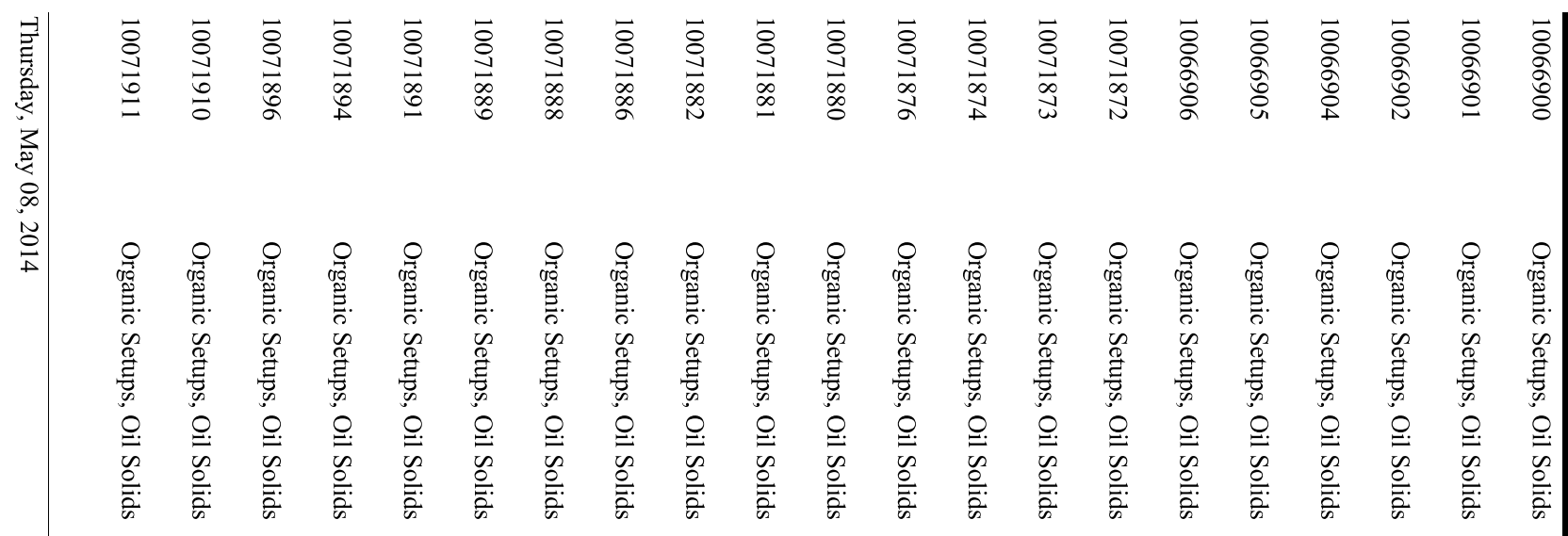

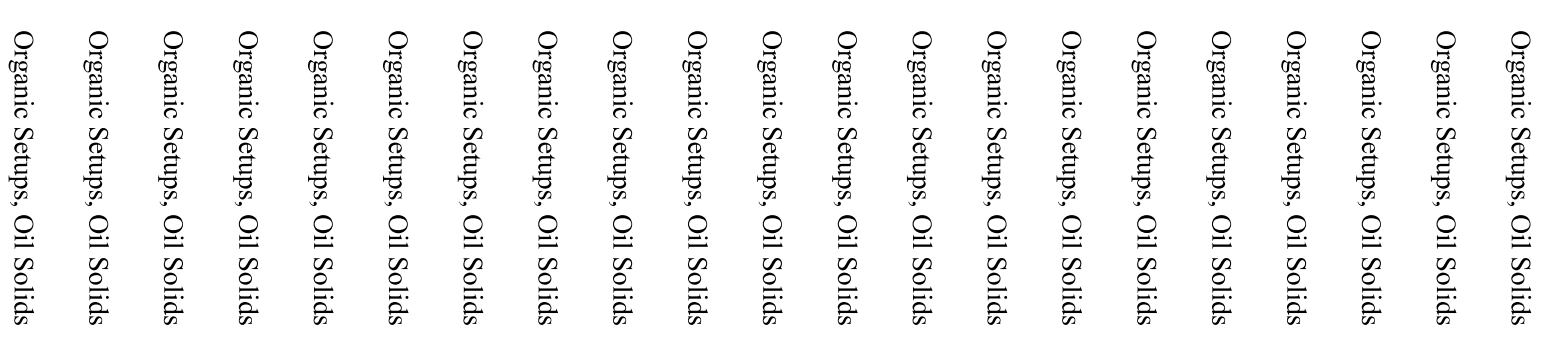

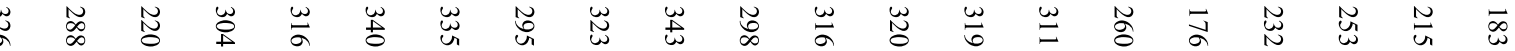

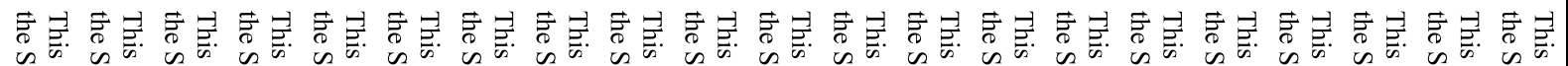

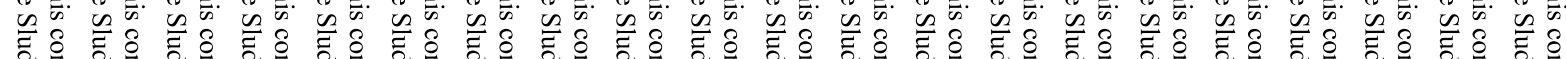

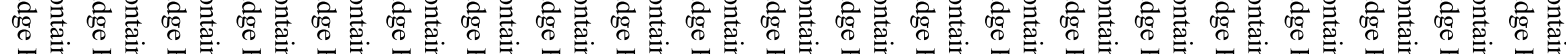

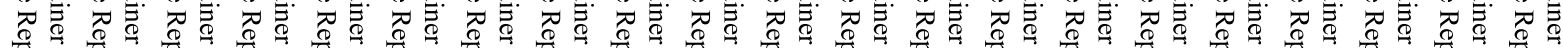

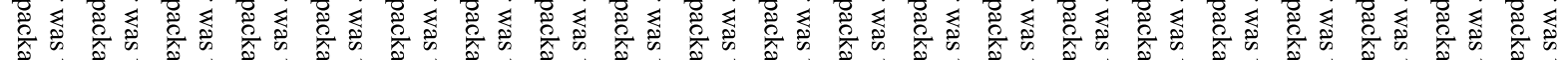

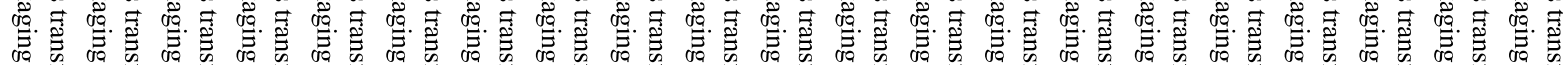

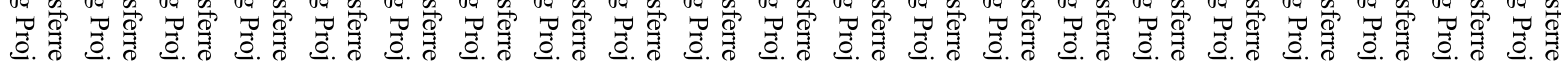

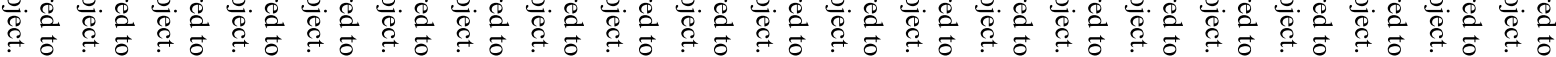

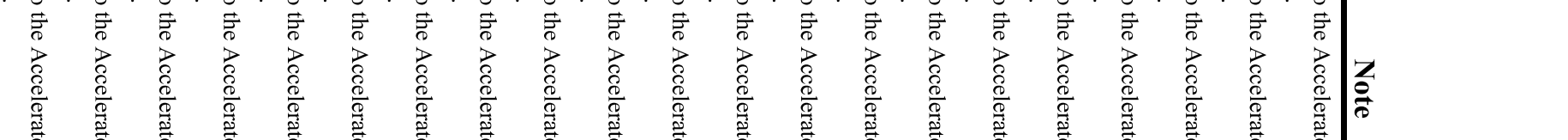




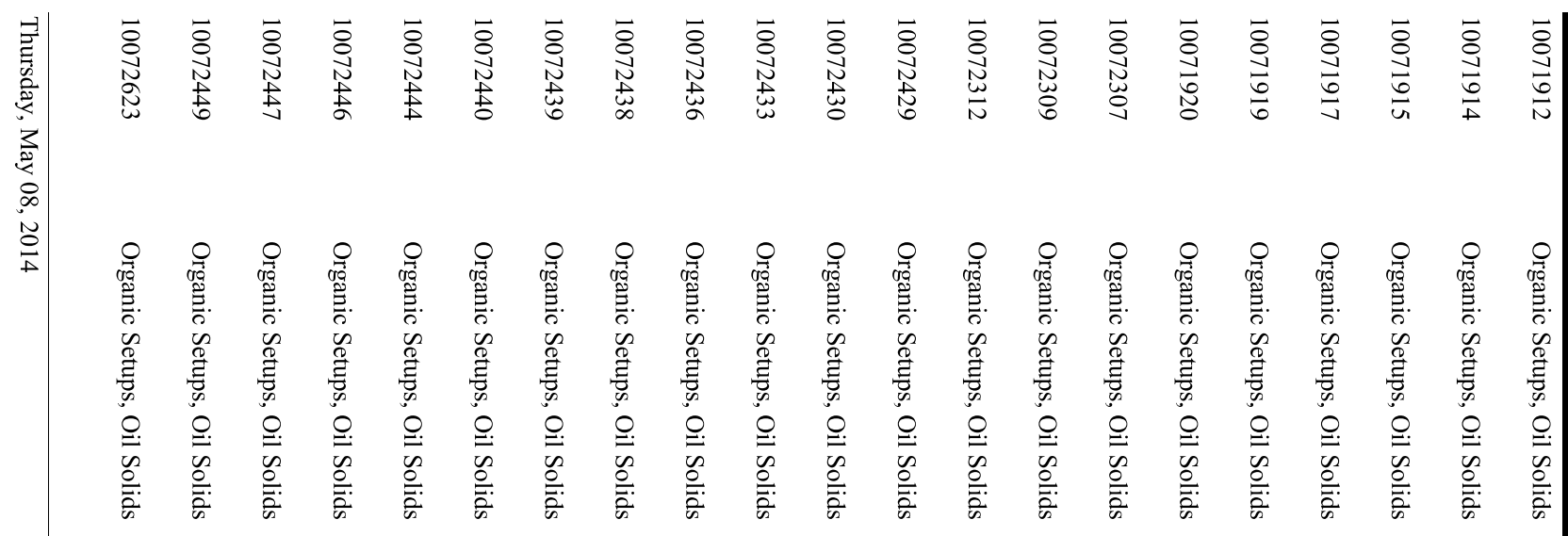

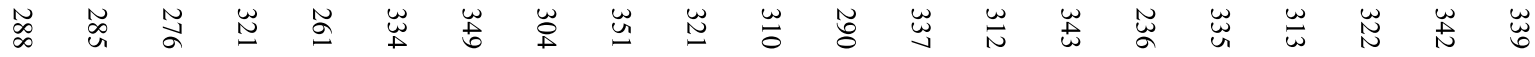

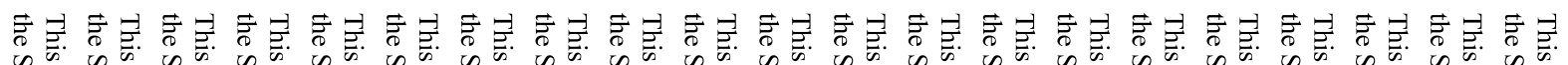

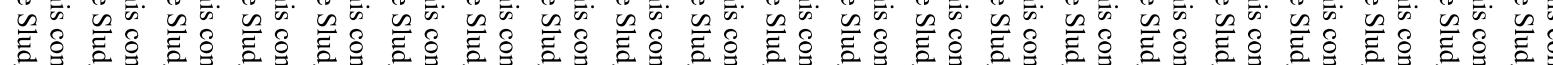

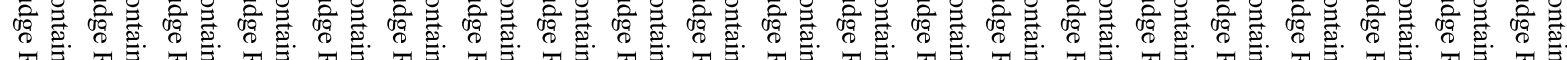
不

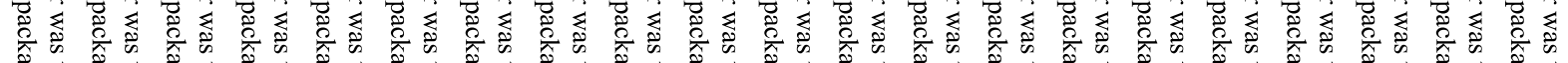

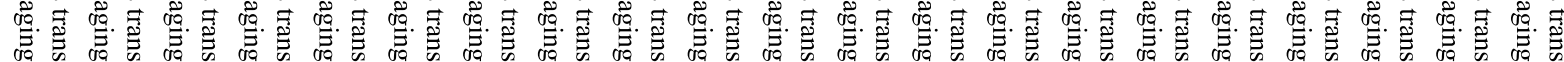

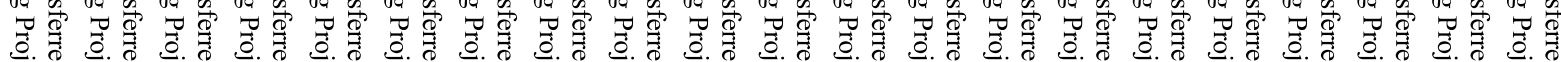

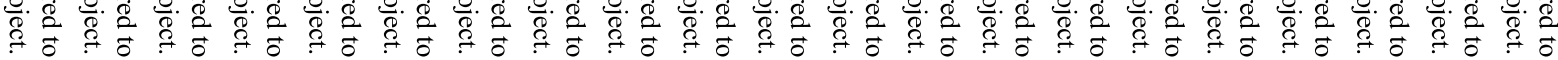

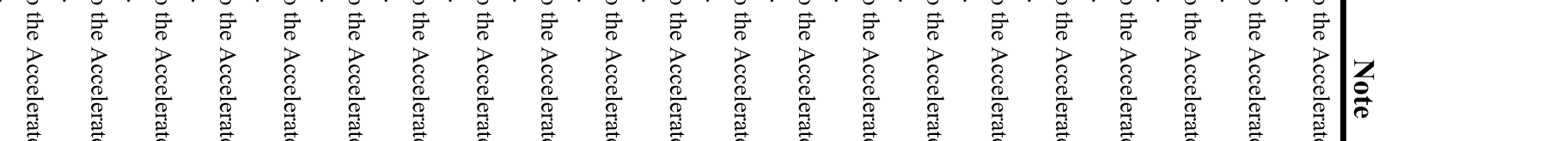




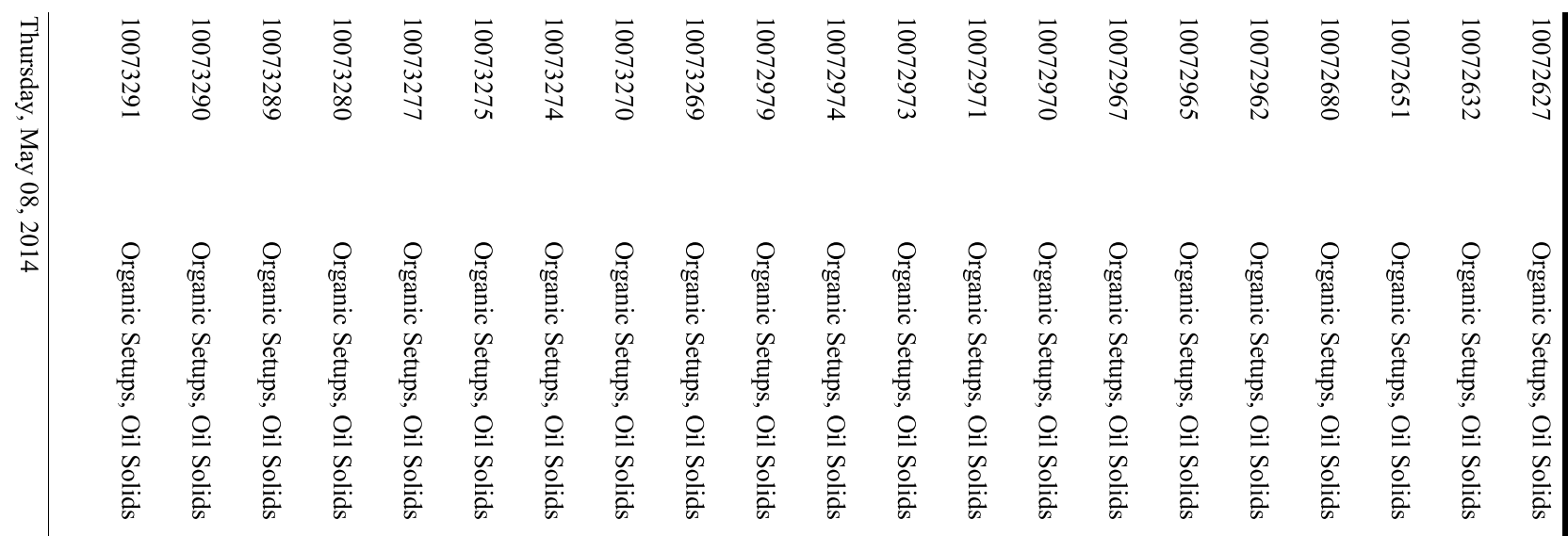

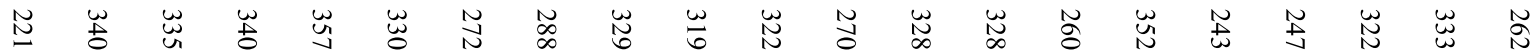

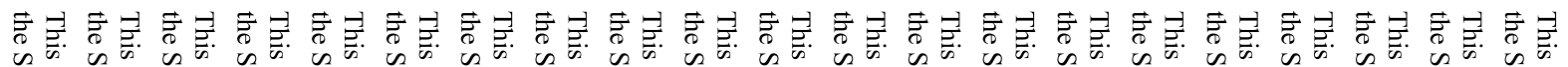

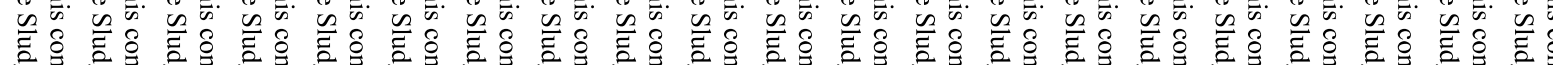

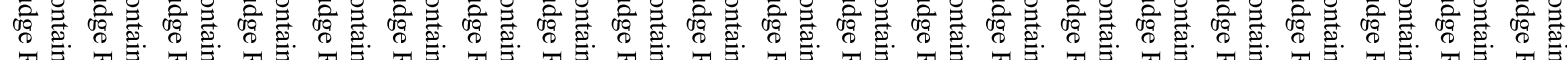
不

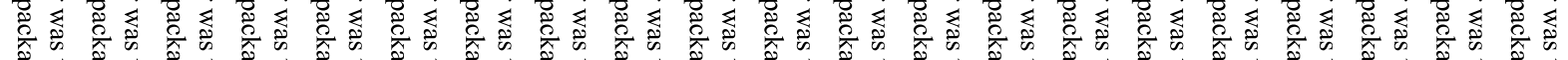

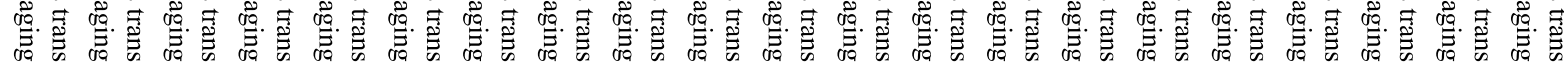

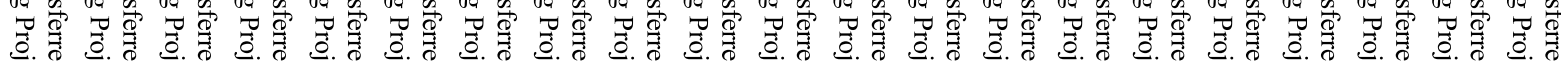

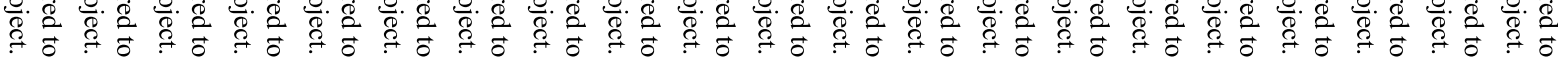

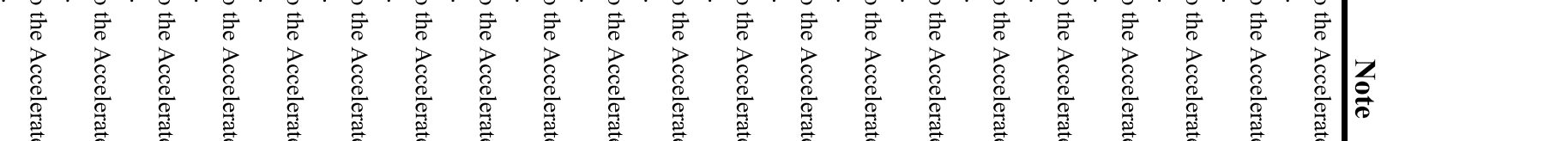




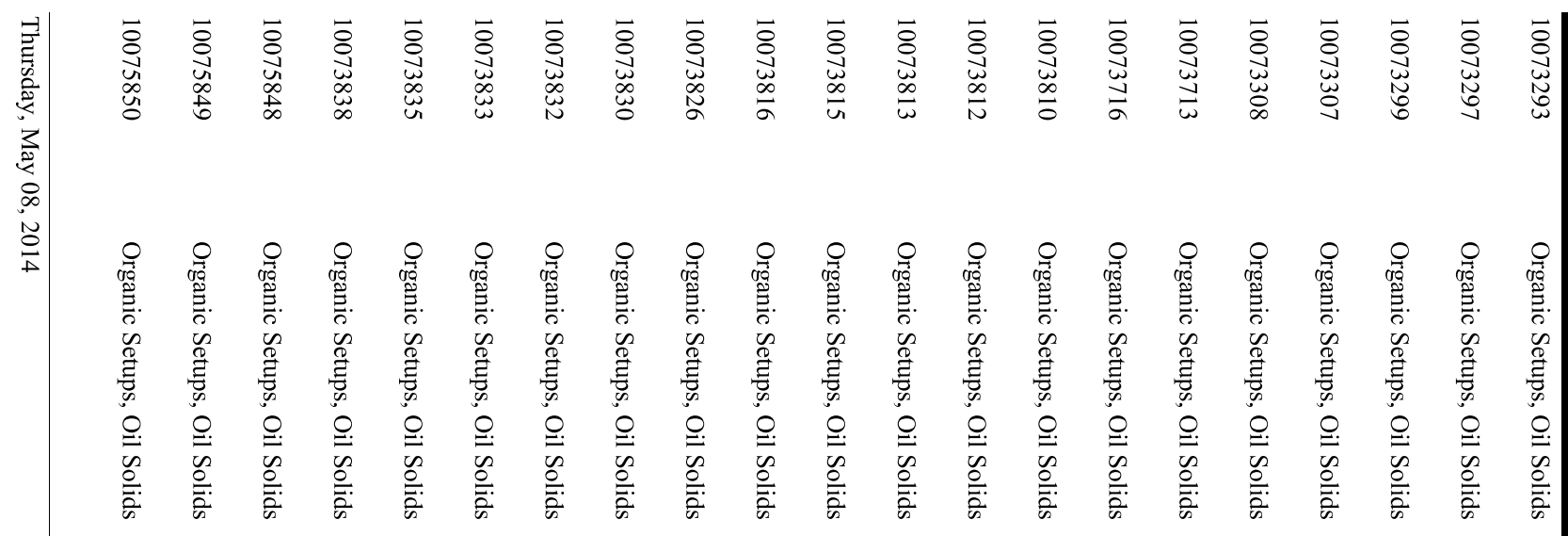

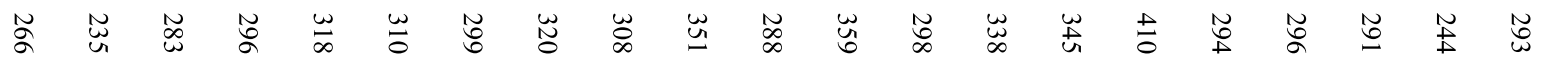

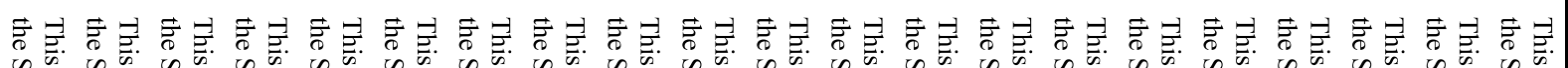

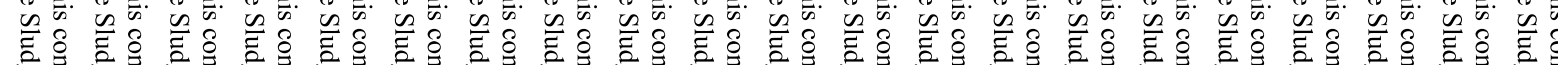

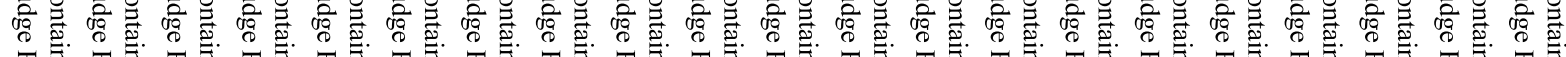
不

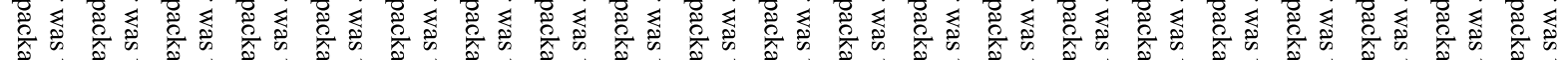

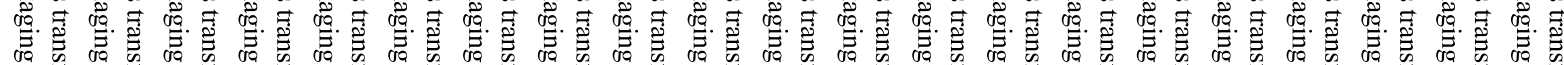

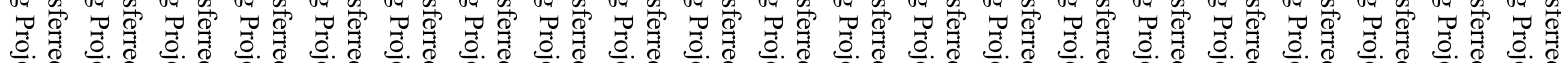

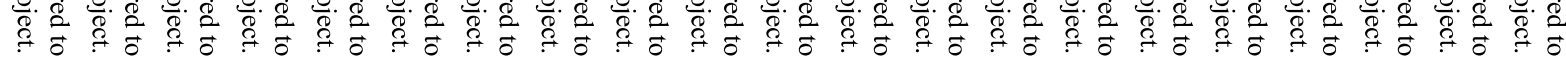

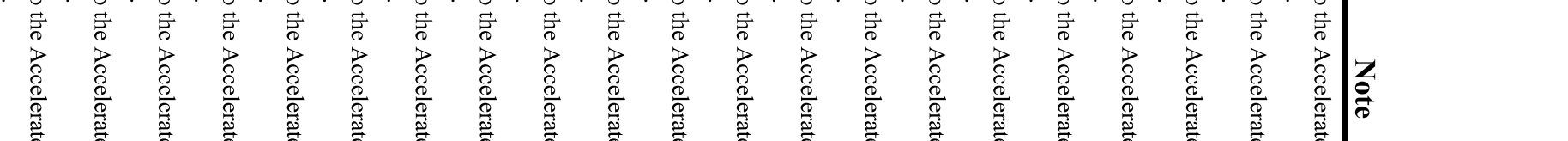




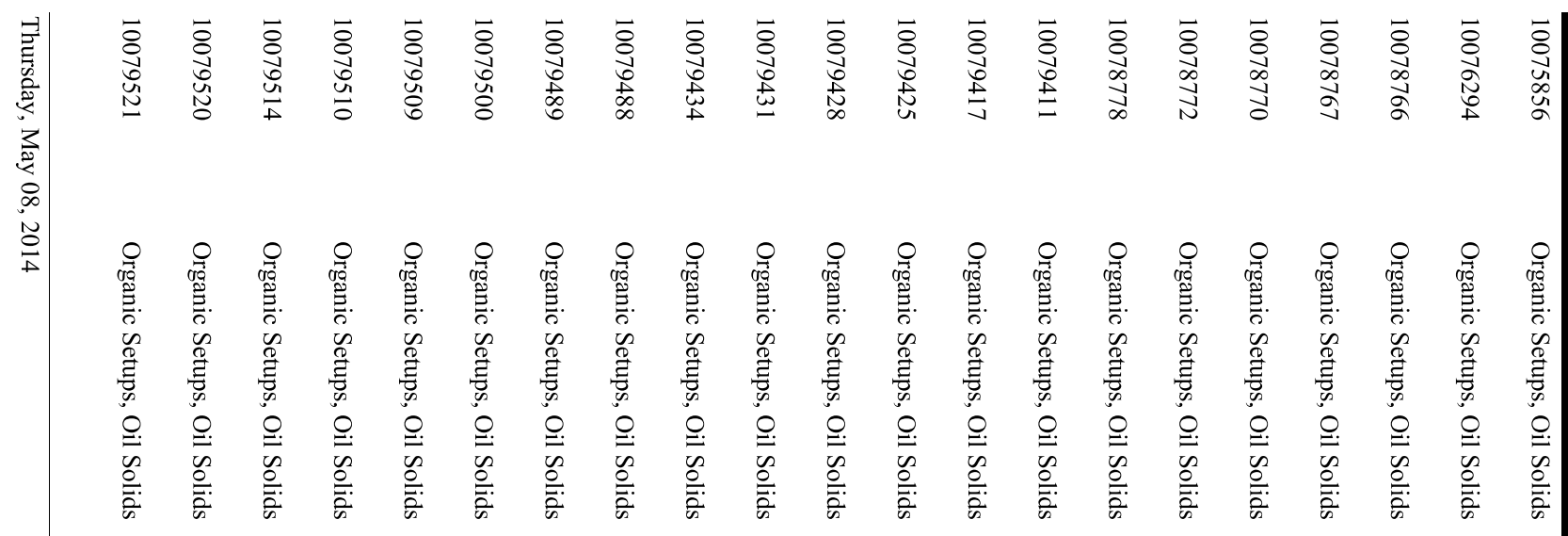

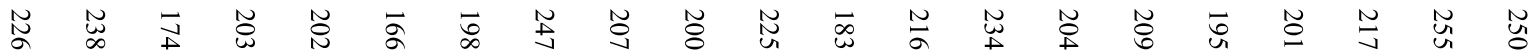

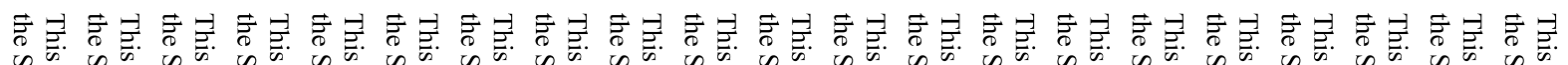

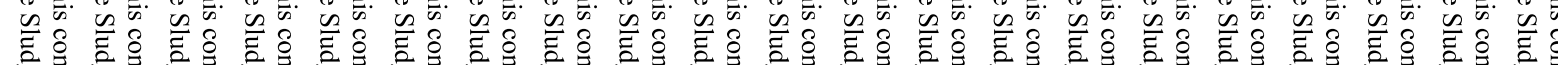

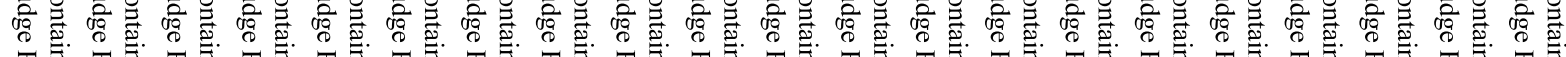
不

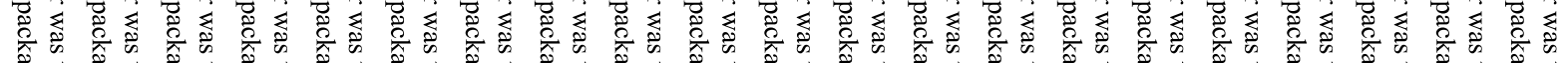

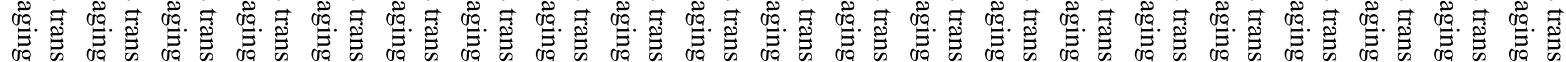

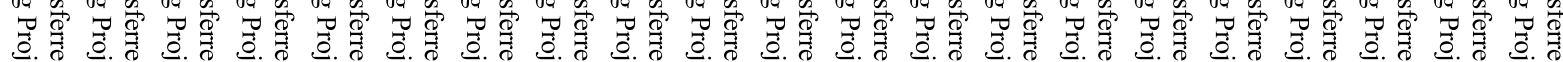

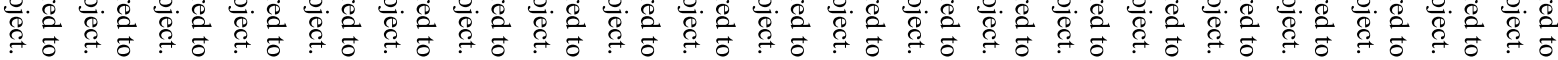

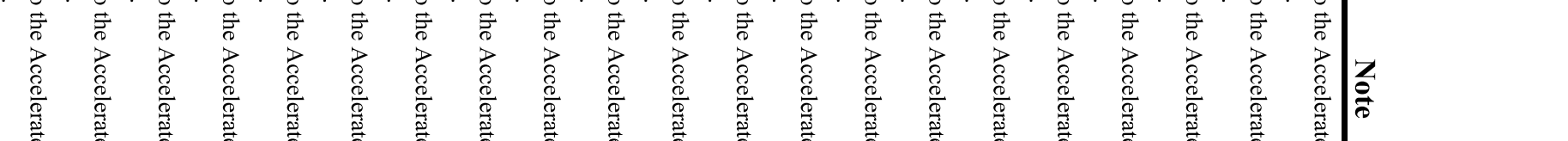




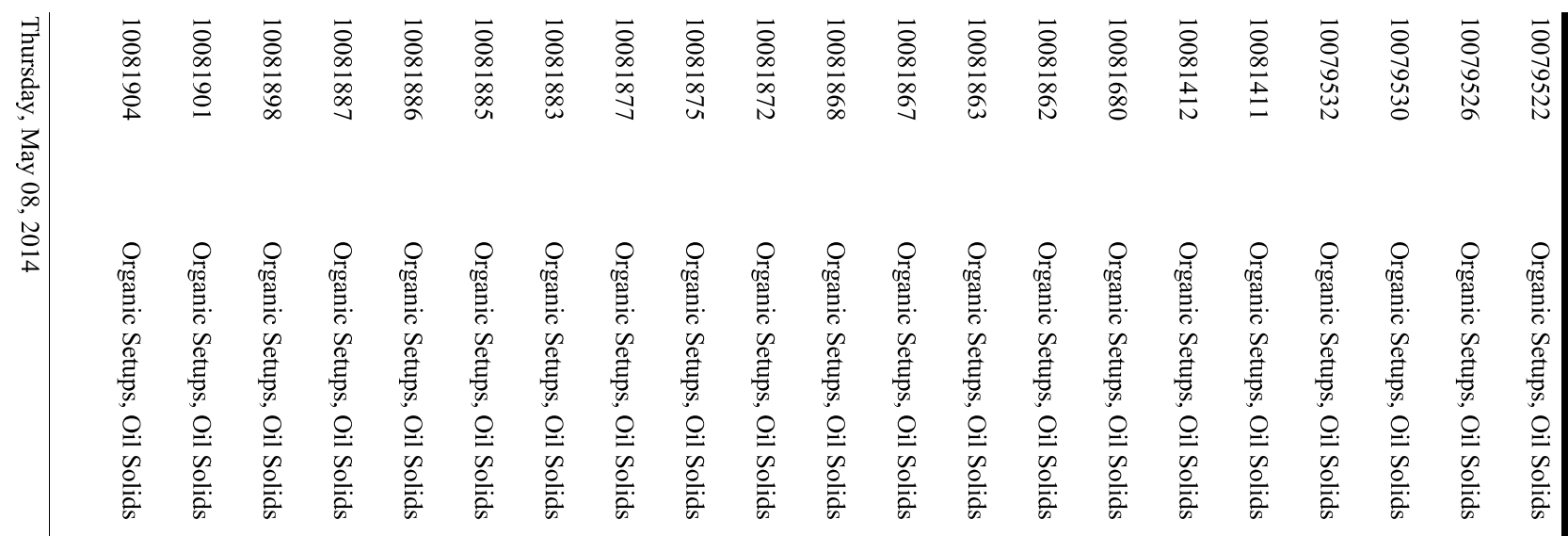

药

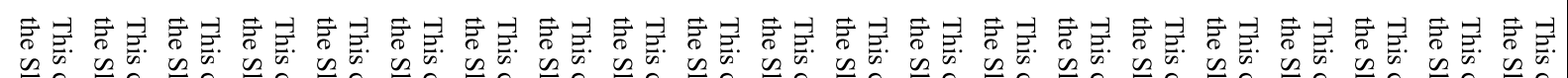

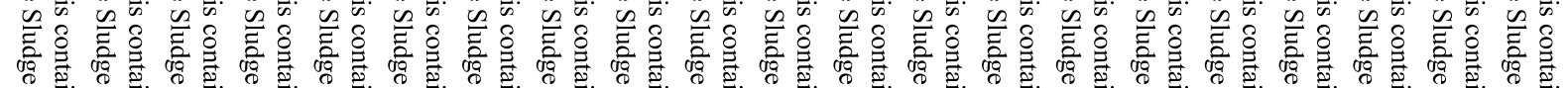

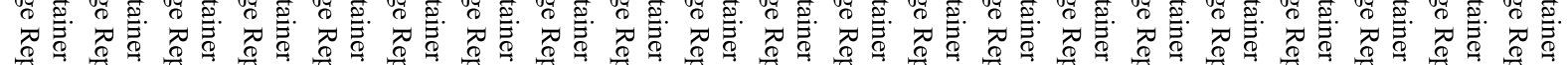

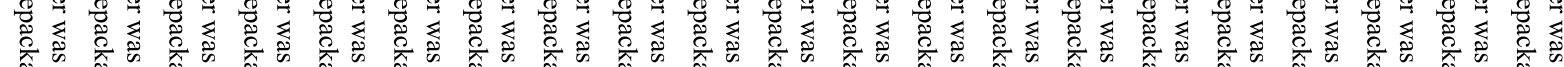

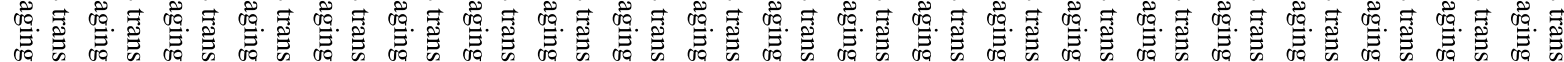

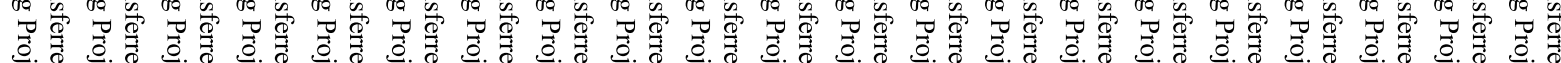

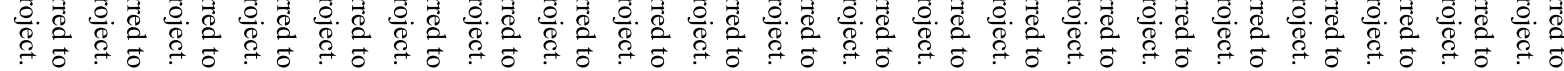

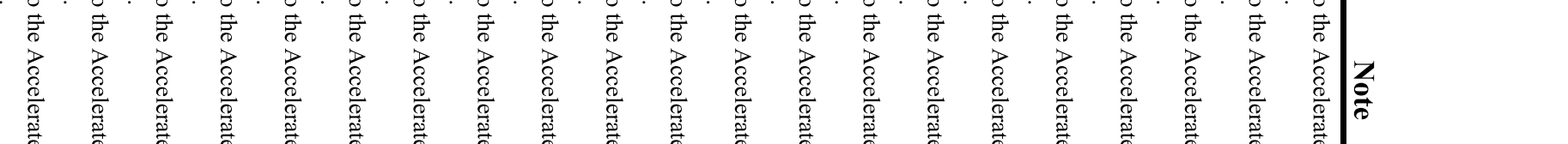




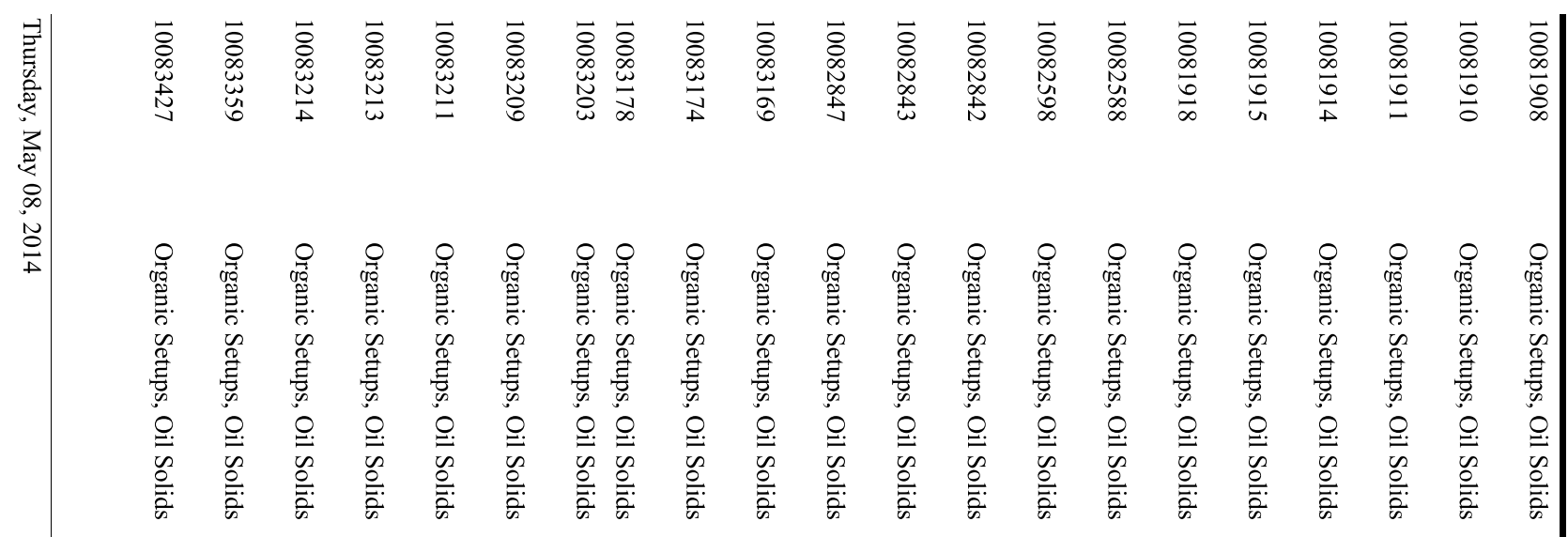

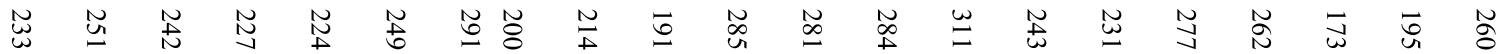

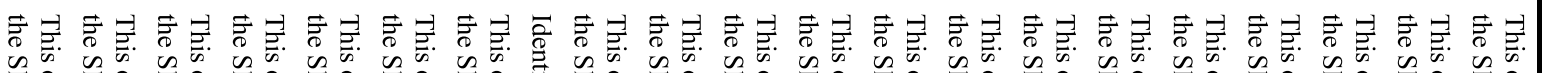

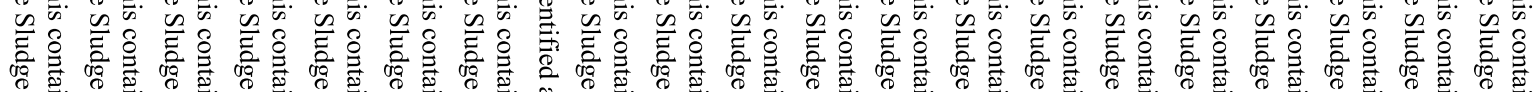

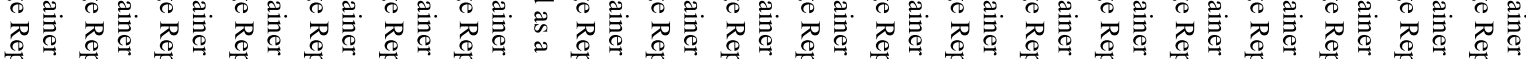

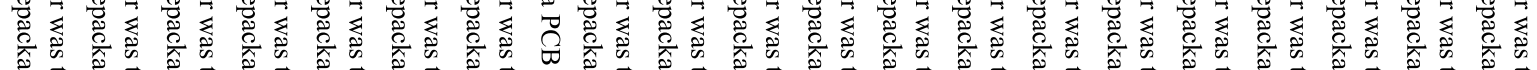

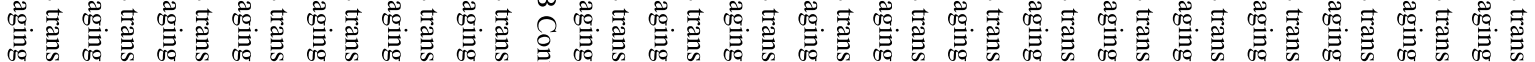

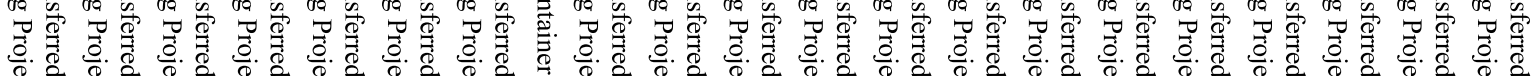

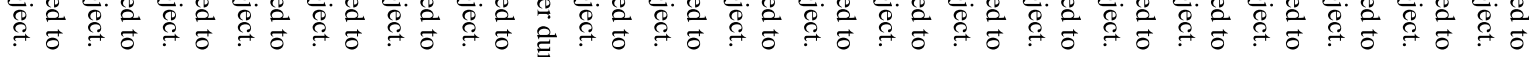




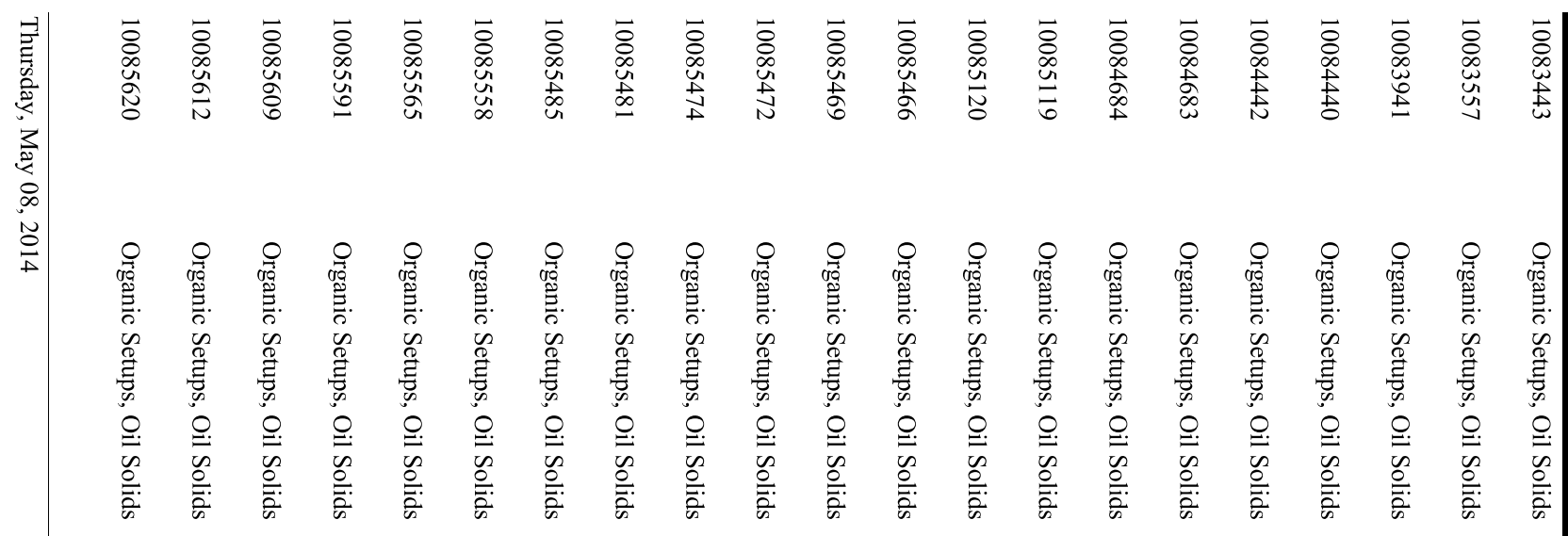

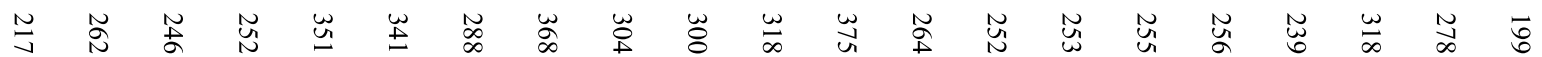

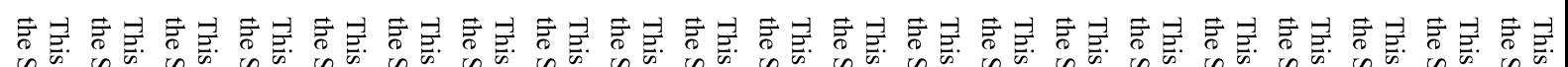

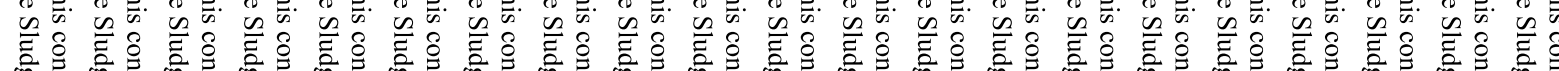

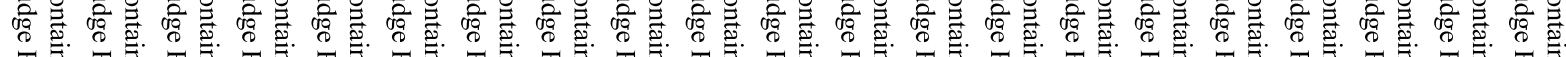
不

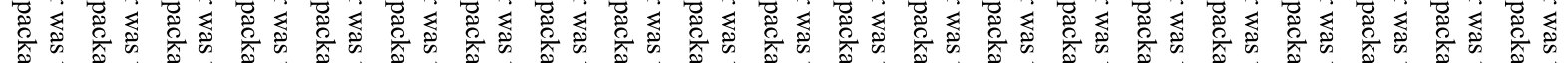

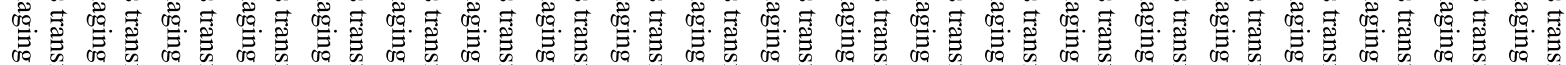

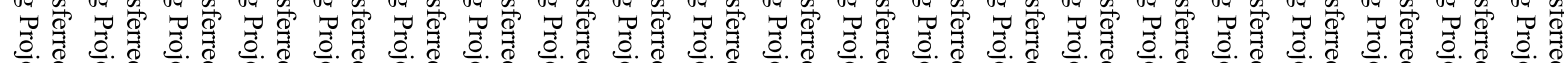

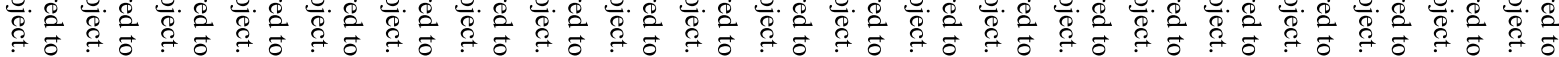

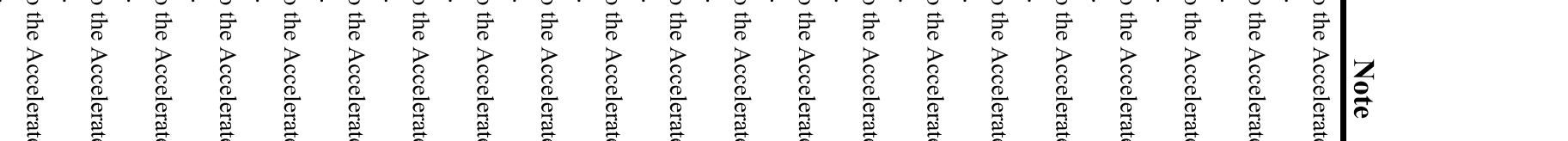




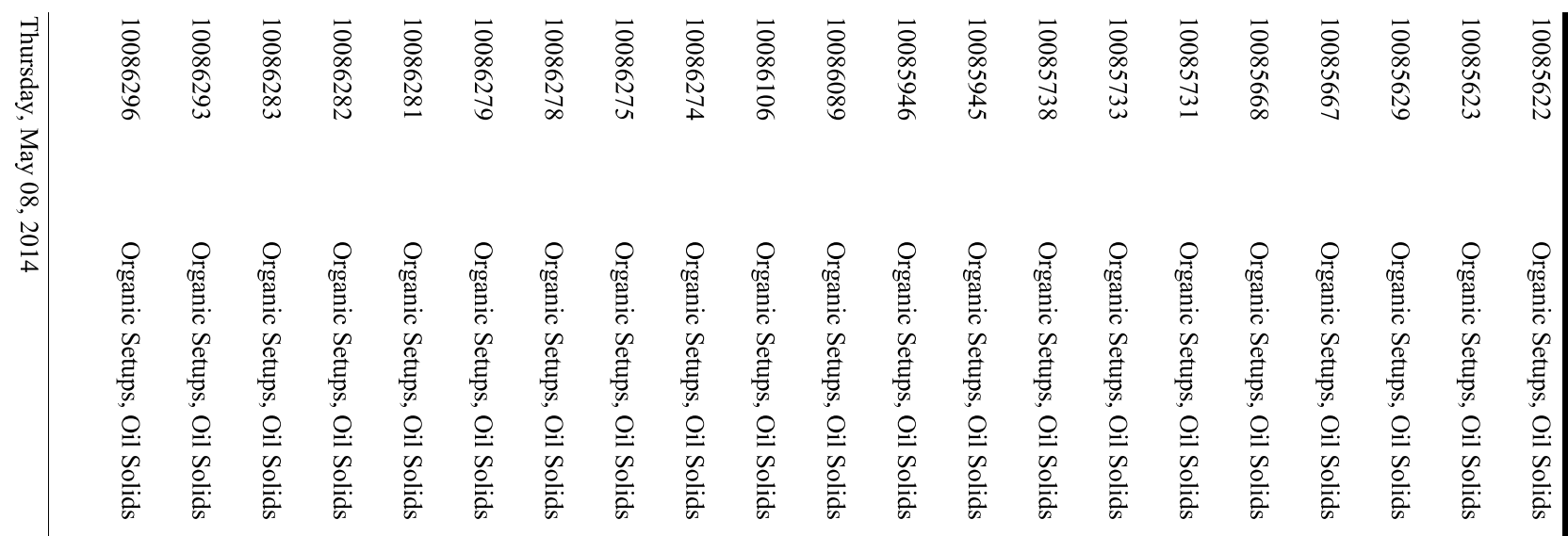

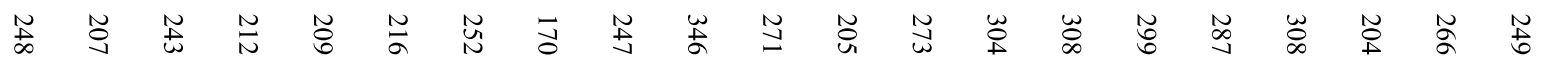

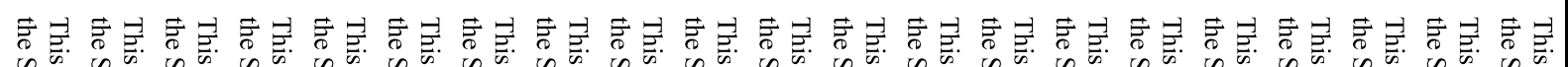

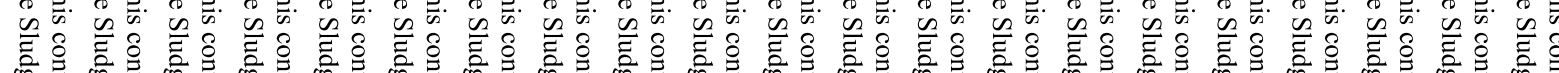

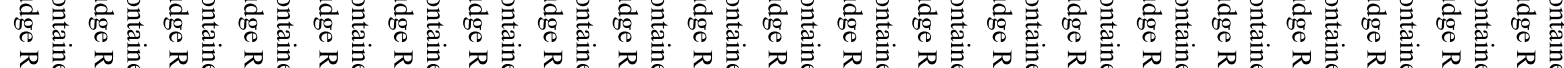

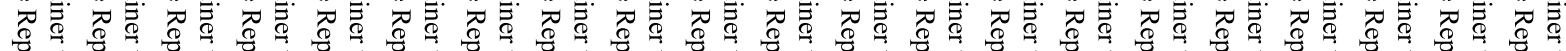

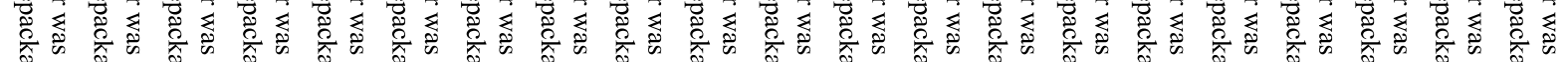

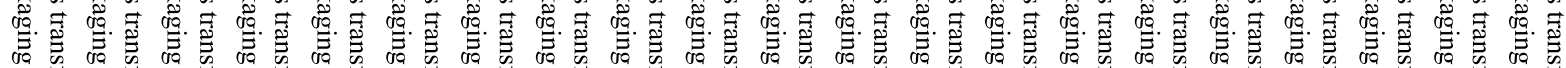

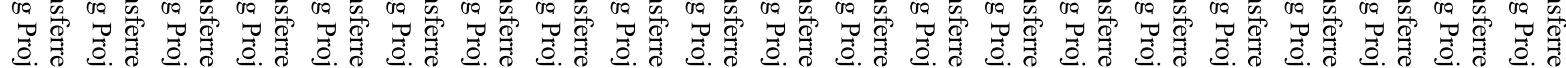

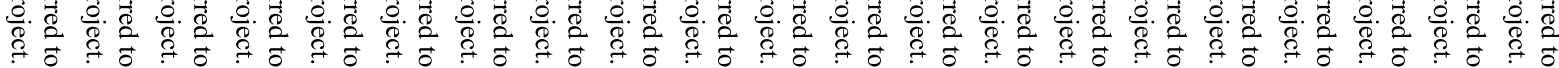

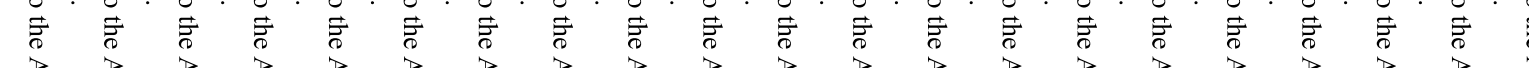




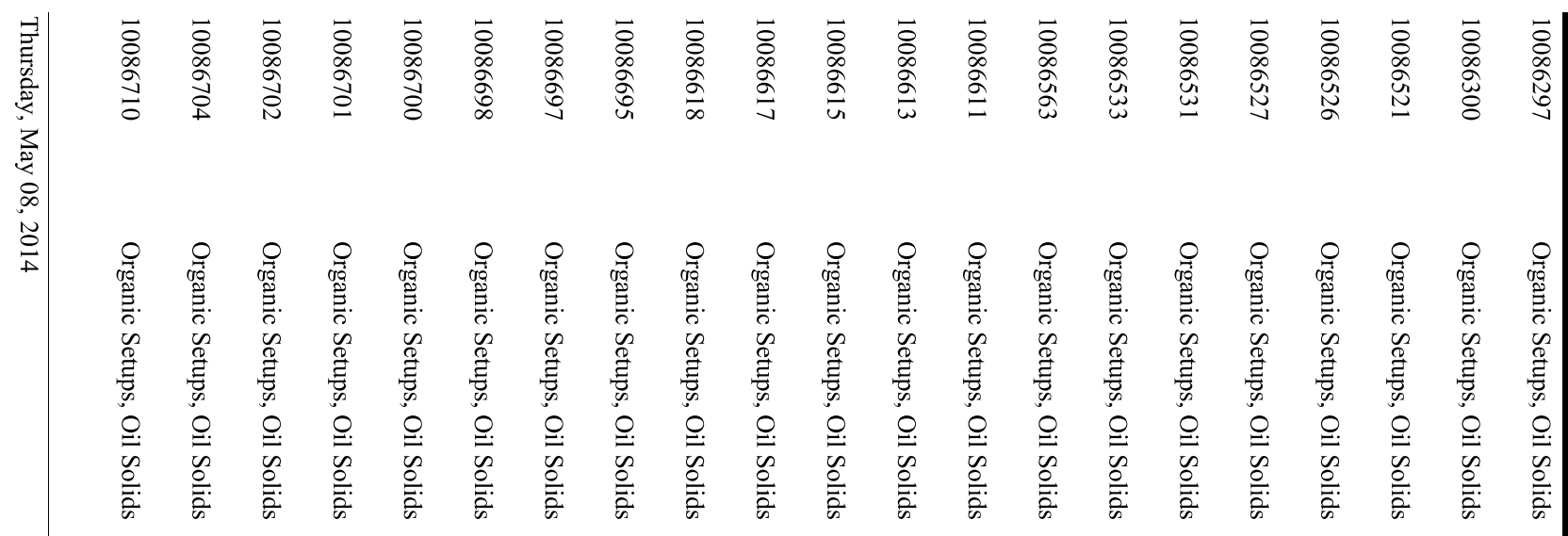

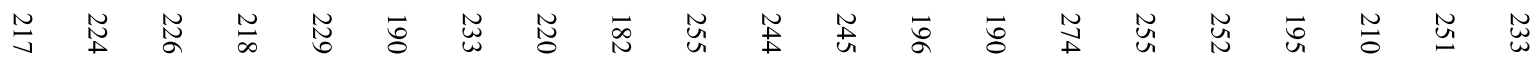

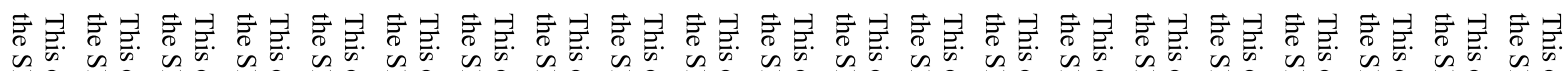

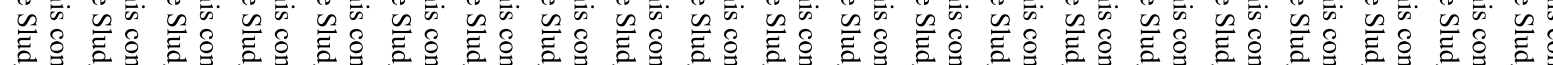

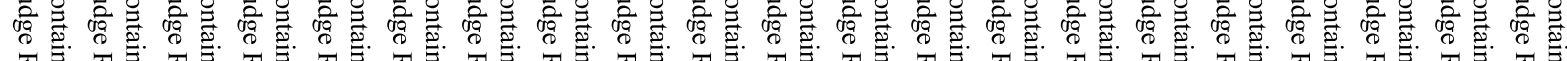
不

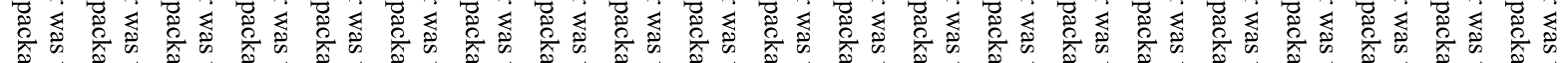

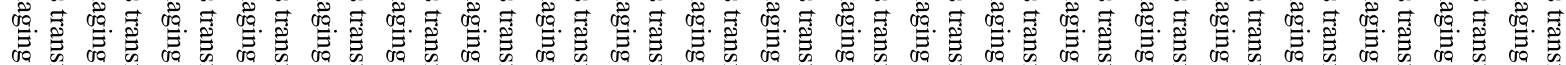

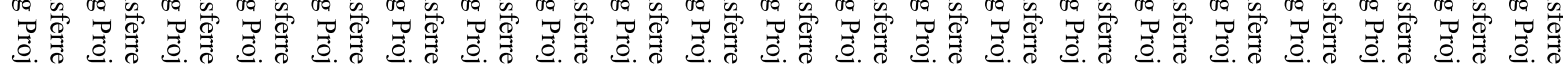

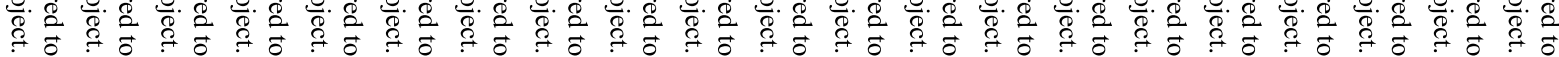

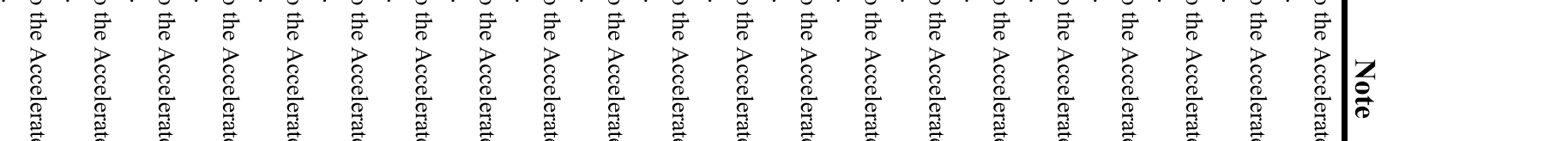




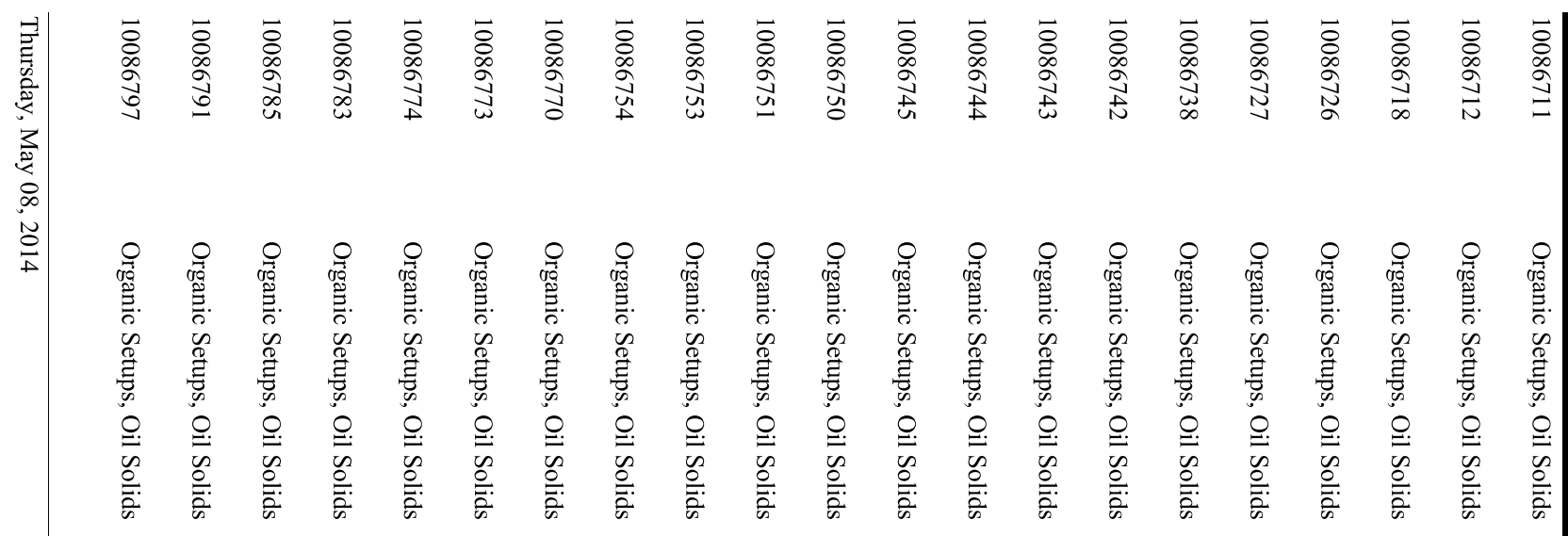

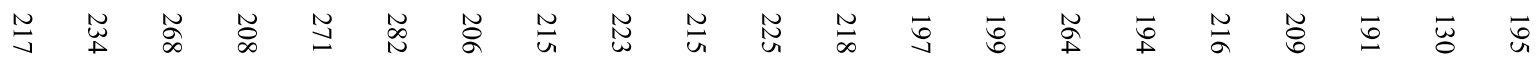

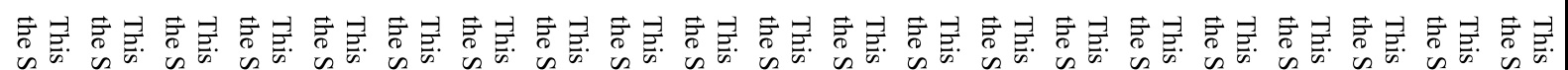

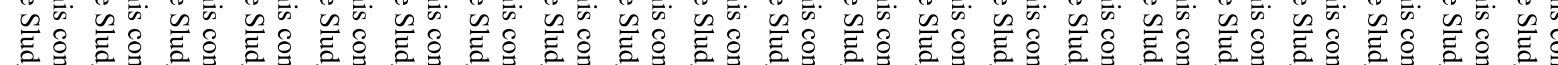

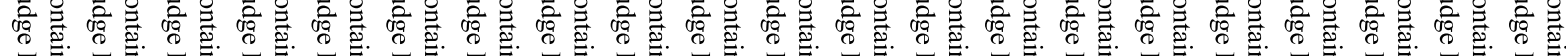
不

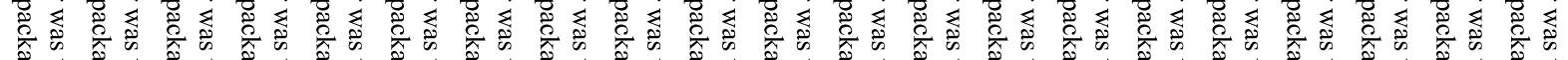

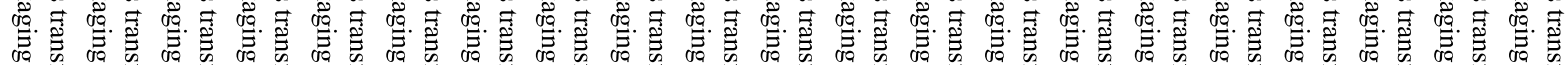

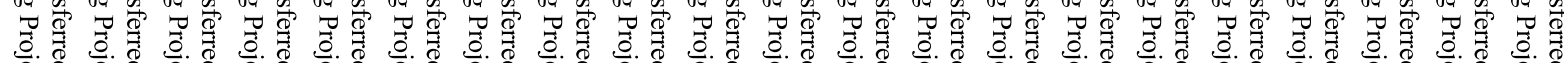

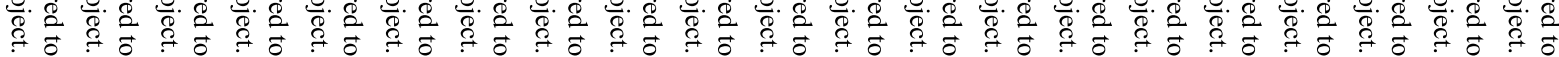

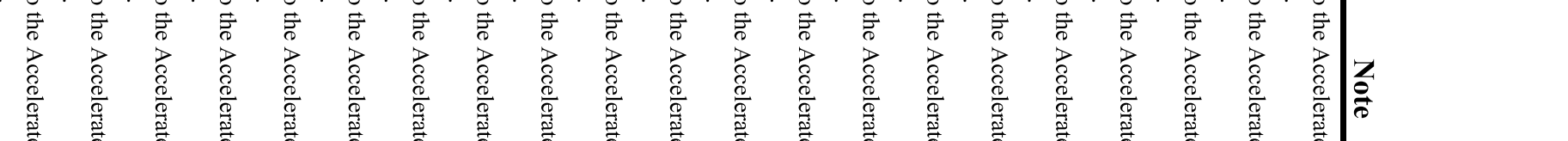




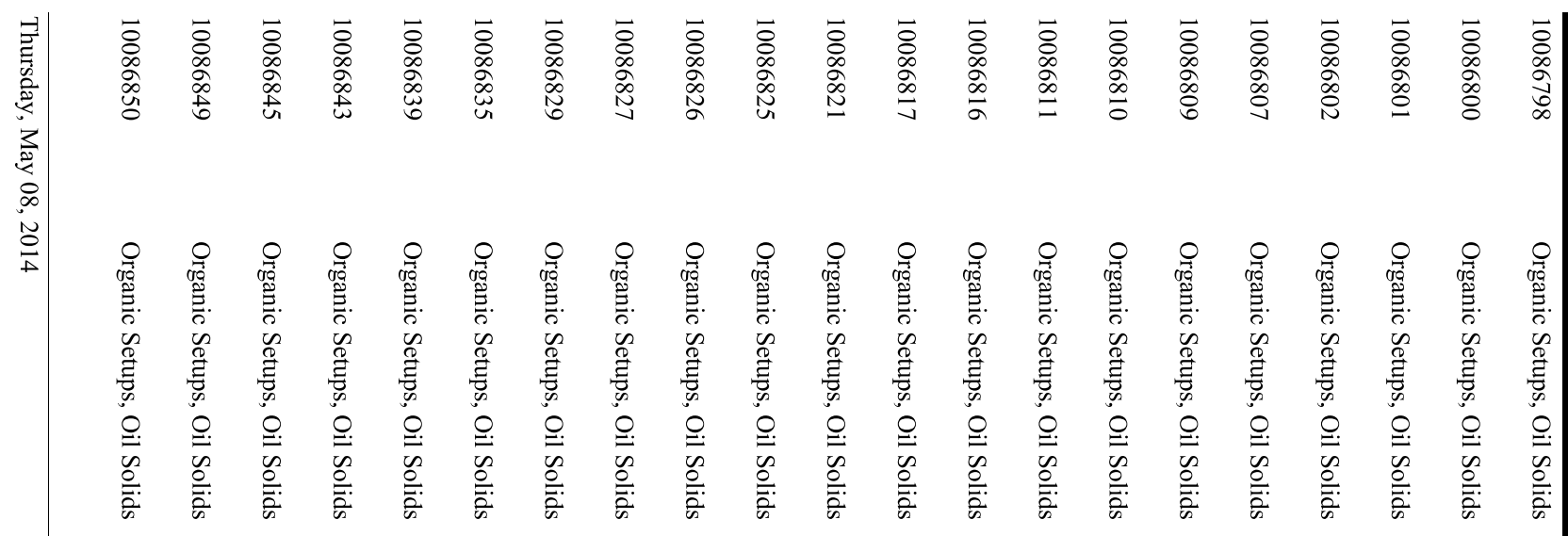

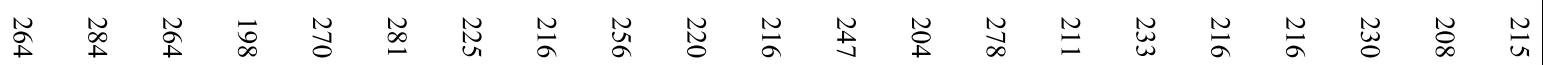

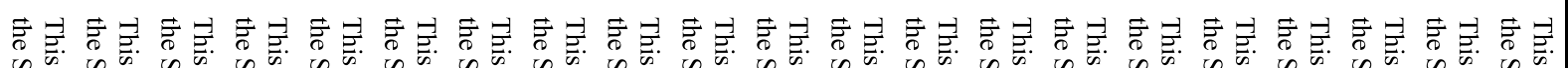

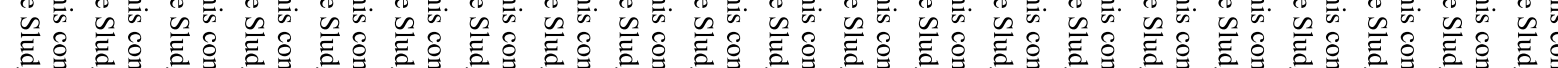

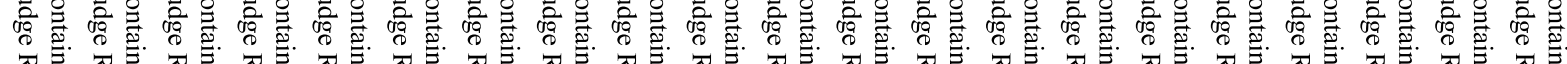

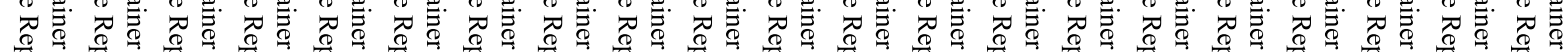

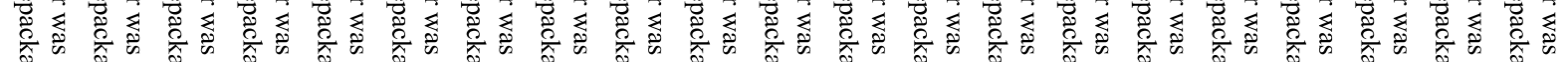

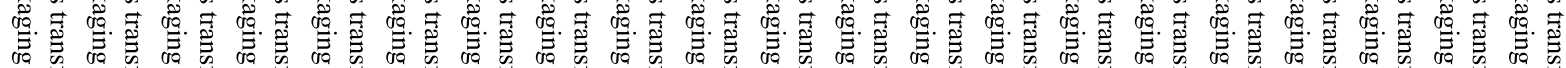

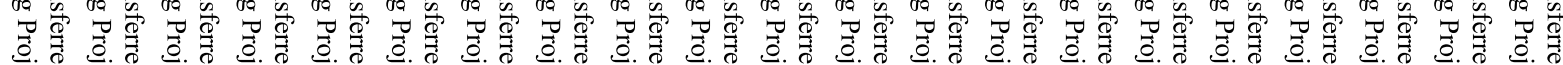

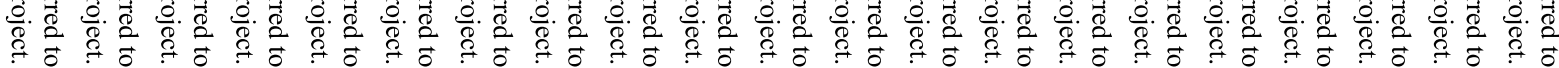

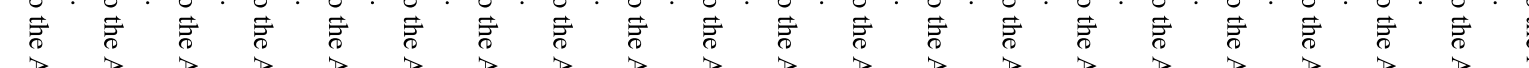

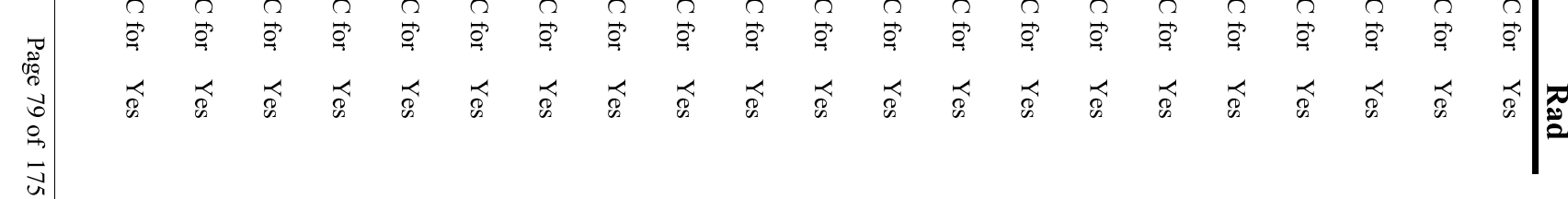




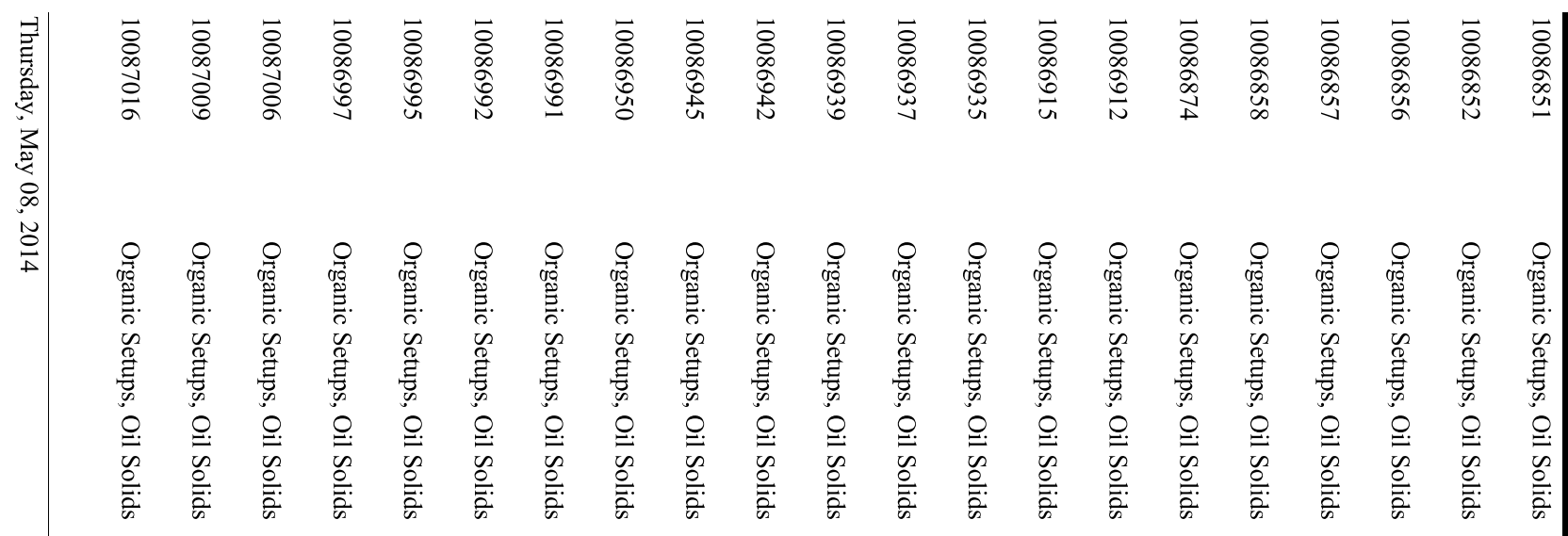

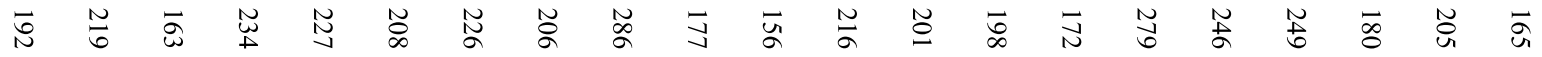

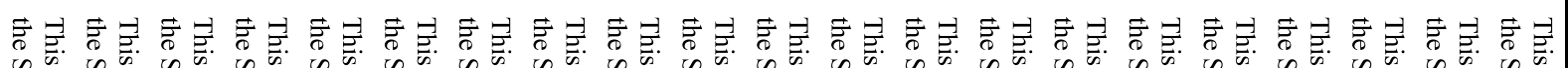

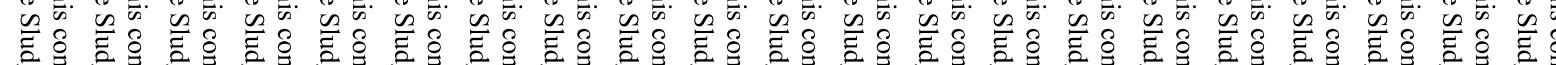

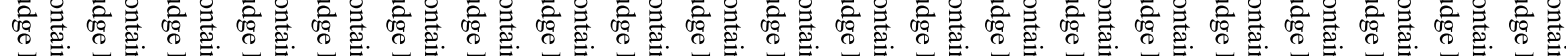
不

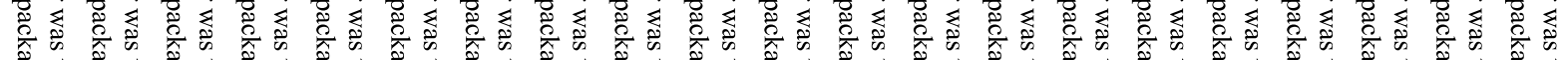

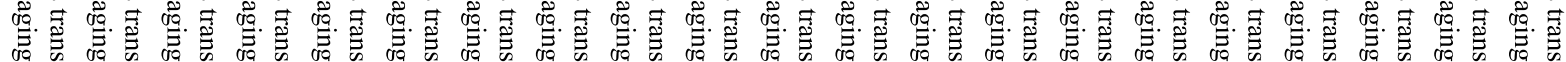

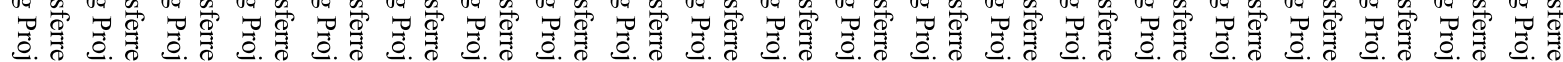

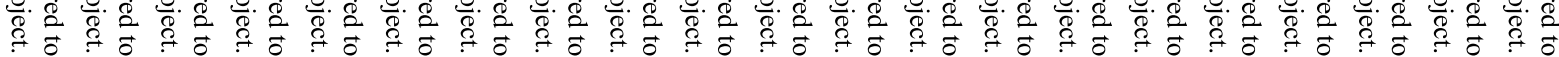

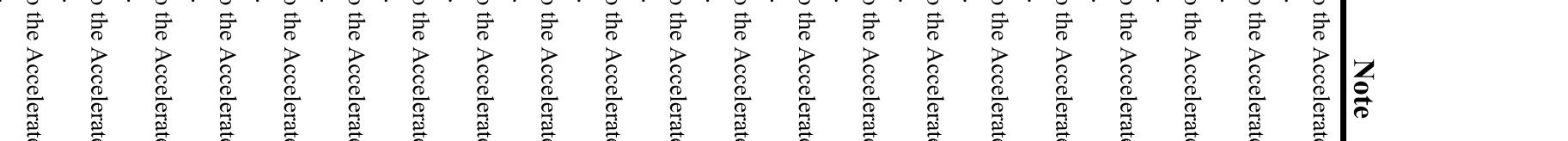




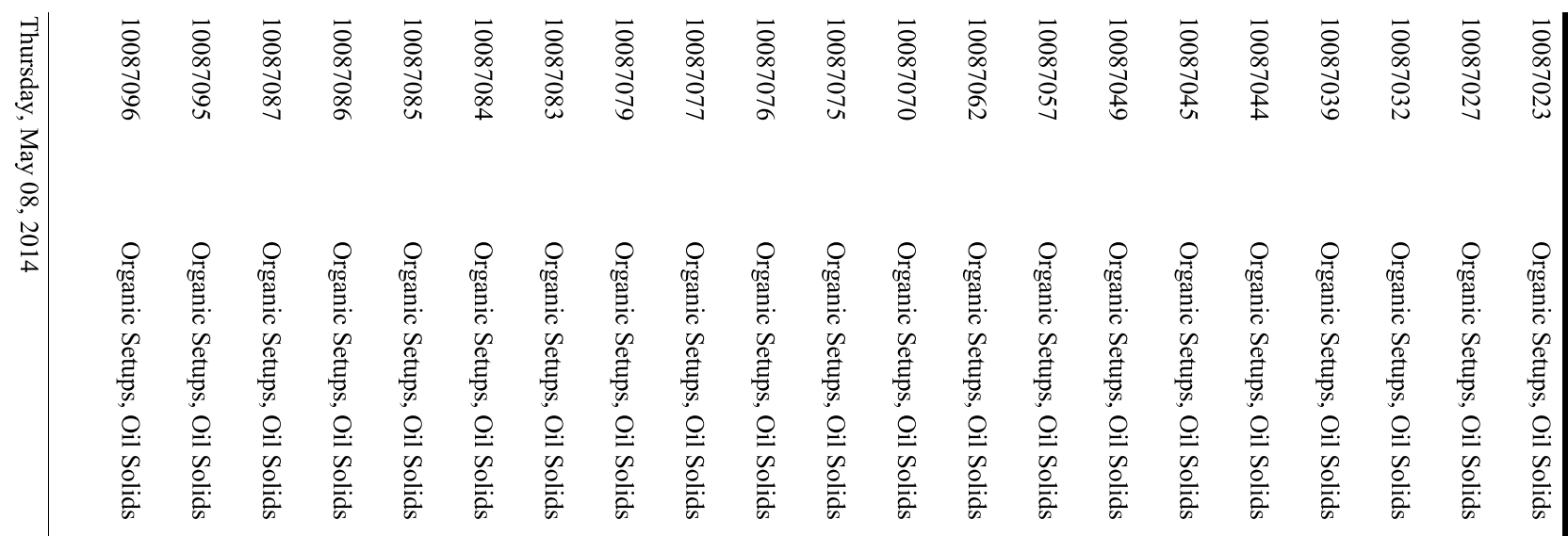

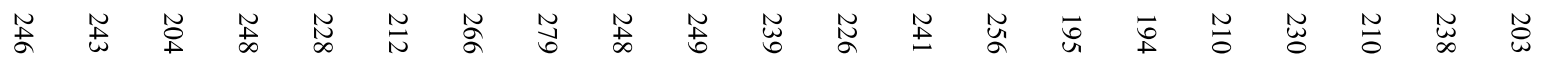

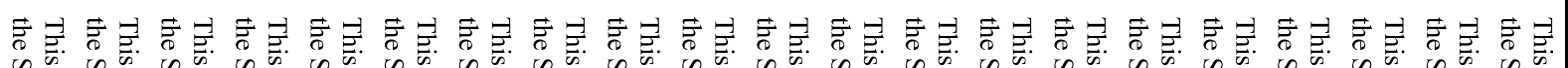

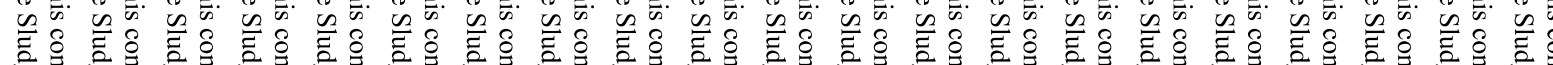

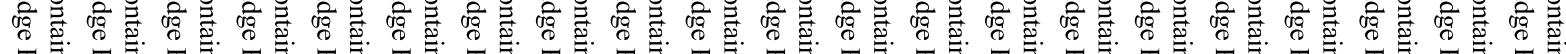
不

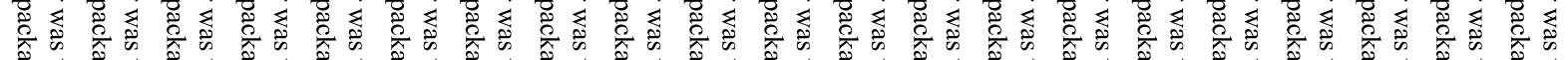

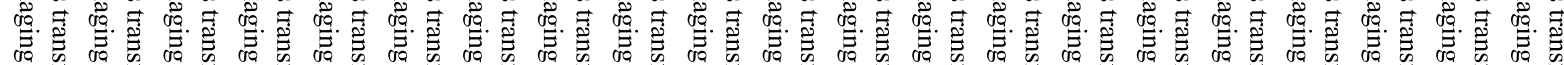

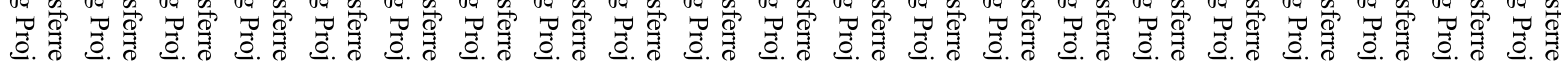

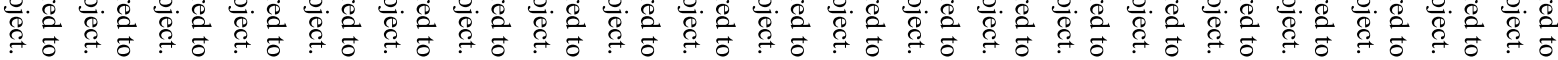

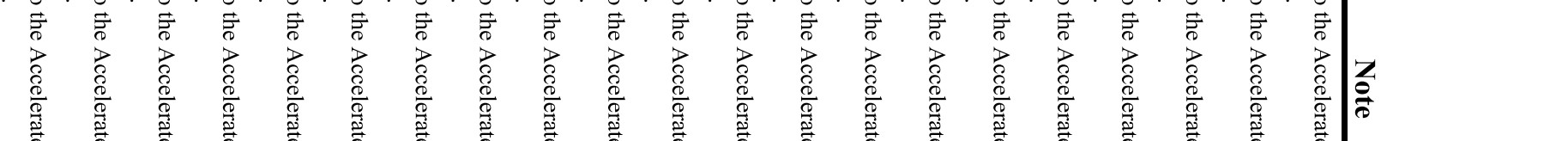




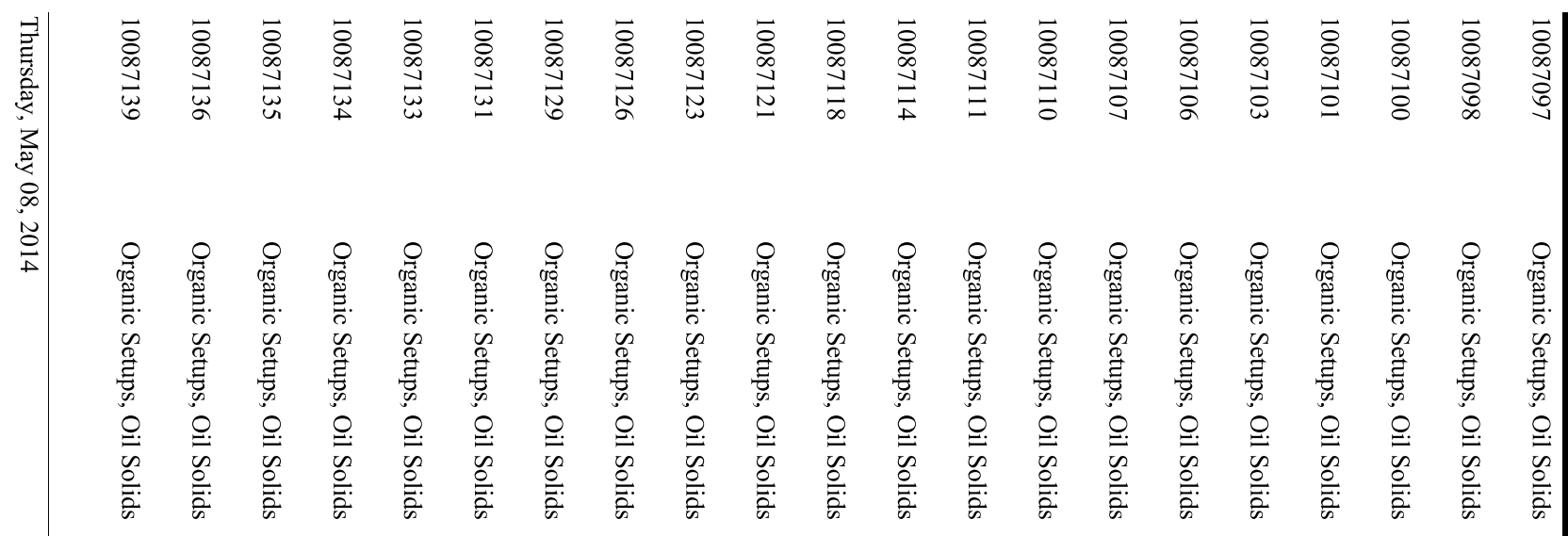

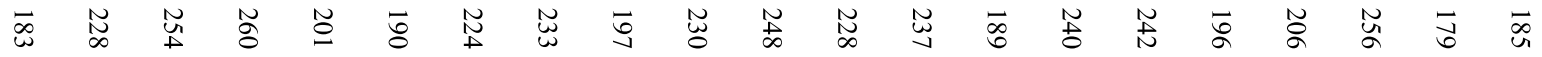

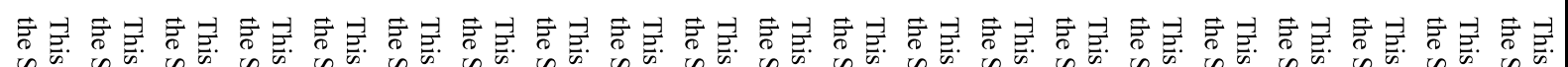

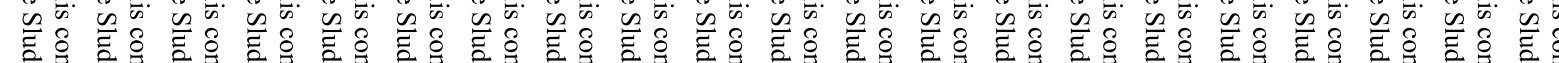

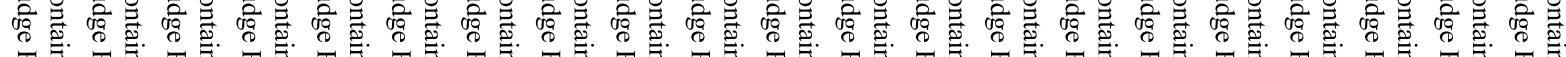

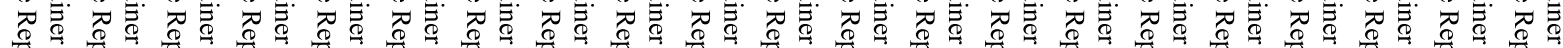

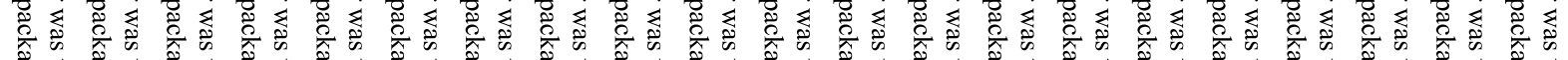

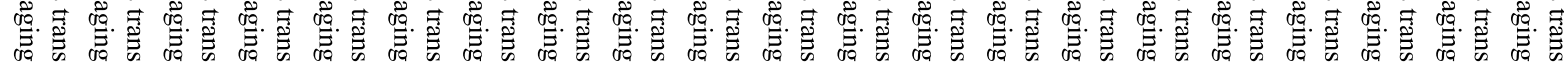

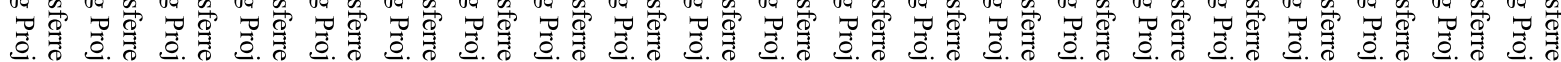

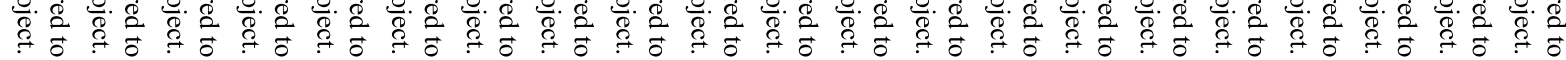

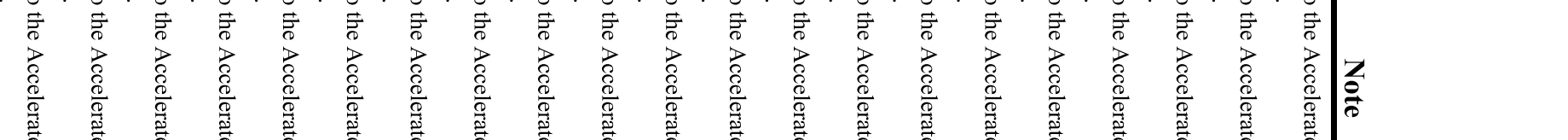




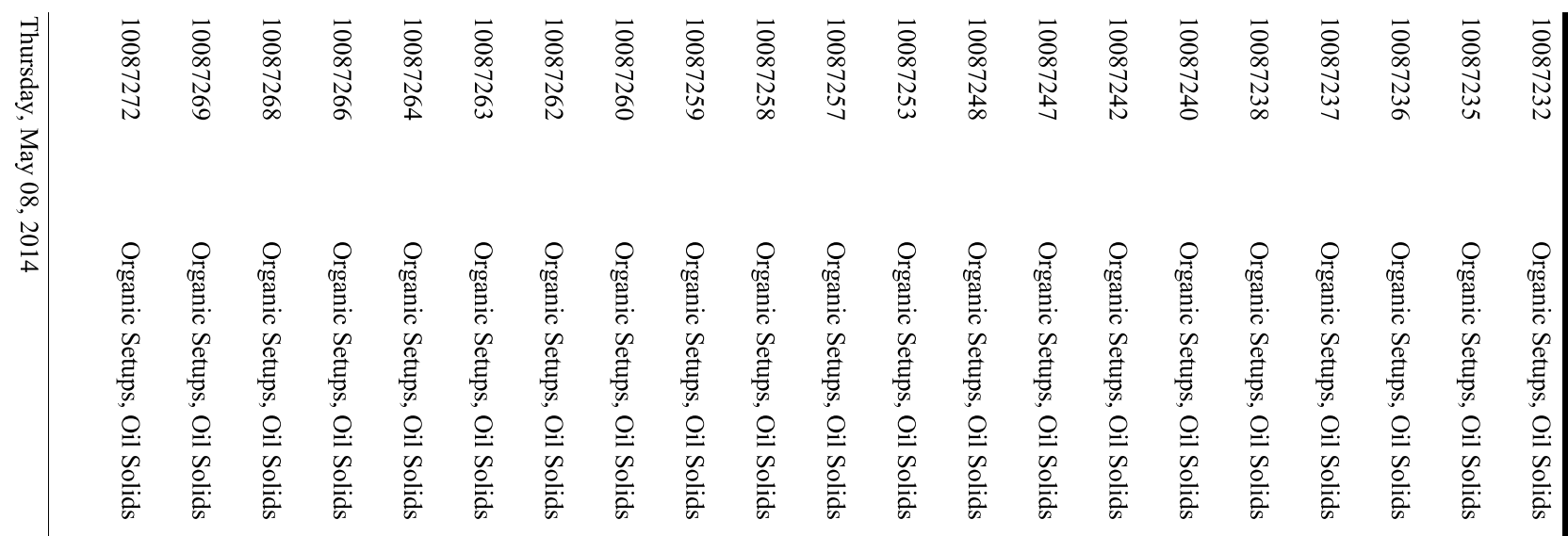

员

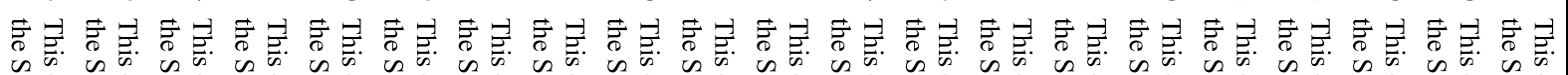

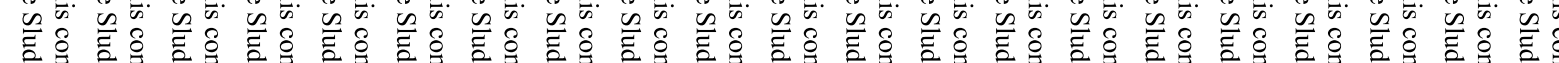

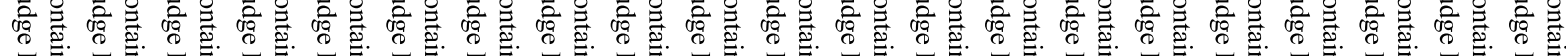
不

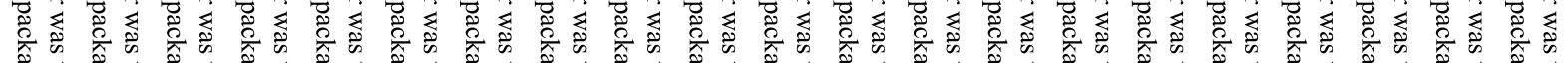

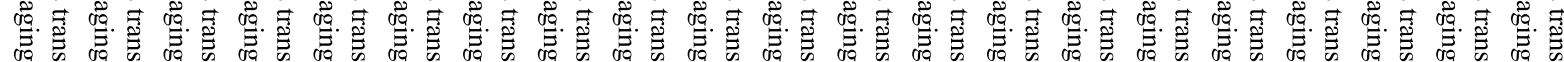

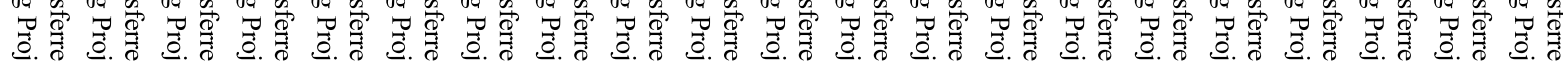

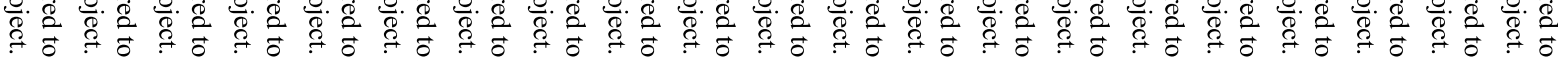

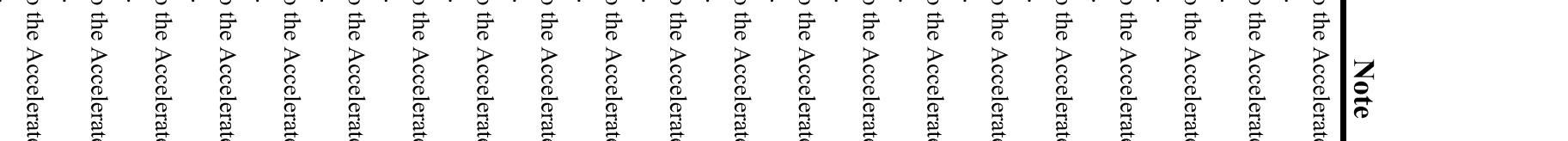




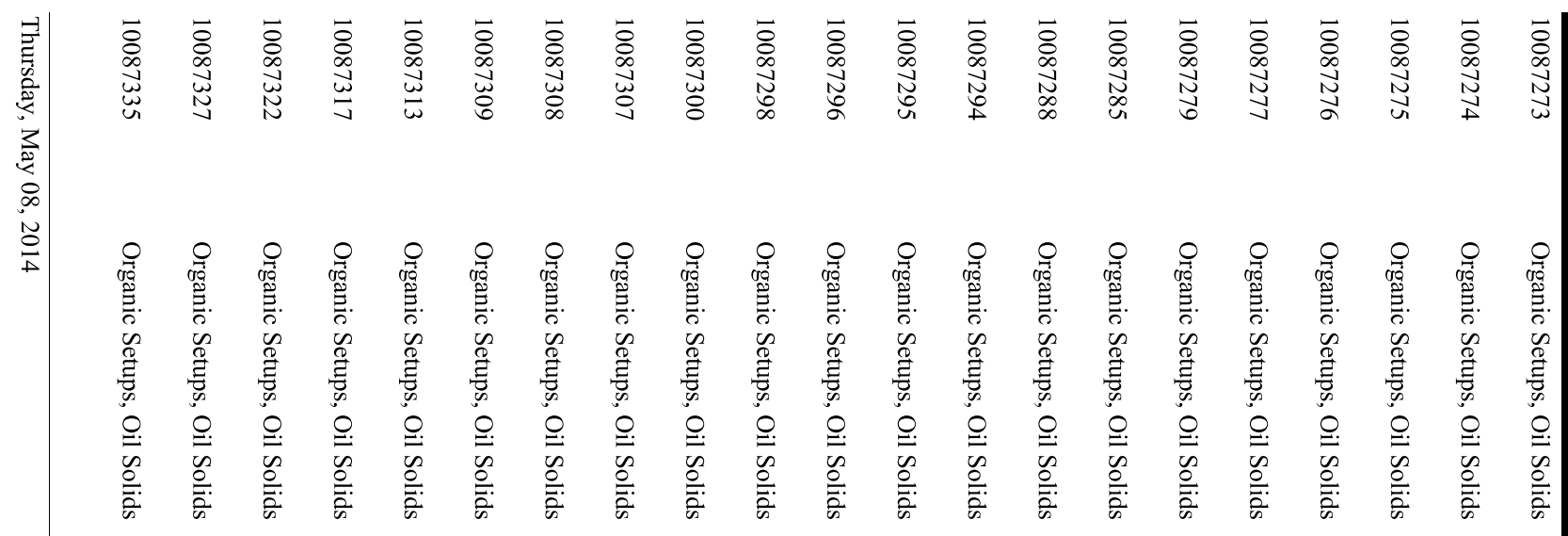

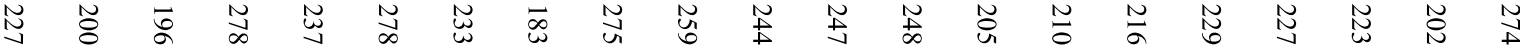

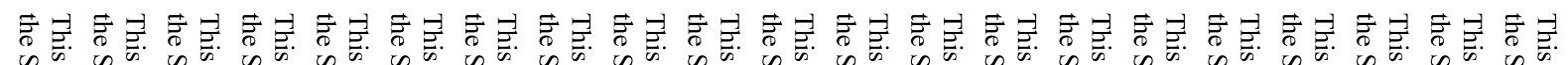

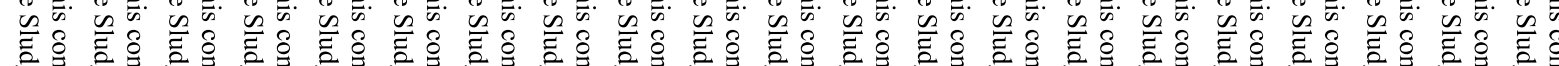

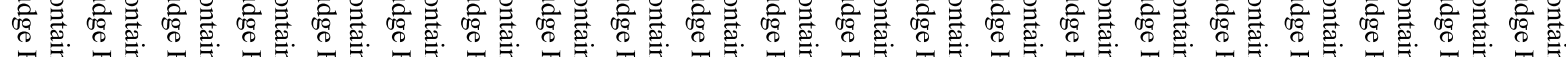
不

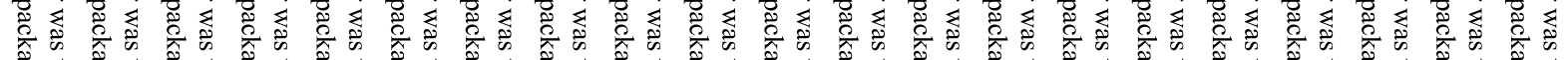

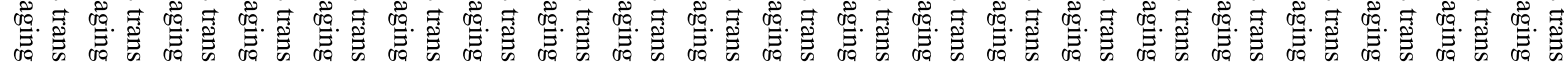

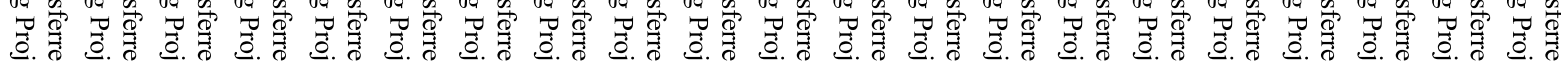

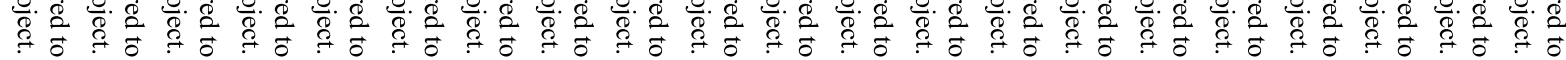

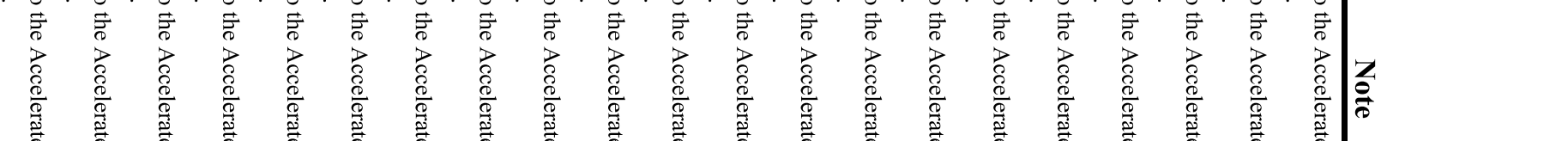




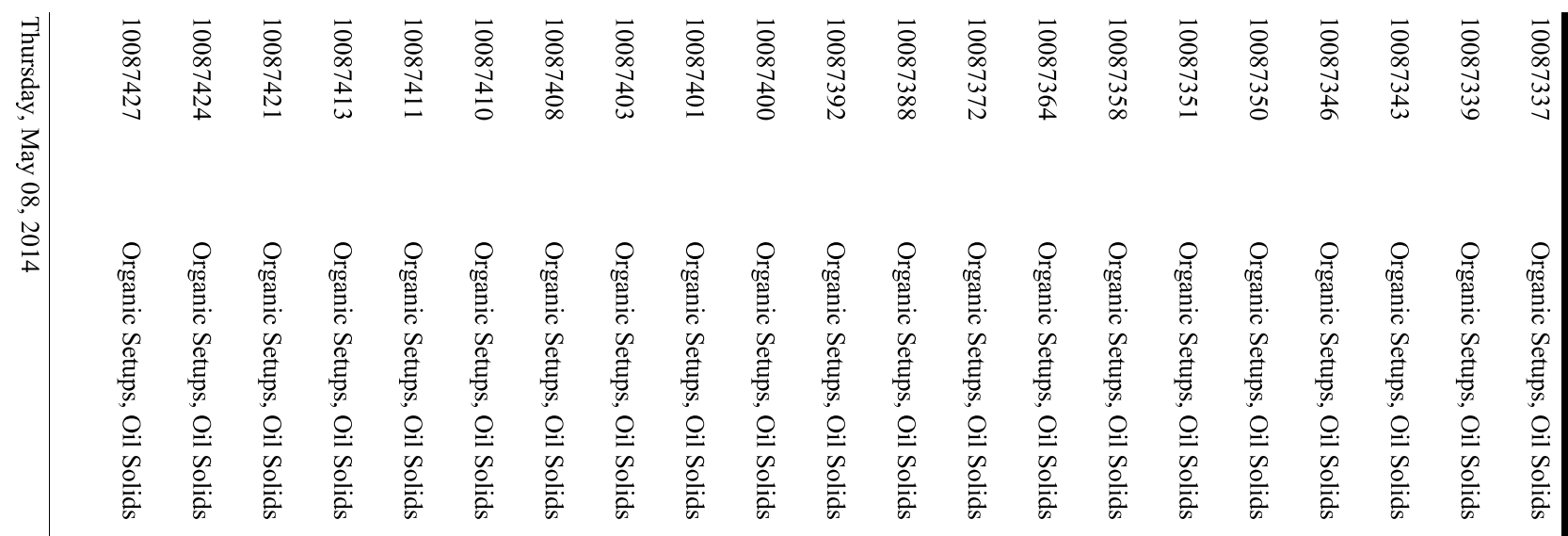

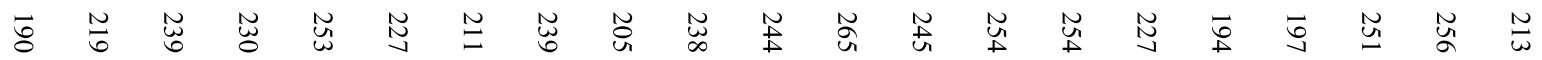

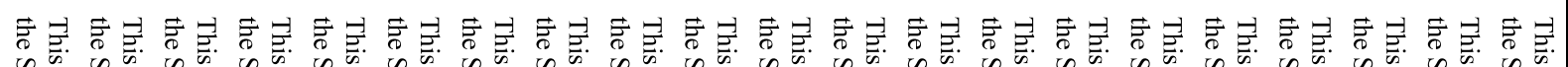

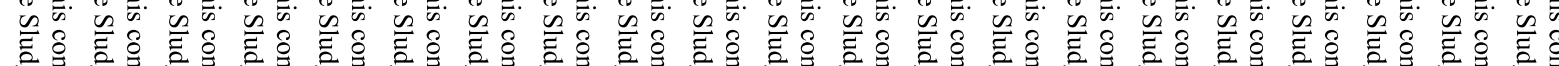

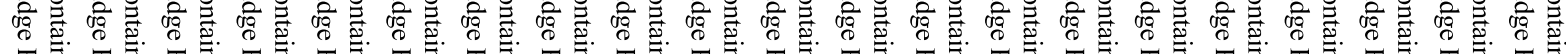
不

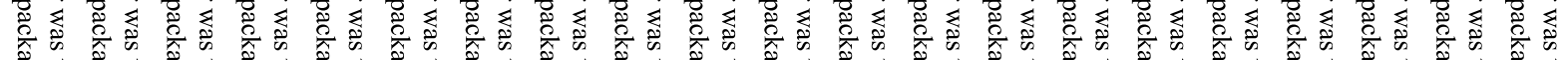

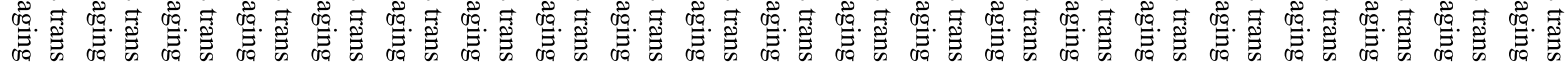

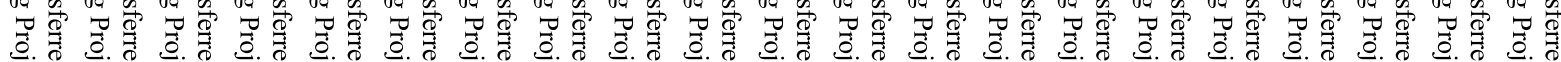

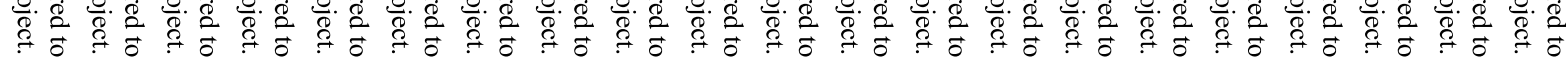

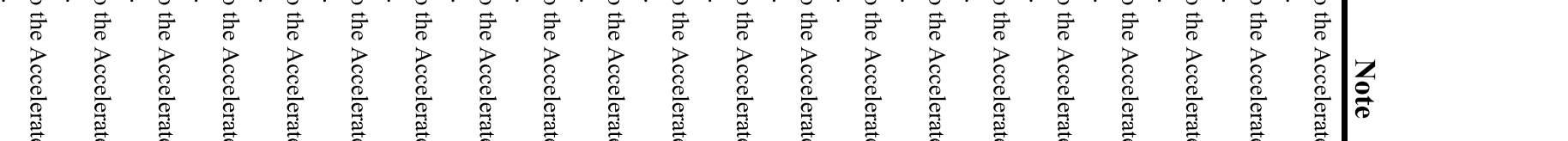




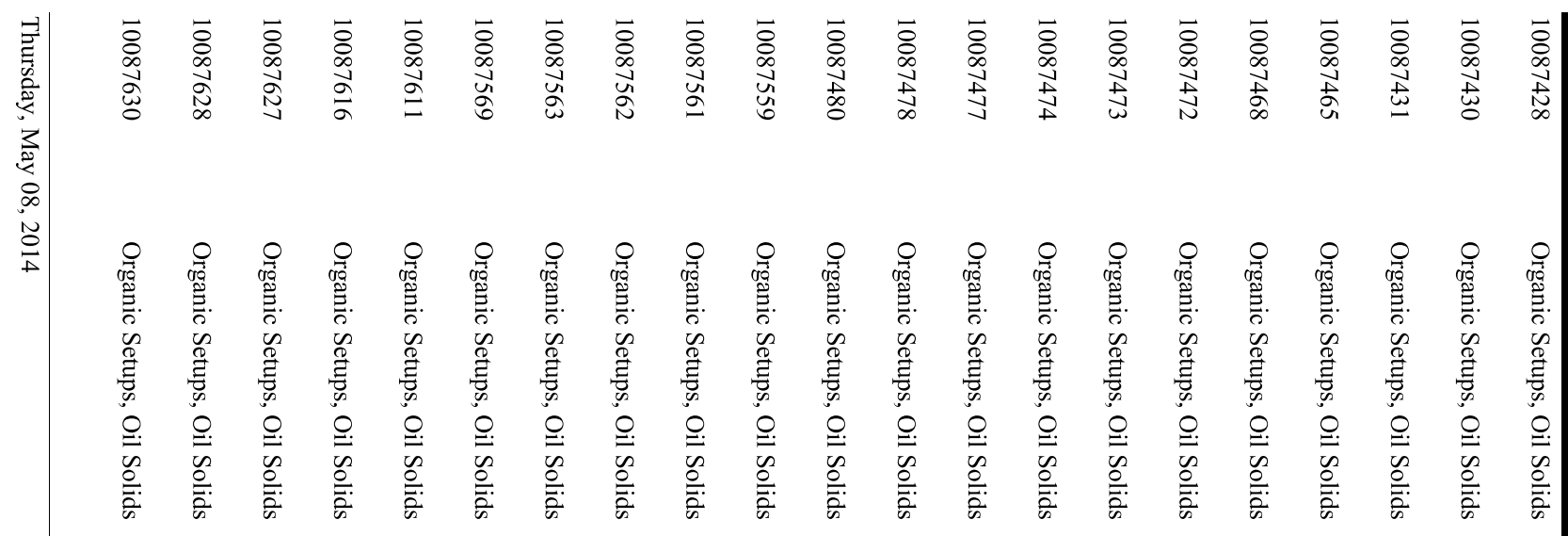

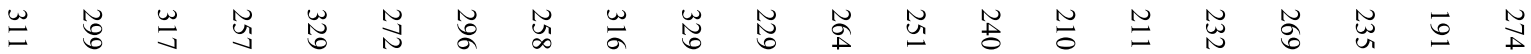

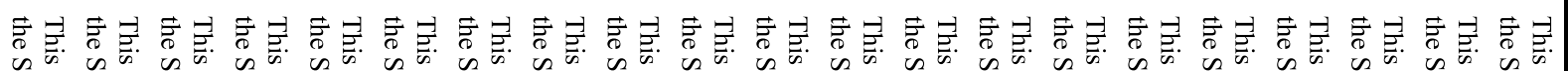

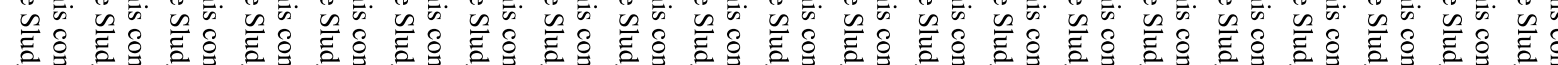

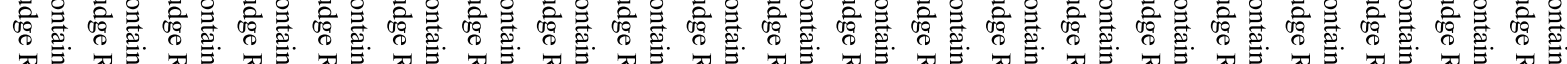
不

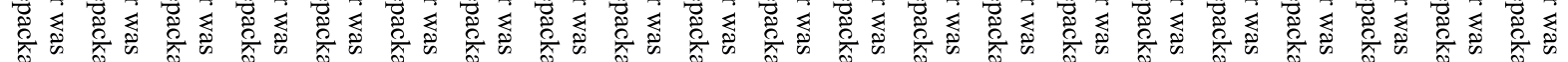

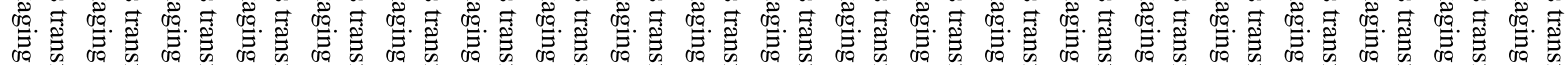

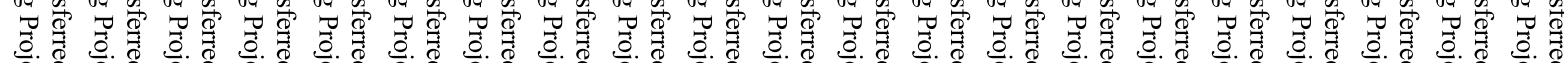

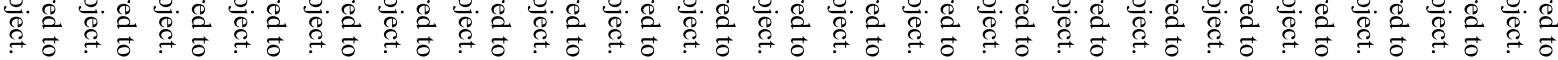

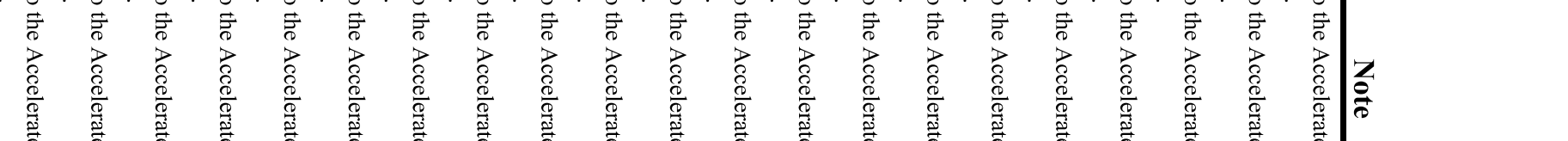




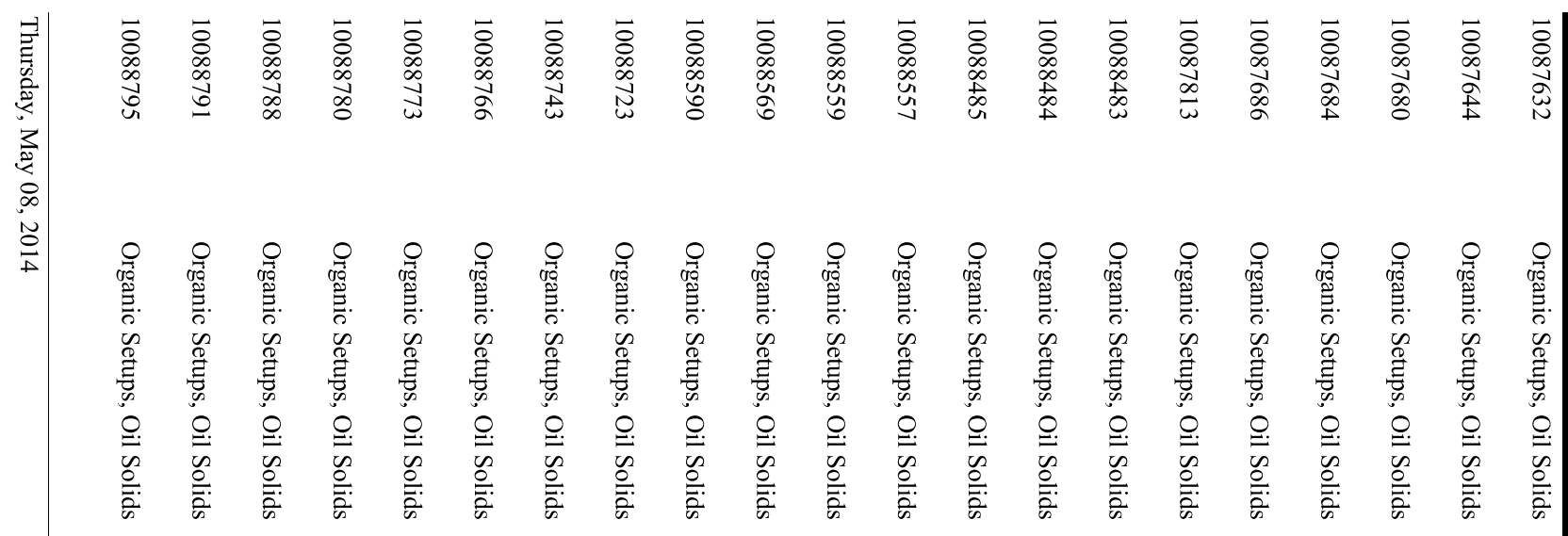

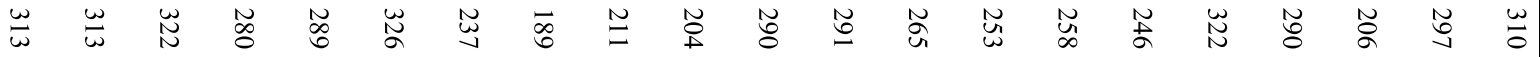

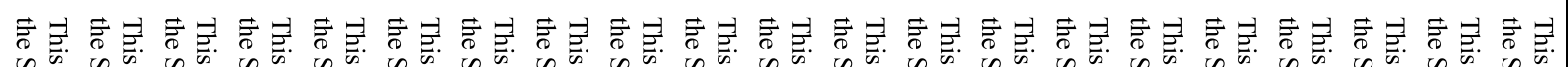

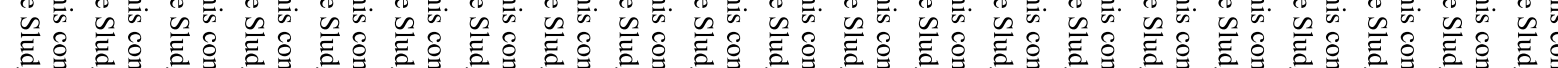

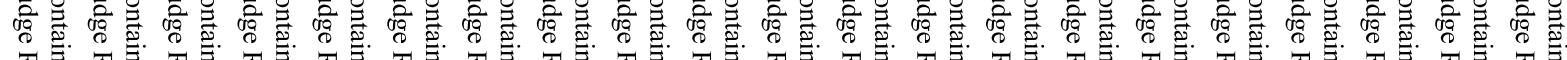
不

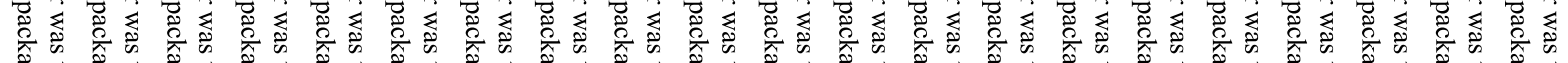

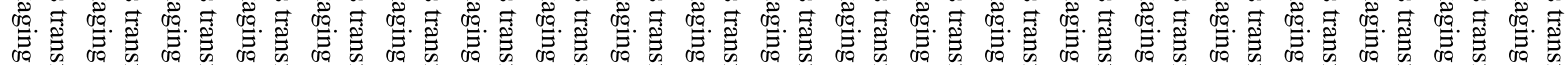

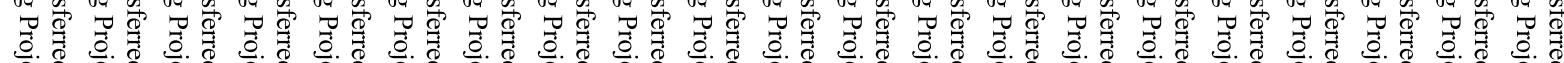

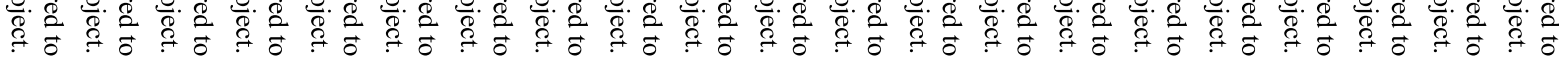

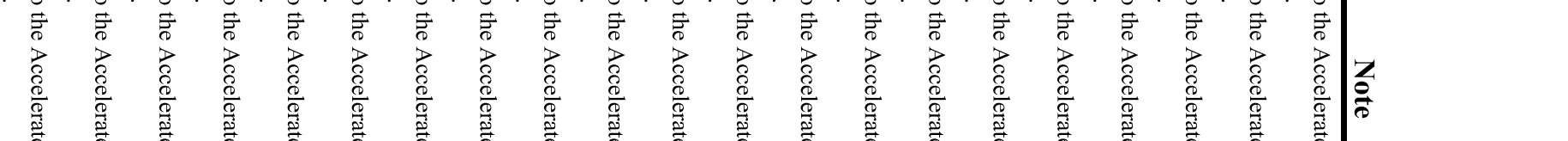




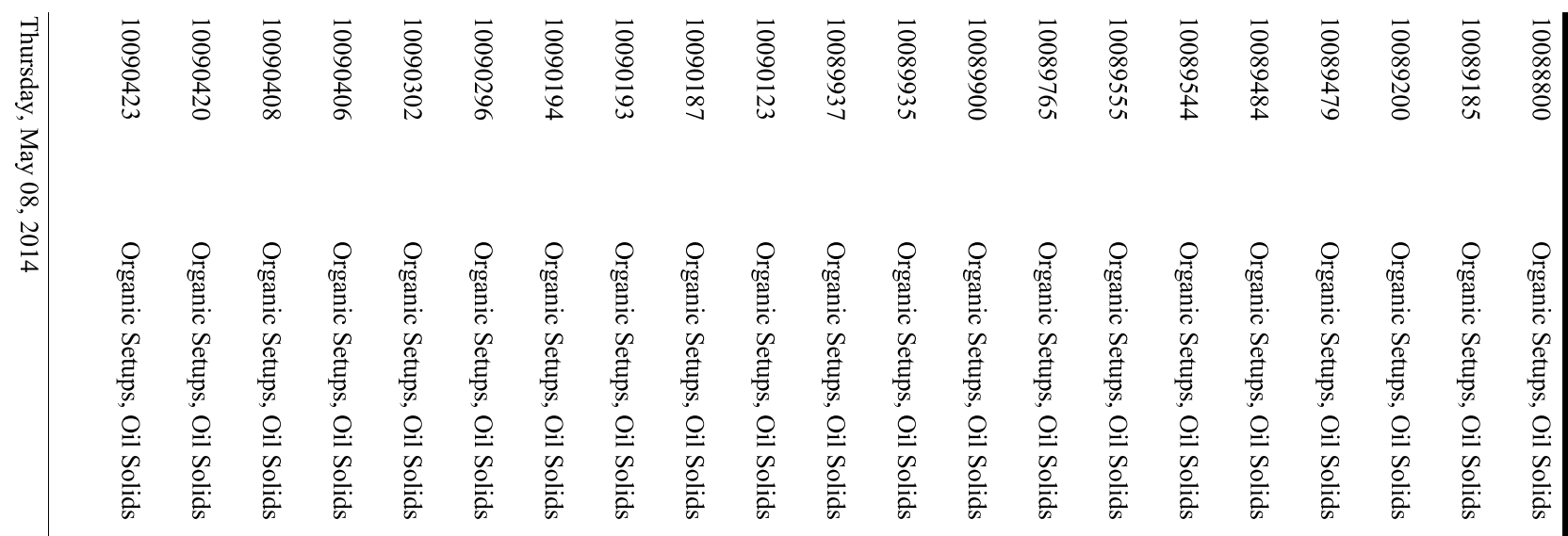

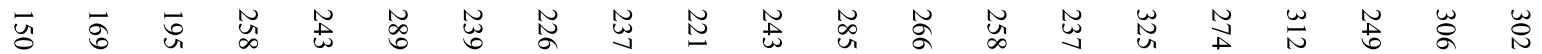

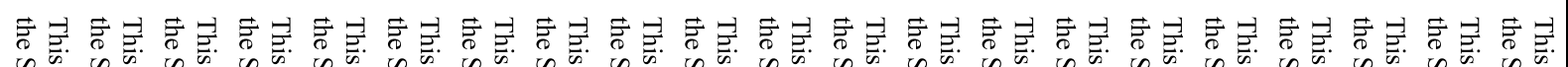

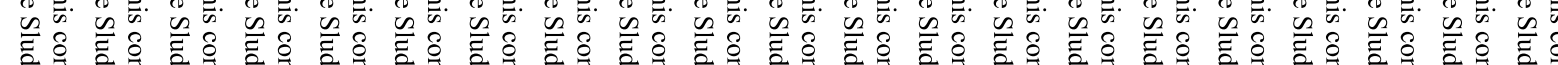

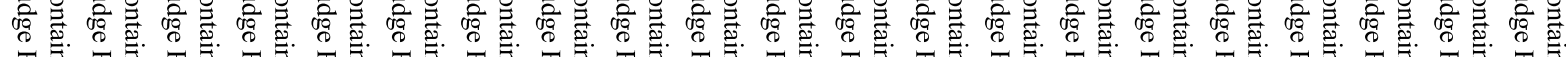
不

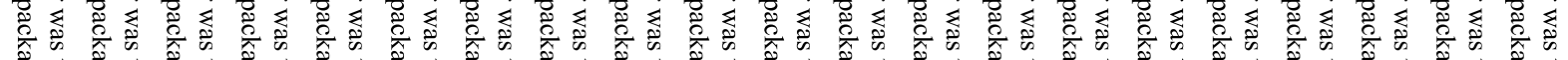

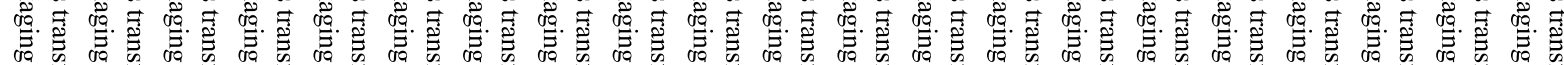

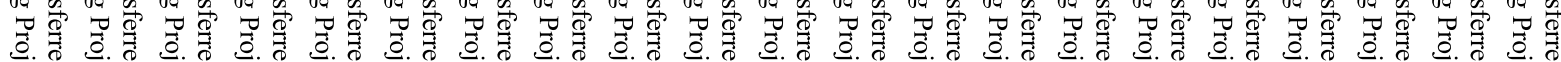

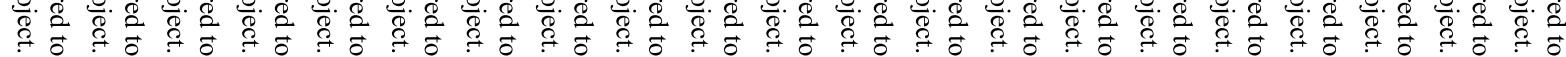

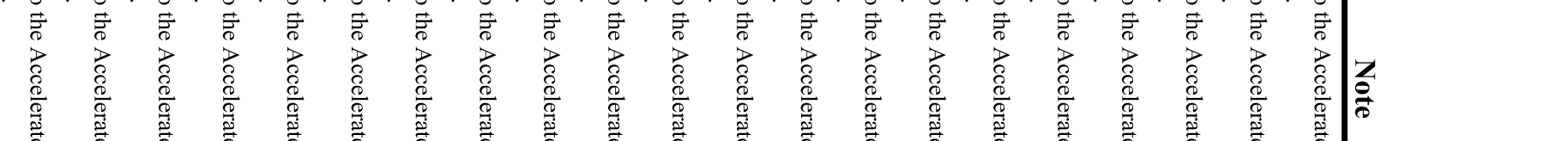




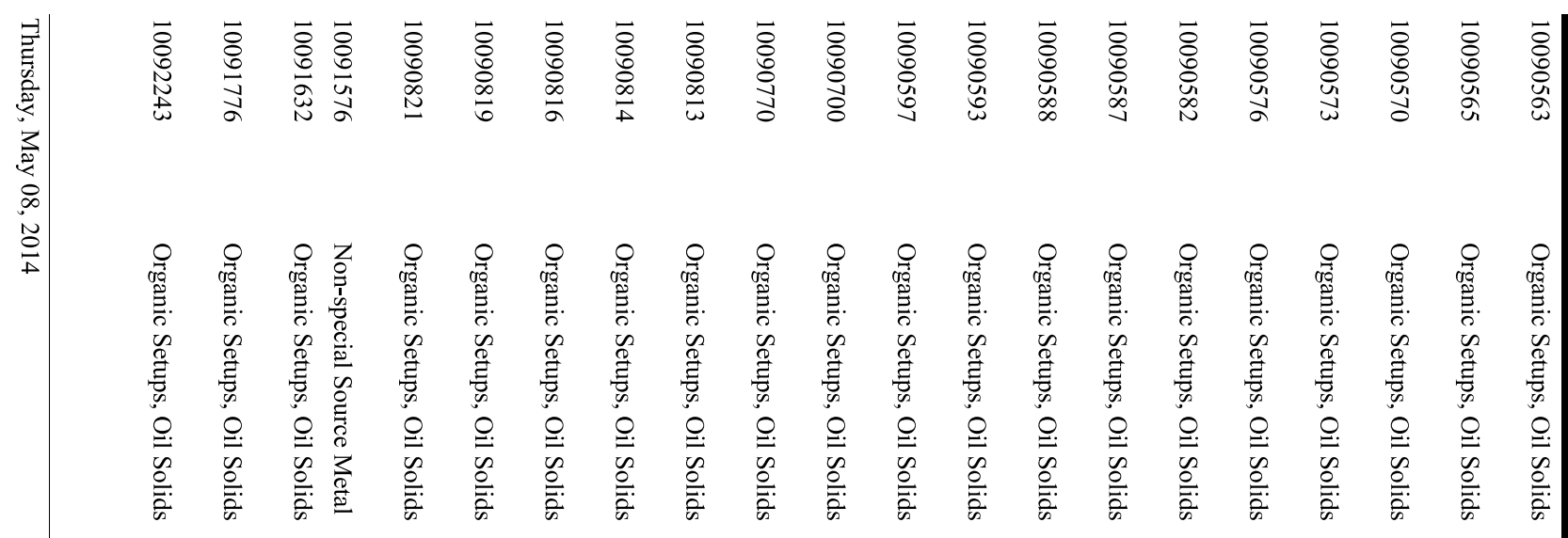

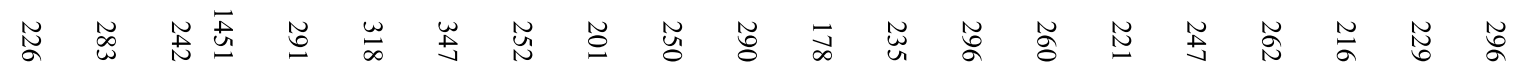

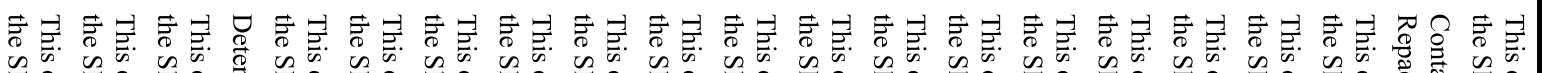

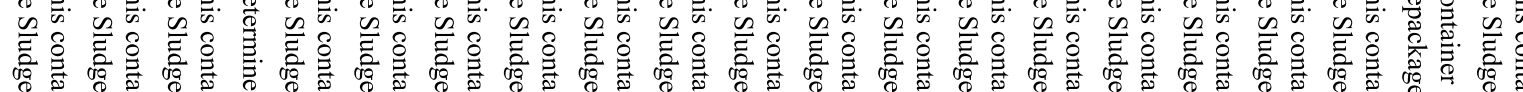

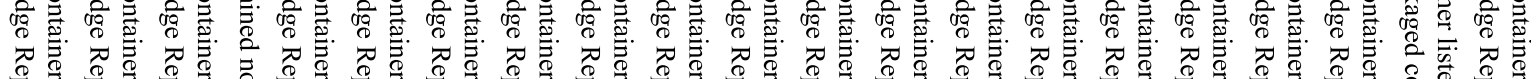

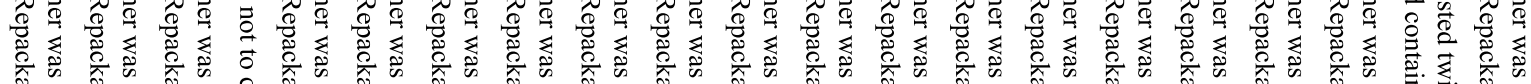

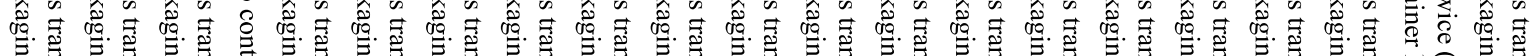

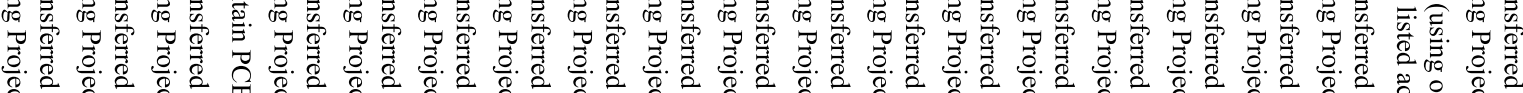

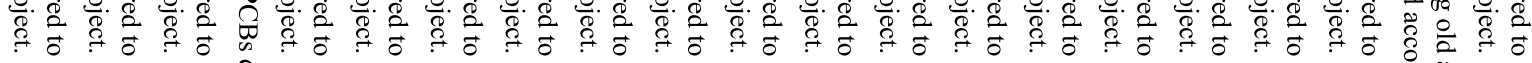




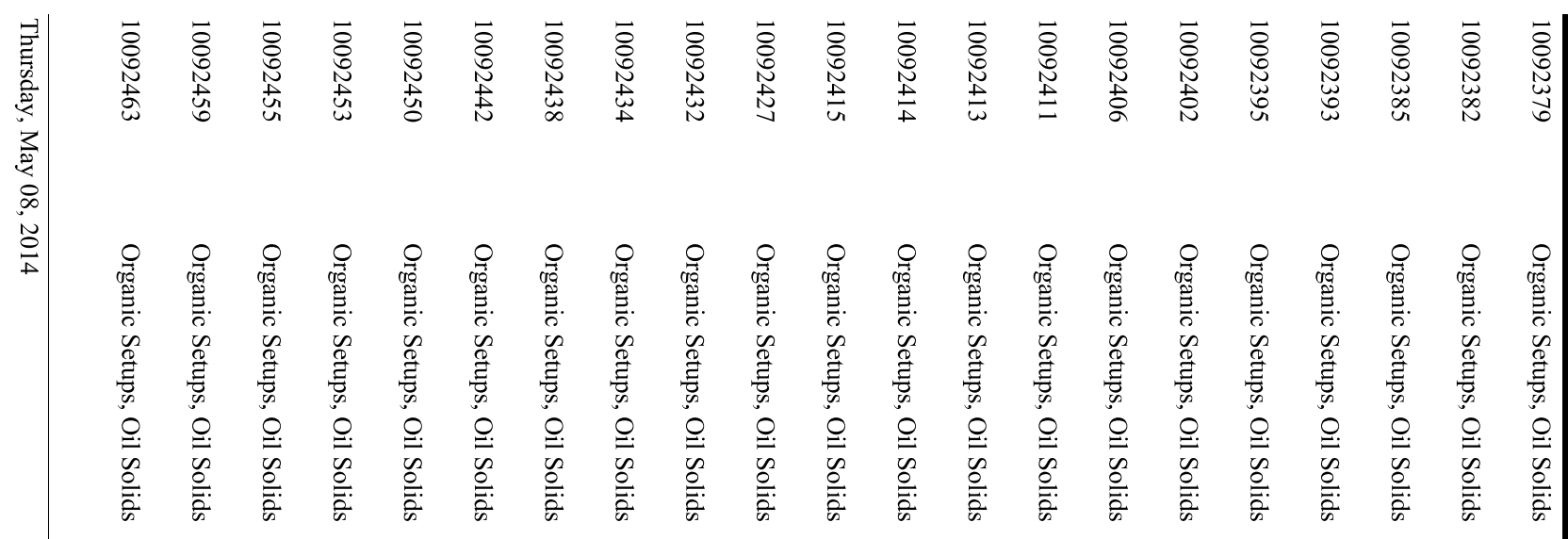

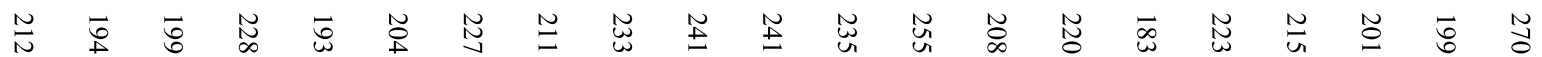

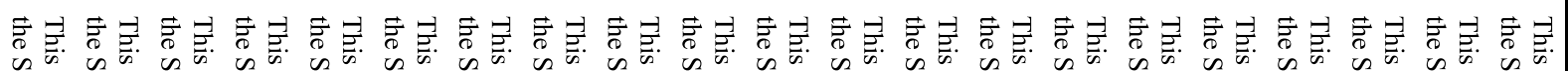

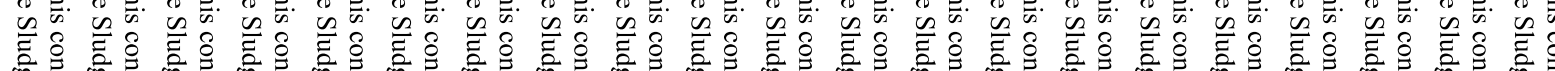

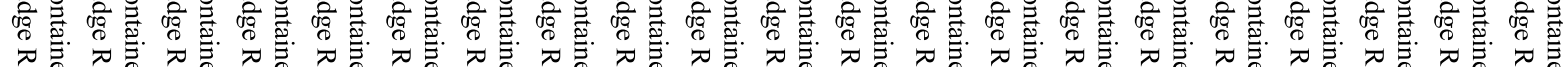
중

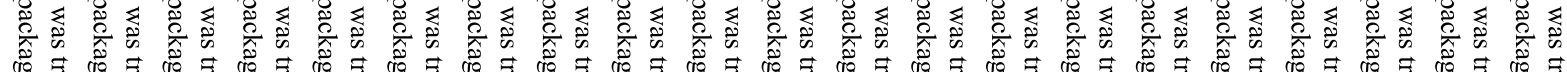

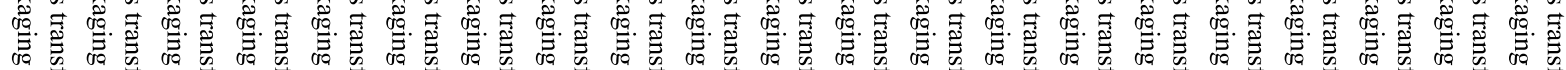

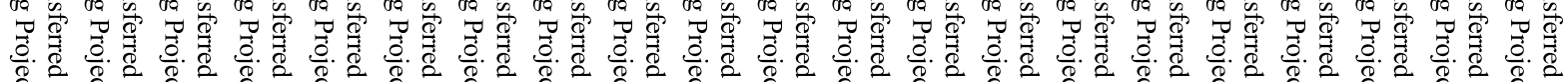

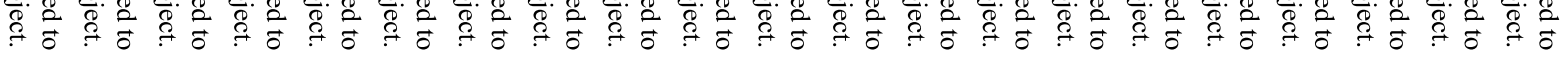

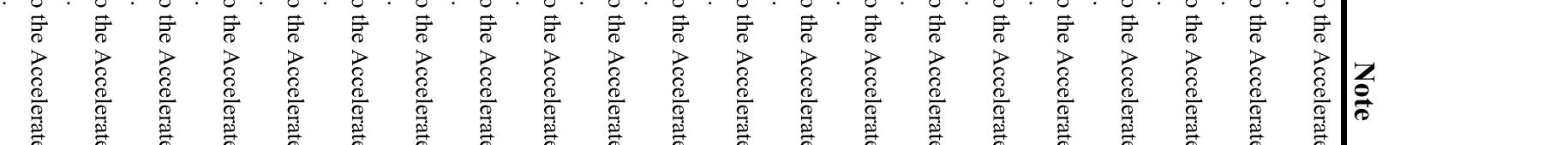




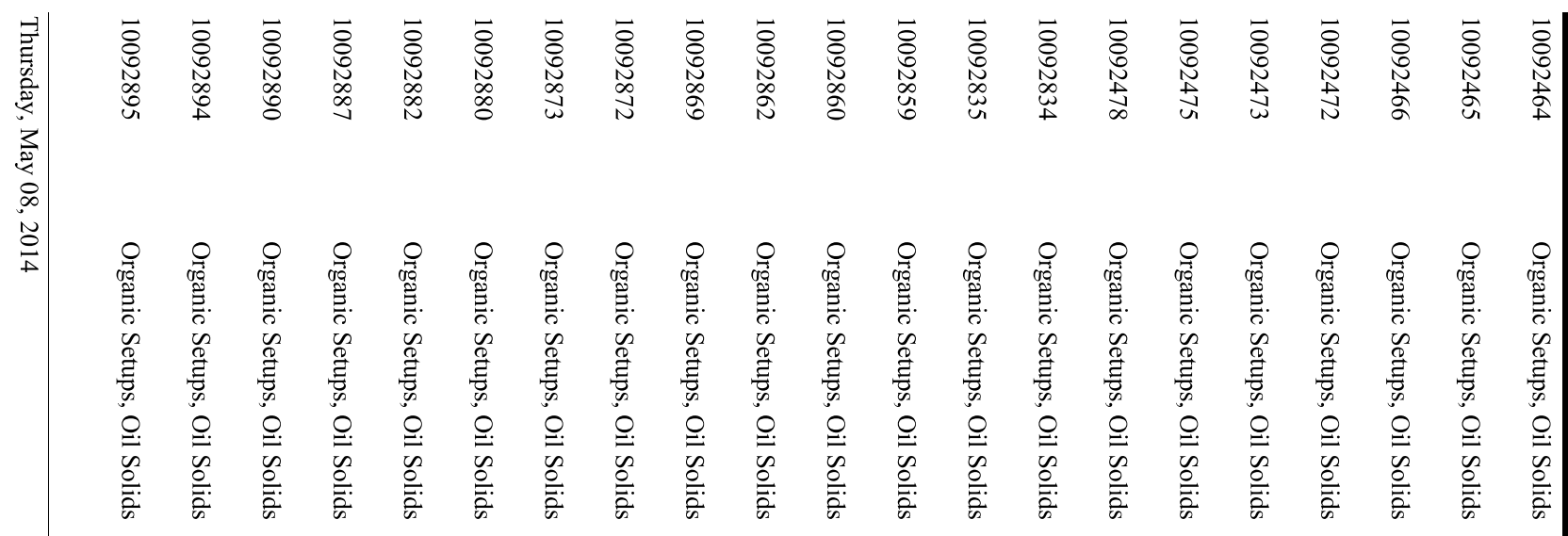

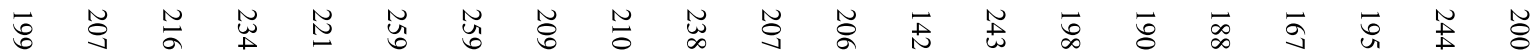

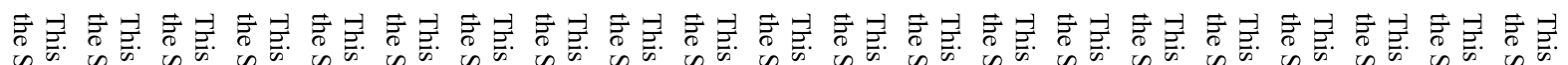

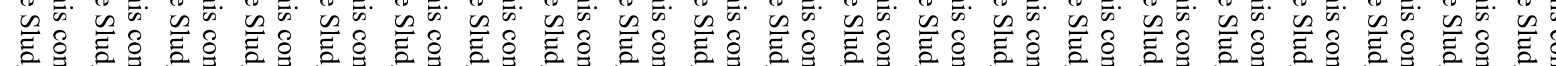

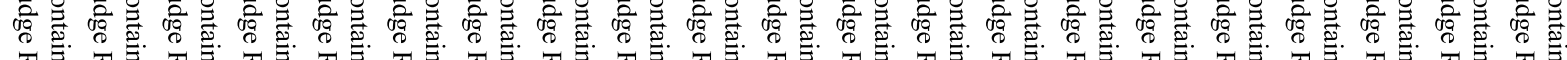
不

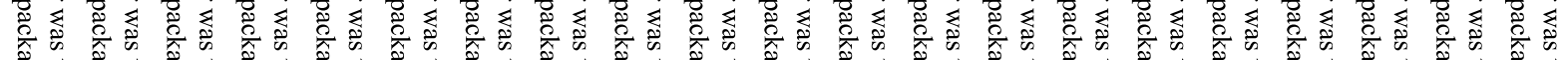

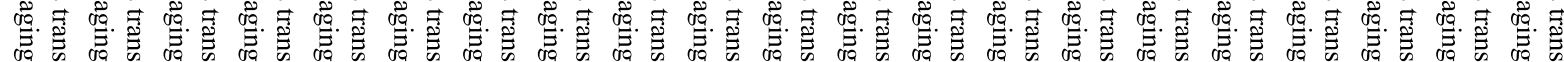

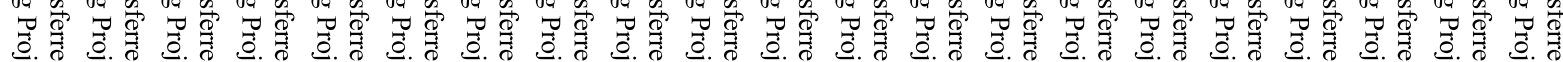

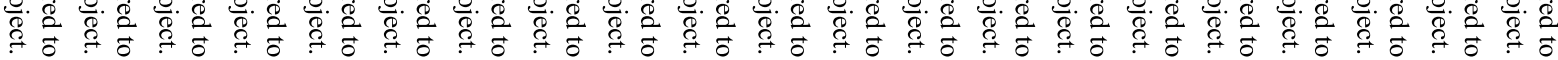

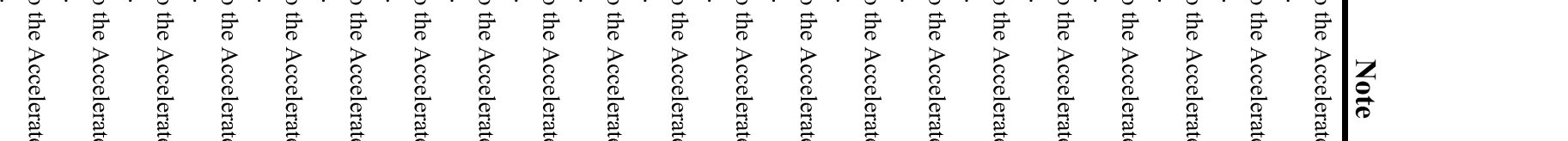




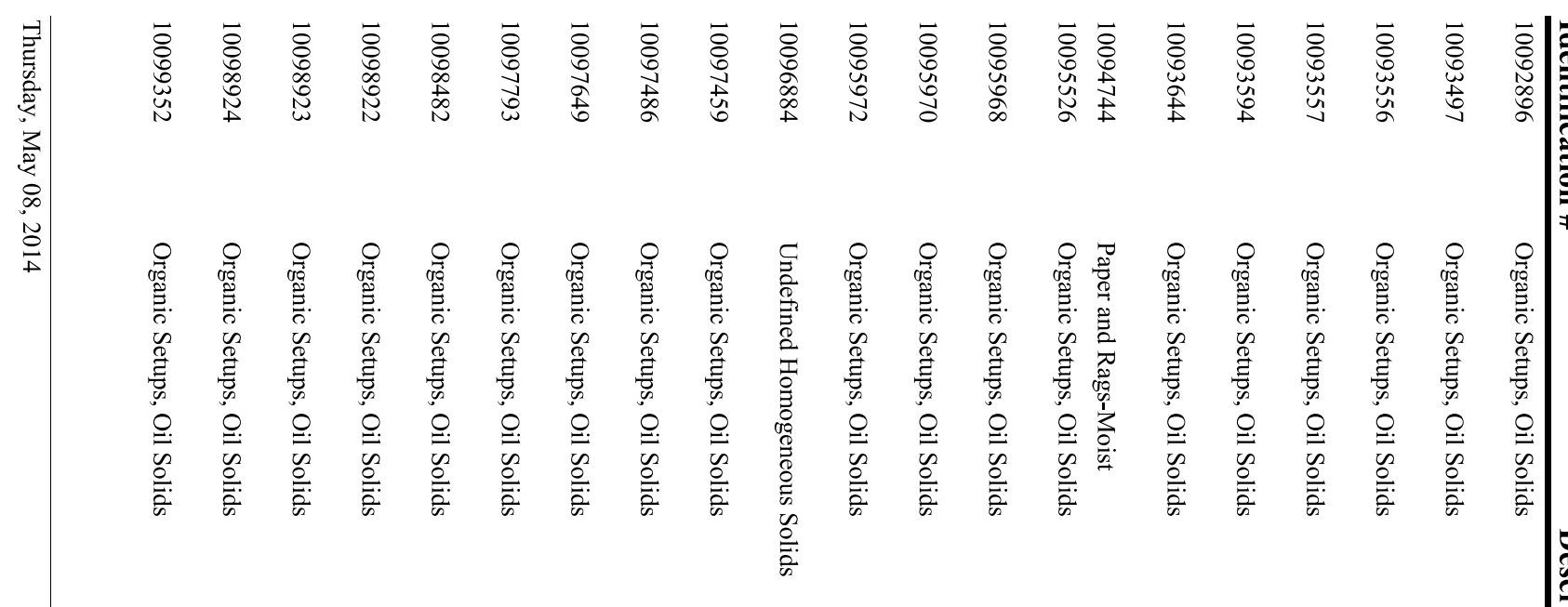

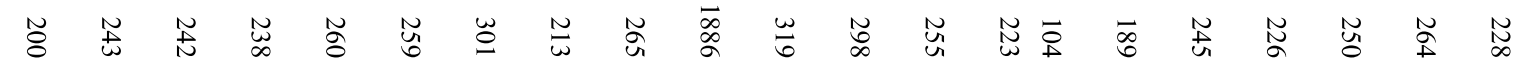

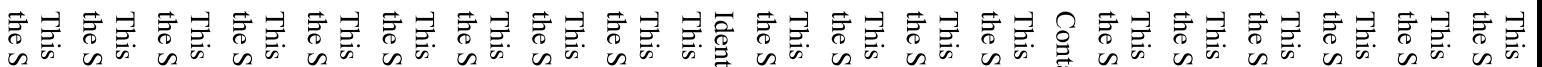

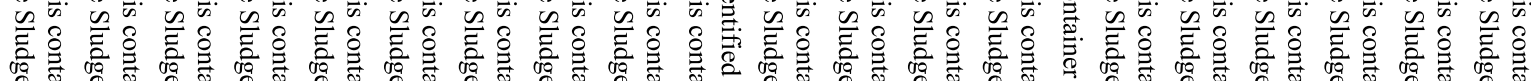

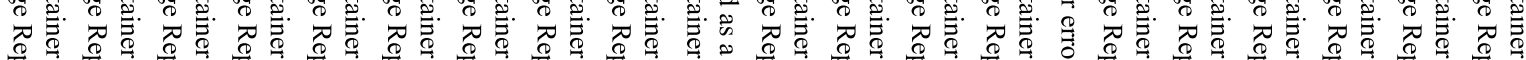

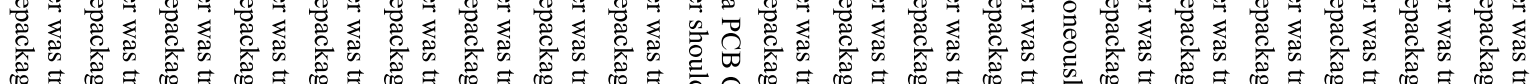

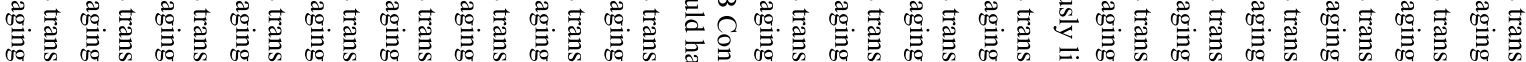

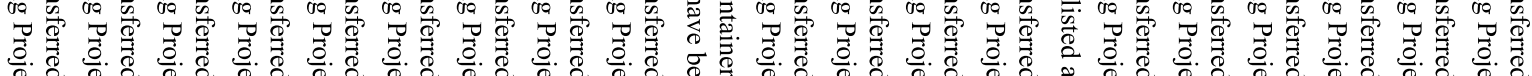

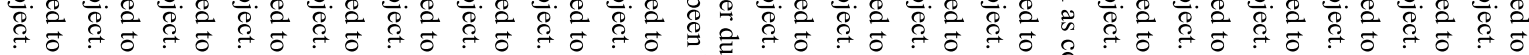




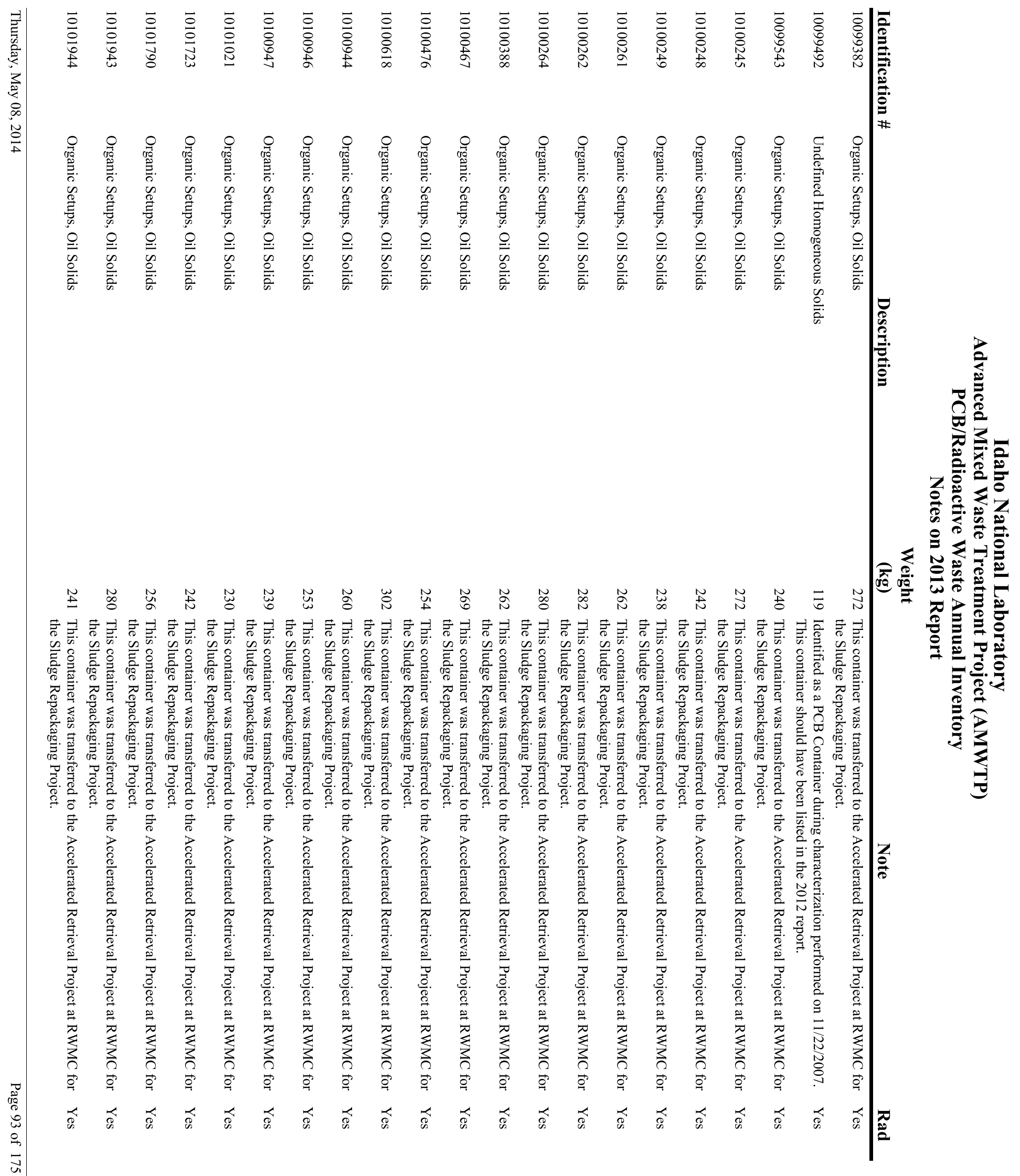




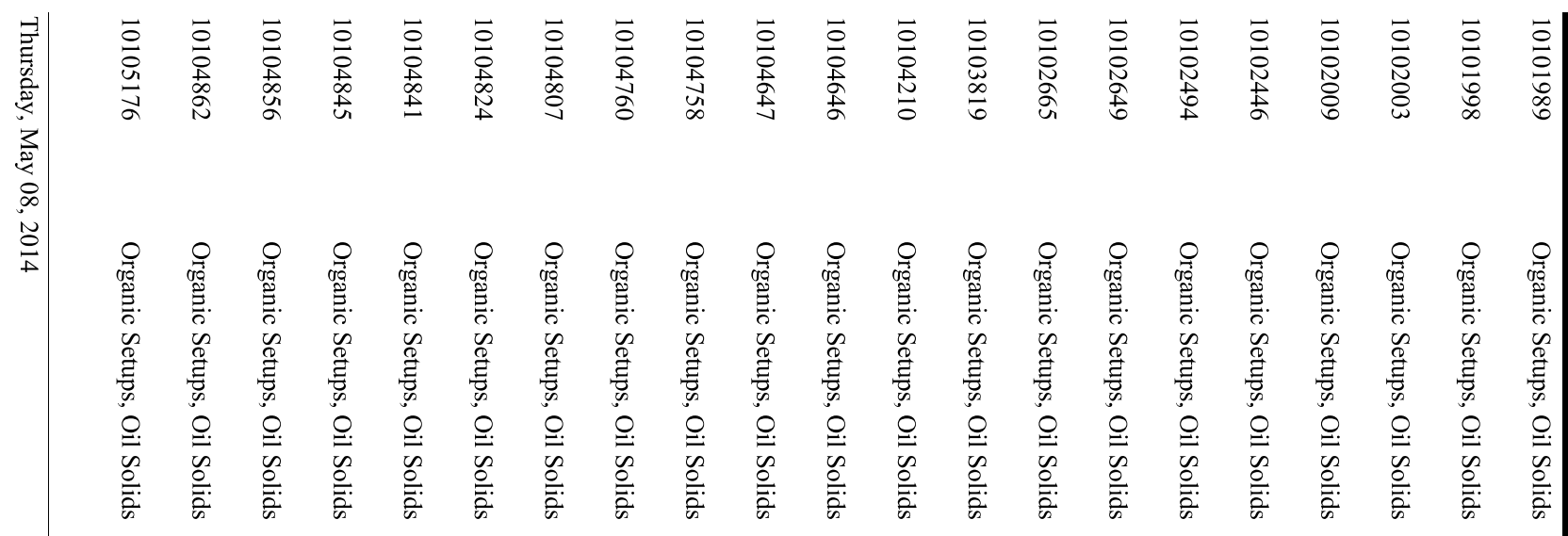

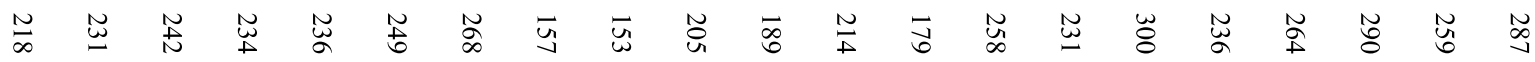

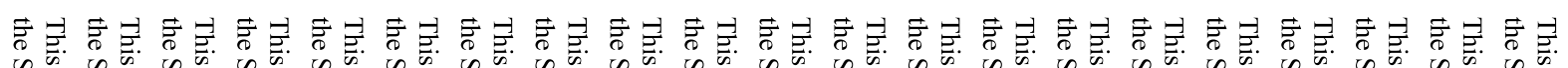

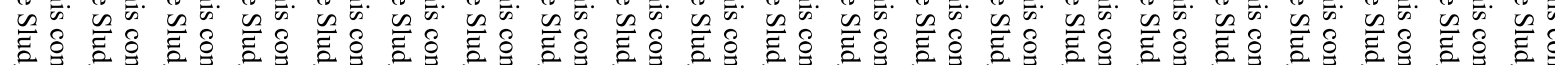

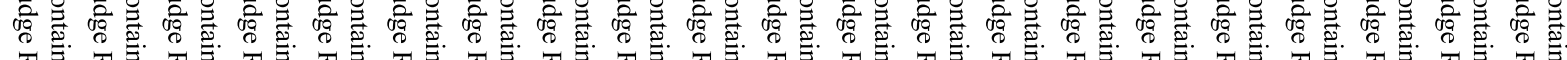
不

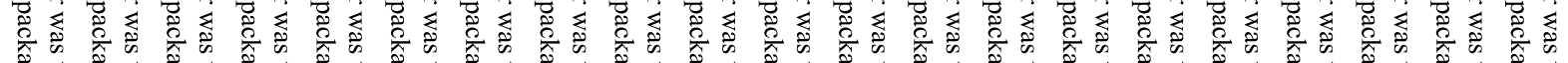

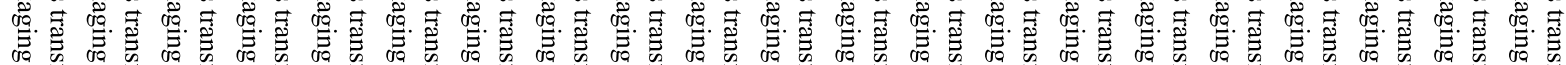

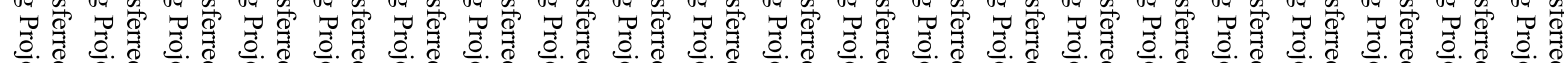

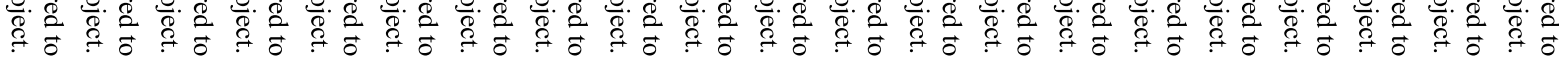

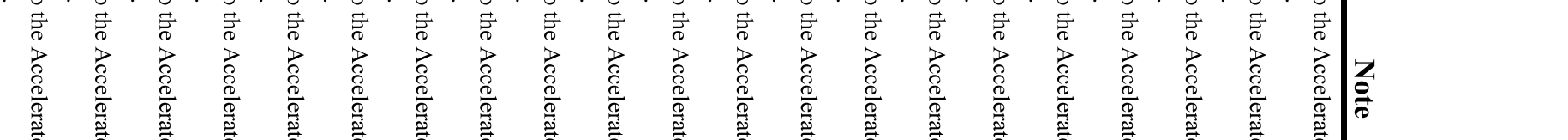




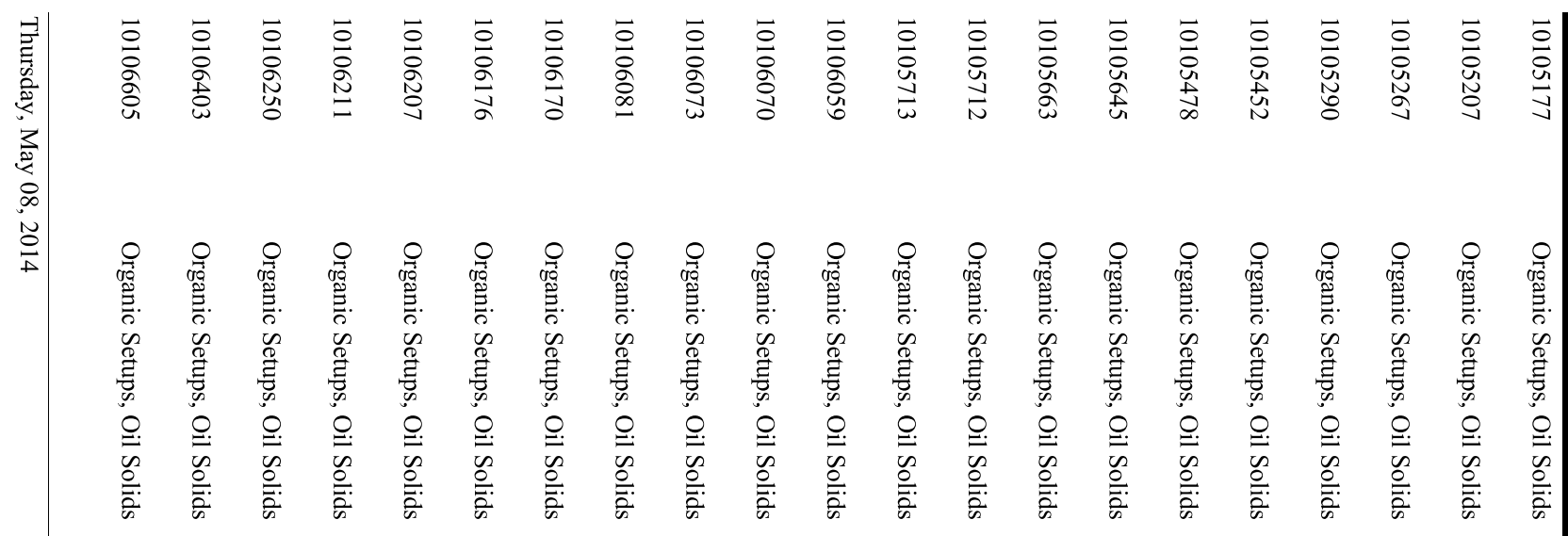

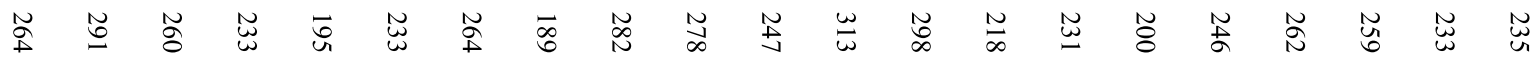

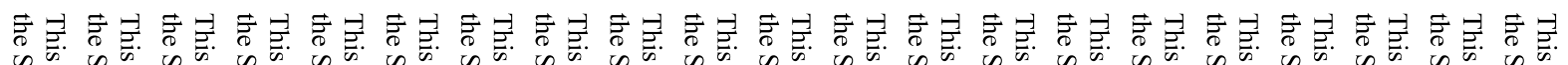

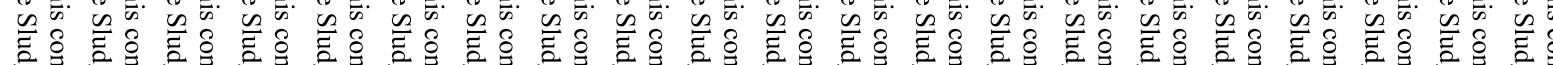

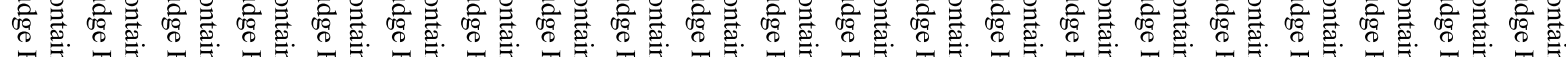
不

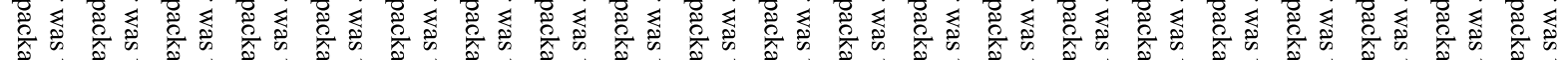

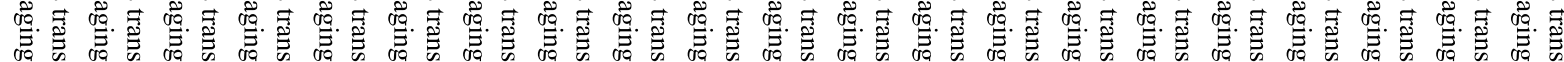

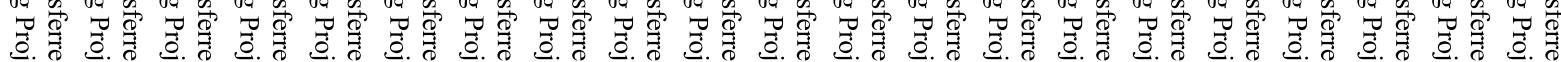

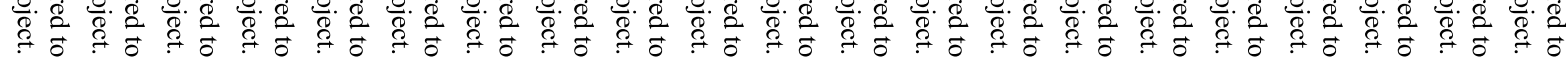

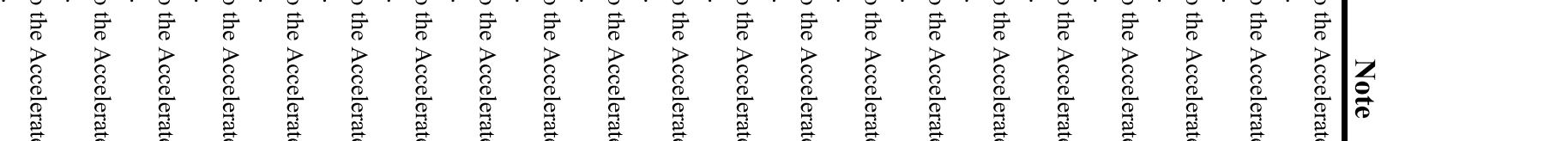




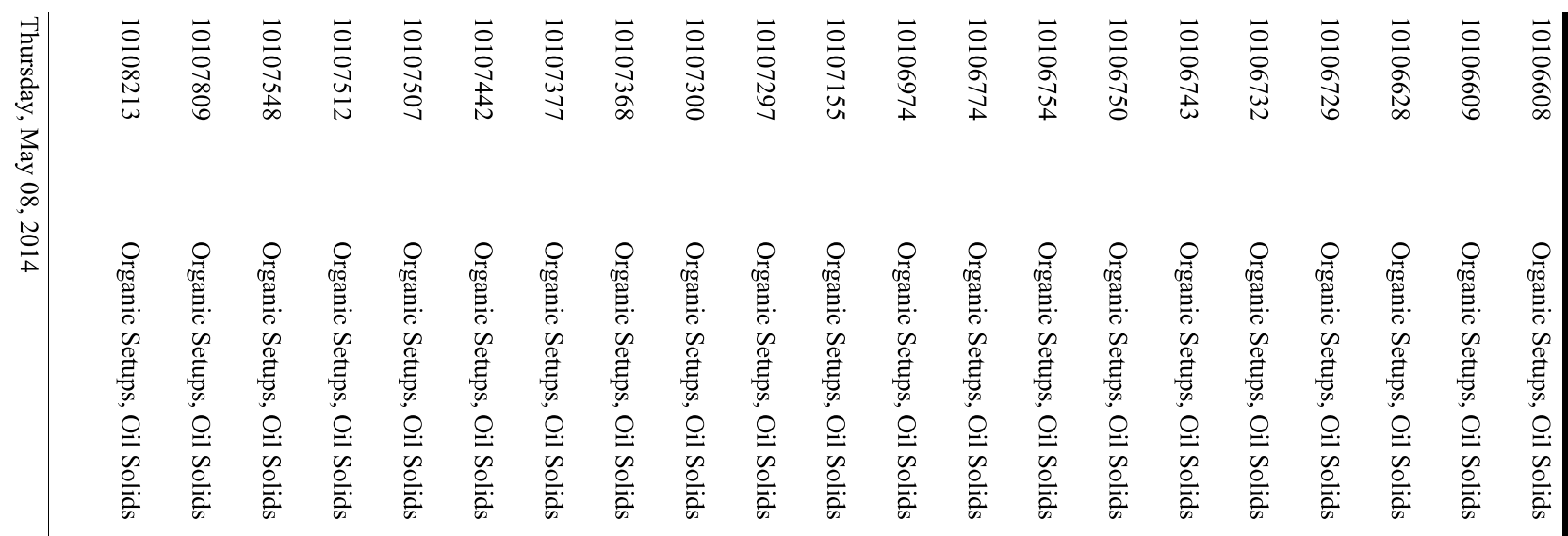

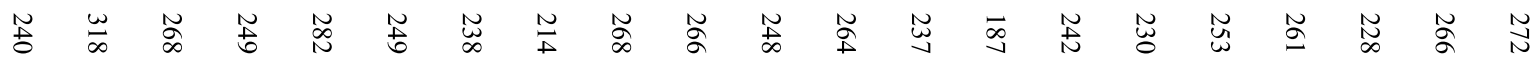

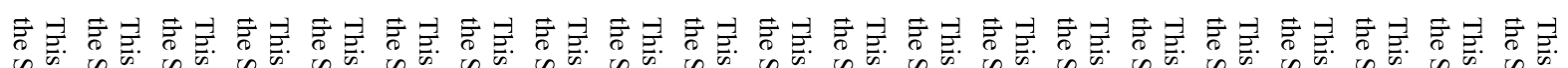

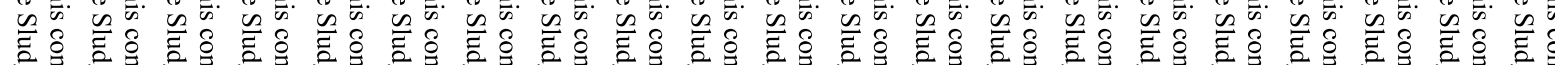

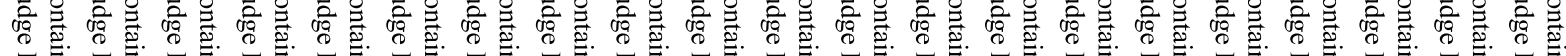
不

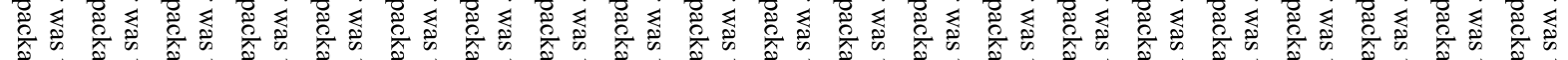

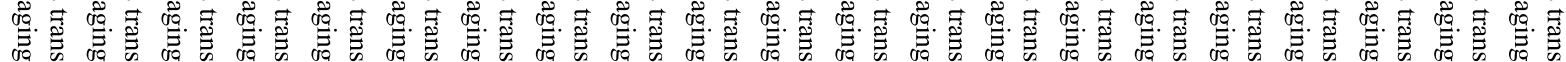

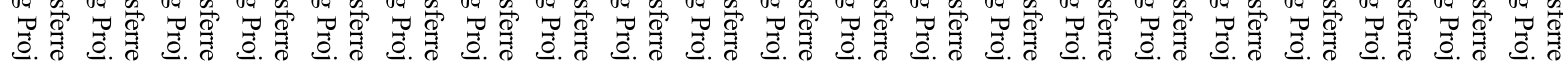

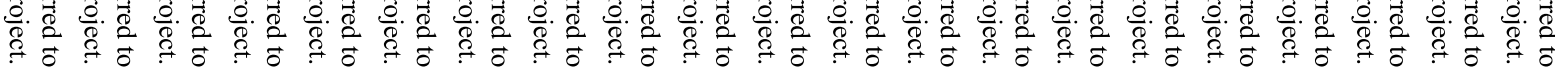

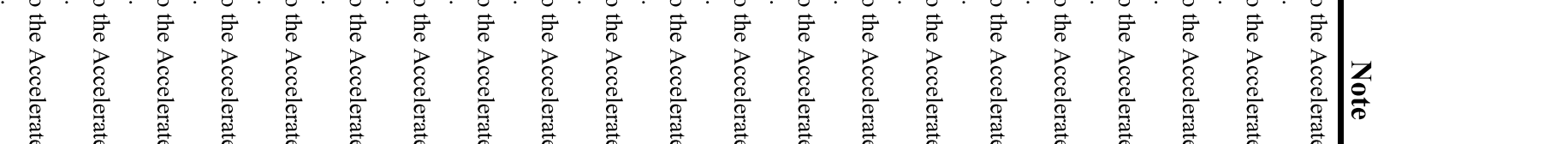




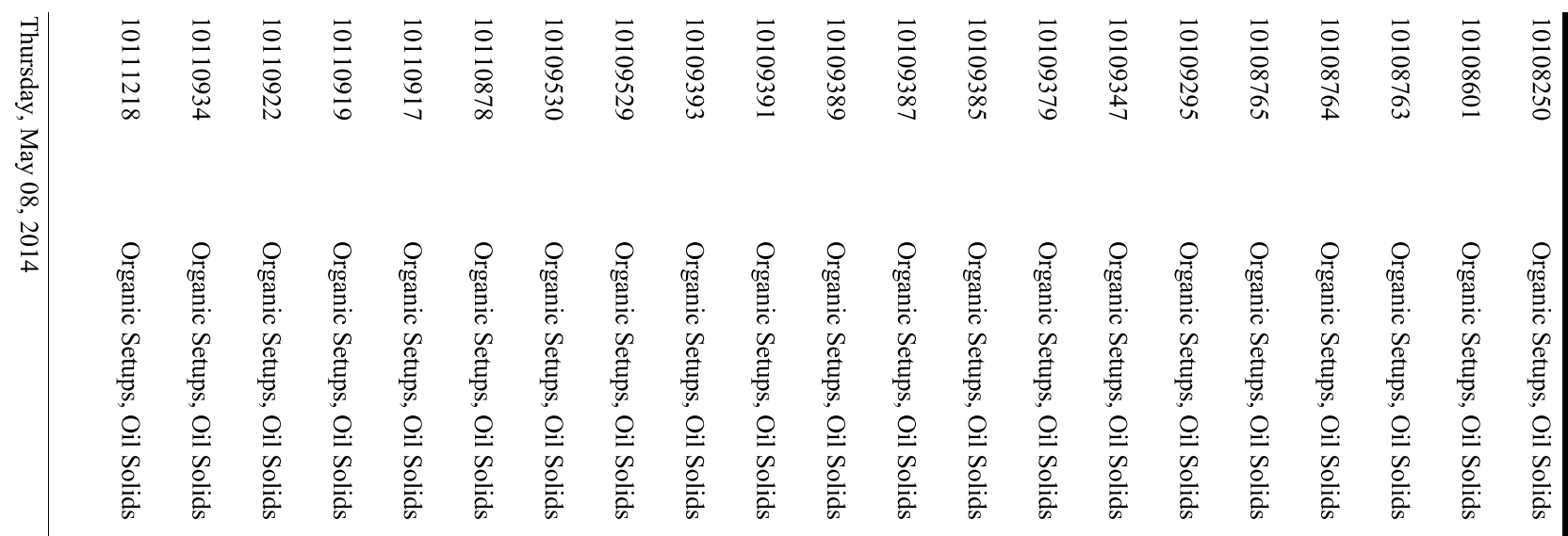

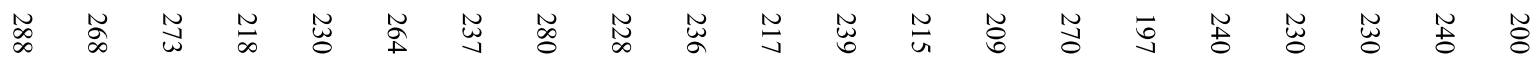

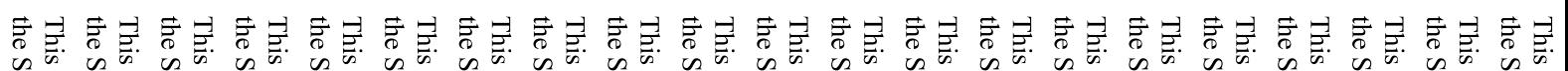

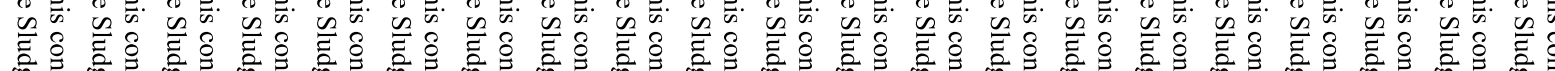

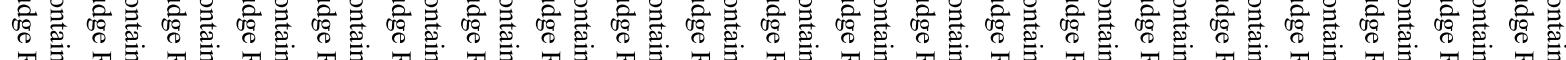
元

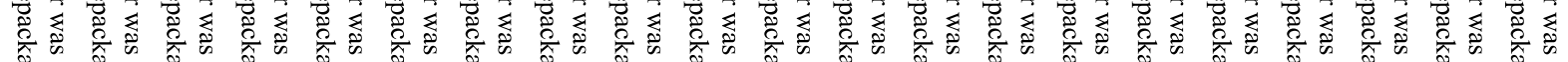

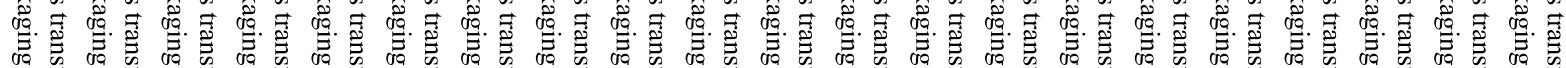

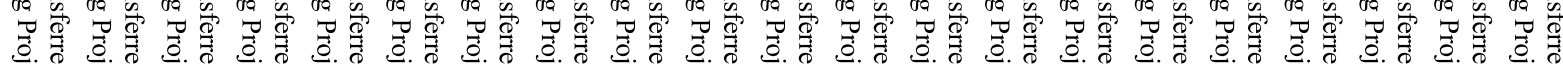

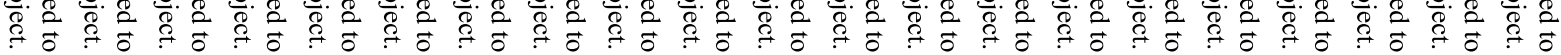

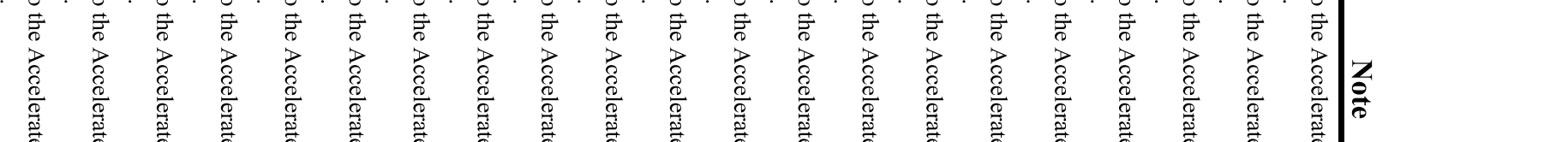




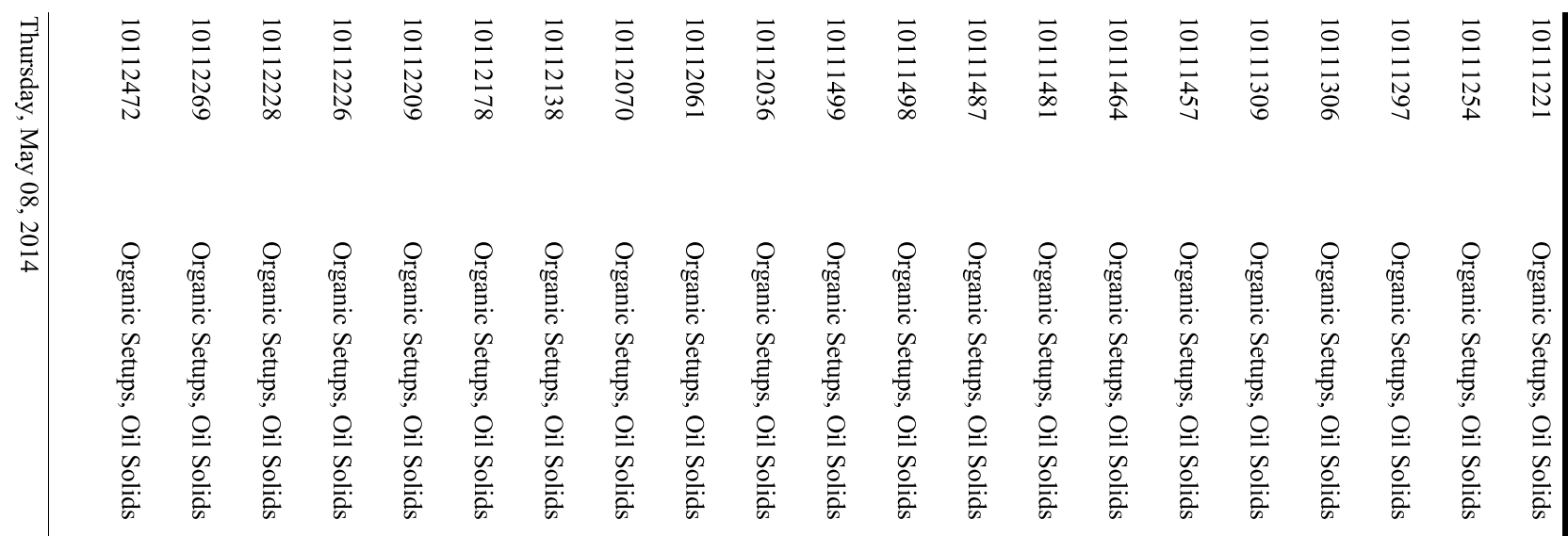

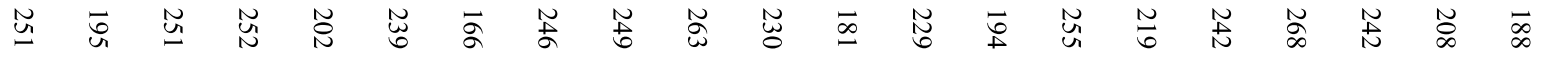

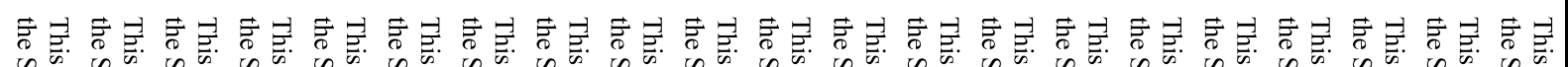

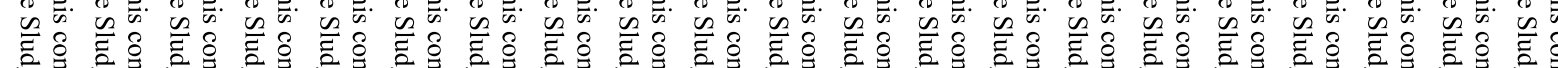

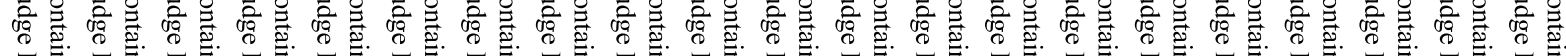
不

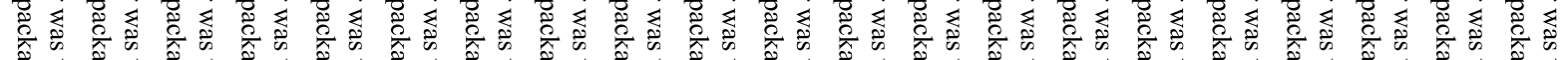

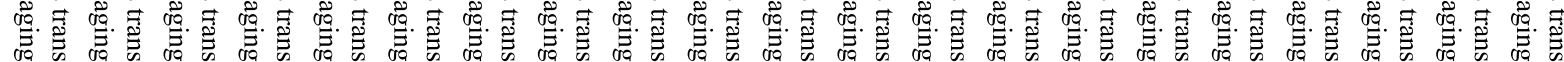

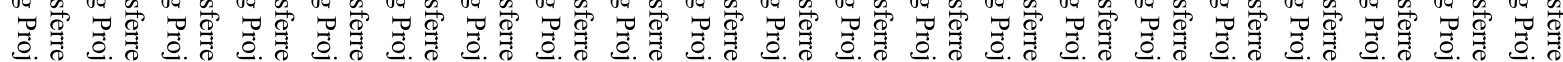

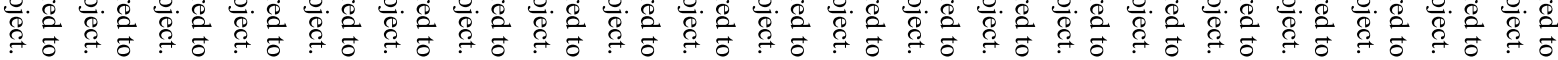

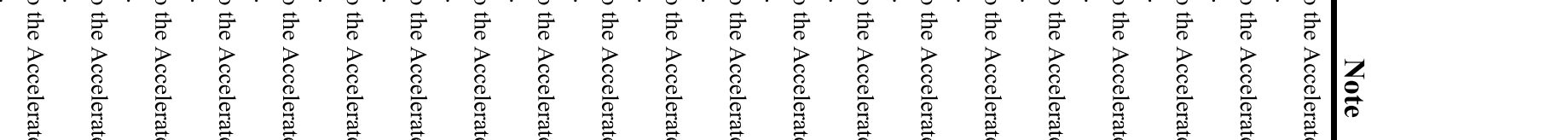




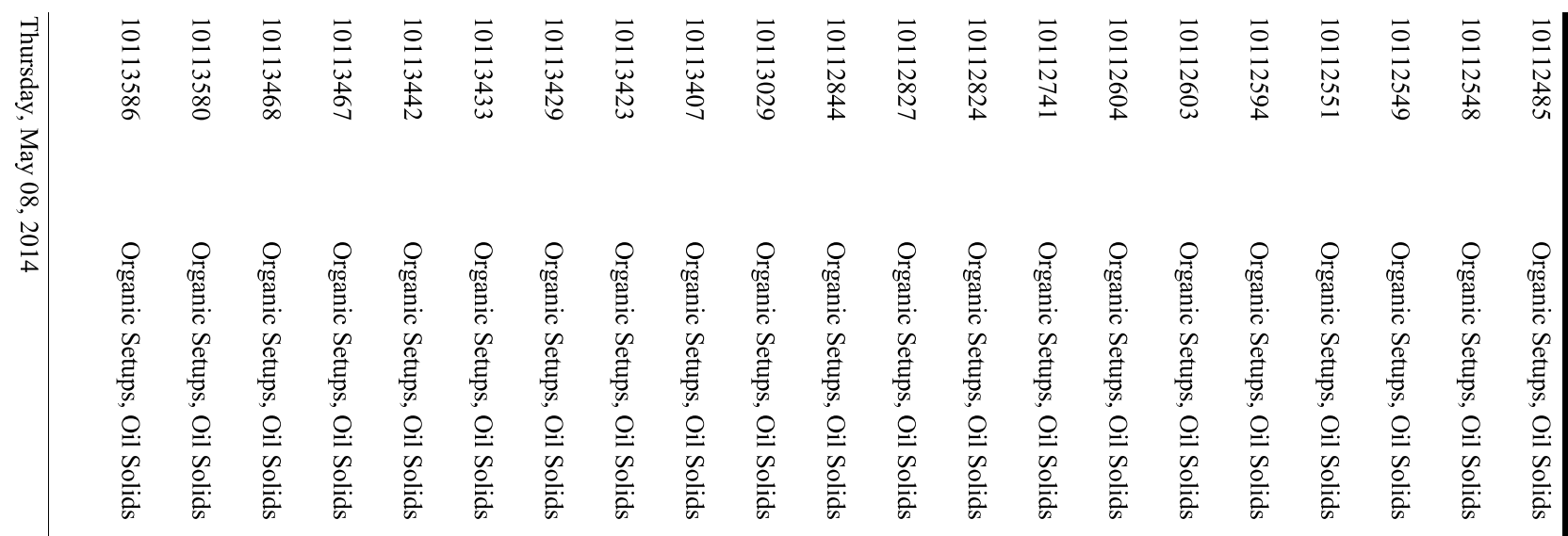

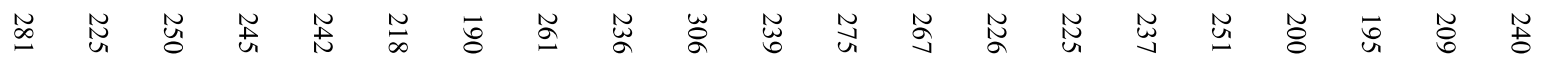

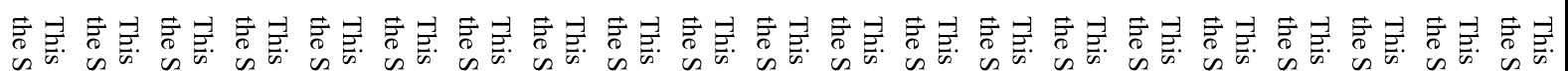

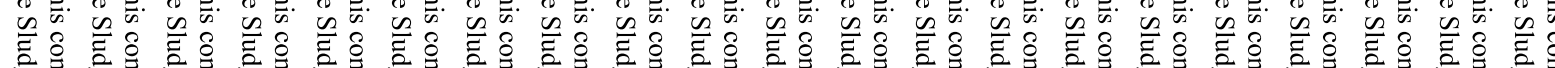

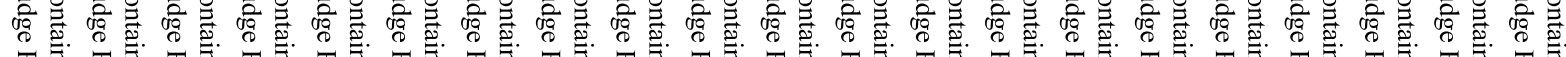
不

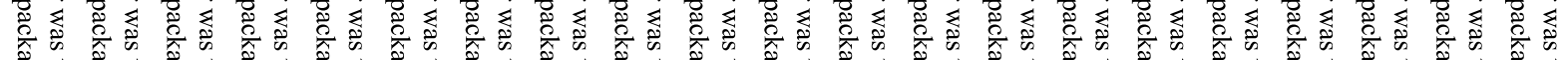

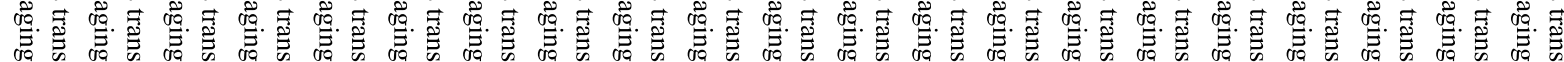

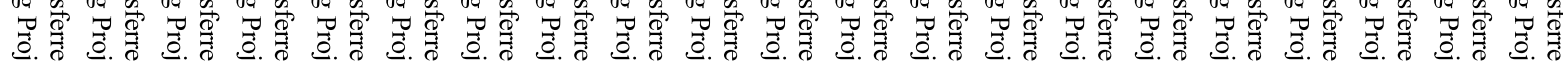

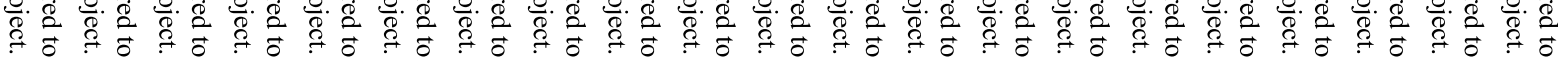

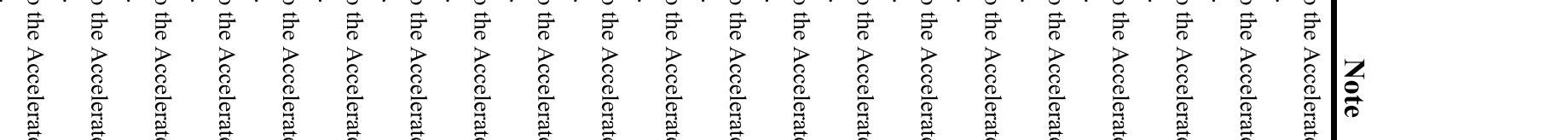




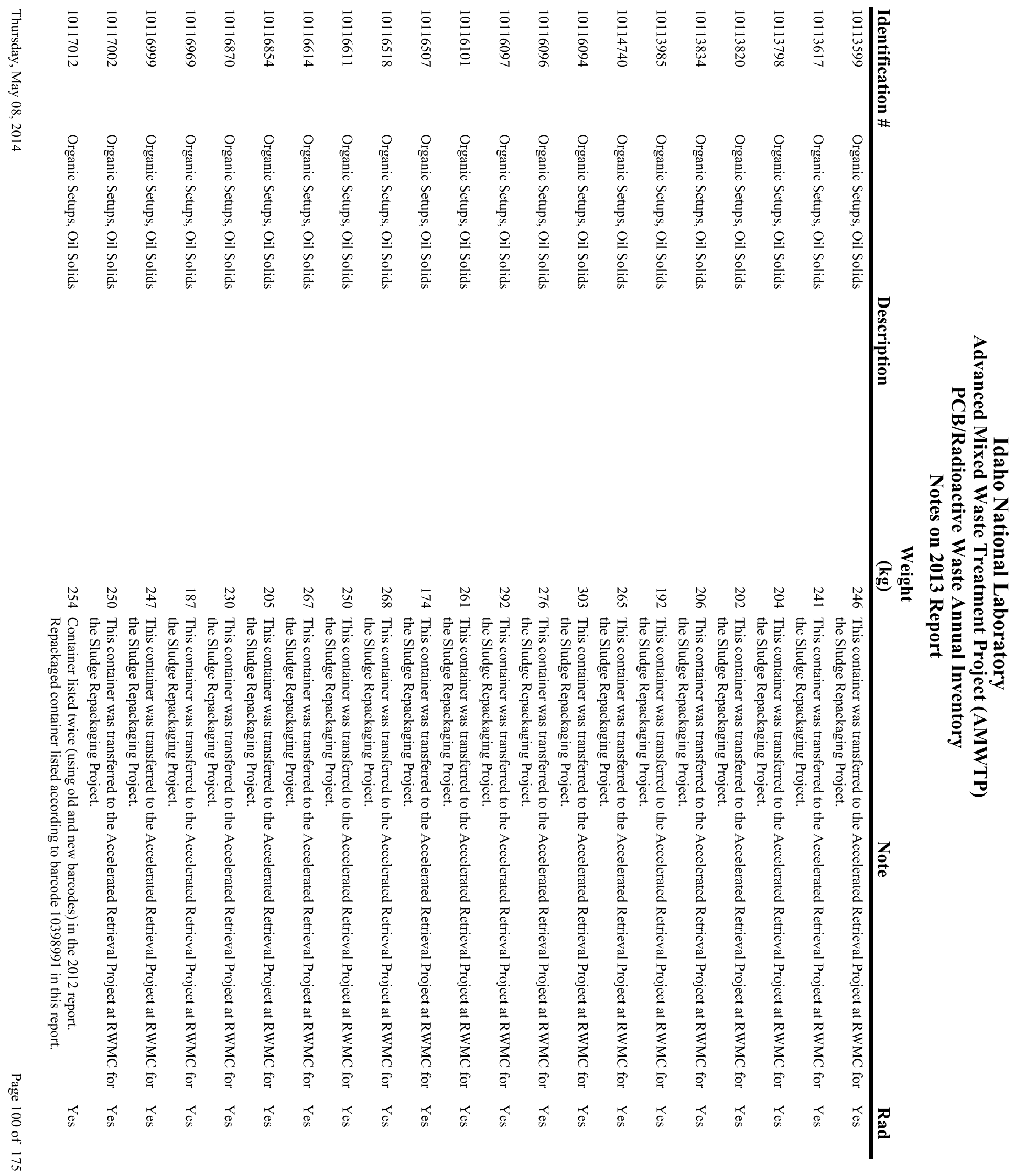




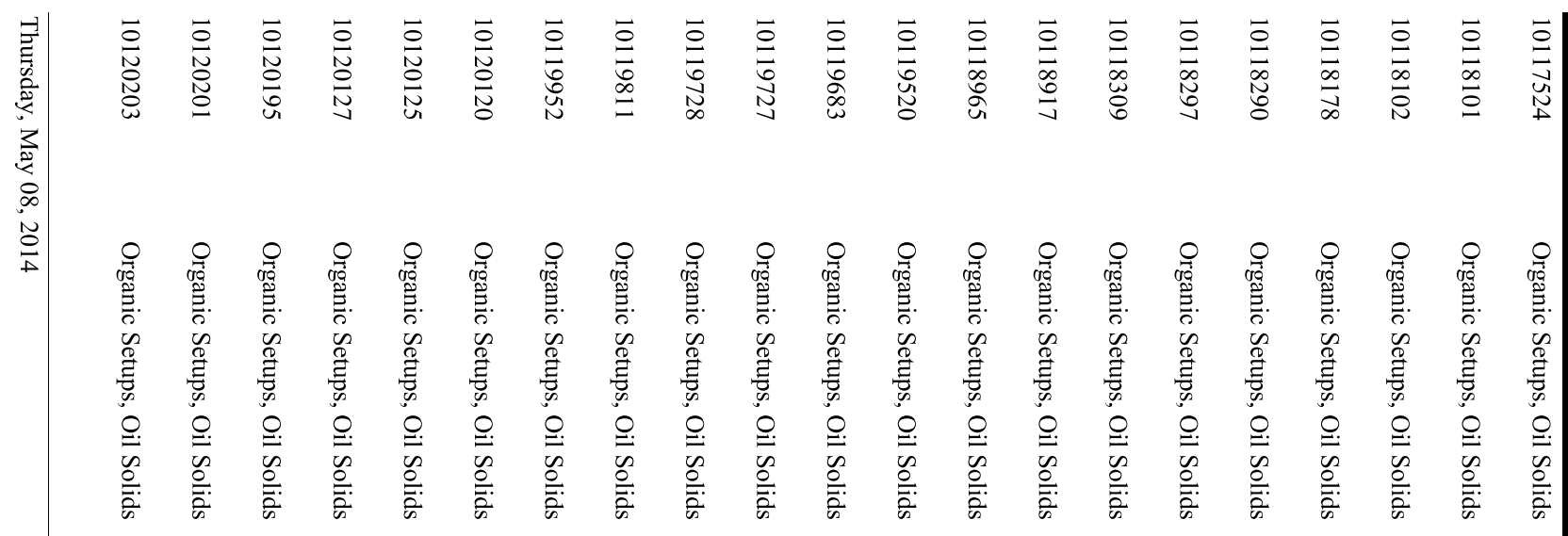

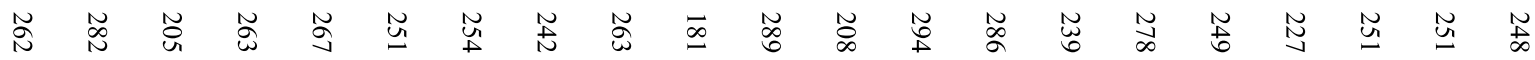

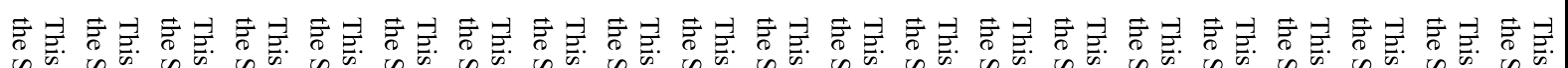

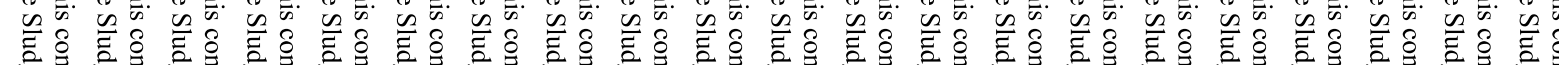

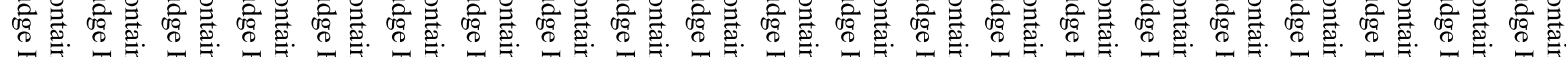
不

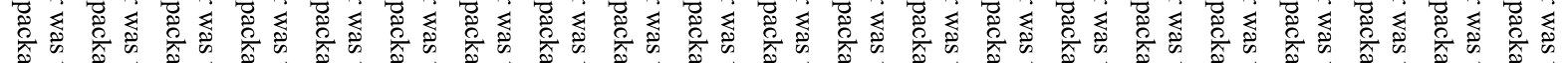

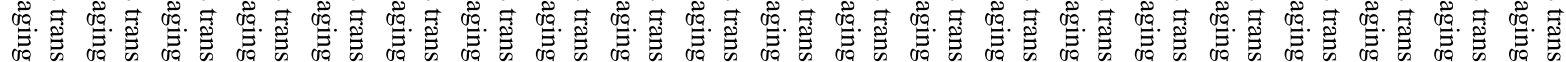

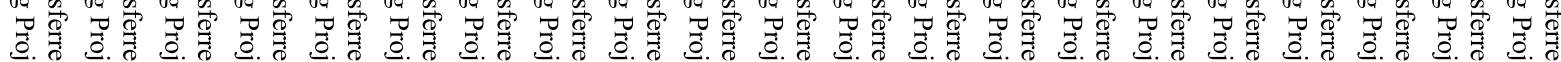

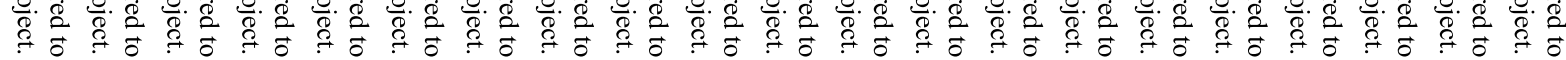

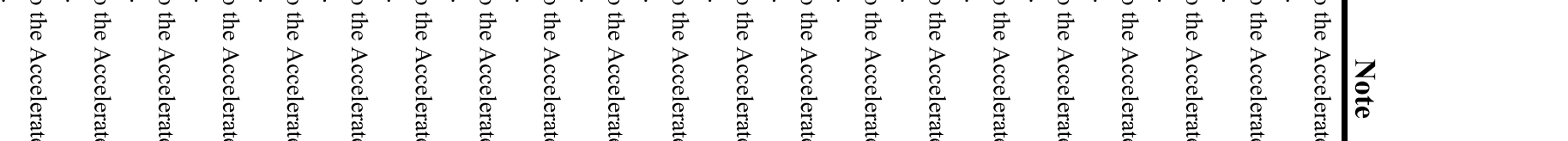




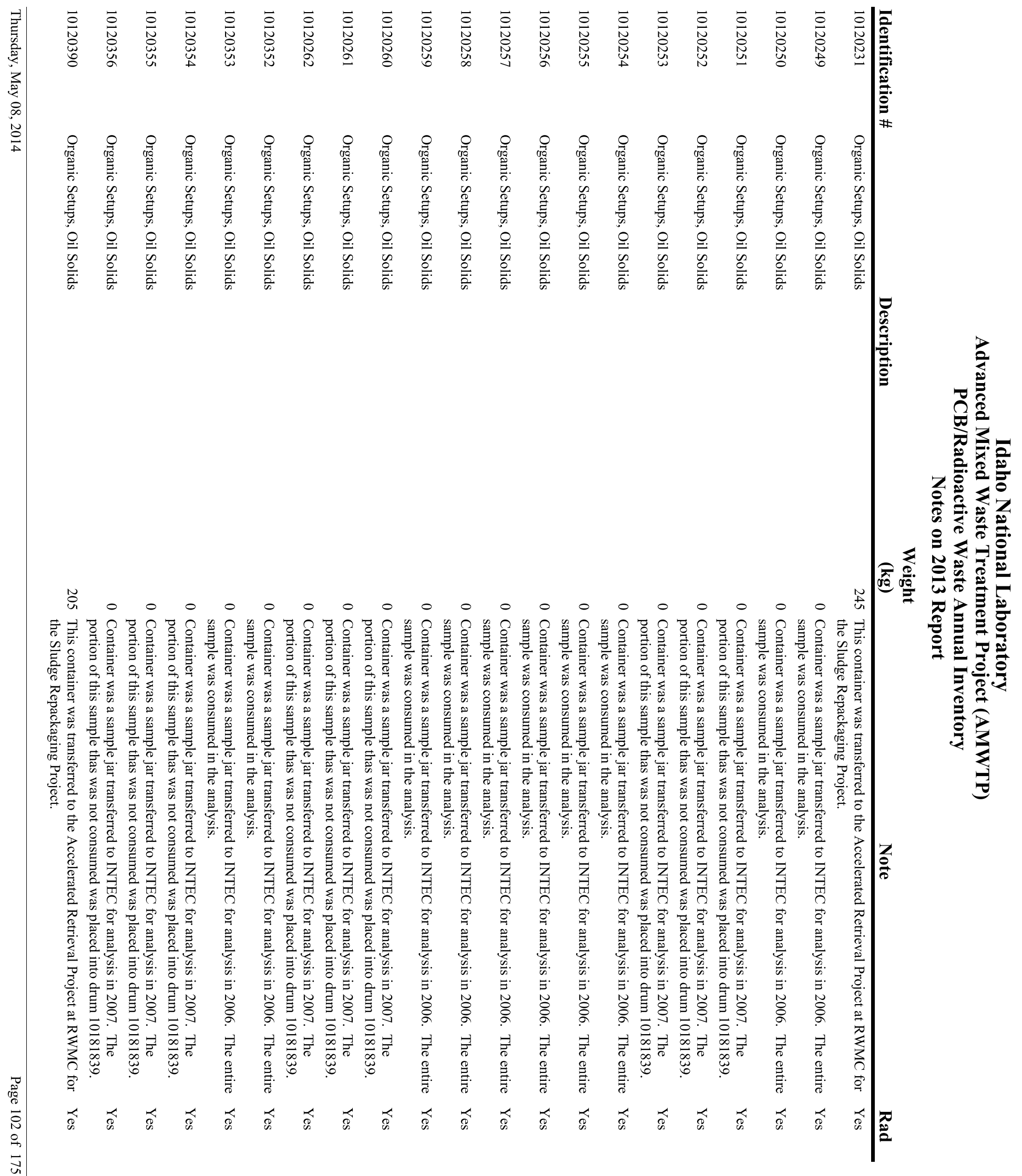




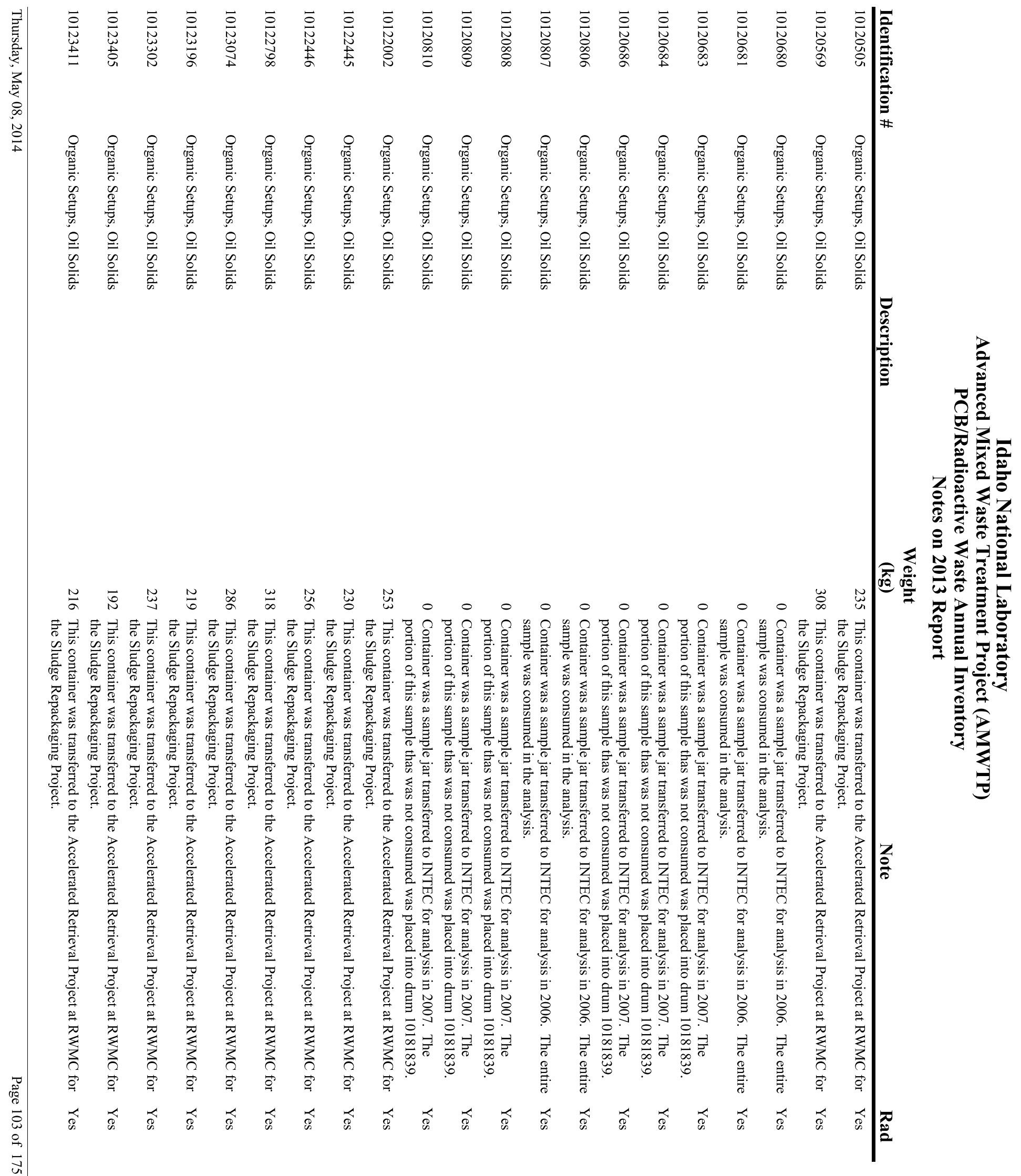




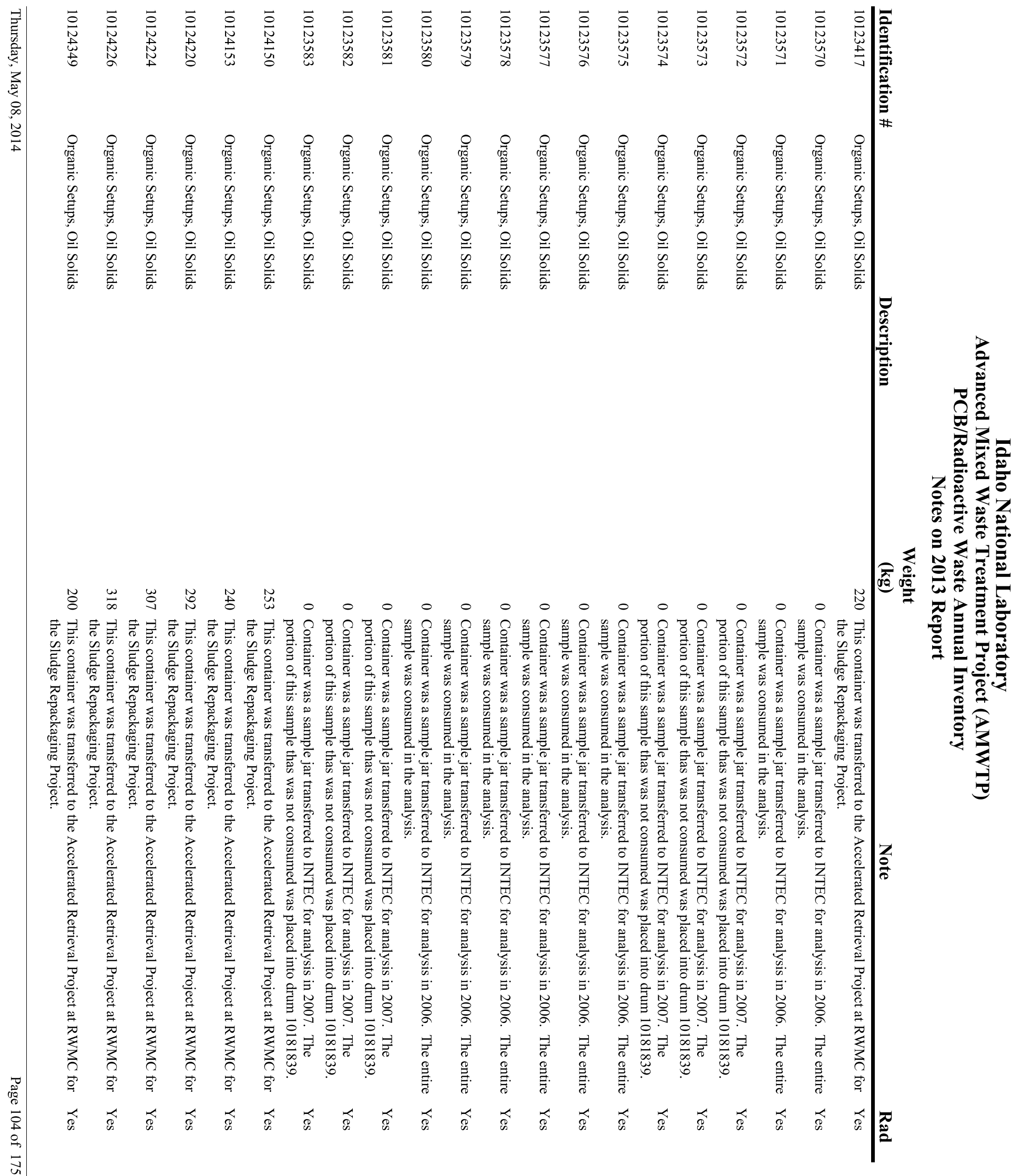




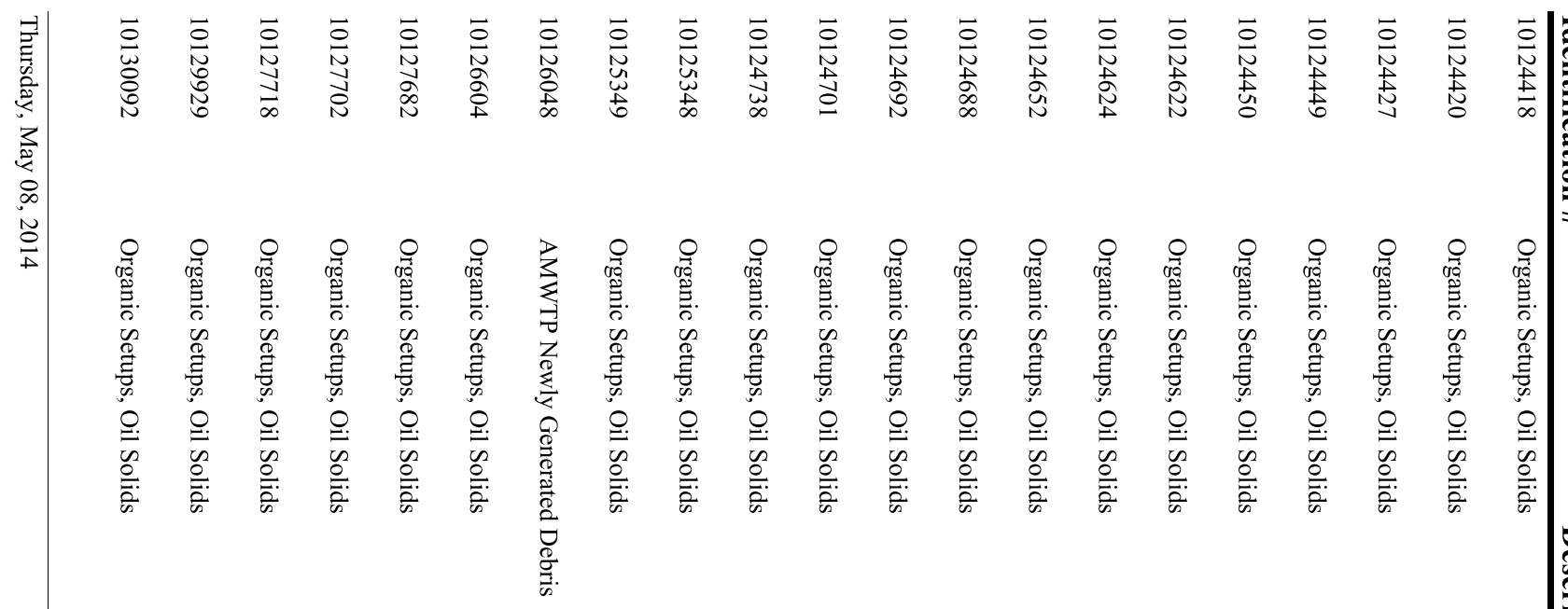

N్ర

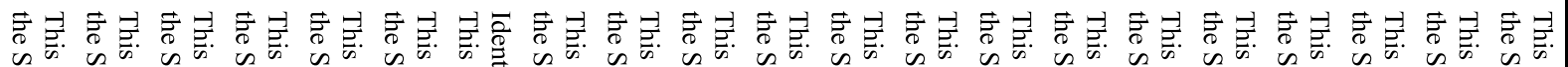

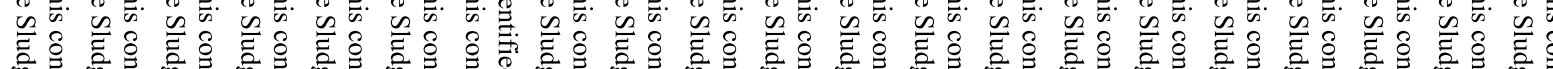

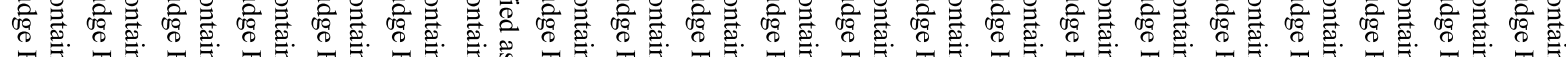

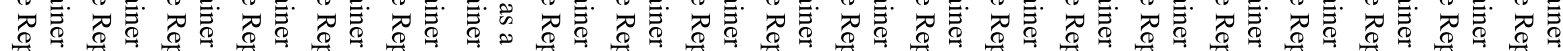

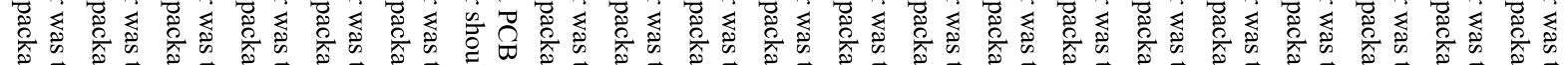

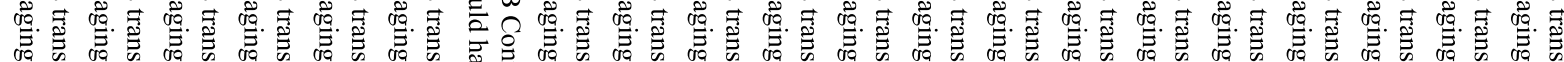

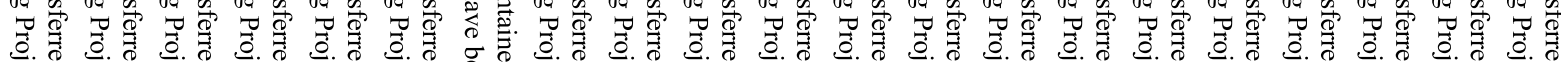

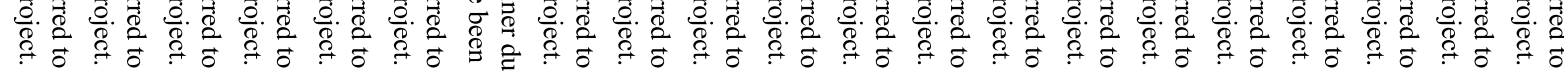

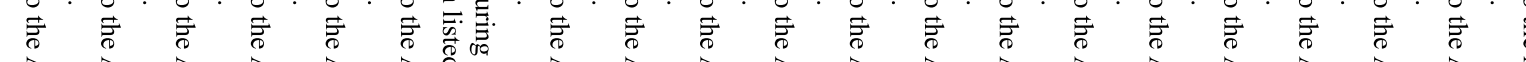

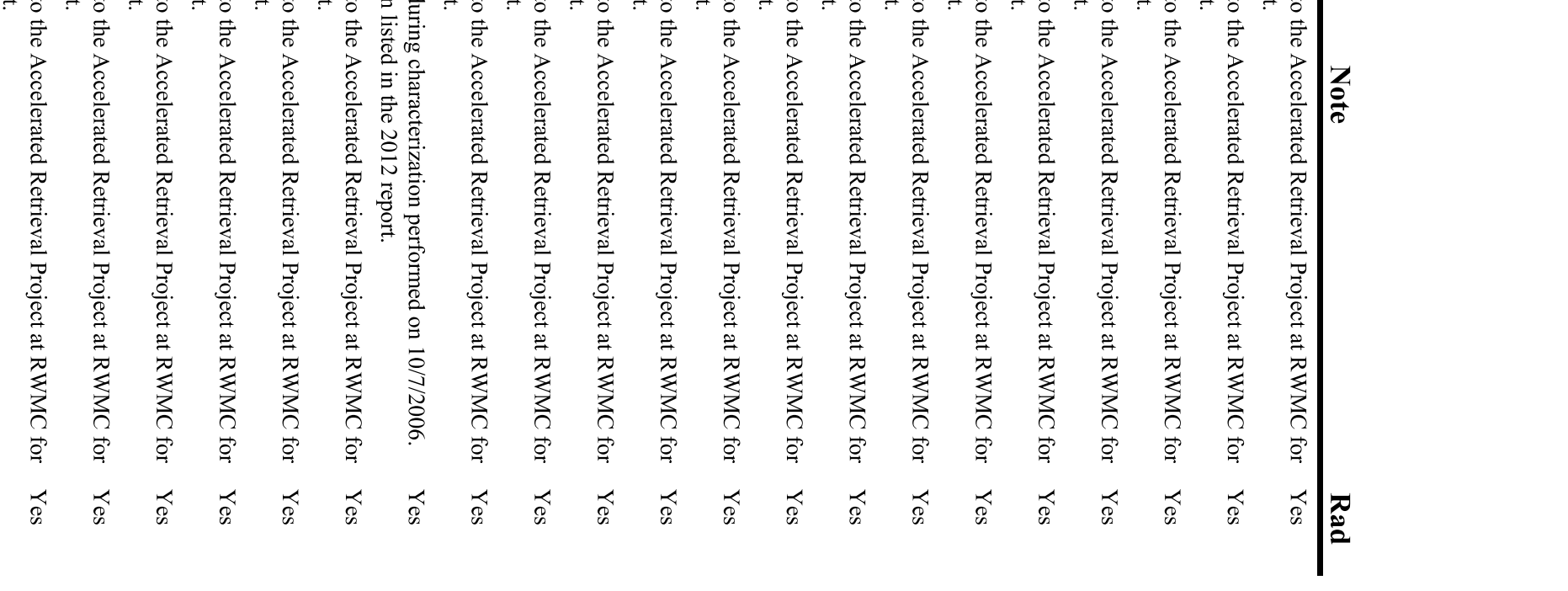




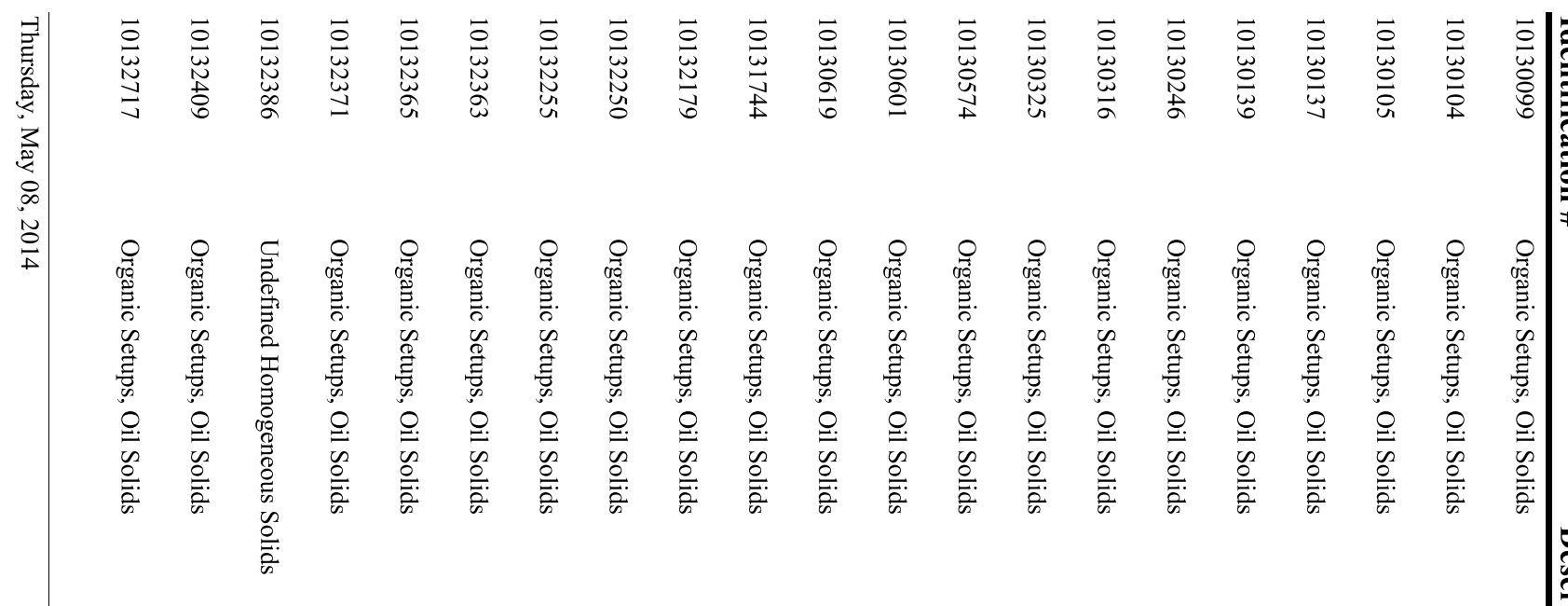

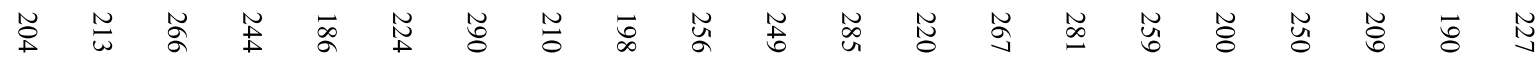

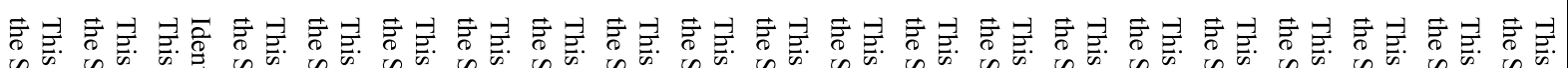

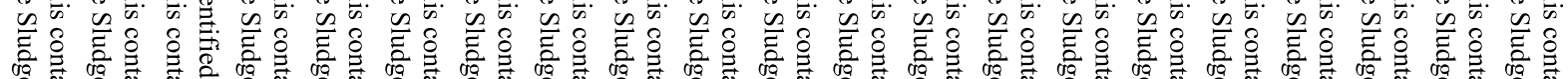

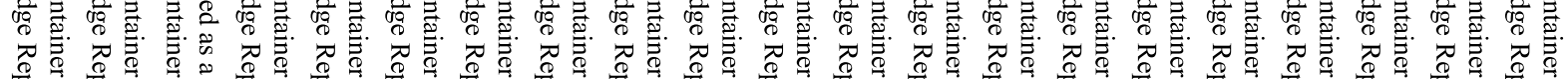

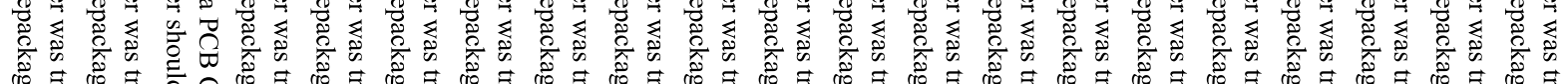

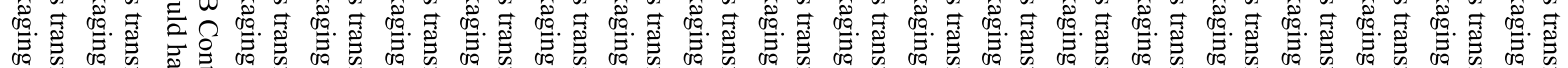

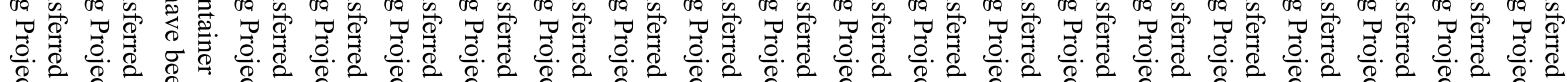

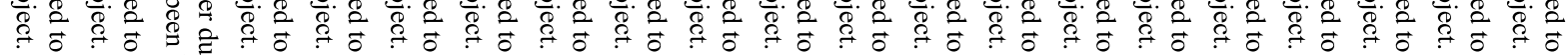




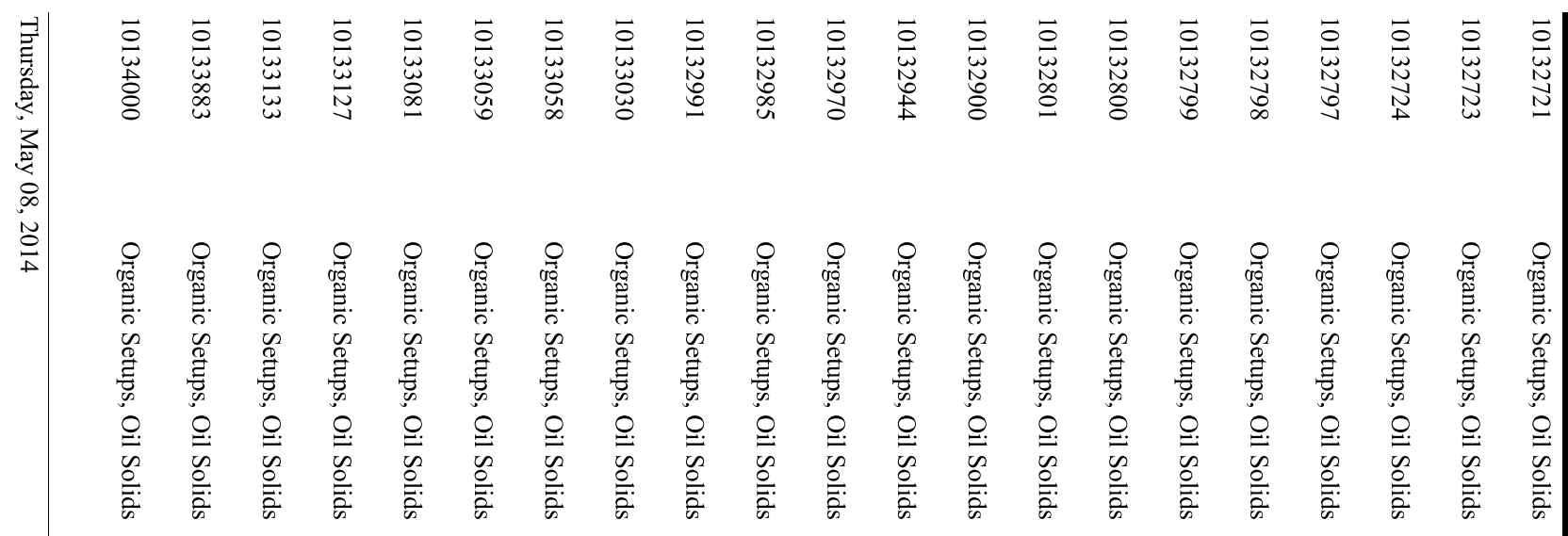

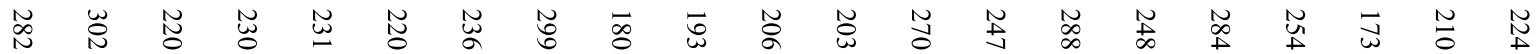

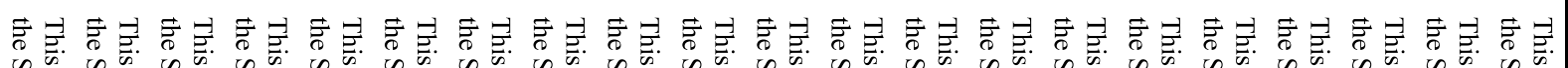

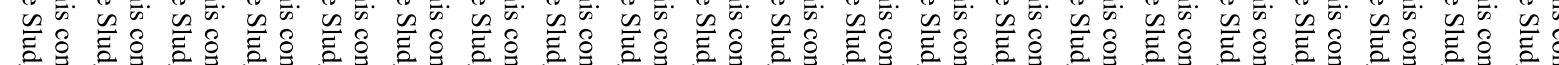

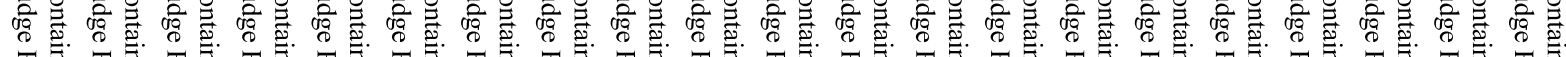
不

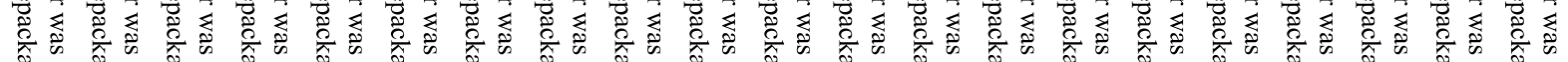

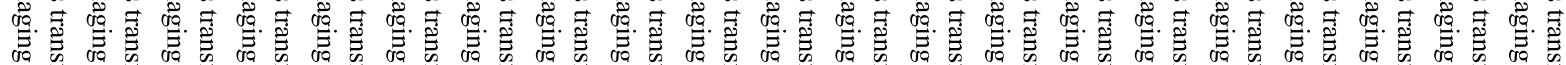

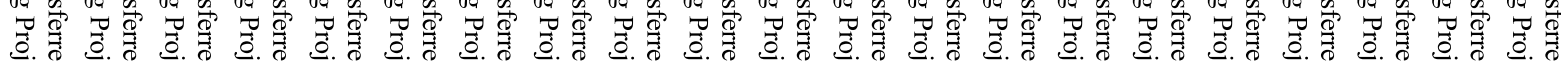

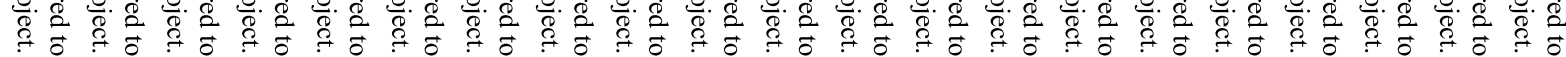

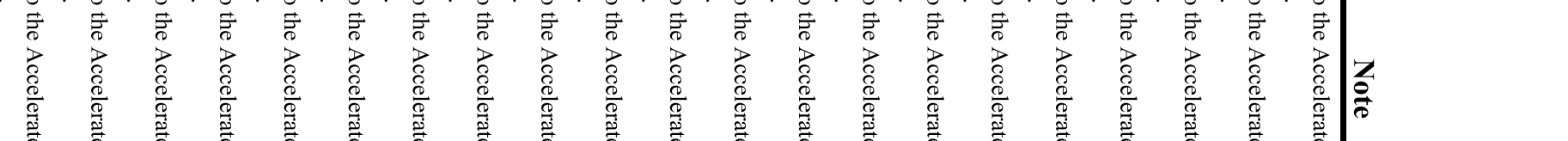




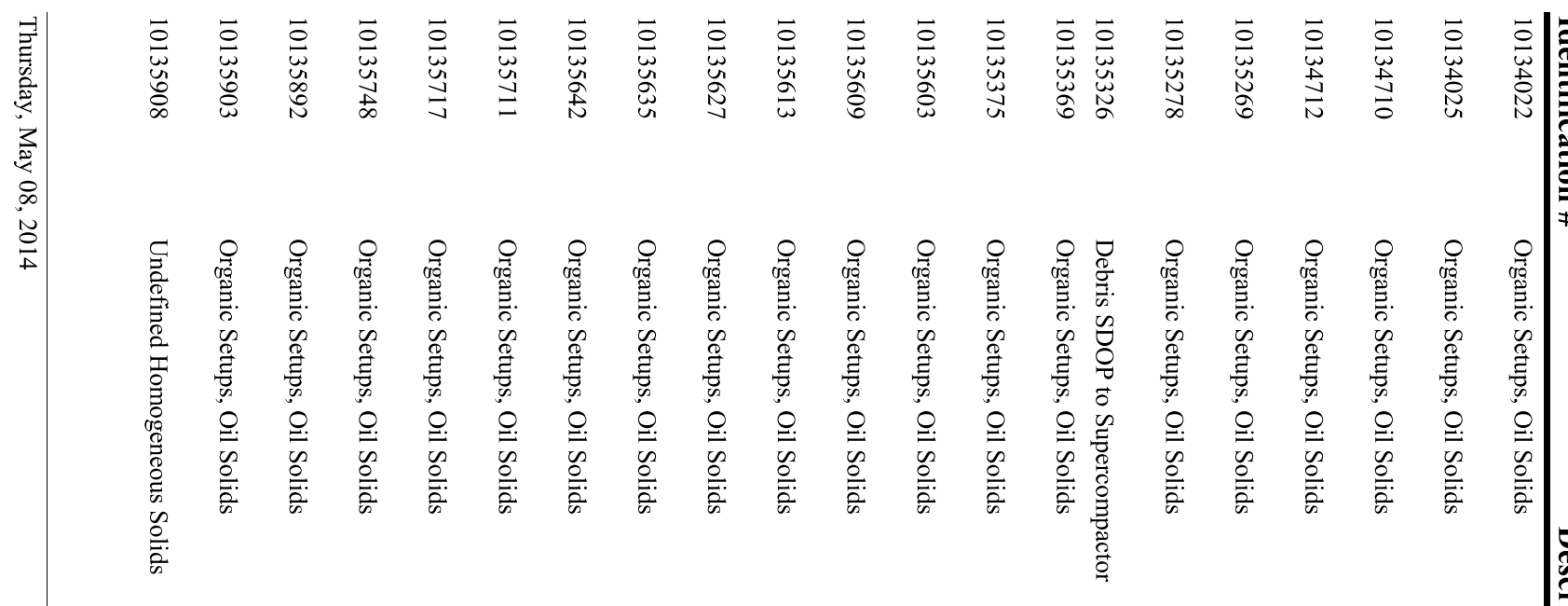

แ

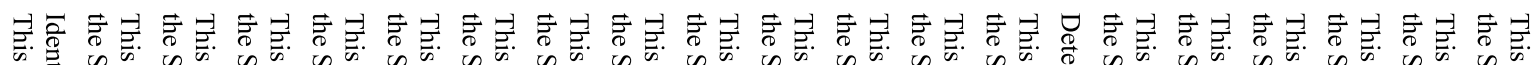

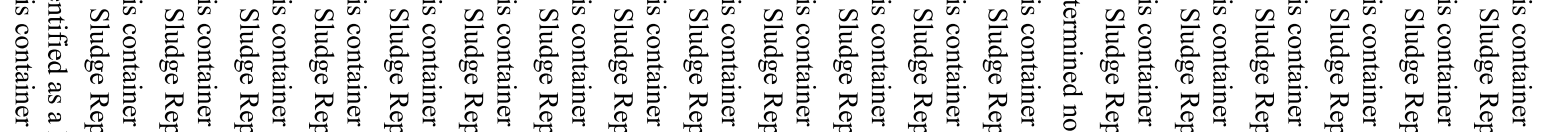

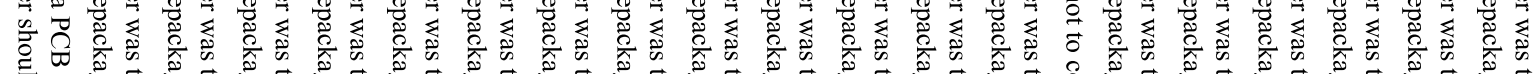

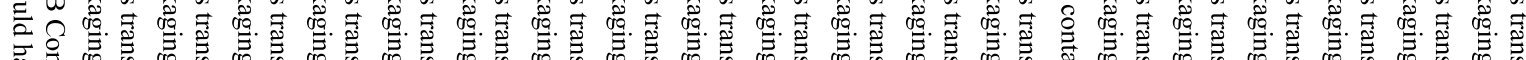

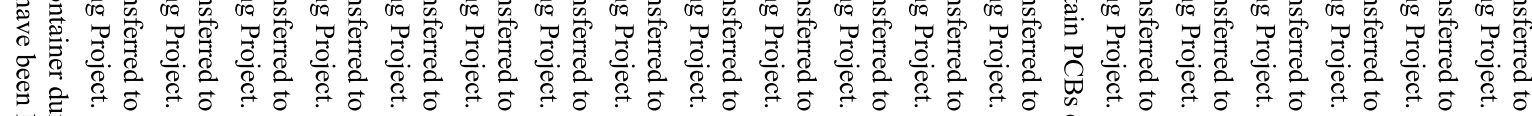

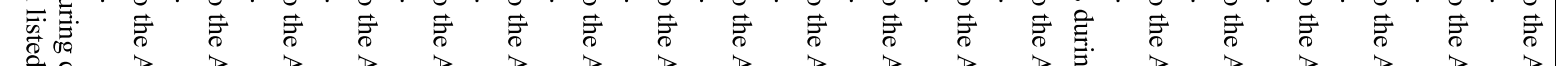

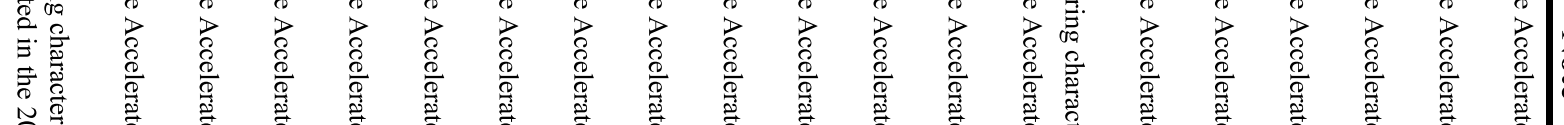

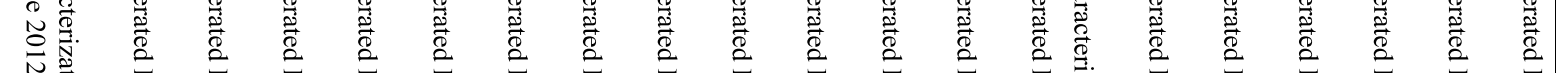
蛋

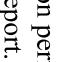




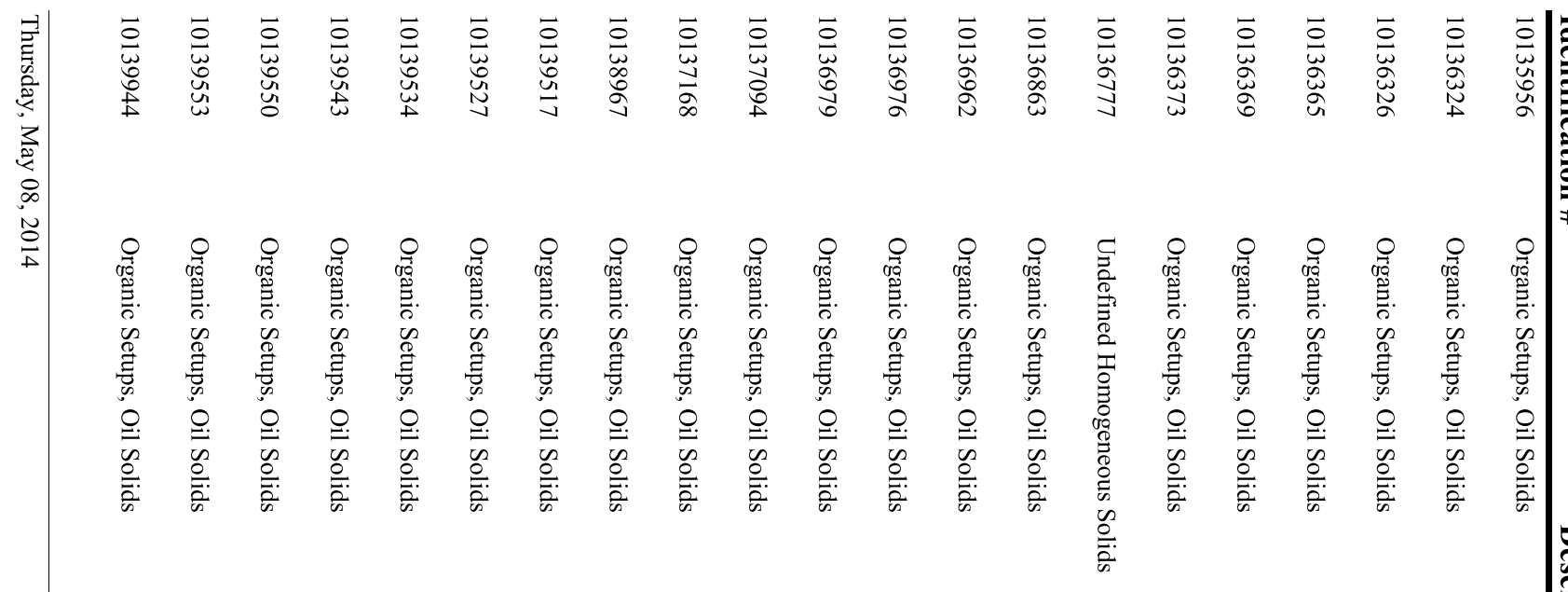

N

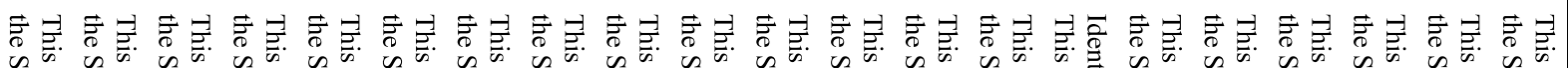

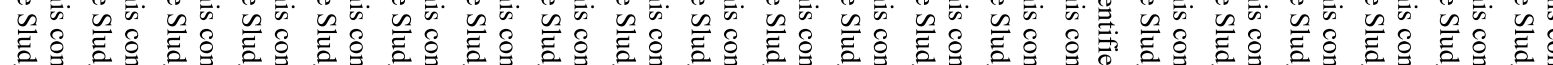

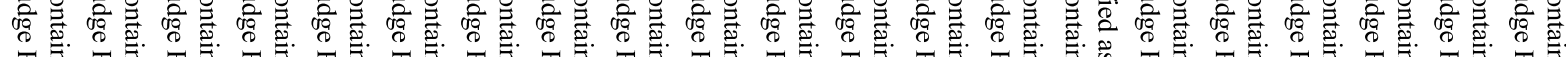

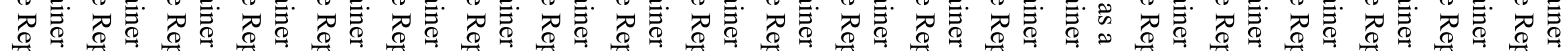

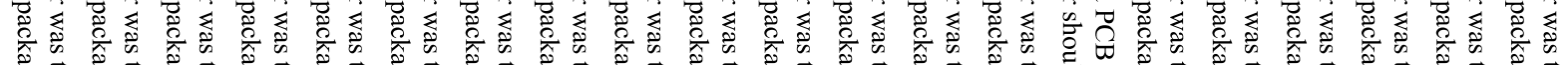

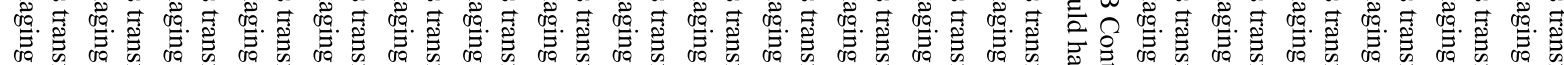

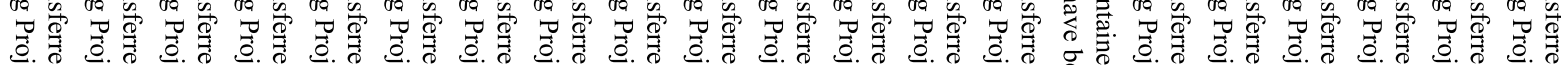

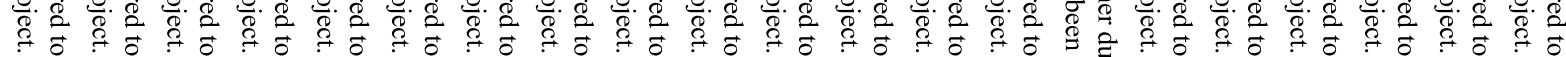

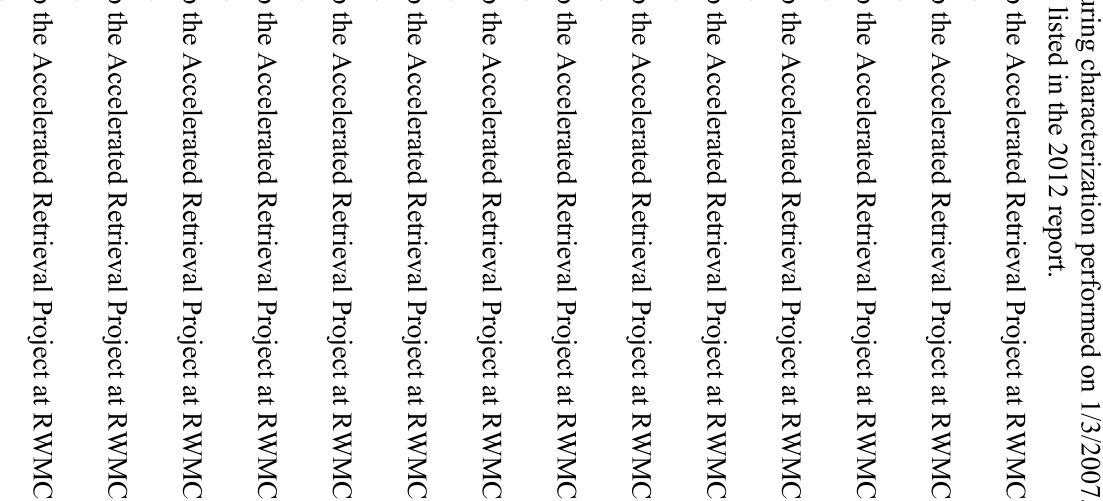




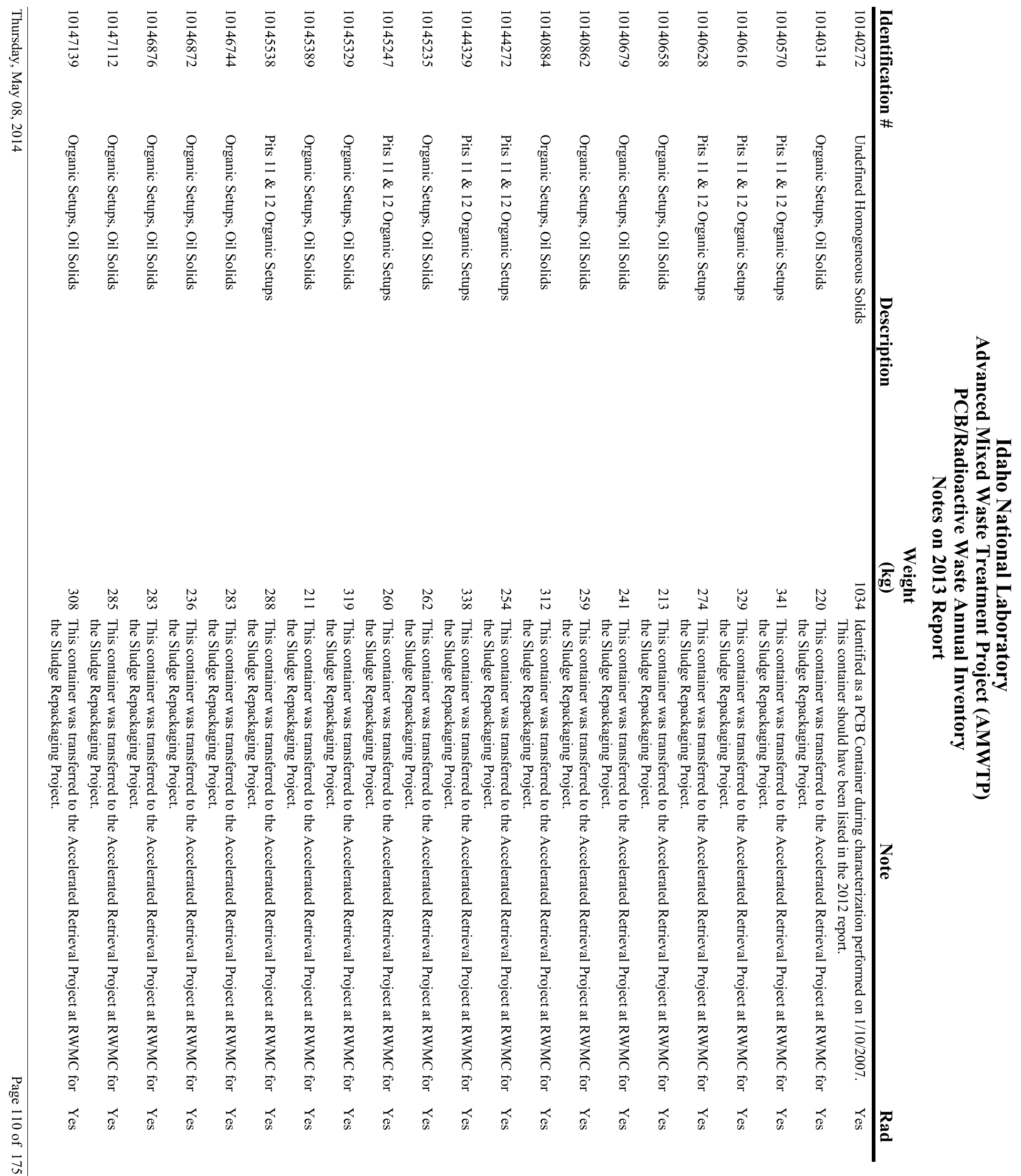




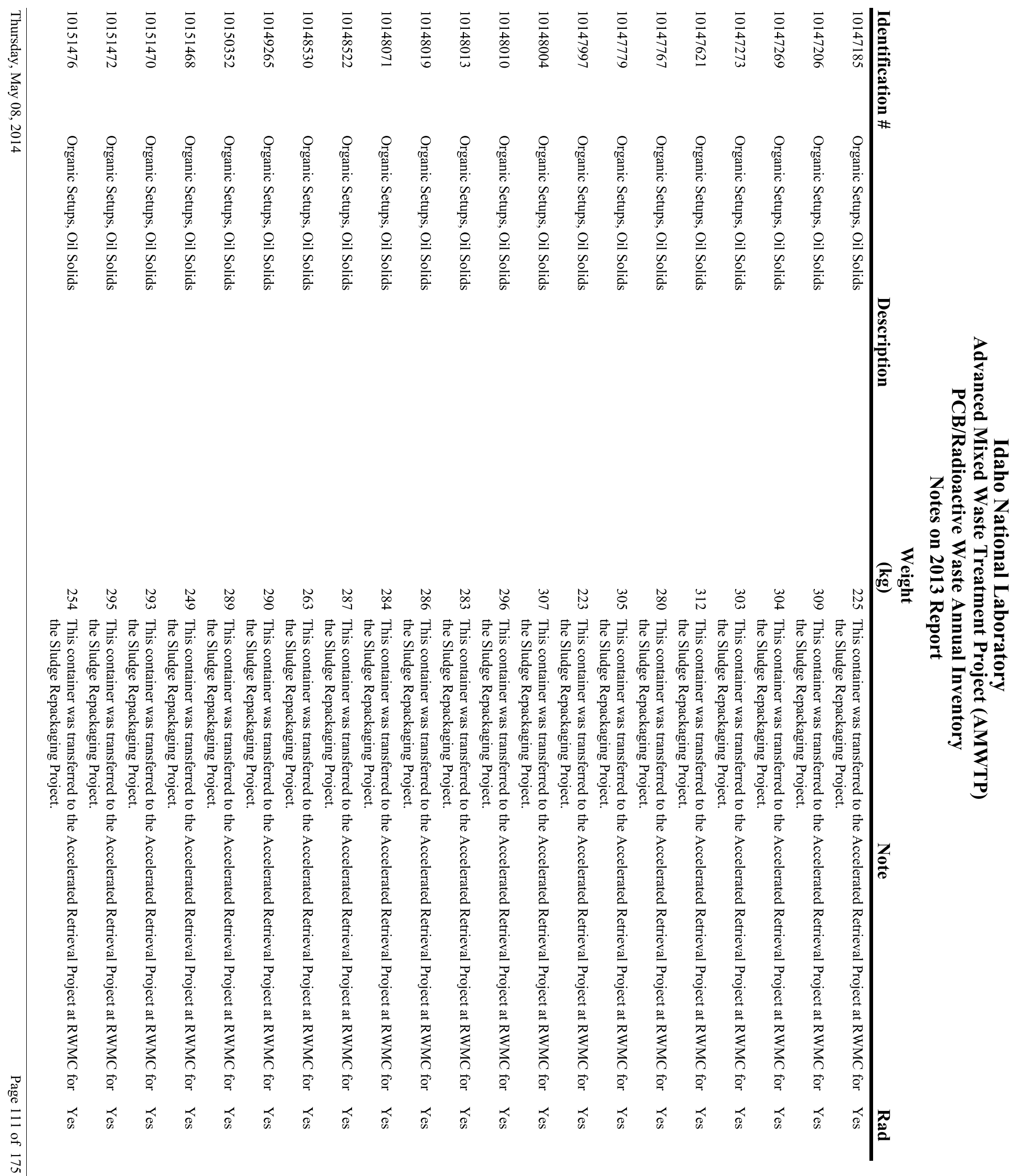




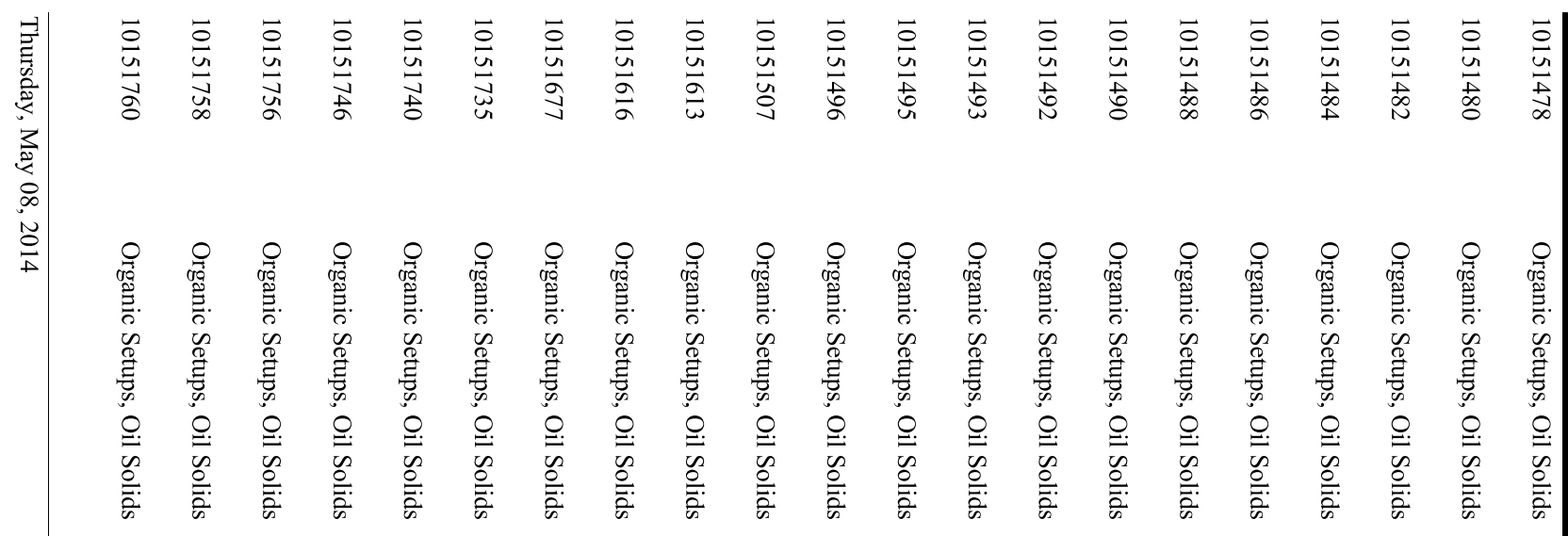

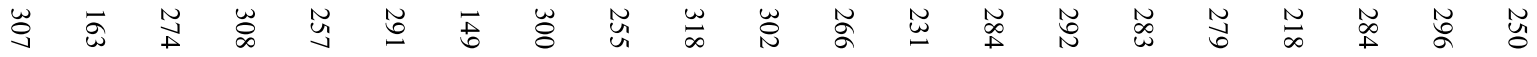

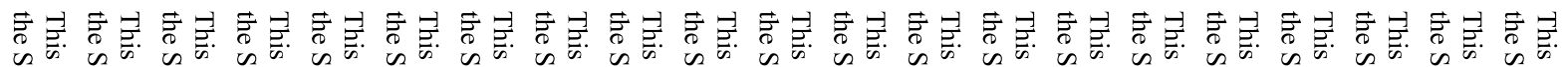

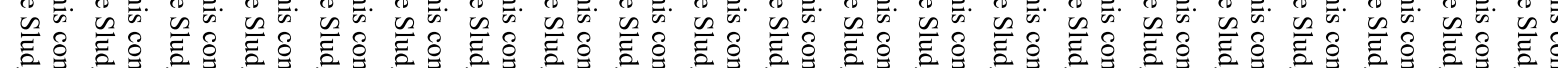

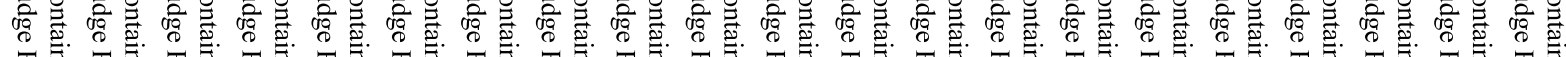

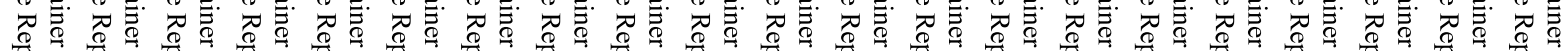

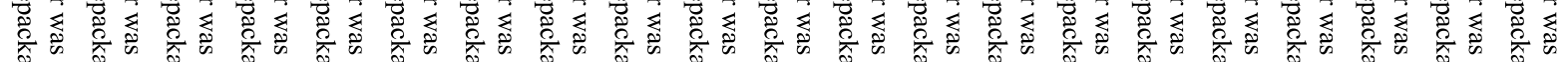

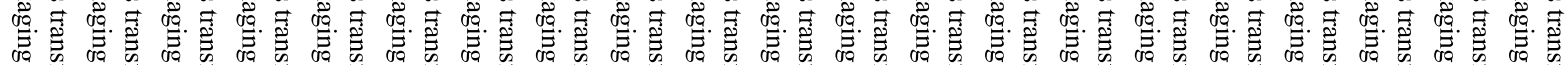

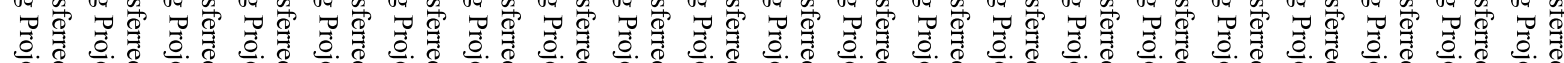

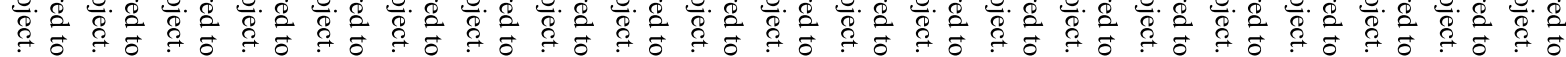

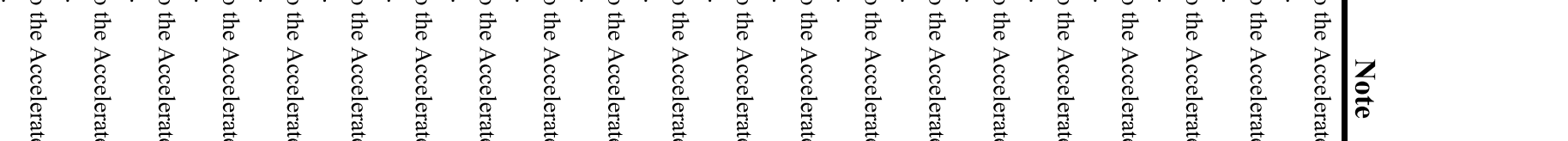




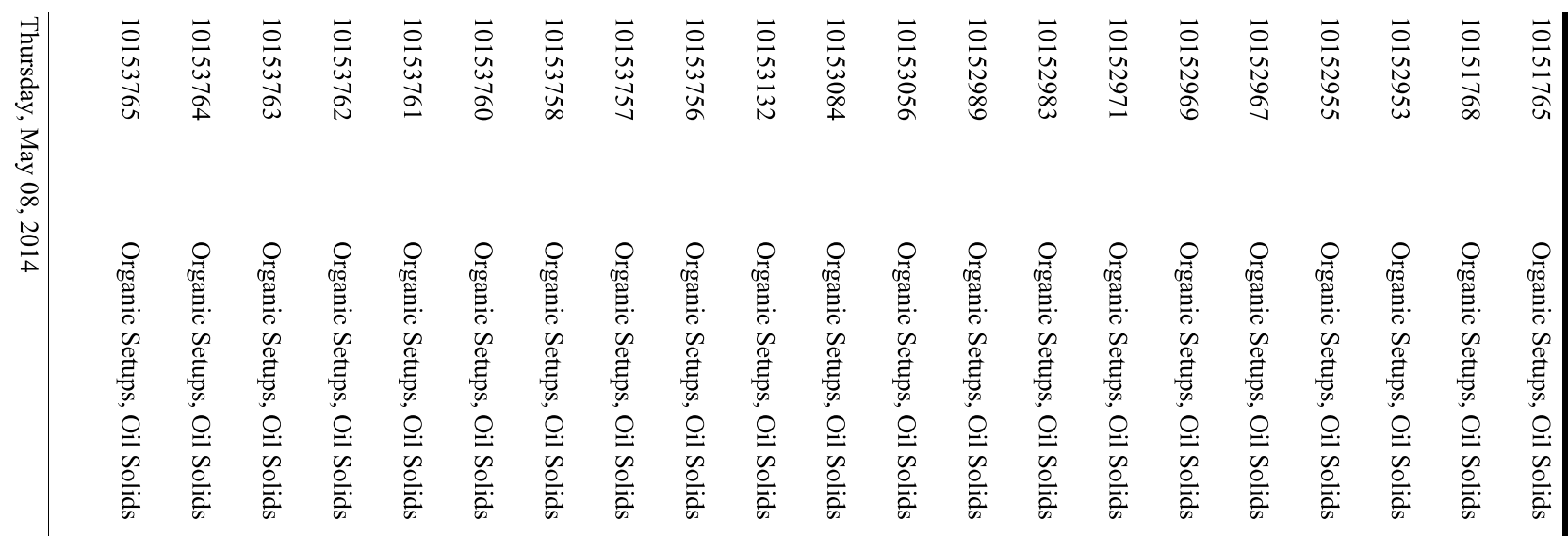

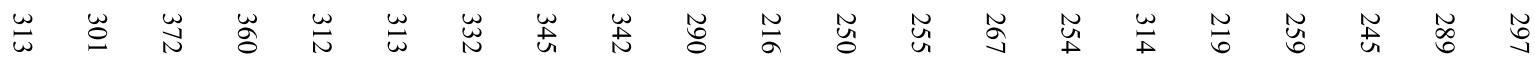

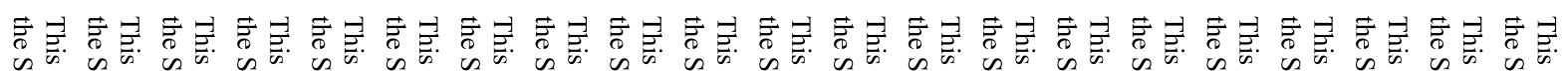

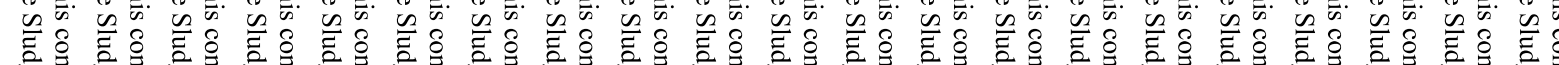

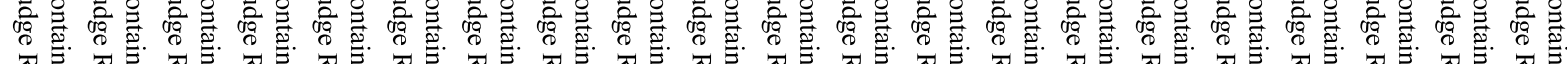

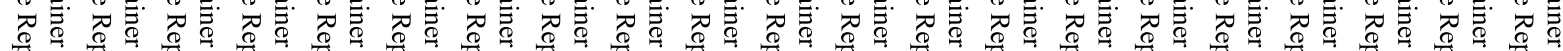

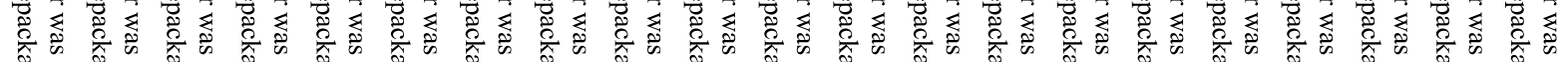

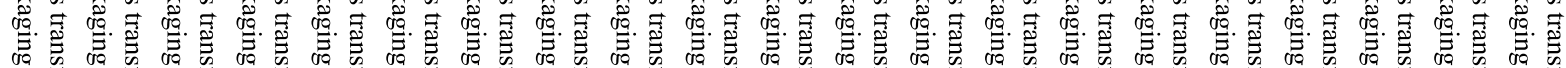

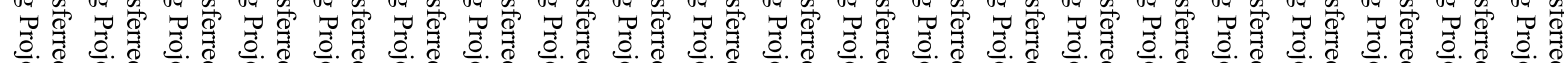

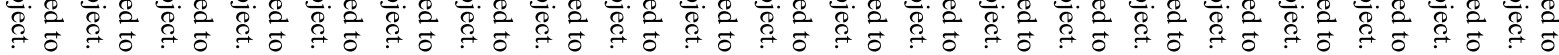

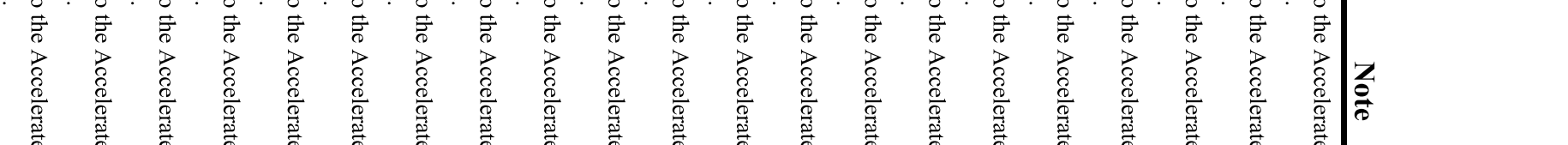




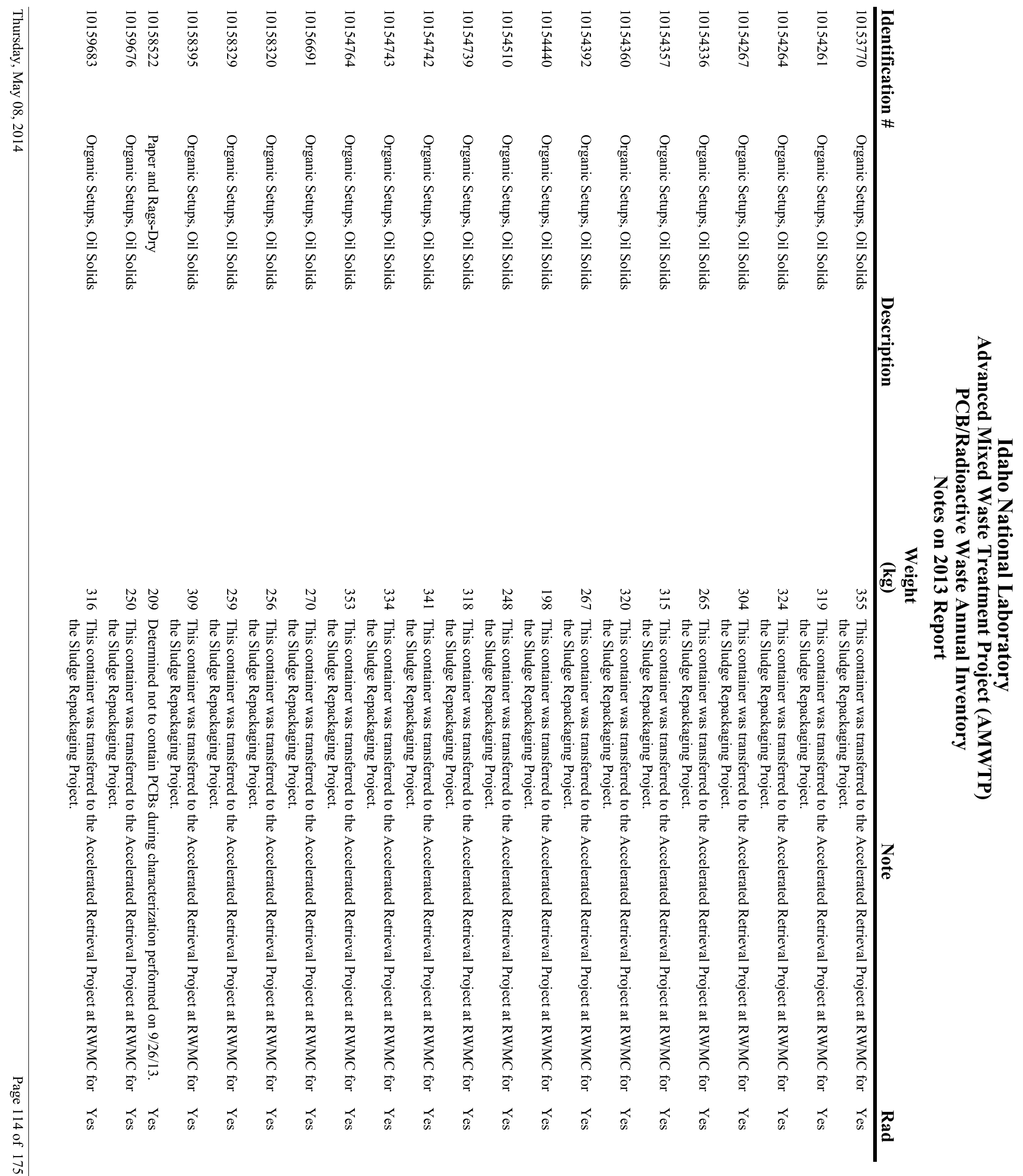




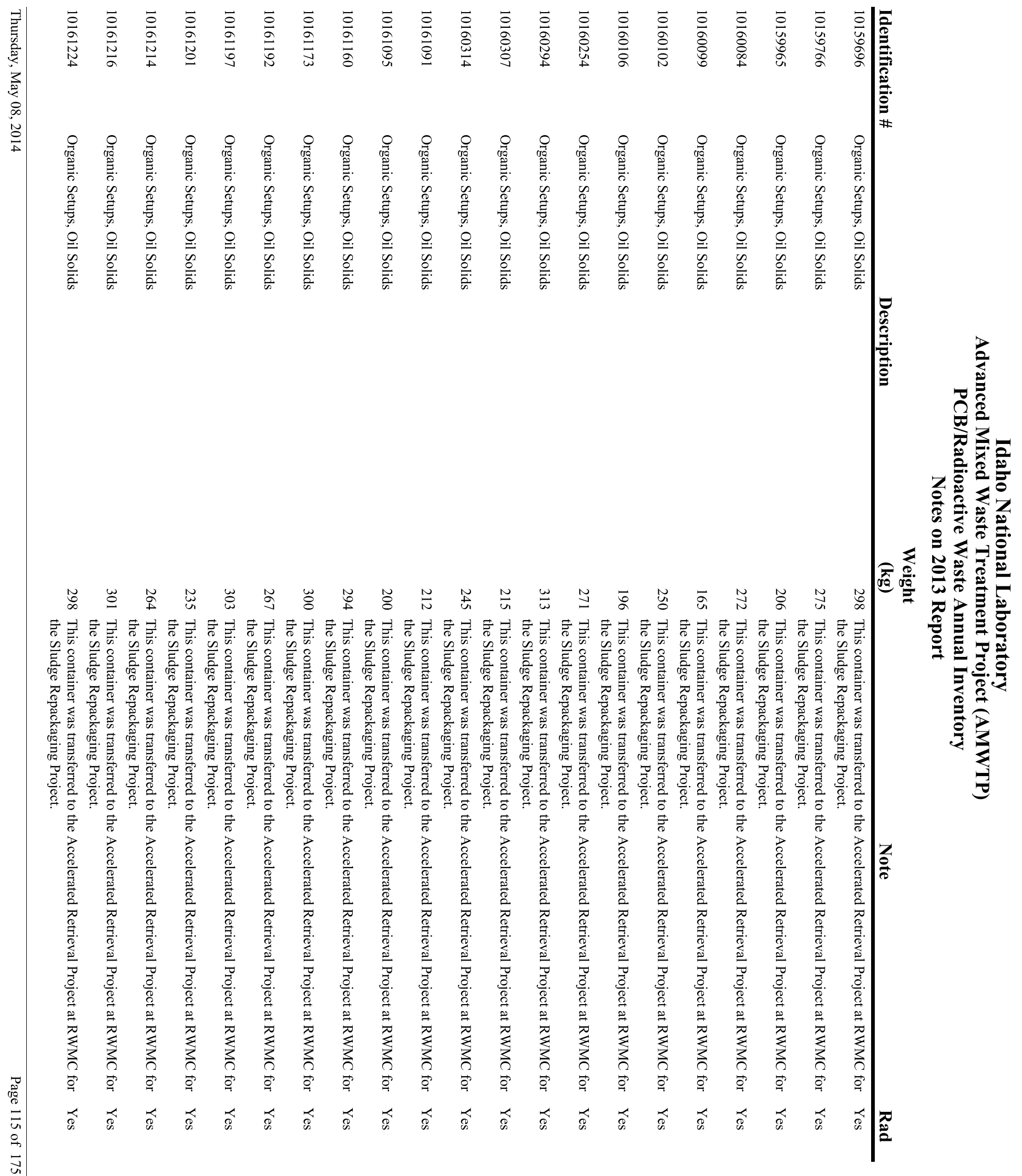




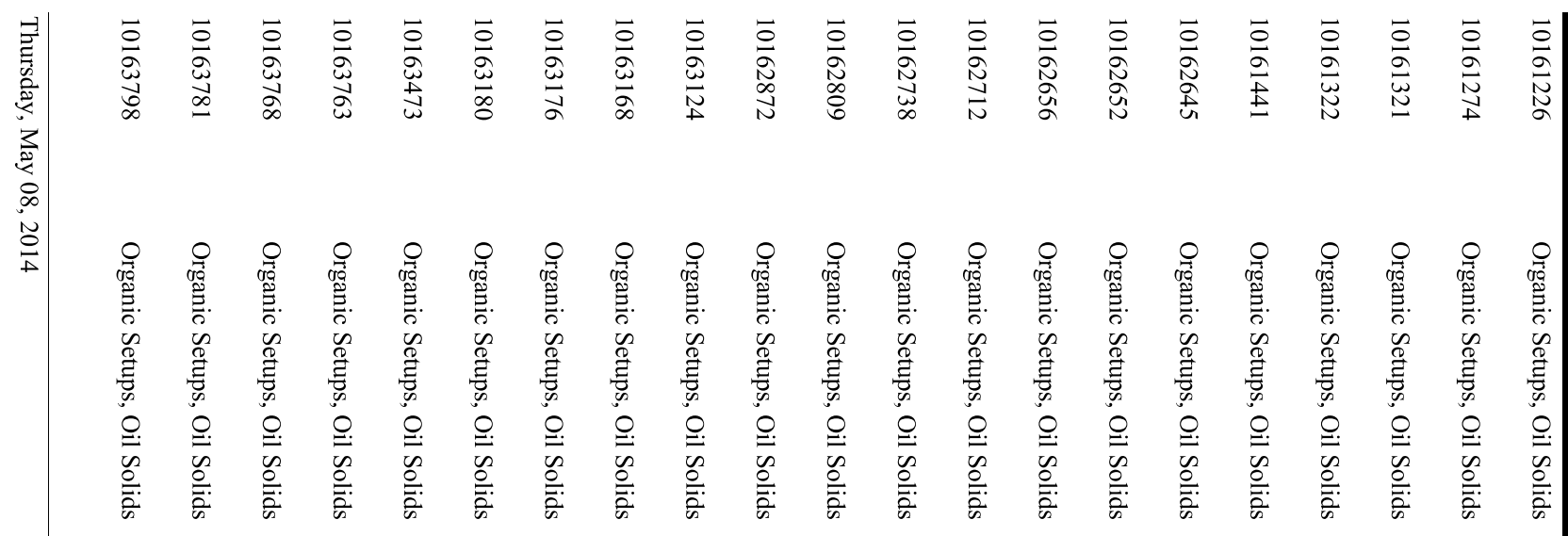

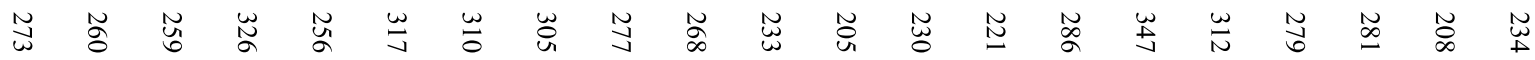

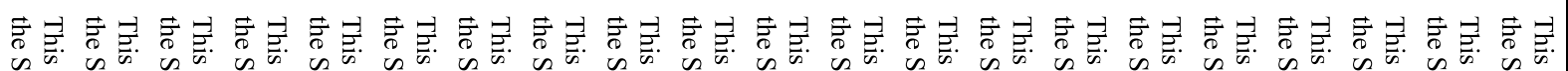

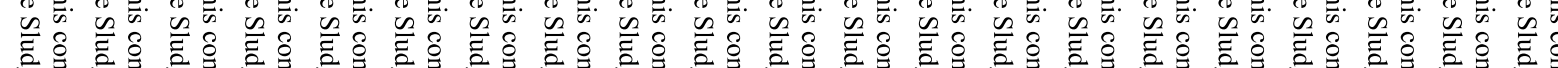

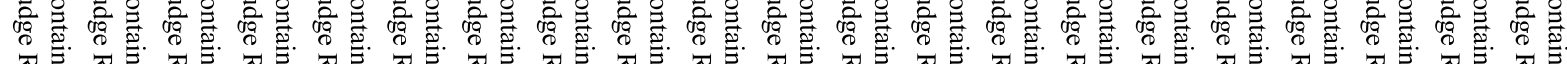

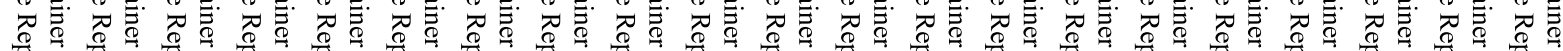

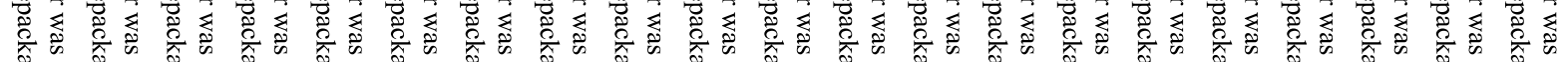

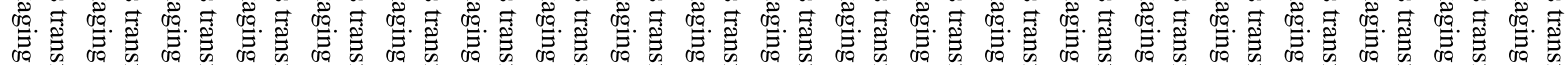

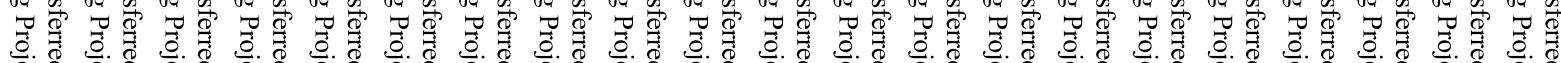

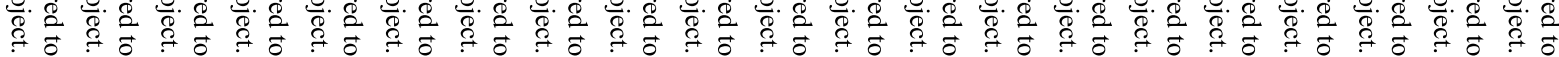

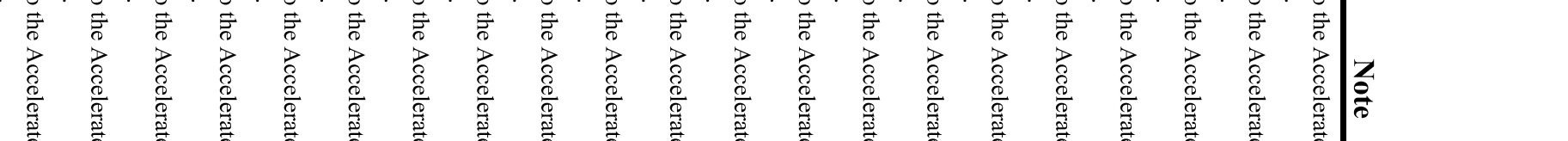




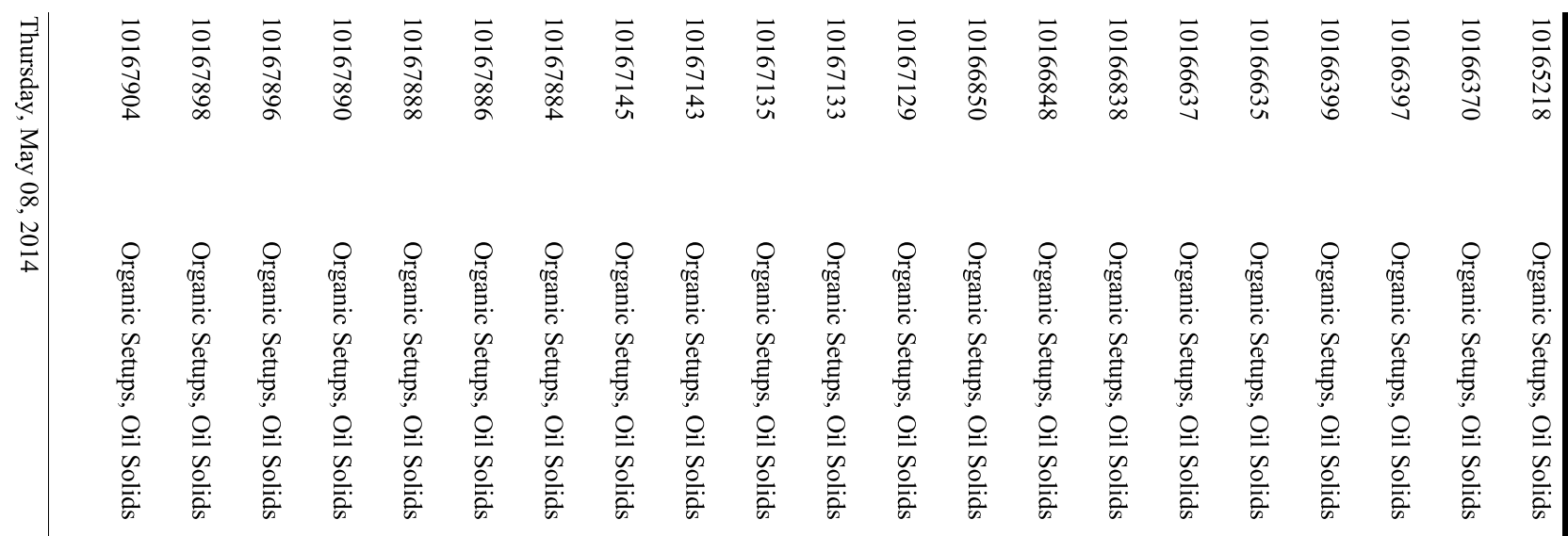

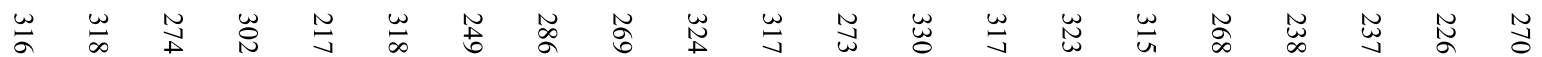

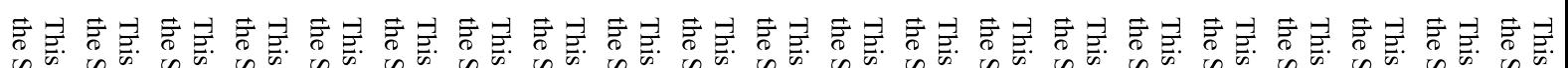

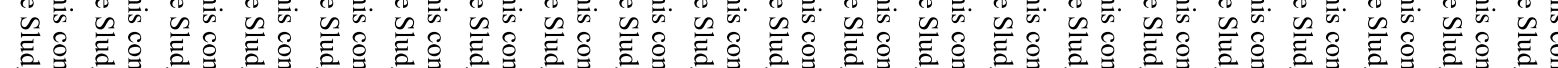

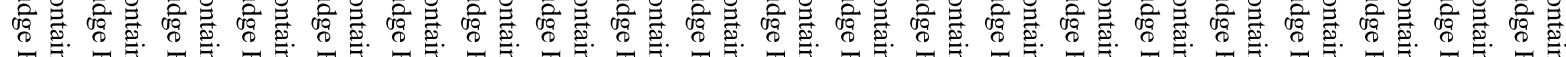
不

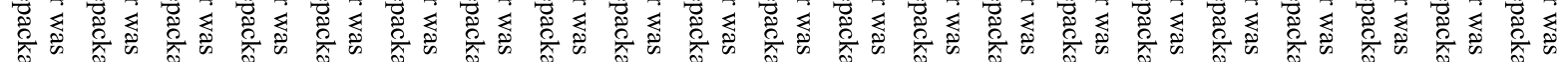

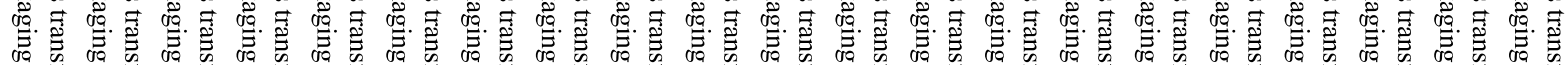

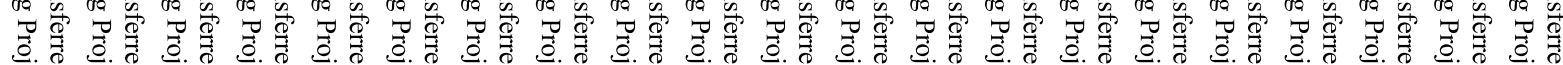

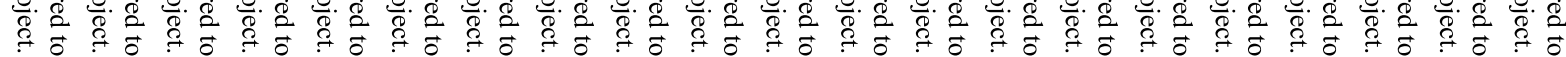

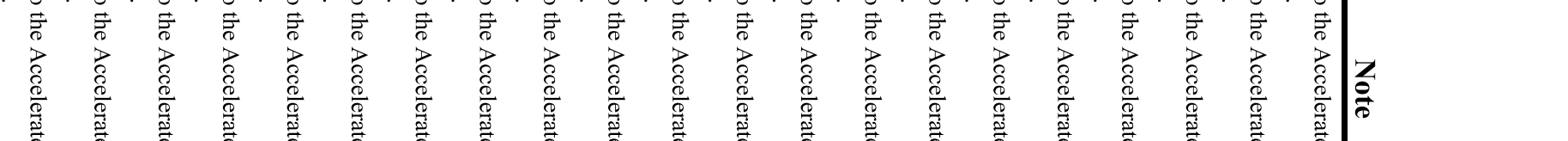




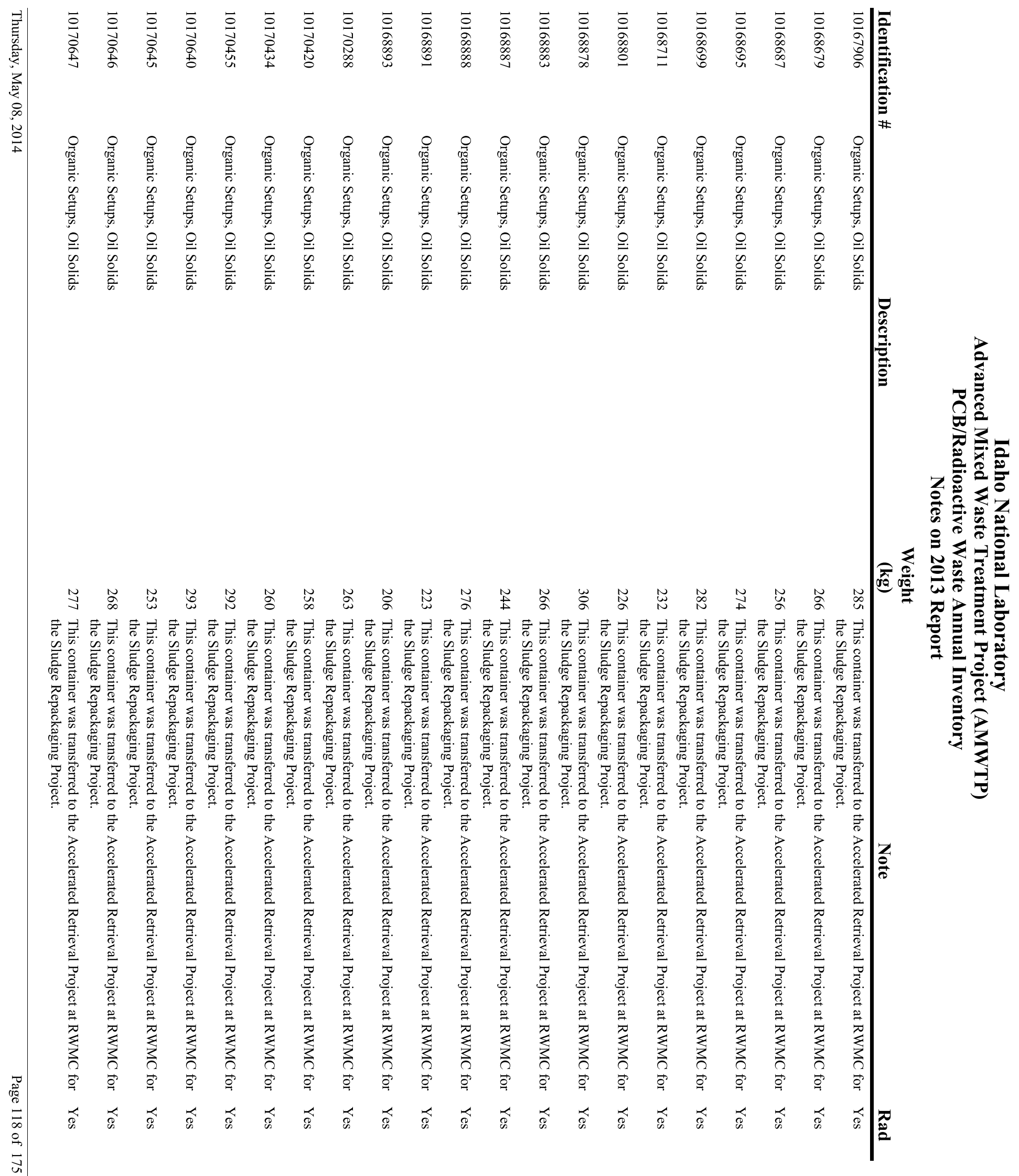




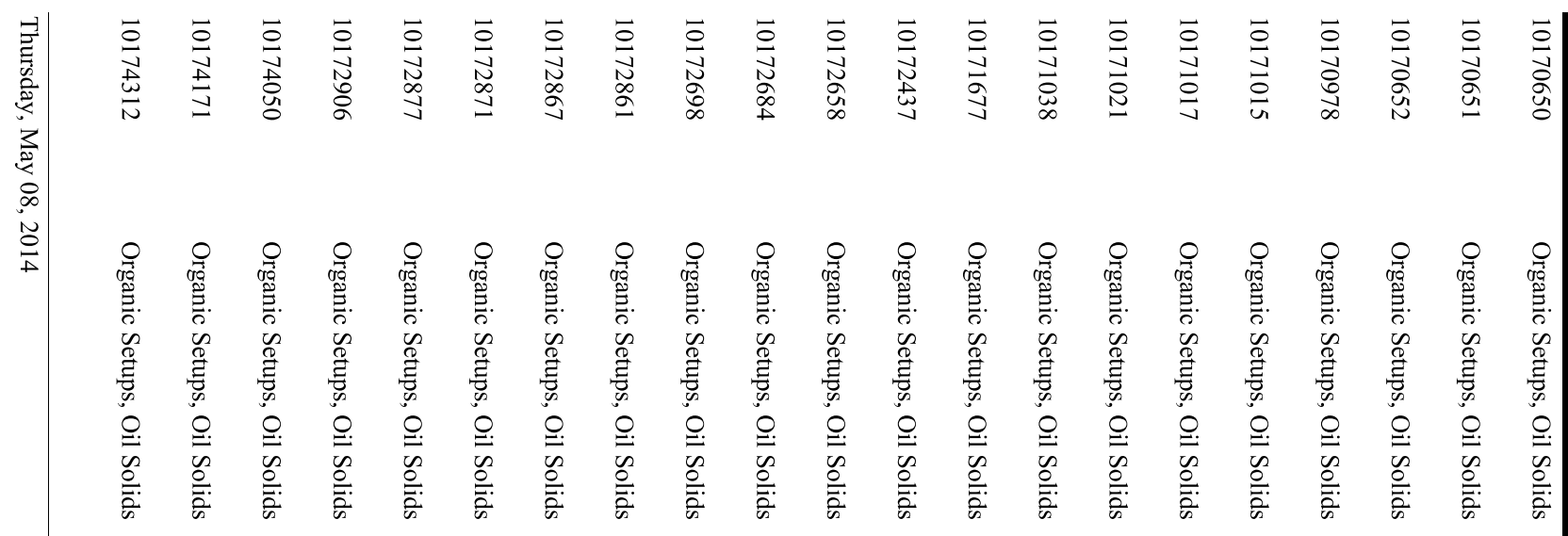

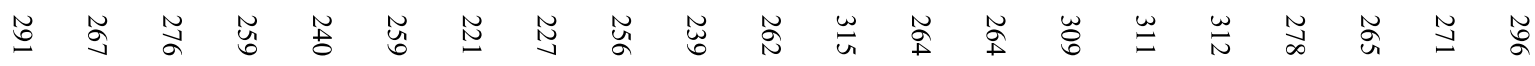

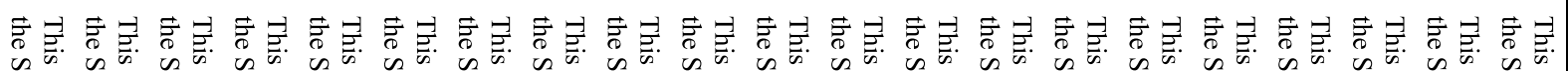

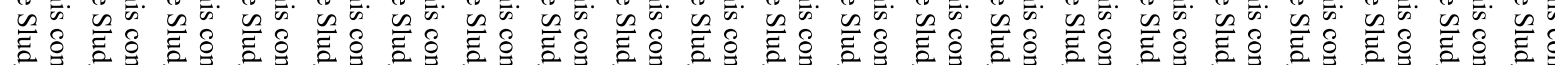

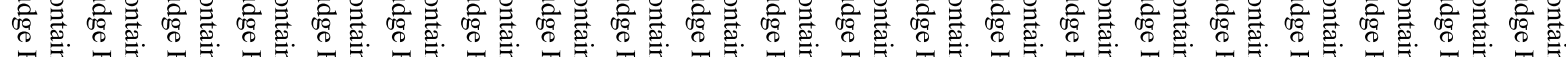

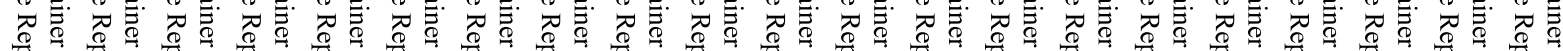

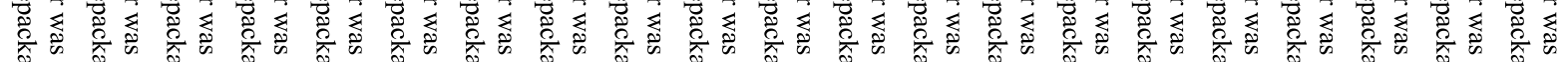

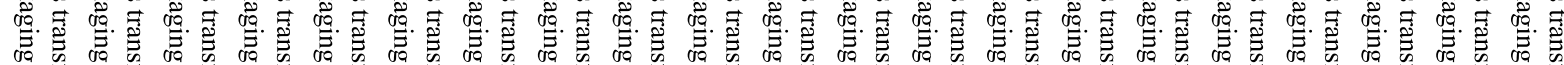

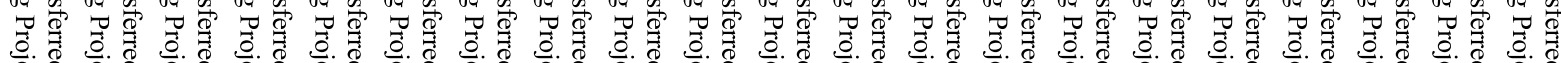

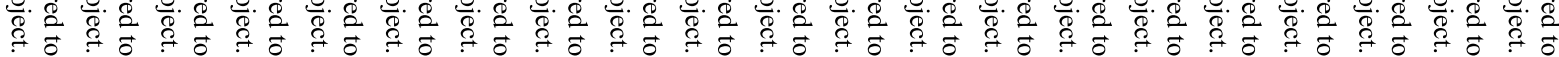

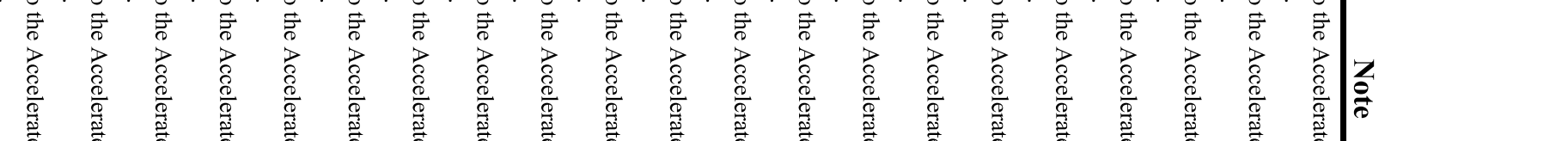




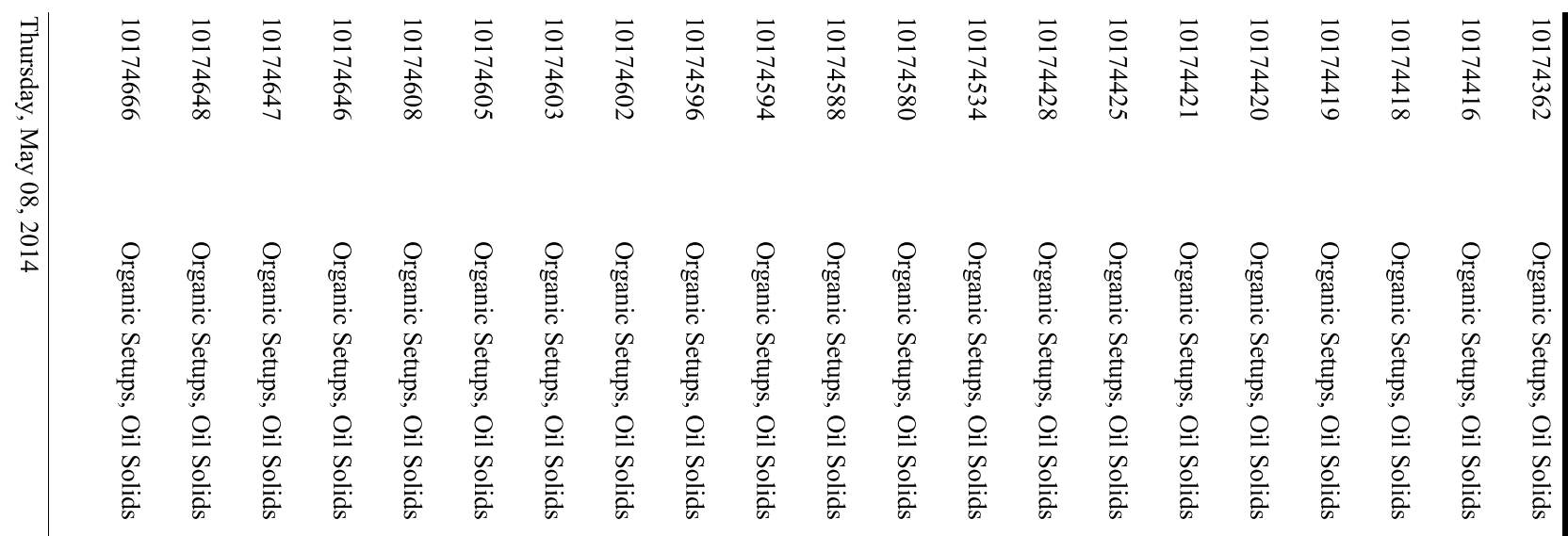

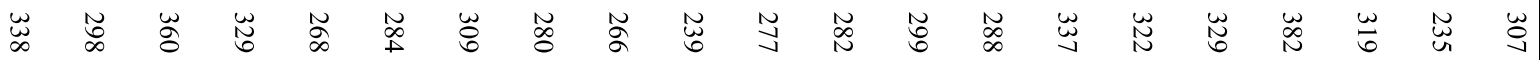

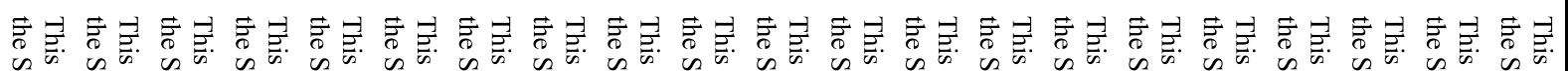

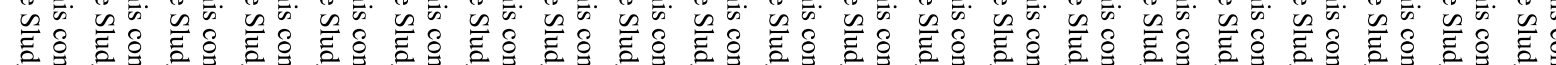

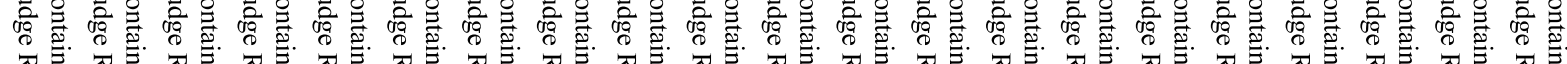

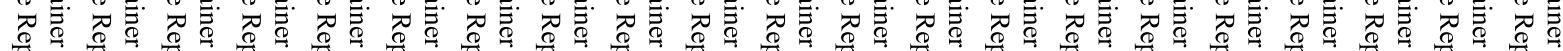

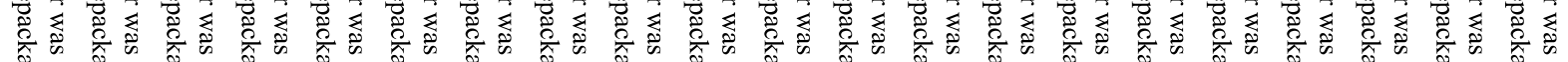

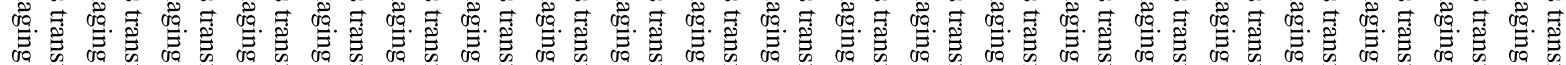

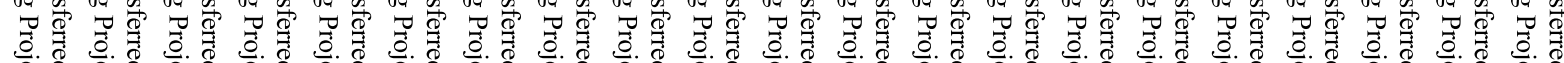

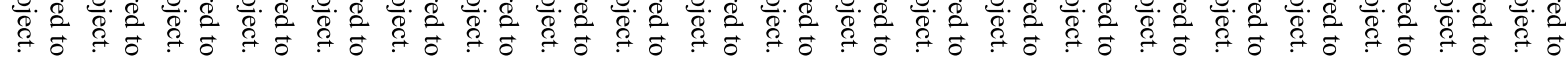

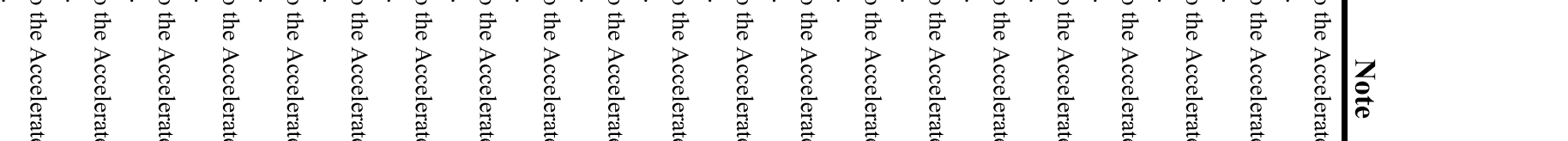




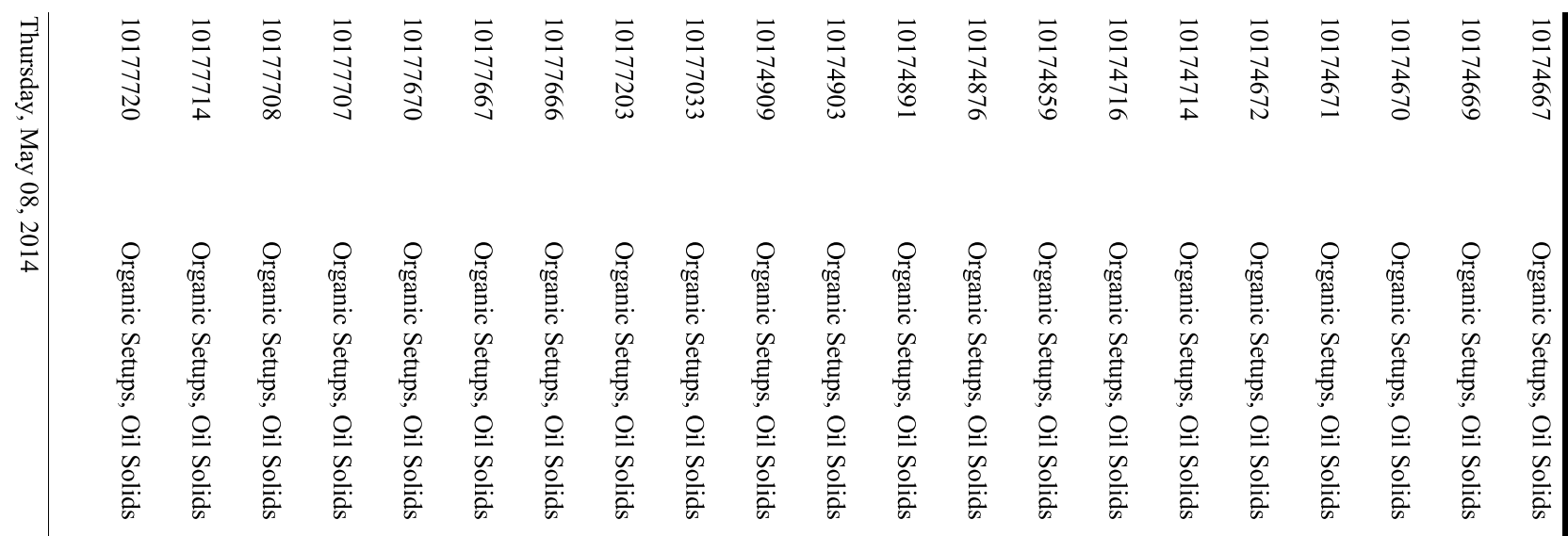

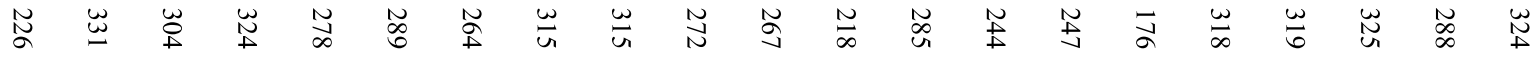

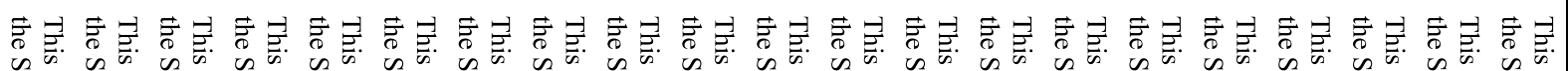

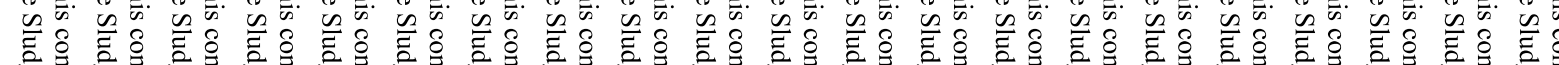

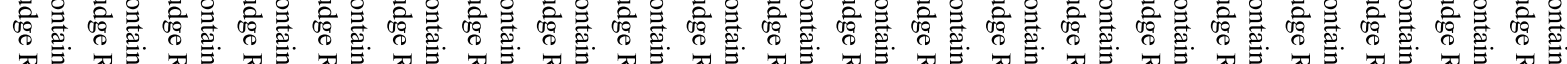

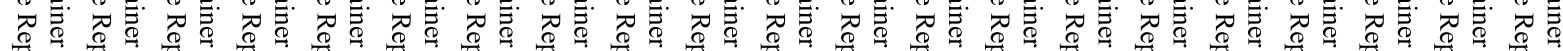

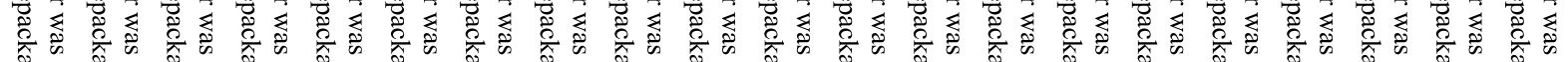

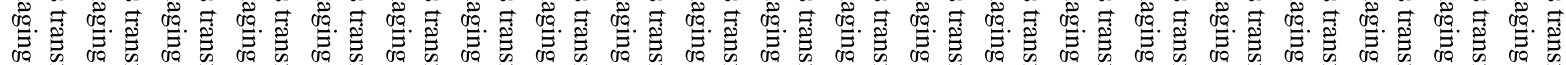

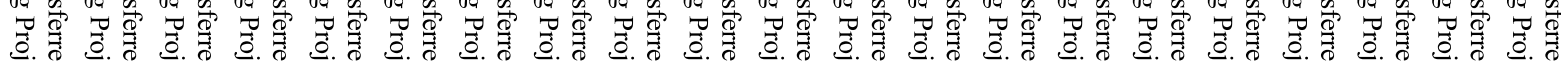

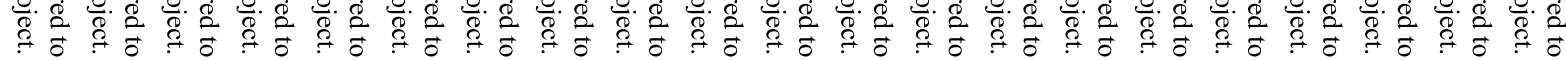

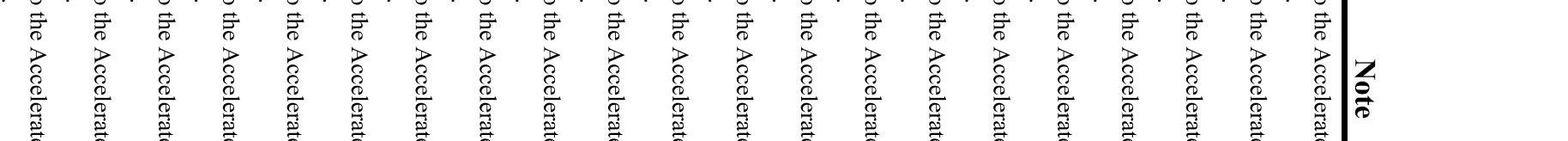




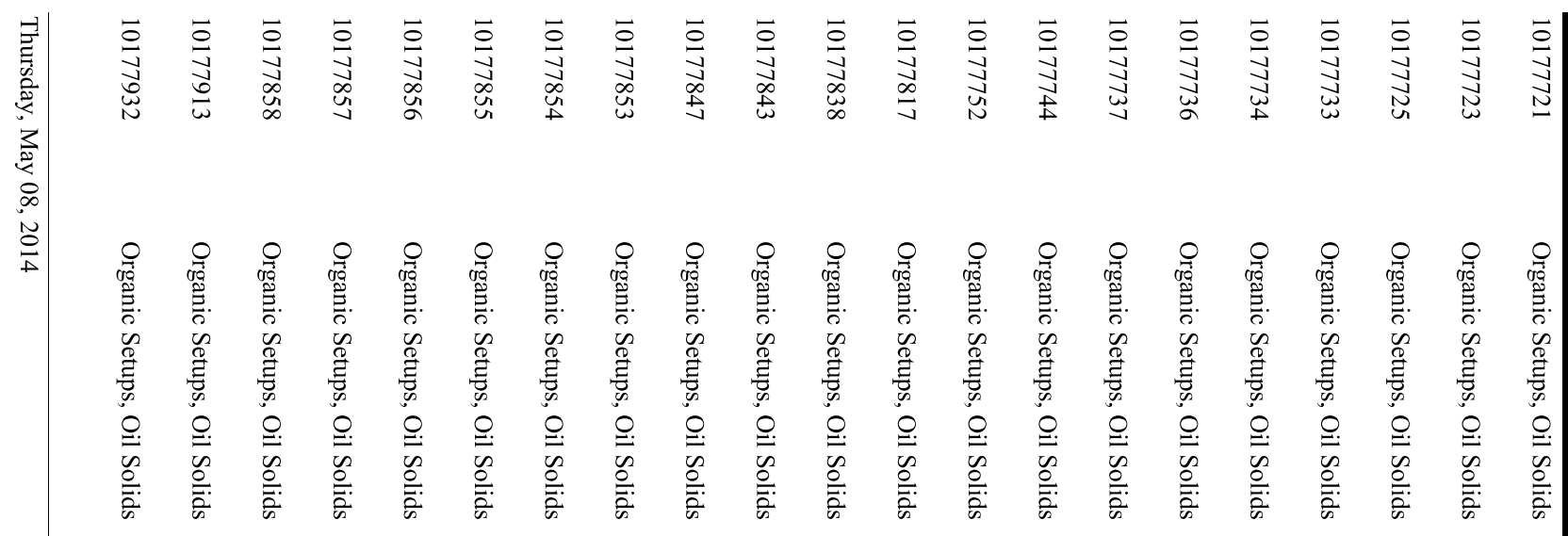

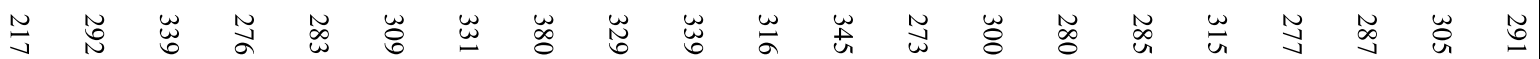

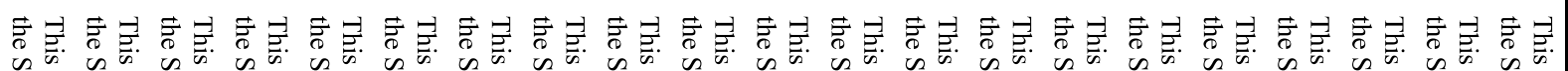

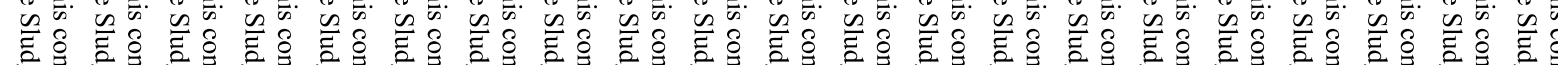

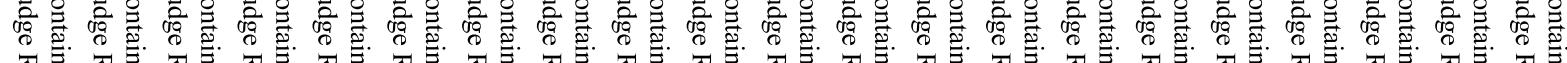

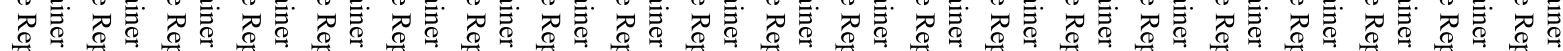

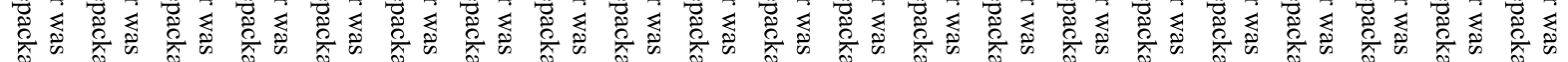

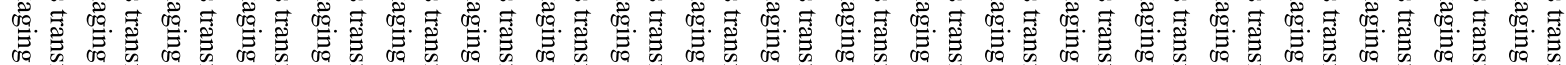

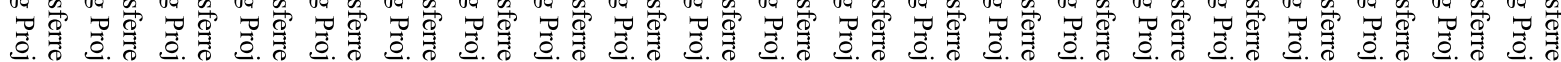

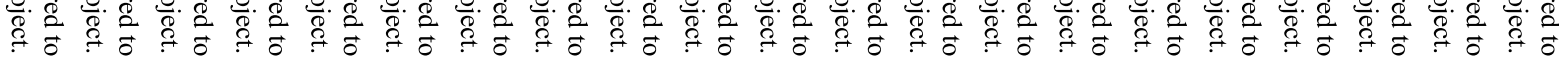

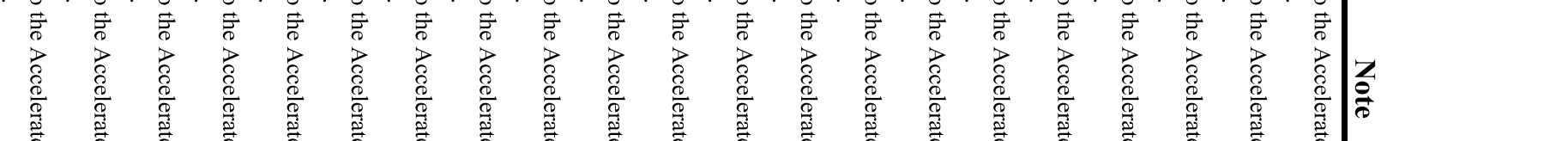




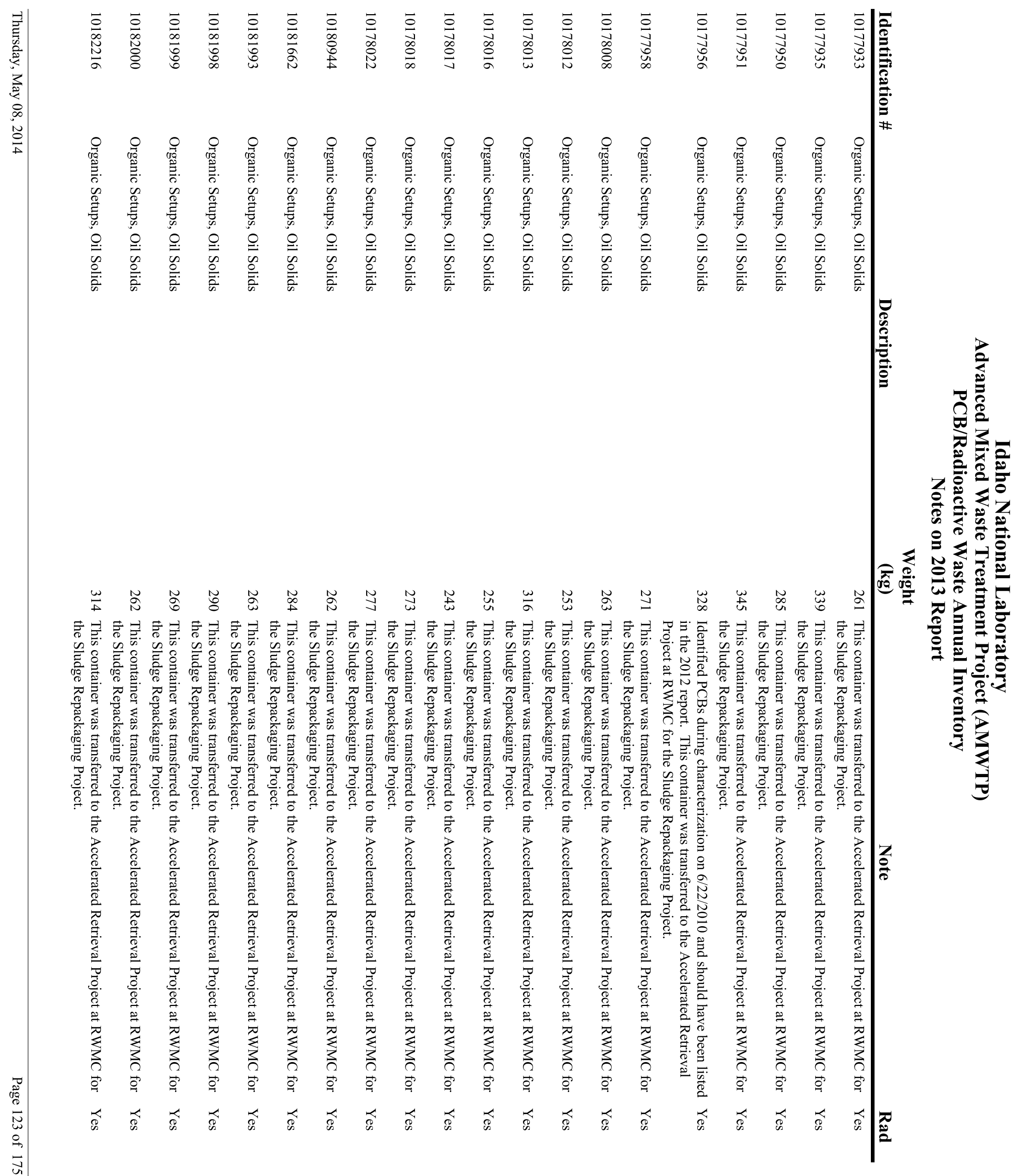




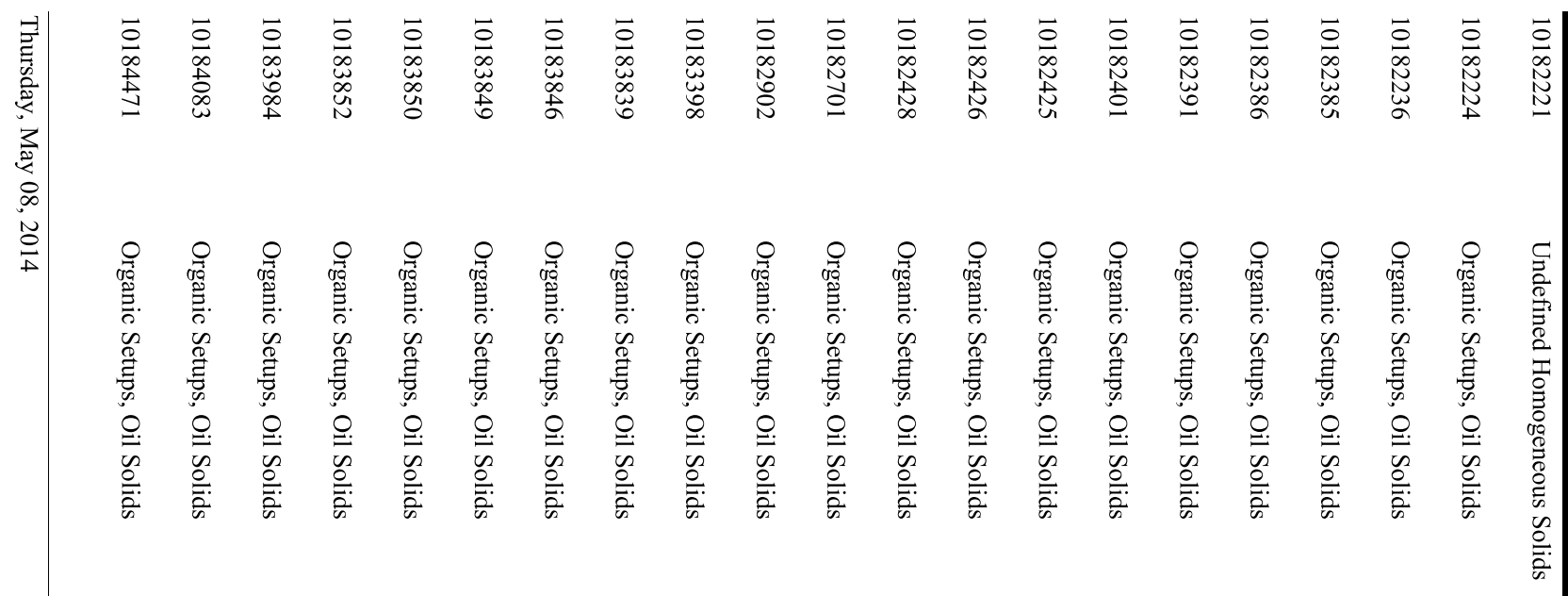

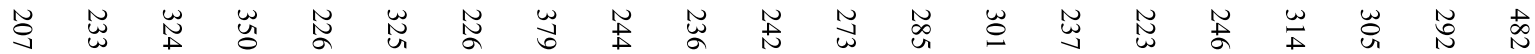

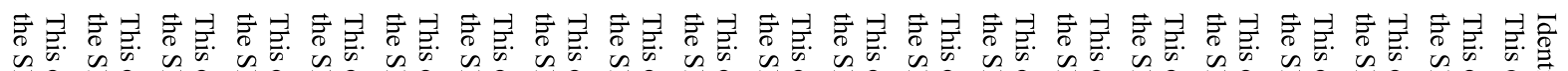

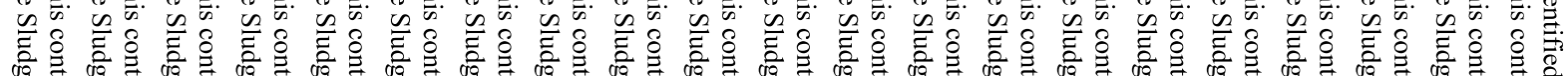

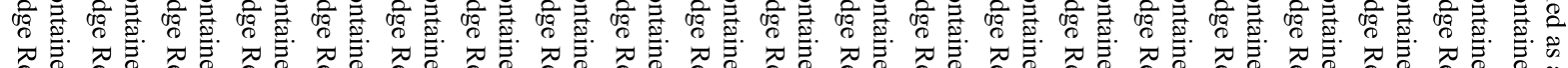

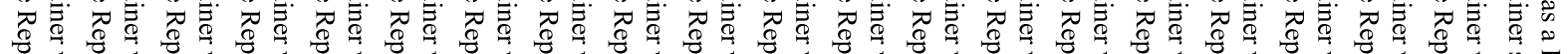

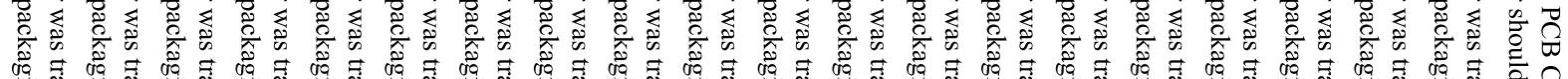

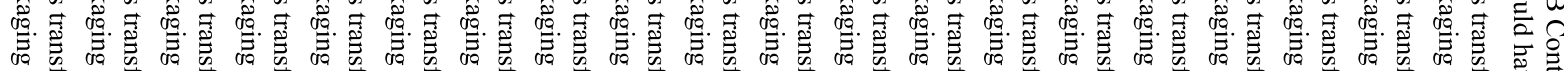

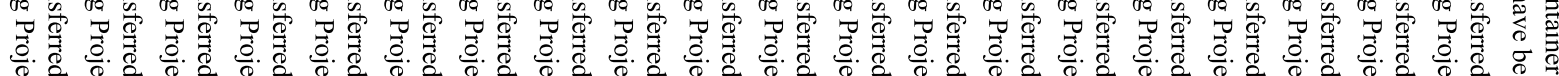

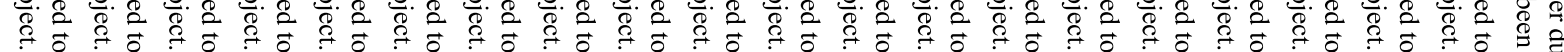

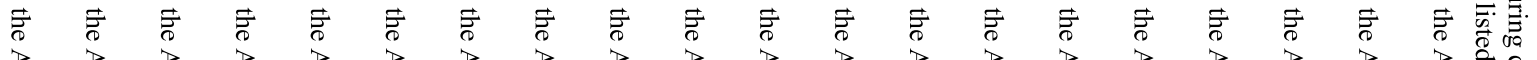

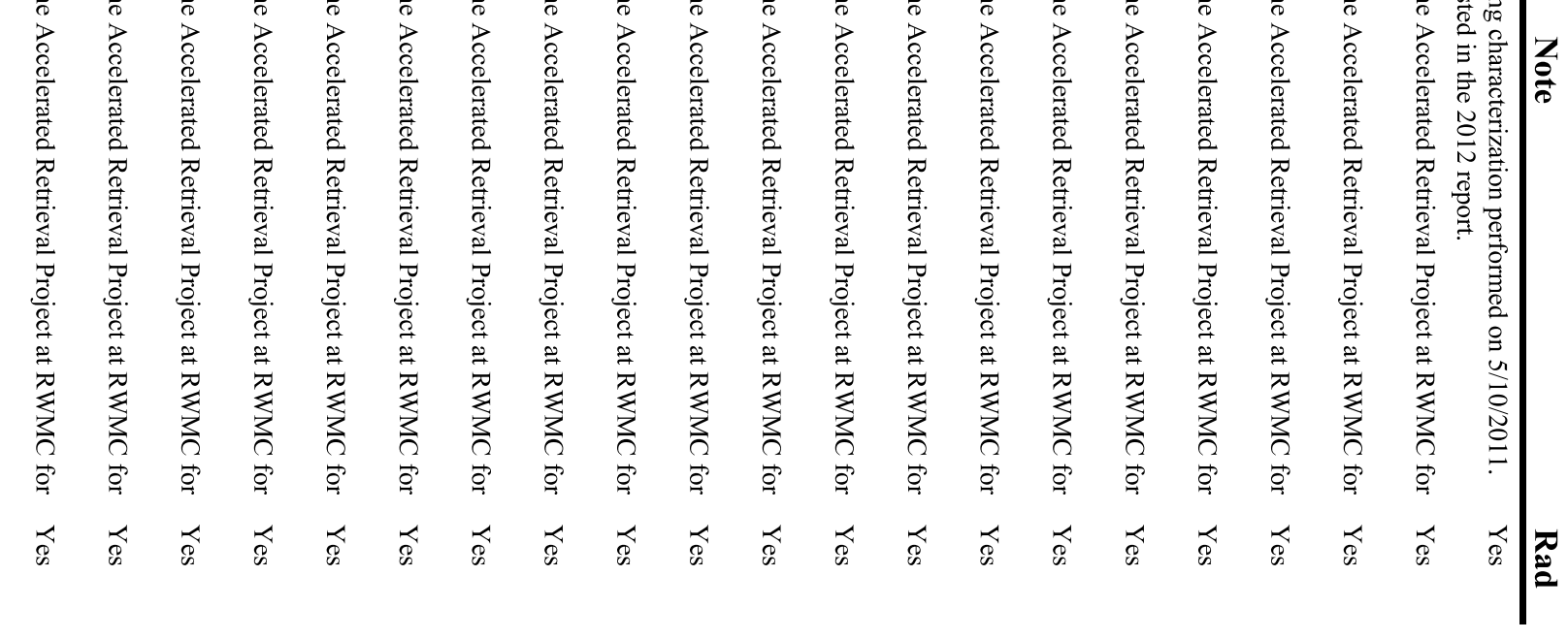




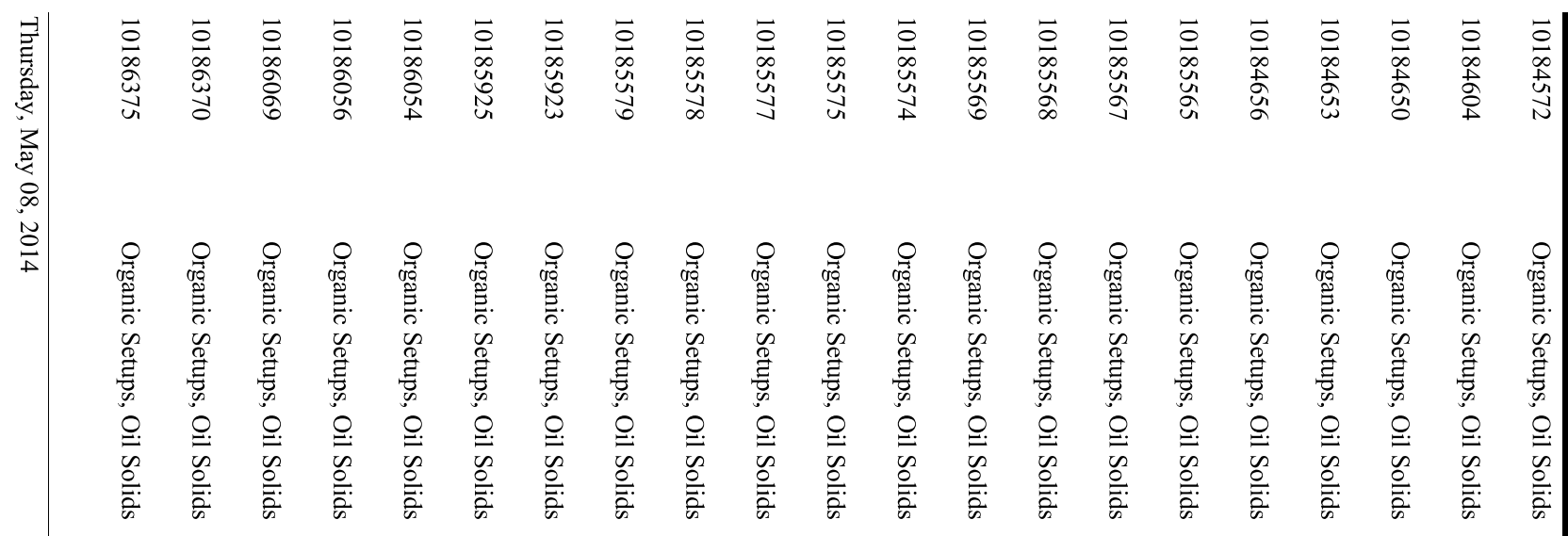

N

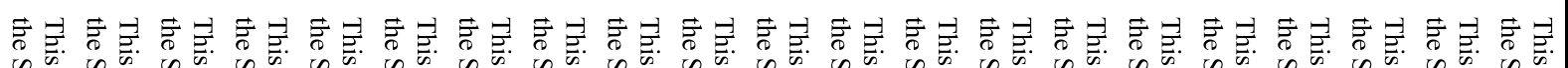

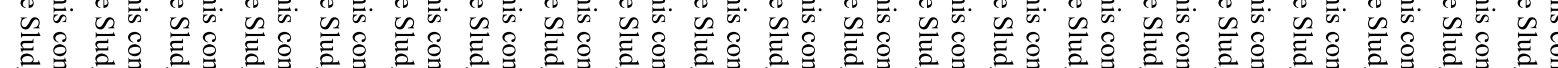

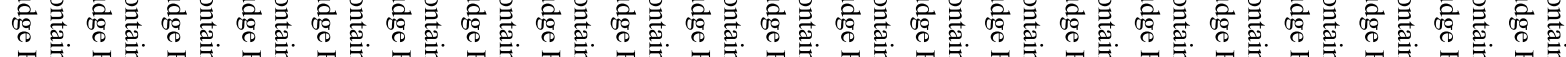
不

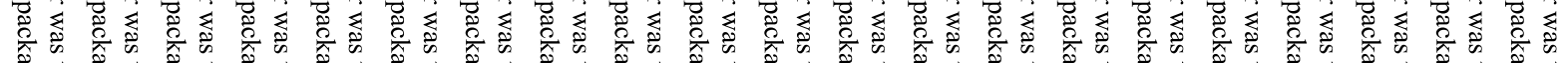

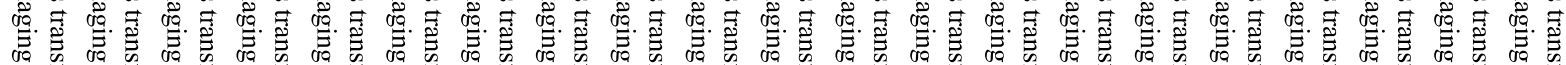

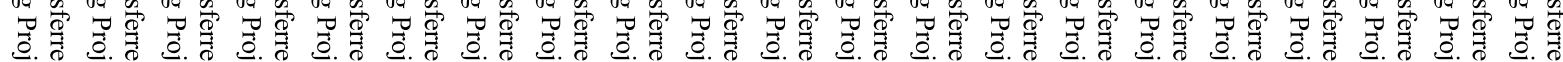

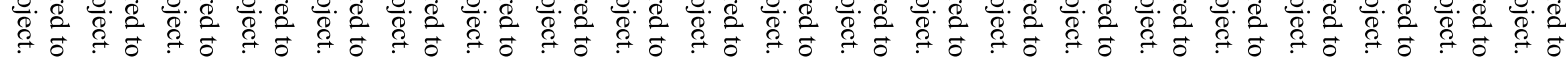

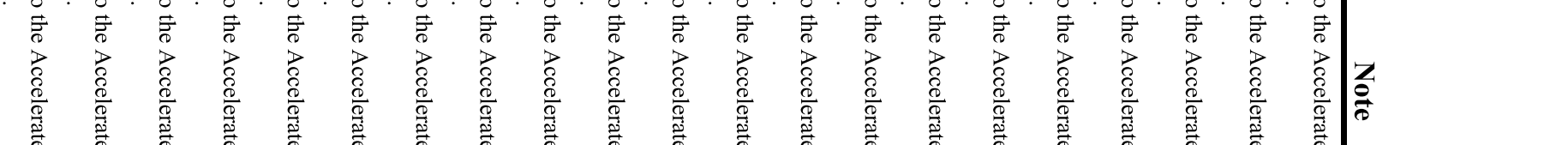




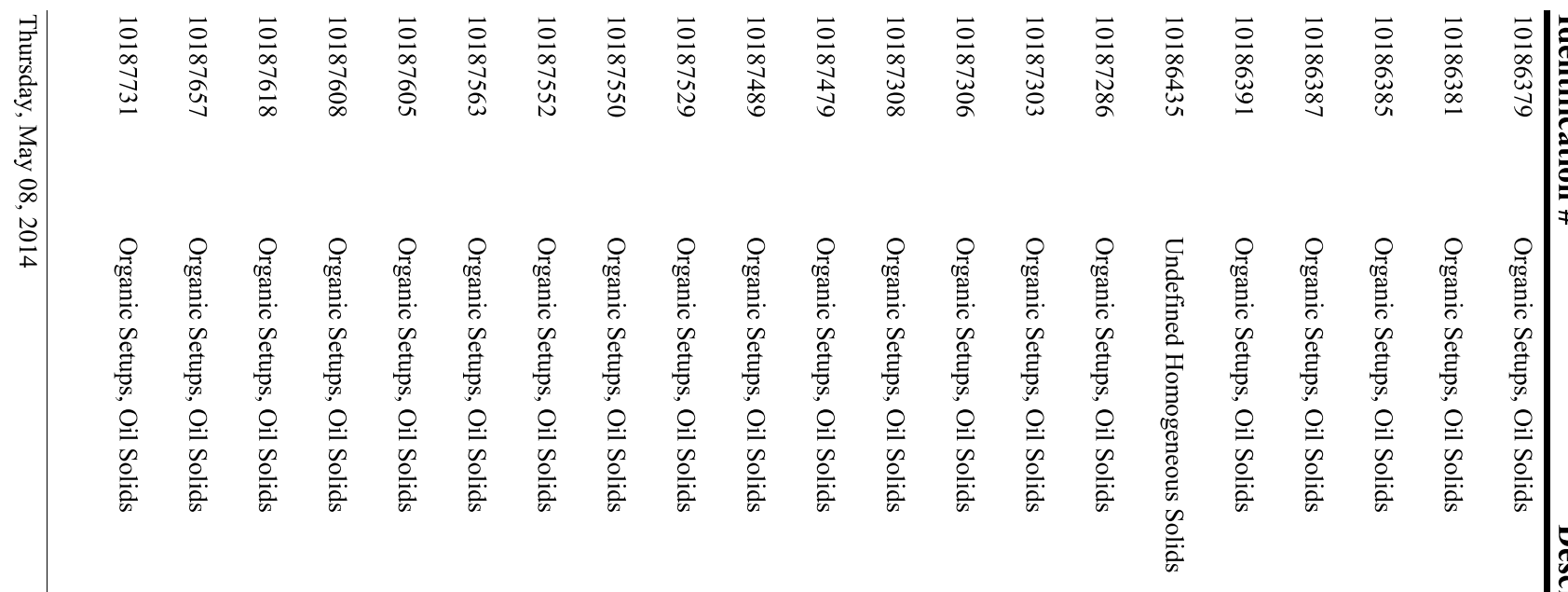

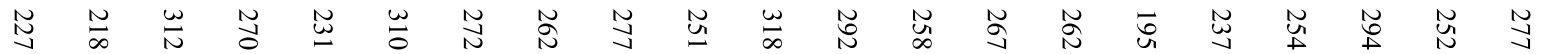

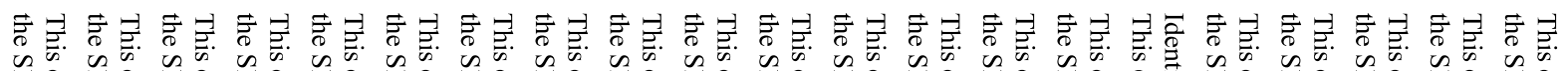

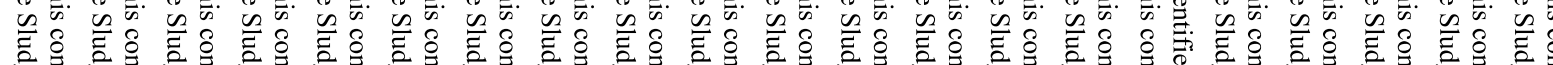

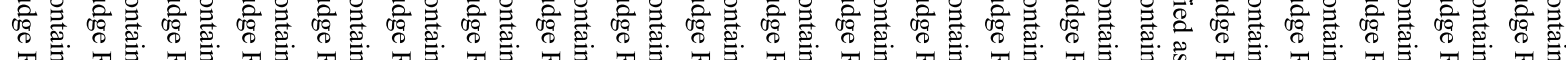

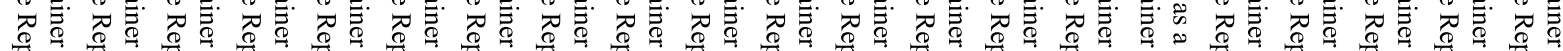

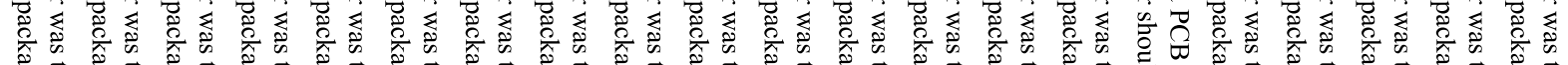

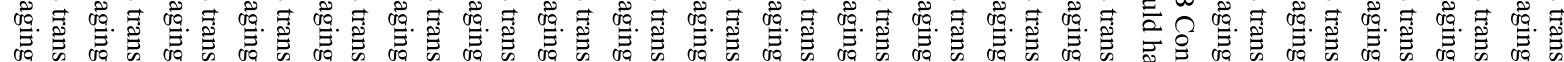

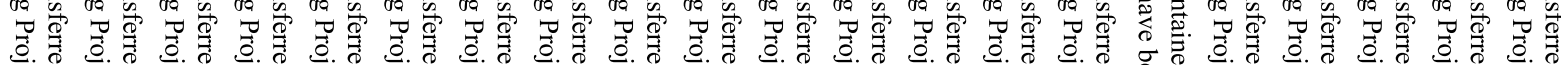

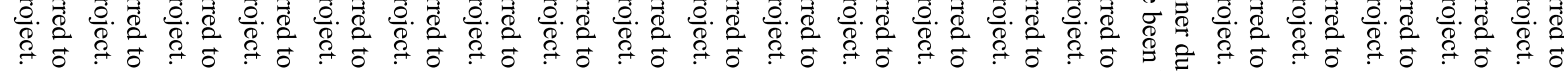

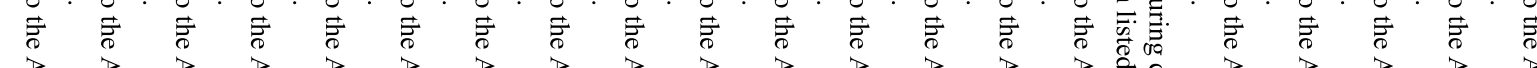




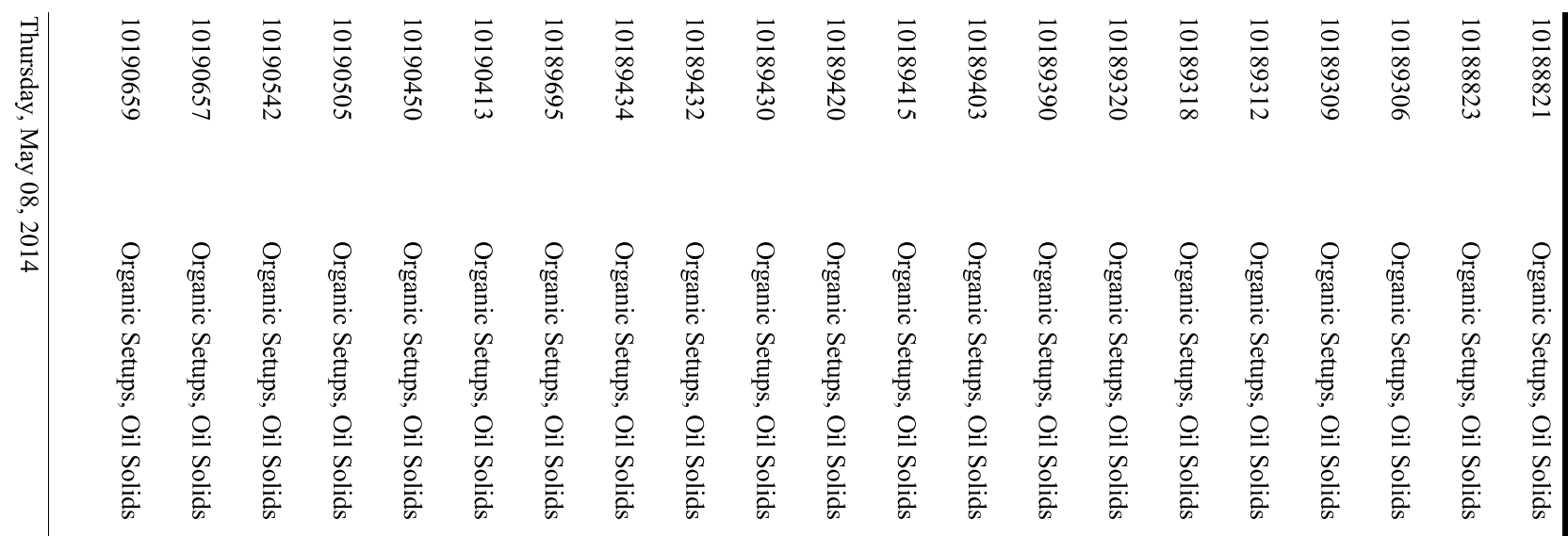

崩 岕 崩

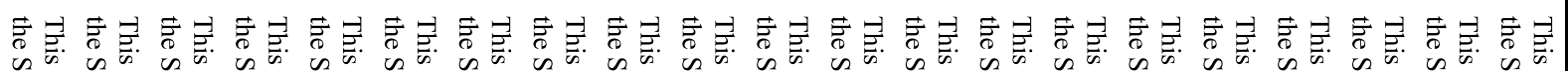

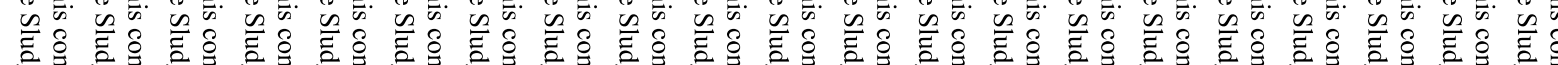

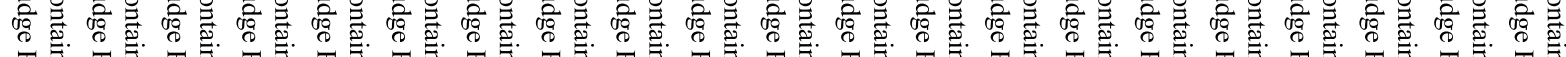

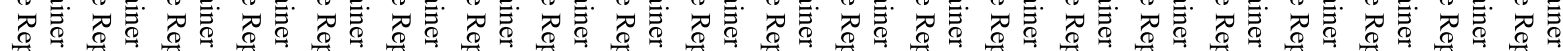

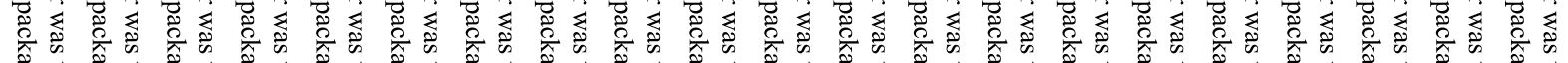

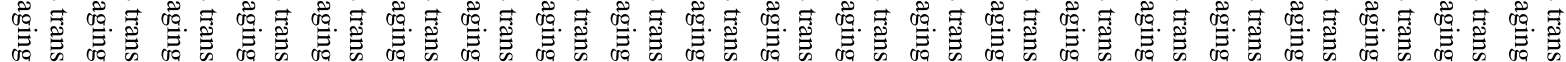

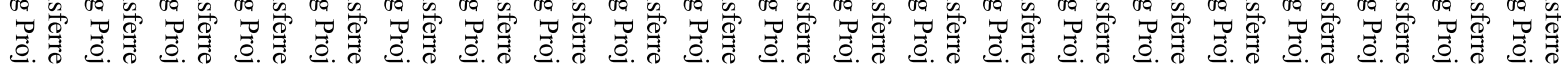

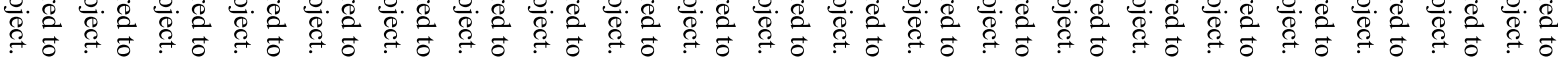

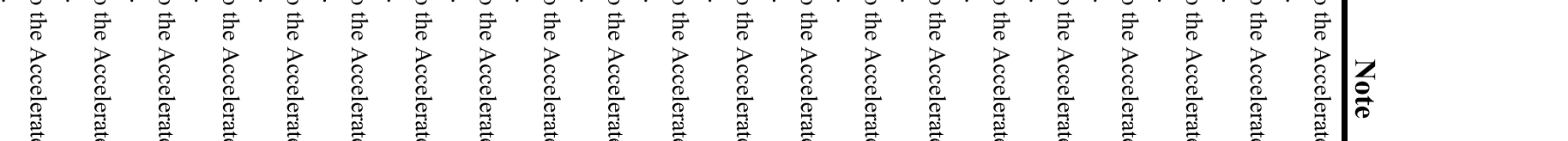




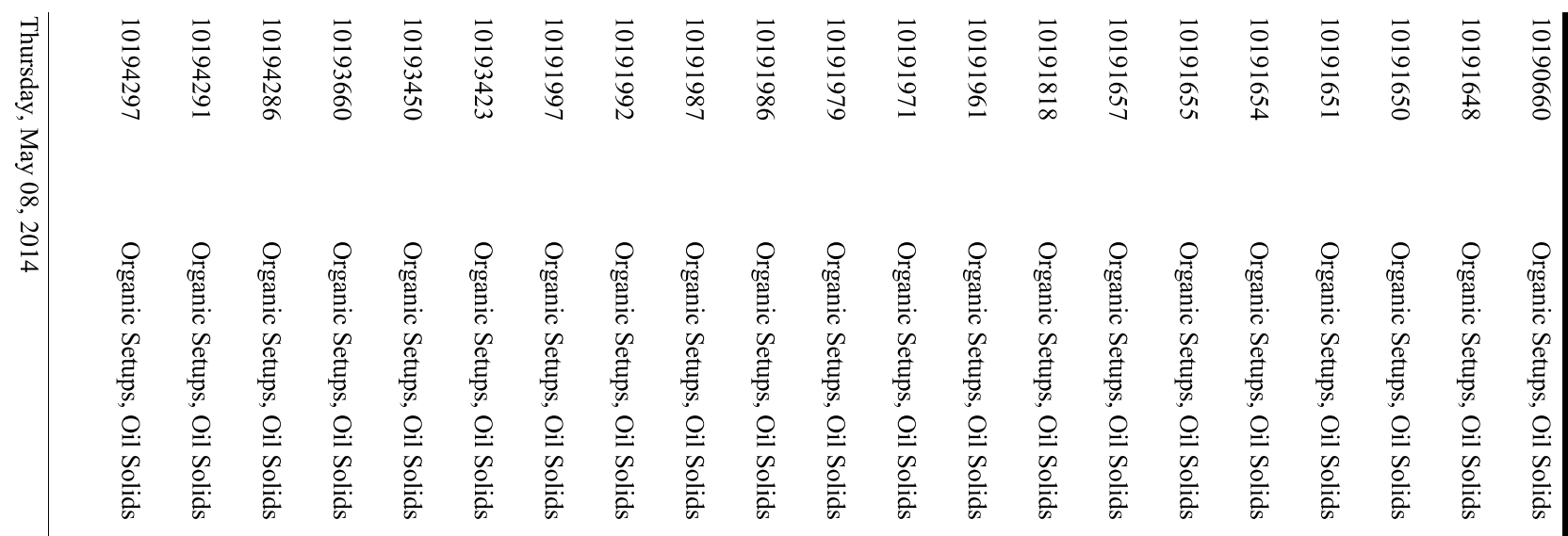

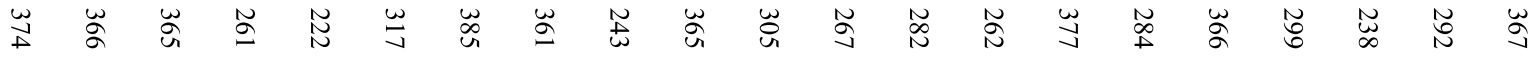

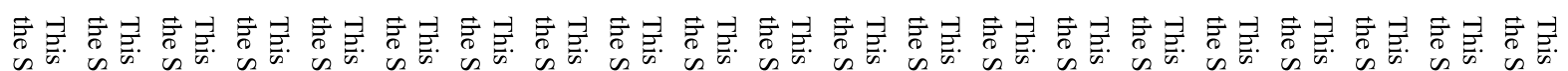

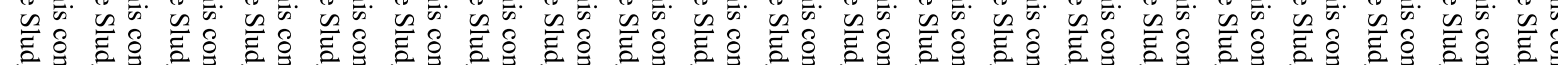

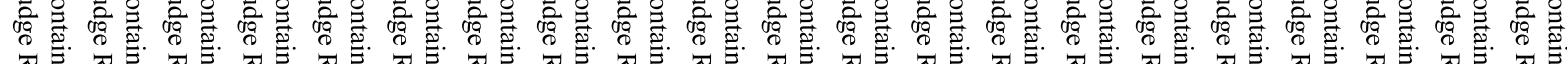

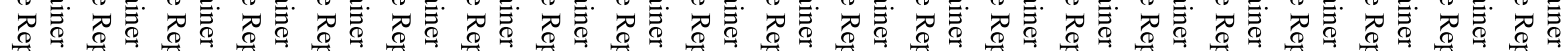

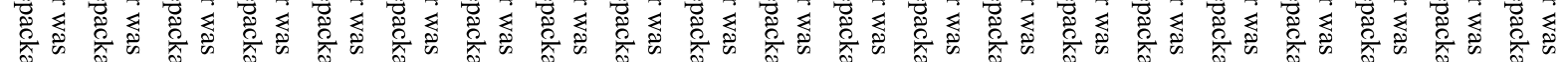

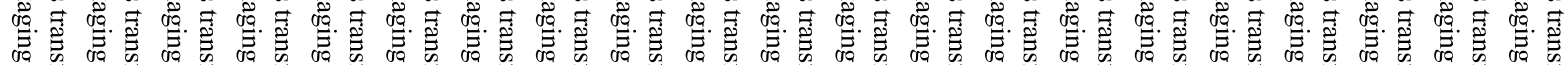

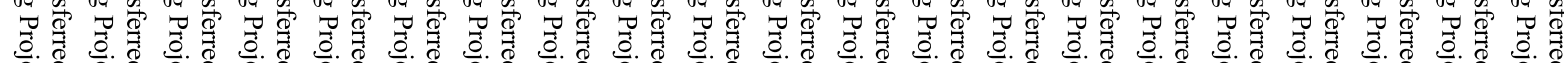

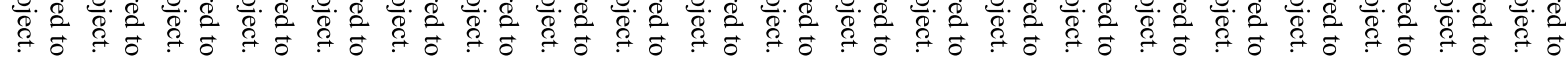

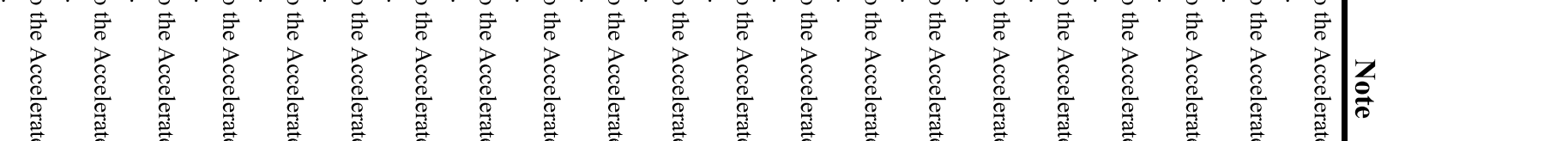




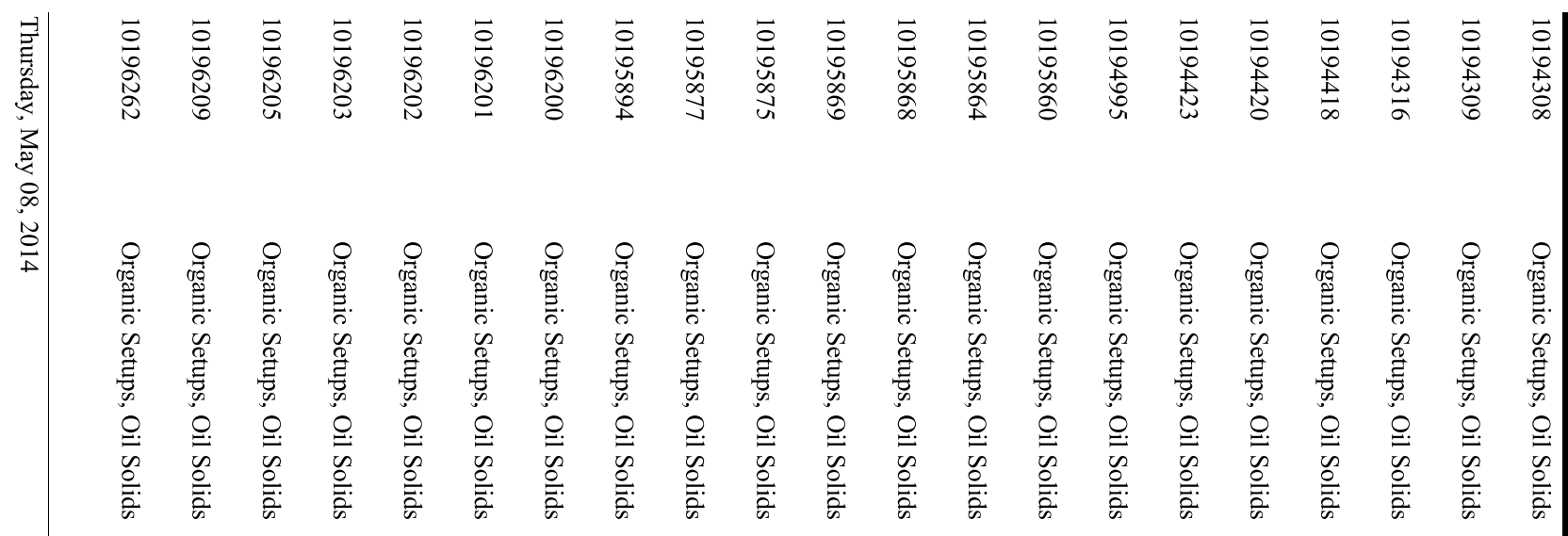

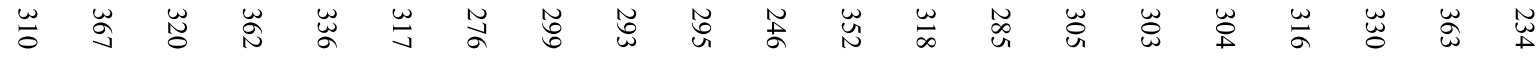

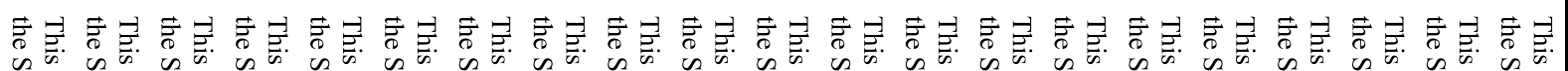

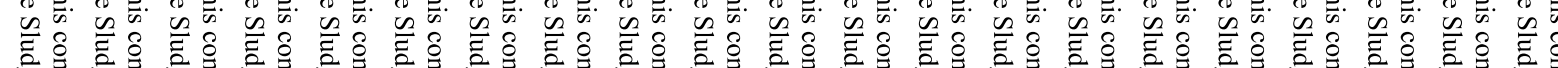

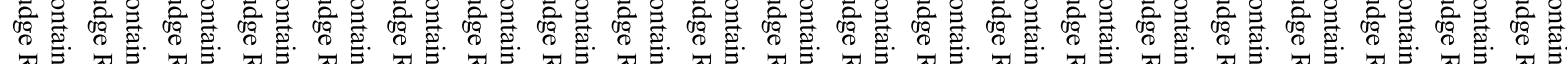

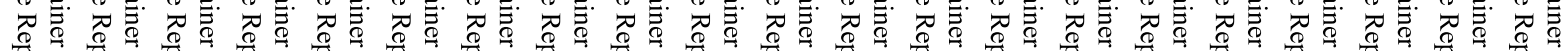

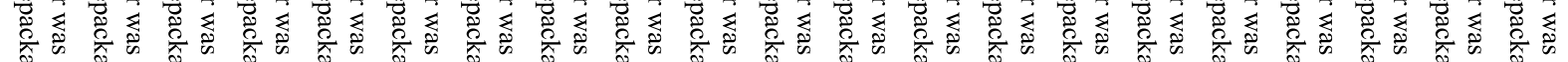

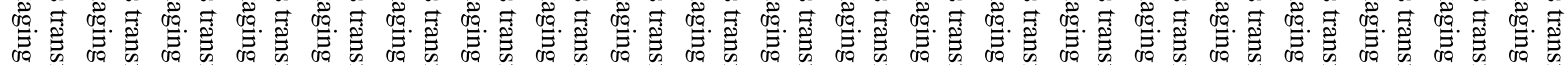

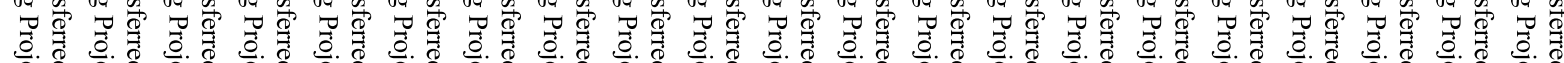

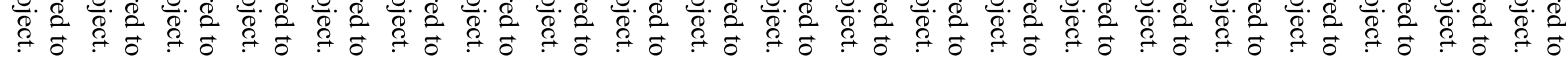

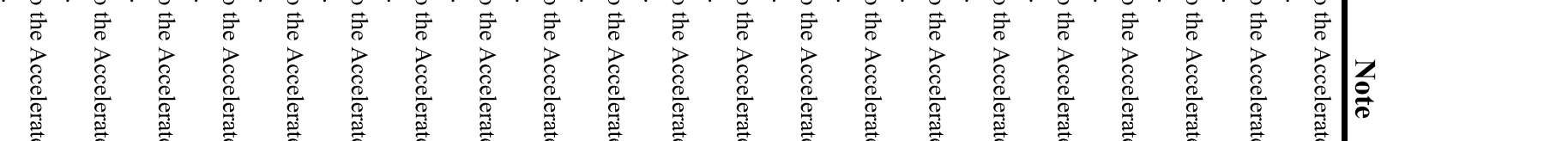




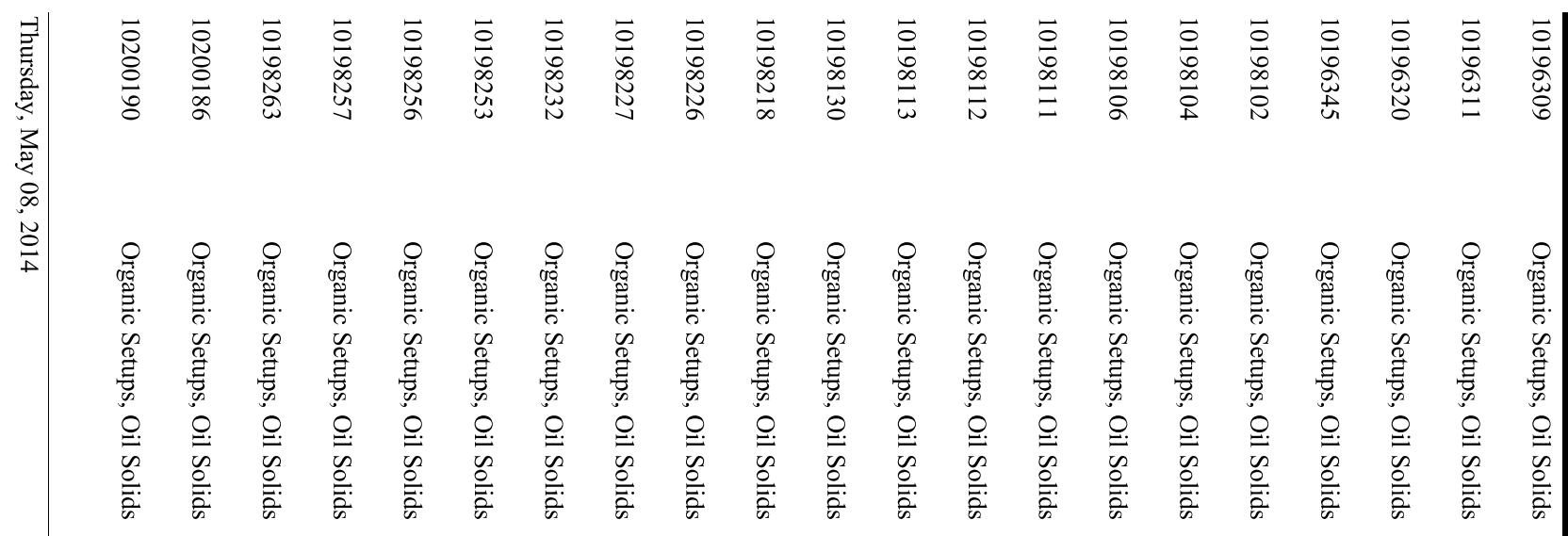

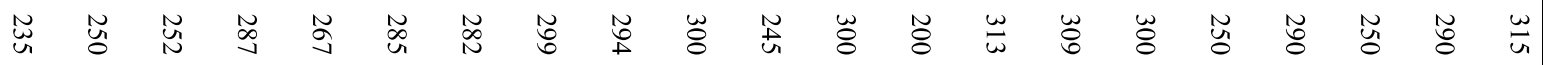

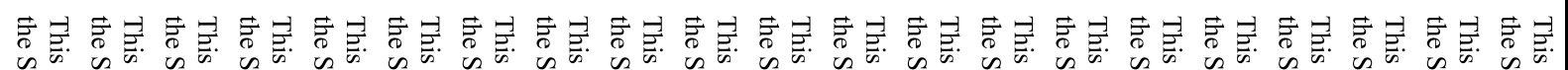

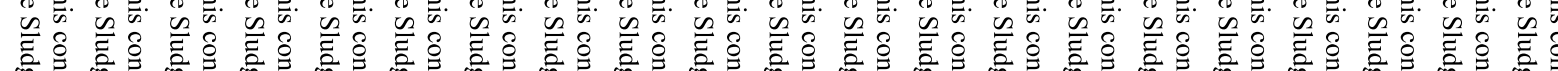

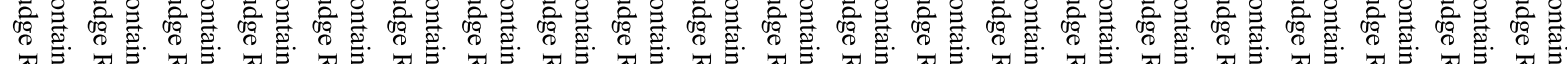

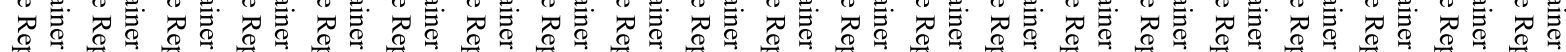

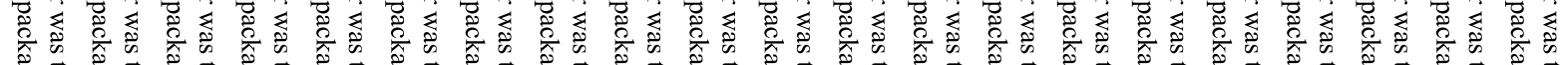

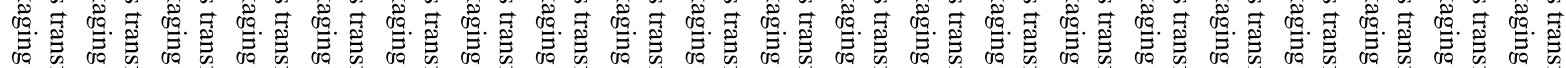

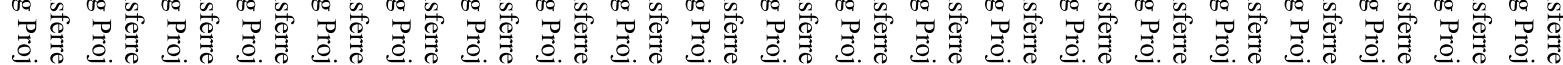

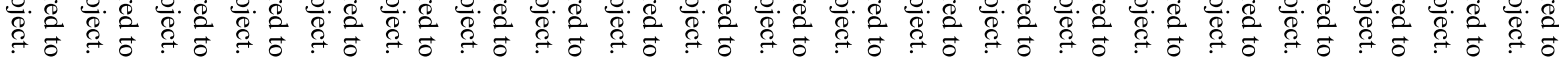

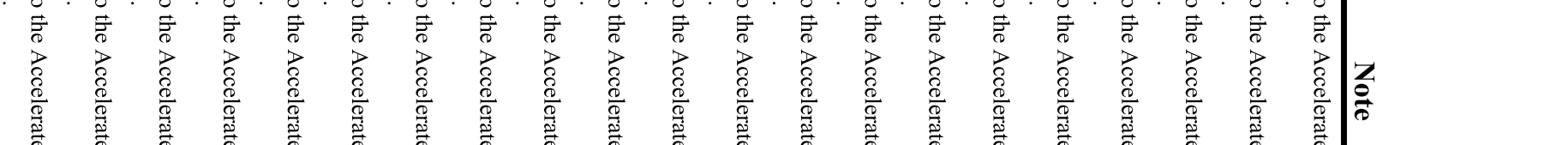




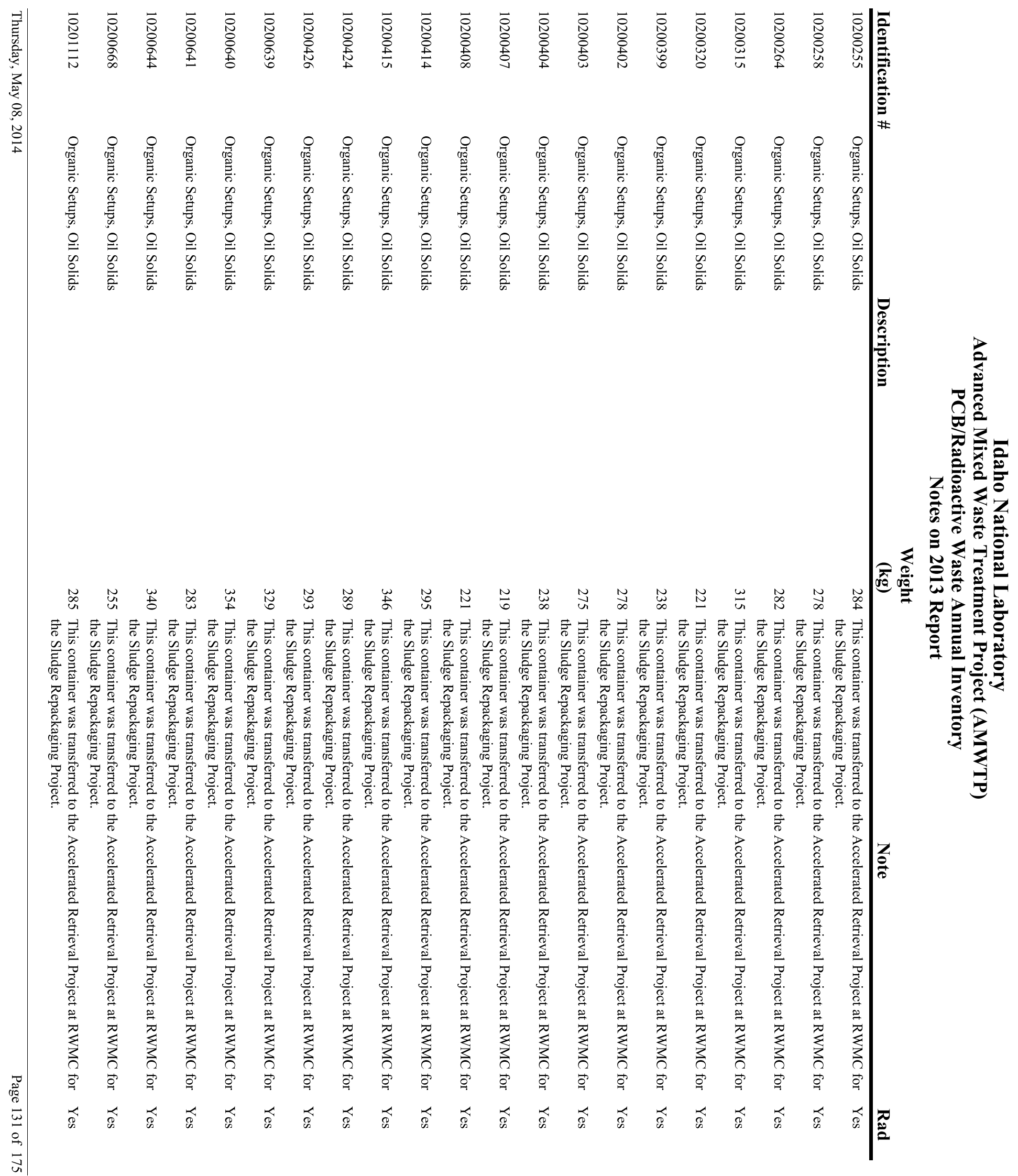




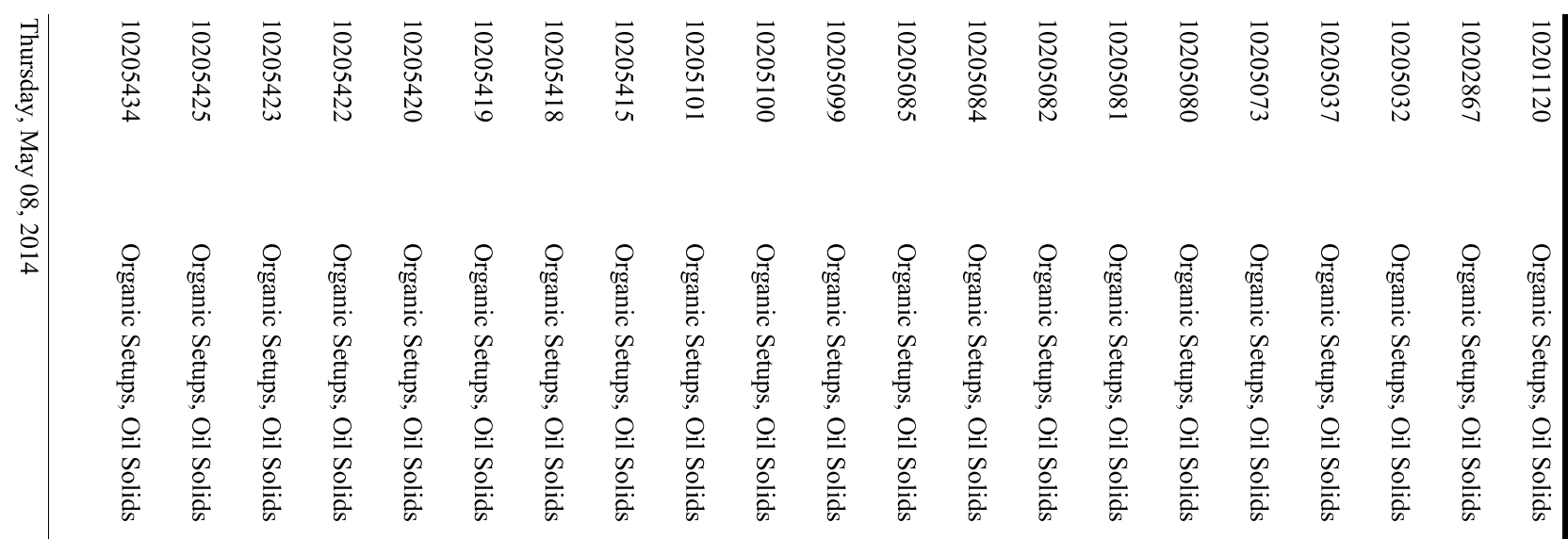

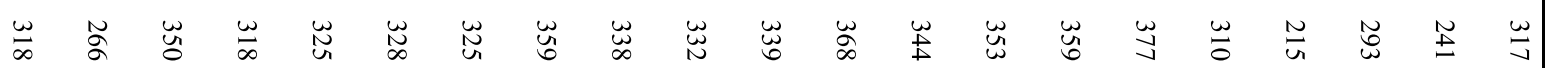

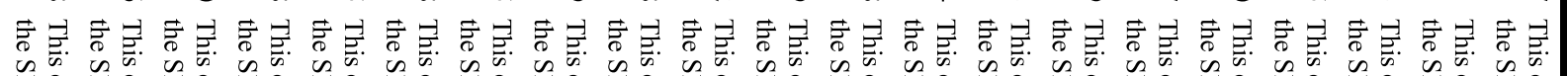

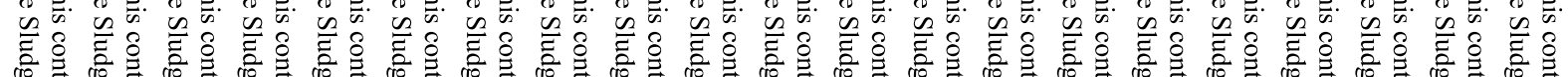

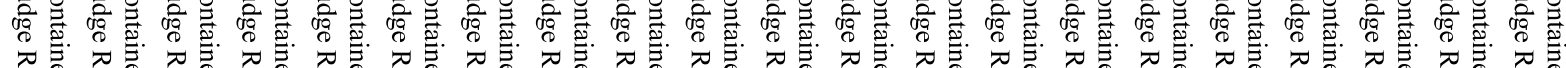

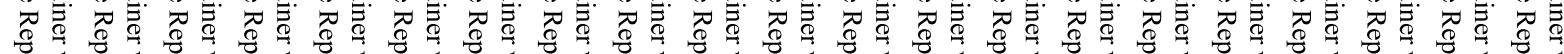

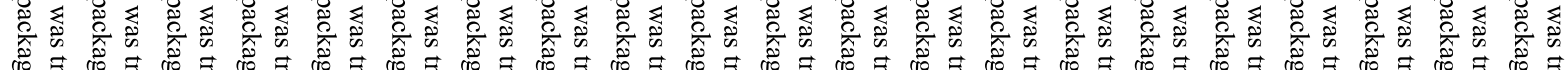

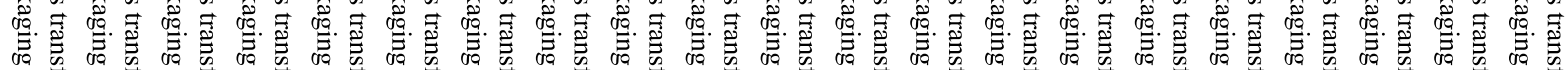

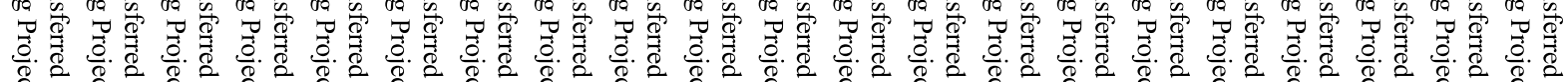

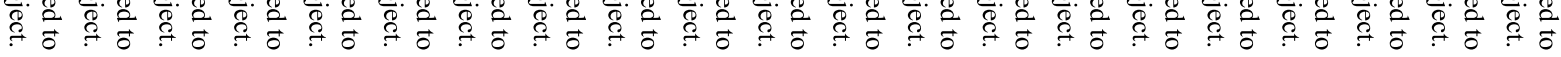

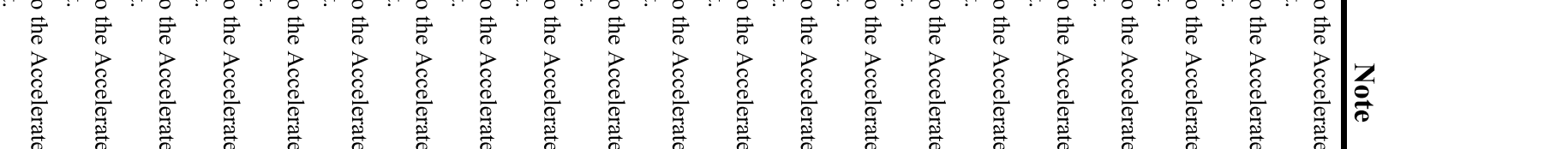




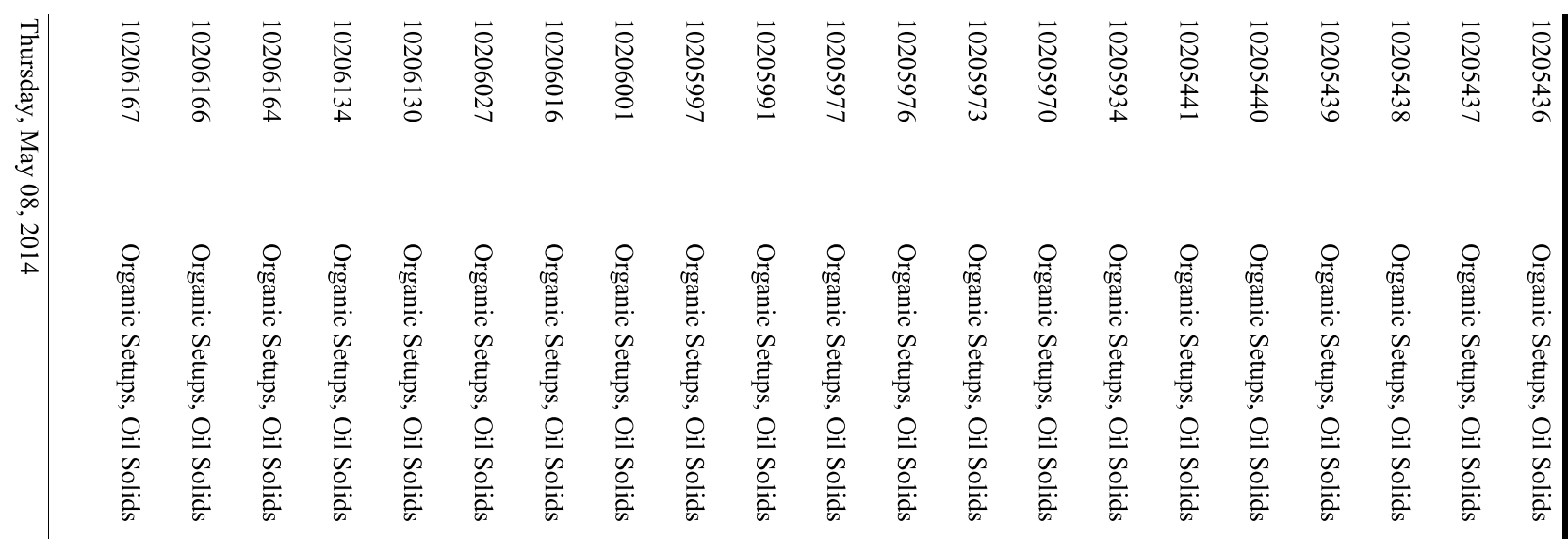

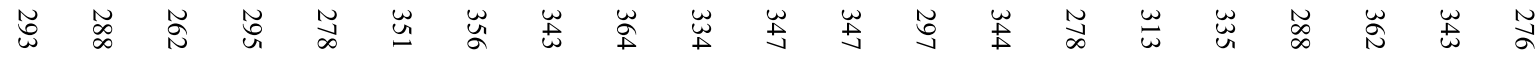

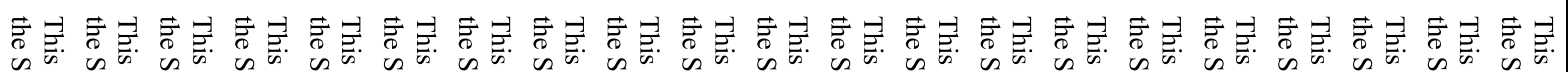

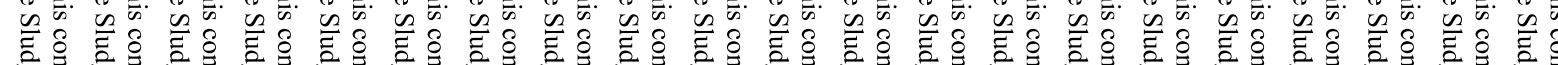

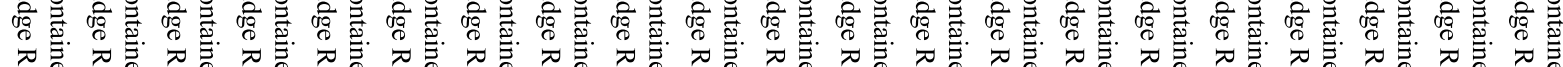

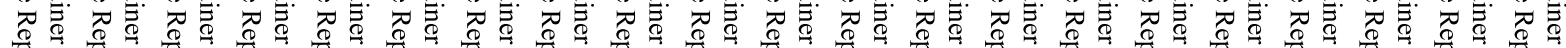

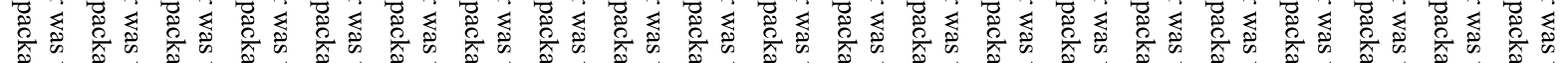

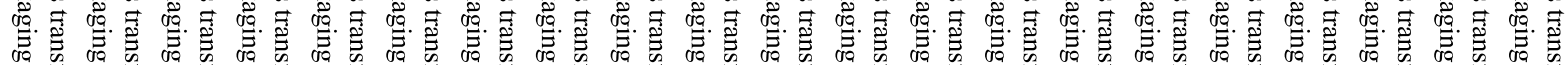

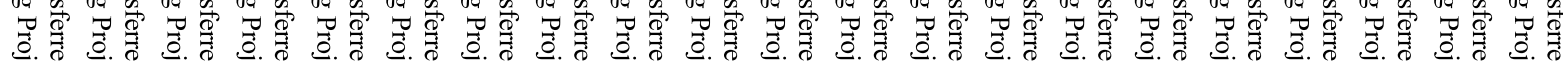

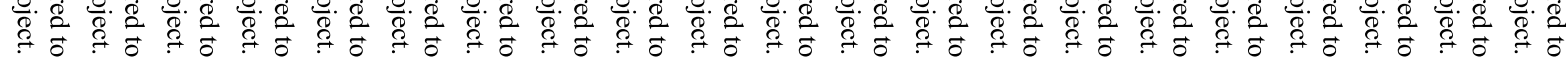

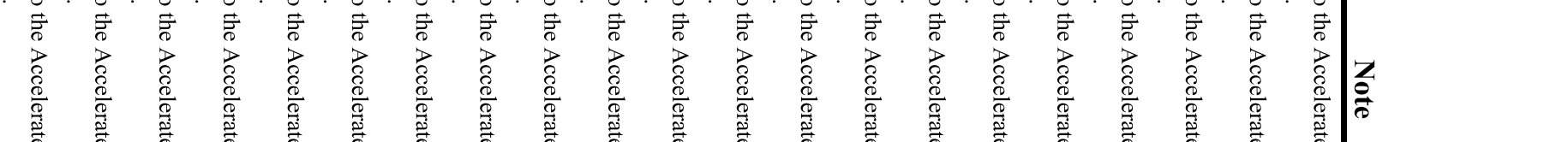




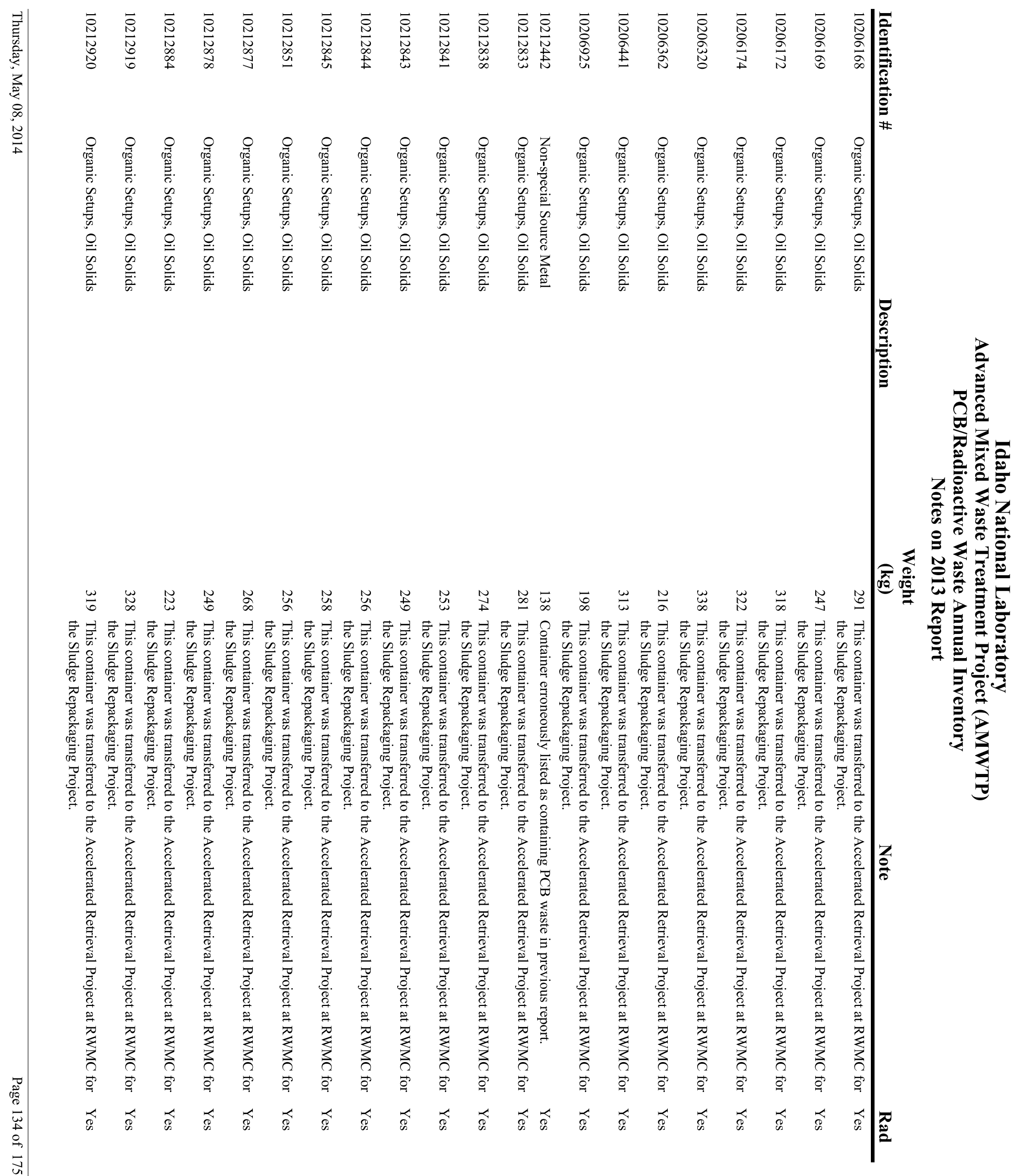




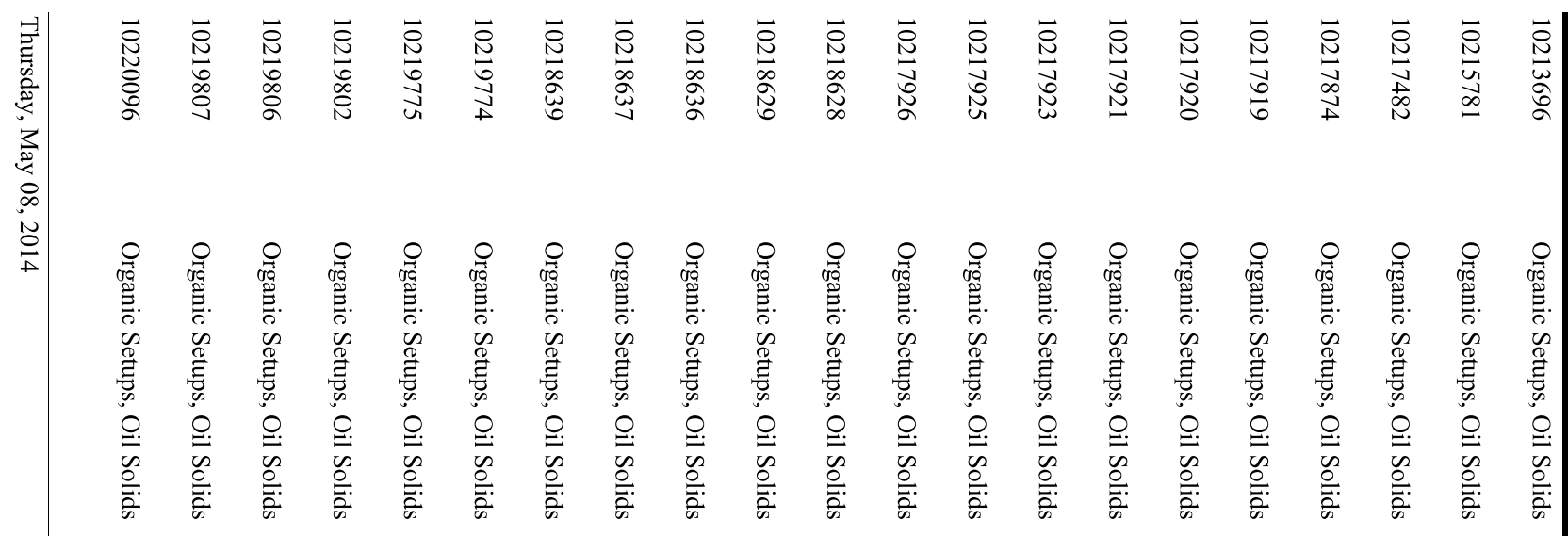

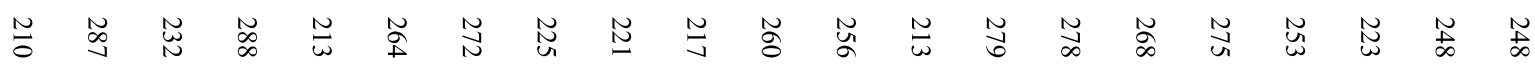

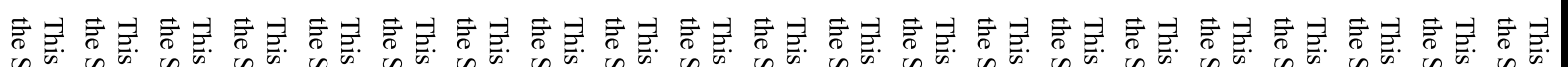

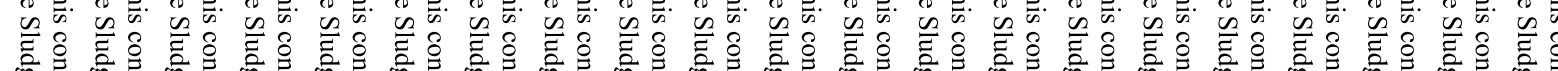

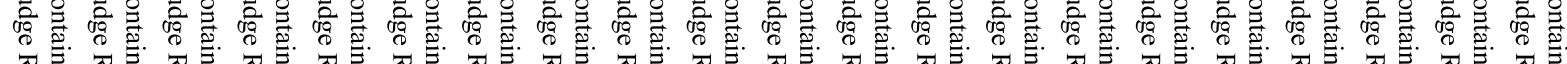

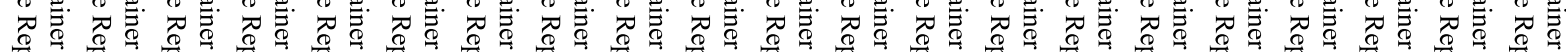

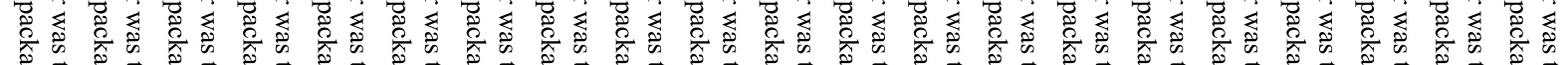

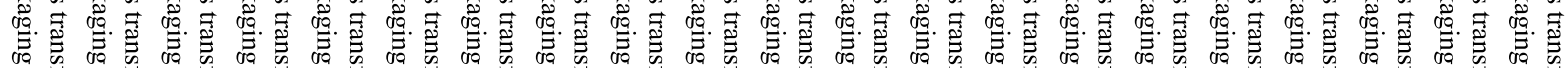

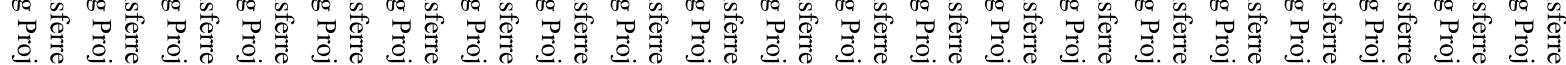

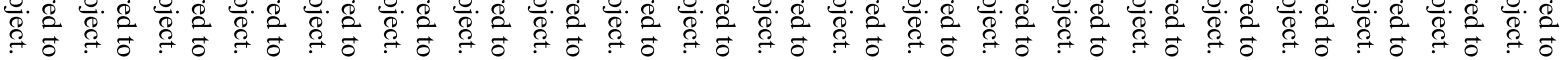

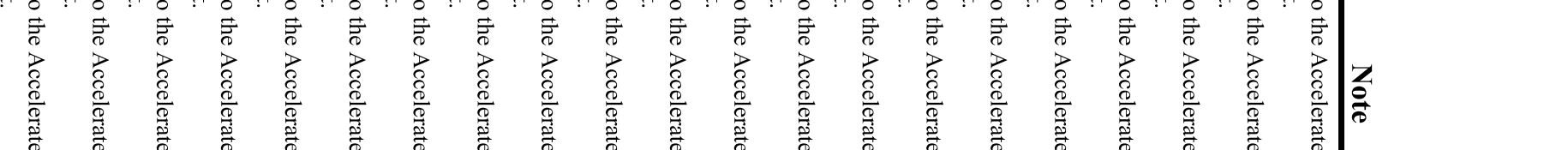




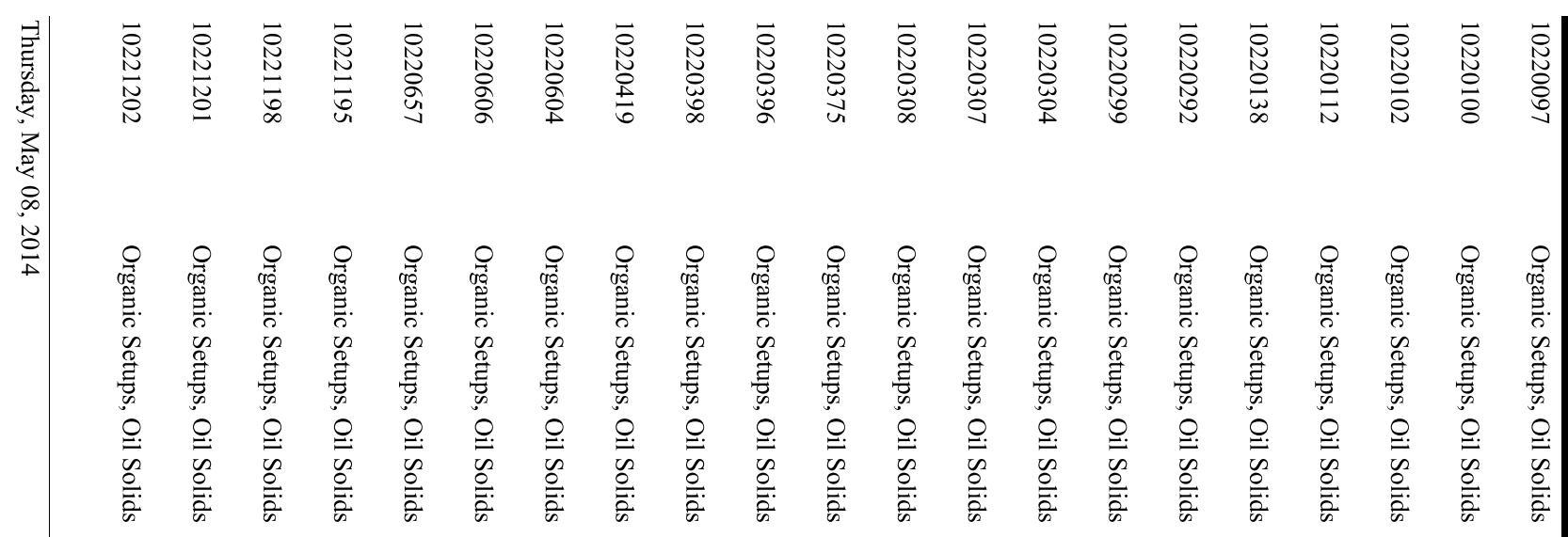

崩 范 N

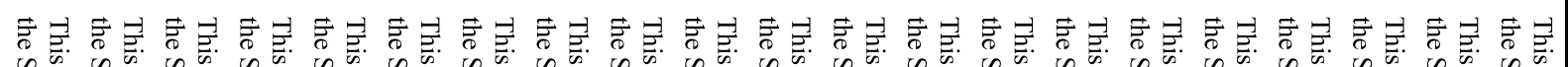

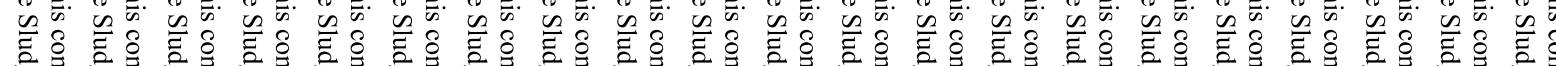

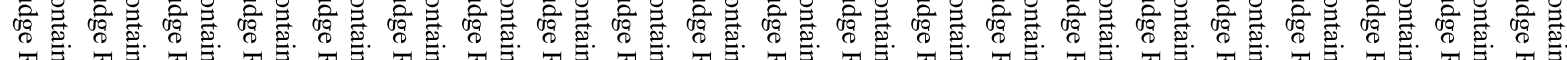

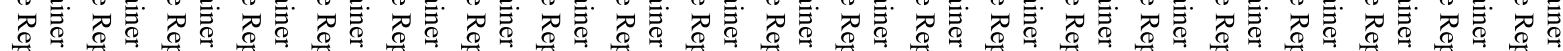

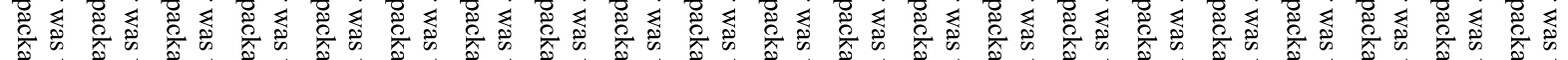

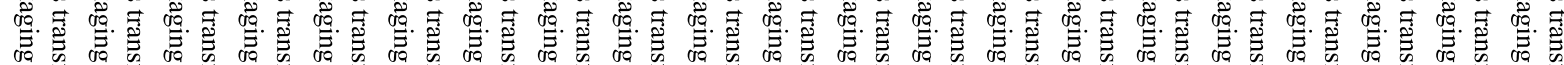

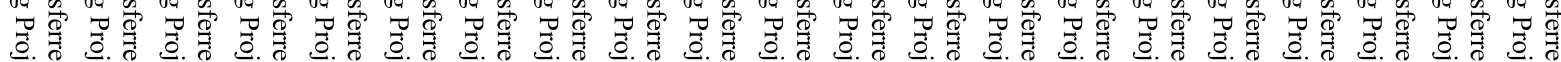

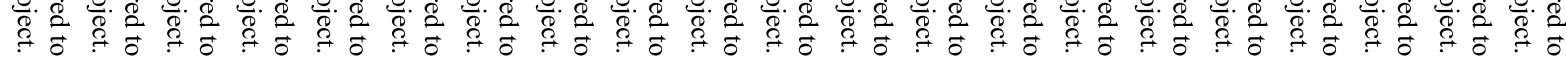

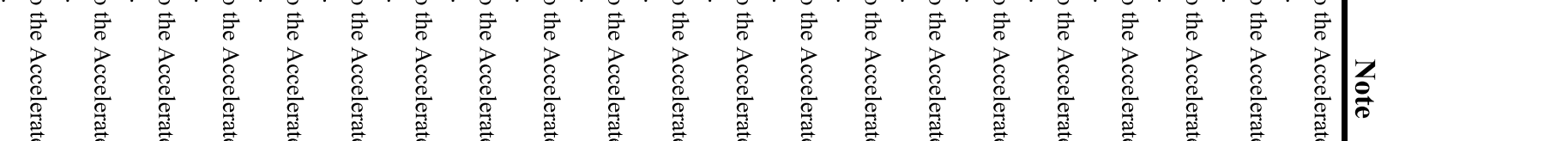




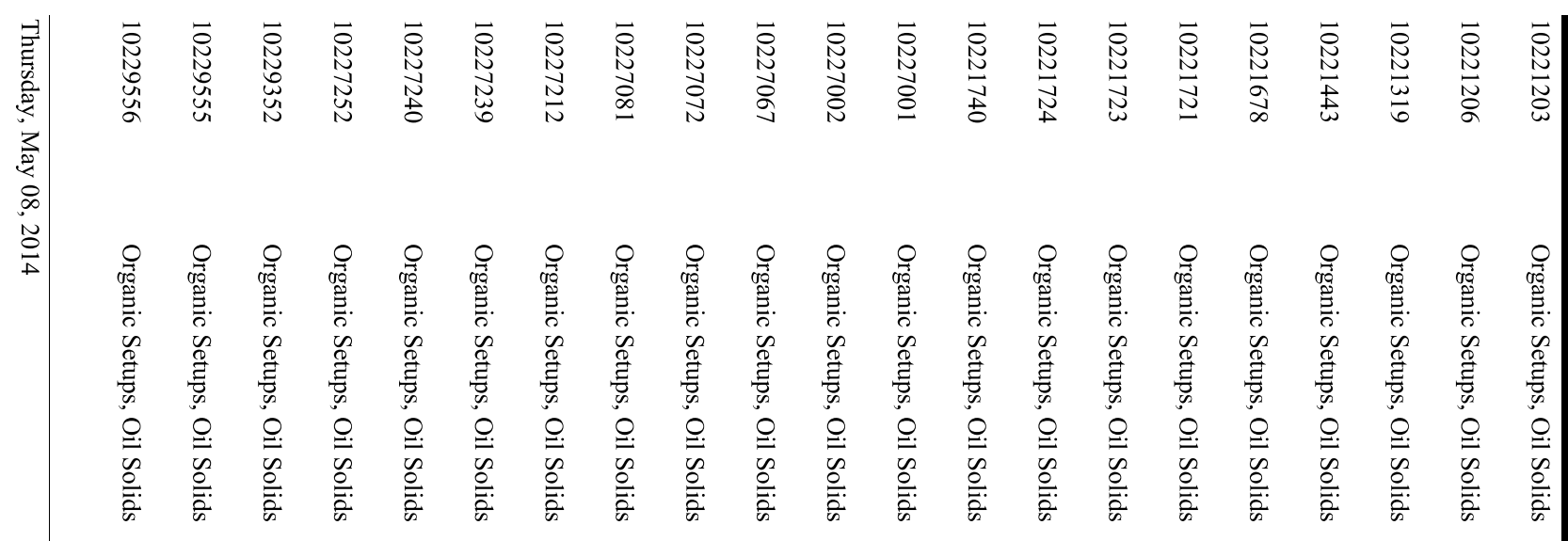

$\tilde{\sigma} \cong \tilde{\Phi}$

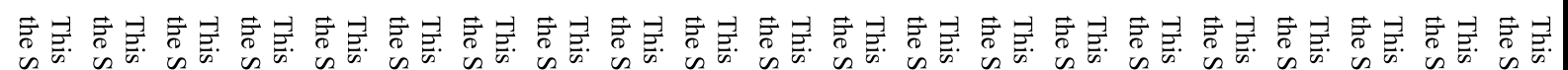

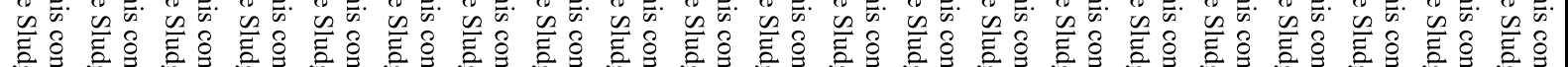

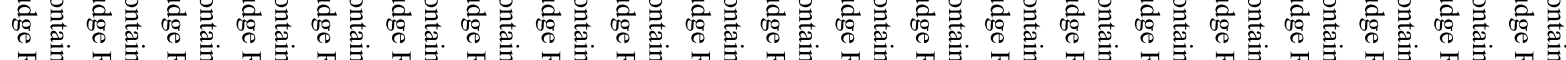

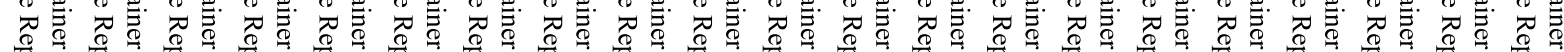

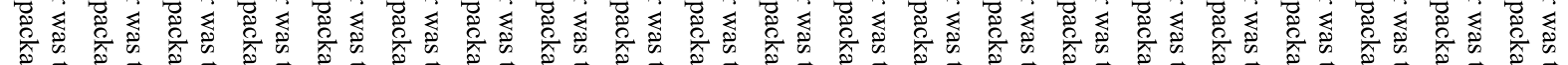

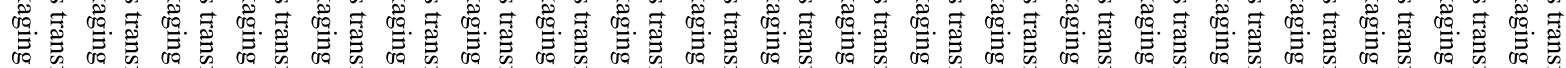

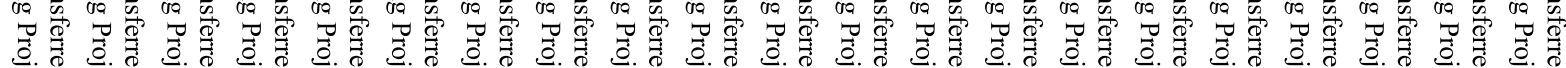

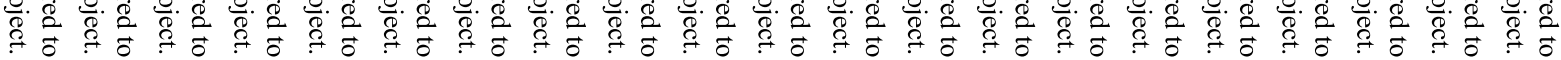

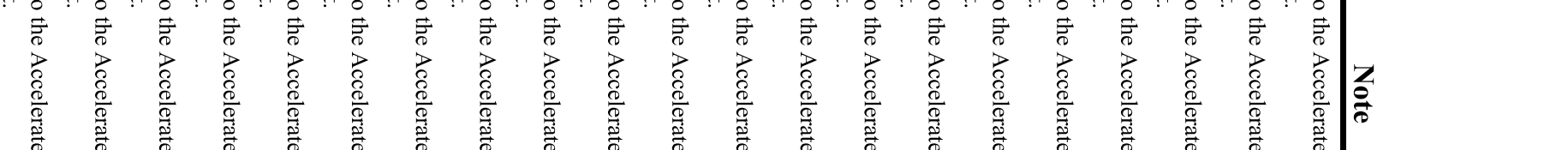




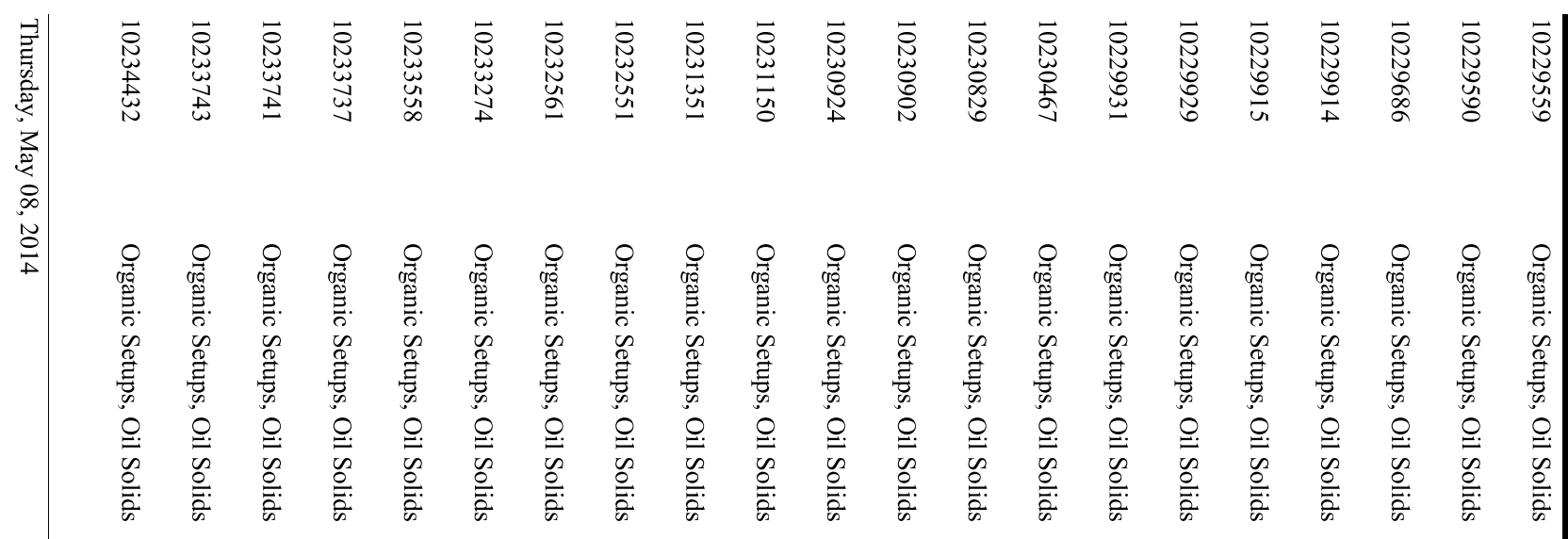

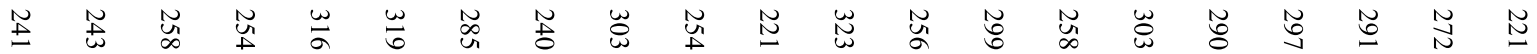

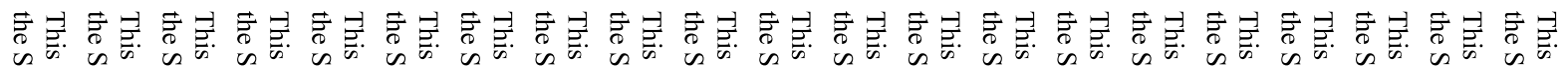

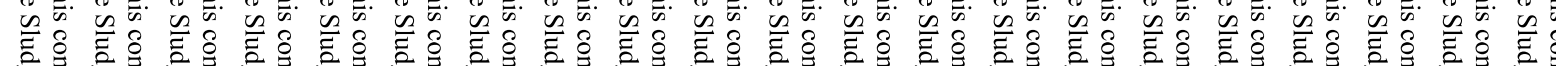

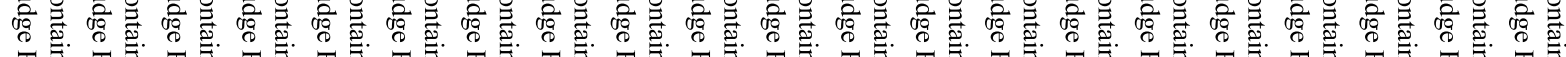

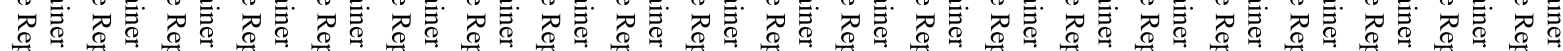

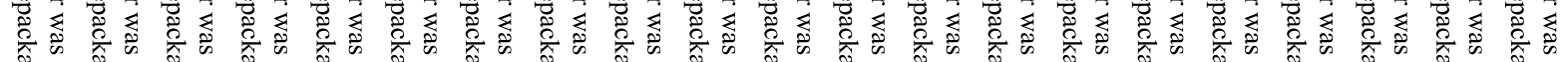

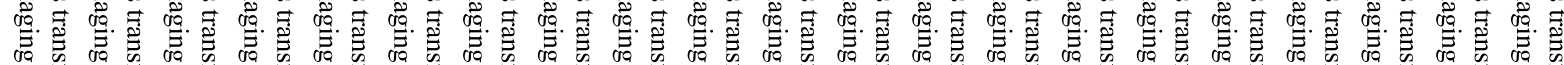

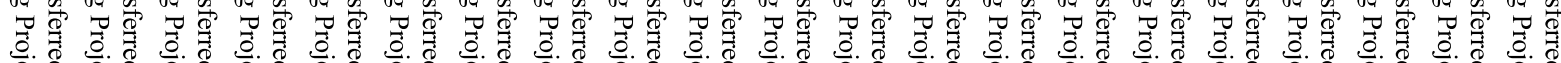

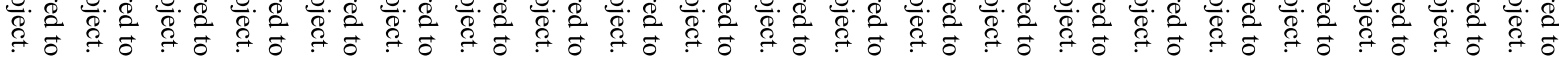

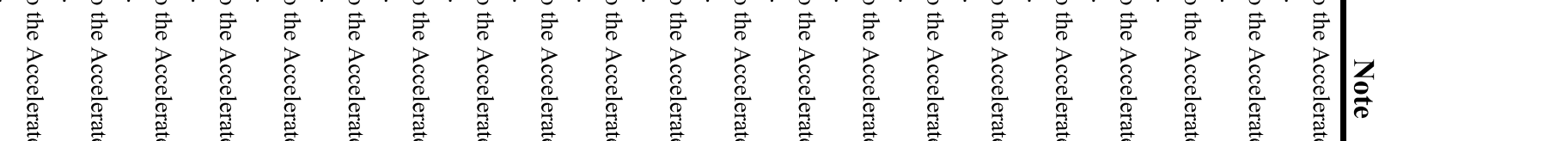




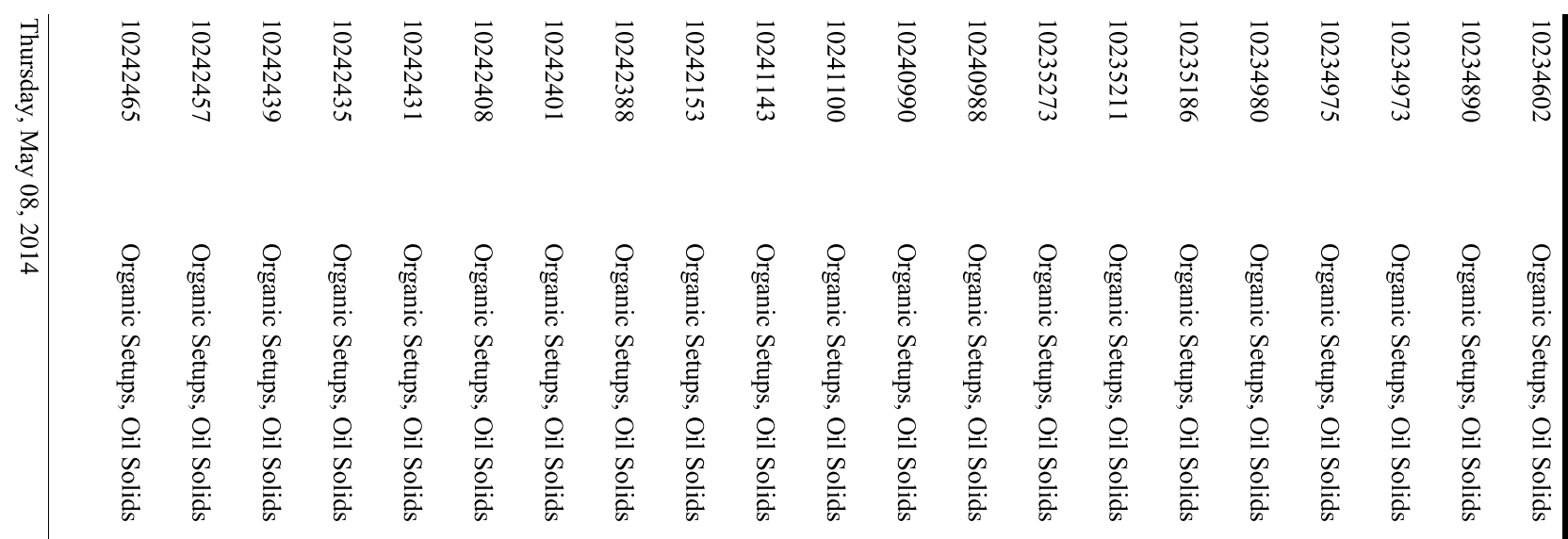

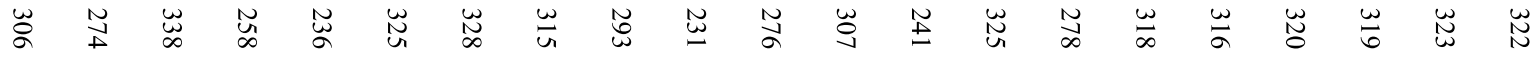

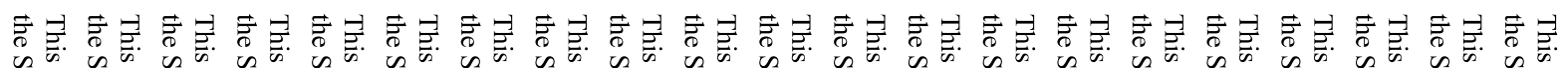

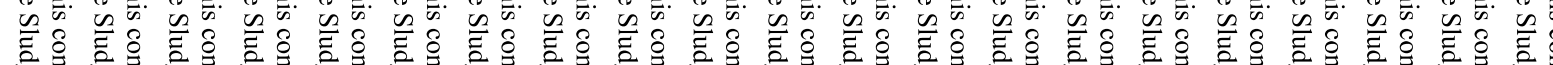

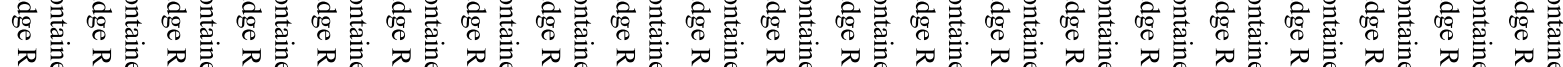

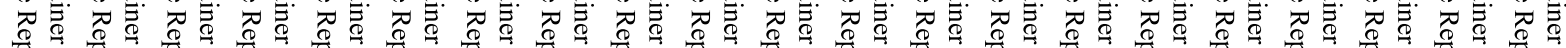

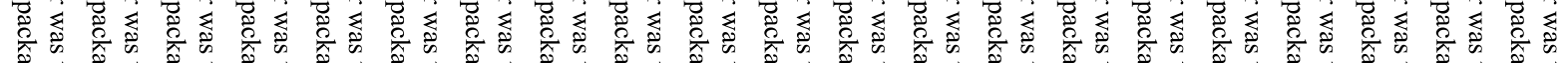

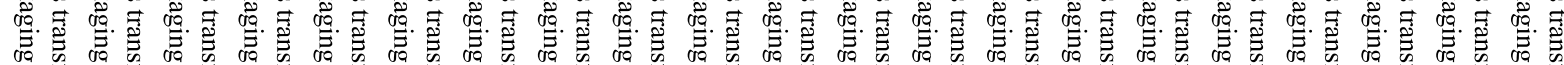

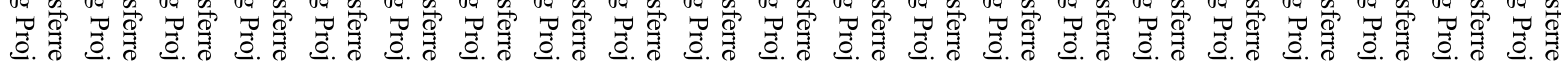

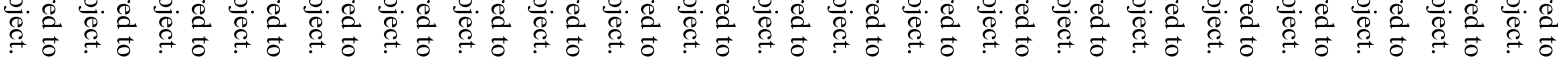

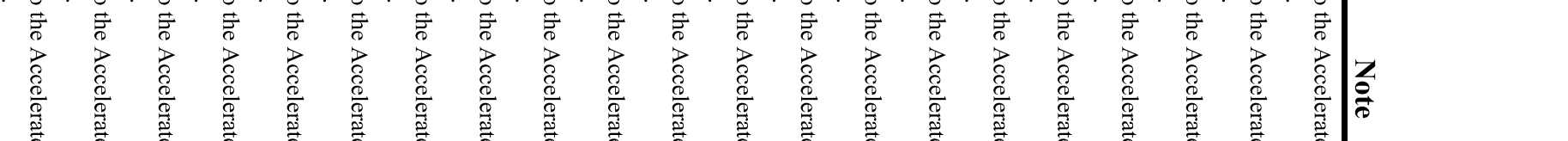




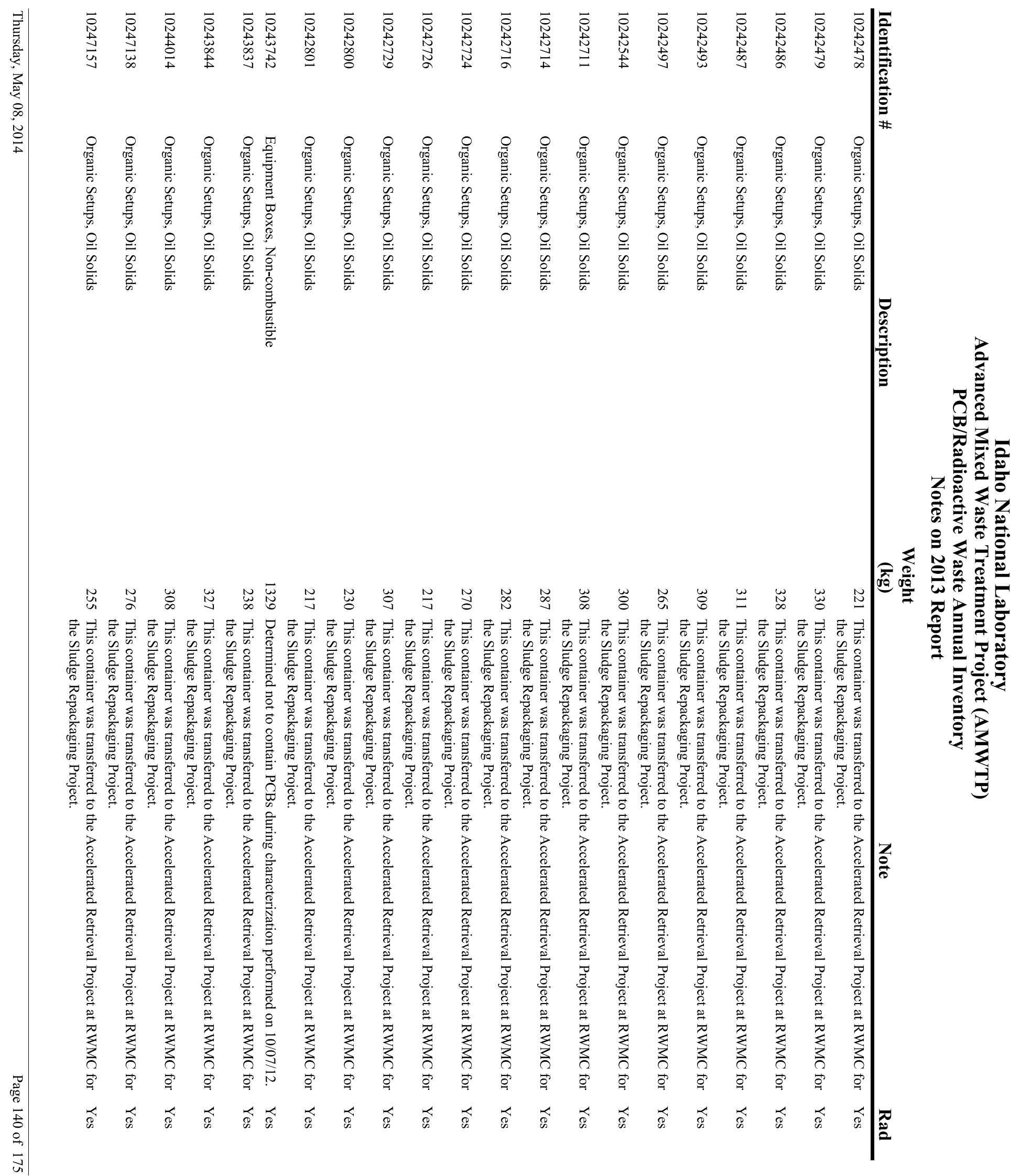




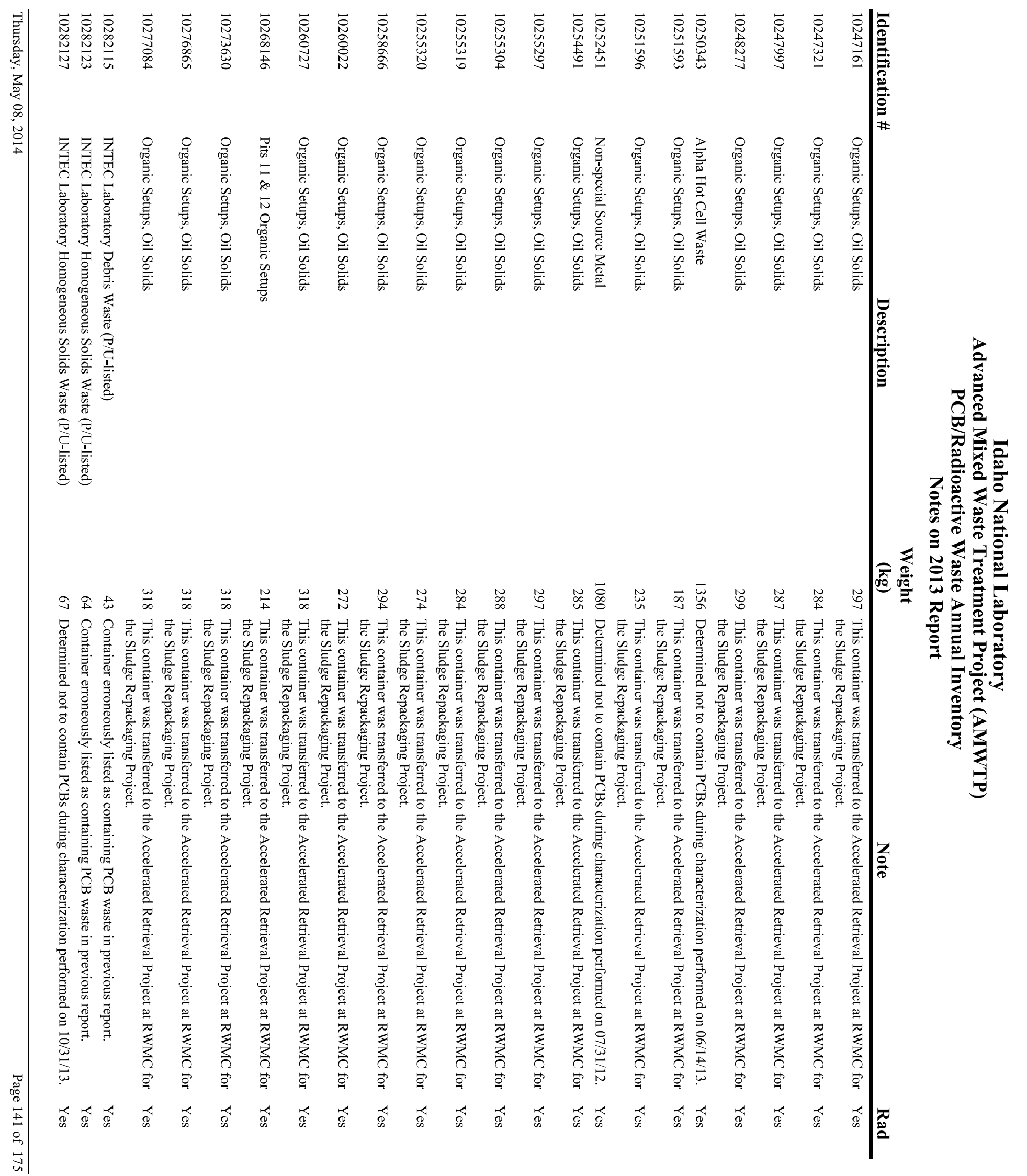




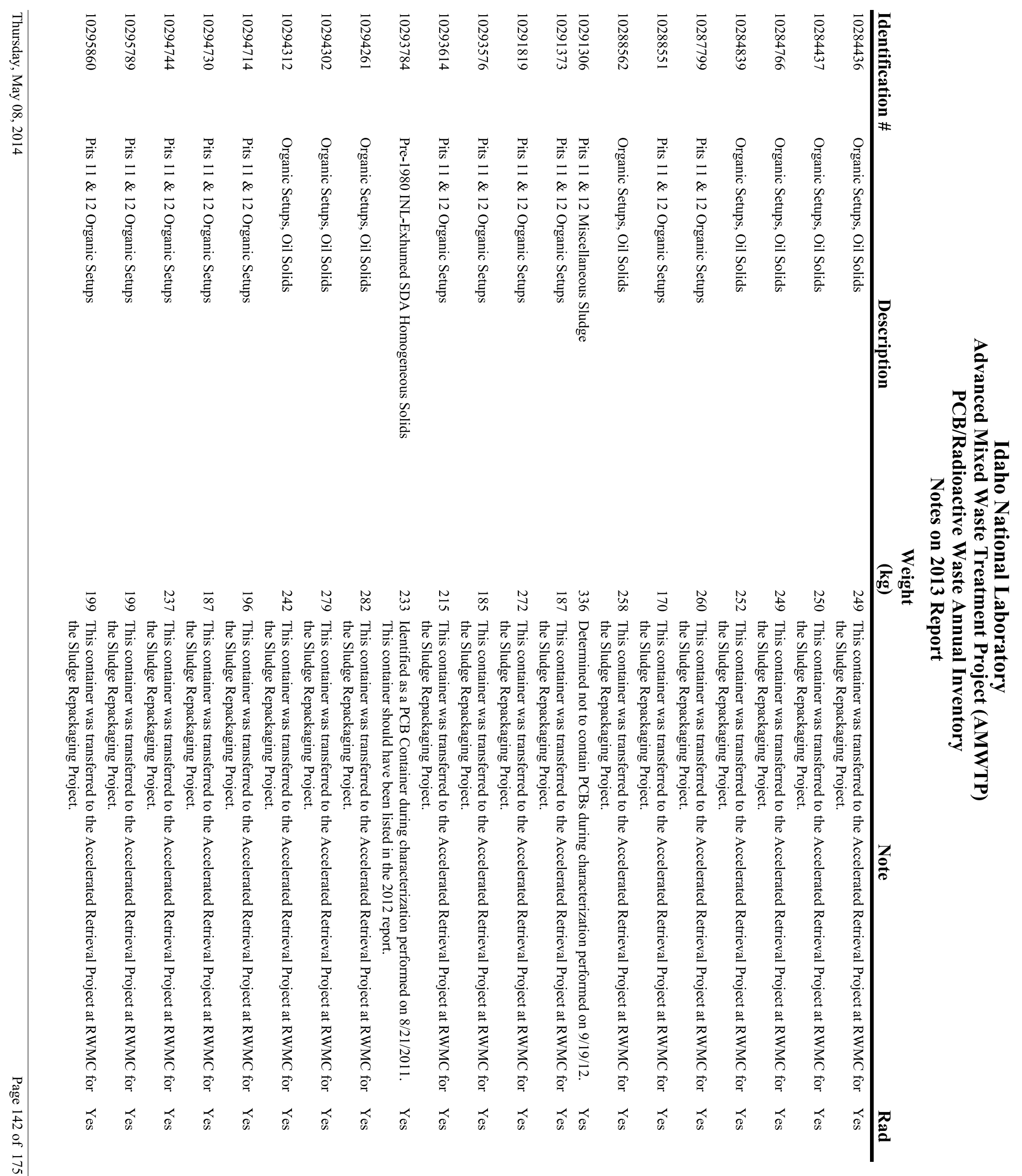




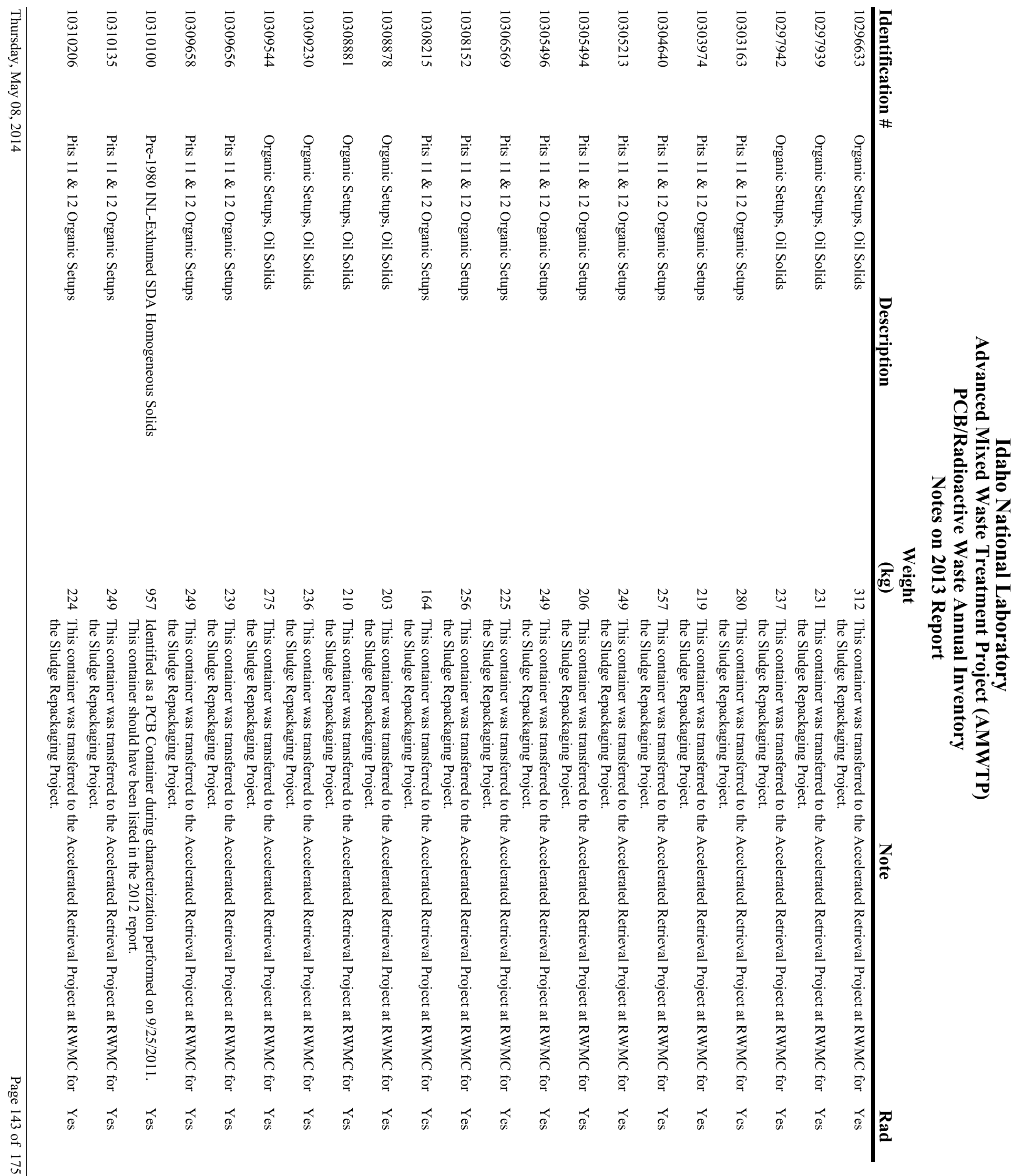




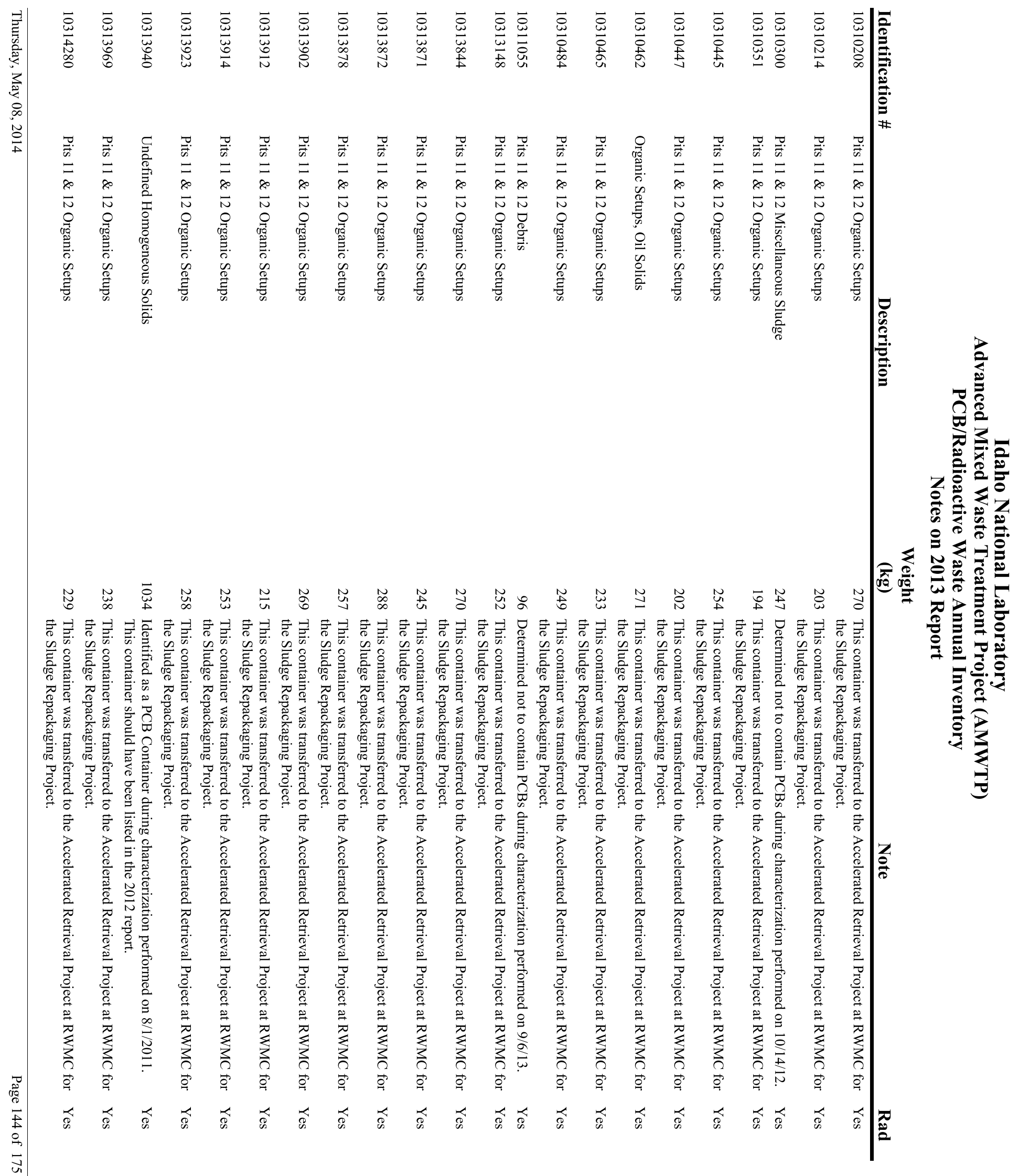




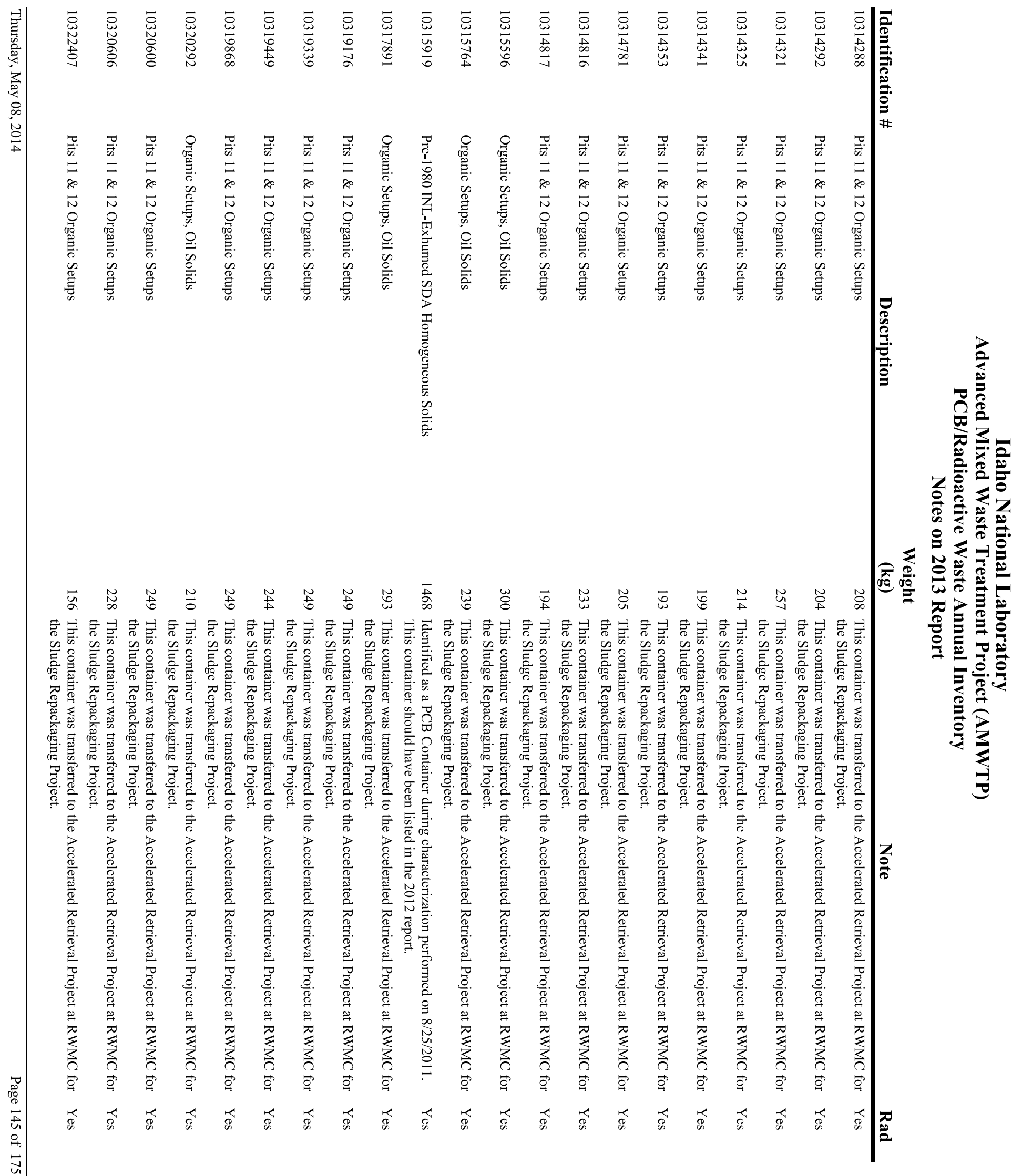




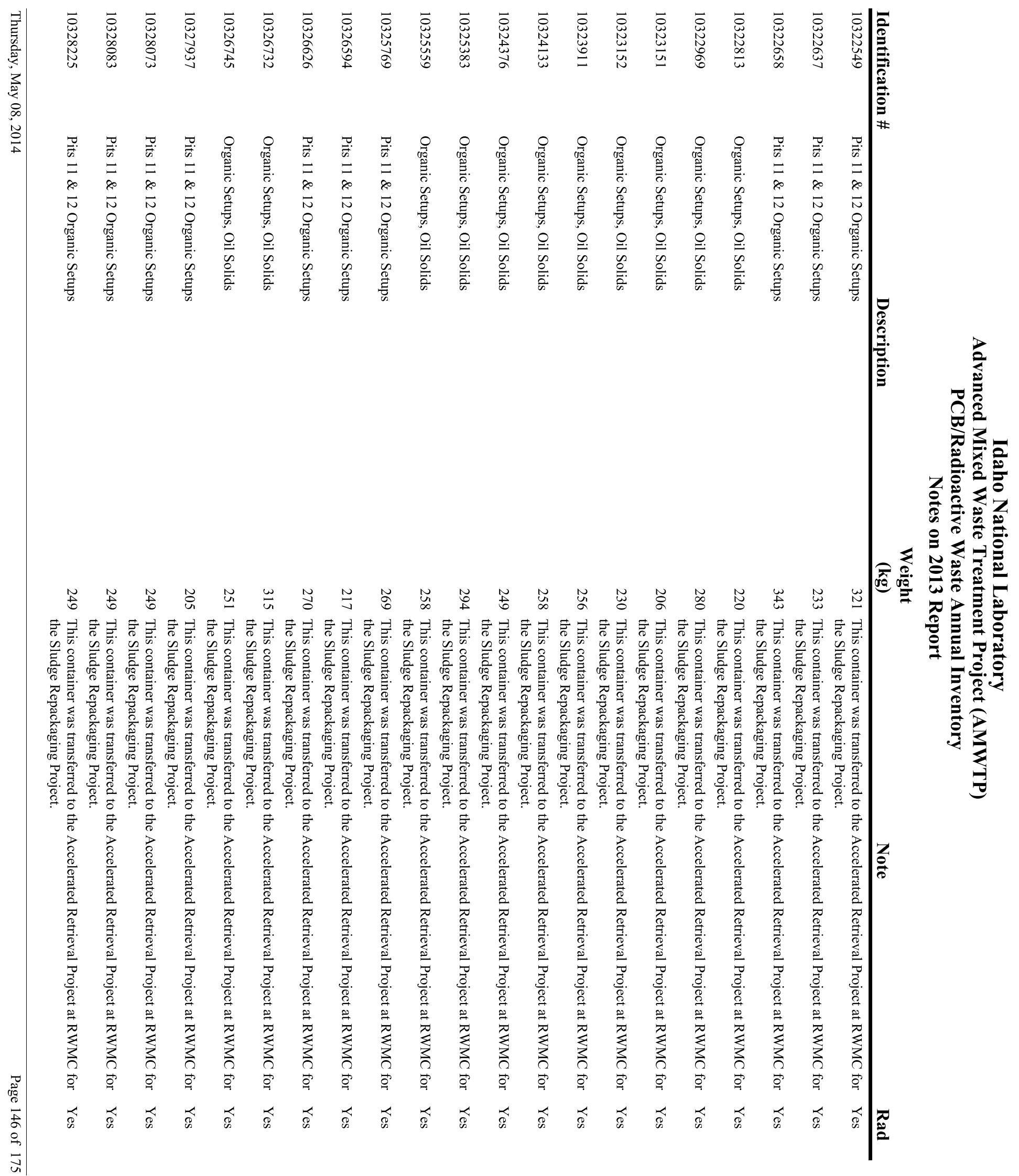




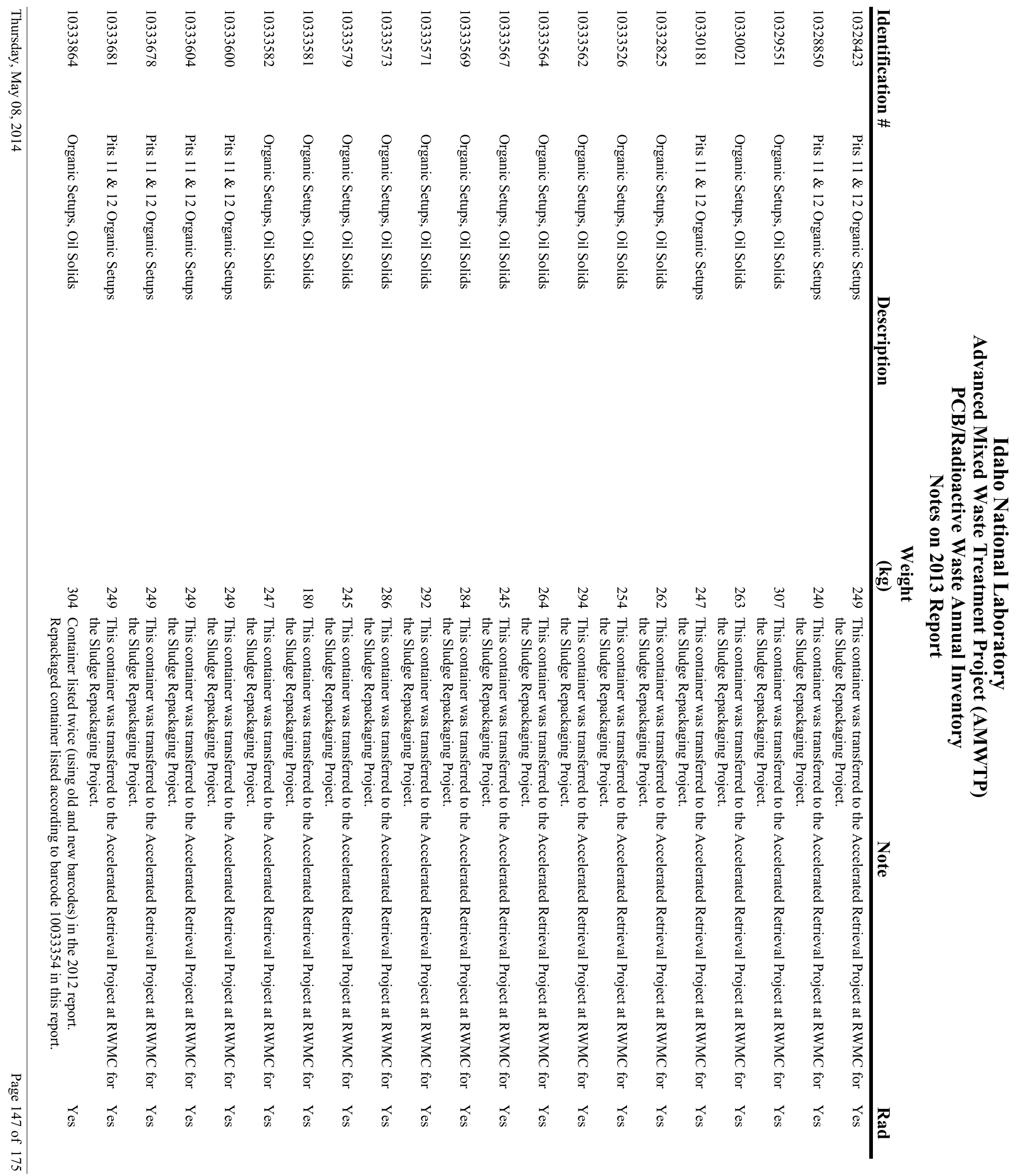




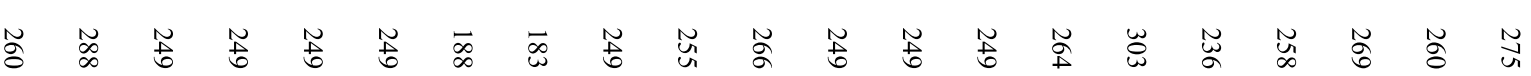

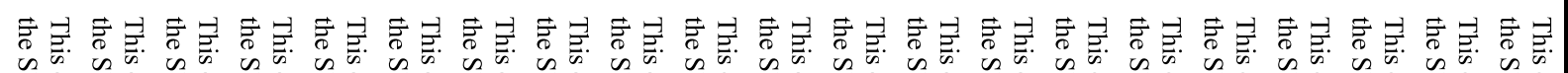

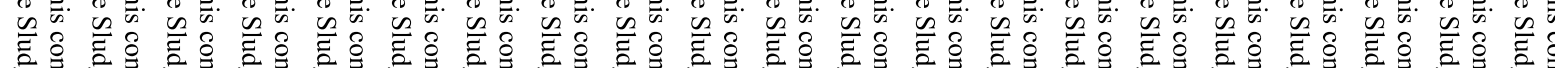

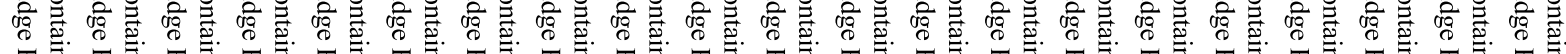
不

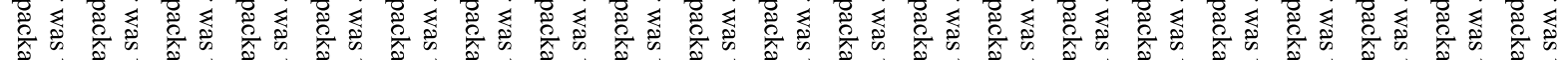

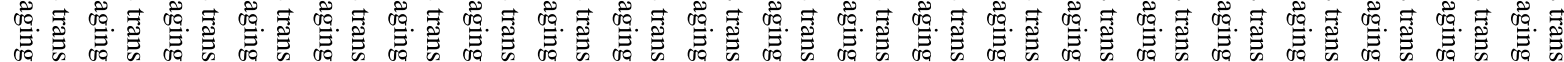

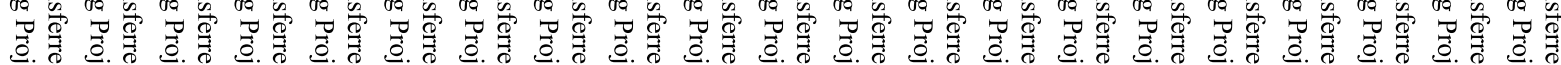

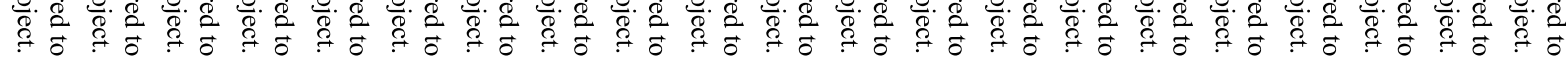




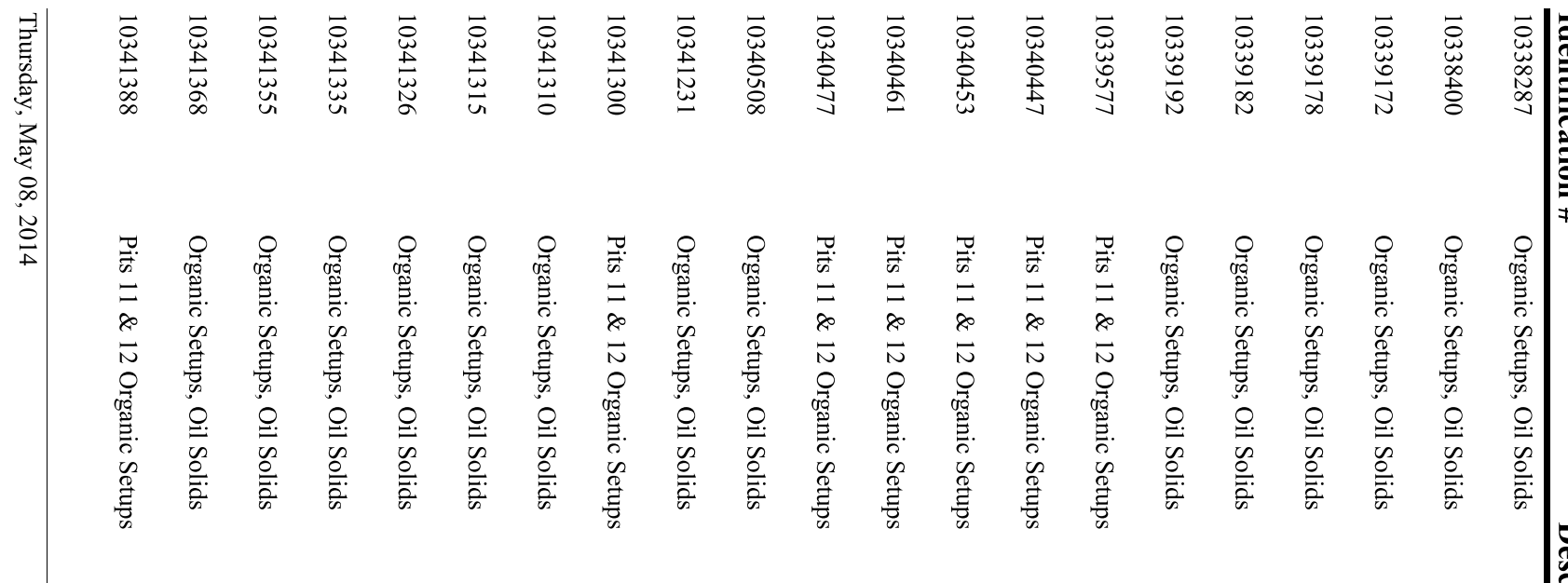

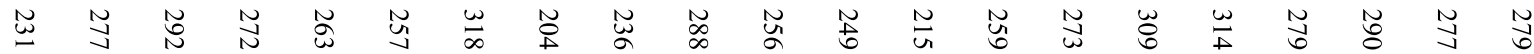

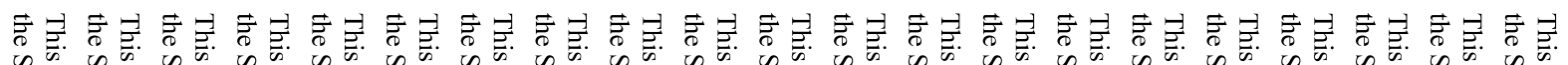

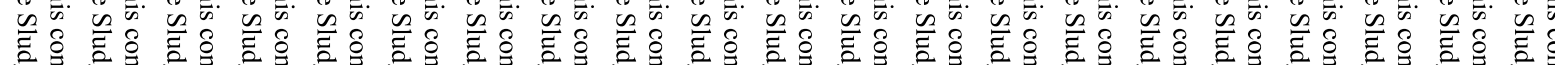

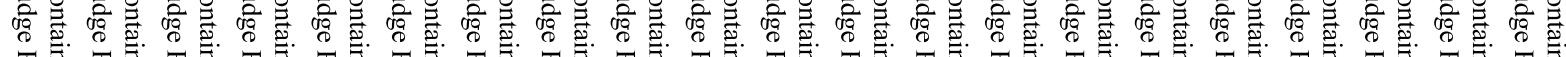

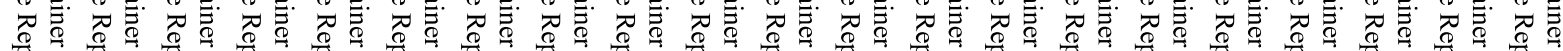

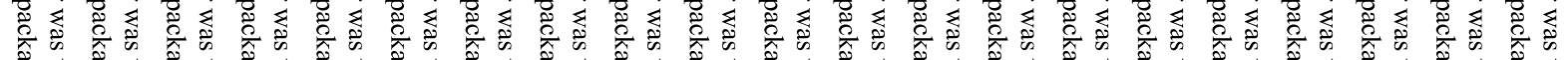

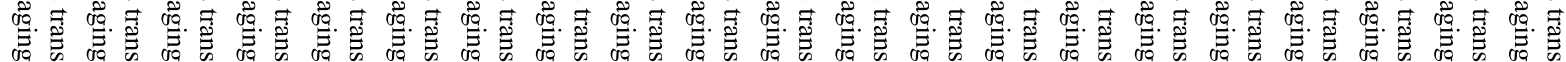

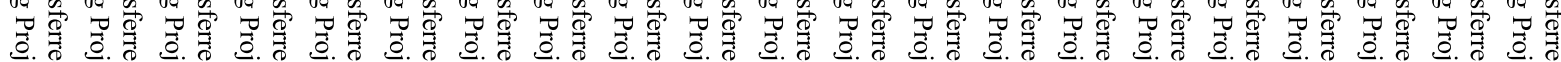

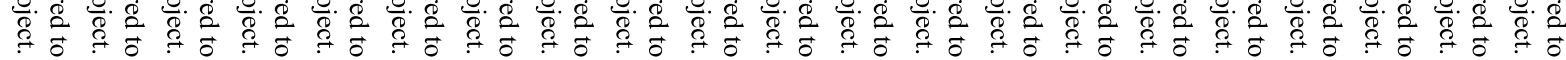

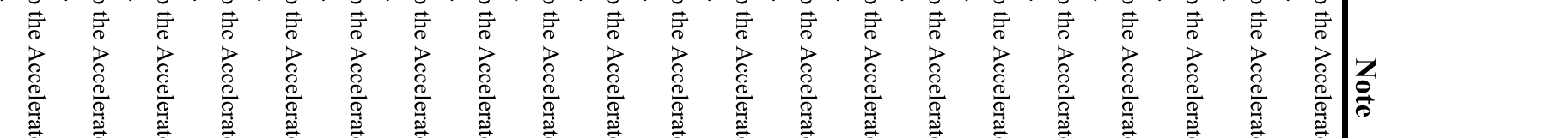




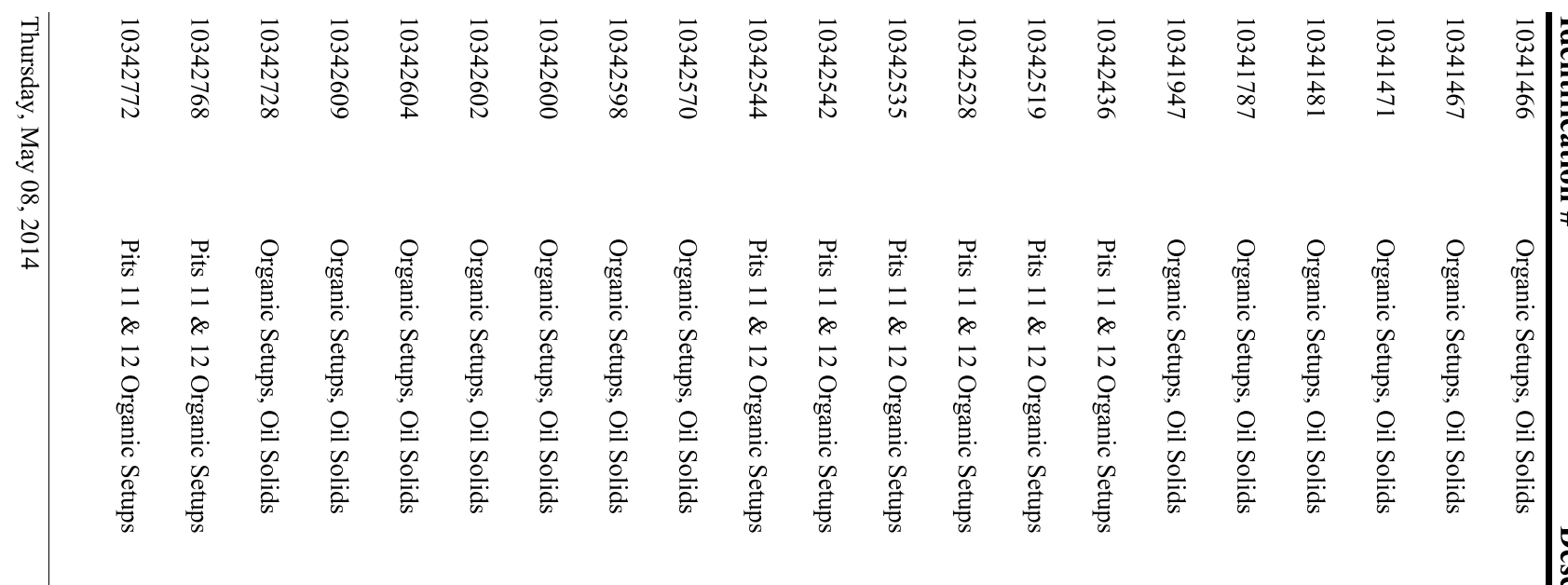

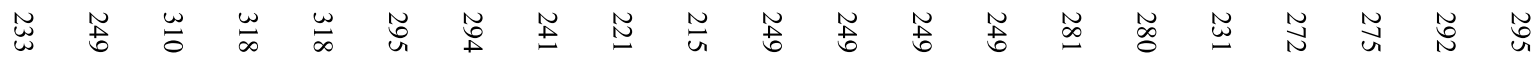

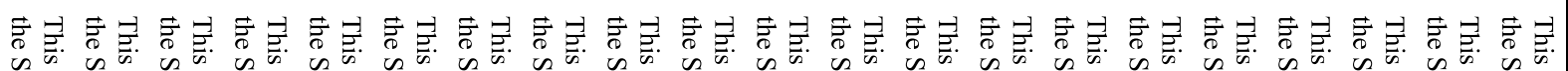

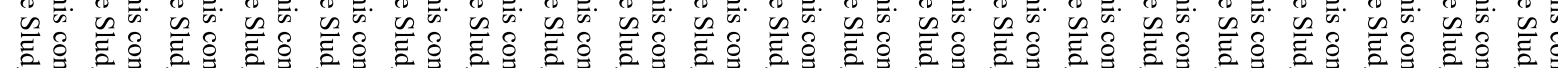

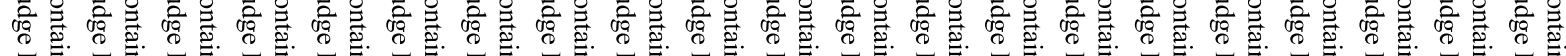

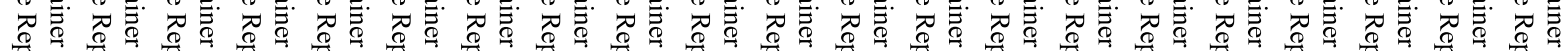

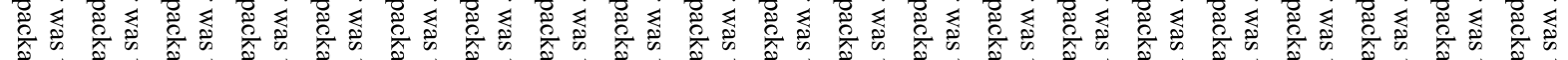

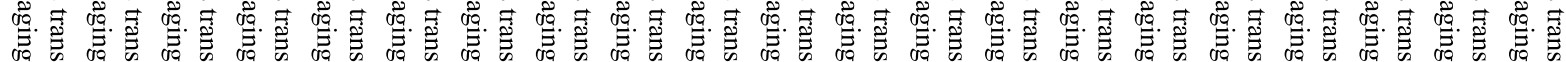

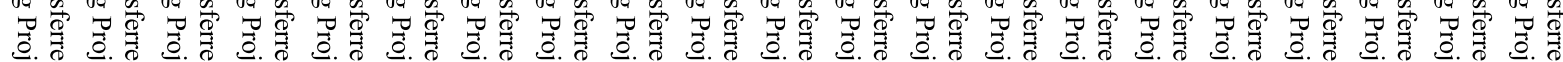

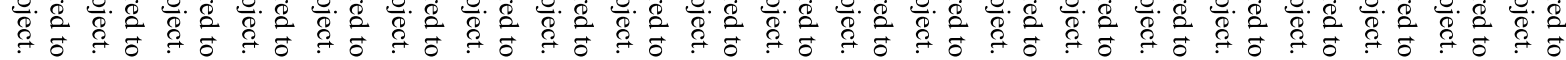

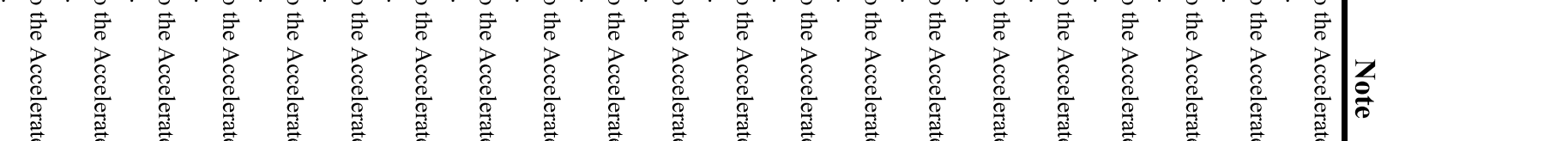




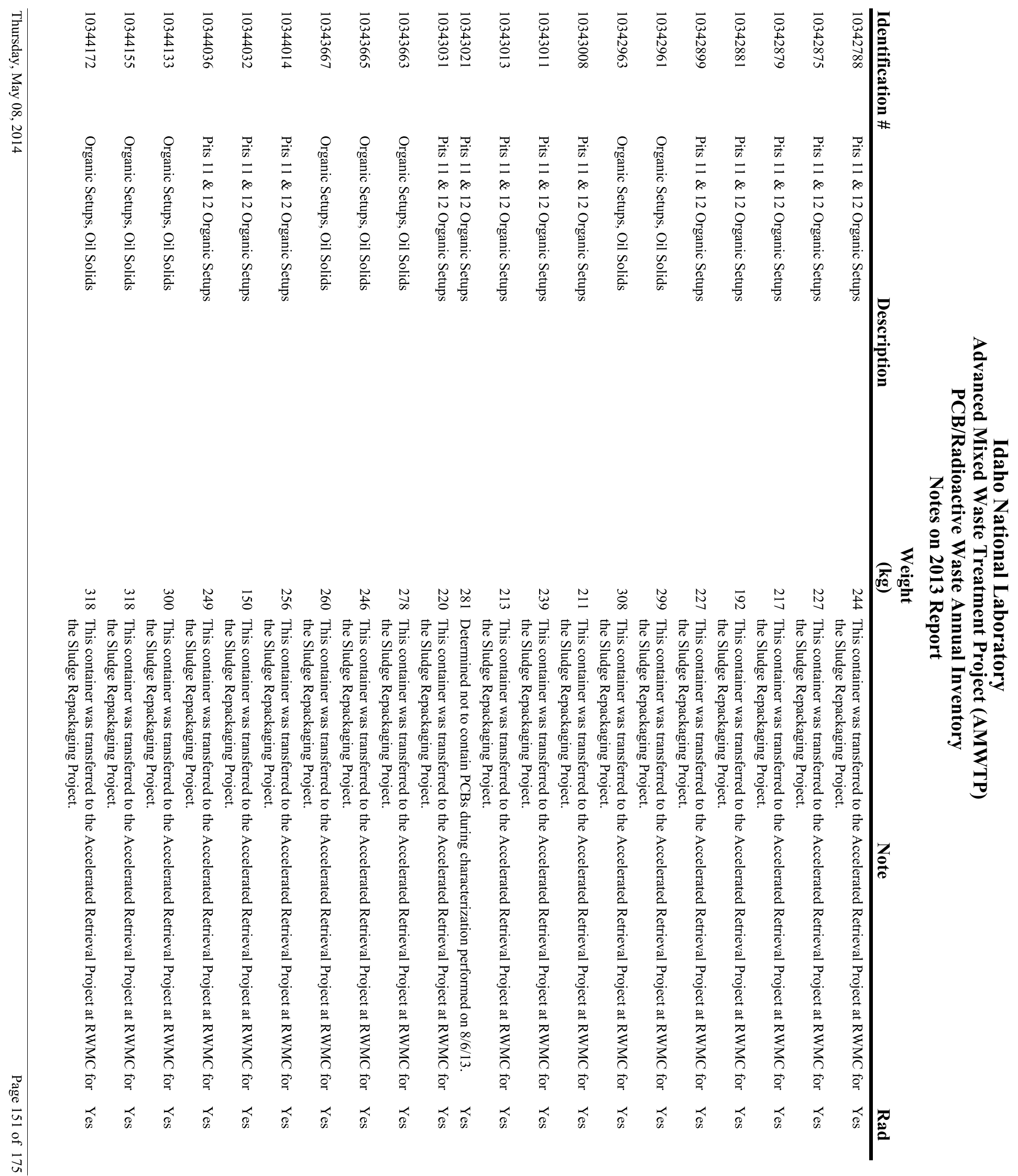




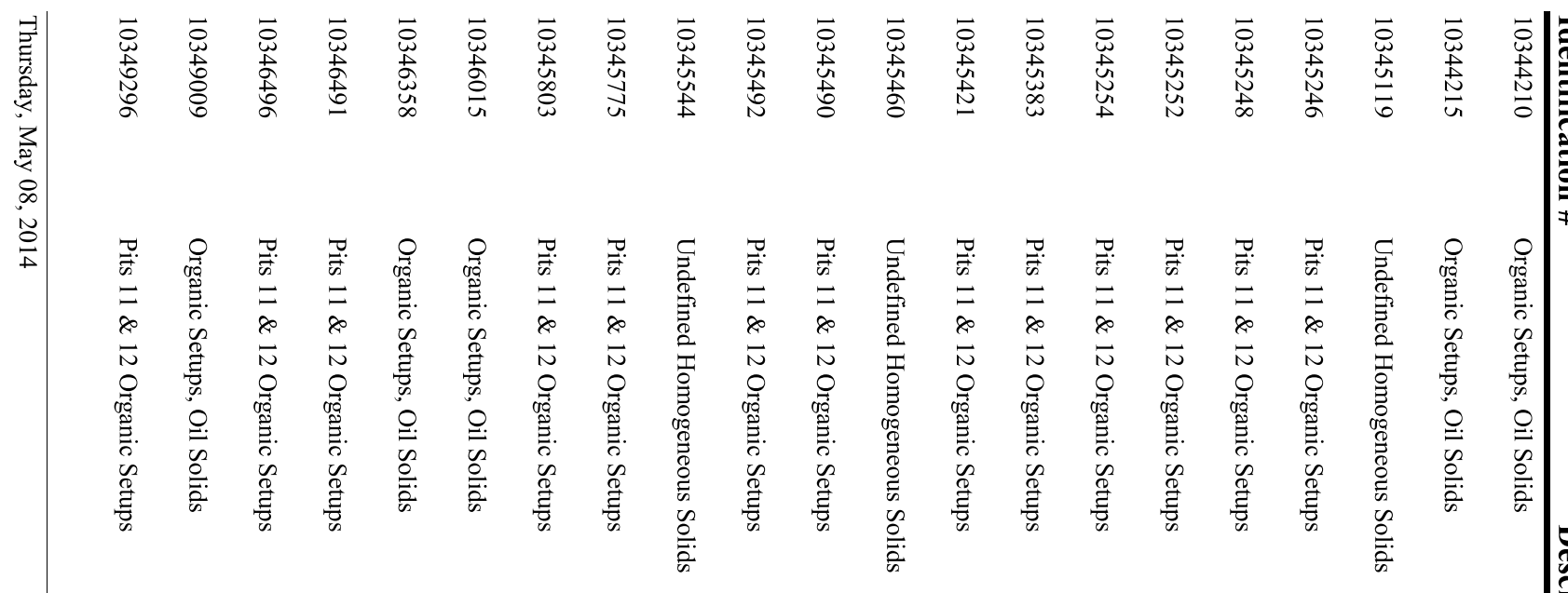

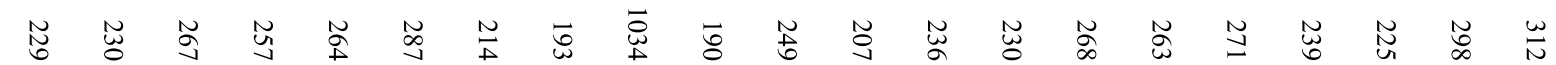

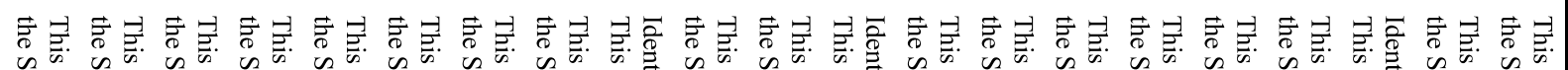

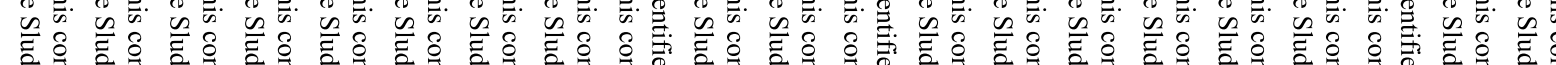

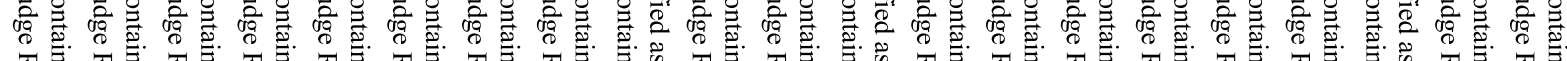

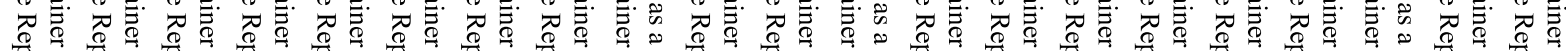

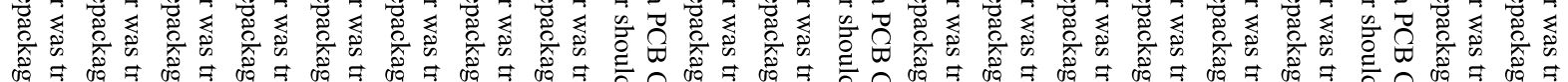

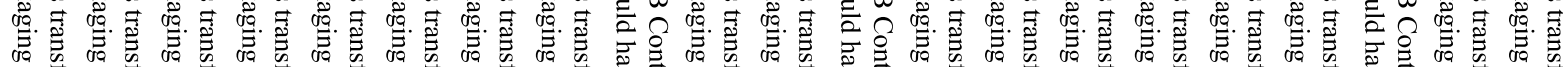

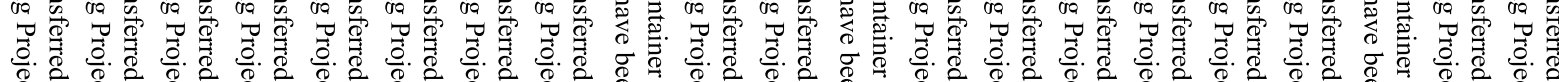

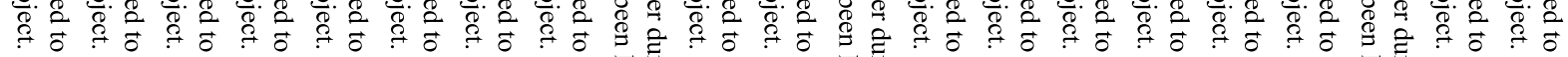




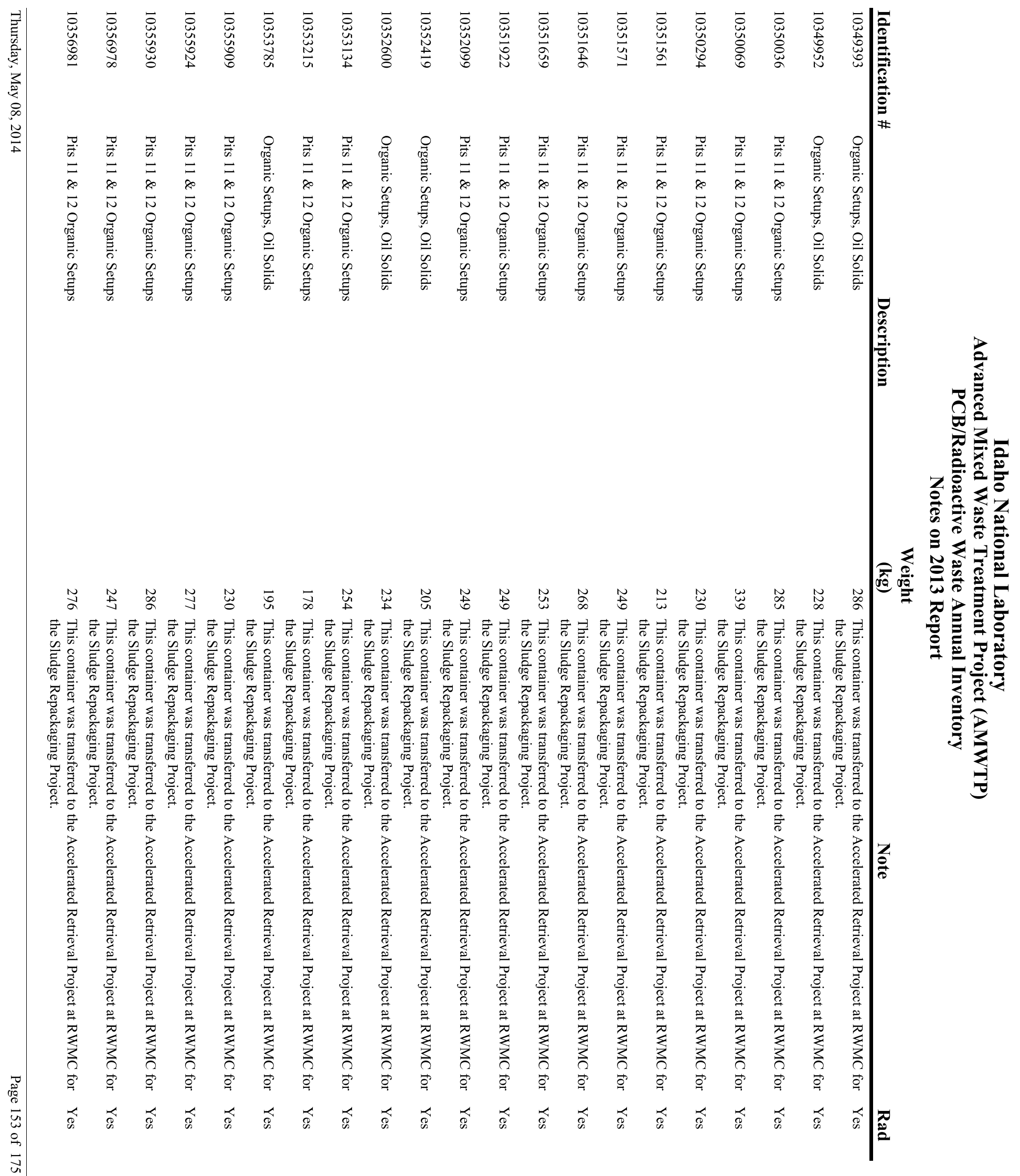




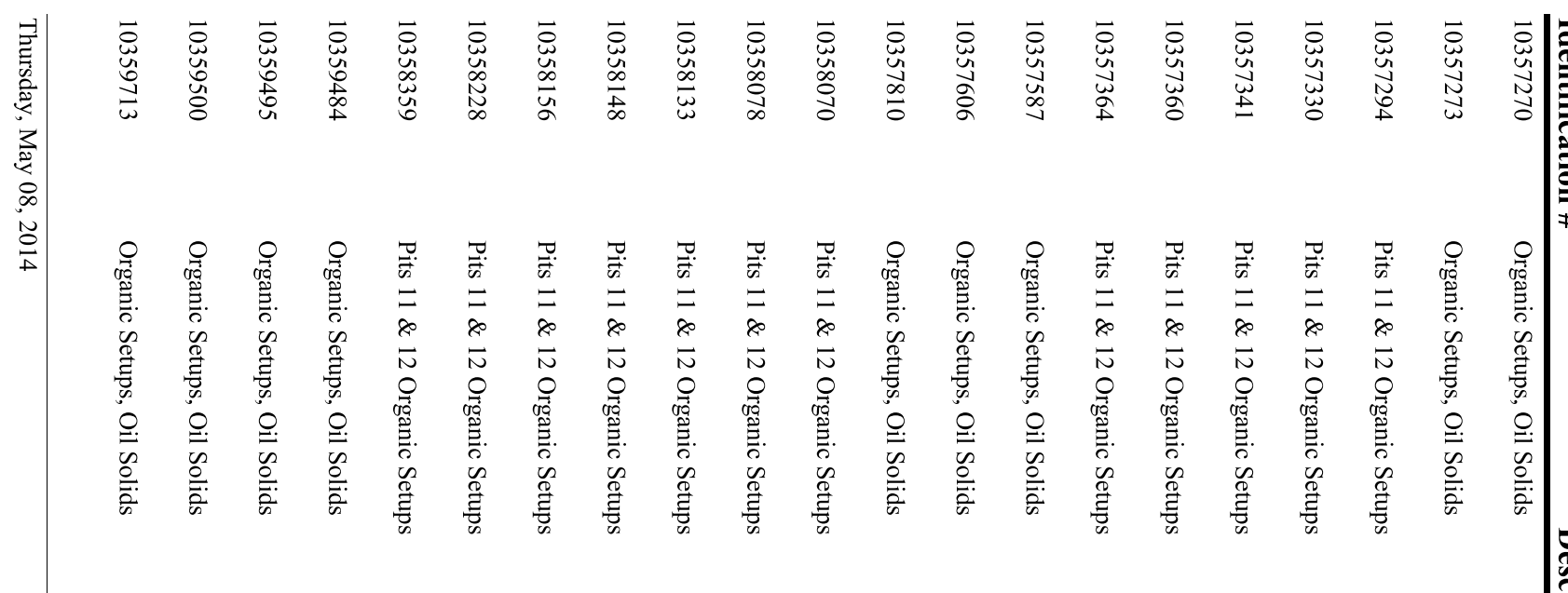

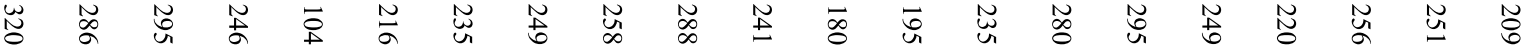

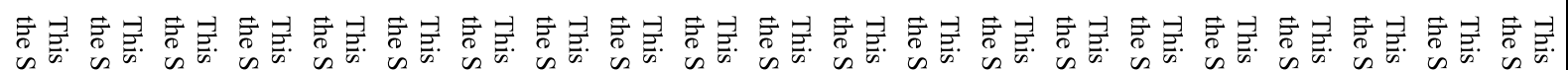

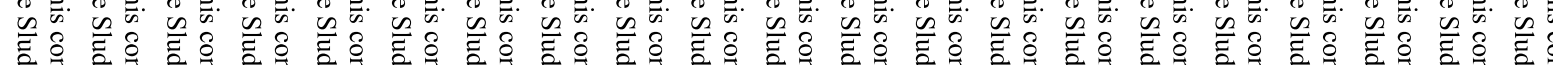

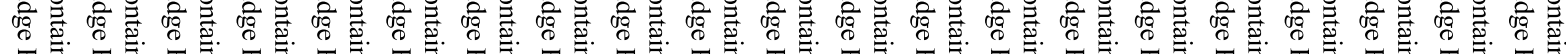

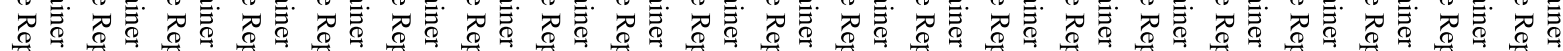

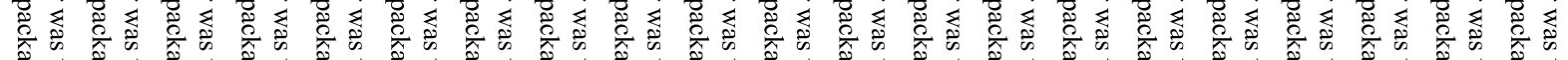

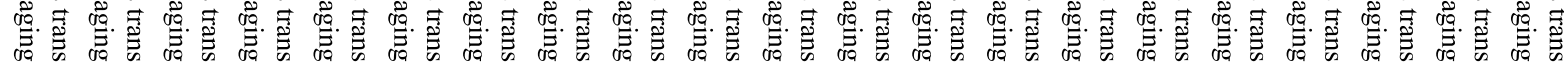

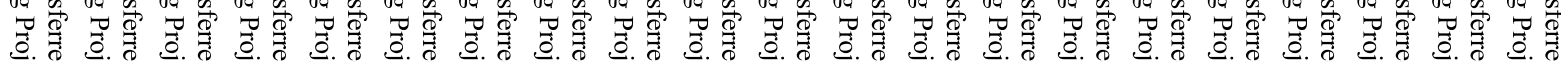

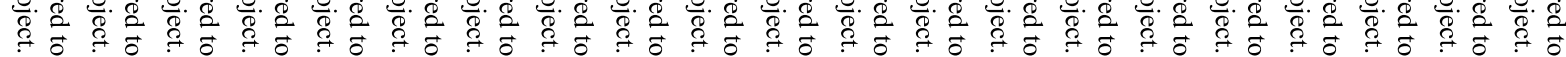

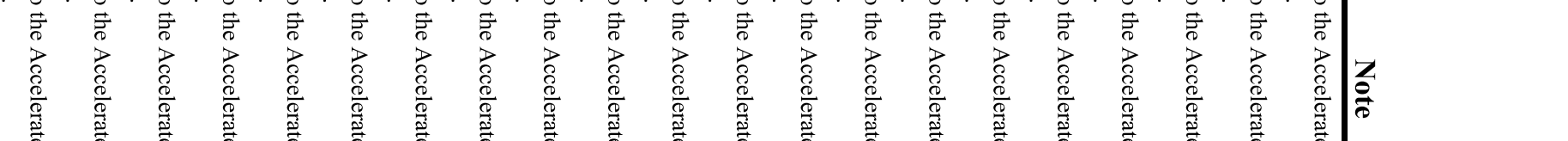




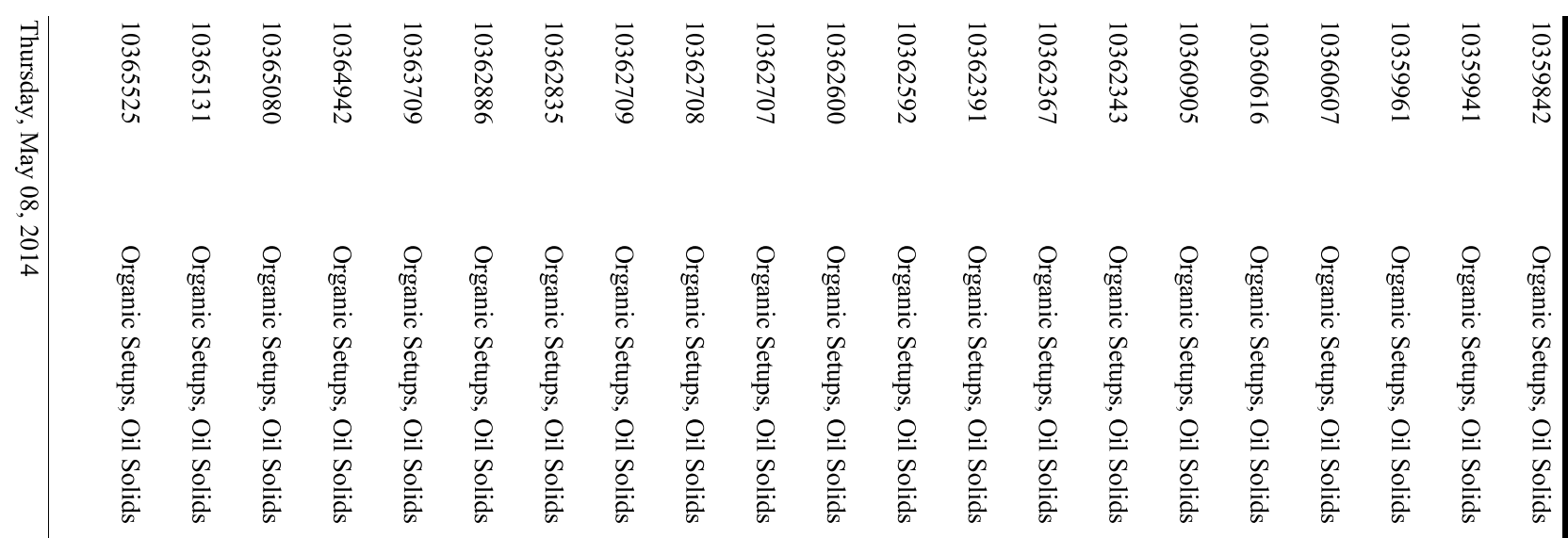

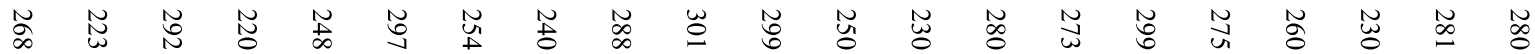

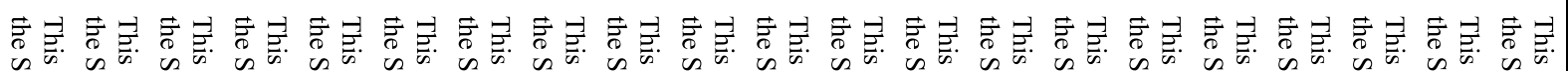

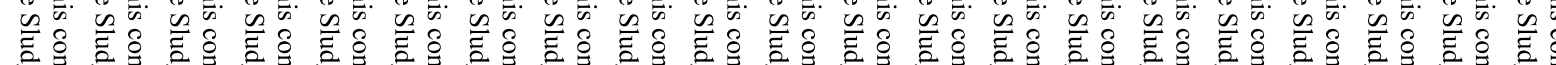

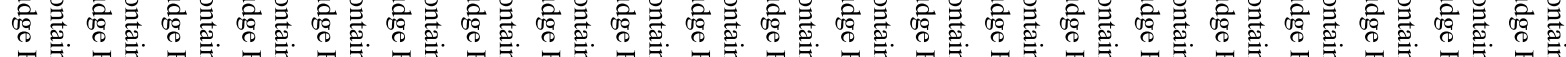

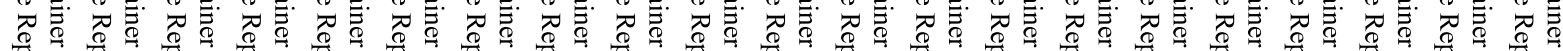

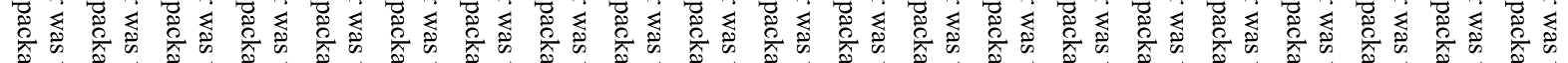

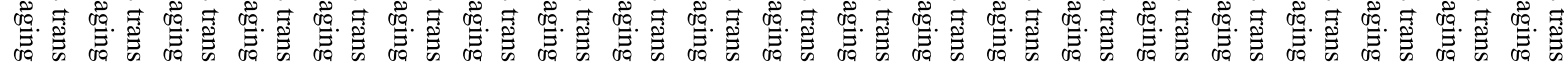

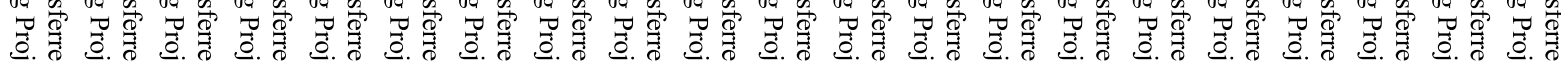

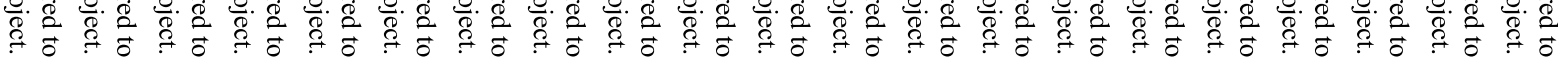

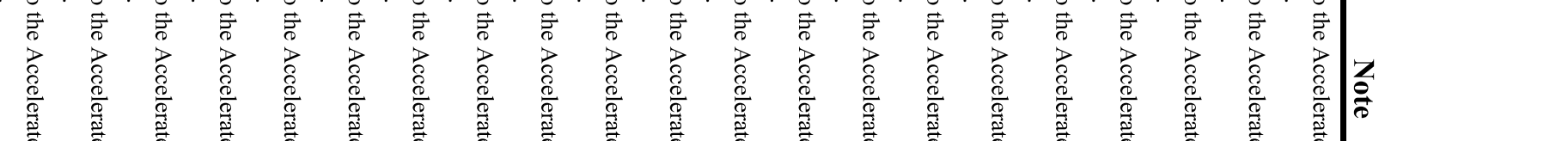




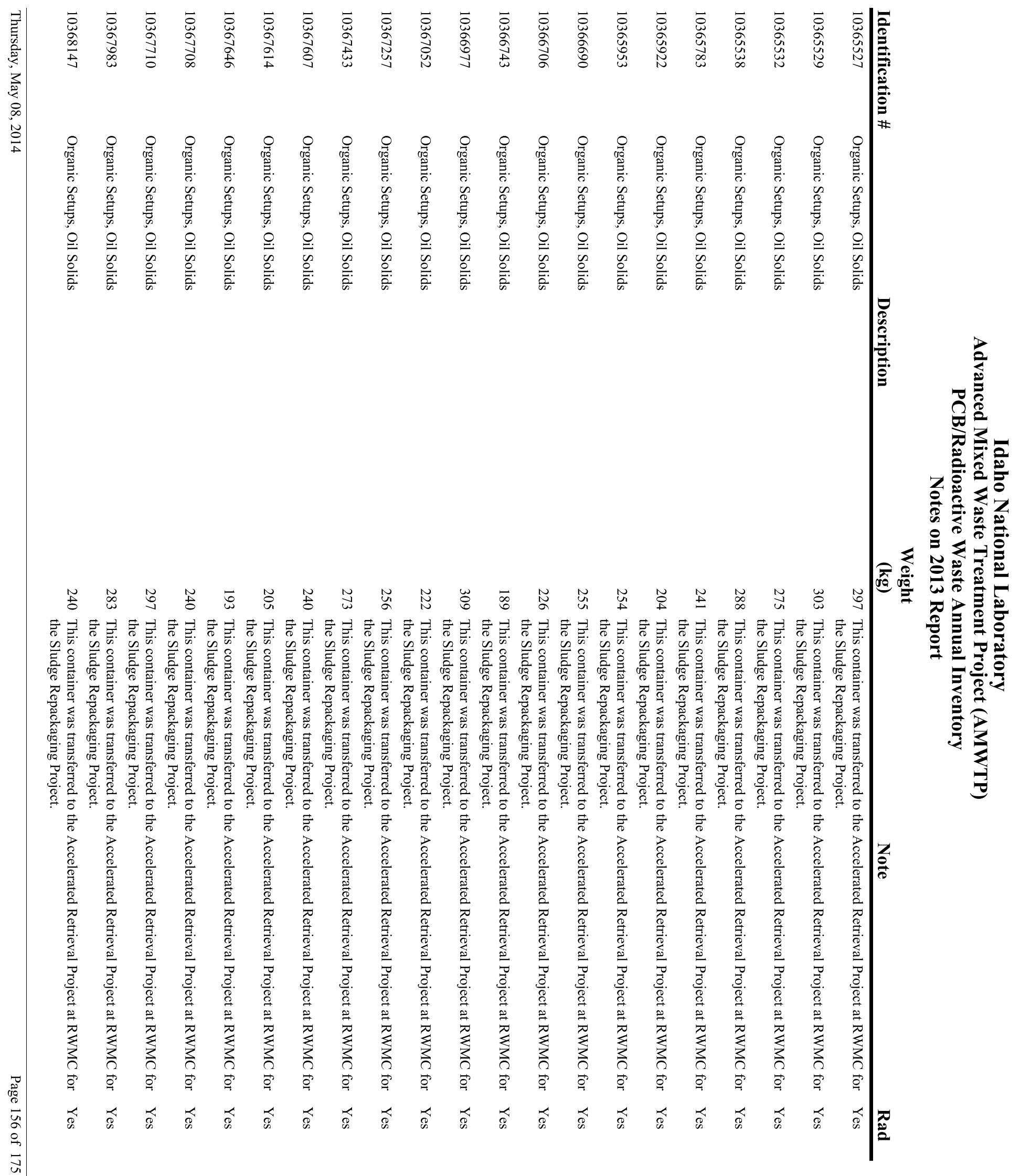




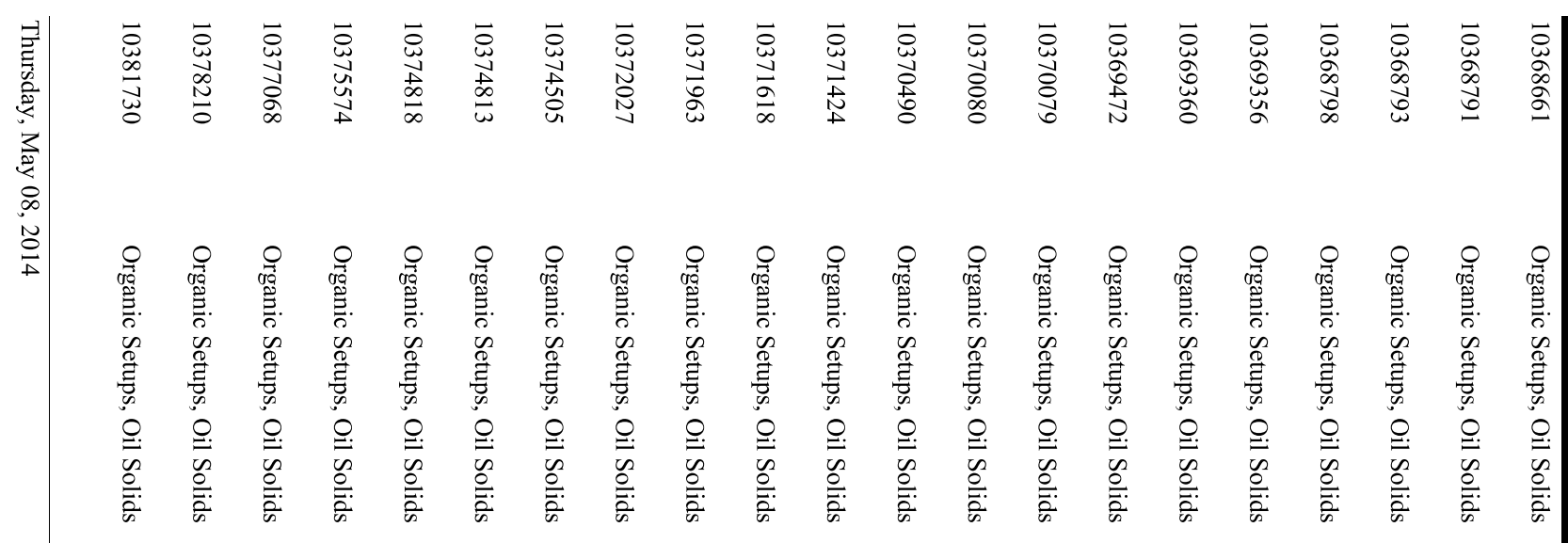

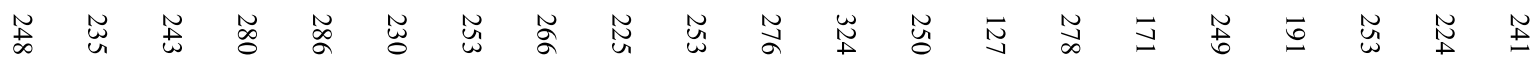

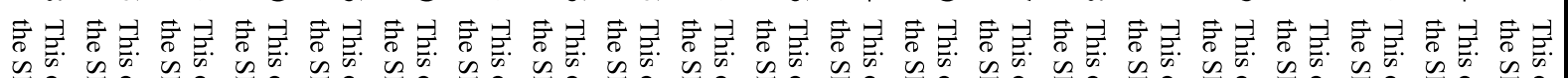

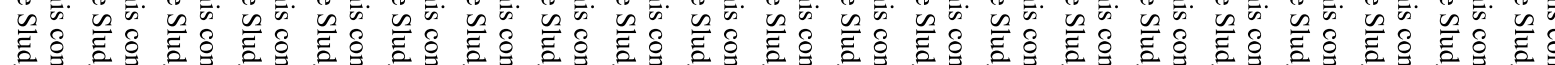

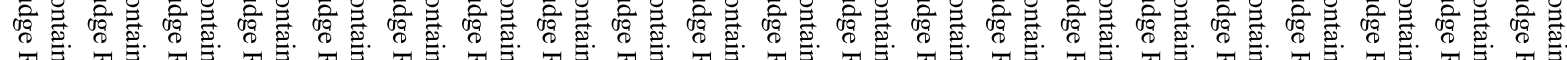

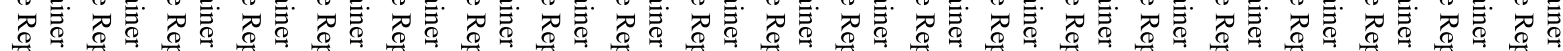

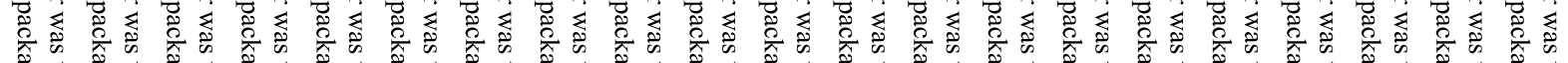

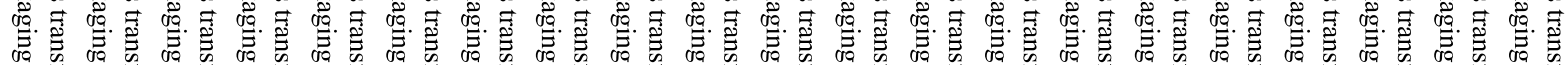

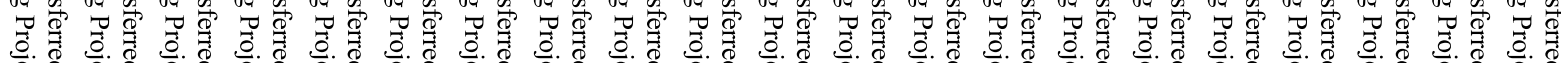

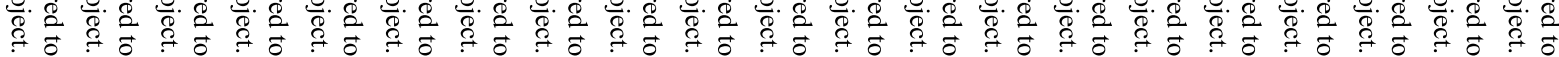

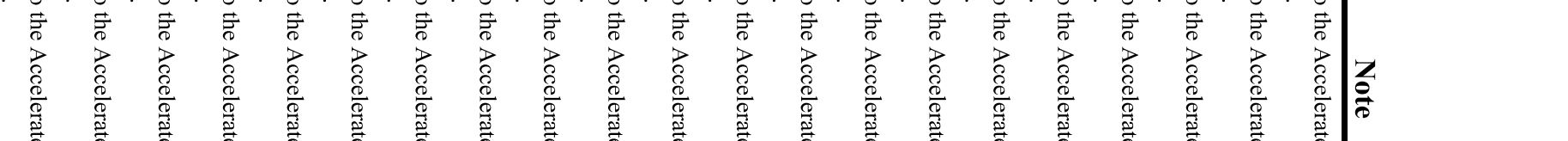




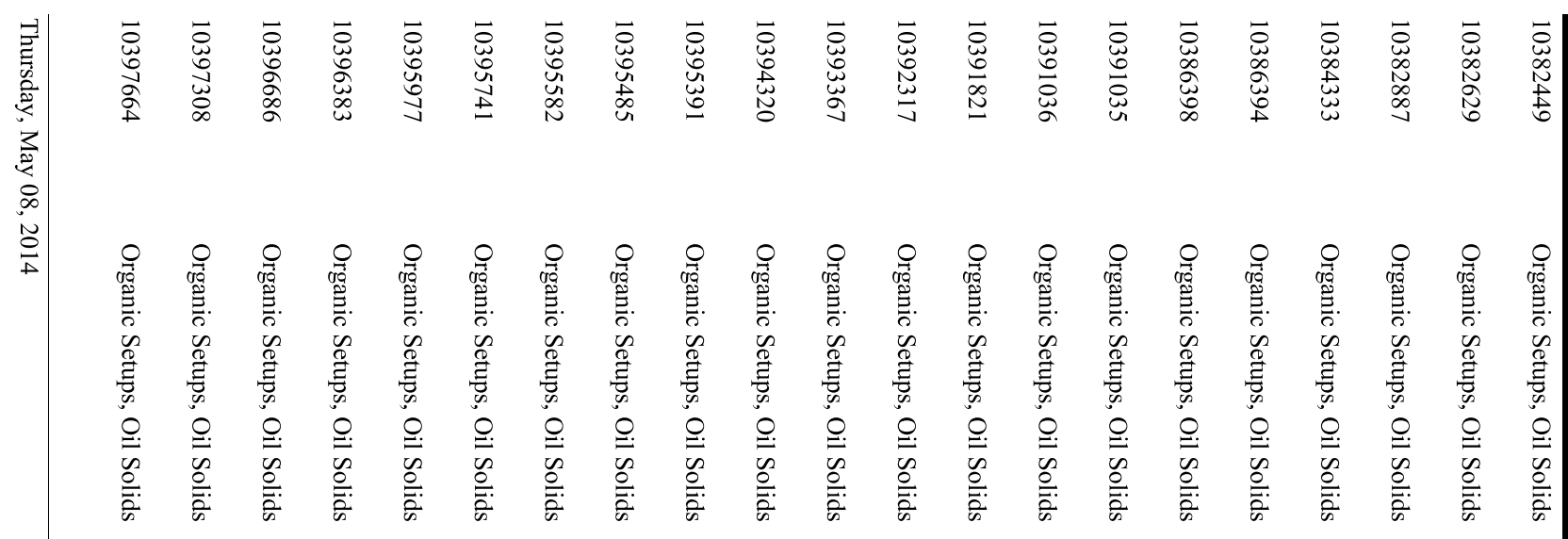

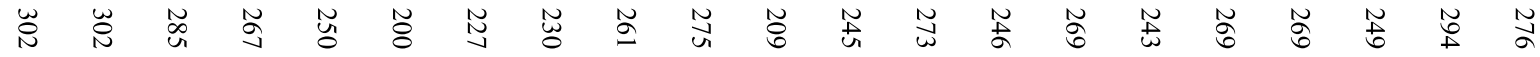

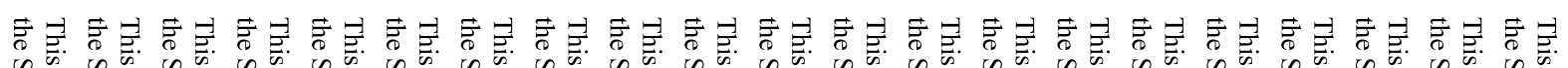

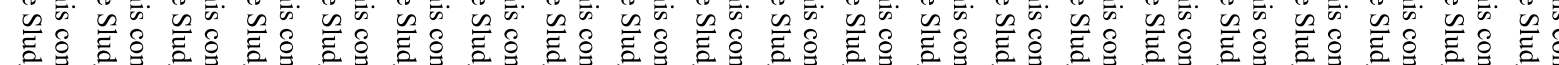

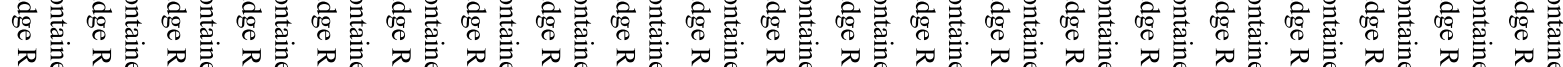

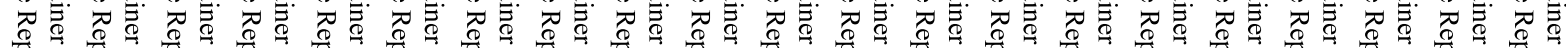

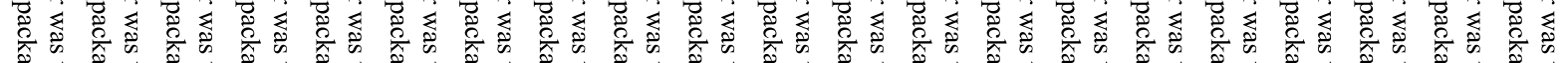

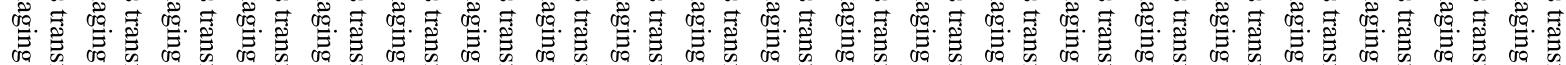

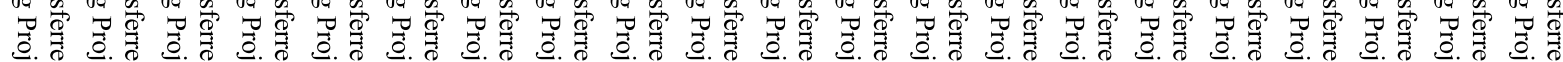

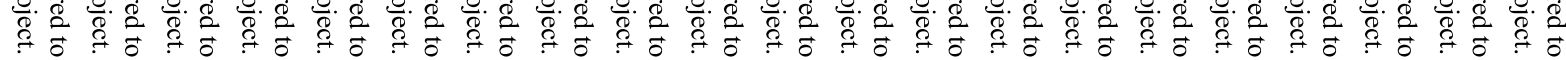

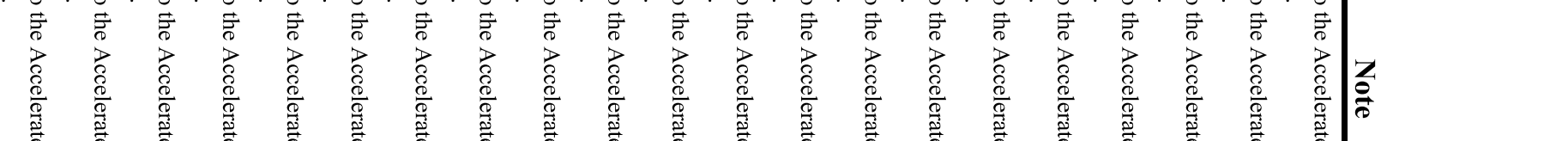




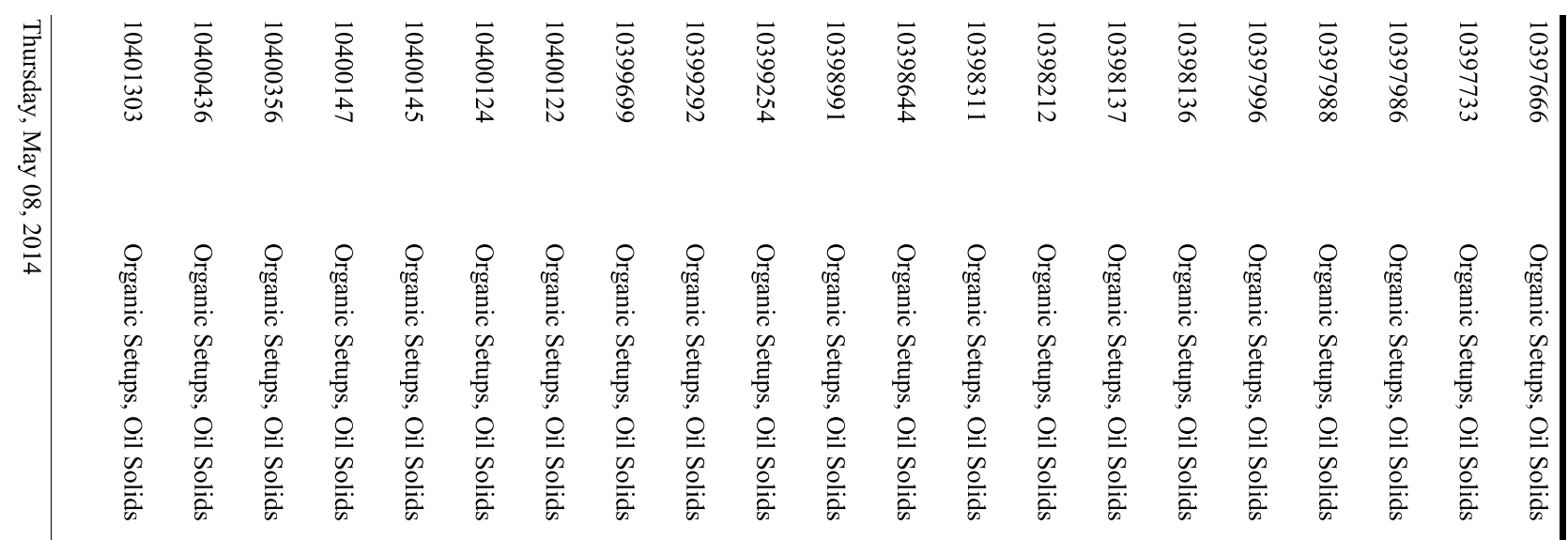

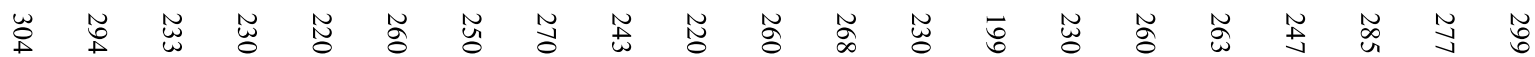

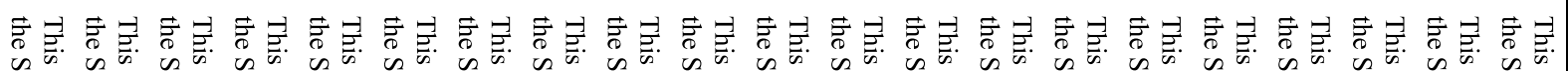

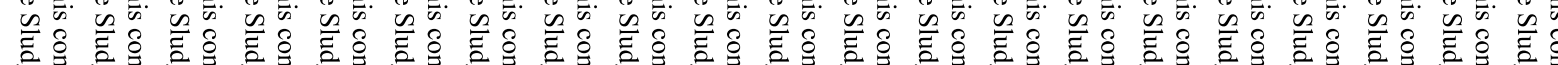

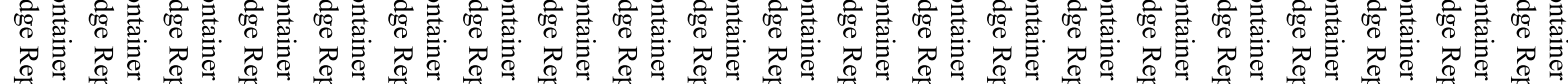

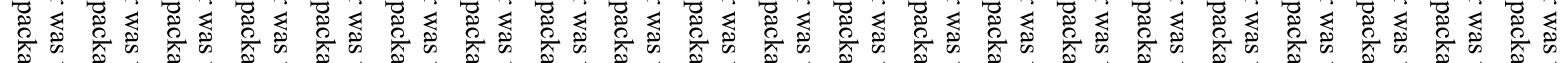

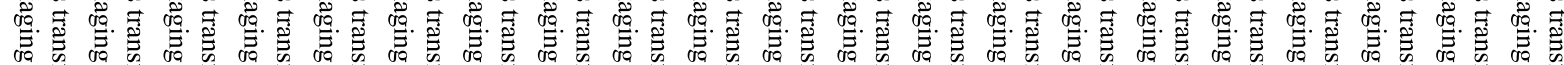

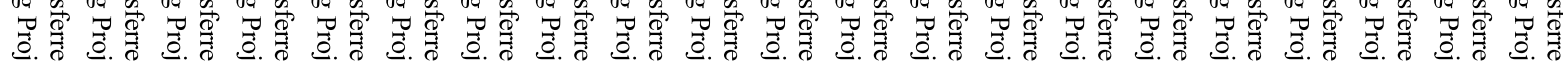

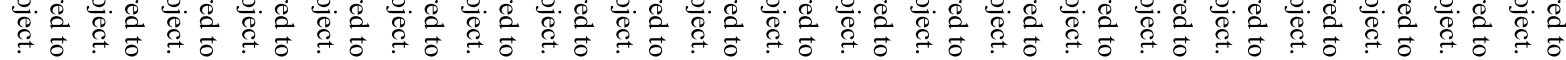

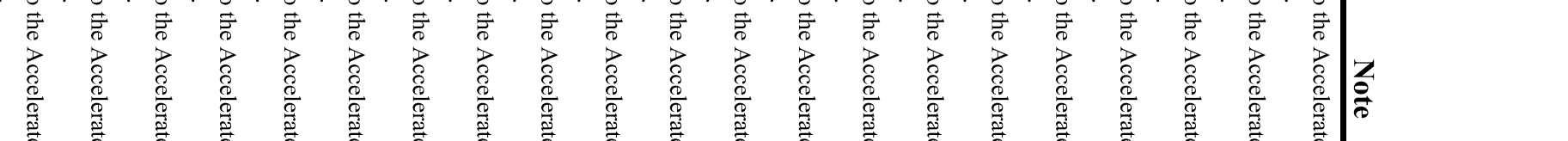




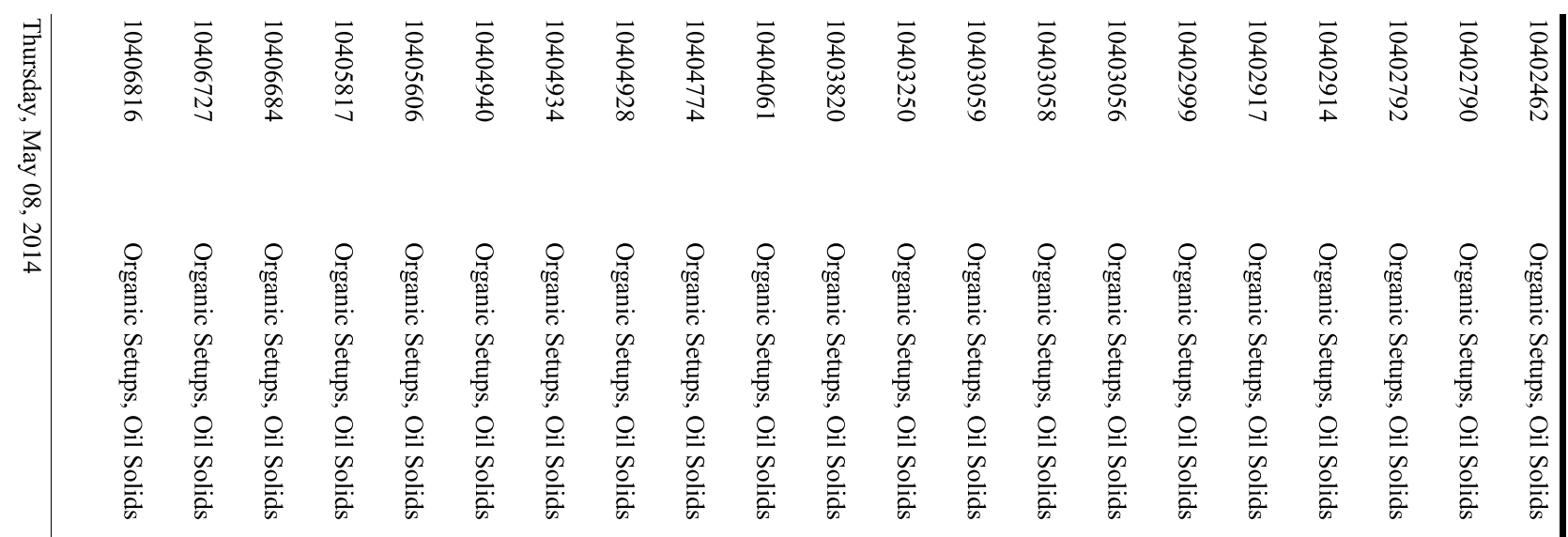

施

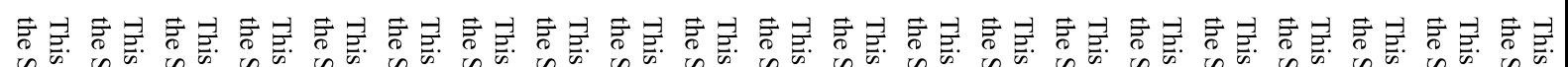

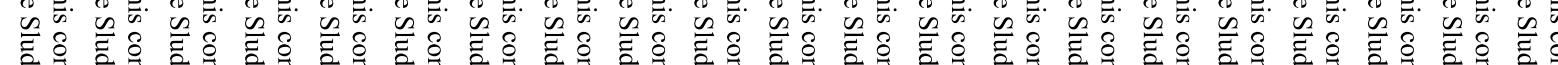

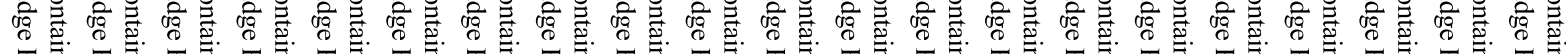
不

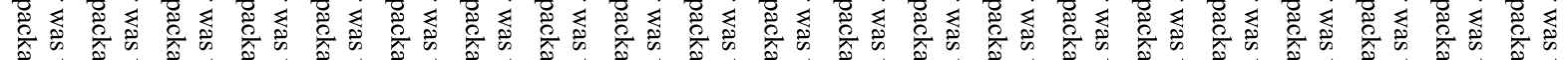

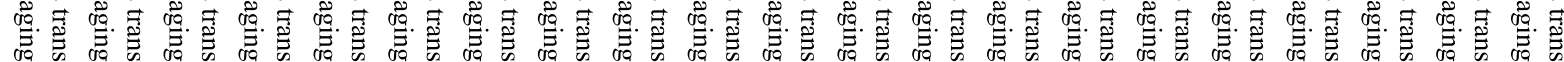

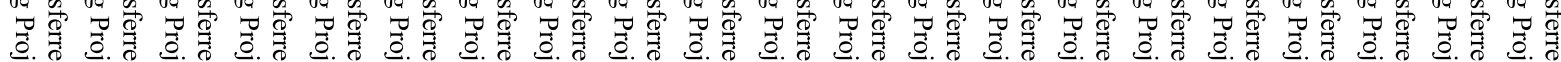

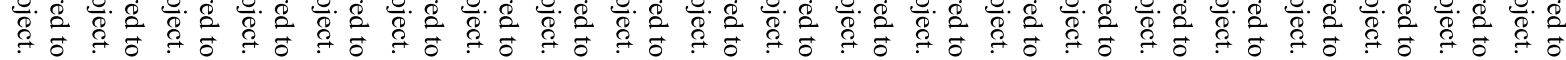

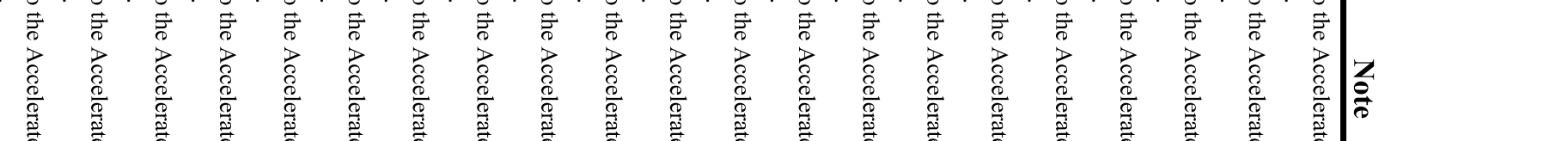




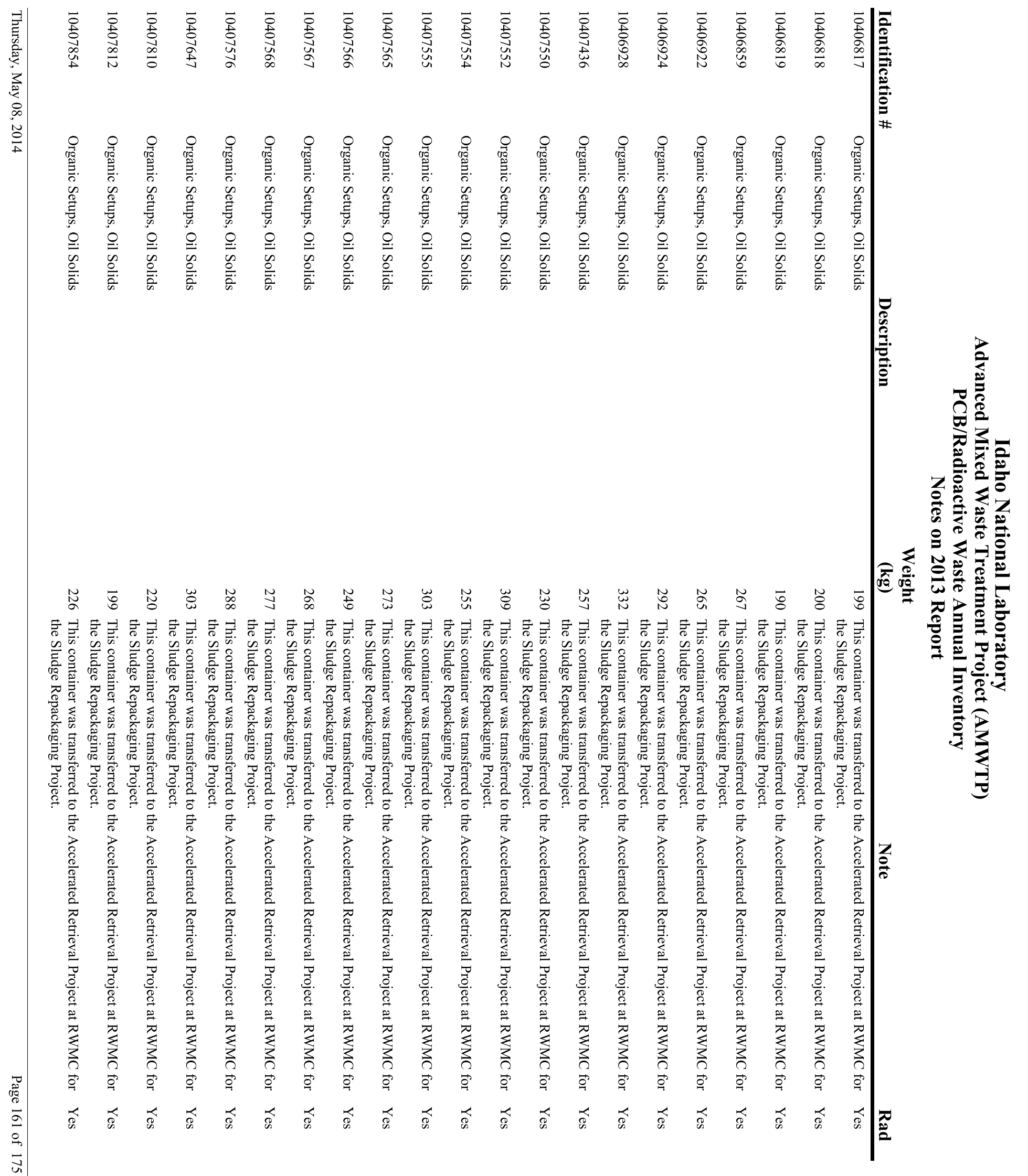




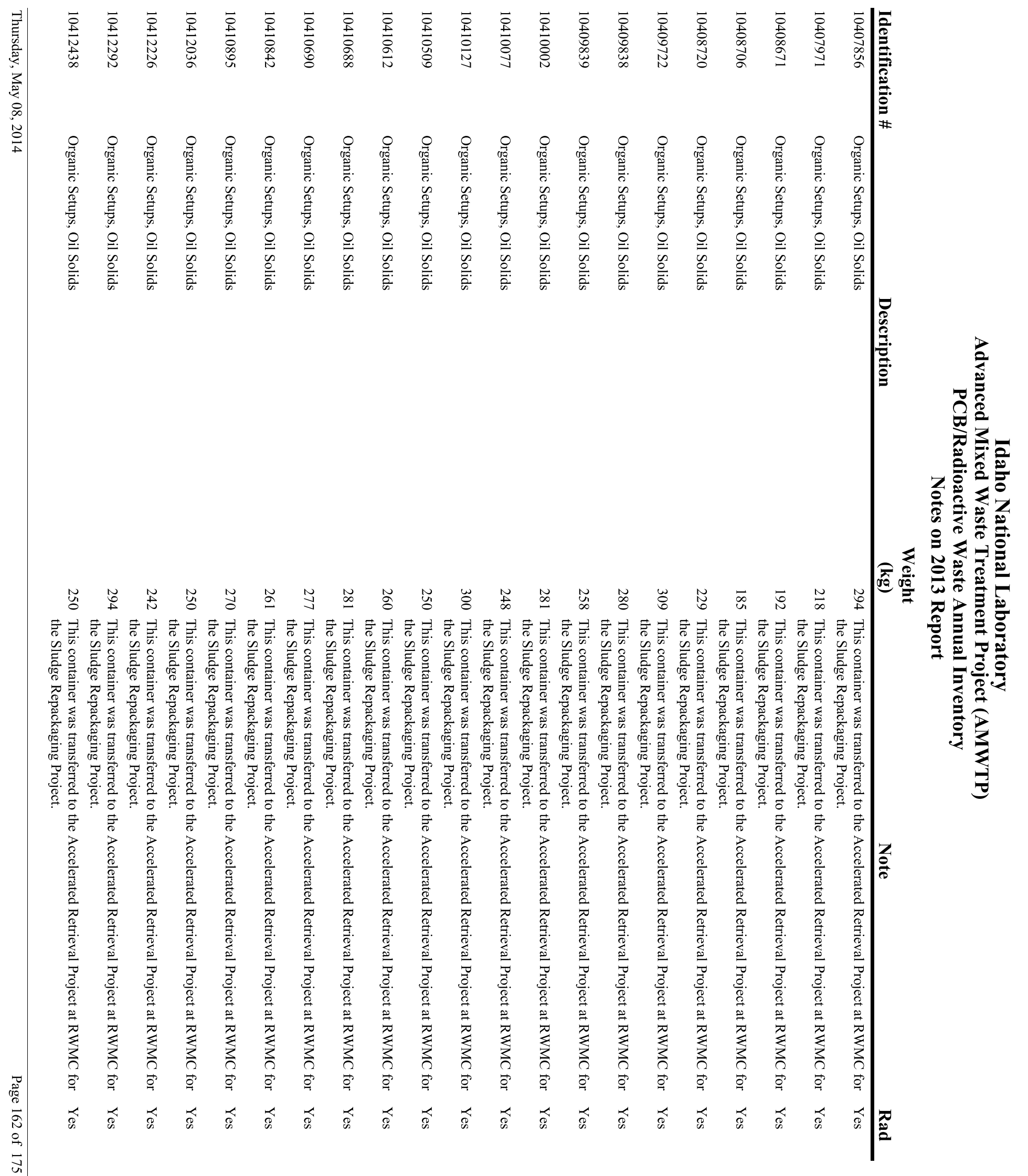




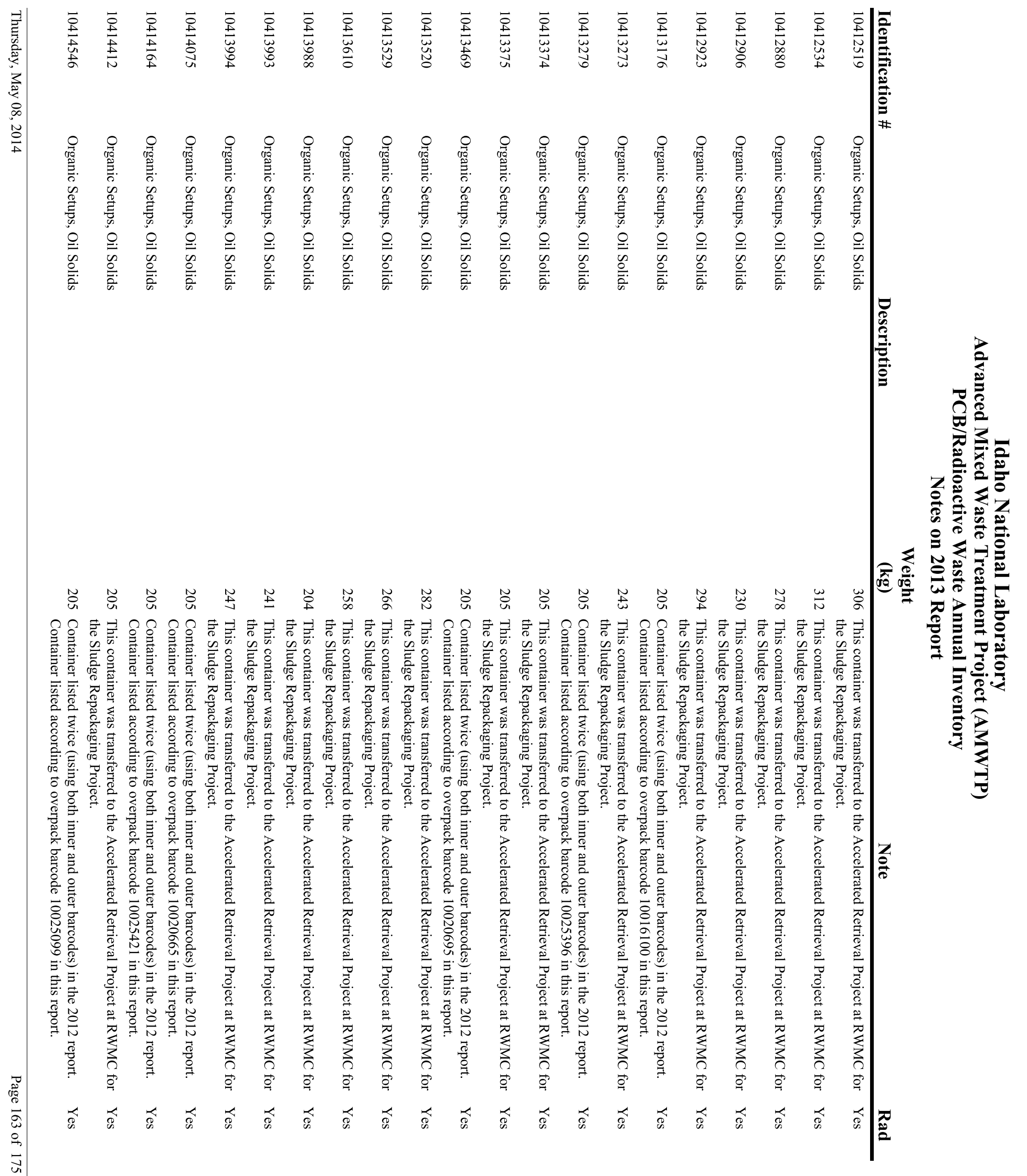




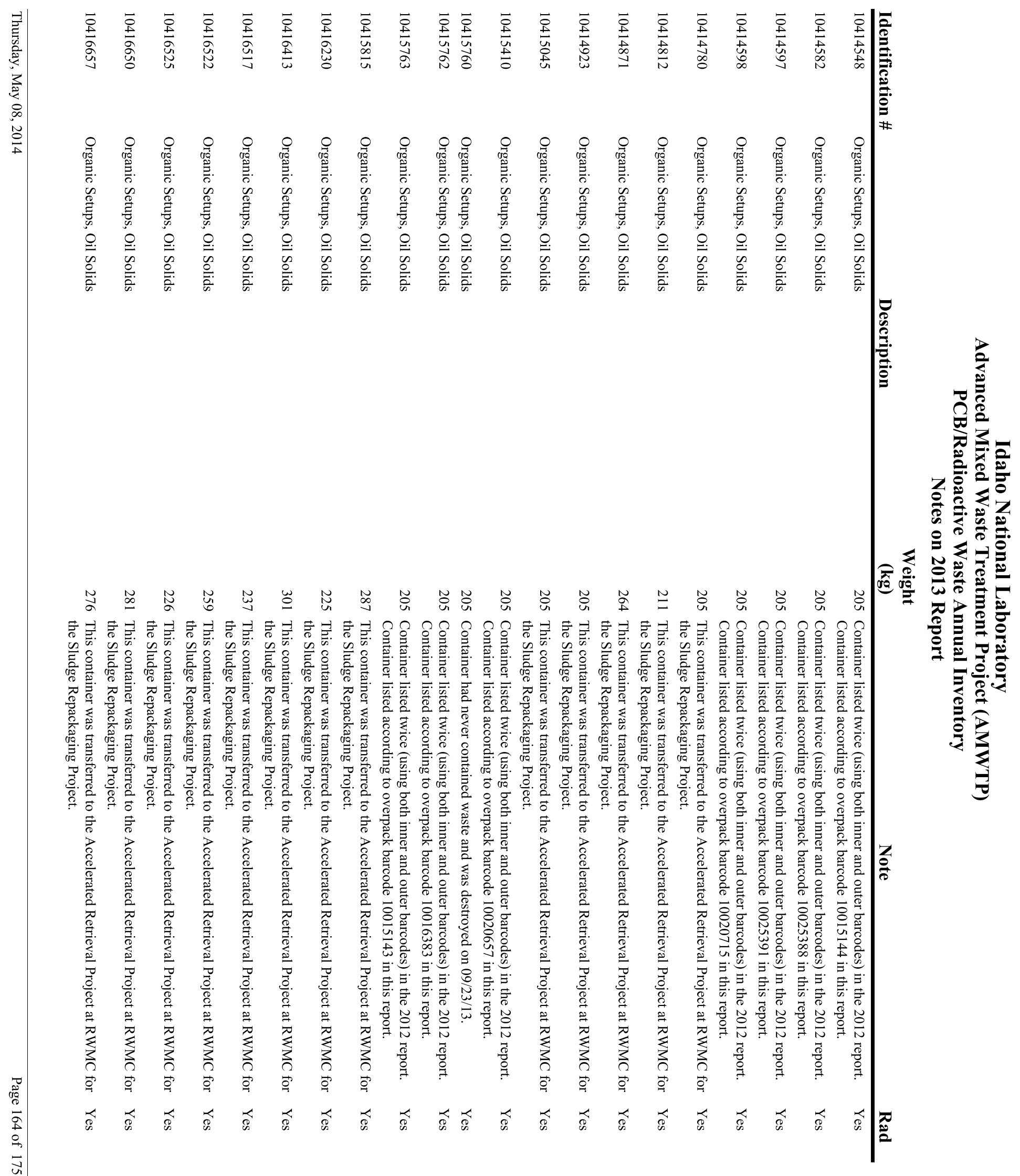




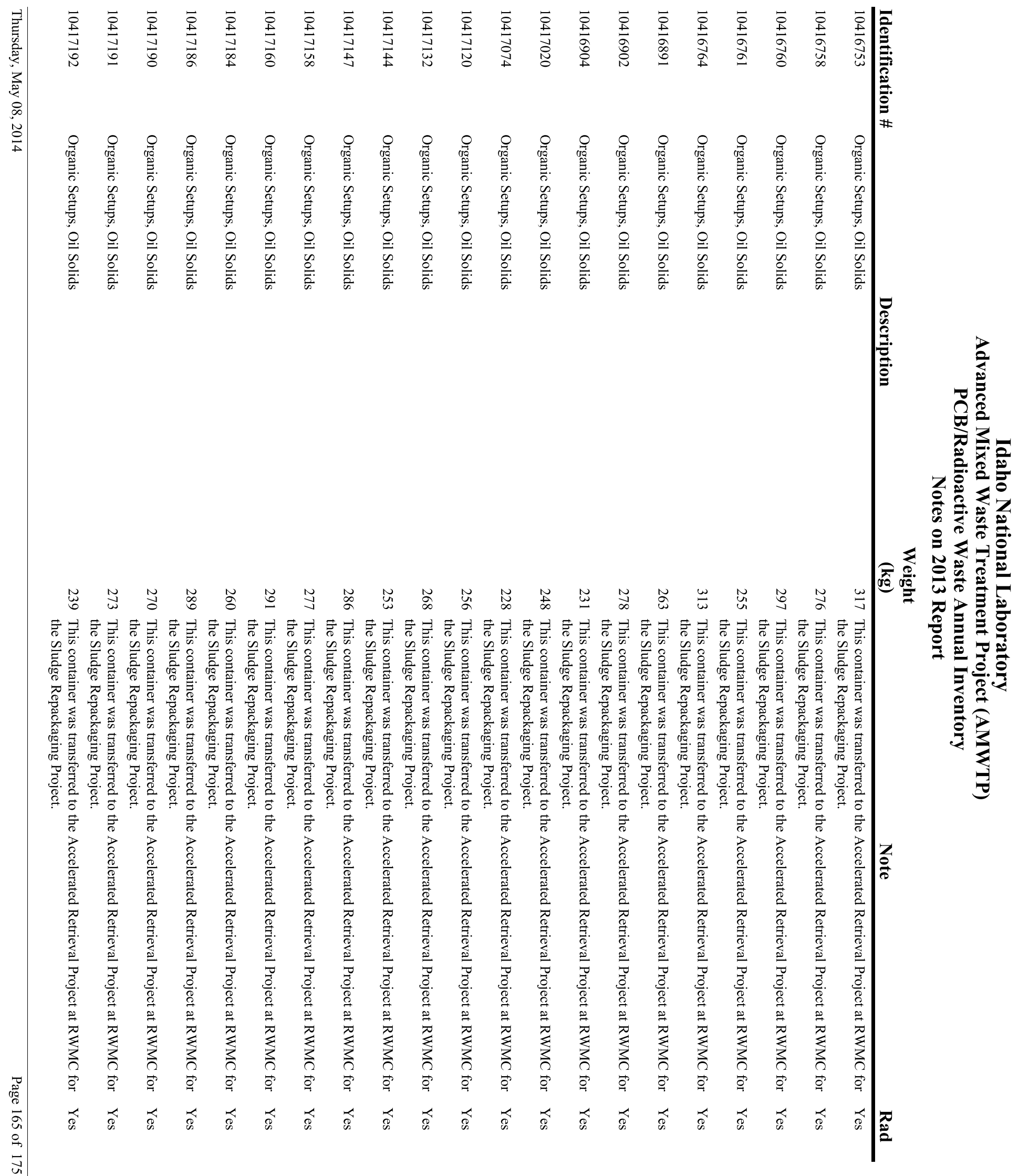




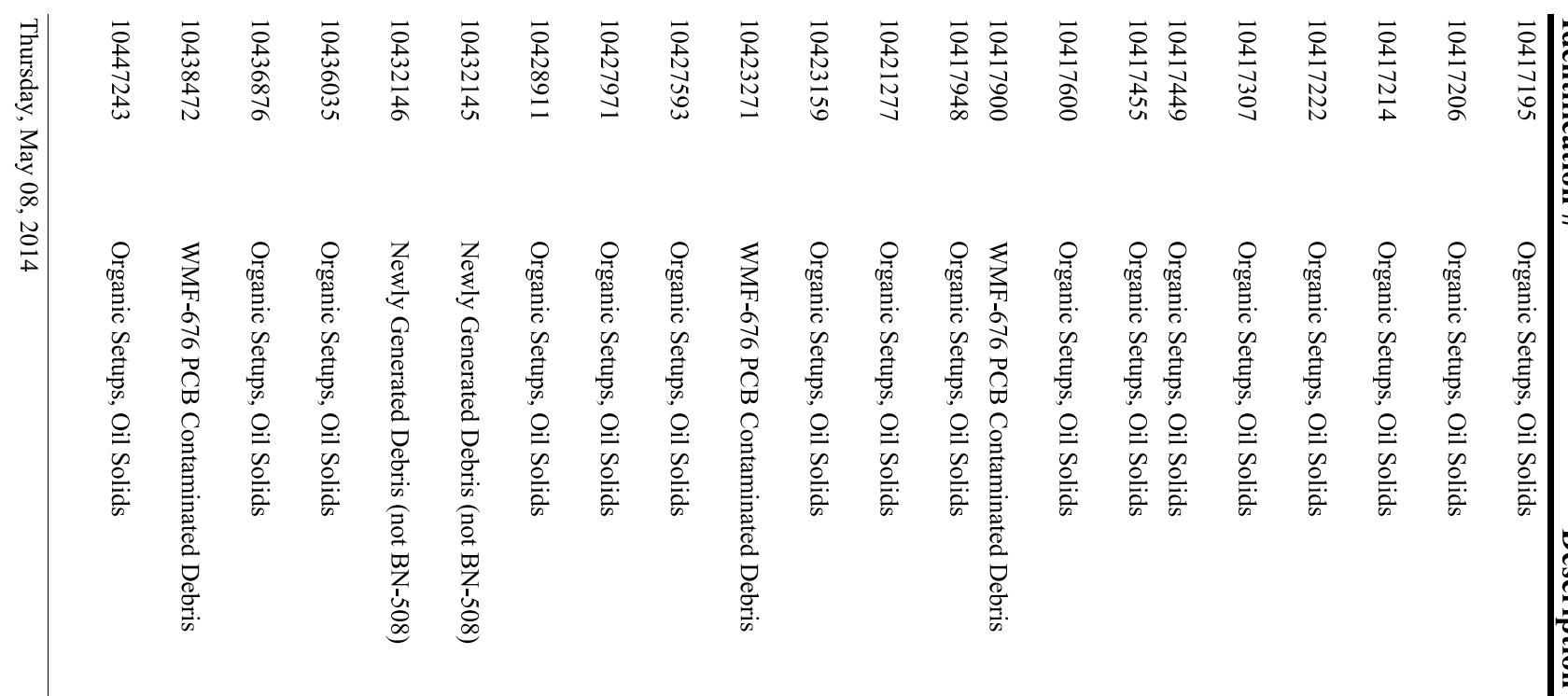

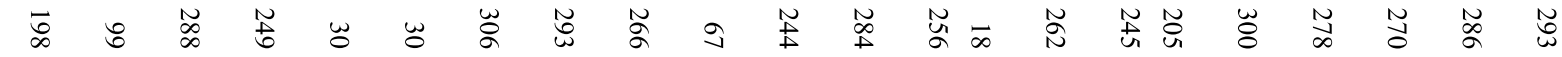

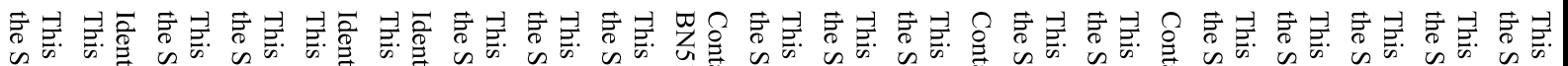

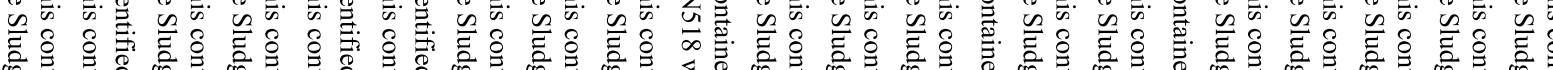

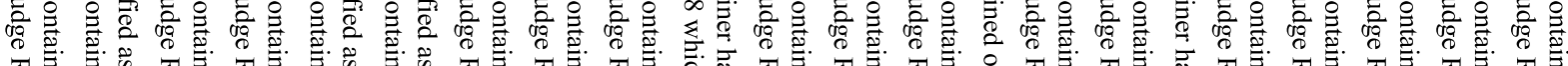

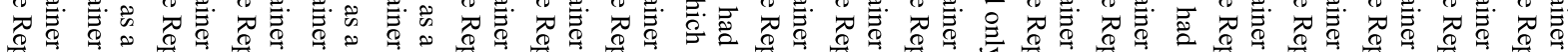

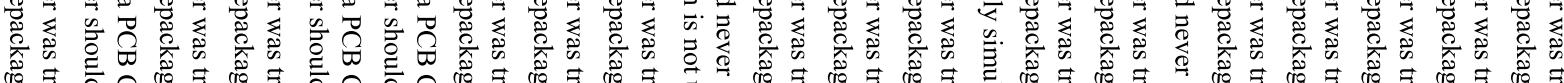

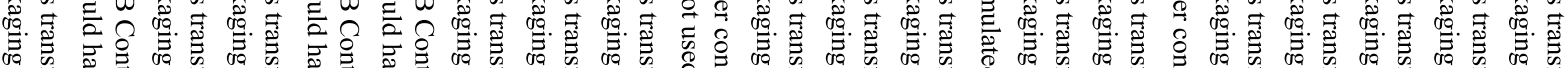

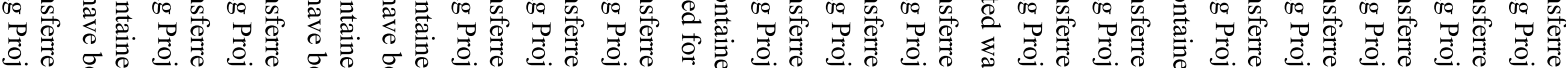

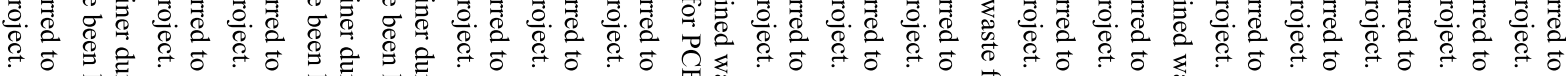

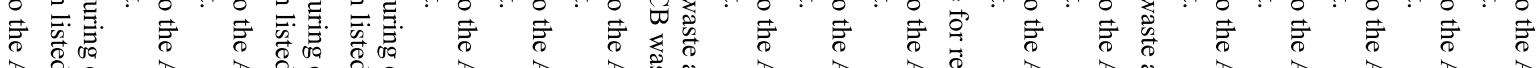

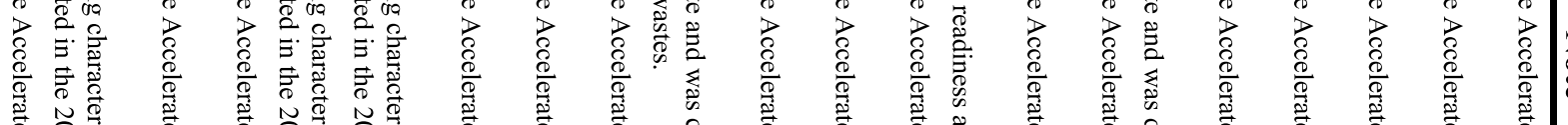

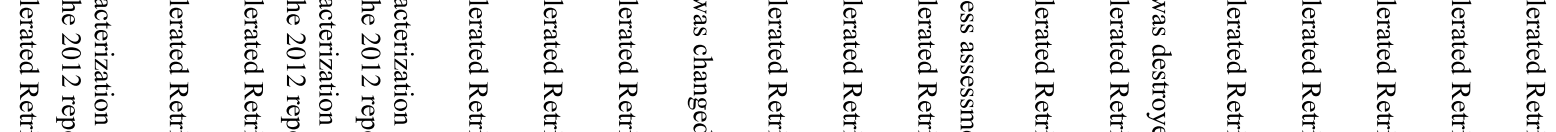

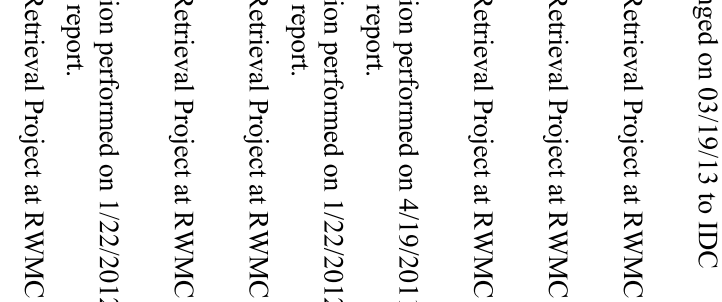

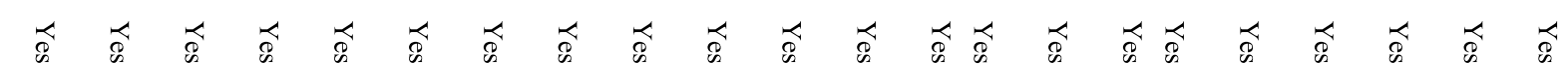

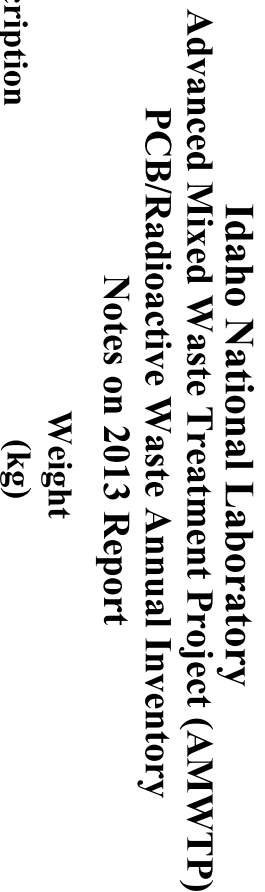




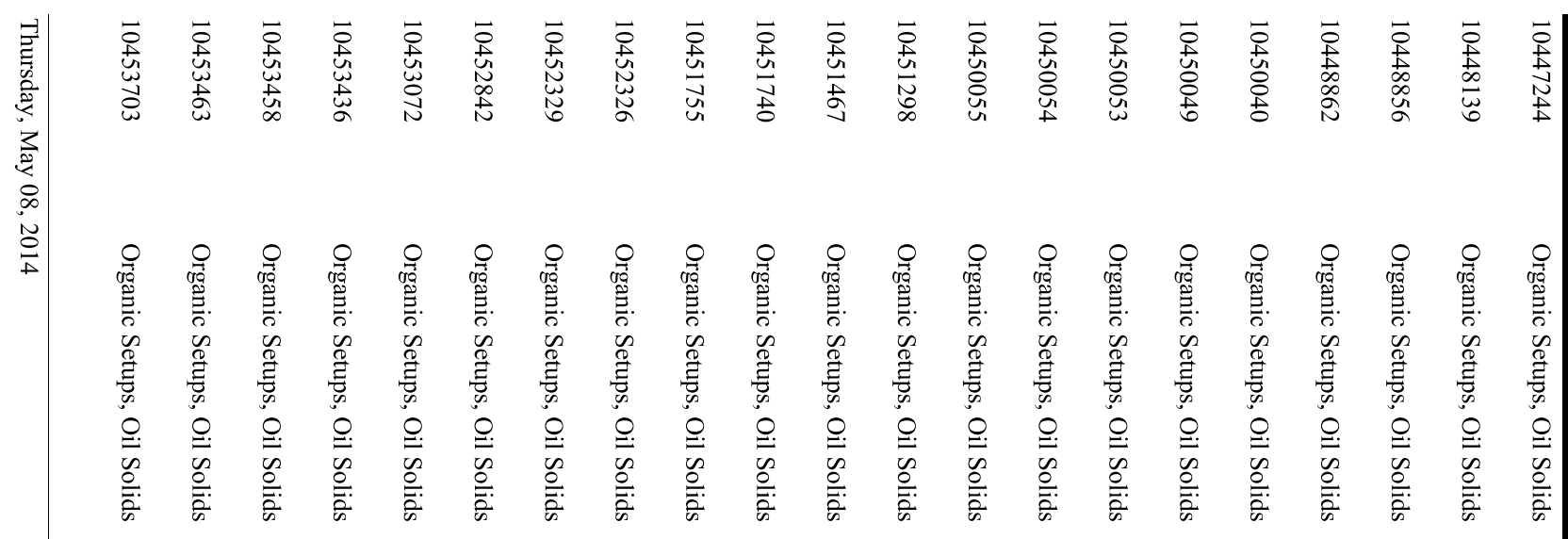

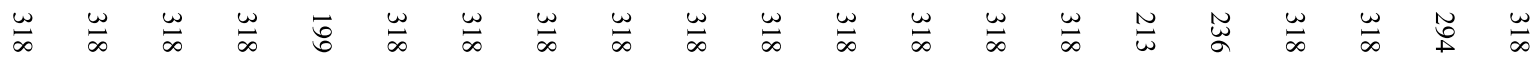

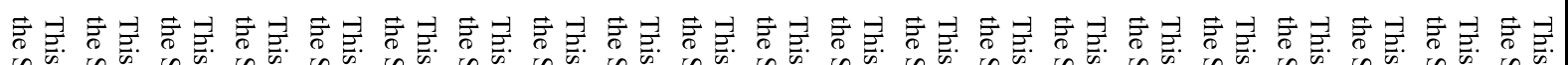

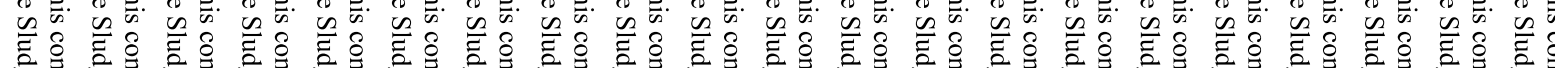

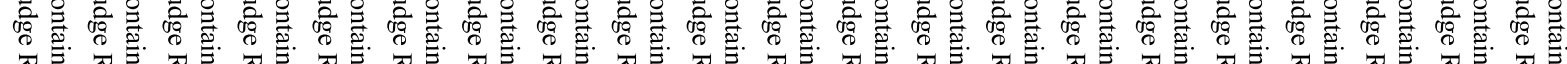

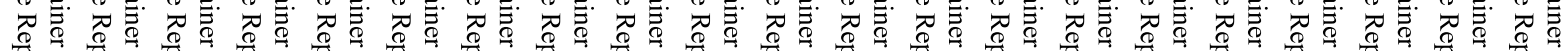

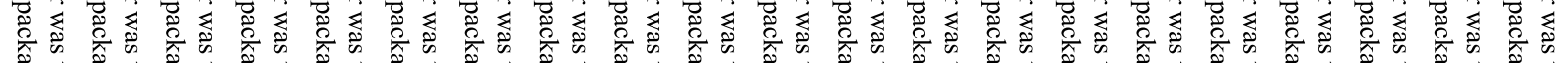

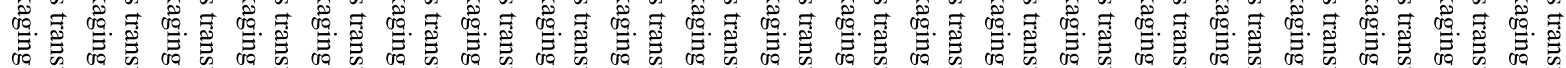

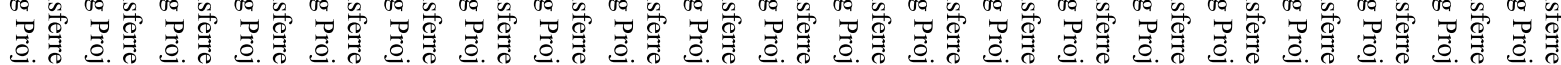

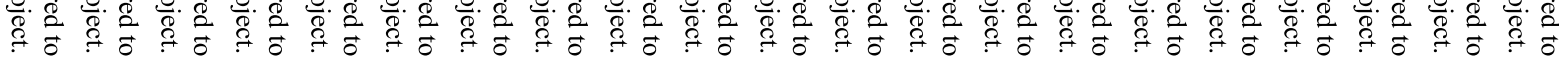

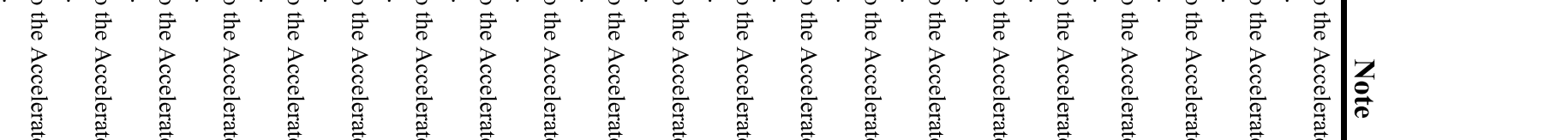




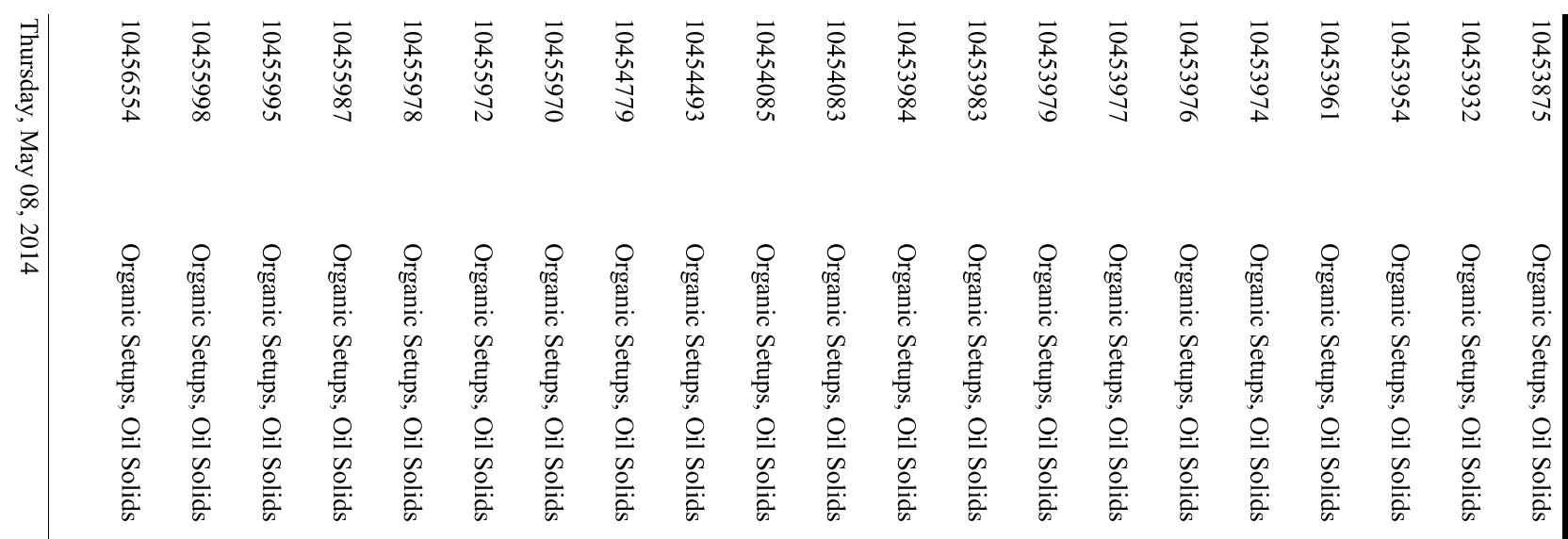

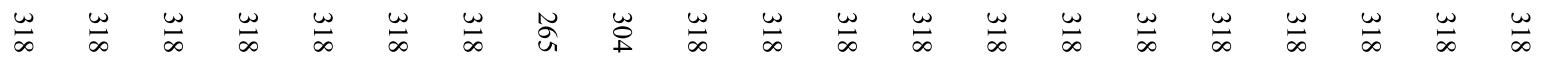

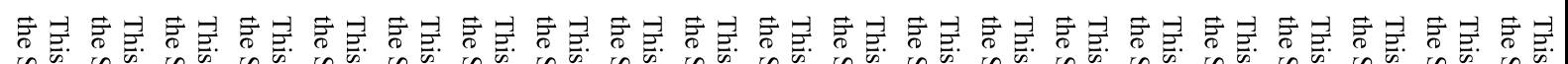

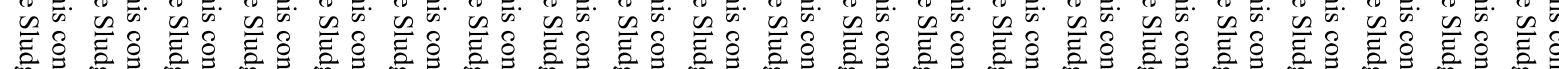

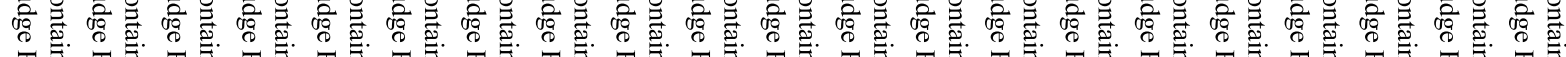

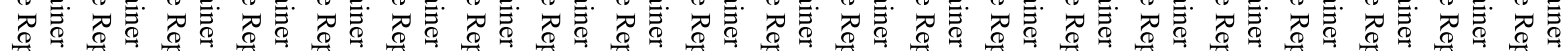

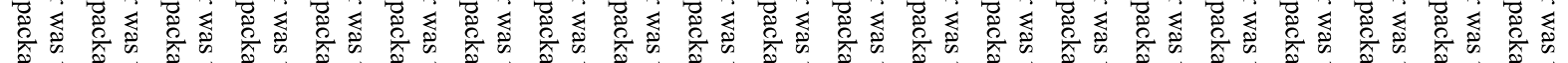

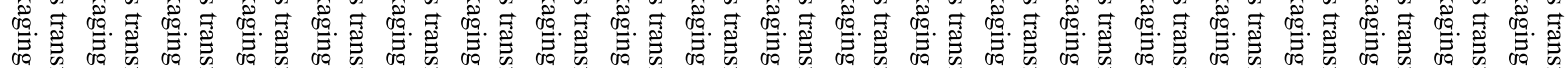

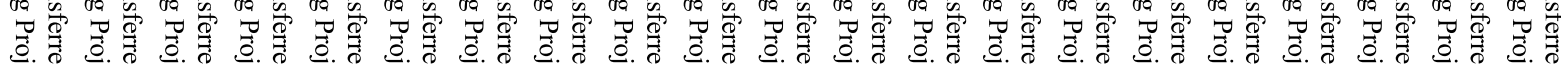

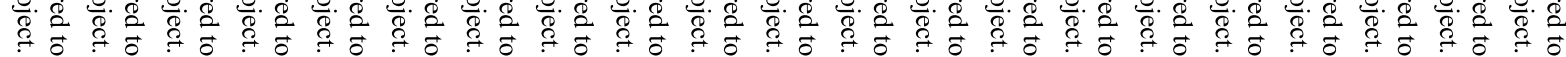

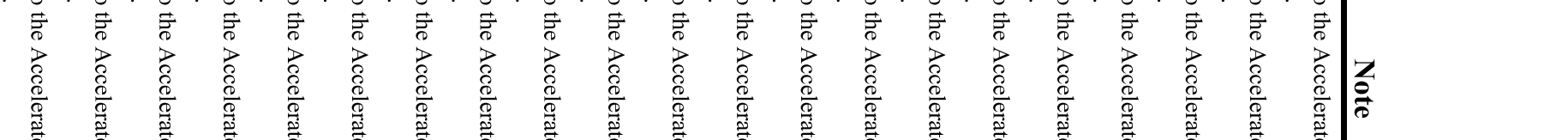




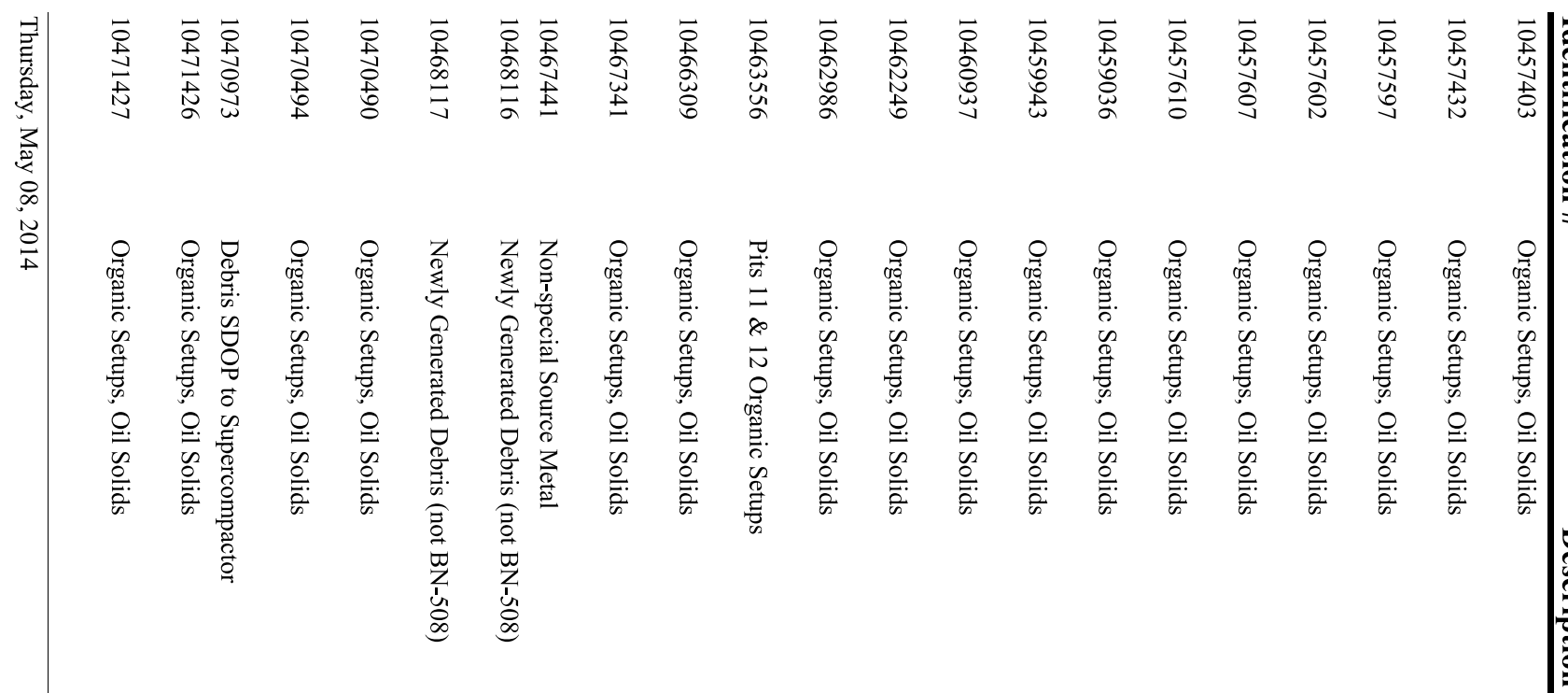

$\frac{\omega}{\infty} \quad \frac{\omega}{\infty} J$

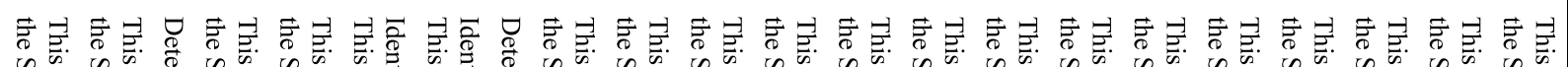

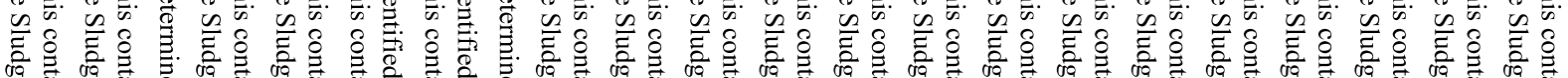

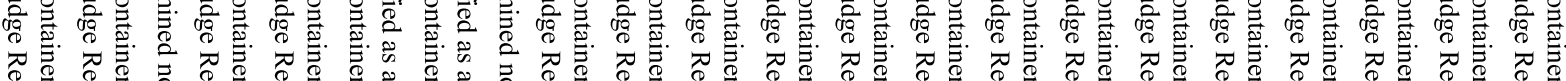

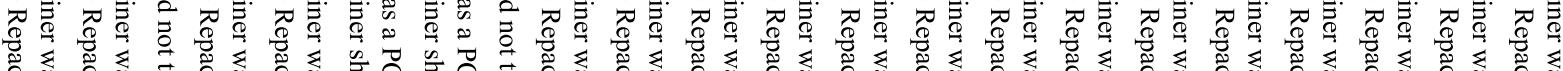

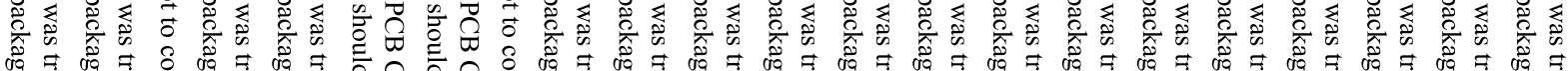

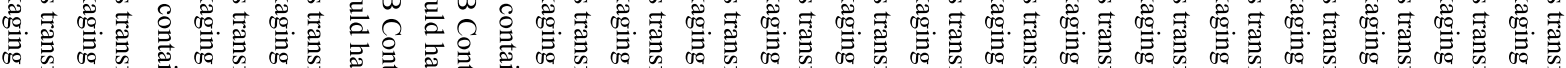

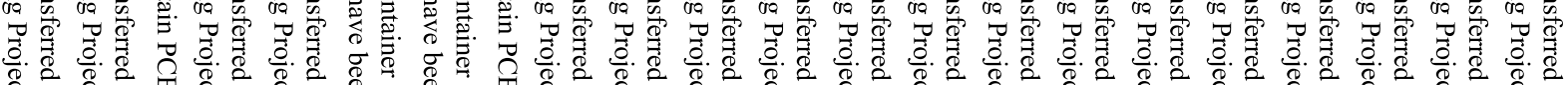

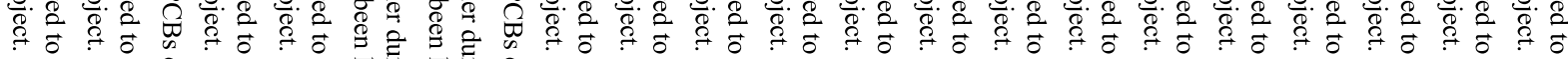

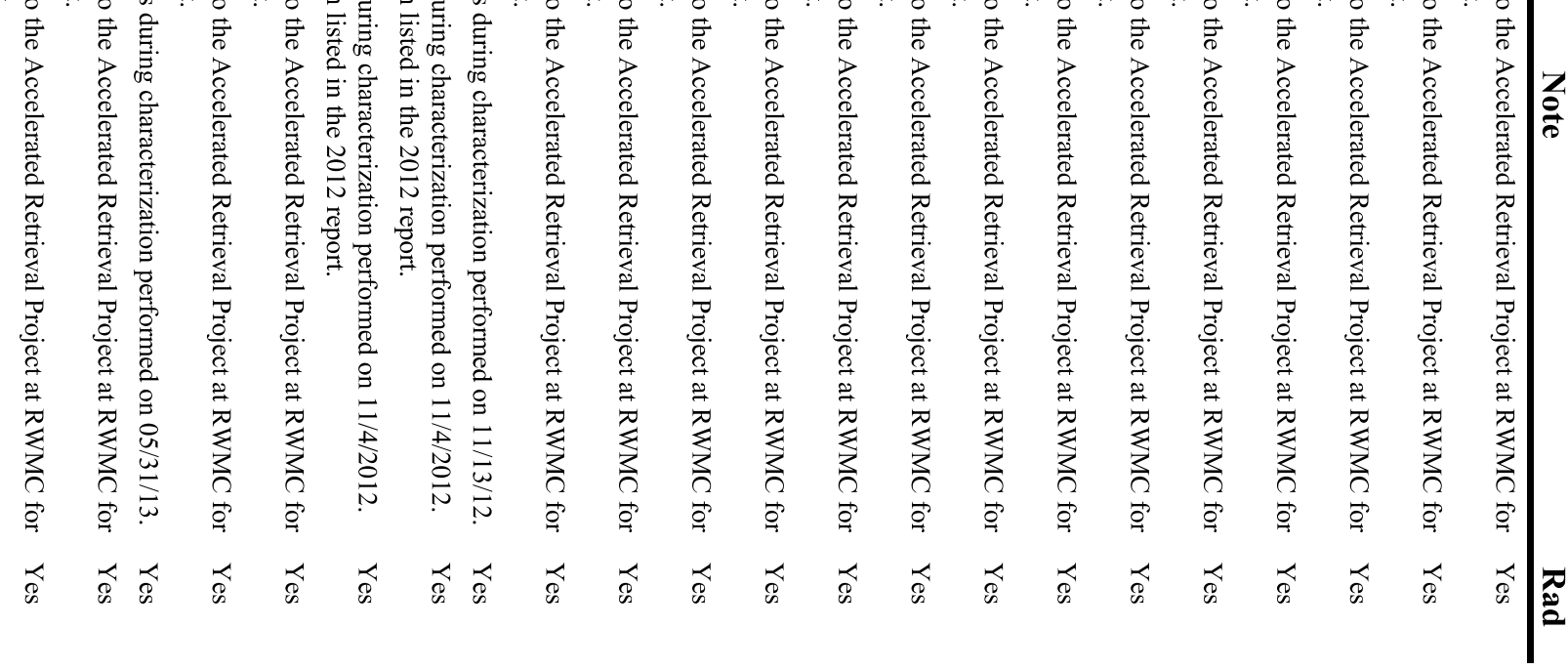

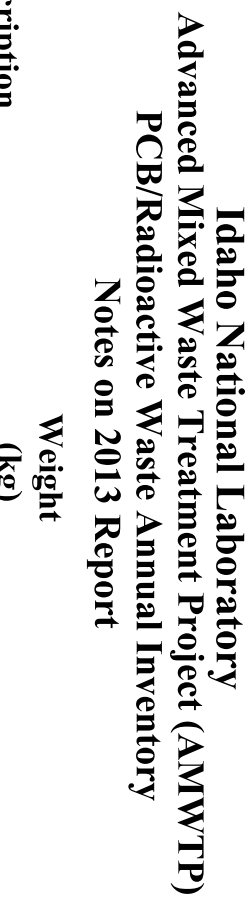




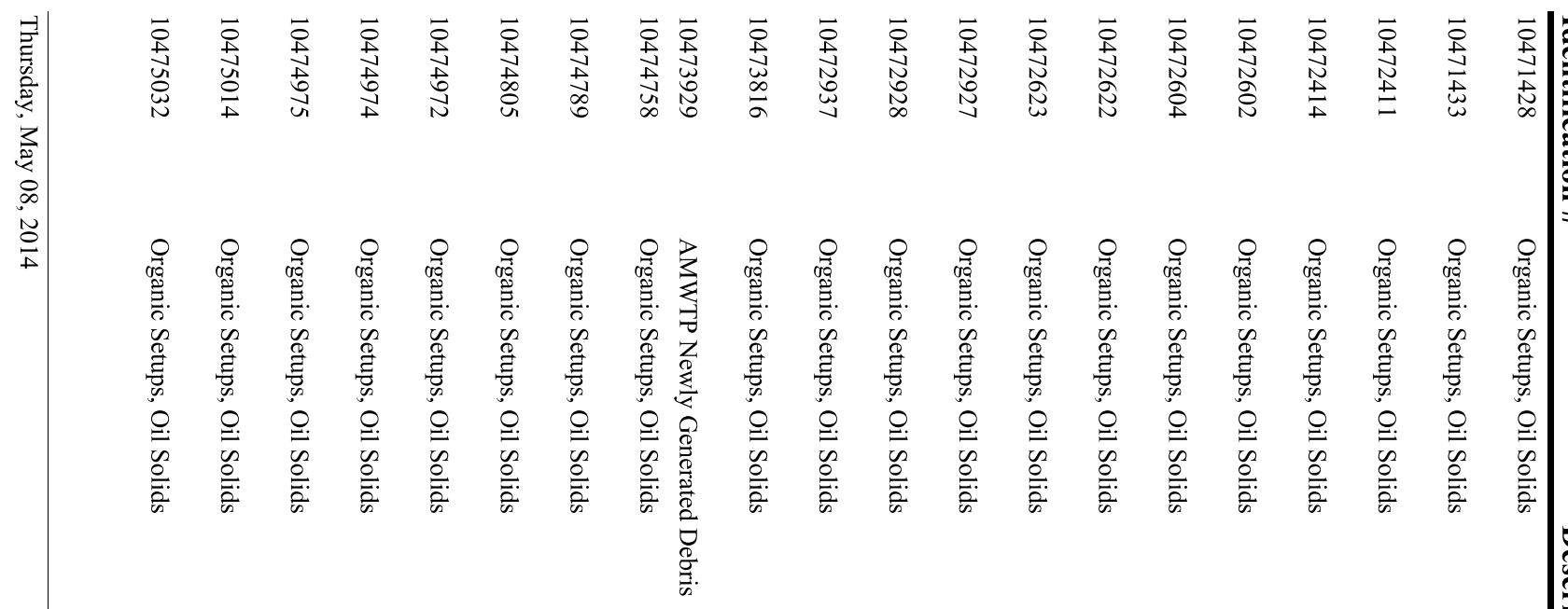

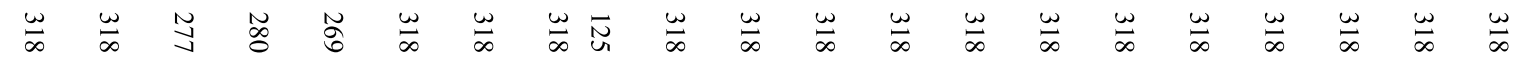

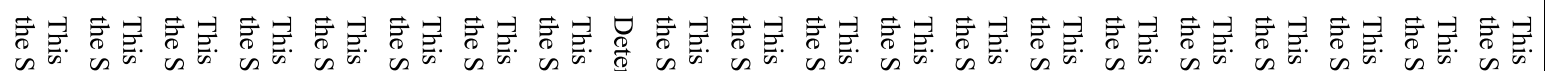

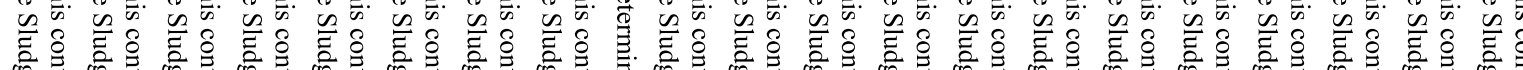

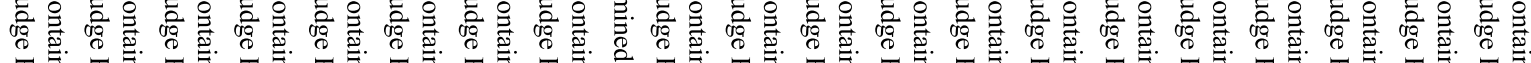

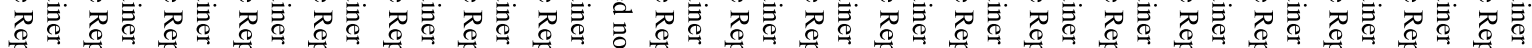

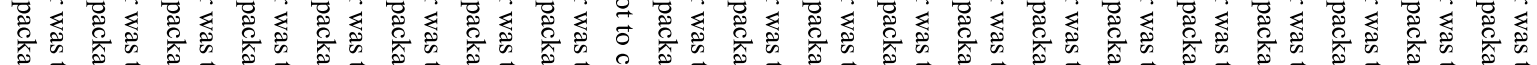

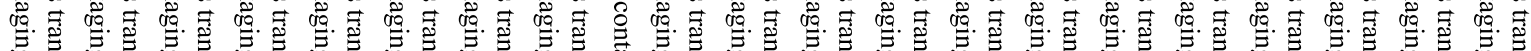

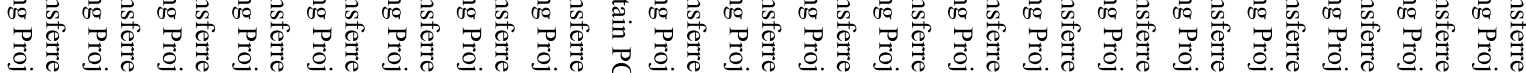

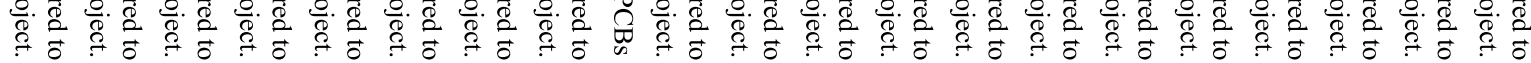

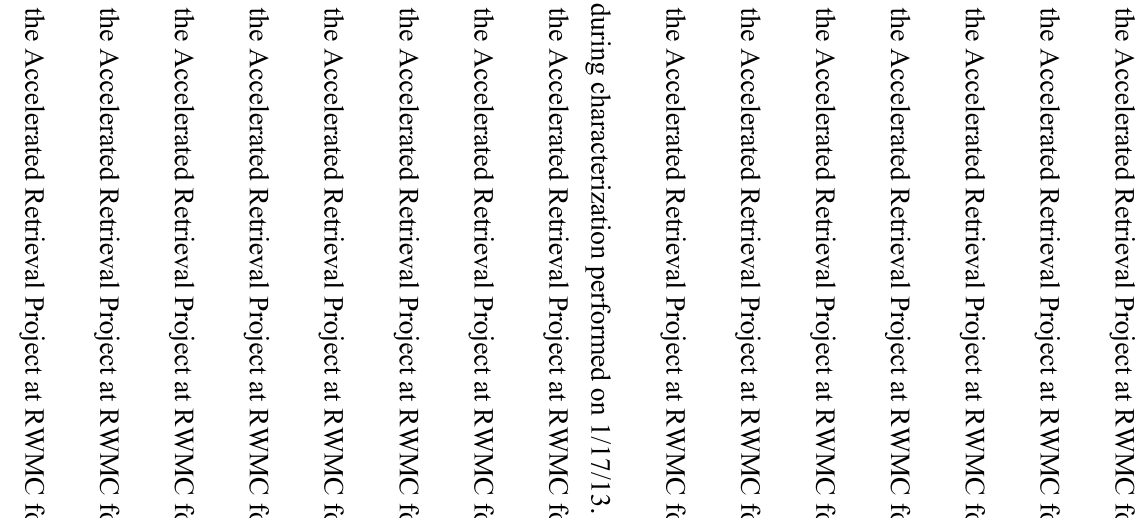




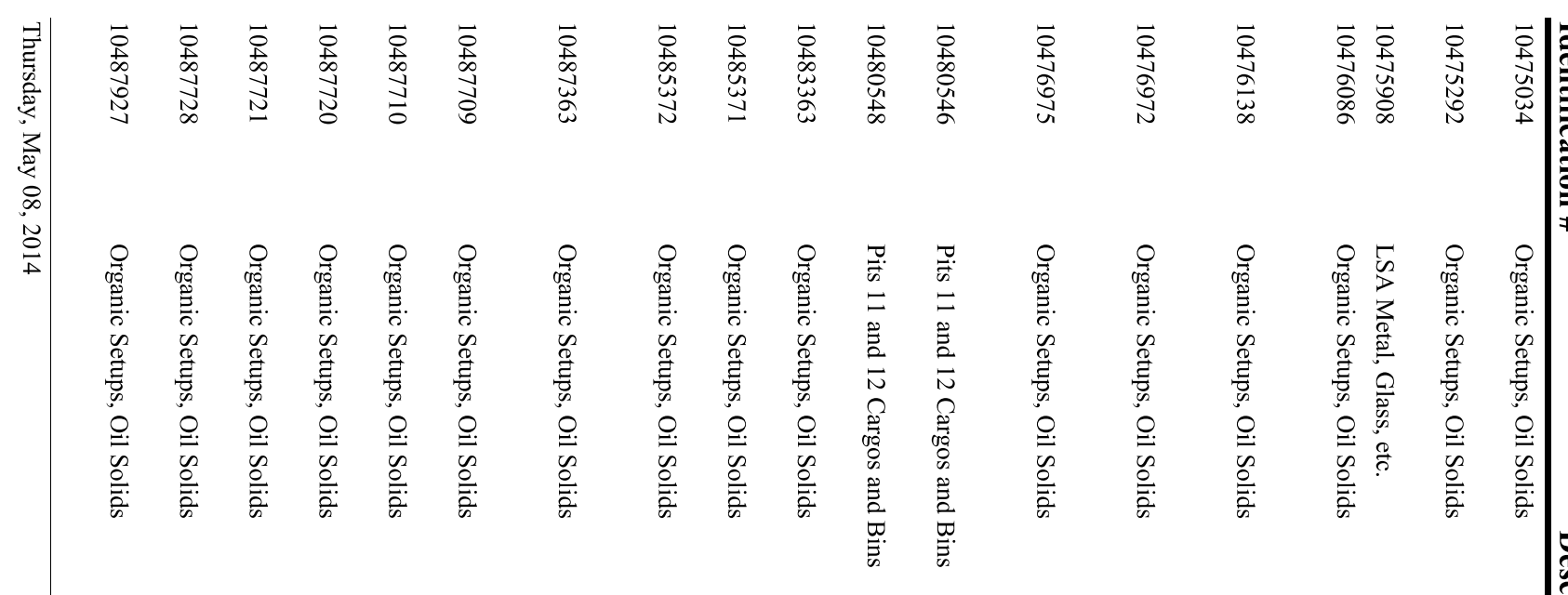

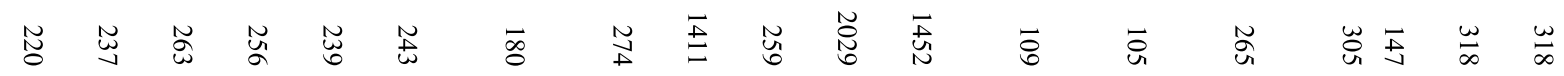

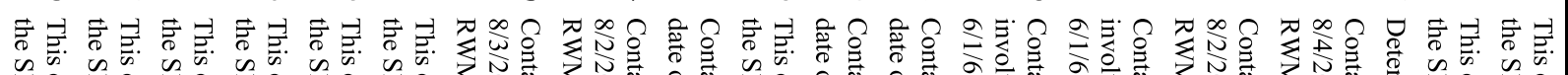

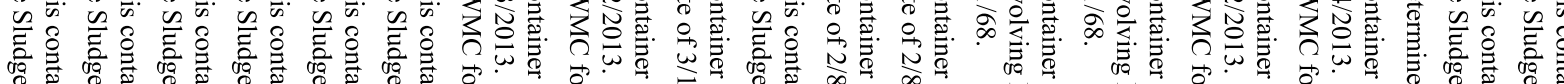

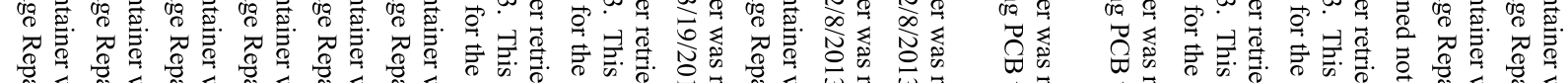

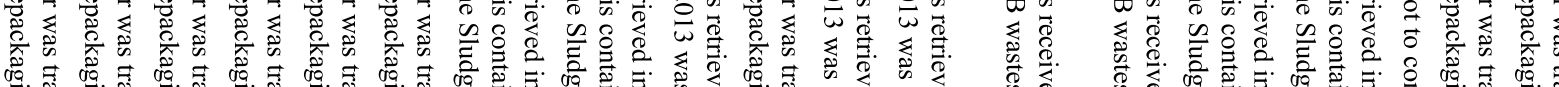

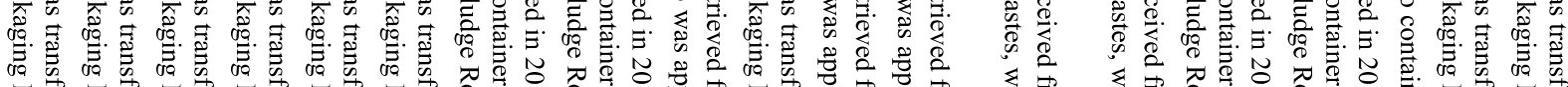

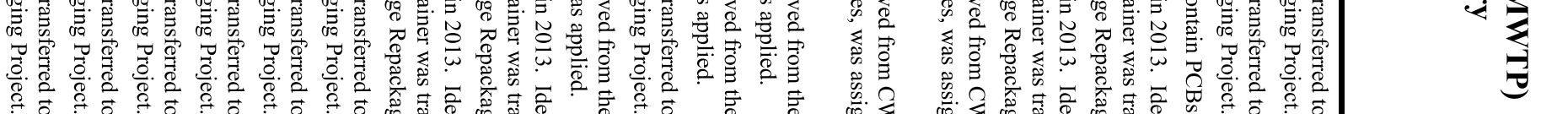

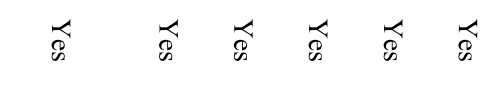

急 


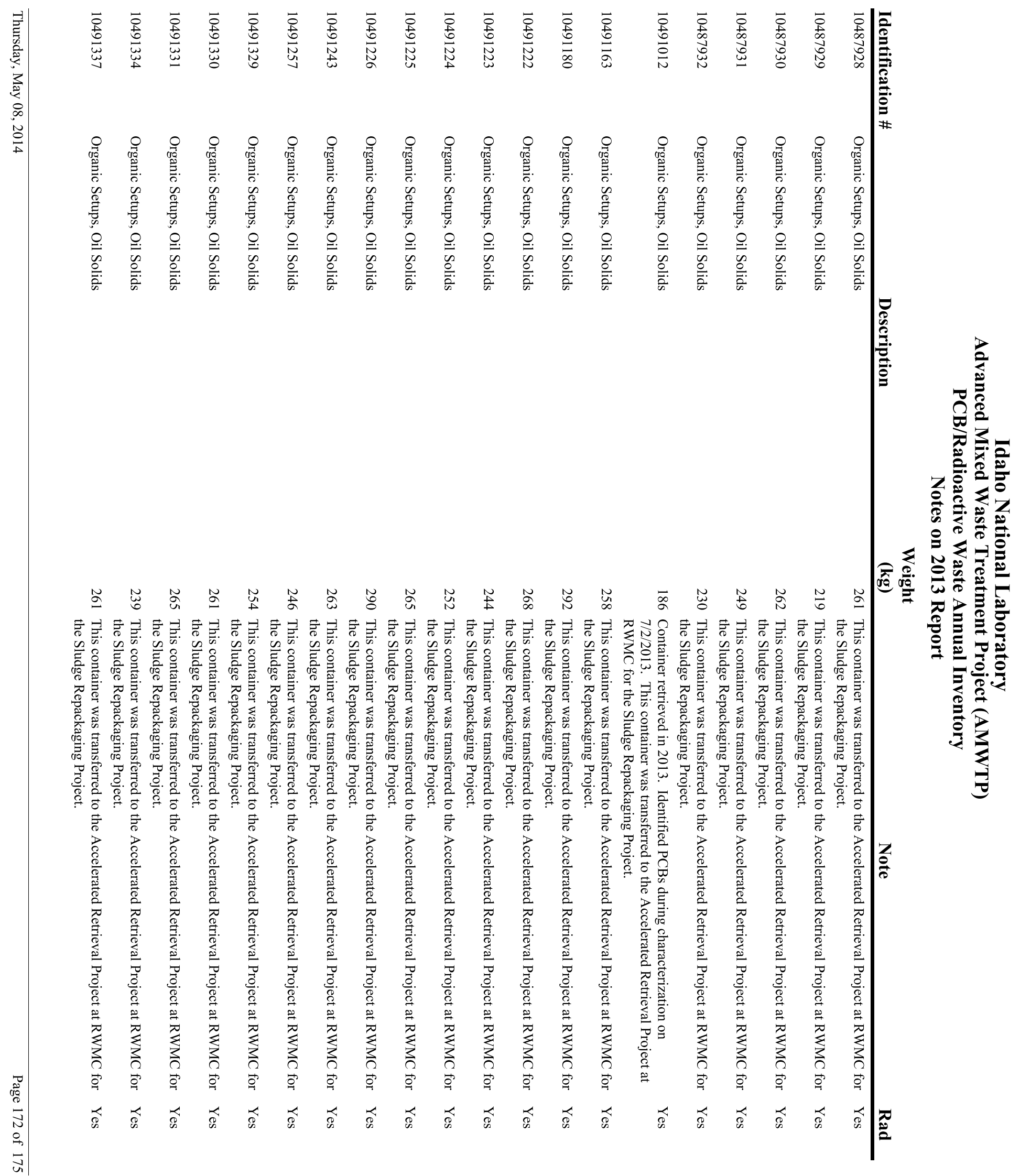




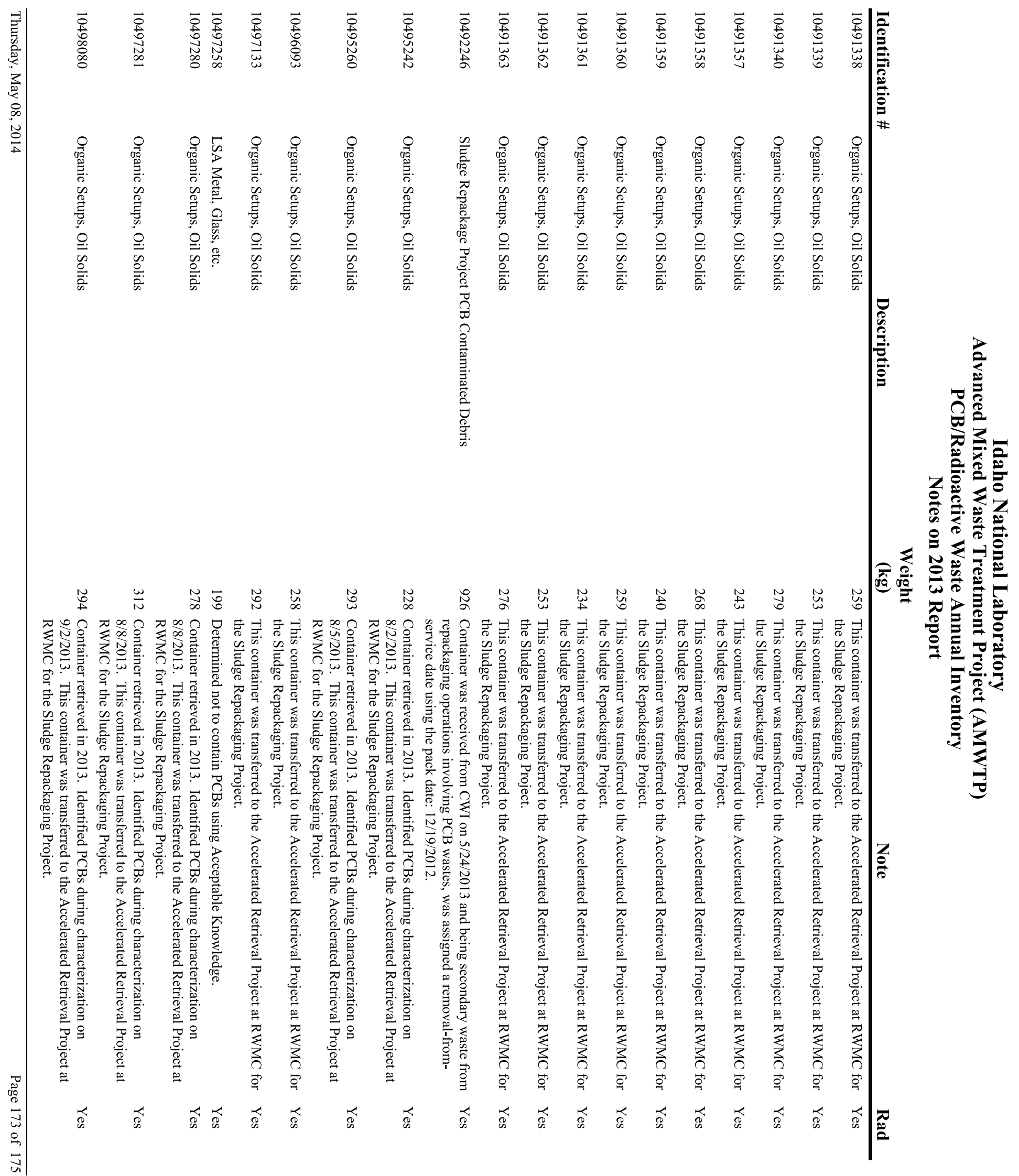




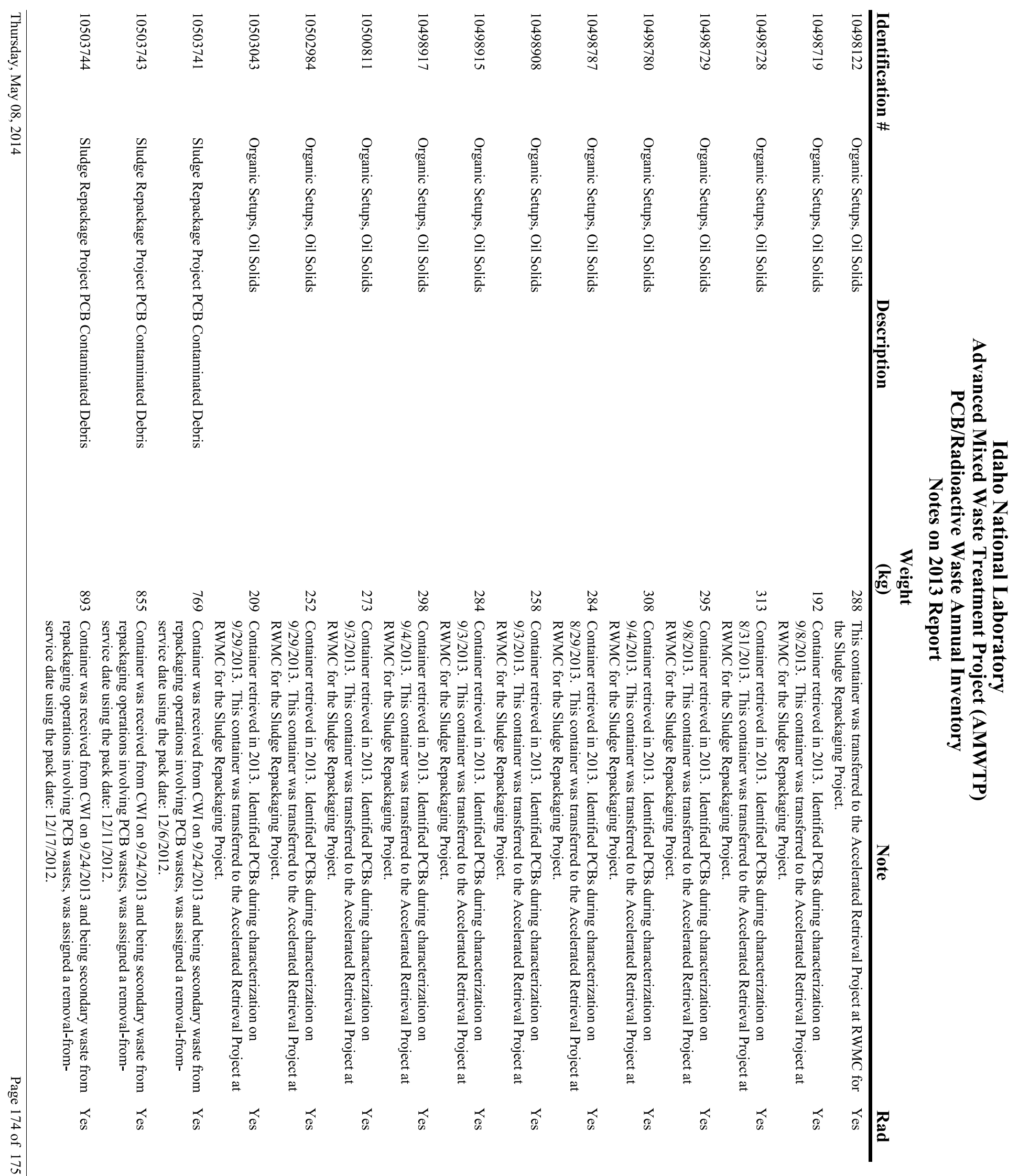




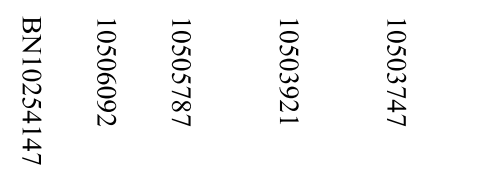

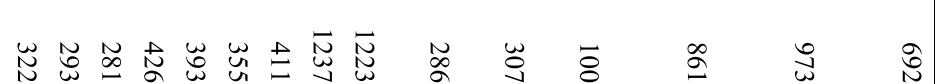

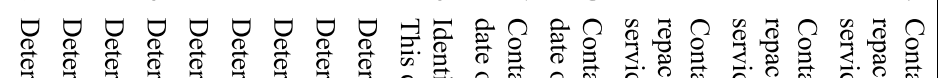

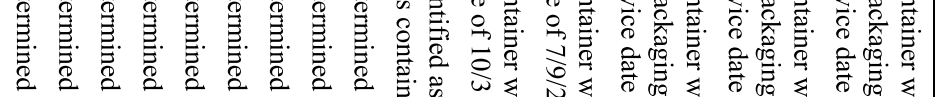

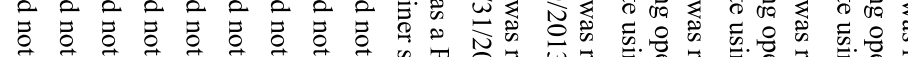

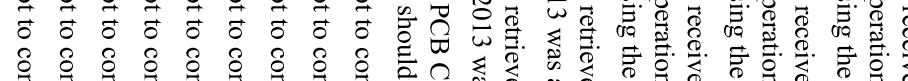

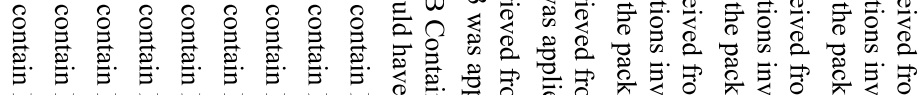

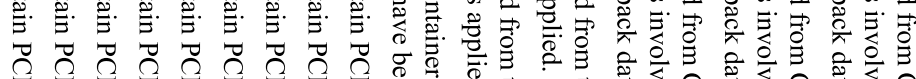

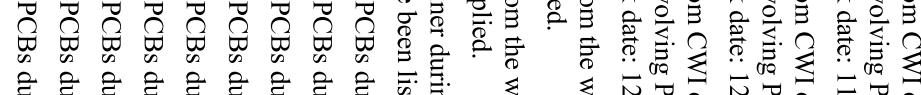

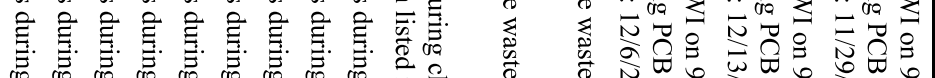

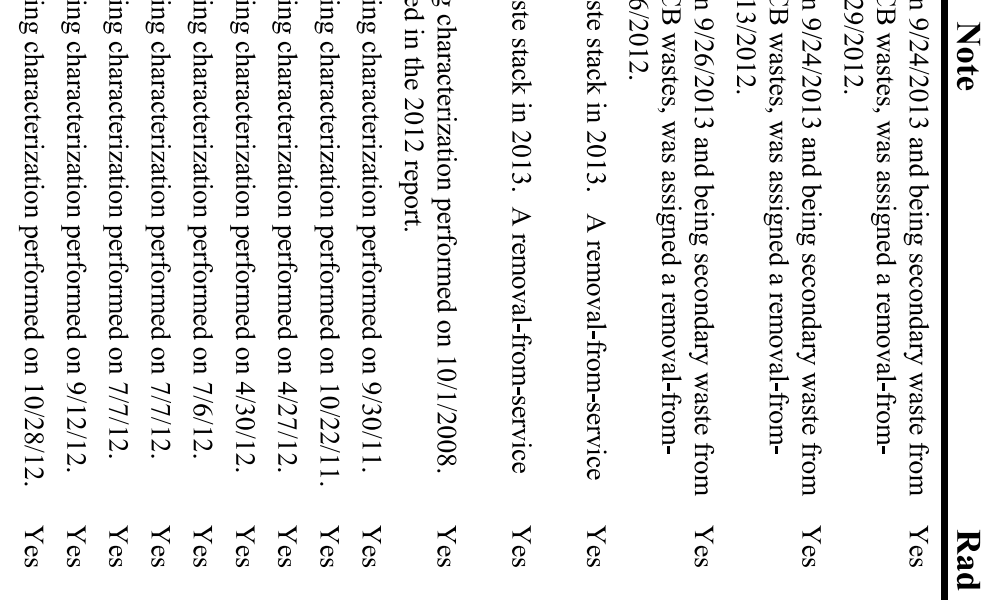

